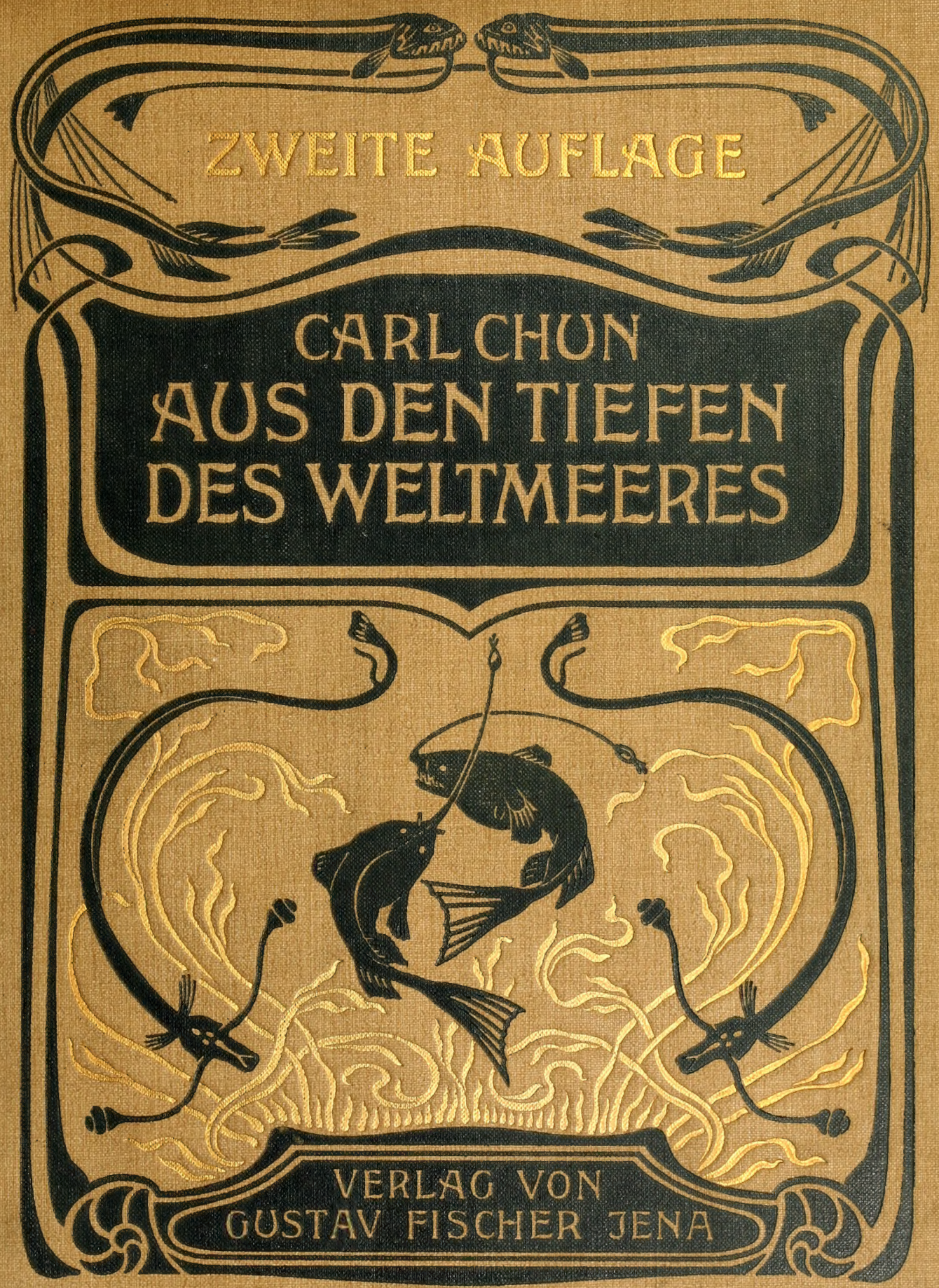




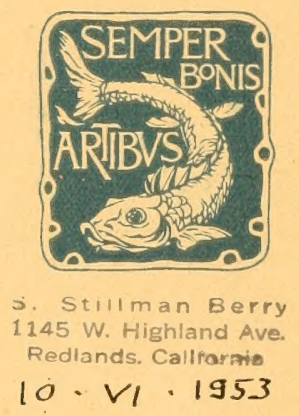




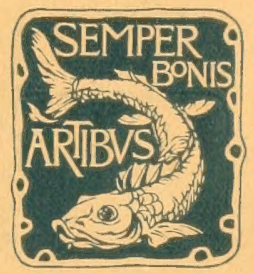




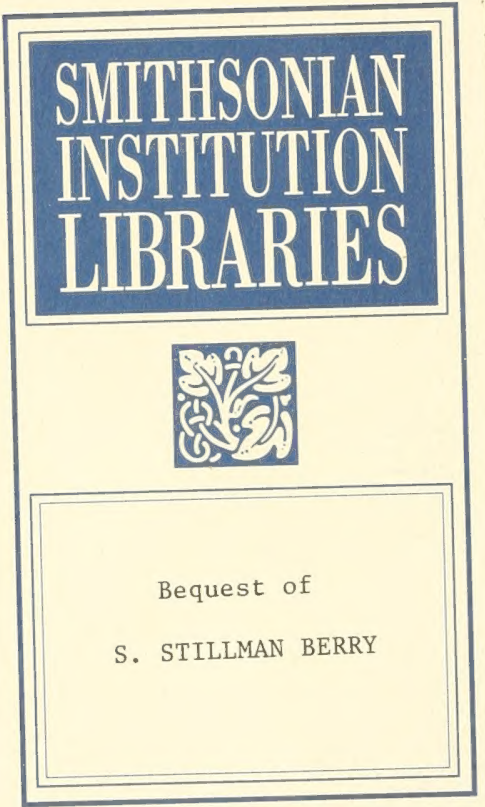




\section{Zlus den}

\section{Tiefen des Weltmeeres}

voll

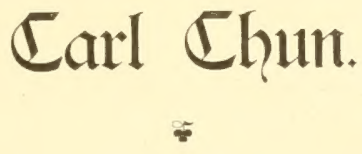

\section{Sthilderungen}

von der

Deutjhen Tieffee = Erpedition.

Wit 6 Chromolitḩographien, 8 Geliogravüren, 52 als Tafelt gedncften Dollbiloem, 3 Karten und 482 21bbiloungen im Tert.

\section{Jaweite ungearbeitete und ftarf permehrte 2luflage.}

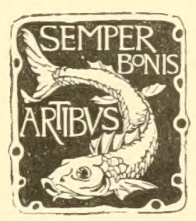

Derlag von (5ujtav fifcher in Jena

$$
1005 .
$$


Alle Redhte vorbehalten. 
Reiner frau und meinen Kindern

gewiomet. 



\section{Dorwort jur eriten 2luflage.}

$\mathfrak{2 i}$ den vorliegenden Reifefhilderungen wird eine Danfesiduld abgetragen. 2lls die "Daldivia" nad neummonatlicher fahrt am I. 2liai 1899 in den Kamburger Gafen jurücfigefehrt war, wiejen die Dertreter des Reihsamtes des Jnnem und des Preufificen Kultusminifteriums in einer Konferenz darauf hin, daf es wünjhenswert fei, wenn in gemeinverjtändliher form der Derlauf und die widhtigiten Ergebnifje der fahrt dargeftellt würden. Dies un fo mehr, als jeder Deutfhe, der Jntereffe an den wifienfhaftiden Unternehmungen des Reidhes hat, aud den Zlnipruh erheben darf, aus einem ihm verftändiकhen Rechenihaftsberiht ju erfahren, in welher Weife mit den groß̧en, von dem Reidistag einftinmig gerehmigten 2ritteln gefhaltet wurde.

(5ern unterjog fith der Seiter der Expedition der Derpflidhtung, in anipruhslofer form jene unvergeflidgen Eindrüle wiederjugeben, weldhe die glühende farbenpraht der Tropen mit ihrer überjäumenden fülle von Seben und die empte 2rajeftät der eifigen antarftijhen Regionen erweften. Gätte er freilich geahnt, welche Sdwwierig feiten fith in den $\mathfrak{W e g}$ ftellten, went es galt, aud die wiffenidhaftlichen Ergebriffe darjuftellen, fo würde er wenger freudigen Gerjens dem Dorfdilage der Regierungs: vertreter jugefimmt haben. Wer es jum eritentale untermimmt, gemeinverftändid 3u fareiben, der hat das Thatiadienmaterial ju beherrident und fich nidit von der überfülle erdrüten ju laffen. 2Tun vermögen wir jwar die oceanographifhen $E_{\mathrm{r}}=$ gebniffe ju überfhauen, nidht aber die biologifhen. Die reidhen Sammlungen find faum erft den einjelnen Bearbeitern überwiejen worden, und fhwerlich werden die nach folgenden Blätter den Sefer einen Begriff von der Bedeutung cines 2rateriales geben, welches die Retfegefährten in fitllem Sdhaffen unabläjfig an Bord fihteten und fonfervierten.

So ijt es dent gefonmen, daf die Shilderung von sand und Eeuten mehr in den Dordergrund tritt, als die Thätigfeit auf dem einfamen 2lieere. 2lber aud in diefer Gimïht müfien wir unjere Unjulängliḑfeit befennen: mur in wenigen fällen dauerte der Zufenthalt fo lange, daf wir in der Sage find, ein einigermafen jutreffendes 3 ild von ber frembartigen Scenerie ju entwerfen.

Selten find einer dentiden Expedition bei ibrer Geimfehr gröpere Ehrungen ent gegengebradit worden, als der unirigen. Jhre 2Najeftäten Kaifer Wilhelm unt König zllbert von Sachien gaben in hulbollen Telegrammen ihrer (5emugthumg 
über den glüfliden Derlanf der fahrt 2lusdrucf; der Staatsjefretär des Jumen, Graf von Dofadowsfy, mit den vortragenden Räten des Reiḑsamtes, der fädhitihe Kultus minifter von Seydewit, Dertreter des preupifinen Kultusminifteriums und des Reidhs= marineamtes, Bürgermeifter und Senatoren der freien Reidsftadt, der greife Direftor der Seewarte, der Uuffithtsrat und die Direftoren der Gamburg=21merifa= Sinte - fte

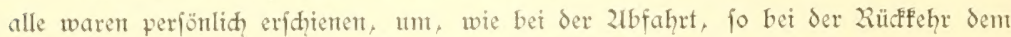
lebendigen Intereffe für die wiffenihaftlihe Itnternehmung des Rethes 2usdrut ju geben. Unfer Zientor, Sir John 2rurray, der den Shatz femer Erfahrung in Tiefieeforjhung mit auf den $\mathfrak{W e g}_{\mathrm{eg}}$ geben hatte, war von Edinburgh herbeigeeilt, und enolich verfanmelte der naturwiffenjhaftlidge Derein von Gamburg alle feftgenoffen ju cinent folennert Konmerfe.

Wem wir aud de in jo feierlider form geäuferte (benugthuung über die glüct: lithe Geimfehr der "Daldivia" mit warnem Danfe entgegemahmen, fo dürften wir uns dod frei von äberhebung wiffen. Reifen maḑt bejhetden - dies jumal dann, wenn man tagtäglich Erjhemungen gegenüber fteht, die der enge Gorizont des Einjelnen weder ju überfatuen nod ju erflären vermag. Die Wiffenifhaft wird ftreng und nüdtern ridhten, ob wir unfere PFliḑt thaten und of die Ergebnifie einen Dergleid mit den Seiftungen der Tieffee= Expeditionen anderer Zationen aushalten fönnen.

Daf das Werf in einem Gewande erfheint, welhent der einfaḑe Inthalt faum entipridht, danfen wir den raftlofen Bemühungen emes längft bewährten Derlegers;

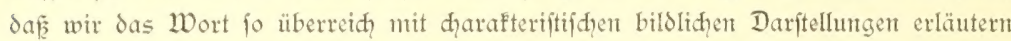
fornten, ift den unabläfifigen Bemühungen des. die Erpedition begleitenden jungen Küntlers, frits Winter, jujufdreiben. Dhotographifhe Darjellungen, weldhe von anderer Seite, namentlid, von einjelnen Expeditionsmitgliedern, beigefteuert wurden, fint als foldye fenutlid, gentaht. Ziiht minder haben wir an vielen Stellen auf die mertwollen 2Titteilungen von Reifegentofien und Bearbeitern des 2rateriales hingewieien; audh ibnen fei insgefamt gebanft.

Seipjig, in Rovember 1900. 


\section{Dorrede jull jweiten Zliflage.}

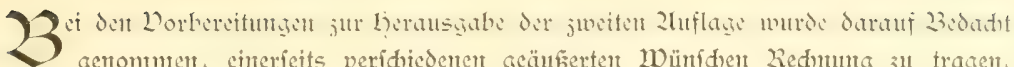

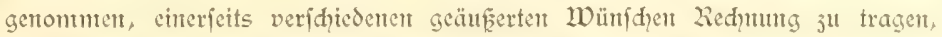

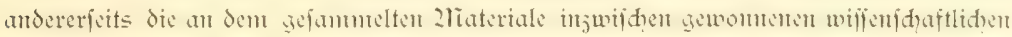
Ergebutife in den Beridit ju verfledten. Es haben daher einige Kapitel, weldhe vor= wiegend die Tieffee=fama betreffen, eme wefentlide Erweiterung erfabren, die aud in den 82 sent Tert neu beigegebenen 2lbbildungen ibqen 2usdrud findet. Lnter den lef̧teren mögen die Darftellumgen der (5̃rundproben und veridiedenter widytiger Typen von Tieffecorgarismen, ridht ninder auth die figuren, welthe den 3au der 2lugen unto die 2lnoronung der Senditorgane von Tieffeeformen erläutert, hervorgehoben werden.

Int ibrigen waren wir bemïht, utgenügend ausgefallene 2ubbildungen der eritent

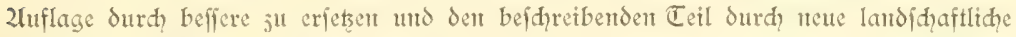
und ethnographifde Dollbilder bezw. Tertbilder ju heleben. Vor allem faiten es an= gezeigt, durh Eimfhalten mehrerer inftruftiver Llufuahmen von Eisbergen und von Kerguelen=Scenterien die entlegenen antarftifhen Regionen den Sejer and bildid näher ju rüken.

Dem occanographifhen Teil wurde aus 2lnlaf der Deröffentlidung der "Wifien=

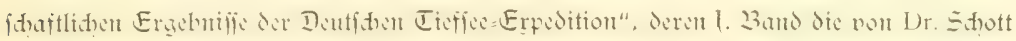
verfaf̧te Dceanographice enthält, dadurd, Redhmung getragen, daf wir dem genamnten

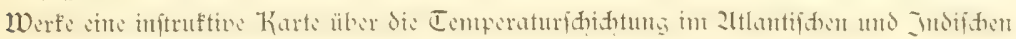
Decane entlehntert.

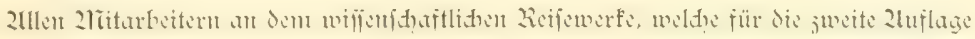

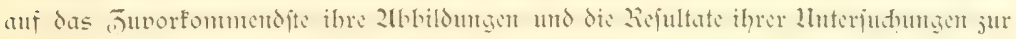
Derfügung ftellten, fei biemit anfriḑtig gedanft. Zïht minder gebührt unjer Danf

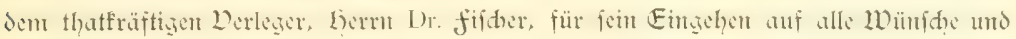
für feine fortgefetsten Bentühungen und würdige Zlusftattung der Reifebefireibung.

Seipjig, 2rovember 1902.

Sarl Chun. 



\section{Inthalts=1)ergetduis.}

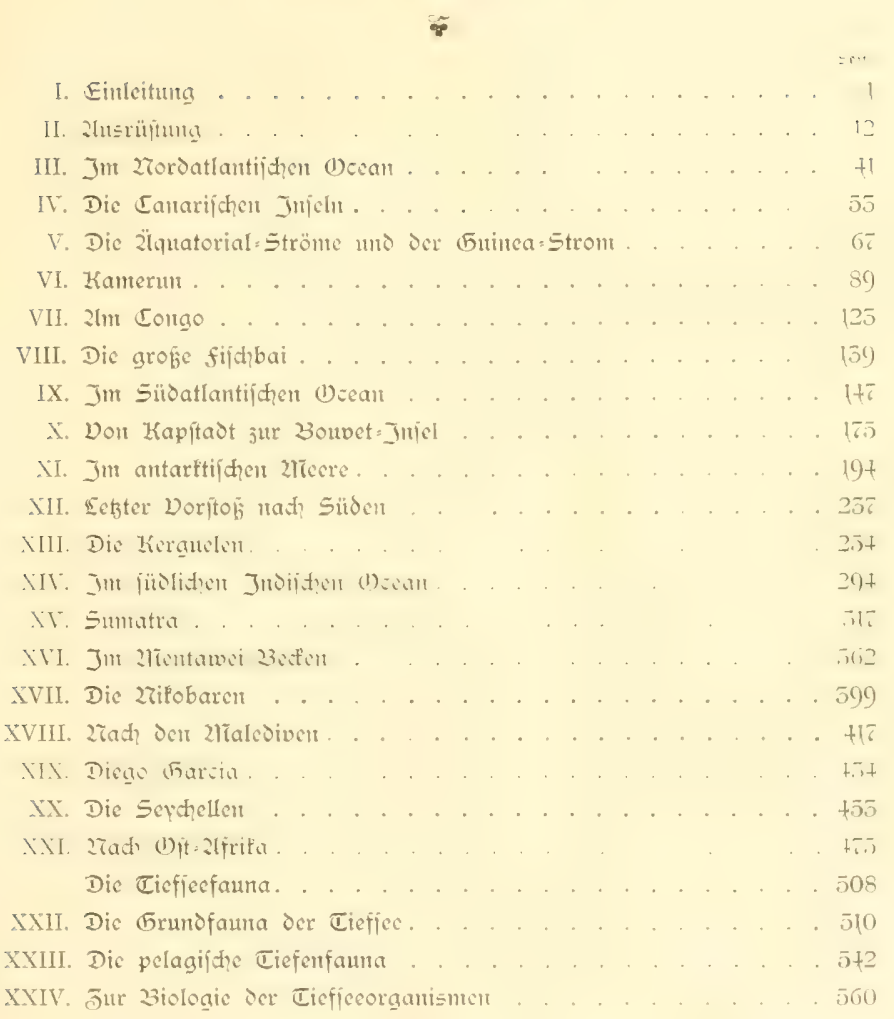

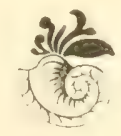





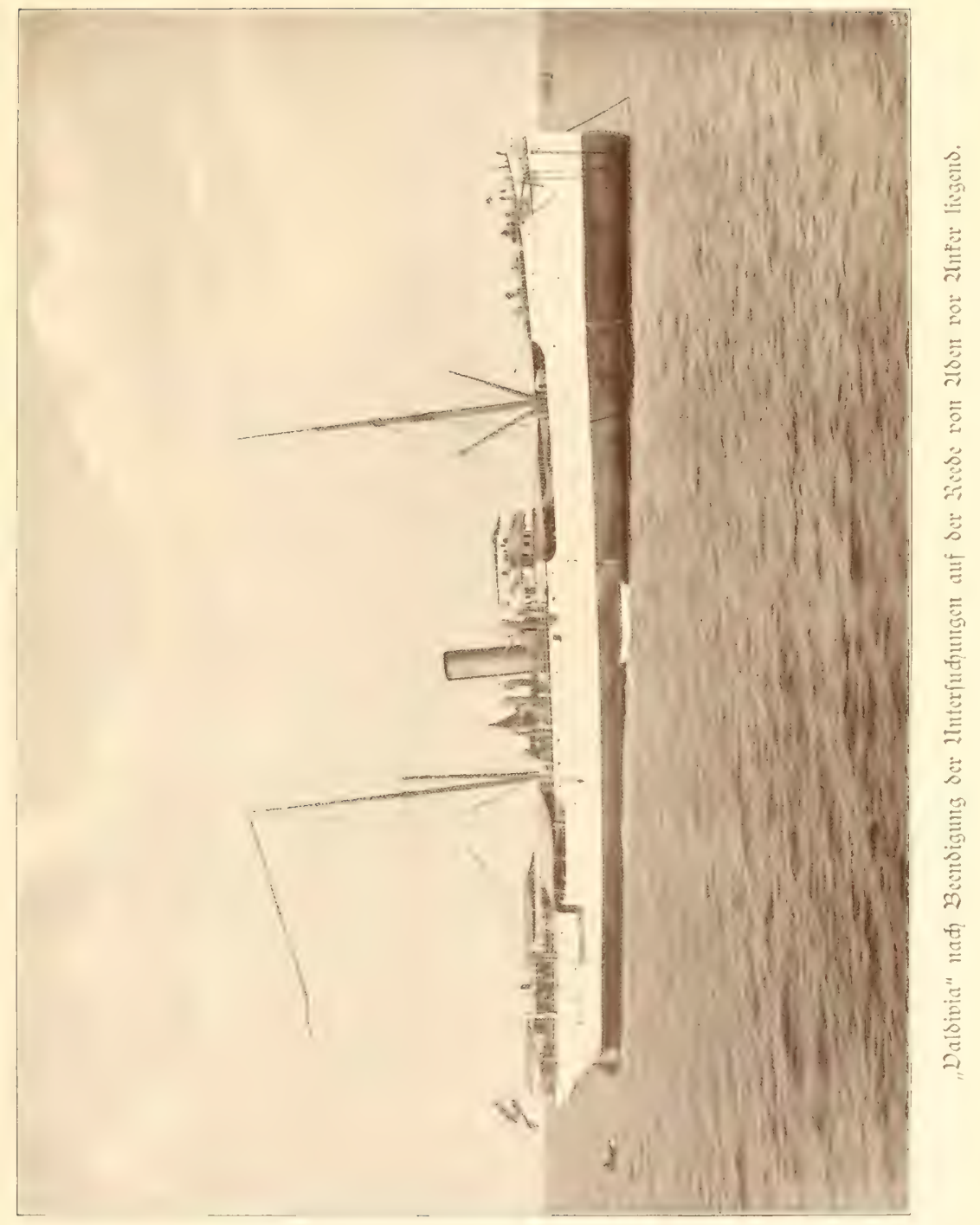





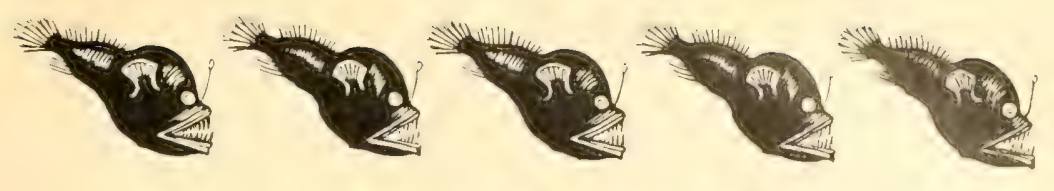

\section{Einleitung.}

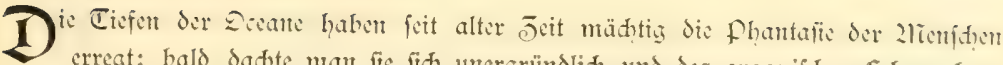
erregt; bald dadyte man fie fith unergründlid und des organifden Eebens bar, Fald bielt man fie für das 2lbbild des Oberflädenreliefs unferer Erde und relebte fie mit phantaftifonen (Deftalten. Das Intereffe für eime singahendere Erforfdumb fallum merte indeffen vollitändig bis jum Beginn unieres Jahrhunderts.

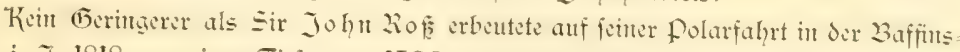
bai i. J. 1818 aus einer Tiefe von $1500 \mathrm{~m}$ einen prädtigen lebenden Sdlangenftern (Gorgonocephalus), der fid, in dic Sotleine verwidelt hatte.

2lit einent Sdylage war dasurh die 2luffafiung feites frantöffhen Jeitgenoffen péron widerlegt, der im Zuftrage der Republif zwei Eroumiegelungen als 2Tatur= forjher begleitete, die 2lnfalauntg nämlich, dafí der Boden der Deeane mit Eis bedefft jet; überzengend war weiterbin nadgewiejen, daf felbft im hohen 2rorden die gropen Tiefen dent organifhen $\mathfrak{E}$ eben jugänglid, fint. Sein Befund geriet indêfen in $\mathcal{D e r}=$ geffentheit, und es bedurfte der ftillen Thätigfeit nordifher forfher, um die von dem

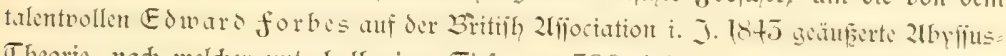
Theorie, nad, welher unterhalb einer Tiefe von 500 faden (ca. $550 \mathrm{~m}$ ) ferme Orga= nismen mehr vorfonmen follten, in ङweifel zu ftellent.

2ridhacl Sars, der fhon als Candidatus theologiae und als Pfarrer in Kind bet

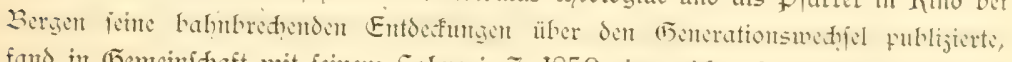
fand in Ëemeinfhaft mit feinem Sohne i. J. 1850 eine reidhe abpfifale fauma an ben Sofoten in eimer Tiefe von 450 faden. Ebenfowentig formten Sovén und der als

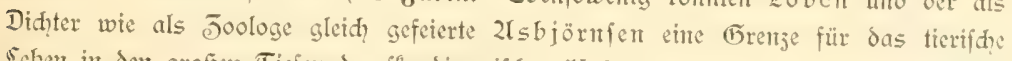

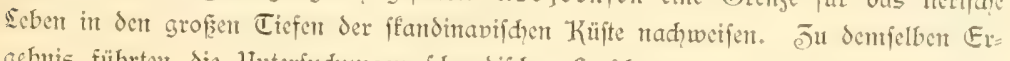
gebuis führten die 2lnterfudyungen fdqwedifher forfher - es feien nur die ziamen Torell, 2iordensfiöld, Théel, Sindahl und 2lialmgren hervorgehoben-welde

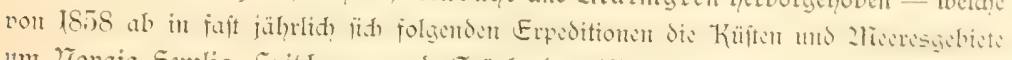
um 2Tovaja Semlja, Spisbergen und (Érönland auff́läten.

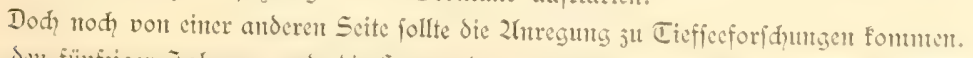

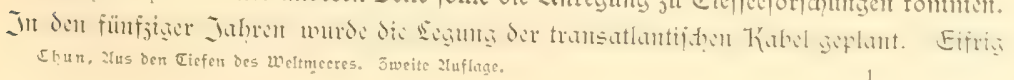


war man bemüht, Sic Tiefen ju lotent, Gevor die Kabel verfenft wurden. Schon bei Siejen Dorarbeiten ergaben fid unjweidentige Beweije für die Exiftenj ciner faunt in Tiefen pon melye als 1000 faden; not draftifher mehrtent fid die Beweife, als das erfte transatlantifde Kabel, welches 1858 gelegt wurde, rif und bald darauf bem Sar= dinien und 2llgier verbindenden Kabel dasfelbe Sdiffal widerfuhr. Beide Kabel wurden wieder aufgefifht: auf betden hatten fid Tiere angeficdelt. Dret Jahre hatten

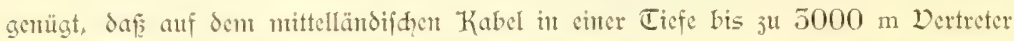
vou 15 Tierarten feftiftzend gefunden wurben.

Uls dam weiterhin der fdyarfinmige 10 allid 1860 in den Eotproben des englifyen Kreujers "Bulldog" aus den Tiefen des norbatlantifinen Dreans bis ju $1800 \mathrm{~m}$ ver: fdiedente lebende niedere Organismen nadywies, ju denen fid gelegentlich von der Sot=

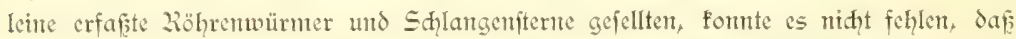

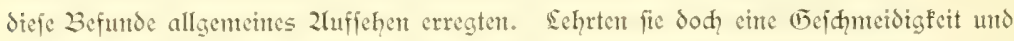
2lupaffungsfäbigfeit des tierifhen Drganisnus an Eriftenjbedingungen Fenner, dic alles überbot, was wir bisher pon der geographifhen Derbreitung tierifder Drgantsment in anjheinens den Seben feindlidhen Regionen wubten. Die gefeierfften Biologen, cin Ehrenberg, Lurley und 2rilne Edwards, äuferten fth in Gutadten über dic Tiefiecproben - fie alle ftimmen darin übercin, dafi bei fyitematif betriebenen Tieffec= forfdungen cine neue Welt dem Joologen fid eröfïnen würde.

Der ridftige 2liam, welder mit umfaffenden Wiffen und nie verfagender Begeiftermig

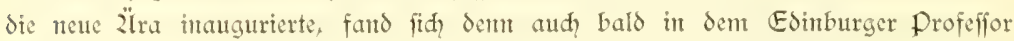
Wyotlle Thomfon. 2lngeregt durh die funde, weldhe Sars an den Eofoten gemadit hatte, getragen von der l̈berzengung, daf, ,auf dem Boden des 2lieeres das gelobte Sand der Joologen liegt", wuEte er gemeinfam mit feinem älteren freunde Carpenter, dent Dicepräfidenten der Royal Soctety, es ju erreidyen, daf jwei fleinere 2Tarinc= fhiffe, Sightning und die Porcupine, jur. Derpügung geftellt wurden. Don 1866-1820 wurden eme Seihe von Sotungen und Dredकjügen um das Injelreid, längs der Küitc

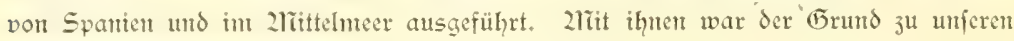
neneren 2urdjaumgen gelegt.

Saphlebiget ift die Signatur der heutigen J̈eit. Kaum vermögen wir uns nod? den כ̄auber ju vergegenwärtigen, den es auf die 2lienfabeit ausübte, als mit dem Eintreffen des erften Kabeltelegrammes Jeit und Raum jwifden alter und neucr Welt mur nad, Brudteilen von Sefunden bemeffen wurden, faum nod vermögen wir das Staunen ju faffen, mit welḩem der Eebildete die Entbecturg der Tieffeefauna ent= gegemahnt.

\footnotetext{
"Da orunter aber ift's fürdterlid,

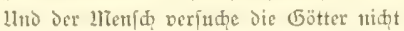

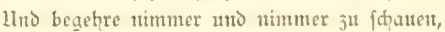

WWas fie antäbig bedcfen mit 27 aḑt mo Granen."
} 
Das war das Scitmotiv, weldes fid durd, die 2liythen des 2lltertums, durd dic Sagen einer neueren Jeit hindurdjog. Into mut trat an Stelle der phantaftifhen (5) ftaltert, mit denen man die Tiefiec bevölferte, einte fauna, fo lippig, fo farbenpräd)= tig und reijuoll, daf man die Begetferung begreifen wird, mit der ein 2litiglied dis Parlaments auftrat und es als Ehrenpflidyt Englands bejeidnete, cine Expedition in grofent Stile ausjurüfen, welde die Tiefen der gefamtent Decante in Sen Kreis ihrer forjofungs=Thätigleit jiehe. Einftimmig wurde der 2lntrag angentommen. 2fm 21. Dezember 1872 verlief sie Corvette "Challenger" England mit einem Stabe ge= wiegter forfiger an 30 ord unter Seitung von Wy ville Thomion; ant 26. 2liai $18 \pi 6$

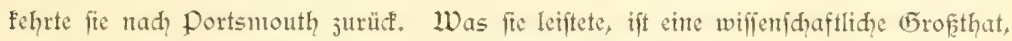
Sic fid) würdig den Ergebniffen der glanjoollften Expeditionen jur Seite ftellt. Dic 58 voluminöfen Quartbände, in denen die Ergebnific der Erpedition, bearbeitet von (5elehrten aller 2rationen, niedergelegt find, fiprechen eine fo beredte Spradge, dafi für die neue Deriode, in welthe die Deeanographie und Joologie cintraten, fein mürdigerer Uusgangspunft denfbar ift.

Dod auh die übrigen 2Tationen fidherten fidh ihe Ehrenteil an der Erforfhung der Tieffee. Praftifhe Interefien, wie fie durd die neugeplanten Kabellegungen bedingt wurden, gingen ja offer mit reit wiffenifhaftliden Land in 5 and.

Allen voran gingen die Znterifaner.

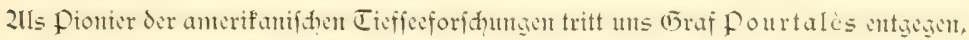
Ser fdon 1867-1869, alio nod vor Beginn der englifhen Expeditionen, das florida= Riff und die angrenjenden Teile des Golfitromes unterfuḑte. Don 1877 an erhielten die injwifhen durd die Jntitative des unermüßliq̨en Speneer 3 airs eifrig geförderten Linterfudungent thre Signatur durd das Eingreifen von Zllexander 2lgaffij. 2leben

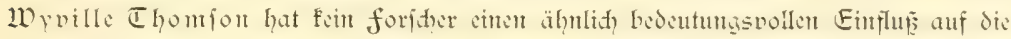

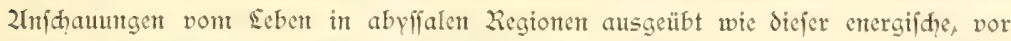

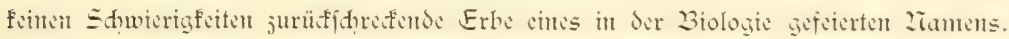

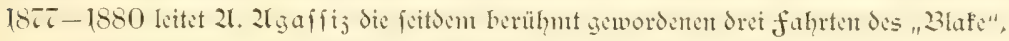

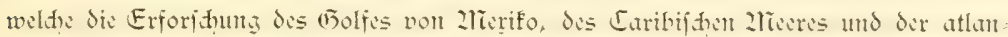
tijhen Küpte der Dereinigten Staaten betrafen. 1891 gilt es dent Pacifif, indent auf dem Dampfer "2libatrof " die abyffalen Regionen der Weit= Küjte von zrierifo uns Jentral=24merifa bis ju den Galapagos= Injeln unteriudt werden. Teuerdings, 1899-1900, verlegte $\mathfrak{Z}_{\mathfrak{g} a f i_{j}}$ fein forfhungsgebiet in den tropifden pacififhen Decan, der von dent "2llbatrofi" in grofent Bogen von San francisco bis Japan lnter befonderer Berïffithtigung der Korallenarhipele gefrenjt wourde. Dent Studium der Korallenriffbildung galt dem vorwiegend aud die fahrt, welde der unermüblide foriher in vergangenen Jahre 1901 nad det 2lalediven unternahm. 24gaffij war

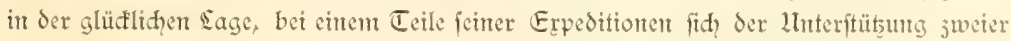


begabter 2rarime= Pffijiere, der Kapitäne Tanner und Sigsbee, ju erfreuen. Sie

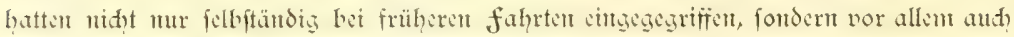

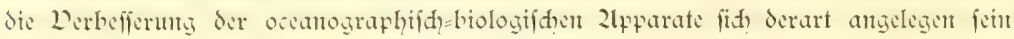

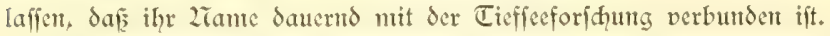

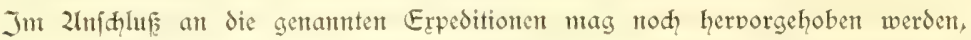

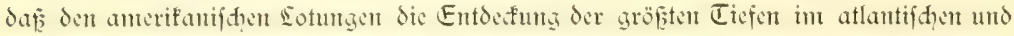

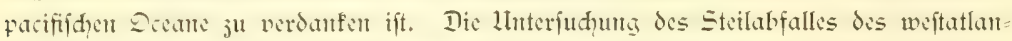

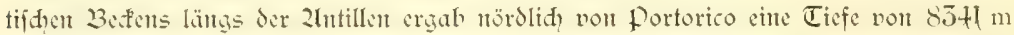
und die Sotungen der "Tuscarora" (1875-75) wiefen weftlith von Japan Tiefen bis ju $8515 \mathrm{~m}$ nad7. Diefe werden nod überboten durd gewaltige Depreffionen von über $9000 \mathrm{~m}$ Tiefe, auf welhe man juerft durh die "Egeria" in der Ziähe der Tonga= und Kermade = Jufeln (9185 und 9427 me Tiefe) aufmerffam wurde.

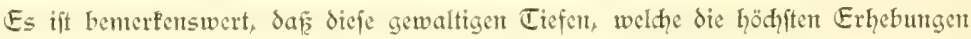
in Fimalaja an 2lusdehnung übertreffen, in der Zräḩe ausgedehnter Störungslinten im Sdhidentean der Erde, weldye oft bont Dulfanfetten begrenjt werden, auftreten. Sie repräfentieren langgejogene und f̧̧male Einfenfungen, fogenamute "Graben", welche freilid cinen un verfhwindend fleinen Brudteil des Tiefenteliefs ausmadyen. Steil fällt ihr dent feftland oder ehemaligen Kontinent jugefehrter Jmmentant in die Tiefiec ab und dicfe Eridgeinung wiederholt fid, nidht nur an den obent erwähntent Einfenfungen, fondem aud bet jenen, weldhe längs der 2lleuten, der hitenifd,

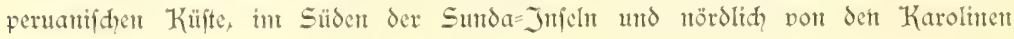
fith) hitrichert.

In der lef̧tgenamnten Orabenteinfenfung, weldye von dent die "Zrero" befehligenden amerifantiden Kapitär Belfnap entbeft wurde, lotete Scutrant Lodges von der

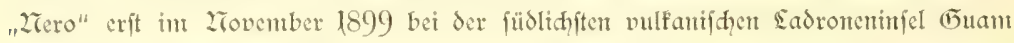
Sie gröpte bis jetst befant gewordene Ticfe von $9644 \mathrm{~m}(=5269$ faden). Berefquet man den Drue ser dort auf dent Grumde laftenden Wafferiäule, fo fommt derfelbe

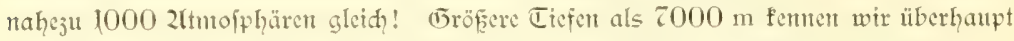
midht auţerhalb biefer burd antertfanifhe und englifhe forfhungen unts befamt ge= wordenen (5rabenverfenfungen; foldhe, welhe zwifdien 6000 und $7000 \mathrm{~m}$ Tiefe fid? bewegen, fpicten gleidfalls cine nur untergeordncte Liolle, während 2lüulden von 5000-6000 m Tiefe in allet Deeanen ju breiter 2lusdehrung gelangen.

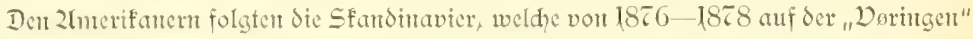
unter der Scitmis von 5. 2Tohn und 5 . D. Sars in hervorragend gewiffenhafter Weife de oceantographifhen Derhältniffe des nordatlantifden Decants und die cigen= artige Tieffecfauna des hohen Zordens erforfhtem. Scit 1880 rüftete frantreid nidyt wentiger dem vier Erweditionen aus, von denen bie bret juerit unternomenten fahrten

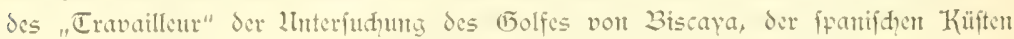


bis ju den Canaren und des weftlidgen 2littelmeeres galten. 1885 holte man danm auf cinem geeigneteren Sdiffe, dem "Talisman", weiter aus, indem die framjöfif wiffenidhaftidhe Konmiffort - wic früher, fo aud diesntal unter den Dorfif von IIphous zrilne=ESwards - von Rohefort über dic Canaren und Capverden das Sargafiomeer auffudte und über die $\mathfrak{H}_{j}$ oren jurücf́fehrte.

In die Erforidyung der abyfialen (5ründe des 2hittelmeeres teilten fidh tociterbin die Italiener mit den D̈fterreihern und den um Derbefferung der Tieffee=2lpparate verdienten füriten von 2ronaco. 1881 lotete der "Waihugton" unter Giglioli die Tiefen un Sardinien bis nah dent Golfe von 2reapel und nad, Sicilien, indent or gleidjeitig eine reidentwidelte Tieffeefauma nad)wies, weldhe in vieler Eimfitht mit der aus dem 2ttlantifhen Deean befannt gewordenen übereinjtimmte. Einen äbntiḑn Reidhtum von abyffalen formen wies der fürft von 2lionaco 1886 durd 2lnwendung feiner Tiefenreujen int öflichen 2lïtelmeere nah. Später dehnte er feine fahrtent weiter aus, indem er mit der 2)aḑt "Lirondelle" den atlantifhen Decan bis ju den $\mathfrak{Z}_{3}$ oren und nad 2Teu $=$ fundland freujte. Eqatten fdon die vier fahrten der flemen

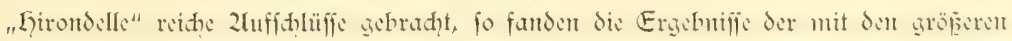

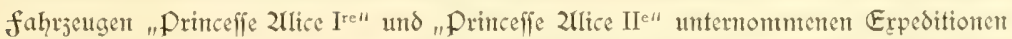

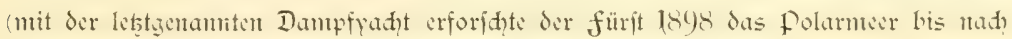
Spikzbergen) in immer weiteren Kreifen die verdiente 1 ürdigung.

Das öfterreidifiche Stationsfhiff "Pola" hatte fid anfänglid als 2lrbeitsfeld das

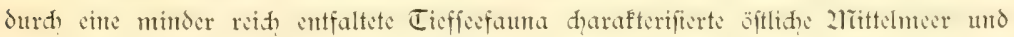
das 2̈̈gäithe 2heer erforen. Seine 1890 begontenen fahrten verlegte es Sam von 1895 an in das Rote 2lieer. Der Sdwerpunft der auf der "Pola" ausgeführter linter= fuhungen lag auf oceanographifhem Bebiete; da fie unter der bewährtent Scitung von J. Inffh ausgeführt wurden, fonte es niḑt fehlen, daf die genamten 2leeres=

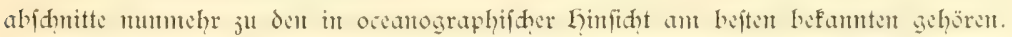

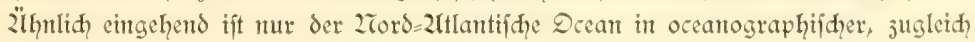

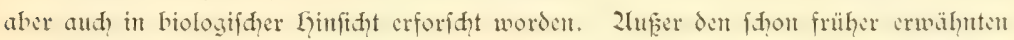
Internebmungen beteiligte fid Dänemarf mit feinen beiden "Ingolf" = Expeditionen

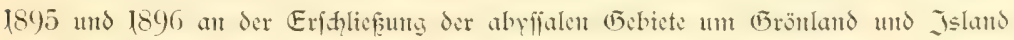
bis Jan 2rayen.

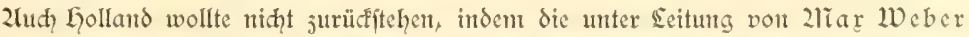

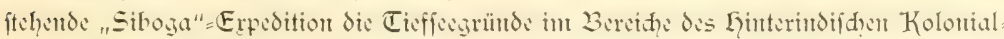
befites fürzlid (1899-1900) lotete und in biologifher Ginjidt similjenhaft unterfuthte.

Went wir endlid nod hervorheben, daf die belgifhe antarfifhe Expedition auf

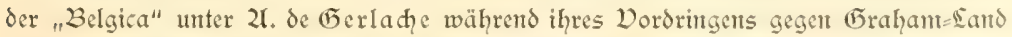

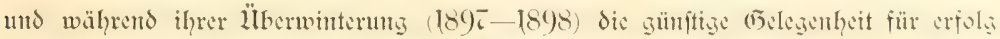

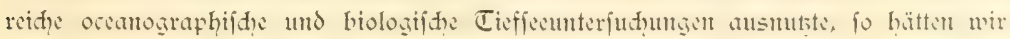




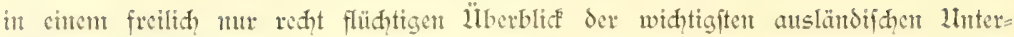
fudungert gedadt.

In präd tig ausgeftatteten Publifationen, weldhe an wiffenfhaftidhent Gehalte faum binter den Reports der Challenger= Expedition jurülfitchen, werden die Refultate der von 2Torwegen, den Dereinigten Staaten, von franfreid, dem fürften von Zlionaco, Eolland und Belgien untenonmenen Tieffee=Erpeditionen niedergelegt.

Wir Deutfde batten bisher jurütfitehen müffen. Dic forgfältigen 2lrbeiten der Kieler Kommiffion jur Lhtterfudung der beutfhen 2lecere exfredelt fich auf cin relatio fladies Bebiet und fijlofien die Erforjdung der Tieffee von vornherein aus.

Die biologifde Wiffendyaft hat es mit frenden begrifft, daf durd die 2lütificenj Sr. 2liajeftät des Kaifers diefe lnterfudungen auf das freie 2keer ausgedehnt wurden, inden die von originellen Eefuhtspunften ausgehende Planftont= Expedition unter der Seitung von Lenfen den aflantifhen Deean freujte und beftimmte Doritellungen über das Quantum an organifher Subftanj gemant, welde an der Dberflähe der Decante flottiert. Die widitige Kolle, weldhe gerade die mifrosfopith flement tierifhen und

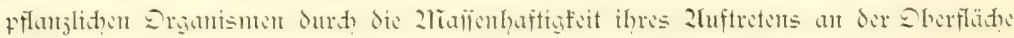
int Gaushalt der 2ratur fpielen, ift durd die Ergebniffe diefer fahrt an der Gand ener fein ausgebildeten 2liethodif der Planfton=2lnteriudung in helles Sidt gerüat worden. 2ridt minder bedentungsvoll crmies fiđ die Planfton=Erpedition für die Erfennthts des Einfluffes warmer und falter Strömungen auf die Derteilung flotticrender Dr: ganismen.

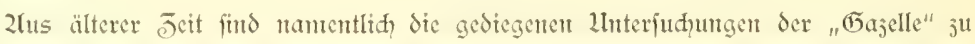
erwähnen, bei denen freilid, die biologifhe Ltnferfudung gröferer Tiefen ausgeffloffen war. Dafür zetdunen fidh thre sotungent und occanographifhen llnteriudungen in weft=atlantifhen, indifhen und pacifidhen Deean, nidyt minder aud die topographifhen

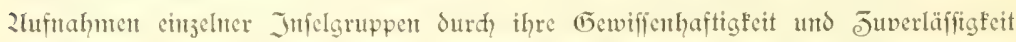
aus. Went wir an Sicfer Stelle der fahrt der "Bajelle" unter dent Kommando des fpäteren zlomirals vou Shleints mu fun'j gedenfen, fo gefhieht dies aus dem (Grunde, weil wir im Derlaufe unferer Darftellung nod Eelegenteit finden werdent, aus cigener Erfahrung unferer 2lnerfenmung über ilye Eetftumgen 2lusdnut ju geben.

Jwet Drittel der Erdoberfläche fint durh die Tieffee=Expeditionen in dent letsten Jahrjebuten uns neu erjdyloffen, ja geradeju neu entdecft worden. Wir wiffen, daf tierifhes Eeben in Regionen üppig pulfiert, wo die äuseren Eriftenjbedingungen die Sebensarbeit als vergeblidhes Ringen erjdeinen laffent, daf cin gewaltiger Druck von mehteren Equnderten von 2tmofphären, eine Temperatur, die um den 2rullpunft fith bewegt, daf ewige finjternis dem Dordringen cher erfautid reichen fauna fein

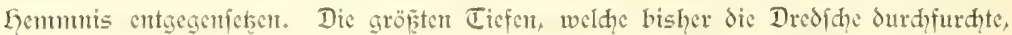


haben fith dem tierifhen Seben nidit als feindidh erwiefen. In dent oben erwähnten Tonga=Graben erbeutete 21 gaffij 1899 aus eiter Tiefe vont $2656 \mathrm{~m}$ (4175 faden) grofe Bruditüle eines lebenden Kiejelidhwanmes, welher wahrideinlich zu der bisher aus weit geringeren Tiefen beḱannt gewordenen Gattung Crateromorpha gehört. Wahrliक, niḑt unr der Joologe, fondent aud der Phyfologe, chemifer und Phufifer haben ein Jnterefle darant, ju ergründen, durd welhe zlittel dent tierijhen Drga= nismus die Eriftenjähigfeit in Taufenden von 2lietern unterhalb des 2lieerespiegels gewahrt wird.

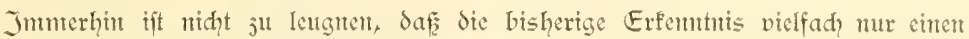
proviforifhen Charafter trägt und daf eine Reihe vor Problemen angeregt wurde, weldhe dic Ecitmotive für fpätere Expeditionen abjugeben haben. Wic verriđhten dic auf dem (1) runde des Dreans fith aufhaltenden Drganismen iffe Scbensarbeit, wie untwideln fie fid wie crmähren fic fid? Wie weit dringen dic polaren 2lrten und Gattungen gegen den Z̈lquator vor? und twie erflären fid die benterfenswerten Kon= vergenjen jwifhen arftifhen unt antarftifhen formen? 2luf alle diefe fragen ver= ntögen wir entweder mur mit Rejerve oder überhaupt niḑ̨ ju antworten. Daju fontsnt.

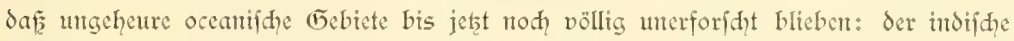
Decan war fowohl in fenten centralen wie aud in feinen wejtliden und öftlidgen

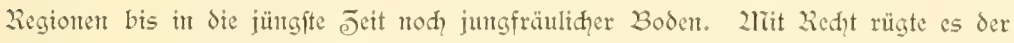

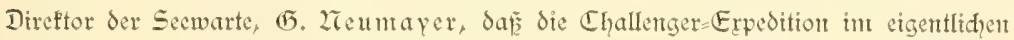
Sime des Wortes den indifhen Drean linfs liegen liefiz und nad inrem Doritof bis jur antarftijhen Eisbarrière den Kurs direft nady 2luftralien riditete. Seiner Eint= wirfung war es wefentlid jujufdreiben, dafie "Wajelle" 1875 die Tiefen von den Kerguelen bis nad, 2lauritius und Sann weiterhin den indifḑen Decan jwifhen 50 und $55^{\circ}$ füblider Breite lotete. Weldye bemerfenswerte Refultate die biologifhe und oceantographifhe Erforfdung des indifhen Decans in 2lusfitht fitellte, das jeigten nidit mur die Sotungen amerifanijher und englijder Sdiffe (unten anden diejenigen der Enterprife), jondern aud, die an der Wefteüfte Dorder= Jndiens bis ju den Saffadiven unt vor allem im Golf von Bengalen unter der Seitung von 21 . Carpenter, Gosf $y$ n und 2đleod von 1885-1896 veranftalteten Dredisüge. Weiterbin ergaben fid wefentlithe süfen in unjeren Kenthiffen des füblidgen atlantifhen Decarts - nament= lith in den an Sübweftafrifa fid anjhliefenden Regionen - und endid bot fid in antarftifdien Scean dic verlockende Peripeftive, einen Beitrag jur Zuffelärung von 2lieeresteilen liefent zu fömten, deren Erforjhung in occanographifąer und biologifdier Ginfiḑt faft gebieterif von der Wiffenifiaft gefordert wurde.

Die L̈berjeugung, Saf Deutihland fid der Ehrenpflidit, int Wettitreit mit anderen

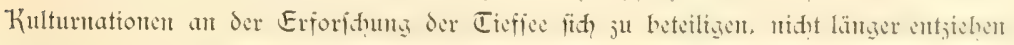
pomte, brad fich allntälylid Balnt. Wollte es fid bet ciner derartigen forfhungsteife 
nidht lediglidh an die engere Intereffeniphäre des heimifhen und folonialen Befitzes halten, wie dies bei manthen früheren Expeditionen anderer 2Tationen in Exifheinung trat, fo war der $\mathfrak{W e g}$ für cine dentfice Tieffee=Expedition von vornherein gewifler mafen vorgejeidhnet: Sie hatte in weitem Bogen 2lfrifa ju unfereffen, den öflidhen atlantifhen Deean ju erforihen, von dem Kap aus cinen Doritof in die falten,

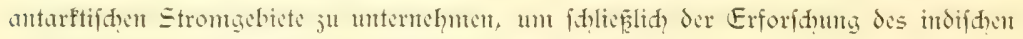
Deeans ihre befondere 2lufmerfianfeit jujutwendent.

Der Plan fand cine luberrafhend süntige Zlufnabnte und in auffälig furjer frift nad, feinem erifen Befamtwerden waren dic 2littsel genthmigt worden und die crifte dentide Tiefice-Erpedition ftand jur 2lbfahet bereit.

Dic Pflidit der Danfbarfeit gebietet cs, in hiftorifher Reihenfolge furj der Thätig=

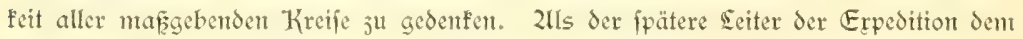

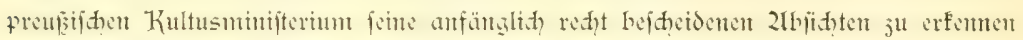
gab, wurde junähft von dent 2linifterialdireftor Dr. 2lithoff darauf hingemiefen, daf is angejeigt fei, den Rabmten etwas weiter ju faffen und die Lilfe des Reidhes jur 3efdraffung der nötigen 2littel in 2luprud 3 n nebmen. Es handelte fith in exfter Sinic darunt, das Jntereffe Sr. 2rajeftät des Kaifers wahjurufen und in emem Inmediatgejud den plan ciner deutjhen Tieffee= Expedition auscinanderjufetsen. Damit dem Ğejude das exforderliḑe Relief durh die Interfitütung der naturwiffen=

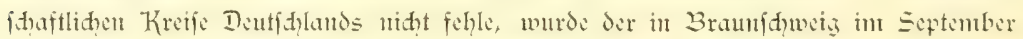

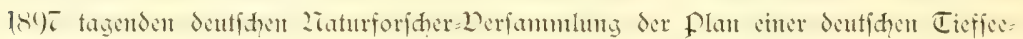

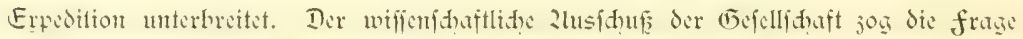

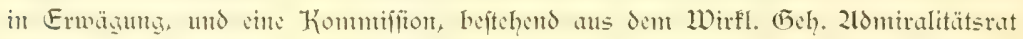

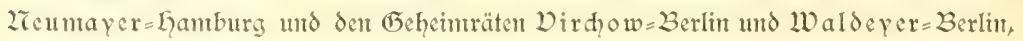

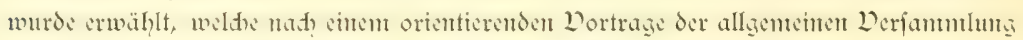
ant 24. September 1897 folgende Rejolution jur 2innahme voridilug:

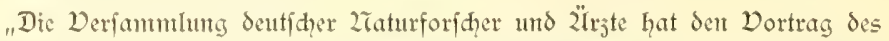
Profeffor Dr. Chun liber chte deutjhe Tieffec=Expedition in den füblidhen zlieeren mit grof̧em Jntereffe gehört, und fie erflät fid, mit dem Redner in betreff der ju ftellenden 2Uffgaben unt der wiffenjhaftliden Bedentung der= jelben cinveritanden unt erntähtigt denjelben, von diejer Erflärung bei der

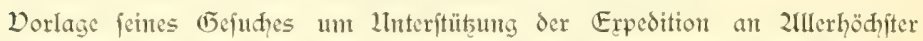
Stelle Gebraud zu maden; fie befürwortet diejes Gefud in wämiter Weife."

Bevor der 2lntrag des Dorftandes jur Zlbftimmung gebraht wurde, teilte der

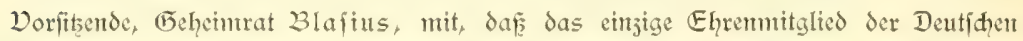

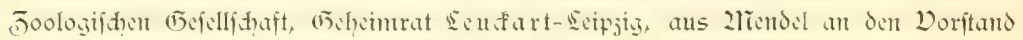
Ser 2Taturforidher=Derfanmulung folgendes Telegramm riditete: 
"Der foeber mix durd Chun jur Befürwortung mitgetcilte Dorfdlag ciner beutiden Tiefice= Expedition würde meinerfets, falls id dort anwefend, aus

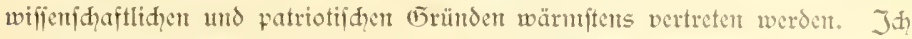
emtpfehle dem Doritand, das projeft ju dem feinigen ju madien."

\section{Sendiart.}

Einftimmig wurde die Refolution angenommen und dent Jumediatgefuch an Sc. 2riajeftät beigefügt.

Wenn fdhon allgentein der l̈̈berjeugung 2lusdruck gegeben wurde, daf unfer Kaifer bei feinem Iebendigen und feinfühligen Intereffe für alle derartige Beftrebungen der Eingabe gegenüber fich wohlwollend verhalten werde, fo darf wohl betont werden,

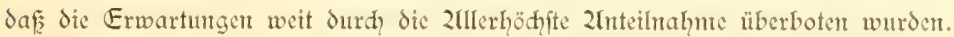

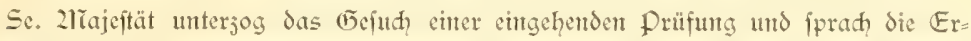
wartung aus, daf die Erpedition in würdiger Weife ausgerüptet werde, olpne Rücfitht auf Eriparniffe, weldhe die Sidherheit und den Erfolg gefährden fömten.

2litgefihts einer fo hodherjigen 2fnteilnahme war es erflärlich, dấ in über=

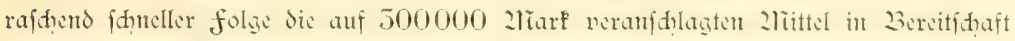
gefeft murden. Durh die Benühungen des vortragenden Rates im prenpifden Kultus=

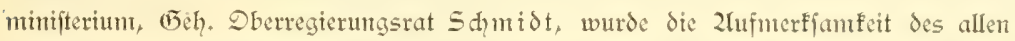

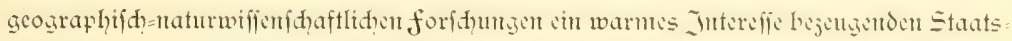
fefretärs des 2ieidsidjatzantes, freiherrn von Thielmann, und des Unters Staats= fefretärs 2lidgenborn auf die Expedition hingelenft. Dem Eintreten des 2iciosihats:

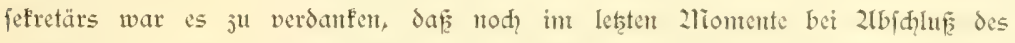
2Tahtragsetats die geforderte Summe in Sen Etat eingeftellt wurde. Dic parlanten= tarifhe Dertretung für die forderung wurde dem Reidsante des Jimeren jugewiefen, das von mun $a b$ gemiffermafen das patronat für die Expedition übernahn. Es ift

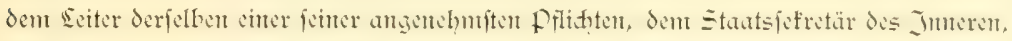
Grafen Dr. von Pofadowsfy, und dem Referenten, Geh. Dber=Regierungsrat $\mathbf{L}$ a uf, auch an diefer Stelle warmen Danf für das jederjeit bewiejene Dertrauen ausjuppredien. Keine fpecialifierte Juftruftion, Peine gebundene 2Tarforoute ftand in Wege, went

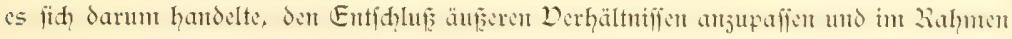
des allgemeinen Prograntmes die gebotene günfitge (E)legenheit ausjumutzen. Sollte dic Expedition Erfolg gehabt und den Erwartungen entiprodyen haben, fo danft fie dies in eriter Sinie der liberalen Zuffafint iher Beftrebungen volt feitent des Reidssantes des Jnmeren!

Einftimmig wurde die fordertutg von cinem hohen Bundesrat und hohen Reidys= tag in der Siţung vom 51. Januar 1898 nah einigen befürwortenden Darlegungen des 2ubgeorbneten Dr. Lermes genchmigt. 


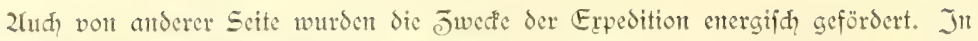
erfter Einte fei bes meitgehenden Juborfommens des Reidsmarmeamtes gedad, weldes als die für die rein occantographifhen 2lufgaben der Expedition Fontpetente und $j^{u=}$

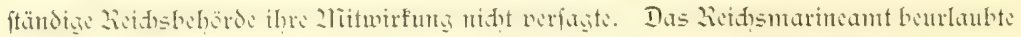
cinten Beanten der Seewarte an Bord des Erpeditionsidiffes behufs 2lusführung oceanto= graphifher Llterfudutgen; es veranla bite die Prüfung des in 2lusfidit genommenen Gandelsdantpfers auf feine Scetühtigteit mo wies die Kaiferlide Werft it Kiel ju Ieihweifer lifberlaffung ciner Dampfbarfaffe und namentlia der vollitändig untgearbei= teten Sigsbeejhen Sotmajhine an. Die Secwarte und das nautifie 2Int veriahen uns mit Secfarten, Inftrumenten und oceanographifder Sitteratur; das Sanitätsant der 2liarineftation in Kiel lieferte eine ärztlidge 2lusrüitung.

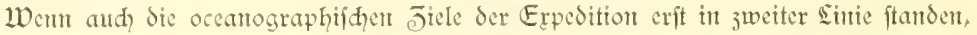
fo hat es dod der Derlauf der fahrt mit fid gebraht, daf fie gerade an entfifeidender Stelle, nämlid, im fermen antarftifhen Sïden, in den Dordergrund des Jntereffes traten. Die Sigsbec'face Eotmaihine hat es uns crmöglidht, dort eine Reihe von Tief= fedotungen durdjuführen, welde der cingebürgerten 2fuffaffung von der relativ gertingen Ticfe des antarftifhen 2lieeres den Boden entjog: möge der Staatsfefretär des Reidsmarinteantes, 2lontiral von Tirpitz, für fein Entgegenfommen des Danfes Ser Wiffenfalft fidher fein!

Endid, fet nod, der 2lïtwirfung cines dritten Reidysantes gedadit. Das 2lus= wärtige 2lunt enpfahl die unter der Reihsdientflagge fahrende Expedition jenen Re= gierungen, deren (Ẽebiete berührt wurden, und fiderte uns von feiten der Gonverne= ments unferer Sकutgebiete cinen warmen Empiang.

Dent Sädfifdien Kultusmintfterium und ben Kollegen in Scipjig ift der Seiter

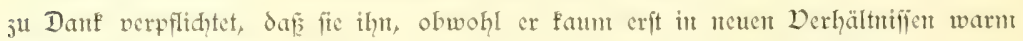
geworden war, trots der unverneidihen Etörungen im 2lnterriḑt oertrauensvoll jiehen lief̧en.

Derjohicdene induftrielle Etabliffements feţten es fid jutr Ehre, die Erpedition mit Inftrumenten utd Zlusrïitungsgegenftänden ohne Entgelt ausjuftatten; fo vor allen Dingen das befannte optijhe Juftitut der firma Jeif in Jena, weldyes uns mit Eupen, 2riffroffopen und treffitid fid bewährenden photographifhen Dbjeftiven verfah. Die hemifhen farbwerfe in Gödft $a$. 21i. und in Elberfeld verforgten uns mit Chemifalien, während die photographifhe zlbteilung der 2lnilin=fabrif in Berlin und die firma $S$ hlleufner in franffurt a. 21i. uns mit forgfältig hergeftellten und ver= padften Troffenplatten austüfteten. Geheintrat $\mathbb{L}$ enfen, der Seiter der Planfton= $\mathbb{E}_{\mathfrak{r}}=$ pedition, ftellte bereitwillig den Shat fener Erfahrungen uns jur Derfügung und über= nalym es fpeciell, and, die Seilleitungen für die Planftonfifherei nad? feinen 2lngaben berriditen ju lafien. 


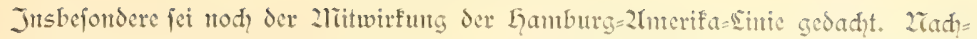

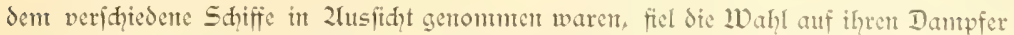
Daldivia, ein fahrjeug, weldies bisher den Dientit jwifden Lamburg und Weftindien verfehen hatte. Don vornherein betradtete es die Simie, anf welde Deutfiland mit Stolz bliffen darf, als einte Ehrenfadye, pefuntäre Erwägungen it den Eintergrund ju ftellen unt das Sdiffi fo praftifh herjuriḑten, als ob es cigens für die Juwede einer Erpedition gebaut jei. Die unfänglishen, im Derlauf von faun jwet 2ronaten vorgentontmenen 2̈̈ndertngen und Einbauten haben fĭ Jurdineg bewährt, wie es aud? faum anders ju erwarten war, nadbent die fürjorge für dic 2lusrüjtung dem er=

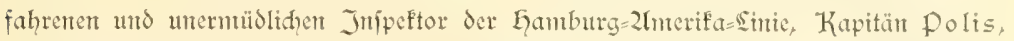
überwiefen war. 2lus dem grop̉en Bejtande der Sinte wurden die qualifijiertejten Dffijiere und 2rannfhaften ausgewählt, und bie führung einem Kapitän anvertraut, defien Dergangenheit allem fdon cinen slüflidhen Derlauf der fabrt verbürgte.

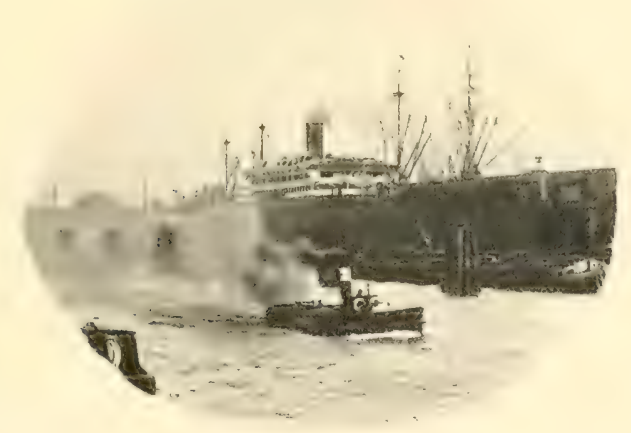

Itm Petericn:(T)ai [5 Samburger Eafert). 


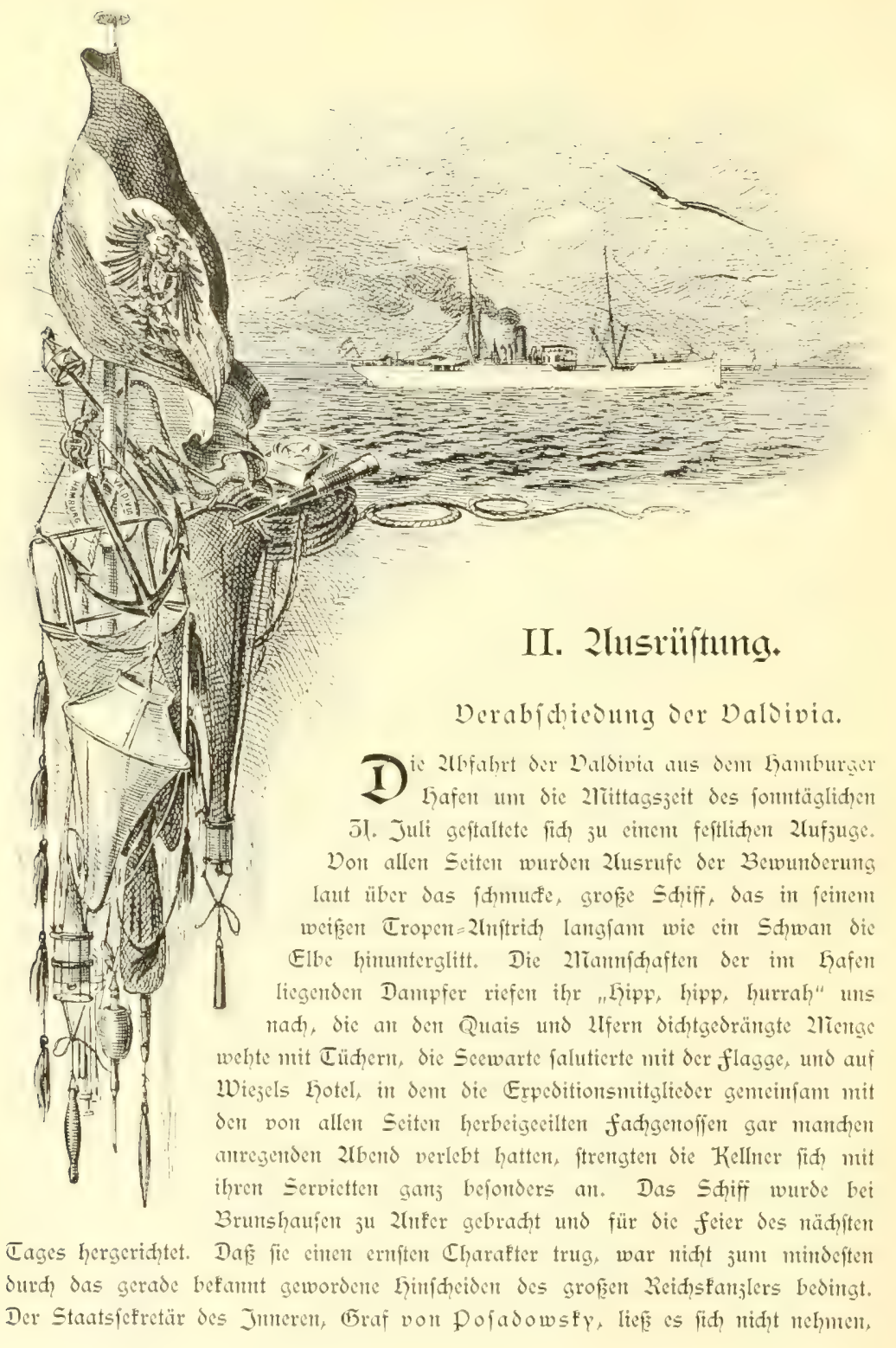


nah feinem Befuch in dem Sterhehaufe in friedriकsruh mit femen vortragenden Räten perfönlich die Daldivia ju verabfdicoent. 2tud der füdfifde Kultusminifter, Dr. von

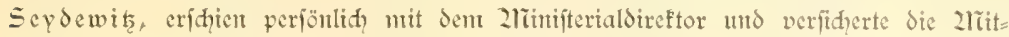
glieder der Erpedition des lebhaften Jutereffes, welhes Se, 2hajeftät König 2ubert at der Entfendung der criten deutfonen Tieffec= Expedition nahn. Dertreter des fönigl. preupįiłhen KuItusminifteriums, des Reidsmarineamtes, der Direftor der See= warte, der regierende Bürgermeifter von Lamburg, Senatoren, die Direftoren und der Zuffihtsrat der Gamburg=2Imerifasinie, befreundete fahgenoffen und der Geraus= geber der Challenger $=$ Publifa $=$

tionen, Siv John 2liurray, gaben der ftoljen feit= verjammlung iffert $\mathbb{C}$ a $=$ rafter.

Es war begreiflid, Sap in der Rede des Staatsfefretärs und in Ser Infprade von John 2liurray das Gedenfen 'an fürft Bismard" in erfter Sinte ftand. Wic hätte man vor Begrün= Jung des Deutidyen Rei= dies daran denfen fömen, sine Serartige wiffenjofit=

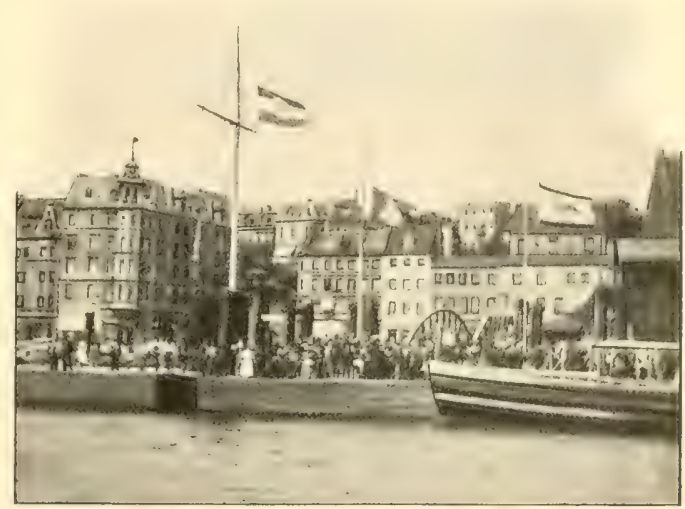
lithe Erpedition feitens Deutidilands ausjurüften! fo flang es in beiden Reden wieder.

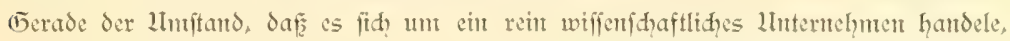
Jas feinen unmittelbaren, praftifd)=wirtidhaftlid verwertbaren Eriolg verfprede, bejeuge den Llnteridied zwifhen dem Einft und Jetst. 2Tan müfe nidit vergeffen, fo betonte der Staatsfefretär, daf es mit den wohlhabenden unt mäditigen Dölferm ähnlid wic mit wohlhabenden pribatleuten fei. Wie diefe niḑt mu für ihre täglichen sebens=

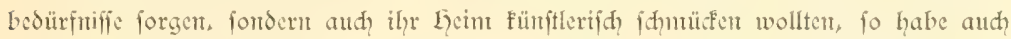
cinte grofe und wohlhabende Zration den Wunf, für rein wiffenfdiaftidge, ideelle อ̈wede Spfer ju bringen. Jut Jer förderung derartiger 2tuternchmungen durd das

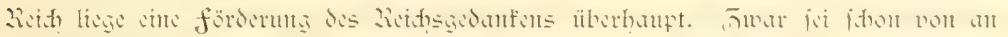

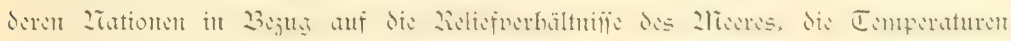
und Sie demifigen Derhältnifie des Secmaffers, dic 2liecesfrömuntgen unt die fauna

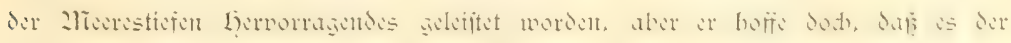

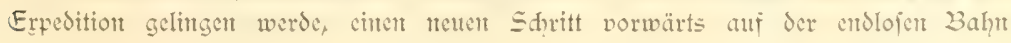




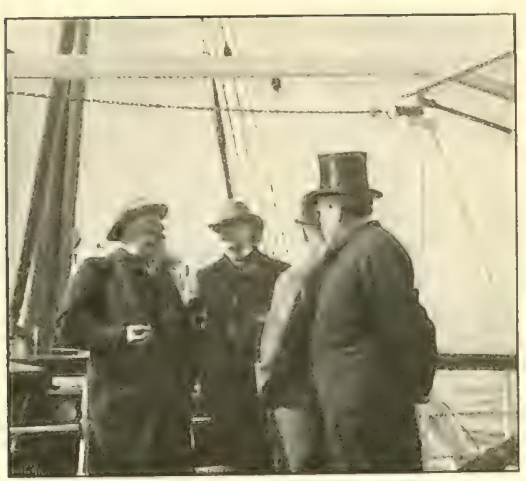

Braf D. Pofabowsfy Sir Jobn 27urray uno Geh. 2Rat zieuntuper. menfdlicher Erfemtnis ju thun. Se. 2liajeftät der Kaijer habe für bas linter= nebquen jein lebhaftes Jntereffe geäuf̧ert und den Befehl erteilt, den 2ritgliedern der Expedition 2llerbösht feine (ธ)lü wünjde ausjufpredgen und gute Reife ju winnjher. 2rödnte (5ott das Sdiff und feme Befatinung auf allen $W_{\text {egen }}$ fđütsen und behüten, und wohlbehalten wieder in den Leimtatshafen jurüd"= fïbren!

Dic Jeit der 2lbfahrt tahte heran. 2Tod ein letster Gätdednce und die Teil= nebmer al der feier verliefen das Shiff.

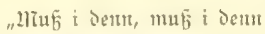

ड̄nm Stäotle hintuss..."

fo flang es non dem fluf̧dampfer, welḑer mit ben Ehrengäften und den 2lnges hörigen der Expeditionsmitglicoer an Bord langam dremal die Daldivia umfuhr, als fie den 2luffer gelidptet hatte. 2liand grofiartige Scenerie jog fpäter vor unferen Zlugen vorbet, aber feine vermodite den Eindrucf ausjulöfohen, den es auf uns mad?te, als unter den Klängen des Dolfsliedes die gefante 2lanmidhaft der Daldivia in ihr Gipp, hipp, hurrah aushrad, als hohe Staatsbeante grïhten, dic Tüdyer der franen, der Kinder, freunde wehtert, und als felbit über die wettergebräunten Wangen alter Seclente cine Thräte flof. Was uns das siebite int seben war, blieb jurül und brahte das Dpfer der Tremtung - wie lange wird fie währen und wird das, was cinen fo vielverfpredienden 2lnfang nahm, aud cinen chrenvollen 2lusgang jugeführt werden?

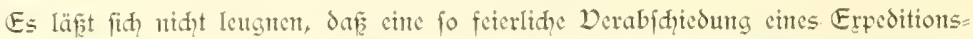
fhiffes für Sic 2litiglieder aud mit cinem gewiffen Lnbehagen verbunden ift. 2lian weif jwat wohl, daf dic Ehrung

nidht der Perion, fondern den wiffenifaftidien Strebungen des Reidhes gilt, aber nidut leidht wird der (bedanfe genommen, da man Träger der 2litifiton ift, dent man Dertrauter ihenft, obwohl nod? feine Seiftunget aufjuwitien find. (5)rade hierin liegt eit mäd)tiger

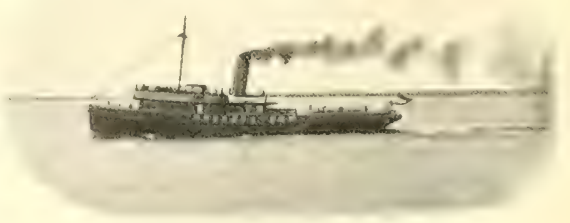

Die "23runshatren" umfäḅrt Die "Daldivia". 
2untrieb, um bei der Eigentart und Dielfeitigfeit des 23ctriebes an 23ord, welthe cinen

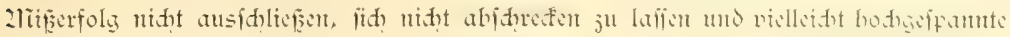
Erwartungen der Rü̈bleibenden ju redytfertigen.

$$
\text { perional. }
$$

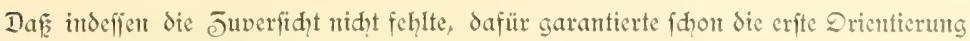
in den neuen Derhältutiffer.

Da war in erfter Sinte unjer verehrter Kapitän, 2loalbert Kred, der mit feinem unverwäptlidhen Gumor und mit jeiner

niemals erlahmenden (5ewiffenhaf=

tigfeit in der führung des Sdiffes

das abjolute Dertrauen erwecte,

dafic wir uns in den beften $\mathfrak{L}$ än=

ben befanden: ,he is a jolly

old fellow", fo fangen es

ihm fpäter 2linifter und $\mathcal{D e r}=$

treter des Kaplandes. Der

erjte Dffijier, 3 runswig,

hatte neben der inm jufom= menden Dberaufitd)t liber die zramihaft alle $211=$ ordmungen für die Erpedi= tionsarbeiten $j^{u}$ treften; daf erfie fpäter, da er feine Wahc mit ju gehen hatte, oft ganj felbfändig übernabur, mag Ser befte Beweis für feine Unufidt fein. - Die beiden jweiten Dffiziere, 2lieyer unt

Goppe, bejogen Tag und

2Taht je vier Stunden die Wadhe

auf der Kommandobrüde. - Der

Zravigationsoffijier Sadjfe war der

Kapitän Kred.

Expedition als 2ritglied beigegeben und hatte auper der cigentlident 2ravigierunt das Regulteren der Kompaffe, fämtliḑe nagnetifhen und aftrononiff̧en Beobaḑtungen und gelegentlid aud in Dertretung des Deeatographen die Eotungen ju übernet?men. Da er aud photographifd gefकult war, ftellte er es fidh jur Fefonderen 2lufgabe, an nautifd, wiḑtigen Punften die Küiften aufjurthmen. 
2lit bejonderem Dant fei des vortreffilí, geidulten 2liafhimemperionals gedadit.

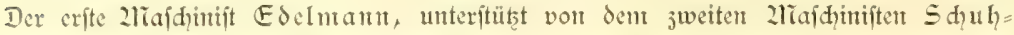

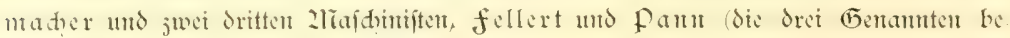
jogen alle vier Stunden die Iliafhinenwade), haben es jumege gebradt, dafi dic Erpedition unbehindert ihren Kurs nerfolgen formte und niemals gentötgt war, wezen

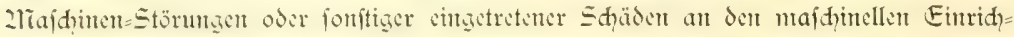

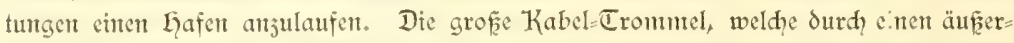

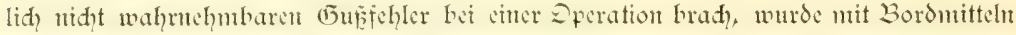
in fürzefter Jeit repariert, und die Sigsbee'fhe Sotmafdine, deren Trommtel fí, als

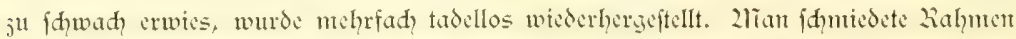
für die Sḑleppneţe an Bord, fertigte Sotröhren und befferte in wentig Stunden die

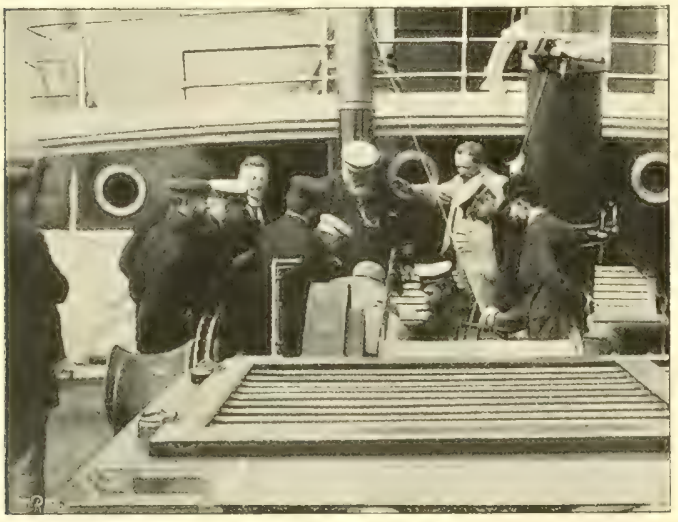

Der Zíapitän wir̀ gemogen. jahlreidhen fleineren S丸̈̈= dent an den Iniptrumtentent aus. - 2uls cine befon= ders nütidice Komman= dierung war es ju betrad, = tert, daf cin überzähliger britter 2liajhinift, S dinei= der, ausfolieflich der $\mathbb{E r}_{\mathrm{r}}$ peditionsleitung zur $\mathcal{V}_{\mathrm{cr}}=$ fügung ftand und dafür Sorge trug, dafic die Eot= majhinen, bie Dantwinit= den und Scilleiturtgen ftän= dig gebrauhsfähig gehal= ten wurden.

Das hicr genamte Dffijicrsperional wurde nod ergängt durd den Jahlmeifter

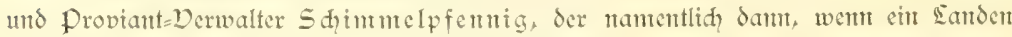
bevorftand, fid redid für die Intereffen der Expeditionsmitglieder abjumühen hatte.

Die Befatzung Ses Sdiffes beftand insgefant ans 45 perfonen infl. Kapitän. Int

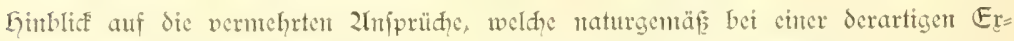
pedition an fie geftellt wurben, war fie etwas ftüffer als auf gewöhntiðhen Landels= Sampfern bencflem, aber immerhin, wie auf Grund unferer Erfahrungen gefagt werden darf, futapp ausreidend, un den verfdytedenartigen Derpfliditungen nadjufonmen.

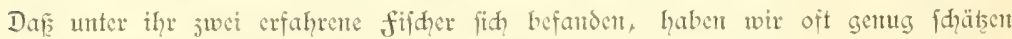
z̧elernt, niḑt minder and, daf ber Segelmadyer, der J̈mmermann und der ftändig

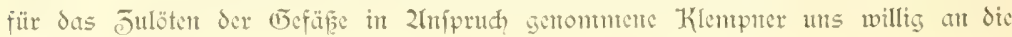
Land gingert. 


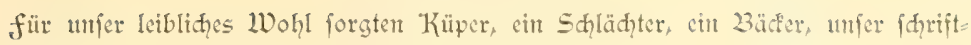
ftellember Kod, cin Dberfteward und drei Stewards.

Gandelte es fid darum, See=Elefanten abjubalgen, einen verwilberten Stier ju jerleget, fijhe ju angeln, einen Lai an Bord ju jiehen oder bei dent auffommenten Sđ̧leppnets behilflid ju fein, fo war man der zrittwirfung aller gecigneten Kräfte fidger. Jmmerhin galt es bei einent reidgen fange auf der Fqut ju fein, da der

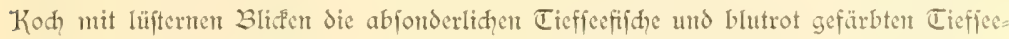
frebfe - er behauptetes, fie fâmen gleiḑ gefodht an die Sberflädhe - beängte und, wie nidht ohte (5rund vermutet werden darf, aud gelegentlid in dic Küdhe wans= dern liter.

Der wiffenjhaftlithe Stab der Erpedition fețte fith auper dent seiter aus folgenden 2litgliedert zufanmen:

Prof. W. Sdiminer (Bajel), Botanifer.

Dr. (1). Shott, Filfsarbeiter an der Secwarte (Gamburg), Decanograph.

Dr. P. Sḑmidt (Eeipjig), Chemifer.

1)r. ‥ 2luftetn (Kitel), כoologe.

Dr. f. Braem (Breslau), כoologe.

Dr. E. Danhoeffen (Kiel), Joologe.

20. Saḑfe (Gamburg), Zravigationsoffijier.

Die hier genamten ficben herren waren offijielle Teilnehnter der Erpedition; ihnen hatten fidh nod freiwillig angefhlofien:

Dr. 2r. 23aḑmant (Breslau), 2lrzit uns Bafteriologe.

Dr. 2r. Brauer (2Rarburg), Joologe.

Dr. D. jur Stra互en (Eeipjig), Joologe.

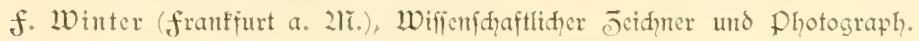

2lis Konfervator begleitete die Erpedition:

R. Sdintitt (scipjig).

\section{Die Dalbivia.}

Zađ lägeren Dorverhandlungen wurde int februar 1898 von feiten der Gamburg= 2Imerifas Simie der Dampfer Daldivia als das für die Erpeditionsjwede geeignetjte

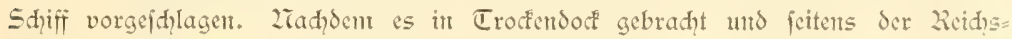

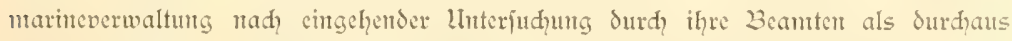
gecignet befunden worden war, entidice fidh dic Reidsverwaltung definitiv, dasjelbe für dic Expedition jul diartern.

shum, alus oen ciefen des welmeeres. J̈meite 2luflage. 
Die Daldivia wurde i. I. 1886 für dic Kamburg=Südamerifa=Dantpfififfahrts= (5efellihaft aus Stahl in England gebant, und war als fraht = und 2luswandererjoiff bis 1896 it den Dicrit jwifich Gamburg und Braftien eingeftellt. Später fant fic

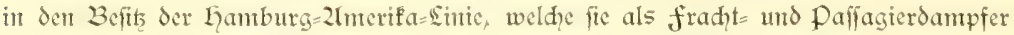
für ihre Einien nad Wejtindien verwande. - Daf die Daldivia gröfer war, als wir uriprünglid, für unfere Jwede in 2lusfd, genommen hatten, erwies fid fpäterhin als von unfdähbarem Werte. Wir gewanten in thr nidht mur geeignete 2lrbeits= und llnter= funftsräume, fondern vermodten aud bei der $94 \mathrm{~m}$ (= $008 \mathrm{cngl}$. fur $)$ betragenden

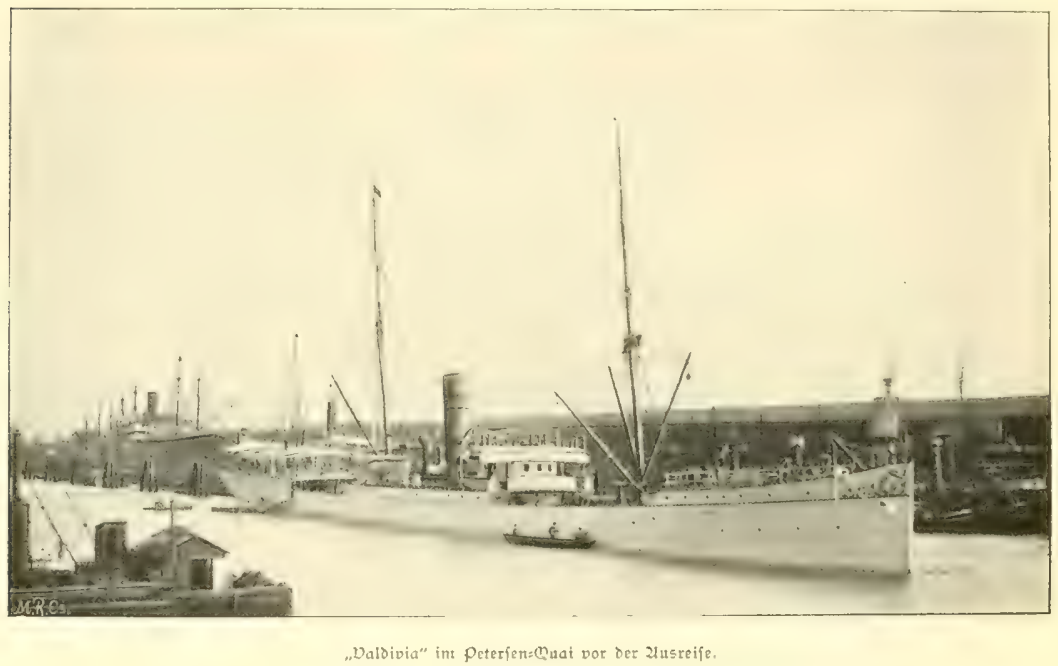

Sänge des Sdifies mehrfad gleidjeitig 2lrbetten auf Dorderdet und auf Linterded vorjunthnten, die bet einem flemeren Dampfer wegen der unfehlbar cintretenden Der= wirrung in den Scilleitungen feinesfalls angängig gewefen wären. Die gröf̧te Breite des Sdiffes beträgt $11,2 \mathrm{~m}(=56,6 \mathrm{cng}[$. fur $)$, dic Raumt Tiefe $\tau, 2 \mathrm{~m}(=25, \tau$ engl.

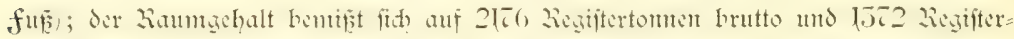
tomen netto. Der fharf gebaute Bug und die eleganten Einien des Dampfers, fowic das güntige Verhältnis jwifhen Sätge, Breite und Tiefe find gute Vorbedingungen für die Sdrtelligfeit und dic berwährten Scceigenjhaften des Sdiffes.

Unjer vielgereifter Botanifer, Profeffor Shimper, erjählte in den crften Tagen

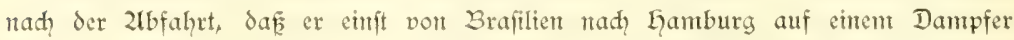
Tijuca jurüdfuhr, der ihm von allen Shiffen, weldhe er fennen lente, die angenehmifte 


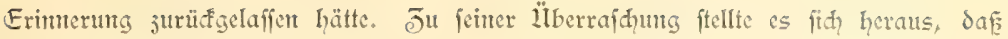
unfer Sdiff dic Tijuca war, weldye bei threm l̈bergang in die Eamburg=2lmerifa= Sinte den Ziamen gewedfilt hatte.

Die Daldivia befitst eine oreicylindrige 2rajhine mit 1400 indijierten Pferde= fräften, welḑe Sem Sdiffi cine 5efdumindigfeit vort 12 bis 15 Kroten in der Stunde) verlich. ES handelte fid aljo un cincn relativ rald läufigen Damtpfer, wie

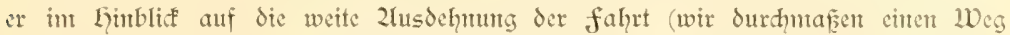
von 52000 Secmeilen) der Expeditionsleitung durdhaus erforderlid fdien. Dic Ex= wartungen, welhe an die (Gejhwindigfeit des Shiffes gefnüpt wurden, haben fith Senn aud vollauf erfüllt. Bet der Benutung nur eines Keffels wurbe cine durh =

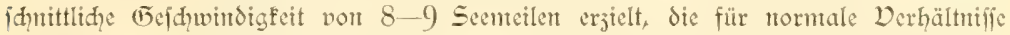
ausreidte. 2̇ur jweimal fuhren wir mit voller Kraft: das cine 2lial, als wir noh bei Tage in den Gajelle-Lafen der Kerguelen cinlaufen mollten, und das andere 2lial, als wir von Ports Said aus nad, Beendigung aller unferen 2lrbeiten in rajher fahrt bent Leintatshafen juftrebten.

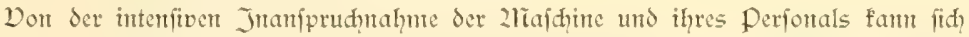
freilidy nur derjenige cine Dorjtelfung mahert, der dent (5)ange der Dperationen bet dem

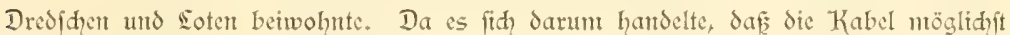
fenfredt reben dem Shiffe ftanden, fo war bei umuhigen Wetter oder im Bercidye der Strömungen ein ftändiges 2lianöverieren mit der 2liafhine notwendig; "Iangiant vorwärts!" "langfam rüfwärts!" "ein Sdlag vorwärts!" fo flang es in furjen Jutervallen währent der genaunten Dperationen. Zrientals, fo darf mit befonderer (5enugthum hervorgehoben werden, ift auch nur die geringfte Störung in der 2lĩaldine eingetreten.

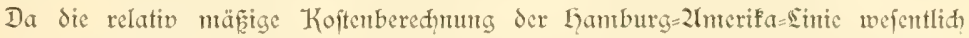
darauf beruhte, dafiz wir den gröften Teil unjeres Dorrates an Letżmaterial mitnabmen, um des teuren 2 nffaufes von Kohlen in ausländiphen Lafenorten überhoben ju fem, mahte die Beidhaffung des gewaltigen Kohlenvorrates feine geringen Sorgen. 2lus den

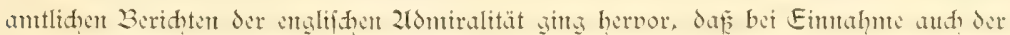
beften Stüffohle die (Gefahr der Selbitentzündung nad drei 2lionaten für ein Sdiff. welches längere ôcit in Tropenregionen zu freujen hatte, nahe lag. Sie mufiste fid in faft unheintlider Weife fteigern, wenn für neun 2lionate der Dorrat an Bord nit=

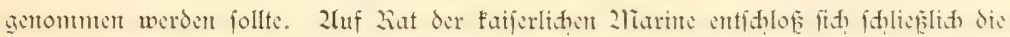
Sinie jur Einnahme deutjher Briquetts, dewen nidit wentiger dem 2100 Tons in cinem Teile des Jwwifhended's und in fämtliḑen Unterräunen forgfältig, wie wern es fidh um 2liauern aus ëiegelfteinent handelte, aufgebaut wurden, nahdem dic Kohlenbunfer mit ca. 400 Tons Stüffohlet aufgefüllt waren. 2ur dicjer 2lia regel war es ju verdanfen, dafs niḑt eimmal cine geringfügige Erhöhung der Tent= 
peratur in den Dorratsräumen cintrat. 2lian hatte gleidjeitig durd 2lnbringen vort wafferdidten Derbindungsthüren in den Querjhotten darauf Bedaḑt genommen, daf bie Briquetts aus den Räumen in die 3 unfer und vor dic feuer gebrad, werden formten.

Die leer gewordenen 2 unfer füllten wir mit unterwegs gefauften Kohlen in (1) ran

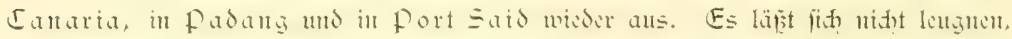
dafs durd den anjehnliden Kohlenvorrat der Dantpfer bei Begim der Reife reḑt tief lag und bei ftürmifhem Wetter reidglid Waffer libernahm; indes wurde dadurd die 2lantöverierfähigteit des Shiffes in feiner Weife becinträhtigt. Erft als der Kohlen= vorrat bet dem letsten 2lbjhnitt mierer fahrt im indifhen Decan jur 2reige ging und das Sdiff fehr hod aus dem Waffer [ag, madhte fid der Einfluf der geritgerent

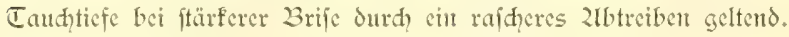

\section{Lmbanten uns Einbauten.}

Es lag in der 2ratur der Sadhe, daf ein Perionen= und fraḑtdampfer für dio

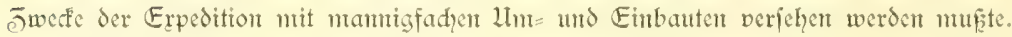
Llnter diejen mögen namentlid, folgende hervorgehoben werden. Ein Defhaus auf dem binteridiff, das duxh jwei Treppen in den Salon und ju den Kabinen hinab= führte, wurde als 2rifroffopierraum hergeriḑtet. Da cs cme (5rundfäde vor $15 \mathrm{qm}$

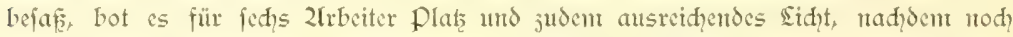
eintge fenfter cingefdnitten worden waren. Es bildete unfer ftändiges Saboratorium, in dem alle femeren 2lrbeiten vorgenommen wurden. Llmanfende Tifdye, die mit den

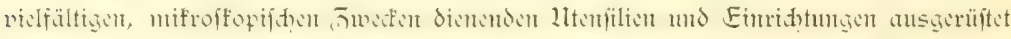

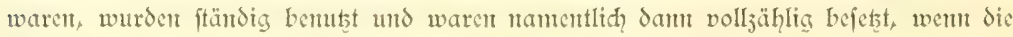
fänge mit den femeren Planttontetsen in den Deçhaufe fortiert und den einzelnen

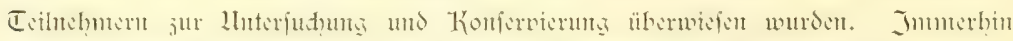
jogen es cinige 2lütglieder vor, in wärmteren 2liceren ihren 2frbeitsplats auf dem vont Eomempase

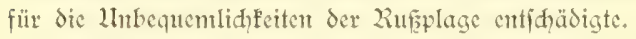

In E)interidjiff wurden weiterhin cine 2lnjabl volt Saboratorien in Jwijhended cingebant. Der Chentifer, Dr. Panl $S$ d mitot, verfügte liber ein fehr praftifh ein= geridtetes demifdes saboratorium mit Sberlid)t und eleftrifher 3 elendhtung von

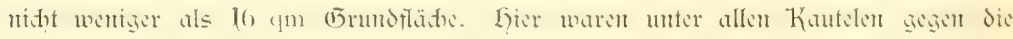
¡dwanfende Bewegung des Sdiffes die jahlreiden Reagentien und namentlid bic für Prüfung des (E)asgehaltes des Secwaffers beftimmten 2lpparate aufgeftellt.

2lu das leţtere lehtute fid das von den 2rojte der Expedition, Dr. Bad?mann, cingeridtete bafteriologifde saboratoriun an, das unter 3iriffiftigung der 


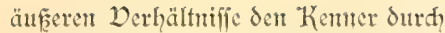
die finnreide und jwedmäfige 2us= wahl uno 2lufitellutig ser 2lpparate iiberraidte. (5)leidjeitig diente es aud? als Doftorfanmer, in der die jahl= reidhen fleiten seiden der Befaţus ihre Behandlung fanden. Es maḑte auf alle eitent melandiolifden Eindrud, als nit dent Eintritt in den indifden Deean diefes praftiph unto unter vielen 2lühen eingeridytete Saboratorium ver= waift dajtand.

Endid war nod als oritter $2 \mathfrak{l}=$ beitsram cine photographifac Dunfelfammer in 2lnlehmung an das baftertologifthe Saboratorim nad? den Zngaben des uns begleitenden

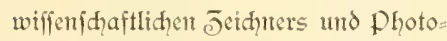
graphen $f$. Winter cingeridet wor= den. Sie war ftarł umworben, da ein furor photographicus vicle 2litiglteder ergriffen hatte. 2iid wentiger als fieben 2liomentapparate wurden auper den grökeren Cameras gehandhabt; nan war nientals fider davor, daf fritifice Situationen von dett auf den 2lnjtand idleidhenden Jüngert der Troten= platten erhaidit und bei feftlidyen $\mathcal{D e r}=$ anifaltungen veröffentliḑt wurden. Bet dert argwöhnifhen Sdwarjen gelang ibnen dies freilith niht fo leidyt: räherte man fich ihnen mit dem un= heintid ausfhauenden Kaften, fo er: folgte meift eine wille fludit. 2lìit (5erugthung fann indes hervorge= hoben werden, dafi fid unter delt Taufenden von Zlufmahmen dod aud? sine ftattlide Jahl befindet, die cint

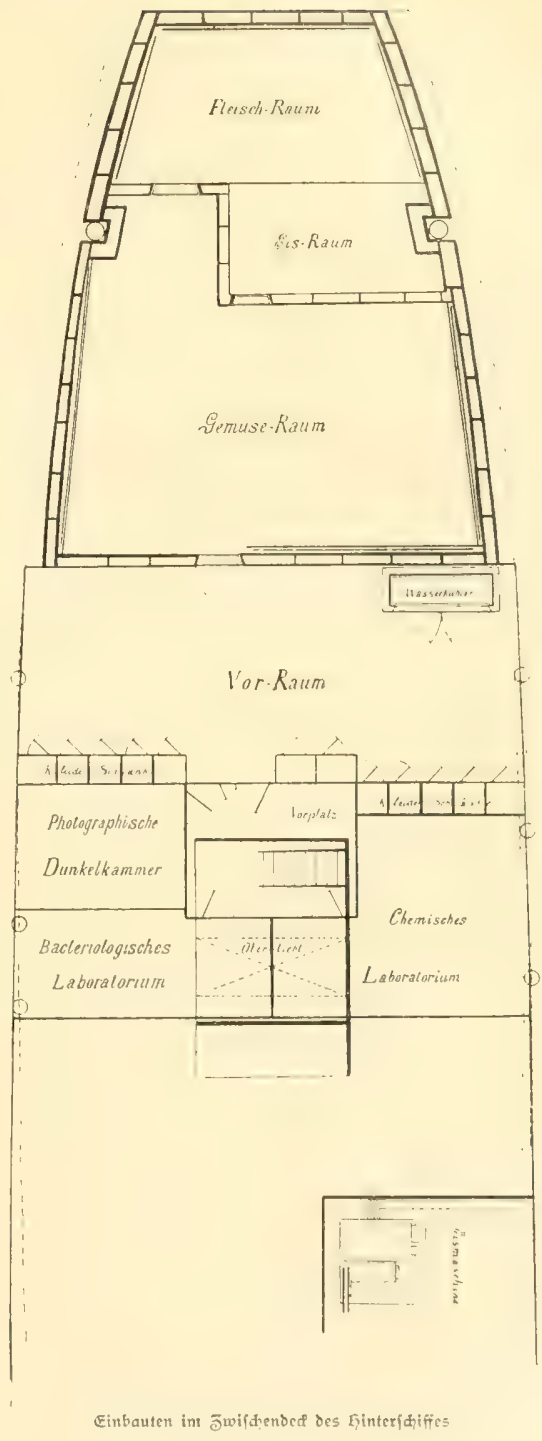


anfdyaulides und wiffenfdraftlid verwertbares Bitd der uns ungebenden Scenerte und zaturobjefte lieferm.

Der größ̧te Raum, weldher für die J̄wede der Erpedition hergeridatet wurde, lag

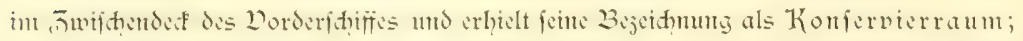
peinte (E)undfläḑe betrug ea. 56 qm. Es war für uns cine wahre Wohlthat, daf wir über cinen fo umfängliḑen und fpäter, nadjdent die anliegenden Kohlenbehälter geräunt waren, fogar nod erweiterten kaum verfügen fonnten. In ibm wourden bic

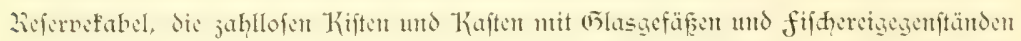
aufbewahrt; an den Decenen hingen die 2reţe, an den Seitenwänden waren die Shränfe und Borte für 2lufbewahrung des 5 andwerfsjenges nno der Reagensgläer angebradt, und vor allem wurde in ihm das gefante foftbare 2liaterial an fonfervierten Drga= nismen aufgeftapelt. Daju gejellten fid die jahlreiक̧en Behälter für die mamigfaltigen jux Konfervienung notwendigen Reagentien und zum Sortieren der fänge dienenden כ̈inffiftet und ङinfwanten. Der Konjervierraum wurde ftäsig in 2lnfprud gentom= men; bet idyledtent Wester fortiertent wir in ihm die mit der Dredihe heraufgebraditen fänge, bei guten Wetter wurden diefelben an Deel rajh ausgefud und nadiher in den genamten Raum enter forgältigeren Behandlung unterjogen.

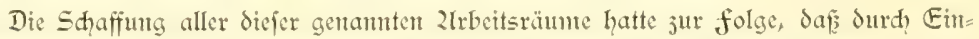
¡dneiden von fenftern für genügende Beleuditung Sorge getragen werden mupte. 2lud? die cleftrifhe Beleuditung wurde crweitert und in die neuen Räume eingeführt. Eime grofe Bogenlampe mit Sdirm diente für fifheretzwede und war uns namentlid bei dent Zuffommen der Dredifen in der Dunfelheit von Wert. Lierbei mag nod? crwäknt werden, dak and, der eleftrifhe zrotor der Sigsbec'fhen sotmaftime den eleftrifden Stron von diefer Seitung erhielt.

Don fonftigen Einriḑtungen, welhe für die J̄wedfe der Expedition getrofien wurden, fei an erfter Stelle der Befdaffung emer Kühlmafdine und cmes Kühl=und $E$ is= apparates gedaht. Die 2lnlage eines Eisraumes, in dem die Temperatut ftändig - 4o betrug, in Derbindung mit cinem Gefrierraume für das fleijd und sincm Kühl ranm für das Gemüle erwies fith als cine wahre Wohlthat. Die Eismafdinte follte täglid mindenftens $5 \mathrm{~kg}$ Eis liefert, dod wurde das genannte Quantum fogar in den Tropen vielfad, überboten. für unjere wiffenfaftlidgen Jwede erwies fid Ser reidlidpe 2orrat an Eis als unfhätzbar. Die Tieffeeorgantsmten leben in cinem Waffer von felpe niedriger Temperatur und geraten bei dem 2luffonmen der 2refze in

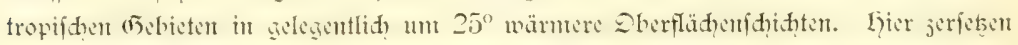
fie fich aufferordentlid rafh, falls niht mit Eis abgefühltes Seewaffer ju ihrer 2lufnahme in Bereitjhaft fteht. Da namentlich die mit den Dertifalntesent erbeuteten Tiefenformen bisweilen nod, lebend jur Dberflähe gelangten, vermodyten wir fie fturdenlang int abgefühlten Waffer ant Eeben zu crhalten, während gleidjzeitig iłh 
Labitus durd? 2lomentphotographien und ihre natürlide färbung in 2rquarellen feftgehalten wurbe. - Die genannten Kühltäume waren in hinteren J̄wifđendect unterhalb des Salons und der Kabinen angebradyt; cin Dorraum jwifhen ifnen und

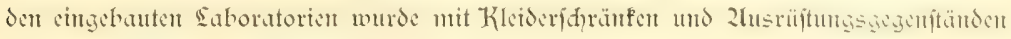
für die 2litglieder der Erpedition bejest. -

Weiterbin erwies fich als notmendig, emen grofen Deftillationsapparat für Sübuafferjwete aufuftellen. Die Daldivia, welde aufer 55 Tons Wafferballaft

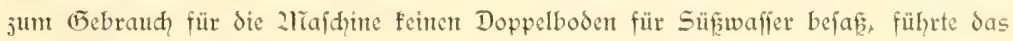
jum Trinfen nötige frifłwaffer in 4 Wajfertanfs von jufammen $60 \mathrm{cbm}$ Juthalt. 2lian war daher darauf angewiefen, Süpwaffer für (Febraudsjwedfe an Bord ju be reiten. Das deftillierte Waffer war fo rein, daf wir es aud für unjere wiffenifhaft=

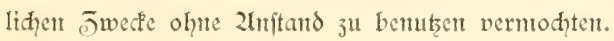

Endlid, mag nod, hervorgehoben werden, daß auh an den Kabinen z̈lnderungen

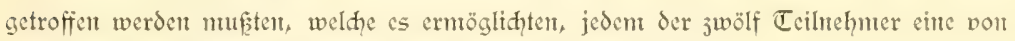
ihm allein bewohnte Kabine zur Derfügung ju ftellen.

Für die wiffenjhaftlitien 2 trbeiten an Bord waren neben den genannten LInt= und

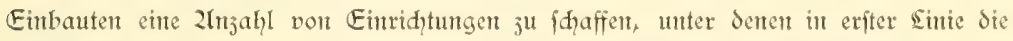
Jufftellung ciner grofien Dampfwinde mit Rohranjdüffen hervorjuheben ift. Die= felbe wurde von cintent der gröferen Dampfer der Lamburg=2lnterifa=Sinte, nämlid der Palatia, auf die Daldivia übergeführt und diente der Bewältigung der fdweren Saften, weldhe bet dem Dredihen aus grofen Tiefen zu heben waren. Da die Sade bäume von fraḑtoampfern in der Regel auf eine Saft vort $2 \frac{1}{2}$ bis 5 Tons berednet fints, fo verftant es fid von felbft, dafi fie den bei den Dredfharbeiten an fie ju ftellent= den 2Inforderungen nidht gewahien waren, infofern wir gelegentlid, mit sajten von ₹ bis 8 Tons ju redinen hatten. So wurde dent cin fhwerer Eabebaum aus Stahl von 10 Tons Tragfähtgfeit am fockmaft angebrad)t und fpeciell mit der Seilleitung

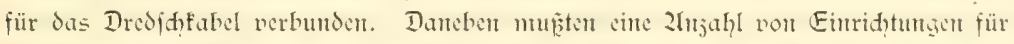
Inftallicrung Ser Sotaptarate, für Zuffellung und 2lufbeifin der Dampflarfaffe uns für die Siderung der grof̧en Kabeltrommeln getroffen werden; fhwere Blöte für die

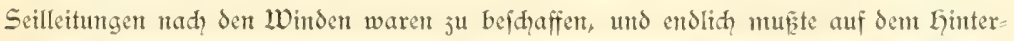
Sedk ein jweiter Regelfomtpaf́ aufgeftellt merden, wie detu aud weiterhin jwei Ertra= Chronometer angefdafft wurden.

2lle die hier genamten Einriḑtungen influfive der nod zu erwähnenden Dredf = fabel und der Derpflegung der đeilnehmer fielen der Reederet jur Saft.

ZTahbent der Reidhstag die forderung für die Tieffee=Expedition am 51. Januar 1898 genehnigh hatte, wurde eifrig mit der Befhaffung und Beftellung der notwen=

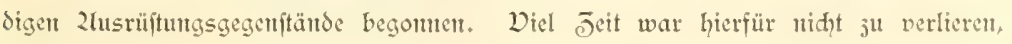


wem der 2lbfahrtstermin am 1. 2luguit pünftich eingehalten werden follte. Won gropen Werte erwies es fid, daf die Lamburg=2lmerifa= Sinte die Daldivia bereits vom Begim des Juti ab aufer faht fekte, wodurd volle jwei 2lionate gewonten wurden, unt alle an Bord notwendigen Ein = und LImbauten vorjunehmen. Diejent Lmịtande war es nidft jum wenigften ju verdanfen, daf ohne l̈̈berhaftung, wem aud unter angejtrengter Thätigfeit alles fo forgfältig hergeriditet wurde, daf es ipäterhin feine Probe beftand.

\section{Die biologifde 21 srüftung.}

Was nut die vou feiten der Expedition zu bejhafienden 2lusrüftungsgegenftände anbelangt, fo mögen junädit jente ins 2luge gefafit werden, welde die biologifhen 1Interjuhungen betreffen.

Fin wihtiger und unfänglihger Zusrüftungsgegenftand war die grof̧e Kabel= trontmel, dic ni丸ht weriger denu $10000 \mathrm{~m}$ Stahlfabel für dic Dredjharbeiten auf dent Grunde des Decans aufnebmen follte. Wir gaben bet der 2lftien=Ğefellidaft "Dulfan" in Wien eine Kabeltronmel in Beftellumg, wie fie bereits auf der ofterreidit= fden Pola=Epedition Derwertung gefunden hatte. Sie wurde mit cinem Stahlguk fettentrad vort der fleinen Winde aus betrieben und befaf cine Dorriditung jur auto=

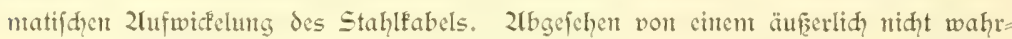

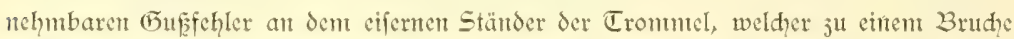
derielben bei ciner Dredidoperation führte - cin Sdyaden, der durd unfer 2läalinen= perforal in Fumer Jeit repariert wurde - hat fidh diefelbe treffilid bewährt.

Befondere 2lnforderungen betreffs der seiftungsfähigfeit waren an das StahIf abel ju ftellen. Es ift ein wefentlidfes Derdienft von Zlerander 2lgaffij, daf er an Stelle des nod von der Challenger= Expedition gebrauditen hanffabels das weit hand= lidhere, wegen des geringeren Reibungswiderftandes in Waffer ein idnelleres 2lrbeiten

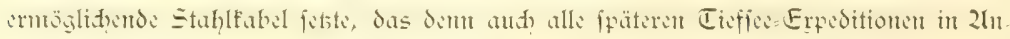
wendung gebraht haben. Das Stahlfabel von $10000 \mathrm{~m}$ Sänge und ein Refervefabel

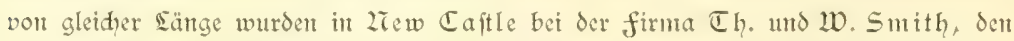
Sieferanten der englifhen 2romirulität, in Beitellung gegeben. Es beftand aus jwei zufammengefpleifeten Kabelt, deren cines bei ciner sänge von $6000 \mathrm{~m}$ einer Durd)= meffer von $10 \mathrm{~mm}$, deren anderes bei ciner Eänge von $4000 \mathrm{~m}$ einen foldhen von $12 \mathrm{~mm}$ aufwies. Die für diefe beiden Kabel garantierten Bruhfeftigfeiten beliefen fid auf 5059 refp. $8165 \mathrm{~kg}$. Die.genannten Brudpeftigfeitent wurden, wie wir aus dent Spiel des Dynamometers ermeffen fornten, fogar noh von den Kabeln überboten, und es fam unt (5enugthuung hervorgehoben werden, daf wir niḑt cimmal in die sage famen, das Refervefabel in Znipruch ju nehmen. 


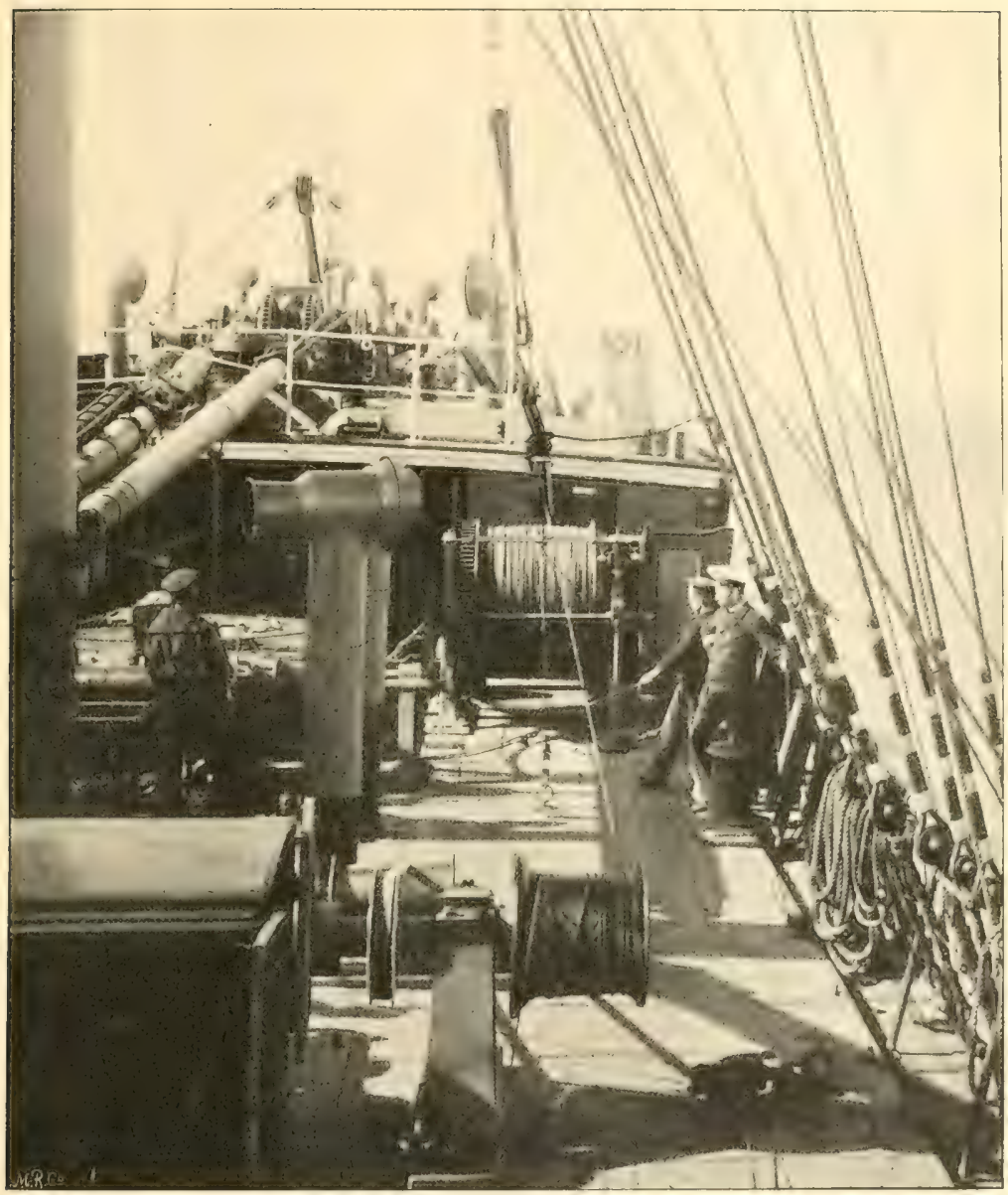

Grofe KabeItrommel und Kopf Der grofen Dampfwinde,

Zud Jer Seilleitung wurde befondere 2lufmerffanfeit jugewendet. Wir hatten dic grofe Trommel auf dem Dorderihiff, Steuerbord, aufgeftellt, unt von hier lief das Kabel über den Kopf der grop̉en Dampfwinde, nut deren Welle gleidjeitig cin อ̈ălapparat in Derbindung gefetzt war, bis ju den Dymamometer. 


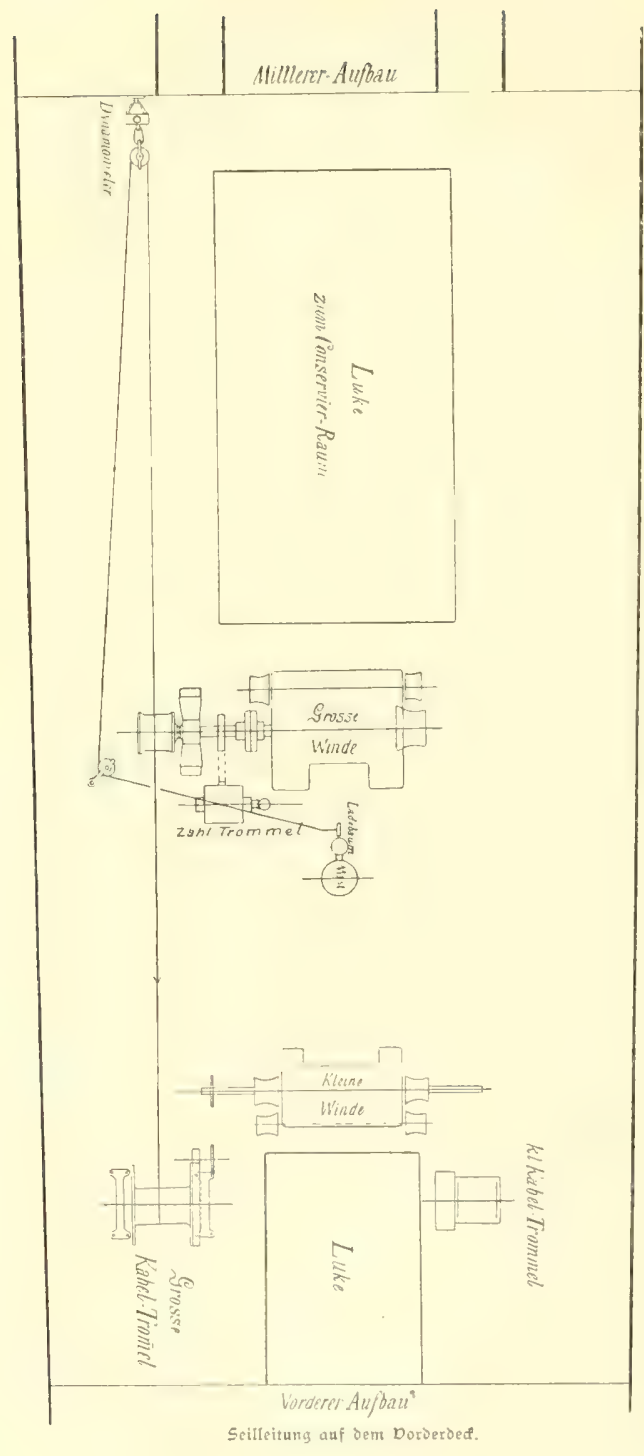

Das leftere Gatten wir wic: Serum nad dent Dorgange der Pola in 2lnwendung gebradt. Es war für einen כ̄ug von 10 Tons eintgeriditet und wurds uns nebjt eitem Rejerve $=\mathbb{D} y=$ namonteter von der firma Shäfer und Bubenberg in 2liagdeburg geliefert. 2lud? dic Dpnamoneter bedurften ftän= diger Kontrolle unt gelegent= lidier Enteuerung ifyes (Fly= cerins, das bei feiner Kom= preffion den Drut auf cine Tadel übertrug, deren Spiel bei den Dredfhoperationen auf bas genaucite beobaditet wer= deit nufiste.

Durd nerfhiedene, nen font= itruterte scitblöde lief dam das Kabel über den oberen Blod ant gropen sabebaum ju dem angehängten Sdileppneţ. Fin $100 \mathrm{~m}$ langes, $85 \mathrm{~mm}$ (im $\mathfrak{H m}=$ fang) ftarfes Lanftau verbanto als Dorläufer das leftere mit dem Stahlfabel. für die fifherci mit ben feineren 2refen aus Seidengaje lieferte uns Beheim= rat Gerien eine bon ibm fort = ftuterte fleinere Trommel, Sie fich bereits auf der plant= ton = Expedition bewährt hatte und gleidfalls auf dem $\mathfrak{D o r d e r}=$ idiff, Baffbord, Zufftellumg fand. Sie nahm cin fawä= dheres Drabtfeil von $7000 \mathrm{~m}$ Sänge auf, das aus drct Teilen 
vout der vorbit genannten englifhen firma gearbeitet war. $2000 \mathrm{~m}$ desfelben be= fapent einen llntfang von $20 \mathrm{~mm}, 2500 \mathrm{~m}$ sinen foldyen von $22 \mathrm{~mm}$, und die letsten $2500 \mathrm{~m}$ einen 2 Imfang vor $25 \mathrm{~mm}$. Die für diefe Kabel garanticrten Budffeftig= fetten betrugen $1975 \mathrm{refp} .24 \pi \overline{r e f p} .5059 \mathrm{~kg}$. 2lud mit dicfer Ecitumb war ein Jählapparat verbunden, von dem aus das Seil über eiten flemen Kopf der grofien Dampfwinde ju dent fleinen sadebaum geführt wurde. - Da die aus fehr jartem

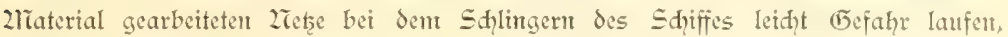
ju reifen, wurden an der Dberfante des Sadebaumes 2lecumulatoren aus einer ftarfen Stahlfeder und aus Kautfhufriemen anges

braḩt. Sic fpielen ftändig bei dent fifhen und brechen den durh das Rollen des Saiffes bedingten ftärferen ङug. Scider haben dic Kautihufrientet durd dic Einwirfung Ser hohen Temperatur in den Tropen gelitten, fo dafs wir fpäter faft mur nod auf die Stablfeder angewiefent waren. Da wir indefien im indifan Deean meijt bei jehr ruhigen Wetter fijdten, wurden wir durd? die $\mathcal{B}_{e}=$ wegungen des Sdiffes wentiger beein= träđhtigt.

Es veriteht fidh von felbit, dafs einen der wihtigiten Teile unjerer 2lus= rüftung dic Beifhaffung der veriditedent= artigen 2ietse betraf. Sie fheiden fith int allgementen in Grundnetse, weldhe bis anf den zreeresboden hinabgelafien werden, und anderereits in Planftonnetse, weldhe be fitimnt find, die oberflädlithen unt tieferen

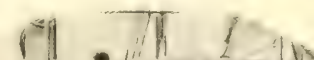
1. 1 Heres $^{2}=$

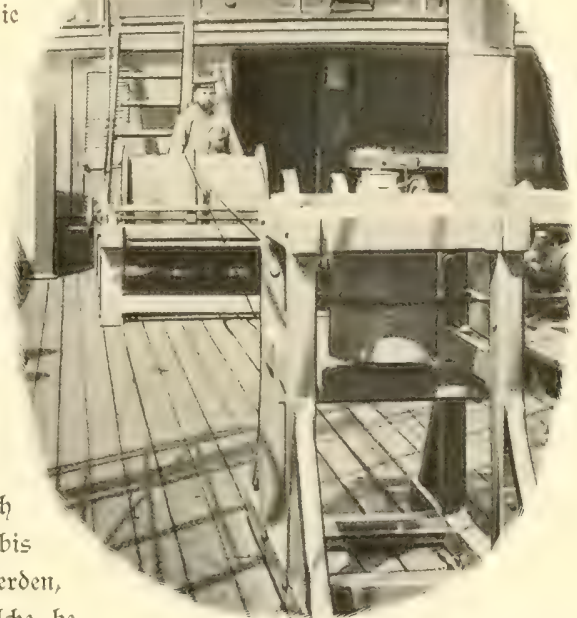

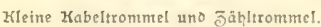

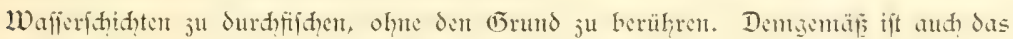
2liaterial, aus dem fie hergeftellt werden, ein perihiedenes: die Brundnetse bejtehen aus cinem 2ieţbeutel, der aus ftarfem 2lianilahanf mit weiten 2liaidhen gearbeitet ift, die Planftomtete aus feiner Scidengaje.

Was junäd) die (5) Dredihe oder das Trawl das widhtigfte Werfigeng. Sie wurden bereits auf der Challenger $=$ Erpedition nad? den Dorbild der von den fifhern der 2rordee vicl fah verwerteten "Kurre" in 2lnwendung gebrad)t und bei den fpäteren Erpeditionent

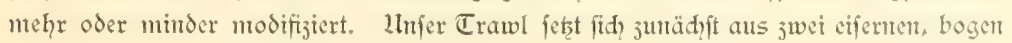




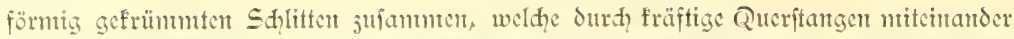
vereint find. Ein an der fonberen 2lufenfeite der Sdplitten befeftigtes, fräftiges Lanf: tau dient 3ur Derbindung mit dem Dorläufer des grofien Dredafabels. 2In dent gerade abgeftutsten Ginterratd der Sđlitten wird der grofe Zietziat aus 2lianilahanf

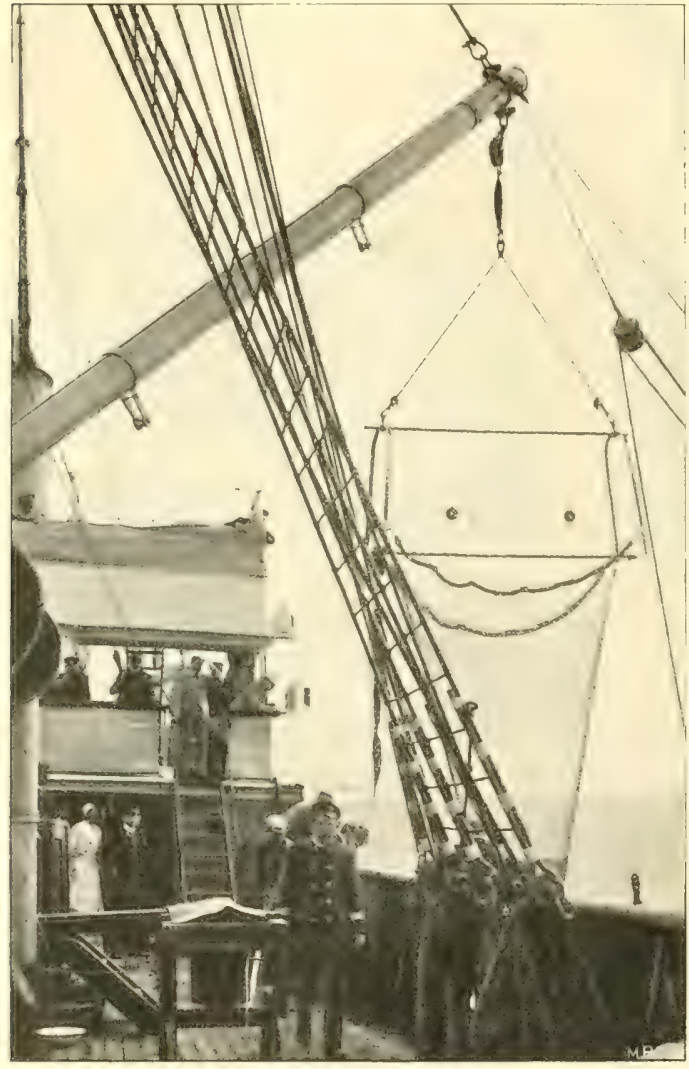

Jrawl ant Eabcbaum aus Staht. angebrad,t, der allmählich (iid) verjüngent sine $\mathbb{S} a ̈ n g c$ voll etwa $10 \mathrm{~m}$ anfweift. In den 2retzalt pelbit ijt nod) cin fleincrer tribter. förnisg geftalteter Beutel mit offenen Ende einge= id)altet, der wie cine Renic wirft und es verhütet, $\delta$ af fijde, die in den hiuteriten 2lbidutitt des 2ietriades geraten fint, entrimen fömen. Llu das דraml auf Jelt (5)und der Tief= fee ju bringen, muf es nod) Surd ciferne Dlinen befdwert werdert, deren gewöhnlid jwei von jo $25 \mathrm{~kg}$ an Ende des 27ets= beutels befeftigt wurden. Der 2retseutel wird durd Stride vor dem fifdent jugebunden und nad dem Eerauffonmten des Trawl ourd) Sofen dericlben ge= öfinet. $\mathbb{E}_{S}$ veritand fich von falbit, da wir cine grobere 2hajahl jolduer Trawls pon perfifiedenen Dimenfifonen ftändig bercit hiclten. Fin Trawl por mittlerer (Gröfse, weldes wir mit Dorlicbe benutsten, befaf̧ vorn cine Weite des 2ietseutels non $2 \frac{1}{2} \mathrm{~m}$. Der grofe Dorteil eines derartig fort

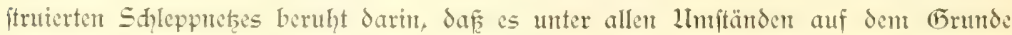
fifidt, mag es auf diefe oder jente Breitfeite fallen. 


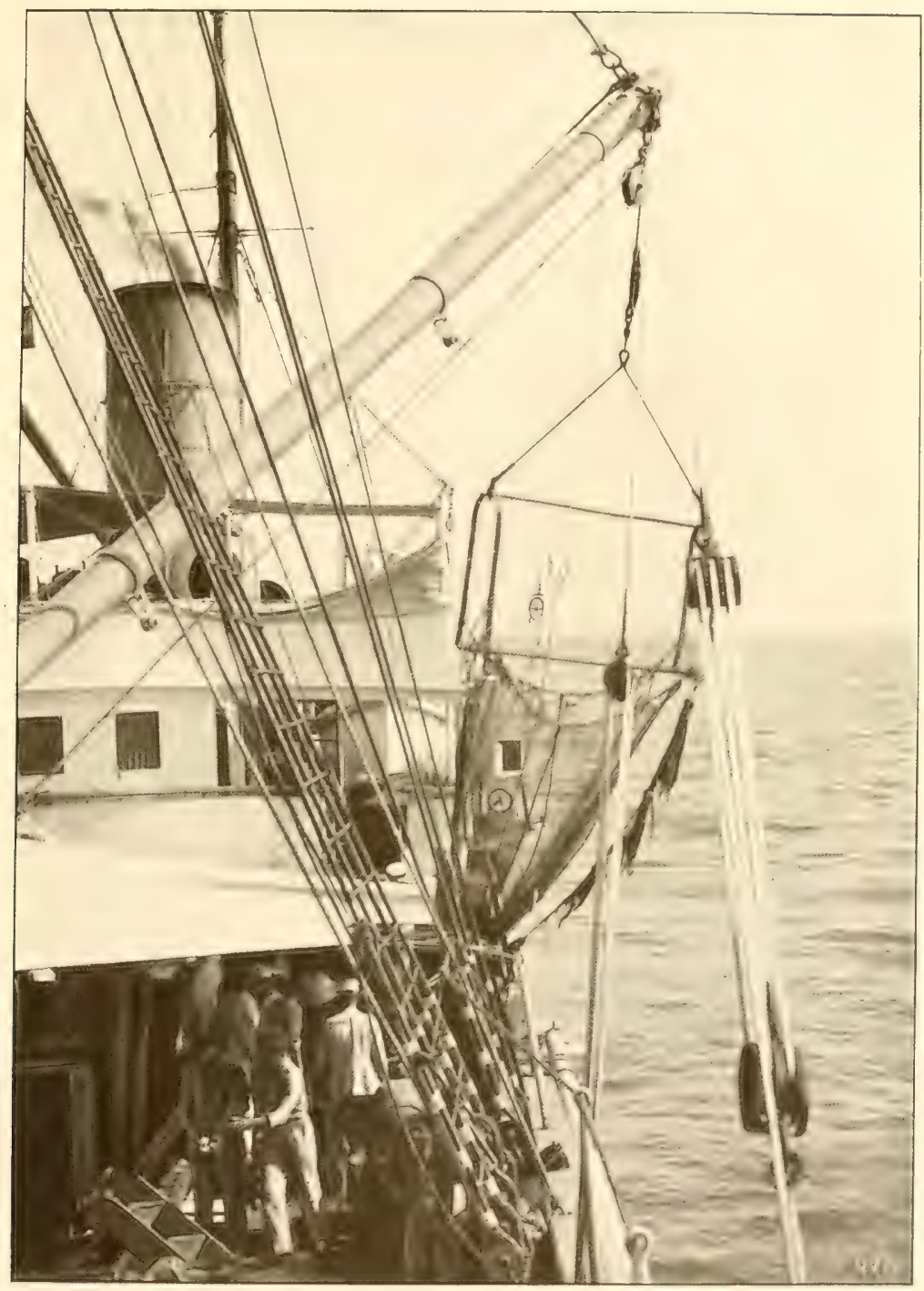

2uffommen des Trawl. 



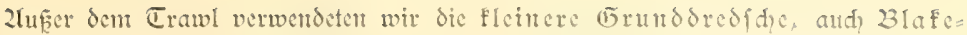

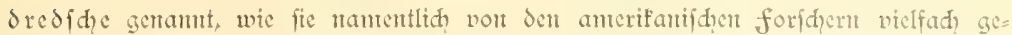
branḑt wurde. Wir haben fie in allgenemen nux feltener in 2fmendung gebraht, Sa fie mit ihrem fharffantigen Eifentrand, der bei cinigent Eremplaren aud urit cimen

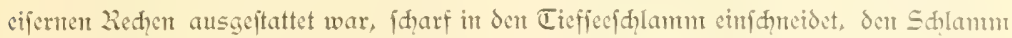
niḑt fo fauber auswäfd̨t, wic das Trawl, und felten dic flüditigen fifhe jur Dber: flädịe bringt.

Ein drittes Ecrät ift dic fogenamte Quaftendredide. Sic ift namentlid, daju beftimut, auf fteinigen Itntergrunde Derwertung ju finden, der von Korallen und von felfigen Ututergrumb liebenden feftititenden formen bejetzt ift. Jut den aus jerfafertem L anf gebildeten Quajten oder Sḑwabbern, weldye vort cinem fonver gebogenen cifernen Eräger herabhängen, verfangen fid aufier Korallen and gen ftadgelige cruftacen und fonftige auf dem Ltntergrunde feitgeheftete Drganismen. Da wir derartige Sduwabber aud feitlith an dent grofen Trawl anbradten, haben wir in allgemeinen von der Quaftendredfhe mu unfergeordneten (E)braud gemad, und verwendetent fie überhaupt nidit mehr, als fie fid auf der 21 gulhaes=Banf jwifhen felfert feftgeklentme hatte und cinen Brud des Kabels bei cinent durd den Dynamoncter angejeigten Juge vout $\tau$ Tons jur folge hatte.

Don dem fürften von 2ronaco wurden juerft fogentante Tieffecreujen in 2ln=

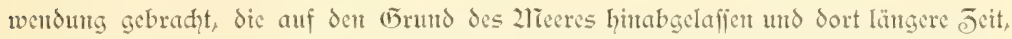
oft einen Tag lang, fid felbit ïberlaffen werden. Sic fund jelbfitverftündid an cinem langen Tau befeftigt, das in eine Boje ausläuft, dic auf der Oherflädhe des 2leeres flotticrt und den Drt, wo die Reufe verienft wurde, andeutet. Es läp̧t fith nidit leug=

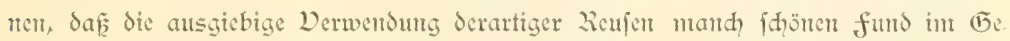
folge hat. Die Reufe wird mit Köder gefüllt und dic denfelben aufitöbernden fif

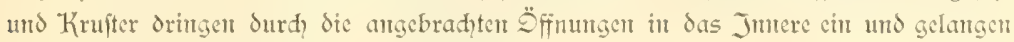
oft in tadellofer Erhaltung an dic Dberflähe.

Wenn wir volt derartigen Renfen weniger ausgiebiget (Gebrauh maditen, fo lag

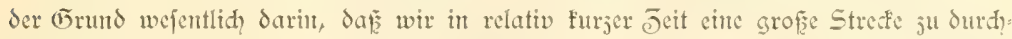
fahren hatten und uns nur ungern entidilofien, cinten Tag an derielben Stelle liegen ju bleiben. Daju fam, Saf wir fhon gleid vor den Canarifacn Infeln jwei Reufen verloren, die auf felfigen (5)unde feftgefommen waren und nidht wider ant die Dberflähie emporgejogen werden fontent. Dagegen haben wir nidht verfehlt, in allen 5 afenorten Reufen ausulfeţen, weldhe biswetlen fehr intereffante Drganisuten crithielten.

Speciell für dent fang von fifden verwendeten wir cin Petterffort'ides foze: namites Dtter= Trawl, das namentlid) in Ser (Ẽofien fifbibai an der weftafrifa nifhen Külte cinte reidhe 2lusbeute licferte. 
Was mut die ans Setdengaje gefertigten Planfton=2ietse anbelangt, fo wur= den auf unferer Expedition wohl junt erften 2liale in größzerent Umfange die Derti=

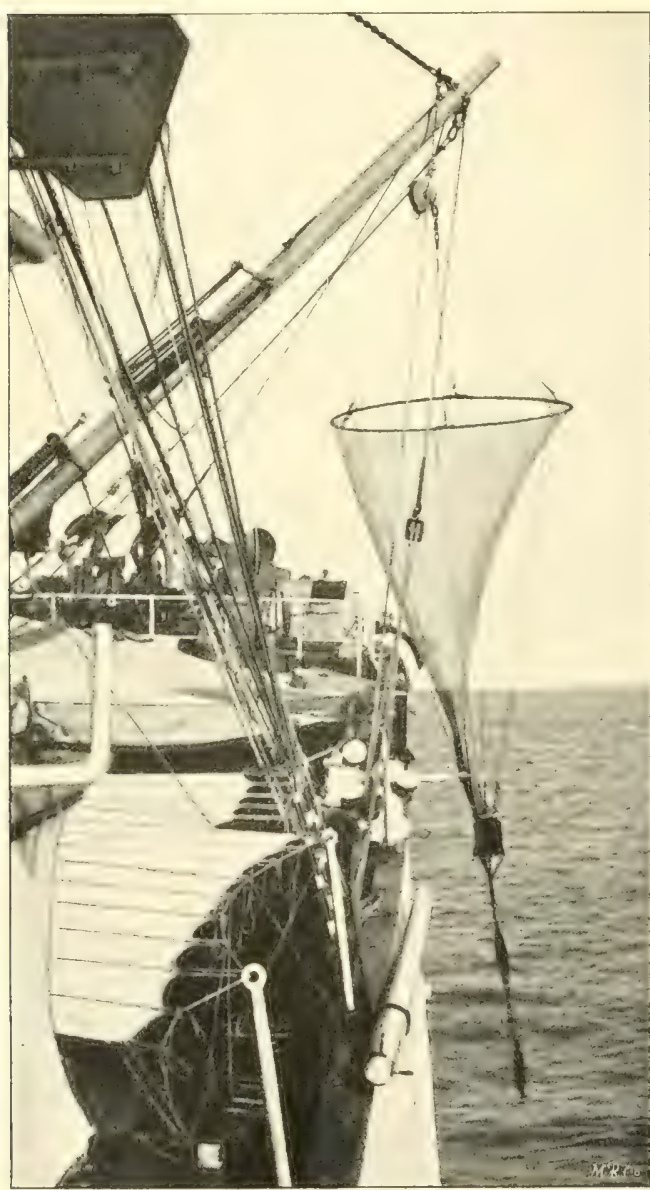

lectipalnets

falnetse verwendet. Sdour die Planfton= Expedition hatte fid) mit einent foldhen 2retse ausgerüftet, verlor es aber leider nad den erifen $\mathfrak{D}$ er: fuchen.

Die Dertifalnetse befitsen cinten weiten Durhmeficr und find beftimmt, in grope Ties fen hinabgelaffen und dant Iargfam in vertifaler Rid = tung wieder gebient $j^{\prime l}$ wer $=$ den. Sie fijdyen neben grö= fieren Drgantsmen aud cinc fülle jenter fleinen unt flem= fter formen, die flotticrend in oberflädlidyen und tieferen Wafferididyten vorfonmten unt neuerdings allgentin als "Planfton" bejeidunet wer: den. Es handelt fid freilid um redit foptipielige Zretze, infoiem dex ans Ecidengajo gefertigte Zetsbeutel cine Eän= ge vor durdfidnittlid $4 \mathrm{~m}$ befitst. Diefer feine Beutel cr= hält ১am nod) sinen fđüsen= Sen l̈berzug Surd cit der= beres, weitmafdiges 2rets= jeng.

Id) hatte auf (5tund früherer Erfahrungen an dent Ende diefer Dertifal=

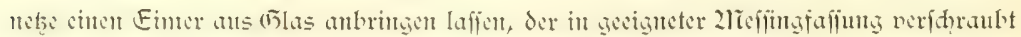
wurde. Dicf: Eimridhtung hat fid vorjüglid bewälyrt. Jwar fifht das 2iets etwas we= niger, als wem fein Grund mit einer filtrierenden flädhe ausgeftattet wäre, dafür aber 


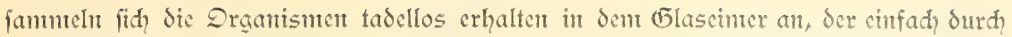
Eoslöfung der Verfhraubung abgehoben wird. Wenn es unts gelungen ift, eine reidge Znzahl von Drganismen unter treffliḑer Erhaltung der langen fühler, Tentafeln, floffenftrahlen und fonftiger Körperanhänge ju erbeuten, fo ift dics wefentlich der ges

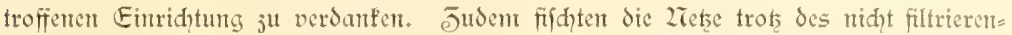
den Einters cin fo anfehnlidies Quantum von Drganisnten, daf der Einter fafit boll ftändig wic mit cinem Brei gefüllt war. Der ausgiebigen Derwertuntg dicfer Dertifal.

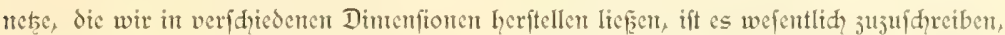
da年 wir in der Kemtnis jener formen, weldye die tieferen Wafferididyten beleben, um cin gufes Stüc weiter gefommen find. Lnt nur cin Beificiel anjuführen, fo ver= danft die Erpedition gerade der Znnwendung der $\mathcal{D}_{\mathrm{er}}=$ tifalnetse dic Entdecfung jener wunderbaren Tieffeefild formen mit teleffopartig umgebilideten 211gen, dic fpäterhin now eingehender geffildert werden follen.

2liodifizicrte Dertifalnetse repräfentieren die von $\mathfrak{\zeta} \mathrm{en}=$ fen fonftruterten Planftontetse. Es handelt fid hiter=

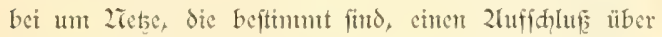
das Quantum alt organifher Subftanz ju licfern, weldye

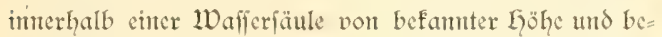
fanntem Qucridntitte flottiert. Sic haben das wefentlide

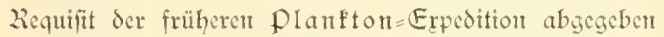
und wurdet fehr regelmräpig aud auf unjerer Expe= dition in 2lnwendung gebrad), indem wir fie meift in cirte Tiefe bis ju $200 \mathrm{~m}$ verienften.

Die hiter genamuten ziebe fijden alle Drganisment weldte fowohl in der Tiefe wie in oberflädlidien Sdidu= ten vorfonmen. Ein fdarfer Entifheid über dic Tiefe, in welḑer de Drganismen lebten, faum felbftuerftändlid,

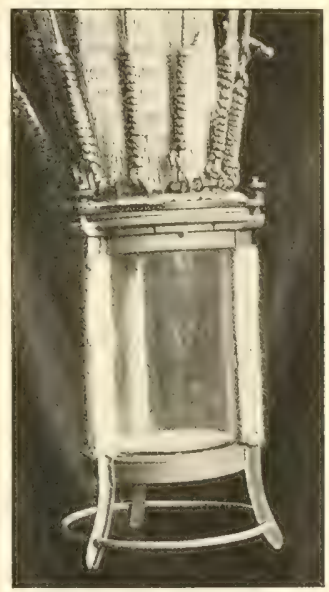

Glaseiner ant $D_{\text {ertifalnct. }}$

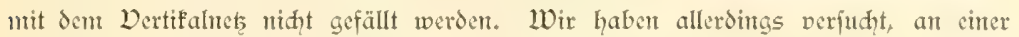
unt derfelben Stelle die Dertifalnetze int veridhiedene Tiefen jul verienfen und aus cinent Vergleich des gewomench 2laterials ein amähent jutreffendes Ltetcil ju gewimten, ob gewiffe eigenartige formen mur in der Ziähe der Dberflädye oder in gröferer Tiefe iḑweben.

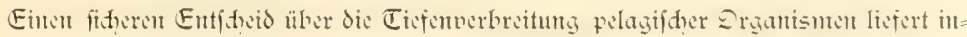
deffen ledtglid? die Znwendung der fogentanten Sdiliefretse. Sie find beftimmt, dic

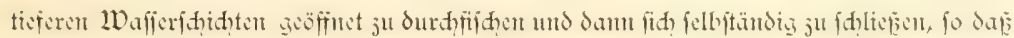

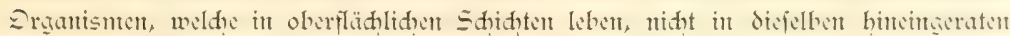

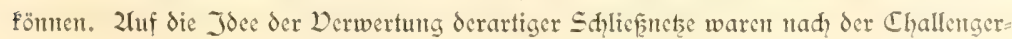


Expedition nthrere forfdyer gefommen. Wir verwendeten auf unferer Erpedifion cinte Korifruftion, die id? dem verftorbenen Ingenieur der Joologifhen Station in 2reapel,

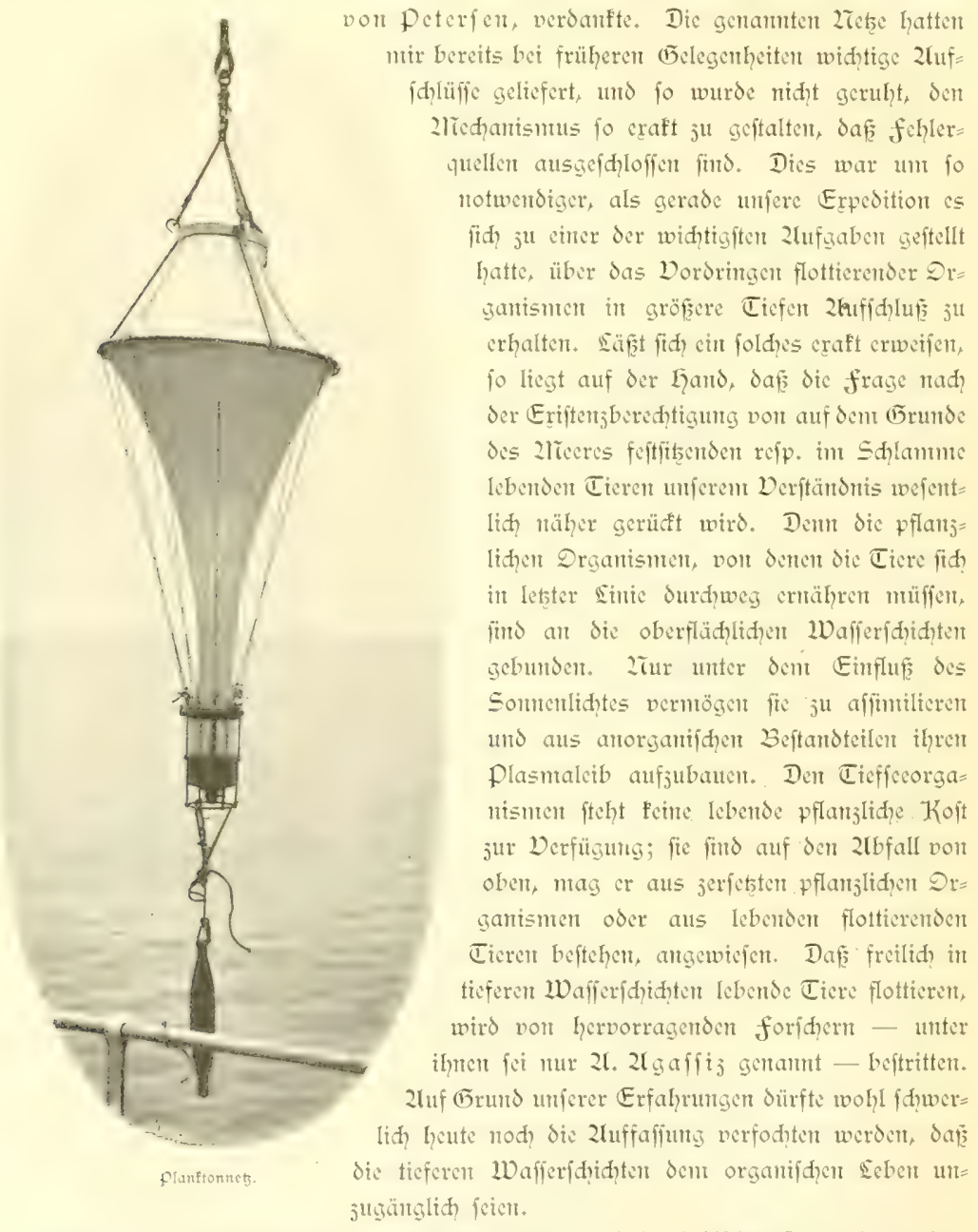

Wir gingen nantentlid in antarftifhen zlicere und im indifhen Decan baju über, an ciner nub derfelfen Stelle Stufenfänge mit don Sdiltep̧netsen ju veranftalten, die 
cin auferordentlid inftuftives 3 ild über dis Derteilumg der Drgantsmen im vertifalen

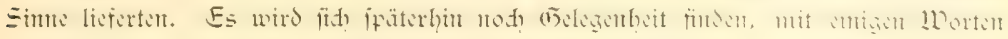
auf die Konftruftion der Sdlicentetse cinjugehert. Dishalb fo:

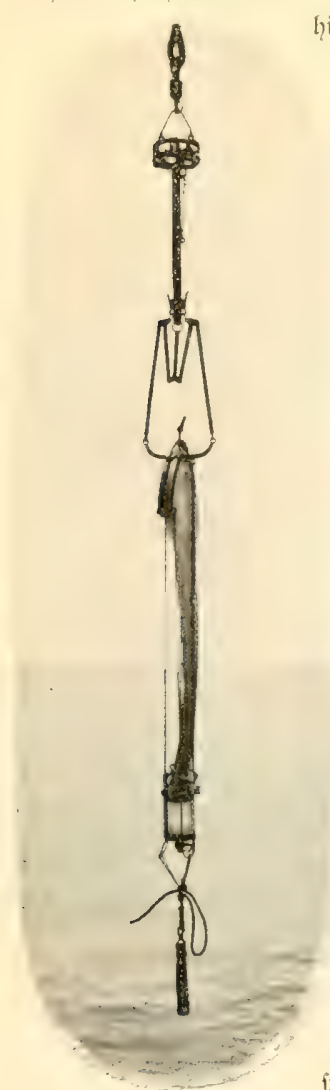

Scliesnetz dor dem Eerablaffer.

hier nur hervorgehoben, das es fid um Ziche. handelt, deren Bath= ment beweglid, gentadt ift, fo da货 fie bald geöfint, bald gefdrlofien itt vertif́alent Sinte durd dic Waffer= fuiduten gejogen werdent. Fin derartiges Sdylepinets wird geldlofien in dic ge= wünfdte :Ticfe verfenft; durd) einen fimmeiden viteḑanismus wird es mit Kilfe eines Propellers juwege gebradit, da हe bei dent 2lufwinden das 2Tetr fitc öfinet, cine $b c=$ fimmute Strecte gröfinet surdfiifd?t, und dant fith

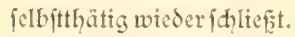
Wir hatten an unferem Sdliefrnetre die Einrity= tung getroffen, dar dic Strecke, die geöfinet durd)= fiidgt werden formte, fid

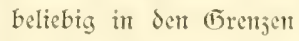
von 600 bis ju $20 \mathrm{~m}$ regulieren lick. Insbefon= dere war unfer Botantifer im ftande, durd? Stufenfänge bei furzer D̈finnungsdauer des Zietzes über das Dordringen pflanjlidger Drganisnten in größzere Ticfen cinen juverläffigen 2tuffd̨luß ju erhalten. 2tnderer= feits vermodytent wir dadurd, da

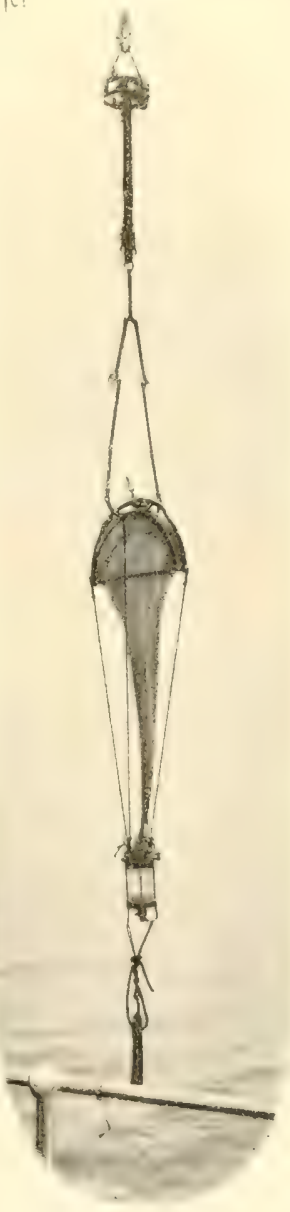

Ediliefnet nah bent ifuffomen. bis ju $5000 \mathrm{~m}$ verienften und cine Strecfe von 5000 bis $4+00 \mathrm{~m}$ Surdfififten, dent Zađhweis ju führen, daf felbit die jarteften Drganismen in fo gewaltigen Tiefen nod? Shun, Zus den Tiefen bes weltmeeres. Jaweite Zuflage. 


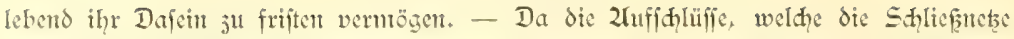
Iieferten, in biologifher Finfid,t befonderes Intereffe verdienen, haben wir von ihnen

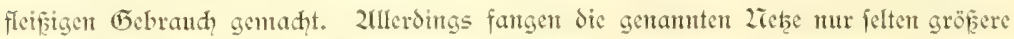
Drganismen, da fie ja cincricts nur fleme Strefen durdfifiden, andererfets in $\mathcal{D}_{\mathrm{ar}}$ gleidh mit den Dertifalneken inmerhin jierlidhe 2lpparate darftellen.

Es veriteht fid von felbit, dafs and voll allen Dorridtungen, die bisher für dic fifferei Derwertung gefunden haben, ausgiebiger 2ruţen an 23ord gejogen wurde.

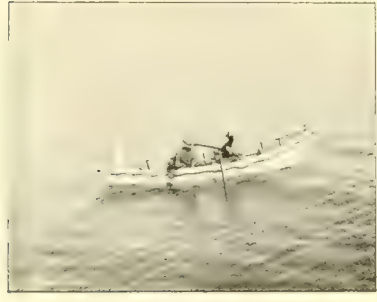

Etliafruticher. 2lian angelte cifrig bei dem Stilleliegen des Sdiffes, und crbeutete namentlid durd? "Pülfen" in rifd = reiden Budten Tafelfidic, weldhe cine ftets geidhäbte 2lbwedflelung für die Speifefarte boten. Zluf der Fodjec waren es die glänjett gefärbtent (5old= mafrelen, weldhe in gewaltigen Sätzen herbeicilten unt gierig nad den glifemden, aus Mietall gefer= tigten fifdghen oberhalb der Zlngelhafen hajdten.

2lit Larpunen und cinem Larpunengewehe wurde den (G) tind: Walen unt Delphinten ju Seibe gegangen, ohne daf freilidy der Wurf jemals geglüft wäre. Kratzer, Shaber und fleme, dré=

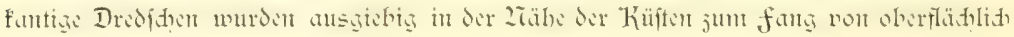
Lebenden Drganismen verwertet.

für fijalereizweffe hatten wir anfer den ket= tumgsboten noh ein fleines Whale $=$ Boot, den fo= genamuten Sdylitfrutider, angejduafit, das treffitidy die See hielt und jedesmal ausgefetst wurde, wem das Sdiff jur Domahme von 21rbeiten längere Jeit

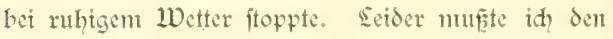
Derfud, dasfelbe int indifdren Decan ausgicbig jum

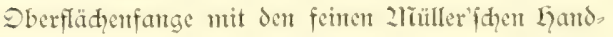
neţen zu verwerten, aufgeben, da dic regelmäßpig

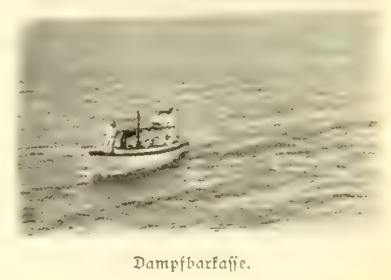

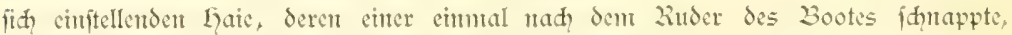
Sic Dberflähenfifheret allju risłant erifhemen lief̧en.

Das die Dampfbarfafie, die uns dic faiferlide 2rarane geliehen hatte, aud für fif dereien ausgicbig Derwertung fand, mag nur betläufig betont werden; namentlid in dem fitllen (Fajelle=Eafen der Kerguelen haben wir durd das Dredihen von der

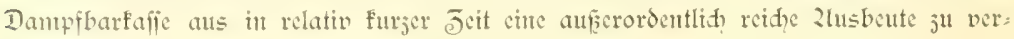
sciduten gehalnt. 
Da wir anf baldige und rationelle Konfervicrung der crbuteten Dbjefte befonders bedadit waren, verfeht es fith non felbit, daf die Erpedition fid? mit allem ausgeriijtet hatte, was die modente Tedunif in diefer Ginfidit erfordert.

So jei unr erwähnt, daf wir nid, meniger als 8000 siter 96 projentizen 2ulfohol an Bord hatten, der in einent eigenen Raune unter ftrengen 2(bid)lus anfbewabrt unto Die farbwerfe in 5 gähit verjorgten uns mit 500 sifern formol; dabei murde an Sublintat und den verihiedenten, für Konjervierungsjwecke in Zetrad) Eommenden Säuren

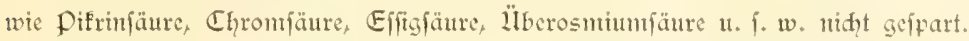

Ebenjomentg war 2liangel an (E)laswaren jur Zlufbewahrung der lebent an Sord fonmenden Dbjefte und der fpäterhin nad Bchandung mit veridicdenartigen Reagen= tien fonfervierten und in 2llfohol ïbergeführten.

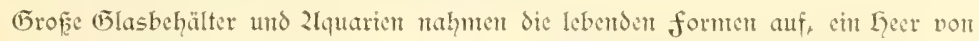
Etöplelgläern, (ธ̃lasdofen, Ricagenjgläfen - von den flemiten bis ju den gröften diente jur Zlufbewahrung des fonfervierten 2liaterials. 2lmfänglihe Drganismen wurden in Konfervegläern der veridiedenartigiten Konftruftion oder in Jinfwantuen und arosen Kiften aus Jink, wahren Särgen, verpaft.

Dancben waren Sicbe, Siebtifhe und Bütten ju beidhaffen, weld bei dem 2luf formten des Trawls Derwendung fandent. Eite mädtige, vicrefige Jinfwante, wic fie auf der dänifden Jngolf=Expedition verwertet wurde, war gleidfalls int Dorder: fuiff aufgeftellt. Wir fanden es indefien praftifher, den aus den (5rundretsen aus=

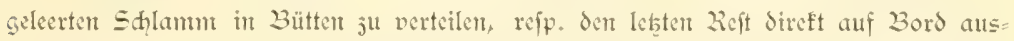
jufdütten. So diente dent die J̈infwame mu gelegentlid jur 2lufbemahrung gröferer

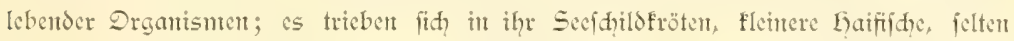
simnal cin Tieffeefiph, umber, unt luftig padselten in ihr die auf den Kerauclen er:

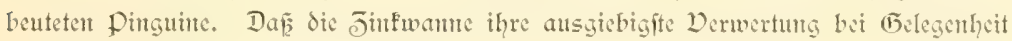
der z̈lquatortaufe fand, mag vielleidt hier falon berraten werden.

\section{Die oceanographifhe 2lusriftuna.}

Wem aud dic biologifhen Intereffen der Erpedition in Dordergunde ftanden und Sic oceanographifden crit in jweiter Sinte Berüffiftigung finden follten, fo hat dod Jer (1)ang der Expedition es gelegentlid mit fid gebradt, daf das Derhältuis fid un= fehrte. So max cs dem für uns vort unjhäţbarm Werte, da von vorntherein auf eine jwedentfpredgende nutb allen widhtigeren 2lrbeiten Redhnung tragende oceano graphifde Uusriffung 3edaht genommen wurbe. Es fet geftattet, in Kürje der veridiedenartigen oceanographijhen und metcorologif hen Jnftrumente ju gedenfen, über weldye der Decanograph der Expedition, Dr. Shott, gelegentlid? in Eemeinforaft mit den Chemifer und Bafteriologen, verfügte. 


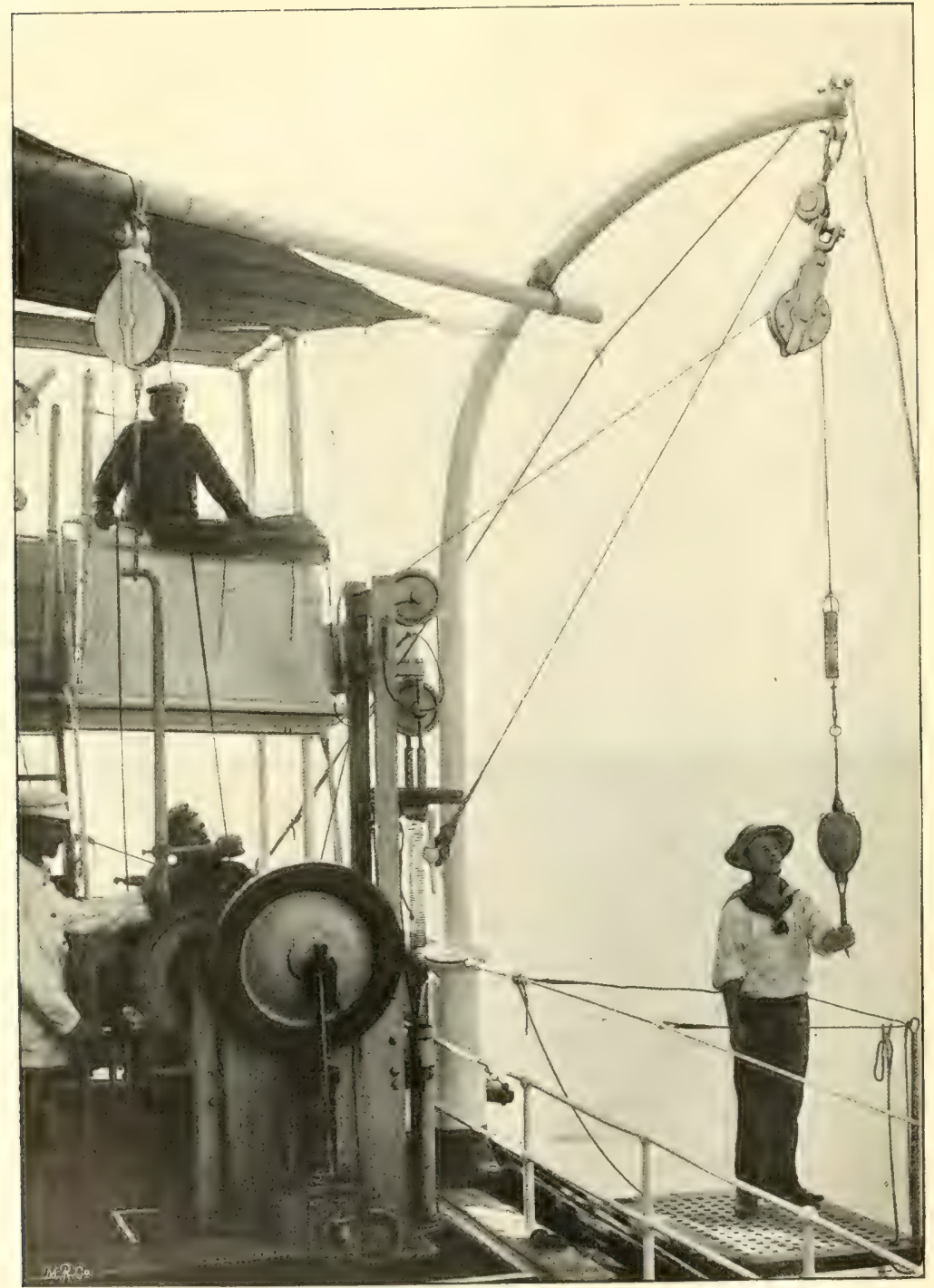

Eotmafhine Sritem Ge Wlane. 
Infere widhtigfen 2lpparate repräfenticrten bie beiden Tieffec= Eotmafditter. Fine Serfelben, von Se Slane in Paris fonftruiert und auf den neteren Erpeditionen des fürifen von 2lionaco und der "Pola" erprobt, wurde neu bejhafft und mittichifts auf Steuerbordeite aufgeftellt. Die nad? oben geführten Dampfrohrlctuntgen wurden mit citer flemen Dantpfmajditue verbutben, welde dic beiden zur 2lufnabne des Sot= Srahtes dienenden Trommeln, näntid? cine gröpere für das gedrehte Stahlicil und eine fleincre für den Klavierjatten Draht, antricb. - Daf vor feiter der Reidsmarinenervaltung uns dic mad dem anterifanifhen Syftem von Sigsbee fonftruterte Sotmaftine Ieifweife liber wiefen wurde, ift fdon oben hervorge hoben mordent. Sie war umgebant und mit einer Dyttamomadhine veriehen wor: den, weldye surd iffen rubigen und ele= ganten Betrieb angenchnt von der ge= räud hoollen Thätigfeit der franjöfifhen 2liafinte abftad. Obwohl die leţtere it ciner nod ju erwähnenden Linfid cinen grofent Dorjug vor der Sigsbee fhen 2liafhine voraus hatte, fo haben wir dod fpäterbin fajt ansfhlieflid dic mittidiffis auf 23atfbordjeite aufgefellt: amerifanifiche zlafobine benutst, $\delta a$ fic fhärfer als die Se Blanc'fde die Crund= berührung anjeigte und dabei etwas rajher arbettete. - 2lls sotoraht ver= werdeten wir, wie bei allen derartigen Tieffee= Sotmajọtmen, Klavierfaitendraht von $0,9 \mathrm{~mm}$ Durduteffer, der eine garan= tierte Tragfähigfeit von $200 \mathrm{~kg}$ befaß

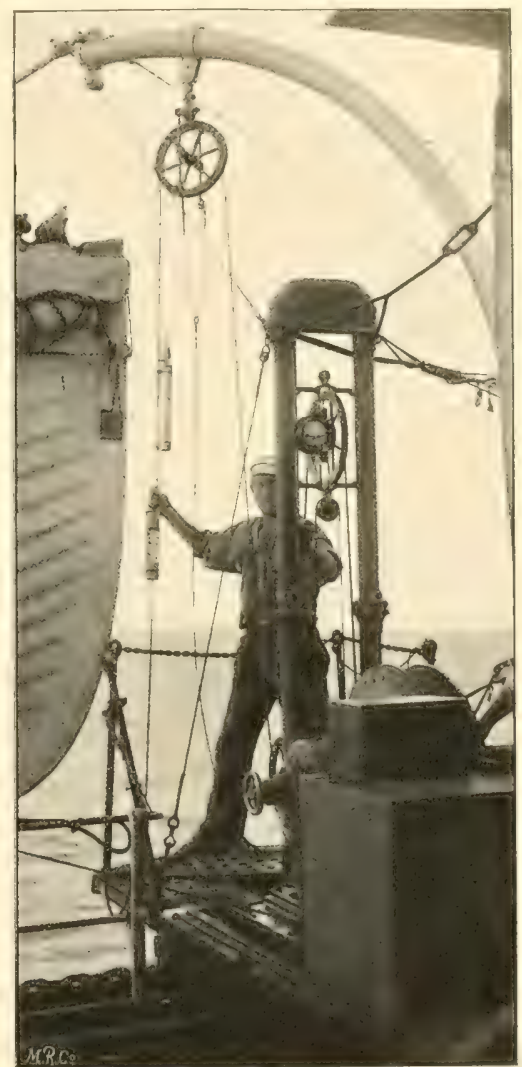

Eotmafuine Spifent Sigsber. und pro $1000 \mathrm{~m}$ nur $5 \mathrm{~kg}$ wog. Eimpdylię̧lid, fpäter crfolgter 2raḑbeftellumg $\mathrm{ver}$ fügten wir über $25000 \mathrm{~m}$ diefes freffliक fith bewäbrenden und durd forgfältiges Reinigen und Einfetten fiändig gebraudşähig erhaltenen Drahtes. Dic Se 23lanc' Sotmajd̨ine war mit etwas diferem Draht, nänlid, ciner gedrehten Eotorahtlitse von 
$1.5 \mathrm{~mm}$ Durhmeffer und cinter Tragfähigfeit von $240 \mathrm{~kg}$ ausgeftattet; $1000 \mathrm{~m}$ der= falbert wogen $15 \mathrm{~kg}$. Wir hattent $14 n \mathrm{~s}$ mit $15000 \mathrm{~m}$ diefes Sotorahtes verforgt. 2 nt das Ende dis Eotorahtes wurden Eotröhren befeftigt, deren wir 6, nänlid?

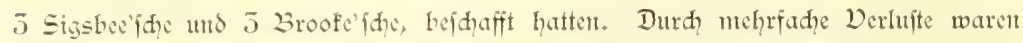
wir genötigt, nod \& weitere Sotröhren vont unjerent 2liafhinenperfonal mit Bord= mitteln anfertigent ju laffen. Ba der Bafteriologe Wert darauf legte, die Tieffecgruno= proben auf ihren (B)halt at Eemfähigen Bafterien ju prüfen, fo wurden nad feinen

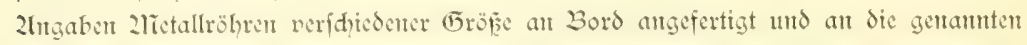
Sotröhren angcfdraubt. Sic füllten fid mit Tieficejd lamm, der freilid mehrfad bei bem Gerauffommen dis Sotes ausgewajhen wurde, fo dafi wir nod über den

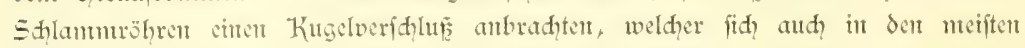
fällen wohl bemährte. 2rit allen für bafteriologifhe Interfudungen erforderliden Kautelen wurden dam aus ber 2lïtte dicfer Röhrent die jur linterfudung beftimmten

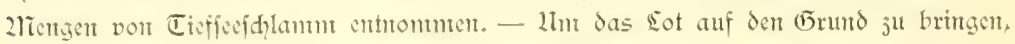

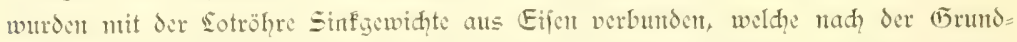
berührung auf dem Ticffecboden liegen blieben; wir verwendeten für gröfere Tiefe

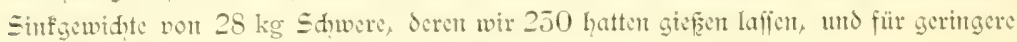
Tisfe folde vor $15 \mathrm{~kg}$, deren wir über 150 virfü̈gten.

2luf die Befdaffung non Tieffee= Thermometern, weldye nit der notwendizen Edarfi die Waffer= Tentperaturen in verfojiedenen, geringeren und gröferen Tiefen

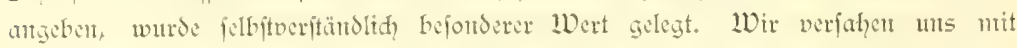

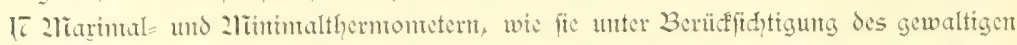
Drutes, dom fis in groben Tiefen ausgefeft find, auf allen neueren Expeditionen Der

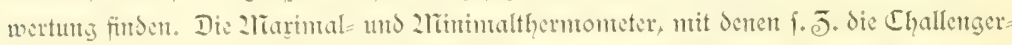
Erpidition allein varchen war, fandent in allen wämteren und gemäpigten oceanifhen (5)bistent aussicbige Dermendung. Da hier die Temperatur vort der Sberfläd bi jum (⿹) jul fonftaterende zlinintaltmperatur genau jence entiprad, weldye in der gröften von dent Thermonteter erretditen Tife herridet. Jn den antarftifhen Ẽebiete mit peiner

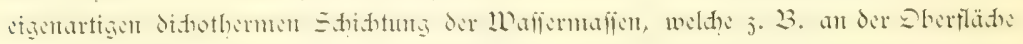
geringere Tenperaturen als in gröferer Ticfe anfweifen, fonnten felbitueritändid dic

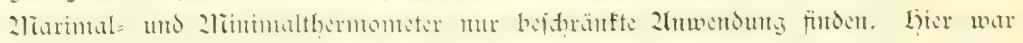
es notwendig, dic von ber firma 2regretti und Jantbra it sondon fonftruterten 2lnt= fipptherntontex in 2fuwendung ju brimgen, deren Prinjip Sarauf beruht, daf das

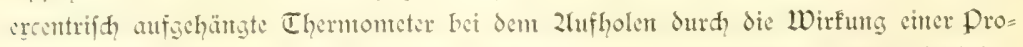
pilferfaraube ausgelöt wird, unfippt und durh einen abgeriffenen Queffillberfaden bis in der betreffenden Tife herridgende Temperatur genau marfiert. Wir hatten uns

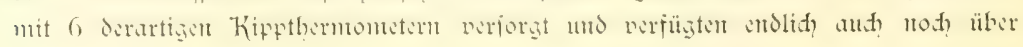


cinen fehr umfänglidgen 2lpparat, nänlid ein von Sientens fontrutertes cleftrifdes Thernometer mit cinem $750 \mathrm{~m}$ langen Kabel. Dasielbe ift beftintnt, Jurd z̈̈n= derung in cleftrifhen Seitungsvernögen ciner Platimpirale die Temperatur aus gröfreren Tiefen dent Beobadter gewifiermafen ju telegraphicren. Es ergab fid freilid, daf ber 2lpparat nod einige 2liängel aufweit, bie erft nad weiteren Derfuden ausgeglidgen

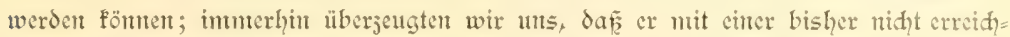

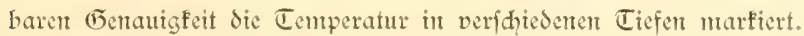

Jux hemifhen Znalyfe des Tiefiecwaffers wurden gleidffalls idhoit auf den früherent

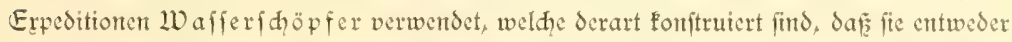
cine Probe des Ẽrundwaffers oder eine foldhe aus beliebiger Tiefe fäöpfen, ohne cine

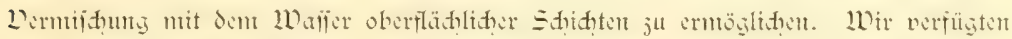
liber fieben nad den 2lngaben vor 2lieyer, Sigsbec und Petterfion fonftruierte

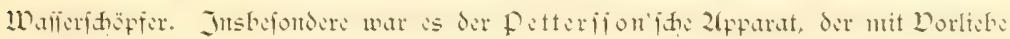
von unjerent Chemifer jum Sđ̧öpfent der 1 Wafierproben Derwertung fand.

für die veridiedenartigen llnterfudungen über die phyfifalijhe Befhaffenheit des Ecemaffers dienten jumäd) 2lräometer, weldhe die Diḑte des Seewaffers antgeben, cinte

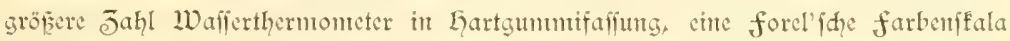
jux Beftimmung der Wafferfarbe, Refraftometer jur Beftimmung des Sidptbredungs= vermögens und damit and gleidjettig des ppecififhen Erewidtes des Seewaffers, und

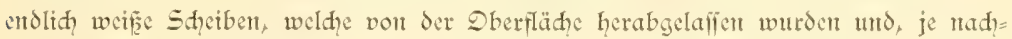

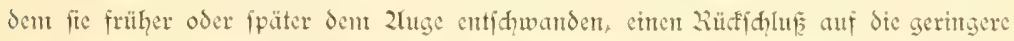
oder gröfere Durdifiditigfeit des Seewaffers geftatteten. Dafí die letstere in freicn Dean wefentlid durd das wedpilnde Quantunt an organifher Subitanj beeitflupit wird, Iehrte Jer Dergleith mit ben Ergebniffen unjerer quantitativen Planftonfifderit.

Went endid nod? der wiḑtigften metcorologifden 2lusrüitungsgegenitände

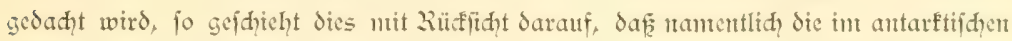
2lieer gewontenen Ergebniffe ciniges Jnterefje beanfpruhen dürften. Die wadhhaben= den Dffijicre führten nad, dex Zlugabe der Seewarte ein meteorologifhes Journal, in

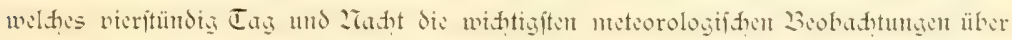
Sidhtung und Stärfe des Windes, über den Druf und die Tentperatur der Suft, übur

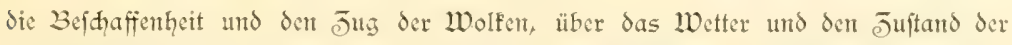

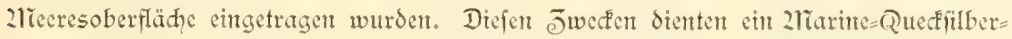
baronteter, jwci 2lneroibbaronteter und mehrere Pfydronteter jur 2lieffung des feud! = tigfeitsgehaltes der Suft, dic Jurh cin 2l Emant'fdes 2lipirationsplydrometer fort= trolliert wurden. Don der firma Riđhard frères in paris waren dant nody weiterhin regiftrerende Barometer, Thermonteter und Ly yrometer befhafit wordsu.

Don fonjtigen meteorologifhen Jnftrumenten fet nur nod cines Jifolationsthermo=

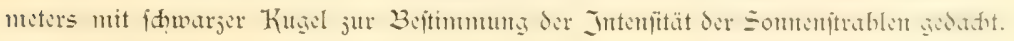


Endlid durfte nod crwähnt werden, dap eine reidhaltige 3 ibliothef in unferem arofien, behagliden Salon auf praftifd, cingeridyteten, bas Lerausfallen der Büdher beim Sdingern des Sdiffes verhütenden Regalen Zuffellung gefunden hatte. Sic enthielt neben natifigen und occonographifhen Werfen die für unfere Jwefe widitigeren joo= logifhen und hotantifhen 2lbhandungen, unter Iftuen die gefanten Bände der Challenger= Expedition, der norwegifden, franjöfifden und amerifantifden Erpeditionen, fowie ene

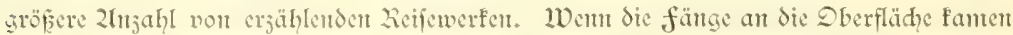
und Glüelta fonferviert waren, war nan ftets eifrig damit befhäftigt, an der Land der Bibliothef dic Drgantsnten 3 befimmen, unt wenigftens cin vorläufiges 2lrteil über den Charafter dex crbeuteten Sebemelt ju gewinnen.

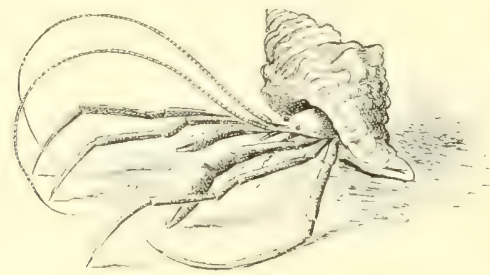




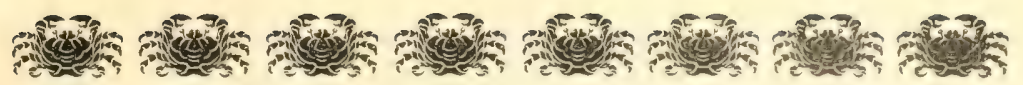

\section{In 2Torbatlantifhen (I)ean.}

E fiel nidyt letąt, in cincn fo vielgeftaltigen und teilweife fomplijterten 2lied)anis= nus, wie er Surdy die 2Tatur der. Erpedition und durd? bie weit ausemander gehen= dent Beftrebungen der 2litiglieder bedingt wurbe, Dronung und geregelten (5)ang 3 u bringen. Immerhin ergab fid dod rajher, als man dad̨te, ein Ineinandergreifen der 2lrbeten und eine 2Torm für den täglihen Setrieb, welde aud bei dem wetteren Der lauf der fahrt eingehalten wurde. freilid, war man von den Saunen der WDifterung bei allen Dispofttionen derart abhängig, daf cin Dorausbeftumen der vorjunchmendent 2lrbeiten mur dann möglich wurde, wenn mit-Sidherheit auf ruhigen Secgang gerednmet werden fonte.

Da wir weiterhit in der Gandhabung enner $2 \mathfrak{H}_{j}$ ahl von 2fpparaten und Geräten nod unerfahren waren, fhien es ratian, nidpt fofort dic gropent Tiefen des Decans aufjufuden, fondert eine 2lrt von Probefahte nad rafh erreiḑbaren Regionen ju unter= nehnen, welhe durdh mäp̧ige Tiefen und durd gecignete Bejhafienheit des Grundes die vorjunchmenden Dperationen erleidftern. 2lis foldhe boten fid von felbit jene für die Tieffecforidung flapifihen Gebiete in 2rorden Sdyottlands dar, auf denen cinft Wyville Thomfon fetme bahnbreḑenden Literfuhungen begomen hatte.

So wurde denn junähị der Kurs durh die ZTordjee über Edinburgh nah den faröer genontmen. Jeder cinjelne war damit bejhäftigt, fid it den neuent und unge= wohnten Derhältnifien jurechtju= finden, was freilidy gar nand?ent nidht leidyt fiel, als nađ Paffieren der fteilen Gelgoländer Klippe ftär= perer Seegang einjetzte und gewiffe unvermeidlide folgen mit fith bradite. Bei dent Diner waren Sie Sitze in dex 27ähe der Thür auffällig bevorjugt, mo bald fand man in Plaids gewidelte, regungs= loje lebende Pafete auf Bänfen und Sehnifühlen zeritreut.

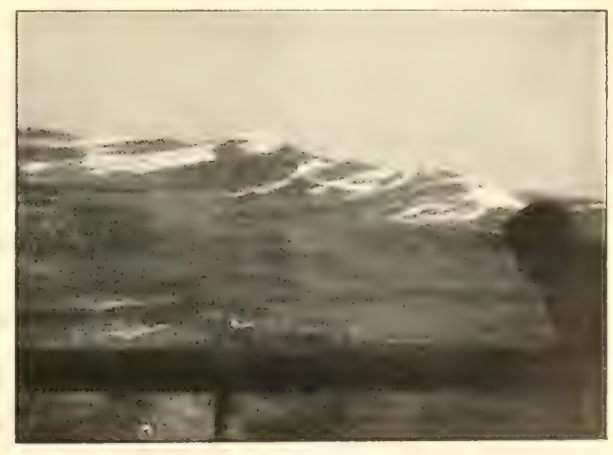

Eother Scegara 
LInt junädift das funftionieren der grofen Kabeltrommel und der Seilleitungen ju crproben, wurden in der 2rordfee, fpeciell auf der Doggerbant, ente 2lnjahl vont Dredfhjügen auf fladen (Brunde ausgeführt, welhe zwar einen rajd it Edinburgh reparierten Sdyaden an der Kabeltrommel jux folge hatten, aber bod immerhin $\delta a s$ Dertrauen in die praftifde 2lnlage der Eeitungen beftürften.

Unjer erftes Reifejiel war Edinburgh, wo wir unferen geidhäten (5)ajt, Sir John

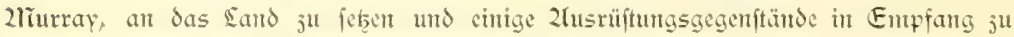
nehmen hatten. Die ziähe der fhottifhen Küfte maḑte fith an ber ruhigeren Sce

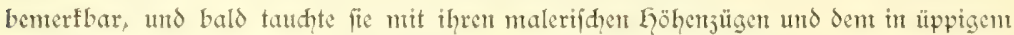
(5rün prangenden Dorland vor uns auf. Zlnt 2Tad?mittag des 5. 2luguft fant der ftrile, Sen Eingang jum firth of forth beherr=

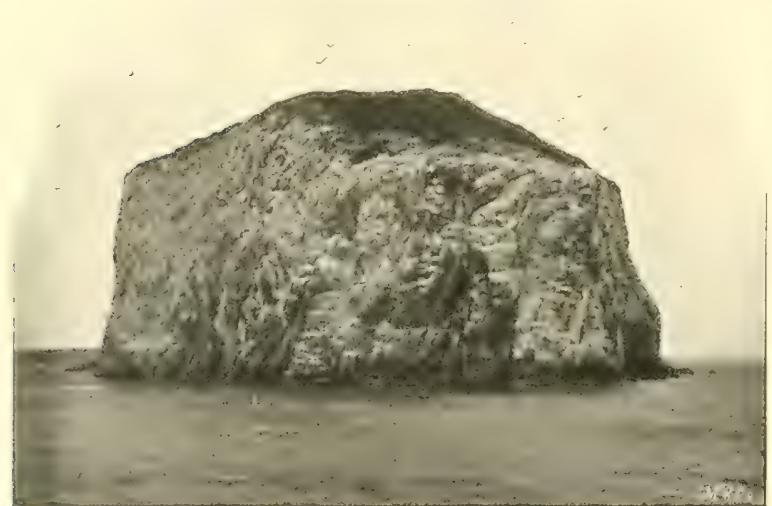

Bab 2iof. (2tpịtein phot.) fidende Bajaltfelfen Baß Rod in Sidnt, belebt volt Tau= ferden von Tölpeln (Sula Bassana), wel= de inn, gefdütst ourd ftrenge gefets= lide Beftinmungert, hevolfirrt. Es war cin fajt libermält: gendos Sthantpicl, als bei dent Paffierent des filims आแ citut abaguhem Eduा hin die Dögel in

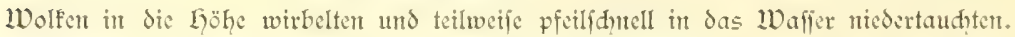
Das sand trat täher heran, wir erfanten die 3 ewohner, weldye ihr fhottifhes 2iationalipiel, den goalf, auf den torfigen 5 ängen am Strand übten, und bald nahte fid bei ciner jence Bajaltfuppen, alten Kraterausfüllungen, weldhe den Ecudthtum tragen, der Sotfi, un bas Sdiff in dent (Franton Garbour ju fugfieren.

Dex furge 2lufenthalt in Edinburgh gab jenen 2litglieden der Expedition, denen das englifhe seben ans cigener Infhaumtg fremb war, (5elegenheit, die gewinnende (Baptreunddhaft und gleidyeitig aud das Eeinmejen eines jener gropen englifhen (5elehrten feunen ju lement, dic niemals im Eeben cine offjitelle Stellung cimahmen. deren Gedanfen und Beftrebutgen indeffen einen Wiederhall in der ganjen gebildeten Welt finden. Die Stmocn, welde wir in Challenger Sodge, dem Geim Sir John 


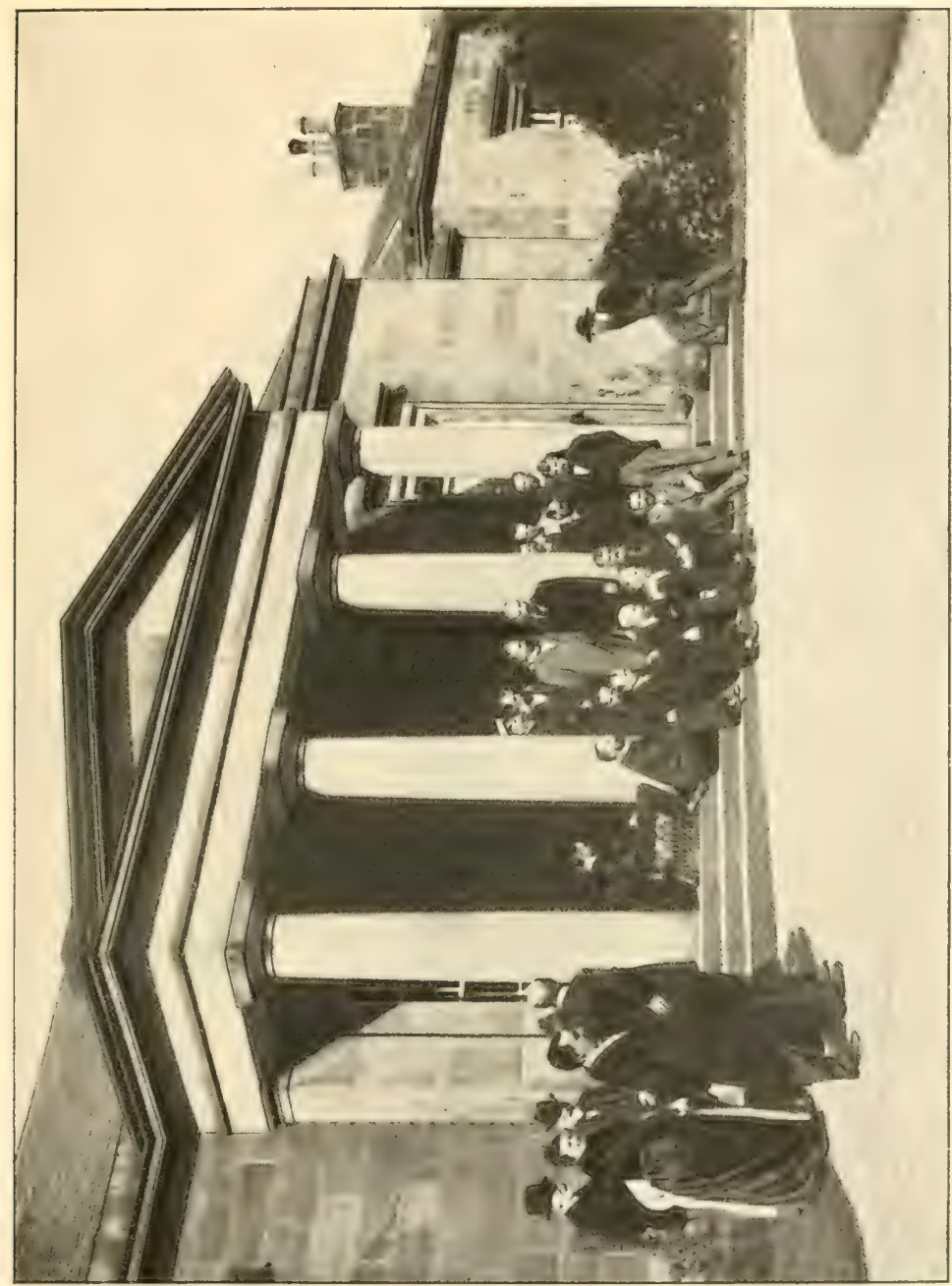

2līuray's, verbradten, bildeten cine der anjihhendfent Erimerungen während der

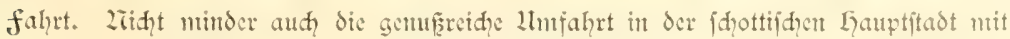




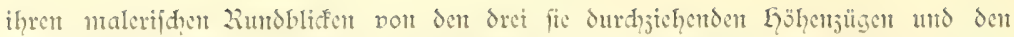
fïlnn die Thalfenfungen z̈berfpantnenden 3 ritten auf das dïjter ragende Kajtell, auf den

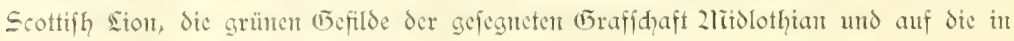
bläulihem Duft verihwintmende 2iordfe. Grofartige modene 23auten legen Jeugnis $a b$, wie für den (B̃encinfim, fo für das wiffenfhaftlide Streben ciner reidyen $2 \mathrm{~B}=$ nölferung, dic pietätooll burd impofante Dentmäler jene 2liämer chrt, weldhe Sdyott= lands Zuhnt unt geiftige Bedentung der Zraduwelt wad halten. Durdpwandert man dic 2lititadt mit der Kathedrale St. Bitles, dent düfteren Königspalaft der Stuarts Loly"

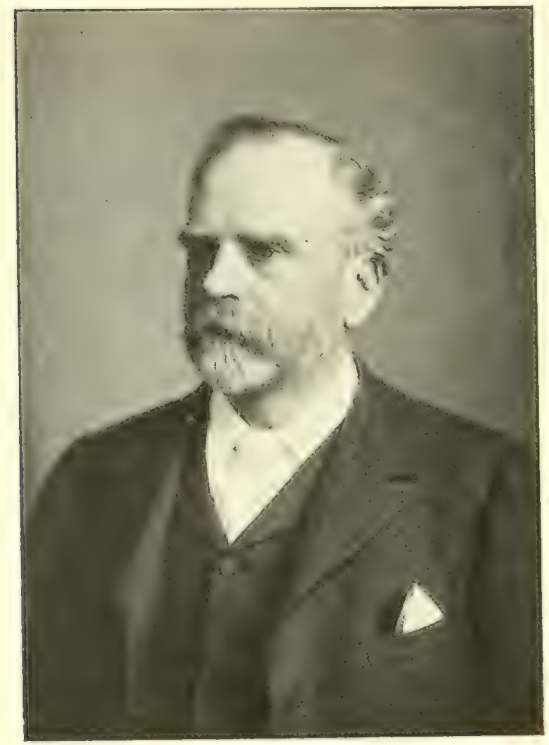

3ohn 11urray. roob, dent Laufe von Krtor, fo taudien auf Sdrift und Tritt dic Erimterungen an das 2litttelalter unt an dic Jeit Ser Ricformation auf, Surdiwebt von rontantifher Tragif und mu felten von cincm sidntitrahl erleuditet und ourd, wärnt.

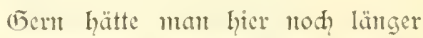
feinten (ธ) Jeit drängte und gar mandes, was mferem Intereffenfreife näber lag, follte nod in 2lugenfhem genommen werden. Der liebenswirdige Direftor des Botanifden (Fartens, Prof. Bal= four, demontrierte dic gropartige Sanmilung von Jifeften frefienden Pflanjen, unt John 2lïuray crläu= terte die jwar in bejacidenen Räumen untergebradite, aber an wifferidhaft= lidhent Werte cinjig daftehende Samm= lung volt Grundprobert aus der Tief= fee (deep sea deposits). Wir haben es Lebhaft bedaucrt, das die Jeit ju fltapp bemefien war, um diefe, für unfere lluter= fuchungen fpecielles Intereffe erregende Sammlung cingehender ju ftudieren. Dic wiffenfhaftlidien Kreife Edinburghs, unter ihnen der chrwürdige Znatom Sir $\mathfrak{W}_{i 1}=$ liam 『urner, fanden fid ant 2radpmittag in Challenger Sodge jufammen und bejeugten mit jener den Sdotten cigenen vorurteilsfreien Eerjlidfeit ihr lebhaftes Interefie an der Zusfendung der deutfhen Tieffec=Erpedition. Sie gaben uns alle das Eeleit jum Lafen, aus dent wir nad warmer Derabjhiedung am 2lbend des 4. 2luguit ausfuliren. 
Der Kurs wurde gegen die faröer gefest, um dort, wo wir jum criten 2ral tiefes Waffer trafen, geviffermafen die Probe auf unfere Zlustuftumg 3 un unternethren. ES ift en flaffifher Errund, auf dem Wyoille Thomfon deremft fente criten Ticfiec= Interid)ungen untenonmen hatte, und der päterhin durd die norwegifhe Cieffec= Expedition auperordentlid eingehend in oceanozraphifher und biologifder Ljinfidyt unterjuḑt twurde. Die Derhältniffe find fo intereffant, da es es der 2lïhe lohnt, fie mit cinigen Worten flar zu legen.

Bei Ser eritent fahrt der "Sight= ning" 1868 waren 1W. Thomion und Carpenter darauf aufuterfiant geworden, ১a卢 nördliक und füdlid? von den faröer die Wafferfdiduten auffällige Unterfidiede der Tempera= tur in gleidien Tiefen aufweifen. In $500 \mathrm{~m}$ Tiefe ift j. 3. das Waffer fübliक der faröer un nahe= ju $10^{\circ} \mathrm{C}$. wärmer, als nördlich ber= felben. Iln Siefe Erideinung auf= juflären unterfuḑte John 2lïurray nath feiner Rüffehe von Ser Challen= ger = Erpedition 1880 und 1882 auf jwei fahrten eingehend den faröer= Kanal. Es beftätigte fith hierbei Sie von Kapitän Tizard, dem Kom= mantanten Ser "Triton", juerft ges

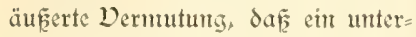
peeifher Rücfen fïdlí, Ser faröer das Kaltwafiergebiet des norb= atlantifiten Decans vort dem $\mathfrak{W}_{\text {affer }}$

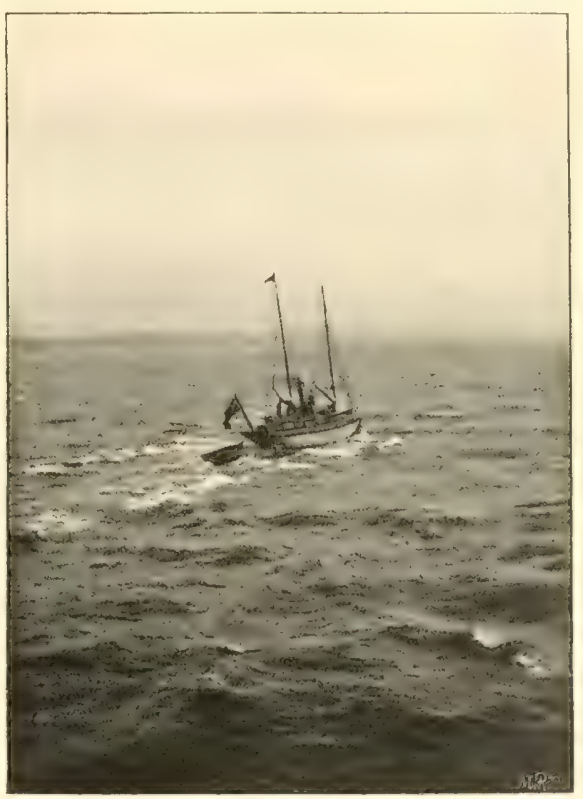

2bjhieb pon Edinburgh. gebiet der füdidyen Regionen fheidet. Diefer "Wypille Thomjon:Rüffen", wie er dent

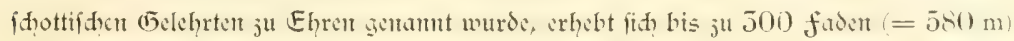
und erweift fich als eine Einfhnürung jwifhen dent breiten "Jsland =2Rüffent und dent flachgebiet der Zrordjee.

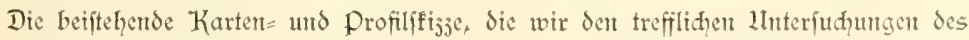
norwegijhen Eilehrten 2hohn entnehmen, mag die Derhältniffe illuftrieren. Eine Temperaturjerie, welde wir ant 7. Utuguft nördlid des Rüfens, an 8. Unguft füblid?

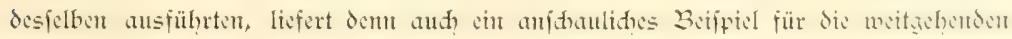
Cemperaturdifferengen inmerhalb cincs räunlid cng begrenjten Eebietes. 
2Törblid vont Thomtion=Riücken:

Süblith nom Thomtion=2kütét:

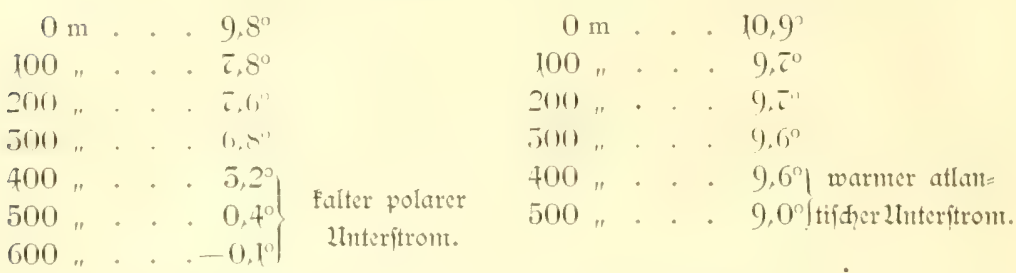

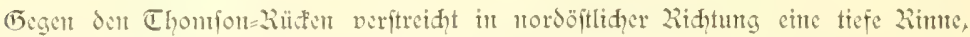
die farber= Shetland SRime, welde von dent nordatlantifden Befen ausgeht und nit cisfaltem Polarwaffer crfüllt ift, deffen Temperaturen unfer den Zullpunft bis ju

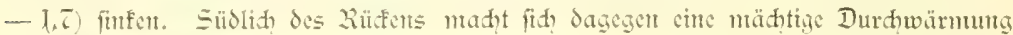

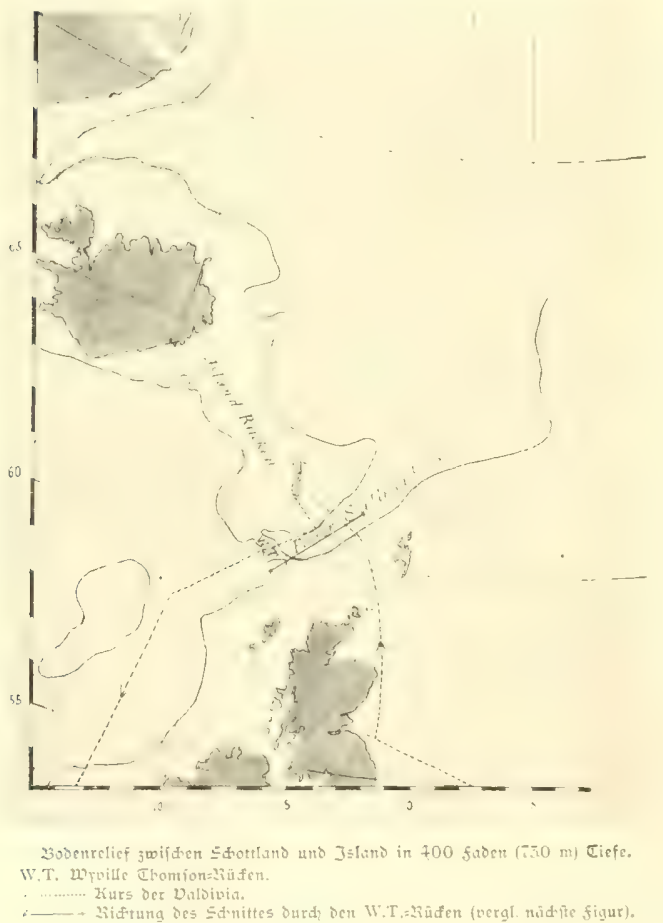
aud bis in ticfere Sthidten geltend: cin deutlider binwcis auf dic Einmirfung des Eolfftrontes, dor ziber den Thom fon=?iufen hins= imcgflutet.

Begrciflith, da diefe auf= fälligen Differenjen in den Temperaturverhältntiffen cine nid) minder fimmfällige $\mathcal{D}_{\mathrm{er}}$ -

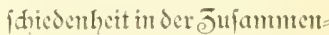
fetsung der Tieffecfauna jur folge habent. Wohl feiner unter uns wird den Eindruf vergeffer, delt es auf uns madite, als wir in relatio

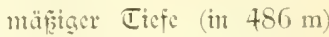
an 6. Zuguif nördida des Thomion=Rütens unferen eriten Tirfen=Dredidintig aus. führtert. 2lls derfelbe gegen 2 thend mit allgentener Spant mutg crwartet auffam, hin: gent int den Quajtet präd tige, mit gewaltigen Stadidn aus: 
geriiftete Secigel (Dorocidaris papillata), die 2rajhen waren überjät mit roten Sdlan= gentiternen und bleiden 3 radiopodent, und

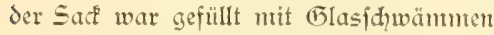
(Feractmelliden), Crimoiden und den bizarr geftalteter Spimenfrebjen (Pycrogoniden), weldhe an ihrem roten oder gelben Seibe cine Srut voll 2radfommen mit fid untheridleppten. Ein Ticffectiing (Lycodes) fprante nod lebent heraus, und allge= meines Staunen erregte das (STlühen der 2lugen der Tieffeefrufter, das durd cin int (STunde derjelben gelegenes refleftieren= des Tapetum bedingt wird.

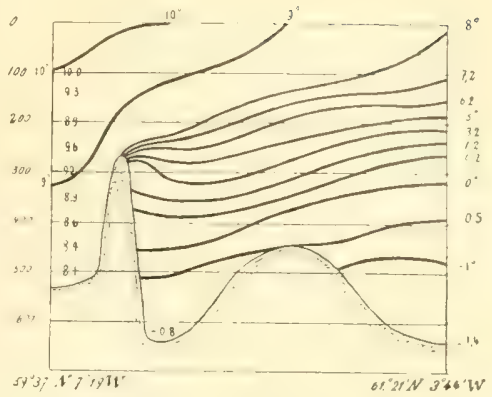

Profit bes Wroille Thomione?üdens mit 21ngabe ber vertifalen Uemeraturididtung.

100...600 Eiefen in faben. Die übrigen Biffern geben die Eemperatur in celfusgraber an.

2luf jwci weiteren Dredjhjügen, die wir in ctwas größzerer Ticfe am 6 . 2luguft ausführten, erbeuteten wir nod cine reidge Jahl jenter für das eisfalte polare Waffer

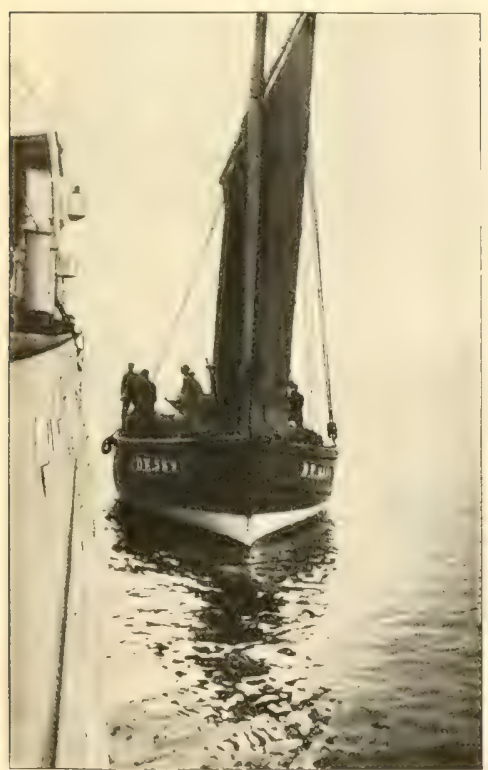

Eintornoeln vor fiftien. diarafteriftifinen und durd, ibre Individuen= Jahl überrafdenden $\mathcal{D}_{\text {ertreter der Tieffee= }}$ fauna. Einmal war das 2ich von weit über 500 Eremtplaren reizwoller Tieffee:

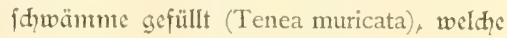
mit Knolpen an den Wandungen des Körpers ausgeftattet waren und offenbar, Danf diefer ungejhledtlidten Dermehrungsweife, (id) ju wahren unterfesifden Raien ju= fanmienicharen.

Während des Dredfhens fan cin fhwar: jer fiidhdampfer, beglettet von ciner fif her barfe, wie cin fliegender bolländer nengierig auf uns $\mathrm{u}^{\mathrm{u}}$, und es gelang uns, von ifm cinen grofent Leilbutt und em Dutsend frifd = gefangeter Doride ju crhandeln. Ju wei= teren $\bar{b} a b e n$ wollte er fith anfünglith nid̦t bereit finden laffen; als indeffen der Kod? sine Spetfeite wie jufällig präfentierte und der Kapitün durd Reiben des Korfes an ciner flajhe Whisfy cinen cigenartigen Sirenengciang ertünen lief, war der 3 ann 
gebrodien und bald verfügten wir über cinen ftattlihen Reiḑtum an Föftliḑen Tafelfidien.

Das Delingen der erfen Sotungen, Dredfdzüge und Temperaturierien wurde wefent= lih Surd? das für diefe (Ëgenden ungewöhnlid prädtige Wetter begünftigt. Es war

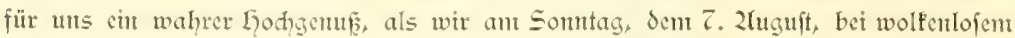
Gimmel die füdlidfte der faröer= Injeln, näntid, Suderoe, untuhren. Kühn ragt fie mit fteil abfallenden Wätden aus bir blauen See hervor, bedecft mit grünen 2liatten, weldhe nach anfwärts itt Lqaidcfrautfläden, und mit isländifhem 2lioos beftandene

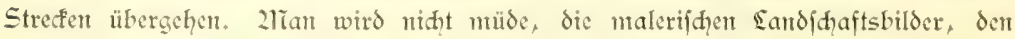

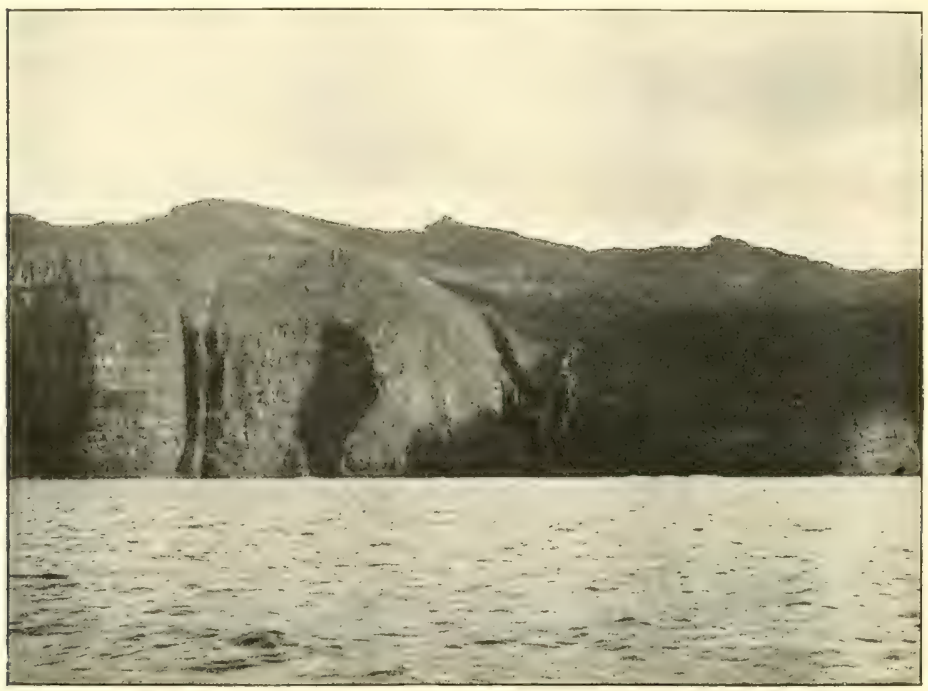

Uitfüfte von Suberop.

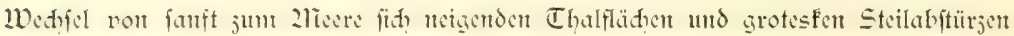
mit ifgren tiefen Sdluditen ju bewundern. Zün gar diefe praht des nordifhen Dogel= lebens! Wie weifse Wolfen wirbelst die 2liöven (Larus tridactylus und marinus) auf und fammeln fid damt, eifrig fifdend, im Kielwaffer des Sdiffes. Gaben fie emen fetten Biffen crwifd,t, fo ftürnt mit lautent $J$-oh eine braune Raubmöve (Lestris parasitica) heran und ruht nidit cher, als bis fie der gellend fdretenden Derwandten die 3eute abgejagt lgat. כuthunlid, unferfen uns die Secjhtwalben (Sterna arctica) mit

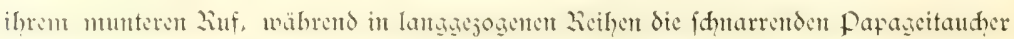
(Mormon fratercula), untermifht nit Gaufen Iuftig taudhender summen (Uria arra) auf 


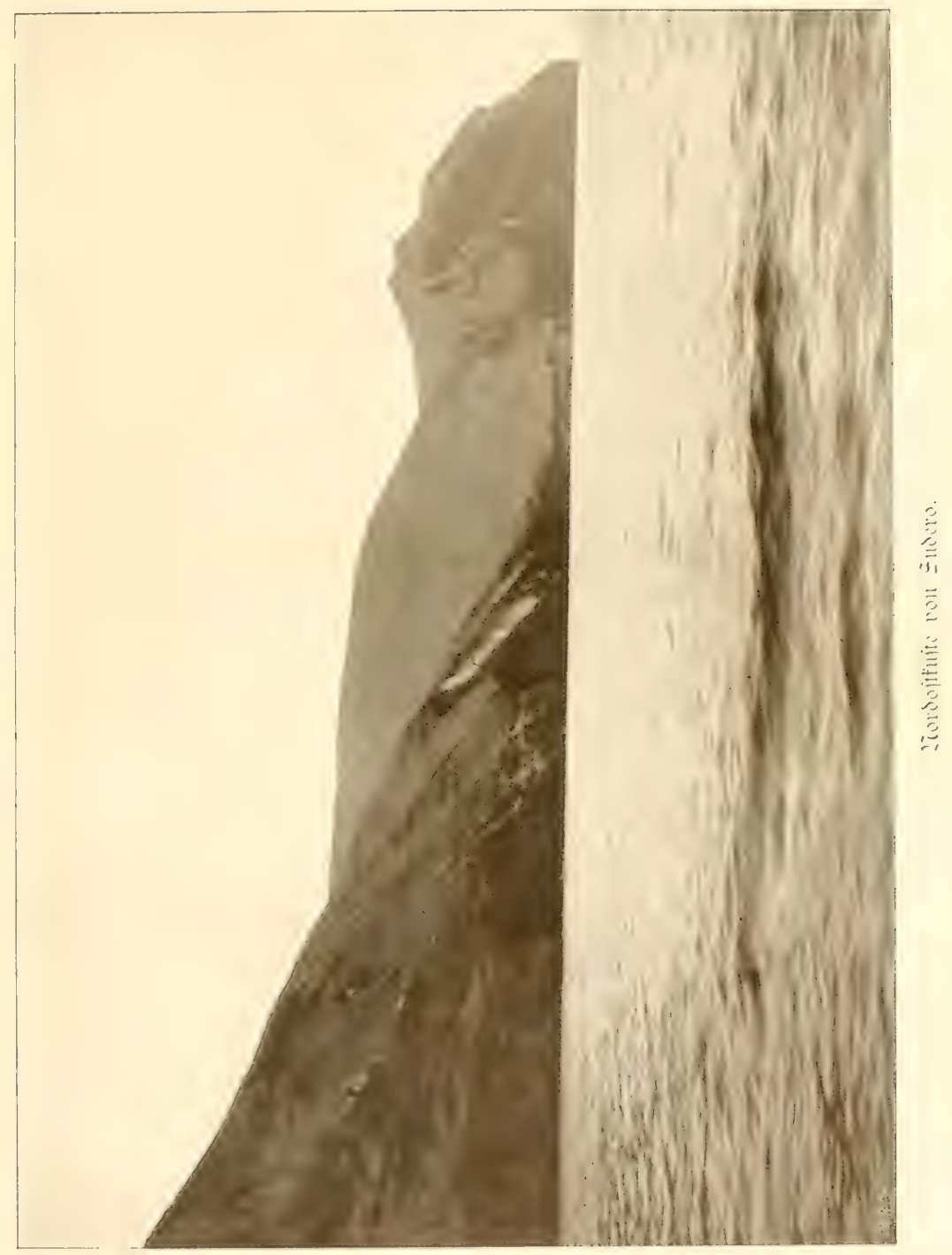


Ser glatten fläde fdwimment. Dereinjelte

Cormtorane (Phalacrocorax carbo) gefellen fih ju den Sturmoögelt (Procellaria glacialis), deren eleganten, fait taubenartigen flug über die Wogentäntme wir nał dent Derlaffen der faröer nod fattiam ju be= wundem (5elegenheit fanden.

Zuf eineu Pfiff mit der Dampfpfeife him, der weithin den Widerhall von den Wänden wedfte, wirbelte das alles faft finnverwirrend in dic 5 öhe, während aus den fleinen gegenüberliegenden Drtidhaften Koalbo und Kablvig dic Einwohner jamt dem Paitor aus der cinfaḑen Kirdhe längs der dunfeln Steinhäufer nad dem Strande rantenter.

2lis wir bei dem Umiabren von Suberoe uns dem 62. Breitengrad genähert und damit den nördidfften Punft unferer gantzen Reife erreidt hatten, grüften dic übrigen

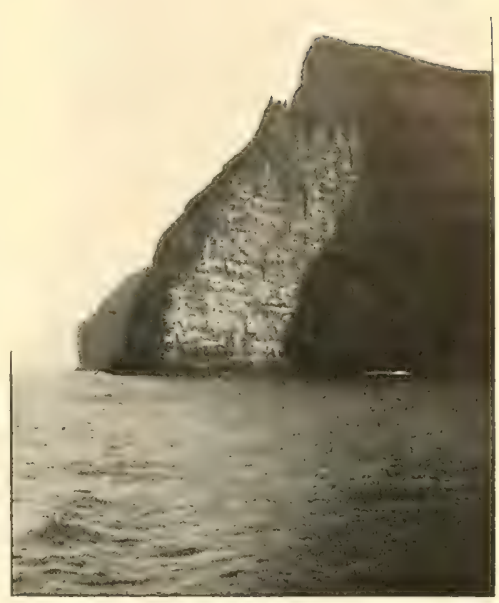

2Tordpitge von Suderoe.

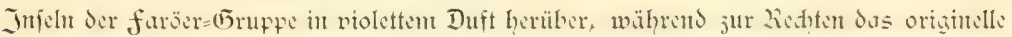

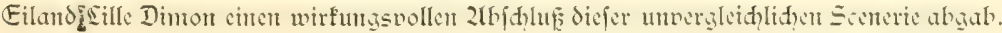

Die Stinmung war allectitig cine gehobene: hatten fid boऋ alle Einridtungen trefilich bewährt und das Dertrauen auf einen glüdlichen Derlauf der $\mathbb{E}_{\mathrm{r}}$ pedition geftürft. 2lllerdings foll midit veriduwie: gent werden, dafi die gropin Sdileppnetic 10. wohl bet bent faröer wie aud bei den Deriuden der nädiften Tage Eille Dimon. mebrmals fid über=" Chun, zlus den 区iefer des weitmecres. D̈weite 2luflaue. 


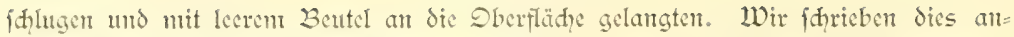

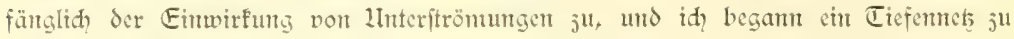
forftruieren, bei dent der gefamte Beutel in den eifenen Babmen singefdloffen ift, fo da cin Huflarwerden ausgef hloffen erfdent. Späterhin überjeugten wir uns indeffen, da wir offenbar die zietse ju rafh in die Tiefe herabgelaffen hatten, wobet der cinen ftarfen keibungswideritand findende 2ueţbeutel langfanter finft als der vor iłm be=

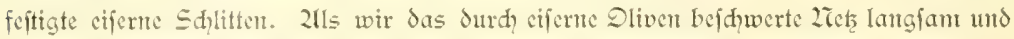

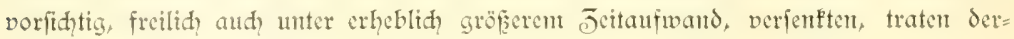
artige unlicbfante fehliḑläge niḑt mehre ein.

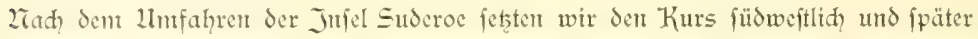
rein füblidh in der Ridqtung auf die Canarifhen Infeln. 2fn der" Erwärmuntg des Dberfädenwaffers und der rajh fid geltend madenden milderen 2 Ditterung wurde deutlidy der Eintritt in das Ebebiet des Folfftromes verfpürt, der fith aber freilid and

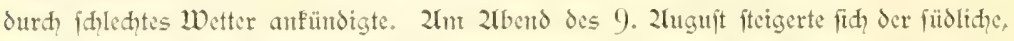
allmählid nah Sübweft und $\mathfrak{W}_{\text {eft }}$ umbrehende Wind jum volfen Sturm. 2lït ge= ringen 2tnterbred)ungen Gielt or bis jum 15. 2luguft bet grober und hoher See an und crmtöglidgte uns erft ant 15. wieder den Begimi der gewohnten 2trbeiten. Es war eine harte, aber aud gute Sehre, welde uns in diefen Tagen gleid ju Beginn der fahrt crteilt wurde. Wegen der ftündig überholenden Seen mufeter alle Sufen ju den Sabora= torien gedidftet werden, Drahtfeile wurden längs der Reeling jum fefthalten gejogen, und trob̧dem fiel es ju jeiten niđht leidht, die Kommmnifation an Bord aufreht ju erhalten, jumtal da aud die Treppe jum Einterdec weggeiḑlagen wurde. Die Wogen domterten unaufhörlid gegen dic Kabinen, und da wir dic Dünunty dwars hatten, war ein ftarfes Rollent des Sdiffes unvermeidid. Was niḑt niet= und nagelfeft war, madte die Bewegung mit; in der Pantry hatte fin ein filtrator ans Stcingut los:

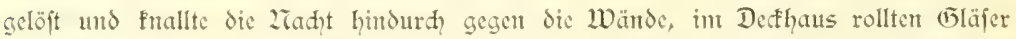
und Solastuben auf dent Boden rhythmifi, hin und her, und bisweilen fteigerte fid

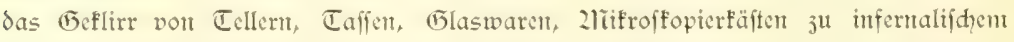
Särm. Büduer lofferten fidh aus den Begalen und begaben fid im Salon auf bic Wanderung, währens in den Kabinen Stühle, Reifejäfe mid Sticfel untermifat mit umgefallenen Seimflafden und Tintenfäfiern ein ammutiges Chaos bildeten. 2ln

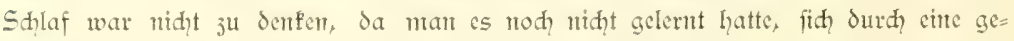
cignete Sage in der Koje feftsuflemmen oder durch jwifhengeftopfte Kiffen cinen feiten Galt ju gewimen. Fatte man alles und fid jelbjt glüclith verfaut, fo verfolgte

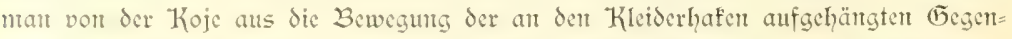
ftände und (5ewehre, die oft in abfonderlid groferm $W_{\text {infer }}$ von den $W_{\text {änden }} a b=$ ftanden. Begreiflid), dap gar mandier des 2liorgens feine Klagen anjubringen hatte, 
bevor er den Rat vout Kapitän unt Difijieren befolgte, fid in das Lnabänderlithe jut fügen und für gefidertes Derftauen der Dbjefte in Kabinen und Saboratorien Sorge ju tragent.

Bei dicfent 2fufrubr fegelten die fdhwalbenähuliḑen Petersvögel (Oceanites oceanicus) und dic allmählid, fïh emiftellenden Sturmtauther (P'uffinus arcticus) clegant über dic Wogenfämme, während $a b$ und ju die Tünmlev ihre lujtigen Sprünge liber Wellent= thäler ausführtert.

Erit ant 15. Zuguft vermoḑten wir wieder unfere lnteriudyungen aufjunehmen,

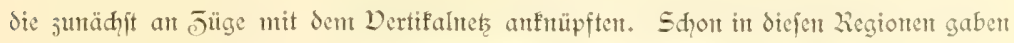
fie uns einen Dorbegriff von der eritaunlidgen Drganismenfillle, die wir fpäterhin nod? auf diefent Wege erbeuten follten. 2lud? die Sțlic है 1tetsjüge, die wir vont 15. 2luguft $a b$ regelmäfig in 马röß̈erer Ticfe veranftalteten, erregten allgememes Inter: cife, fait jeder war damit befdäftigt, die aus beftimm= ten Tiefen erbenteten Drga= nismen ju priffen und bie= jenigen 2lrten, toeldye nod? lebend oder in abgeftorbenen Beften in gröferen Tiefen [âmebtert, ju vemterfen.

Jn der Löhe von Gibral= tar urd 2liadeira jteigen ans bem $4000 \mathrm{~m}$ tiefen 2lieere sine 2lnjahl von 3änfen,

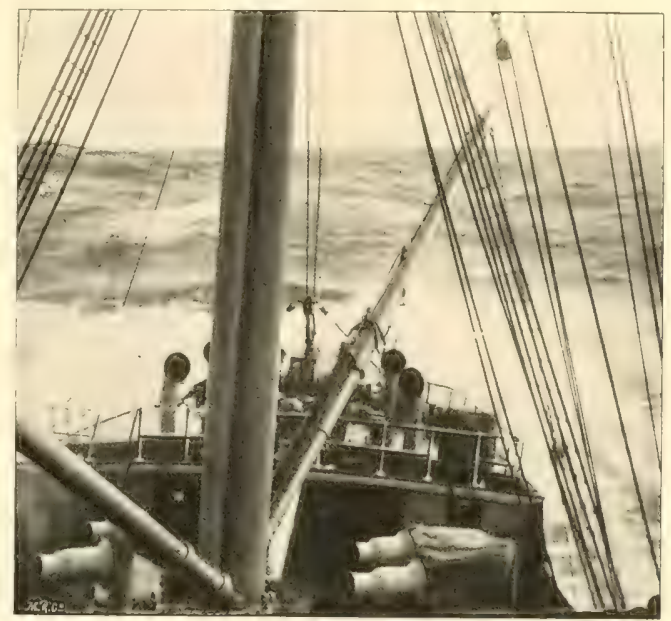

Don Dorn ûberfommende See. de Kuppen unterfeetfder Dulfanfegel, fhroff auf, deren jwci, nämlid, die Jofephinen Bant" und die bei Zrabeira gelegene Seine=23anf, wir anjufteuert verfudten. Da dic Sage der Jofephinen= 3 anf in den nautifien Lanbbidjern verfdieden angegeben ift,

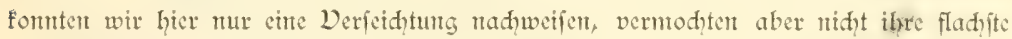
Stelle aufjufinden. Befferen Erfolg hatten wir an 18. 2luguit mit der Seine=Banf, deren Pofition unts durd die "Silvertown Submarine Telegraph Company it Sondon genau angegeben war. In mur $150 \mathrm{~m}$ Tiefe führten wir mitten auf der 3 ant cinten Sdleppnetzug aus, der uns mit cinem wahren Regen von Crinoiden (Antedon pha-

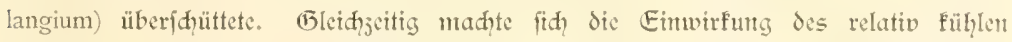

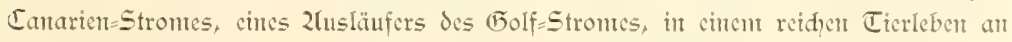
der Dberflädye geltend. 
Die wie Segelboote geftalteten blanen Delellen bedeften in Sd,wämten dic Dberflähe; veildenblau gefärbte Sdnetfen (Janthina) flottierten ant ihrent langgejogenen, mit Suft crfüllten flof, das fie fid aus den Shlemtonifen ihres Dorderfufes bilden. (⿹) ihnen

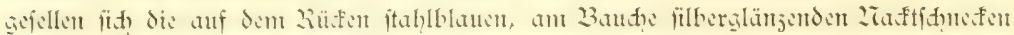
(Glaucus), weldie fid Saburd? nahe ber Dberflähle in Sdwebe erhalten, daf fie Suft jhlufen und in threm 2lagen aufipeidern.

Blau ift der (i)tundton aller auf der 2leeresoberflähe flottierenden, paffin ourd, Wind und Strömungen bewegten Drganismen; wäp̧te man es nid̨t fịon längit, fo würde fier nod cingehender darauf hingewiefen werden, daf es fid um eine Sduth färbung handelt, welthe mit dem tiefen Blan des Deeans harmoniert.

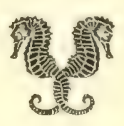




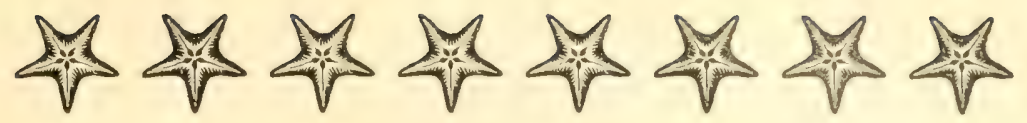

\section{Die Camarifhen Jujeht.}

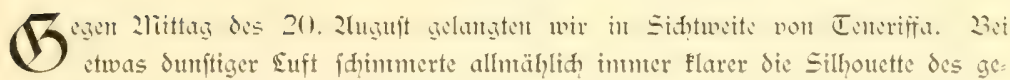
waltigen, $3716 \mathrm{~m}$ hohen Pif durd, nad cinigen Stunden hob fid an der Dftipitze die wild jerflüftete 2tuaga=Kette violett und rötlid? fhattert $a b$ und dic weif̧en liäula

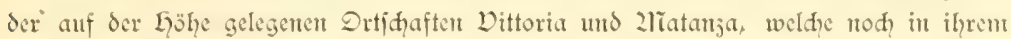

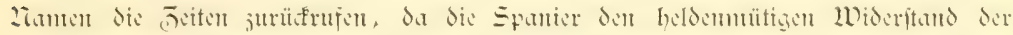

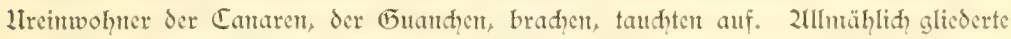
fid, bei dem 2nntenem der 2Tordfüfte die Sceneric dentlider; das gefegnete, üppig bebaute Thal von Drotava, linfs Surd, die Eöhen bet Sta. Llriula uns Surd dic dunflen Säunte der bis jur Cumbre fidh hinjichenden Pinienwälder, rechts von dem Steilabfall des Tigayga begrenjt, bot fid, unferen Blifen dar; dic Gauptitadt der

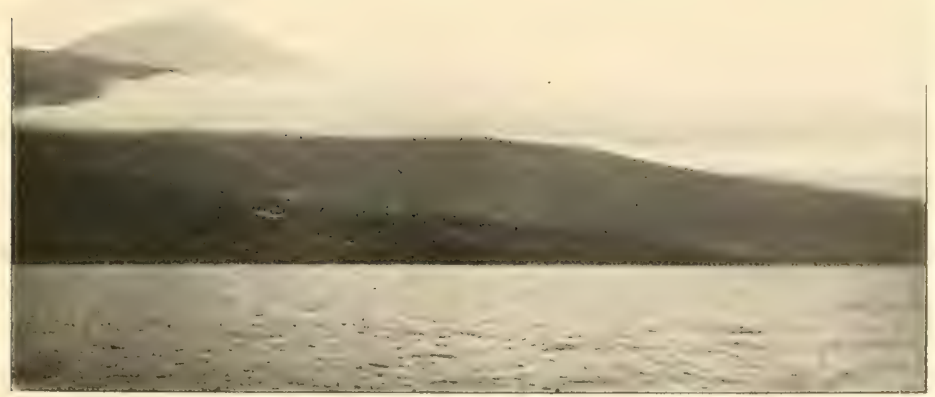

Fil von đenerifia. 
2Tordfüfte, die Dilla de la Drotava, grüpte herüber, während unten alt dem Puerto dic Brandung gegen die Riffe der Savablöfle topte.

Es war mir eigenartig ju 2liute, als id, dic *Islas afortunadas", auf denen ith sinft vor ll Jahren 8 2lionate in genufrether, ftiller 2lrbeit verbraht hatte, wieder begrilfen durfte. Welde flut von Erimerungen taudte auf, als dicje grofartige,

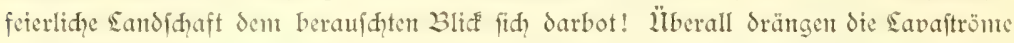
in das 2lieer nor und laffen fid oft hod hinauf bis ju threm Eruptionsfegel ver.

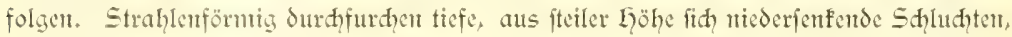

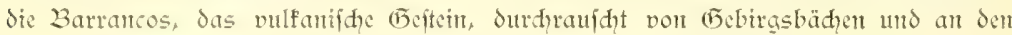

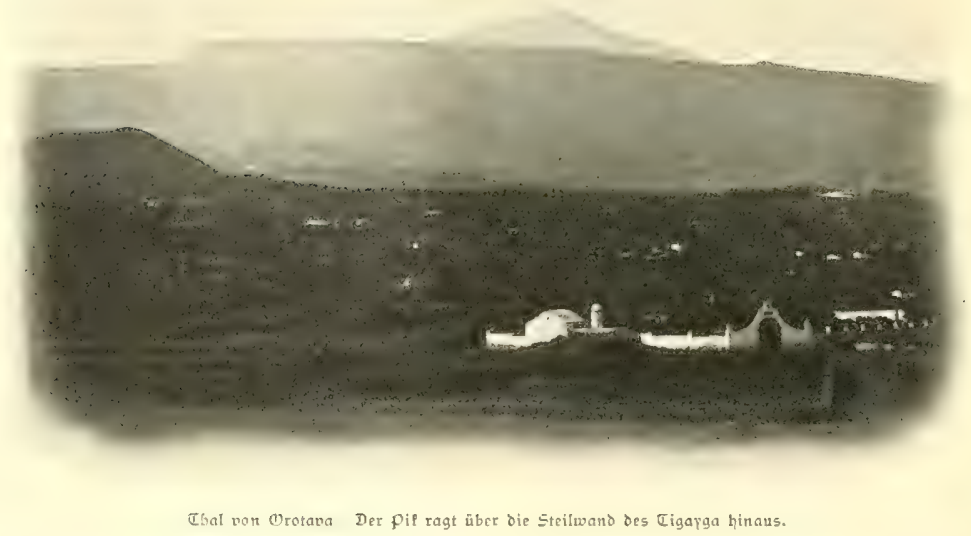

Wänden mit Sen Fald reijvollen, bals bijarr geftalteten Dertretern der Canarifhen felfenflora bedectt. Der vulfanifhe Boden ift erftaunlid fruḑtbar. Emfige 2lrbeit bradte an den Längen einte üppige Kultur juwege; bas ganje Thal von Drotava ift liberfät mit Stäbten, Dörfern, Sandhäufern und Kayellen. In die Pflanjungen Srängen fich die Charafterformen der Canarifhen flora ein: die Canariempalmen, weldye an wud̨tiger Entfaltung threr Belaubung den Dattelpalmen weit überlegen fins, vereingelte Draḑenbäume unt die überall an den felswänden wie Kandelaber auf= ftrebenden Euphorbien beherriden die Scenerie. Göher hinauf bentmmt eme horijontale Wolfenmand den 2lusblick und badet in ftändige fenditigfeit die Region der leider nur 


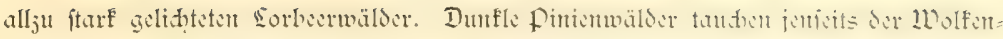
wand auf und herrihen vor bis jul dem wildjerflufteten (E) birgsfantm, Ser Cumbre. Das alles wird überragt von dem fhwärzliḑen zlifhenfegel des $D i f$, der aus einem der grofarartigften 2Imphitheater der Welt, den Cañadas, aufiteigt. Wie gar mandmal hatte id diefent von Steilwänden begrenzten Cirfus, dent alten längit mit Saven, Bints= jteitr und 2lidhe ausgefüllten "Krater, durdjifteift! Baumartig aufftebende (5infter, das Spartium nubigenum, bilden in ihm die herrfhende Degetation. Went fie fid in frühjahr mit weiß̧en Blüten bedecken, ift die Suft mit balfantifhem Duft erfüllt, der meilenweit dem Secfahter dic Zlmäherung an die Canarent verrät. 2kühjelig if́t

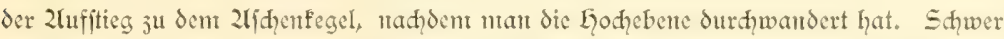
feuhen die Saumtiere unter iherer Eaft von Deffen, Waffer und proviant, bis endlid das 2radqtquartier in halber Eqöhe des Kegels erreiht ift. Der Sdylaf will fid freilid, lange nidyt einftellen. Einfant und weltwerloren, hod über dem (Fetriebe der 2renidhen ftaret man auf diefe $\mathfrak{W}_{\text {elt }}$ von Trümmen und 2 fide hinab bis ju der den weiteren 2lusblitf benehmenden Wolfenwand; in nie gefehener Praḑt flimmert der Stemthimmel tund faft gejpenfitifh ragt der Kegel auf, dem mur fpärlidfe weiflidge Dampfmaffen,

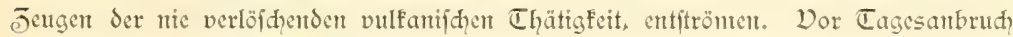

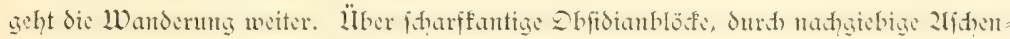
maffen bahnt man fid mühfelig den Wegg; gar oft wird angehalten, um in dev dünnen Suft 2ltem ju holen oder eit Pifveilḑen jut pflüfen, das felbft in diejer böhe nod, feine Pfaḩlwurzel in die 2lïhe treibt. Endlidh ift der Gipfel bejwungen und erifhöpft

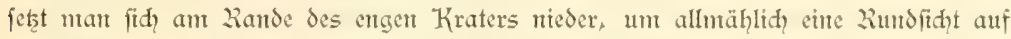

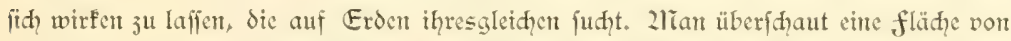
5б00 Quadratmeilen, cinen Raum, Ser gerade einem Diertel von ganj Spanien gleith fommt. Wie eine Sandfarte liegen unter uns die fieben Canarifden Jnfeln ausgebreitet: dort im Weiten palma, ferro und Gomera, dort in Pften (5ran Canaria unt die dent afrifantifhen feftlande näher liegenden fuertaventura und Eanzarote. Teneriffa fheint mur den Sofel für den 2rifhenfegel abjugeben, der weit nad Weiten feinen dunflen Sdhatten wirft. Lnd mun gar der Deean! Woer von der Endlofigfeit des 2lieeres überjeugt fein will, der leme es nidit mur auf fahrten femren, die monatelang cinen unbegrenjten Gorizont darbieten, fondern fhane es bon dem Gipfel des pifes von Teneriffa! Da der Forizont in gleiḑe Göhe mit dent Zluge des Beobachters ver= legt wird, fo fheint es eirem ftahlblauen Triḑter ju gleiden, an defien Wänden lang=

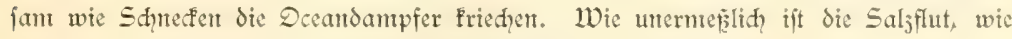
łlein fint die Jnichn, wie winjig die meniḑlithen Siedelungen!

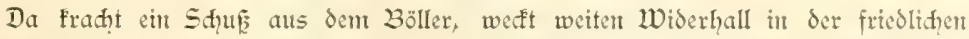
Sandfdaft und idfreft den Träuner aus alten Erimerungen auf. Der 2tnfer raffelt auf der offenen Reede des Puerto de la Drotava nieder; das Wolf, mifktranifd on des 


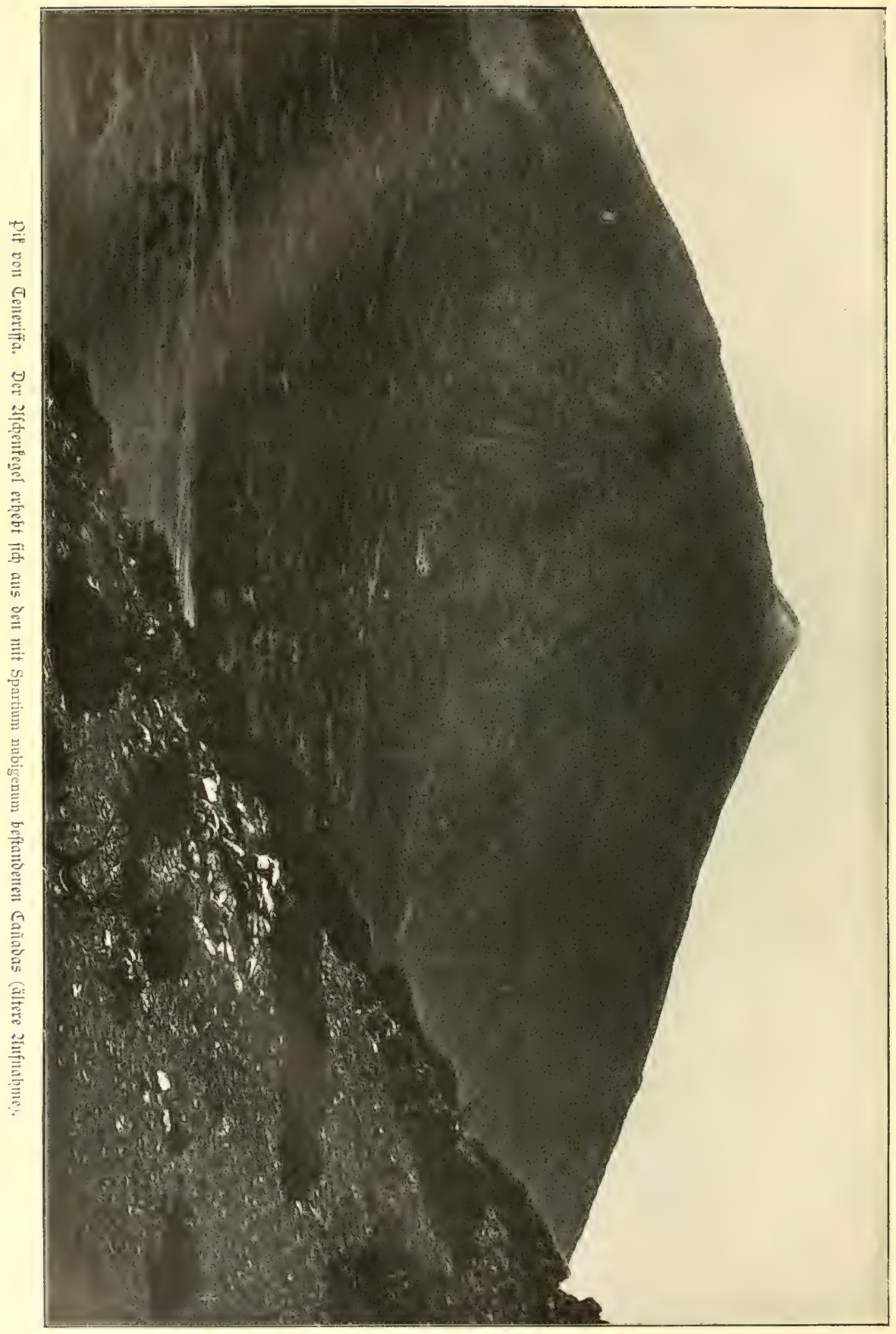


grofen weipen Dampfers, ftiebt ausentander und porfihtig naht fif das Boot mit dor Sanitüt. 2lls man die deutjde flagge erfennt, Iöft fid det 3 ann - es find feme 2lmerifaner, welthe trots der eingeleiteten friedensverhandungen feften fuf auf den Cantaren faffett wollen! freudig tehmen uns des 2lbends alte Befamte an Quai in Entpfang und in gewohnter Behaglidfeit läpt man es fid in der fonba der forg: lithen Doña Juana wohl fein. "Wer cimmal dic Canaren gefehen hat, fo meinte fic,

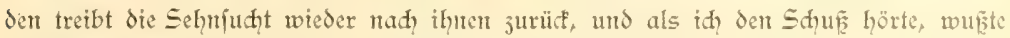

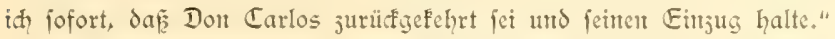

Da unfer Botanifer 10 ert darauf legte, de berühnte endemifde cantarifie flora aus eigenem Zlugenfhein Eenten ju lernen, wurde für den tähjten Tag chr 2lus= flug längs der Küfte bis nad? dent durd, feinent alten Drahenbaun berïhnten Jros in 2lusfidit genomt= men. 2lït eitrent wahren Бodhgenuf erfrifhte mast fich in der frühe vor der 2lbfahrt an der alt= gewohnter Stelle in der zähe des an Strande gelegencru Kirdhofes durch eir Bad, und dann ging es durd? das ftille Stäßthen umb üppig bebaute IInterland vorbei an dem grop $=$

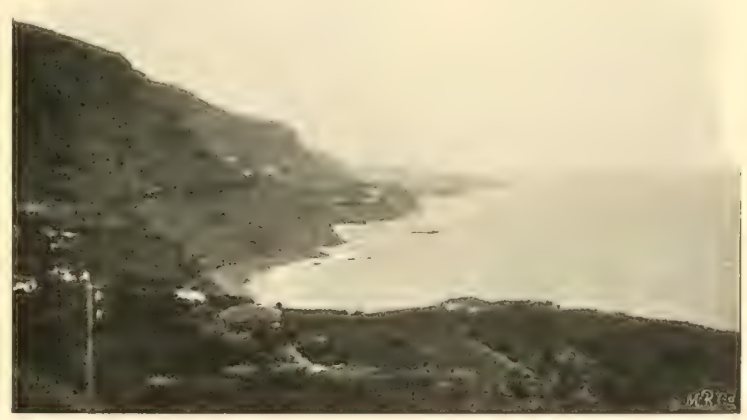

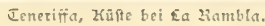

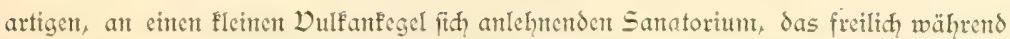
der Kriegsjetten vollitündig leer ftand. Ï̈berrajhend war die frifhe und lïppigfeit der Degetation hier auf der ZTordeite, troţdem wir uns am Ende des Lodyfommers befanden und nod fein (E)witterregen eingefetst hatte. Die von Eucalpptus, Tanta= risfen, dem Schinus molle und der mit ihrer roten Blütempradit unt überfülttenden Dleandern eingejäumte Sandfrafse gewährt überrajhende Zlusblife red)ts nad dem Strande, Iinf's bis jur Cumbre und voraus auf den immer wudtiger entgegentretenden Steilabiturj des Tigayga, der den Ẽipfel des Pif verdecft. Bananen=Pflanjungen und Rebengelände mit vereinjelt eingeftreuten Canarien-Palnten und fleinen Dradfenbüumen (Dracaena draco) wehfelt mit üppig fultivierten feldern ab, welde durd cin fint = reides Syften von Bewäfferungsanlagen beriefelt werden. Die Sandfrafe überidneitet in Serpentinen eingelue Barrancos und windet fid an den fauberen Sealejos vorlei, 
wo cinft der faft 100 jährige Kampf um den Befits der Canaren mit der Kapitulation

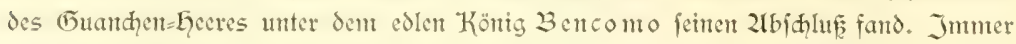
fhroffer drängen die felsmaffen des Tigayga vor, von wild jerflüfteten Barrancos Surdriffen und überfät von den Charafterformen der canarifhen felsflora. Da er= heben fith die an Kafteen crimenton weit uber 2liameshöhe erreidhenden Euphorbien, die Euphorbia canariensis und dic ftraudförmig gcitaltete Euphorbia regis Jubae; Polfter der Sentperviven entiprie Ëen den felswänden, die Büjhe von Ciftus und der fandelaber=

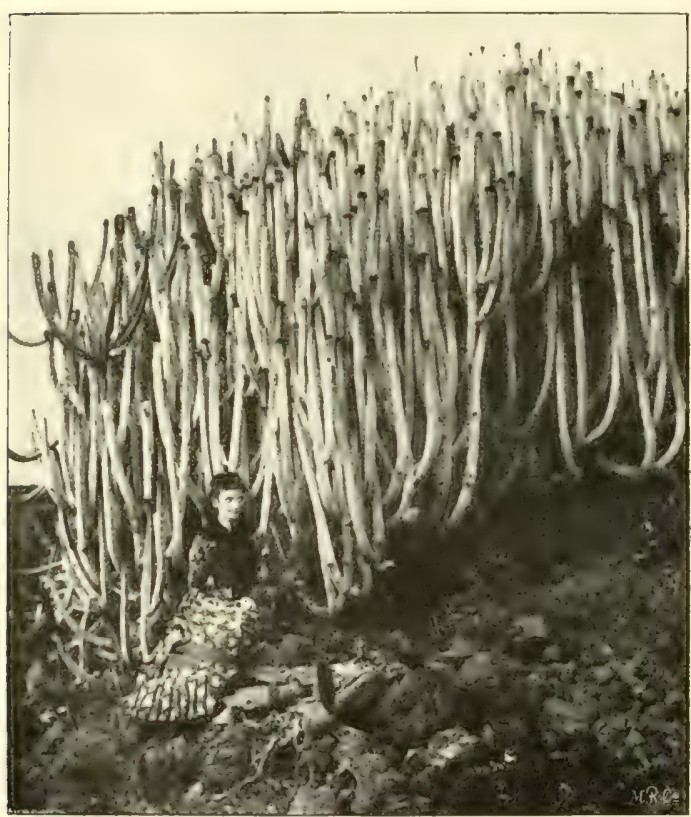

Euphorbia Canariensis. artig verjweigten Com= polite Kleinia dräıgen fid lïberall vor. 2lin 2Tatur= fhönheiten fan der Steil= abfall der Küjte bei $\mathbb{E a}$ Rambla es mit den ae= pricjerftert Strecfen des jüJlihen Jtalien und des Kaplandes wohl aufneh men. zran wird midit müde, den Blide hinauf ju dett wilden bängen, linab ju der tiefblauen See mit ifher tofenden Brandung und dent vor= Itegenden, üppig fultivier= ten Gelände, aus dent dic Canarienpalmen mit ihrer vollen Belaubung herauf= grüzen, gleiten ju lafjen. - Ginter sa Zambla, wo ausgedehnte Eavafel= der durdfidutitten werder. nimmt die Scentre curen cinförmigen Charafter an; alles erideint veritaubt und ausgedört, uno erjt gegen Jrod ju tritt wieder lippigere Kultur in den Dordergrund. Bleidjzeitig eröffnet fid der 2lusblidf auf den in feiner ganjen Praht vor uns liegenden Kegel des Pif, der gerade von hier aus fid, an freieften dem Bejhauer darbietet. Eeider wurde uns

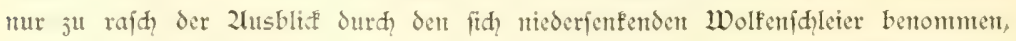
weldher cinen von der Bevölkerung lange erfehnten fanften Kegen fpendete. Das Stamen in Jeod über den zablreiden frembenbejuh war fein geringes. Die Engländer. 


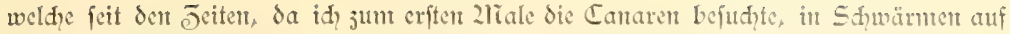
ihnen eingefallett waren, hatte der Krieg verfhend,t, die (bafthöfe waren gefdjloffen, und es foltete 2lühe, cine bejheidene Wirtihaft ausfindig ju maden. in der man unfere leiblidhen Bedürnifije befriedigte.

Das ganje Jnterefic wert=

dete fid felbitnerftändid?

den Drahenbaume

ju. Iqätte ihน L)un= boldt gejehen, fo wuirde fdiwerlid? der längit vom Sturnt gefnide Dradienbaum vor Drotava ju jo hohen Ehrent ge: langt fein. 2In LInfanü undrait: ftrobendemi20ud!s überbietet der alte Risfe von Jroo mit feinent aus

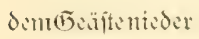
häıtgenden suftt= wurjeln und der wudptigen Belau= bung alle auf den Canaren nod er= haltenen Erent= plare. Es liegt etwas lingefüges in diefem chrwür= digent Stanme, der als Jenge einer grofien Dergangenheit einft die Stein=

fibe bejdyattete, auf dencn neben Dradembaum von Jcot.

dent Körtig die Beften des Guand,unolfes ihren Tagoror, den Wolfsrat, abhielten. Wie alt er fein mag - wer will es fagen? 24m 25. Jult 1496 fapitulierten dic (5uanden bet Realejos nor der faititianiphen Ritteridgaft, nadidem fie 2 Jahte juwor 
in Sent Barranco bei 2liatanja naft und mur mif der fiḑtenen Sanje und der Stein= falcuder bewafinet dic sepanjerten unt fdywer gerifteten Spanter naheju vernidytet hattent. Das gewaltige kimgert un den Befits der gefegneten Jnfeln, weldies 1402 mit der Sandung des colen normantifhen Ritters Jean Béthencourt auf Eanjarote begonten hatte, fand fenten crgreifenden 2lbjhlub. 500 Jahre find feit jener Jeit verfloffen, wo cin von glühendent fretheitsdrang bejeeltes hirtenvolf, das phantafifthe

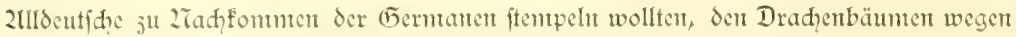

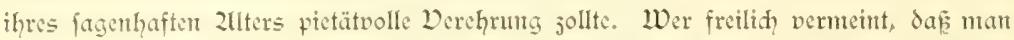

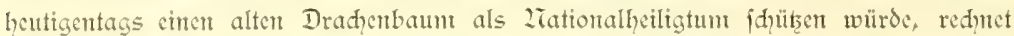

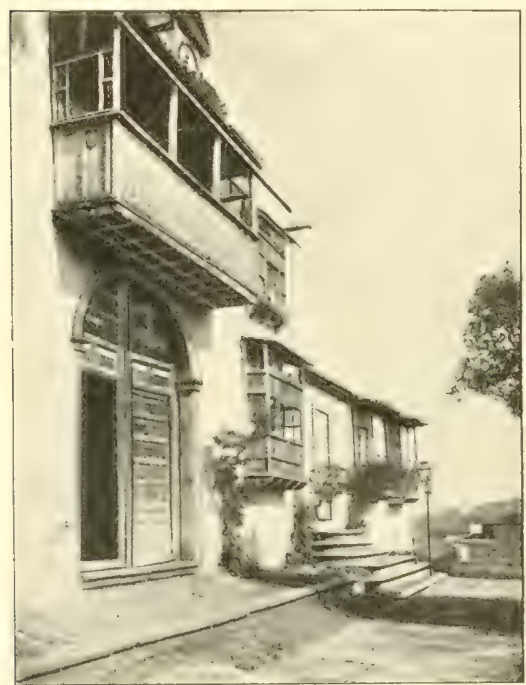

Eambhäufer in Jcob (ăltete Zlựttahnte). nidyt mit dem mangelhaft entwidelten hiftorifhen Sim und dent gänjlid feh= lenden naturwiffenfoftliden Interefie des Spaniers. Er fteht in cinent engen (5ärtden, deffen 2liauer fith an den Stamm anlehnt und von der cinjigen Stclle, wo man ihn fret überblift, dic breit auslaufende Bafts verdedt. Der Befitser, cin einfadier sandmant, bot mir fein 2luwejen mitjant dem Bame für 5500 Duros (etroa 14000 2rarf) an unt wäre wohl nod unt ein Exheb lidhes herabgegangen, wenn id thatjädy = Iid) ju cintem 2Infaufe 2liittel und 2rit= gung gehabt hätte. früher - fo erjählte mir der Direftor des botanifiden (5)ar= tens in Drotava, der Stwweijer Wild= pret - trug or fid mit der abidit, Sen Baum fällen ju lafjen, weil er Sic Kulturen im (5ärthen ju ftark be= Whattete, - crit als frembe fidh häufiger cinftellten und cin bejdeidenes Entgelt ent= ridteten, blicb er vol der Derniditung bewahrt!

Icos ift cin cinfahes Sandfädthen, das dem Drahenbaunt und dent grofartigen Zlusblit auf den pif die Zlujiehungsfraft auf Jen frembling verdanft. Ihm feblen Sic altipanifden Palafte, wic fic nad Ser Erobcrung vort Tenteriffa von 2locls= gejdledtern in der Dilla de Ia Drotava und in Eaguna aus emtent 2lateriale gebaut wurden, das Jahrbunderten Trots bot. Dem ihre reizpollen (F) Gerien futo aus dem Eoljz der Camarienpinic gefdntist, und die Treppuaufgänge beftehen aus den foftbaren Stünmten des Sorbece. In Jeos trifft man mur die befbeidenten cint= oder jweiftöffigen 


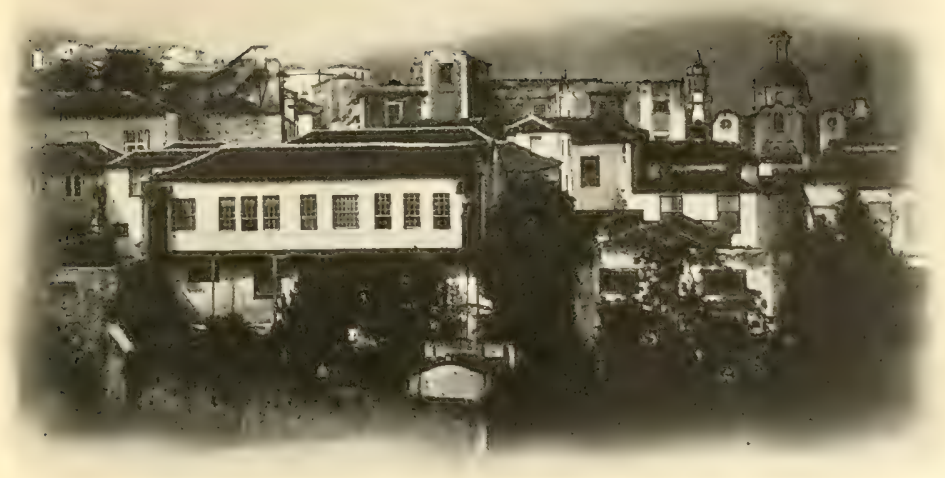

Villa de la Orofava. 2tm pif lagert Die wolfenmand (ältere Ztufnahme).

Sandhäujer, weldhe indeffen durd ihre (5alerieen und vergitterten fenterläden emes

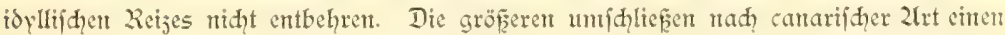
offenen, von Ealerieen umgebenen Patio, in dem Palment und duftige Blütempflanjen gejogen werden. Der Eintretende wird mit gewinnender Siebenswïrdigfeit empfangen unto mit cinen wahren Sabfal, nämliđ cinem (ôlafe füblen filtricrten Walfers, bewill fommnet. Der filtrator aus Kalfinter, Sen man bet sas Palmas bridit, feblt in Feinen Laufe; er filtriert un fo reiner, je tippiger er mit dem reijvollen Demushaar (Adiantum capillus Veneris) bewadifen ift.

Fine Eleme 2luböhe, von deren Rampe man die patende Rundidnt voll gentefit, wird non der einfaḑen Kirḑe gefrönt. 2lus ihr bewegte fid, als wir uns jum 2luf

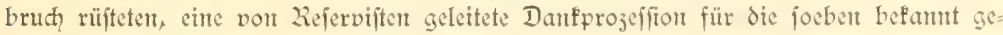
wordente Beendigung bes Krieges. Die ganje Jnjel war durdjdwwärnt von Refer viften in blamen Drilljafen, welde ihrer frende darüber, daf die Canaren volt dem Befuhe ancrifanifher Kriegshdifie veridont geblisben waren, lebhaftm 2lusdrut gaben. - Es fehlte miht in den an der Strafe gelegenen fonden an reidilithen wiba tionent, und dic "zlemanes" fonten fid faum den Ltmannutgent und Dirbribsturgen 
entjithen. "Die Philippinen den Deutidyen!" fo flang es allerorts, "unt dic Karolinen daju!" fo lautete der kicfrain. Weldy eine Wandumg gegen eine jeit, die nur wentige Jahre zurüfliegt!

Der nädjite Taţ galt cinter Durdqquerung der Jnfel, während gleidyzeitig der

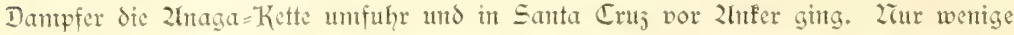
Etellen find in Teneriffa nod norhanden, wo die alte einheimifige Vegetation, fo= weit niḑt die felfenflora in Betraht fommt, fidh ungeftërt erhalten hat. Dies be= trifft ipeciell den Sdmuct der canarifhen Jujeln, nämlith die Sorbeerwälder. So war

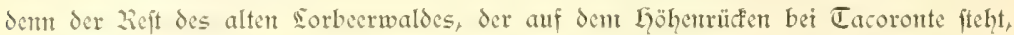
das rädfte zliaridntel. Wir fhicden von Doña Juana, die uns mit ihren ju antmutigen Blüten crwadfienen Cöḑtern den 2lufenthalt behaglid geftaltet hatte, und wendetent uns der gegen Saguna füfhrenden Eandfta ga ju.

Sic gewährt von ber Lqöhe von Santa llifula aus, wo oft dic Palmen fid ju

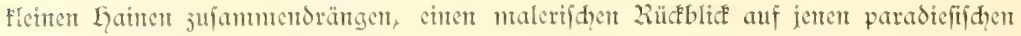
fleffen Erde, der fid Walle de la Drotava nemt.

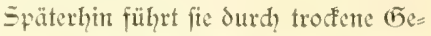
biete, die mit ihren 2lgaven und Kaftus oft cinen mehr italienifhen Charafter ant=

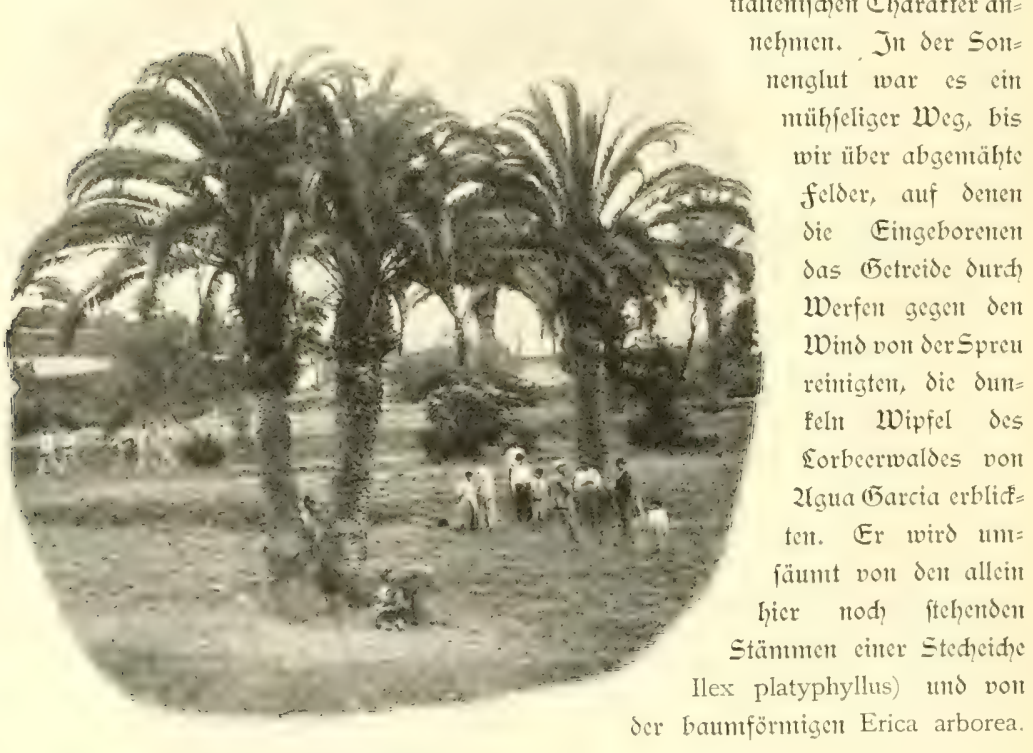

Satta Uriula, falmen (Thoedix camariensis). 


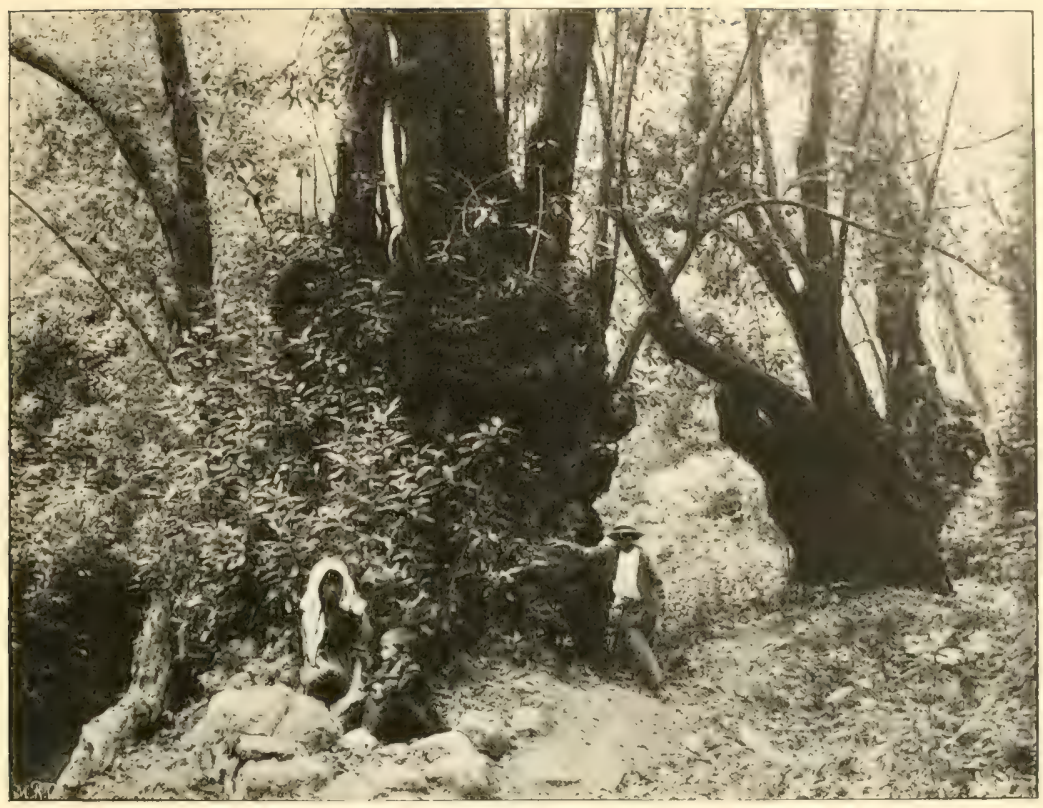

Im Eorbcerwalo von Zlgua Garcia. Strüfe der Persea indica.

Der Sorbeerwald felbft wird hauptfählid, von Laurus canariensis und der von den Eingeborenen Viũatico genantert Persea indica gebildet. Das üppige 2Interholy, Sie an den Stämmen fid anfëelnden farne und die bereits die Eianen der Tropen vorbereitenden Shlinggewähie geben dem Walde einen auferordentlid anbeinelnden 2Inftrid. 2lleroings fant id niḑt verhehlen, daf er mehr und mehr trotz der ftrengen, aber niemals forreft durhgeführten forfigefetze ausgeholjt wird. Daf er

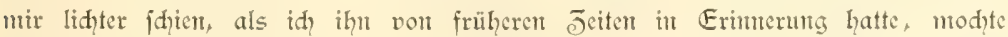
freilich auch durd die trodene Jahresjeit bedingt fem. Jnmmerhin hingen in der an einer laufdigen Quelle begimenden Sdluḑt die langen Wedel der Woodwardia in elegantem Sđwwung an den felswänden nieder, währent das feltent, ant Ende Ser Sdyluht vorfonmende fhwarjgrüne Trichomanes radicans ju diefer Jahresjeit mur in färgliden Wedeln gefunden wurde. 2lït dent geheinntsvollen Dunfel der

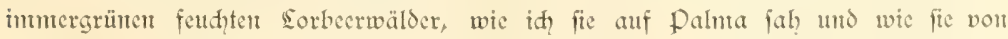
Sem cinfanten Gontera Fenter ftimmungsvoller fdilderte als cht deutfher Botanifer, Bolle, fam es der Wals von 2lgua (Farcia nidht aufnehuten. Trotzen verfehlt 


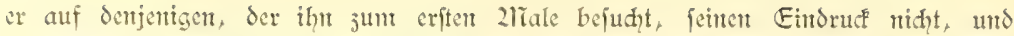

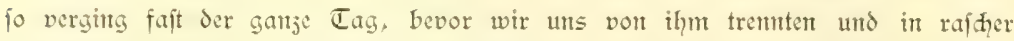
fahrt über Tacoronte in Eaguna, Ser einftigen Gauptifast von Teneriffa, cintrafent. 2liit ihren alten Paläten, die von vergangener Pradht und wohlhabenheit jeugen,

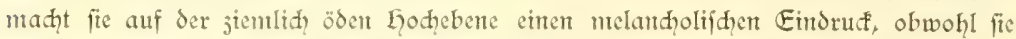
im Sommer, wo die Bewohner von Santa Cruj auf die fühlere Glöhe flüdten, mehr Seben aufweift, als im Winter. Zlud Eaguna befitht feinen alten Dradenbaum, der ïth indeffen mehr in die Breite entfaltet hat und durch feinen ungefügen Stamm citen etwas plumperen Eindrut madyt, als derjenige vort Jeod.

2lls wir die zahlreiden Serpentimen hinab auf dic Sübfeite der Intel nad der gefhäf= tigen Eqauptifaot Santa $\mathbb{C r u j}_{3}$ fuhren, fam es uns vor,

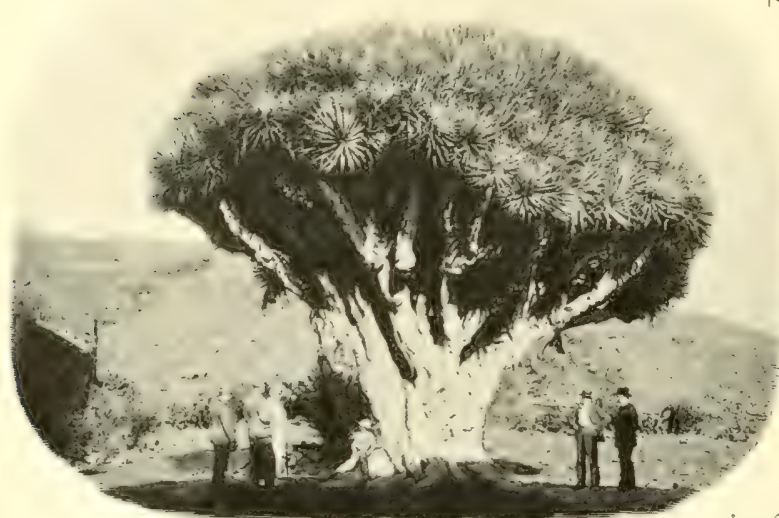
als ob wir aus para= diefilificr Gegend in cin Stüđ Sahara ver= jetzt worden feien: alles war fahl, öbe, veriftaubt und ver= trodfuct. Wir waren froh, als wir dem Treiben der heifen Straf̣en entrüft auf dent luftigen Derded der Valdivia in $\mathfrak{5} e=$ meinifhaft mit unteren in Santa $\mathbb{C}$ ruj anjäjifgen Drafienbaunt not saguna SandsIeuten - von der Dilla

des Konjuls grüf̧e die deutjde flagge - den 2lbend verplandem fomten.

Wem fdion bei der 2lnnäherung an die canaren die Suft ihre gewohnte Klarheif vermiffen lief, fo rahm the immer auffälliger cinen cigentüntid, diffen, unfidtigen charafter an. Wir fuhren in der Zahht nad Sran Camaria $a b$, das nad Somen= aufgang erft in allemädhiter zrähe ju erfenten war und den Zlusblicé auf feine wild jerjaffe Cumbre neidif verwehrte.

Da felbit die nahe gelegene Kauptitadt Las palmas fith bei der mit Wüftenftaul erfüllten Suft den Blifen entjog, mutsten wir gern den furjen durd? 2luffüllen der Bunfer mit Kohlen entfitehenden 2lufenthalt aus, um ihe cinen Befud abjuftatten. Die junt Lafen führente, vont ciner Trambalqn durdjogente Sanditrafse wird durd cine Wanderdüne eingeengt; ihre Staubuaffert wirbeln faft unerträglid̆ auf und geftalten 
Sie fahrt im Godjonmer ju ciner peinlidyen. Daf man Sie grofartigen nenen botels gerabe an dieje Sanditrafse in cine wertig anjiehende Lmegebung verlegte, weldye nidht cimmal über einen günftigen Babeftrans verfügt, fommt beinahe entem fehlgriff gleid?. Jnmmerfin wurde verfithert, dafis fie im Winter von Engländent volfzïlylig beject find.

In nod weit höherem (Frade als bet Santa Cruj mahte fich hier der Einfluf ber Dürre geltend. Der fluf (Fumiguada war vollftändig verfied, und erift bei dem Eintritt in die wohlhabende Stadt wird man angentehm enftäujdt.

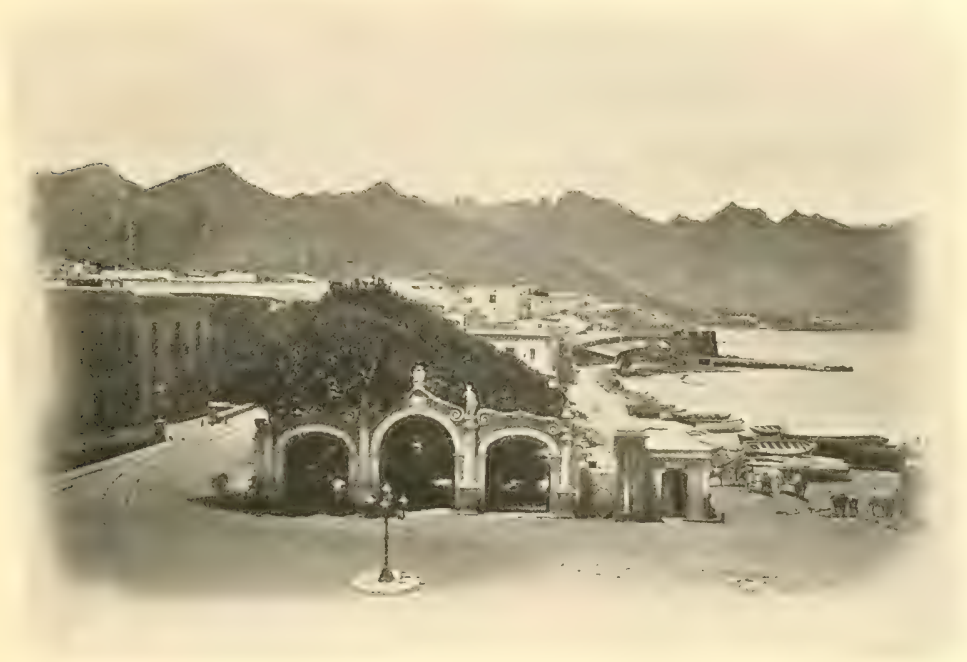

Die Zlamedo von Santa ভruz; int Fintergruno bie Ztnaaa=Kette.

Sas Palntas ift unter den cinen rein curopäifhen Charafter tragenden Städten dic am weiteften nad Süden vorgefdobenc. Die Bevölferung hat fid von der Beimijdung fremben 3 lutes frei gehalten und jeder Derfehr mit den verfommenen Berberftänmen Ser nahen afrifanifden Küite iff ihr ftreng unterfagt. Dies gilt nanentlith für dis fijher, welde bie eritaunlid reidien fifhgründe jwifhen den canaren und dent feft= lande ausbeuten. So madt dem sas Palmas cmen durdqaus fübipanifhen Eindrut, der fïh nidit nur in dent Treiben des Dolfes, fondern aud in der Banart der Läufer und der aus dunflen Quadern crridteten Kathedrale wiederfpiegelt. Eine energifhe Kaufmamifhaft und intelligente sandwirte, weldqe die grofen (5)iter der vort der

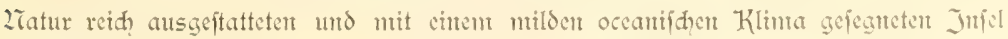


bewirtidaften, Gaben rafd die Krifen überwunden, welde durd den Ziiedergang der

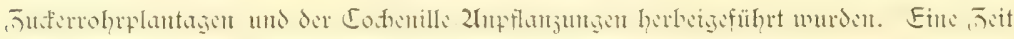
lang überflügelte es Santa Cruj durdy feime trefflidgen Liafenanlagen an der Jsleta; da

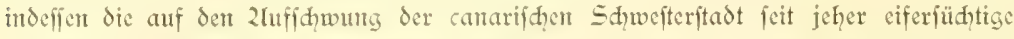
Gauptitad von Teneriffa durd cinen unter enormen Koiten aufgeführten Damm ihre

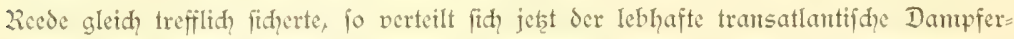
verfehr gleidhmä̈ig auf beide freihafen. Die Bejiehungen ju dent 2liutterlande waren feit jeher imige (Sie Canaren bilden feme Kolonie, fondem eine fpantifye Provinj) und gerabe sas Palnas hat eme ftattliche Jahl von Staatsmämern gelicfert, weldhe den ftreng redtlidfen Sim der canarifhen Bevölferumg auf ihren gröferen Wirfungs= freis übertrugen. Keine ipanifhe Provint, vielleidyt mur wenige Sanditredfen Europas weifen einen ähnlid geringen Projentfat an Derbredien gegen Eigentum und Scben auf. Jener graufant อ̈ug, welher den ftoljen und felbftbewhten Spanier häufig an= haftet, feblt den 3ewohnern der Cantren; man fent dort niht die 2lietseleien der Sticrgefedite und die abgöttiface Derehrung ungebildeter, faltblütiger Toreadores.

Daf aud, für wiffenidiaftlidue Beftrebungen in Sas Palmas Raum ift, bejeugt das

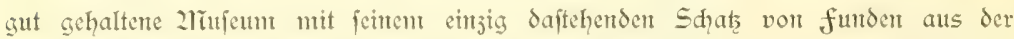
(5) and fareiber der Canaridgen Infels, Don Gregorio Chil y Zaranjo, meinen Befud abjuftatten. Dafer alten 2lialvafier aus freude über das Wiederfehen fredenjte, nahnt man wm fo danfbarer hin, als aud die fahrt durh den an Sas palmas fid? anfhliefenden Barrantco feco nif feinen Bananenhainen und feiner Pradyt an alten canariempalmen uns mit Staub überihülttet hatte.

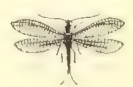




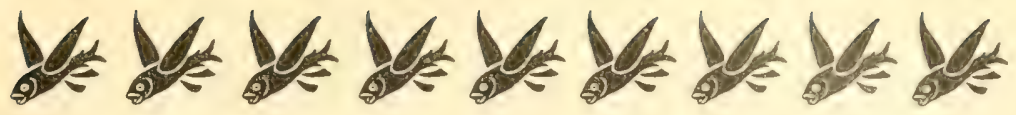

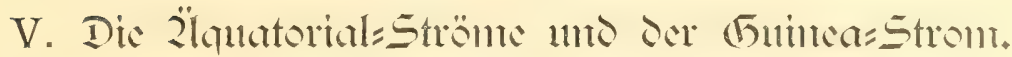

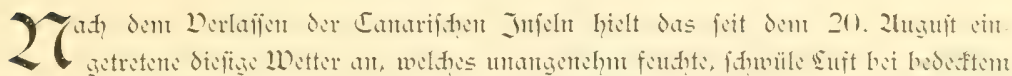

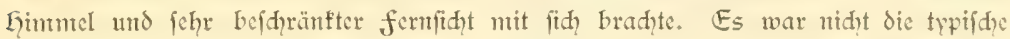
Paffat:Witterung, wie man fie in diefen (5egenden erwarten durfte. Der Einflup der thahen Wiifte mad̨te fid gerade währent unferer fahrt untangenehm geltend und wurde Sent Zluge dadurdh fentlid, dafi feiter, rötlider Wüftenftaub auf der sub=Seite des Sdiffes fich niederifhlug und die weifen Stütenen des Somnenfegels deutlid rot tönte. Der fonftant wehende 2rordoft= Paffat entführt indeffen nidht nur bie bet Sandfinrment aufgewirbelten feinen partifel, fondent bedingt aud, an der Küfte in Bereide der

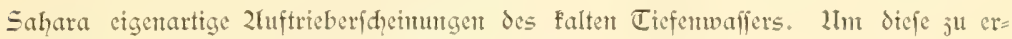
flären, jei es geftattet, etroas weiter ausjuholen.

Wie fhou Gerfhel und franflin nahwiefen, und wie der verftorbente Köntgs= berger (5eograph Jöpprit auf (1)und mathematifher Beredmung darjulegen veriudte, fo ift wefentlid der herrfhende Wind jenex 2liotor, der dic oberflädliden Wafferidjihtent in Bewegung feţt und Deranlafiung 3 u den in fonftanter Kidfung flief̧enden Strö= mungen des 2leeres abgicbt. Da wir in den nädiften Tagen oret mädtige uno für die äquatorialen (bebiete des atlantifhen Deeans widhtige Stromgebiete paffieren follten, nämlid, einerfeits den 2Tord=2̈lquatorialftrom, in den wir gerade eingetreten waren, weiterḩin den (5)incaftron und endiक den Süb=2̈̈quatorialftron, fo nag daranf hingewiefen werden, daf die genannten Strönungen fidh in entgegengefetster Riḑtung bewegen: Ser 2iord=2̈̈quatorialftron flieft int allgenteinen von Diten nad? Weften,

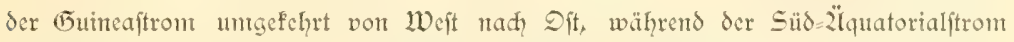

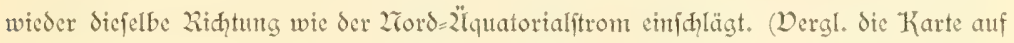
S. 72.) Die Bejiehungen ju den fonftanten Windriḑtungen find hier nidit minder fim fällige, als wir fie fpäterhin aus dent äquatortalen indifhen Drcan werden femten lemen.

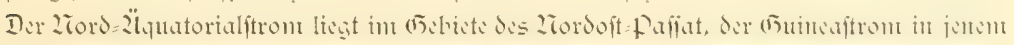
des Sübweft=21onjuns und der Sild=2̈̈quatortalitrom im (5ebiete des Siidoft=paffat.

Da mun der 2Tordoft=Pafjat die warmen oberflädylidgen Wafferfhiḑten vor der afrifanifdyen Küfte weg in den freicn Decan treibt, fant chn Erjats für die abfliefenton 


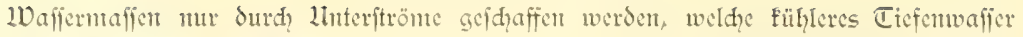
an Sie Dherfläde befördern.

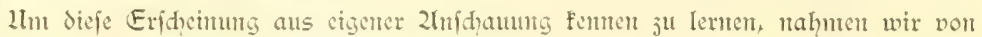
Gran Canaria aus den Kurs gegen bie afrifanijhe Küfte, und jwar gegen jenen leidht vorfpringenden Punft, der als Kap Bojador bejeidnet wird. Das 2lufquellen falten Waffers jeigte fid uns wentiger deutlid, als früheren Beobadtern, welde in 2luguft bei 2liogador mu $15,6^{\circ}$ maf̧en: Temperaturen, denen man in der gleidhen Jahresjet erft

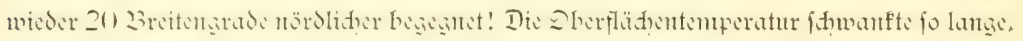
als wir in der 2Tähe der Küffe unferen 1Interfuhungen nahghingen (an 24. 2fugujt waren wir mu 40 Scemeilen von the entfernt), jwifhen $20,5^{\circ}$ und $22^{\circ}$. 2radjden wir it =

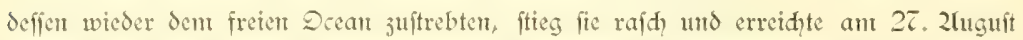
bereits 26. Das fund im Limblite auf dic auffälige Konftanj der Temperatur in den

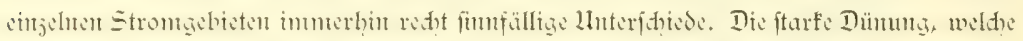
der fräftig wehende 2Tordoit=Pafiat bedingte, erleiditerte es uns freilid, nidt, unferen ge= wohnten 2trbeiten, dem tüglidhen Soten, fijhen und zliefjen der Tiefentemperaturen nat)= jugehen. Das Sdiff rollte ftarf́ während des Stilleliegens und nahm mandie See riber. Der Chemifer und Bafteriologe waren gertötigt, die Sufen über ihren Eaboratorien dichten ju laffen, und die Joologen wurden ju häufigen Ltmarmungen ihrer 2lïtroffope veranlaह̧t.

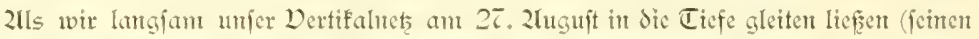
(5lascimer unwifelten mir mit ciner 2liatte, um bei den 24uffommen ein ङerbreden

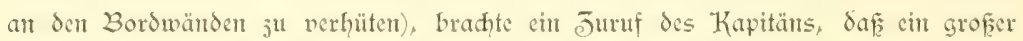
Lat das Sdiffi umfreife, alles in 2lufregung. 2lian ftünt auf bic 3atf, wo raid?

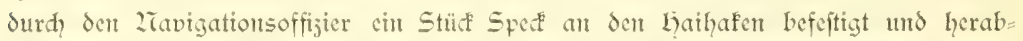
gelaffen wird. Bald gewahren wir den Carcharias mit graubrüutlidem Rücen, grofeen 23rujt= und Rücenflofien und breitem Kopfe, der langam um das Drahtieil des Der

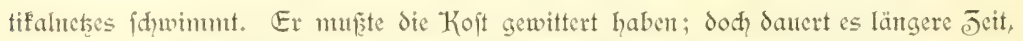
bis or in die zrähe des Lafens gelangt. Einten ungement feffelnden 2lnblic gewährte es, als dic dic Gaie ftets begleitenden piloten (Naucrates ductor) nit ihrer Jacbra= Streifung gleidfalls fidytbar murden und unemüblid alle Wendungen des riefenhaften Genoffen in elegantent Bogen mitmadten, indent fie bald über Sen Dorderförper (đ)wammen, bald unter den Bruftfloffen fid decften. 2lït gefpanter 2lufmerfianteit verfolgen wir alle bewegungen, bis fdlicfilid der Lafen dadurd gefapt wird, daf der Gai finh auf die Seite legt unt mit dem unterftändigen 2liaule den fetten Biffen ju ver= idlingen fudpt. Dies giebt das Signal jum 2ufjichert. Jeder greift an, aber es ift

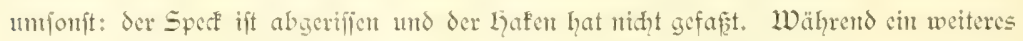
Stüc巨 an letsterem befejtigt und angebunden wird, verfündet ein Jumf, daf ein jweiter

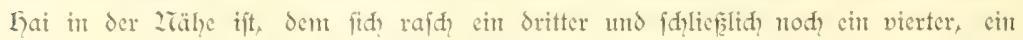
jeder mit feinen flemen Begleiten, hinjugejellt. Bubtg und langfam in eleganten 
Sogen mufreifen die mädtigen Tiere das Dorderteil des Shifies, während cin jweitur Köber an Gafen ifhen jugeworfen wird. Es dauert dent aud nidt lange, bis der crite Lafen gefalst wird und im kaden fepthaftet. Die wilbe 2lufregung, weldye fid

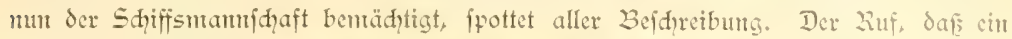
Gai an der Larpune häugt, dringt in dent Zliajhinenraum, in die Kühe unt in die Kojen. Don allen Sciten ftürmt de zliamidaft herbet und jicht an dent Tau, während der Lai, fei= nem Element entriffen, an Sem Lifen fid wils bäumt unt mit Ser Sdwwantlofie dic Bord= mantung peitidit, fo daf weithin dic Sdylägc Sröhnen. Bals criheint fein blutiger, mit orei=

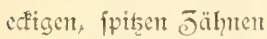
bejetster Radyen an der Reeling; einen Rud und bie Beftie liegt an 3ord, nady alfen Sei= ten fid emporjduncllend und raiend mit dem Shwanje um fidh filla= gent.

Da heifst es vorfich = tig fein, um nidyt $\delta \mathrm{cm}$ 2Tanle oder der weit ge fährlideren Sdhmanj= flofic nahe ju fommen.

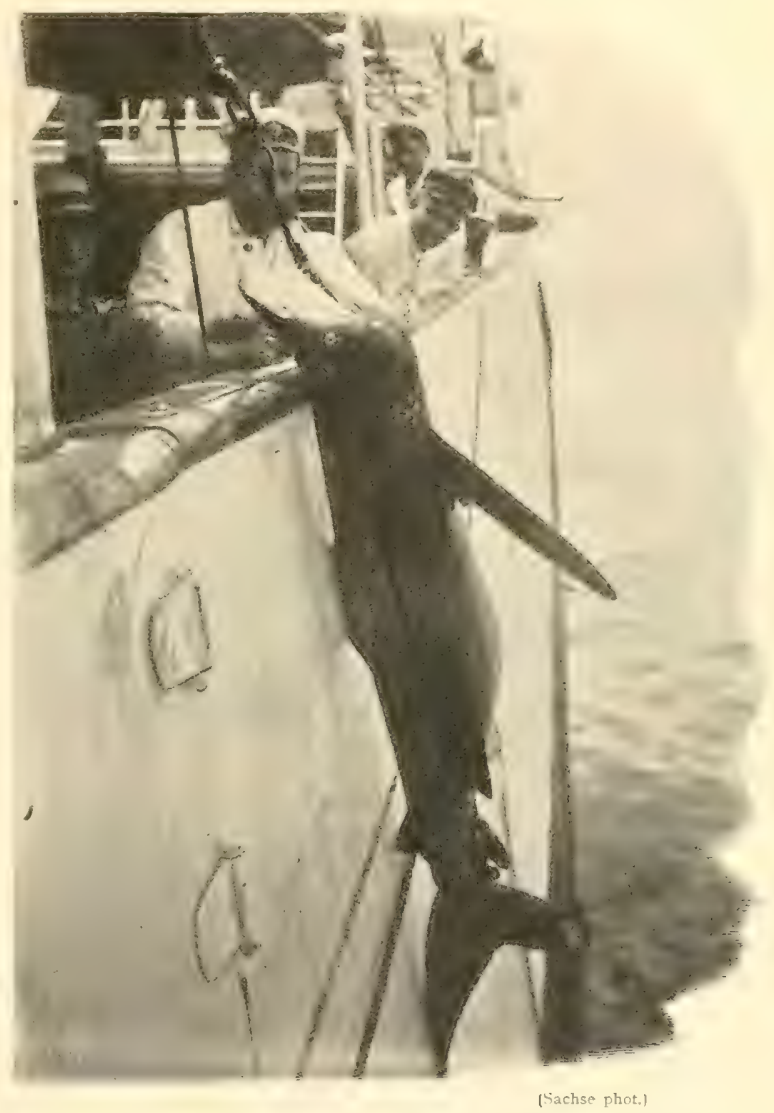

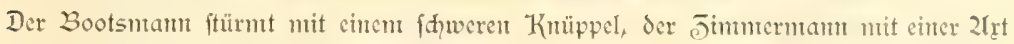
herbei, während andere ein Tauende um den Sdiwanj ju werfen verjuchen, das den! aud falteflid fast und eng um cinen Blod gewurden wird. 2rur mit 2liühe gelingt

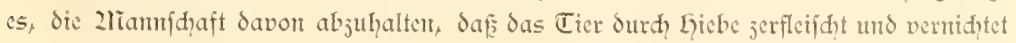


wird. Der Lai ift der gefduorene fento des Semantmes, unt nie habe id wildere Edimpfworte gehört, als fie dent gefeffelten 3eherrfher der 2lieere ju teil wurden.

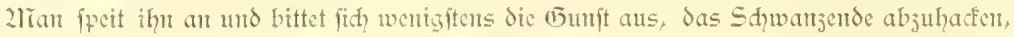
aus dem das 3lut in diffen Strönen hervoridiefst.

Während wir nod tm das crffe Dpfer befdäftigt find, verfündet cin frenden=

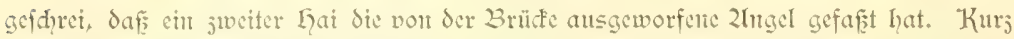
darauf betint der dritte, follieflid aud der vierte an. Jesesmal wiederholen fid die=

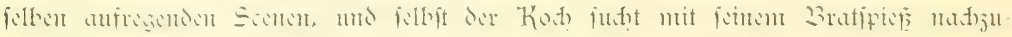
Gelfen, daf dic wütenden Beptien glüflid über dic Recling an Bord gehifst werden.

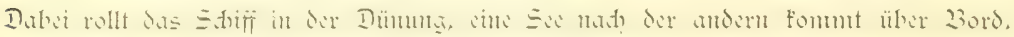
übergiefst den z̈bereifrigen photographen und wirft die andern nieder, die angitboll nad den Tauende greffen, un uidht in den blutigen Gifd̨t, in dem die Late das Devf

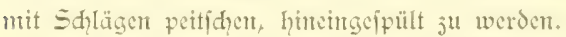

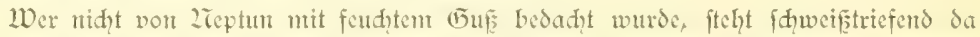

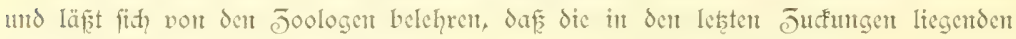
Eaic Ser (5)attung Carcharias, und jwar der in diefen kegionen häufigen 2lut Carcharias Lamia, angehörent. Darauf deutet die ungewöhnlithe 3reite der Bruftfloffe, dic Stellung der hohen, vorderen kïfenflofle, die abgerundete, wenig verlängerte Sdmauje

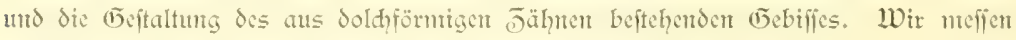
cin Ermtplar und finden, dafí es dic immerhin beträd)tlidye Sänge von $2,48 \mathrm{~m}$ (von der Sduaujenfpitse bis jun Ende der Shwantaflofic) anfweift. Bet der Sction, die

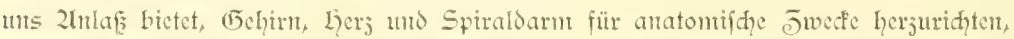
crgilbt es fid, daf der zliagen vollitändig leer war. Dic Befticu milfen einen wabren Geiphunger verfpürt haben, da es fonft faum erflärlid? gewefer wäre, daf fie trots der abgefuerten Sdüfle der Reihe nad anbiffen und uns in fo reider Jabl jum Dpfer fielen. Laififde haben fpäterhin mu allju oft dem ftilliegenden Sdyiff Befuch $a b=$ geffattet und uts leider gar mandumal die Suft benommen, das fleine Boot ausfetzen ju laffer, unt der pelagifden Dberflähenfifderet nadyugehen.

ïtber die aufregende Jagd hatten wir faum darauf gead)tet, dafi wir den Wende= freis überfhritten unt in die Tropenregion cintraten. Die junthmende Wäme der letzten Tage überjeugte uns hiervon redt cindringlid, nitht minder aud die folgen des hohen feuditigfeitsgrades der Euft. Die Kleider in den Sdränfen, dic Stiefel, Sederembände der Büdjer, felbit dic Cigarren hatten fid mit cinen grünen Sdinmel= belag überjogen, und die Injtrumente nebft Stahlfedern begannen ju roften.

Der fräftige Paffat hatte von dem feftlande her cine gröfere 2lujahl von Dögeln veridylagen, welde jum Teil vollfändig cmattet bas Sdiff als Ruheplats aufíthiten. Dbwohl wir uns bereits in grofiem Zlbitande von der Küpte befanden, war bod die 2Irtenjahl der Dögel, von denent wir mur ungern cinige als intereffante Belege für dic 
Deriḑleppung von Drganisment crlegten, cine auffälig grofic. Din Gauptbeftandteil bildeten mehrere Würger (Lanius senator) und flemere Singuägel, die fald cifrig an 3ord auf die jablreidien Sdmetterlinge, fleme Eulen, Spanner und andere formen Jago madjten. Die reide Kolleftion von verfdilagenen Jnfeften, weldie überall auf dent Somenfegel erbentet wurden, ift ein Seutlider fingerzeig dafür, daf nran de Derbreitung flugfähiger Drganismen durd Wind und Sdiffe nidht unterfäbisen foll. Wir fammelten an 28. 2fugut auf dent Somrenfegel 50 Sdmmetterlinge, weldye un= sefähr 15 2renten angehören.

Erit in der Zähe der capverden maḑte fich am 29. 2luguft ein Witterungs umfdilag geltend. Er war von ciner auferordentlid heftigen Regentöe begletect, dic $19,6 \mathrm{~mm}$ 2Tiederidtag und cine angenehm empfundene 2tbfühlung der 5 uft von $2 \pi, 5^{\circ} \mathrm{C}$. auf $24^{\circ} \mathrm{C}$. mit fid? bradte. Dafi man Sen Tropentegen willfommen hief uns mit (5̃muf dic vont Gimmel nieder.

geherde Dujde ausumbte,

Iag auf der Lqand: wir

hatten ja feinte Da=

men an Bord.

Shon it der

radit jum 29.

zugujt fidfeten

wir dic ant wei=

teften öftich ge=

legene Injel ber Cap=

verden, Boavifta. 2Uls

Ianggeftredtes Eiland mit vor=

gelagerten Dünen und Fahlen, ijoliert

Bouvifta.

aufftrebertden, fteilen Kegeht, denen freilid der pittoresfe 2lufbau der Canaren febli, bot fid uns diefe vegetationslofe, nur in den Thälern hier und da grüne Streifen auf= weifende Capverden=Infel dar. Ein prädtiger Tropenabend nah dem (5emitter lief; uns bei Sonnemuntergang einen DorgefomatF von jener 2liffumb farbiger Tinten cmpfinden, wie wir fie fpäter nod fo vielfad, bewundein follten. In violetten, nad? Somemuntergang fajt fdwwarjen Tönen lag Boavifta vor uns; in Weften waren die Wolken blutrot gefärbt, während die See fḑwärlich wie gefdmoljentes Blei fid ausnahm.

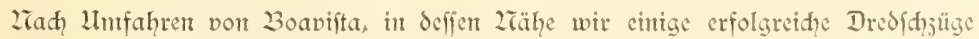
ausführter, die uns namentlid) an (5lasid̨wämmen (Geractinellidnn) und Korallen (Isis) mit orange gefärbten Polypen cine reidge 2lusbeute lieferten, wurbe der Kurs in

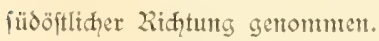




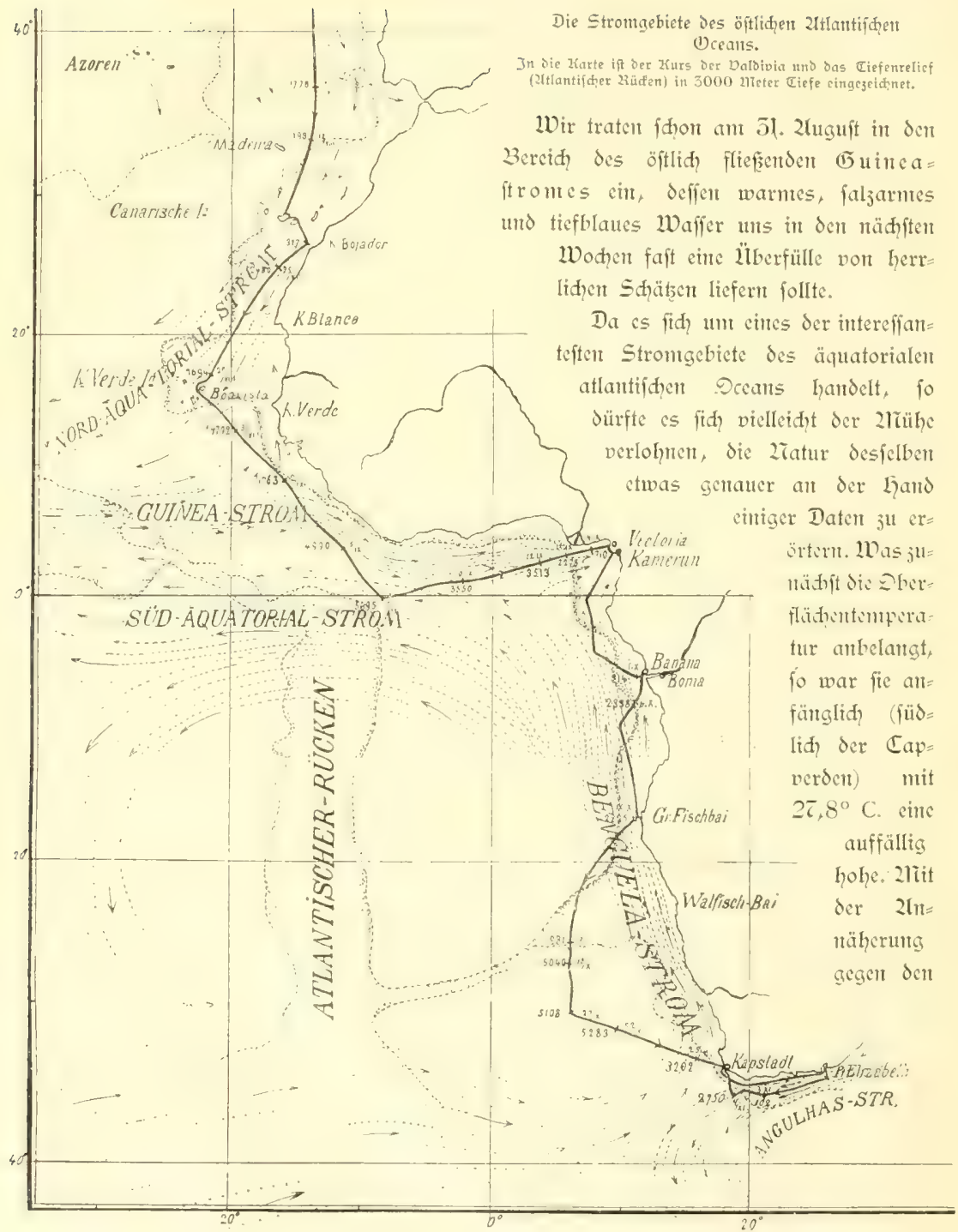


Z̈̈quator fanf fie etwas, offenbar unter dent Einfluffe des regnerifकen Südweft 2lionfuns. Befonders auffällig ift indeffen das Derhalten der Tenteraturen in tieferen Sd fidten. Eine Tentperaturferie, die wir am 2. September immitten des (Tuinteaftrontes ans führten, ergab nad, den Beobaditungen des Decanographen folgende Reithe:

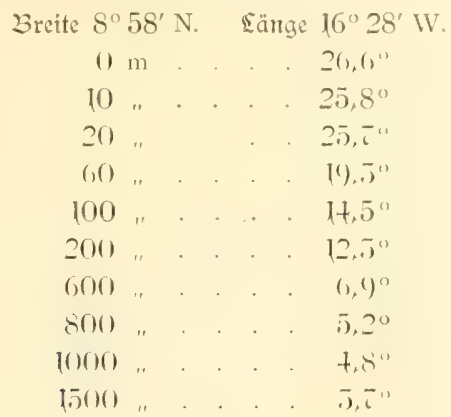

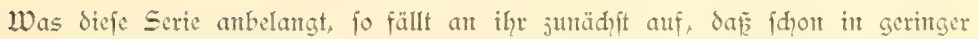
Tiefe das Waffer auffällig fälter ijt, als an der Dberflähe; wir fanden es berets an 50. 2ugujt in $50 \mathrm{~m}$ Tiefe um $10^{\circ}$ fübler, als an ber Dberflüde, imfofern damals in $50 \mathrm{~m}$ Tiefe $1 \tau, 8^{\circ}$, an der Sberflähe hingegen $2 \tau, 4^{\circ}$ gemeffen wurden.

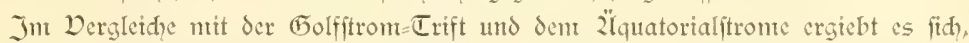
daf die Tiefentemperaturen int (Jumeaftrome erheblid, niedriger liegen. Hut dies an einem fpecicllen 33 cifpiele ju crläntern, ntöge eine Temperaturferie aus dent Cantarien= ftrome (öflid von 2liadeira) derjenigen aus dem (Sumeaftronte an die Seite geftelt werden.

Cantarient $=$ Stront

$\begin{array}{rcc}m & \text { Fuincajtrom } & \left(52^{\circ} l^{\prime} \mathrm{N} \text {. unt } 15^{\circ} 5^{\prime} \mathrm{W} .\right) \\ 0 & 26,6^{\circ} & 21,6^{\circ} \\ 100 & 14,5^{\circ} & 16,9^{\circ} \\ 200 & 12,5^{\circ} & 15,2^{\circ} \\ 600 & 6,9^{\circ} & 11,4^{\circ} \\ 800 & 5,2^{\circ} & 9,9^{\circ} \\ 1000 & 4,8^{\circ} & 8,8^{\circ}\end{array}$

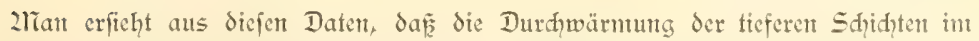

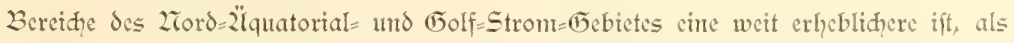
diejenige in (5ebiete des Enumeaftromes. In $1000 \mathrm{~m}$ Tiefe ift das Scewafier in crifteren um $4^{\circ}$ wärnter, als in Ietzerent, obwohl die Dberfläd)ententperatur des Gumea= ftrontes beträd,tid höher liegt. 


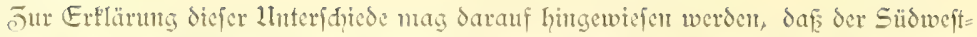
2lomfun bei cinent ftändig hohen feuditigteitsgehalt der Suft fonwüles und regnerifines Wetter bei metift bedecftem Limmel jux folge hat. Die Derdunftung an der zreeres= oberflähe wird herabgefetst, die niedergehenden Regenmaffen tragen jur Derminderung des Saljgehaltes bei und das fpecififo leidnte Waffer wird ftarf erwärmt, olpte in dis Ciefe ju futem.

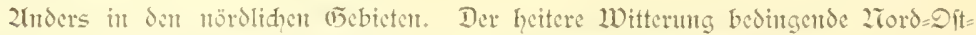
Paffat hat eine ftätfere Derdunftutg des Dberflädfumaffers in Eefolge. Infolge=

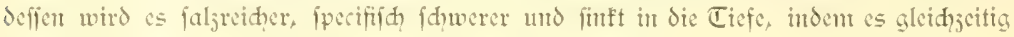
feinen Wirmevorrat an bie tieferen Şidjten abgiebt.

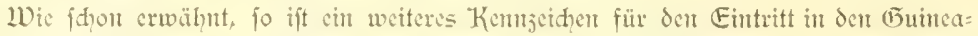

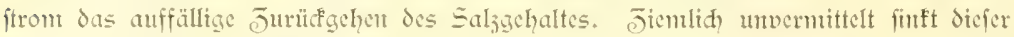
Wert vort 56\% im Paffatzebiet auf $57_{0 \%}$; ein Betrag, der ungeführ der Salinitüt

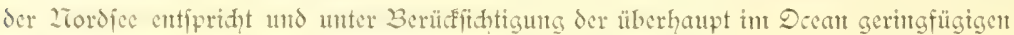
Lluterfajede cin redpt beträdflider genant werden darf.

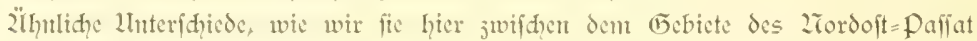
Into des (5umeaftromes Gervorfoben, traten uns, mir in ungefehrter folge, ent= segen, als wir jehn Tage nad) dem Eintritte in den Guineap̣tron uns dem Z̈̈quator näherten uns die Wirfung des Sïdäquatorialftrontes veripürten. Der Südweft=21Tonfun

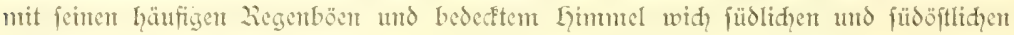
Winden, fo daf wir bereits am 6.-8. Septentber, als das Shiff den z̈lquator pafierte, ein 2lufflaren des bimmels und heitere, dem Sildoft=paffat entiprediende

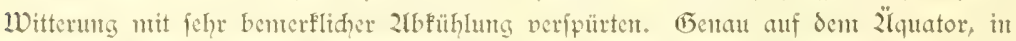
Jer Zradit vom 7. zum 8. September, traf es fid, daf wir cine für dic Tropen anfer= ordentlid nicdrige Suftemperatur bort $21,6^{\circ}$ und eite Waffertemperatur von mur $21,9^{\circ}$ hatten. Was dicfe anbelangt, fo ift fie nidyt verwunderlid, da wir ohne Jొwetfel in den Südäquatorialftrom reip. in die letsten Zlusläufer des fühlen Benguelajtrontes cin= getreten waren. Dafür fprad, aud die auffallend veränderte Wafferfarbe; aus dem tiefen Blau ging fie in cine blaugrüne über, und sic Durdyfthtigleit des Wafjers, die int (5) der Sinte jurïf bis auf 12-15 m. 2luf̧erdem waren die Stromverjetzungen, die vorher Surdweg nach Sit und Südoft geridftet waren, feit dem 8. September nad 2rord und 2iordoft geriḑtet. Fin weiteres 2unzeident für das Derlaffen des Fuineajtrontes war die mumrehr allmählid, vor fid gehende Junahme des Saljgehaltes des Dberflähen= waffers, der indefien nidft den hohen Betrag des 2rordopt=Paffat=(15ebietes erreidit.

2lït den hier gefdilderten oceanographifden Derfdiedenheiten der orei grof̧en

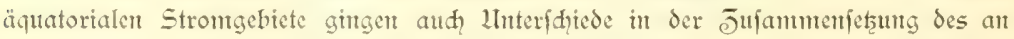
der Dberfläde flottierenden 2liaterials von Drganismen, des fogenamnten Planfton. 
Gand in Land. Da fie immerbin ciniges Jutereffe bieten und aud fpater nodh von unts herangejogen werden follent, unt die Biologic der Tieffec=Srizanismen verftändid erfocinen ju laffet, fei es geftattet, dieje furj ju diafafterifieren.

frühere Unterfudiungen, insbefondere audh diejenigen Ser Planfton= Expedition,

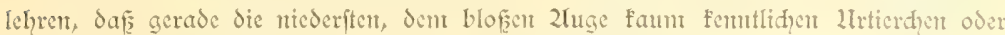

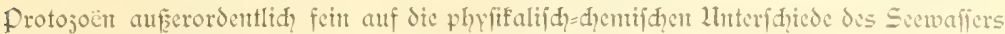
in den verfdicdenen Strontgebicten reagie= rent. Es handelt fid hierbet umt cinjellige Drganisnten, die uns das Echen in denffor cinfadifter, faft natter form jur Shau tragen. Dicje Protojoën fáciden fid in forment weldic einerieits mekr pflanjlidhe, andererietts mehr tierifac Charaf tere aufrocifen, obnc daf indefien, wie mat it tteucrer बeit er: fannte, ein fharfer Ent= fheio möglid) wäre, fic dent Tier $=$ reip. Pflan= jenreidie jujurediten. Unter jenen Protojoën, ïber deren tierifde rejp. pflanjlide ziatur jeit jeher Botanifer und Joologen ftreitert, ver= dienent cit befonderes

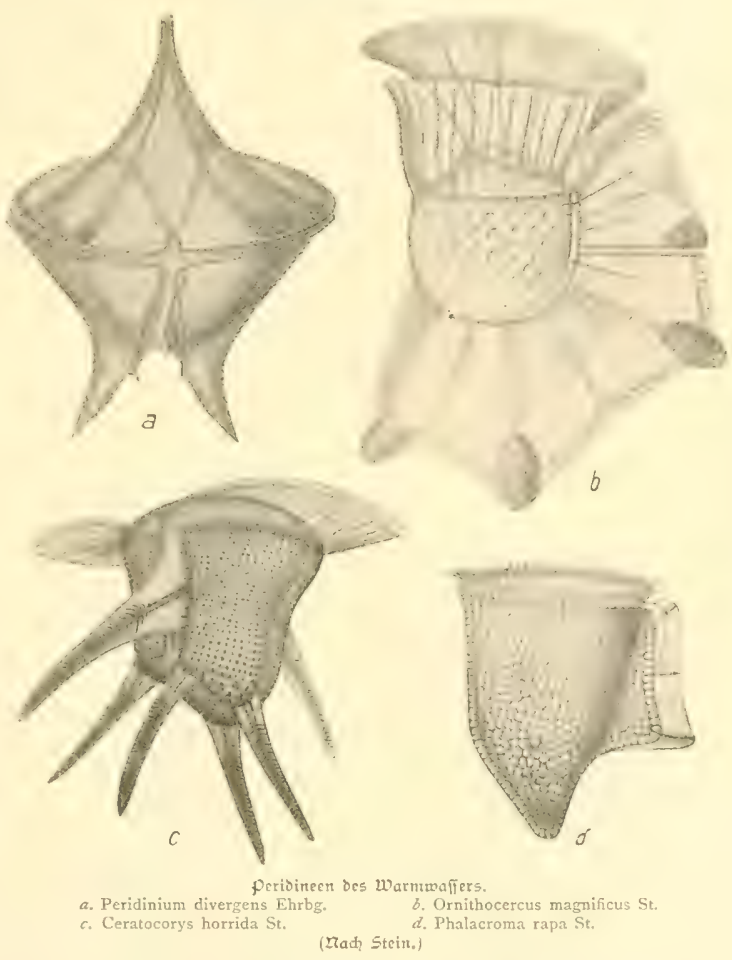
Jutereffe die fogenamnten Getfäelinfujorien oder flagellaten. Ein Teil derielben ift mit der fäbigfeit betraut, nad? 2lrt der Pflanjen aus den vom Secwaffer abforbtertent unt in ihnt enthaltenen anorganifhen Beftandteilen, vornehmlid aus Kohlenfünes = und Stifftofjuerbindungen, unter der Einwirfung des Somenlidis ihren aus Eiveif be= ftehenden อ̄elletb aufjubauen.

Dies vermögen freilith mur jene, weldhe einen dent grünet farbitoff der Pflanzent, 
dent Chlorophyll, nahe verwanden bräun= liden oder gelbliden farbiftofi aufweijen. Er iift an fugelige oder fonctbenfömntige łleme Protoplasmaidiollen, fogenamte Chromato= phoren, gebutden, weldye der כellwandung anliegen. Da nut gerade dieje flagellaten in befonderer zlaffentaftigfeit an der $\mathcal{D b e r}=$ Flädxe des Decans flotticren, erweifen fie fid als 2Tabrungsproduzenten, welhe in lehter Sinte die Eriftenj aller höheren marinen Dr: ganisment bedingen.

Lnter den für den baushalt des 2liecres widtigen flagellaten ijt die familic der Peridineen Surch jwei (5eifeln ausgejeidunet, deren cine in einer den Jellförper quer unt= fümmenden furde gelegen ift, während de andere aus cincr fenfredt ju derielben geftellten, tiefen (5rube hervorragt. Ein ftarrer Panjer, oft durd lange fortiätze oder durd flügelähnlidhe, wie Segel oder fallidirme ge= ftaltete Derbreiterungen ausgejeidnet, fdütht den Weidförper. Da den letsteren bisweilet die Chromatophoren fehlen, find miḑt alle Perioineen als "2rahrungsproduzenten" be= fähigh ju affimilieren. Es ift bemerfenswert, Saf das Vorbandenfen oder der 2liangel von 2lfimtilationsorganen durdhaus nidht ber fyite= matifhen Dermandtjhaft parallel läuft; fo entbehrt j. 23. Das Peridinium divergens der chromatophoren und ift auf organifhe Koit angewiefer, während andere 2lrten derfelben (5attung 1rad) 2lut dev Pflanzen ju affimtilieren int fande find. Es foll fpäterbin nod darauf hingewiejen werden, daf das Überwiegen pflatilider refp. tierifder Charaftere, wie es durd das Dorhandenfem oder durd? den 2lian= gel vou Ehrontatophoren bedingt wird, vont wejentlidem Einflufi an dic vertifale Tiefent= 
verbreitung der Peridineen ift. Jnt wumberbarer Pracht und Ïlppigfett traten unts diefe peridineen in dent Gebicte des (5umeaftroms entgegen. Dic bei= ftehenden 2lbbildungen, weldhe Dertreter der Gattungen Peridinium, Ornithocercus, Ceratocorys und Phalacroma dariftllent, möger stuen Begriff geben von den 2lrchiteftontf unt reijvollen Sḑalen Sfulptur dicfer win= jigen formen. J̄u thnen gefellen fid dic langen, ftabförmig ausgejogenen 2lrten der (5attung Amphisolenia, und die mit drei fort= fätzen ausgeftatteten Dertreter der Fattung Ceratium. Zuferdent trat nod cine fleine, cinjellige, fugelige allge, die durh ihr seudhtvermtögen ausge= jeidnete Pyrocystis noctiluca, maffenhaft auf. 2rian

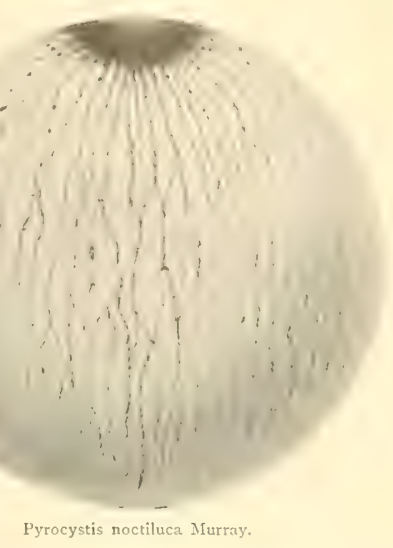
glaubt juerit, daf man es mit bijarr gejtalteten Kindern ciner nad ifpen Samten

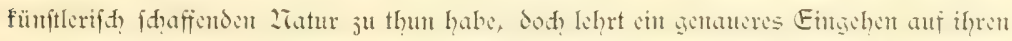

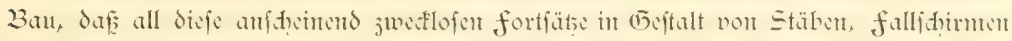
und Segeln che widtige funftion ju erfüllen haben. Wic cint tühtiger Kenner der

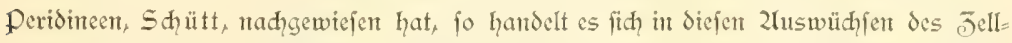
reibes um Shwebevorrihtungen, welḑe Reibungswiderftände in dem Seewaffer folfaffen unt es ermögliḑen, daf die ohnehin leiḑten Drgantsmten in den Waffer auf ungefähr gleidiem Zitweau fid jedenfalls folange fiqwebend erhalten, als fie noh unter dem Einfluffe des Sontenlidites ju affimilieren im ftande find. Profeffor Sdimper madhte

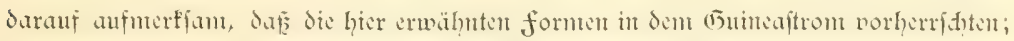
fie traten reiḑlidyer alf, als wir die erften Deränderungen in der Qualität des See=

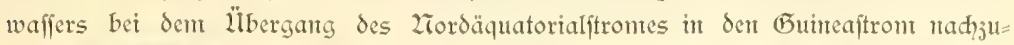
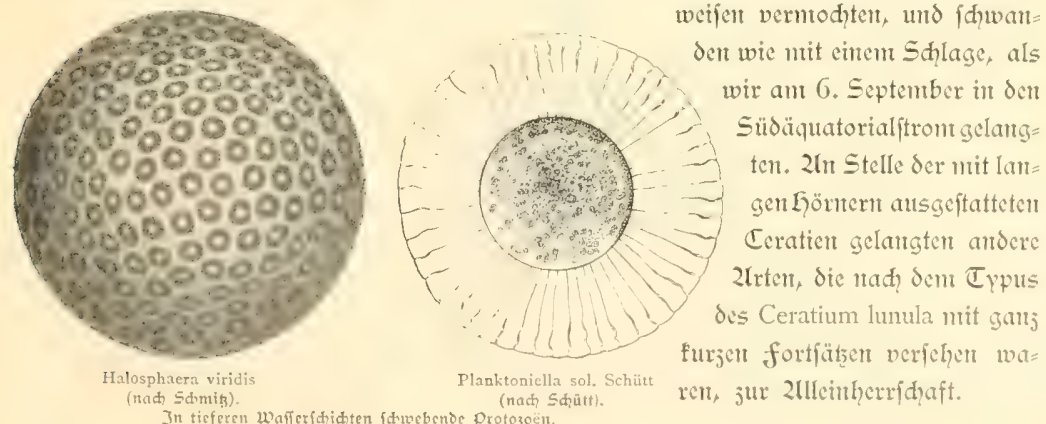
In tieferen Wafferfdiditen fatiobende protozoen. 
Dagegen ergaben unfere Bcobadtungen mit den Sdpliefnetsen, dap in den drei Etromgebieten gleidymäfigig 2trten von Peridinen, cingelligen 2Ilgen und Diatomen vorfanten, dic freilich an der Dberflädye vollitändig fehlten, und erit in den tieferent Wafferfdidyten von 80 bis $100 \mathrm{~m}$ an beobadytet wurden. Dicie "Sdyattenflora", welhe die intenfive Beliditung und hohe Temperatur des Dberflähenwaffers fdheut, befteht cincrieits aus ciner fugeligen, cinjelligen, mit grünen Chlorophyllërpern ansgeftatteten Zlge, Halosphaera viridis, andererfeits aus jwei Zrten der (Gattung Planctoniella, uno endid aus cher mit relatio difem Kicfelpanjer ansgeftatteten Diatomee aus der (5)attung Coscinodiscus; fie fheinen nidht unterhalb $500 \mathrm{~m}$, wo für unfer 2luge bereits

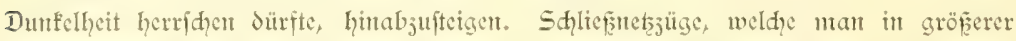
Tiefe ansführt, bringen jwar ente fülle $\delta$ er genamten formen al die Dberflädye, aber cine genauere linterfudung ergiebt, dafs entweder mur nod die ftarre 2lĩentbran vorhanden ift, oder der Protoplasmaförper ftarf jerfetst vorlegt.

2luf bie hier furz ffijzierten Beobadtungen werden wir in weiteren Derlauf unferer Darftellutg nod jurüffommen, und fo möge dent mur cine frage, die fíh vielleiḑt

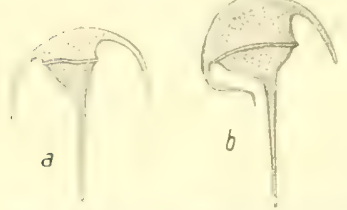

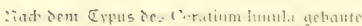

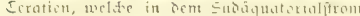
vorherrifien. dem Ecfer aufdrängt, beantwortet werdent: Woher

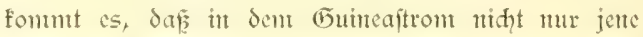

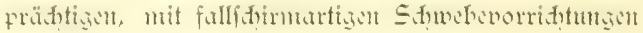
ausgeftatteten formen vorherriden, fondern nor allem aud) Sic Ceratien mit monftrös langen Görnem ver: fehen find, wähıend in den z̈̈quatorialftrönen formen mit fihr furjen fortfätsen and relatio mangelhaft ant. widelten Sđwebevorriłhtungen vorwiegen?

Da es ja mfer Beftreben ift, die Ōeftalten der tierifden und pflanjlidgen Körper. ju crflären und mit den äuperen Exiftenbedingungen in Einflang ju bringen, wird man maturgemäf dic verfhiedene Qualität des Seewajfers in Red)mung jichen. Da verdient nun in erfter Sinie hervorgehoben ju werden, daf der (Ëutteaftron durd? geringen Saljgehalt unt hohe Dberflädentemparatur vor $\delta \mathrm{em}$ 2Tord = und Sübäquatorial= ftron fid ausjeidnet. Berednet man das abfolute ppecififhe (5ewiḑt des ober: flähenwaffers nad) der formel $S_{4^{0}}^{t^{\prime \prime}}$ (wobei $S$ den Saljgehalt, $t$ die Waffertemteratur bedeutet), fo ergiebt fid, für den 2rordäuatorialftrom der 10 ert 1,024 , für den (Bumea= ftrom 1,022, unt für den Sïdäquatorialftron wiederum 1,024 . Wem es fid aud? Gierbet un Werte handelt, die erft in der dritten Decimale jum 2lusdruff fonmen, fo lehren doh immerbin diefe Ltrterfaiede, dafs das fühlere Waffer der 2̈lquatorialftröme

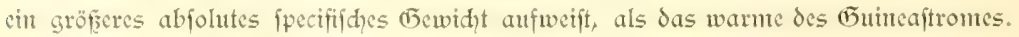

Jd war anfünglid genteigt, die verfifiedene Didte des Seewaffers in den einjelnen Etrongebteten für dic mehx oder ntinder ausgicbige Entwidelung der jum Sduweber 


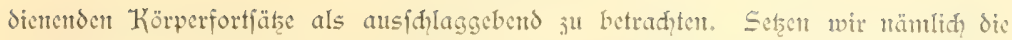
Sdpwebefähigfeit cinem Sinfen mit mimmaler (5efduwindigfeit gleidy, fo mürde es

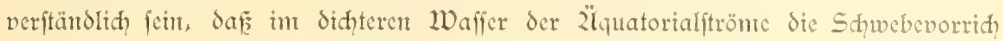
tungen weniger ausgiebig entwidelt find, als im weniger didnten des Gutneaftromes. Jitdeffen bit id, Surd meinen Kollegen, Prof. Ditwald, darauf aufnerfiant gentadyt

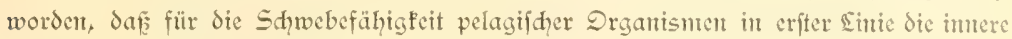
Reibung des Waffers in Betraḑt fommt. Die letstere ift von der Tentperatut in sinen fonftanten Derbältnis abhängig, imjofern fie jientid? genau für cinten forad $11 m$ 2"\% abnimmt. So beträgt 3 . 23. bei ciner Temperatur von $25^{\circ}$ die imere Reibung gerade die Lälfte von derjenigen, welde bei $0^{\circ}$ vorhanden ift. Da mun bet gleider Sinfgejdywindigfeit die Dberflähe des finfenden Körpers proportional der interen

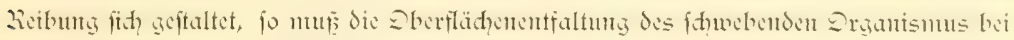
ciner fonftanten Temperatur von $25^{\circ}$ doppelt fo grof feir, als bei cince foldqen vont $0^{\circ}$.

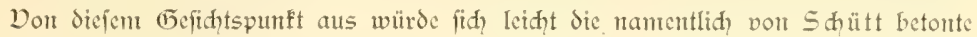
Thatiade crflären, dafs die Ceraticn des falten polaren Waffers durd ihre cinfadie

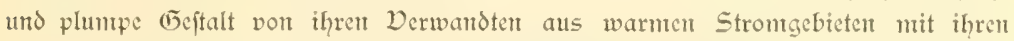

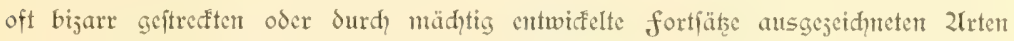
fid) unteridgeiden. für die oben erwähnten 2Interfḑiede zwifhen den formen aus den

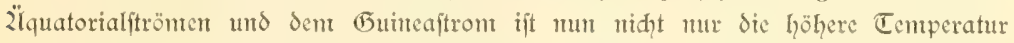
des Ieftgenamten Stromes, fondern aud fein geringerer Saljgehalt in Redununty ju jiehen. Dem die intere Reibung wird bet geringerem Saljgehalt etwas - went aud mux wentig - herabgefest: ein Llntfand, dex wicderum auf die Derlängerung

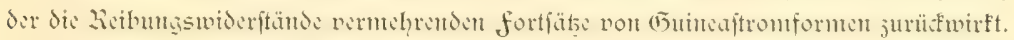

Wenn wir überhaupt dic Sdrwebefähigfeit pon Drganismen cinent Sinfen mit

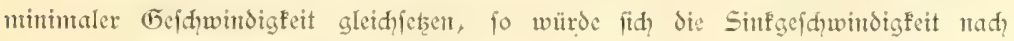
Ditwald in folgender einfaher formel ausdrücén laffen:

$$
\text { Sinfgefdwindigfeit }=\frac{\text { l̈bergewid̨t }}{\text { Jmmere Reibung } \times \text { formwiderfand }}
$$

llnter "Z̈bergewidgt" oder Zbtriebfraft würden wir hierbei bie Differenj der fpecifi= fhen Ģewidhte von flüfïgfeit und finfenden Körper verftehen. Es liegt auf Jer Lanto, daf́ ein Drganismus um fo rajder finfen wird, je gröfer die Differenz in den ge= narnten fpecifijdien (5)widhten ift.

Die imere Reibung, ftarf becinflust vont Temperatur und gelöfen Stoffen, verbält

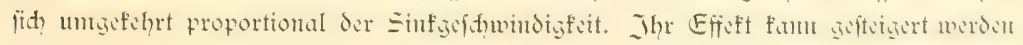
durd die Sdhaffung von forntwiderftänden, weldye int allgententen anf einer $\mathcal{D}_{\mathrm{cr}}=$ gröferung der Dberflähe der finfenden Drganismten beruhen. 
Lnt indeffen vort den ēwergent der 2liceresoberflähe den 3liff wieder den Kiefen jujumenden, fet eines Dorfommutfes ant 51. 2uguft nad Derlaffen der Capverden nod gedaḑt. Während wir in der frühe cine Ticfe vor $47+0 \mathrm{~m}$ loteten, wurden aus der feme die Rüdenfloffen jahlreiduer Wale bemerft. Jd jählte deren niḑt wentiger dem 44, weldie rafh in die 2rähe des Shiffes gelangten. Deutlidy ver= nahmen wir ihr Blajen beim Zluftauden aus dem Waffer, und bald wurde es aus

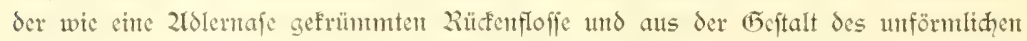
Kopfes flar, daf wix es ntit dent (5rindwal (Globiocephalus melas) ju thum hatten.

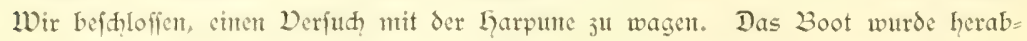

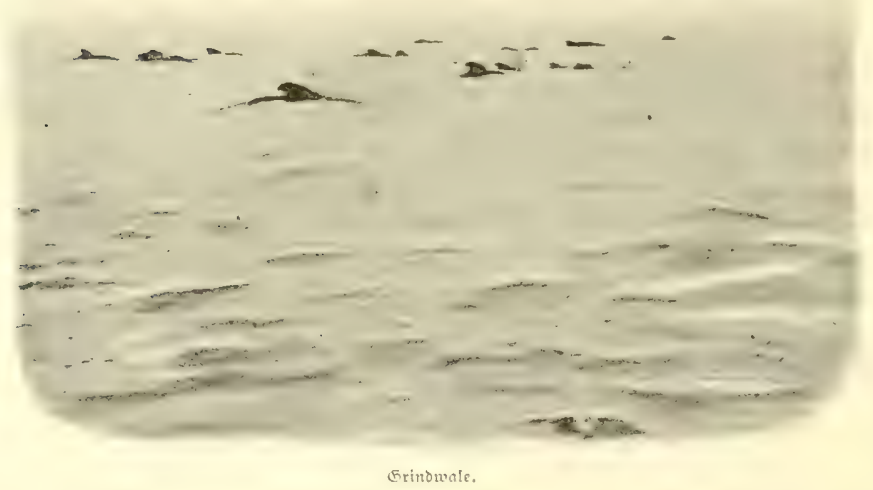

gelaffen und mit tüđtigen Ruderent bentant, während unjer erfter Dffijier fïh mit der Larpute bewaffinte. Wir gelangen rafd in dic Zähbe der itattlidgen Tiere, dic cin wahres 23lasordhefter aufführen, bald in elegantem Bogen anffeigen und ihren ganjen Rü̈fen jeigen, hald den unförntidhen Kopf, der wie ein Baumftrunf fich aus= mimmt, über $W_{\text {affer }}$ crheben, bald mit der Sdqwanjfloffe die Sberfläḑe peitjhen. Daf die Garpune viemal vergeblid, geworfen wurde, mag der 2fufregung ju gute gehaltent werden. freilid fümmerten fid die (5rindwale wertig unt unfer Thum, unto Sa fie meift in Trupps vort etwa 12 Stülf fdwammen, gelang es uns leidit, ihnen den $\mathbb{D}_{\mathrm{eg}}$ abjufduciden. Zllntälid wurden fie etwas fdener, und während id vorher

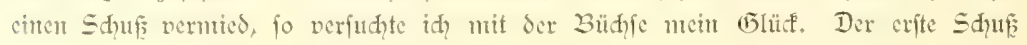




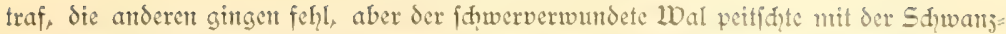

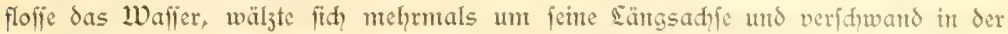
Tiefe, ohne ju unferem sciowefen wieder an die Dberfläde ju fommen. Went wir aud nod mehrmals den Walen nahe waren, die bisweilen in ängtlidger 2rähe des Bootes auftaudten, fo wurden die Tiere dod, fकlię̧liक fdeu und veridwwanden, ehe ein Sduf anjubringen war. Dielleidht war es ein Glük, daf die Garpune nidht

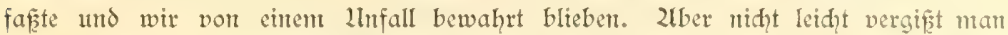
das Blajen der auftaudienden Beftien, weldhe unjer Boot an Sänge übertrafen, dic

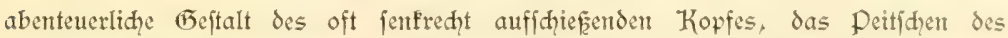
Waffers mit der Ehmangfoffe und die begreiflihe 2lufregung dir Jago inntitten diefar Lltgetüme, wilhe uns niḑt minder als die nom Dampfer jufatanendin Erpeditions mitglieder in 2ltem hielten.

Was nut das Rejultat unferer Trawljüge anbelangt, die wir jum Teil in redit grofien Tiefen bis ju $4990 \mathrm{~m}$ ausführten, fo mag jur Würdisutg dirfalban herror: gehoben werden, daf wir uns teilweife in nidht alljugroferer Entfermung von der Küjte berwegten. Der Tieffeegrund wird in diefen Regionen volt einem unangenelqmen jähent

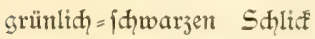
gebildet, dem Beftandetle des von den weftafri= Paniforen flüfien mitge= fübrten Shlammes bet= gemengt find. Erit als wir in der Lähe des z̈lquators weiteren $\mathfrak{S a n} \delta=$ abjtand gewannen, fekzte fid) der Tiefjeegrund rein aus jenen 2lblagerungen $3 \mathbf{u}=$ fammen, weldye zliurray als pelagiiche bejethnet. Wor allen Dingen handelt es fifh hier um jenen "(5lobigerinend lamm", der in Sen äquatorialen und gentäß่̧gten ฮ̄o= nem aller Desame meiti flät)in bedectt. Er wird von den Kalfidalen flemiter

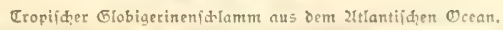

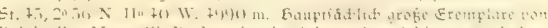

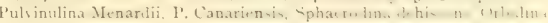
universa, Pullenia obliqueloculata, Globigerina bulloides. Derar. ${ }^{25}$. 
82

Slobigerinenfdร

Llutiere gebildet, die als foramini. feren in oberfläd)lidyen Sdidytent flottieren. Zaad, dem $2 \mathfrak{d} b=$ fterben des Weidförpers finten dic häufig nit Sd) gen in Eิeftalt fei ner Kalfitadheln befetzten Shalen auf den 2lieeres boden nteder, um fid hice im saufe der อ̄eit ju nüdy= tigen Sdiditen an= jujantmelı. Bei dent langfamen 2tic= derfinfen wird in Sent tieferen Sdidi ten der Bejat von Kalfnadeln auf= geloit und 乌äufig aud?

Zoroaster fulgens Wyy. Thomson. $3240 \mathrm{~m}$. Fwifden Kannen uno Kapverden 
die Shale felbft mely oder minder ftarf angegriffen. Jumerhin fanden wir nod in $4990 \mathrm{~m}$ die Shalen fo wohlerhalten, dafe die eingelnen forminiferenaten leidht beftimmt werden formter. Da es inmerhin von Jntereffe ift, cine Dorftellung non der כufammenjeşung des Tieffechlammes ju erhalten, geben wir in voritehender 2lbbildung bei fhwaher Dergröferung eine Daritelfung desfelben aus der genamten

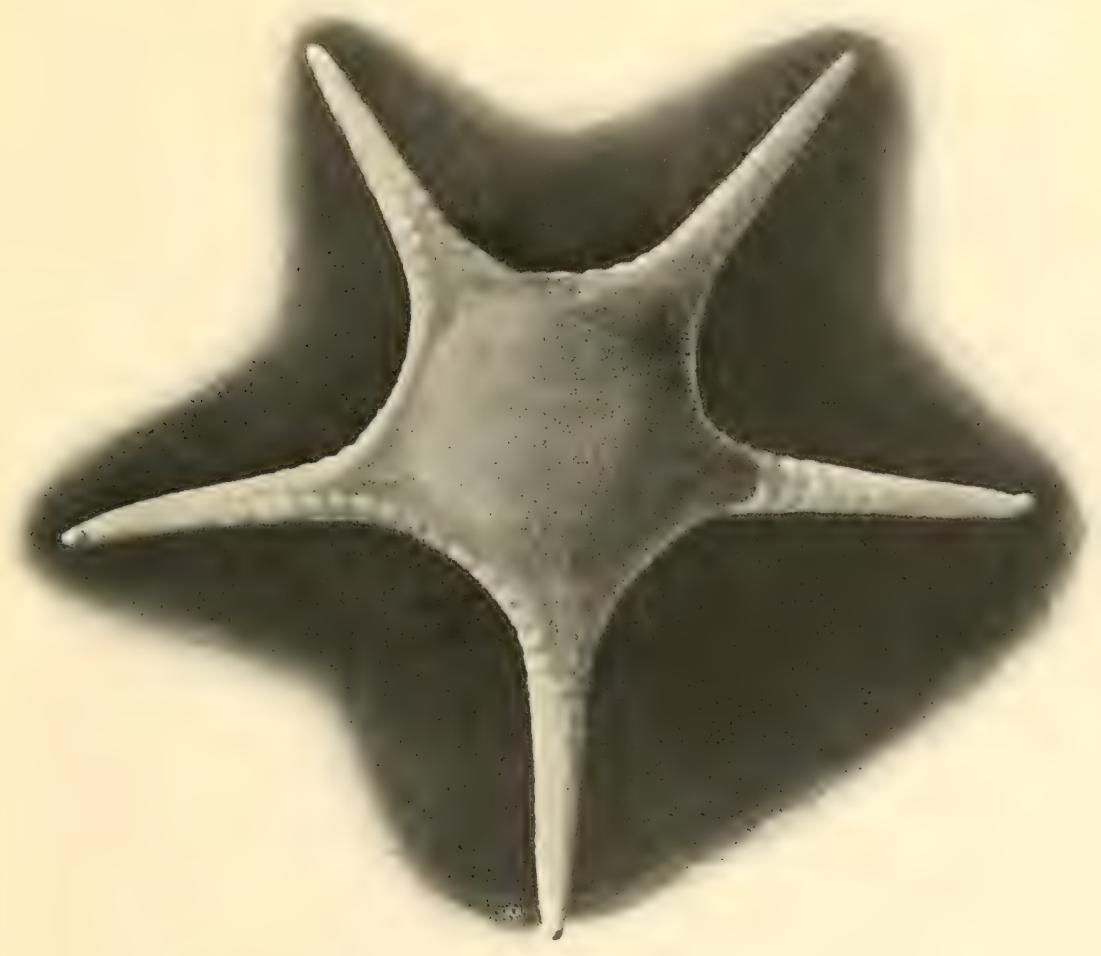

Hyphalaster Valdiviae Ludwig n. sp. $4900 \mathrm{~m}$. Golf port Guinca. Ziat. Brȫe,

Tiefs von $4990 \mathrm{~m}$. Benterft fei mur nod), daß̧ fäntlide in der figurenerflärung namentlich aufgeführten 2lrten eine pelagifde sebensweife führen.

Der Tieffecfdlamm enthält nad den Lnterfudungen unferes Chemifers ftets chit, wem aud mur geringes, Quantum vont organtifier Subitanj, das von dem offenbar nod niḑt völlig jerfeţten Plasnta der foraminiferen uns anderer auf den Boben 


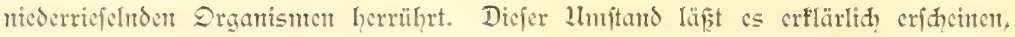

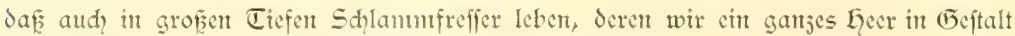
von Seewaljen, Sdlangenfternen und Secfternen crbeuteten.

Die 2lusbeute von der weftafrifanifhen Küifte und aus dem Golfe von Bumea bietet, wie ju crwarten war, cin nur geringeres Jnterefie, da wir hier meijt nur be= fannte formen, wem auh gelegentlid, in befonders fhöten Eremplaren, dredfįten.

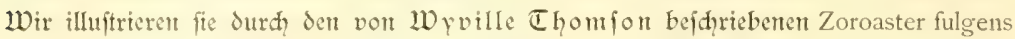
aus der familic der Joroafteriden. Jnmerhin lieferte aud das 2ttlantifhe (5ebiet

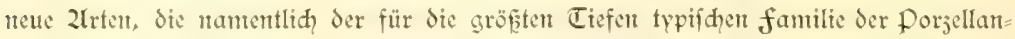
afteriben angehören. 2lus cinem 2lbgrund von $4990 \mathrm{~m}$ haben wit in Guinea=(5olfe den pradhtoollen, der Gattung Hyphalaster jugehörigen porjellanajteriden herauf = gebradit, welden unfere 2lbbiloung vorführt. Er unterfheidet fid von dem ihm nahe ftehenden Hyphalaster Parfaiti Perr. (den wir mehrmals erbeuteten) durdh die gröfere ह)ahl von cribriformen Drganen auf den Randplatten und durch eine abweihende (5eftaltung der Platten der Bauhfeite. Ju Ehren des Erpeditionsidiffes hat ihn Prof. Sudwig als H. Valdiviae bezeidhnet.

Eir feltfamer fund fam am 5. September aus einer Tiefe von $4990 \mathrm{~m}$ an dic Dberflähe. In den Shwabbern des Trawl hing eine mit Seemaffer gefüllte Cham=

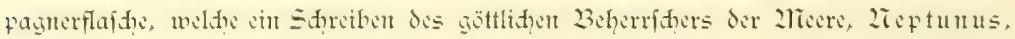
barg. Er erflärte dem Kapitän der "Daldivia", daḱ er am näđfiten Tage mit feinem unterfecifhen Gefolge an 3 ord bes Shiffes erfheinen würde, un die meeres: üblidie Taufe vorjunchmen, die fid um fo eindringlither geftalten würde, als peine Edwegermutter fehr ungehalten jei, weil wir the fo fdwere Sote auf den Kopf geworfeı hätten.

Punft 5 lthx ant 6. September ertönte ein Sđuf aus dem Böller: 2reptunt mit grofent Exefolge fitieg aus den Wogen auf und begab fith in einem phantajtifh

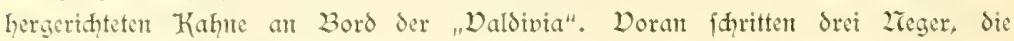
Paufe, CYmbeln und Gammonifa bearbeiteten; ifnen folgten ein 2litronon, ein 2Totar unto mehrere ertrunfene 2liatrojen. Endid erjhien Se. götlithe 2liajeftät in Iang= wallendem Barte mit dent Dreijate in der Kand, und hinter ifht frau Zreptun, eine anmutige Dame mit Strohbüthen, langen Jöpfigen: ganj Parifer Chic, wenn aud nur wenig der Dorftelfung entipredent, die man fid von 2lmphitrite bildet. Sie

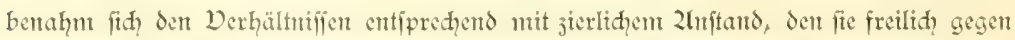

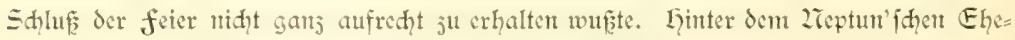
paar fojritt der Dolizeileutnant in Eojert, die wohl 1898 angängig waren, niḑt aber im fittfanten Jabre 1900 geduldet werden würden. Dier unterfecifhe Polijiften in martia=

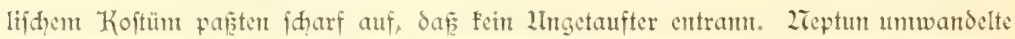
mit (5) folghe die gantje "Daldivia", hielt in Lecrantetern eine Ilnfpraḑe an die 2littglieder 
Ser Erpedition, worauf fein 2ljtronton mit mähtigent Jirfel und fermohr dic Breite beftimmte und entdecfte, dafi wir uns gerade auf $0^{\circ} 0^{\prime} 0^{\prime \prime}$ befanden. Da toar es hödjte כeit, die Taufe vorjunehnten. In feictlidhem J̈uge begaben fid die Sergottheiten nad dem Vorderdecf und gruppierten fïh malerifh um die 2iesc der Erpedition. 2Injer gropes Seewafferbeden diente als Tauftifh; cinen gecigneteren hatte fdywerlid) je cin Sdiff jur Derfügung, ১as den Z̈quator überfdritt. Der Seiter der Erpedition maḑte den Zlnfang, wurde von 2ieptun mit einer finnigen 2lnfprahe begrüpt, exhielt cinige Kübel Waffer über den Kopf, worauf man ibm fein Diplon ausfertigte, in dem 2Ceptun thn in feinem Reidge willfonmen hief. - Wentiger gelind berfuhr man

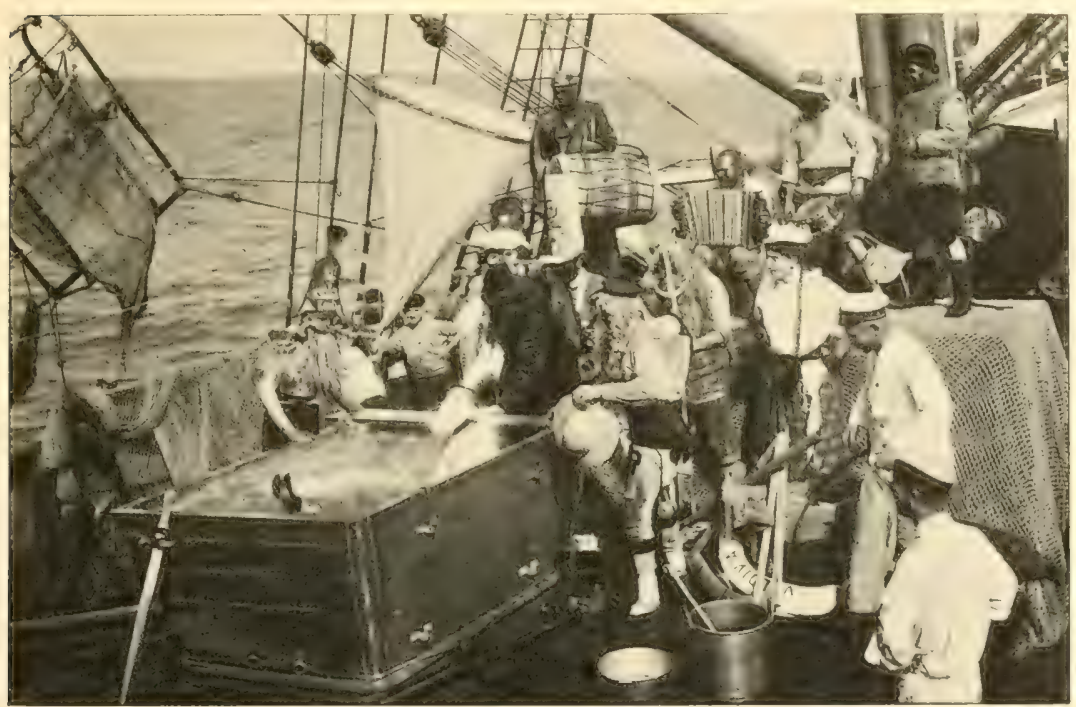

mit den fonftigen 2reulingent. 2lan verband ihnen die 2lugen, feifte fie cin, bearbeitete fic mit höljernen Raftermeffern, und nahbent zieptun mit Donnerittmme ibnen ihre Sünden deflamiert hatte, befahl er dic Taufe. Ein Rut von dent Polizeileutnant, und hinterrüd's faufte man in das Taufbeden, worauf reichlidier 2łbgus aus dem Sdilauthe der Dampfiprite das übrige bejorgte. So ging es Sdilag auf Sdilag, gleidgültig ob es fith um Privatdocenten oder Sdiffsjungen handelte, weld leţfere freilid erft nod emen Sthlauh aus Segeltud ju pafferen hatten unter reidilifier Zadįilfe mit der Dampfipritze von hinter.

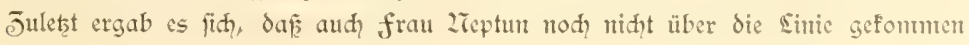




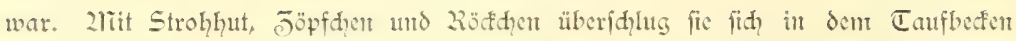
unt gab dann, wie alle (5)tanften, den auf den Zlufer geleifteten Sçwur ab, daf man von mun an trener Diener fetner göttlithen 2liajeftät fein wolle. - Dam ging es in grof̧em, naffem Juge unter erhebender llufif wieder un die "Daldivia", worauf zeptun uts feines bauenden Wohlwollens verfidgerte und it feinen unter fecifhen Kryptallpalait hinabitieg.

2aadjoem wir an $\tau$. September den z̈lquator allerdings nur um $15 \mathrm{~km}$ über fdritten Latten, crgab cinte Sotung dic beträdtlid\}e Ticfe von $5695 \mathrm{~m}$. Es ift dies

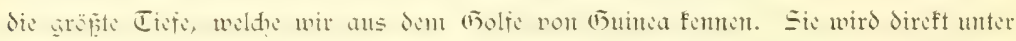
Sent Z̈̈quator mur von der durd das Dermefiungsfdiff La Romanche in $18^{\circ} \mathrm{II}$.

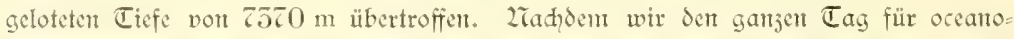
graphifhe und biologijdge 2lrbeiten verwendet und die bereits oben berührten 2lnter

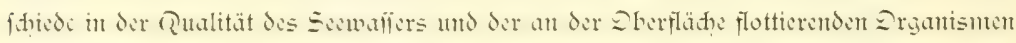

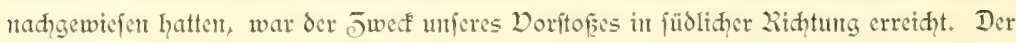
Kurs wurde nu auf Kanterun, unfer nädftes Reifejicl, gejeţt. Die angenehne, relativ fühle, an das Paffatgebiet erinnembe Witterung maḑte allmählidy wieder der für den

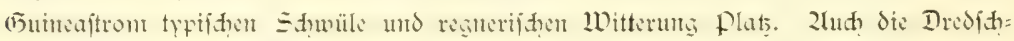
jüge, weldhe wir ausführten, lehrten, dafi wir bals wieder it das fFebiet der auf Sandnähe findeutenden 2lblagerungen gerieten. Wie juvor an der Küfte von Sene=

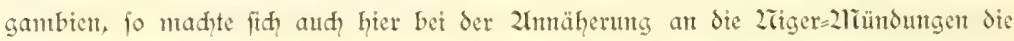

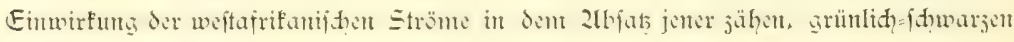
Sd)lammmaffen geltend.

für die relativ pärlidie, den Tieffecfllamm bevölfernde fauta wurden wir indeffen auf der gangen fahrt nah dem Verlaffen der Capperden durch die geradeju

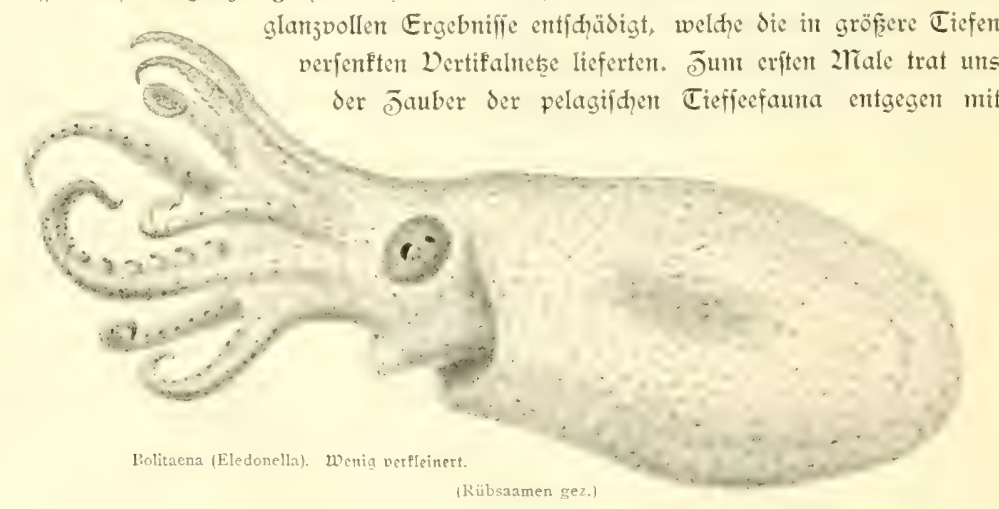


ciner wahren l̈berfülle neuer und durdy ifhe Drgantifation bemerfenswerter Tppen. Da wir diefelben nod in anderem Jufammenthange fḑildem werden, May der Ginneis

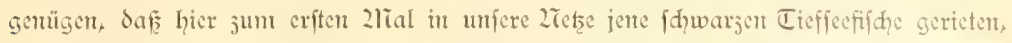
weldye durd ihre 2lusrüfung mit seuditorganen und Surd? ihrent bijarren Gabitus feit jeher das Jntereffe der forfher in be

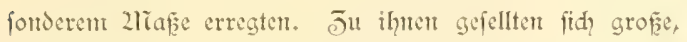

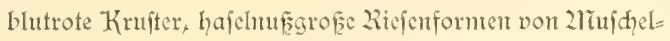
frebfert, durdfifditige Tintenfifine, nit roten Darm aus= geftattete Pfeilwürmer, violett gefürbte 2lièdujen, duf= tige und ungemein zart geftaltete fapwinmende $S_{e c}=$ waljen, bisher nod, nie beobadtete Tieffeeformen der Rippenquallent und cine Z̈tberfülle von Rabiolarten mit į̧ren reijvollen Kicfelfeelettent. 2lian war in ftän= Siger Erregung über diefe ungeahnte praḑt bet dem 2luf= fommen der 2reţe; alle hünde hatten voll ju thun, um

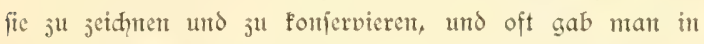
enthufiaftifhen Worten feimem Staunen über den farben=

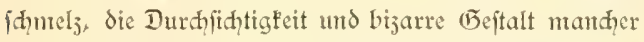
formen 2Uusdrut. In feiner eigentartigen $\mathfrak{W}_{\text {eife }}$ that dies unier Künftler. 2lls er jum erften zliale den abjonderlidien Tieffeefifd Melanocetus ju Gefiḑt bekam und ju jeidinen ver=

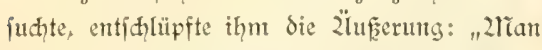
meint, unfer Gerrgott habe alle Dummheiten, die er gemadit, in die Tieffee verifteft."

Unm indeffen dem Sefer cin arrfhaulides Bild von einigen pelagifden Tieffecformen ju geben, greifen wir jwei 2lrten von aḑtarmigent Tintenfijidgen heraus, weldhe Surdh ihre 2lnpafiunts an eine flottierende Sebensweife Int= tereffe erwectert.

Die eine 2rrt führt einen Dertreter der (5)attung Bolitaena vor. Sie erweckte mit vollem Ređtte das lebhafte Interefle des verftorbenen Stecuftrup, weldher das erfte, freilich

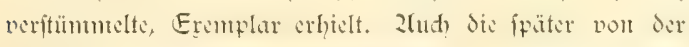
Challenger=Expedition erbeuteten und als Eledonella refp.
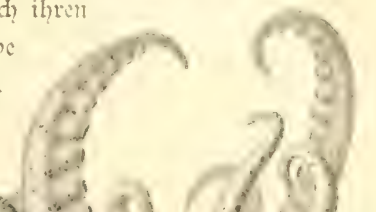
rotgelb pigmentierten Bolitänen genauer befamnt, $\delta$ a wir fie in den verfhiedenten Zlltersftadien tadellos erhalten an die Dberflähe beförderten. Das int vorftehenden Bilde dargeftellte Exemplar ift ein 2liammchen, deffen dritter 2lrm der redten Seite fräftig entwidelt und ju cinem Begattungsapparat ungebildet (heftofotylifiert) ift.

Der jweite Tintenfifक, den wir im Bilde vorfübren, ift ente der abenteuerlidftent (5eftalten unter den pelagif̧en Tieffecformen. Er gehört ju der familie der Cirrho= teutbiden und unteribeidet fid, vort allen befanten (5attungen dadurd, dafer er vier gefonderte Rüfenflofien beftst. Wie alle Cirrhotenthiden, fo find auh unfers Erem= plare (wix haben deren dret in jugendlidyen Stadien erbentet) mit cirrhen ausgeftattet, weldye an jeden der durd breite Säune verbundenten 2lrme in jwet Reihen fíd vor= finden. Sie bilden bei dent Jufanmenfallagen des 2lumtriditers ente 2lrt von Reufe, in der die 2rahrtiere jutüfgehalten werden. Die Tiere find fammetidwwarj gefärbt mit cinem Stich in das Diolette und jeigten bei dent Lerauffontmen einen rubinroten Inşentintergrund.

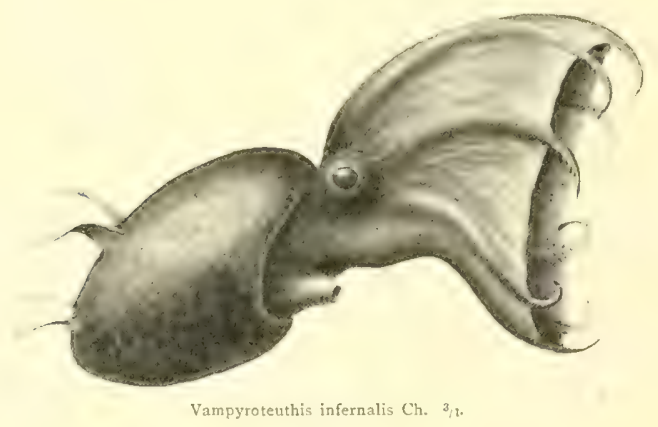




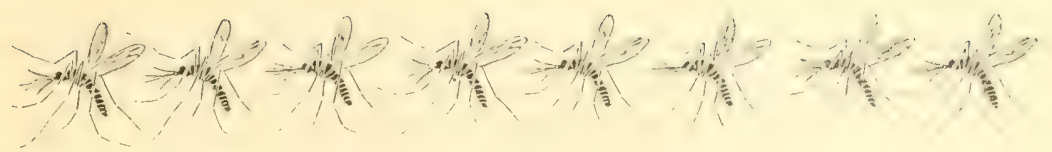

\section{Kamerult.}

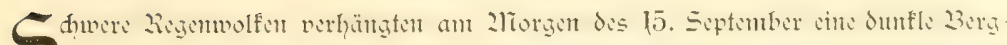
- landfhaft, die düfter gegen das in hellem Somenfdein redts vor uns liegende fermando po mit fenten Clarence=pif abfad. 2lit dem femmoly wurden bald die Wipfel graugrün gefärbter Urwaldricfer fenntlid, welhe diḑt bis an dent

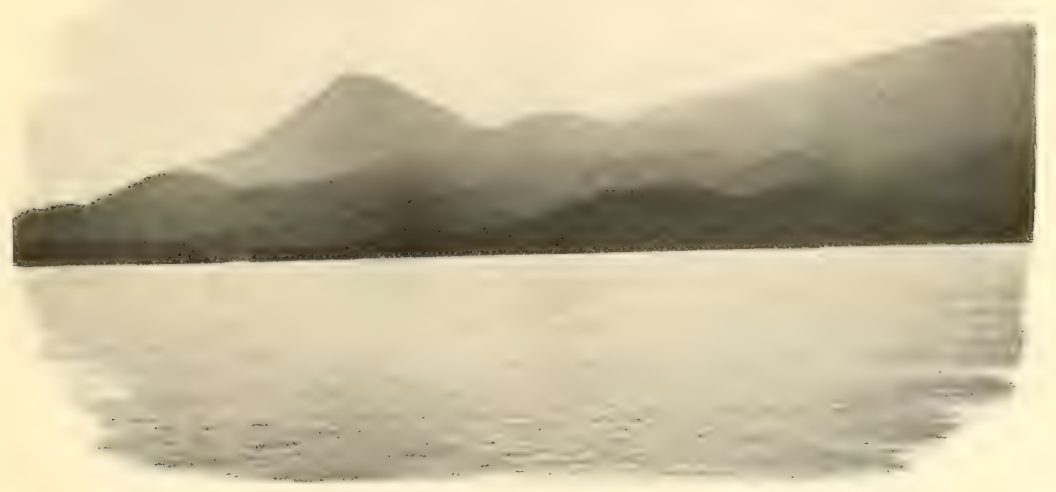

Der Pleine Kanterunpil.

Strand berantreten. Lier und da hebt fid eine Kuppe $a b$, Ginter welder der 2iebel Sampft; in verfhwommenen Konturen, die oft rafd wieder durd fdqwärjlidgraue Striḑwolfen verwifdyt werden, giebt fid der Steilabfall des imerifen 2 Wintels der Futnea=Buht fund. Das Ufer untfäunten die weifen Kämme dev Brandungswogen,

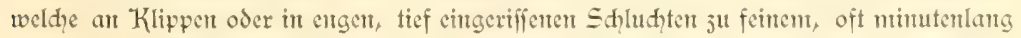

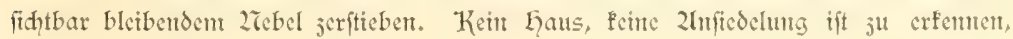




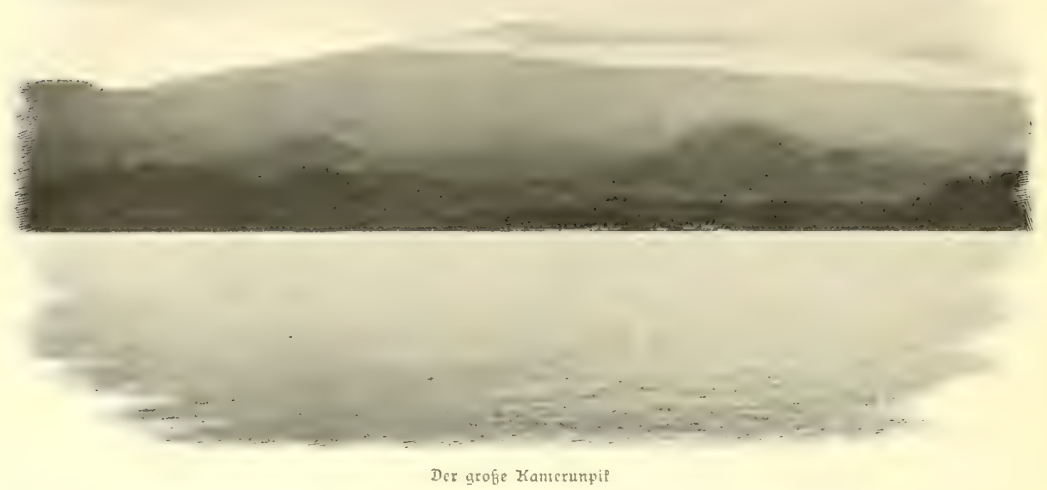

nur der tropifhe Regenwald, wie er in diefer Eigenart gerade für das Kamerut= gebirge typifd ift, prägt in enifter 2lajeftät Ser Landidhaft ihren Charafter anf.

Zllmählid, gliedert fith die Scencrie. Jwwar verhindert eine horijontale, idharf abgefhnittene Wolfenfhidht den Zlusblit auf die Löhen, aber in ftets wehfelnden Bildern fhieben fith bet der Inmäherung an Dietoria die diḑt bewaldeten 5 and= jungen und Kuppen vor. Die $2 x_{\text {mas }}=3$ udt, jene perle in deutjhen Kolontal= befts, gleidpt dem dunflen Rahmen emes hodgebirgfees, aus dem freundid, die

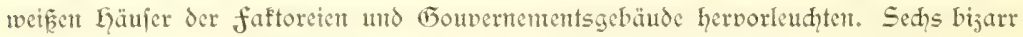

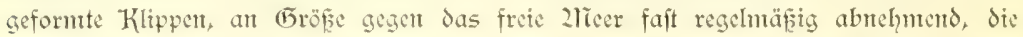

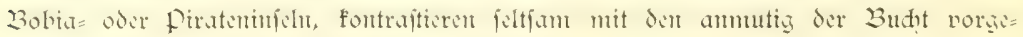
Lagerten Eilanden 21 mbas und 2liondoleh.

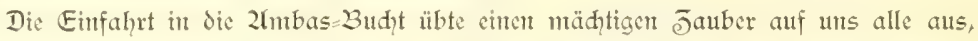
da wir wohentang dic Sonte aus dem 2licere anftauḑen und an fernen Lorijont blutrot untergehen fahen. 2rit cinem Sd,lage waren woir in eine unnergleiḑlid grof artige und fimmungsvolle Sandidaft verfetst. Die 2rebelwolfen jagten, von dent in

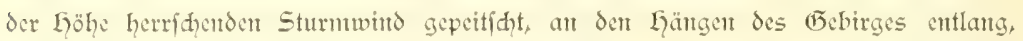
unt faft wie durd cinen Jauber lüftete fid der Sdleier, welder neidifh den 2lusblitf benahnt. Juerft taud)te der fteil gegen die Küfte abfallende, völlig bewaldete fleine Kamerumberg und bals darauf der langgejogene Rü̈en des $5960 \mathrm{~m}$ hohen Kamerm= pifs auf. Deutlid wurden in der oberen Waldregion dic weifsidacn Stationsgebäude 
von Buëa fïtbar; weiter oben verlicf fidh die Bammegion, oft in lange J̈hrfel vorgejogen, geșen das hellgrünlid, fưmmernde Grasland, das allnählid an dent langgejogenten Kanm mit feinen tief eingeriffenen Sdludten in bie anfacinend

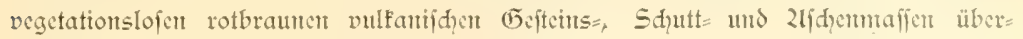
geht.

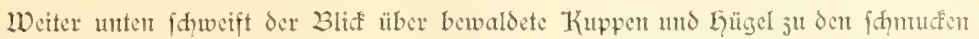

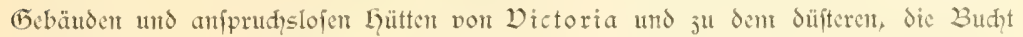

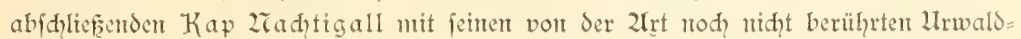
refen, in deren Dunfel der Gorilla unbehelligh hauft. Dorbet an den faft unzugäng= lidhen Pirateninfeln, auf deren größter und dem Sande junädhit liegenden ein 2reger= dorf fidtbar wird, jwifhen dem palmenumgürteten 21 mbas und 2londoleh nimmt der Dampfer feiten Kurs, um int Sdqutze der leţteren Injel den 2unfer fallen ju Laffer. Weithin hallt der Sduf aus dem Böller wieder, auf dem Gouvernement fteigt die deutihe flagge auf und mühfam fudpt vont Sande her das von Sdwarjen in ¡dmmufer 2liatrofentrad)t geruderte Regierungsboot gegen die Wellen anjufänufen. Wir erfahren von dent an Bord pommenden Beamten, der - wie das in den Tropen gang und gäbe ift - in cinter Perion den Lafennteifter, Jollinipeftor und Polijei=

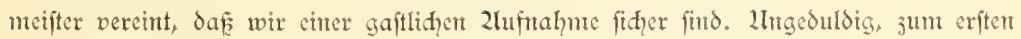
Irale den fuF auf afrifanifhen Boden und auf deutides Sdutzgebiet ju jeţen, lafjer wir uns an cand rudern. Da gerade zliarfttag ift, herridit an der candungsitelle cin lebhaftes Treiben. In den langen, fdimalen, aus cintent cinjigen Baumftamm gefertigten Canoes häufen die von fifherei lebenden 2ieger die früdte auf, welhe fie gegen fifdie umtaufdaten. In fitsender Stellutg rudern faft nacte 2lämer uns Weiber mit ihren furzen, in cine fharfe Spitze auslaufenden paddeln gefdict ourh de Wogen; hier hodt an Strande ein Trupp von anfprudisloien (Febirgsnegern, dort drängt fid einte buntbefleidete 2licnge vor, un dic 2reu= linge anjugaffen und in unerfक̈̈pfliकen Wiţ, der ladyenden Widerhall findet, fid ju ergehen. Wir haben allerdings während unferes 2lufent= halts in Dietoria redid, daju beigetragen, daf das dem 2Teger angeborene Talent für Witz nno Jronte reidhlid, Zahrung fand. Da rannte der Eine mit Spirtusgläern hinter Krabben, Käfen und Sdyntterlingen her, da mübte der andere fich ab, fliegen ju fangen, Blüten unt ङweige Durd? mädtige Rauḑbrillen ju betrahten und fie in umfängliḑe 23otaniftertrommelı ju ftecten.

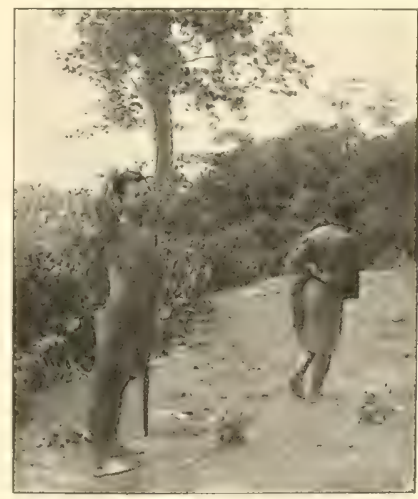

(sichmidt phot.) 


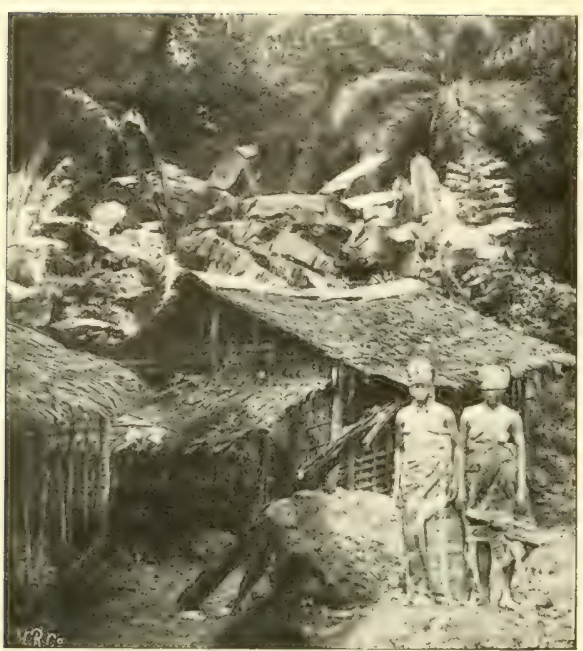

L)

(Sachse phot.)

während oer dritte mit unbeim= lichen photographifhen 2lpparaten

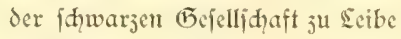
riucte und fith wunderte, wenn dicje bei der Erpofition nad allen Windrichtungen ausenanderitob. 2lĩaḑte nun gar der Photograph fid) auf dem (Bouvernements= Pony - dem Sdyweindyen - beritter. indent er mit dem Stativ herum= fudftelte und mit dent langen Beinen faft den Sand berübrte, fo fomte is midht befremden, wem dic 5 ütten der 23 afwiri von frohem Eadien widerhallten, fo oft cin Sthwarjer mit umadyahmlidher Draftif das Treiben der fonderbaren fremd= linge der grinjenden 2lienge jọil= derte.

Dictoria, cinft in englifhen Kolonialbefiţ, wurde durd dic semühungen des unvergefliden (E) gebicte angegliedert. Die 2luftedelung hatten aus fermando po vertriebene finwarze Dictorianer gegründet, Seren Ziadfonmen hente nod? in auffälig fauberen und oft von fleiten Blumengärten ungebenen Läusdhen wohnen. Sic fetzen den mittelften der drei Etrafsenjüge jufammen, aus denen die Znfiedelung befteht. Die vorderite, dem Strande parallel laufende "Sodent Strafse" hat gantj curopäifhen Charafter. In the liegen die

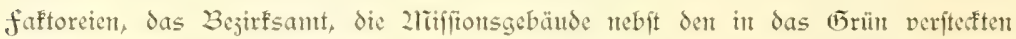

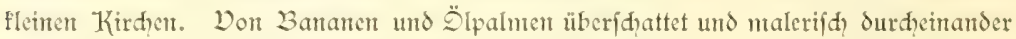
gewürfelt bilden endidh die Gütten der eingeborenen 3 afwiri den hinterften Strafen=

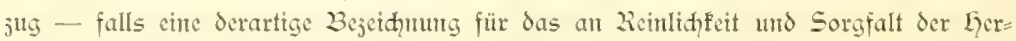
ftellung bedenflid? jurüdftehende 2Tegerviertel jutrifft.

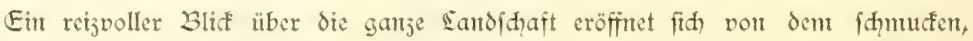
anf cittent Lügel gelegenen (5ouvernententsgebäude, in das wir vort dem ftellver= tretenden Bejirfsantmant, Dr. Gorn, nad, herjlidem Willfommen geleitet wurden. Der Eindruck, welthen dic majeftätifdyc sandihaft auf midh maḑte, als ith nach unferer Rüffehr von der Lodigebirgstour gaftlide 2lumalqme in Gouvernentents= gebäude fand und in der 2liorgenfrühe auf den Balfon trat, wird mir ftets un= vergefslich bleiben. Weit fdyweift der Blif hinaus über die blaue Saljflut, aus 
Der fid in violettent Duft der fanft auffeigende Kegel des Pifs von fermando Po

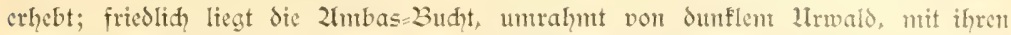
Injelı und Klippen ju unferen füfen ausgebreitet, und in Gintergrund ragh folj das Kamerun=(5ebirge nit feinen wallenden 2rebelịhleien auf. 2rad, drei Kiegentagen,

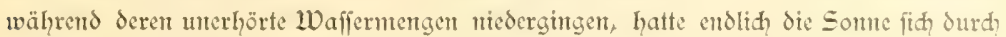

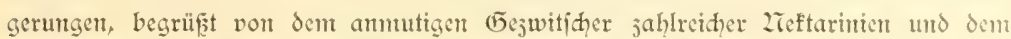
melodifhen, an unjere Sdwwarzamfel erimernden Sdlage der Bülbül (Pycnonotus Gaboonensis). Das fdyrille Konzert der Cifaden ift verftummt und zahllofe bunts falter wiegen fïh um die mit Blüten überfäten Geftrände und Bäume.

Das (Fouvertentent wird von dem weit ausgedehnten botanifhen (5arten umgeben, der unter der Seitung von Dr. Preuf fteht. Id hatte die bejondere freude, ihn als ehemaligen Ethüler hegrüfen ju fömen, und virdanfe diefem tühtigen Kanner der einheimifaen flora und fauta, der feit 12 Jahren in Kamerungebicte anfäfifg ifit und wohl den älteften dortigen "2lirifaner" abgicht, gar mante gimuperit) 23elehrun bei unferen Wanderungen. Zlian darf an den botanifhen Garten, der namentlid der unermüblithen fürjorge des früheren Gouveneurs, v. Soden, fein 2ufblühen

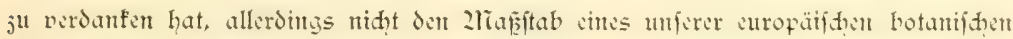
Gärten legen. In iḩm ift eine Joee verförpert, welche Limboldt vorfdumebte, als

Dictoria.

(Apstein phot.) 
Intereffe von feiten der Regierung nidht hintausfant, impontert die grofertige 2lulage in

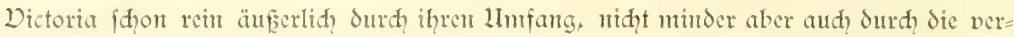
ftänonisvolle Bawirtiḑaftung. Ficr werden die Erfahrungen über dic Einwirfungen des Kanterunter Regenflima auf int Sdutzgebiet nidht heimif he Zuntzpflanjen gefanmelt und bereitwillig den Pflanzem übermittelt. Wenn dic Kafaoproduftion der Kolonie cinen ähulidy immofanten 2fuffḑwung genonmen hat, wie in fernando po und San Thomé,

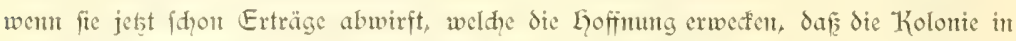
abfehbarer Jeit fid aus eigenen 2littteln erhält, fo foll dabet nidht vergefien werden,

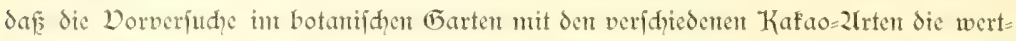
volliten Winfe abgahen. Sollte freilid? der (Ẽarten ju ciner Derildsplantage in grofent Stil ermeitert werden, weldhe den Pflanjern eit amtähent fidheres 2trteil über dic Ertragfähtgeteit und Rentabilität bietet, fo würde das hierfür ausjeid̨net gecignete

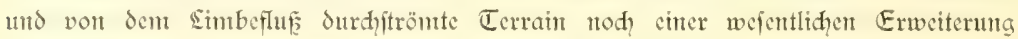
bedürfer.

Wer indeffen glaubt, dafe ein botanifher (Farten, in weldhem Pflanzungen von

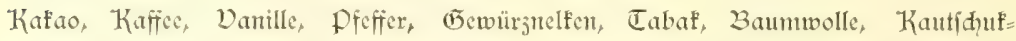
bäumen, Bananen und fonftigen tropifichen 2intpplantzen angelegt wurden, einen für das 2luge monotonen und wenig malerifhen Eindrud darbietet, wird fid auf das 2 Ingenchunfte enttäujd,t finden. L̈̈berall drängen fid in den Garten und in dic angrengenden Kafaoplantagen die Llrwaldriefen ein, weldie man als willfonmente Edhattenffender fdonte. Bei cinem ant erften Ziadyuttag in Beglettung von Dr. Effer, Sieutenant Bornmüller und dem Kapitän durh den Б̄artent und die Kafaoplantagen der Weft $=2 l$ frifanifinen Plantagengefellifhaft unternommenen Ritte war es wentiger die

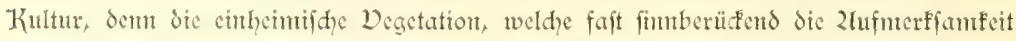
feffelte. Jente gewaltigen Bauntriefen, umranft von Sianen und überfät von phantaftifich Drdidecen und farmen (cin alter ficus nidgt weit von dem Wohnthaufe von Dr. Preuf

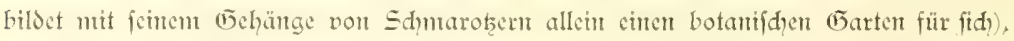
jener Wedfiel von sandjhaftsbildern, weldye die in üppiger fülle ftrobende Degetation am simbeflup fdafft - dies alles wirfte beraudgend. Der für uncrfüllbar gehaltene Traum der Jugend war verwirfliḑt und in beriufender Praḑt eröfrnete fith der Einblicf in ein 2trwaldgebiet, das an wudtiger Entfaltung und an Reiditum von formen auf Erdent feintesgleithen fudht. Weder am Eongo, nod in Sumatra, nod? auf Ecylon unt den übrigen Infeln des Jndifhen Decans wurden uns Degetations= bilder geboten, weldhe den Dergleid mit dem Kameruner Lltwald ausgehalten hätten; mein Reifegetoffe Sḑimper, der die füdamerifanifhen und Ginterindifhen Lrwälder durdhwandert hatte, verfidherte mir, daf bic Waldregion des Kamrerunpifs fid ebent= bürtig den grofartigen Scenerien diefer vielgepriefenen Jonen zur Scite ftellt.

Einch genaucren Einblite in dicfe parabiefithe Eandfhaft ju gewinnen, war unfer 


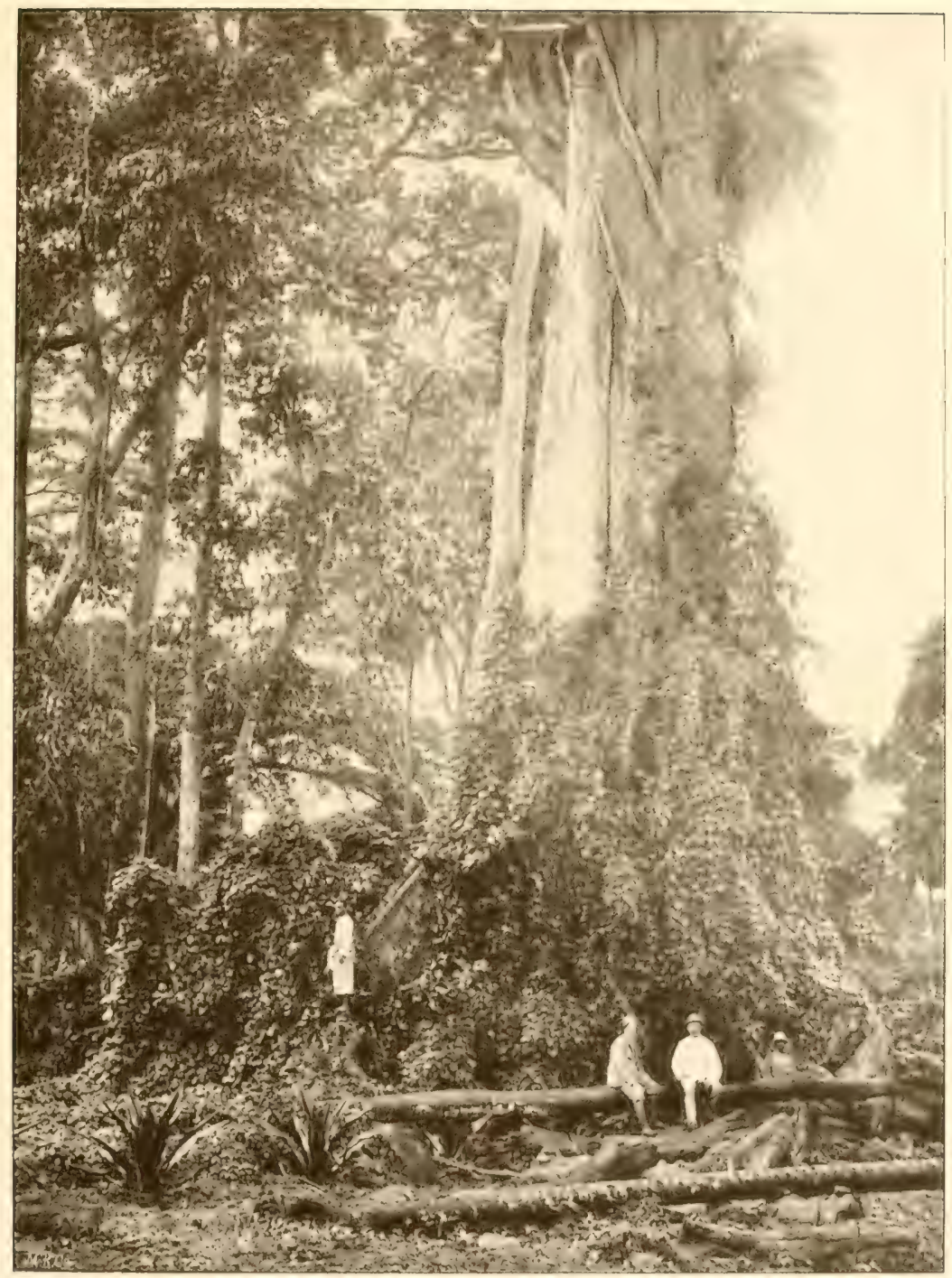

21 iit Simen bedefter Stamm cines Eriodendron in 23otanifhem (5arten von Diftoria. 

brentender Wurja. Don allen Seiten wurde uns ans geratert, eine orcitägige Tour über Buea bis in bie (5rasregion des Dif's ju unterntehnen, und rafd? waren bei dem licbenswürdigen Entgegenfonmen dic Dorbereitungen für den nädjiten Tag ge troffen. Träger wurden geworben, Pferde wur Sen jur Derfügung geftellt, und frohen 2lutes fetste fid die fleme Karawane frîhmorgens in Bewegung. Ein gut gehaltener, nur in den oberen Regionen etwas fdwierigerer, won der Regierung angelegter $\mathrm{Deg}_{\mathrm{eg}}$ führt in etwa 4 bis 5 Stunden hinauf nad Buea. Da wir uns mit Sammeln und photographieren aufhielten und ge: legentlid vor dent wie einte Sündfut nicdergehender Regen Sdut fuhten, verging die doppelte Jeit, che wir auf der Station bis anf dic Gaut durd)näft anlangten. Daju famen dic Sduterigfeiten, mit denen der in den Tropen reifende photograph ju fämpfen hat: dic Kamera war ver= a) erfolgt war, fek̨te der Regen von neuem ein und jwang häufig zu fhleunigen Eimpafen. Wir muften allerdings auf derartiges gefafst feir, da wir uns in eimem Tropengebiete

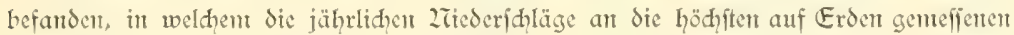
Werte heranteidin. Während der nördlihe Teil des Sduthgebietes nur eite Regen= jeit aufweift, treten beren jwet im füblithen auf. Das Kanerungebirge bildet injofem eine Shetde, als bic Regenmengen in feinem Weften um ein Beträdtlides dicjentgen des Dftens liberbicten. In Debundja füblith von Bibundi an der Weftfeite des Gebirges wurden jährlidhe Regenmengen von $897 \mathrm{~cm}$ gemeffen; das find 2rieder fdjlagsmengen, weldye nur nod) vot emem Orte der Erde (Cherrapunit an der Süb: feite des oftindifden Chajïa=(B)ebirges) übertroffen werden.

Dic gewaltigen während der Lauptregenjeit volt Znfang Jult bis Ende September niedergehenden Waffermengen, dic feudtwarme Treibhausluft und ein humusreidher,

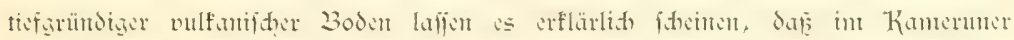
Ltrwald alle Bedingungen jufantmentrefien, tunt dieje überwältigend: Entfaltung der Degetation ju bedingen.

Da der Wald fid weit den Berg hittanf bis in cine Göhe vont ungefähr $2200 \mathrm{~m}$ (in den Sd)luhten faft bis $2700 \mathrm{~m}$ ) erftredft, fann es nid̨t auffallen, dafs die fühlere obere Region einen anderen Charafter aufweift, als dic untere. Die ungefähre (5renje jwifden beiden Etagen liegt bei Suea refp. in einer Göhenjone von etwa $1000 \mathrm{~m}$.

In der Zähe von Dictorta, wo offenbar fdon feit alter Jeit Zegeranficdelungen 
beftanden, ift der Wald lidfter. Diefer Imtjtand trägt niḑt wenig daju bet, den nalerifhen Charafter der Sceneric ju heben: jwijhen den einjelnen Utrwaldriejen

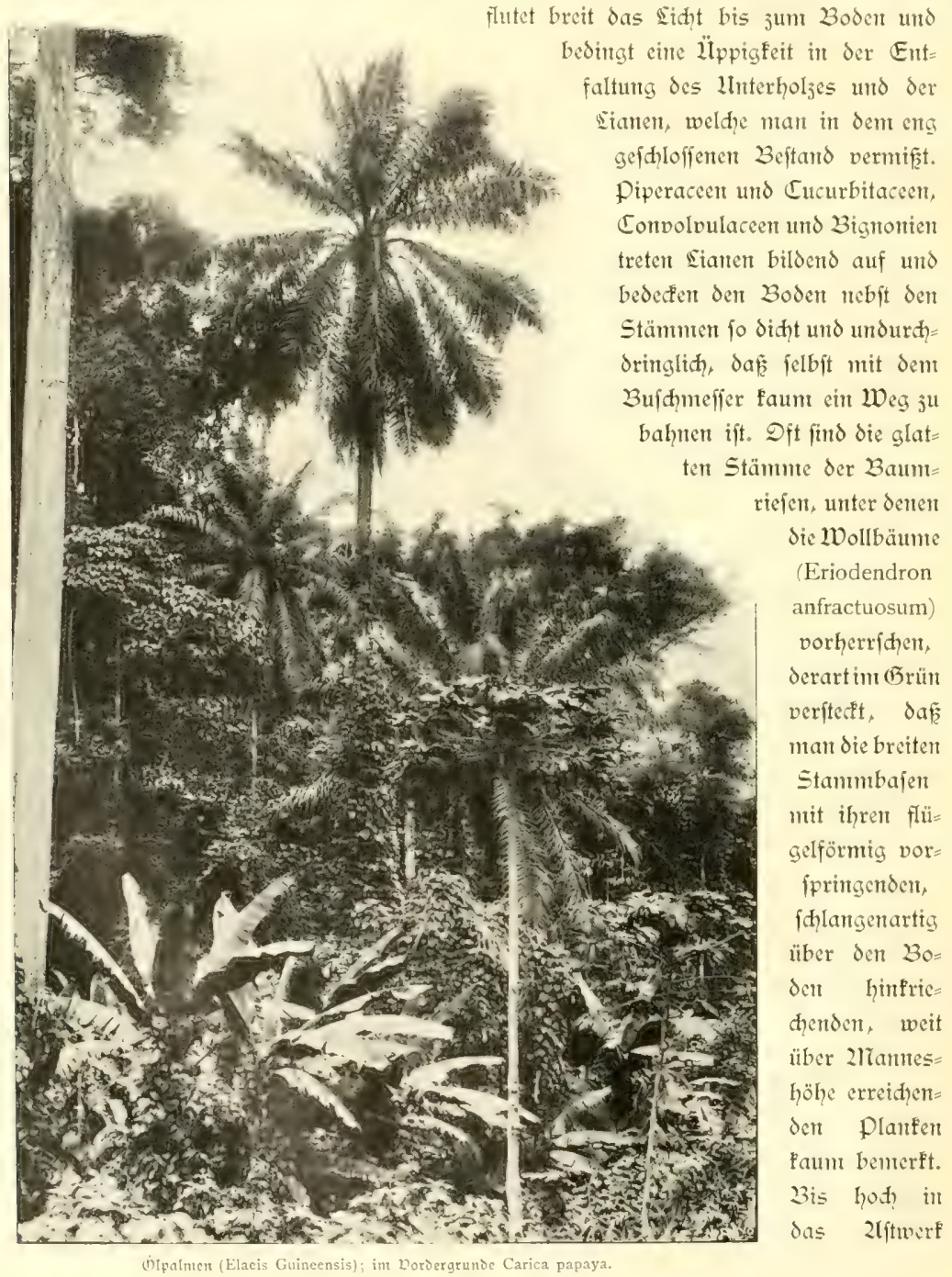




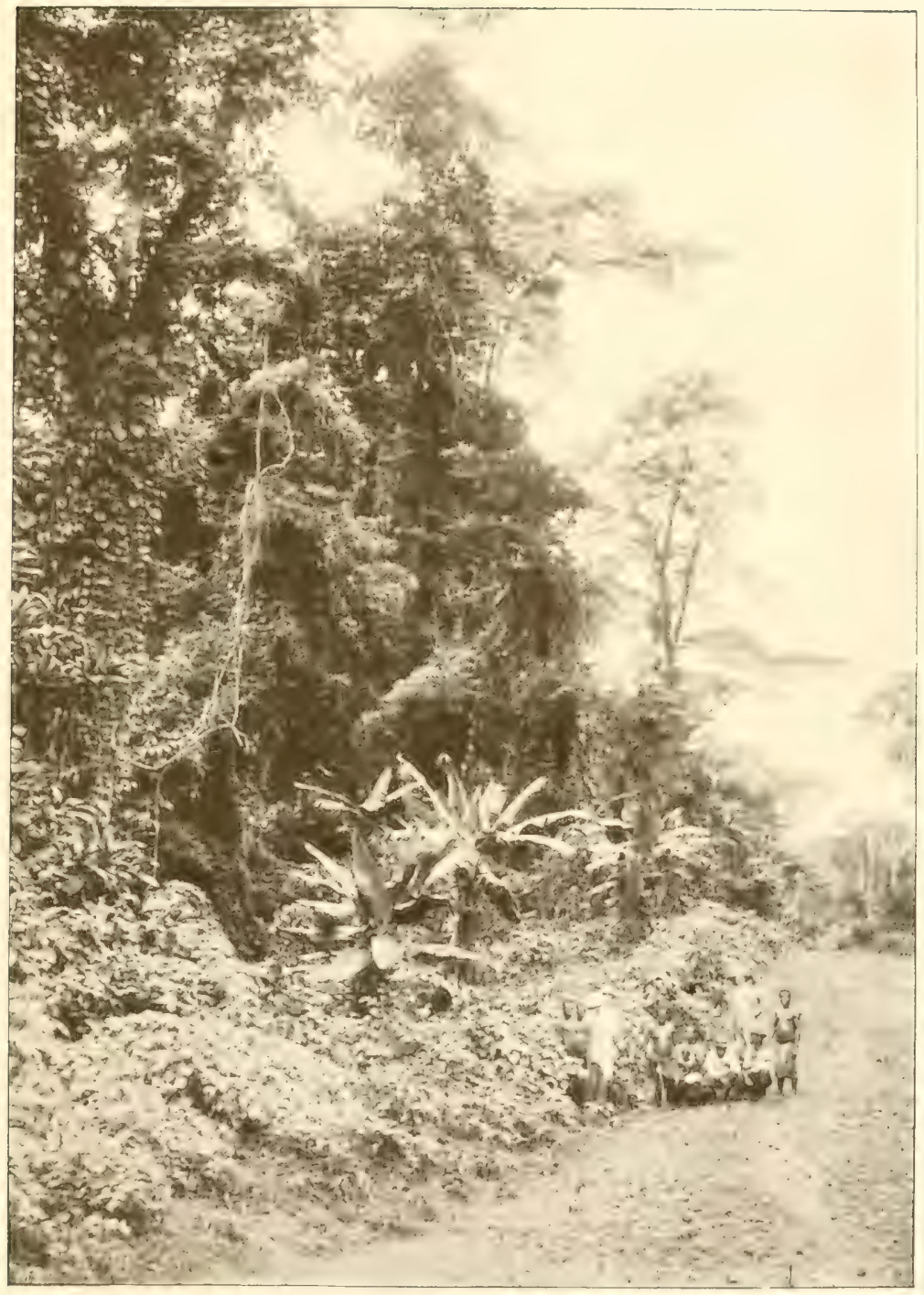

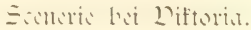



flettern die Sianent, und da in dent tropifaen Kegenwald dic Entwidklung des Eaub= werfes gefördert, die Loljbildung dagegent jurülgedrängt wird, hängent oft breite grün Couliffen nieder, jwijhen denten in anmutigem Słwung die feilartigen Stänme fid hinjichen. Wo die Sianten Raum fret laffen, fiedeln fid als Lalbparaften Drdhiben und farne an, unter weld Ietsteren die 2lsplenten und die platycerien mit ifren geweih $=$ artig veräjtelten Wedeln befonders auffallen. Überall drängen fich die grajiojen Ölpalmen (Elaeis Guineensis) cht, ohte indeffen didte Beftätde ju bilden, während Sic Wcimpalme (Raphia vinifera) etwas vereingelter auftritt. Beide licfern den Palnt= wein, dem wir bei unieren Wanderungen bals den Dorjug vor anderen Getränfen gaben. Won der Weimpalnte bezieht Ser eingeborene Bafwiri das 2raterial jum Sau finer anjprudslofen Lütten und jun fertigen der 2Tatten, während die D̈lpalme in ihren Kernen und dem aus thuen bereiteten palmöl nod anf lange jeit hinaus der Kolonic widytige Landelsartifel liefern wird. In den unteren Wafferläufen ftehen auf Eteljen die pandanus, und überall an Wege als Refte früherer Siedelungen dic Bantanen und langftänmigen 2Telonenbäune (Carica papaya).

So werden dem ju beiden Sciten des breiten Weges nad, Buea Eandidaftsbilder

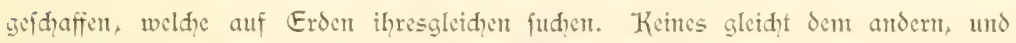
bod tragen fic wicder ähnlidfen Charafter. Die crnften Waldriefen bilden die Streben, an benen fith in fajt übermütiger fülle die Eianen emporranfen, um in ju Saub gewordenen Kasfaden niederjuwallen und cinen wirfungsvollen Rabmen für die ftoljen Kronen der Palmet abjugeben.

Einförmiger ift das Bild des lirwaldes dort, wo nientals der Derfud? gentadit wurde, ihn ju lid̨ten. Zuf der 2Tadptigallhalbinjel jwifhen der 2rmbasbudit unt

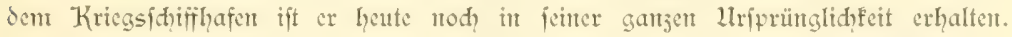
Die glatten Stämme ftehen didfter, und da die Kronen eng julanmenfąliefen, fo wudiert in dent Galbdunfel das Unterholj weniger üppis. Dafür drängen fid liberall Sie Termitenbauten, riefigen Gutpilyen vergleidbal, ein. Wem fie es mur abuten laffen, welhye fülle tierifhen Sebens der Wals birgt, fo witd nan bei Somten= untergang nod, fimfälliger hierauf hingewiejen. Inter fđweren flügelfłlägen fanmeln fich die 2rashornvögel in den Kronen, um vereint mit den grajiöfent Turafos und den grauen Papageien in frembartigen frädjenden oder tiefen Tönen

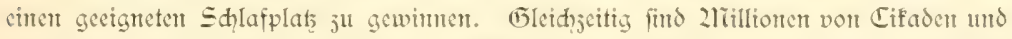

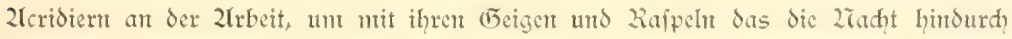
währende Urmaldfonjert aufjuführen. (5)ökere Säugetiere wird freilid der flühtige Seifende faum in gejdlofienen Walsbeftand ju Gejidnt befomment. Wer fie gar erlegen wollte, fant mur dam auf Erfolg refincu, went er geborener Jäger und mit den Ecwohnheiten der jagobaren Tiere genau vertraut ift. So fei denn mur fur rrwähnt, dấ gelegentlid, der Elefant feinen $\mathbb{W}_{\mathrm{g} g}$ bis ju den Pflanjungen findet, 


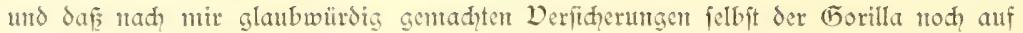
Ser Zradtigallhalbinfel vorfonmt.

Dod jurü ju dem Wege nad 3uea. Ein lebhaftes Treiben herridt auf ihm, da er dic Gauptoerfehrsader jwifhen den Stämmen der (⿹勹birge und der Zitederung abgiebt. Sthwer beladen und auf eiten Bergitot fith ftütsend fommen die Bafwiri= Weiber oft in Gantjen Karawanen an. Die älteren find meift von abihreffender L jüge. Dafür entịädigt freilid - wie bei vielen ziaturvölfen - die tadelloje unt oft grajtöfe Ealtung des fräftizen und unterietsten Körpers, weldhe nidt wentig durd dic von frül, auf geübte (bewohnheit, dic Saft auf dent Kopfe ju tragen, begüntigt wird.

Daf die im Durdidnitt nidht über 2littel

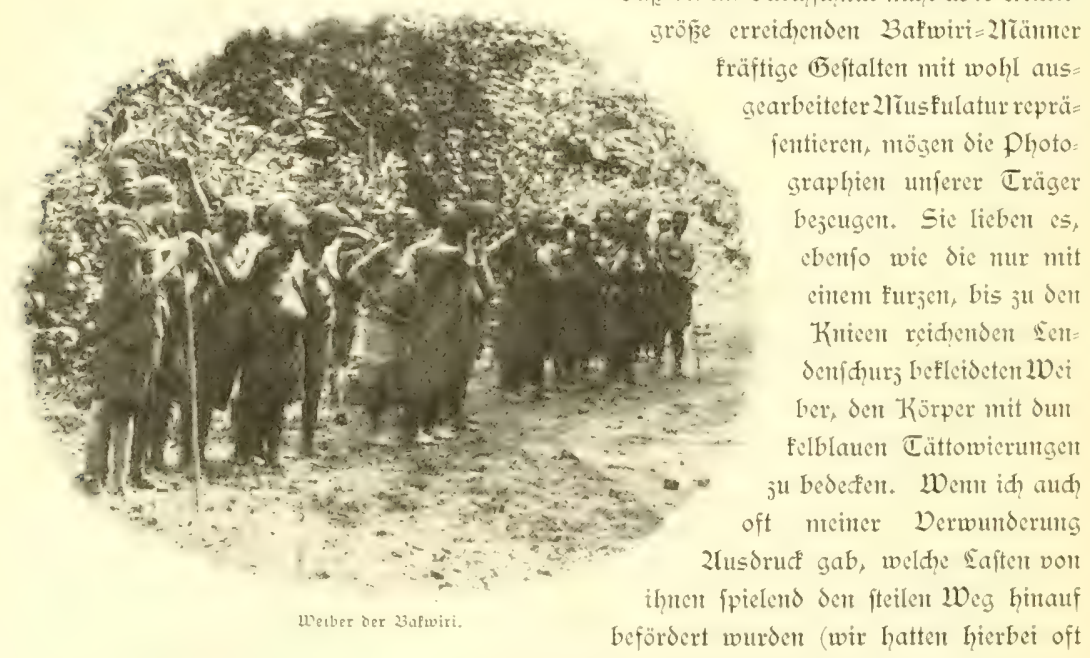

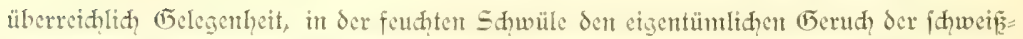
triefenden Zleger fenten zu lemen), fo haben fith dod die Bafmirt als Plantagen= arbeiter nidit bewährt. Fine thnen angeborene Jndolents und ihre 2lbneigung gegen

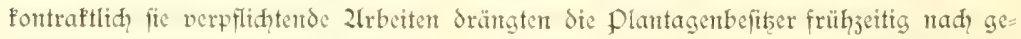

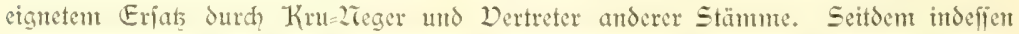
cine Lamburger firma die Derdingung der Kruboys monopolifiert und weientlith ver:

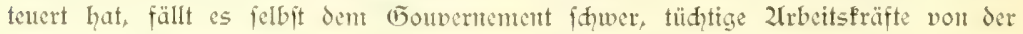
Siberiafüfte ju bezichen.

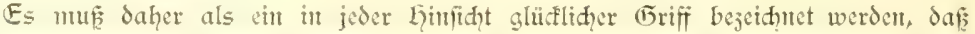
Sic bereits, von Jintgraff angefnüpten 3 ejiehumgen mit Ģarega, den König der 
Bali, Surd die in Eemeinfhaft mit criterem unternommene Expedition von Effer (1896) 3ut eimer befriedigenden Söfung der 2rbeiterfrage ausgenutzt wutrden. (B) arega,

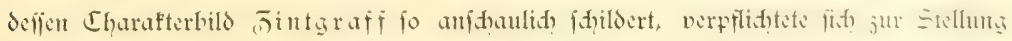

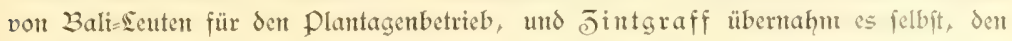
erften Transport aus dem Jumern des Kanteruner Godplandes nad der Küfte ju geleiten. Das Kontraftverhältnis mit den meift auf ein Jabl fith verdingenden Sđwwarjen wurde durd dic kegierung geregelt, und der fürjlid, veritorbene (T)arega müfte niḑt der fhlaue und aufgeflärte Despot gewefen fein, der mit eiferner Land

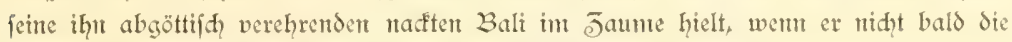
Dorteile eingefehen hätte, dic ihn aus dem zlbfommen zufloffen.

כur כeit unferer 2lnwefentheit waren auf den bis Buea fidh eritrectenden Terri:

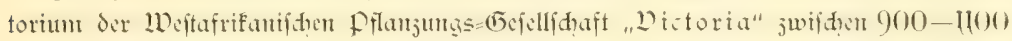
Plantagenarbeiter aus dem Bali=sande befhäftigt. Etwa 920 ha waren gerodet und mit über 400000 Kafaobäumen bepflanjt, weldhe bereits int dritten Jabre die den Banaten ähnlidgen broumoten frühte ant Stamme jur Entwicthung bringen. Int ihmen find die Bohnen enthalten, welhe forgfältig von fleifhe befreit unt in Troften= Gänfern mit dent 2liayfart'fhen Kafao=Dörr =2lpparat der weiteren 3ehandung unterjogen werden. Da die funhtbarkeit des Bodens cine fo ausgiebige ift, baf vierjährige Kafaoftänme über dem Kopfe des Reiters ihr Laubwerk entwideln, wird man die hodffiegenden Erwartungen begreifen, welhe an dic weitere Zlusbildutg der Kafao=Kultur in Sdqufgebiete anfnüpfen. Sie werden in Erfüllung gehen, went durdh gefdidfte Judhtwahl und durd rationelles Trodenverfahren ein crifflaffiges Produft in den Landel fonmt. Eine Dorbedingung ift freilich die geregelte Jufubr von fduwarjen flantazenarbetern. Die fürjlid entifandenen lituhen in binterlande haban jur folge gehabt, daf̧ der Juzug der 3 ali und der neuerdings herangejogenen Jaunde jur Küfte abgejdinitten wurde. Lat eimmal die Sḑuţtruppe Dromung gefhafien und find die Derhältniffe fonfolidiert, fo wird die günjtige Prognofe, welde die Sadpver:

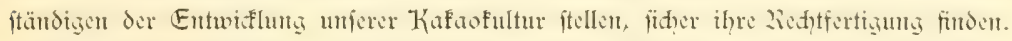

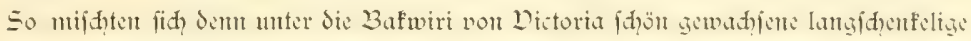

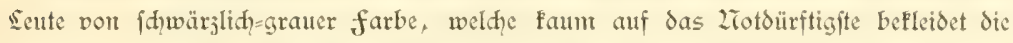
Plantagenarbeiten $j^{u}$ allgemeiner Jufriebenheit verrihteten. Dft famen fie uns in

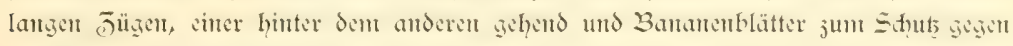
den Regen über den Kopf haltend, entgegen. Zluf dem Dorwerf Boana, das unter der

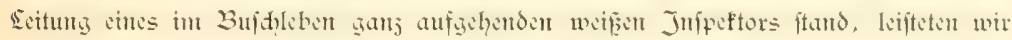
gern der freundichen 2luffordenutg jum Eintritt folge. Sheu ftarrten uns die Bali

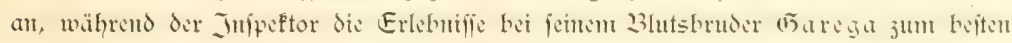

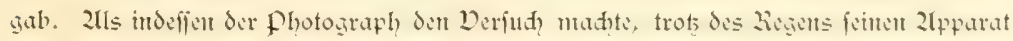
ausjuframen und die fdiwarzen Eciellen aus den Limterlande im Bild fejtjulyalten, 


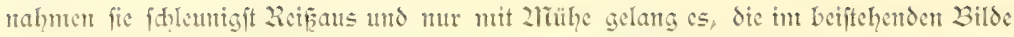
vereinigten Eđwwargen jum 2lusharren ju bewegen. Llnjere Bafwiri hatten längft ihre

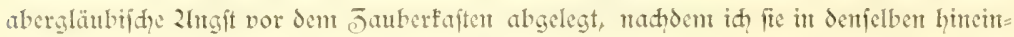

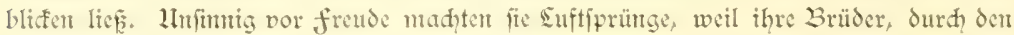
2lpparat betradłtet, auf demt Kop广e ftätton.

Ginter Boanta wird der Piad nad Buea fạmieriger und führt bisweilen fteil durd? Gohlwege, welthe von tropifhen Eäumen mik oft feltfant geftalteten früdoltent über= fhattet werden. Die mäd̆tigen Wollbäume treten jurüt und oft fâmeift der 3lift über ausgedehnte sidhtungen mit 2Tegerhürten oder über die unter Seitung von Lerm (5) unther ftehenden Soppo=Plantagen rad) dem Kanteruthaff und den fernen in Duft

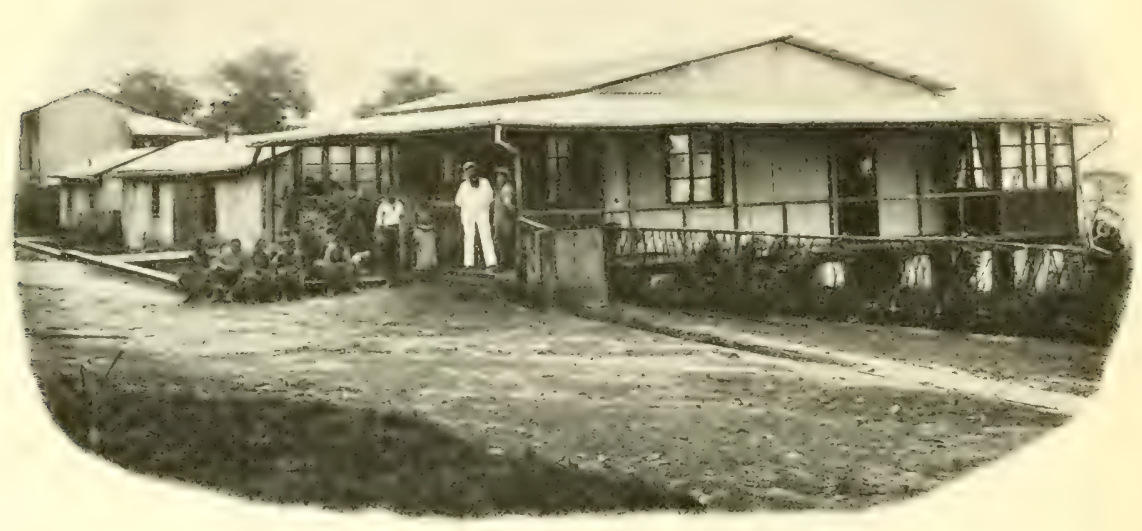

Stationsgebăùc iı Buca.

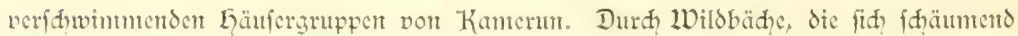
Sen Weg über Bajaltflippen jwifden farngeftrüp bahnen, gelangten wir endid in von dem Serze fid herabfenfendent Ziebel nad ber Station Buea.

Fin fanmules (5)ouvernententsaebände, ungeben von (5artenanlagen und Tenntsplat jur Sinfer, vor uns cin Wadthaus, aus dem dic Polizeijoldaten in das Ecwehr tretert, dabinter das freundiche cinftöftige Stationsgebäude mit Zebemräumen und fid

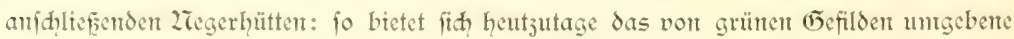
Buca dar. Doh dic Phantafte idfocift weiter und malt fid das jufünftige Buea als Dillenfolonic aus, welde Jurd cinte Ëebirgsbahn nit Dictoria und der das "Ginter= land erfaliefenden Centralbahn verbutden ift. 2lian lädele nidgt über derartige 


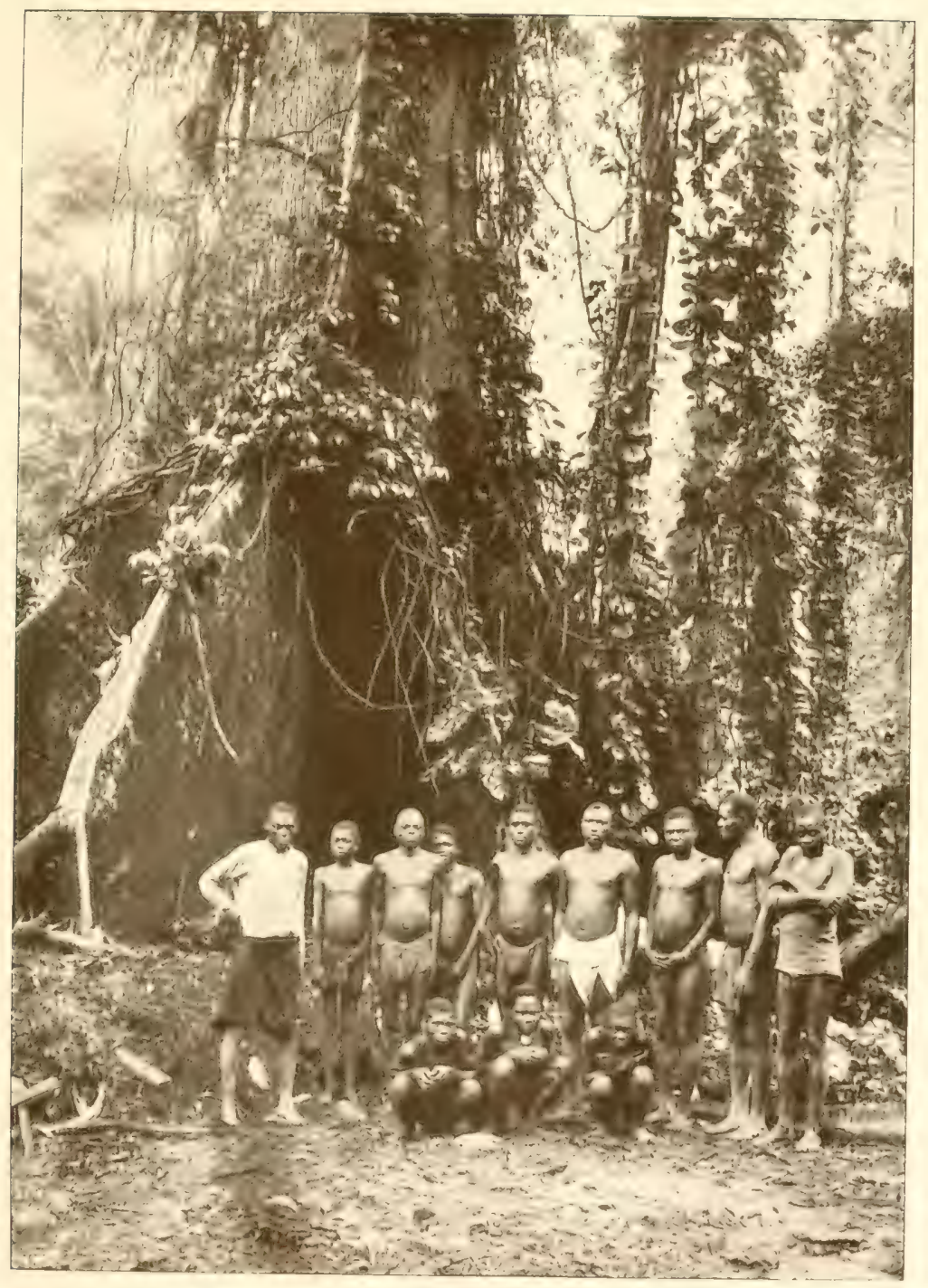

23ali= Scute. In Lintergmud: Etantum cints Eriobutoron. 

Suftąlöfer, dent Buea ift beftinmt, dereinft in ber Entwiftung ber Kolonis eine hervorragende Rolle ju fpielen. Es wird nidit mur das centrum der weit an 3erge

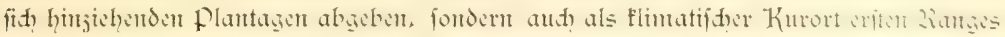
von feinem Punfte der Weftafrifantifhen Küfte übertrofien werden. Sdion jeft fudst Dort der fieberfranfe Ẽenefung und der Beamte Erbolung vor der anftrengenden Thätigfeit in dex heifen Ztiederung. 2lan atmet freter auf in biefer herrliden (bebiris luft, laujd dem Raufden der in der Regenjeit ftarf angejhwollenten Bädhe, erfreut

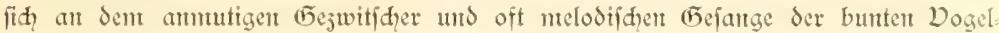

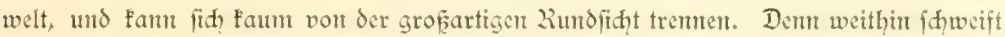

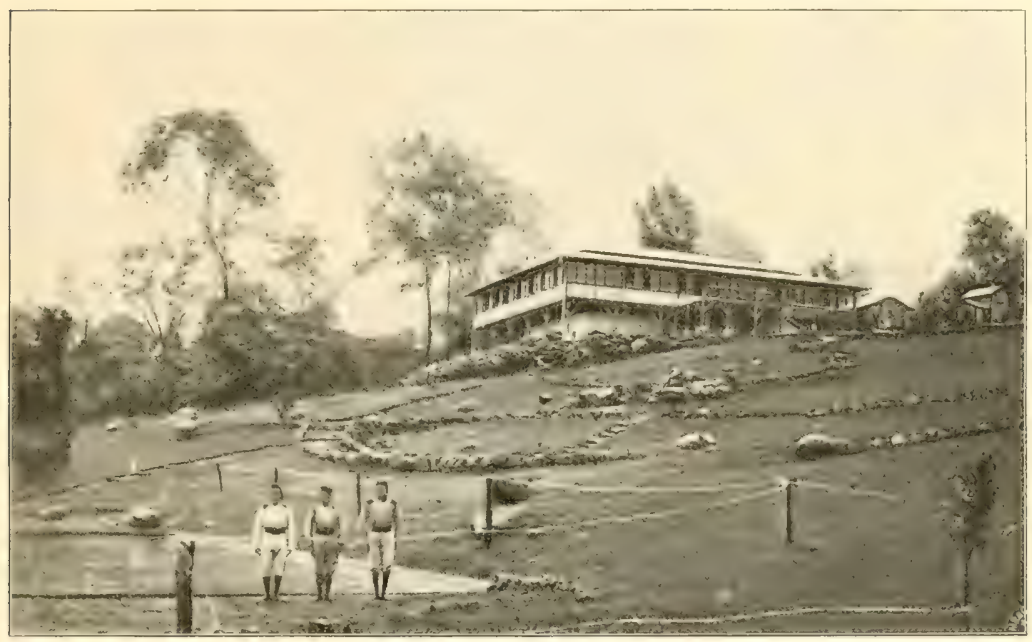

Bouvernententsgebäube in 3 usa.

der Blit über den Lrwald himweg auf das 2lieer und dic Zitederung bis ju den flar hervortretenden Regierungsgebäuden von Kamerun und ju den in bläuliḑem Duft fid verlierenden 2ifolit 3 ergen. Im Lintergrund hebt fith faharf der Ianggejogene Kanm

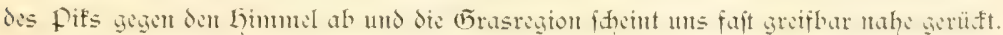

Wir haben die obigen Jeilen fo ftehen laffen, wie fie auf den erften Eindut hin niedergeforieben wurden. Injwijhen - nad faum drei Jahren - haben fich dic Derhälntffe völlig geändert unt manḩes, was wir als Spiel der phantafie bejeid = neten, ift in Exfüllung gegangen. Dies niht jum mintepiten Surd Sen 2lmptand, daf: die Regierung fith entidylok, dan Sif des Goupernements aus der wegen der 2ralarta verrufenen Ziederung nah dem fieberfreien Buea ju verlegen. Stion hegintt in dut 
Ljöhe chte Dillenfolonte fidh ansjudehnen und nidht lange wird es dauem, bis die von der Weftafrifanifhen Pflanjungs=(bejelljhaft in ciner Sänge von $60 \mathrm{~km}$ geplante felsbahn aud Buca crreitht hat.

Buca liegt in cincr Göhe von $920 \mathrm{~m}$. Während die mittlere Jahrestemperatur von Dictoria und Kamterm jwifhen $25-26^{\circ}$ beträgt, jo ift es in Buea un $5-6^{\circ}$ fühler. Das ift für dent an das gleidumäpäge Tropenflinta der Küfte gewöhnten Europäer cinte nedt beträd)tlidhe Differenj, weldye nantentlid während der trodenen Jeit von 2Tovember bis 2rai fid? um fo angenehmer geltens madt, als 2ralaria

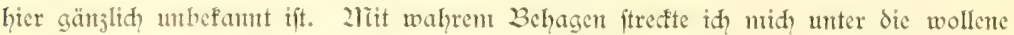
Dede und nahm frühmorgens cin erquitendes Bab im frifhen Debirgswaffer. 2lls wir

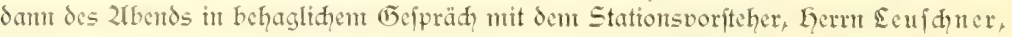
und deffen (5attin jufammenfafen, nti Lauptmann v. Beffer und den ummohnenden Sandslenten alte Ermmerungen auffrifdten, da fiel es oft fower, fid in den Gedanfen hereinjünden, daf man mur + Brettengrade entfernt vom Z̈lquator lebe.

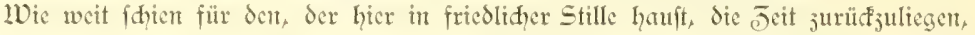

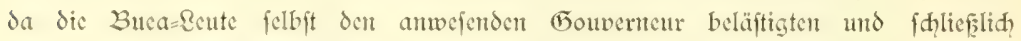
Dr. Preur cingefhloffen hielten, bis die Sdutstruppe unter führumg von Gauptmam

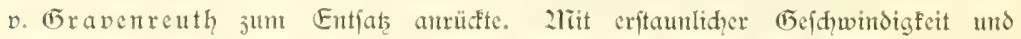

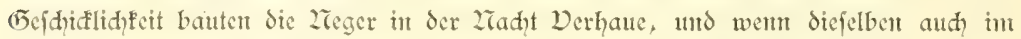
Sturme genonmen refp. ungangen wurden, fo war dod der Sieg mit den Tode Gravenreuth's fower erfauft. Er fiel am 5. 2rovember 1895; fein Tos hat cinten grofent Eindrud auf die Bafwiri gentaht, dic nidht verfehlten, mir die Stelle $j^{11}$ jeigen, wo er pon dem 3lei getroffen niederfanf. Erft nadjdem im darauffolgenden Jahe das Strafgeridnt liber die immer nod aufäfigen Eebirgsteger ergangen war, fehrte Ruhe ein. Dier Jahre hatten genügt, da auf dem Shauplats wilder Scenen ein

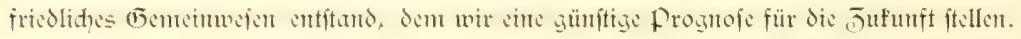

Kurz nad unferer 2lbreije jog allerdings 3 uea in unliebfamer Weife die Zufmert= famfeit auf fith. Die Polizeifoldaten (neift Wei=2reger von der Liberia=Küfte), welde dem Stationsleiter unteritellt find, wurden aus geringfügigem 2fula widerfeţid und fanmiedeten cin Komplotf, den Eeiter und fäntlide Weife umjubringen und frau Ecuiduter in den LImald ju fdileppen. Der Plan wurde verraten und dem ener= giljhen Eingreifen des Stationsleiters war es ju verdanfen, daf man im Derein mit

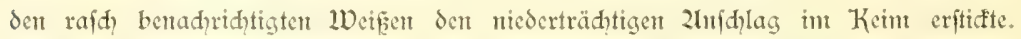
Einige Soldaten wurden niedergefoffien und der Reft flüdtete in den Wald. charaf= teriftifich für die dortigen Derhältnifie ift der 2lmptand, daf die Bafwiri, weit entfernt,

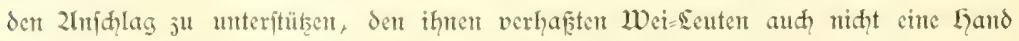
voll Reis verabreidhten. Galf verhungert famen die 2lienterer auf die Station jurüf, um das Strafgeridit über fid ergehen ju laffen. 
Der nähifte Tag (17. Septem ber) galt eitter botanifhen $\mathbb{F}_{x}$ furfion in das (5) rasland des Kantrumpifs. Fine Beftei= gung des (5ีipfels, wie fic mehrmals durd) Dr. Preup und Gauptmanm v. Beffer ausgeführt wurde, lag toeder in unferer zbitot, nod aud wäre fie währento der Regent= jeit ratiant gewefert.

So pilgertert wir dem, mit mu leid)tent (ธ̄epäd ver = ichen, durh das üppig ful=

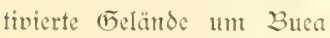
Ser oberen Llrwaloregion ju. Edion bei dem Eintritt in Sicfelbs gemahnen vereinjelte Baumfarne daran, daf $\delta \mathrm{er}$ Charafter der Degetation in Set fühleren Eöhenlage fid जeändert hat. 3ei wetterem Dordringent auf dem fteil an= iteigenden fhlüpfrigen Pfad ipringt der phyfiognomifde Unteridjied jwifhen dem $\mathfrak{U r}=$ wald der Ztiederung und je=

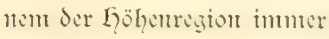
fintufälliger in das 2luge. Knorrige Stämme mit brei= tert Kronen treten an Stelle ber fdilant aufftrebenden Rie= fert; häufig bilden ihre Suft= wurjeln mächtige Strebepfet= ler, jwifhen denen der Pfad in malerifhen Krüntmungen fid wintet. 2roole, fleine farte und fledtert über=

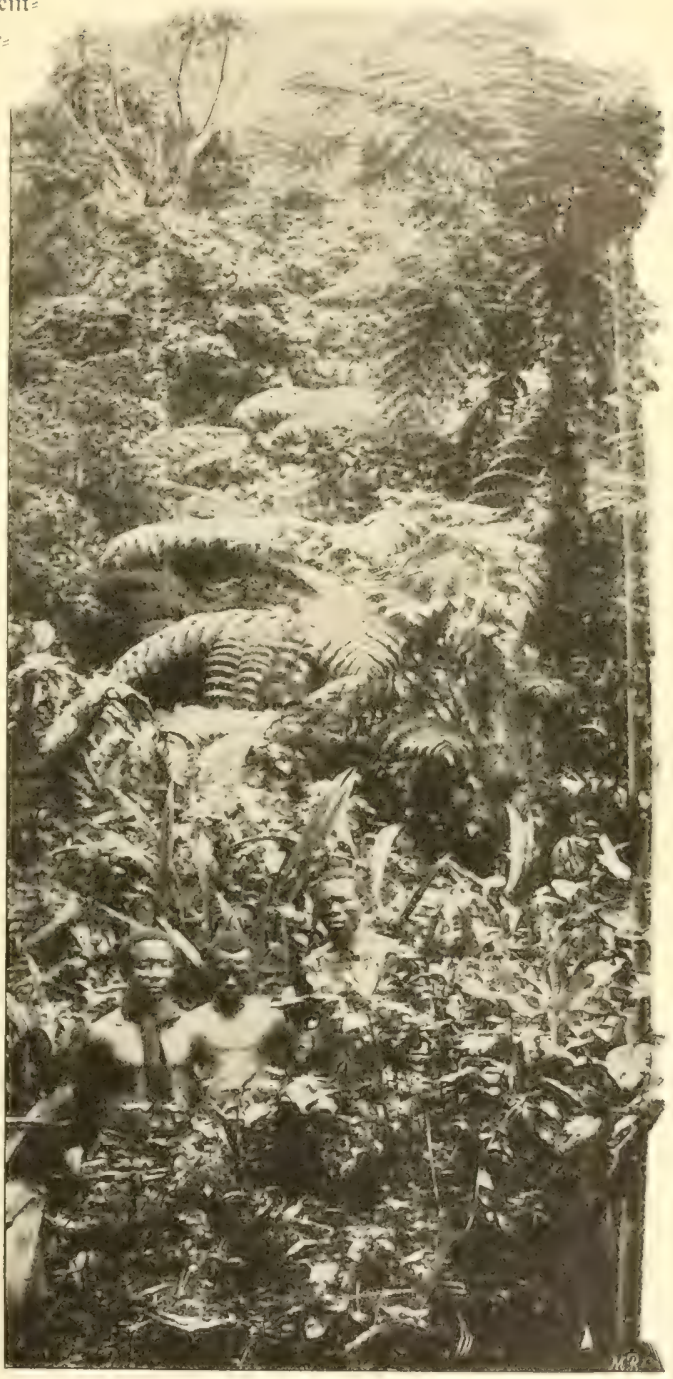

2trwals am Tamerumpif in $1000 \mathrm{~m}$ 5öhr. 
wudjem das 2ljtwerf, und cin undurdobritglides Gewirr von Sianen, farmen und tiederem Bujdwerf hemmt das fortfommen. Der Kameruner Ltrwald ift reid an

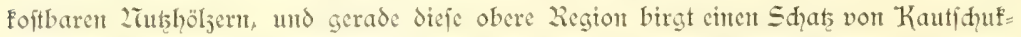
bä1nten (Landolphia), Ebentholj (Diospyros) und fonfitigen harten, fhweren Ljölzern,

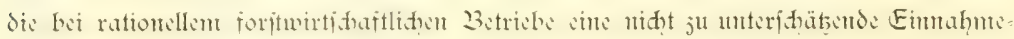
quelle für die Kolonte abgeben werdent.

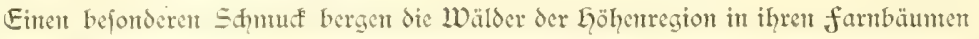
(Cyathea). Bald veremgelt oder in (5rupper jufammenjtehend, bald wieder fleme ge= fifloffene Beftünde bildend, tragen fie nidgt wenig daju bei, den tropifden Charafter der Sandidaft jum vollendetiten 2usdnuf ju bringen. Wie oft hatte id nidht im fitllen mids gefehnt, mit eigenen Zlugen die Praḑt der farmwälder ju fdhauen, wie fie der auftralifden und neufeländifden Region jufommen: nun nahn ein farmwalo uns in fein gehcimutsvolles ङwielidit auf, der an wudtiger Entfaltung der fuwwarjen

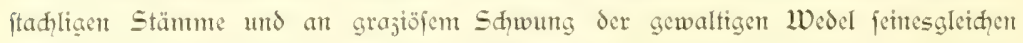
fudit. Dic eigenartige Stmmung von Sd)warj und (5)ün, untermifht mit dent Braun der abgeftorbenten alten oder hirtenftabfömrig gebogenen jungen Wedel, der harafteriftifde Duft und das durd dic fiederäfthen gedämpfte sidht wirfen faft jauberifd auf den utbefangenen 3efhamer. Ken Palmenthain der Kofosmfeln hat

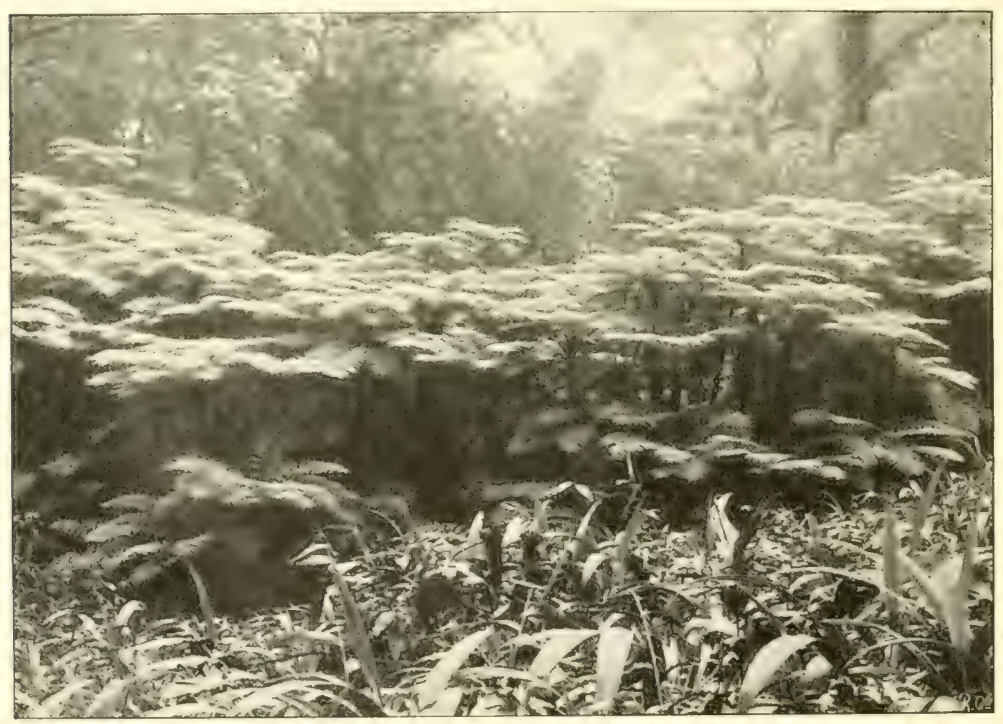

farnbiume ant Saume des 1trualdes in $2000 \mathrm{~m}$. Fishe 


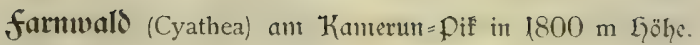

Ilquarell poit $f$. Wlinter. 


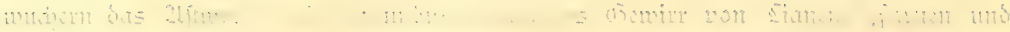

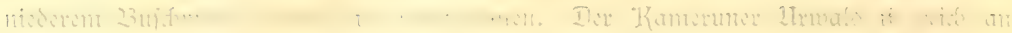

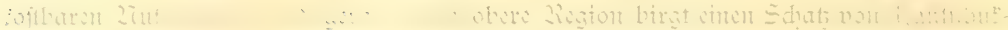

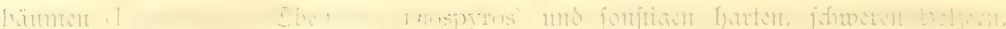

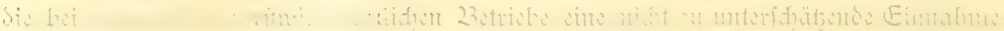
vilt 1'

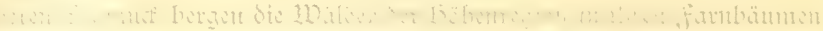

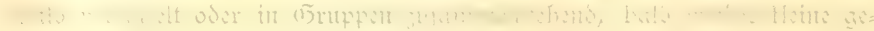

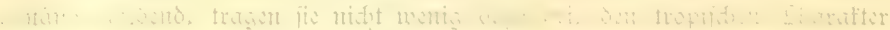

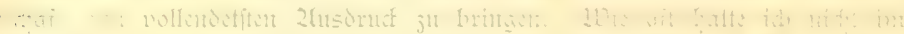

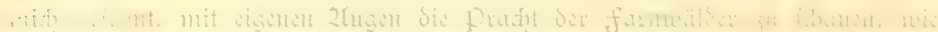

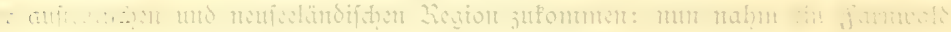

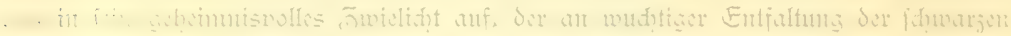

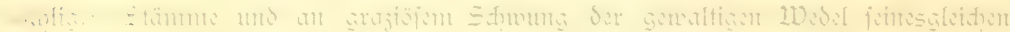

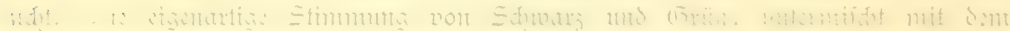

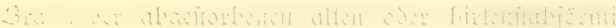

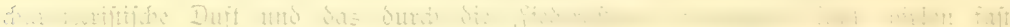

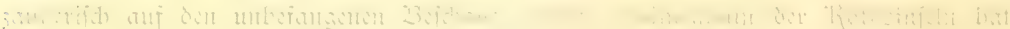

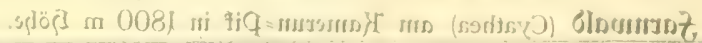

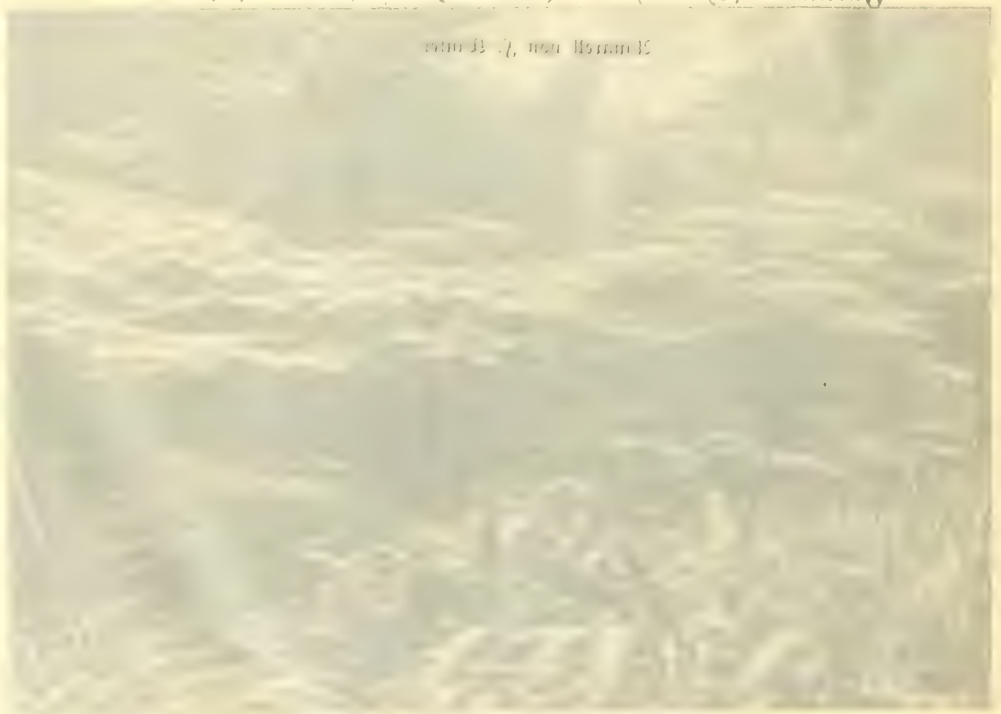




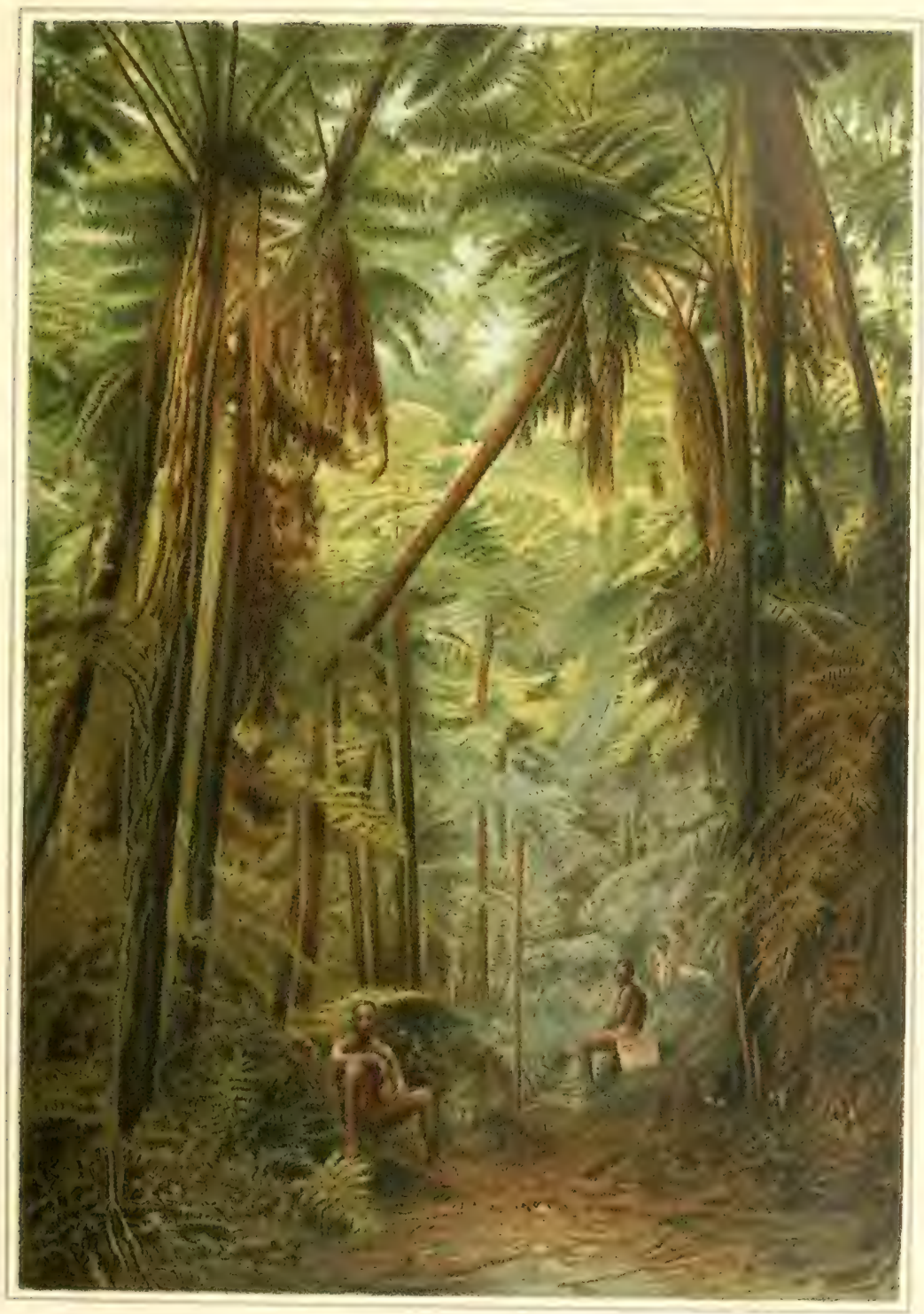


es mir fo angethan, wie diefer ans bem 2ldel der niederen pilanjumelt gebildete 3ejtand!

Steil windet fid der falmale Pfad berganf durh cine faft fimberwimende fülle von verjatedentartigen Waldbäumen, bis endid in etwa $2000 \mathrm{~m}$ Ljöhe dic obere (1)renge

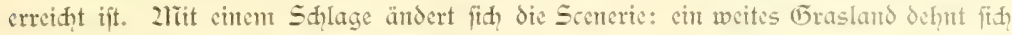
vor uns aus, juerft fanft, bann fretler gegen die rötlich=grauen länge des faft greifbar nah gerüften langgeftreften Kantmes anfteigend. In den Sdluditen jicht fidh der $2 \mathrm{ll}$ wald nod bis 3 faft $2500 \mathrm{~m}$ binan, hier und ba an fement Rande pon flemen (5ruppen der farnbäunte wirfungsvoll umrahmt. Das (5) tagelang in der Treibhausatmoiphäre des Hrwaldes pilgerte, fenten bejonderen 2eitj. 2rit wahrem Entjüfen atmet man dic fräftige Bergluft cin und gentef̧ man das grofartige Panorama. Wie cine Eandfarte liegt die Kamenmer Ziedenutg und der (5umea= (5) If vor uns ausgebreitet, hiet und da fiehlt fid die Some durh das graut (5)wöle und hebt cine Kuppe, cilt Stüt der Ebene wirfutgsvoll von den düjteren Grau=grün des Urwalds ab. 2fn dem Kanme des Pifs jagen fith die Zebelidwwadem,

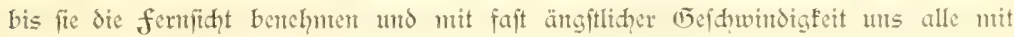
ihrent Sdyleier verhüllen.

Das $\mathfrak{W}$ anden in der Erasregion ift mühflig und erfordert gepannte 2lufmerf:

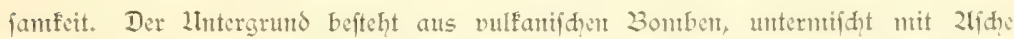
und gröferen Blöfen. Dies alles wird von oft bis jux Bruit reidenden Ẽrasbüfhen überwudịert, jwijhen denen in überrajhender fülle bis amtutigen Kinder enter bunt blïhenden, häufig ftraudförmtig entwidelten flora fprtefen. Sic verdectt dic trïge

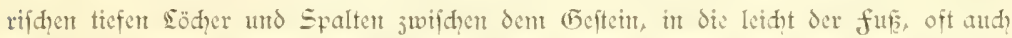
der ganje Körper einfinft. 2lïr fduwebt nod inmer unfer Photograph vor, als $\mathrm{cr}$ mitjant feinen 2lpparate, wie non der Erde verjhlungen, dem Blidt entidjwans unto nur mit zlühe aus der unbehagliden Eage befreit wurde. 2lit Redit befürditete

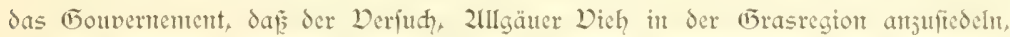

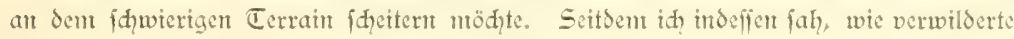
Rinderherden auf der im Jndifhen Deean einfam gelegenen vulfanifhen Infel 2Ten

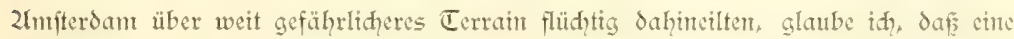
Befiedeluntg der Erastegion mit heimifden Zinderrafien 2lusfidt auf Erfolg dar= bieten wird.

So überwältigend und fimberanjḑend aud dic Eindrüte warn, weldhe wir während der erften dret in der üppigften Tropenfeneric verbradten Tage entpangen

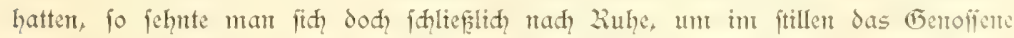

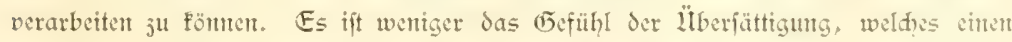
überfommt, - dies habe ih auf der ganjen keife nidht verfpürt - als die $E_{1}$.

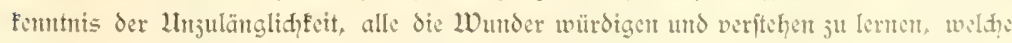


(it) in den Tropen oft auf den enģten Kaum jufammendrängen. Die fülle an tierifhen und pflanjlidgen neuen 2leten wirft finnorwirrend, unt went man fie aud allmäblid fenten und von verwanden fornten unteriheiden lente, fo wäre dod damit mur der erfte vorbereitende Sdritt ju ciner ticferen Einfidjt gethan. Dem fie fediten ins= gefant ihren Kantf un das Dajein aus, fie ftehen in innigen Wedficlbejtehungen ju chander und find Kütder des feudtwarmen Klimas. Wen freund Shimper während der Wanderung darauf aufmerffan maht, wie der Kameruner llrwald fith

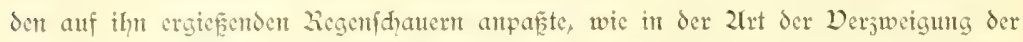
Bäume, in der fornt der Blätter und in den Sduthvorridatungen der Knopen fid

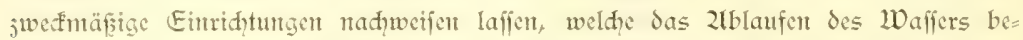
gïnjtigen, fo hat man wenigftens cinen allgemeinen (5)ffhtspunft gewonnen, den man gen anf den Spectalfall überträgt. Da lent man and de frendige l̈berraf̧hung des Botantfers würdigen, went er jwifd̨en den auf den Stämmen fđ̆marofzenden Zrten cine Utricularia findet, cin Pflanjhen, Sefien nädfte Verwandte in unferer Geintat als Bewohner Ser Sümpfe in Torfmooren vorfonmten. Während die Blätter

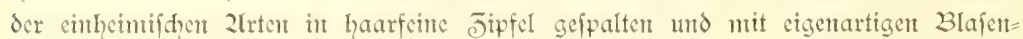
fallen zum fang vor fleinen Stifiwafferftebien ansgerüfet find, bleiben fie bei diefent tropifdien sandbewohner unjerfpalten unb ordnen fid ju emer kofette ant, aus deren 2litte der Stengel mit feinen prädtig gelb und violett gefärbten Blüten fprieß̨t. fadenfömig verjweigte Würgelden, welhe den Wafferformen fehlen, dienen zur

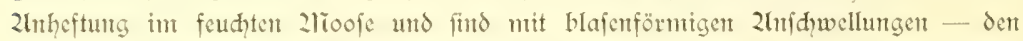

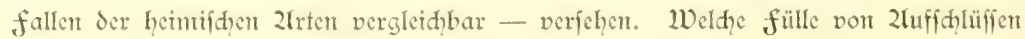
veripridit nidit die cingehende IInterfudung cines einjigen befdeidenen Tropen= prlänghens, das fid nont Wafferleben an den 2lufenthalt im feudten 2lioofe des regengefdwängerten Lrwaldes artgepafit hat!

Infere Shwarzen forgten freilid Safür, daf man derartigen Gedanten niḑt lantg madhing. Sdion lange fauerten fie frierend und finatternd int Lodhgebirgsnebel, mit webleidigen Bliden das Signal jur Unfehr erwartend. 2Ind als es dam endid wieder bergab ging, als nad emem in behaglidien Geplander verbrahten abeud und nad) einer jweiten crquiftenden Zaditruhe int gaftlidhen (5ouvernementsgebäude von Buea die Treibhausatmoiphäre der unteren Llrwaldjone uns wieder aufnahm, da brad die angeborenc frohtatur durd. Troţ der fduweren Eaftent, des fhlüptrigent

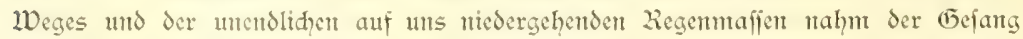
fein Ende, weldher in cinförmigen Ritornells (fie crimerten midy gar oit an dicjenigen Ser neapolitanifhen fifder und Gafenarbeiter) dic fleiten Shwäden der PFlanjen und

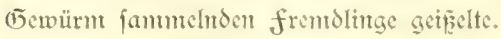

Bevor wir am 19. September dem an 2raturfhörheiten überreiden Dictoria den Siidfen wendeten, waren wir nod? Jengen eires eigenartigen Shanfpiels, das fid auf 


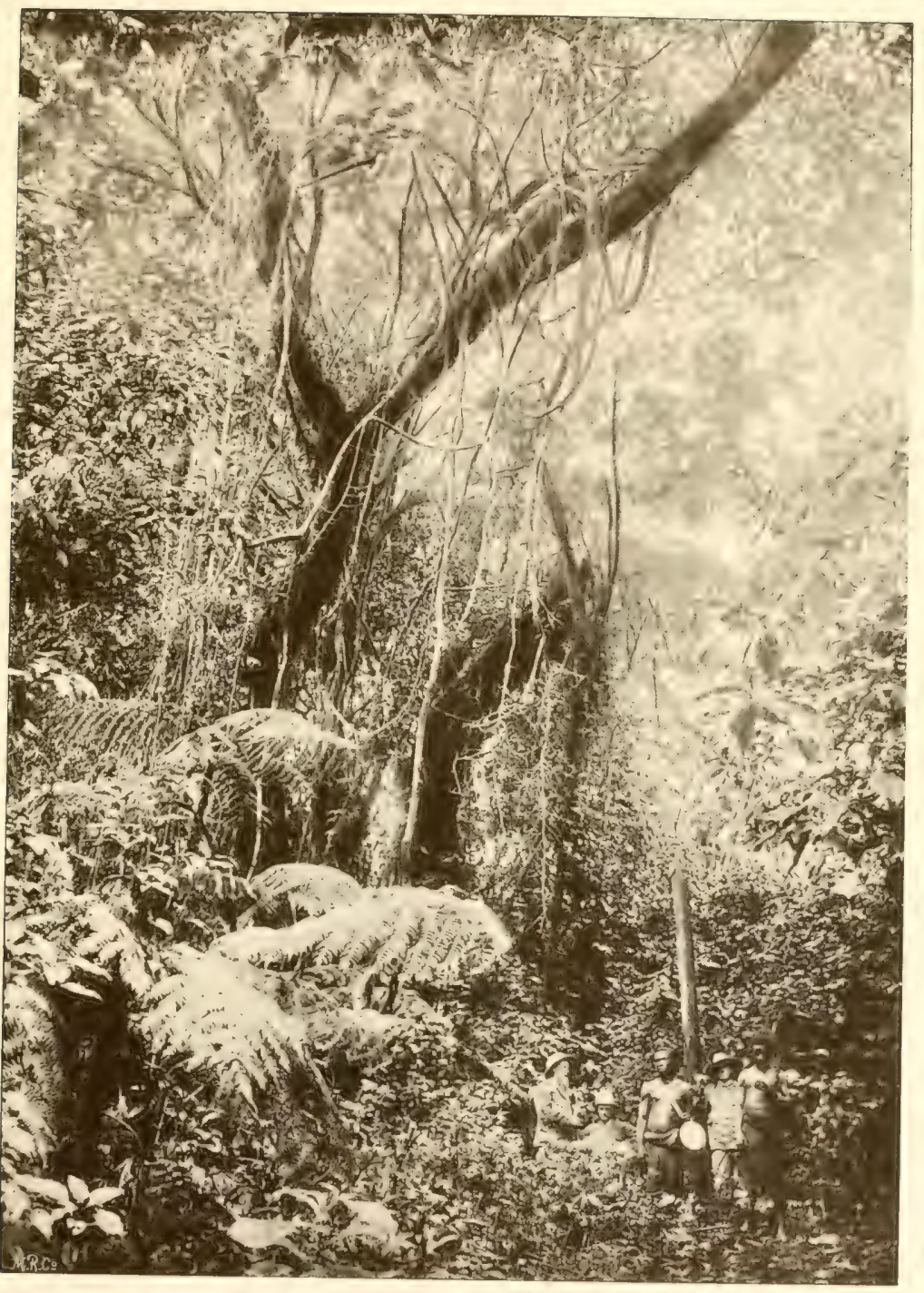

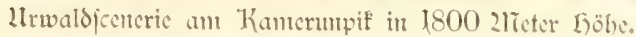





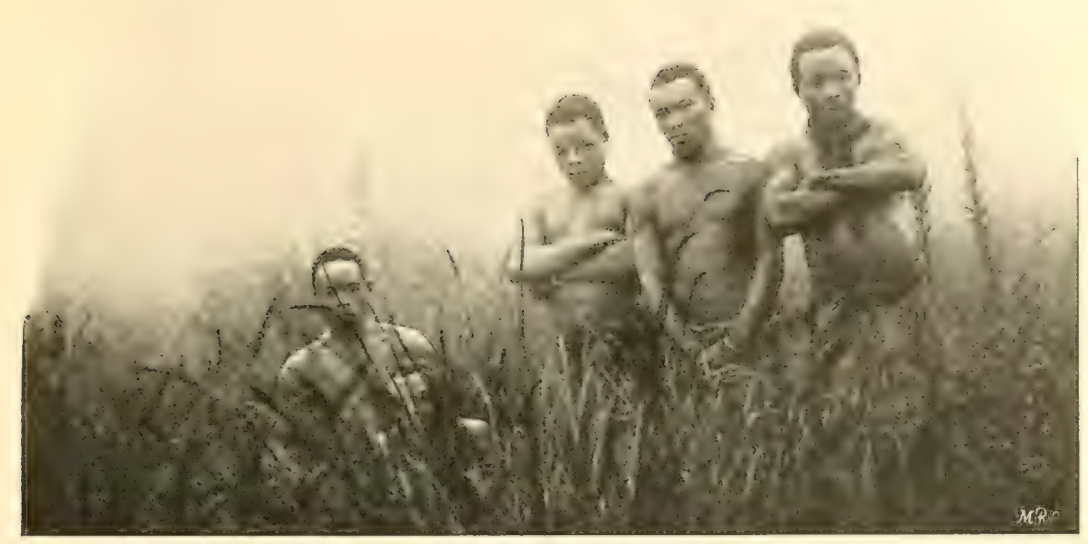

Infere 3afwiti int 2Tebel Der Brastegion

siner der fleinen Bobia= Jnfeln abipielte. Der nidat bolfreidje Stantut von 2iegent, welder fith auf der gröften dicjer fteilen Klippen angefiedelt hat, lebt hauptfäḑlid? von den Erträgniffent der fifderei. Eegen feindliche ü̈berfälle, wie fie früherhin öfter vorfamen, als die Bobia:2ieger nod, cintge Siedelungen an der Küifte bewohnten, ift

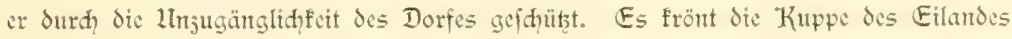
und fann nur auf einem über felsblöffe führenden fteilen Pfade crflettert werden. Eine fhmale Junge bietet dic 2liöglidłpeit ciner Sandung. Fier herridnte jwifhen den primitiven auf den Strand gejogenent Canoes ein gefdäftiges Treiben; der ganje Stanm, 2länmer, Weiber und Kinder, war um cinen furchmoal von mitflerer (5röfe verianmelt, den man ant Tage vor unferem Befudge harpuniert hatte. In Ginblie auf die primitiven 2litttel, über weldhe die Zeger verfüger, wird man den

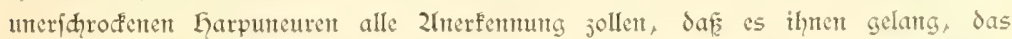

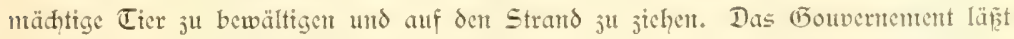
is hierbei an 2luregung nidit fehlen und fo war es denn bercits der jweite Wal, welder im Saufe des Sommers erlegt wurde.

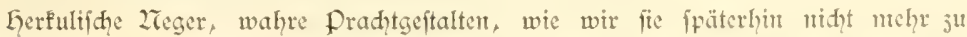
(5eficht befanten, mühten fith $a b$, den $1 V_{a l}$ aus feiner Scitenlage auf den Baud ju

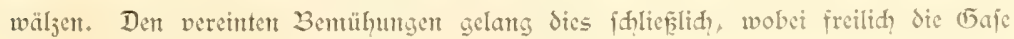


aus den bereits ftarf aufgetriebenen Eingeweiden chtwidien: für die Shwarjen cin licblidges 2troma, für uns eme wahre Peft! Da Walfifdfleifd, jumal wem es dent nötigen haut-goût crlangt hat, bei den Küftentegern als gefhäţte Delifateffe gillt, für Sic fie bereitwillig thre beften Tanfhartifel hergeben, fteht ein harpunterter Wal hod im Wert. Die Barten werden freilid faum gewürdigt, und diefem IInftande hatte id? es ju verdanfen, daf mir bereitwillig ein Teil derfelben ausgehauen wurde.

Der Larpuneur fhenft den Wal dent Stamme und der leftere jögert niðt, dem Danf und Ser frende über die grofartige Gabe entfprehenden 2usdrud ju verlethen. Die Kunde von dem glïflidgen fang verbreitet fid rajd, und von allen Seiten fonmen dic Cantoes herbei, beladen mit Taujdwaren und mit einer geifuwätigen zlienge, die an dent freudenfeft teiljunebmen gedenft.

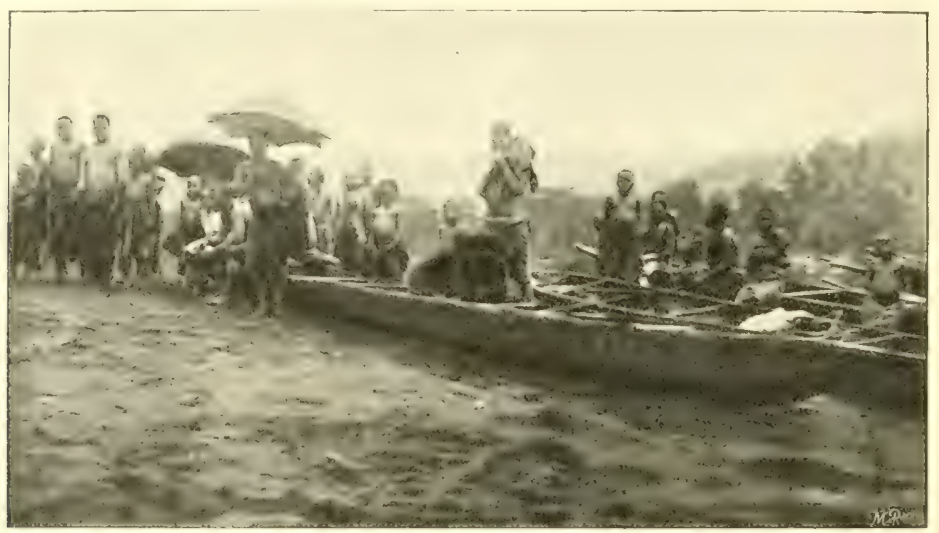

Rieger son ier Bobia= Injel.

Den Weifen ju Ehren hatte der alte King fein feftlides (Ẽewand angelegt, und fo ftad er dem im Tropenlyclm und weifen Talar, un den als Shärpe cin frottier handtuक gefhlungen war, redpt ftattlid, vort feinert faum mit dem 2rotwendigften befleideten 2Intergebenen $a b$. Er finüttelte mit cinem fräftigen "(5uten 2liorgen" dis Gand und war fidtlif erfreut, da年 wir den fteilen Pfad ju der Siedelung erflommen, in der freilid, weil alles um den Wal verfammelt war, nur fhwarjes Borftenvich den Willfonm grunjte. Als wir jurüdehrten, bot fid uns cin eigentartiges 3 ild dar. In langem Juge, angeführt von cinent in abjonderlidhen Sprïngen fith crgehenden Sdywarjen und von thm folgenten abforedend häflithen nadten Detteln, umfereifte cin Teil des Stanmes den W Wal. Die jüngeren Weiber und 2lämmer folloffen fith in cinter lang gejogenen Reihe an unt rüften nur langfam vorwärts, indent fie unter 
rhythmifhen Singlang tanjende Bewegungen ausfübrten und ein langes Stül Tud

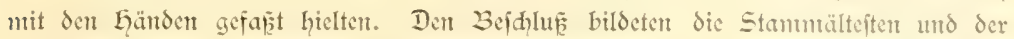

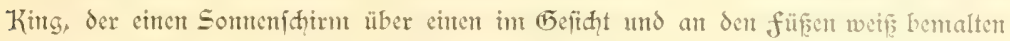
Kerl hielt. Es war der glüflide Garpuneur, wie mir der King durd? Pantonimen

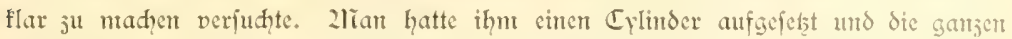

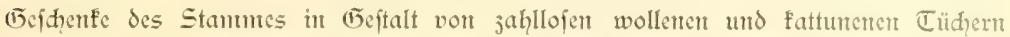
ungepadt. Shweiftriefend und mit ftoifher Ruhe fekte er langlan Sdritt vor Sdritt, unt fundenlang dauerte der tanjende Lmgang, während die Weiber preifend dic bände erhoben und fie dann auf das harpunierte lngehener legten. 2rod Iange, nadidem wir die Jnfel verlafjent hatten und uns jur 2lbfahrt rïfteten, tönte der monotone Rhythmus des Eobgejanges nad und hiclt die Erimerung an eine Scene

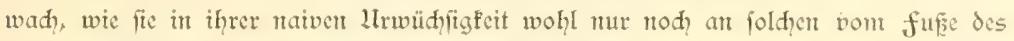
Weifen felten betretenen Eilanden fïh entfalter dürfte.

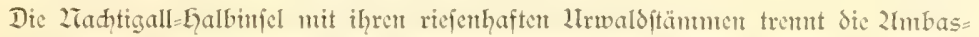
Sai von den Kriegsidifihafen und giebt für den leţteren jugleid cinen vortrefflidgen Edutwall gegen die Weftwinde ab. So fommt es dem, daf der Kriegsidifihafen, wie aud fein 2rame fdion andentet, mit Vorliebe von Sent flenten, in den Kolonien ftationierten Korvetten als 2nferplatz benutst wird. Dic Budt gewinnt durd die engere

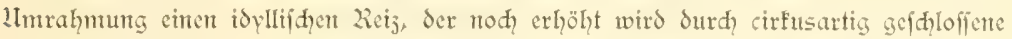
(5rotter, weldhe nur fdimalen Jugang jum 2lieere haben. Sie dienten in früherer Jetf den Dorfabrent des King 3 ell als gefhütste Derfecfe für die crbeuteten Sflaven, und die mit Sianen behängten Stcíhände mögen wohl J̄eugen gar mand gex granentwollen Ehredensfene gewejen feir. Der ftarf verengte äuz̧erfte Jipfel des Eafens bietet güujtigen Jugang ju der faftoret der Kanteruter sand = und Plantagen=(5éfllidjaft, Seren weipe Gebäude jwifher Palmen veritedt fhon von weiten herübergrïfen. Die unter der Scitung von Lerm friederict ftehende faftorei hat fid ju ehrer 2lüufer=

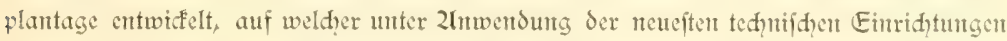
wiederum in eriter Sinte die Ẽewintung und Derarbeitung des Kafaos in Betracht fontmt. Wir folgten der Einladung ju ihrer Befidhtigutg unt fo licber, als wir auth jufällig in dem Kriegsiḑiffhafen auf unjere Korvette "Labid̨t" ftiefen, deren Komman: dant und Dffijiere fith dem Befudie anjhloffen. Sie hatten mit Jnterefle die oceano= graphifde 2lusrijtung der "Daldivia" in Zlugenfdein genomment und fafienen and? niḑt gerade ungehalten darüber, dafi wir "2lündhener frifक von faffe" dem Kühl raum entuahmen. So gab es dem cinen ftimmungsvollen Tropentabend auf der gaft liden Plantage; die Cieaden geigten ihr Kontjert um dic Wette mit der Sdiffisfapelle, utten tangten dic 2ieger und oben pofulierten die $1 \mathrm{D}_{\text {sifpen. }}$ 


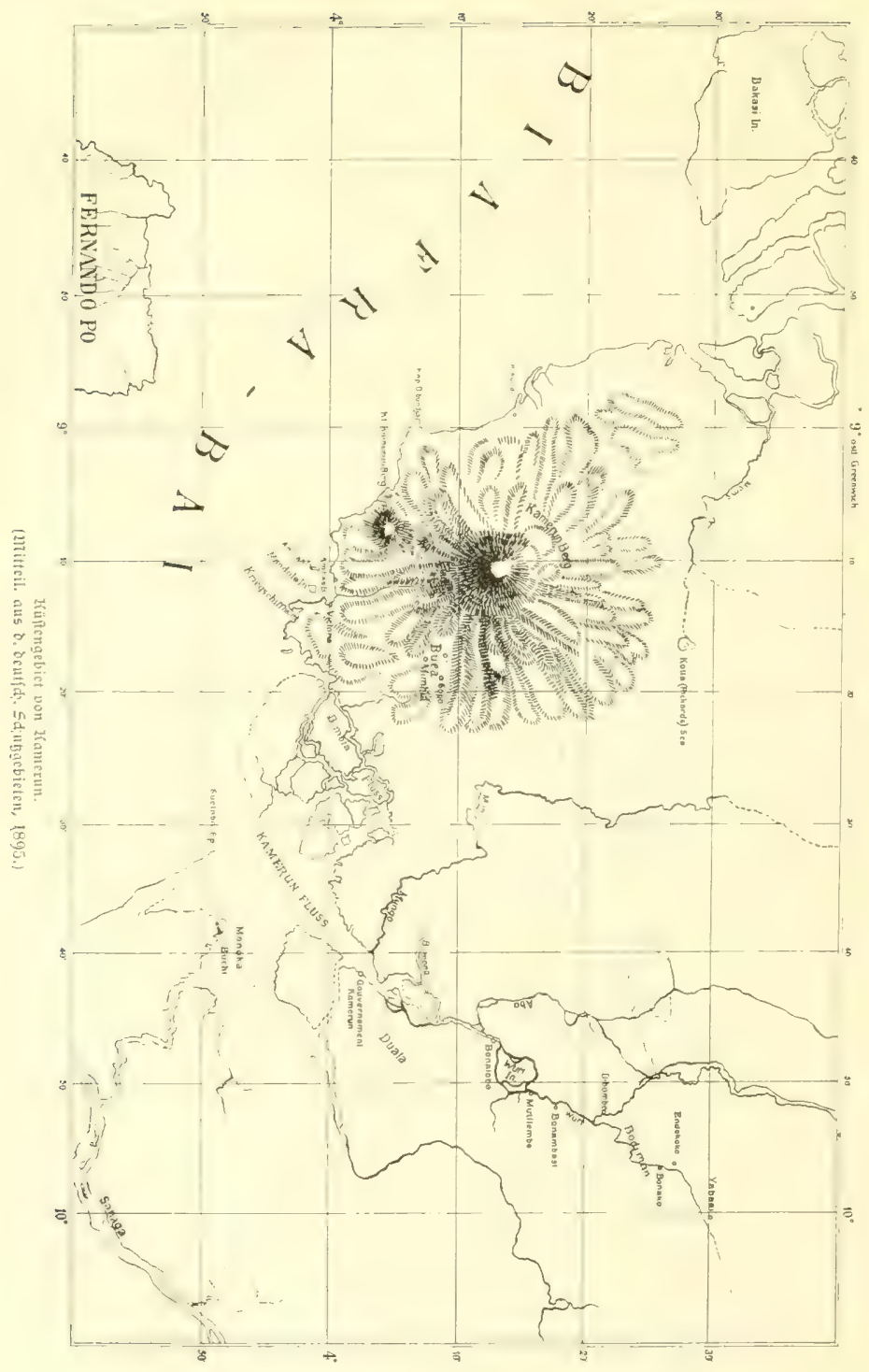




\section{5onvernement Kamerun.}

Der nähite Tag brahte uns nad? vierftündiger fahrt jum Eauptorte unjerer Kolonic. Ein merfwïdiger Kontrait mit der sandidaft um Dictoria: bier cine romantifhe, von dent gewaltig anf= ragenden pif beherrif̧te 23ai, bort ein durd den

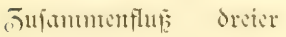
Strönte, nämlid des 2liungo, des 10 uri und des Dibantba gebildetes

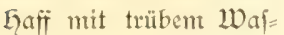
fer; bier die riejenhaften Stänme des Ultwaldes, bort eine 2liangrove zieberung auf flaḩem Strande; hier die ur= wüdfigen und nod we nig fultivierten Bafwiri, dort die fdlauen, weit in das Imtere den ङ $\mathrm{wi}=$ fhenthandel beherrjaen= den Dualla; hier nur wenige in europäijhent Stile gebaute häuler, dort cinte fdimude Stadt, wel= d)e mit thren für tro= piface Derbälnifice grof : artigen Bauten den Eirt= oruf auf ben frentoling nidit verfehilt. - Ka= merun ijt durd? die jahl= reident Shilderungen in

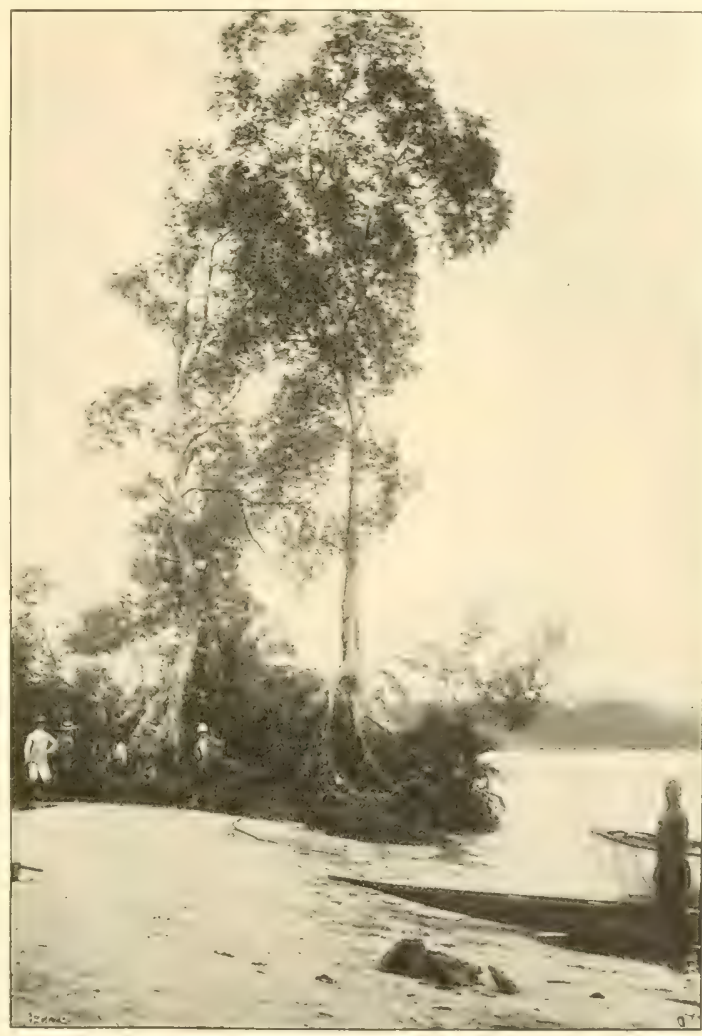

likangrove am Ziamerunhafit.

(Sachse phot.)

Deutihtand fo befant geworden, wie faun cin anderer Drt unferer Kolonien. 2IIs es mun palmenumgürtet in friedlidger Stille auf der gegen das 21 fer fteil abfallenden Jof $=$ Platte vor uns auftaudite, mufterten wir mit begreifliḑem Intereffe die Stätten, auf denen gar mandher wilbe Kampf fidh abgelpielt hatte, bevor es ju einer Konjoli=

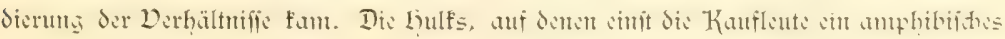




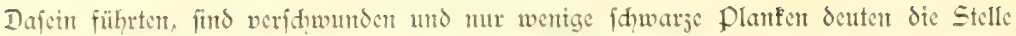
ant, wo fie veranfert lagen. Sic wurden erfetst durd hehaglide und luftige, von breiten (5artenanlagen umgebene Wohnhäujer, weld̨e in Gemeinjhaft mit dem Ẽouver= nement und den in feinem 2lmfeis jerftenten, von fihattigen Deranden umfäumten Begierungsgebäuden den (5anjen einen durḑaus anjichenden und idyllijhen Charafter verleiber.

2lian mödte den 2lufenthalt in Kamerun für cinten bencidenswerten eradtett, wenn es fid nidyt un cinen flecf Erbe handelte, der unter ber Feifel der Tropent, nämliक der 2lĩalaria, in befonderem 2liafe ju leiden hat. Jntmerhin ift ntan in der Befämpfung ifrer verhänghtisvollen 2Tadwwirfungen, insbefondere des Sdwwarjwaffer= fiebers, neuerdings durd veritändige Regelung des Chiningenuffes einen guten Sdritt wetter gefommen. Da jic Jahl der durd fieber verurfadtent Todesfälle wejentlith herabgefetst wurde, da管 die 2rialaria niḑt mehr wie ein Würgengel durd das Eand geht, ift en Derdienft unferer Tropenärate, unter denen der Kamerumer Regierungsarjt, Dr. 2llerander Plehu, gewif nidht an letster Stelle ju nemen ift. 2liti begreiflidyem Stolje jeigte uns biejer erfahrene Kenter der Tropert, jugleid and cin letdertidyaft= Iifher und glüdlidier Jäger, das unter feinen Zufpicien teu erriḑtete Sajarett. Wentige Znlagen haben uns durth ihre praftifde imere Einridjtung, weldye der Eigenart von

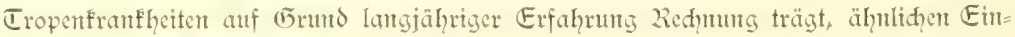

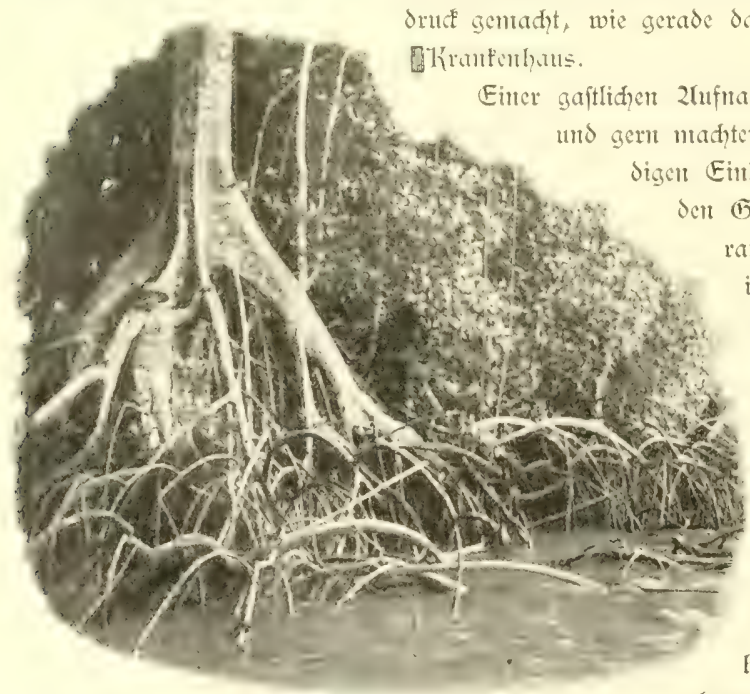

Etamtnbafis der manarooe (Rhizophora mangle).
(Sachse phot.) beengten $\mathcal{D}$ erbäItmiffen auf $\delta \mathrm{cm}$ gebäude ju ühemahter. Scinte 2Inlage rührt von dent umt die Kolonic hodpoerdienten früheren Goutucrucur vou $S_{0}=$ den her, und id fam verfithern, dafic dic wei= tert, Iuftigen Räunt nad) dem langen 2 ufent= halte in den naturgemä berigter Dethaltitimen auf dent 
Shiffe uns ein befonders wohl= thuendes (5efühl der Behaglid̨etet verliehert. 2lls bei dent Ermadent sin Eeer von fleinen Dögelnt an= ntutig jwitfinerte, als die Bülbül ihren melosifhen (5)efang ertöten lieķen utd grajiöfe graubraute Tau= ben jwifhen den Palmwedeln fid? umhertriebert, da ficl es fidwer, fid 3lu vergegenwärtigen, daf dort, wo alles auf eine wohlgcordncte fried= lidhe Eriftenj hindeutet, gar mandhes 2renjimenleben feinen tragifden $2 \mathrm{lb}=$

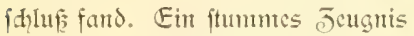
hierfür legen dic Denfmäler vor den (Donvernementsgebände $a$ b, unter

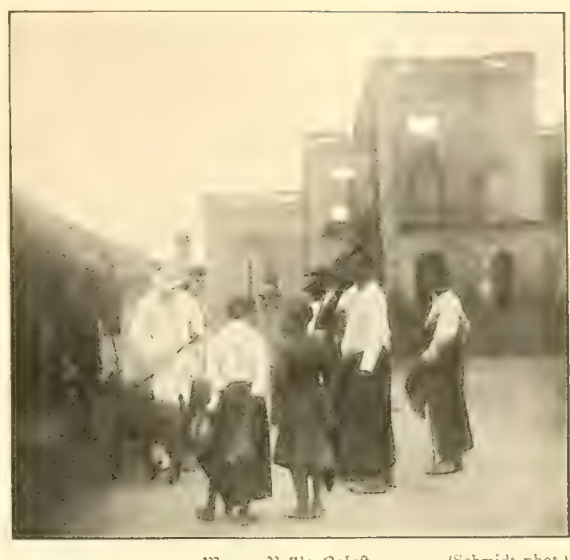

manaa 23ell's pulait.

(Sichmidt phot.) derten namentlich das mit cinem söwen gefrönte, ju Ehren v. (5)avenreuth erriḑtete ins 2luge fällt.

Es war felbittoritändid, dafs wir dent aus auffällig fauberen hüften aufgebauten und von geraden, Greiten Straß̧en durdjogenen Dualla=Dorfe cinen Befud abjatteten, Ser uns dem auh Gelegentheit gab, bie Befanntichaft von 2lianga Bell ju madyen. Er war gerade danit bejdäftigt, che Geridtsfitzung in der zähe feines arfpruds vollen, nadh europäfhent 2lüfer in Rohbau hergeftellten, aber aus 2liangel an 2litteln niḑt vollendeten Palaftes abjuhalten. Er entfing uns als vollendeter Buentleman, bewirtete uns mit Chanpagner und fhenfte nir als Gegengabe für das grope Bils des Kaifers, das id thm überreidyen lief, cinen Jiegenbot. Wohl fdumerlid durfte cin

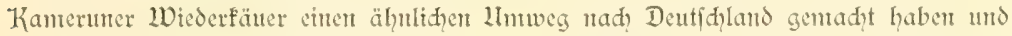
unter fduvierigeren Derhälntifen feme Sebenszähigfeit bewiefen haben, als der "23ell= Bod". Bis Kapitadt hatte er nod gute Tage, aber als es in dic antarftifhe Region ging, flüdtete er in den Keffelraum, verbrante fid bet den foweren Stürmen urt= jäblige 2liale die Sdienfel, verweigerte harmädig die an Stelle von Brrünfutter ge= reid̨ten Konferven, unt nährte fit redid, von Setungen, Gobelfpänen und Cigarren=

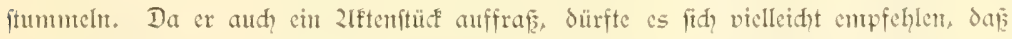
man böheren Drtes die Befrebungen vou King $3 \mathrm{cll}$ in der Jud fo herworrazens

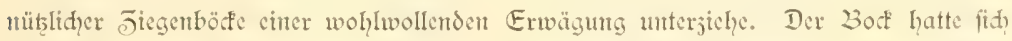

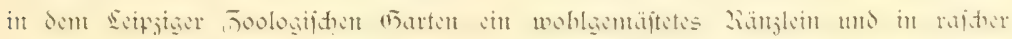
2lupafinng an peränderte Bedingungen cinen didfen Winterpelj jugelegt. In defem crimnerte er bei dent gedrungenen und ftämmigen Bau auffällig an dis Strinböte. 
(5ewohnt, 2lienfhen und Tiere tapfer angugreifen, ging er in bem Kanpfe mit cinem Kamelhengit ehrenvoll ju (5runde.

2lianga Bell erwiberte den Bejud mit cimem Teil feines Gefolges auf der "Daldivia" und gab feinem Intereffe an umperer fahrt dadurd? 2fusdrut, da er mid, bat, feimen jüngiten Buber mitjunehmen und in Deutfdiland erjichen ju laffen. Es bedurfte cines längeren, in (Femeinfhaft mit feiner Sdwwefter franjisfa in menter Kabine abgehalten palavers, um ihn ju überjengen, dấ es in 2fnbetraḑt der weiten

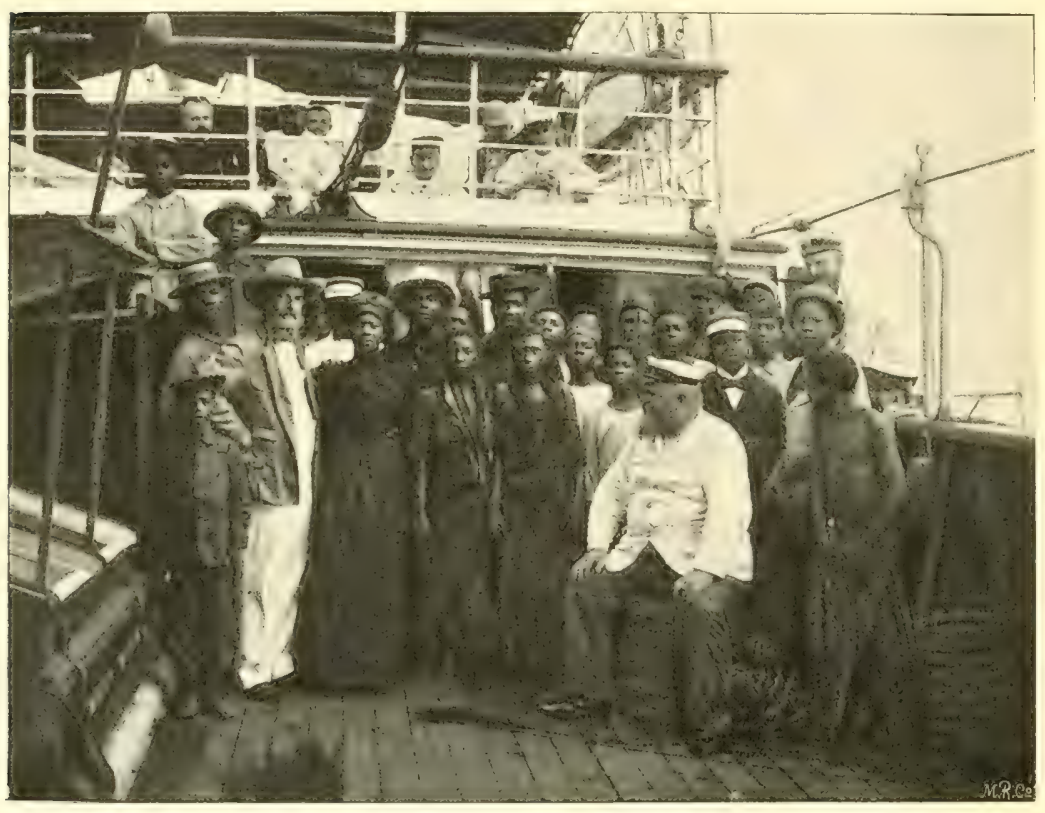

Manga 23 ell und Befolge auf der valdivia.

(Sachse phot.)

und für cinen 2Tegerjungen leiđt verhängnisvoll auslaufenden Reife niđht angängig fei, auf feine Bitte cinjugehert.

Das (Fefolge hatte es fid injwifden im Salon bequen gemadit. Fin wunderlihes

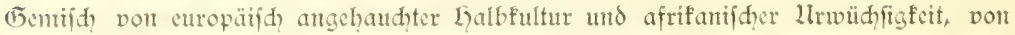

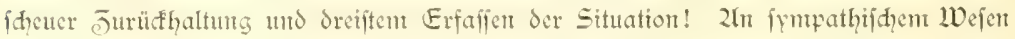

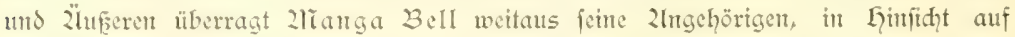
adrett fitsendes Koftüm und auf folagfertige Kunft der Mnterhaltung vermodite es der wiblide Teil des Gefolges nidht mit Pringer franjisfa aufjuthmen. 2ulf dem 
Blatte cines fäders, der als frembenbud der "Daldivia" diente, jeidunete fid dic familie 3 ell ein; id bewahre es als fympathifdes 2litgedenten, das fdon mandyen wegen der gewanden und flüfïgen Sduriftjüge überraidte. 2lls man fid verabidjedete und es befannt wurbe, daf der Königsjohn den heimithen (E) filden treu bleiben werde, verfehlte man niḑt, ferfel unt Bananen, die man als Sodfipeife für (Gewährung der lïberfahrt an Bord gejhafft hatte, forgfältig wieder cinzupacten.

Ein befonderes Intereffe gewährte der Befuch bei dem Kommandeul der Sduts= truppe, 2liajor von Kampt. Zicmand hat, wie er, das Sdutzgebict - freilid nid)t

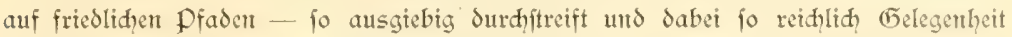
gefunden, mit offenem Blice und humanem Sim die Charaftereigenfaften der hinter= ländijhen Stämme femen ju Iemen. Seine luftige behaglide Wohmung bildete cine 2lrt von ethnographifhem 2lüupum, in dem niḑt nur die primitiven Erjeugniffe wejt= afrifanifder Kunftfertigfeit - darunter Stülfe von hohen Intereffe - aufgeftapelt find, fondern aud? die veridgiedenen Tppen in persona eine Iebendige Illuptration ju dent Lausrat abgeben. Da traten drei als Getrehn jurücbehaltente Söhne von 5)äuptlingen des Banestanmes an, gefolgt von dent gefangen eingebrad)ten 2ieffen des Gäuptlings Tunga; prähtige, felbitbewuf̧te Jungen, dic nidhts wentger als un= jufrieden mit ihrem Sofe f̧ienten. Ein Soldat ber Gauffa in feiner malerifhen Tradt, 2ränter der Jaunde und Pangwe mit ihrent originellen Putz über den Dhre, und

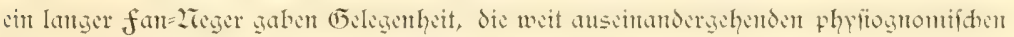
Eigentünlihfeiten der Stänme aus dent Jnmern ju ftudierent.

Intereffanter, als alle diefe fhon vielfad gejhilderten Typen, war ein $\mathfrak{W e i b}_{\text {der }}$

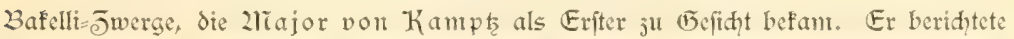

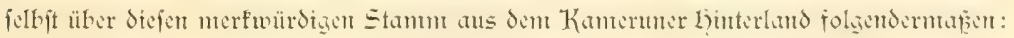

"Während des 2lufenthaltes in Tunga war es mix vergömt, jum erftemrale mehrere seute des bisher mur dem 2ramen nad befamten Jwergvolfes der Baflli ju fehen. Die Bafelli bewohnen den weftlichen 1trwaldgürtel und fommen haupt= fählich in Zigumba=, 23afofo= und Buligebiete vor. 2rad? wiederholter Zufforderm! braḑte mix Tunga einen Gäuptling und feben 2Kämer diefes Dolfes. Id habe dic Körpergröfe dicfer adt Eeute gemeffen, die von 1,45 bis $1,60 \mathrm{~m}$ varitert. Die 3 afellt haben fid augenfideinlid fdon vielfad, mit anderen Stämmen gemifd,t, mu bet dert flemften 2läntern waren die hellere, beinahe gelbe Gautfarbe und die edigen ftarE =

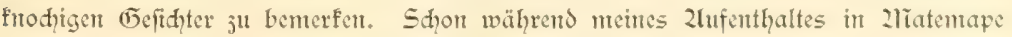
waren volt einer Patrouille ein Bafelliweib und ein Knabe ergriffen worden. 2rur

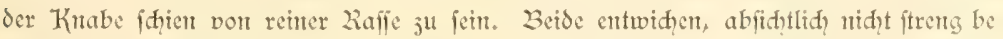
wadyt. Späterhin faufte id in Solodorf von einem 2 Ggumbahäuptling cin ausgewad fenes Bafellimädden frei; dasfelbe ift 1.24 m grof; id habe es behufs 2liefiumgen und

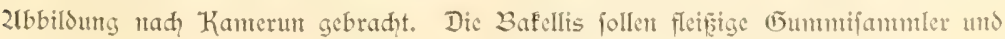


Jäger feits; troh

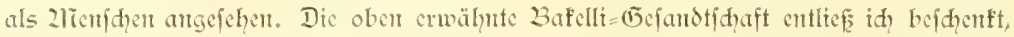
nadbent id ihnen gefagt, daf fie ibre bisherige Sden vor Weifen ablegen follten."

Die beiftehende 2lbbildum des 23afcllimäddens mag den Labitus verfinnliden und

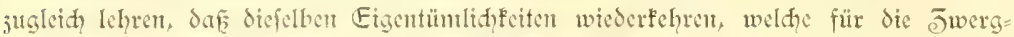

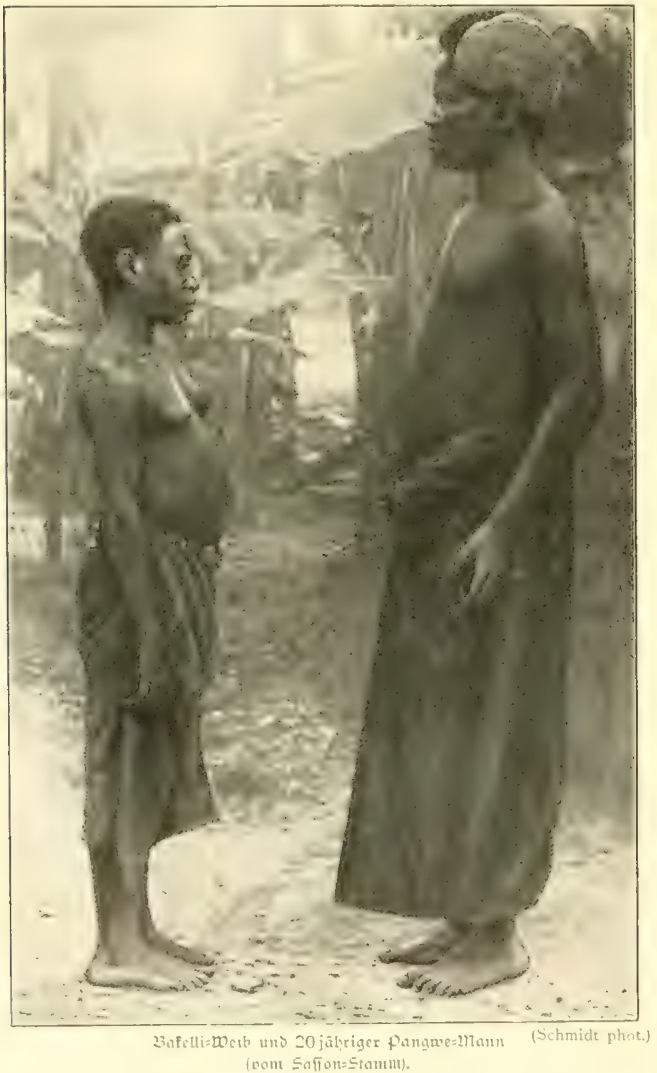
völfer Jmmer $=2 l$ frifas typifd find. Fine in das 23räun lifgelbe fpielende Gautfarbe, das furjfiligige Laar, die furze und breite Platmafe, aufge= wuljtete sippen, ein fdeuer mifanthropifher Bliff, fowad? intwicfelte Brüfte: das fint dic hervorftedyenditen phyfiogno= mif hen J̈lige. Daju fommt dic trots der völligen Entwidlung auffällig geringe (5röfse von $1,24 \mathrm{~m}$ und cin ungewöhnlid ftarf ausgebildeter 2iegerge= rud?. Trotzdent das Bafelli= mäddyen gut behandelt wird, ent widh es dod öfters in ben Bujd, wo es bald von den finwarjen Spümafen wieder aufgefunden wurde. "She smells the bush" erflärten grimfend die Soldater, wertr fie der flemen aromati= forn (1)enofint hab haft wurden.

Daf aud der Kameruner Itrmald serartige ङ̄wergoöl fer birgt, welde als gefdicti Jäger und Einfammler von (5)ummi nomadifierent ihut ourdjitreifert, ift vort nidst ge=

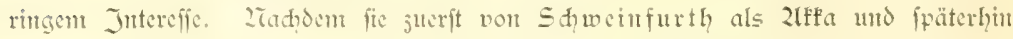

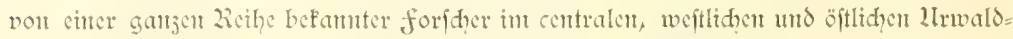

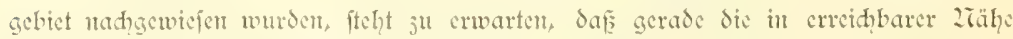

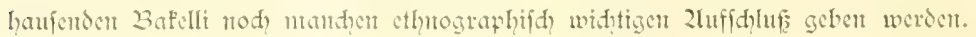




\section{$21 u f$ Dem $\mathbb{D}_{u}$ risflutj.}

Don feiten des Gotwemenents war uns in liebenswüroiger Weife der Dorfalag gentaht worden, cinen Zlusflug in das linterland ju unternehmen. 2lian hatte dent Regierungsdampfer "Soden" für uns bereitgeftellt, und fo wählten wir dent in 2ln= betraḑt der bef̧ränften jeit die fürzejte der vorgeldlagenen Routen. Sic galt den Wuri fluf bis hintauf ju feinen Etromfdnellen bei Jabaffi. Er ift der mittlere der dret in das Kamerun=L్fif cinmündenden Ströme, und fonnte, da er infolge der kegen: jeit ftarf angefdwwollen wax, Ieidyt mit dem Dampfer befahren werden.

Es fällt fकwwer, mit wenig Worten die wedfielvollen, bald anjiehenden, bald monotonen Panorament wiederzugeben, weldye dem ob fold feltenen Eenuffes faft trun fenen 2luge fich darboten. Ulus dem üppig fultivierten Vorlande, das ju beiden Seiten Ses allmählid, fid verfḑmälemoen 5 affes gelegen ift, gelangt man faft unvermittelt in cin Wirrjal fleiner fluf̣läufe, welhe das

Wuri=Delta jufammenfetzen. Der Blick wird eingeengt und an Stelle reider Dualla=Dörfer, wic Jlfwatown und Gitfory, ftattlidier 2liifftonsgebäudc und idyllifher, an Llfer gelegener Bujd $=$ faftoreien tritt niedriger, ans Rhizophora mangle gebildeter 2lian= grovewald. Fin tippiges (5eptrüpp von Raphia=Palmen, untermengt mit gelegentlid? Lantg ausgejogenen Pandanus= Beftänden und bis in die Wipfel der 2lian: Riegierungsoampfer .Soben". grove fïh emporranfenden Rotang=Palnten, fäumt dic llfer cin, währent dic duftigen

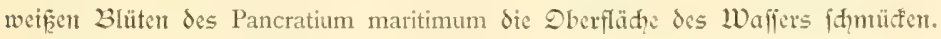

Das allmähliḑe ङurüftreten des bei der flut vordringenden Braffwafiers, weldies

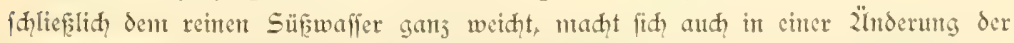

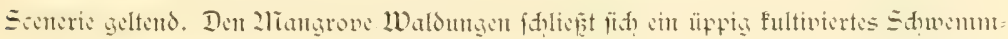
land an, Surdjetzt von jahllojen Dörfern der Baf́ofo=2reger, welde gerabe jetst jur Regenzeit faft vollitändig unter Waffer ftehen. In den Uferfneipen, wo erfrifjender Palmwein gereidyt wird, herridnt ein lubhaftes Treiben, niḑt minder aber audy längs der ganjen Strecte bis Jabaffi. Die Kunde, daf der (5ouvernenr auf den Regierungs= dampfer cine fahrt flupaufwärts beabfidhtige, hatte fid bereits verbreitet und cifrig war eit der Trommelfprahe fundiger 2reger bemüht, von Bord aus die Ljoljtronmtel mit den Sḍlegeln ju bearbeiten, un nähere 2lïtteilungen ju geben. Sie wurden am sande aufgenonmen und ftundenlang genoffen wir das merfwürdige, volt Drt ju Drt 
weitersegebene und in der ferne vertlingende Trommel Drdefer. 2Iuf den Tanarifden Infeln hatte id cinft de Pfeiffpradye der Bewohner von Gomera Fennen gelernt; id

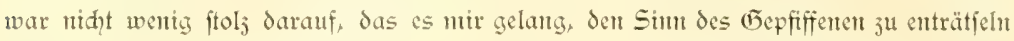
und den Girten 2ritteilumgen freifend jufommen ju laffen, weldhe diefe ihrerfeits ver= ftunden und beantworteten. Ob aber aud die Trommelipradhe der Kamermuzieger darauf beruht, da官 nan Klangfarbe und Betonung der Wortfilben, ähnlidh wie bei der Dfeiffpradhe, miederjugeben verfudht, vermoḑte id um fo wentger mir flar $z^{u}$ madyen, als hierzu die genauejte Kenntnis der Spradye und Denfweife der Eingeborenen

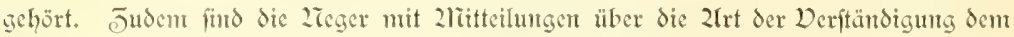
Weifen gegenüber fehr jurükhaltend; fie hüten die Trommelfpradge wie en ihnen anvertrautes (5)heimuts und fo vermodyte aud niemand unter mferen sandslenten 2luffläruntg ju gebent.

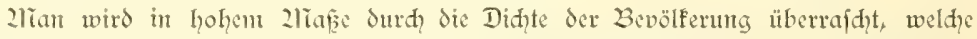
ihrer Soyalität durdh Zhushängen von flaggen und gelegentlith etwas ftarf mitgenom= menen fdywarz=mei

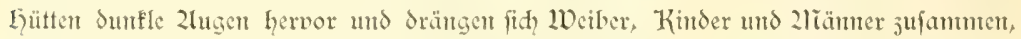

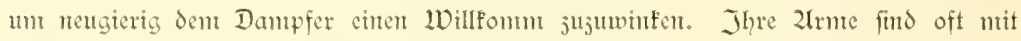
grof̧en Elfenbeinringen behängt, und um dic Бhüfen werden grell gefärbte Tüder

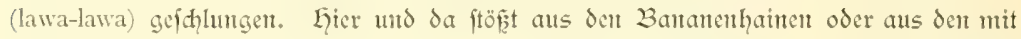
Sdilif und Colocafient bewadjenen Llfern eit Boot hervor, das mit den jugeipitzen Paddeln gerndert wird. 2lieift find bie aus Rotholj gefertigten Canoes gefdwärjt und häufig aud? mit faft fdwarzem Segel ausgeftattet.

Ziad)dem der Wuri flue den von redts fonmenden 2 lbo in einer hügeligen be= waldeten Eandidhaft anfgenonmten hat, gabelt $\mathrm{er}$ fid, um die weite, fogenamte Wurt= Jnfel ju unfaffen und dam bet zrutimbelembe eine sambidaft ju durdfflieken, dic

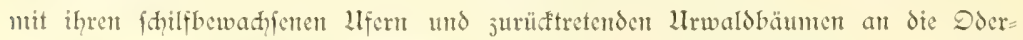
landidhaften erintnert. Ein pon weitem auffälliger, bon Rethern und fonftigen Sumpfö̈geht bevölferter Baum deutet dic

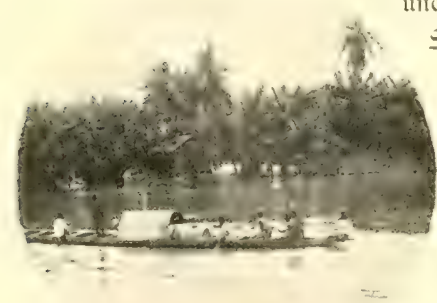
Stelle an, wo der während der trodenen Jahresjet von flufpperden bevölferte Dibombe vou redits cint= mündet. Der lisţere bildet jugleid die (5) enje der Sandidhaft Bodiman. Sie num beionders didit bevölfert fein, dem allmählid fäumen D̈rialmen, Bananent= und Jutferrohrpflanzungen mit thren cingeftreuten Giütten in faft endolojer 2lionotonic bic Llfer ent. Dafür entffiädigt der 2lusblice auf dic

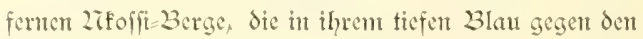
mit fhweren Regenwolfen verhängten Gintergrund, das in 


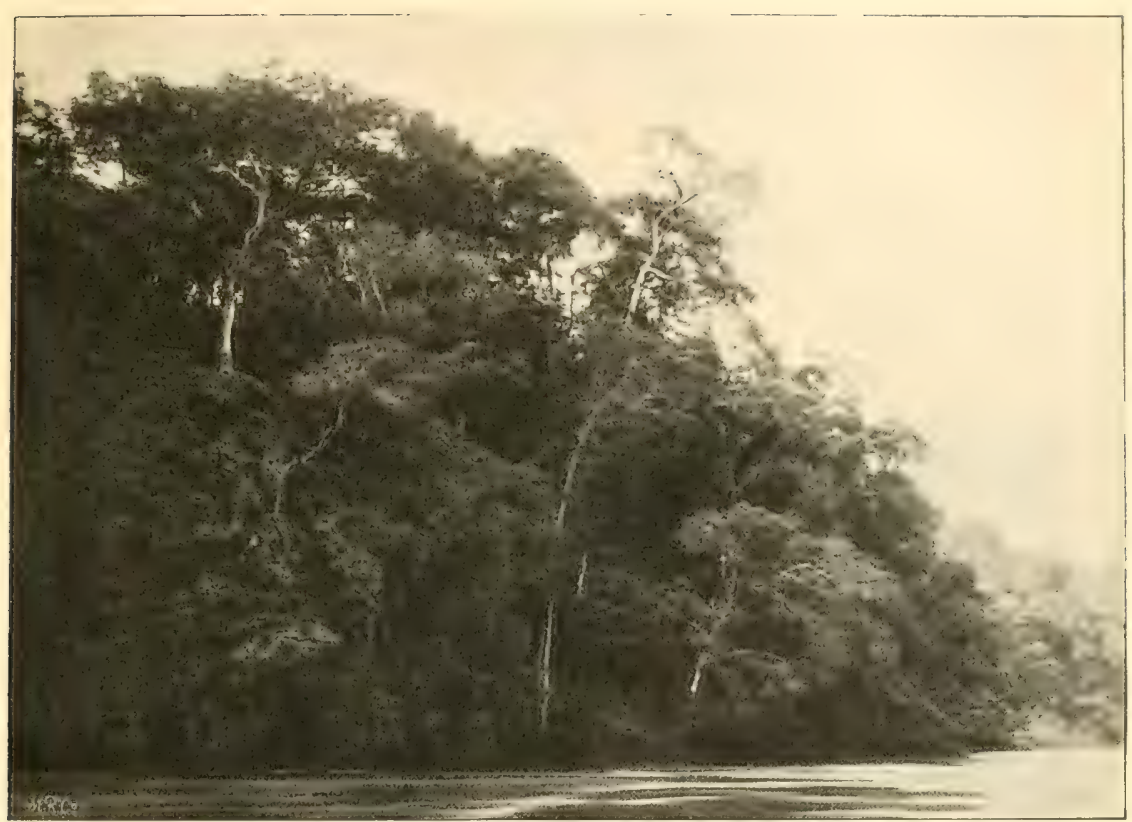

Baleriemalo bei Jabaiñ.

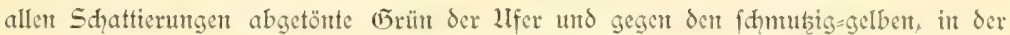

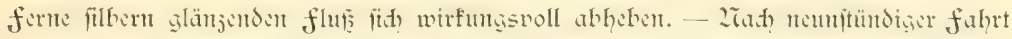
langten wir endlid vor Jabaffi an, cinem flemen 2regerdorfe, von dem aus die be=

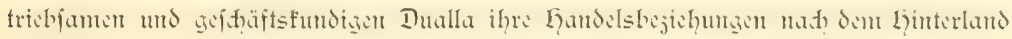
des Wuri aufredt erhalten.

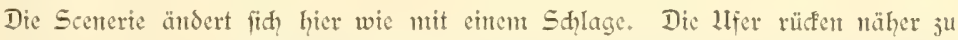
fanmen und die eine furje Strefe oberhalb Jabafit auftretenden Stromidntellen fetsen

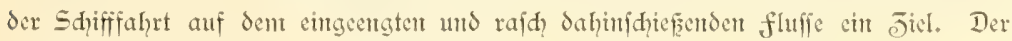
malerifhe Charafter der hügeligen Sandfhaft wird nidht zum wenigften dadurd be= dingt, daf ein mähtig aufftrebender Ealertewals die 2lfer umfäunt. Die fülle der veridiedenen 3aumarten ijt eine überrafdende; in die fdirmförntig geftalteten oder wie eine Kuppel gewölbten Kronen flettem die sianen an den grauen Stämmen entpor, um dann mit ammutigem Sdywung bis ju der Dberflädie des Waffers niederjumallen. Shwer trieft aus dent saubdad der Regen auf die ärmlidien Lï̈tten nieder, deren röt

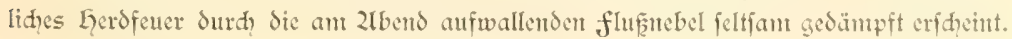


Sange nod fafen twit in der feudtwamen. Tropemadit auf dem Derdecf des 1)ampfers und laufhten den Ergählungen unjeres vielgewanderten Dopffeus, des Kontmandeurs der Shutstruppe. 2lles fhwärmte dafür, eḑt afrifanifh in den Lütten Jer Eingeborenen ju übernaḑten. 2ln nädifen 2liorgen gaben mix freilid die meiften redit, dafich cin gutes felbbett auf dem Dampfer der Poefie von 2regerhütten vorjog: diefen hatten die 2rosquitos jerifodhen, jenem waren Ratten über die Beme gelaujen;

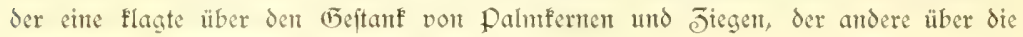
Intimitäten der nebenan baufenden 2Teger.

IIs wir, jum Teil ctwas übernädtig, nađ Kamerun jurücfuhren, ahnte man

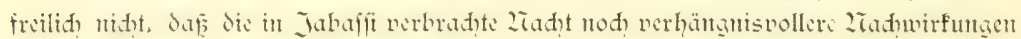

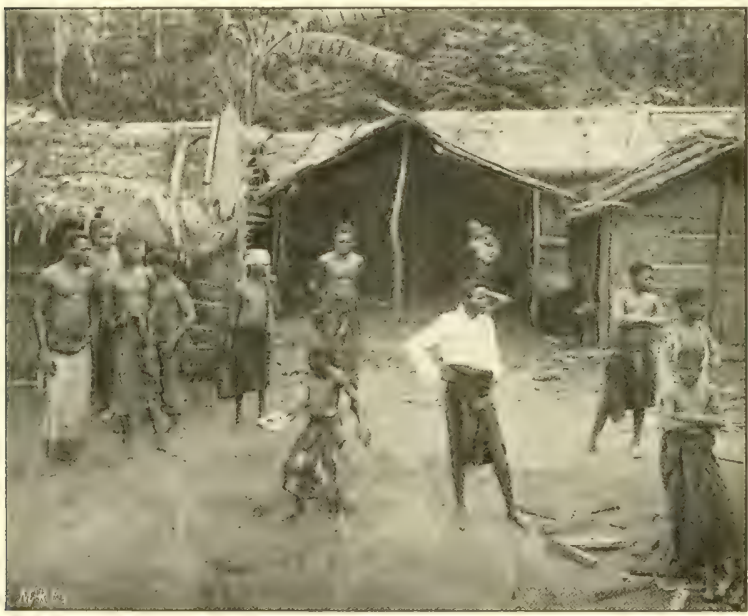

Ereiben in Jabuifi. im (ธิ) follte. 2rad? adt bis jwölf Tagen, als twir bereits den Congo in Sidnt be= fommer hatten, er= Eranften von den elf Teilnehmern an ber Wurt $=$ fahrt neut an 2ralaria unter den für dic $\mathrm{Ka}=$ merumer fornt typi= fhen Erfdeinutgen. Don den jwölf $E_{r}=$ peditionsmitgliedern blieben mur orei fie: berfrei; ener batte an Sand übernadtet,

der andere fdilicf an Bord und der dritte war in Kanterun jurüdgcblieben. Wenn die ITalaria auf einer burd? den Stid blutfangender 2rüben verurfaçten Jufeftion beruht, fo dïrfte nad) unferen trüben Erfahrungen vor dem l̈lbernadten in den dent verfdieden= artigften Llugejicfer Lnterid)lupf bietenden flufbörfern der Zieger befonders gewarnt

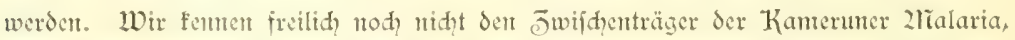
düren aber nach den Lnterfudyungen der Joologen, welde in der frage nad der Z̈ltologie des Tropenfiebers ein gewiditiges Wort mitjufpred en haben, mit Sidqerheit

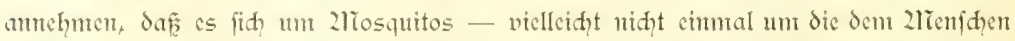

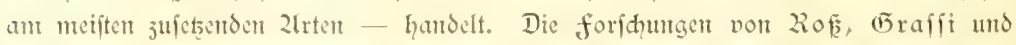

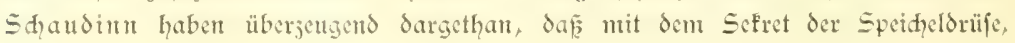




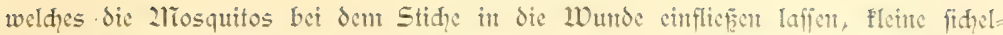
förmige Keime übertragen werden, weldhe dic roten Blutförperden warntblütiger Tiere angreifen, in diefen ju dent Plasmodium malariae heranwahjen, und fdicliclid? in cine Brut fleiner Keimgellen jerfallen. Diefe fudhen mun wiederum neue Blut=

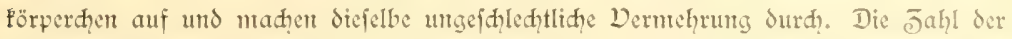
ficberanfälle, welhe jedesmal eintreten, menn die in die Blutförper cintgednungenen

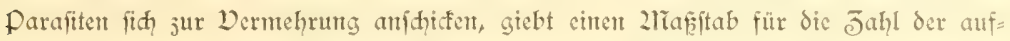

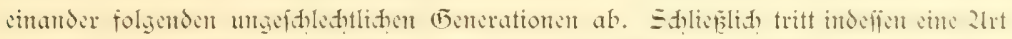

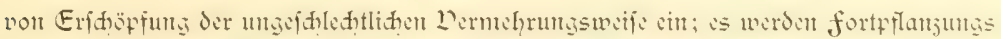

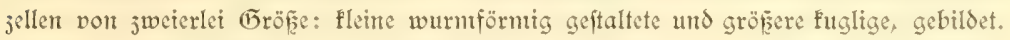
Die fleinen entipredien den Samenfäben der höheren Tiere, die gröferen den Eiern. Wie mun bei letsteren die Befruḑtung dadurd, erfolgt, daf die Samenfäden in sic Eijelle eindringen und diefe jur Teilung antegen, fo fann and cine Weiferentwidflung der Vlalaria=Parafiten mur dadurd, crmögliht werden, Saf ein fleiner wurmfömriger Kem nit einem gröperen fugligen fï vereinigt. 2lian bejethnet diefen der Befrud = tung höherer Drganismen entiprehenden Dorgang als Konjugation.

Zitemals erfolgt die Konjugation innerhalb des Körpers von 1 armblïtern refp. des 2lïenfhen; wir vermögen fie indefien füntllid ju erjielen, went wir die abgejapften Bluttropien fith abfühlen laffen. Diefer llmitand deutet bereits darauf hin, daf das Blut fieberfranter in faltblütige Tiere übertragen werden mus, Sanit eitre Kon=

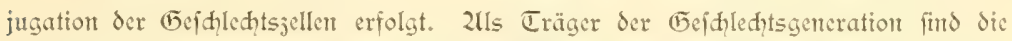
2liosquitos erfant worden, welhe thren 2liagen nad? dem Stihe nit Blut füllen. In 2liagen erfolgt die Konjugation, die vereinigten Jellen durdfetsen die 2ragen= wand, enevftieren fid unterhalb derfelber und jerfallen in cine Brut flemer fidfelförnicg geftalteter Keime. Diefe wandern in die Speidyeldrüfen ein und werden nad̆ den Stidhe mieder dent Blute des 2lienjhen einverlcibt.

Die fortpflanjungsweife der 2lialaria=Parafiten ift alfo durdy einen Generations=

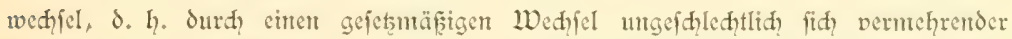

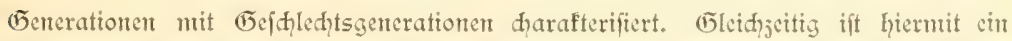
Wirtswedycl verfnüpt, injofern die ungefdelehtidie (5entration in 3 lute des 2rient= ¡hen, die Gejhleditsgeneration hingegen in den 2rosquitos fith findet.

2luf Grund der neuen forfhungen, weld̨e der uralten Dorftellutg von Bejiehungen jwifhen 2liosquitos und zlialaria eine geftherte (O)undlage geben, fömen wir be= haupten, da in jener Tropengegenden, wo 2losquitos fehlen, aud feine 2lialaria herridt. Wir lernten ein derartiges tropifdes Küjtengebiet in der Ungebung Ser

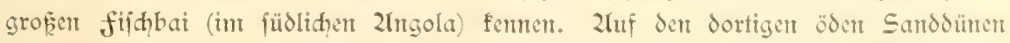
gedeiht fein Bufh, feit Grras wegent völliger 2lbwejenheit von Sübwaffer. Da

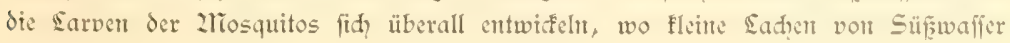


auftreten, fo crflärt es fidh, daf dic gelegentlid, von allen Qualen des Durftes gepeinigte Bevölferung der fifdbat nađh mir dort jugegantgenen 2litteilungen menigitens bon der 2lĩalaria verfhont wits. Der Derlauf unferer fahte bradte es mit fid, daf dic

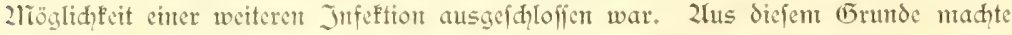
unfer 2rrat, Dr. Baḑmann, Sie Jurd, mehr als drei zronate anhaltenden Recibive an 2lialaria junt Eegenftand einer fpeciellen 2tuterfudung, deren 2lbjd̨luf freilid fein früher Tod cin Jiel fetste.

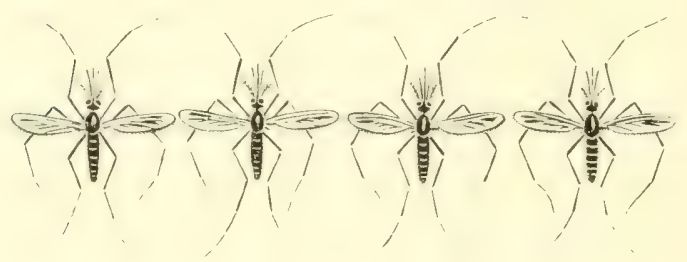



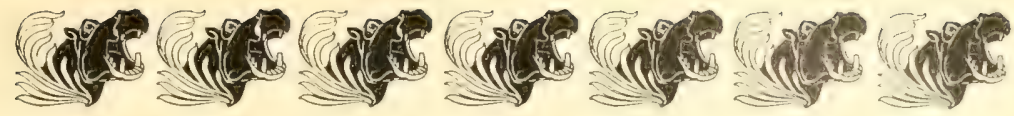

\section{2lut congo.}

1 ie Reifenden verfehlen niḑt, auf den überwältigenden Eindrucép Ginjumeifen, weldyen

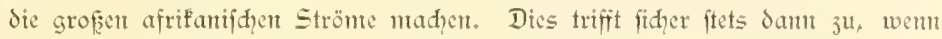
der 2liarih fich Surd wette, cimfame Savammen erftedte, bevor die oft anmutiger 2tfer des fegenfpendenden Stromes in Sidnt fonment. Znters geftaltet fid der Eindrud auf jene, dic lange fein Sand ju (5efidht befamen und fid felbit ba cingengt füblen,

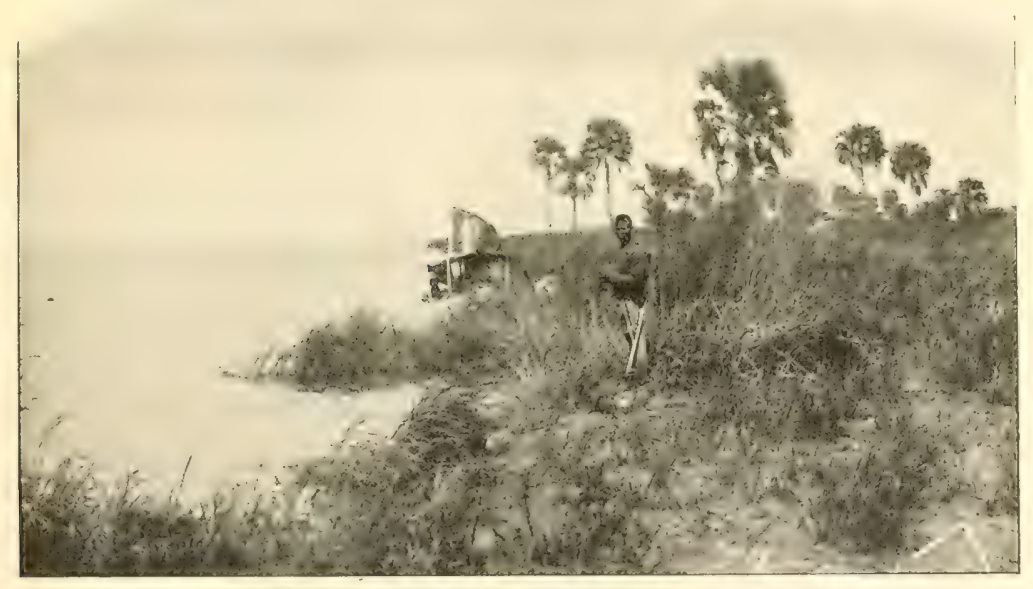

2111 Ltfer bes Congo.

wo, wie in der 2liundung des Congo, das gegenüberliegende Llfer mur duftig ver fhwommen fidhtbar ift. Daf es fith freilid um cin gewaltiges Stromgebiet handelt, Savon überzengten uns fịon an Tage vorher, fajt 150 Semreilen von der 2ründung des Congo entfernt, dic 2tnterifuntgen. Das Dberflädyenwaffer war etwas verfärbt,

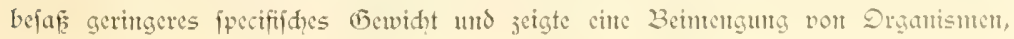




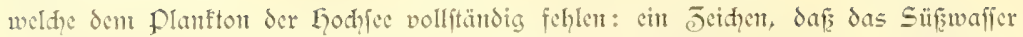
des Congo weit hinaus in das zreer feine Wirfung geltend madit. Ie mehr wir uns dem 2liündungsgebiete des fluffes näherten, defto aufälliger nahmen dicfe $E_{\mathrm{r}}=$ fdeimungen ju. Die Dberfläd̨e jeigte einen dumfelbrauncn Ton, und hödht eigenartig tabm es fid ans, als in dem Sdraubenwaffer das grüngefürbte Secwaffer empor= gewühlt wurde. Sdjon mit dent bloken 2luge benterft man den Lnterfdicd, wem das

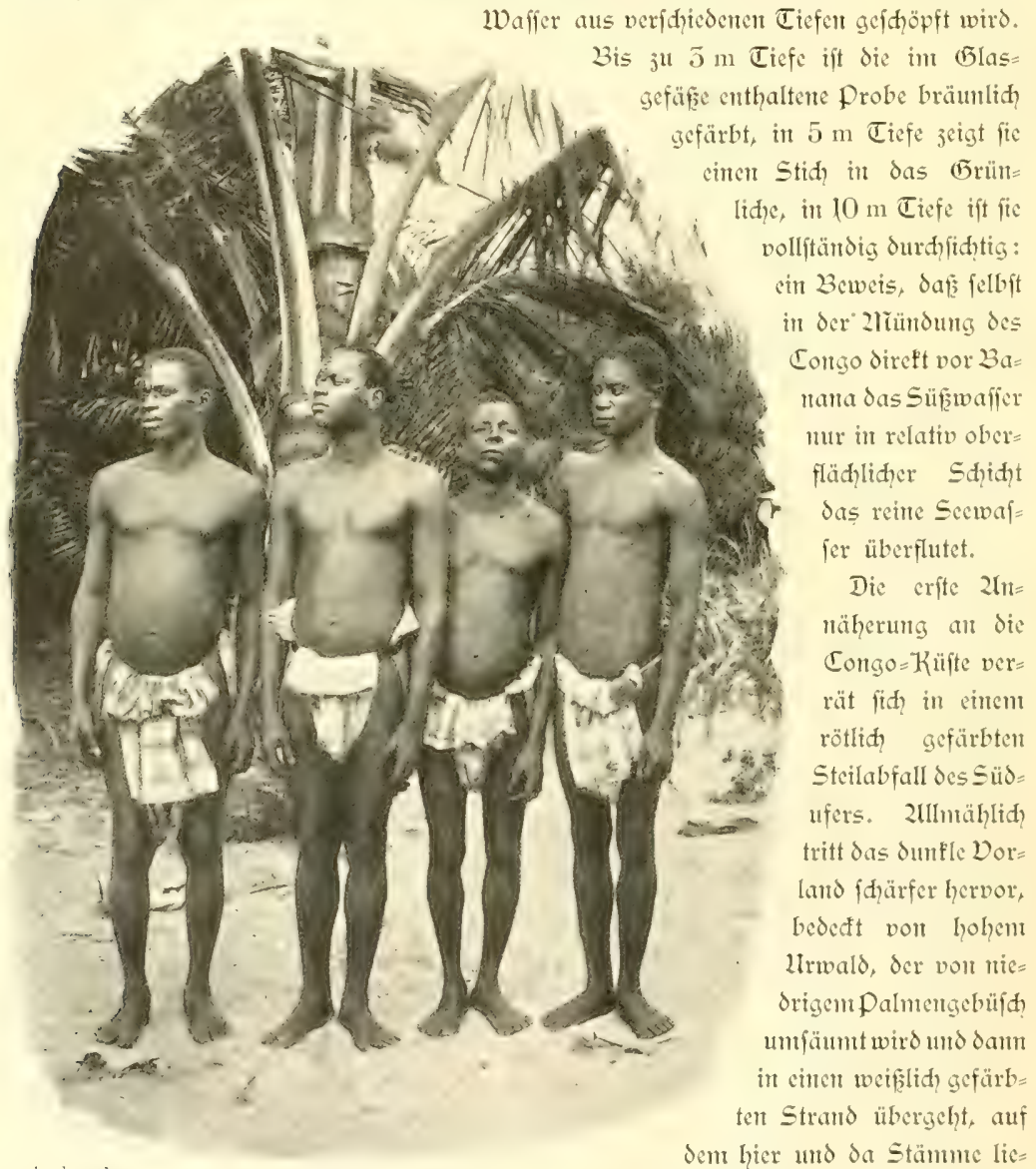


Jer Erpedition mit Sebhaftigfeit für Krofodile in 2rniprud genonmen werden. Reijvoll im (5) rün

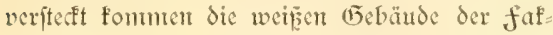
foreicn jum Doridgen, unt bei der 2fmähermitg an das Südufer bei Shark=Point wird dic portu= gicfifhe flagge gehifit, deren (5rup wir vom Sdiffi aus erwidert. Die langgejogene, palmen= umgürtete Sandjunge des 2Tordufers, auf der die faftoreien von Banana liegen, fifeidet cir ftilles 2lltwafier ( Creef) von dem Deean, das cinte trefflid gejdüthte, volt Shifien belebte keede abgicbt. Sic grentit fidh allerdings gegen dic congontündug durh cine Barre $a b$, welde bet niedrigem W afferitande erft nach Eintritt der flut von tiefgehenden Shiffen pajifert werden famt. Woir halfent an Sit 3oje nor der Barre uns warten die 2utunft des Sotfenbootes $a b$, das

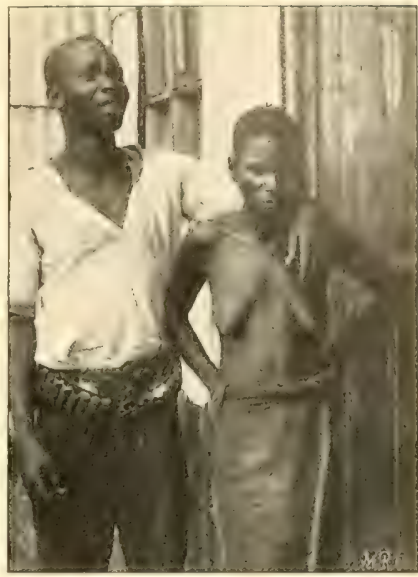

Thentiat i he

Bangala, mantr utro weib, gewardt vort Bangala gerndert wird. Die Congo=Regierung verwendet diefe Bewohner des imteren Congo=(Gebietes als juverläfitge Dolijeifoldaten und 2rarinare. Bijarr genug bieten fie fidh demienigen bar, der fie jum erftemtal ju Gefid)t befommt: meift

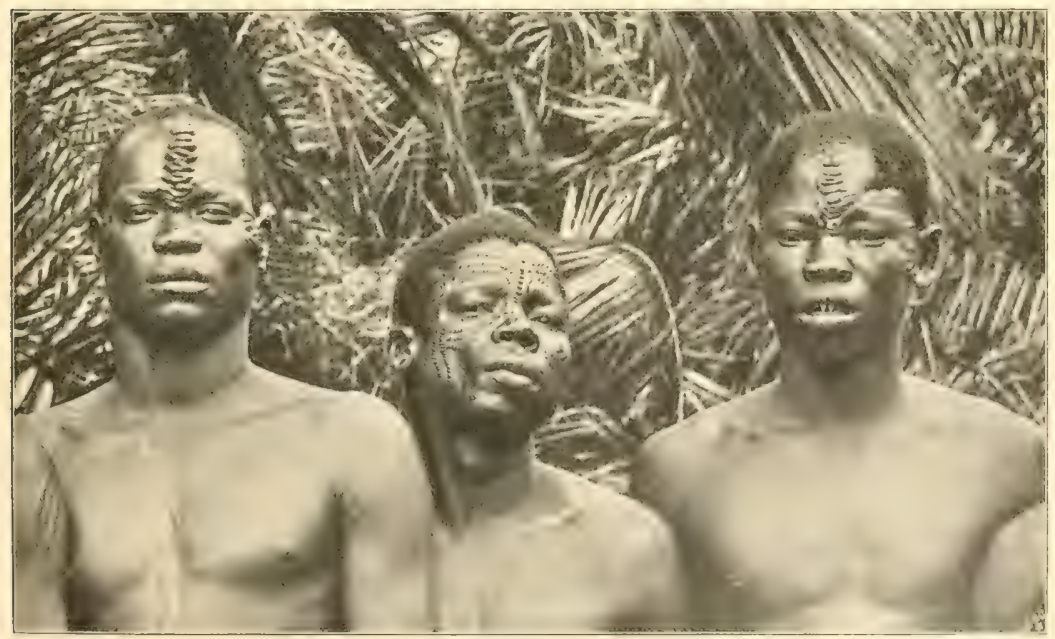

Istowicrungen ber 23 anduna 


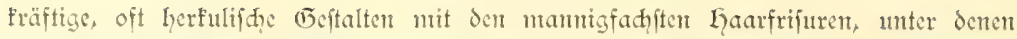
namentlid jene Seute auffallen, weldye den Kopf fahl fdeerent und nad, 2lrt der Saupe auf demt bayrifden Lielm einen medianen Wollfamm jühten. Sie licben es,

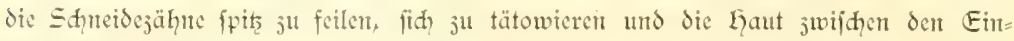

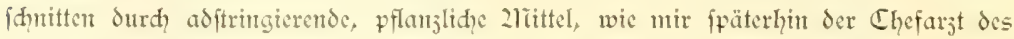

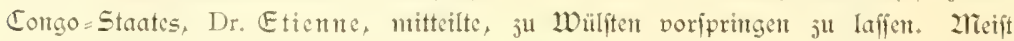
jiehen fid dicfe tätowierten 2 Dülfte über die 2littte der Stim weg, vielfad and werden fie unterhalb der 2lugen horigontal bis ju den Dhren angebracht, und etrige hattent das ganje Trefidgt fo feit wie dic 2liaori 2Teuseelands mit Tätowierungen bedect.

Während der Einfahrt in den Crecf lernten wir das aufecrordentlid reid entfaltete Tierlehen der Congo=2liündung fenten. Fiter und da blicfen Wale, Sḑwärme nont Seefdwalben umflatterten in grajï̈fen fluge das Sdiff, und die Geteradler (Gypohierax Angolensis) mit ihrem weifen Kopf, weiker Brujt und fḑwarjen flügeln jogen cinfant thre Kreife. Es gelang unts, wehrere der leţteren jull erlegen und uns an

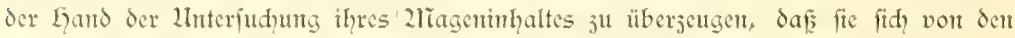
früđten der D̈lpalme und vorwiegend von Krabben und Einfied

Ziadidem wir vor Banana am 2lbend des 1. Dftober den 2lufer hatten fallen laffen,

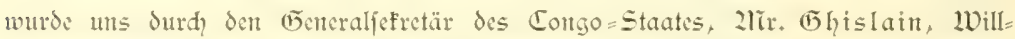
fonmen geboten und jugleid? die Einladung von feiten des Bouverneurs ju cinem Bejudge in Boma übermittelt. In Kamernm hatte Regenjeit geherridt; hier am Congo, jenfeit des Z̈lquators, waren wir gegen Ende der troffenten Jahresjet ant= gelangt, unt fo mad) der relatio niedrige $\mathfrak{W}$ afferftand des fluffes es leider ummöglid, mit ber immer nod ticfgehenden "Daldivia" bis Boma ju gelangent. Da uns dic

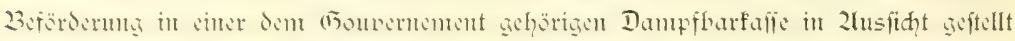
murde, nahmen wir das 2literbicten um fo danfbarer an, als fid anf dicfem 1 Wege

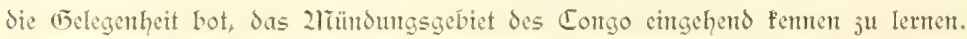

Wir hatten es dem aud nidy ju berente, daf wir jwei Tage unter allerdings stwas beengten Derhältniffen in der Barfaffe verbraḑten. Sie drang gleid nady dens Verlaffen von Banana bei Somenanfgang in das Sewirr von 2lltwaffern (Ereef's)

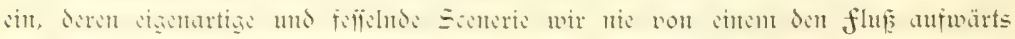
fahrenden Dampfer hätten in Zhugenfigenn nehmen fönten.

Die llfer find volt dent niedrigen (Geftrüpp cince Stadelpalme (Phoenix spinosa) unfäunt, hinter dent chne intmer höher aufftrebende 2langrove= Degetation den Iandidhaftliḑen Charafter Eedingt. Ein merfwübiger, auf Stelgen ftehender Wald, Sicfer impofante 2liangrope2lrwald des Congo! Der Stamm der Rhizophora mangle läuft in bogenförmig gefrünmte und gabelifaltig fidt teilende Dourzelftelzen aus, weldze ibnt im Sdilantme veranfent. Thnen gefollen fid suftwurzeln bet, weldhe oft aus be= deutender Löhe wie lang ausgejogene Spinnfüden niederhängen. Da fie gleidfalls jur 


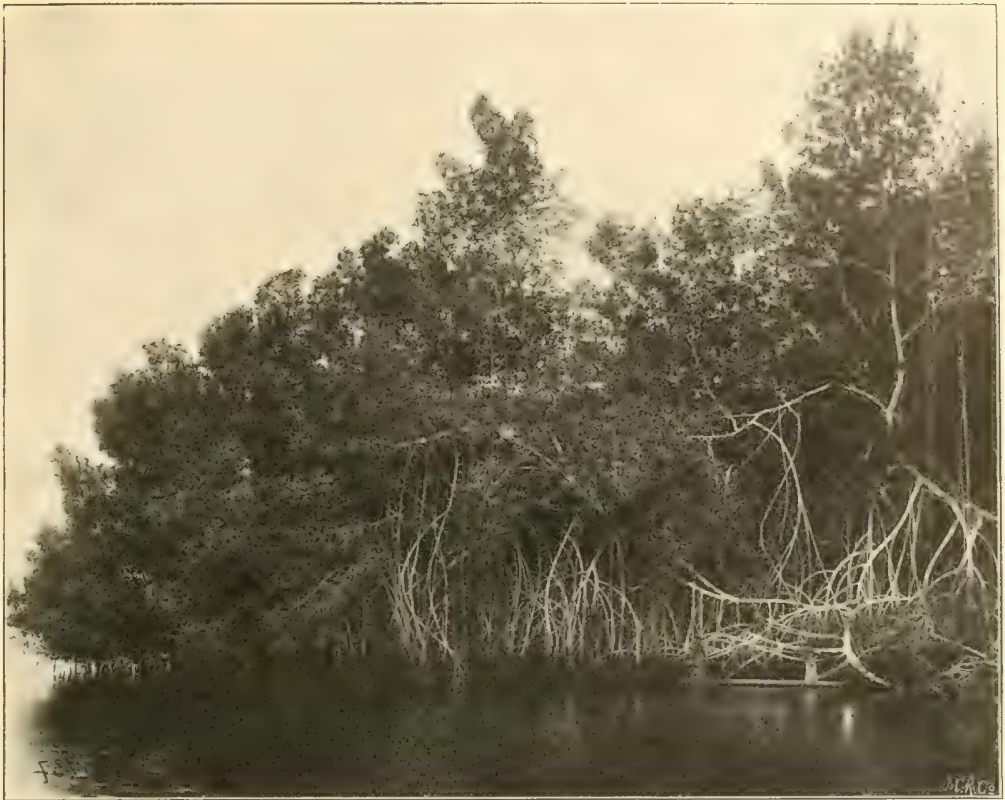

217angrove (Rhizophora mangle).

(Sachse phot.)

Deranferung beitragen, wird cin undurdbringlides Wurjelwerl gebildet, das gegen die cinjelnen Stämme mit ihren emften, in ihrem Charafter an unfere Erlen ermutnden Saubmaffen fonvergiert. ङwwifhen den Zliangroven wuhernt die Wedel eines farn frautes (Chrysodium), das fosmopolitifi, überall da vorfommt, wo zlangrove= 3 il dung herridt. Einen bejonderen Sdnut erhalten indefien dicfe ftillen Creefs durd die Raphia-Palnten, die fị überall vordrängen und mit thren grajiöfen Wedeln cin

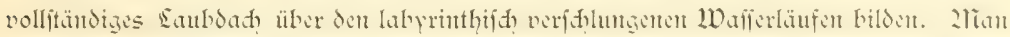
bemundert dic Sidherheit, mit welder der fhwarje Steuermam in diefen Wirrfal fid jurehtfindet, unt das Gejhick, mit den er die fharfen Krüntmungen unter den dic bin fuicfende Barfafie ftreifenden Palmmedeln paffert. - 2lb und ju tretent die 2rangrove jurïđ, und es erfheinen die bijarr geformten pandanus nebit D̈lpalment und mantig faden Lrwaldfänment, über weldhe Sianen - meift von Ipomoea gebildet - hinfriedien.

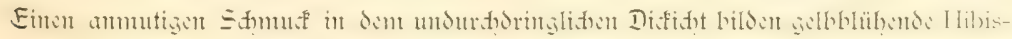
cus, rolafarbene Drdidecn und fleifhrote 21pocyneen. 2lian wantdelt freilidy nidyt un geftraft unter Palmen: als wil von der Barfafie aus dic buntblübenden formen ju 
124

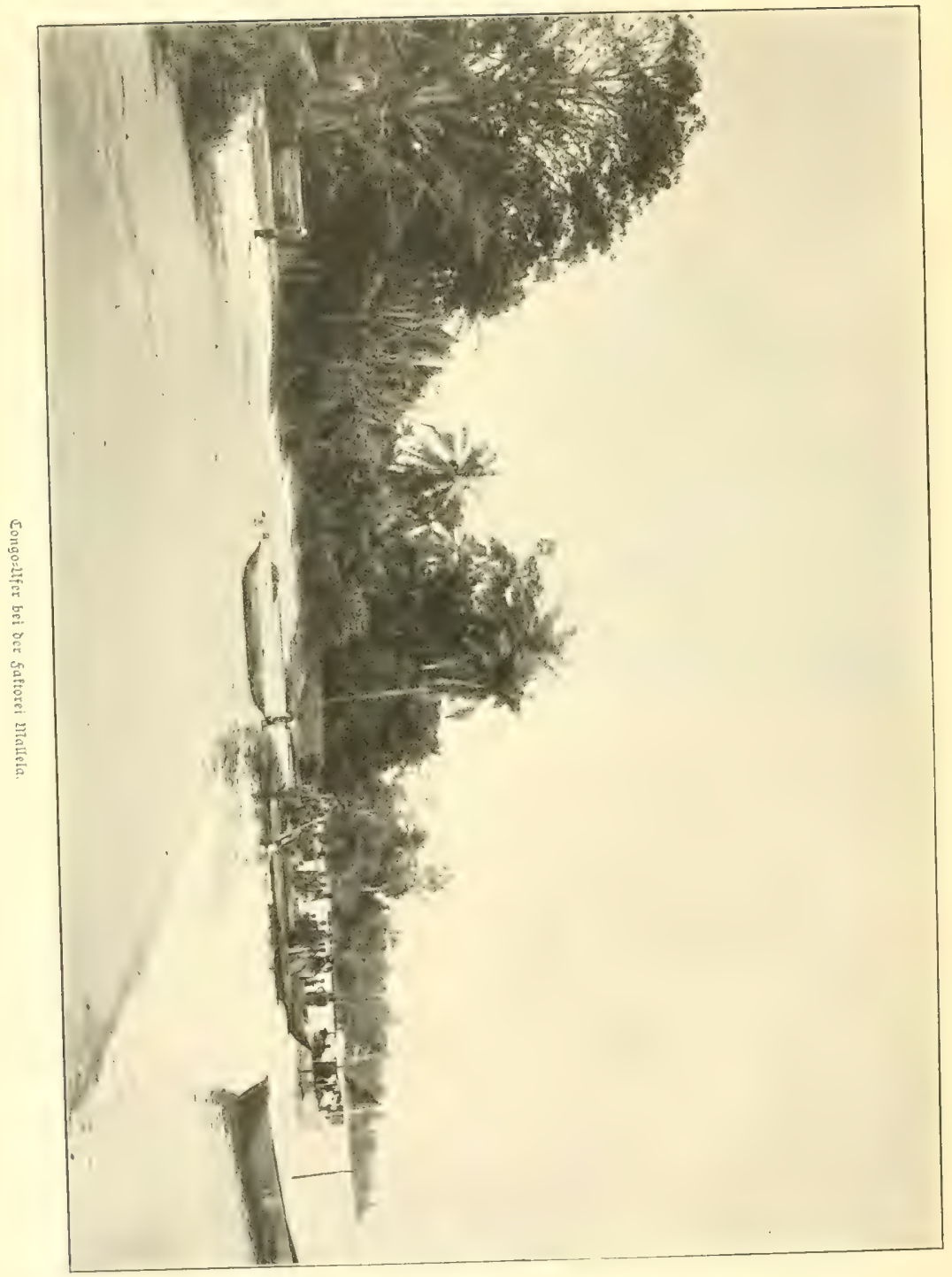




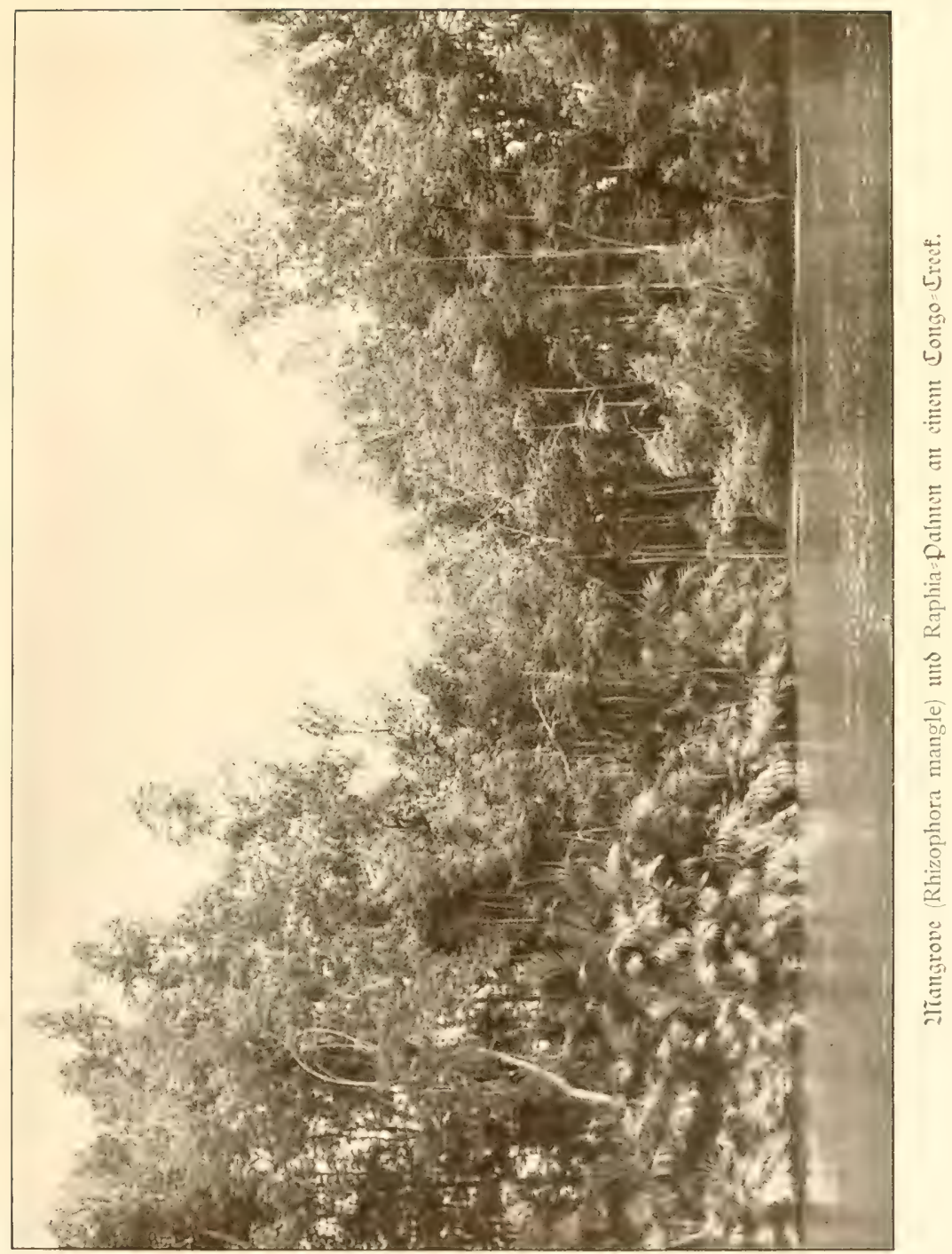



fanmeln verfuchten, gal es auf demt Dorderded eine crragti Esme. Dit (1)emehre murdent weggeworfen, die Röle ausgejogen, und wie von der Tarantel geftodien fprang alles

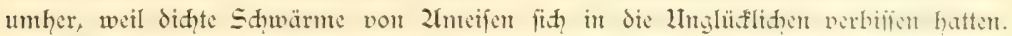

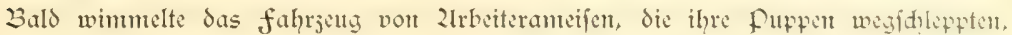
und biffigen Soldaten, die mur unter Derluft ihres Kopfes von der Gqaut abjuftreifen waren. Die 2lneifen gehörten der in den Tropen weitnerbretteten (5atturty Oecophylla an, weldie auf Bäumen lebt und ihre 2refter aus miteinander verwobenen Blättern herftellt. Sonderbare Dinge beriḑtet ein englifher Beobadter, Lolland, über dic Zrt der Gerftellung des Zieftes. "Die ju verbittenden Blätter werden erft von den 2funcifen mittels ihrer Dherfiefer in di riditize Sagi gebradt und jufammengehalten. Dann fommen andere in grozere Jahl, jede eine Sarve im 2laule tragend, und fahren mut mit dem Vorderende ber Sarve von einer Kante des Blattes jur andern. Wo

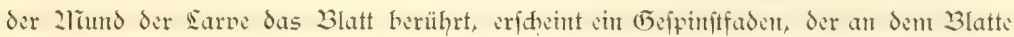
feftflebt. Diefer Prozef wird fo lange fortgefest, bis die Blätter an thren Rändern

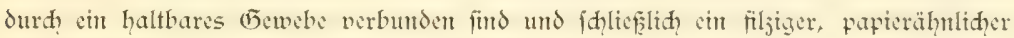
Stoff fid bildst, der aus unjählitgen, überimander liegenden und fidf frenjenden Spintu= fäden befteht." Diefelben Zlmeifen follen audh rings um den Stamm, auf demt ifr.

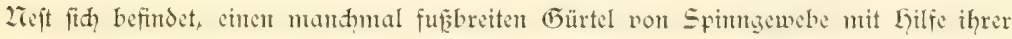
Sarven weben, in dem fid Fleine 2lmeifent einer andern 2lrt, mit denten fie ftändig im Kriege leben, verfangen. Gewif ein eigenartiger und in der Tierrethe faft einjig da= ftehender Inftinft, fich niḑt der eigenent, fondern getrenter lebendiger Werfizenge ju

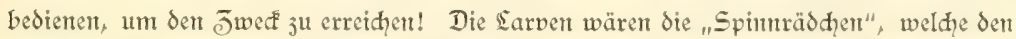
gefdidten 2lrbeiterinten den fadent liefern. 2lls mid der ausgejeidquete Kenner der

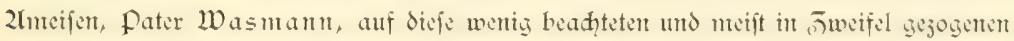
Beobadturgen aufmerfiam madte, veranlapte id cinen Sdüler ju einer genauen anatomifhen Unterfuhutug der Oecophylla-sarven. Da ergab es fid nut, daf diefe Spimbrüjen befitsen, welde an muswöhnlider Entwiflung alles übrbisten, was wir

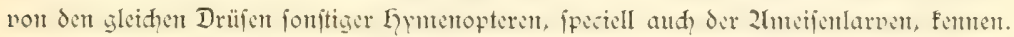

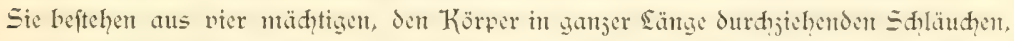

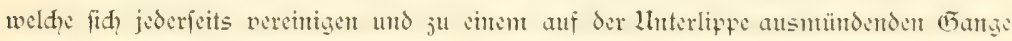

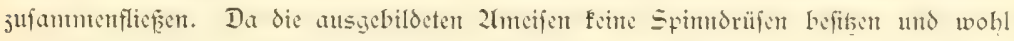
fapwerlith mit thren Dberficferdriffen den faden herftellen, dürfe man mentiger daran jweifeln, daf die Eiftorie von den "Spimträdden" auf ridhtiger Deutung des Dor ganges beruht.

Zur felten begegnet mant in dicjen cinfanten Crefs einent Cantoe, defient Infafien fid bei der Znnäherung fiqeu in das 2rangrove=Buffiwerf orüden.

Lm fo reidier ijt dagegen das Tierleben entwicfelt. Fier und da hufhen 2Tomenaffen (Cercopithecus mona) von 2 lit ju 2 lit, Eisvögel (Ceryle rudis), bald fdowarj und weif 
gefprenfelt, balo aufällig bunt gefärbt, beleben mit Sđilldraben (Corvus scapulatus), Shattenvögeln (Scopus umbretta) und den auf cinjelftehenden Strünfen aufbäumenden Geierablern die Scencrie. Wir hatten bereits cine jiemlid reiche Jagdausbeute gemadt, als von dem Vorderteil der Barfaffe unfere Jäger cin Sdnellfeuer eröffneten, und wir an

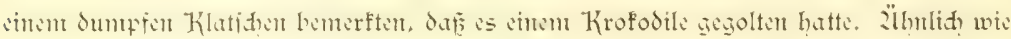

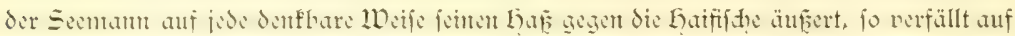
dem Lande das Krofodil der Derfolgungswut des 2lieniden; fo viele wir aud in naher und weitefter Entfermung erbliften, fo wurde dod, niemals Pulver und Blei gefpart, um

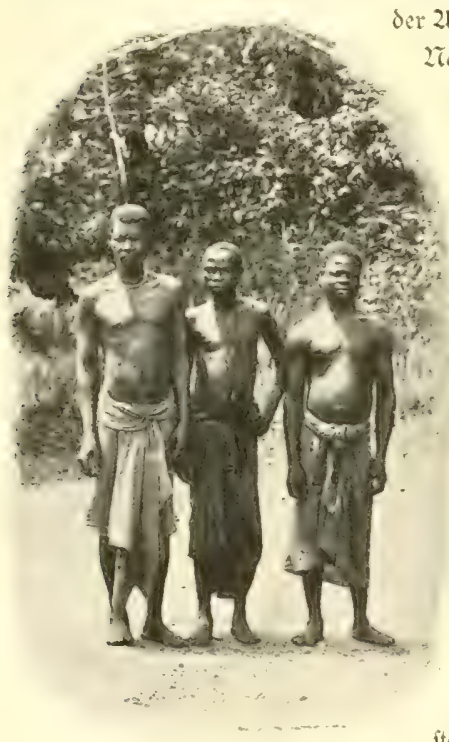
er 2lbueigung gegen dicfe Sheufale 2lusdruf ju gebert. Lah dreiftündiger fahrt erweitern fich die Creefs feeartig, und bald cröfintet fid der Zlusbliff auf den Congo felbit. Zluf dem jenfeitigen Llfer tauchen die weipen faftoreten von Janga auf, durd die [uftipiegelung nodmals ver= fehrt über dem Drte felbit fidwebend. Llts jur Scite liegt bie fleine 2hrtiedelung 2kallela, an ber wir halt maden. Die plantage wird durd 2lutuferonghes, vom portugiefithen $21 \mathrm{fer}$ herübergcfonmene Zteger, bearbeitet, weldhe fid teils unter eincr mädtigent, nod in volfem Saube ftehenden zldanjonta malerif gh gruppiert hatten, teils fith in den am Strande liegenden ranoes zu idhaffen madten. Sie treiben, wie alle Congo=2teger, bas aus cinem ausgehöhl= ton Baumftanmme gefertigte fahrzeng in auf= redter Stellung nit langen Rudern vorwärts - im Gegenfate ju den Kamerun=2Tegem, dic 17tuा̆eronghes

ftets fit tend thre fürjeren Paddeln handhaben. Der ganje Strand war hier mit 2liujdelidialen aus der

(5attung Galathea didțt bejät, die in Bonta zu Kalf gebrant werden und, wie wir dort mehrfad fahen, aud jut pflafternutg Derwertung finden.

Die Mlferfenerie begimnt hinter Mallela fid vollftündig ju ändern. Das 23raffwaffer

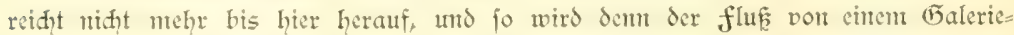
wald umfäunt, in dem alser 2lbanfonten namentlidh die ftämmigen Ficus, bie hod? aufftrebenden Wollbäume (Eriodendron anfractuosum) und die zahlreiḑen P̈lpalmen cimen harafteriftifdent Beftandteil bilden. Direft am Llfer ftehen Pandams, hinter

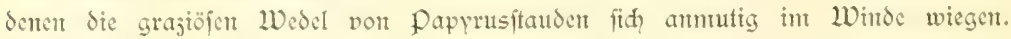

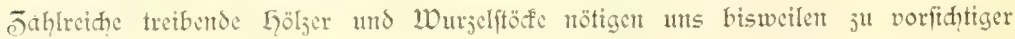


fahrt, während die 2riitte des fluffes von Sandbänfen und langgeftreften Jufeln eingentommen wird, auf denen oft cinte überrajdende fülle von Reihern und Sd)winmt vögeln umberitoljteren. 2luf den cinjelnitehenden Stäntmen am flup̧ufer fiţen mit

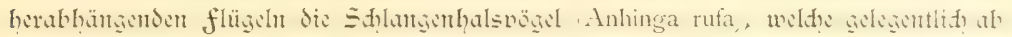
fliegen und durd ihre erftaunlidge (5e:

fdhicflidféfit in Sdiwimmen und

Taudien uns manden bewun=

Dernden Zusruf entloden.

So wirb denn allmäh = lif, der ẗbergang 3 แl der Savamenland= fhaft des Congo vorbereitet, die unt fo mehr zur berr= fhaft und (5eltung gelangt, je näher wir an Boma heranfommen.

Stadjlige 2lit: mojert untermifat mit rotblühenden Gibiscus und gell ben Papilionaceen werden überragt por mantshohem Gras und Sdilf, in weldyem die 1 vebervägel ihre jahl= reiḑen refefter aufhäntgen.

Zeben dent bisweiten ausge dehnte Beftünde bildenden Papyrus treten die Charafterformen der $S_{a}$ vante inmer mehre in den Vorders= gruno. 


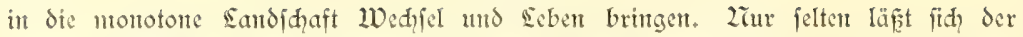
Stantm, allmählid fith verjüngend, bis jum Wipfel verfolgen; bald löft cr fid unt= vermittelt in drei oder vier auf gleider $50 ̈ h$ ftehende z̈lfte auf, bald eriḑöpft er fith

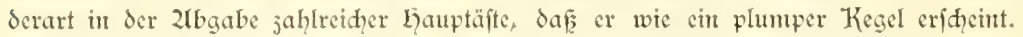
Int leţteren falle fteht der gewaltige Llmifang der Stammbafis von 6 bis $8 \mathrm{~m}$ um fo wentiger int Derhältnis ju der Göhe, als häufig die Verģweiguntg fdont diḑt über dent Boder anfiebt. Int vielgeftaltig, wie der Stamm, eridheint aud das 2liftwerf. Bald ftehen die Lauptäfte gefpenfififd lang gerefft von dem Stanme horijontal $a b$,

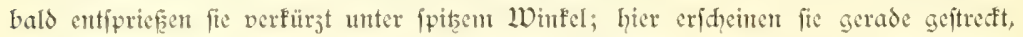

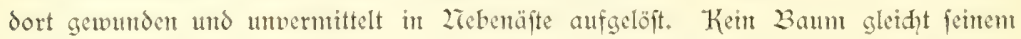
Zathbar und dod wiederholt fidh überall der gleidhe phyftognomifale charafter, weldher bald den Stammt, bald das 21 ftwerf - oft aud beide jufammen - beherridgt:

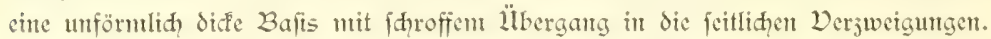

Ulralt mögen mandfe diefer "2liaftodonten des Pflanjentreids" fint, wie fie Picree

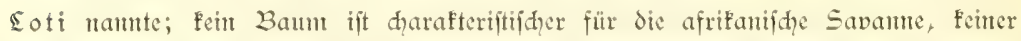

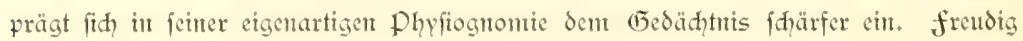
begrüfetent wir den 3aobab wieder, als wir, ein halbes Jahr fpäter, unts der oft= afrif́anifden Küjte näherten.

Während die zldaufonten erj̣t bei der 2lmäherutg an 23oma häufiger auftreten, fo bedingen weiter unterhalb die Savamentalmen (Hyphaene) den Charafter der

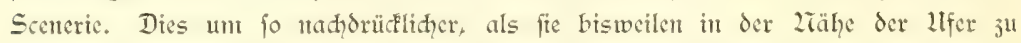
Eleinen Lqainen jufanmentreten. J̄wifhen den jüngeren Stämmen ftreben vereingelte alte Riefen auf, deren vertrothete Blatfäḩer unterhalb der etwas ftarr und fpröde fïh ausnehntenten saubfrone dem Stamme diḑt angefdntiegt herabhängen. Da die Savante durd die Zieger regelmäpig in Brand gefetzt wird, fo ergreift die fohe and? das dirre Blattmere der Palme und vernidytet es bis auf die augefengten, fperrig vom Stamme abitehenden Blattftele. Es erhält fid, mur an gejdühţen, dem fener unzugängliden Stellen; von weitem hat man dam den Eindruc, als ob ein ungefüger, gegen die Krone an Diffe junehmendor. Stamm der Palme eigen fet.

ङ̄wifden Baobabs und Sabannenpalmen eingeftrent trifft man als alte Befannte vereingelte D̈Ipalmen แnd mäđtige Wollbäume. Sie überragen ntedrigere Stänme mit fdiminförmiger oder fugliger Krone, unter denen namentliđ Vertreter der Ğattung Anacardium und die ftraudförmige derbblätterige Anona Senegalensis auffallen.

Der Boden ift bedecft mit meterhohent fperrigem (5ras, das in cingehten Buifhen wädyft und mur felten zispen von doppelter zliameshöhe treibt.

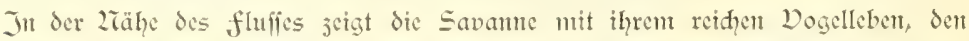
cingeftrenten 21ferpflanjen und den weit ausgedefynten Beftänden pon Papynus, deren

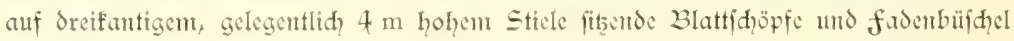


Baobab (Adansonia digitata)

in der Sabanne am unteren Songo.

f. Llinter phot. 


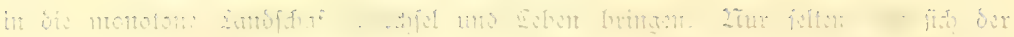

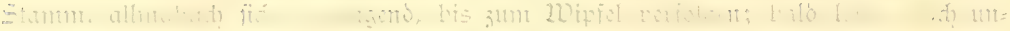

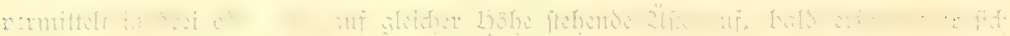

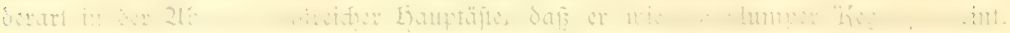

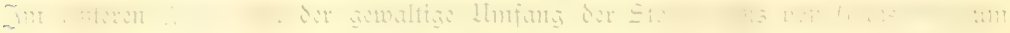

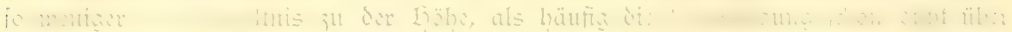

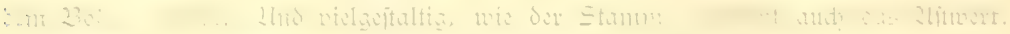

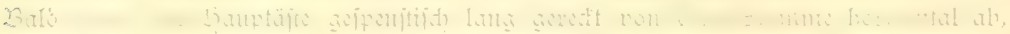
The

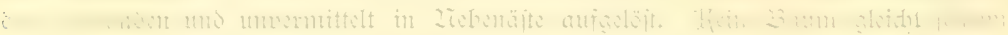

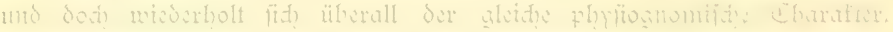

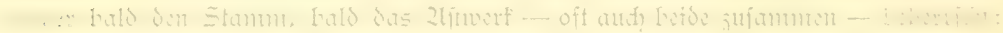

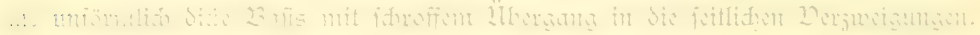

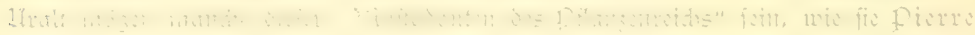

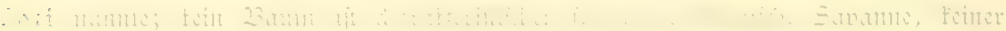

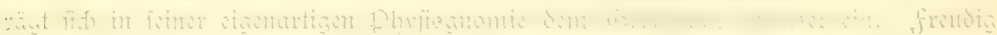

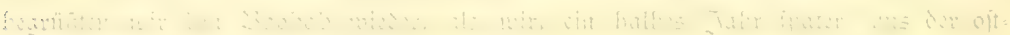

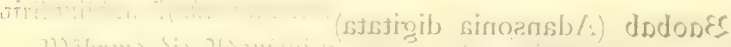

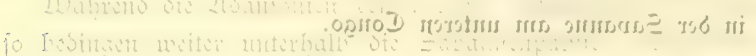

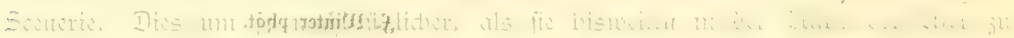

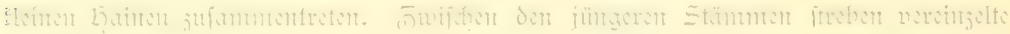

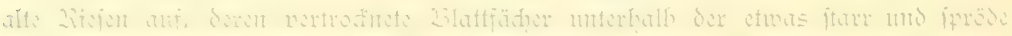

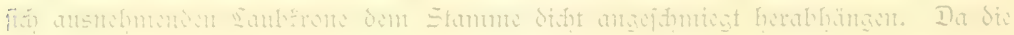

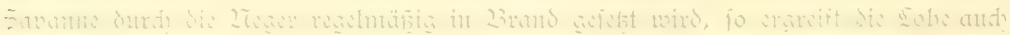

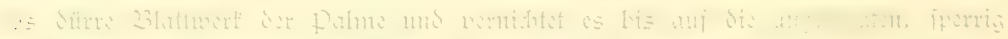

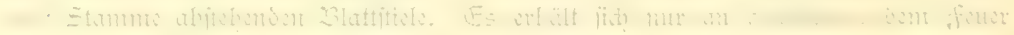

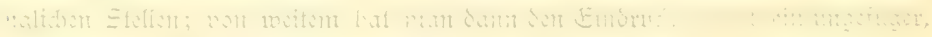

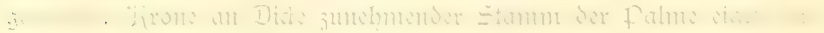

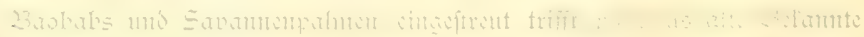

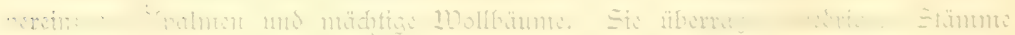

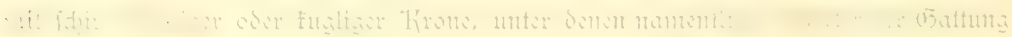

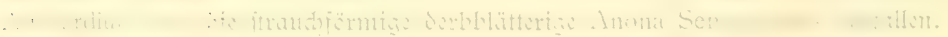

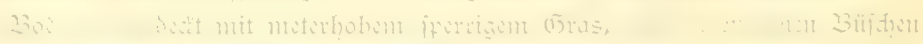

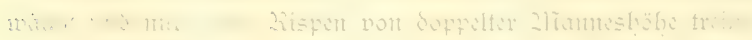

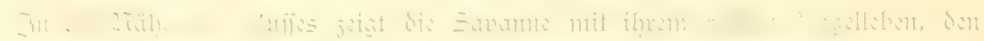

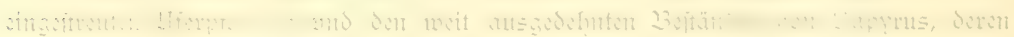

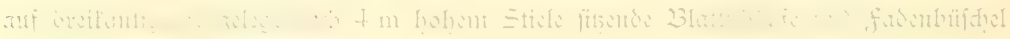




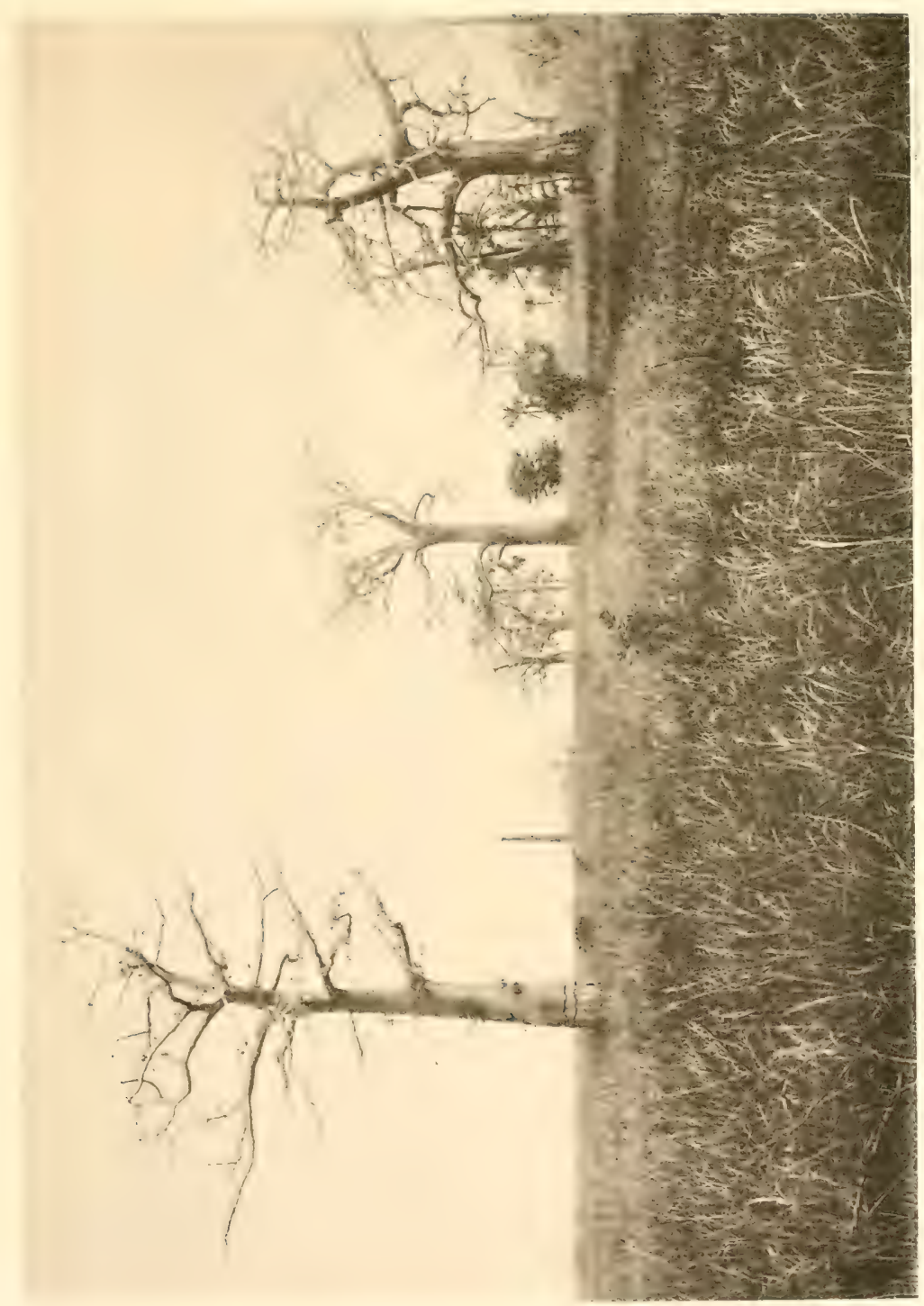





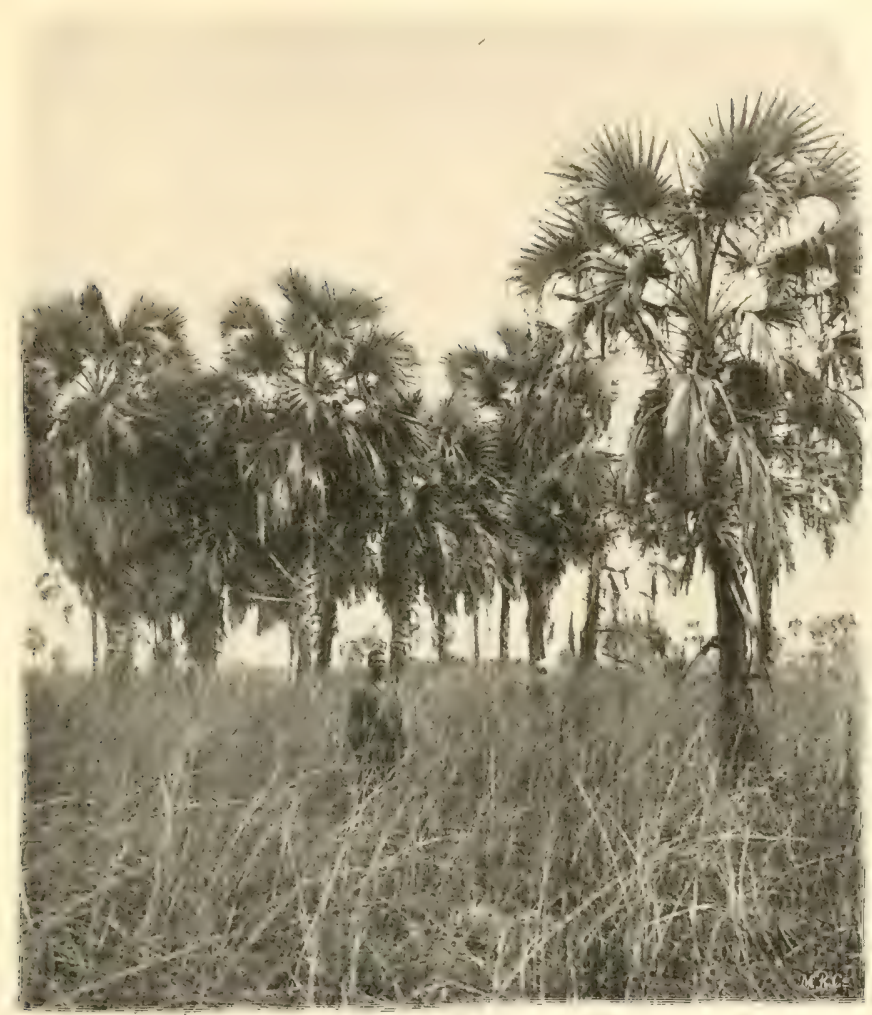

Hyphaene in ber Congo:Savanne.

fid) anmutig in der frifhen Brife wiegen, einen durdians anjiehenden Charafter. weiter landeinwäts entjicht fith das Tierleben den 2lugen des Beobaḑters. Zlles

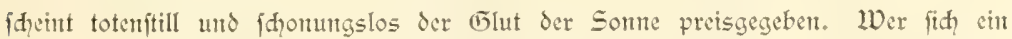
Bild von der Savanme während der Trosenenzeit maḑen will, der denfe fid weite, aus fperrigen Lalmen gebildete Frasfläd̨en, über die gerade nod, das 2luge des $\mathfrak{W}$ an= derers hinwegblift, dajwild̨en öde fhwarje, durd das feuer verfengte vegetationslofe Infln, überall auftauthende Baobabs, weldge gefpenftifh ihre in der trodenen Jahres= jeit des Eaubjhnufes entbehrenden z̈lfte jum finmel refen, hier und da cine Savantenpalme oder cinen grinen Buin det Anona; man denfe fith weiterhin das 
aus roten Saterit gebildete Terrain wellenfömig gefaltet und den Lorijont von roten Lügelreihen mmfäumt, welde oberhalb Boma in die fahlen E)rantherge übergehert.

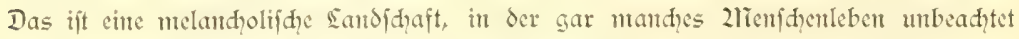

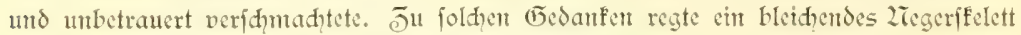
an, Sas mit ben nod, erhaltenen 2letallringen neben einem 3aobab von den Reife= gefährten gefunden wurde.

Der 2lbend brah hereit. Eine fräftige Seebrife fräufclte die Wellen des raf́ dahinfliefenden Stromes, und blutrot ging die Somte unter. 2Tur furz daucrte die Dämmerung; in der herembredenden finfter:

nis waren die llfer und dic roten Eaterit=

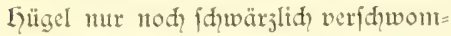

men Eentridy, wälįtend ab und ju

dic Savame durh einen feucr= brand erleudtet wurde. Die Bar= faffe fämpfte fower gegen den Strom an, und es wurde fpät, als die mädtiger aufftrebenden Berge die 2fmräherung an $\mathcal{B}$ onta verrieten. Kaum war das unterhalb der Stadt erriditete fort mit feinen 6 Dreh= türmen fenttlid, demt an gegenüberliegenden por: tugiefifden 21 fer ctwas ntebr front= abwärts - ein nods in Ban befindidues wohl fdwerlid? ge= wadyfen fein dürfte. Uls wir endlid des 2lbends 10 2lly in Boma landeter, wurden wir Surd Sen Directeur de la marine bewillfomm= net und nad, dem glät= jurb srluthten, ,istum rant Scopold II." Geführt. Da wit als (5äjte des

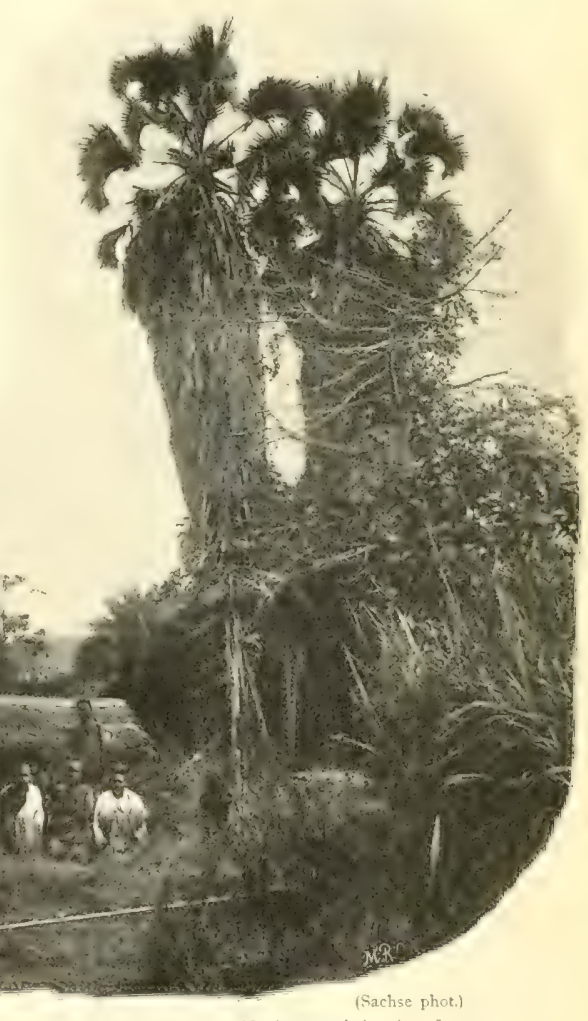

(Sachse phot.)
den Den Stamm 2ieaethitte bet 23anana; int Einfergesnde Hyphene mit 


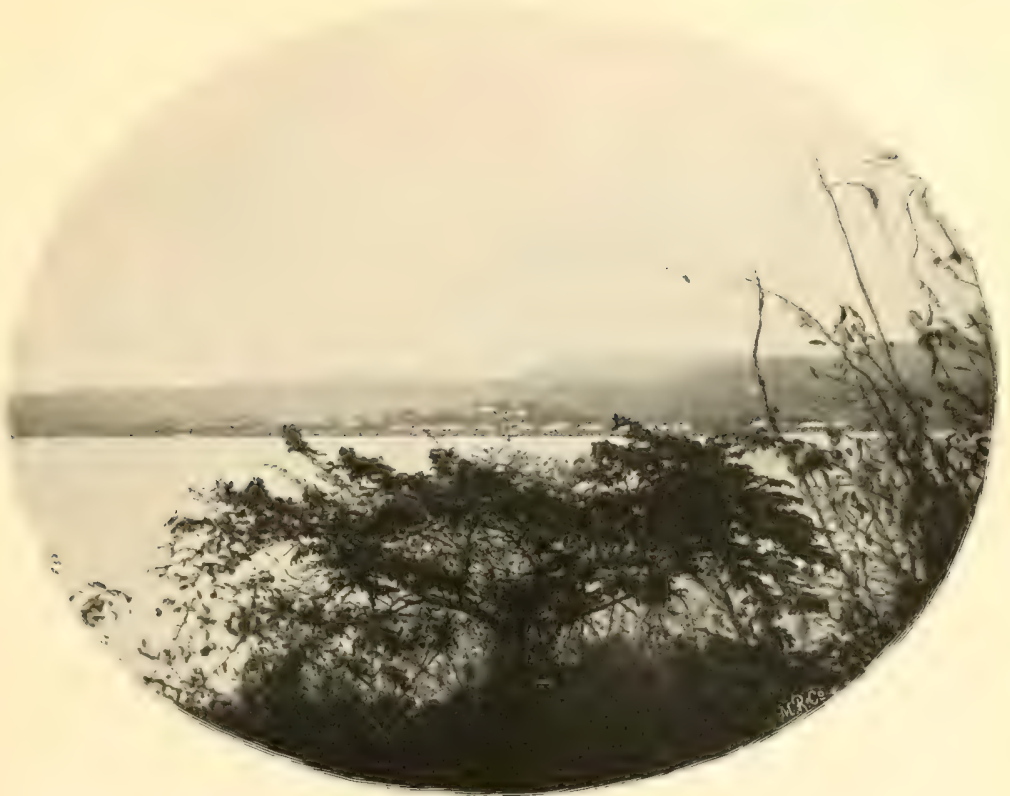

2lid auf Soma von ber Congo-3niel.

Congoftaates in folemer Weije bewirtet wurden, hatten wir erift an folgendent Tage (5elegenheit, genauer die Eigentïmlidfeiten des vont Portugiefen geleitetent und von

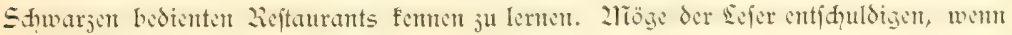

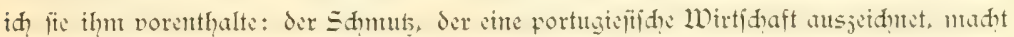

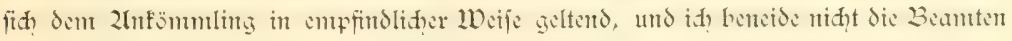
des Congoftaates, dic darauf angewiefen find, Jahr aus Jahr ein ihre Zniprüde ant

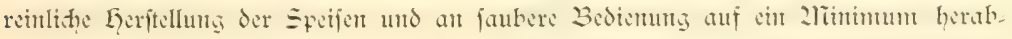
zujtinmen. Dagegen waren wir in unferem an fluE gelegenen Lotel den Llmftändent nadh behaglid? gebettet, wobei freilich in Betradit ju jiehen ift, daf mant in eirtent

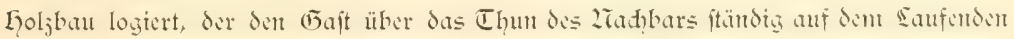
hält. früh fhon wurde man durh das gefduwätige Treiben der 2iegerbevölferunts auf der Strafe gewedt, und mit begreifliden Intereffe gentof man non der Deranda

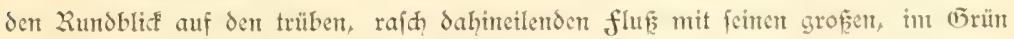
verftedten Injeln, denen in weiter Entfermung rote Lügel und in feinem Duft fdim= mernde Berge folgen. Daf wir uns in einer rafi aufitrebenden Stadt befinden, 
jeigen die ftattlihen Regierungsbauten, dic in langer Reihe bis jum Quai hin fith eritrefer. Die Bedeutung von Boma liegt weniger auf fommerjiellem Gebiete, denn auf feiner Zratur als 2lietropole des gewaltigen Congoftates, und fo trägt es audh mehe den Charafter einer Beantenftadt, in welcher der Kaufmann an Geltung zurück= tritt. Immerhin wird es figon allett aus demt (Grunde ftets aud eime fommerzielle Bedeutung bewahren, weil niḑt fehr tiefgehende Damtpfer bis Boma flußzaufwärts ju fahren vermögen und an den praftifin eingerideteten Quais das Gaden der Gäter bewerfitelligent.

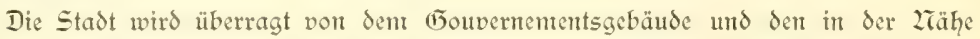
liegenden Kafernenbauten, ju denen cin Dampftram hinführt. Im übrigen ift die Sceneric fahl, und überall drängt fid dic Savame nit ihren Baobabs, 2lïmofen, Papyrusgebüfden und dent roten Eateritboden cin.

zith̨̧ minter find aud in der Bevölferung die Kontrafte ausgeprägt. Die Stadt

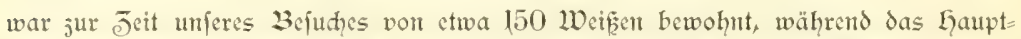

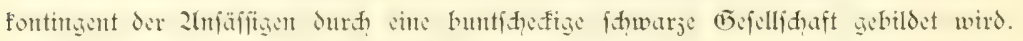
Dom vollendeten (5igerl mit Steḩragen bis herab ju den auf das Zrotoürftigfte bełleideten, in Trupps und Karawanen anlangenden 2läajumba werden fämtliḑe Typen der mehr oder minder von der Kultur beleften afrifanifhen Bevölferung uns dargeboten. 2ln meiften Interefie erregen die urwühfigen, aus dent Jumern anlangenden Karawanen:2teger, unter denen namentlid, die fhwerbelafteten Weiber

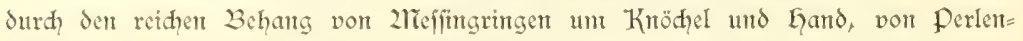

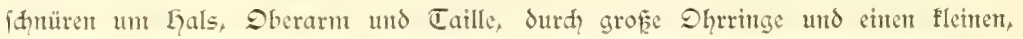
aus Bajt geflohtenen Güftfhurz auffallen. Jhre saften, gelegentlid aud die auf dent Rüfen reitenden Kinder, fdgleppen fie in geflodtentent Tragfäcén, die mit emer Binde um die Stirn befeftigt find. 2lian mag fid das Staunen ausmalen, mit dem diefe naiven Kinder der Zatur die auf dem fahrrad dahincilenden Weiken, oder das iđnaubende Untgetüm, weldhes die Tramwagen jicht, betrad̨̧ter. Wemn fie aud? mit

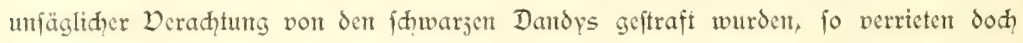
lef̧tere nod in ciner Finfiḑt die Zlupaffung an ihren Hriprung aus einer Savament=

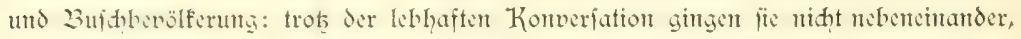
fondern in langgejogenen keihen hintereinander. Indefien mus idh jur Ehre der Schwarzen, wie wir fie in Dictoria, Kamerun und am Congo unter den mannig= faltigiten Verhältniffen antrafen, hinjufügen, daf uns niemals aud, mur ein cinziger angebettelt hat.

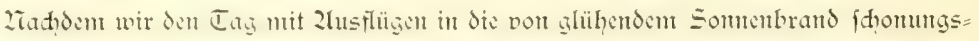
los heintgefudte Savame und auf die grože, Bonta gegenüberliegende flü̧míl ver=

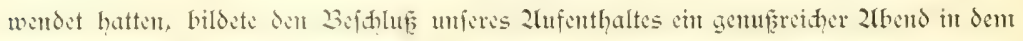
(5)ouvernement. Der Gouverneur, 2lir. fuhs, imponterte uns durd die Sidherheit 
und Ruhe in der Beurteilung der Derhältnifie und durd dic 2lrbeitsfrendigfeit, mit der er, niemals von Kranfheiten heimgefudt, fein verantwortlidges 2lutt führte. Er ift von Seutihem Uriptung und einer feiner Dorfahren hat als tüdtiger Botantfer bei Benenmung der befamten G̈erpflanje, der fudyfia, pate geftanden.

Zur ntit fđwwerem Gerjen lehnten wir die in liebenswürdiger form gemtad?te Einladung $a b$, auf der Congobahn audy den mittleren Sauf des Congo fenten ju Iernen. Wir waren num eimmal auf den Deean angewiejen, und fo fuhren wir dent an 4. Df= tober in Begleitung des Chefarjtes des Congo=Staates, Dr. Etieme, rafक fromabwärts. Wir wären wohl in fürjefter frift mit der flei= nen $\mathcal{B}$ arfaffe in $\mathcal{B}$ anana angelangt, wenn niḑt die injwifhen cinjerzende und bis weit in die Creets hinent fith geltend madiende flut an rafdent fortfommen gehindert hätte.

Die jurüdgebliebenen (5)fährtes hatten injwifhen eifrig die Begend um Banana durdhitreift und ver= fügten über manḑ intereffante Jagd trophäe. Da dic Trabition an dic Sflabenjagden aus früberer Jeit nod? lebendig war, erwiefen fith die $\mathrm{Be}_{\mathrm{e}}$ wohner der in Wald veritedten Sied $c=$ lungen häuftg noḍ recht iḑeu und flüh? teten bet der 2Innäherung der $1 \mathcal{D}$ ei So pornte dent aud in allev 2lüe eine fetijhbütte photographiert werden, vor der in abenteuerlidien 2lufputz auf einer Kifte ein roh gefornitztes Jool ftand.

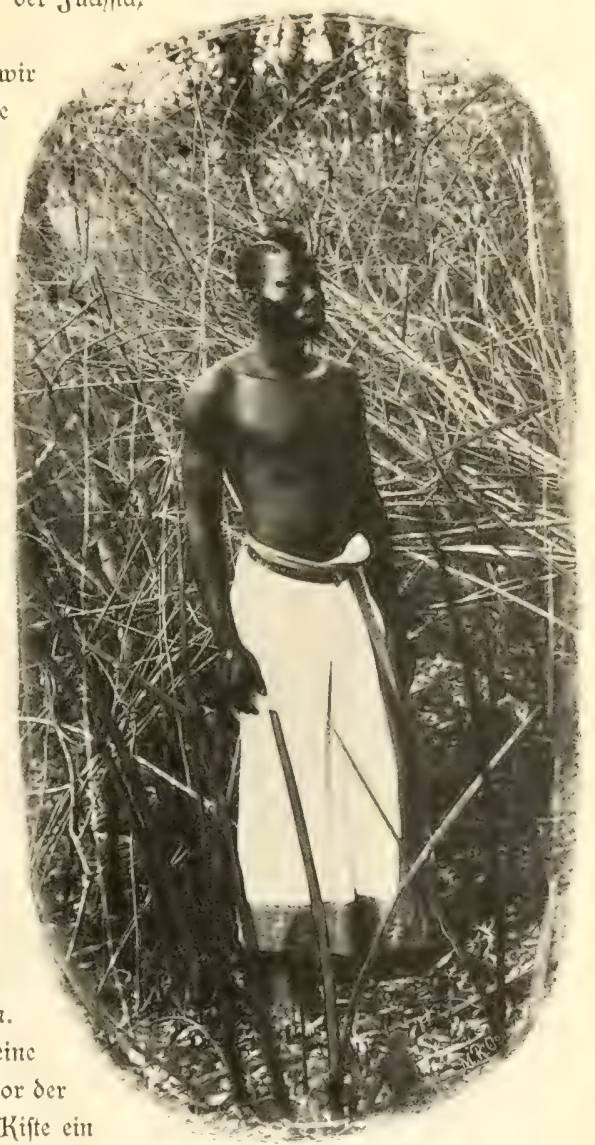

3angala in Bufdimalo der Congo =3nfel.

Daf aud unferem Kapitän die Jeit nid̨t $j^{\sharp}$ lang wurde, dafür forgte ein weif = bärtiger Kollege, der ein ganjes 2lienfhenteben hindurd den Congo befuhr. Wie cin Roman Flang es, wern er von dent "f fönen Jeiten" erjählte, wo der Sflavenhandel 
blühte und an fowwarzer Ware cin Derntögen verdient wurde. 2lian bradte es fertig, Sen alten Bärnt, dor feit Jahren fein Sdiff niḑt mehr verlaffen hatte, ju einem $\mathcal{B}_{e}=$ fude auf der "Daldivia" ju bereden. Kopffdüttelnd betrahtete er Sotmaifinen, Kabel und Sdileppretse, und andäd tig hörte or $j^{u}$, als ber Kapitän thm fdilderte, was wir 2lles mit einem Kabel vor $10000 \mathrm{~m}$ Sänge aus $15000 \mathrm{~m}$ Tiefe heraufholtent. "Junge, Junge, du lügft", brummte der 2llte und verabihiedete fid?.

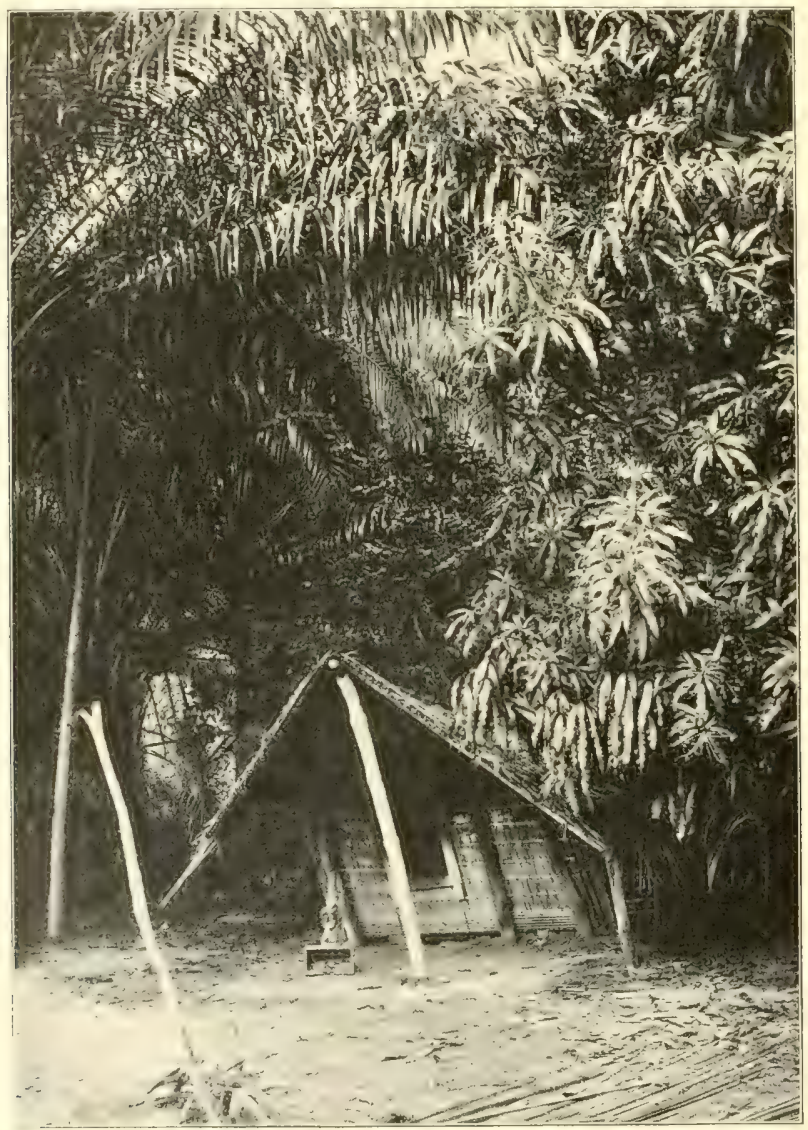




\section{ว21}

\section{Die Grolje fijchbai.}

Tus dent Tropengegenden in Kamerun und an Unterlauf des Congo, über welhe die Ratur mit verfdwenderifher Pradit das füllhorn ihrer Reize ausgegoffen hat, möd?te iḑ den Eefer in ente nod im Tropengürtel gelegene Eandjhaft führen,

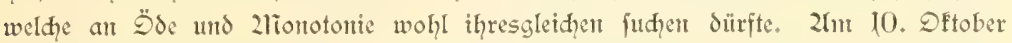
fidteten wir gegen 2 llhr bei trübem, regnerifhen Wetter dic von fteilabfallendent

2Infiebelang auf ber Eiger Elalbinfel.

Sanddünen gebildete Küfte und gelangten gegen 2lbend in dic (5rofe fifąbai, and? Tigerbai genannt. Sie liegt mur 25 Seenteilen nördlid, von der zliündung des dis

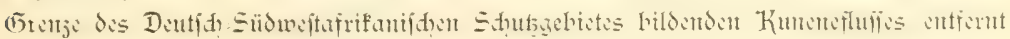

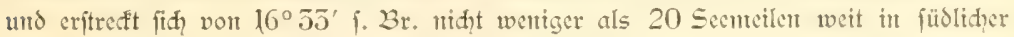
Ridhtung bei einer Jurdhidnuttlidgen Breite von 4 bis 5 Seenteilen. früher galt dic

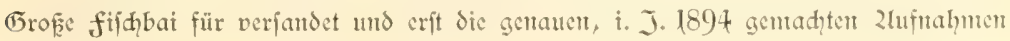




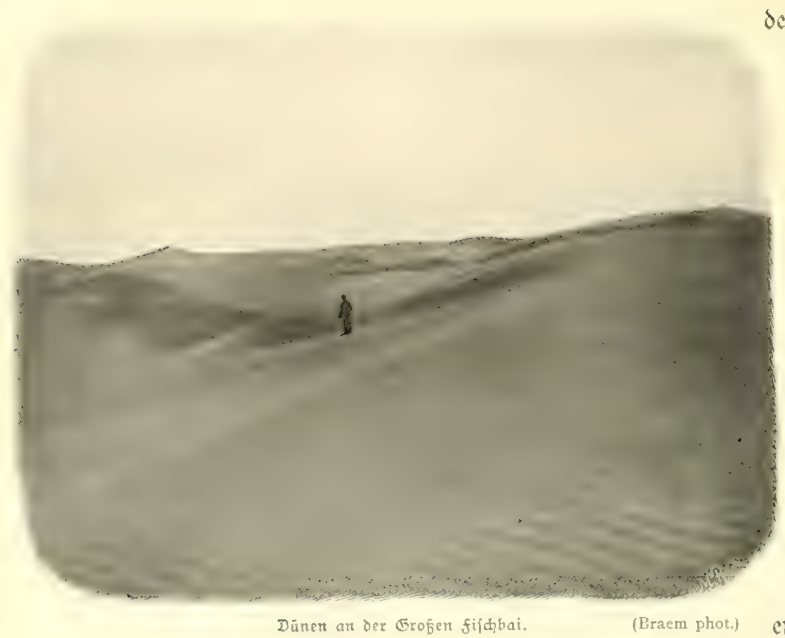

ber "Waterwith", wel= de in eitrer treffe= lithen englifthen 2 Iontiralitätsłfarte niedergelegt finto, lehrtent, da fer felbjt die größ̨ten Kriegs= fdiffie in der gant= 3en Zlusdehnung der Bat güritigen Zfnfergrumb findent. Keine Barre ver= wehrt den Jugang bis jum fiildidict Ende, da cine Sce= meile vom Eande entfernt ourd,fduittlid) $18 \mathrm{~m}$ Tiefe fonftatiert werden. Uuf der feftlandfeite wird die Grofe fifįbai von 90 bis $150 \mathrm{~m}$ hohen Sandbergen, deren formation fortwäḩendem Wechfel unter= worfen ift, ungeben. Don dem 2lieere tremt fie cine nur wentige 2lieter hohe, lang= gejogene Diune, dic fog. Tiger=Glalbitifel. D̈de und troftlos ijt die Scenerie. Wer

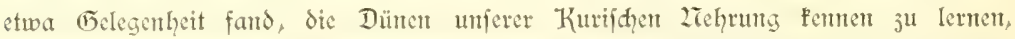
wird fid chen Begrifi von diefen grofartigen Sandbergen mit ihter durd den Lino

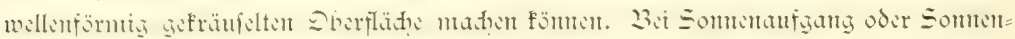
untergang jeight dic Sandidaft ctwas meht Seben. Dant feffeln nidht mur die fon= traftreiden farben des rötlidi=gelben Sandes, des grau=violetten Fimmels und der sunfelblauen Budt, fondern vor allem aud die tiefen Sd̨lagidatten und das fharf fith abhebende Syitem von Wellenlinien auf den Wanderdünen. Dergeblid fihaut man

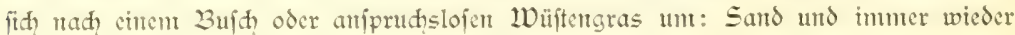
Sand ift dic Signatur dicfer cigenartigent Eandida aft.

2tber als ob dis Zratur dem troftlofen Eimerlei einen Gegentpart hätte ihaffen wollen, fo birgt die Bai eiten geradeju erftaunlidyen Reidgtum an niederen Drga=

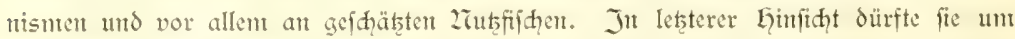
fo weniger von irgent cinem Punfte der füdweftafrifanifden Küjte tibertroffen werden, als wir allen Grumb ju der ZInnahme haben, dafi fie, den flaffen der Qitfee

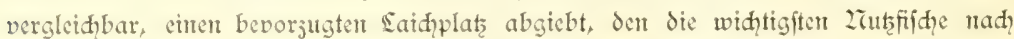
unjerent Wahrtehntungen in der jweiten Fälfte des Dftober aufiudher. Es madhte sinen fait märdhenhaften Eindorud, als am 2rbend mad unferem Eintreffen die 
Dberflähe des Waffers zu phosphorescieren begann und fid cin Rafetenfeuer von Gunderten glühender Streifen entwidelte, dic ebenjo rajh wieder veriḑwanden, als fie auftauḑten. Es waren grof̧e fildye, welhe bei dem Durdifineiden des Wafiers

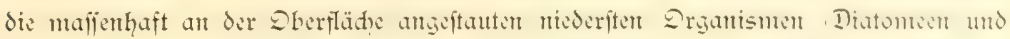
Pyrocyitis) jum Seudten bradtetr. Wir verfenften bis in dic 2rähe des 2Dafier= ppiegels unjere grop̧en eleftrifhen sampen und fahen, dafi, angeloft durd ihren Shein, aufer fifhen Lumberte vort Ringelwiumtern (Heteronereïs) faft pfeiljhnell Jurd das Waffer cilten und vergefellidaftet mit einer fülle von niederen Drganismen dent eleftrifhen Sidjte juftrebten. Llufere fifher holten die langen Angellemen hervor und "pülften" in furzer frift einige grofe Dertreter ber im Kapland gefdätzten "Қap= Sdyellfifhe (Sciaena aquila). Bald war die ganje 2liammidaft damit bejhäfigt, die Seinen ausjuwerfen unt oft mux mit 21 nftrengung die im 21 rittel $15 \mathrm{~kg}$ idoweren, mit

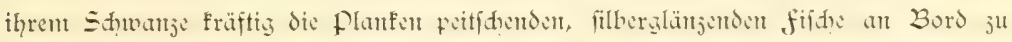
jiehen. 2luh während der nädften 2lad̆t lief die Zlufregung und die Erwartung auf eine gefhätste Koft unfere 2liatrofen nidht jur kuhe fonmten. 21m 2lorgen lohnte denn aud reiḑer Eewinn: gegen 150 Praḑteremplare der Sciaena - darunter cines von $50 \mathrm{~kg}$ Sdwere - lagen alt 3ord.

Wie die Unterfudyung des 2liageninhaltes ergab, fo näbren fie fidh vort dem fübliḑen Gering, der benn aud, nody einent jweiten, feineren Tafelfifक, nämlid, dem prädtig rofenrot gefärbten Dentex rupestris jur Beute fällt. Der leţtere hält fid im Gegenfat zu der Sciaena mehr in der zähe des Erundes auf.

Ein eigenartiges Shaupiel bot fid uns an 2liorgen des 12. DFtobers dar, als

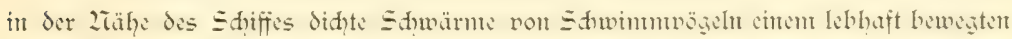

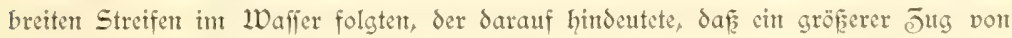
fifhen längs der Küfte feinen Weg nahm. Sofort wurden unjere beiden fifher mit demt Petterfortident Sdleppnet (Dttertrawl) beordert, weldye vom Sand aus das= felbe zogen. Der fang bejtand faft ausfhliefitich aus Leringen und lieferte cine

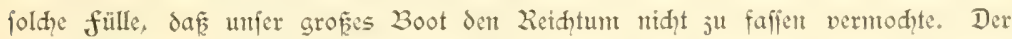

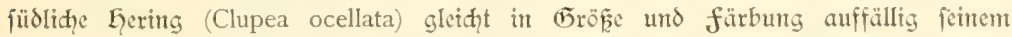
nordifhen Derwandten und dürfte ihm aud in (B)efhmad faum nadjptehen. Eifrig war die 2liamnhaft damit bejdäftigt, den fang cinjujaljett, einjupöfeln oder auf andere Weife als willfommene 2lbwedffelung für den Speifejettel ju verwertert.

Dieje Beipiele mögen allein fdon genügen, un den geradeju ftaunenswerten fijh = reidftum der Tigerbai zu illuftrieren; immerhin fet erwähnt, daf wir auf̣er den genamten 2iutifidien nod, Scejungen, 2lafrelen und Triglen erbuteten. 2Iupser= ordentliक gemein muE in der Bai der fleine Dorsthai (Acanthias) feit, da wir ihn in unferen Reujen und mit der Zlngel in 2lëenge fingen. Den Eeringen idgemen dem aud die Wale, wahr rheinlid der (5attung Balaenoptera angehörig, ju folgert, deren 
wir drei im Jumern der Buht blafen fahen. Es liegt anf der Ķand, da fo gewaltige, lange und didhtgedrängte Sdqwärnte vont fijḑen ju ihrer Exiftenz eines entipredienden Quantums von zährmaterial bedurfen. So fei dern erwähnt, dafe die quantitativen Jüge mit unferen feinen Planftonteţent als der 2litte der Bai cine derartige fülle niederer pflanglider Drganismen ergaben, wic fie bisher nur während der fogen. Laffiblüte in den Kaffen der Pftfee jur Beobadtuntg gelangte. Sie fetzen fid aus

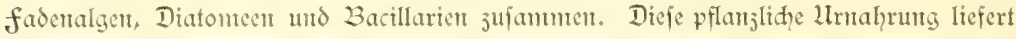
das 2hatertal, volt demt fith 2liprtaden fleiner fdwimmender Krufter, Wümer und Miollusfen nähren. Sie fallen ihrerfeits wieder gröferen formen zum Dpfer und werdent

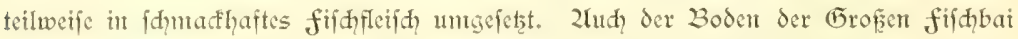
birgt an manden Stellen einen überrajdenden Reiftum von reijvollen polppent (Veretillum), weldhe wie Blumenbeete thn auf weite Streden bedeffen müffen. כ̄u iłnen sefellen fid Secjterne, Sdynefen, Cruftaccen und Röhrenwürmter in foldher fülle, dafi oft unfere zietse von ihnen vollgepfropft erfitienten. Trolzdem idgeint der mafienhaft

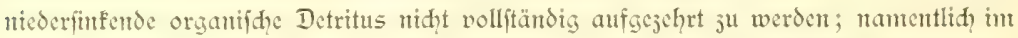
Ginteren Teile der Budt, wo aud dic Grumbfauna nur fpärlidy entwidfelt ift, war dem

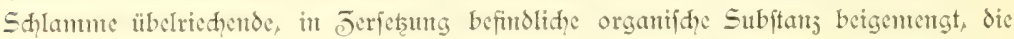
Surd die Bewegung der Sđjraube ju unjerem lebhaften Lhtrbehagen aufgewirbelt wurde.

Zuf dent Reidtum an fijden, ZTollusfen und Kruftern beruht die üppige Ent=

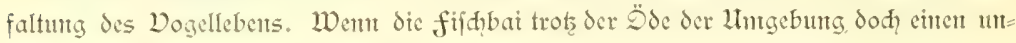

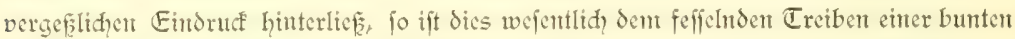

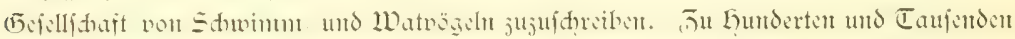

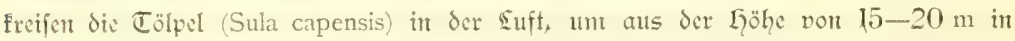

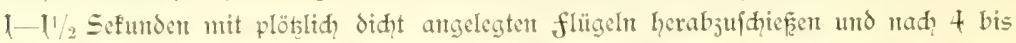

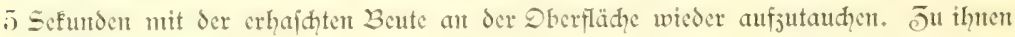
gefcllen fid Sturmtaucher (Puffinus), fđtwarje Sturmwögel (Procellaria aequinoctialis)

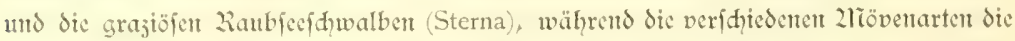
Brandung an der 2tupenfeite der Tiger=Galbinfel als Jagorevier bevorjugen. 2luf

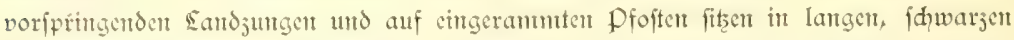
Zieihen die Cormorane (Phalacrocorax capensis), während auf der Düne didłte Sharen der Strandläufer und Regenpfeifer (Charadrius hiaticula) juthunlidh vor uns hertrippeln. Die weftafrifanifhe Küptemregion ift in ornithologifder Einfitht fo genau durdforidgt,

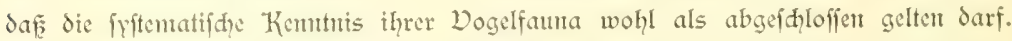

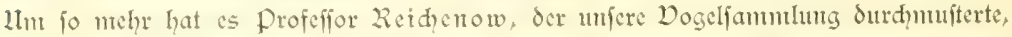
überrafdt, da befant, weldye cr Charadrius rufocinctus nante. Jhren 2lrtnamen hat fie von ciner hell-rotbraunen Kropffinde erhalten, dic fid von der weifen llnterfete des Körpers fharf abhebt. 
Finen eigenartigen Keiz gewähren dic in 5 dywary=10eif $=$ Rot getleideten flamingos (Phoenicopterus roseus), weldhe bald in langen Reihen nebencinander fifden, bals in Sđwwärnten ju mehreren Lumberten aufflegen und den Gorijont rofa unfäumen. Einen fonderbaren 2nblid bietet es, went man von Bord aus den Treiben differ gravitätifa?

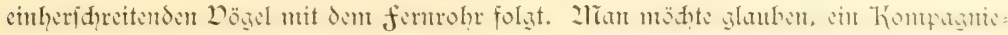

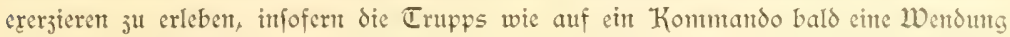
halbrehts madent, würdevoll eine Jeit lang einherfhreiten, bald mit halblinfs wieder die alte Rihtumg cinfdlagen oder in aufgelöten Sinten einen 2lulauf gegen das Hiper nehntert.

Den Drrithologen wird viclleidgt am meiften die Thatfahe lïbrrafhen, daf der Grofenen fiphbai auth die Pinguine niḑt fehlent, deren Dordringen in dert Tropent gürtel des weitafrifanifhen (5ebietes wir jum eriten 2lial nahjumeifen in der Sage waren. Wir bemenften allerdings mur Jugendformen von enförmig granent Tone und dunfler gefürbtem Kopfe, mit lebhaften, fđwwarz glänjenden 2lugen, welde wentg fheu oft in direfter zähe des Sdiffes und der Boote auftandten. Intmerhin waren fie fhwer burch einch Sduf ju erlangen und wir muften froh fein, daf wir wenigftens ein Exentplar crbcuteten, in weldem Prof. Reidenow die Jugendform des an Kap der guten Loffinung niftenden Spheniscus demersus crfannte.

In Unfreis der Grof̧en fijhbai fehlt Süf̧wafier vollitänig. Da fein Rimnal in die Bat eimmündet, fo erflärt es fid, daf der Saljgehalt bis jum Ende der Budpt fid gleid bleibt und mit $55,4 \%$ fid anf derfelben Göhe hält, wie in dent angren= jenden Deean. - Die Tentperatur des Waffers betrug an der Dberflädye 15,5 bis $16,5^{\circ}$, in $20 \mathrm{~m}$ Tiefe (der mittleren Tiefe der 3ai) $14,1^{\circ}$. Da im allgenteinen dic Sufttemperatur der Dberflädententperatur des Seewaffers gleidfommt, fo erflären fid hierdurd die abtorm niedrigen Temperaturen in diefer Tropentegion. Wir fanden es empfindlid? fühl und es hätte nidit erif des Thermometers bedurft, um uns ju überjeugen, daf wir in das Gebiet des falten Benguclaftromes engetreten waren. der lärtgs der füdwẹtafti=

fartifhen Küfte

veritreidit und

jeine Wirfun=

gen felbit bis it dic zähe des Z̈̈qua= tors geltens madit. Das Waffer war in folge der reidilich

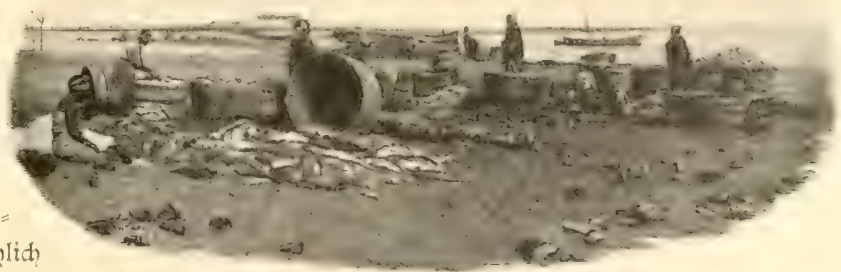




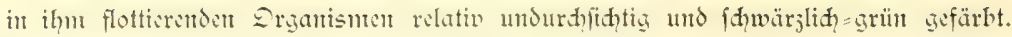
Zod 100 Secmetlen von der Kü̈fte entfernt ntaḑte fith diefe färbung geitend und widf erft dann dem blauen, oceaniffien Ton.

Sthon bei der 2miftuerung an die Tiger= Kalbinfel bemerft man cinige wentige, polid

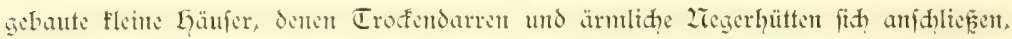

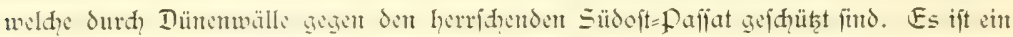
clendes und wahrlid niḑt beneidenswertes Dafein, welches dic Bevölferung mit den wenigen portugiefifhen Bicamten dort führt. Sic leht ausfhließslidh von dem Erträgnis

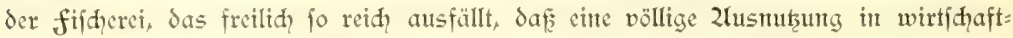

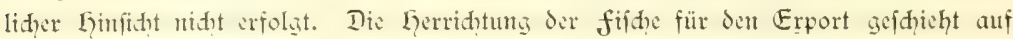
hödyjt printitive Weife, indent 2ingola-2iegerimen - fie tragen jum Sdhut gegen den Fühlen Wind Jatfent aus Shafpelj - mit Betlen den fifden den Kopf abhatfert, die Eingeweide auf übelriehende, volt 2liyriaden von fliegen umiḑwärmte Gaufent

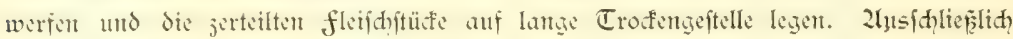
Sciaena unto Dentex werden getrofinet; für cine Verwertung des Reiḑtums an

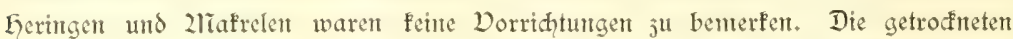
fifde merdin nath zlioffamedes, hauptfïhlith aber nad den portusicfifden Jufeln Principe und St. Thonté verfradţtet. Die etwa 500 Bewohner, welḑe ju cinem Drittel aus portugiefifhen fifdern und $3^{4} 3^{\text {wet }}$ Dritteln aus 2trgolanegern beftehen, werden vont 2roffamedes aus mit Süp̧waffer und Diftualien verforgt. Bet dem voliftündigen 2liangel von Trinfwaffer hat die Regierung nod dafür Sorge actragen, da官 in dem fifherdorfe auf der Tiger=halbinfel ein Deftillationsapparat aufgefteflt wurde. L̈ber die Befdaffenheit des von zlioffamedes fonmenden Süp̈= waffers wurbe lebhaft KKlage gerührt, weil dasfelbe hänfig Dysenterie erjeuge; weldhe Juftände bei portugiefiifher Wirtfhaft fïh gelegentlid emftellen, mag eint uns juge= gangener Brief des auf der Galbinfel anfäfitgen Geiftlḑen bejeugen. Ex lautet in Ser l̈̈berfetzung:

"Id bitte um die Gefälligfeit, mir ein fa官 Süp̧waffer ju überlaffen oder zu verfaufen int Ginblit auf den 2 tmitand, da nements nidht funftioniert und der Bevölferung fein Trinfwaffer liefert."

2rian ftelle fid vor, welde Eeiden cine von allen Qualen des Durftes gepeinigte,

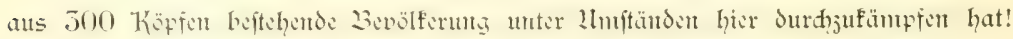
Es verfteht fich von felbit, daf wir den Bitten um ülberlafiung von deftilliertem Waffer bercitwillis intfraden und dicjem nod mand anderes sabfal beifügten.

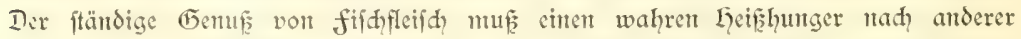

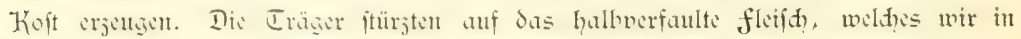

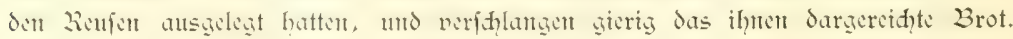
Da die Entfermung volt der Tiger=Bai bis zum Kunene nur cinen Tagemarfh 
beträgt, der über ein wohlgangbares, felfiges plateal füht, fo ift es fdywer ner=

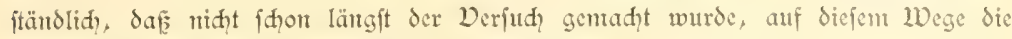
Bevölferung mit dem Ziotwendigiten ju verforgen.

2liti jener fait an das Wunderbare grenjenden Sdynelligfeit, weldye bisweilen dic

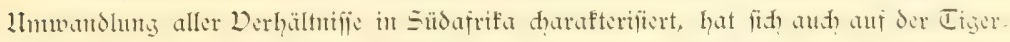
Galbitrel feit unferem Befuthe die Eage geändert. Wo flamingos, Cormorante und

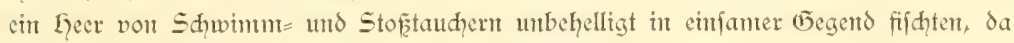
herridt jeţt geräufhoolles Treiben. Eijenbahnidienen werden gelegt und nid) lange wird es danern, bis die erjte afrifantifhe Querbahn den 2ltlantificen und Indifden

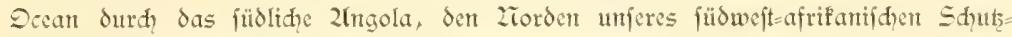
gebietes, Jurd Betfhuanaland und Transvaal verbindet. Sie findet 2lnidhluß an jentes gewaltige linternehmen, weldes Kapftaot mit z̈lgppten durd cinen Sdienenftrang in Bejiefung fetst.

Dat die South $=W_{\text {eit }}=2$ frican Company, in der deutifhe und englifhe Kapitalien jufammenflicfen, gerabe die grof̧e fifdibai jum 2lusgangspunft cines Bahnunter= nehmens wählte, weldies junädýt den Dtawi=Kupferminen gill, liegt in der 2ratur der Sadhe begrünet.

Dic Grof̧e fifdbai ift der grandiofefte natürlidhe Gafen der ganjen Wefteüte; in ihr vermöd)ten fämtlide flotten der Welt gletdyjeitig vor 2lnfer 3 ut gehen, olyme unter dem jhweren Wogengang zu leiden, weldyer gegen die Tiger= Lalbinfel - diefen lang= gejogenen Wellenbreder - anftümt. Während der jwei Tage und dret 2rädhte, dic wit in der fifhbat fo ftill verbradten, als ob wir im Gamburger Lafen lägen, madite fid draupent eine grobe See geltend, die in gewaltigen 3redhern ihre Kraft an

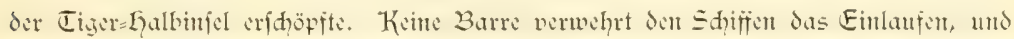
wenn aud jur Jeit die Zntfeuerung wegen der geringent Erhebung der Düne und der in Siefen Gegenden herridgenden Refraftion niḑt günftig ift, fo werden fidh die $\mathcal{D e r}_{\mathrm{c}}$ hältniffe beffern, fobald an Stelle der Bafe auf Tiger=point (der äuf̧erften Spibe der Galbinfel) cin seudtturnt erriditet wird.

Wic bereits oben erwähnt wurde, fo verdanfen wix wejentlid den englifipen Dermeffungen im Jahre 1895 die Kemtnis der Thatfade, daf die grofe fifhbai nidht verfandet ift und in threr ganjen 2lusdehnung güntigen 2lnfergrund bietet.

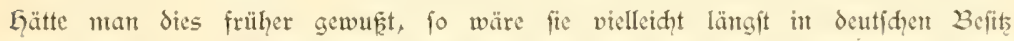
übergegangen. Das portugiefifhe Gouvertentent in 2roffamedes ftief im füdidyen Ingola auf fo viele ourd? Eingeborene und Wanderburen veranlafste Shwierig=

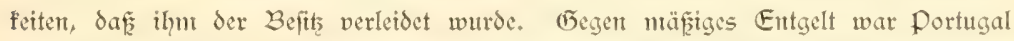

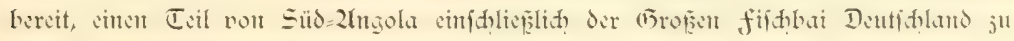


überlaffer. 2Taḑdem injwiphen der 2retallreidfunt des Ğebietes und die günftige Beidaffenheit der $B_{a}$ erfannt wurde, lag es in der Liatur der Sadie, daf man, unbefüntmert um etwaige fpätere territoriale (Ẽeftaltung, die natürtiḑe Einbrudhs=

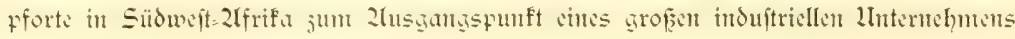
wählte,

Wie ein Joyll aus längttergangenen Jeiten wird demjenigen, der das gefdätige

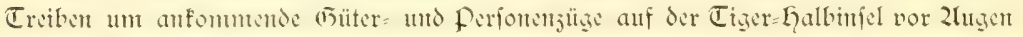
hat, die Sduilderung flingen, weldye wir non der jur Jैeit unferes Befuhes nod ein= famen und weltwerlorenen Grofent fifłbai gaber.

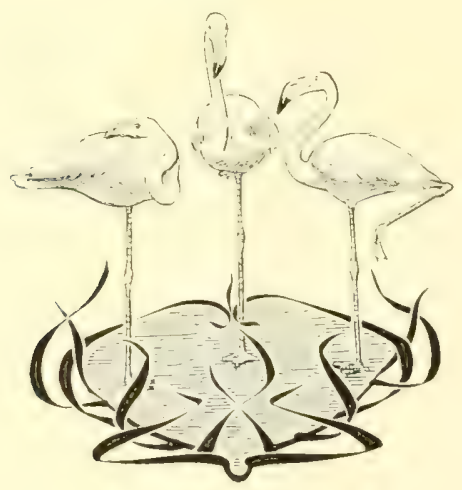




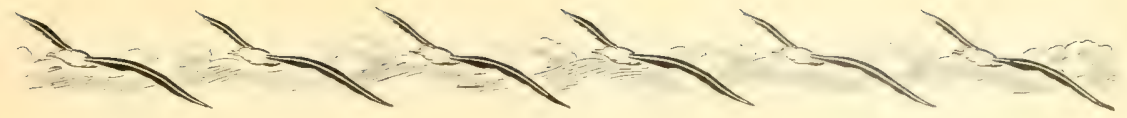

\section{Im Sïbatlantifhen (1)erant.}

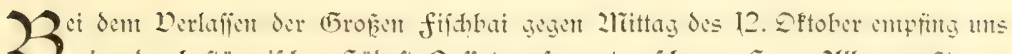
eine durh ftürmifhen Süboft= Pafiat aufgeregte, fowere See. Zlles munte ge= diḑtet werden, das Shiff holte reidilid, Waffer über, und für die an 2ralaria=Rect= diven leidenden 27itglieder geftaltete fich das Siegen in den Kojen oft recht peinlith.

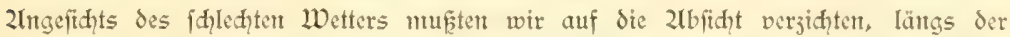

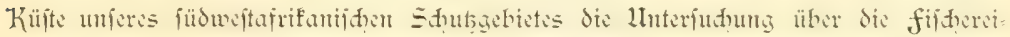
verhältniffe, wie wir fie in der grofien fifhbai begonnen hatten, fortjufetzen. Es murde weit vom Eande abgehaiten, und erit ant 15. OF= tober gelang es, zur 2rot wieder eintige 2robeiten vorzunehmen. Fine Ent=

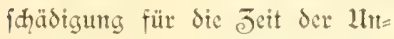
thätigfeit bot das 2luftaudhen Ser Kaptauben (Daption Capense), denen fid bald aud? dic críten 2llbatrolle anjhloffen. Jath habe sieje niedlihen, fhwwary= weif gefprentelten Kaptauber -

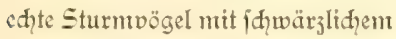
fdiwahem Sdhabel - wahrhaft lieb gewornen, juntal fie uns aud? fpäterhin bis in den äuferften Süden treu blieben. Dft waren fie in grof̣en Sduwärmen verfantmelt,

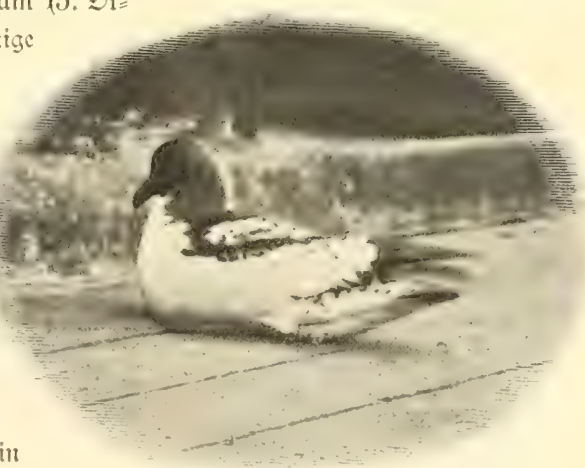

(Schmidt phot.)

Kaptaube (Daption Capense) an 230ro.

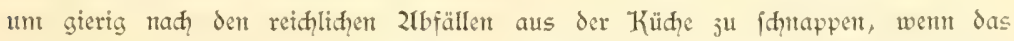
Shiff bet den verihiedenen Dperationen ftoppte. Sie jhwinmmen rajh auf dic an der Oberfläh treibenden Broffen los, tauhen aber niḑt, wie ihre Derwandten, nad der fihon tiefer gejunfenen fleifhitüten. Sonjt folgen fie mit dem den Sturntögeln

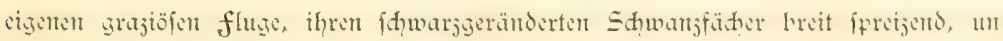
crmtïblid dent Sdiffe.

ziaht minder feffelte es, dem grofartigen fluge der zlbatrofie (Diomedea exulans

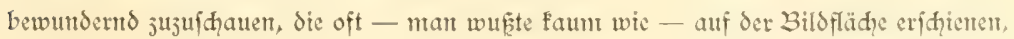


unt entweder nach wenigen 2limuten wieder dent Befidtsfreife ju entiduritden oder ftundenlang in weitent Bogen das Shiff ju umfreifen. Die Laltung bei den fliegen ift nidit gerade grajiös ju nenten, imfofen der Gals fharf eingejogen wird und der Kopf etmas plump dem Körper anfitift; unt fo mehr aber inmoniert es, wie dieje Segler obne flügelfallag bald über den Wogenfümmen fhweben, bald hod über das Shiff fid cr= heben unt in allen Stellumgen den Körper und die flugflähe der bewegten Suft darbietert. Zlud fie waren eifrig daranf erpidt, bie Kühenabfälle fich ju nutse ju madien, trieben iid) oft in fletnen Gerden um das Shiff unther und biffen gierig nad der für fie eigens hergeriḑteten 2lngel, an der wir fie mit seidhtigfeit an Bord ju jichen vermod)ten. bier beninmt fid der gefantene zlbratos in hohem 2liafic ungefhict; er vermag nid̨t aufjufliegen, erhebt fid felten auf die füpe, um einige watidgehde Sdritte vor= wäts ju ntaden, und duft fid dant rubig ergeben nieder, rengierig die Lntgebung muftemb, ab und ju mit einem fräftigen Sduabelfiebe unter ärgerlihem heiferem Blöfen den ihm zu nahe Kommenden verfheudhend und gelegentlid den öligen Jnhalt des Kropfes volt fith gebend. כ)un 2lbtöten wendeten wir Chloroform an, was uns wefentlid dadurd erleidhtert wurde, daf der mähtige Dogel fích faum abwehrento verbielt.

(5)währte das Treiben der Dögel bei Tage gemufreidge Unterhaltung, fo war bei 2lbend das 2licerleuhten nidht minder feffelnd. Zitentals ift es uns in ähnlidher Praht geboten worden, wie gerabe während dicjer ftürmifłen J̋eit. Wie Rafeten

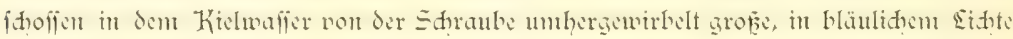
erglühende, waljenförmige Körper unher, welde bei einigen gelungenen Derifhen, fie ju crbenten, fich als feucrwaljen (Pyrosomen) erwicjen. Dagegen trat das durd) Fleine Ecuhtfrebje und fonftige niedere Organismen bedingte phosphorescieren mehr in den Lintergrund. ES war auffällig, wie fhwad entwidelt das 2liecrleudsten fid unts fpäterhin darbot; insbefondere vermif̧ten wir während der ruhigen 2äate im äquatorialen Indifhen Drean dic aus dem 2ltlantifipen uns befannte Intenfität.

2lls wir endid - ant 17. Dftober - unfere gewohnten Unterfudungen wieder aufanthmen vermoditen, hatte fid, längft fhon eine gewiffe 2lorm für den Gang der vorzunchmenden oceanographifhen und biologifhen 2lrbeiten herausgebildet, die wir - jelbit auf dic Gefahr him, den Sefer mit Einzelheiten ju crmüden - dod nid̨t unterlaffer wollen, ju fhildern. Eine Befdreibung der wiḑtigften von uns benthtent oceattographifhen Inftumtente mag daju dicnen, thre Landhabung bet den entjelnen Dperationen verftändich erjheinen ju lafien.

Uls unabucislich ftellte fid heraus, das Tagewert mit ciner Tieffeelotung ju beginnen, die wir aus (5tünden, weldhe noch erwähnt werden follen, aud an foldhen 
Stellen vornahmen, wo frühere Expeditionen bereits gelotet hatten. Da dic Sotung midht nur ïber die Tiefe, fondern aud durh die aufgebrahte (Brumbprobe über die Befdaffenheit des 3odens 2luffdiluf gab, hing es dam wefentlid von diefen beiden

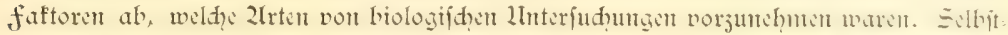
verftändlid war aud der Seegang und das Z Ubtrciben des Sdiffes in Strömungen für den weiteren Gang der 2lrbeiten ent= fiteidend.

Was nun dic Sotungen anbelangt (idn fdildere die occantographifhen 2trbeiten mit Berutsung von 21ngaben, die ih un= ferem Deeanographen, Dr. Sdyott, ver= darfe), fo begannen wir mit ihnen jient= lid) regelmäñig früh an Tage, metft um $5 \frac{1}{2}$ 2the morgents. Die 2liafininen= wadhe wurde vorher benadiriditigt, daf Geftoppt werden follte, und lief den Dampf= oruct fallen, worauf das Shiff vor Wito und Strom fo hingelegt wurde, daf auf jener Seite, pon weldyer aus gearbeitet werden follte, Suv war. Wem aud, wic früherhin auseinandergefest wurde, in den meiften fällen die herrihende Wind= riḑtung und die Stromesridhturg jufam= menfallen, fo fomment doch immerbin 2lbweidhungen vor, die befondere Dorfidyt in der Gandhabung der Zpparate be: dingen.

(5leiđh đąwierige Derbältniffe fömnen fid ergeben, wemt, wie wir es im (F)intea= from und im 2lgulhasftron fehr auf= fälig bemerften, eine Riłhtungsdifferent jwifhen der Strömung der oberen Waffer=

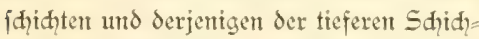

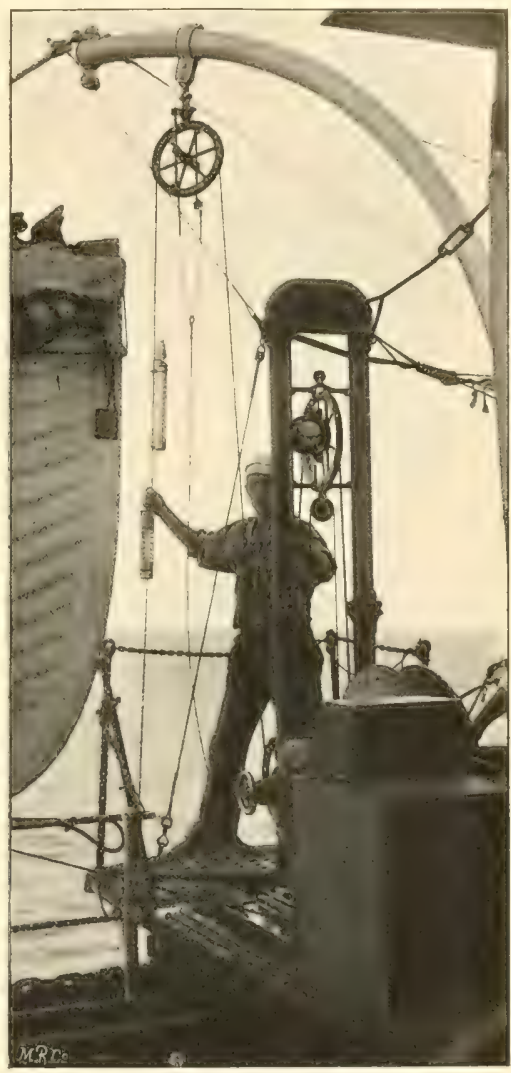

Eotmaidyine Siftent Sigsbee.

ten vorhanden war. In foldhen fällen ftand der Draht juerjt fenfredht, bis er plötilid

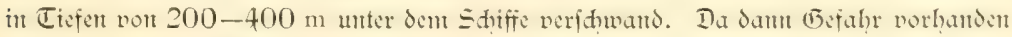
war, daf dic am Draht angebundenen, foftbaren Jnftrumente durd, die Reibung an den Bordwänden verloren gingen, bedurfte es des ganjen feemämifhen Ëcfjittes 


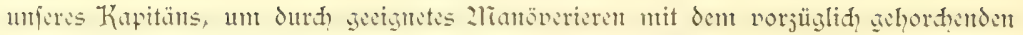
Shiff den Draht wieder fret ju befommen. In allgenteinen fam hervorgehoben

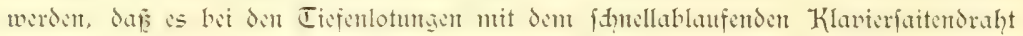

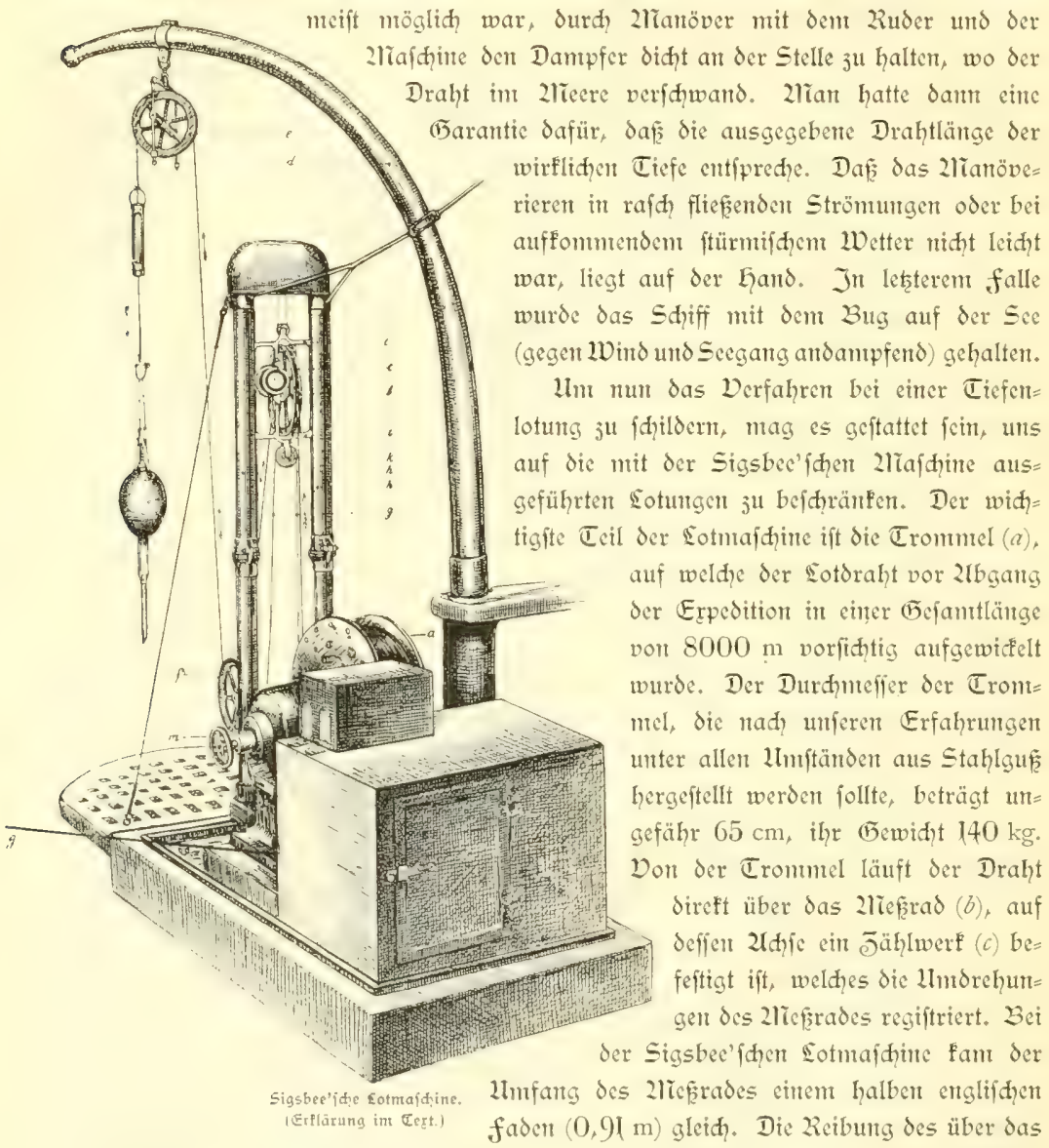

2liefred gelegten Drahtes genügt, um das Rad in Bewegurg ju fetzen. Don dem zlier rad würde mant den Draht direft in die See geführt haben, falls die 2Tafhine an Gert Zlufftellung gefunden hätte. Da fie mittfdiffis Baftbord ftand, muß̨te man nodh Bord= abitand ju gewinmen fuden; defent Jiwefe diente der Davit $(d)$, an dem cin Bloct $(e)$ 
Ging. Der Draht glitt mun von dem 2liefras über einen Bloct $(f)$ und den am Davit hängenden Blot" $(e)$ fret nom Sdiff in das Waffer. Dak der von unts für die Sigs= bec'fhe 2kafhime benutzte Lotbraht einen Durdumeffer von nur $0,9 \mathrm{~mm}$ aufwies und eine garantierte Tragfähigfeit von $200 \mathrm{~kg}$ befar, wurde fhon gelegentlid, der Befdreibung der Zlusrüịtung hervorgehoben. Wir hatten polierten Stahldraht bon der firma Poehlntam in Zä̈nberg bejogen, der fid trefflith bewährte. Da= mit er nidht rofte, wurde er bei dem Zlufholen des [otes durd

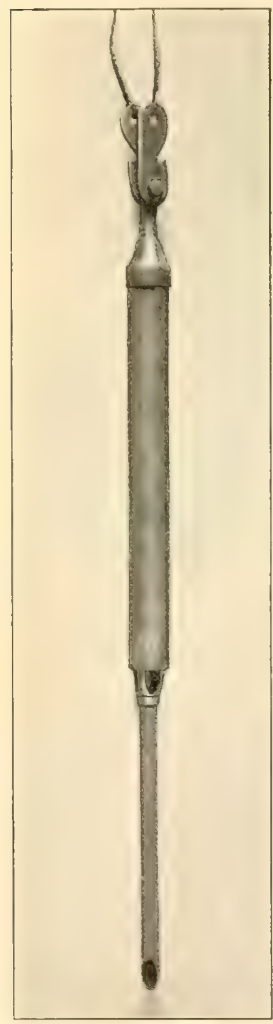

3roope'ithes Eiefieclot bei Dem Zluffommen. einen 2latrojen von Secwaffer gereinigt und vor dent Zlufwinden auf die Tromt= nel ourd cinen jweiten 2lann forgfältig cingefettet.

2fn dem Ende des Sotdrahtes war eir Vorlänfer aus Ganf angebraḑt, an demt das cigentlide Tiefenlot bing. Die Tieffeclote finto int allgenteinen derart fonftruiert, $\delta a \tilde{B}$ un dic Sotröhre ein cifernes Sinfgewid an gebradt wirs, weldhes den Draht zunt 2lieeres= grumbe hinabjichen foll, um dam unten lie= gen ju bleiben und die Drahtleitung für das

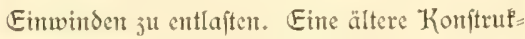
tion, nüntidh das Brooke' ihe Ticf= feelot, jeigt die meffingene oder ciferne Eotröhre (b), weldhe vort Sent ovalen, in der 2litite durdy=

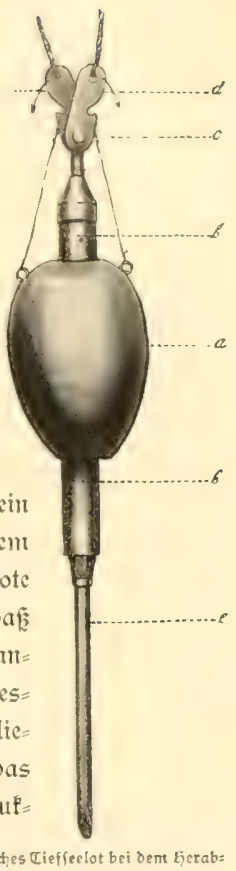
laifer.

3roofetides Tiefieclot bei dent Eierab: e Sdlammröhre zur Ecwiınung von Brunoproben. (Erthïrung int Eert.)

bohrten Sinfagwidt $(a)$ untideidet wird. Eethteres wird mit Draht an einter felbitthätig wirfenden 2uslöfevorriḑtung auf= gehätgt. 2In dent oberen Ende der Köhve find nämlid zwei furje, un ben Boljen $c$ beweglidie 2lrme ( $d$ und $d_{1}$ ) ange= bradt, und in der fladhen Einferbung jedes dicjer Zlrmte ift jener Draht, der jum Sinfgewiđt führt, anfgehängt; wemt das sot dent Grund berührt, fallen die jwei 2lrme in der durdh Elente Pfeile angedenteten Ridhtung infolge ihrer Shwere ctwas abwärts und die Drähte gleiten $a b$, fo daf das Sinte gewidt jelbit abfällt. $E_{S}$ fommt indeffert vor, dafe mur cin Draht abgleitet und das fonwere Gewid hätgen bleibt, was immer unatgenchnt ift, da es die Tragfähigfeit des Drahtes 
bet dent Einwinden auf eine fritifde probe ftellt. In diefer Kinfidit arbeitet das Sigs=

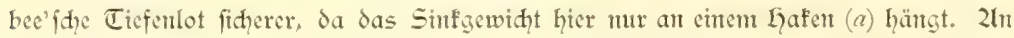
die Sotröhre wurden nod, Sd?lanmtröhren, weldye unjer Bafteriologe, Dr. Baḑmann, forffruiert hatte, angefdraubt; fie beftanden aus Gasröhren von verfdicdener Sänge unb verfhiedenem Durdmeffer, welde, um ein 2luswajhen der Sdilanmprobe bet dent 2lufholen des Sotes ju verhüten, oben durd? cin Kugelventil gefhloffen waren. Wem wir grope Tiefen erwar= teten, bemutzten wir Sinf'gewid̨te von $28 \mathrm{~kg}$ Sḑwere; bet geringeren Tiefen (unter $1000 \mathrm{~m}$ ) gernïgte ein (Bewiḑt von $15 \mathrm{~kg}$, um das Sot auf den (5)

Bei dem Zusgeben des Eotdrahtes darf man das $\mathfrak{L}$ ot

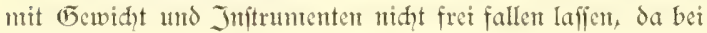
der Grundbertihtrung infolge des Trägheitsmtomentes der fith drehen, den 2liafininentronmel mo des Eigentgewidtes des Drahtes dic $B_{B}=$ weguntg niḑt jum fofortigen Stillitant fontmen würde. Eäpt man das Sot zu rafh auslaufen, fo mur man gewärtig fein, da dic (5rundberührung nidht crfant twird, während gletdgectitg der in

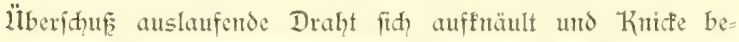
fonmt. Das feine soten grof̧er Tiefen ift eine Kunft, dic durd Erfahrung gelent fein will. Es fontmt wefentlith darauf ant, Surd Zntitehen einer Bremic an der Trommel fo viel

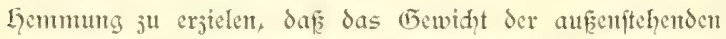
Drahtleitumg - ausidglieflid des Sinfigewidhtes - immer font penfert ift; fobald damt das fhwere Sinfgewiḑt den (5) rund

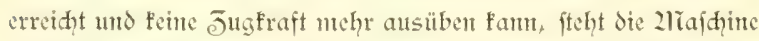
ftitl. İierbei ift weiterhin ju beaḑten, da per Draht trot feiner feinheit und feines geringen Gewid)ts (1000 $\mathrm{m}$ des Drahtes wiegen in der suft $5 \mathrm{~kg}$ ) einen foldzen Reibungswiderftand int

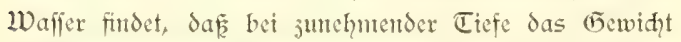
der aukenfthenden Drahtlemte ausgegliden wird. Bei

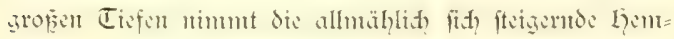
mung derart ju, daf fie durd ein suffen der Brentie überwunden werden muF. Jü Regulierning der $2 \mathfrak{l b}=$ laufsgefduwindigfeit dient cine Brentsleine $(g)$, deren $\mathcal{D}_{\mathrm{er}}=$

Sigsbecides Tiefieelot bei dent Gerab= lañen.

a. ITafe des Shlippers, welther bued einen pallhebel $(c)$ bet ben Jierablatien feftuefolten wirs. Sici ior (f) rührung fenpt fid der pallbebel (c) und giebt den Shlipper frei, oer ourh eine

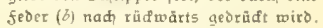
Die das Sinfgewint tragende Draht= fallinge fällt dann ab.

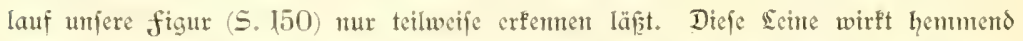
an der Tronmtel, indent fie in ente freisförntige kimne eingrefft, die an der auf der figur niht fidhtbaren Tronmelfeite angebraḑt ift. Je ftärfer man das Bremspeil anjicht, defto ftärfer ift dic โ̧emmunţ. 


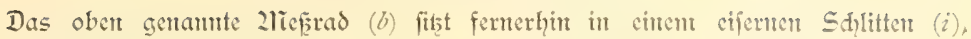

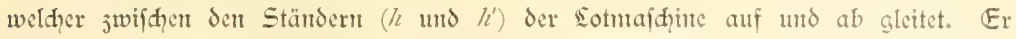

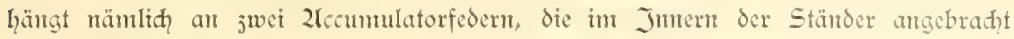

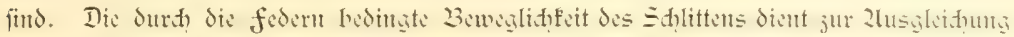
der den auslaufenden ober hereinfontmenden Draht in unerwün [d = ter Weife beamiprudenden Sdriffsbewegung. Jügledd ift in fint= retder Weife für ein gletdymäp̧iges saufen der Tronmel $(a)$ daduch geforgt, daf die Bremsleme aud mit dem fedenden Sdlitten (i) in Derbindung gebraḑt ift, wie die figur unfer $k$ erfemen läfit. Bollt das Sditif ftarf́, fo dehnen refp. fon= trahieren fid die federn; der Sdllitten geht nieder oder auf und infolgedeffen wird das in der friftionstime der Trommel liegende Bremsfeil felbjtthätig lojer oder fefter angeprefiet. Während man den Draht mit einer Gefhwindigfeit bis ju $2,5 \mathrm{~m}$ in der Sefunde ablaufen lief, wurde er nad der

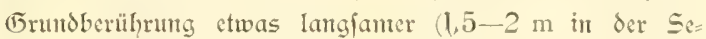
funde) wieder aufgeholi. Giterju dient ein Eleftromotor, det it dem grofent Kaften (int Dordergrunde der figur) ent= halten ift. Bei $m$ ift der Griffi angedeutet, vermittelft deffen man das Ein $=$ und 2lusfoppeln der Trommelwelle vom Eleftromotor ausfühth; die 2liotordrehungen werden ver= mittelft cines Sdmefenrades überfetst.

Eine Tisfenlotung von etwa $5000 \mathrm{~m}$ beanfprndyt un= gefähr $1^{1 / 2}$ Stunden jeit, eingeredznet 5 z 2rimuten, die man vor Begitn des 2lufwindens abwartet, damit das Tiefenthernonteter ant 2lieeresgrunde fid ridytig auf die 3odentemperatur cinftellt. Bei dem Einwinden des sot= drahtes wird die Trommel ftarf beanfprudgt, da cinige Taufend widtelungen mit einer an fid nidgt grofent, aber fidt Sireft adsicrenden Kraft auf die Tronmel fommen. Da dic Trommel der Sigsbee'fden Sotmafdine nidyt aus Sumitahl be= ftand, wurde fie mehrmals ausentander gedrïfft, und mur der Gefdidflidyeit umperes 2liajdinemperfonals war es ju verdanfen, daf die Reparaturen ftets rajh und eraft ausgeführt wurden.

2lls Beifpiel für die näheren Lmftünde und fpeciell auథ für die Jeitangaben mag cine an der Eisgrente ausgeführte Eotung nach dem Protofoll des Deeanographen angeführt werden. 


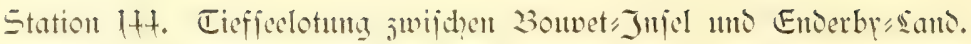

Datum: 9. Dejember $1898 \quad 5^{1 / 2}-\bar{t}^{1 / 2}$ a. m.

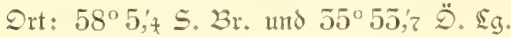

Wind: rw. NO. 5.

Leffiges Sdineegeftöber während der ganjen Sotung; Eisberge und Treibeis ringsunt.

Seegang: rw. NO. 5; hohe lantge Dünung ans NIV.

Suftemperatur: $-0,5^{\circ} \mathrm{C}$.

Temperatur des 2liecrwaffers an der Dberflädie: $-0,6^{\circ} \mathrm{C}$.

$$
\text { ant (็)rund: } \quad-0,4^{\circ} \mathrm{C} \text {. }
$$

Benutht wurde die Sigsbee'fde Sotmaidine, ein Sinfgewidnt von $28 \mathrm{~kg}$ und cin ZTegretti=-Jambra'fites 'Kipptherntometer.

Die untenftehenden Jahlen geben - indem der Beginn der Eotung auf $0^{\text {"n }} 0^{\text {m }} 0^{\circ}$

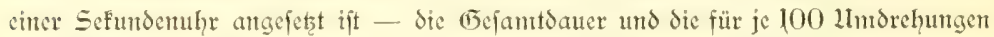
des Jühlwerfes benötigte ōeit an; eine Llmbrehutng des Jählrades war genau $1 / 2$ englifiter fader.

Draht hinab:

\begin{tabular}{|c|c|c|c|c|c|c|c|}
\hline \multirow{2}{*}{$\begin{array}{l}\text { 11mbrehungen } \\
\qquad \frac{1 / 2 \text { fabcn) }}{0}\end{array}$} & \multicolumn{2}{|c|}{$\begin{array}{c}\text { 3rit } \\
\text { (min. Sct.) }\end{array}$} & \multirow{2}{*}{$\begin{array}{l}\begin{array}{l}\text { Jntervall, } \\
\text { pro too llnorehunger } \\
\text { Sefunden }\end{array} \\
0\end{array}$} & \multirow{2}{*}{$\begin{array}{l}\begin{array}{c}\text { Uniorebungen } \\
(1 / 2 \text { faoen })\end{array} \\
+700\end{array}$} & \multicolumn{2}{|c|}{ 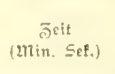 } & \multirow{2}{*}{$\begin{array}{c}\text { 3ntervall, } \\
\text { pro } \begin{array}{c}100 \text { Limbrehungen } \\
\text { Sefunden }\end{array} \\
45\end{array}$} \\
\hline & 0 & 0 & & & 29 & 25 & \\
\hline 1000 & 6 & 0 & 36 & +500 & 50 & 10 & 45 \\
\hline 1500 & 9 & 25 & 41 & 7600 & 50 & 55 & 45 \\
\hline 2000 & 12 & 75 & 40 & 4700 & 51 & 52 & 72 \\
\hline 2500 & 16 & 7 & +0 & 4800 & 32 & 20 & 45 \\
\hline 5000 & 19 & 70 & +5 & 7900 & 55 & 5 & 75 \\
\hline 5100 & 20 & 20 & 40 & 5000 & 53 & 45 & 70 \\
\hline 3200 & 20 & 57 & 37 & 5100 & $3 t$ & 50 & 45 \\
\hline 5300 & 21 & +0 & 4.3 & 5200 & 55 & 12 & 72 \\
\hline $5+00$ & 22 & 15 & 55 & 5500 & 35 & 55 & 45 \\
\hline 3500 & 22 & 52 & 57 & 5400 & 36 & 40 & 75 \\
\hline 5600 & 25 & 55 & 45 & 5500 & 32 & 23 & $4 \overline{5}$ \\
\hline 5700 & 24 & 18 & 43 & 5600 & 58 & 7 & $\forall z$ \\
\hline 3800 & 25 & 3 & 45 & 5700 & 38 & 50 & 45 \\
\hline 5900 & 25 & 50 & 47 & 5800 & 59 & 53 & 45 \\
\hline 4000 & 26 & 50 & 70 & 5900 & to & 18 & 45 \\
\hline+100 & 27 & 12 & 42 & 6000 & 41 & 5 & 47 \\
\hline+200 & 27 & 55 & 43 & 6100 & 41 & 43 & 38 \\
\hline$\$ 500$ & 28 & 40 & 45 & 6200 & +2 & 50 & 47 \\
\hline
\end{tabular}

Bei 6270 des Jählwerfes ftand die Sotmaidine, d. h. die Tiefe war 6270 halbe faden $=5155$ fadcn $=5753 \mathrm{~m}$. Das sot war aljo in rumb 45 zlitmuten bis jum 2lecessgrund gelangt, und die mittlere fallgeidwindigfeit betrug bon 
$5000 \mathrm{~m}$ Tiefe an ungefähr 44 Scfunden pro $100(1 / 2$ faden) oder pro Sefunde $2.1 \mathrm{~m}$.

Das Einminden des Drahtes mittels des Elcftromotors Dauerte $1^{\text {li }} 0^{\mathrm{m}} 55^{\mathrm{s}}$; pro Scfiude wurden alfo $1,6 \mathrm{~m}$ eingehiebt.

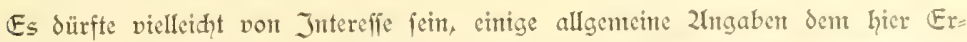

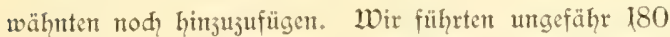
Sotungen aus, bet denen rund $868000 \mathrm{~m}$ Draht bewegt wurden. Da wir $6622 \mathrm{~m}$ Draht verloren, fo beläuft fith

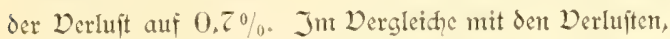
weldhe dic Kabeldampfer verzeidnen, Fönnen die unfrigen als fehr mäpigige gelten. Woentr mant weiterhin in Betraḑ̧t 3ieht, daḱ wir von dem Klavierfaitendraḩ der Sigsbee= 2läaline nur $117 \mathrm{~m}$, volt der gedrehten Drahtliţ̧e der Se Blane=2Tajdine dagegen $6505 \mathrm{~m}$ verloren, fo würden die Eotungen mit erfterer alleit mur $0,01 \%$ der benegten Draḩlänge an Derluft ergebert. Die Derhältmiffe liegen für bie anterifanifhe 2rafdine infofent nody güntiger,

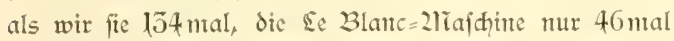
benuţten. Fierbei wurden 119 Sinf́gewidgte à $28 \mathrm{~kg}$ und 54 $\operatorname{Sinf} \mathfrak{g e w}$ difte à $15 \mathrm{~kg}$ verbrautht.

Dberhalb der Lotröhre wurde ftets cin Tieffeether= mometer befeftigt, weldes die Temperatur des Waffers ant 2reeresgrunde angab. Da in den tropijden und ge= mäpigten Regionen die Temperatur fuecefíwe gegen den 2rieeresgrund abnimmt, fo verwendeten wir hier 2liari= mum= und 2hinimumt= Thermometer, die gegen die ge= waltigen Drudfe (pro $10 \mathrm{~m}$ cine 2 (tmoiphäre) durd? eine befondere (Glashülle gefhüht find. 2lĩan lieft an ihnen die 2lïnimum =Seite $a b$ unter der Dorausfetzutg, da dic 2limi= mum= Temperatur der gröpten Tiefe, in die man das Jn= ftrument verienfte, jufonmt. In dent antarftifden 21 ǐeere

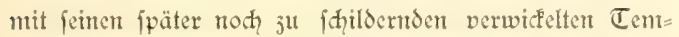

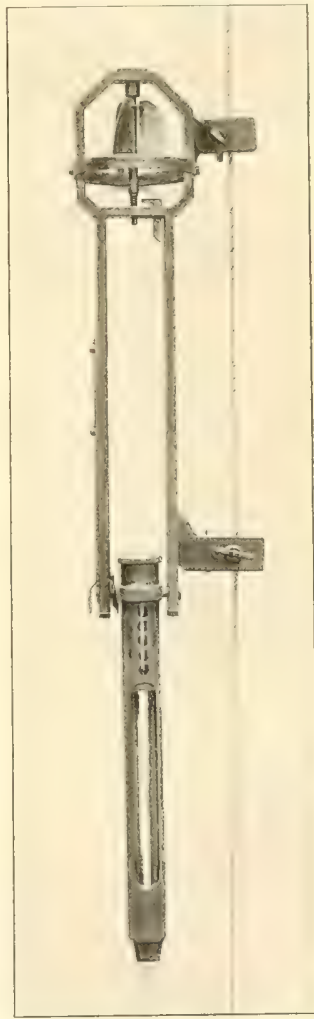

Kipptherntometer bei dem Zuffonter. peraturverhältniffen (an der Dberflädye ift es fälter als in tieferent Sdyidtten) erwies es fid als notwendig, die von 2iegretti und Jambra forjtruierten Kippthermometer ju ner=

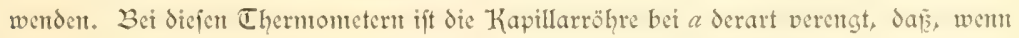
man das Jnftrument umfehrt, ein der betreffenden Tentperatur genau entfpreḑendes 


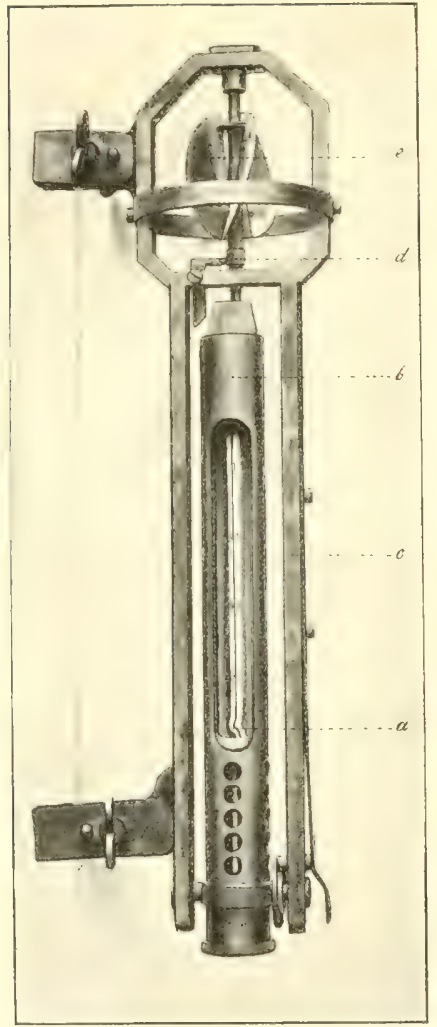

Lippthermometer von 27caretti und Jambro bei dem lierablajien.

Stürf des Quecfitlberfadens abreipt und in den unterent Teil der Kapillarröhre fällt, wo es als fleine 2raffe fo gut wie feitte Z̈̈nderungen ourd fpätcre Temperaturemwirfungen erleidet. 2tm mun diefes lintippen ju bewerfiftelligen, wird das

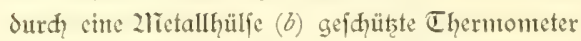
in cinen 2retallrahuten (c) in labilem (5lcids = gewid̨te aufgehärgt. Das Thermometer fippt um, fobald die Spindel (d) des Propellers (e) fid auf= wärts ans der Therntometerhülfe herausgedreht hat. Dicies freigeben des Thermonteters exfolgt, maḑden man das Jnftrument durd eine $10-15 \mathrm{~m}$ mädıtige Wafferidhicht aufwärts gewunden und dic Propellerfhraube (e) dadurd in Thätigfett gefetst hat. Dic Jetlung nad, Graden ift auch gleidh für dieje Stellung und für den abgeriffenen Qued:= filberfaden beredinet und ange= bracht.

Ziiḑt genug Janit, da man bet ciner Sotung liber die Tiefe, die Befdraffentheit des Sdylammes und die Ticfentemperatur orientiert wirs, fudgt man audh cine probc des Tiefenwaffers jum Jwede he= mifher LInterfudtutg ju gewimner. Diciem Jwecte bienen Tiefiee= waferfḑ̈pfer, deren wir meh= rere Komftruftionen benuţter. Jur Gewimmung non Grundwafferproben verwendeten wir meipt den Sigs= bee'fhen Wafferiḑöpfer, jumal da es fid? um fleinere Inftrumtente von $1 / 2$ Siter fafiumgsvermögen handelte, dic ohne Bedenfen dem Sot= oraht anvertraut werden fomten. Das Gefäf wird durd einen 2licefing= cylinder (a) gebildet; jwei Dentile, pon denen mur das eine (b) fithtbar ift, und die miteinander durd eine Stange verbunden find, verfhliefen oben und unten den Cylinder, fobald durd, dent flïgelpropeller (c) bei dem Zufholen des Juftrumentes die Sdqranbe $(d)$ it Bewegung gefetzit wird. Die leţtgenannte wird hierbei auf das obere Ventil aufgedrüctht,

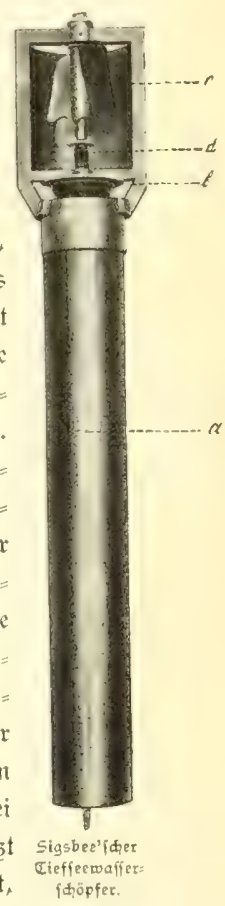


flemmt fowohl dicjes, wie aud das nit ihm durd ene Stange verbundene untere auf den Cylinder feft und ftellt dadurd einen fetheren Derfaluß her. Die Sigsbee= iden $2 l_{p p a r a t e}$ find für die fefftelling des Saljgehaltes oder des fpecififden Ge widtes des Scewaffers fehr bequem; fie cignen fid aber nidht für (b̃asbeftmmmungen,

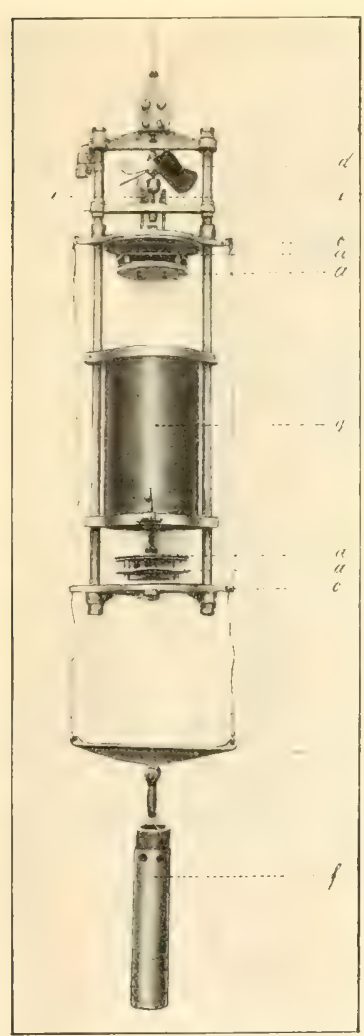

Petterfion's ifolierender שiefenwajieridöpfer bei bent Eerablaflet. weil das heraufgebradte

Waffer niḑt gegent die in den $\widetilde{T}$ ropen ftarken Tent: peraturänderungen $\jmath_{\mathfrak{m}}$ i= iden Tiefe und Dber= fläd)e gelduütżt ift. In dicjer Eimfidyt ift ihnert der Petterffon'fde ifolierende $\mathfrak{L a f}=$ ferfiöpfer über= legen, den wir in cinem jientlid grofen Eremplar an Bord hatten und für alle Ulnterifudungen, bet denen es fid 4 m $\mathfrak{B}_{e}=$ ftimmung des (5asge: haltes handelte, ver= werteten. Der $\mathfrak{Z}_{p p a}=$ rat idüţ dadurch ein Quantum Tiefenwai= jer gegen nađ̧träg= lidie Tentperaturein= wirfunger, da管 er aus einer Reithe in= cinandergefügter, Fon= jentrifiner 2refifingevlin= der befteht. 2uur der innerite Waffercylinder wird für die Entrahume der Probe benutzt; un ihn Iiegende Lafferringe follen bei der grofen fpecififden Wärme des Waffers refp. der grof̧en Trägheit gegen Tenteraturänderungen den imrerften Teil gegen $\mathbb{E}_{\mathrm{r}}=$ wärmung fhüţen. Die beiftehende figur jeigt den 2lpparat offen und fertig junt

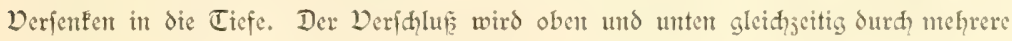


Summiplattent $(a)$, welche an Deffel (b) und ant Boden (c) befeftigt fint, bewirft, und jwar dam, wem der Sdrraubenpropeller $(d)$ die Eqafen $(e)$ fo weit auseinander bewegt hat, dafi der unter dem Juge cines Gewidnts $(f)$ ftehende obere Veridhluf̧dectel (b) mit Gewalt herab auf den ylinder $g$ fällt. Tritt dies ein, dann fällt aud der Eylinder famt Def́el auf den unteren zlbįhlu $c$ und es ift ein gröperes Quantum Tiefenwafier allecitig abgejperrt, das ntan fpäter mit $\mathfrak{B}_{\mathbb{e}}=$ quemlidfect vermittelft eines am Boden befindliḑen Dentils abfüllent fanm. Es braud?t wohl faum erwähnt ju werden, dafis der Sdraubenpropeller $(d)$, wie bet veridicdenten fhon vorher

Muerfdutt ourch Den petterfion'fater wafierítiöfer. a. Der innere, die Wafjerprobe ente haltende Crlinder. erwähnten Injtrumenten, fid infolge fdunellen zlufholens in

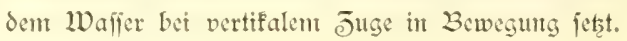

Wie notwendig es war, daf man vor Zlusführung aller fonftiger Dperationen fid ju=

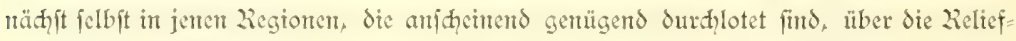
verhälturiffe des 2lieeresguntes orientiert, mag cin Dorfonnnnts ant li. Dftober Iehren.

2lls wir am genamten Tage bei ruhigerer See wieder unfere gewohnten Zfrbeitent in volfent 2 hnfange aufjutehmen vermod,ten, befanden wir uns unter $25^{\circ} 26^{\prime}$ f. $3 \mathfrak{r}$. und $6^{\circ} 19^{\prime}$ o. S. Die Secfarten geben in der zäh̆e diefer Pofition ankerordentlid grofe Tiefen ant, unt fo wurde int Finblicf auf die frïheren Sotungen ein Dertifalzug bis $2000 \mathrm{~m}$ Tiefe angeordnet. 2lls das 2retz hod fam, war es ju unferer l̈tber= rafdyung auf den Grund geraten und teilweife gefüllt mit cinem feinen, gelbliden

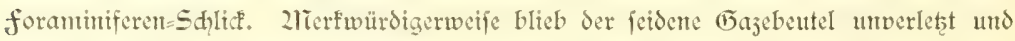
enthielt cine in den Salia eingebettete auffällig grof̧e, hod,rot gefärbte Krabbe aus der Fattung Geryon. Die fofort vorgenommente Sotung überjeugte uns von der über= rafhenden Thatfade, daf wir auf ene bisher unbefant geblicbene Banf geftoknen waren, auf der wir jwei Sotungent nit 981 unb $956 \mathrm{~m}$ ausführten. Da derartige mitten im Dean gelegene Erhebungen nah früheren Erfahrungen ftets ein reides Tierleben aufweifen, wurde cin Sdileppjug angeordnct, der dem audh das reidfite Refultat lieferte, dafí wir nad, dem Verlaffen der faröer zu bejeidnnen hatter. 2riehr. als humbert groker, rote Krabben (Geryon), cin Duţend jener cigentümlid̨en, mit phumpen Kopf nut monftös vergröß̨erten Zlugen ausgeftatteten Tieffeefifde aus der

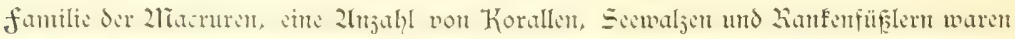

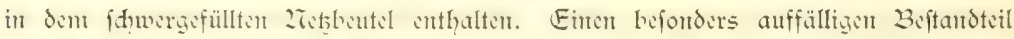

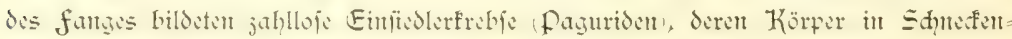
fdralen fteffen, weldhe ihrerfets wieder von violetten zlftinien aus der Gattung Zoan= thus befeţt warem. Dic Dolppen fint grof und rofettenförmig int 2lmtereife der Sdhale 


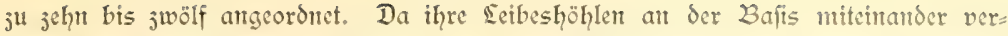
einigt find, ftellen fie eine Kolonic dar, deren Einjelindividuen in cine gallertige Grundjubitanj eingebettet fint, über welche fie nur ntit ihrem vorderen 2tbidnitte hinausrazen. Die hofoladebraunn falten der 2lï̈ฐеn, an denten dunfilrote Fimalfin hängen, heben fidh fein abgetünt von dem Diolett der (5)allerte ab. Die folypen hattem

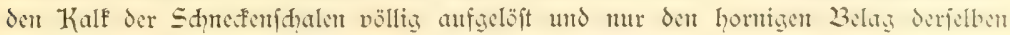

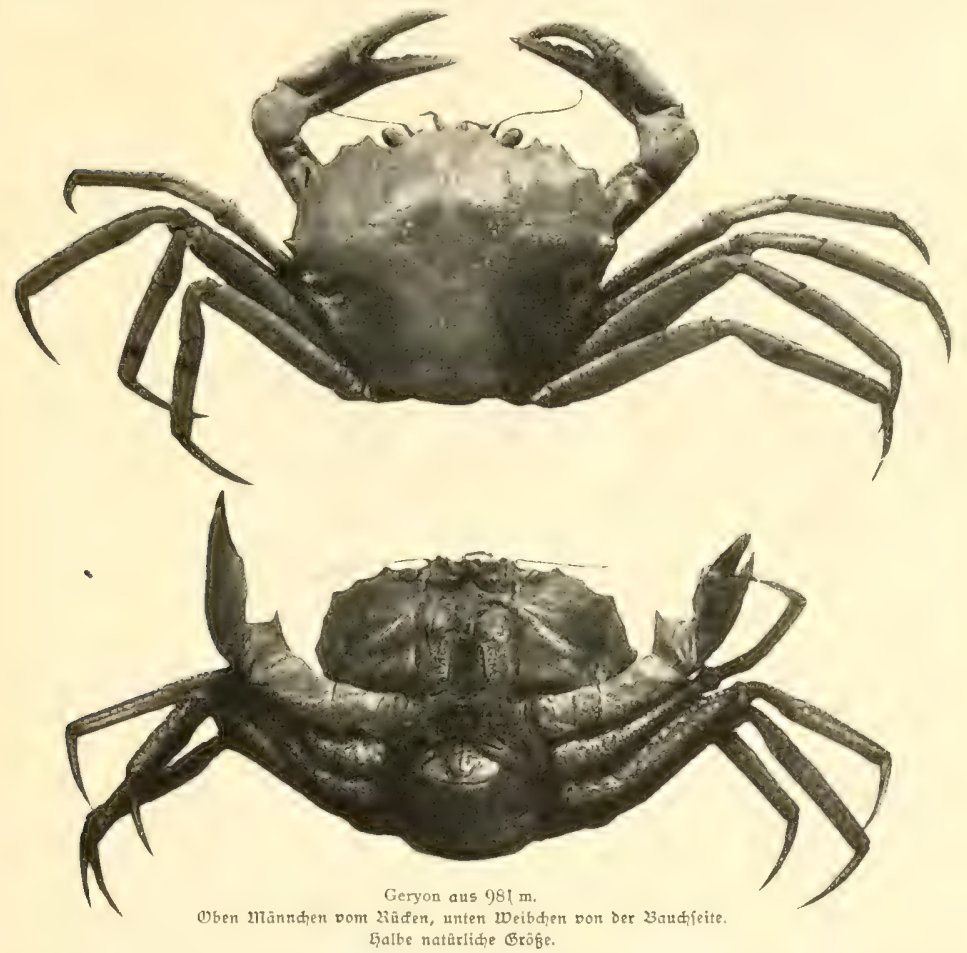

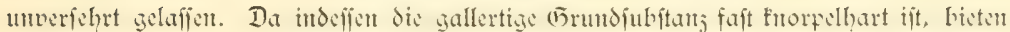
fie dem Einftedlerfrebs genügend Sđ̧ut für den zarten Einterleib. Eine derartige Dergefellithaftung oder Symbioje jwifden pagurident und 2fftinien ift aud bet Dber= fläḑenforntent weit verbreitet. Beide haben ihren Dorteil vort derfelben: die 2fftinten, indem fie von den Speifereften der Krebje leben, die Einftedlenfrebfe, indem fie durd, die mit Zeeffelfapieln ausgejtatteten polppen gegen 2lngriffe Sd dut erhaltert. 


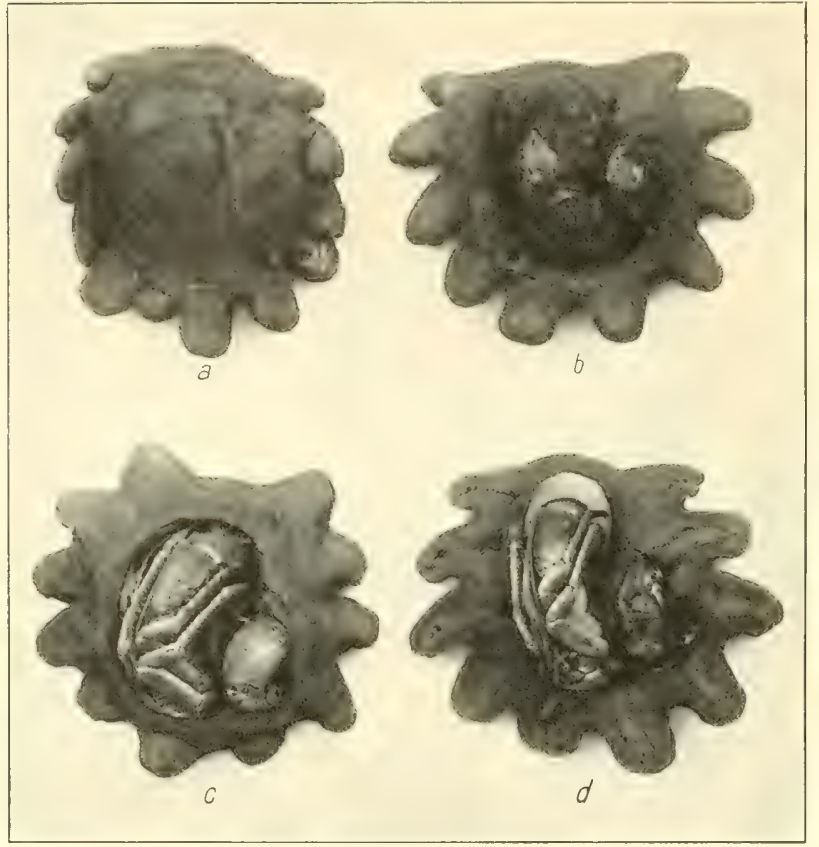

Paatriven mit Zoanthus veraciedidaftet, aus $981 \mathrm{~m}$.

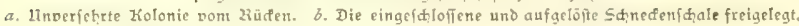
c. Der Einfieblerfrebs freiaclegt. $d$. Polrpen im Eângsínitt und Krebs. Ȩalbe natürliţ̨e Brö́ge.
In occano. graphifher Litit= fititit dïrfte der von uns gefülorte radiweis cince mitten im fïl = lidhen Decan ge= legencr Llntiefe nid)t ohne In= terefic fein. 2Dern man $\mathrm{cr}=$ wägt, dafi wir ficon an mäd? = iten Tage, mur 1/3 3reitegras fiidlicher, cinc Tiefe von 5040 m lotetert, fo $\mathrm{cr}=$ gicbt fich jui= jhen beiden $P o=$ fitionen eine Dif $=$ ferenj. von mehr als $4000 \mathrm{~m}$. Derfpäteren oce anographifdert foridumg bleibt es vorbchalten, ein interefiantes problem ju löfen, auf welhes Prof. Supan im

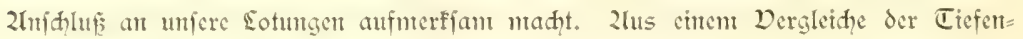

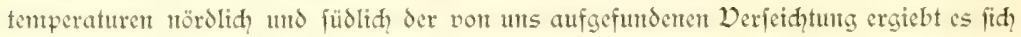

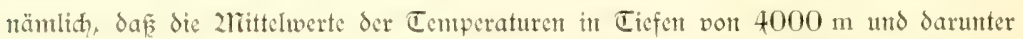
Interffiede von nahezu 2 (5rad aufweifen. 2rördich, in der "Sïdafrifanifanen

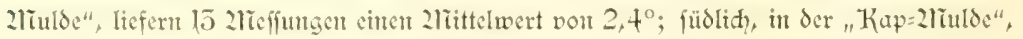
erhält man aus 9 2licpinugen chen 2litttelwert von $0,8^{\circ}$. Ilus dicjen Differenjen jieht

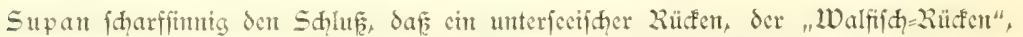

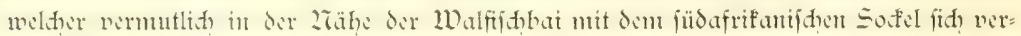

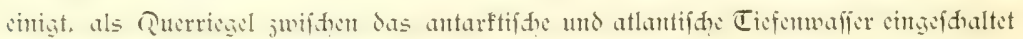
ift. Wis aus unferer Kartenffijge auf 5.72 erfiditlid ift, fo bürfte der Walfif

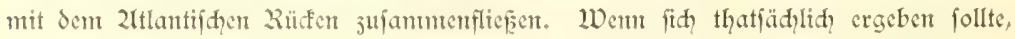




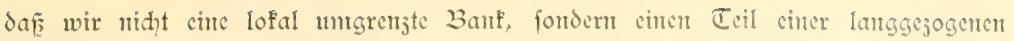

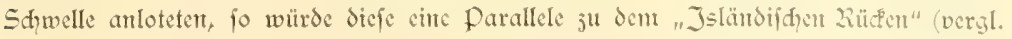
S. 46) darbieten. Wie Ictzterer das falte arftifde Tiefenwaffer boir den mordatlan tifdyen Decan abgrenjt, fo würde der Walfifh Rücen den Dordringen des falten ant: arftifden Ticfenwaffers in den fübatlantifden Decan enten Riegel vorffichen.

Der Südoft=Paflat hiclt bis zum 28. Grad 1. Br. an, und widh dam medjelnden Winden, weldhe ruhiges Wetter im (E)folge hatten. Wir muthten es für Stufenfänge mit den grof̈en Dertifalnetzen an einex und derielben Stelle in verfditedenen Tiefen aus. Sie follten hauptiädilia daju dienen, die obere Derbreitungsgrenje cinter 24njahl cigen= artiger, von uns ftets in den Tiefentetsen erbeuteter Drganismen fenten ju lemen. Da diefe gropen, freifhwimmenden Krufter und fifde den flemen Shliefinetsen aus= weidyen, vermodyte lediglidh dic Zfuwendung der Dertifalnetze den inmerbin bemerfens=

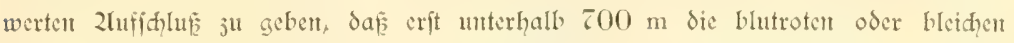
Krebje, weldie jum Teil blind find, die fammetfọmarjen Tieffecfifhe und ungentein zarten, durdfidhtigen Cephalopoden vorfommen. Daj wir die Jahl der pelagild? lebenden, d. h. freifhwinmenden, Tiefiecorganismen bei diefer (5elegenheit durd, dic Entbefung von neun Centinter grof̧en zlppendifularien bereidgerten, mag beiläufig er= wähnt werden. Jhre Derwandten fint Jैwerge int Dergleidge nit diejen durdfifhtigen Riefenformen, die wit un fo weniger verfehlen werden, den Scfer in Bilde vorjuführen, als der fund nad? femen Befamtwerden das allgemeine Intereffe der Joologen erregte.

Da wir von den ausgefetenten Boote aus aud sifrig der fifderei an der Dberfäde nadgingen, fo mag mur hervorgehoben werden, da jwei Tage hindurd eine bisher mur fehr felten beobadtete Salpenart (Salpa flagellifera) in erftaunliden 2liengen auf= trat. Sie bildete bisweilen gelblid? gefärbte Sdpwärme von der sänge des Sdiffes,

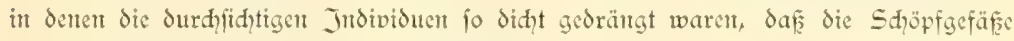
wie nit chem lebendigen Brei erfüllt jdicnen.

2ln 20. Oftober entfoloffen wir uns ju cinten Sdleppnetzjug in der größten bisher von uns durdfifhten Tiefe von $5108 \mathrm{~m}$. Es fhien wündhenswert, das wir das Kabel und dic Seillettung vor dem Eintritt in das antarftifde Eebiet, weldes vorausfidtlid? feinte geringen 2lnforderungen an die Seiftungsfähtgkeit der 2lpparate ftellen würds, bet den jḑwierigen Dperationen in fo grop̈er Tiefe einer gründiden Prüfung unterjogen.

Ltu dent Sefer cine Dorftellung von der Jeit ju geben, welde cin Dredistzug bei Tiefen über $5000 \mathrm{~m}$ beaniprud̨, foi folgendes erwähnt. Das grofie Sdileppnets (Trawl) wird vor Begint des Juges hergeridtet und mit dei cifernen Oliven von je $25 \mathrm{~kg}$ (jwei binten an 2reb̧act, eine an dem Dorläufer aus Eanf direft vor dem 2uetse) belaftet. Während die 2liafdine ftoppt und der Dampfer ftill liegt, läuft fo vicl Drahticil aus, als die Sotung anjeigt; ijt das 2rets über dem (5)tunde angelangt, 
fo wird langame fahrt gemadyt und nod? ein Drittel der bisher ausgegebenten Seillänge hinjugcfügt. 2lm eine Setllänge von $6700 \mathrm{~m}$ ausjugeben, bedurfte cs 5 Stutden. Jntent mun bei Rürđwärtsgehen der 2liajdine eine Stunde lang unter ftändiger Beobadytung des Dpnamtometers gedrediht, und päter in $4.1 / 2$ Stunden das

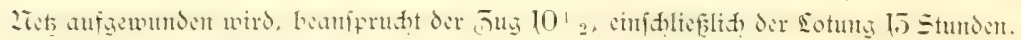

Ein Dredfizug in grofent Tiefen ftellt an alle Beteiligten, nidht jum mindeften aud an das fecmännifhe Sefdid des Kapitäns, hohe 2lnforderungen. ES würde ju weit

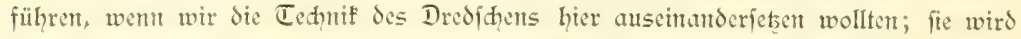

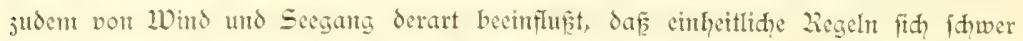
geten laffen. Wie das Sd diff dafür Sorge getragen wird, dafi Ser nidit mehr als $50^{\circ}$ Eetragen man während des langanten (5runde die 2liajthine vorwärts

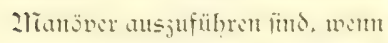
die normale (Trenje ïberiteigt Sem (F̂runde fefftommt: dies alles

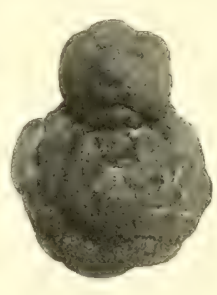
Ginjulegen ift, anif welde Weife das Kabel unter cinemt Winfil, joll, frei vom Ediffe abjteht, ob Sdyleppens des Trawls auf dem

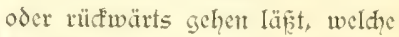
dir जusi auf din Dymantontitir oder werm gar bas Trawl auf ift den jeweiligan äuß̌eren $\mathcal{D}_{\mathrm{er}}$
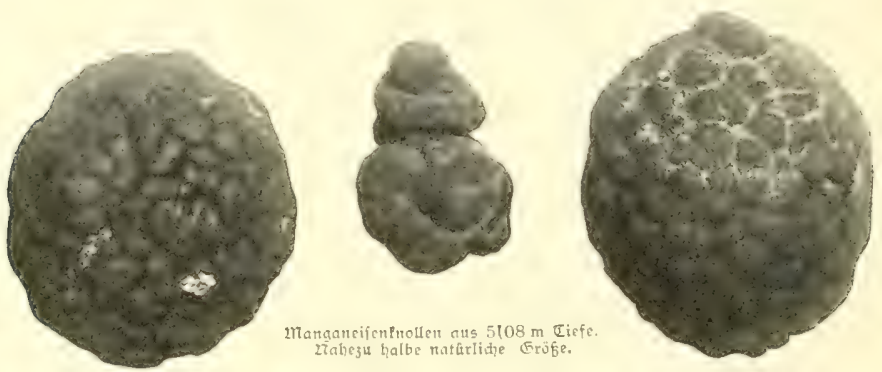

hälmiffen anjupaffen. Dabet hat der bie Seilleitung übermadende Dffijier feine 2luf=

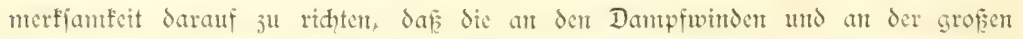
Kabeltronmel befdäftigten 2liatrofen zufanmenwirfen und fid gegenfeitig unterftuitzen, da anderenfalls cint Lnfall im Ginblite auf dis hohe Spamung, weldher das Kabel ausgefetzet wird, niḑt ansgeftloffent ift.

Wenn niemand mährend des Dredfhens verunglüđfte, wie dies früheren Expeditionen nidpt cripart blicb, fo ift bies wejentlid der gefpannten 2lufmerfiamteit und Gingabe aller Beteiligten ju verdanfen. 2län atmete jedesmal auf, wem das Trawl aus grofent Tiefen glatt auffam, und dic Beflemmung madite der Erwartung auf das Rejultat aller zliühent Plats. 
In umferem falle entiprah das lețtere infofern nidht den Lofimment als nur ein Bruḑitü emer Seewalje in dem Ziek̨e entf̧alten war. Dafür entfhäbigte ein anderer

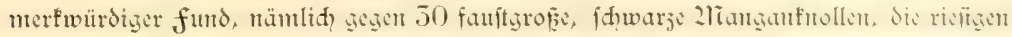
Brombeeren gliḑen. Es waren ungewöhnlid fđöne Stü̆fe, wie fie bisher nodh niḑt in 2ltlantifinen Drean jur Bobahtung gelangten. Dis Ehallenger= Erpedition uns Der "Zllbatrok" haben fie häufig int Centrunt des füdpacififd̨en Deeans gedredidht, aber nur felten gröpere Stüde, als die von uts erbeuteten (das gröple Eremplar befitst einen Durdmeffer von $8 \mathrm{~cm}$ ) erlangt. 2luf dem Durdfidnitt weifen fie eine

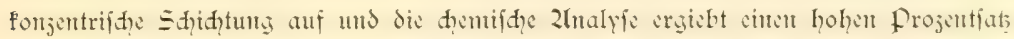
von 2langaneifen. Es wird 2lufgabe des Chemifers fein, ihre bisher nodh nidgt

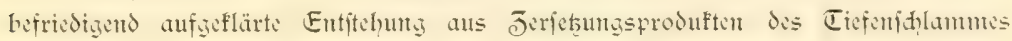
flarjulegen.

\section{Das fïbliche Kapland und Sie 2lgulhas:23ante.}

Währetto wir feit dem 18. Dftober grofe Tiefen über $5000 \mathrm{~m}$ gelotet hatten, fo belehrte uns die raif erfolgende zoflachung am 25. Dftober, da wir uns dem Kaplande näherten, das denn auh gegen 2radimtitag des 26. Dftober juerft duftig, dann immer flarer hervortretent vor unferen Bličen auftauḑte.

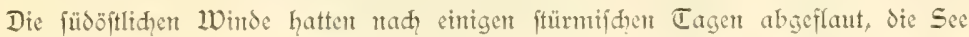
war ftill, das Baronteter begam bei leidtent Sübweft ju fteigen, und fo wurde der

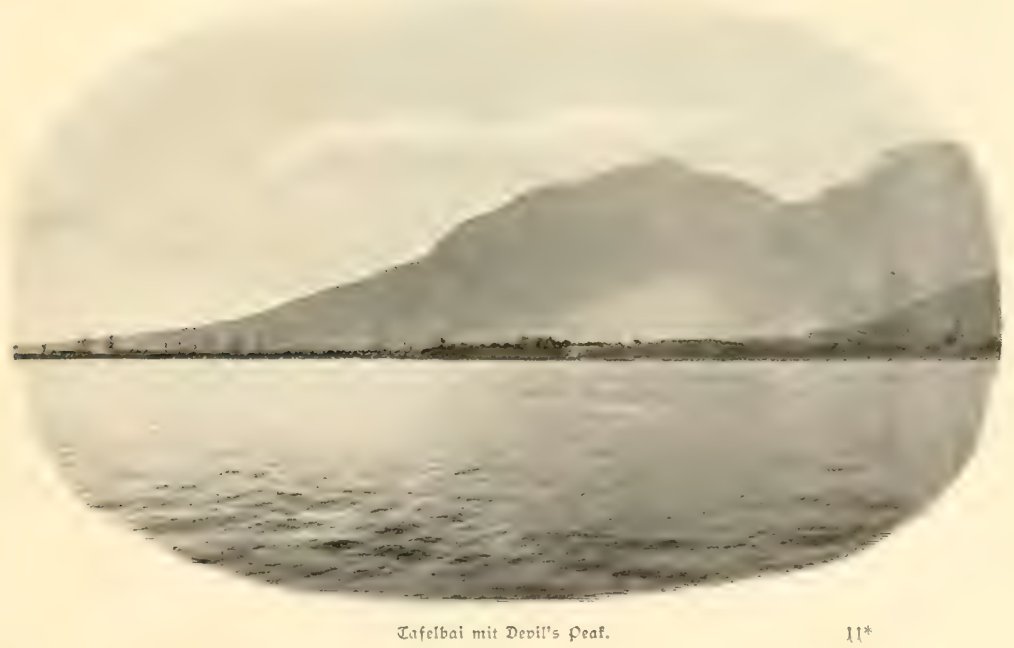




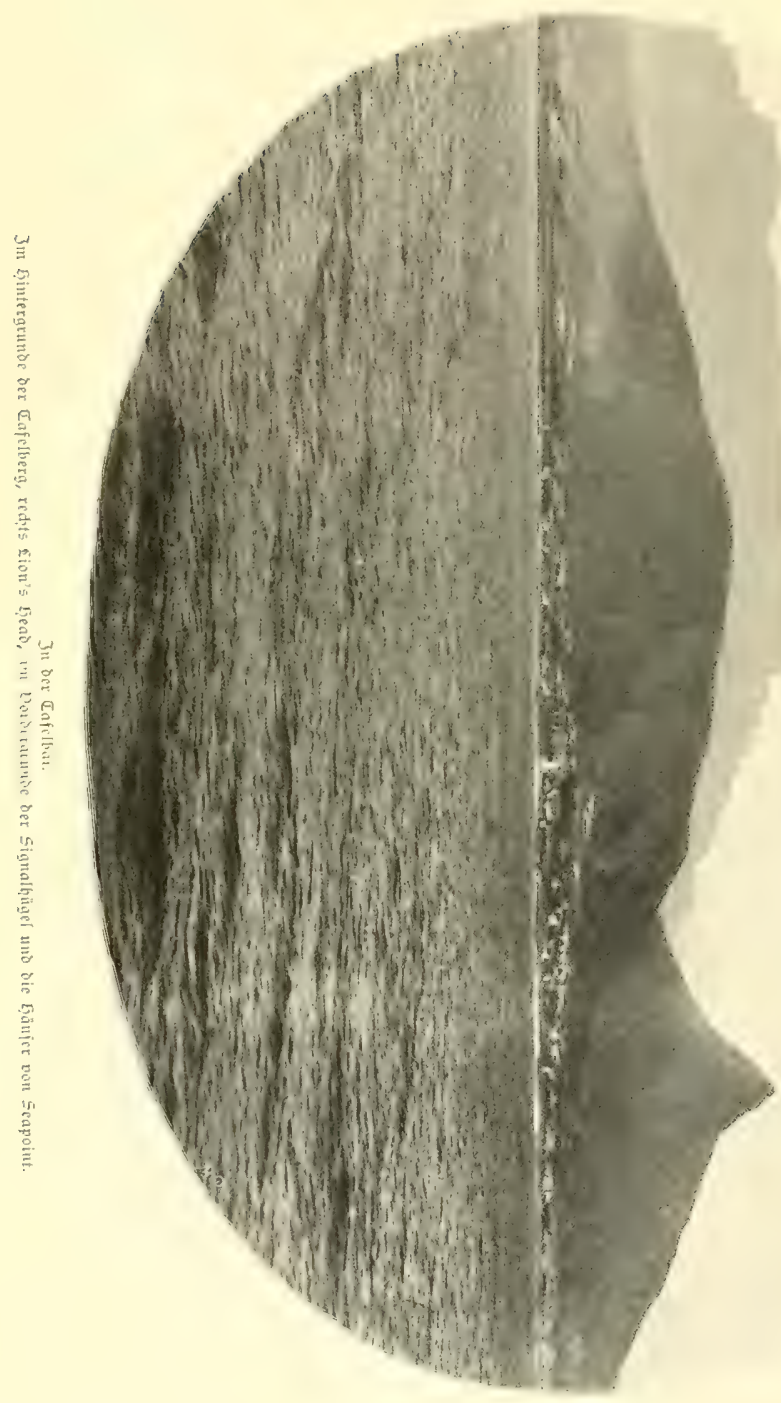




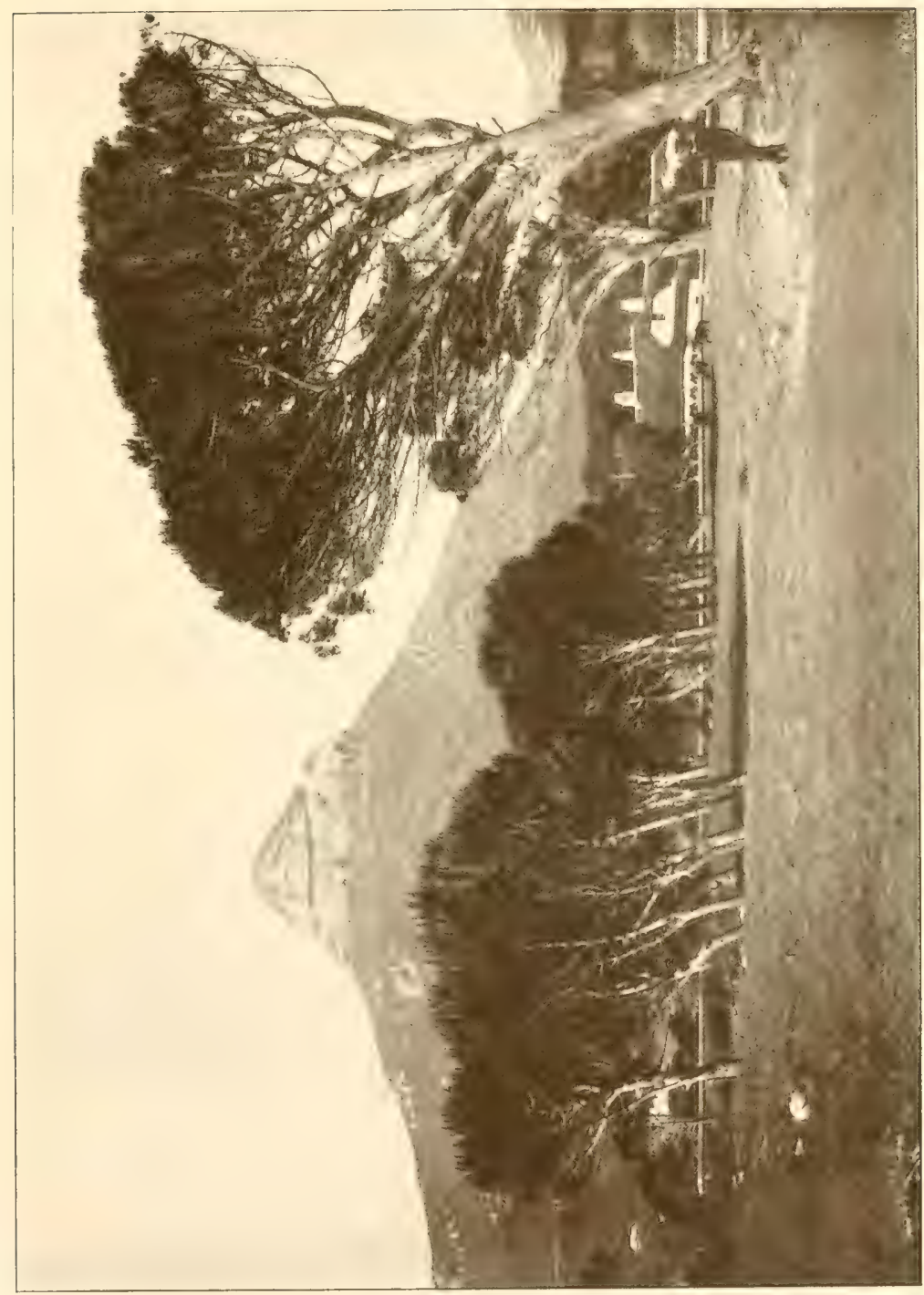

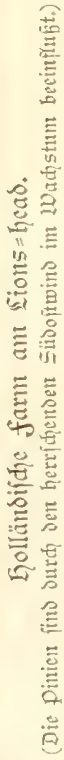



Entiकluf gefapt, obne 2lufent: halt in Kapftaot unverweilt die Unterjuchung der wegen ilprer Stürme berüdtigten, dem $S$ ü= Der des Kaplandes vorgelager: ten 2lgulhas= 3 ant in 21ngriff jut rehmen. Es fiel uns aller= Jings fdwer, uns pon dem grofiartigen panorama losju= reifen, das fid dent über: rafdyten Blife darbot. Der Tafelberg beherridit die Scene= rie, Inffs vor dem fteil abfal= lenden Kegel des Devil's Peaf, redpts voll dent Sion's Lead

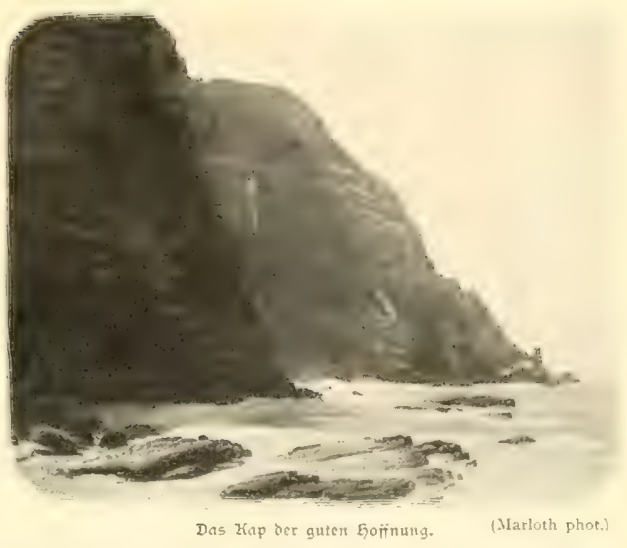
flanfiert. Es ift ein grofartiger Rahmen für dic Kapltadt, weldhe wir nur flühtig

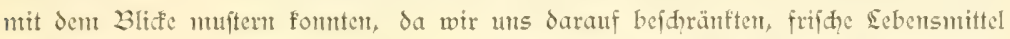
cinjunehnten und Profeffor Sdimper an sand ju fetsen. Der letstere bemtiste die

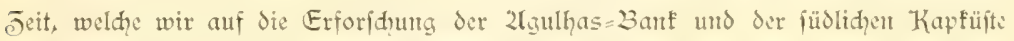
verwendeten, 3 einer botanifhen Exfurfion in die forften volt Knysua und auf Dhjentwagen - warob er von uns viel beneidet wurde - weit in das Jumere des Kaplandes lis ju der Karroo.

2lls wir ant 2lbent dis Tafelbai verltefen, taudite die Sonme in bas 2lieer und Hibergof den Tafelberg und das romantifi, an ihn fith anfhliepende 2lpoftelgebirge mit tiefent Rot, während das 2leer fdwwärjlith=blau mit faft glühend roten Kämmen fharf volt dem Sande fith abhob. Wir hatten den fultenen 2ubliff der lüber dem Tafolberg wie cit getwaltiges Polpter ausgebreiteten Wolfentafie, des fogmannten Tafeltudes: cin unfehlbares Jeidyen, da cin llmidlag in der Witterung bevoritand. Bei dem Llmfahren des fteil und wudhtig in das 2lieer abfallenden Kaps der guter Loffnumg madte fid bereits cin frifher 1 Deftwind geltend, der dem aud während der näd)ften Tage häufig ftürmif anfahend anbiclt und uns nötigte, unfere Zrbeiten in die Budpten des füdlichen Kaplandes ju verlegen. - 2litit der Tafelbai fam es an wirfungsvoller ltmrahmung mur noh die ifr gegenüberliegende falfebai aufnebmen, mährend fifon gisin den füdidften funft des Kaplandes, nämlid sision das Kap

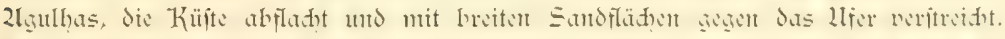

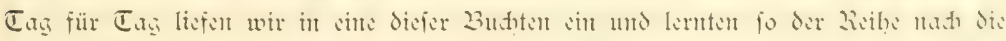

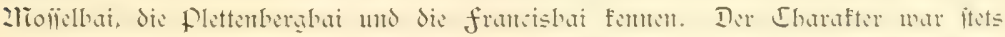
ein ähnlidger: ein weites, ju Beginn des fïbliden frühjahres mit grünm 2liatten 
bedecftes Dorland, in Lintergrunde niedrige Löhenjüge, über weldhe ab und ju bie Gebirgsfetten des Jmeren in bläulidem Duft hervorragten. 2ur die Plettenbergbat wird jum Teil von ausgedehnten Waldungen, dem berühmten, in rationelle Kultur genonmenen forft vort Knysna, umrahmt. 2ln den vorfpringenden, in Klippen aus= Iaufenden Jungen, welde die Budten abgrenjen, ftand ftets eine fanwere 3randung und die aufgepeitfd̨ten Waffermengen löften fïd in femen, die gefährlidgen Riffe ver= hüllenden Stanb auf.

So domerten dem and ant 2lbend des 29. Dftober die Wogen gegen das ftumt= umbranfte Kap Recife an, nad deffen Limfahren fid der 2lusblid auf die 2llgoabai cröfinete. Sandflädyen, Steppen und fahle Gügel umfäumen dic gewaltige 23ai, in

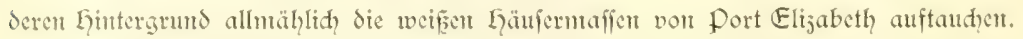
Die offene Reede bot inmerhin Sdyutz gegen den ftürmifhen Weftwind, und es fan uns felffant ungewohnt vor, als wir nah dent fdweren Secgang der vorausgehenden Tage anf rubiger, glatter fläde anf́erten.

Das Erfinemen des grofien weifen Dampfers, welder die Reidisdientflagge führte, erregte 2lufiehen in Port Elizabeth. 2lian vermmtete erit cin deutides Kriegsidifi, vermodjte aber dic Eadcbäume mit dicfer Deutung nidit in Einflang 3 th bringen. 2uf Deranlaffung des deutihen Konfuls fant rajh cin sotienfutter angefabren, deffen führer freilid ob der ifhm erteilten 2lusfuntf fopffdüttelnd das Weite fuchte. Zluf bic frage, woher wir fämen, Lautete die 2lutwort unferes Kapitäts: ,from the Northpole". 2uls man dam jögerno das Reifejicl wiflen wollte, croböhnte es ebonfo prompt: ,to the Southpole".

Konful Shabbel, der mit Dr. Fofntam, den betagten uno rüftigen deutidien

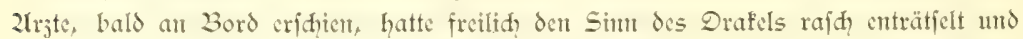

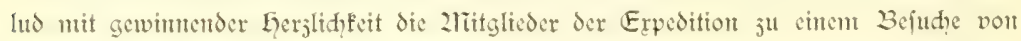
Port Elijabeth und ju cinem gefelligen ఏufammenfein in der deutiden "Siedertafel" cht.

Port Elijabeth mit feinten 26000 Einwohnern mad) den Eindrucf einer rajh

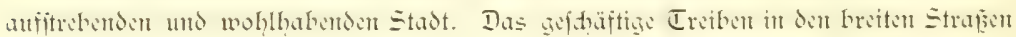

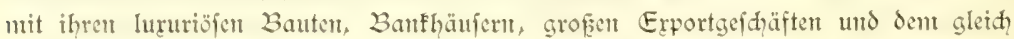
ant Lafendanm fid erhebenden eleganten Stadthaus deuten darauf hin, dap wir es mit ciner Landelsempore ju thum haben, weldye Kapftadt an Bedeutung faft gleid fonmen düfte. In der That repräfentiert port Elijabeth den natürliden Stapelplats und 2lusgangspunft für den Kandel mit dem nördlidgen Kapland, dent freiftaat und Traitsvaal. 2lllerdings führten unfere Sandsleute, von denen wir mit Stolj fagen

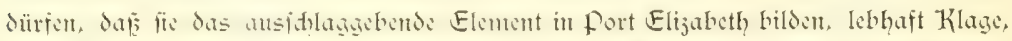
daf nad dent Einfall non Jamejon der Export von Transvaal merflid, abgentonmten

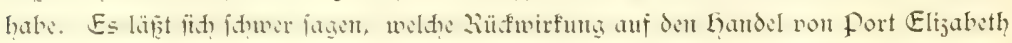
Ser unglüflige Krteg haben wird und wie die dortigen Derhältniffe fid weiterhin 


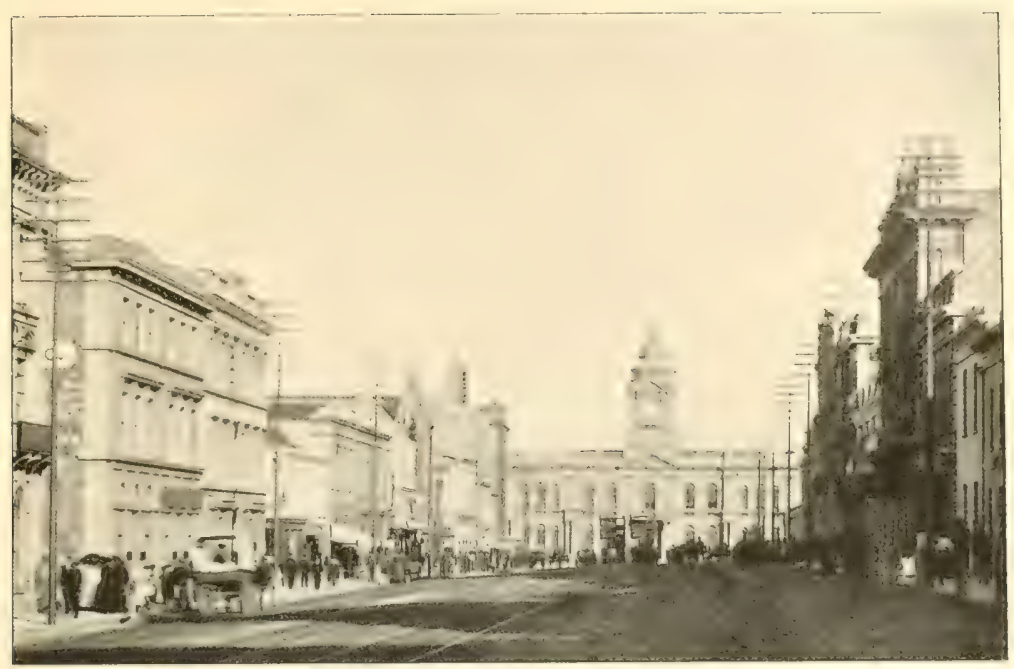

Princef $=$ Etreet in fort Elizabeth (ältere 2tufratme).

stwickeln werdert. - Die Stadt ift mit cinev eleftrifden 23abn ausgeftattet, weldic fteil gegen die Löhen durd, ammutige Strafenjüge auffeigt, die von niedrigen, um. jweiftöfigen und von Deranden untäumten Dillen gebilbet werden. 2luf der Liöhe liegt der Sammelplat der Bewohner, nämlid der Stadtparf, bet deffen 2lnlage man darauf

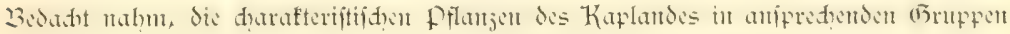
vorjufühten. Dies alles ift dem trodenen, rötliden Steppenboden abjerungen, über den ungehindert die Weftwinde braufen und dic Stadt mit Sand und Staub überidütten. Jnt Suben und Weften wird fie von ciner nalerifhen Sdyludyt umfäunt, jenfeits derer cin Kaffernfraal errid)tet ift, dem wir nid,t verfäunten, chnen Befud abjuftatten. In

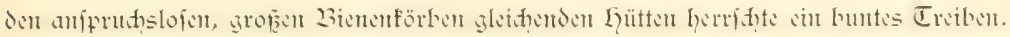
Da die Kaffers ju den mantifadyfen Dienfteiftungen in der Stabt herangejogen werden, fo weifen fie durch vielfältige Dermifhung jum Teil nidit mehr den reinen Typus auf, wic dent auh andererfeits 2liifhlinge mit den Lottentotten uns häufig entgegentraten. In der Stadt gehen fie nad Poligetworidrift vollftändig befleidet, in ihren Gü̈ten werfen fie den modernen Plunder ab und füblen fid wieder als Kaffern. - Wir wurden anfänglid mit miştrauij̧en Bliffen und oft unwilligen Worten em= pfangen, bis fpäterfin das fawarje Dolf allmählid jutraulider wurde in der Erfemnt nis, dẫ wir feitte Geheimpolijiften waren, weldhe dic Gütten nad dent Ziationaltrant, dem Kaffernbier, revidieren follten. Dies wurde allerdings reidplid fredenjt mo dis 


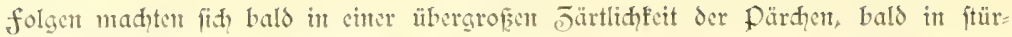
mifden Willfommenbejeugungen uns gegenüber geltend. Inmterhin verdient hervor= gehobut ju werden, dafi die Kaffermmädden wegen ilprer moralifheren Sebensführuug weit den Gottentottimen als Dientitboten vorgejogen werden.

Don den Löhenjügen oberhalb port Elijabeth bietet fith cint präditiger Blid auf die ntit Sdiffen überfäte Reede uns die weit ausgedehnte 2llgoabai. Es läpt fin

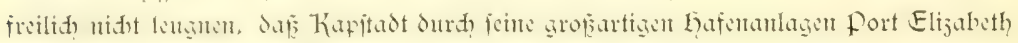
weit überlegen ift, deffert Reede bei gelegentlich cintretendem Sïboftfurme die Shiffe

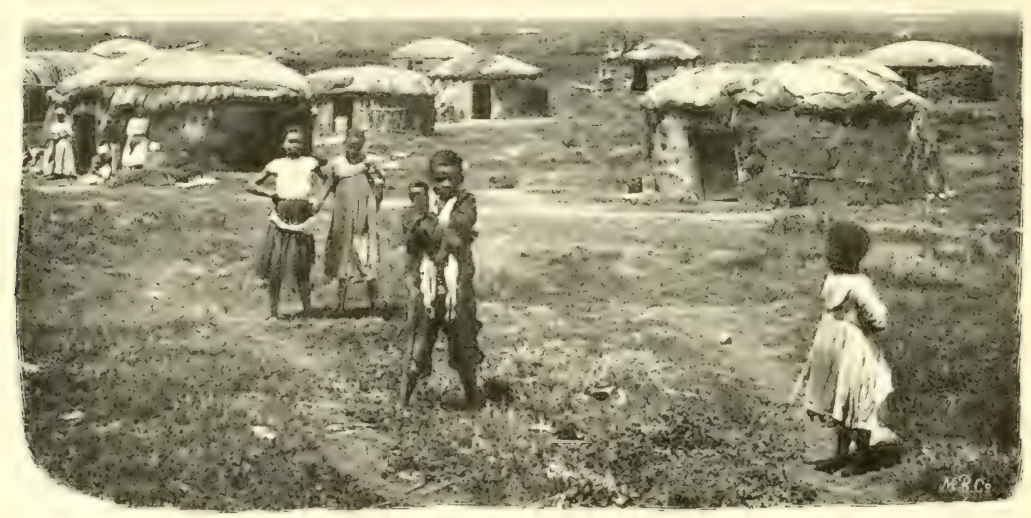

Int Lafiernfral bei port Elizabeth.

allen Lthbilden des Eceganges preisgicbt. Dft find fie dam genötigt, die 2lnfer $j^{\text {H }}$ liditen und gegen die See anjudampfent.

Da uns das Wetfer günjtig war, nerwendeten wir cinen ganzen Tag anf die lnter= fudung dex Zllgoalsat, die uns an manden Stellen einen überrafdenden Retd)tum von

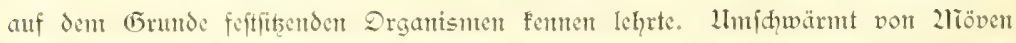
und fdwwärgliden Etumitauhern (Puffinus), von denen die erfteren gewandt im fluge nad ausgeworfenen fleifhituifen fhnappten, dic Iethteren erft fid auf das Waffer niederlię̧en, de Broffen fap̧ten und dam über dic Dherflähe weggtrippelnd aufflogen, gelangter wir in die ziähe des imfamen, vegetationslofen Eilandes St. Croir. Lier 
gewahrten wir jum crftenmal aus der Entfermung eine Kolonit vont Pinguinen (Sphe-

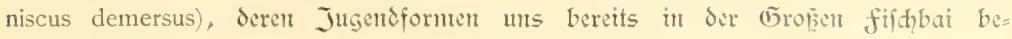
gegnet waren.

Die Rä̈ffahrt von Port Elizabeth nad) Kapitadt führte uns mitten über dic von

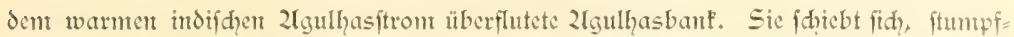
dreieftig geftaltet, dem Kaplande vor bei einer wethelnden Tiefe von 70 bis $200 \mathrm{~m}$.

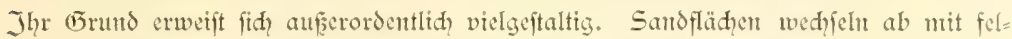
figem Boden, Konglomerate mit grünlidhem, glaufonitifdent (5) rund, der namentlid im Weiten der Banf herrifiend wird. Weil die Seefarten nur nad gelegentliden Eotungen die Bodenbeidhaffenţeit angeben, fo fanden wir häufig an Stellen, wo günitiger Dredidh=

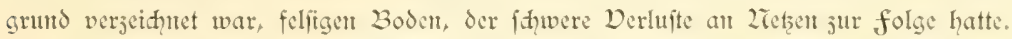

Die Banf fält fteil in cine Tieffee vort riber $4000 \mathrm{~m}$ ab. Wir verntodten in ihrem 1 beften durd cine in cincr peilung gelegente Eotungsicrie das profil des Steil=

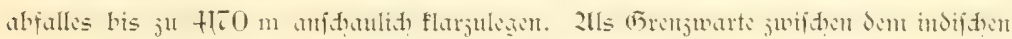

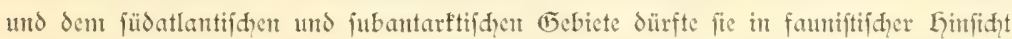
befonderes Intereffe darbieten. In unferen Sammlungen fehlen faft vollfommen $\mathscr{D b}=$

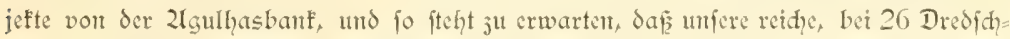
३ügen gewormene Zlusbeute die Joologen in ftand feţen wird, über dent tiergeographi= fhen Charafter der dort crbeuteten Drganismenwelt cin fidferes Ltrteil ju fällen.

2lus den bis jeţt vorliegenden Berthten der cingelnen Bearbeiter des gefammelten 2 liateriales geht hervor, dafi nidt mur cinc auffällig grofe Jahl neuer formen er=

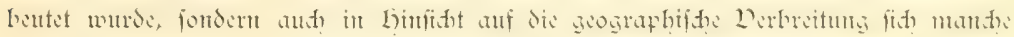

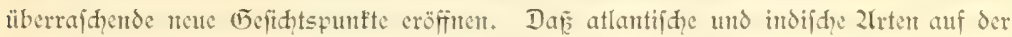
Banf vergefellfhaftet fid vorfinden wütdent, war von vornherein ju crwarten turb hat

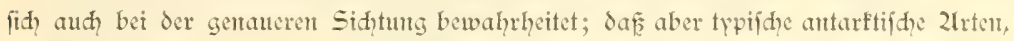

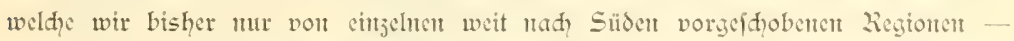
frectell von der zlagelhaensftrafe und non den falflandsimfeln - famten, aud der

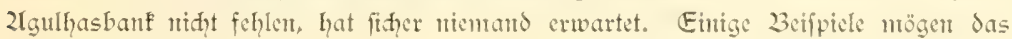
(5)efagte crläutern.

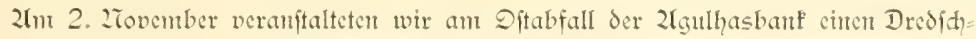
jug in $500 \mathrm{~m}$ Tief:. Die Bodententperatur betrug $\tau, 8^{\circ}$ und ber (Frund crwies fith als feiner (5) bobigerinenidglice. 2uls das Trawl auffam, wurden wir mit ciner foldhen fülle von Drgantsment überifhüttet, da familien namthaft ju madfen, weldhe oft durd zahleridge 2rrten vertreten waren. Don dent fijhen an bis herab ju den Sdywämmen formten wir faft alle marinen Typen nadyweifen. Wollte man die Eeiten fummeren, welde die Bearbeiter des 2kateriales branḑen, un den Jnhalt dicfes einjigen Juges (wir haben mehrere ăbulid) retde 


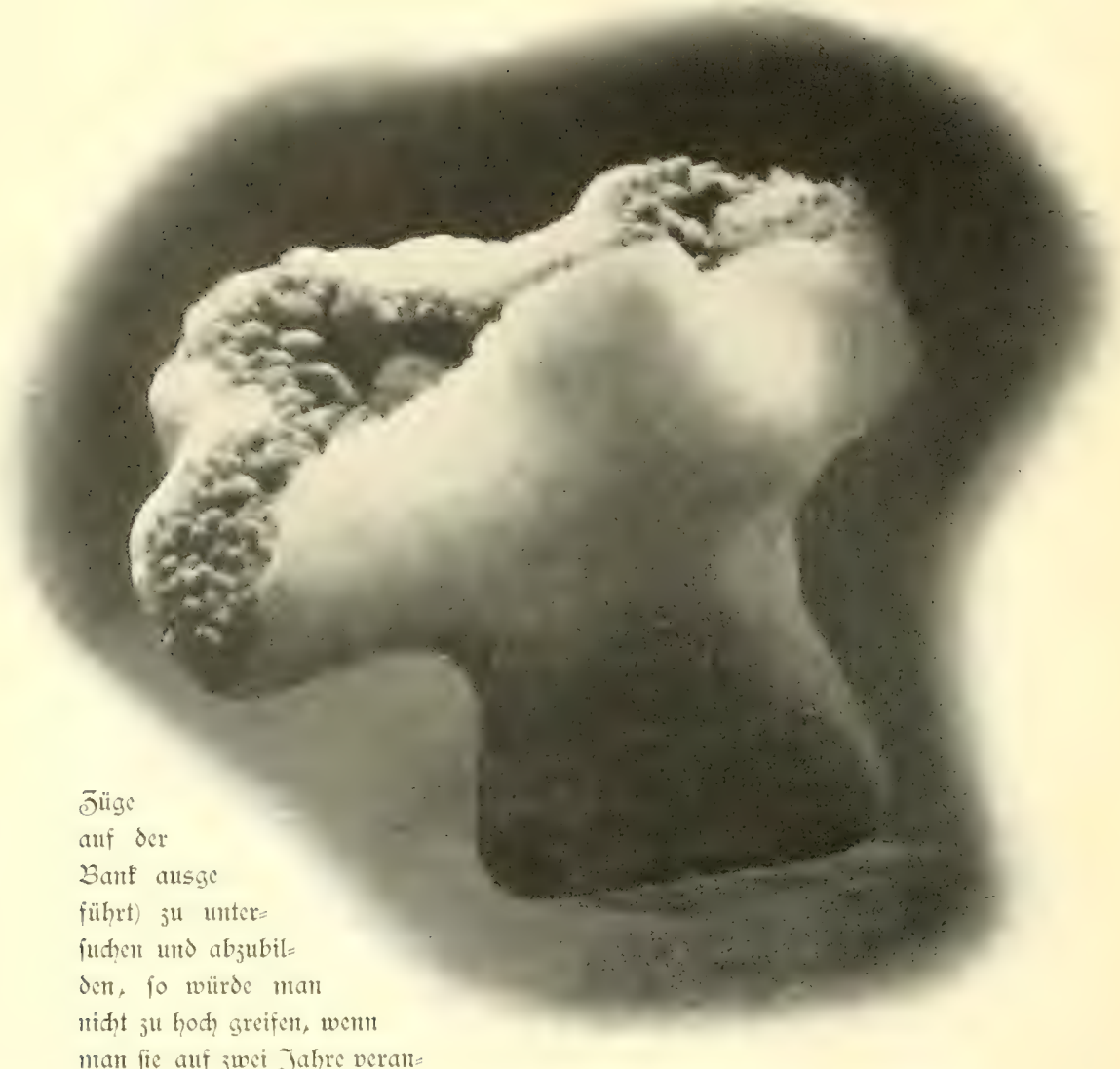

man fie all jwei Jahre verans

idilagt.

Eodrot gefärbłe 2lftitrie.

Da die 2rgulhasformen in

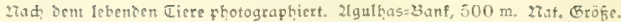

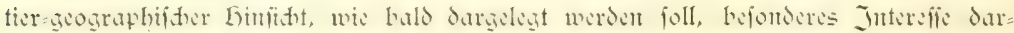
bicten, wollen wir wentiftents den Derfud madien, cintige darafteriftifige Dertreter des in $500 \mathrm{~m}$ Tiefe veranftalteten Jüges dem $\mathbb{E} c j e r$ in $\mathfrak{W}$ ort und Bild vorjuführen.

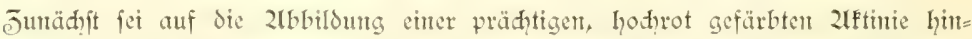
gewiefen, die der Tieffecgattung Polysiphonia wegen der darafteriftifden Derfürzung ber fangfäden gleidit. 
Inter den jahlreiđen Seefternen tung Gnathaster $a b$, der durd dic

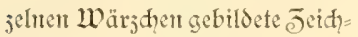
teriffert ift. Beionderes bilden wir einen Dertreter der Gat: jicrlidie wabenförmige, aus ein= mutg ber Dorfalflädie dharaf Interefie fnüpft fid an bas

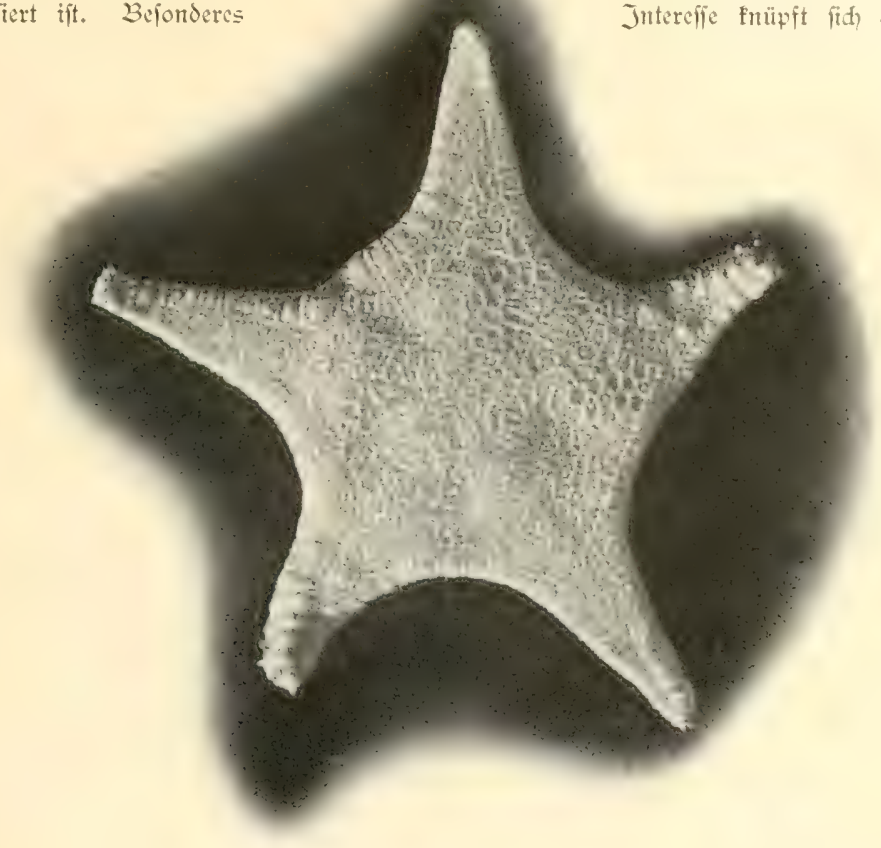

Gnathaster (3;sp. $500 \mathrm{~m}$. 2tauthas:Bamp. Zat, Erōfe.

Wiederauffinden der vou Slaben bejhriebenen (5̃attung Astrophiura. Dic fün beuteten Exemplare gleiden fleiten Seeftemen und crft bei genamerem Jujehen ergibt es fid, das fie den Sdilangenfermen (Dphiuriden) $z u=$ gehören. Die Seitemplatten ifher erften fieben 2limglieder find derart erweitert, dafi fie inter= radial jujammenjtopen und cine fajt gerade, mit Jähnhen bejeţte Randinte bilden. 2Uu den Ecfen des fo entitehenden funfed's ragen

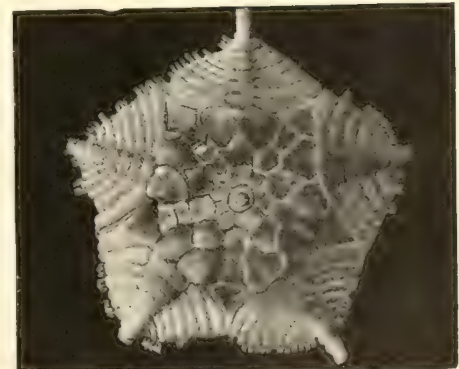

Astrophiura sp. 2laguthas=3ant. $3 / 1.500 \mathrm{~m}$. 


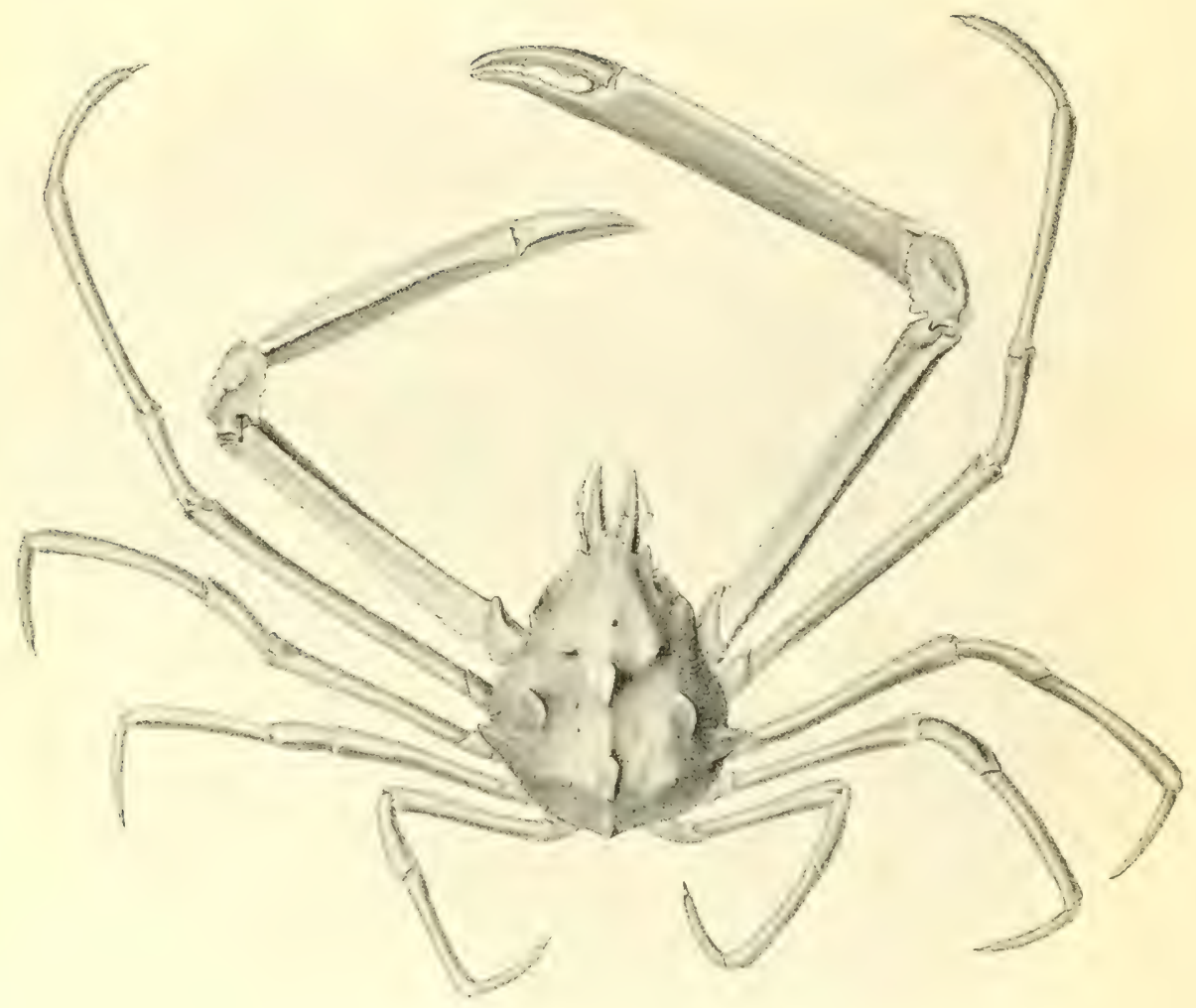

nod cinige mentge, rudintentüre 2trmglieber frei hervor, dic freilid faft überall $a b=$ gebroden find. Trotz diefer aberranten Bildung der Z1rme befitizt die form in gewifien Teilen des Sfeletts den printitiviten Bau unter allen bisher befanten Dphiuren.

Finen befonders anffalligen Beftandteil des 2liateriales bildeten zahlreide Dreiefts: frabben, von denen wir eine meue, der (Ẽattung Scyramathia jugehörige 2lrt im Bilde vorführen. Diele Eremplare derfelben waren mit parafitifhen 2lifeln (Bopyriden) behaftet und anferdem hatten fid auf ihnen Banfenfüpler (Cirripedien) angeftedelt. 
Ziiht minder reidhlid waren in dem fange jahlreidhe grofse Sdnecten mit gewun= denem Echäule, welde nah der Beftimmung von Prof. v. 2liartens der antarftifden Irt Trophon Magellanicus Chemn. angehören. Wie feltiam fid indifde, atlantifige und antarftifhe 2lrten hier begeguten, mag die Durdhmuferung der in demfelben Jüge ent= haltenen Secigel beweifert. 2Tad, den 2litteilutgen vont prof. Doederlein ift die indifhe Gattung Stereocidaris durdy cine neue 2lrt vertreter, neben der typifd atlant= tifde formen, wie Spatangus Raschi und Brissopsis lyrifera fith finden. Јु ihnten gejellt fid wicderum cine antarftiface 2lrt, näntid der mur von der 2läagelhaensftrafie

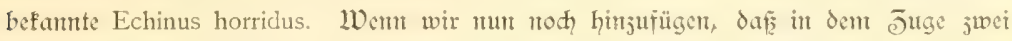
neue 2lrten der (5attungen Echinus und Strongylocentrotus enthalten find, fo gefdicht

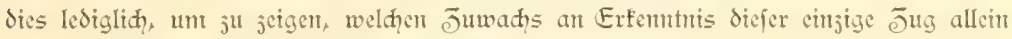
fhon für cine fharf untgrentste Ōruppe bringt.

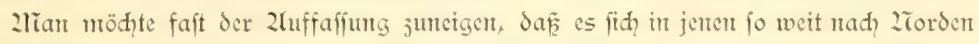
vorgejhobenen antarftifhen formen un cine Reliftenfauna handele, dic fidh auf der von den warnten 2Gulhasftrom beftridgenen 3 anf aus ciner Jett crhielt, wo dic flimatifhen Derhälniffe wentger günjtige waren. Fine geringfügige Fntiodigung der mittleren Jahrestemperatur un wertige (Frade müte jur folge haben, daf die mörd= lithe (5)enge der ftürmifd wehenden Weftwinde bis zum Kap verlegt wurde. Die mäḑtige, nad Dften geriḑtete Ströntung der Weftwindjonte wird dann weit energifiner, als es in der Jetstjeit gefdicht, den warmen, entgegengejest fliefenden 2lgulhasftron abgelenft und ihreriets mit faltem Waffer die dem Kaplande vorgelagerte Banf über= flutet habert. Daiz thatjählion and den fubantarftifinen Regionen eine Eisjeit - jum mindeftents eine Jeit, wo dic mittlere Jahrestemperatur um einige (Brad niedriger lag jufam, foll in einem anderen Jufammenhang nod dargelegt werden.

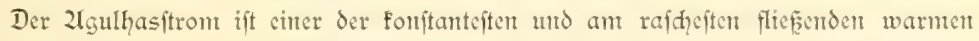
Ströme, die wir aus jenen (b̃ebieten Eenner. Die Sotungen in feinem Bereidhe waren mit ganj ungewöhnlid̨en Sđwierigfeiten verbunden. Exit nad vier vergeblidgen $\mathcal{D}_{\mathrm{er}}=$ fuhen gelang es uns, füdlid von der 2llgoabai bas sot bis auf den (5runt ju bringen und eine Tiefe von über $1900 \mathrm{~m}$ nadjuweifent. 2lllerdings betrug die Stromgefdqwitt= digfeit während diejes Deriuhes an 1. 2Tovember 5, 7 Seemeilen in der Stunde. IIm dic Sđwwierigfeiten ju würdigen, weldhe dem Kapitän bet feinem Bejtreben erwudjen, den Dampfer an derielben Stelle ju halten, wo das Sot veridwand, fei nur erwähnt, daf cine Strongefdwindigfeit pon $5, \overline{6}$ Seemetlen in der Stunde faft genau der (bee fonwindigfeit gleidformmt, mit welderer dic Donau bet Wien flickit. Würde mant fith denfen, dak dieje cin jwei Kitometer tiefes Bett ausgewühlt hätte, fo mödyte man es fhon als einte hervorragende seifung bejeidnen, immitten cintes fo rafd fliefendent Stromes eme Solung ju bewerfftelligen. Lierbei ijt weiferhin nod ju berïfïhtigen, daf mur die oberfläd lidhen Wafferididgten in rafhent flukf fid befinden. 2iad unferen 
Wahnehmungen, die fing auf dic Stellung des Drahtes bet dem Soten, Dredihen und fijden mit den Dertifalteçen gründen, erftrefft fid im 2lgulhasftrom das rajde flickent mur auf dic oberften Sđiḑten bis $200 \mathrm{~m}$ Tiefe.

Int allgemeinen waren wir bei der Rüffahtrt in diefen durd ihre Stürnte berüd tigtent Gegenden ungewöhnlidy von $\mathfrak{D}_{\text {etter }}$ begünftigt, und erit als wir auf dem Weftrande der Banf anlangten, fadyte der 2iordwint fo ftürntifh all, daf wir am 5. 2rovember Jufludt in der falfebai vor Simonstown fudpen mufient. Die falfebai wird nodh von 2lusläufern des 2lgulhasftromes berührt, und aus dicfen Lmrfande

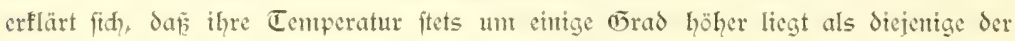

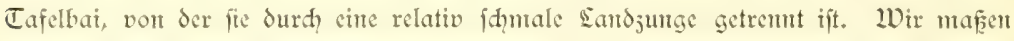
in der falfebai cine Dberflüdentemperatur von $1 \bar{z}, 5^{\circ}$, währento gleidyeitig die Tentpe= raturen in der Tafelbai mur 12-14\% betrugen. Z̈lhnlidhe Erfahrungen madte die Challenger $=$ Expedition, welde mehrere Woden mit dem Drdnen ihrer Sammlumsen

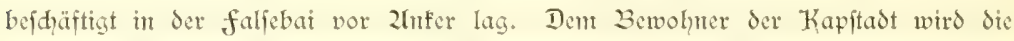

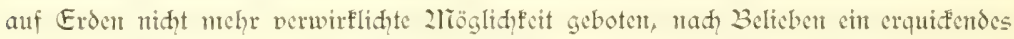
Bab in den fühlen fluten des Ittantifden Deeans ju nehmen ober nad cinftündiger fahrt fid dent Warmwaffer des Indifinen Decans anjumertransm.

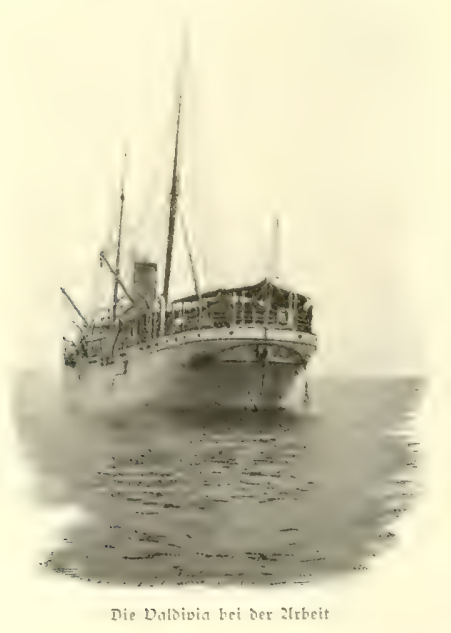




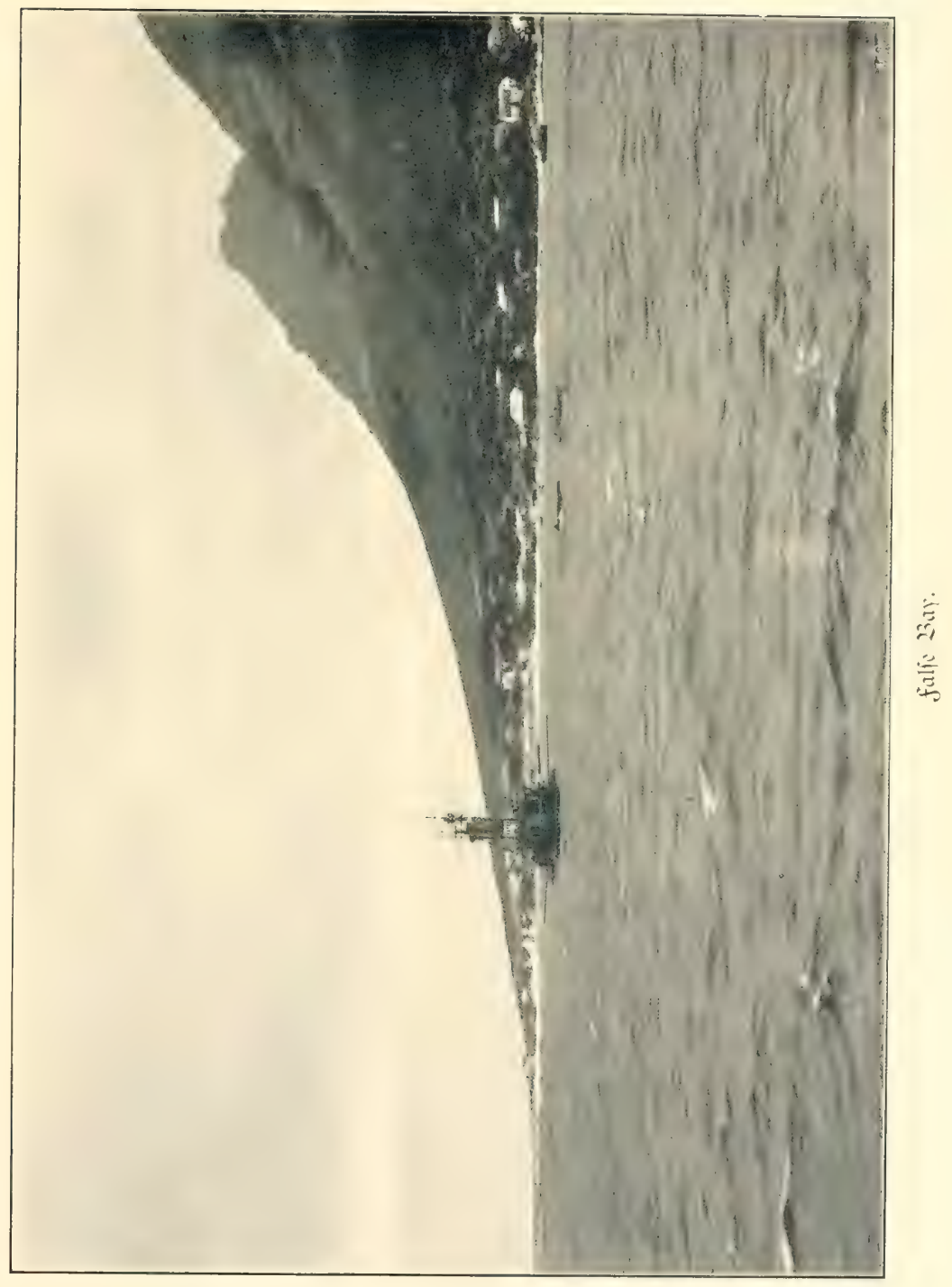





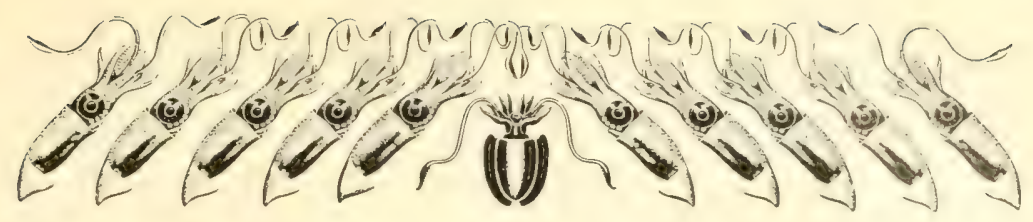

\section{Dou Ifapitad jur 23ounct Inil.}

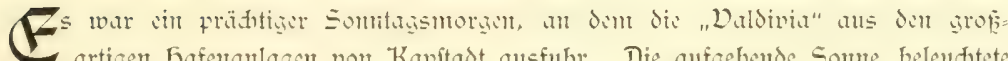
artigen Lafenanlagen vort Kapftadt ausfubr. Die aufgehende Some beleuhtete ant IJ. Dftober bet wolfenlofent Limmel den Devil's Peaf und Tafelberg fo fdräg. das alle voripringenden Riffe uno cingeriffenen Shluhten fidh fharf abhoben unt wett wirfungsvoller, als un die 2littagsjeit, das (5ebirgsrelief hervortreten liefien. Es fiel uns fhwer, der gaftlifhen Kapitadt Dalet ju fagen, nahbem wir die 7 Cage, welhe wir dort verbraditen, in angeftrengter Thätigfeit ausgenutst hatten, un unfere 2lus= rïjtung ju vervollitändigen und nebenbet aud das überreid mit 2iaturidgönheiten gefegnete Kapland fenten ju Iernen. In dent Beftreben, der 2latung vor den wiffent= ihaftlidgen Unternehmungen des Deutihen Reidhes 2lusdrut ju geben, crwies man der Expedition befondere Ehrungen. 2lnfere in der (Ẽfelliḩaft "EFermanta" vereintigten Eandsleute veranfalteten cinen feftidfen Kommers, bei dem der Lymor in fem Redyt trat, und muffalifhe Talente mit rednertiden wetteiferten, den mit emem füdafrifanifhen Sumpen= Drhefter eingeleiteten 2lbend ju eintent genufreiden ju geftalten. Wie in Port Elijabeth, io berührte es unts aud in Kapftadt auf das wohlthuendite, die Summe von Intelligenj und Thatfraft, die dem deutihen Elemente des Kaplandes imewohnt, fenten ju lernen und surd cigenen 2lugenficin uns ju überjengen, welde hervor: ragende Rolle demielben in dem (B̃etricbe der Kolonie jufällt. Es war faum ein Jahr vor dem 2lusbrude des Krieges; die Derhältniffe hatten fid in dem Parlament, wo Sie holländifhe partei in die 2liajorttät gelangt war, bereits jharf jugefpitst, und fo

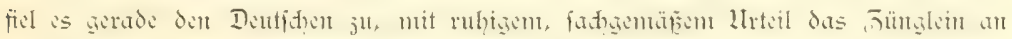
Ser Wage det widerftrebenden Interefien zu bildent.

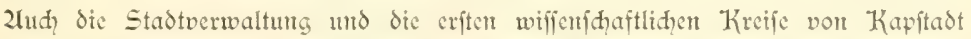

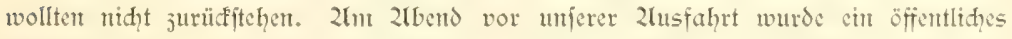
Banfett ju Ehren der Daldivia = Expedition unter den 2lufpijien des 2liapor vor Kap= ftadt und des Präfidenten der South-African Philosophical Society, Dr. Steward, veranftaltet. Was Kapftadt an 2lännerm von Bedeutung anfwies: Dertreter der Wiffenfhaft, Zinifter, hervorragende Bcante und Private, fand fid, jufantment. 


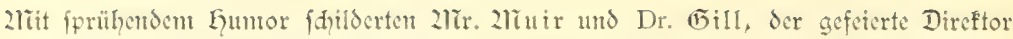

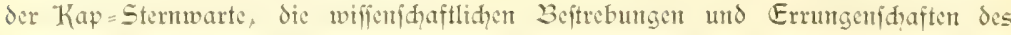
Kaplandes, wobet fie im Eimblief anf cine dentide Expedition, welde dic Küften der Siidipthe vort 2lfrifa in den Bereith ihrer Lnterfudyugen gejogen hatte, es nidit daran fehlen lictien, cine fọarfe, wem aud nidht verlebende zlbredinung mit dem anwefenden 2limifterium ju halten. Zluf ihre Daritellung der 2lühen, Sie es gefoftet hatte, um

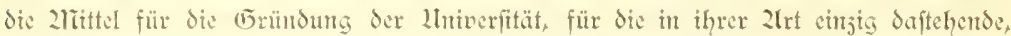
weltberübute Sternwarte und für das präditige, foeben vollendete 2linfeumsgebäude bewilligt ju crhalter, antwortete der fdylagfertigite Redner des Kaplandes, finanz= minifter 2lierriman, in feiner farfaftificn Weife. Jutdem er die Expedition im Ziamen der kiegierung willfonmen hiefs, fudte er die Derdiente der letsteren um förderumb wiffenfhaftliher Beftrebungen - im Ēegenfats ju feinen Dorrenen, dic den Datifiden mur erjählt hätten, was dic kiegienung nidht that - flar ju legen. Der Eapländifde 2lïnifter gletde cmen fliegenden fifd, der in dem 3eftreben, dem Radhen

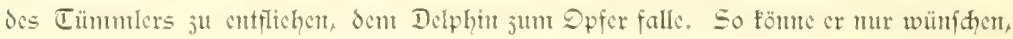

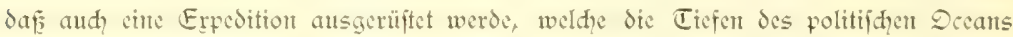
lote und jur Kenntnis der merfwüdigen Tiere, die fie da entdecten würde, beitrage. Wer hätte dantals geglanbt, daf fene Znipiclung fo bald in Erfüllung gehen follte! Dafs wir alle ihn mit vollem Eerzen zufthmuten, als er dic Sceneric des Kaplandes,

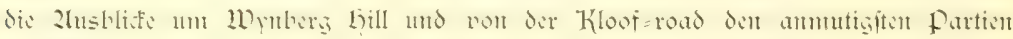
des (5)lfs von Zreapel an die Ecite ftellte, brandyt nidgt erft verfidiert ju werdent.

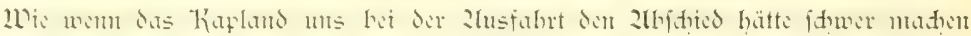
wollen, fo jeigte is fid? nad den vorausgegangenen regnerifhen Tagen in feinem ver= führerifhiten Ẽemande. Sangian glitt dic "Daldivia" surd de fpicgelglatte Tafelbai; Equnderte von Kormoranen und Ziönen frädjten heifer Dalet, während der Dorfitiende des dentihen Dereins, unjer freund Dr. 2liarloth, es fid nidit nehmen lief, perfönlid dis guten Wünfor unferer Sandslcute für den tweiteren Derlanf der fahrt ju überntitteht.

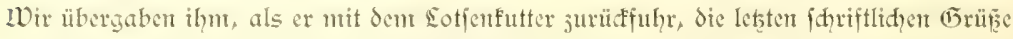
an die feruten Lnjrigen und verabidiedeten ihn mit cinent fraftigen Lip! hip! hurrah!

Der Signalhüael wurde umfahren, die anmutigen Dillen und Eqüfermaffen von Scapoint Glänten in der 2liorgenfone, und fharf hob fid dev Eion's Lead mit feinen in feitten Dufte verfdutumtenden Beftäıten von Silberbäumen (Leucadendron) $a b$. Bald offnete fid der Bliff anf dic Kamp= Bai, und deutlid fomte man den fidmalen Pfad verfolgen, der uns bei ciner Befteigutg des Tafelberges durd die 1droffi $a b=$ fiürzenden Ed]ludten auf den Kanm geführt hatte. Es war das cine Erfurfion, dic in (E)menfdhaft mit jwet fo gewiegten Sotantfern, wie 2liarloth und Sdimper, Sen ganjen Jauber der wutberbar üppig entwicfelten und in der Welt durd den

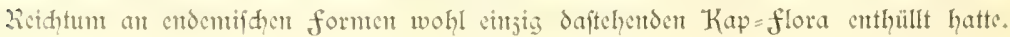




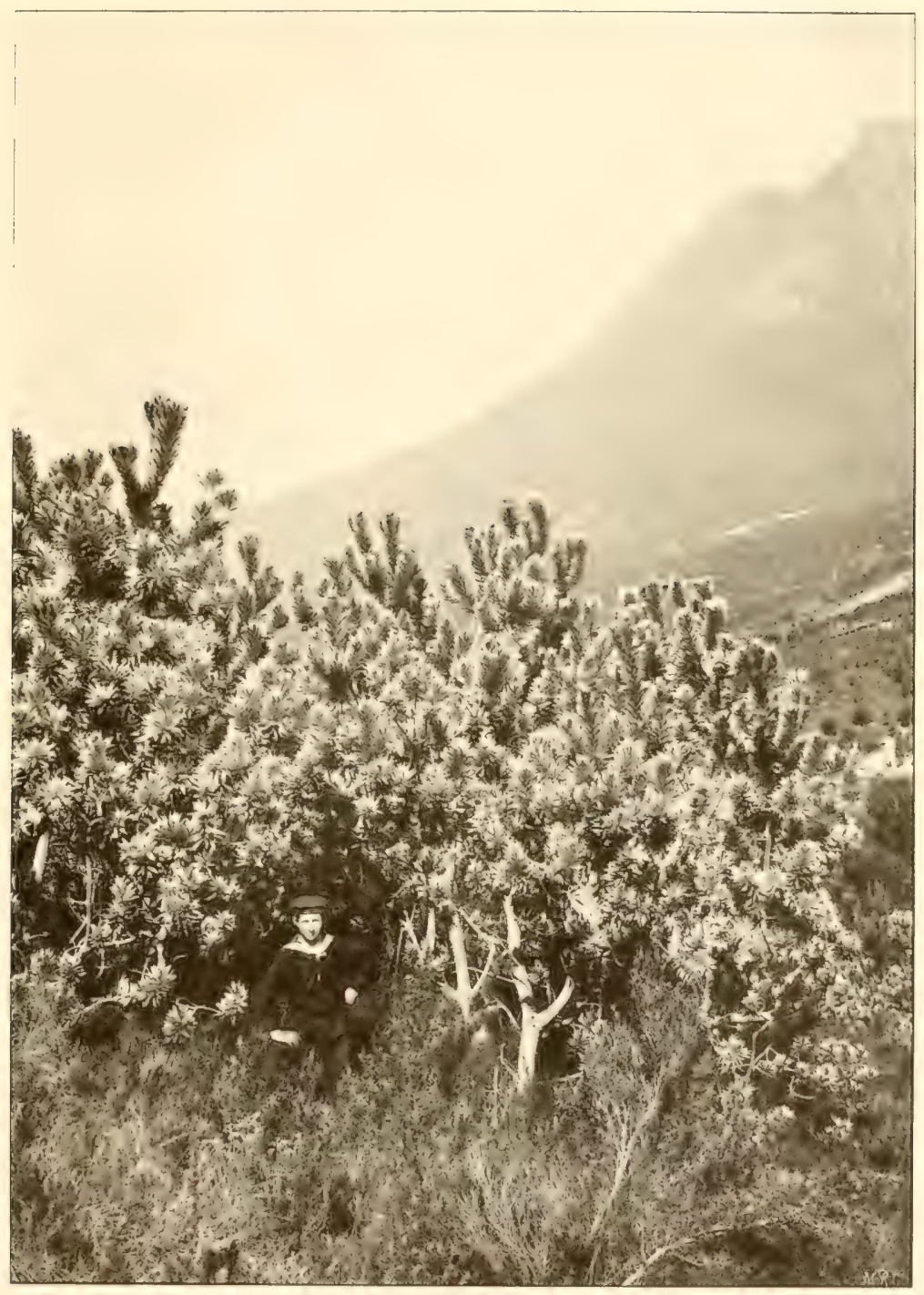

Leucadendron argenteum (Silver-trees) ant sions=head (Kapland). 

Die weit liber mamshohen Bäjhe der für die Kap=flora durafteriftitint froteaceen,

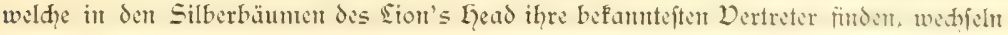
ab mit von Blüten überfhütteten felargonien und anmutigen Drdidesn, mit 23aten der

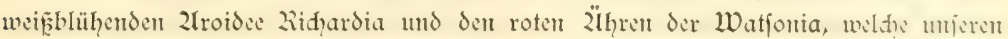

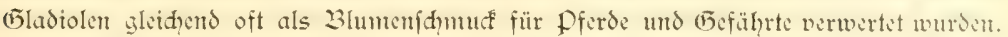
Das Kapland dürfte es an fülle fhön blühender und duftender Blumen wohl mit den geiegnetiten Eebieten unjerer Erde aufnehmen; allein an Kontpofiten fommen im

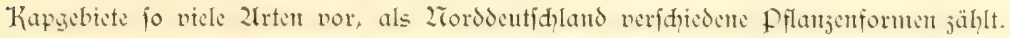
Das Degetationsbild wird freilid nidit unmefentlid, aber für den 2iordländer fifonders

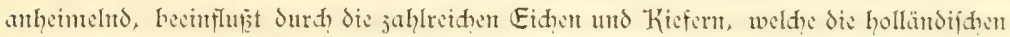
Koloniften anpflanjten. Dom Shiffe aus vermodten wir nod die dunflen Laine hei=

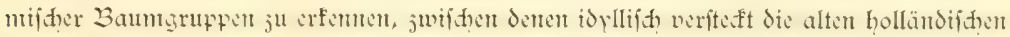
farmen liegen. Dorbei ging es dann an den 12 2 Ipofteln mit ihrem idjarfgejaften

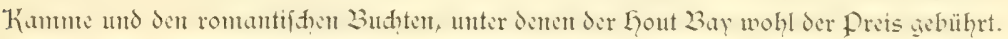

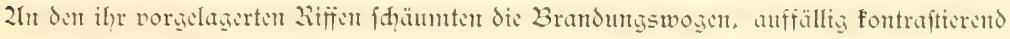

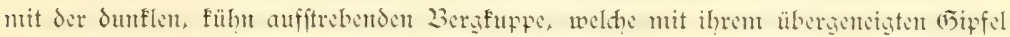

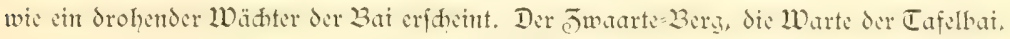

hatte fith in Wolfen gehüllt, hinter denen in feitem Duft die beiden Spitzen des Kaps der guten Lofinnung über die vorgejogene nicdrige Eandidaft

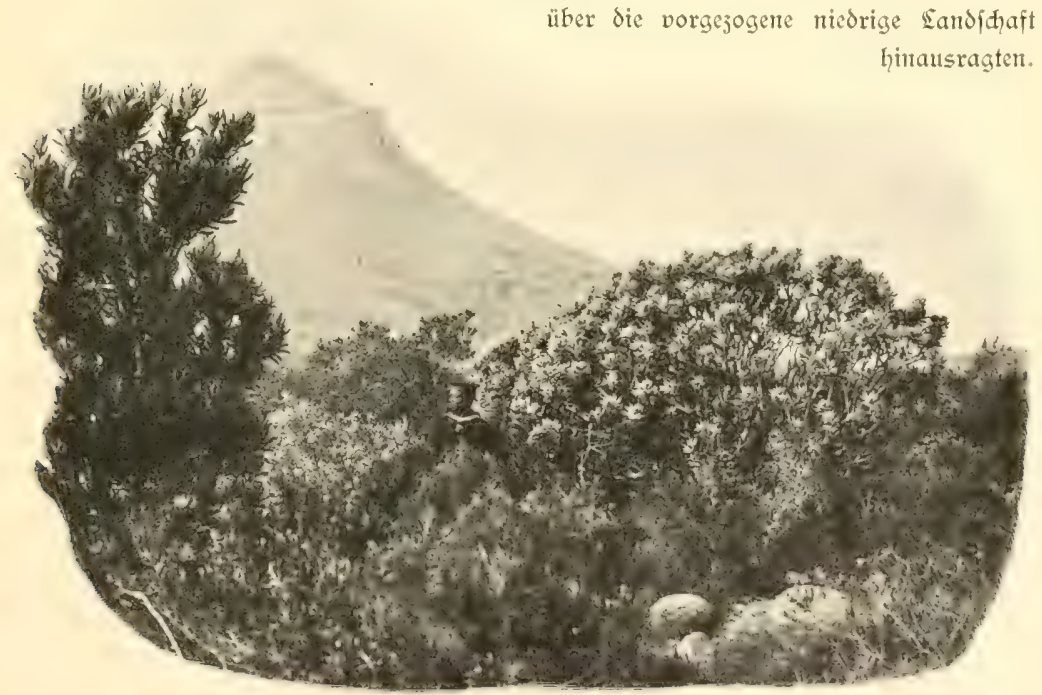

Proteacent an fufe des Eion's Eeab. 
2lls wir das Kap zur linfen Seite liegen liefen und nit SSW.-Kurs dem endlofen fïbliden 2lĩeere juftrebten, utag ntan wohl auf cinem von Diten fommenden Zuptralien= falprer fid feine cigenen (Gedanfen üler den fonderbaren Kurs eines Dampfers gentad)t haben, der mit weifen Tropenanftrid cine feit meby als fünfzig Jahren von fement Sdiifi gewählte Route cinidhlug.

Es galt der Lhterfuchung des antarftifhen 2lieeres. 2rur cin Expeditionsfoifi. weldies dic oceatographifhe und biologifde Erforfdung der Tieffee fidh jur 2lufgabe geftellt hatte, nämlich der "Challenger", war in bas antarftifhe Gebict vorgedrungen. Lnter Benthuntg der fajt ftändig wehenden ftürmifhen Weftwinde folug de englijhe

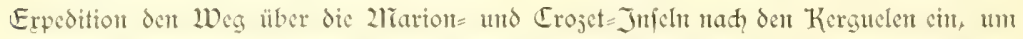
non bort aus in füböfliḑer 2Ridntung emen Dorftof bis $66^{\circ} 40^{\prime}$ i. 3. ju unternehmen. Don Kapitadt aus hatte fhon por dent Challenger die "Eajelle" faft dicfelbe Ronte gewählt, um nad den Kerguelen ju gelangen. Da beide Sdiffe unterwegs occano= graphifhe und biologifhe lnterfudungen ausführten, hatte man wertigtens cine ciniger= mafien befriedigende Doritellung von dent Tiefenrelief der befahrenen Strede erlangt.

Es widerftrebte uns, denfelbet 33 abnen zu folgen, welde jwet mit wifienfidaftliden Interifdungen betraute Korvetten cingejd̨lagen hatten. Süblid vom Kaplande dehnt fid ein weites 2lieer aus, das in oceanographijher Limfiht utterforiht war. (5)leid? hinter der 2fgulfas=2Banf bredien alle Sotungen ab und niemand fonnte vorausfagen,

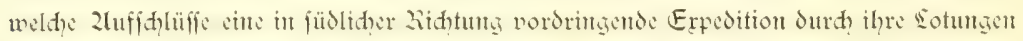

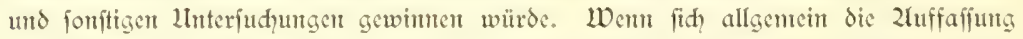
eingebürgert hatte, daf man es mit einem relativ feiḑten 2licere ju thum habe, deffen Soden allmählit? gegen den anturftiffen Konfment anfeige, fo fonte jur Etütse diefer and in Tiefenfarten niedergelegten Dorftellung lediglid de Thatfahe herangejogen werden, dafi der "Challenger" und die "Gajelle" jwifhen dem Kap und den Kerguelen niḑt gerade beträđtliḑe Tiefen naduwefen.

Derfolgt mant auf den britifhen Seefarten die weite unbefđriebene fläd e füdlid nom Kaplande, fo ftöbt man mur anf cine 2lngabe, die freilid aut wieder als unfider

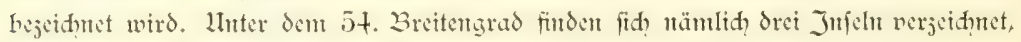
welhe als dic "Bounet= (5ruppe" jufammengefabt werden. 2lus gleid ju crmälnenden Bründen fdien es verlofend, den Kurs auf diefe Jnfelgruppe ju nehmen.

Die SdywerigFeiten, welde emer derartigen Route im $\mathfrak{W e g}_{\mathrm{e}}$ tanden, wurden nitht unterfätht: wir hatten de Kegion der ftürmifiten Weftwinde mif ihrer hodgehenden

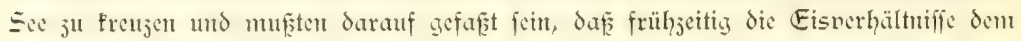
Dorjtof ein Ende mahen würden. Dent aus dem Studium der Karten über die

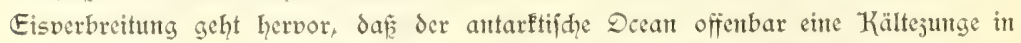

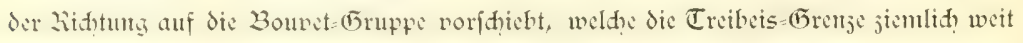
nördlid, verlegt und sine befonders reidhe 2lnhäufung von Eisbergen jur folge hat. 


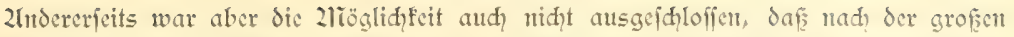

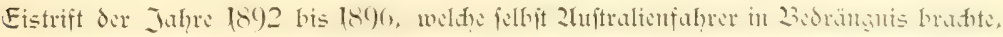
die Derhälniffe fith günifiger geftaltet hatten, und baf wir rafder als auf anderent 1 ecg in das eisfalte antarktifde Waffer mit feiner cigenartigen pelagifden fauna gelangen

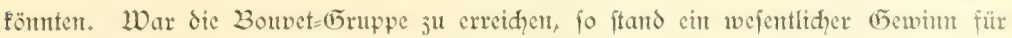

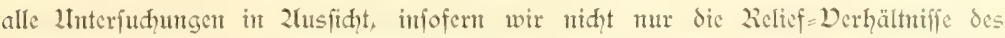
27eeresbodens und die Befhaffenheit des (Frundes in Grebieten auffläten, weldie niemals mit dem sot durdforfht wurden, fonden aud Eclegenheit fatden, die (Frumb. fauna it jenem CEebiet ju erbeuten, weldes ein Bindeglied jwifhen der uns wohl befamten fauna der Zliagelhaens=Strafe und der Kerguelen abgiebt. Endich reijte is aud, ju der Sofung cines geographifhen Problents cinen Beitrag ju liefern, das immerhin einiges Interefie darbietet, injofern hervorragende forfdungsteifende fith vergeblid bentïhten, die Exiftentj des ant 1. Januar 1759 pon dent Zeeftor der autarf = tiphen forjdqung, Sojiex Bouvet, unter dem 54. füblidien Breitengrad und $4^{\circ} 20^{\prime}$ o. S. geftuteten „Cap de la Circoncifion" ju erweifen. Weder Coof (1675), nod, Jantes RoE (1845), noh 2roore (1845) vermodten trot aller hicrauf verwendeten 2liühe Sic "Souvet= Infel", als welthe injwifhen das vermeintlidic Dorgebirge eines Süd Kontinents erfamt war, wieder anfüinden. Jmmerhin hatten in zlufang diefes Jahrhunderts jwei Kapitäne von Walfifhfängern, welche im Dienit der Sondoner firma Enderby ftanden - nänlid, Eindjay (1808) und 2Torris (1825) -, beftätigt, daf in der von Bouvet bejeidnteten Region eine bejw. jwet Injeln liegen, deren Pofition fie freilid abweidgend beftintmten. Zeuerdings neigte man, im Linblid auf die vergeblidien Bemühungen un ihre Wiedcrauffindung, ju der Dermntung, dafe dic Jnicln, deren 2ratur 2rorris ausdrüflid, als vulfanifh bejeidntet, entweder der

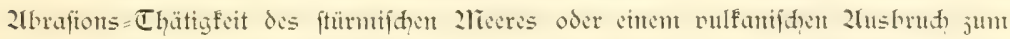

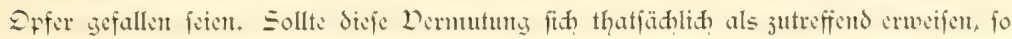
ftand ju erwarten, daf wir durd, Solungen in der Sage waren, derartigen Eypotheien cine geficherte Interlage ju geben.

Da die "Daldivia" fin als ein vorjüglidhes Expeditions=Sdiff bewährt hatte, reifte int Dertrauen auf die umfiditige Sdiffsführung nou Kapitän Kred der EnthluE,

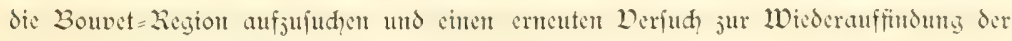
von drei Expeditionen vergeblid gefubten Infelgruppe ju wagen.

Die günftige Witterung hỉlt nad, der 2lbfahrt vort Kapftadt aud, während der nähiten Tage an, und fo vermodten wir alle 2lrbeiten in wïnfhenswerter Weife ju fördern. Zhit Rüffidht darauf, daf̧ wir von jeţt an in Regionen vordrangen, deren

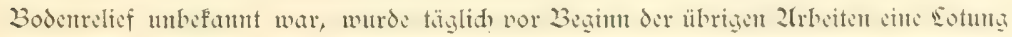


ausgeführt. Sdion die crite, am 14. ZTovember vorgenommene, überjeugte uns von

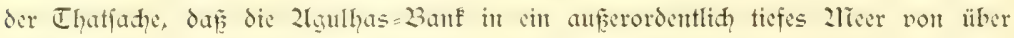
$4000 \mathrm{~m}$ abfällt. Es mag aud gleỉh darauf hintgewiefen werden, da w wir während Der näd,ften Jeit feine Derminderung der groken Tiefen nahweifen fonnten. $2 \mathrm{Im}$ 17. 2Tovember loteten wir des 2liorgents allerdings nur $2595 \mathrm{~m}$, dod, wurden wir fihon an Zadhmittag desfelben Tages durdh den Zaadweis einer Tiefe von $5250 \mathrm{~m}$

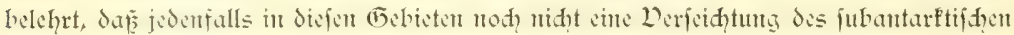
2rieeres ju erwarten war. Weldhe ïtberrafdungent uns die weiteren Sotungen bei dem Dordringen nady Süden braḑten, foll nod eingehender fpäterhin gewürdigt werden.

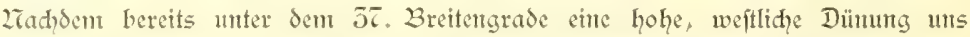
belehrt hatte, daf wir in dic Regiont der ftändig wehenden "braven Weftwinde" cin= getretent waren, auf deren Bedeutumg für dic Segeljdiffahrt nah Zluftralien zuerft James Rof hingewiefen hatte, begann an 16. 2Tovember der Weftwind ftürmifh cinjufetzen. Wir begegneten an diefem Tage cintem englifhen Sdiffe, dem Dantpfer "Titania", der auf der fahrt nad Süb=2luftralien begriffen war. Es war für lange

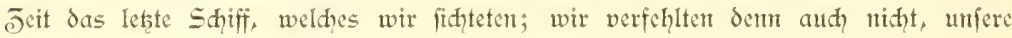
Route mit der Bitte unt 2lieldung ju fignalifieren.

Während wir bisher uns nod in dent Warmwaffergebiet bewegten, das cine Dber= flähentemperatur von durdijhnittlid $1 \tau^{\circ} \mathrm{C}$ anfwies, fo gelangten wir jwifden dem 39. und 40. Breitengrade in Regionen, wo die warmen 2lusläufer des 21gulhasftromes

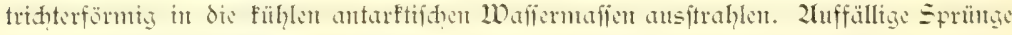
in der Dberflädsutentperatur, welthe ant 16. 2roventber Interfdiede bis ju $6^{\circ} \mathrm{C}$. anf= wiefent, perrieten dic zluflöung des warmen indifhen Stromes, die aud dadurd fhon

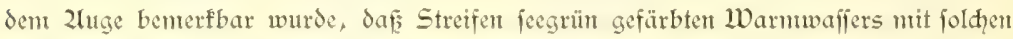
von intenfiw blau gefärbtem Kaltwaffer abwedficlten. Es war dies um fo auffälliger, als päterhint bei dent Eintritte in die Warmwafier des Indifdent Decans dic färbung (id umgefehrt verhielt, und gerabe das Warmmaffer durdy feimen tiefflauen Ton hervor= ftady. Die Temperaturiprünge erfolgten oft fo rajh, da wir mit den Thermometerablefungen faum nadjufonmen vermodyten. Ilm durd einige fpecielle Daten aus umferen ftündlid crfolgten Tenteraturablefungen dic Derhältniffe ju beleud̨ten, fei hervorgehohen, daf am 16. 2Toventber mittags $1221 \mathrm{hr}$ die Dherfähţentemperatur

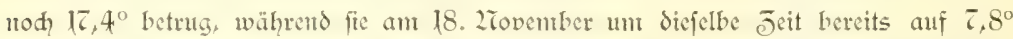

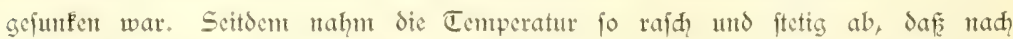
Ïtberfhreiten des 55. Breitengrades an 2ł. 2Tovember bereits Dberflädhentemperaturen von $-l^{\circ}$ gemeffen wurden.

2liit dicem faft unvermittelt erfolgten Eintritt in das antarftifine Kaltwailer= (5ebiet ftand aud cine böllige 2̌nderung in der Jufammenfetsung der an der Ober= fläḩe flottierenden Drganismen, des fogenannten planfton, im อ̈lfanmenhamg. 2In 
17. 2Tovember trafen wir jum erftenmal im Dberflädenwaffer jene Diatomeen und niederen Drganismen an, weldhe bon nun ab faft jwei 2lionate hindurd, die Seit= formen des Falten Dberfläd,entwaffers repräfentierten.

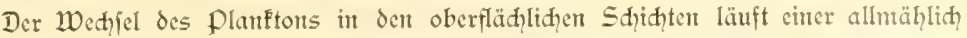
arfolgenden Z̈hnderung in der Befhaffenheit des 2liecreshodins parallel. Witul non dem Sande, wo die jogenanten "pelagijden Sedintente" in dem Tiefenfilam vor= herrfhen, fpiegelt fidh in den unterfecifden Grabitätten das Eeben an der Dberflädhe infofern wieder, als die abgeftorbenen Eeiber niederriejeln und die unlösliḑen Skelette den Gauptbeftandteil des Bodens bil= den. ZTahbent wir wohenlang

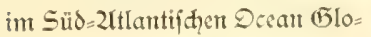
bigerinenjकlantm angetroffen hatten, mifditen fid demíl= ben von etwa dem 40 . fïis= lidfen Breitegrad an immer reidylidfer bie aud in nite= origeren $\mathcal{B}$ reiten nadhweis= baren Diatonteenidhalen bei, welde allmählid von dem 44. Grad an die Dber= hand befanten und fiflief̧lid cinen reinen Diatomeenflylid bildeten. In das Grenjgebiet ihaltet fidh ein idmaler Streifen ein, der vorwiegend aus den Sthalen groferer und fräftiger Radiolarien gebildet wird. Die beiftehende 2rbbildutg mag dent Sefer dicfen intereffanten antarftifden $R_{a}=$ diolarienfकlicte verfintuliden, den wir unter dem 49. jübliđen Breitegrad antrafen. Die
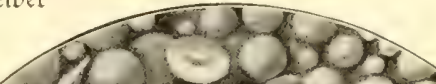


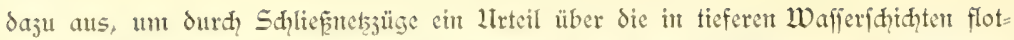
tierenden Drgatismen ju gewinten. Befonders die am 18. 2Tovember ausgeführten

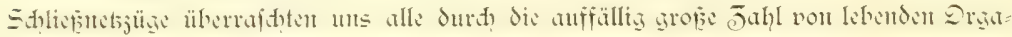
nismen, weldie wir bei jwet Jügen in Tiefent jwifden 1600 und $1000 \mathrm{~m}$ fḑwebend

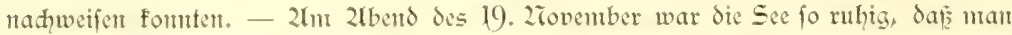
vermeinte, auf der Elbe ju fahren. Fin interfifues zlbendrot, von der bleifarbenen Dber-

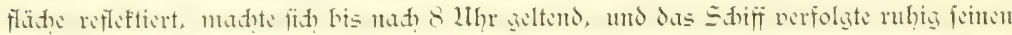

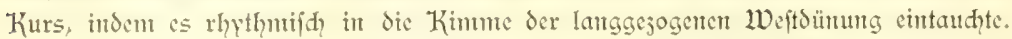

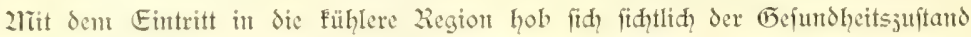

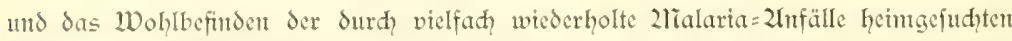
2ritiglieder der Expedition. Zlllerdings madte fidh an den nädfiten Tagen die rajale 2lbfilflung der suft, weldhe ungefähr gleidhen Sdyritt mit der Temperaturabuahnte des Dberflädquwaffers hielt, fo emtpfinslidy geltend, da faft nientand von Katarrhen veridgont blieb, die indeffen fantell vortibergingen. 2tud forgte die ant 19. 2Tovember jum exftemmal angelafiente Dantpfheizung dafür, dafi.wir in Salon und in den Kabinen uns behaglid fühlten.

Das gute Wetter follte freilid nidgt lange anfhalten. 2fun 20. 2Tovember beganm das hodfftchende Barometer won $760 \mathrm{~mm}$ auf 758 zu fallem, und gleidjeitig fadte der von Zrordoft nad Weit ju Süb ungehende Wind jum fdqweren Sturm an. Da

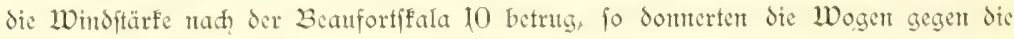

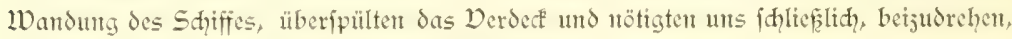
unt gegen den gewaltigen Seegang arjudampfen.

Das rajdye fallent des Baronteters petzte uns an ppäteren Tagent mid̨t mehre in Ïtberrajdutg, aber als wir es junt erftenmal erlebten, maḑte die tief nadh abwärts fteigende Kurve des Regiftrierbarometers cinent faft unhemtlithen Eindut. Dabei ver-

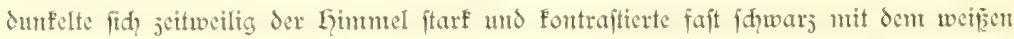

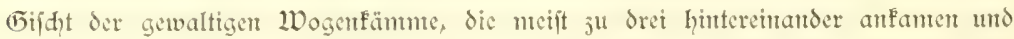

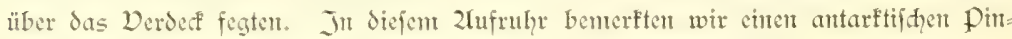
guin, der mit heiferen Sdyet durd fräftige Sḑläge mit den ju flofien untgebildeten

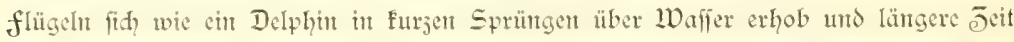
dem Sdiffe folgte. So redit in ifrem Elemente fühlten fidh die Sturmwögel, unter

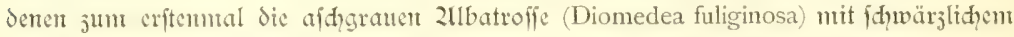
Kopfe und weipen 2lugenlidrändern gefpenfitifo wie Dampyre ihre erftaunlithen flugfünjte in ruhigen eleganten Kurven unt das đdwer arbeiterto Sdiff ausführten.

21 th 21Torgen des 21. 2Tonember bot das 2lieer bei gelegentlid durḑbreḑender Sonne

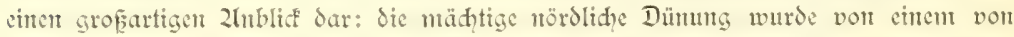
Weften formenden Wogengang durḑfreugt und bedingte cite wild aufgeregte, pradit. voll blau und weişăämende Sec. 
Da wir in weftlider Ridfung gegen den Wind andampften, wurde in regefmanaigen Intervallen das Sdifff durd die von Lorden fommende Dünung geparft und jur Seite geworfen. Dies hatte ein faft unerhörtes Sdjlingern jur folge, bei dem in den $\mathfrak{S a b o}_{0}$ ratorien dic Ğläfer aus ihren Repofitorien herausfuhren, die Treppen mit Zieagentien übergoffen wurden, und gar mandjer dem angefdraubten Drebftuhl Dalet fagte, um in unfreiwilliger Reffe mit dem anderen Ende des Salons Befantidiaft zu madyen.

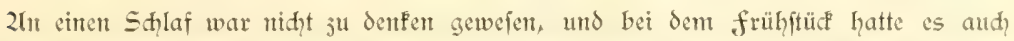

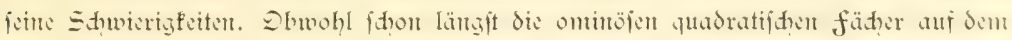
Tifhe befeftigt waren, fo flogen bod, Teller, 2lieffer, Söffel - midht minder aud die Stewards - unther, und niemand war ju beneiden, der etwa gleidyjeitig ein weidhes Et und eine Taffe voll Thee ju bewahen hatte. - Ebenfo rafd, wie das Barometer gefallent war, begam es an 21. 2Tovember wieder ju fteigen und die für

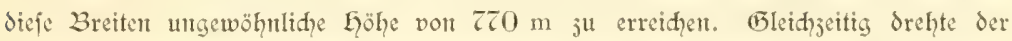

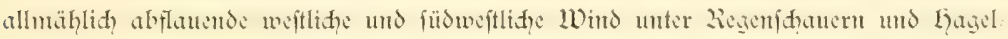

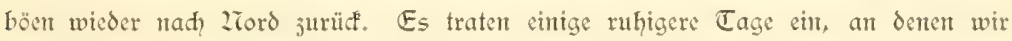
freilid, durd die von num an häufiger fidh einftelfenden 2rebel an einem rajdgen Dor= wärtsfonmen gehindert wurden. Wir waren öfters genötigt, ju ftoppen; gints es trotzdem bei 2rebel mit halber Kraft vorwärts, fo ertönte in regelmäß̨igen Jutervallen die Dampfpfeife, um das Edyo von cinem etwa vorliegenden Eisberge zu weden.

So trafet wir denn am 24. 2roventber in der Fiöhe des 54. Brettengrades auf jente Region, in weldher die englifhen 2romtiralitätsfarten drei Jnfeln verjeidnnen und fie als

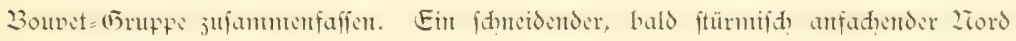
hatte das Derdet mit Glatteis überjogen, und mehrmals fin einftcllende Zrebel er

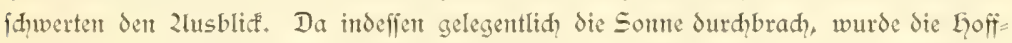
mutg niḑt aufgegeben, über das Sdhiffal der Jufeln 2lufidhluf ju erhalten. Während in dent leşten Tagen fehr anjehtlithe Tiefen zwifhen 4000 und $5000 \mathrm{~m}$ (jweimal fogar Tiefen über $5000 \mathrm{~m}$ ) gelotet worden waren, ergab eine am 25. Zovember vor= genonmente sotung $5585 \mathrm{~m}$, und die an 24. ausgeführte nux $2268 \mathrm{~m}$. Fierdurd? war

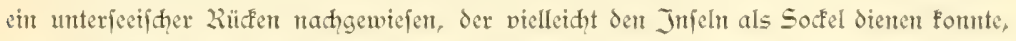
und es handelte fid nun darunt, fyftematif die ganze Region abzuinden. Der Zavi= gationsoffijier hatte zu diefem äwede die von Bouvet, Eindfay mo 2rorris an gegebenen Pofitionen ihrer Eandidtungen in cine Karte cingetragen, und man beganm

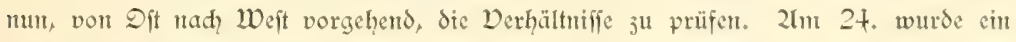
Erfolg nidht erjielt, obwohl der Fimmel jweimal aufflarte und auf furze jeit ganj wolfenlos war. Immerhin blieb die Euff eigentümlid, diefț, während das Waffer durdh mifroffopifhe 2llget, weldhe geradeju einen Brei an der Dberflähe bildeten,

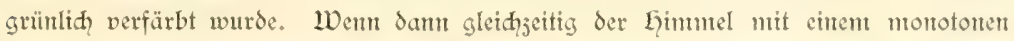

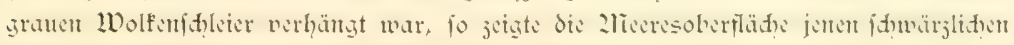


Ton, deffen fo oft in der Reifebefdreibung des "Challenger" gedadt wird. Fegen 2thend brath die Somte wieder durd und gints hinter ciner impofanten Wolfentmand unter, in die man anfünglith hohe Imfeln hineindeutete, bis erft allmählid dic Cüu= fhuntg erkantut wurde.

2 tm 21torgen des 25. 2Tovember loteten wir mitten jwijd̨en den angebliden Eand= fidtungen von Bouvet, Eindiay und 2rorris cine Tiefe von $3458 \mathrm{~m}$. Dantit

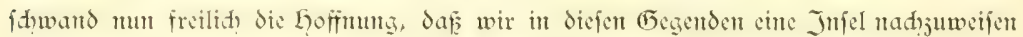

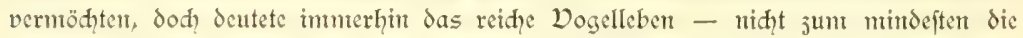
Erbeutung jweier Kaptauben mit Brutfled - auf die Zähe von Sand hin. (G) legentlidy auffommende Sdueeböen wedfielten mit einem Zufflaren des Gimmels ab (aud) während der furjen ziad, war die Enfft jiemlid fiḑtig), und fo wurde die sudpe

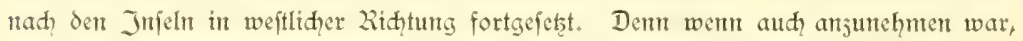
da隽 dic alten Secfahrer die Brette jiemtid, riḑtig angegeben hatten, fo war ein Jrr=

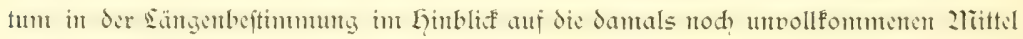
nidht ausgeidlofien.

(5egen 2litttag des 25. 2Tovember fant der erfte grofie Eisberg in Sidht. Er madte,

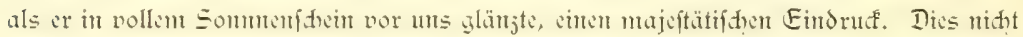
jum mindeften durd die ftolge kuhe, mit welḑer der Kolof mie veranfert dalag, wäh=

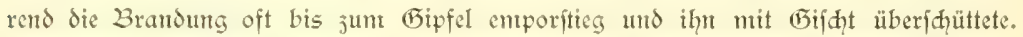
Gatte man bisher den Shaunt der Wogen als den Inbegriff des blendend Weifen betraḑtet, fo war mant überrajht, da biejer fin von den wie frifd überifmeit er= fihemenden fläḩen cines von der Sonne befhientenen Eisberges graugelblid abhob. Dabei fdien ein feiner bläuliḑer Duf̣t über demt Cranjen ju liegen, der in den Spaltent und Grotten in ein tiefes Kobaltblau überging.

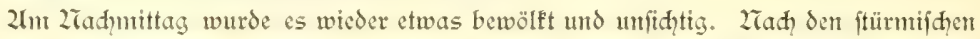

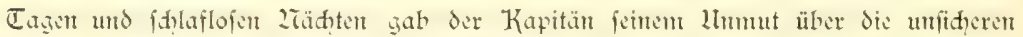

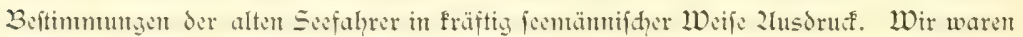

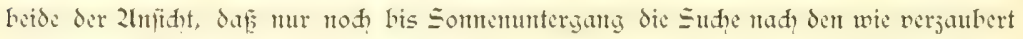

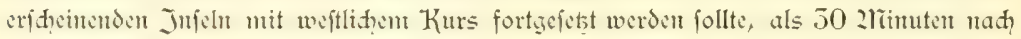
5 Llhr unfer erfter Dffijier mit dem 2lusruf: "Die Bonvet's liegen vor uns" das ganje Sdifif in Zlufregung bradte. Zlles ftürmte nad vorn und auf die Brürfe, und da lag denn in veridfwonmenten, bald deutlidfer hervortectenden Konturen, nur 7 Seemeilen reḑt voraus, in feiner ganjen antarftifhen praḑ̨t und Wildheit ein fteiles Eiland.

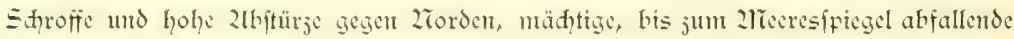

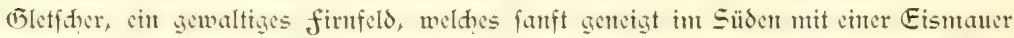
im 2lieer endet, die Kämme der Ģ̈̈hen in Wolfen verftedf - das war der erfite Eindrud", den wir von der feit 75 Jahren verihollenen und von drei Erpeditionen vergeblid gefud\}ten Injel empfintgen. 


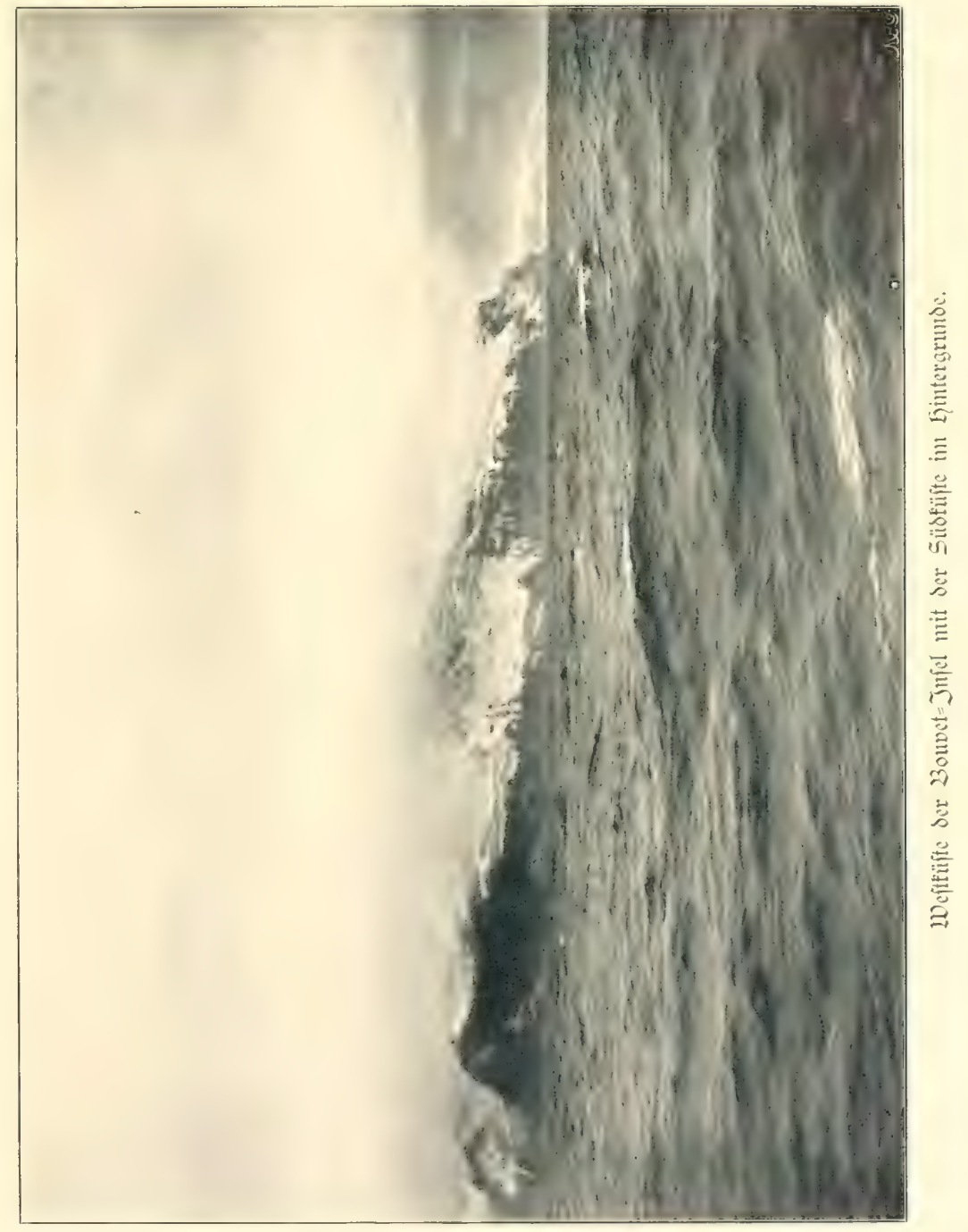





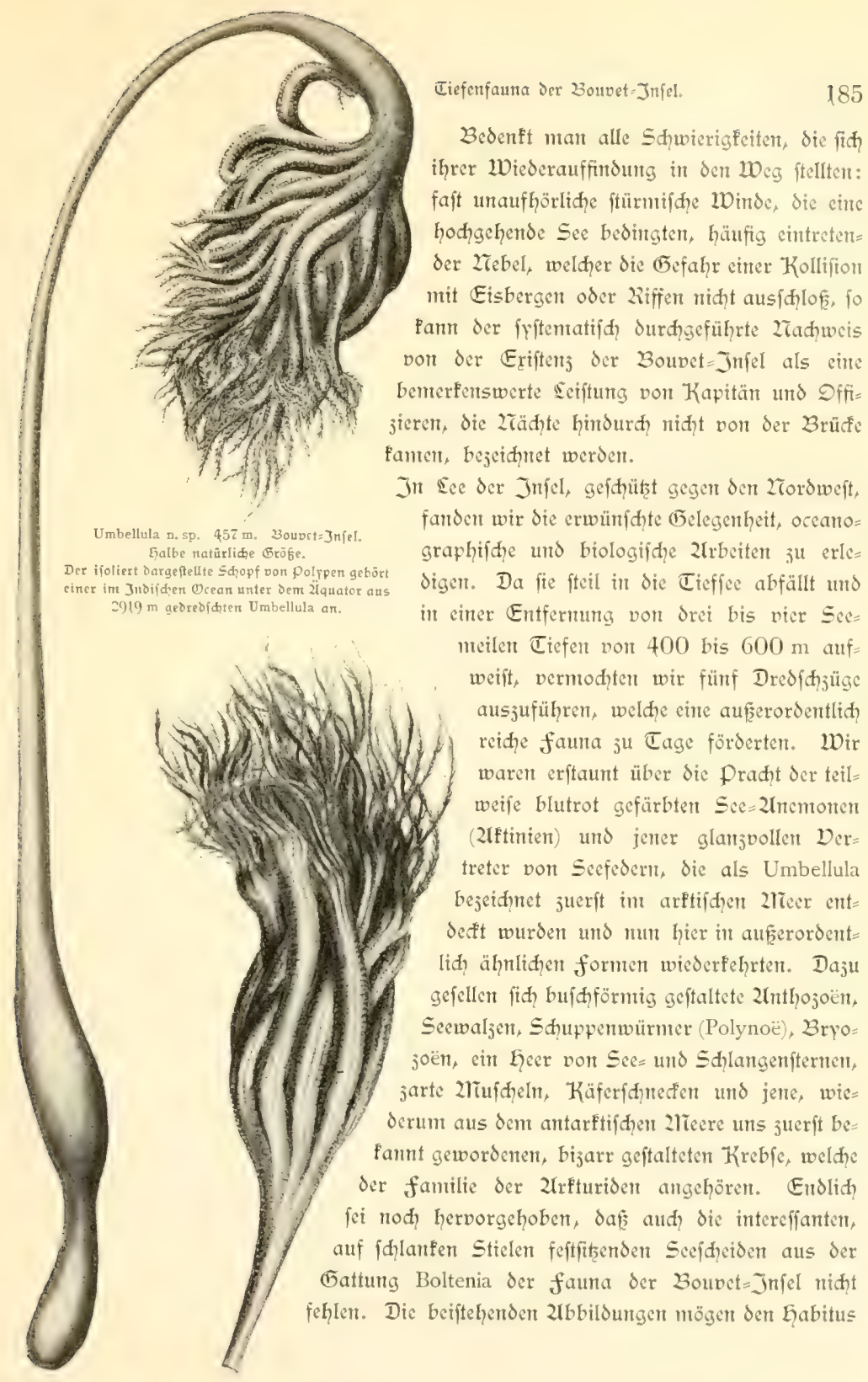


cintiger Polypen verfinmlidien; fie geben freilid feine Dor: fitlinng von der wunderbaren farbenprad,t, welde diefen Bewohnern der antarktifhen Tiefen eigen ift. Die Umbellula befitst einen orangegefärbten Stiel, von dem jart violett fhattiert dic grofen Polypen fich abheben; dic übrigen 2ron weifen ene nidht minter feine farben= jufammenftellung in Roja und Weif auf.

Was den allgemeinen Charafter der Tieffeefauta bei der 23ouvet = Infel anbelangt, fo giebt fie, wie von vornberein erwartet werden fomte, thatfäblid ein Bindeglied zwilhen der Kerguelenregion und der 2liaghellan'foun fauma $a b$. Zreben befannten formen tritt indefien cine fo grope Jahl neuer 2lrten auf, daf man faft den 2Infhein erbält, als ob es fid unt cine Lnterregion mit manden eigen= tümliden formen handele. LIm das Ḡejagte ant etner eng ungrenjtent artenreichen (5ruppe ju erläntern, fei auf die fünfarmigen Stlangenterne (Dphiuren) binge= wiefen. Zrah den Zlitteilungen des Bearbeiters diefer (5ruppe, Prof. jur Straffen, wurden neun Dphurentarten gedredfdt, von denen feds neu find. Don den oret befamten formen ift eine in der Sïbhemifphäre weit ver:

Anthomastus antarcticus n, sp. Kükenthal. riahezu doppelte Bröe. $566 \mathrm{~m}$.

breitet (Ophiacantha cos-

mica Lym.); cine andere (Ophioglypha Lymani Ljgm.) fenten wir pou der patagonifden Weitfüfte, cine dritte (Ophioglypha Deshayesi Lym.) von der Kerguelenregion. Lnter den meuen 2lrten finden wir Dertreter jweier (5attungen (Ophiopyren und Asteronyx), die bisher in Ser 2untartis nidit beobahtet wurden. Wir bilden sine der letstermähnten (5̃attung naheftehende neue form ab, weldye mit ihren langen an ben Enden priral aufgerollten 2lrmen fidh an Rindenforallen (Primnoella) anflammert (5.187).

2lud die 2tusbeute an Seefternent dürfte für die Erfenntuis ifyer geographifhen Derbreitung fid als wertvoll erweifen. Diefe antarfifich formen gehören nad den 2litteilungen vou Prof. Subwig nidt weniger denn freben (ธattungen an (Pontaster, Bathybiaster, Luidia,

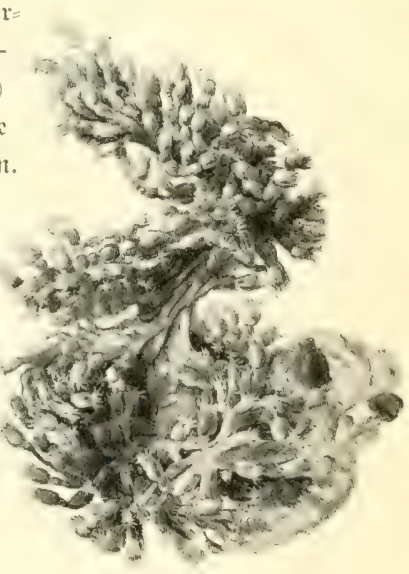

Paraspongodes antarctica n. sp. Kükenthal aus $566 \mathrm{~m}$ bet ber 3ouvet $=3 \mathrm{nicl}$. 
Gnathaster, Porania, Solaster, Asterias, Brisinga), deren Bejie= hungen 3 den bis jetst befannt gewordenen See= ftemen des ant= arftifdren (5)bie= tes ourd ein eingehendes Studium geprüft werden müifien.

Was endid? die Krufter aus Ser familie der Irfturiden anbe= triffit, weldhe auf Sull erften Blict meinut des mal= jerförmigent be dornter Körpers ihre อีugehörig= feit jul den 2lfipl= frebjen faum ver= raters, fo fint fic fijon surch dic Expeditionen der "()ajelle" und des "Ehallenger" in eitrer gröperen

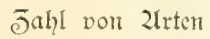
im antartijonen (5ebiet nadige wiefer worden. Eine genauere Unterfuḑung er= giebt, dan alle

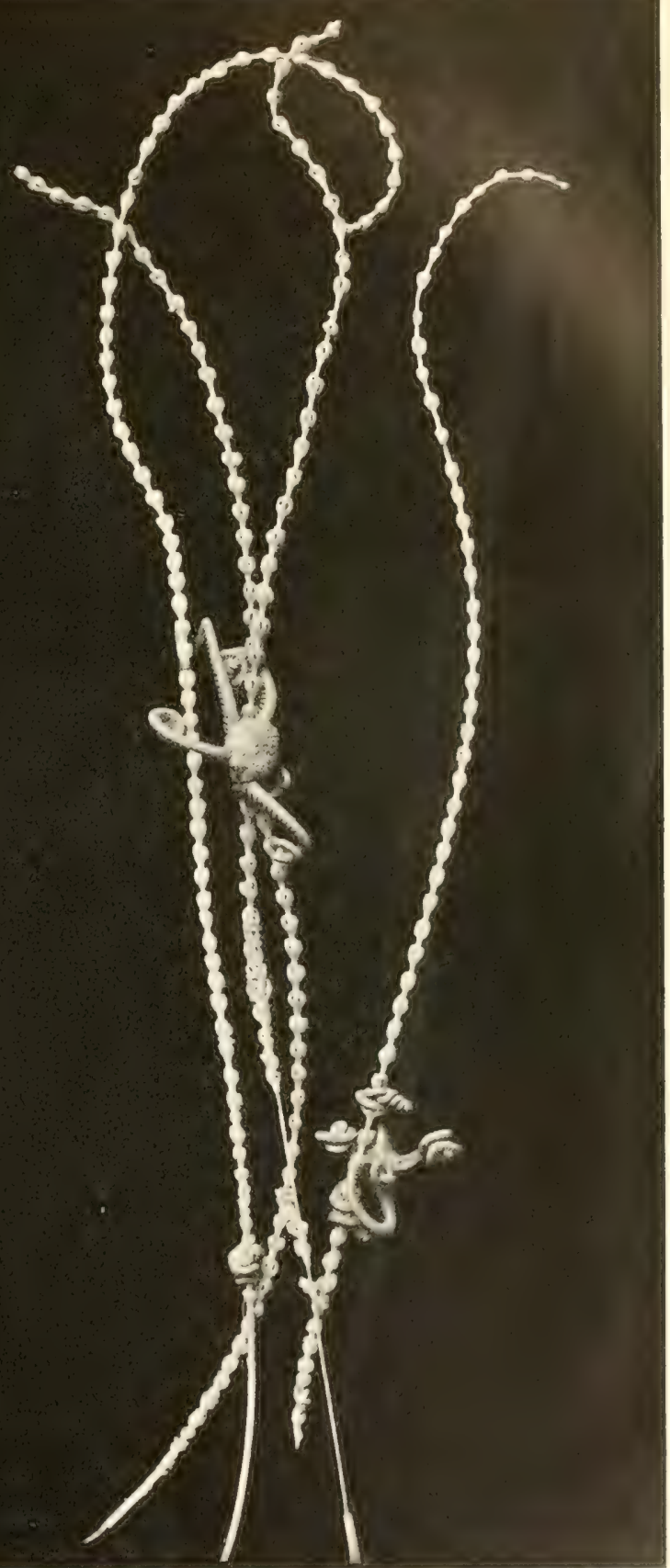

Zeue, Der Gattung Asteronyx naheflehende Ophturibe, an 2iindenforallen (Primnoella) fid anflammerno 30 uvet 3 infel. $450 \mathrm{~m}$. 2iat. Gr. 
antarftifden Zlrten durd, gewiffe ge= tifhen Eattung Arcturus veridhieden für bie erfteren cine neue (ธattumg: der Bouvet $=$ Jufel wurden dic allen bisher befaunt gewor= bentet, weldye wir int beifol= (5. 189) vorführer.

meinfante อ̈̈̈ge von der arf" find. Jur Strajfen hat daher

Antarcturus begründet. Bei größ̨ten und fđönftent unter

denen 2rrfturiden er= genden Bilde

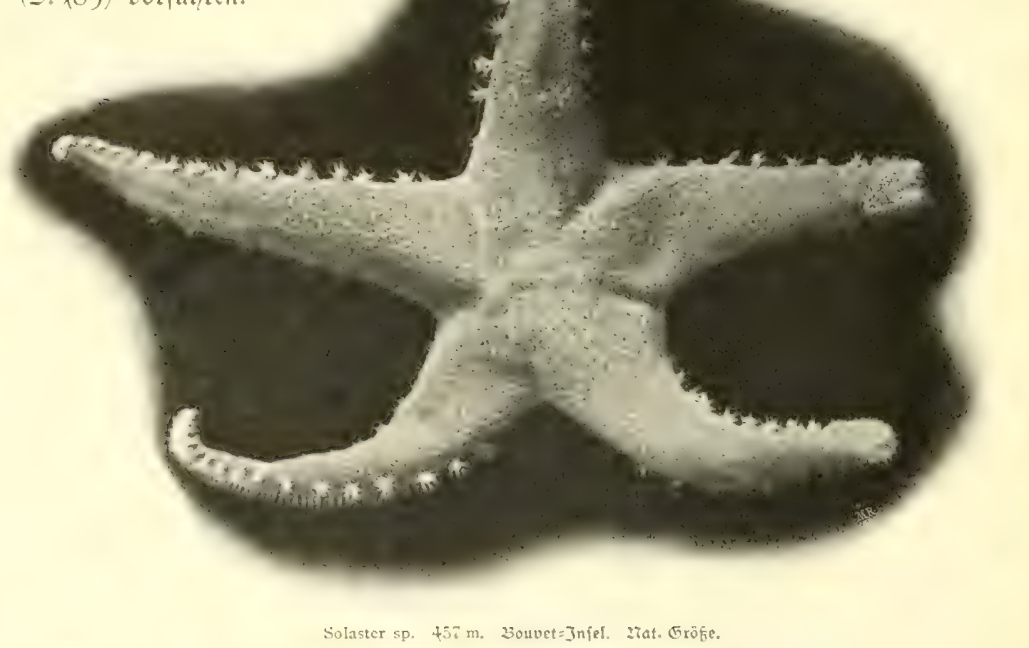

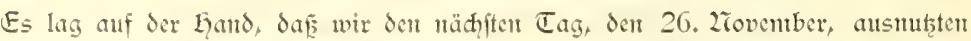

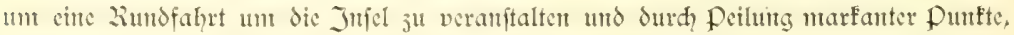
die unfer Zravigationsoffijier unter Zlïtwirfung des Kapitäns und des erften Pffijiers ausführte, cin Bild von der Geftaltung des wiedergefundenen Eilands ju gewinnen. Photographifde 2romentauftahmen, Sic freilid vielfad dadurd eridgwert wurden, daf bet der hodgehenden See und unfidhtigen Suft cint flares $33 i l d$ nidht ju gewimen war, unterftütsten den durd Deilungen gewormenen Einblicf. Es fei geftattet, an der Fand diçer 2lufnahmen cine furze Befdreibung der Jnjel ju gebert.

Die 2litte der 23ouvet = Infel liegt unter $54^{\circ} 26, x^{\prime}$ ศ. Br. und $5^{\circ} 24,2^{\prime}$ ö. S. In

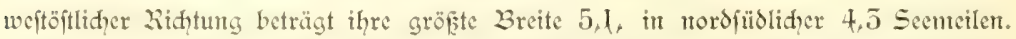

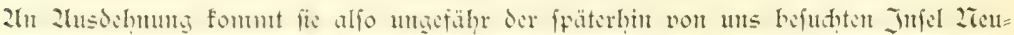

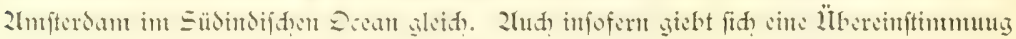
Funt, als dic Bonvet Jnjel (wie dies 2Torris ausdrüflith für fein Thontpion= Jstant lyervorhebt) vulfanifder Zratur ift. Wir haben zwar fein arftehendes Ẽeftem falagen 
fömen, bemerften aber bei den eriten Dredfjügen, daf wir uns auf grauem vul= fantifem Boden befanden, der gelegentlid, den Zetzen fdlimm jufeţte. Die in den

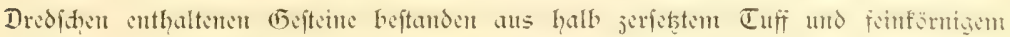
Bafalt; da fie forgfältig gefammelt wurden, wird eine fpätere Unteriudung nod, ge= naueren Zufidluf geben. Zluf die vulfanifhe Ziatur der Jnfel deutet vor allem aud ihre eigenartige Beftalt bit, die fich freilich mur eimmal (am 26. 2Tovember, mor gens 5 Ithr) fret von Wolfen ent= fihleierte.

Fine 2lios: mentaufnabme jeigt eirten twei= tell, fharf ge= jadter Krater= rand, von dem nadh Sïdent und Diten in fanf= ter 2reigung dic Gänge jum 2 lieer abfallen. 2tu dent 2Tord= oftfap madit fid indeffer bereits cill Steilabfall geltent, wic er für die ganze nördlidhe und weftlidye Küfte (a) farofiften auf Ser 2iord. wefticite) typifd ift.

In dantba: rex Erinnerung an das Juter= vili, wildis ai $^{-}$ ne 2lĩajẹtät an Sir Expedition

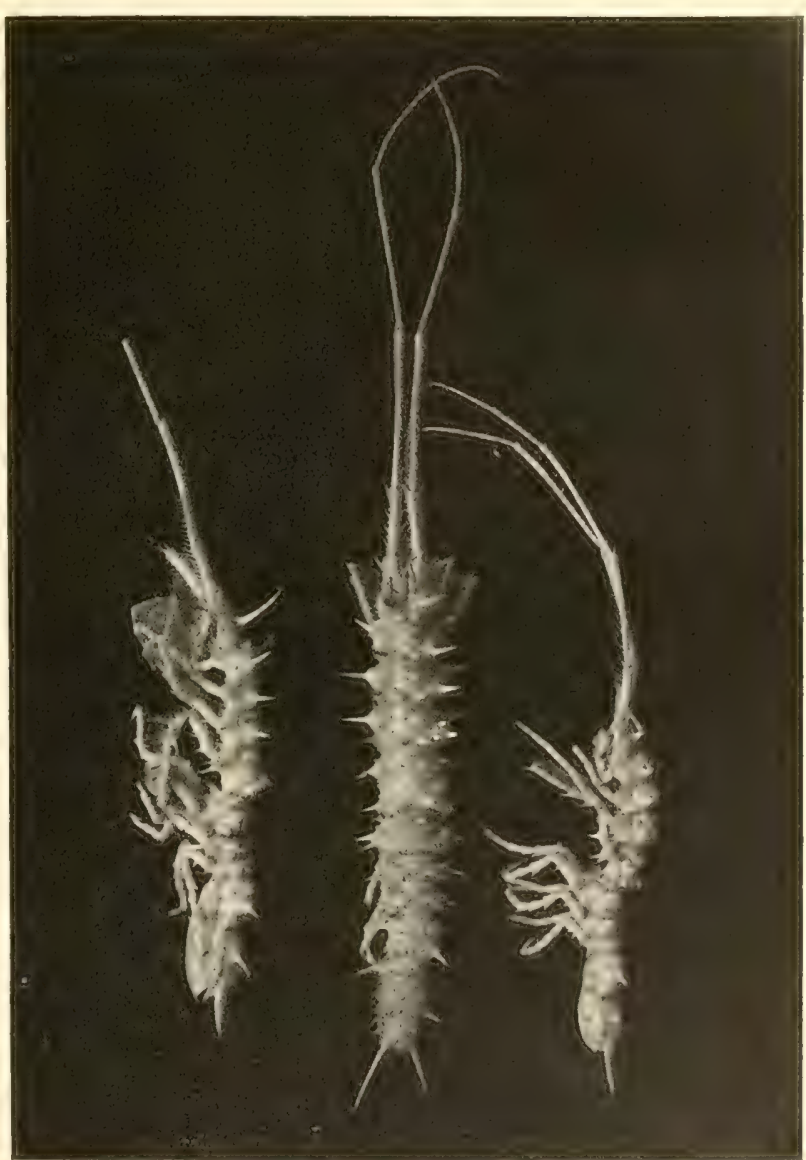

Antarcturus oryx n, sp. כux 5 traffen. 23uvet $=3 n$ nef $450 \mathrm{~m}$. 2Tat. 5r. 


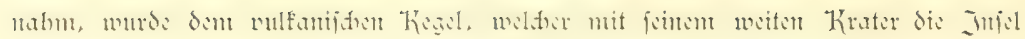
beherrfdt, der ziante "Kaifer Wilfilm=Pif" beigelegt. Die hödfte Erhebuntg des Kraterrandes lieght auf der 2Torofecte uno beträgt $955 \mathrm{~m}$.

In fünf Stellen, näntid im Ziorden, 2Tordoften, Süden, Südweften und ZTordweften, fpringt die Infel ctwas vor. Das nördithe Kap länft in cin grokes felfenthor aus; wir haben bas erffere als "Kap Daldivia" bejeidnet. Dergeblid wurbe nad einer tiefen

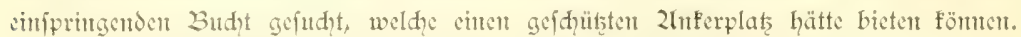

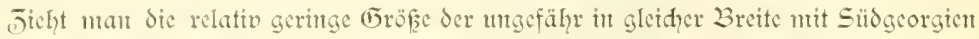
gelegenten Jufel in Betradt, fo überrafdyt die ausgedehnte Dergletfherumg in hohem 2las. Sic fam mur darin eine Erflärung finden, da das antarftifhe 2lieer in diefer Sidtumg cine Kältejuntge voridhiebt, wie fie fid aud in der auffällig niedrigent Tem= peratur des 2riecres und in der gerabe unter dicfen Eängen weit vorgefhobenen Treib=

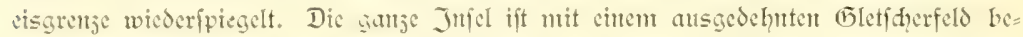
decft, weldies auf der fanft gencigten Siid= und Diffeite bis jum 2liecresfpiegel fith berabfenft und bort mit einer fenfredhten Eiswand abbriḑt. 2lüufd̨elförmige 2lusbrüde an ihrem siand denten daranf hin, daf flemere Eisberge finh von ihr loslöjen. 2ln dem Steilabfall ber Küjte fteigt die Eiswand in die höhe und fhiebt fith überall fo woit vor, als dic Eismafifen nody halt firdort. Ein prädtiger, in blaue Eümgsipalten

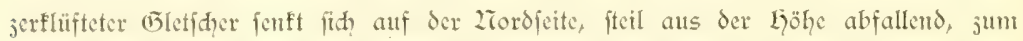
2licer. Wir legten ihm den zianten pofadowsfy= (5letfifer bei. 2lud auf der Süd=

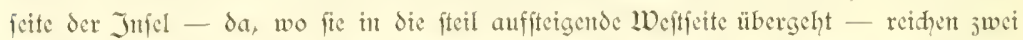
furje (5Itetidger, von denen der eine jienlidy breit ift, bis jum 2liecrespiegel. Jhr Band fdien die cingige 2lïglidfeit ju cinem Sandungsverfud ju bieten, dor indeffen wegen der nod intmer hodgehenden See und der gelegentlid fid cinitellenden zrebel niḑt ansjuführen war. 2ln allen lübrigen Stellen mad)t die fteile Kü̈fte oder die fenf= redte Eismaner cinc Eandung unmöglid?; fie wäre judem and dort gefährlid, wo

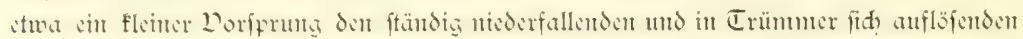
Eismaffen ḩalt gewährtt.

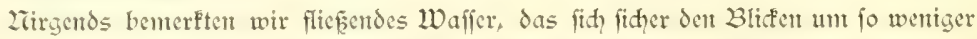
entjosen hathen fanm, als der Eteilahfall der Küfte die Bildum ron Kasfaden hedimim würde. 2rur an ciner Stelle der willd und jäh abftürjenden Weftëüfte fiel mir ein filberglänzender Strid auf, der fid bei dem zäherfonmen als ein $j^{u}$ Eis eriftarter

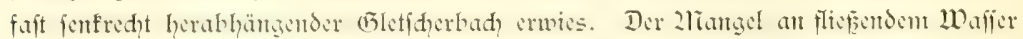

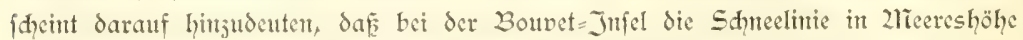
liegt; idwerlid dürfte auf Erden eine jweite Infel fid nadhweifen laffen, welhe unter gleid niedriger Breite ähnlidh ungürrtige flimatifde Bedingungen aufweift!

2lus unferen Sotutgen geht hervor, daf der vulfanifde Kegel jiemlid fteil int das 21reer abfällt. Inmmerf̧in find cinige Klippen vorgelagert, unter denen namentlich 


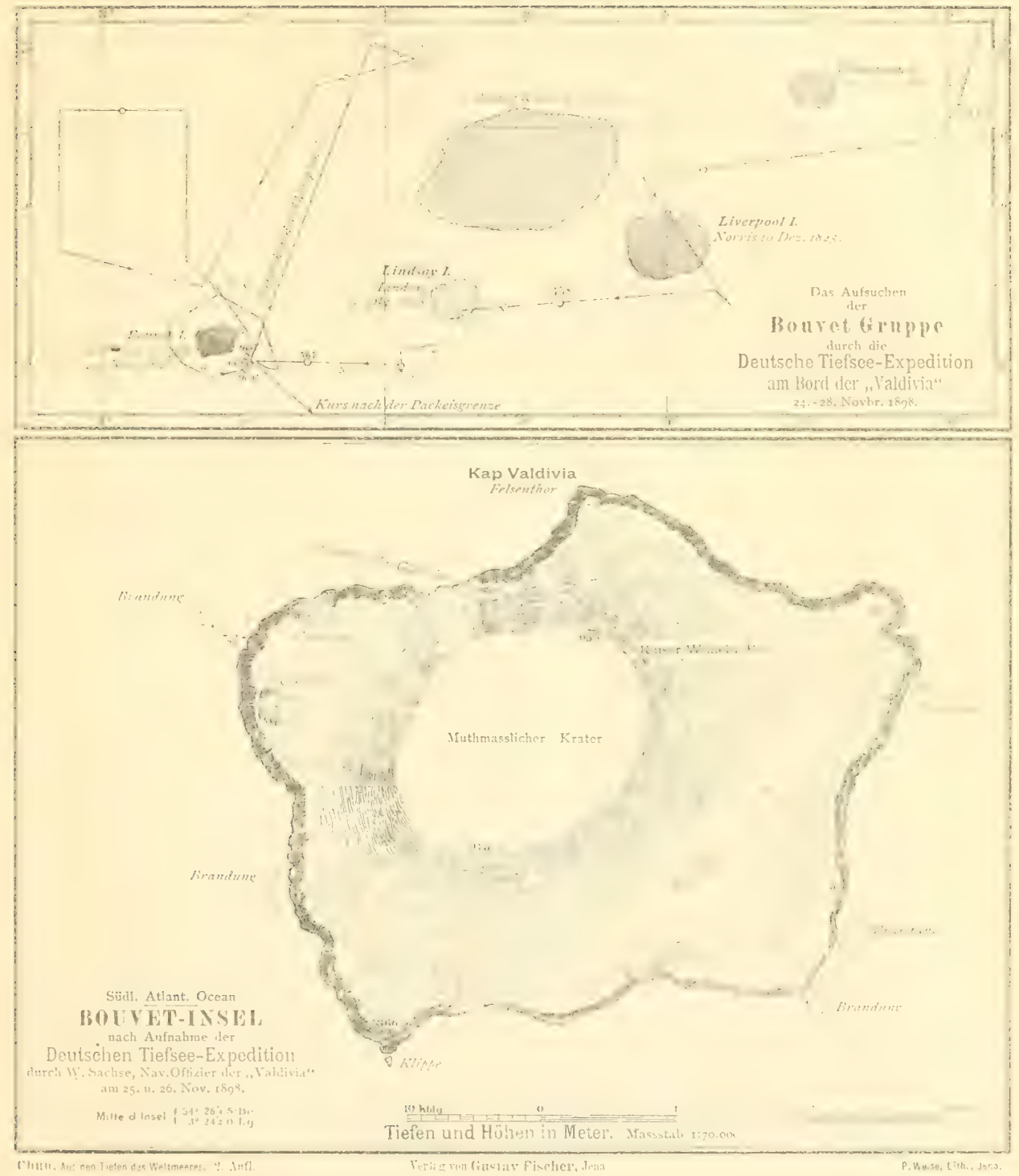





\section{Bouvet Jnjel.}

Suboftfeite bei Somnenaufgang aus 8 Seenteilen Entfermung.

26. 2rovember 1898.

Shauarell volt $f$. Illinter. 


\section{igimi: tormisis}

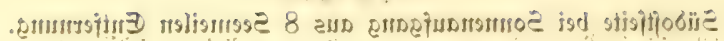
.8681 igdinsuost . .

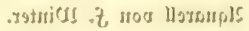




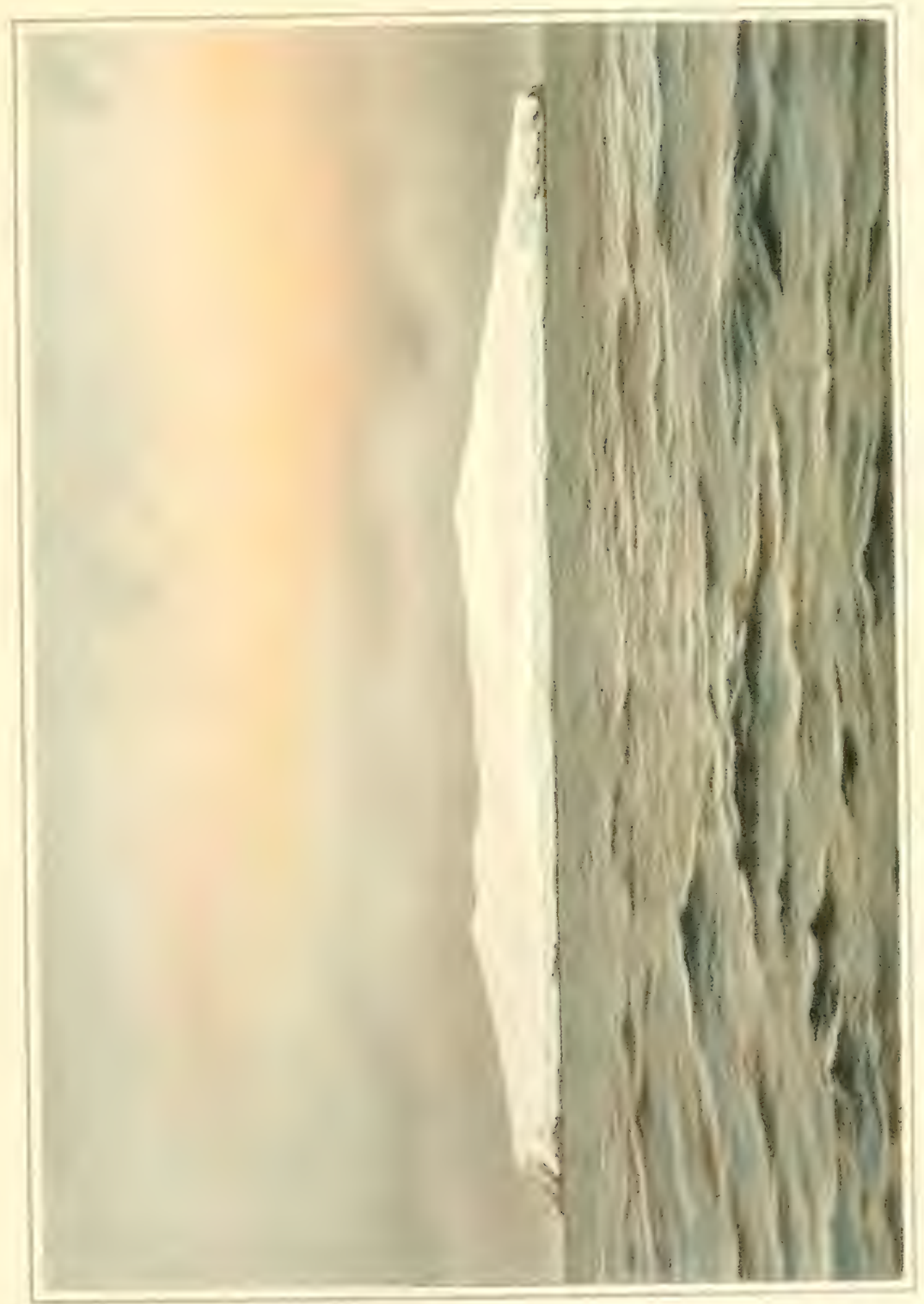





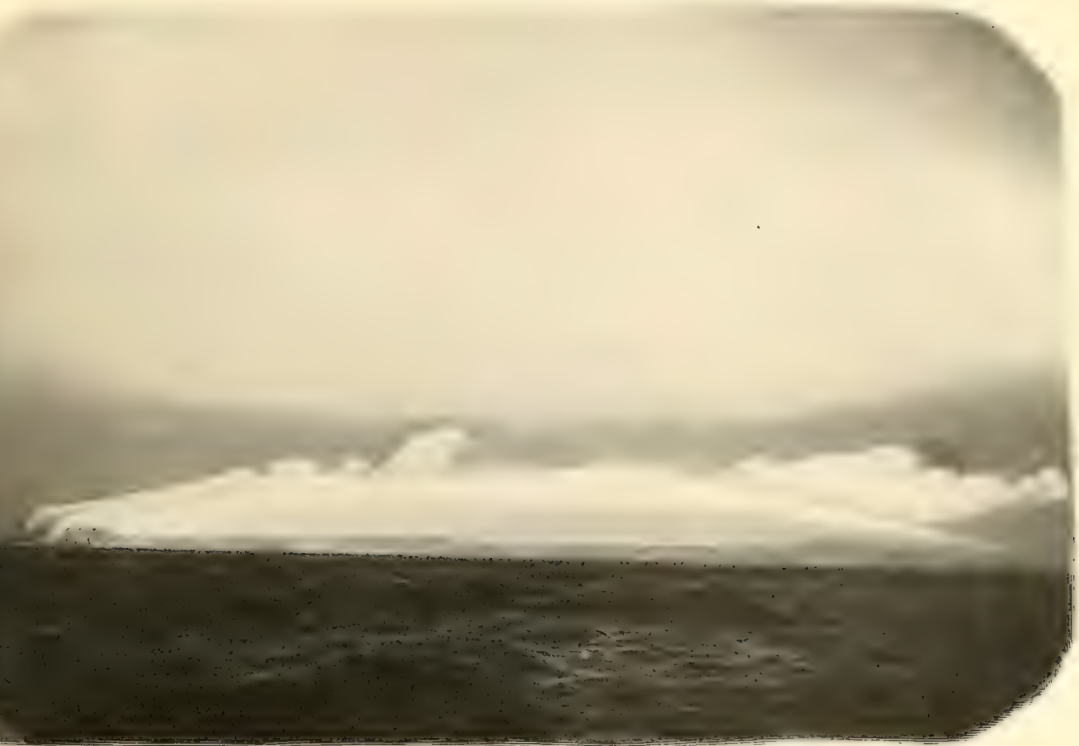

Dic 3ounet Jniel, frei bon Wolfer.

(Sachse phot.) Süboftecte ans 8 semeilen Entfernung. 26. 27ovember 1898.

sine vor dem Sübfap gelegene und feilförmig geftaltete, fowie cinige unterjecifhe, nur durh Breher fin verratende vor dent Südoftende hervorjuheben find.

Int Gegenjat ju Bonvet und Sindjay, welde von einem Baunwuds beridten, verdient herborgehoben ju werden, daf mit dem fentrohr feine Spur einer Degetation (audh nidyt aus einer Entfernung von mur jwei Seemeilen) wahrjunchmen war. 2lud?

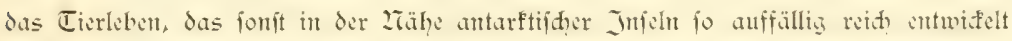

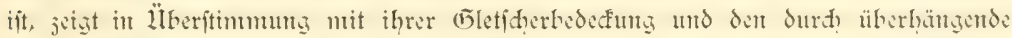

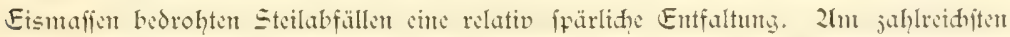

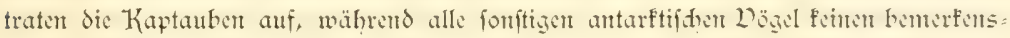

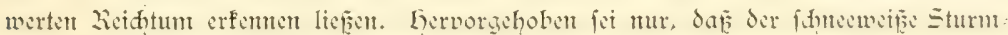
vogel (Pagodroma nivea), den fidon Rof mit vollem Redit als fidieriten Jeugen für das nahe Fis auffüht, jum erftemmal bet der Bouvet = Jnjel das Sdiffi untreifte.

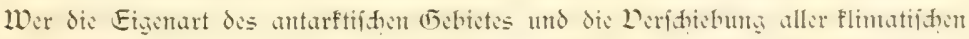

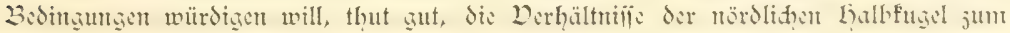
Dergleide heranjujichen. Zluf gleidher Breite wie die Bouvet= Jnjel licgen nördlid 
vom z̈̈quator Felgoland und die Jnfel Rügen. 2läan ftelle fid mun vor, dak Rügen mit ewigem Sdynee bedeft fei, Gletfher bis zum 2lieere entfende und aud im

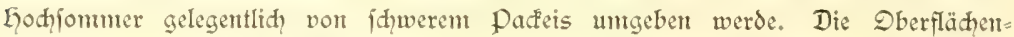
temperatur der 2Tord $=$ uto Ditfee fet - dies ftets im Sommer - unter den 2tullpunft

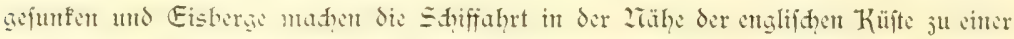
fäwierigen. Ein fahrjeug, das bis zu den Sofoten durd, Pađfeis vordringt, würde int den 2fmalen verjedduet werden, und wer gar Spiţbergen erreidte, das heutzutage von Vergnügungsreifenden auf Salondantpfern befudțt wird, würde als fühner Ent= deffer geprtefen werden, der weiter vordrang, als es cinem James Clarf Rof ver= gönnt war!

2rorris beridtet, daf er 45 Seenteilen entfernt vou "Eiverpool Island", welthes vielleiḑt mit der ję̧t wiedergefundenen Infel identijh fein dürfte, eine jweite Infel in NNO. fidftete. Er namte fie "Thompion Jstand" und vermod,te mit einem Boot eine Sandung ju bewerffelligen. Die Befatzung fiflug dort Robben und pinguine, fonnte indeffen wegen ftürmifhen Wetters erft nad freben Tagen wieder an Bord gelanger.

Da wir dent als ziuhetag geltenden Sontag, den 2б. ZTovember, auf andere Weife

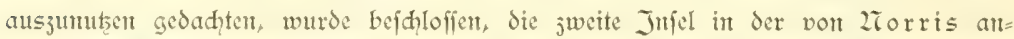
gegeberten kidhturg aufzufuden. In der 2raḑt fuhren wir bei heftigem Sdineetreiben non der Bounet: Infel ab und langten morgens $6 \mathrm{lthr}$ an der Stelle an, wo Thompion= Jsland ju vermuten war. Die Suft war unfithtig, und da cine Sotung die relativ geringe Tiefe non $1849 \mathrm{~m}$ angab, fijien es ratian, in diefer Region ž freuzen und cin 2lufflaren abjuwarter. Segzteres trat bet rajh fallendent Barometer für einige Jeit cin und geftattete, im Llmfreis non ctwa 10 Seemeilen ju fehen. Da feine 2tr= deutung won sant ju benterfen war, und cine etwas öftlither vorgenonmene Sotunt die Tiefe non $2521 \mathrm{~m}$ crgab, wurde der Tuurs bei fidftigem Wetter junäđit weft= Ith und dant im Gimblie auf den ftürmifh anfadgenden 2rordweft wieder in der

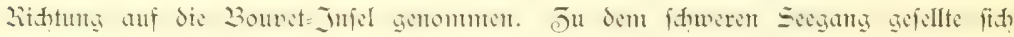
gegen 2lbent 2rebel. Jeder Zlusblit wurde benommen und fo fhiten es ratfant, dic

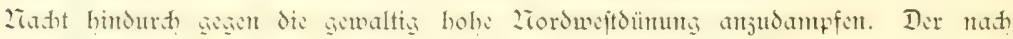
Weft drehende Sturnt jagte die feinten Santecflofen faft horijontal durd die Suft, das Tauwerf war vereift und erit gegen 10 2thr morgens flarte es auf. ZTađidem es ge=

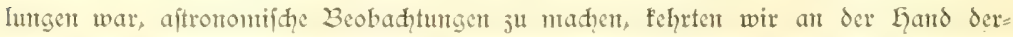
felben nady der Bouvet= Infel jurüf, die crft in einer. Entfernung vont dret Seemeilen gefiḑtet wurde. 2tuter Edntecböen, denen jeitweiliges 2lufflaren bei faft blauent Gimmel

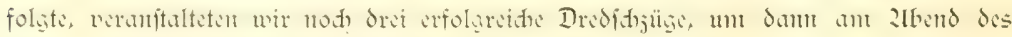

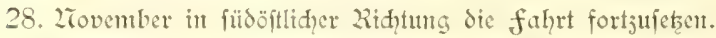

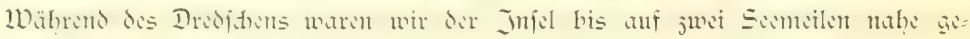
fommen. Einen leţten 2 lusblitf auf fie verfagte uns neidifid cin didhter, fie verhüllender 
Sotivet Jin fl.

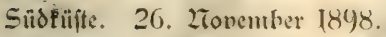


1

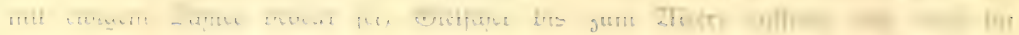

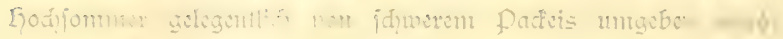

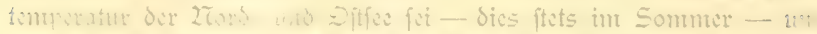

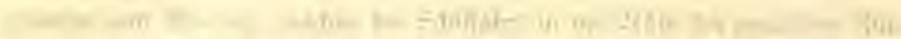

16.

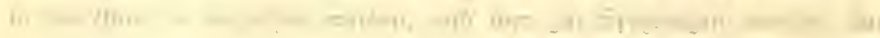

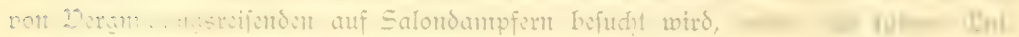

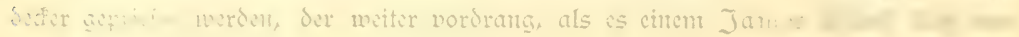
जïmt an:

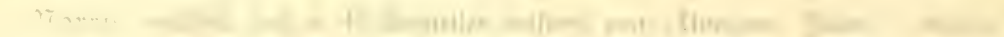

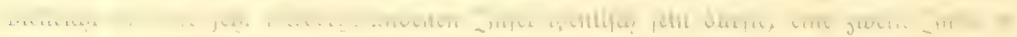

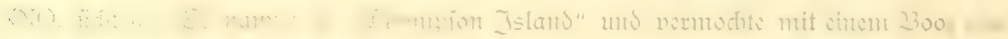

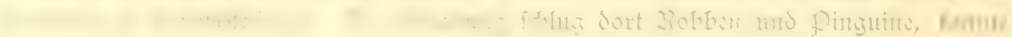

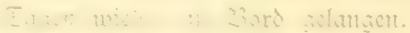

$\because \quad \ldots \quad \therefore \quad \cdots$

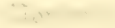
!nsit:

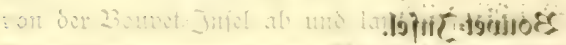

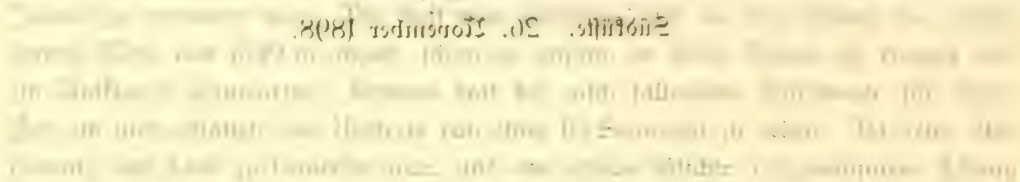

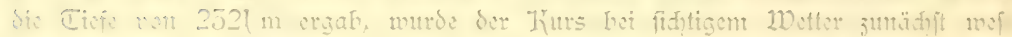

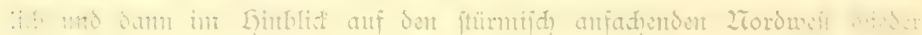

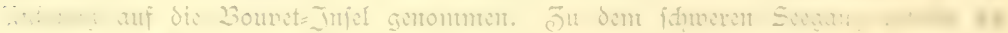

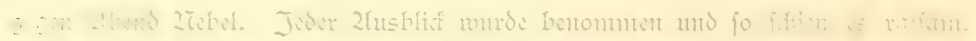

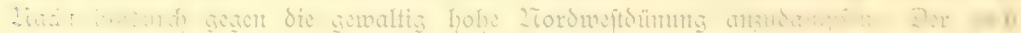

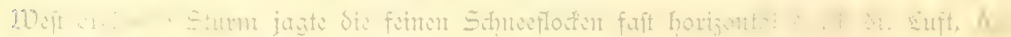

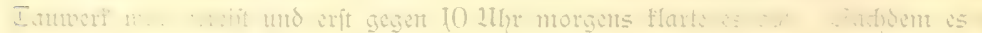

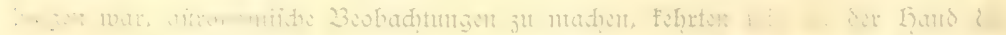

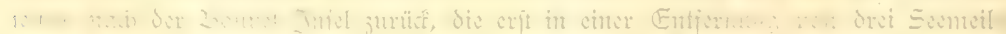

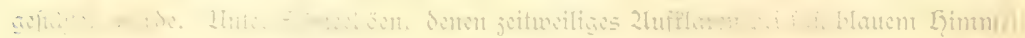

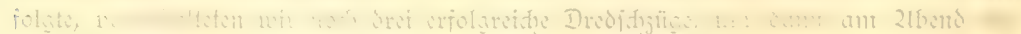

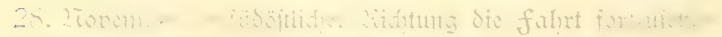

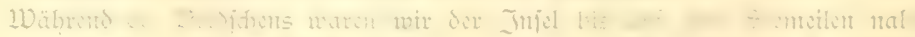




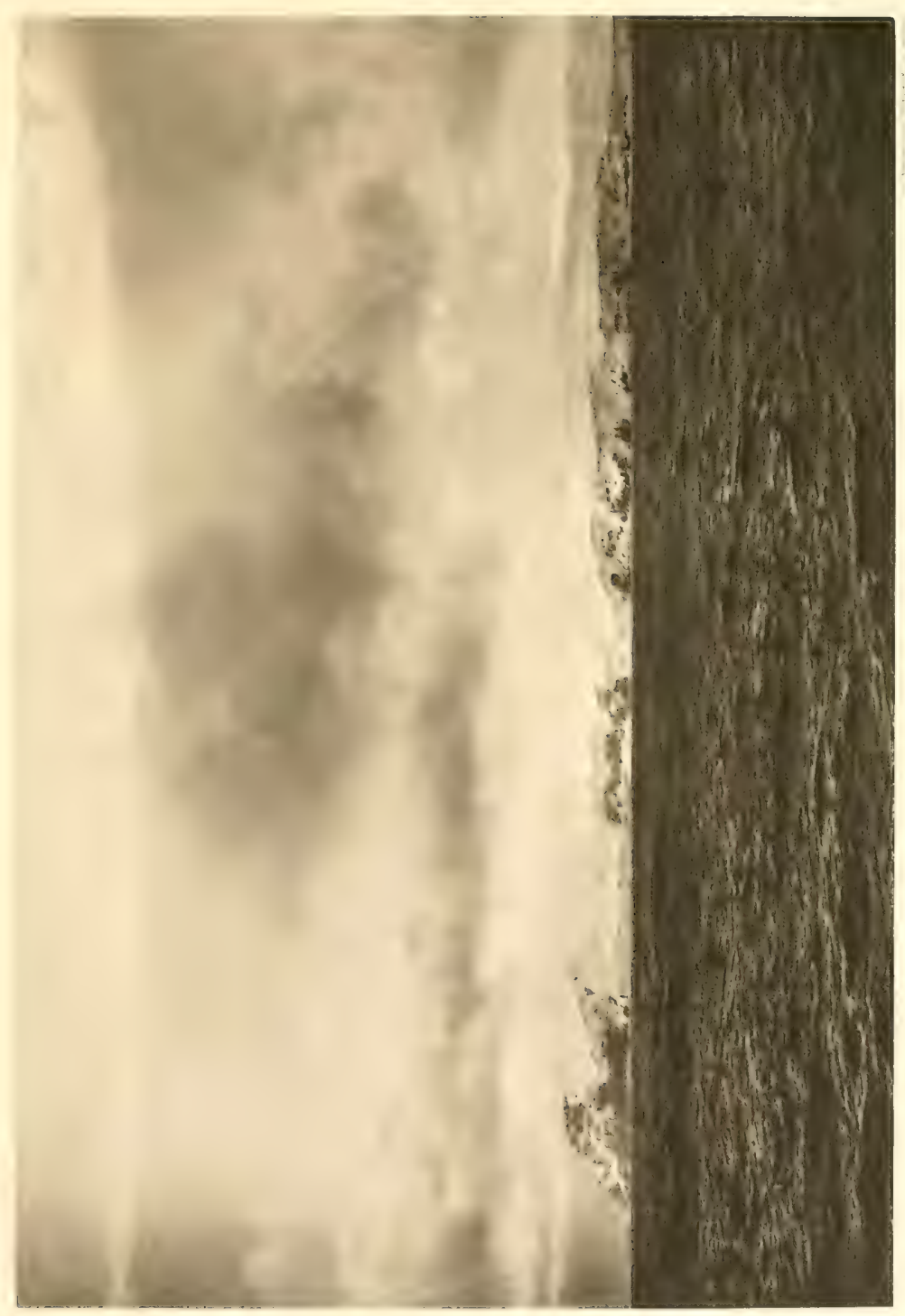



Wolfenfdleter: da verftandent wir, dafi Rof feine Spur von ihr erblifte, obmohl er nad dem von ihm genau angegebenen Kur|c faum vier Seenteilen entfent vorbeffuhr!

Int Finblick auf derartige Erfahrungen fam nidht in 2lbrede geftellt werden, da nod cirte stweite Infel eriftert, die wir indeffen nidgt aufalufinden vermoditen. Eine Erörterung der frage, ob dic jeţt wiedergefundente Jufel mit den Eandfidftungent von Bouvet, Sindfay und 2Torris identifd ift, würde in dent kahmen diefer Darlegung jul weit führen.

Wahrfacinlid find Bouvet's "Cap de la Circonciftor", Sinday = Jsland und das von ZTorris gefidtete Eiverpool= Jsland identifdy mit der von der Erpedition wieder= scfundenen Injel. Bouvet und Sindiay fandent fie mit Paffeis umgeben, beridten aber überenffimmend, da fie in SSO. refp. O. niedrig und flad ift. Sindjay fand

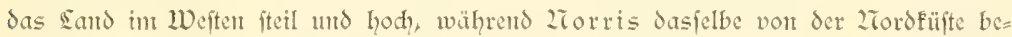
ridftet und widderum hervorhebt, dar dte Sübjeite flad war. 2fus diefent lïber= cinftimment mit dent thatfäbliden Befund dürfte hervorgehen, dafes fidh um eine und diefelbe Jufel handelt, der wir ju Ehren des Entdecfers dent 2Tamen "Bounet: Injel" belafien.

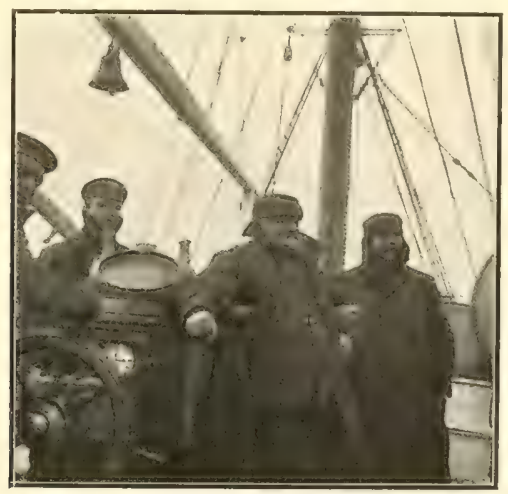

2tuf bes Sude nad ber 3 oudet $=3$ nicl. 


\section{In antarftilchen Zliecre.}

(1)

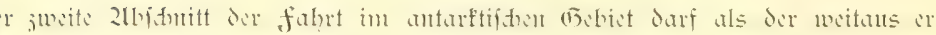
folsreidffe bejeidnet werden. 2liag es an der Wahl der Route gelegen haben,

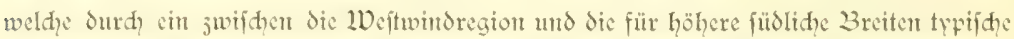
Ditwindregion fith einfhaltendes Kalnengebiet führte, oder mag den Lhtermehnen das

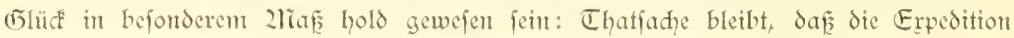
bet emen für antarftifde Derhälntife ungewöhnlid günftigen Wetter orei Woden hindurh fait ungeftört ihren 2lrbeiten nadgehen fonnte, fiplieplich mit einem feines= wegs für die füdliđen Eisverhältniffe beredneten Dantpfer den 64. Breitegrad über= fitritt und in die zähe des vermuteten antarftijden Kontinents gelangte.

Daf gerade defer Teil der fahrt trots der günftigen Witterung an das (5efdif und die llmfidgt non Kapitän und Dffijteren befondere 2lnforderungen ftellte, liegt anf Ser Land. Läufig cintretende 2rebel, heftige Sdnceböen, jahlreidhe Eisberge und weit nad) 2Torden fid ausjiehende Treibeisfelder nötigten uns ju vielfadhen Kursänderungen und mehrmals jum Durḑbredyen der vorliegenden Eismaffen. Durd vorfidtiges

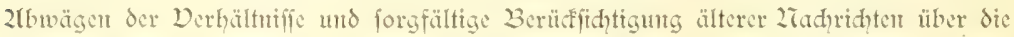

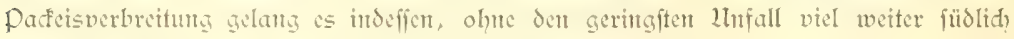
norjuldingen, als bei 2lutritt der falprt porausjufetsen war.

Sefre förderlifi war der 2lmftand, daf die Expedition bereits in 2Toventber von Kapfast anfbrad) (aljo weit früher als vorhergehende Expeditionen) und gerade jur

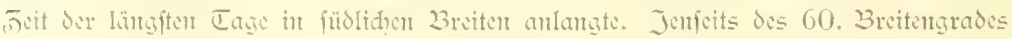


war es trot des ftündig bedefften Limmels and um 2littemadit fo hell, dafs man bequem ju lejen vemtodite.

Kurj nad Derlaffen der von Stürmen umbrauften Boubet = Jnfl (am 28. 2Tovember) flaute der Wind $a b$ und erreidyte während naheju dret $2 D_{0}$ den mur jelten die Stärfe F oder 8 nad der Beaufortffala. ङwijhen dent 55. unt 60. Breitegrad war dic Wintriditung unbeftündig. Es herridten int allgemethen nad, Süden oder meift nad) Zorden umgehende ganj flane Winde von der Stärfe 1-5 vor; erfit jenfeits des 60. 5rades begant dic öflide Windriditung fid fonftant geltend ju maḑen und um fo mehr jur Gerrihaft ju gelangen, is weiter dic "Daldivia" nad, Süden vordrang.

Giermit fteht in ëlifammenhang, daf wir während der ganjen fahnt längs der

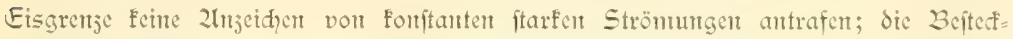
verietsugen waren in allgemetmen geringfügige und alle Dperationen wurden dadurd

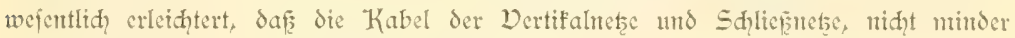
and? der sotoraht, genau jenfredt ftanden.

Jene heftigen Sdiwanfungen des Suftorucfes, wie fie unter plöblidien Windätse rungen für die Weftwindregion typifh find, deren füdlidpe Grenje ctwa durch den 55. Breitengrad gebildet wird, vermiffen wir während der fahrt längs der Eisgrenje. Dabei war der Limmel vort cinem monotonen grauen Wolfenfifleter verhängt, der nur felten fid lüftete und auf cinen furzen 2lioment dic Somte hervortreten lief. Das oceanifhe Klima bringt es weiterhin mit fid, daf bie Temperatur nur in geringen (5renzen fow wanft. Der antarftifhe Lodfiommer war in 2lnjug und wir gentoffen ifh

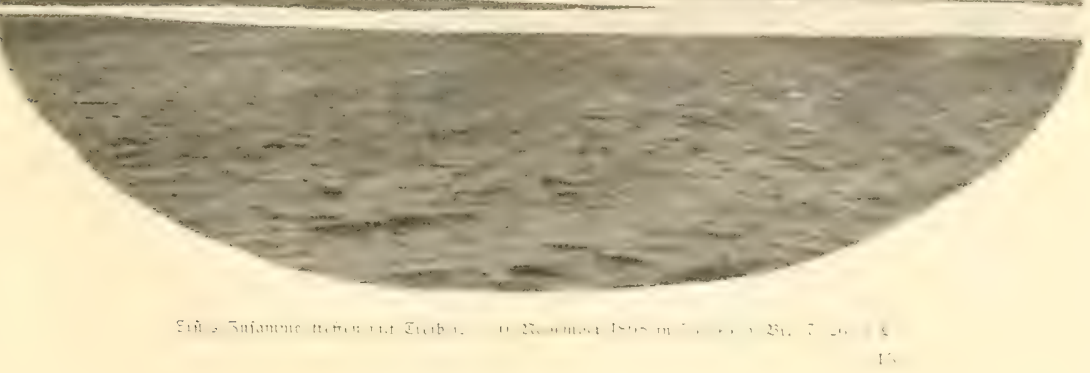


196

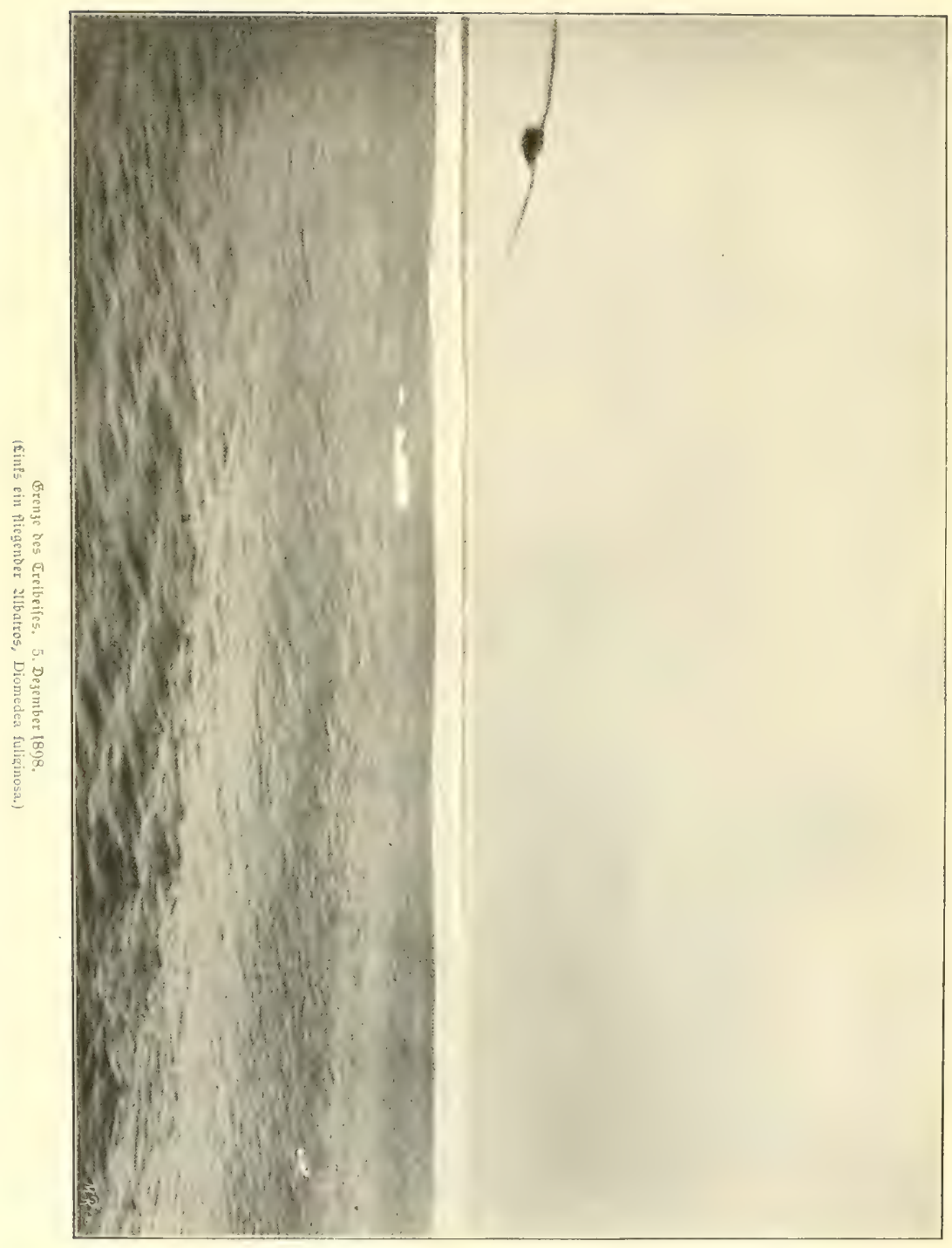


unter selegentlid cinfetzenton Shneeböen

bet einer Temperatur, die mu felten

liber $0^{\circ}$ betrus und nie unter

$-2,5^{\circ}$ iant.

Bereits ant 50. 2Tovent=

ber erreidfert wir bei ruhiger fahrt nittags fury nad? 2 Uhr unter $56^{\circ} 45^{\prime}$ sic Treibeisgrenje. Wie immer bei der 2lmäherung an das Eis, 10 jeigten fie aud hicr junäbift flempte Sdyollen oder Broden, die hänfig mit dem Winde zu langen Streifert fid ant =

ordueten. 2luf fie folgten gröfere und Keinte Ereibeisjallen. breitere quer zur 20 indriḑtumg geftellte felder von Treibeis, bie almählid mmer didter wurden und offenbar, wie gelegentlid cin heller Eisblinf perriet, in fduweres Pacfets übergingen. Die Treibeisfelder fetsten fid aus jum Teil ftarf jertrümerten Sdollen $j^{u}=$

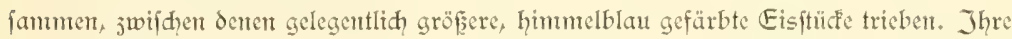
ans dem 2 affer hervorragende Partic war oft bijarr geftaltet und gewährte der Phantafie den freieften Spielraum ju Dergleithen mit Statuen, Tieren und Gerät. Es handelti fid metift um fdnteeweifse Kuppen, die auf dem tiefblauen in Waffer flottierenden Poftamente ruhten; ihr unterer noh von den Wellen befpülter Ceil war ftärfer auf= gelöt als sie obere, mandhmal anf ciner fdlanfent Eisfäule ruhende Partie. Die Kuppen beftehen wohl in der Gauptiadie aus mehrfad gejdiditeten und jujamment= gefrorenen Sdneelagen, welde man mit dem Kuder des gelegentlid, ausgejetsten Bootes leiḑt ju durdfiteḑen vermtodute. Die gröperen Shollen maf̧en hier 2 , felten $5 \mathrm{~m}$ im

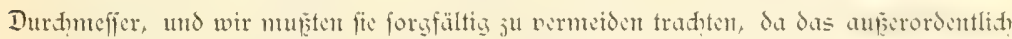
ipröde Eis leiḑt einen Sḍaden an der Sdiffsidraube hervorgerufen hätte. Jwifhen den bald langgeftredten, bald atollartig geftalteten Treibeisfeldem war das zlieer öfter fo ruhig wie ein See. Wir muţten dicfen lImitand mehrfach aus, un mitten in dem Eije unferen 2rbeiten nadjugehen. 2llerdings hatten fid während der oft cinen gatjen Tag dauenten Unterfuhungen, bet denten das Shiff ftill lag, die Eisfelder hinter uns vielfah veridhoben, und fo waren wir genötigt, fie fowohl gleidh an eriften Tage, wo wir auf das Eis trafent, wie aud fpäterhin (3. 33. ant 5., 5. unto 11. De = jember) ju durdibredien, um wieder offenes Wafier ju gewimen. Gierju jwang un

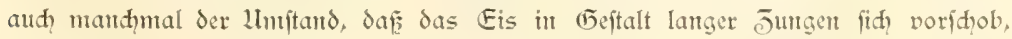
die fenfredt ju unferem Kurfe geftellt waren. Es war ftets cin grofiartiger, aber aud 
mit mambigadyen Beflemmuntan nerbundener 2lontent, wemt dic fenteswegs für die

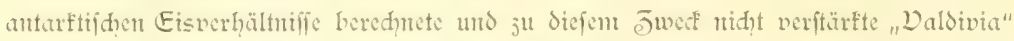
mit Dolldanpf gegen de Eisfelder anfuhx, crit direft vor ihnen ftoppte und fid mun ourd? die fradpenden Edollen ibren Weg halphte. Wir waren allerdings fo vorifhtig, uns

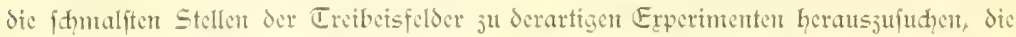
redt verhängnisvoll hätten ausfallen fömen, went die Kraft des Sdiffes durch den 2lnorang der Sdollen gebrohen worden wäre, und wir mitten im Eife bie 2liajhite hätten in Bewegnug feţen müffen. Wefentlid erleiḑtert wurde unfer Dorhaben durd sinen "Eisbredru", welhen der talentvolle Kod aus jwei flafich Portwein und einer flaphe Cogmac herifellte. War die Sage befonders fritif, fo verwendete mant als

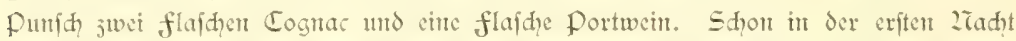
nom 50. 2rovember auf den 1. Dijenber waren wir genötigt, unter mannigfadyen Kursänderungen mehrmals die felder zu durdfahren, und fdwerlid dürften bet dem unbeintliden Krahen und Kniriden an den Wandungen des Sdiffes die Infaffen den Ed)laf gefundert habent.

Ziadjoent es uns am l. Dejentber gelungen war, wieder it freies Waffer ju font= men, bejoloffen wir, in allgeneinen cinen füdöflidgen Kurs fo lange cinjuhalten, bis de Treibetsfelder uns etwa ju einer 2̈̈nderung desfelben nötigen würden. In gropan und gangen darf demt aud hervorgehoben werden, daf wir 21/2 Woḍen hindurd?

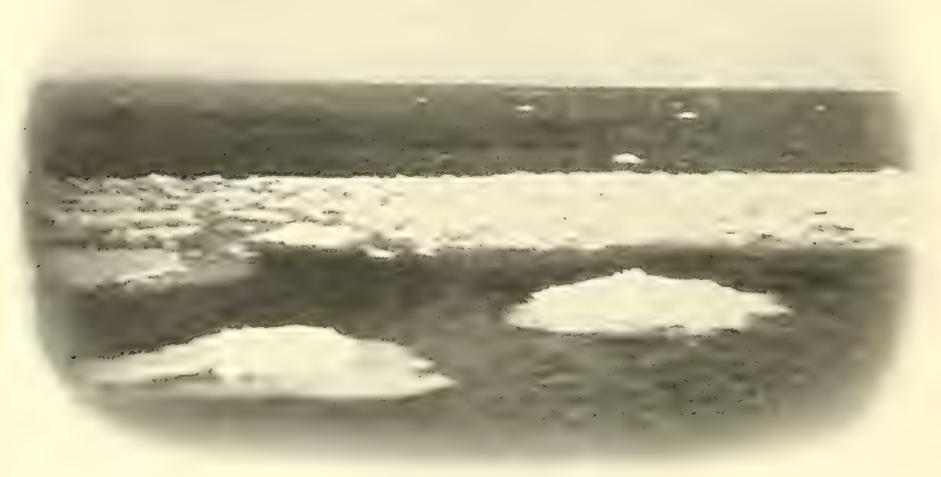

Jreibeis ant 5 . Desemher 18098 in $55^{\circ} 2^{\prime}\left\{\right.$. $23 \mathrm{r}$., $20^{\circ} 50^{\prime}$ o. . 
ungefähr dicfe fahrtridtung beijubchalten pernodyten und dadurd in die Sage fanten, auf cinter Streffe von naheju 50 sangengraden dic Trribeisgrenje wäfrend des fübs lidjent Sommermonats Dejenber fejţulegen.

Dic unter relativ günfitizen äuferen Bedingungen längs der Eisfante erfolgte fahrt

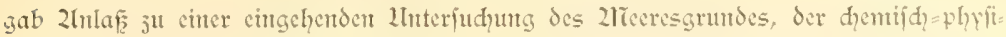
falifhen Derbälntiffe des Seewaffers und der pelagifhen Tierwelt, wie wir fie reid? intfaltet an der Dberflädhe und in gröferen Tiefen antrafen. Da es etwas monoton flingen würde, went wir in dironologifdzer Reihenfolge unjere flemen täglidgen und

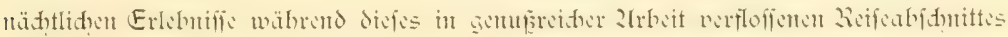
fdilldern würden, mag es geftattet feit, die widjtigeren Ergebniffe und Eindrücte im อิufanmenhang dem scjer vorjuführen.

\section{Die sotungen.}

Das widhtigfte Ergebnis unferer faht längs der. Eisgrenze mag vormeggenomment werden: es betrifit den Zadwweis ches gewaltig tiefen antarftifhen ziecres. Don fieb= jehn Sotutgen jwifhen der Bonvetregion und Enderby $=$ Sand weifen nidit weniger als slf Tiefen jwifhen 5000 und $6000 \mathrm{~m}$, fünt foldhe jwifhen 4000 und $5000 \mathrm{~m}$ und

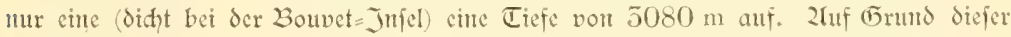
Solungsferie (der erften, welde in foldyer Dollitändigfeit int antarftifden (bebiet ourd): geführt wurde) erfahren die bisherigen Dorftellungen über das Tiefentelief des ant= arftifden Deans eine wefentlide Erweiterung und Beriḑtigung. für das Derftändris Ser Tiefenverhältniffe des antarftifden 2lieeres lagen vor der fahrt der "Daldivia" mur 15 Tiefenjablen füdich von den 50. Breitengrade vor: dic Expedition hat füdid von dem 50. (5ras 29 sotungen bis jum (5rund durhgeführt und im đ̄egenfat ju der herridenden Dorftellung, dafi das antarftifhe 2lieer cin relativ peiḑtes Beffen Saritelle, den 2iaḑweis feiner unerwartet grof̧en Tiefe gefübrt. 2luf ber umferen Shilderungen beigegebenen "Karte der 21eerestiefen", welde Dr. Shott auf (Frund des bis jum Jahre 1900 veröfientlidpten 2lateriales entwarf, find die Pofitioner der widhtigften Daldivia $=$ Sotungen cingetragen. Indem wir auf dicie verweijert, fet be= merft, daf mant früher lediglid auf theoretifhe Erwägungen hin den 2lieeren in der

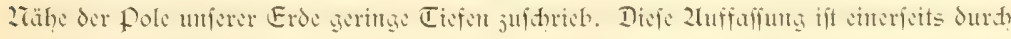
Ranfen's Ergebnifie im Dolamtecre, andererjeits durh diejenigen der "Daldivia" im antarftifhen 2lieere endgültig widerlegt. Unfere Sotungen liegen allerdings in geringeren Brettent, als dicjentigen der arftificn Erpedition, aber fie erftrecten fid immerhin bis didht an den Rand des antarftifhen feftlandes über cinen fläd)enraun von fünfjig Sängegraden.

Es lag in der Ziatur der Sahe, daf mant in Linblict auf fo merwartete 2luf: idjlüfe den oceanographifden IInterfudungen in antarftifhen 2licere den Elyremplats 
cinrüunte. Dic tägliden Sotungen hielten uns nad Derlafien von Kapftast länger als cince 2lionat hindurd in ftändiger Spamung: für die kidgtung unferes Kurfes längs der Eisfante wurden fie geradeju ausjalaggebent.

\section{Die Temperaturverhälnife bes antartifhen meeres.}

In allen wämeren Decantent nimmt dic Temperatur dis Scewaffers vont der Dber=

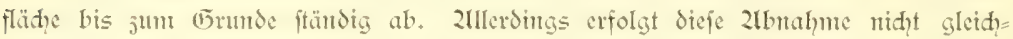
mäzisig, fondent gelegentlid? mit mehr oder minder auffällig fid geltend madyenden

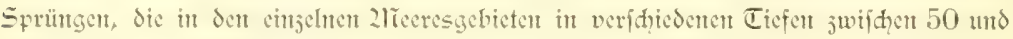
$200 \mathrm{~m}$ liegen. Wem wir davon abfehen, fo geftattet de immerhin allmählid cr=

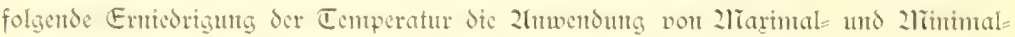
thermometent, infofern man mit Sidyerheit daranf redunen fam, daf dic auf dem

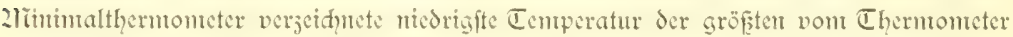

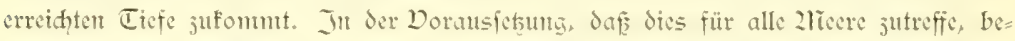
diente fid die Challenger $=$ Expedition ausfylieflid, der 2larimal= und 2linmalthermo=

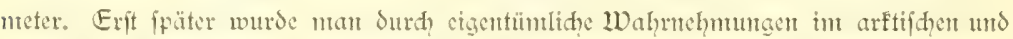

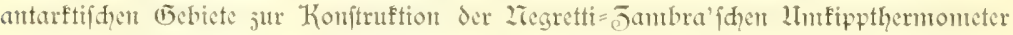

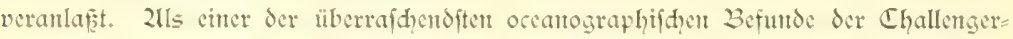

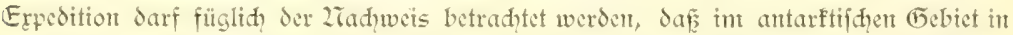
der ziähe der Eisgrenje das Dberflädentwaffer fälter ift, als darmuter liegende $\mathfrak{W}_{\text {affer }}$

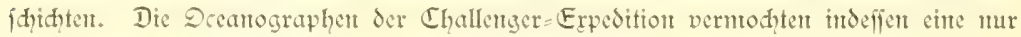
anmähernde Kemtnis von den Temperaturverhältniffen der tieferen Sdidţten ju ges wimen, infofent dic von ihgten abgefühlten und in gewiffe Tiefen verfenften 2lintintal= thermometer bei dem 2lufwinden der Seine in fälteres Waffer gerieten und daher ent=

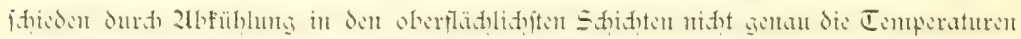
wiedergaben, dic an den tiefíten von dem Thermonteter erreidten Stellen obwaiteten. Wir verwendeten daher ju unferen 2Interfudungen in antarftifhen Gebiet faft aus=

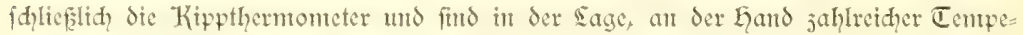
raturferien cin wefentlich forrefteres Bild won der Sdiditung der warmen und falten Waffermengen im vertifalen Sime ju gehen. Dic Beobadtungen lehren im allge= meinen, da bis ju ciner Ticfe von $150 \mathrm{~m}$ das Dberflädenwafier Temperaturen unter

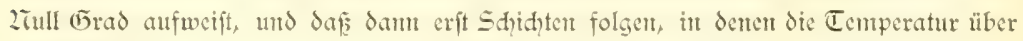

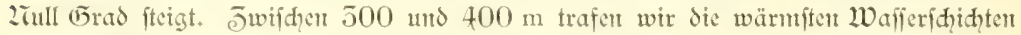
von ener Temperatur von $+1,7^{\circ} \mathrm{C}$ an. Don hier an nimmet dic Tenteratur in allgementen langfant $a b$, unt erft in relativ beträdfliden Ticfen von 5000 bis $4000 \mathrm{~m}$

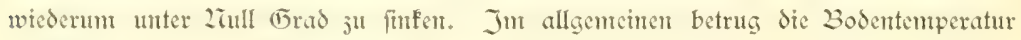
in $5000 \mathrm{~m}$ im antarftificu Deen etwa $-0,5^{\circ}$. 



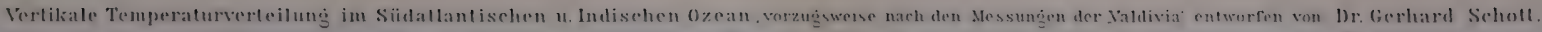
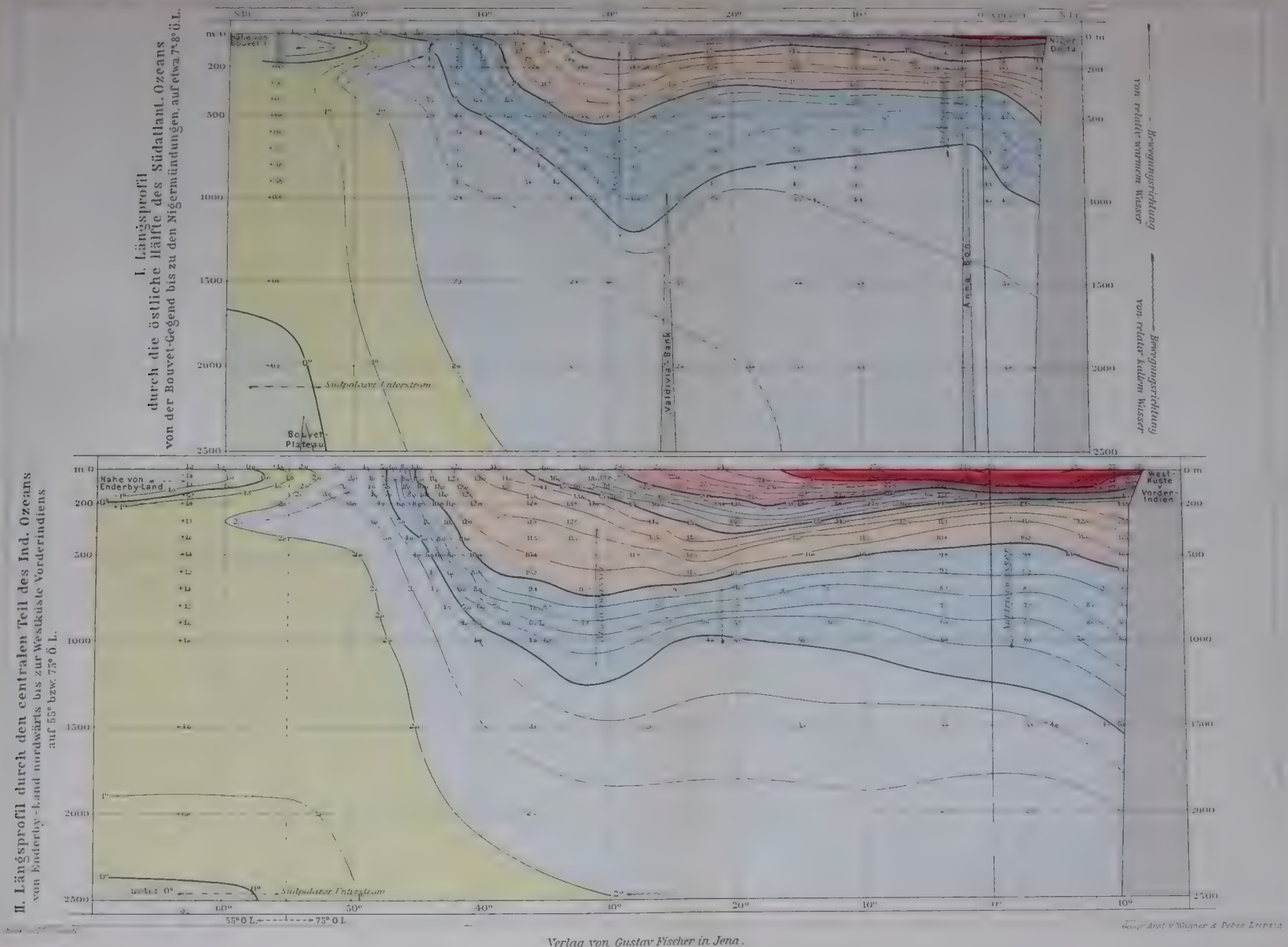



\begin{tabular}{|c|c|c|c|c|c|}
\hline \multirow[t]{3}{*}{ Tiefe } & \multirow{2}{*}{ 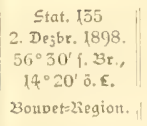 } & \multicolumn{4}{|c|}{ 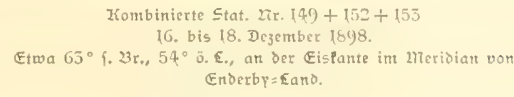 } \\
\hline & & & Salsgehalt & 0 & $\mathrm{CO}_{2}$ \\
\hline & - Cels. & - Cels. & $\%$ & $\mathrm{ccm}$ & g \\
\hline 0 & $-1,5$ & $-1,0$ & 35,7 & 8,0 * & 0,0520 \\
\hline 10 & & $-1,1$ & & & \\
\hline 20 & & $-1,2$ & | & 2,95 & 0,0521 \\
\hline 40 & 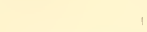 & $-1,2$ & i & & \\
\hline 50 & $-1,6$ & $-1,7$ & & 2,98 & 0,0525 \\
\hline 60 & 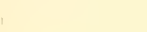 & $-1,4$ & & & \\
\hline 80 & & $-1,7$ & & 6,81 & $0,0 \tilde{5} 5$ \\
\hline 100 & $-1,5$ & $-1,1$ & & 5,47 & $0,05+5$ \\
\hline 110 & & $-0,5$ & & & \\
\hline 120 & & $-0,5$ & & 5,19 & 0,0553 \\
\hline 150 & $-0,6$ & $+0,2$ & & & \\
\hline $1+0$ & & $+0,8$ & & & \\
\hline 150 & $-0,5$ & $+0,8$ & $3 t, 0$ & 4,81 & $0,05+1$ \\
\hline 175 & $+0,2$ & & & & \\
\hline 200 & $+0,5$ & $+1, t$ & & & \\
\hline 250 & & & & & \\
\hline 300 & 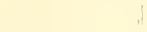 & $+1,7$ & & 4,14 & $0,05+7$ \\
\hline$\neq 00$ & $+0,6$ & $+1,6$ & 57,4 & $4,3 t$ & 0,0545 \\
\hline 500 & & & & & \\
\hline 600 & & $+1,2$ & & & \\
\hline 800 & $+0,8$ & $+1,5$ & & & \\
\hline 1000 & $+0,8$ & $+1,6$ & 37,5 & & \\
\hline 1500 & $+0,1$ & $+1,6$ & $3 t, 6$ &,+ 35 & 0,0576 \\
\hline 2000 & & $+0,6$ & & & \\
\hline 2750 & & $-0,3$ & & & \\
\hline $\begin{array}{c}\text { Bodenticfe } \\
\text { int } \mathrm{m}\end{array}$ & 5093 & +636 & & & \\
\hline $\begin{array}{l}\text { Bodeut } \\
\text { temperatur }\end{array}$ & $-0,5$ & $-0,5$ & & & \\
\hline
\end{tabular}

Don Jntereffe ift die Thatfade, daf dic 2lbfilhlung, weldye fid in der Bouvetregion bereits an der Dberfläde des Zlieeres durd auffällig niedrige Temperaturen von $-1,5^{\circ}$ geltend madt, aud? für die tieferen Wafferidjihten gill. Eine Temperaturferie, welde der Deeanograph ant 2. Dezember in Ser 2Tähe der Bouvetregion ausführte, jeigt in den Tiefen von $150-1500 \mathrm{~m}$ in allen Sdiduten eine um oft mehr als $l^{\circ}$ niedrigere Tentperatur, als wir fie an unferem füdlichtent Punfte in der 2rähe der Paf́eisgrenje von Enderby = Sand nadjumeifen vermodten. Lier wird die ftärfere Durdhwärmung

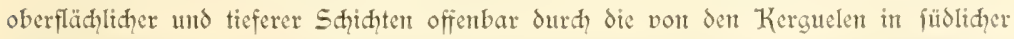

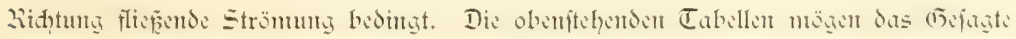
vielleidgt beffer als Worte crläutern; insbejondere fet auf die graphifal eingetragene 
Vor Enderby-Land,an der Packeisgirenze.

Temperaturreihe. Cels.

Deturn: 15. 18. December 1809

Station No 143,152 u.153 \{ Position : $63^{\circ}-64^{\circ}$ s. Br. $55^{\circ}$ o. L. Tiere: ca.4700m.

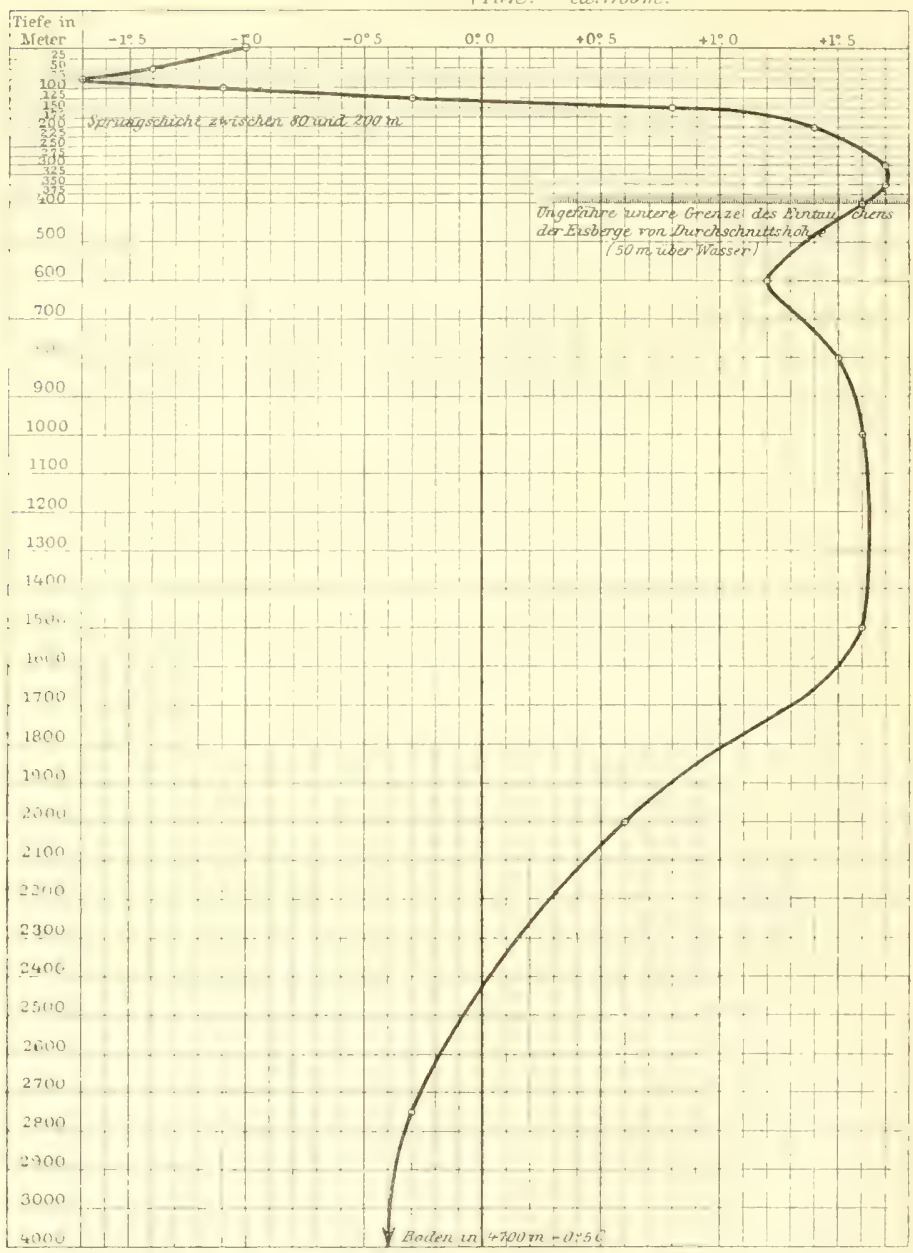

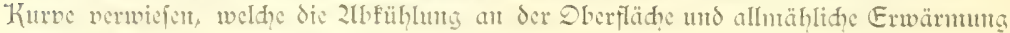
nad der Ticfe veramfdauliden. 
Die Kurve jeigt insbefordere, SaE das 2lithinum der Temperatur nidht Sireft an der Dberfläds, fons dern erft bei 50 bejw. $80 \mathrm{~m}$ Tiefe liegt. Es fdeint, daf dic lnter fatede jwifhen der Dberflädien= temperatur und der in etwa $100 \mathrm{~m}$ Tiefe fith geltend madienden etwas weiter offlich, wo der "Challenger" feine Beobaditungen anflellte, be= trüdtlider find. 2litdererfeits darf wohl darauf hingewiefen werden, daf die Befunde von Zianfen cine hödhit auffälige ïtberemitinmung in den Temperaturprofilen der arf = tifdent unt antarftifhen W Waffer= maffen crfemen laffen. 2lud wirb is wohl von vornherein cinteud? ten, daf die auffälige zbfriblung des Dberflähenwaffers durd den Sdmmeljungsprojef ber Eisberge unt des Treibeifes bedingt wird. Das Sdmeljwaffer ift fpecififd lcid = ter als das Seewaffer, und diefem Lmijtande allein ift es juzuidjreiben. dafi es, obwohl fälter als das let: tere, dod eine oberfläd)liche $\mathbb{E} a=$ gerung cinnimmt. - 2 tm das (5):= fagte durd einige fpecielle Daten ju belegen, fet hervorgehobert, daf wir den Saljgehalt des Dber= flähenwafiers bei Enderby $=$ Land auf $35, \bar{\tau} \%$ bereducten, während er in $150 \mathrm{~m} 54 \% 00$, in $1500 \mathrm{~m}$ $5+, 6 \%$ aufweift. - parallel der Junahme des Saljuchaltes mit der

Vor Enderby-Land,an der Packeisgrenze .

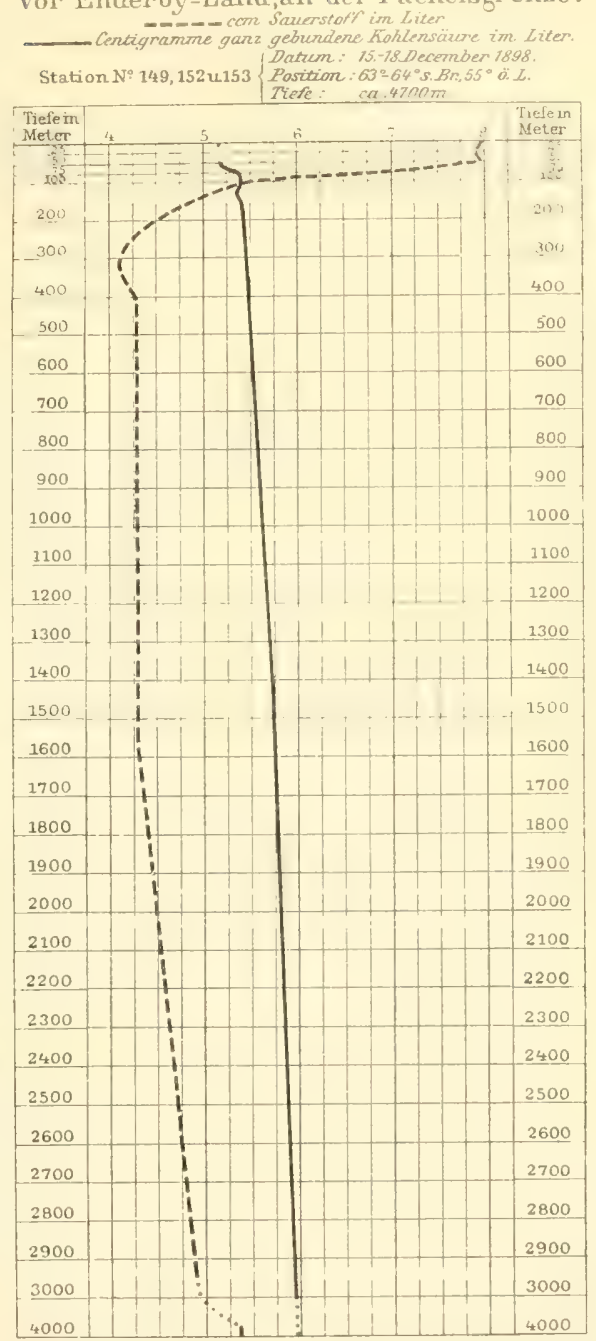
Tiefe läuft nad den 2Interfudungen unferes Chemifers chte Jumahne des (Ẽhaltes

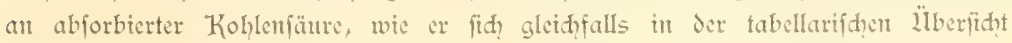


ausdrült. - 2lndererfets nimmt der Gehalt an abjorbiertem Saueritoff von der Sber= fläd) nad) dex Tiefe fontinuterlich $a b$ uno beträgt beifpiclsweife in $1500 \mathrm{~m}$ Tiefe nur die Gälfte des Saneritofigchalts der Dberflähe. Jmmerhin erihetnt der l̈ber= fdquF an abjorbierter Kohlenfäure, dent cine Derminderung des Saueritofigehalts parallel geht, nidit fo beträdtlid, daf er dem organifhen Seben fich als feindlid? erweifert wïrde.

Das 2luftreten ciner über $2000 \mathrm{~m}$ mädhtigen Sdidht relativ warmen Waffers int antarftificen 2licere ift cine Erfdethung, deren Bedeutung wir fowohl in oceanogra= phifher, wie aud, in biologifher Einfidht miḑt hod gentug würdigen fömen. Das

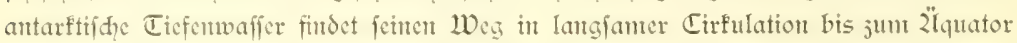
und int Jubifden Decan logar weit über denfelben Linaus. Wenn mu aud die ftarfe Erwämung der Dberfläche in gentäf̧igten und tropifhen 2leeresgebieten die tieferen

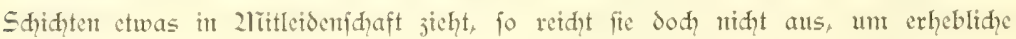
Interffiede in der Temperatur ju bedingen. Jn $2000 \mathrm{~m}$ Tiefe ift das Waffer des centralen Indifäen Decans direft unter dent 2̈̈quator nur um 2 Grad wärmer, als in dar 2ähe des antarftiphen Kontinentes. Das finto fo geringfügtge Interjobicde, dafi fie cin benerfenswertes Ergebnis miferer ฮüge mit den Dertifal= und Sdlief: neţen erflürlidh erihgeinen lafien: diejelben pelagifhen Drganismen, weldhe dent tro= pifden Tiefenwaffer eigen find, haben wir teilweife aud in demijentgen des antarf=

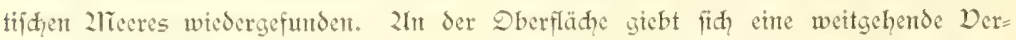
fdiedentheit in der Jufanmentetsung der fowwimmenden sebewelt fund, in der Tiefe cime auffällige lilbercinftimmung!

Wir geben unferer Bejdreibung jwet Sängsprofile bet, welde die vertifale Tempe= raturverteilung cincrfeits von der Bouvetregton durd den fübatlantifhen Deean bis ju den 2Tigermtündungen, anderericits non Enderby = Sand durd? den Indifhen Decan bis jur Weftëfte Dorder= Jndiens darftellen. Sie jeigent amfhaulider, als wir mit em=

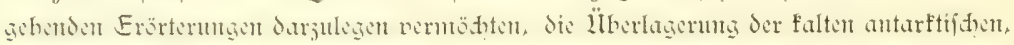

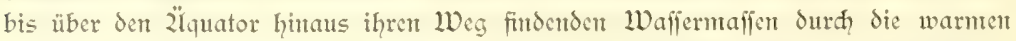
Sdidten der fubtropifden und tropifinen Regionen. Bet Gelegenheit der Sdilderung

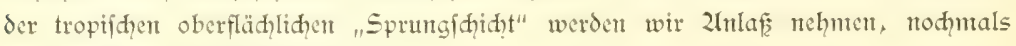
auf sic Karte jurüdjufommen.

Hm indeflen das für die polaren Regionen harafteriftifhe 2luftreten einer falten,

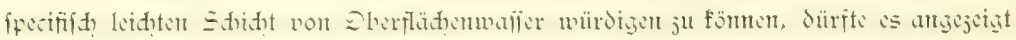
feit, der Struftur unts allmählihen Jerjeţung der antarftijhen Eisberge eine furje Betraditung ju widmen. 


\section{Die Eisberge.}

2ln der Bouvet Jnjel fällt dic Sdneegrenje mit der 2liceresoberfläde jufamment. Wir wäfften faum eme Jnfel ju nemen, welḑe in fo geringer Brette cine ähnlid? ausgiebige Dergletfderung anfweift. Draftifh giebt fid, hier bie Wirtung jener Kälte= junge fund, weldhe das antarftifhe (5ebiet gegen die Bouvetregion hin entjendet. Dic früheren Secfahrer fomten fïh der Jnfel nid̨t nähem, weil fie volljtändig von padeis ungeben war. Wir fanden fie fret von foldem, vermoditen näher heranjufahren uno

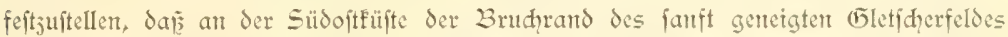
eine 50 he vort $57-155 \mathrm{~m}$ crrciat. Er ftellt fidh dar als cine fenfredt in das zlieer

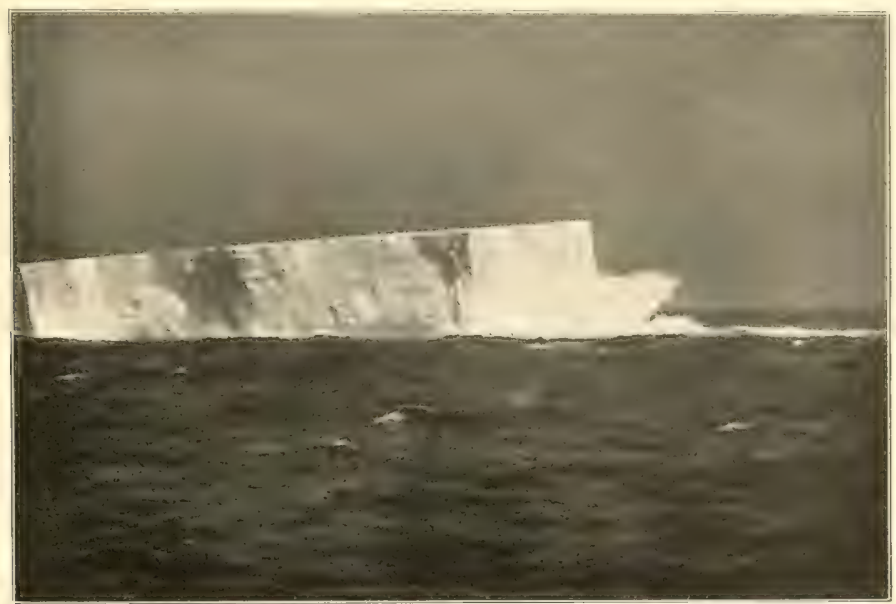

Tafelförmiger Eisberg mit 3randungswoge. Föhe $37 \mathrm{~m}$, 23reite $119 \mathrm{~m}$. 19. Degentber 1898. $9^{\mathrm{h}} 30 \mathrm{a}, \mathrm{m} .61^{\circ} 40^{\prime}$ 1. $3 \%$., $61^{\circ} 5 \mathrm{I}^{\prime}$ ö. $\varepsilon$.

abftürjente Eismauer, weldie das vulfanifhe Geftein mur da ju Tage treten läfst, wo die Küfte fteil abfällt. 2h den Längen drängt die Eismauer oft in bedeutender Lqühe fo weit vor, als ifre Stimflähe nod? Galt auf dent Lntergrund findet; in den wenigen

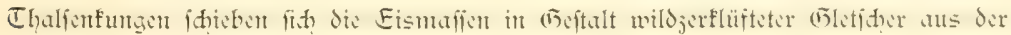
Lähe bis jum Strande vor.

Die Eismauer, mit welder an der fanft geneigten Südoftüüte das mäditige bis

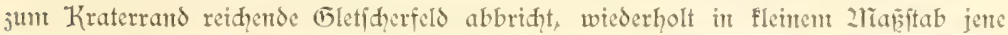

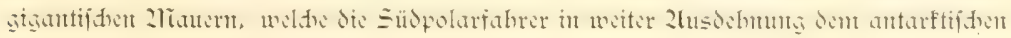
Kontinent vorgelagert fanden. 
2lllgentein befannt iit die gewaltige Eismaner, weldhe $2 R$ of in füblidgiten Teile des Diftoria= Sandes nadjwies. Er fhätste ihre 53 hle auf $60-70 \mathrm{~m}$ und vermodite fit auf che wette Strecte hin s̈ftlid vont 2liount Terror ju verfolgen. Sie bildet dic

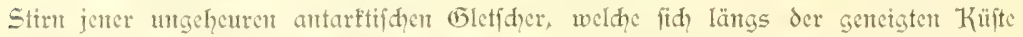
weit in das 2lieer vorfdieben. Die sotuntgen von kof lebren, daf die oft nehrere Scemeilen über den Kontinentalrant vorgejhobenen 2liafien von Julandeis nidgt mehr feftem 2lntergrund aufliegen, fonden infolge ifpres geringeren fpecififhen Gewidntes

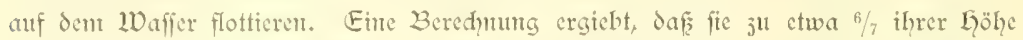
in das Waffer intaudien und mur mit cinen Sichentel über dasfelbe heransragen. Wütden wir alfo dic Bletjhergunge des Diftoria= Sandes uns direft in der böhe des Etrandes abgebrodgen denten, fo müpte fie die gemaltige böhe vor $400-500 \mathrm{~m}$ aufweifen.

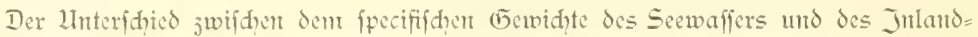

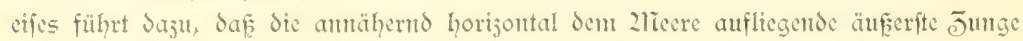
des (bletfhers - mag fie mehr oder minber breit feit - einen fladjen Winfel mit

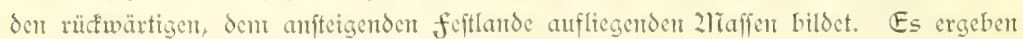

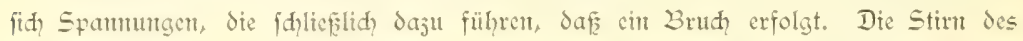
(5letfdiers löt fid $a b$ und fdwwinmt als tafelförmiger Eisberg davort. Db mun dicfes "Kalben" des (bletiders lediglid Jurd? den hiex dargeftellen fogenamten Zuftrieb des Waffers erfolgt oder ob rod andere Kraffte hierbet in Spiel find, müffen weitere

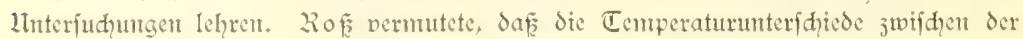

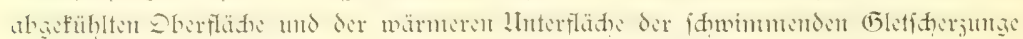
jur Éfuntg beitragen möd̨ten. Dicfe Dermutung ift nidht ohne weiteres von der Land ju weifen. Intiere oben enwähnten Temperaturmefintgen des antarftifhen Tiefenwaffers

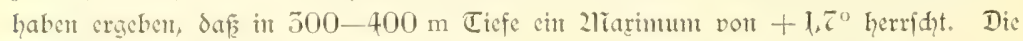
(5)letfherjungen tauden bis ju diefer Tiefe ein und werden von einent Waffer unt= ipuilt, das um $5^{\circ}$ wärmer ift, als das Dberfädentvaffer. Db dicfer Wärmeüberiđuf

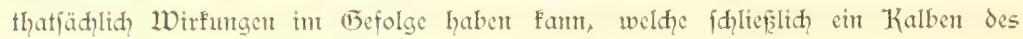
(5letfhers bedingen, hat der Phyifer und Decanograph ju entfheiden.

Die Eisberge verbreiten fith almählich non ihrem llriprungsherd aus über ein weites (5ebiet des antarftifien und fubantarftifden 2leeres und vermögen unter 1 m ftänden felbft dic Sdiffahrt nad 2luftralien ju gefährden. So madite fid in den

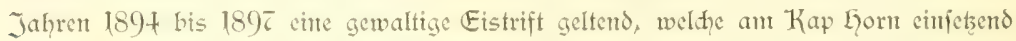

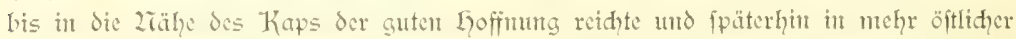

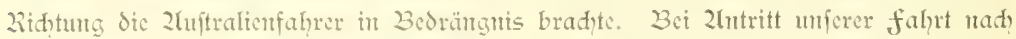
Ë̈bent waren wir daher in fenter Weife in der Eage, uns cir liteil darüber bilden 311 fömen, wic dic antarftifhen Eisverhälntifie fid ntöd)ten geftaltet haben. Da wir unhelindert bis jux 230 wet= Jnfal gelangten, darf man wohl amehmen, daf bic 
Gauptmaffe des Eifes in ojtlther Ritatung abfanvanm und falieblid in den wämneren Gebieten der Jerjetsung anheimfiel. Wir trafen erit jenjeits des 55. Breitegrades dic

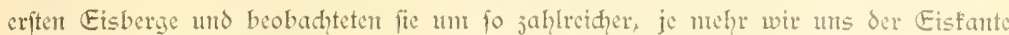
näherten. Ilnfere wathhahenden Dffiziere führten Protofoll über dic cinjelnen non uns gefehenen Eisberge und verzeidyneten deren in ganjen 180; ansgenommen find freilid Sie fait unjäblbaren Eisberge, weldhe wir an unferen füblidfiten punfte am 16. und 16. Dejember beobaditetert.

2uffällig war ihr frühes Derffuwinden auf der fahrt nad den Kerguelen. Wir jidhteten den lesten Eisberg am 19. Dejember ungefähr anf dem Sdinttpunft des 61. 3reitegrades mit Sem 61. Jftliden Eängegrad. Die von den Kerguelen nad Silden feţende warme Strönung ftant die Eisberge jurïf und bedingt eine ungewöhn=

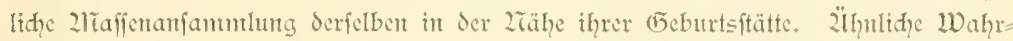
mehmungen maḑte aud der "Challenger", der im februar 1874 crit nad, L̈beridnretten des 60. Breitegrades Eisberge fidtete.

Was nun die (E)ftalt der antarftifden Eisberge ambelangt, fo ift allen Beohaditen aufgefallen, dafi fie in der Zrähe ihres Entfitehungsherdes tafelfömtige Riefen non cin= fömigen 2lusfehen darfellen. Da fte aus Gletfdereis beftehen, fo ergielt die Bereh. mung, daf fie ju etwa $1 / 7$ aus den Waffer hervorragen, während nidit weniger als ${ }^{6}$ \%

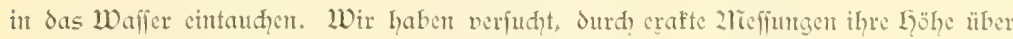
Waffer zu beftimmen, inden wir behufs Ermittelungen der Entfermung des Sdiffes von dem Eisberge die fortpflanjungsgejdwindigfeit des Sdalles in (5eftalt des prädtig von demfelben widerhallenden Exos bemtiten. Es wurden Sdülfe abgefuert, mit Ser Sefundenuhr genau dic जecit

jwifden Kutt und Edyo fort=

trolliert, und dann mit

dent Sertanten dic

Löbe des Eisberges

gemelfen. Eine cirt

fache Rednuming er:

gab den 2radpweis,

JaE ntandier Ser

volt uns gefehenen

Eisberge die beträd̆t=

lidhe 5 öbe vor naheju

$60 \mathrm{~m}$ erreidhte; dic 21 ichr.

jahl war nticoriger und wies

cinte mittlere $50 ̈$ he von $50 \mathrm{~m}$ auf.

Die sätge der von uns gemeffenen

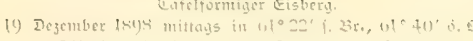

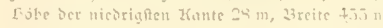




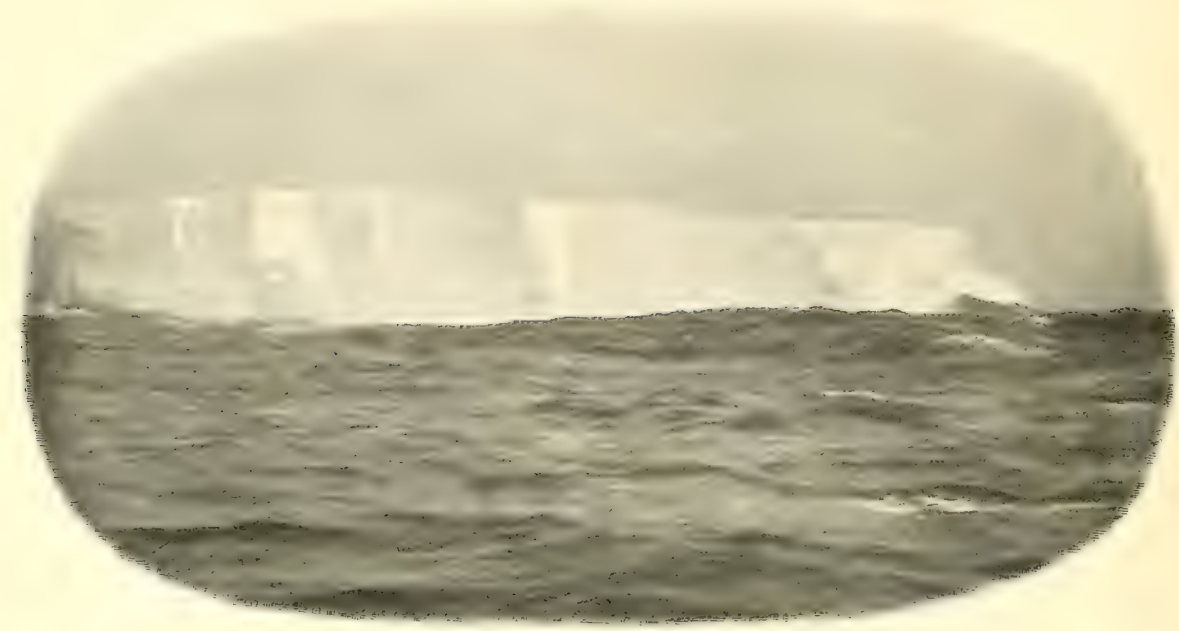

Eafelformiger Eisberg vont 19. Desentber aus gröferce 27ahe. 2iedts eine 3ranoungsmoge.

Eisberge fdywanfte felbftwerftändlid, in nod viel weiteren Grenjen, als dic Föhe. Einen der längften, den wir maßen, trafen wir an 14. Dejentber alt; er war $54 \mathrm{~m}$ hod und $5 \overline{7} 5 \mathrm{~m}$ breit. Gewaltige Berge, wahre Eisinfeln, fahen wir in der 2iadyt vom 17. jumt 18. Dejember bei Entorby=Sand. 2Ils wir uns dantals aus dem Paffife herausarbeiteten, befanden wir uns in nidht weiter Entfermung von cinen Eisberge, den idh anfänglid? für dic dent feftlande vorliegende Eisntauer hielt, bis es fidh herausftellte, daf wir es mit enter Eisinfel ju thun hatten, deren 2lus= dehnung von den Dffijierent anf 4 bis 5 Secmetlen geldätht wurde. Soldhe Bitefent=

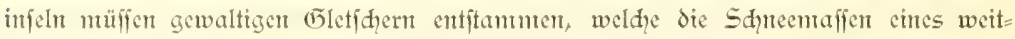
ausgedehnten und fanft gegen die Küfte abfallenden Finterlandes dem 2liecre juführen.

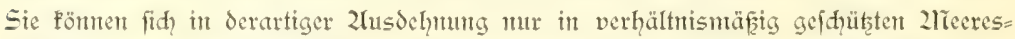

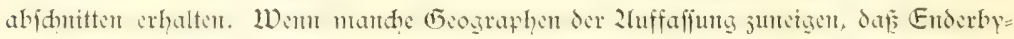
Sand cine vort $\delta \mathrm{cm}$ antarftiffyen Kontinent getremte Injel darftelle, fo müfte fie zum

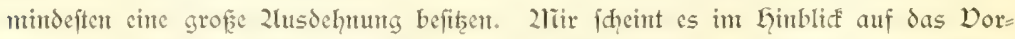

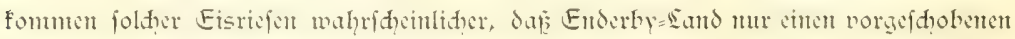
Teil des weitausgedehuten antarktijigen fejtlandes bildet.

Säntlidge früheren Beobadter weifen übercinftimmend anf die dharafteriftifde Strei= fung der tafelförntigen Eisberge hin, welhe im allgenteinen dem Plateau parallel läuft.

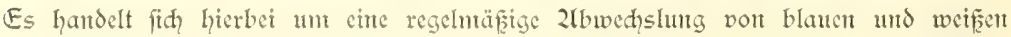


Caffelförntiger Eisberg, gefiḑtet bei Torboft=Sturnt ant 19. Decentber 1898. Einfs eine Brandurgswage. Liähe 34 2leter. Eänge 119 21reter. 


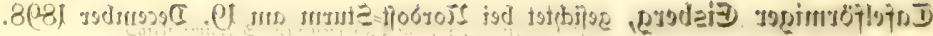

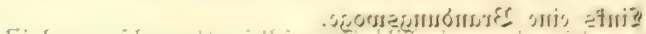

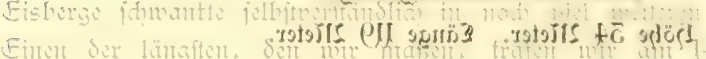

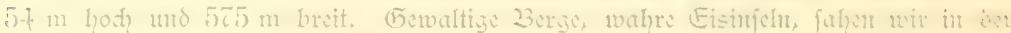

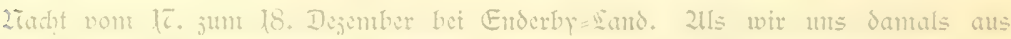

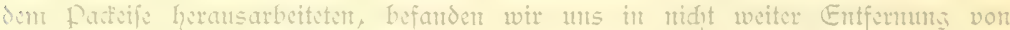

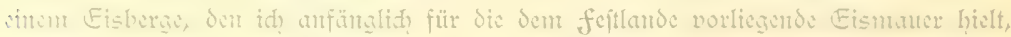

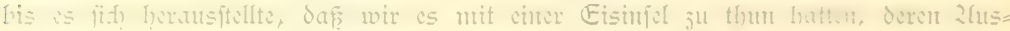

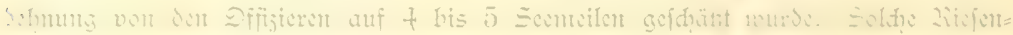

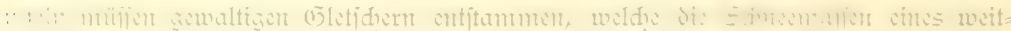

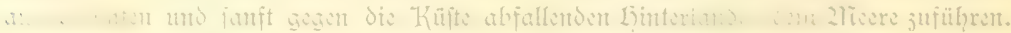

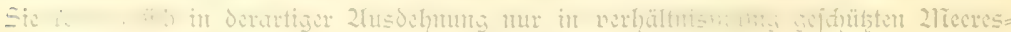

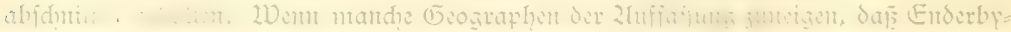

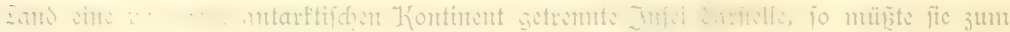

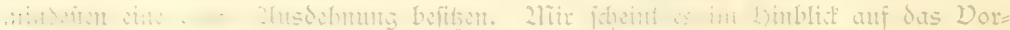

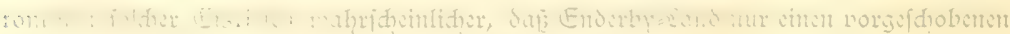

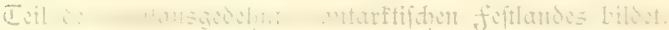

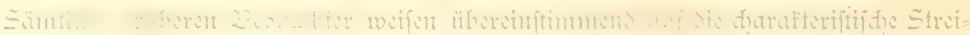

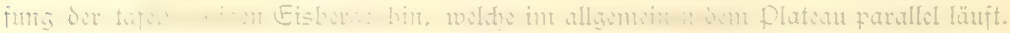

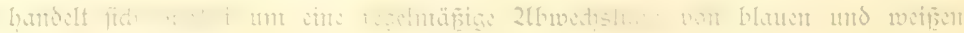




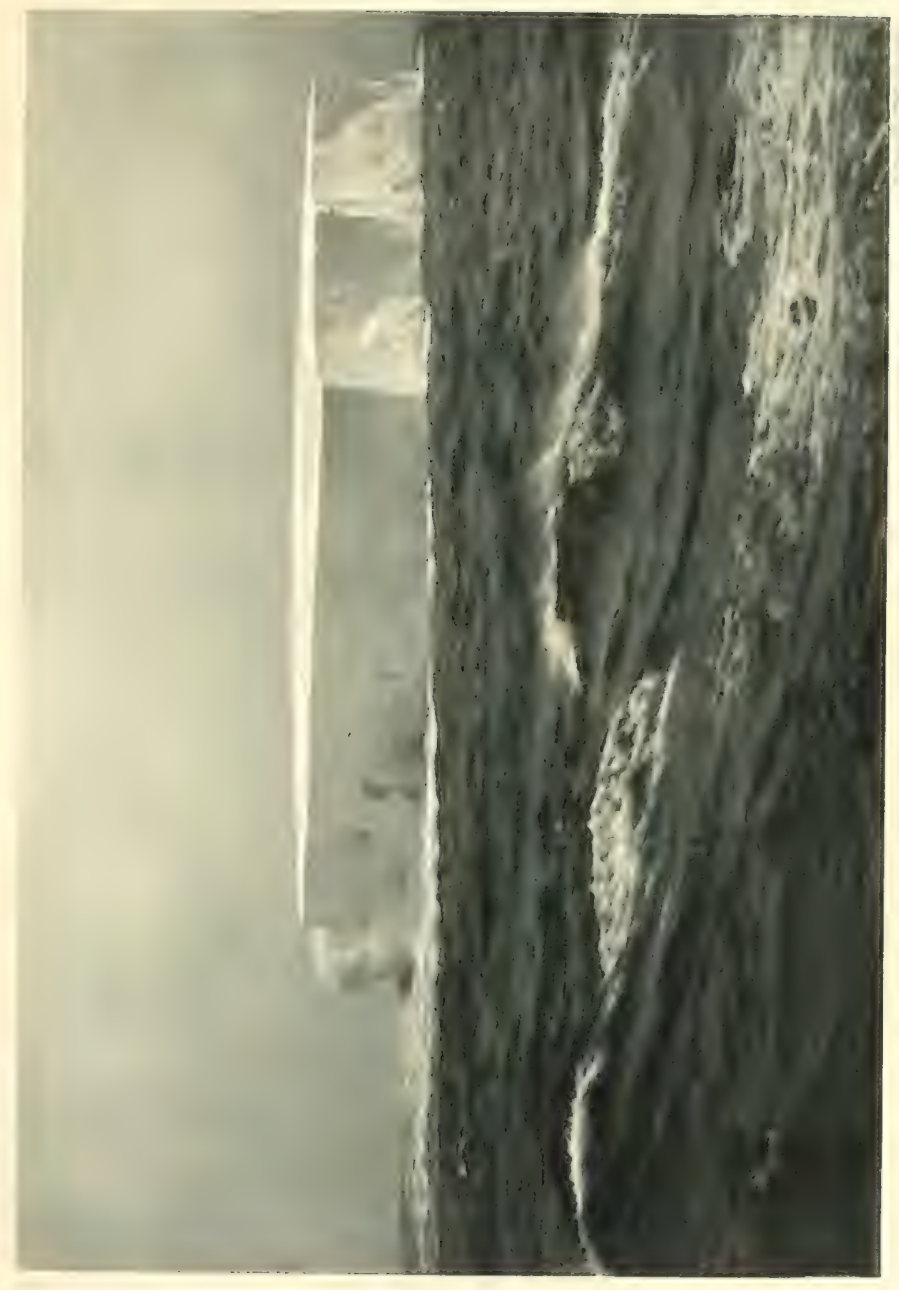


. 


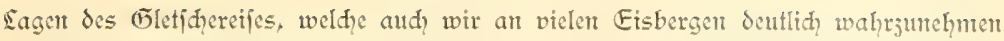
nermodhten. 2fllerdings tragen die jerftörenden Wirfungen der fdłweren Brandung und dic Sdunceftürme daju bei, dafis dic von ihrer 2triprungsftätte weit abgetriebenen Eis=

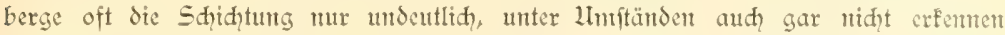

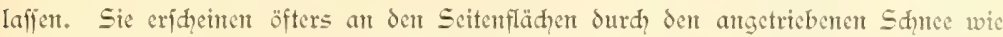

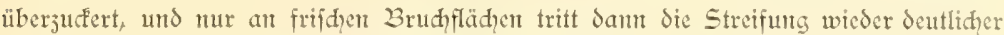
hervor. Ganł ungewöhnlid ausgebildet jeigte fie fid bei cinem am 1. Dejember in der 2tähe der Bouvet= Infel beobadteten Eisberge, infofem mehrere Zlieter didfo Shidhten fobaltblanen Gletfhereifes mit dünnen fdnteeweifen Sagen abwedyelten.

Unt die veriḑiedente färbung der einjehnen Sdidten ju erflären, bedarf es eimes furzen Eingehens auf die Struftur des Eifes. Vlan war früherhin allgentein der

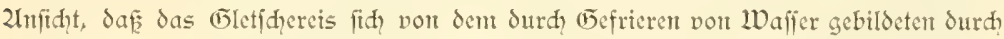

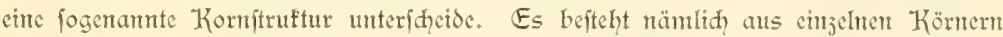
oder Jndividuen, weldye wohl uriprünglich aus Sdqnecfrỵitallen entfitanden find. Dic

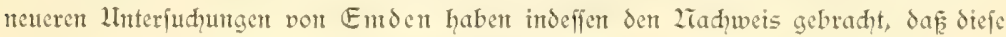

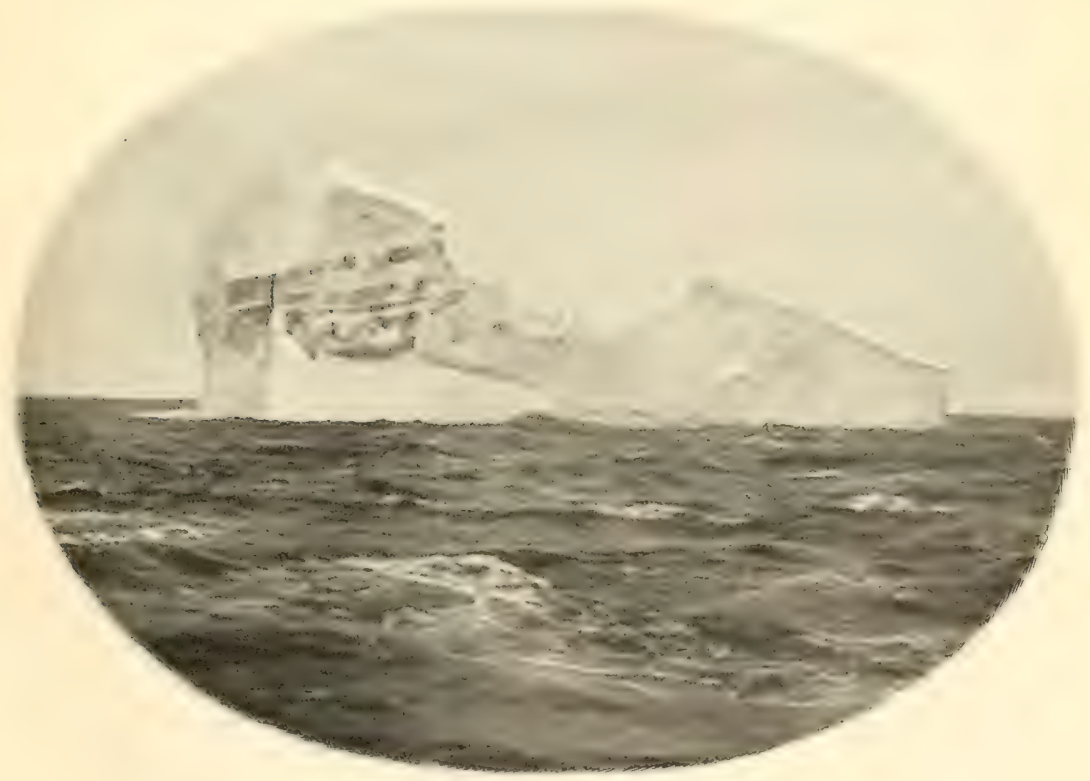

Fisbers mit Dider Stidten blaten Eifes.

1. Dezember 1898 in $56^{\circ} 26^{\prime}$ 个. 3r., $11^{\circ}$ I $^{\prime}$ o. c 
Kornftruftur fämtliden Eisarten zufonmt, und allerdings mur da deutlith hervortritt, wo cine Eismaffe in freier Eage ciner mäfigen Erwärmung der Enft ausgefetzt wird.

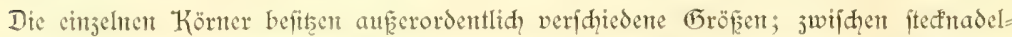

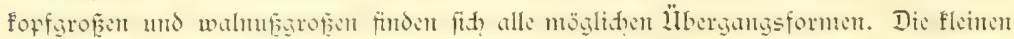

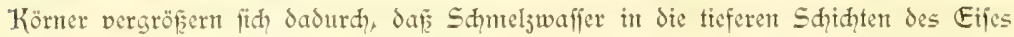
fitfert und gefrierend fid um fie ablagert. Sie preffen fid bet ftarfent Drucke, der

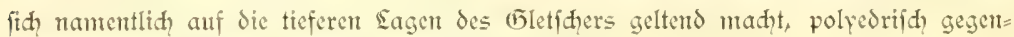
eitander ab und bilden optifid einadjige Kryftalle.

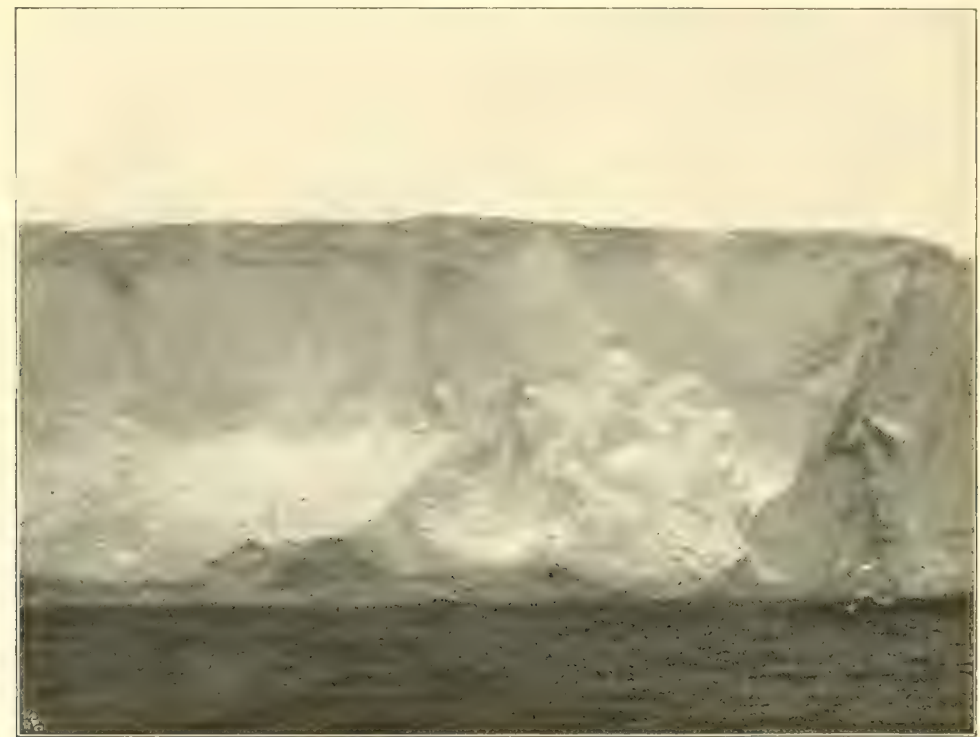

Teil der wandung des am 3 . Dezember 1898 in $56^{\circ} 0^{\prime}\left\{.23 \mathrm{r}\right.$., $16^{\circ} 18^{\prime}$ o. E. gefidpteten Eisberges.

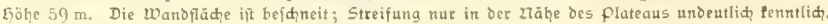
Iufrakme in rebet.

Linter den Beimengungen, weldye die farbe des Eifes bedingen, find in erfter Sinte nad, den Interfudungen von Drpgalsfi Suftemfd̦luffe von Widhtigfeit. Sie finden iid) nidft allem an ben Kontgrenzen, fondern oft aud innerhalb der Körner. Is

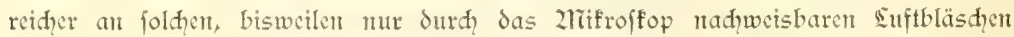
das Korn ift, defto weifer erfincint dic gefante Eismaffe. Wird ihre Dberflädje von

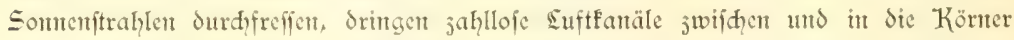

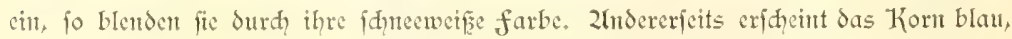


wenn Wafjer die Euft verdrängt hat und in den 5ohl= räumen ausgefro= reut ift. Je wentiger Beimengungen an Euftbläsdyen bem: nad das Eis befitzt, Defto blauer ift es getönt. Es liegt auf ber Gano, daf jei= ne farbe aud nod? surd mannigfade fortitige Bement gungert, wie Staub und Sand, beein= fluft wird. frübore foriḑungsreifende beriditen pon Eis= bergen der antart =

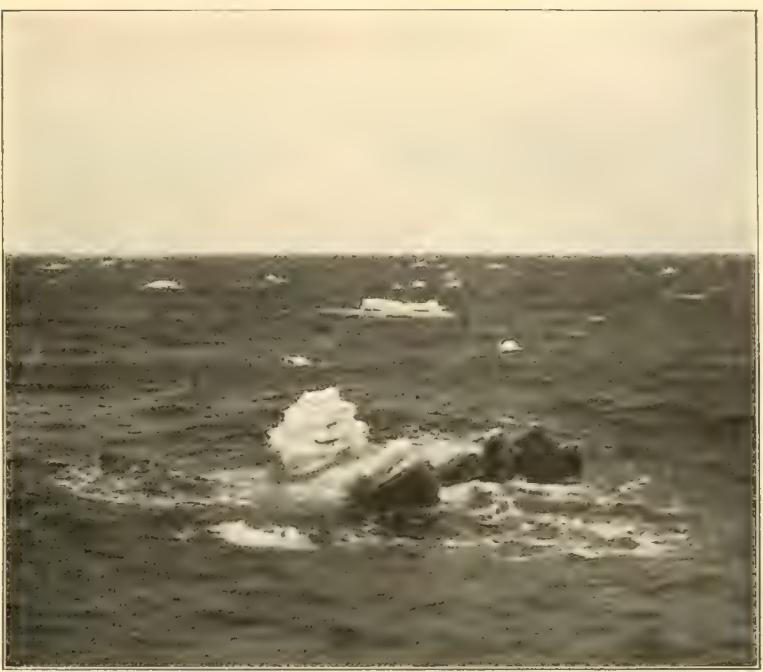

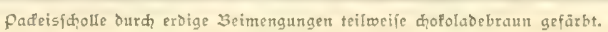
16. Dezentber 1898 bei Enberby = Eand.

tifhen Region, weldhe gelegentlich mit Sduttmaffen bededft waren und ein fdynutsigs brautes Zusfehen darboten. Uns find derartige Eisberge nitht begegnet, wern twir von jwet Pafeisfhollen abjehen wollen, dic wir an unferent fübliditen Punfte, vor Enderby = Sand, beobaḑteten. Sic jetgten fid jum Teil hofoladcbraun gefärbt, und es gelang uns vermittelit cines ausgeletsten Bootes, von denjelben Eisfüle abjufdilagen, weldye Iebrten, daf Sic anorganifhen Beintengungen aus ciferidü̈fit: gen, in regelntälsigen parallelen Sdiditen ange= ordneten Sand = und Quarjförndien beftanden. Was nun die Entftehungsweife diejer regel= mäß̈ig abwehielnden blauen und weiken Bätder des bletidicreties anbelangt, fo neigt man dev 2luftilt ju, daf es fid un eine Eriheinung handelt, dic einerjets durd den EDrud der auf den tieferent Eagent laftenden 2rafien, anderericts durd, das langiame Vor= rüfent des ETletiders bedingt wird. Wie finon dic Challenger $=$ Erpedition naduwies, fo werden dic Das gefarbte fưfeis wito vont 3oot aus abgefdlagen. 16. Dejentber 1898. 
tieferen Sagen des Eisberges weientlith aus dem blauen Eije gebildet, jwifden denten

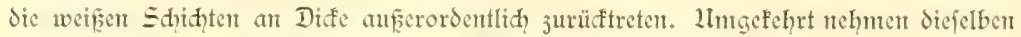

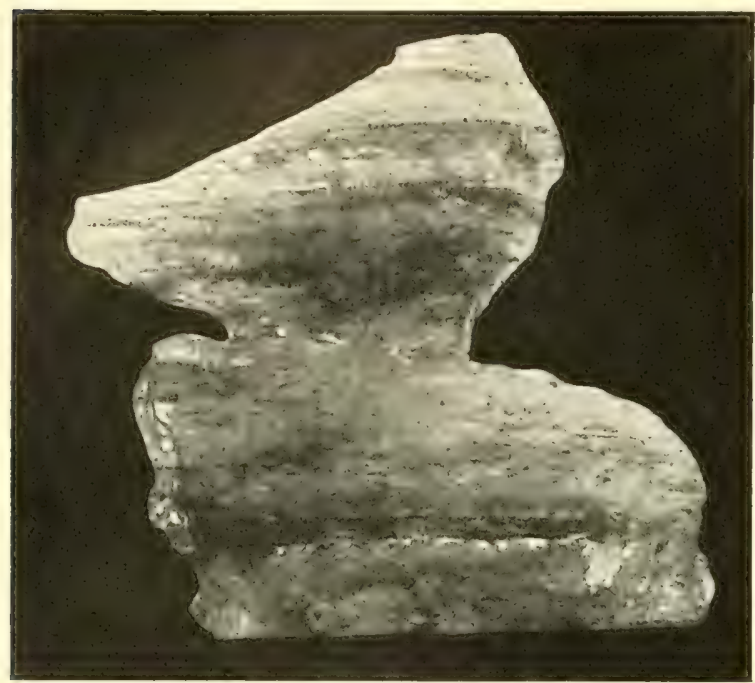

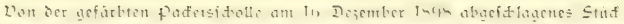

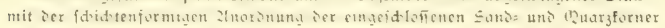
gegen das plateau des Eisberges ant 2riäđtigfeit ju. Ein originelles Erperi= ment, weldhes auf Ser genamenten $\mathbb{E x}_{\mathrm{r}}$ pedition ausgeführt wurde, lehrt, dafi die fobaltblanen $\mathbb{S a}$ gen bedeutend fprö= der find, als dic weificen Sdiduten. Es wurde näntid cin Eisberg mit der Ka= notte befidofien, und dabei crgab cs fid, dafi dic Kugel bei dent Eindringen in die unteren Eagen oberhalb derloaffer= limie grofe Stücfe Eis abjplitterte, während fie in der zähe des plateans ohne weitere fichtbare Wirfung in die weisen Eismaflen cinfdug.

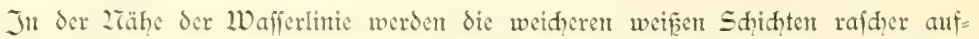
Gislöft, als die fpröden 23laubänder, wie dics befonders anffällig bet cinem gewaltigen Eisberge hervortrat, in defien zähe wir bei zrebel ant 4. Dejember gelangtert.

Kanm cntfitanden, wird der tafelförntige Eisriefe bercits unter den Einwirfungen der 2lufenwelt ungeformt. Die gewaltigen Klöte, welde aus 2litllionen von Tomn Eis beftehen, unterliegen der fduntelgenden Wirfung des Waffers und der Suft, nidgt minder aud? den medanifhen Eingrifien der Brandung. Wie lange ein antarftifher Kolof: den äneren Einfliffen ju wiederftehen vermag, läpt fid bei dem 2rangel an

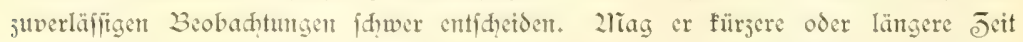

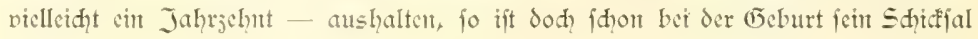




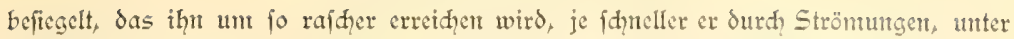
Imritänden aud durd, ftändig wehende Winde, in warnte Gebiete getricben wird.

In eriter Sinie ift die meḑanifhe Wirfung des Waffers hervorjubeben. Das antarftijhe 2lieer ijt ftets bewegt, und felbit bei anidheinend glatter See gelingt es faum, mit einem Boote ïh den Eisberge direft ju nähern und etwa feften fuñ auf ihm ju faffen. Sangiant, wie mit regelmäfigent Pulsfylag, arbeitet die Dünung in der Göhe der Wafferlinie an den flanten des Berges; Eränflt ein Wind die Dberflähe, fo beginnen dic Wogen an ibm ju nagen, und herridht jhwerer Sturm, fo bietet fith dem Seefahrer cin geradeju überwältigendes Sdqaupiel Sar. 2läđhtige Wogenfäntme ftütmren gegen den in majeftätifher Ruhe daliegendent

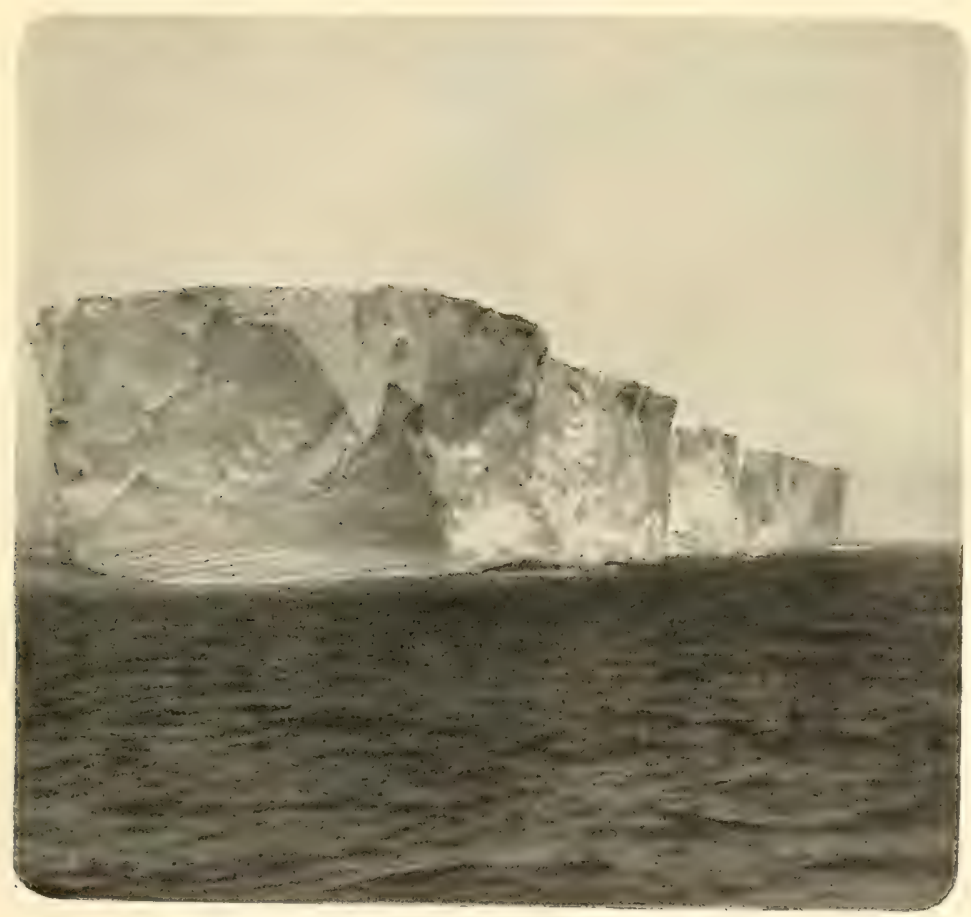

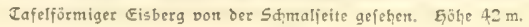

Mlan beadite bie Streifung nahe ber Wafferlinie; gegen Das plateau gu tritt fie weniget beutlid hervor. Der Eisbera

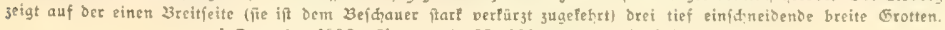

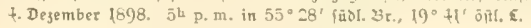
Uufnahme bei nebeliger Euft. 
Eisfolof an, jerificben bei dem 2huprall in feinen Gijht, um in Brandungswogen von fait unerbörter böhe längs der ciftgen 2liauern fid aufjubäunten und das Plateau

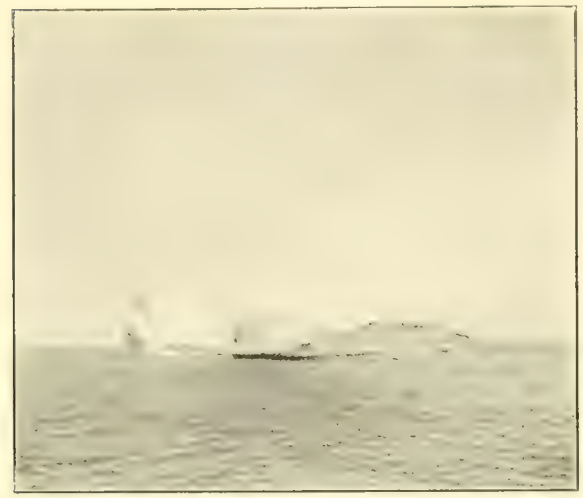

Eisterg mit Gohlfetle in Mecresniveas. (Schmidt phot)

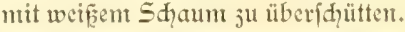
Fin derartiges Schaupiel bot fid unts dar, als wir nad? Verlafien von Enderby $=$ Land bei fduerent Ditfturm die lețten Fisberge fiđ teten. 2lian glaubte dumpfen $\mathrm{Ka}$ nonendonner ju vernebuten, wenn die Brandungstoogen anprallten und ihr ฮ̄erftörungswerk mädhtig för derten.

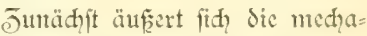
nijhe Wirfung des Waifers dut dic Bildung eitrer bohlfehle in der Göhe des Wafferipiegels. So lange der Eisberg nod in faltem Waffer, Seffen Dberflähe unter Zull frad crutedrigt ift, fduwimmt, fann eine Sdimeljung des Inlandeifes nidit ftatfinden, wohl aber wird durd die ftändig von den Wogen

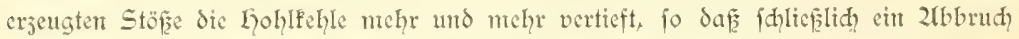
der über ify gelegenen Eismaffen erfolgt. Jndem Sie der Envfette jugefehrte flädye des Berges rafder zeritört wird, als dic seceite, tritt dant durd? cine leidite Derlegutig des Sdywer= purftes die Loblfehle frei ju Tage. Die faräg ju der fläde verftret= dienden und an ben flanfen auf= fteigenden Wogen polieren dam oft den unteren Teil des Eis= berges fait glatt. Die อ̄cricturu wird mu weiterhiut dadurd be= günitigt, daf flcine Sängsfpalten, welhe oberhalb der Wafjerlinte aufteten, neue 2lngrifispunte

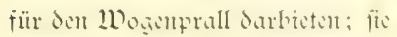
werden erweitert, bis fie fdilieflidy

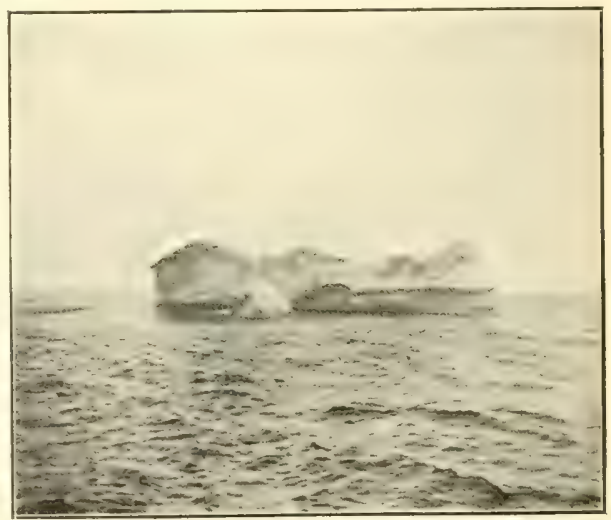

Eisberg nit getrobener Eoblechle.

(Schmidt phat.)

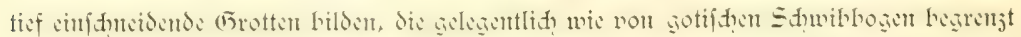
bis geger bas plateau hinaufrager. Jit ein langgeftrefter. Eisberg Wodhen hindurd 
mit der cinen Breitfeite dem Wogenprall preisgegeben, fo fam es fonmen, daf feine

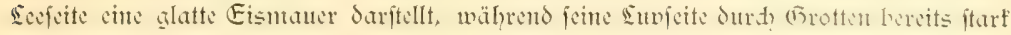
durḑlödert crifheint. Einen derartigen Eisberg beobaḑteten wir am 4. Dejember; er madte auf der Ditfeite den Eindruct, als ob er aus drei gewaltigen Bergen fich

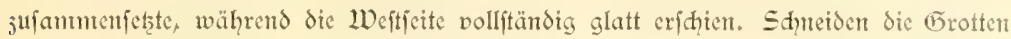
tief ein, und gehen vont ihren Defen Spaltent aus, die bis ju dent Plateau vordringen, fo flaffen dic burd, fie getrenten Eisblöte auscinander, neigen fid etwas jur Seite

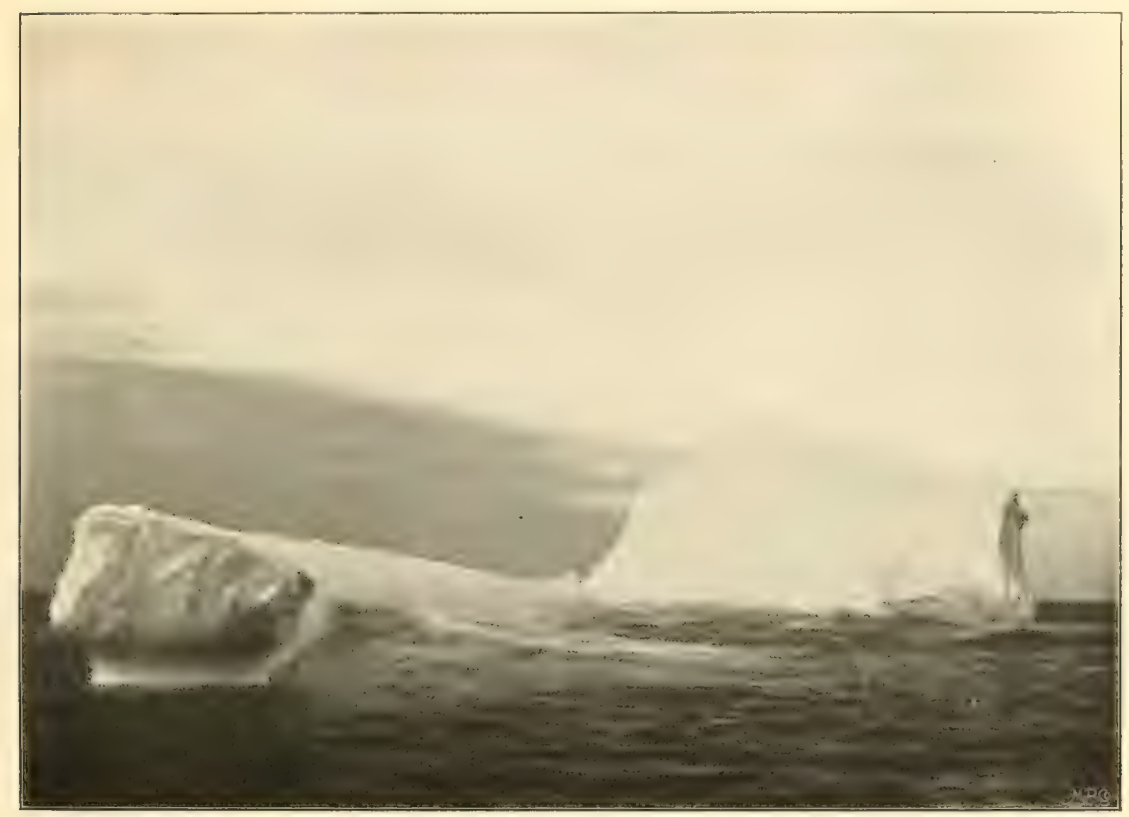

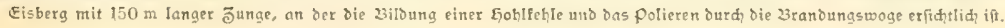
17. Dejember 1898. 6li $30^{\mathrm{m}}$ p. m. in $58^{\circ} 39^{\prime}$ f. $33 \mathrm{r} ., 45^{\circ} 56^{\prime}$ ö. ह. E⿱㇒冋)he $30 \mathrm{~m}$.

(Sachse phot.)

unt fuhthen 2lntehnung an die benahbarten. Dann nimmt die Streifung an den

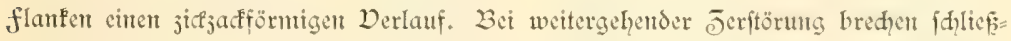
Lidh die Eismaffen jufamment und bilden unter Blmftänden Sturmböfe, deren fid der Wogenprall bedient, um den nod ftehentgebliebenten Teil der Eiswand in zhitleidents

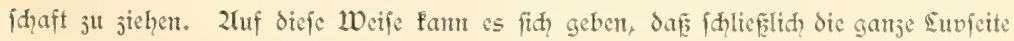
des Eisberges vernidgtet und ju cinem weiten 2mmphitheater untgeftaltet wird, deffen 
Ltmwallung die auf der Secfeite nod crhaltene Eismauer abgiebt. It werde niemals den Eindrut vergeffen, den einer der größ̨ten Eisberge auf uns ntadte, weldhen wir ant Z. Dijembir herits ans cinter Entfirmung ron 20 Secmetlen fidteten und fräterhin umfuhren $(5.219$ n. 220). Woir feţten damtals cin Boot aus, um ihn von diefem aus mitfamt dem Dampfer bei relativ ruhiger See zu photographieren. Don der

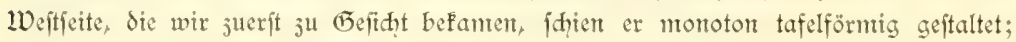
als wir indeffen auf die Pitfeite gelangten, vermodte niemand einen 2fusruf der $\mathfrak{B}_{\mathfrak{e}}=$ wunderung über den grof̧artigen 2lnblitf ju unterdrüden. Sie bot fid uns als ein

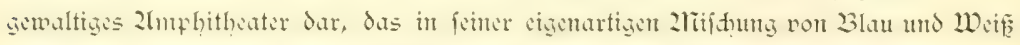
wohl die riefenhaftefte 2lrena darftellte, weldye unt je zu Eefiht gefommen war.

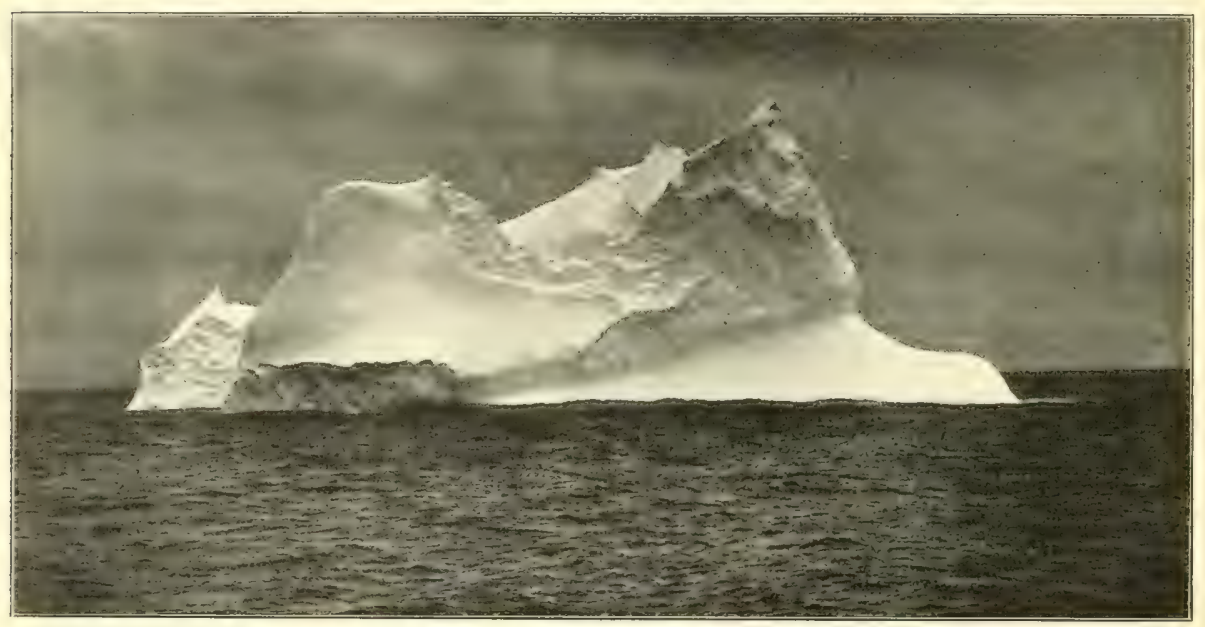

Jerfebter Eisberg mit hohliegender GohlPehle und polierten wänoen, 4. Dejember $1898,2^{\mathrm{h}} \mathrm{p} . \mathrm{m}$. in $55^{\circ} \mathrm{zh}$ 1. $33 \mathrm{r}, 19^{\circ} 36^{\prime}$ o.. E.

(Derielbe Eisberg ift Don einer anderen Seite in Eeliogravire rargeftellt.)

Es liegt auf der Fand, daf bei foldhen einfeitig jerftörten Bergen der Sdwerpunft verlegt wird. Sie neigen fith cin wenig in der Ridjtung der nod ftehenden Eiswand und der jerfẗ̈rt: Teil taud?t immter höher über Waffer auf.

Derartig geftaltete Eisberge trafen wir recht häufig an. Sie beftehen gewiffermaf̌en aus jwet Etagen, nämlid, einer ntedrigen Plattfornt, deren Dberflähe fehr unregel=

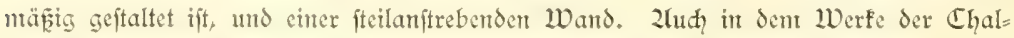
Ienger = Expedition finden fich mehrere 2lbbildungen derartig geftalteter Eisberge.

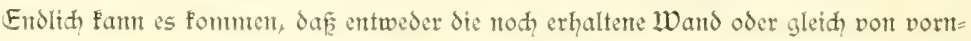


Eisbera, gefidtet an +. Darmber 1898 .

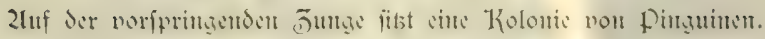




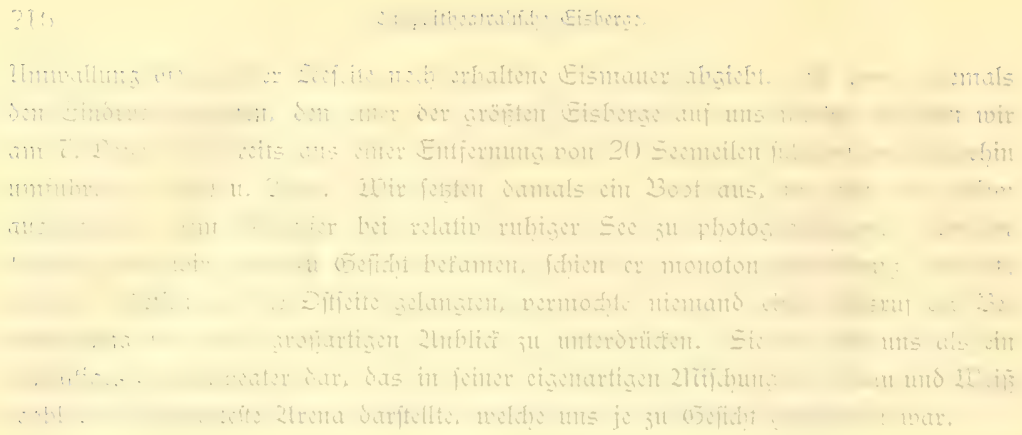

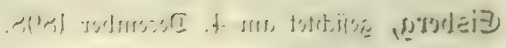

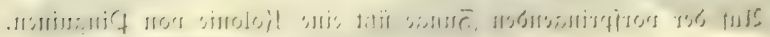

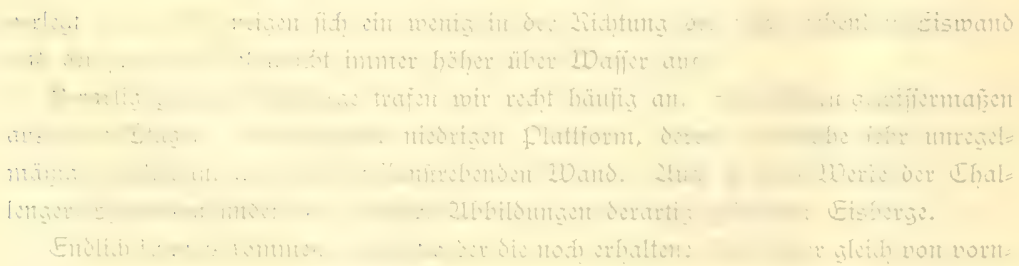




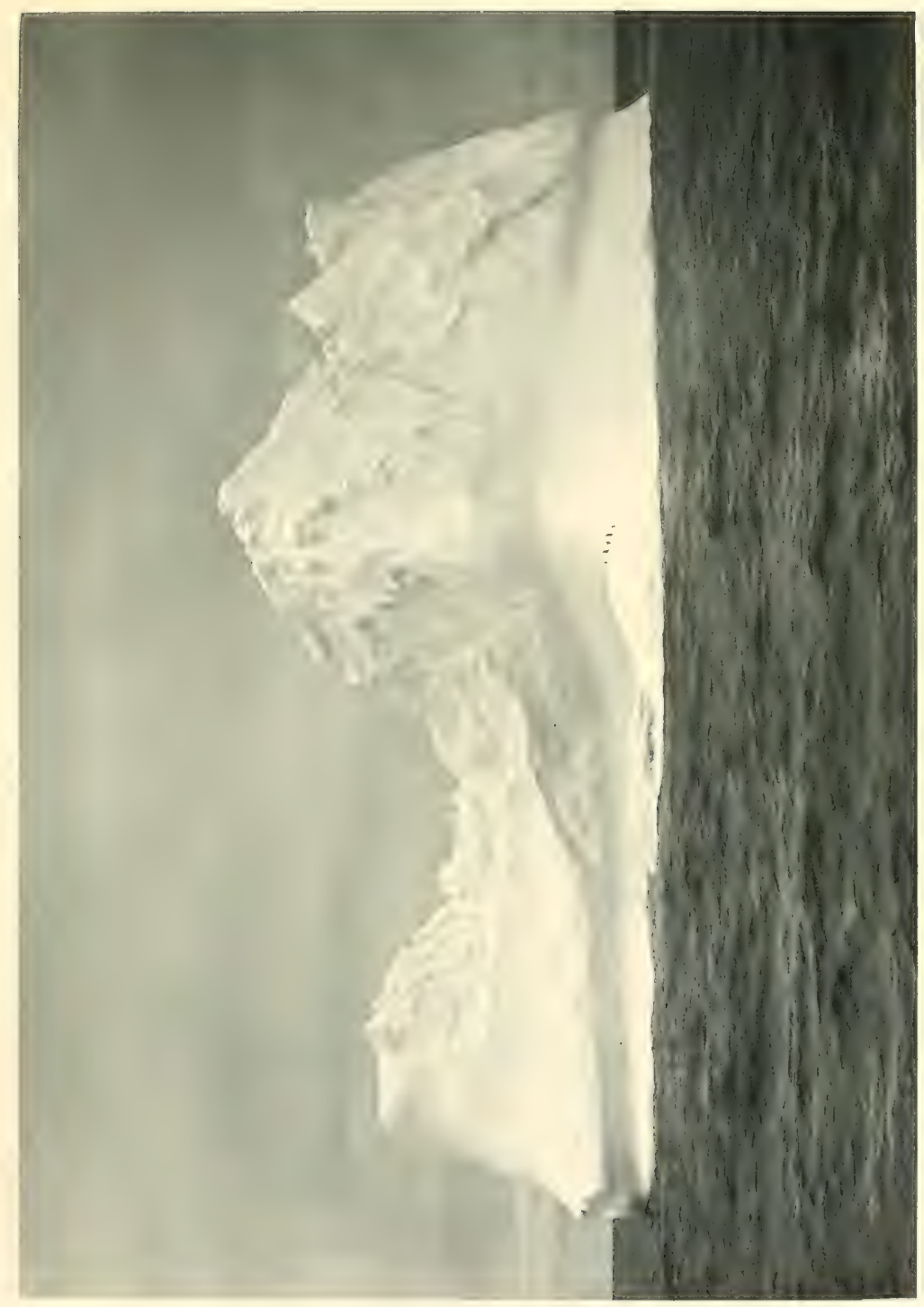



herein der ganje Eisberg durd tief= cinfarneidende und ftändig erweiterte Spalten in mehrere Ubteilungen jerlegt wird. Die ftetl auf= frrebenden ङ̈imnen, welthe dem biswei= len ganj vont Wai= jer bededten zliafio auffitsen, eximern Sam lebhaft an die Ë̈hnert formen der Dolomiten.

Da wir unfere Darlegungen auf

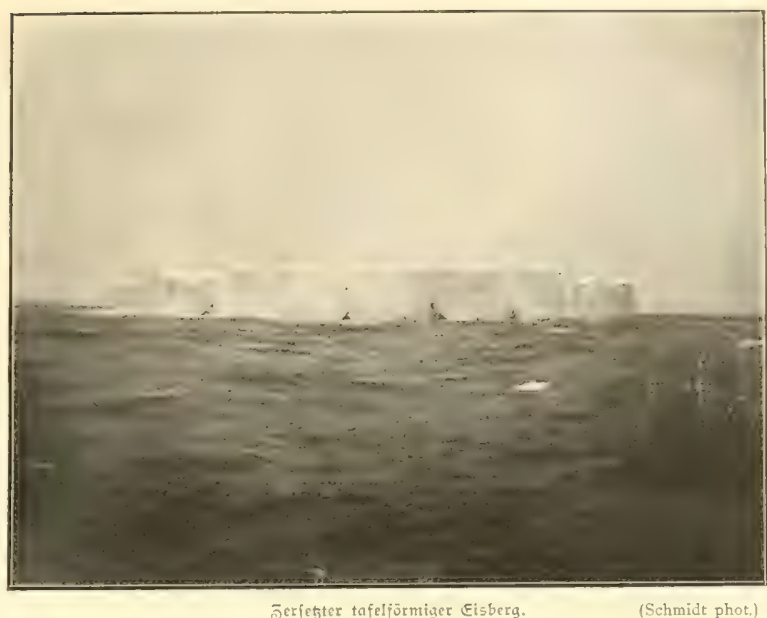
17. Dezember 1808. 9h a. m. it $60^{\circ} 15^{\prime}$ f. $23 \mathrm{r}$., $52^{\circ} 55^{t}$ ö. E

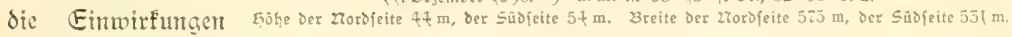

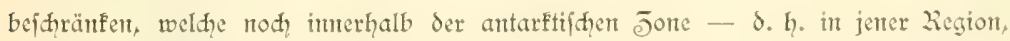
wo die Dberflähententperatur des Waffers unter $0^{\circ}$ finft - den Eisberg betreffen, fo mag dex furje Linweis genügen, da in in niedrigen Breiten ju der mechanifhen Wirfung des Sberflähenwaffers and die fameljente fiłh hinjugefell. In höheren

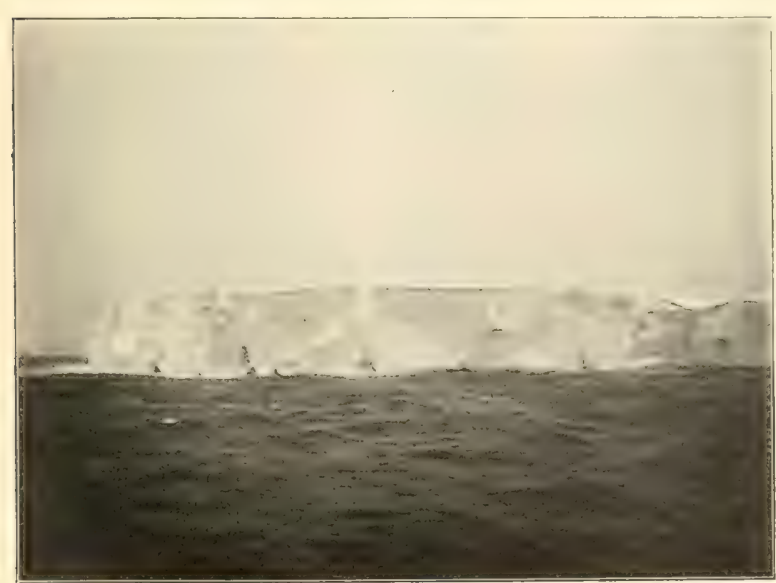

Jeit bes Eisberges nom 17. Dezenber"mit Streifung.

Breiten fommit Sicfe jwar nidht in 3etrad), wohl aber erwetft fid die in den Som mermonatent er= böhte Temperatur Ser Suft als ver= hängnisvoll für

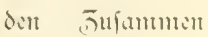
halt ber Eismafie. Steigt dic Tent peratur über $0^{\circ}$ und fintf fie ander: jeits un mur cin (5eringes unter den 


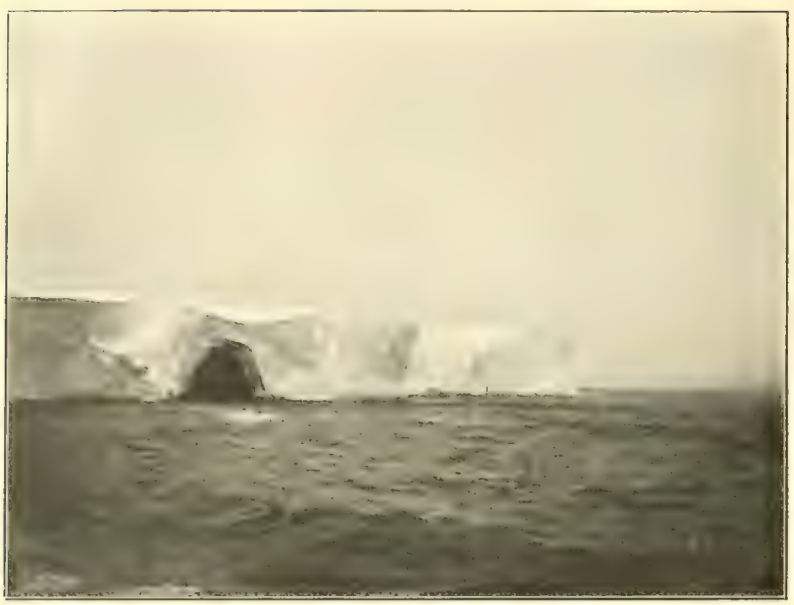

Brotte im Eisberg vom 17. Dezember.
Ziullpunft, wic dies gerade für den größ̧tent Teil der non ults surdfabrenen Regiont lätss dor Eisfante jutrifft. fo crfolgt cin ftän= diges 2luftauen unt Wiederge= frieren der ober=

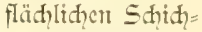
ten. Das Sdmely= waffer fitfert in dic Spalter und iibt, da es bei Sent (5efrieren fith ausdehnt, cine Sprenguirfung aus, welḑe eine ausgiebige Jertrünmerung jur folge hat. Bei dem Limfahren des vorhin erwähnten amphitheatralifo geftalteten grofen

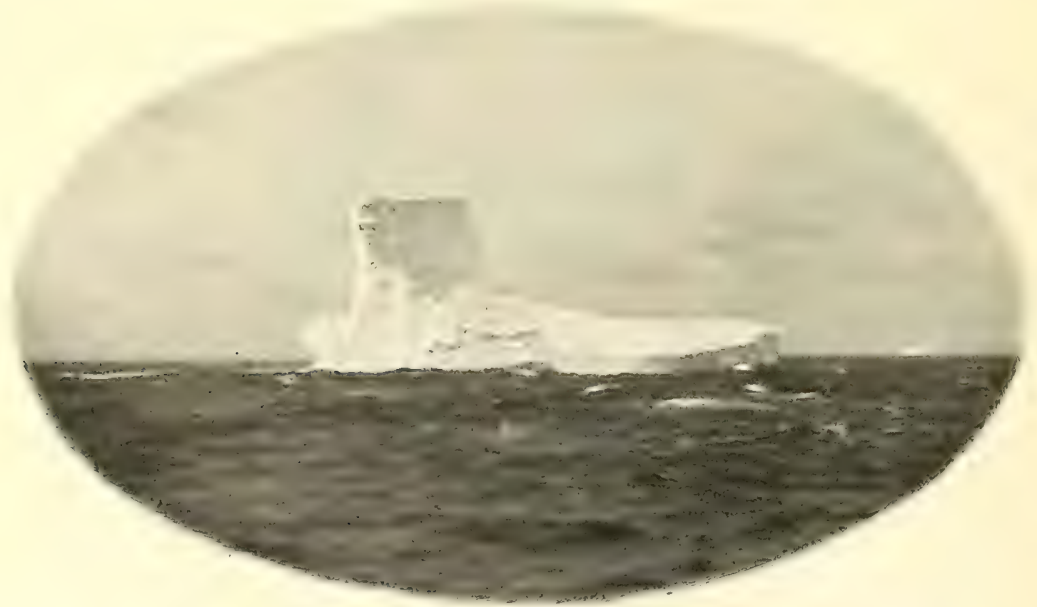

2tus 3 mei Etager beftehender Eisbera. Einfs eine 23randunasmoge 20. 27opember [808. $51.50^{\prime}$ a. m. in $55^{\circ} 14^{\prime}$ fübl. 23r., $4^{\circ} 4 u^{\prime}$ ötl. E 
Eisberges löłten fith volt den Seiten des Plateaus gewaltige 3löffe $a b$, die unter

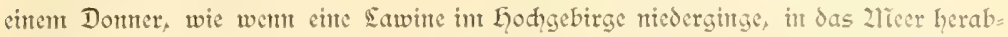
praffelten. So findet man dent auh gewöhntlith den Eisbers auf jeiner Eeefette vor jahllofen Shollen ungeben, welhe fidy dem Treibeife beimifdzen und Surdy if̧re fobaltblaue färbung von dent mehr blaugrün gefürbten 2reereife fith abheben. Durdh ihre Färte fint fie der Sdiffiahrt bejonders gefährlid und feit jeher vont den Süd= polarfahrern genticden worden. Dafiz ein ftädiges 2uftauen und Wiedergefrieren während der Sontmerntonate in höheren Breiten erfolgt, lehren and die gewaltigen Eiszapfen, weidge wir oft von den Kändern des plateaus nitederhängen fahent.

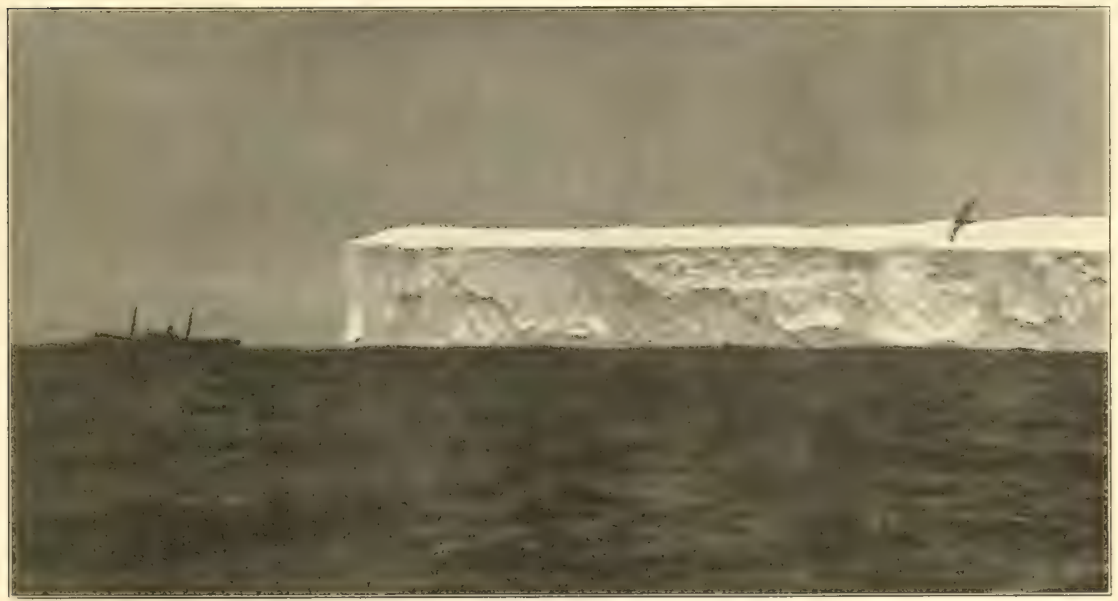

"Daldivia" einen tafelförmigen Eisberg umfahrend.

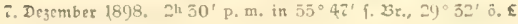

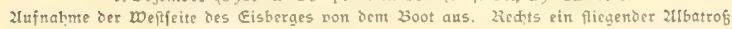

Eine ähnlithe Wirfung wie dic crwärmte Euft übt dic Somtenftrahlung aus. Sie dürfte fíh freilid in jenen Regionen, die wir durdfuhren, wegen des faft ftändig bedecten Fimmels weniger geltend maḑen, als in fübliḑeren Breiten, wo der Finmed häufiger aufflart. Rof bemerfte an den Dorfwrüngen der gropen Eis= mauer des Diftoria-Sandes Iange Eisjapfen, deren 2luftreten bei der dort herrfinenden niedrigen Sommertemperatur wohl wefentlich auf Red?ung der Somtenftrahluntg ju jetsen iff.

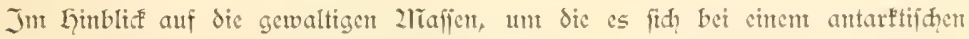
Eisberg handelt, fant es niḑt überraidgen, wemt dic durd, 2luftauen entftandenten 


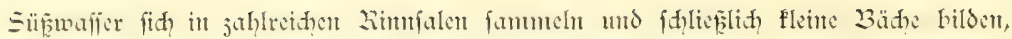
die in Kasfaden von dem Rande des plateaus in das 2lieer abfallen. 2ln dem be= reits erwähnten Eisberge nom 7. Dejember fahen wir mehrere Wafferläufe über den

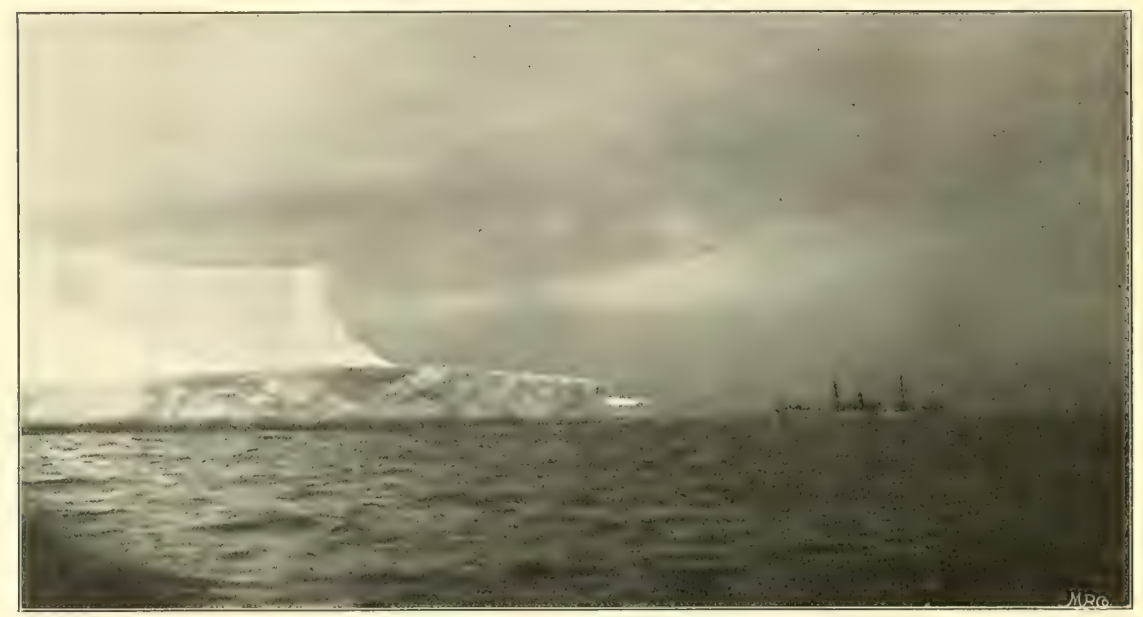

Eeil des Eisberges nom 7. Dejentber (Bitfelte),

Die "Dalbivia" befindet fid auf gleid,er böhe nit Dem Eisberg.

niedrigen Teil des Plateaus fith in die See ergiepen, obwohl ju der Jeit, als wir anfuhren, die Euftemperatur - $1^{\circ}$ betrug. Da wir immerhin ant nädyften Tage um die 2littagsjeit cine Tenmeratur von $+0,4^{\circ}$ beobahteten, fo begreift man, went bei

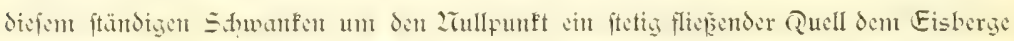
cntîtrömt.

Es braudt nid?t nod? befonders darauf hingewiefen ju werden, weldie Gefahren für dic Sdiffahrt die Eisberge darbieten. Sidh ihnen direft ju nähern, ift unter feinen

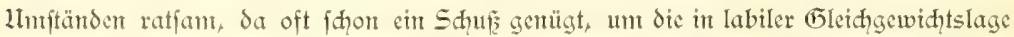
befindiden, durh die Sprengwirfung der frierenden Sdmteljwaffer geloderten Blöde jun Lerabftüzen ju bringen. Da weiterhin in defen (B)ebieten mit einer oft unheint=

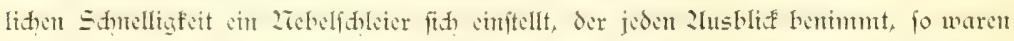
wir häufig genötigt, die 2liajhine ju ftoppen, wenn vorher Eisberge gefidtet wurden. Eridien der Gorijont fret und fam 2rebel auf, fo fuhren wir immerhin mit halber Kraft und fudten durd? ftändiges Jichent an der Dampfpfeife das Etho von etwa vorliegenden Bergen ju weckert. Durd cincn limitand wird allerdings aud bei difem 
Eisbery, zefiditit ant โ. December $(80) \AA$.

Zlquarell voll $f$. Winter. 


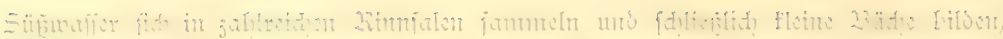

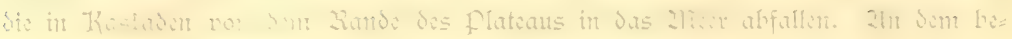

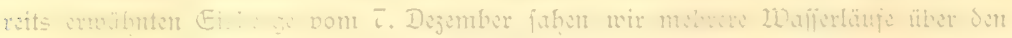

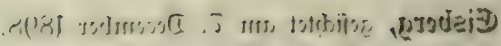

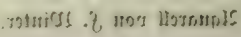

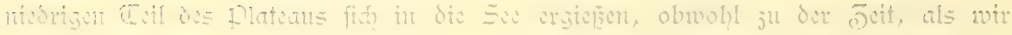

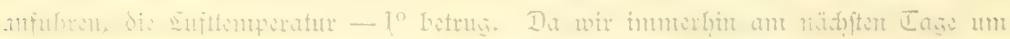

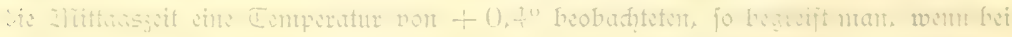

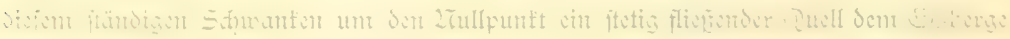
vetitant.

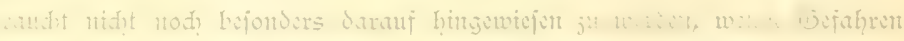

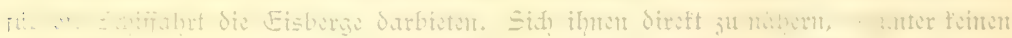

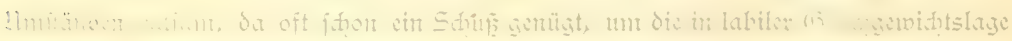

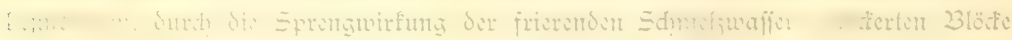

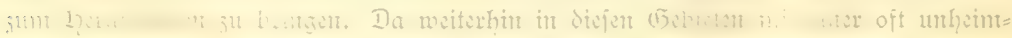

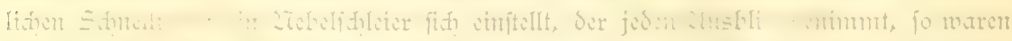

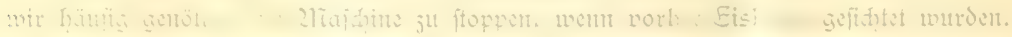

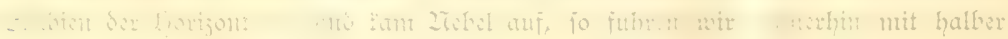

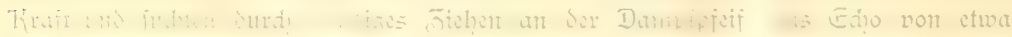

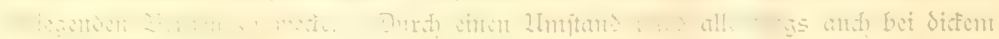




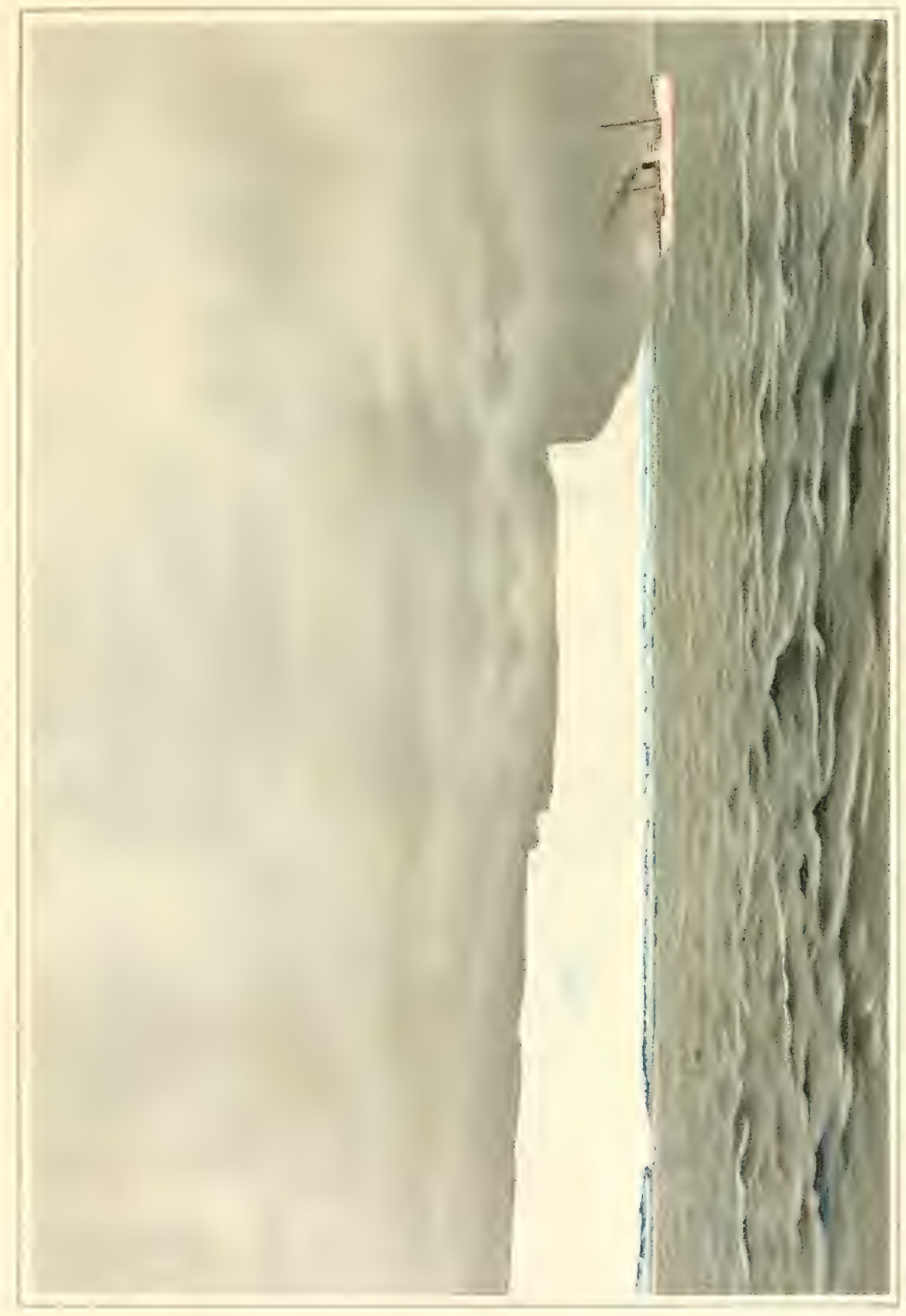



Wetter die 2mmäherung an den Eisberg verraten. In ummittelbarer 2Täbe des= felben erfolgt näntlid, wie wir mehrfad, ju exproben (5elegenheit fanden, cin 2 fuf= flaren, welhes offenbar dadurd bedingt wird, daf die von dent Eife ansftrahlende Kälte cin Gefrteren und ZTiederfallen der Wajferteilḑen in der ungebenden suft jur folge hat.

Zlle die hier genamten Enmirfungen von Wafjer uns Euft betreffen nur die oberflählidye Partic des Etsberges. Weit wirfungsvoller dürfte fid indeffen anf (5rund unferer lnterfudjungen dic Jerftörung erweifen, welde dadurd? bedingt

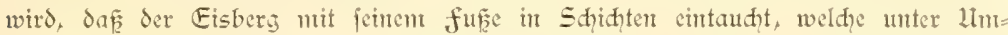
ftänden um $5^{\circ}$ wärmer find als das Dberflähenwafier. Es ift fdon frihher daranf bingewiefen worden, daf in 500-400 $\mathrm{m}$ Tiefe, aljo in jener Tiefe, bis ju weldher der gröfte Teil ber Eisberge hineinragt, cine Temperatur von + 1, $7^{\circ}$ herridt.

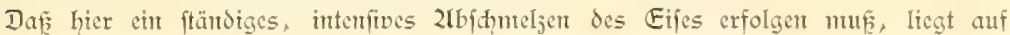

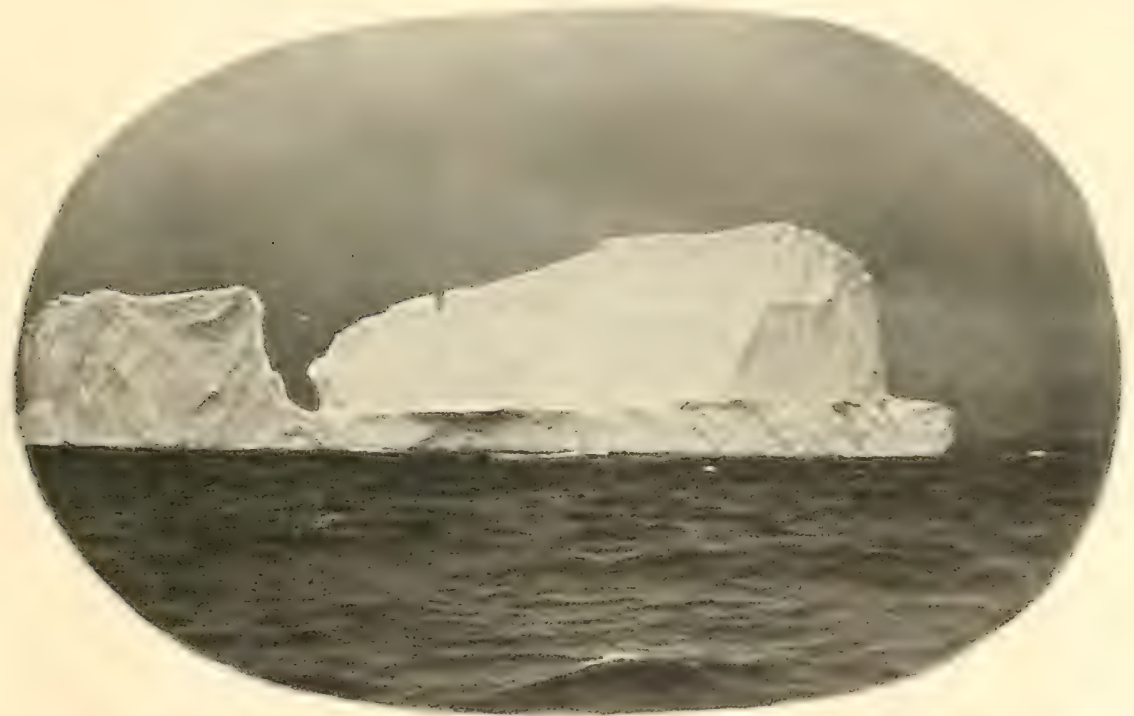

In зmei Eälften zerlegter Eisberg, von denen die fleinere (Dem Befdauer zugePebrte) fid in eine Eismaner fortjetst.

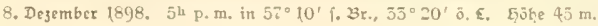

Ser Gand. Diefe fpecifif leidten, aber falten Sdmeljwaffer fteigen jur ober= fläde und breiten fith liber das ganje antarftidie Gebiet in allerdings dumner 


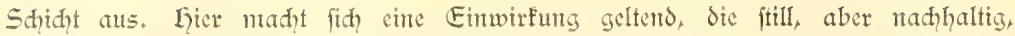
fitherlid, alles überbietet, was Wogenprall und warmte Suft an dem über die Dberflübe herausragenden Teile des Eisherges juwege bringen. Fin beträdtlidier Wämevorrat wird dem Ticfenwaffer entjogen und durd das Sdintzen des Eifes gebundert.

(5erät mun gar der durhh das Zuftaun von unten ftätdig leidhter werdende Berg in wärmere siegionen, wo der Sdmeljprojef aud im Dberflähenwafier fith gelteno madit, fo fann es fith wohl geben, daf der Sobverpunft völlig verlegt wird und ein Utmwäljen erfolgt. Fin folhes haben wir freilid niemals in falten Gebicte ju

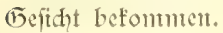

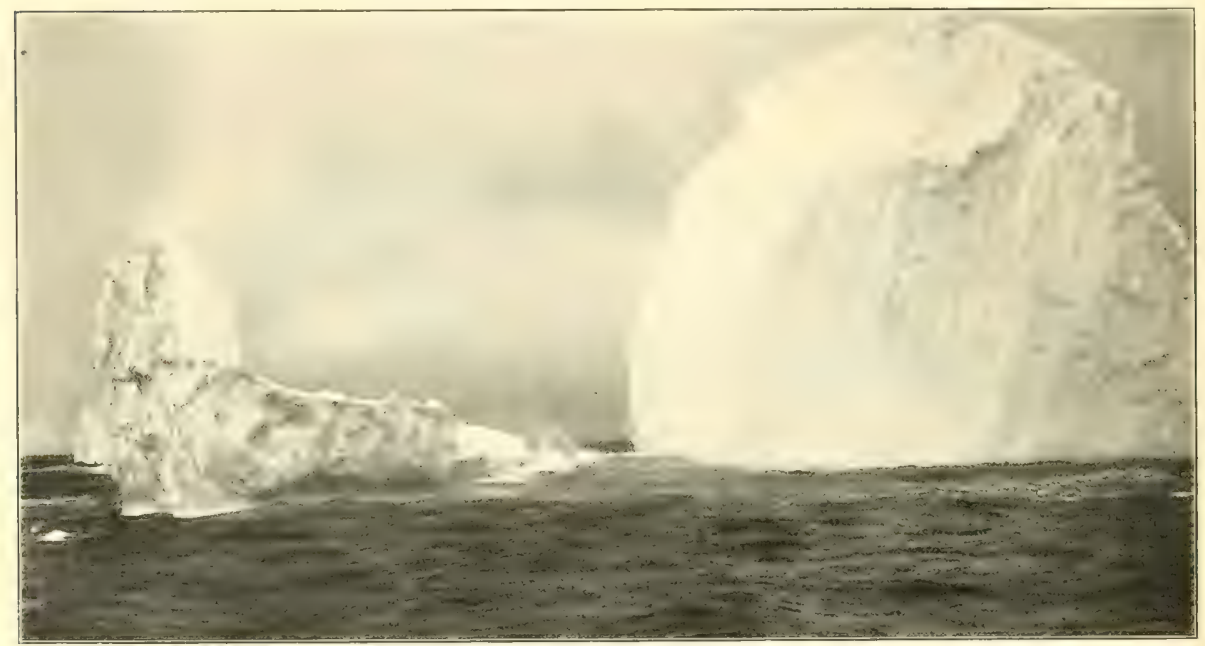

Eisberg nom 8. Dejember 1808. (5. 22I).

Infict bon oer erefeite mit treibenoen, von ihm abgelöten Shollen.

Int allgenteinen ijt wohl der Shluf gerediffertigt, dafi ftart zerfetzte Eisberge in weiten 2lbftand volt ihrer Urfprungsftätfe angetroffen werden und demgentäf aud? auf cine grof̧e Entfermung des antarftifhen Kontinents himmetien. Die crften Eisberge, weldhe wir jenjeits des 55. Erades gemahrten, deuteten dem aud darauf hin, daf fie offenbar eine lange keife jurüdgelegt hatten. Dorfiḑt ift indeffen bei derartigen Edlüfen notwendig, wie dies aus der Thatjahe hervorgeht, daf wir bereits am 5. und an 4. Dejember, alfo nod in der Bouvetregion, tafelförmige Eisberge an= trafen, welhe durdians den am füdidhiten Punfte der fahrt beobaditeten glidyen. Der 
ant 5. Dejentber in $56^{\circ} 0^{\prime}$ i. 3r. und $16^{\circ} 18^{\prime}$ o. s. gefiditete und in feiner Weife jerfebte Eisberg war judem mit $59 \mathrm{~m}$ der höhite, weldgen wir maj̄en.

Zndererfeits bereditigt das Dorfommen fleiner unregelmäfig geftalteter Eisberge durchaus nidit ju dent Sdiluffe, daf man fid weitab von dem Sande befinde. Die

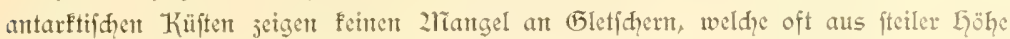
niederfallend ebenio ftarf jerflüftet find, wie die grönländijhen Eisftrönte. Es liegt

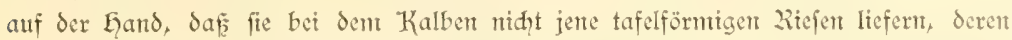
wir bisher gedaditen, fondern unregelmäfig geftaltete Berge, wie fie dem arftifhent Gebiete cigentünlidh find. Dic wenigen Berid̨te über das Wäljen antarftifher Eisberge dürften vorwiegend an foldhe anEnüpfen, weldhe den (DIetihern von Stcilfiiften

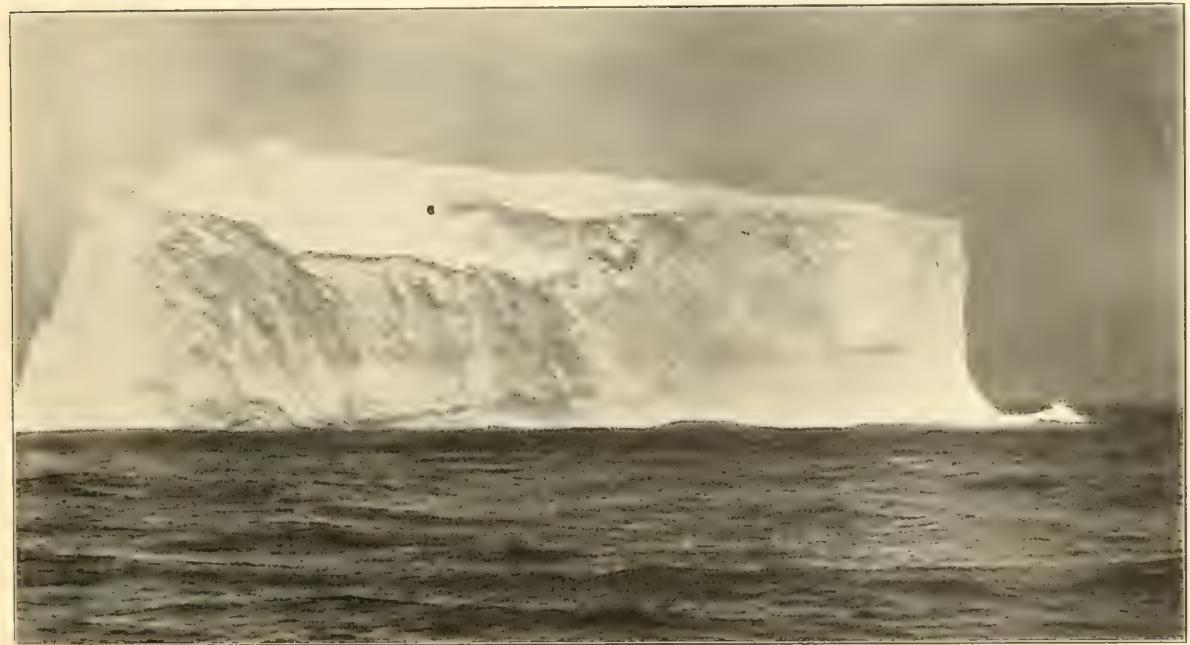

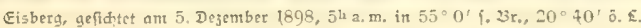

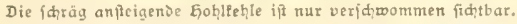

entftamment. Intmerbin unterfdideit fid, wie aus älteren Beridhten hervorgeht, biefe umregelmäfig geftalteten in nahem Eandabitand gefundenen Fisberge dadurd von den

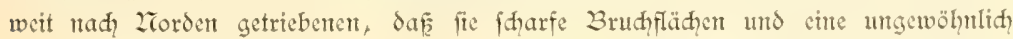
Sentlidh ausgeprägte Streifung aufweifen. Dagegen find ihnen Gohlfehlen und durd die Brandung glattpolierte flähen nidht in dem 2rafie eigen, wie den bis in die 1Deft= windregion verjdlagenen Bergen. 
Die bisherige Darfellung vermag mut freilid feinen Begriff von der überwältigen= den Praht ju geben, welhe dicje antarftifhen Koloffe darbieten. Kein 2raler ijt im ftande, diefe wundervollen Sdiattierungen des 3lau wiederjugeben, wie fie in der 2iähe cintes Eisberges jum 2lusontef gelangen. Fin feiner Duft fheint über dem (ธ̄anjen ju liegen, hier und da treten blendende, fanteeweif̧e fläden hervor, während die Spalten,

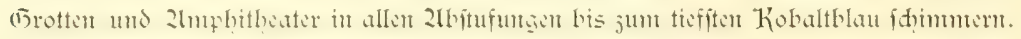
Das den Fisberg befpülende Waffer nimmt die färbung von Kupfervitriol an und hebt fid fharf ab von dem bei bededtem Limmel grau erfdeinenden 2reere. Dabei geben die bijarren formen der ftarf jerjetzen Fisberge der Phantafie ftändigen Spiclraum;

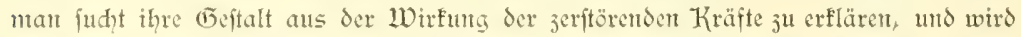
niḑt mübe, dicfe feftungen mit ihren Jinten, diefe Dome und fteil anfrebenden Türme, Sicfe 2mmphitheater und wild jerflüfteten Eisgebirge vor dem ftaunenden 2luge vorriber= jiehen ju laffer. Sie werden belebt von Pinguin=Kolonien, die fre als Standquartier bei ihren Reifen durd? das antarftifhe (B)biet ausnuten, und umflogen von Sturnt= pögeln und 2llbatroffen, welhe in der Srandung des Eisberges ein günftiges Jago= gebict findent.

Wer midh fragen wärde, welher Teil des freien Dreans den nađhhaltigften Eindrut Ginterlafien hat, dent wïrde id ftets ohne Sammen das antarftithe 2lieer nemen.

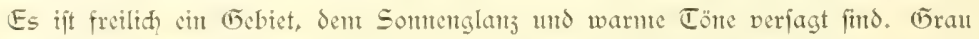
ift der Limmel verhängt und grau wird cr von der Wafferflähe widergefpiegelt. In langgejogener Dünng fdyeint das 2lieer wie mit rubigen 2ltemjügen emem tiefen Sdlafe verfallen. Seme Dede bildet cin Ziebelideter, Totenitille herridgt ringsum und mit halber Kraft verfolgt das Sdiffi jögent fement Kurs durh unbefante Regionen. 2lud? auf der Brüfe ijt es ftill geworden; mit gefpannter 2lufmerfiamfett fuchen 2luge

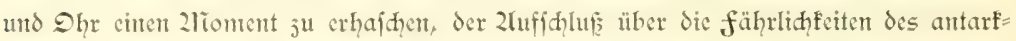

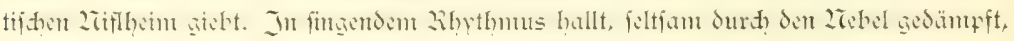
Ser Ruf der Wade wieder, und mit greller Diffortant heult die Dampfpfeife in die 2radt,

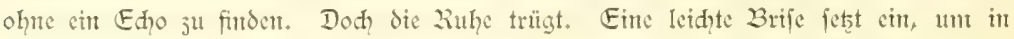
überrajhend furjer ฮ̄eit ju fđweren Sturm anjufaden, der jwar den 2rebel ver=

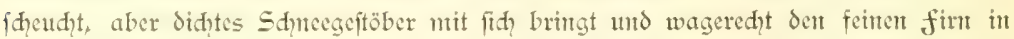
die fonmerzenden 2lugen jagt. Der Seegang wird fräftiger und bald ftümen Wogen= fämme von cincr sänge und 5 öhe ant, wie fie in femem andern 2liece je boobahtet wurdert.

Die Spamfräfte haben fich in Iebendige Kraft ungefetst; eit wildes Treiben, ein froh pulferendes Eeben herrfht ringsum. Sdywäme von Sturmbögeln und gewaltige zllbatrofie unferifen das Sdiff, bald hod über den 2liaften fhwebert, bald in dic Wellenthäler nederjaufend. Treibetsfelder unterbreduen die 2lionotonie der Sberfläd̨e und cndid, übermitteln Sie Wunder des antarftifhen Südens, sie fryftallenen paläte 
aus Eis, unnahbar und in majeftutifher suhe der tofendent Brandung inge wein und

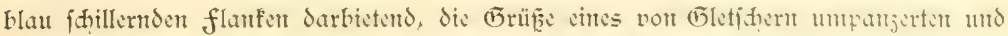
von dem Shleier des Geheinmisvollen ummobenten Kontinettes.

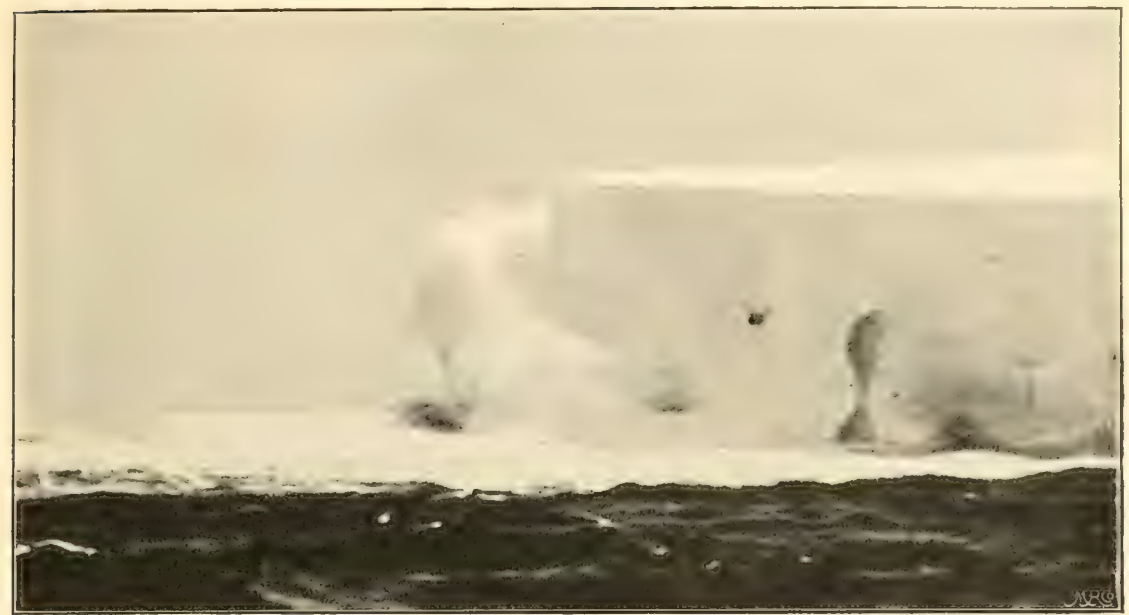

Brandungswoge an einem $54 \mathrm{~m}$ hohen Eisberg. Das wafler it mit weifem Gifat bedeft 19. Dejember 1898 in $61^{\circ} 40^{\prime}$ \{. 3r., 61 $3 l^{\prime}$ ò. ⿷.

\section{Das antartiface planton.}

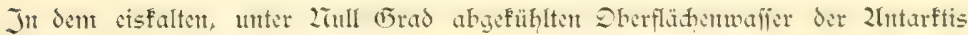

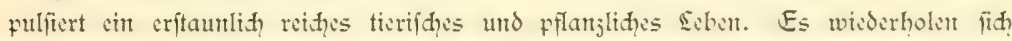
Gier ähnlidge Derhältniffe, wie wir fie aus dent arftifhen 2licerent femten, deren fro=

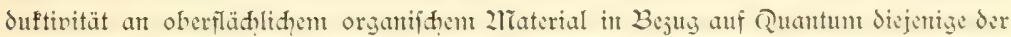
gemäpigten und warmen zheere überbietet. 2lllerdings wiffen wir, daf bifi zhafien=

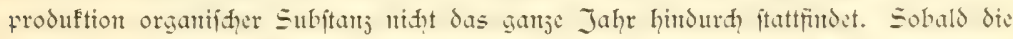
Some im frühjahr über den Eqorizont fteigt, Feginnt die Dherflü.ţe fith mit mifro=

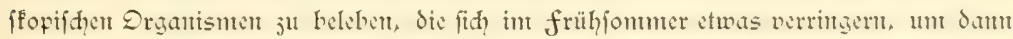

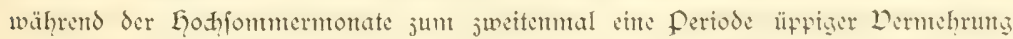
eitrzuleiten. Dam nimmt ihre อ̄ahl $a \mathfrak{b}$, und während der Wintermonate dürfte die

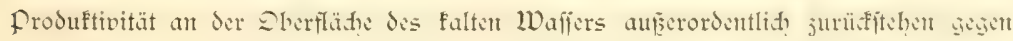
jene wärmerer 2lieeresgebiete. Wir waren offenbar gerade ju jenter jeit nad? Süden

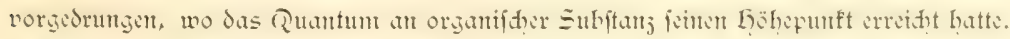

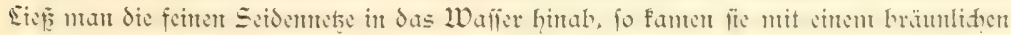


Brei von Drganismen gefüllt wieder auf; glühte man demfelben, fo erhielt man cine

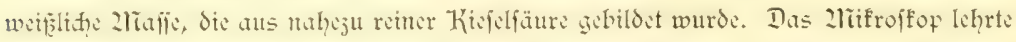

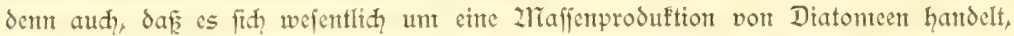
die, ähnlid wie int arftifhen Gebiet, auf weite Streffen hin das 2ricer verfärben.

In dem fufe der Eisberge, am Rande der Sdyollen benterfte man einen gelb=

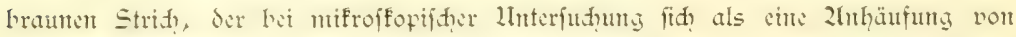

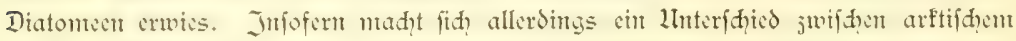
und antarftifdem planfton geltend, als die dem erfteren mafferthaft beigemengten

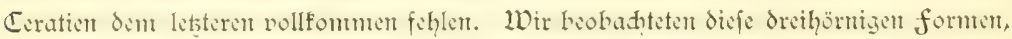

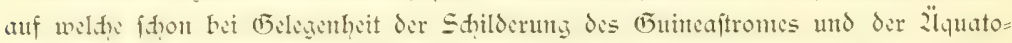
rialftröme hingewiefen wurde $(S .76)$, an der Dberfläḑe nod, häufig bis zum 17. 2To=

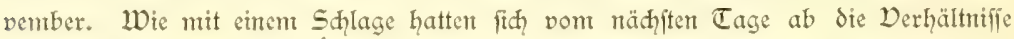
geändert. Eine neue Degetation trat an der Dberflühe auf, und zwar genau an dem= jentizn Tage, wo uns jum letstemmal das Thermometir die Einmirfung dis marmen 2laulhasftromtis nerrict, und die füdurförmitg in ihn vordringenden falten Wafferftrifen die Dberhand gewonnen hatten. Don mun an waren es wefentlith nur Diatomeen,

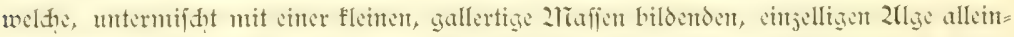

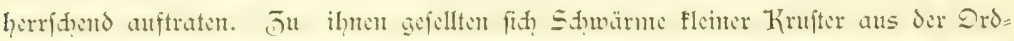

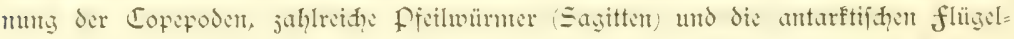

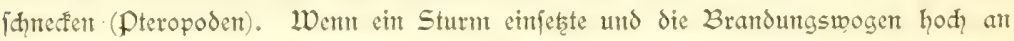

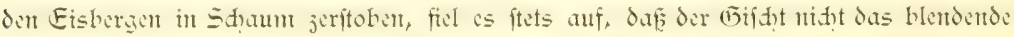
Weif der Eisberge jeigte, fondern häufig gelblid, oder grau verfärbt eridien. Dies rührt allew ron der mafimhaften Esimifhung flemer und fleinfter Drantisment her. Da wir wodpenlang uns naheju ausfdiliç̨lid, mit dem fangen und dent Studium

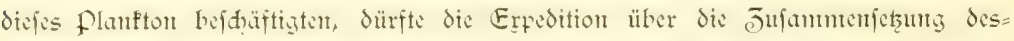

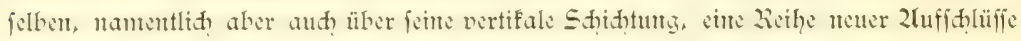
gewomten haben. Es fei daher etwas eingehender diefer Derhältniffe gedaḑt.

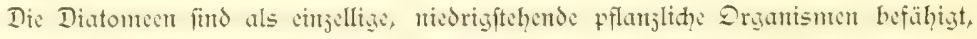
aus anorganifher Subftanj unter dem Einflü von Sonnenliḑ̨t und bei dent Dor= handenfein gilflith oder brüunlid gefürbter Ehromatophoren die Eimeişubitanjen ju bilden, aus denm the flimir Jillenleib fith aufbaut. Diefe Chromatophoren bedingen

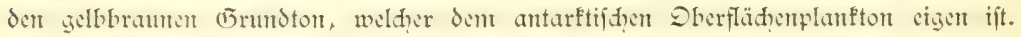

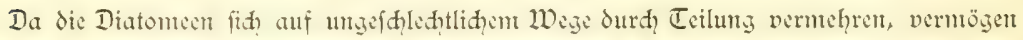
fie in furger äeit fo mafienhaft fith anjuftaum, daf dic Dherflädi dis 2liceres ver= färbt erifheint. Jhre Jellwandung wird aus Kiejeläure gebildet, die fo reijoolle Sfulpturen aufweift, da fie feit jeher Eichlingsobjefte für das Etudium der 2litifro= fFopif́er abgaben. Da der Khiefelpanjer aus jwet Gälften befteht, die wie der Dečel auf eime Shadtel fidh insinander fdieben, fo fanm aud leidt bet der Teilung der 
Verband beider Sdalenhälftent gelöit werden. Sie ifieben fid auseinander mo die fehlende Panjerhälfte wird, cingejhaḑtelt in die alte, neugebildet.

Das antarfitifhe planfton feţen 2lrten jufammen, die meift nur der 21rt nad von jenen der anderen 2lieere verfifieden find. Dor allen Dingen treten in gröfter 2Taffen= haftigfeit Dertreter der Gattung Chaetoceras auf, deren Jellleiber nit langent, die 2lnordmung ju Ketten ermögliḑenden fortfäłzen ausgeftattet find $(\mathcal{S} .250)$. In der Zähe des Eifes herridten fie in dem Dberflähenplanfton vor. 2aeben thinen fimb es

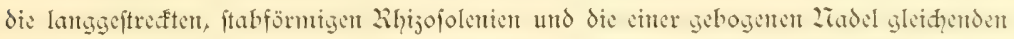

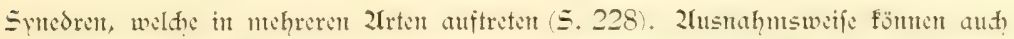
Zrten der reiznollen (5attum Corethron und Fragilaria durch ihe 2raffenhaftigfeit auf=

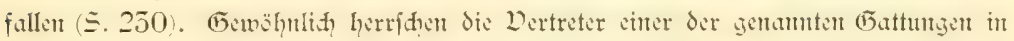
dem Dberflähemplanfton derart vor, da mant von cinent Chaetoceras-, Rhizosolenia-, Synedra- und Corethron-planfton fprechen fant. Weit feltener treten an der Dber=

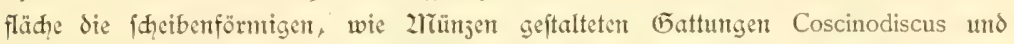
Asteromphalus (5. 255) nebjt anderen formen, deren Zamen wir niḑt erwähnen

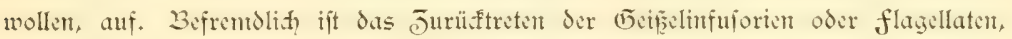
unter denen, wie fđhon erwähnt, die Eeratien vollitändig feł̧len, während die übrigen peridineen mur durd wenige 21rten vertreten find. Ilian darf indeffen nidit voraus=

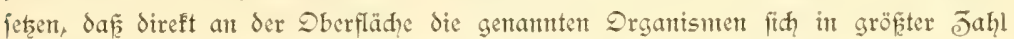
anftauen. Es fiel uns fofort auf, da管 bis zu etwa $40 \mathrm{~m}$ Tiefe die Dberflühte ärmer

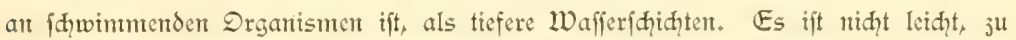

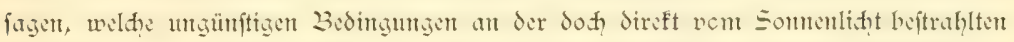

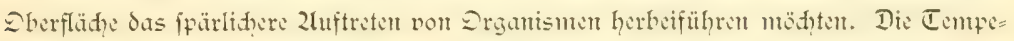
ratur fann faum von Einfluf fein, da die Dberfläd̨e, wie wir früherhin betorten, cin

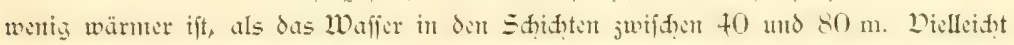

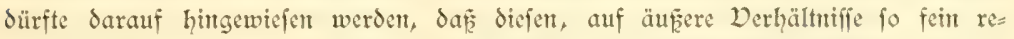

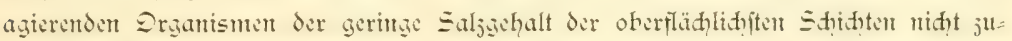

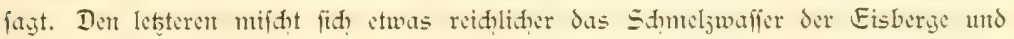

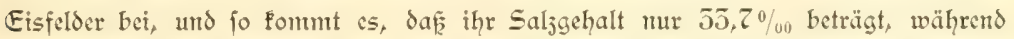
cr erfit in tieferen Sdidhten (bei $150 \mathrm{~m}$ ) $5 \neq \%$ erreiḑt und dam langfant gegen dent (5runt junimmt. 2riehrmtals fiel es uns auf, daf in nädhfter 2tähe der Eisfelder Sic Dberflähe ant ärmftent an Drganismen war.

Unf die von meift mifroffopifhen pflanjlithen Drganismen an der Dberflähe ge= bildete "2trnaḩung" ift in leţter Einic der gejamte Tierbeftand des 2reeres - die Tieffeefauta nidgt ausgettontmen - angewiefert. So einfah und felbftberftändidh

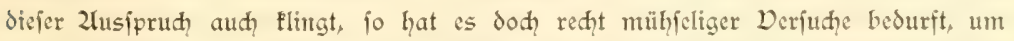

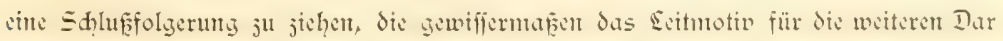
legungen abgeben foll. 
Wirfung des Eidites.

Eine cinfache lïberlegung läp̧t die Sđhwierigfeiten würdigen, weldhe ciner Söfung der frage nadh der $\mathbb{E}_{\mathbf{r}}=$ nährung der Tieffecorganismen in $\mathfrak{W}_{\text {ege fteher. }}$

Dic Diatomeen und fonfitigen niederen pflanjlidien Drganismen bedürfent des sid̨tes für ihre affimilatorifhe Thätigfeit und vermiögent bet ftarf́ abgedämpfter $\mathcal{B}_{e}=$ leuditung nidht mehr juh eriftieren. Soweit wir bis jeţt Kemtnis von dem Dordringen des Sidftes in tiefere Wafferfhidhten befithen, dürfen wir wohl amtehmen, daf unterhalb $500 \mathrm{~m}$ abjolute finfternis herridht. Sind die oberfladylithen Shidhten reid mit planfton durdh= fetst, fo wird das Liḑt nidit fo weit vordringen, wie in dem fryitallflaren, an fhwebenden formen armen Waffer, wie wir es 3. 3 . im nordweftliden Teil des indifden Decans antrafen. So viel ift fither, daf das siḑt gerade in demt antarftifhen 2lieere mit feiner überraithend reiden pro= duftivität an der. Dberflähte bei feinem Vordringen in tiefere

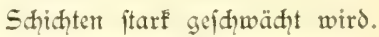
Einen amtähemd frderen 2lia =

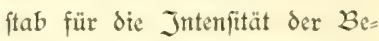

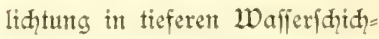
ten wird ftets das Dordringen affimilierender Drganismtent lie= fern. Säfit es fith nadqweifen, daf fie von beftinmten Tiefen an feḩlen oder eine Derände= rung ihres Jellinhaltes auf = weifer, wie wir fie durd fünjt= lidpe Verdunfelung herbeiführen fömtent, fo dürfen wir aud an= nehmen, da nis nidt mehr genü= gentes Gidpt vorkanden ift, um irgend welhe 2lffimilation ju crmöglident.

(1) berfläenflanftort aus bent antarftifiten neere, Detar, 13/2. 


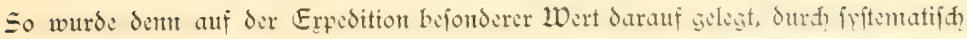

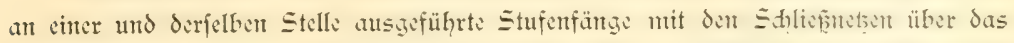

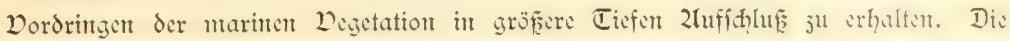

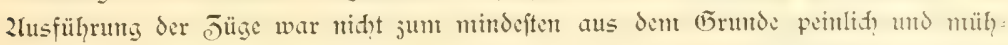
felig, weil es fith um Drganismen handelt, welhe ju den Pleinjten gehören, die wir

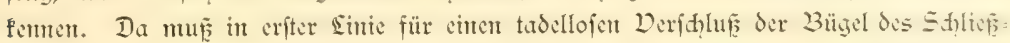
netes Sorge getragen werden, der durdyaus verhütet, daf bei den 2ufwinden des gefdiloffenen 2icţes lebende formen aus oberflähliḑen Shidhten arbentet werden.

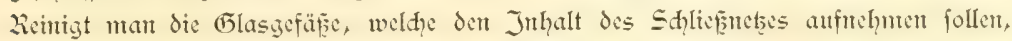
niḑt auf das jorgfältigite, fo genügt ein Tropfen Seewaffer von der Dberflähe, um durḩ die in ifhnt enthaltenen Diatomeen das Rejultat $3^{u}$ trüben. 2roh mehr 2hufmerffamfeit erfordert das 2lusfpülen des Zithbutels mit deftilliertem WDaffer, um ğleidfalls fehlihlïfi ju vermeiden. Bei allen derartigent Stufenfängen maḍten wir

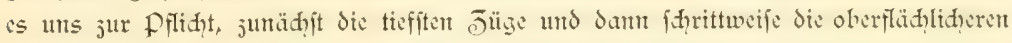
ausjuführen. Würde nan ungefehrt verfahren, fo fönnte es fidh leiḑt geben, daf

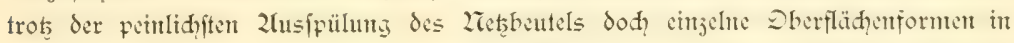
den 2liaihen hängen blicben und unter das Tiefenmaterial gerictent. Es darf wohl hervorgehoben werden, daf wix redt bald in der Sage waren, ju beurteilen, ob irgend cine fehlerquelle vorhanden $\mathfrak{w a r}$, die ju einem anfheinend unerwarteten Sefultate bit der mifroffopifden Interfudung führte. Profefior Sdimper unterjudte in Gemein= Whaft mit den Joologen den Jnhalt der Sallef̧neţe gleid, nad? dem Zuffommten, und feinen Bemïhungen verdanfen wir folgende Ergebniffe über die vertifale $\mathcal{D}_{\mathrm{er}}$ breitung der pflanjlidgen, lebenden Drgantismen.

Die Gauptmaffe des pflanglidien Planfton ftaut fid jwifhen $40101880 \mathrm{~m}$ Tifie

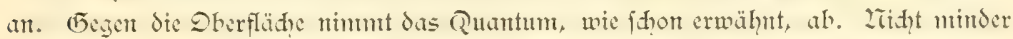
anfällig ift aher and sic rafde 2lbnahme unterhalb $80 \mathrm{~m}$. 2fuf (1)rund unferer 2tnter= juđhungen fönten wir mit Siđherheit behaupten, dafí die untere Grenje für die Ver= breitung lebender pflanjlider Drganismen jwifhen 500 und $400 \mathrm{~m}$ liegt. Itnterhalb $200 \mathrm{~m}$ find lebende Diatomeen berits fo fpürlid gemorden, daf man oft lanze Jeit

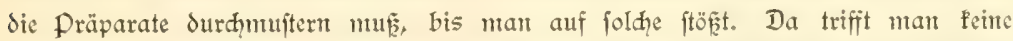
Ketten von Chaetoceras, fondern nur nod cinjelne Bruthitüfe dificlben; dis 21rten der (Battung Corethron fehlen unter $80 \mathrm{~m}$ gänjlid), und nur äuferit felten wird nod eine Rhizosolenia, Fragilaria oder Synedra wahrgentommten. 2luffälliz ift es hintzezen, dar die Jahl der Eremplare von Coscinodiscus und Asteromphalus fid bis gegen $200 \mathrm{~m}$

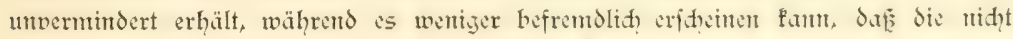

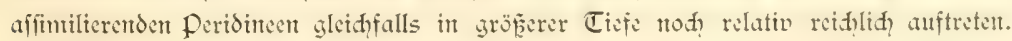

Don einer eigentlichen "S\$)attenflora", wie wir fie aus den wärmeren 2licerent berits fennen lemten, ijt im antarftifhen (B)bite ntidits wabrjunchmen, jumal da 


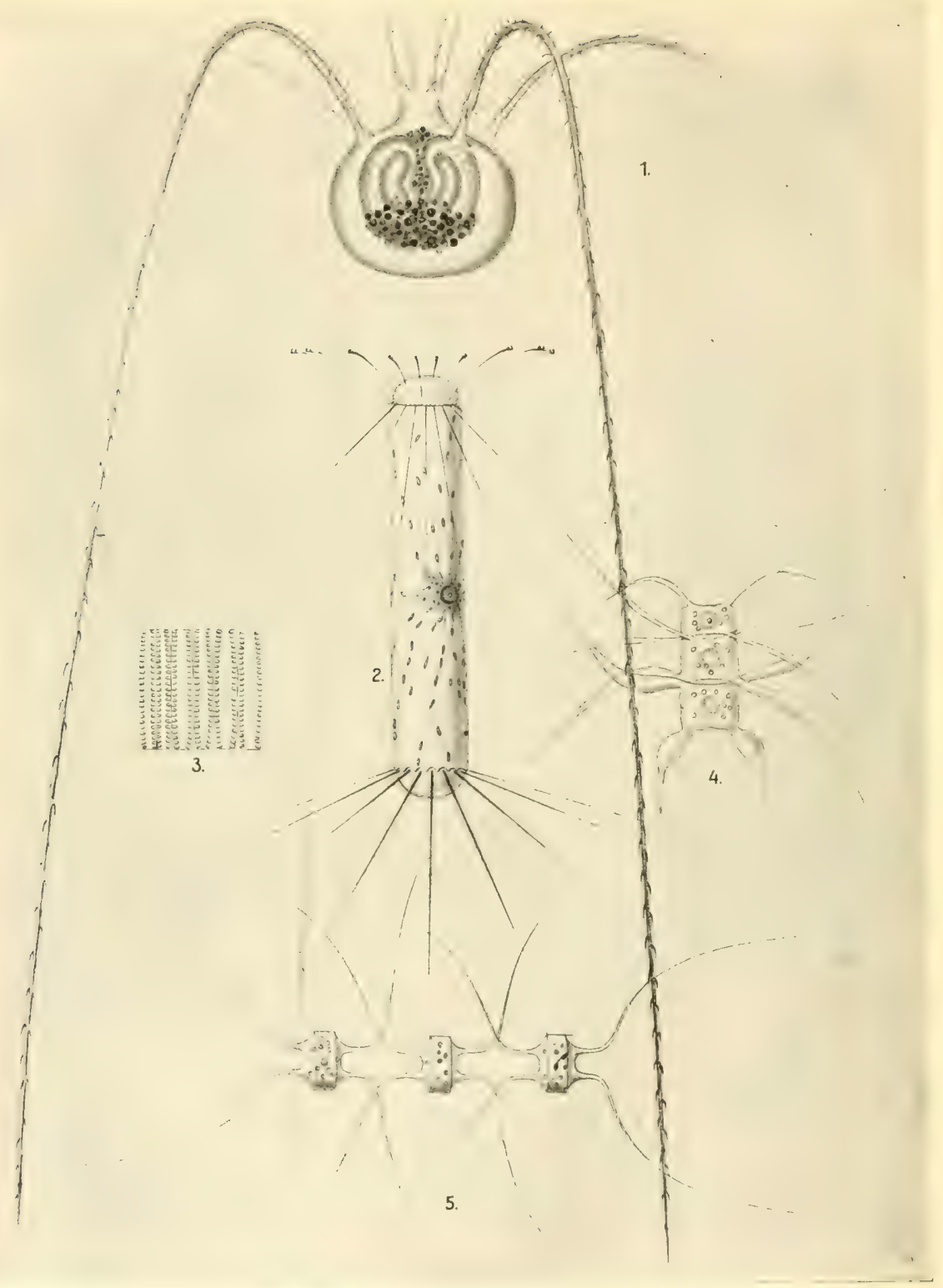

(0) berflühen= und Ciefenplanfton aus dem antarfifich meere.

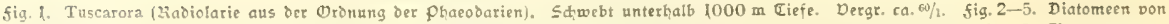

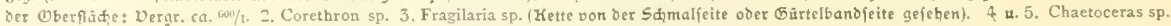
fig. 2-5 rac 3eifinungen oon Ehrmann. 
and cin dharafteriftifher Dertreter Siefer formen, nümliḑ die Eattung Halosphaera, mit dent Eintritt in das Kaltwaffer fehlt.

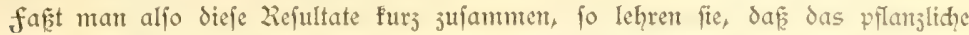

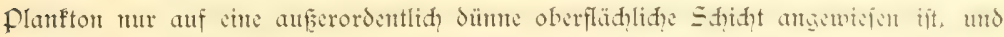

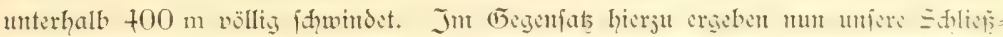

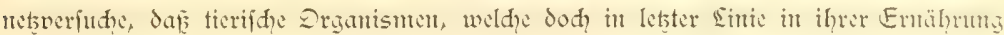

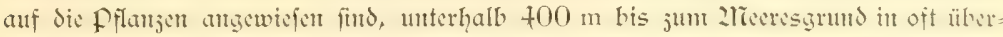

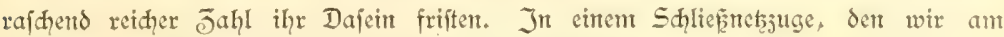
12. Dejember zwifdyen 5000 und $4400 \mathrm{~m}$ ausführten, fanden wir lebende Radiolarien (Acanthometra), Iebende Copepoden, die vier Fattungen angehör= tent, nebft jahlreidzent, lebhaft fith bewegenden Earvent derfelben, und einen lebendent 2rü ḑel frebs (Ditracodent). Dbwohl diefe Drganis: men dem gewaltigen Druffe von $500 \mathrm{Z} \mathrm{It}=$ mojphären ausgefeţt find, fo jeigten fie fidh dod in ihrer Struftur wohlerhalten. Wir müffen allerdings bedenfen, da ja ja dicjer Drut nidjt cinfeitig wie zwijd jwei $\mathfrak{W}_{a l j e n}$ wirft, fortdern da管 er fich nađ befautten Gejeţen im $\mathfrak{W}$ affer all= feitig verteilt. Der einjelne Drganismus glethyt gewifiermañen cinem winzigen Waffertröpfđen, das, wie wir wiffen, bei fo hohem Druct eine faum naḑweis= bare Komprefifion erletiet.

Dor diejen gewaltigen Tiefen bis hinauf ju der Dberflähe haben umfere Sđhlief̧netfänge ohne Jusnahme bet

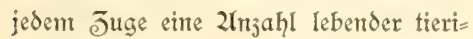
fher Drganismen ju Tage gefördert.

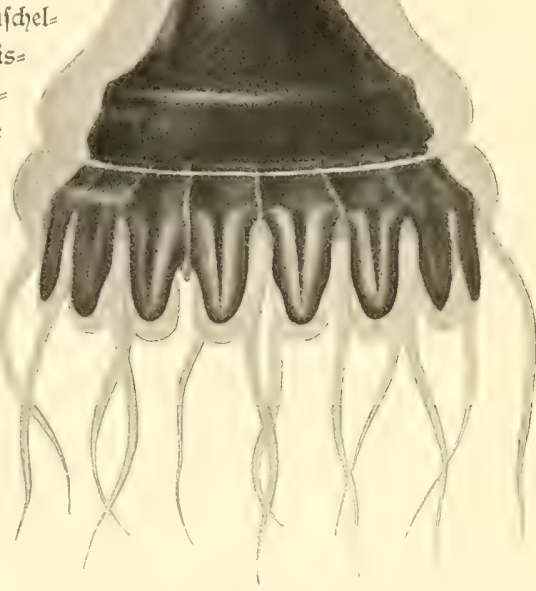
Inter ifnen find namentliक Radiolarim aus den familien der 2tcanthometren und

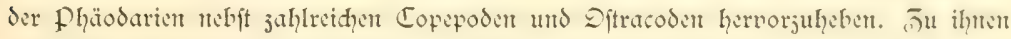

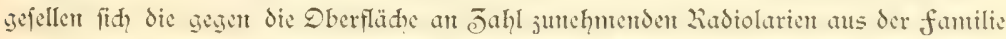
der Challengeriden, die Globizerinen, ffeilwürmer, Earnen non 2futeliben (P'elagobia), vereinzelte flügelidneffen (Limacina), 2redufen und 2lppendicularien.

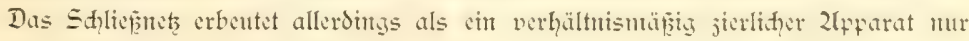

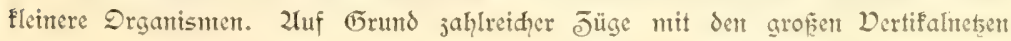




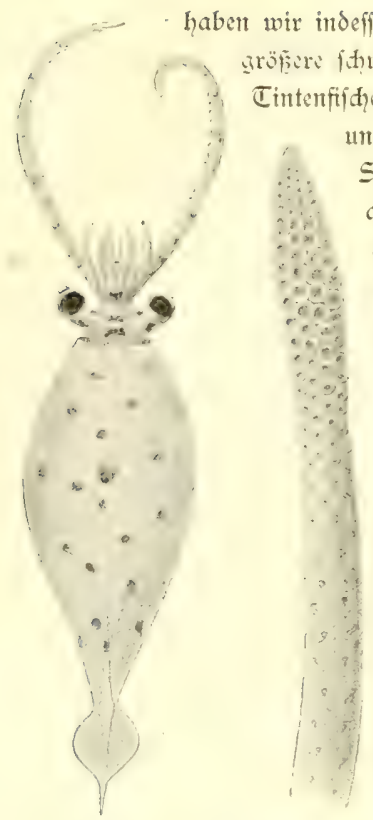

Reue Battung cines fticläugigen Tinterfild̨es aus oer familie der Cranchiae.

10. Dezember 1898. Dertifalnetg bis $1500 \mathrm{~m}$. Dergr. $1 / / 2$ mal.

Daneben bie Tentafelfeule itister pergröfert. (Rübsaamen gez,) und violetten 2riedufen (Periphylla) zuzuldreiben. Da die Sdiliefrntetfänge nod nidit gefidgtet und eingehender be= arbeitet find, läpt es fid einftweilen fdwer fagen, ob eine gewiffe vertiflale Shidtung unter den veridgiedenen hier erwähnten Titerformen zum 2usdrucfe fommt. Es ift uns 3. B. aufgefallen, daf wir die prädtigften aller Radiolarien, nämlidy die Tuscaroren (vergl. S. 250), mux dant erbeuteten, wenn wir die zeeţe in grofece Tiefen hinabliesert.

Der sejer wird fith wohl fhon längft gefragt haben, wie es denffbar jei, da管 Tiere in Regionen vorfonmen, weldhe dem pflanglidyen Eeben, von dem dod, die tierifdye Exiftenj abhängt, fith als feindlich erweifen. Zluh diefe frage erhält

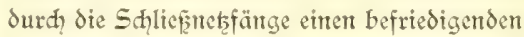
Zufficluze Der maffenthaft at der Dberfäđhe gebildete pflanglide Detritus ficfert näntlid langam in tiefere Sdyid̨ten hinab. Der Fonfervierenden Kraft des falten Seewaffers ift es ju= zufhreiben, da管 das proto= plasma nidht fofort jerietzit wird, fondern mehr oder minder verändert und von der

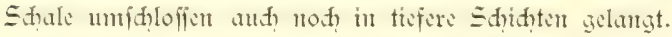
2lindmal war der Inthalt der durd Eräftige Edyulen ausgejeidneten Diatomeen nod fo wohlerhalten, daE man die betreffenden formen aus etwa $1000 \mathrm{~m}$ Tiefe für lebent hăfte halten mögen, wenn niđł̣ die veränderte (5rufpierung der Ehromatophoren daranf hindentete, dak es fin um bereits abgeftorbene Drganismen handelte. Don Der reidhbefeţtent Tafel an der Dberfläd̨e fallen alfo immerhin niḑt wenige Brofamen in die Tiefe, weldhe den dort befindliden tierifden formen das Dafein er = möglidhen. Ie tiefer man fifht, defto feltener werden
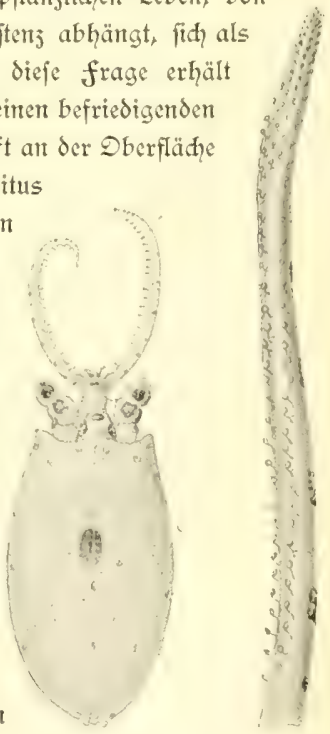

Owenia n. sp. Eephalopode aus oer fam. der Cranchiae.

3. Dezember 1898. DertifaInety bis $2000 \mathrm{~m}$. vergr. $21 / 2 \mathrm{mal}$.

Daneben die Tentafelf́cule färf́er vergr. (Rübsaamen gez.) 


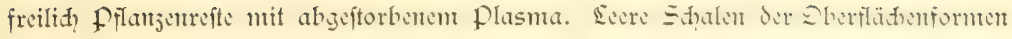
liberwiegen um fo mehr, je tiefer das 2⿰ę herabgelaffen wird. Benterfenswert ift es, dấ gerade die gemeinften Dberflähen=Diatonteen, nämlid, die 2Trten der Gattung Chaetaceras, unterhalb $600 \mathrm{~m}$ naheju vollfommen dadurd fhwinden, daf niḑt nur

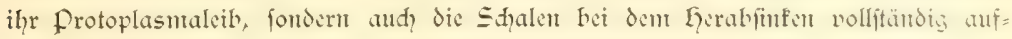
gelöt werben. Dagegen gelantgen die Shalenrefte von Rhizosolenia, Fragilaria, Synedra und Coscinodiscus bis auf den 2reeresgrund; in den tieferen Wafferfifithten überwiegen namentlid, die widerftandsfähigen Ş̧alen non Fragilaria und Coscinodiscus.

2lit diefen Beobaḑungen fteht es in Einflange, daf aud das ticrijhe Seben gegen die Tiefe zu eine auffällige 2lbnahme erfennen läft. $\mathcal{D}$ on 400 bis $1500 \mathrm{~m}$ Tiefe trifft man nod eine reiḑe Jahl lebender formen; darunter werden fie um fo

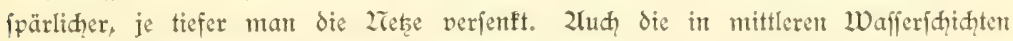
rethlich vorfommenden ticrifhen Drganismen fterben $a b$ und finfen ju Boden; ifre Eeiber find es, die nun wieder den in den tiefiten Shifhten lebenden 2Irten jur Beute

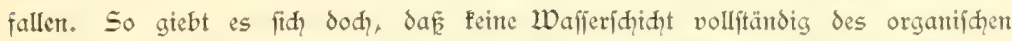

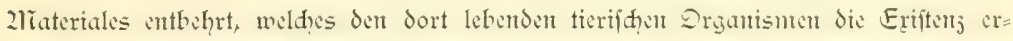

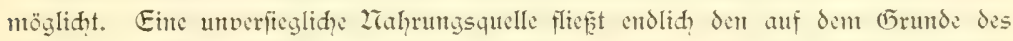
2reeres angeftedelten Tieffecorganismen. 2llles, was aus oberfläd̨lident, mittleren und tiefen Shiकhten abgeftorben und halb oder ganj jerfeţt nicderfant, was direft über dem 2recresboden todh lebent flottiert, fällt der Grundfauna jur Beute. Je gröfer das Quantum von organtiher Subftanz ift, welhes an der Dberflädie produjiert wird und wie ein feiner Regen in tiefere Sdidten triederriefelt, defto lippiger entfaltet tritt uns die pelagifhe Tiefufauna entgegen, defto reibhaltiger ift das Tierleben anf dem (5runde ausgebildet. 2lle Wahrnehmungen weifen unjwetdeutig darauf hin, dap die

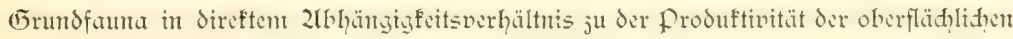
Shidhten fteht: in dem antarftifhen 2rieere mit feinent imponierenden Reiḑtum an Eberflähenorganismen crmsift fie fíf filbit in Tiefen jwifhut $\$ 000$ unt $5000 \mathrm{~m}$, wie an der hand unferer Erfahrungen nod dargelegt werden foll, erfaunlid reid, haltig entwicfelt.

Der 2lieeresboden ift eine riefenhafte Grabftätte für alles, was an der Dberflähc feine Sebensarbeit verrihtet. Die organifhe Subitanj wird jwar bei dem Ziiderfinfen aufgelöt oder fällt anderen Drganismen zur Beute, denen fie dic Eriftenjfähigfeit fibert, aber die anorgantificu Sdalentefte crmetfon fid als miderftundsfähizer und

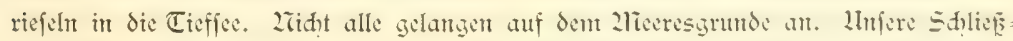

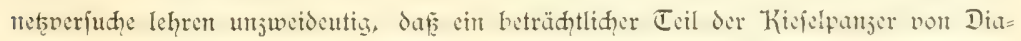
tomeen auf der langen Keife in unbelidịtete Tiffen aufgelojt miro. Dies betrifft mamentlif die an der $D$ berfläde fo mafinhaft angeftauten 2lrten der Dattung Chactoceras und 
Corethron, weldie mitfamt iḩren Sfeletten fiton in geringen Tiefen dem Ltntergang geweiht find und unterhalb $600 \mathrm{~m}$ naheju vollfommen fehlen. Da aud die Kalf=

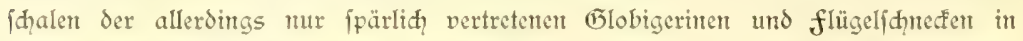
gröferen Tiefen aufgelöft werden, feţt fid der Grund des antarftiffen 2rieeres, wic

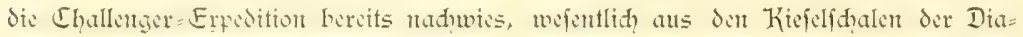
tomeen jufammen. In gewiffent Sinne giebt der 2liceresboden einen Spiegel für liḑte, fomtige Regionen $a b$, aber immerhin einem foldhen, der midht getreu das $\mathfrak{E}$ eben und $\mathfrak{D}_{\text {eben }}$ an der Dberflädhe refleftiert. Von der Bouvet=Region bis gegen Enderby= Sand finden wir thn aus fajt dqemifh reiner Kiejelguhr gebildet; erft an unjerent füd=

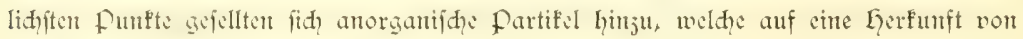
dem nahen Eande hindeuteter.

Jmmerhin wollen wir nitht verihweiger, daf jwifhen dem 26. und 29. Sänge=

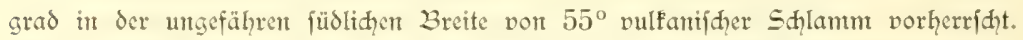
In den beiden Grundproben, die wir am 6. und 7 . Dejentber aus Tiefen bis ju $5552 \mathrm{~m}$ gewannen, waren bis ju $60 \%$ Bmditüfe von Bimsftein und anderen vul=

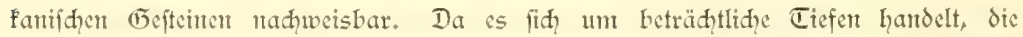

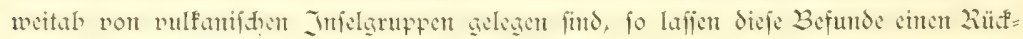

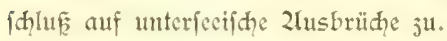

In der nebenftehenden 2lbbildung wurde der Verfuh gemaḑt, möglidfit gewiffent= haft den Erhaltumgsulutand und das 2liengenverhältnis der den Boden in Tiefen jwifhen 5000 und $6000 \mathrm{~m}$ jufammenfeţenden Drganismten wiederjugeben. Eine

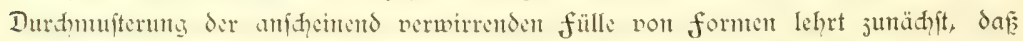

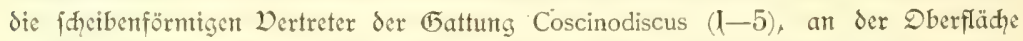

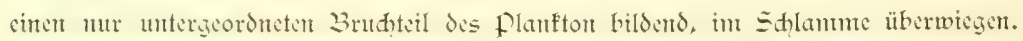
Sie find niḑt inmer unverfehrt (I, 3), fondern häufig mehr oder minder aufgelöft.

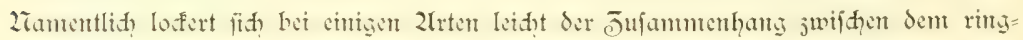
förntigen Rande (2) und dem mittleren 2lbiḑnitt der Sḍale (4), welh' lef̧terer damt

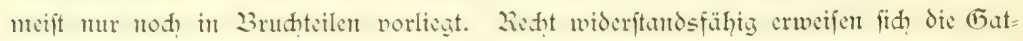
tungen Asteromphalus (6) und Fragilaria (F). Die leţtere bildet mit den meḩr oder

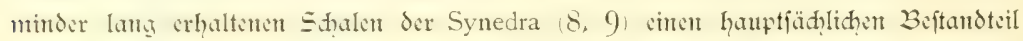

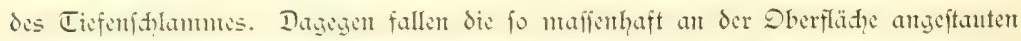

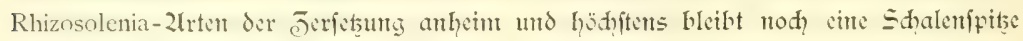

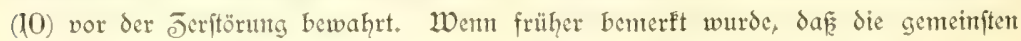
Dberfläđhenformen, nämlid Chaetoceras unt Corethron, bereits in geringer Tiefe auf= gelọ̈t werden, fo bedarf dieje 2lngabe ciner fleinen Einfdränfung. Ganz vereinzelt

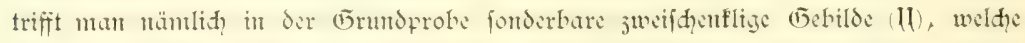

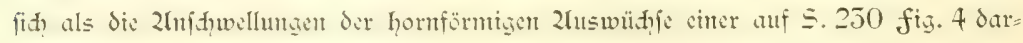
geftellten Chaetoceras-2lrt crweiferr. 


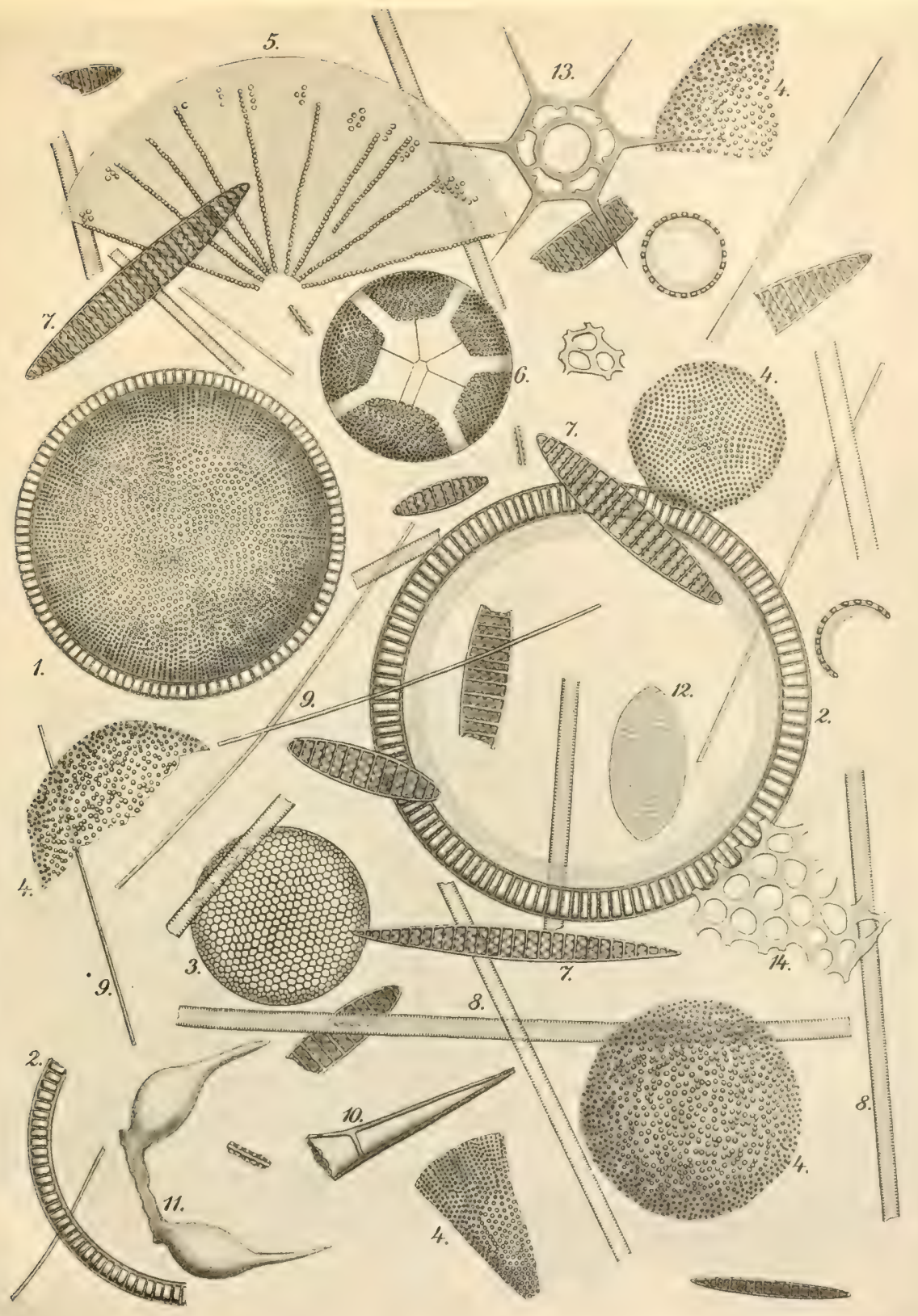

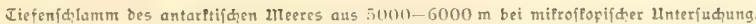

IRübsaamen gez.

1-5. Coscinodiscus sp. 6. Asteromphalus. 7. Fragilaria, 89 9. Synedra. 10. Rhizosolenia. 11. Chaetoceras. 15. Dictyocha, 17. 2iadiolarie 
Int Dergleidhe mit den hier erwähnten Diatomeen find die Kiefelpanzer fonfitiger marner Drganismen mur gantz vereinzelt naḑweisbar. Treffilid erhalten fidh die jier=

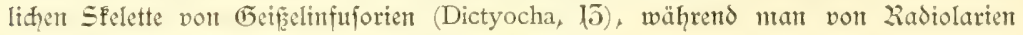
faft nur Brudjitüçe (1+4) antrifft.

Werden derartige Lhterfudungen über den Erhaltungsjuftand der Schalen auf ver= fditedene Tiefen ausgedehnt, fo fömtent fie aud dent Grologen fingerjeige über die Zratur gewiffer fedimentärer Sdifhten abgefen. Er wird unt fo leidter die Tiefe des

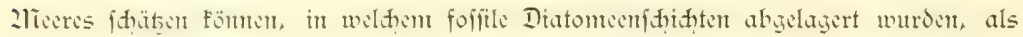
diefe winjigen formen, von dem ummodelnden Einfluf äukerer Bedingungen faum

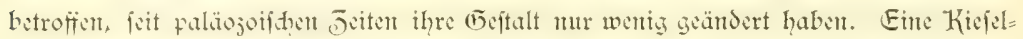

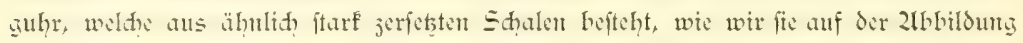
darftellten, deutet darauf hin, daf fie in cinent fehr tiefen und Falten 2liecre zur 2lblage= rung gelangte. Sind die Sdalen wentiger angefreffen und gefellen fid ihnen vereinzelte Globigerinen hinju, fo liegt ein Sediment aus mittleren Tiefen vor. finden fich end= Ith nodh wohlerhaltene Refte von Chaetoceras, ganje Rhijololentien und dem Corethron ähnlidge formen, fo darf mant fider darauf fdliefen, da es fid um den Boden einer flachice handelt.

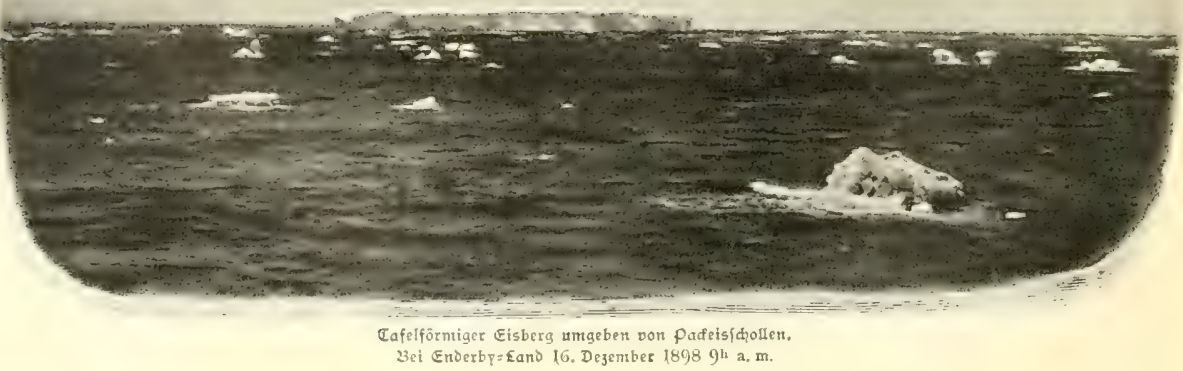




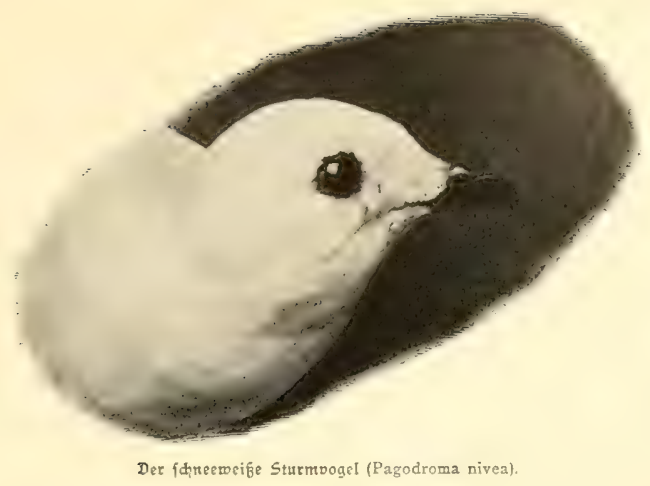

\section{Eetster Doritofiz nach Siiden.}

2 mi Dientag den 15. Dejember befant fich die "Daldivia" auf dem Sduittpunfte des 60. füdichen Breitegrades mit dem 50. öftlihen Eärgegrad. Wit waren weiter nad, Stiden gelangt, als wir bei der 2lbfahrt non Kapfadt mit unjeren fülntiten Erwartumen norausfizen durften. Tays juvor hatte uns das am 2liorizen aufflarende

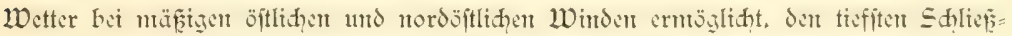
neţjug bis ju $5000 \mathrm{~m}$ ausjuführen. Gegen 2lbend frifdte indeffen der sftlidic Wind

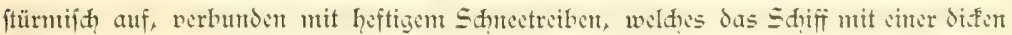

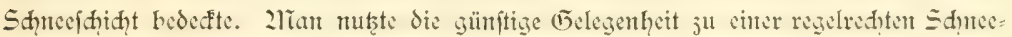

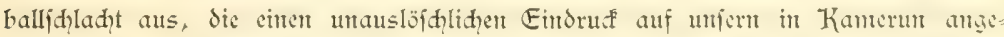

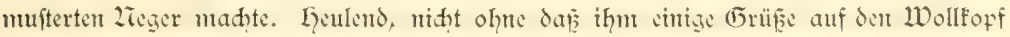
nahgefendit worden wären, flühtete or in die Koje. Der etwas nad 2Torboft herum= gehende ftürmiface Wind ftand den sanjen 15. Dejember hindurh und crleid)terts niant gerade die sotung, weld we wir indeffen bis ju $5566 \mathrm{~m}$ tadellos durdjuführen ver= modten. Wiederunt gelangten wir gegen 2 llhr nadintitags in die ziähe von Treib= eis, das uns ju nordöfllidjem 2lusbiegen nötigte. Wir verloren es indeffen bald aufer Sid̨t und fonnten daher den früheren Kurs nah Dften beibehalten.

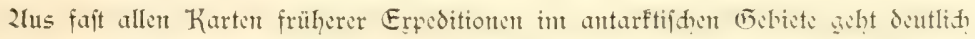
hervor, daf gerade in jener Region, in die wir jetst cintraten, die Grenje des Treib= cifes unter fharfem Winfel weit nah Süden ausbiegt. Es fam dies mur darin femen Grund haben, dafi eine etwas wämtere, von den Kerguelen nah̆ Süden reidende Strömung ihren Einfluf ausübt. 2lls wir daher in der frühe des 14. Dejentber 
itsfreies 2lieer füdlid von uns hatten, wurde die frage nahegelegt, ob man es wagen

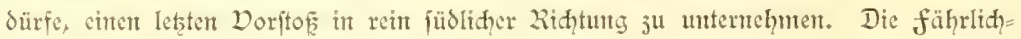

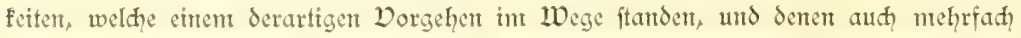
2lusdruef gegeben wurde, waren niḑt jut unteridyätzen. Dem wemt aud offents 2lieer

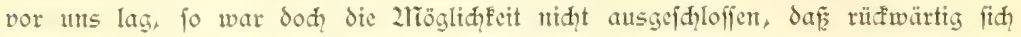

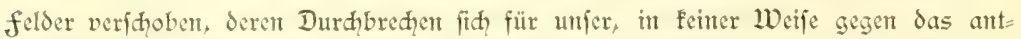

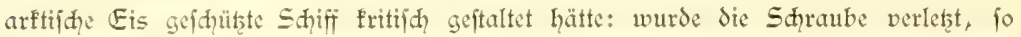

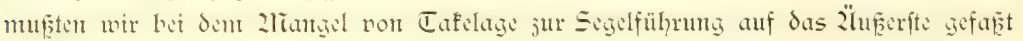
feir. Troţdem wurde der Derfudy gewagt, und nad 6 lthr morgens der Kurs trahe dent 55. Eängegrad redttweifent Süd gefetzt. Ein Dergleid mag vielletḩt beffer als Langausgefpontnene Erwägungen die Stimmung wiedergebert, in der man fith befand. 2lian denfe fid jwei Shadfipieler, welhe fith ju einer Partie jufammenfeten; der eine

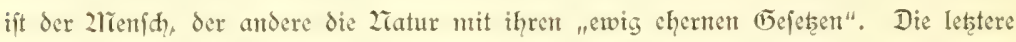
jieht an und thut immer den denfbar beften Jüg. Der 2lusgang liegt auf der hand. 2lber wie der erftere fich wehrt, wie er in die 2lbfïhten feines Ẽegners cinjubringen verifud, um nidjt von vornherein die Partic aufjugeben, fortern erft nach langer Deit mit Ehren fidd fhaḑmatt ju erflären, das ift fein Derdienft.

In Derlauf des 14. Dejentber lief fidh umfer Beginnen vielverfprentent an. Der

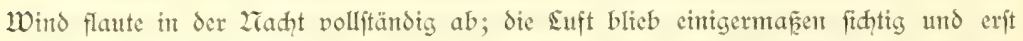

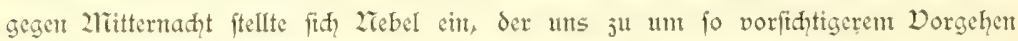
unter jeitweiligent Stoppen nötigte, als wir an diefent Tage nidht wentger als 14 Eis= berge paffierten. Die juterft uns begegnenden waren auffällig flein und ftarf jerfeţt;

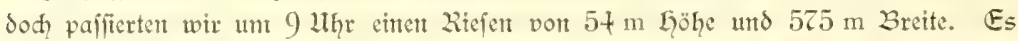

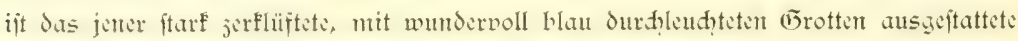

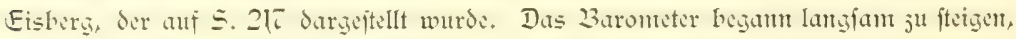

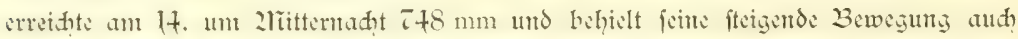
an Sen nädjiten Tagen bei. 2 $2 \mathrm{~m}$ 15. Dejember überjdyrittent wir bereits den 62. Grad

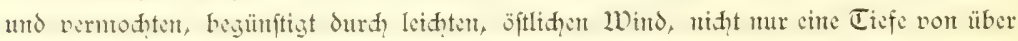

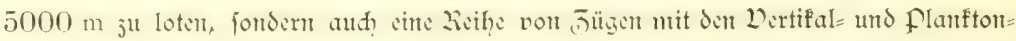
neţen ansjuführen. WDiderum begegneten uns fleinte, ftarf jerfetste Eisberge und

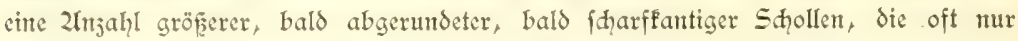
wentig üher die Dberflüthe hernortraten und bisweilen unter Puntpbewesungen auf= und niedertauditen.

Die Temperatur des Dberflähenwaffers fant bis $\jmath^{4}-1,5^{\circ}$; mit ihr hielt denn

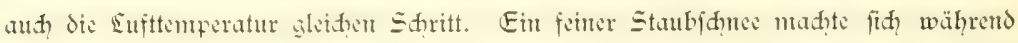
des gangen 2radymittags geltend, und gleidzzeitig jeigten fidh ebenfo, wie an dem

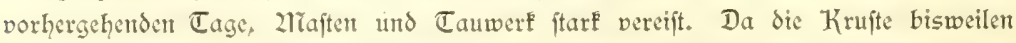
$2 \mathrm{~cm}$ did wurde und um die 2rittagsjeit in grofenen Stüden herabftel, war einige 


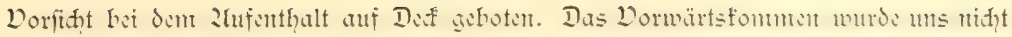

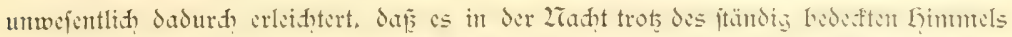

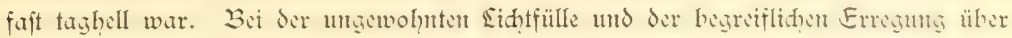
den weiteren Derlauf des Doritofes dahte man nur wenig an Shlaf und fuhte nur auf furze Stunden die Koje auf. Zls id midh ant 2lbend des 15. Dejember jur Ruhe

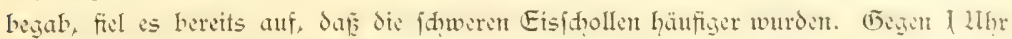
lief midh der Kapitän weden, da wir uns mitten in fdqwerem Padeis befanden. Der

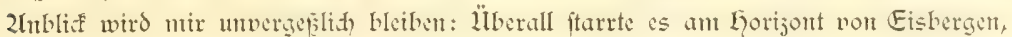

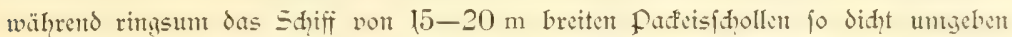
war, daf ein meiteres Dordringen ausfiḑtslos erifhien. Wir befanden uns anf $64^{\circ}$ $14,5^{\prime}$ ๆüßL. Br. und $54^{\circ} 51,4^{\prime}$ ojitl. $\mathbb{S}$. Es war der füblichifte Punft, den wir auf der fahrt erreidht haber. Unt ihn feitzu= legen, wurde nadits nah 2 1thr durd den Tavigations= - fifjiter eine $\mathbb{S O}_{0}=$ tung veranftal= tet, die, danf Ser 2fnitren= gurtg aller $\mathcal{B}_{\varepsilon}=$ teiligten, glatt

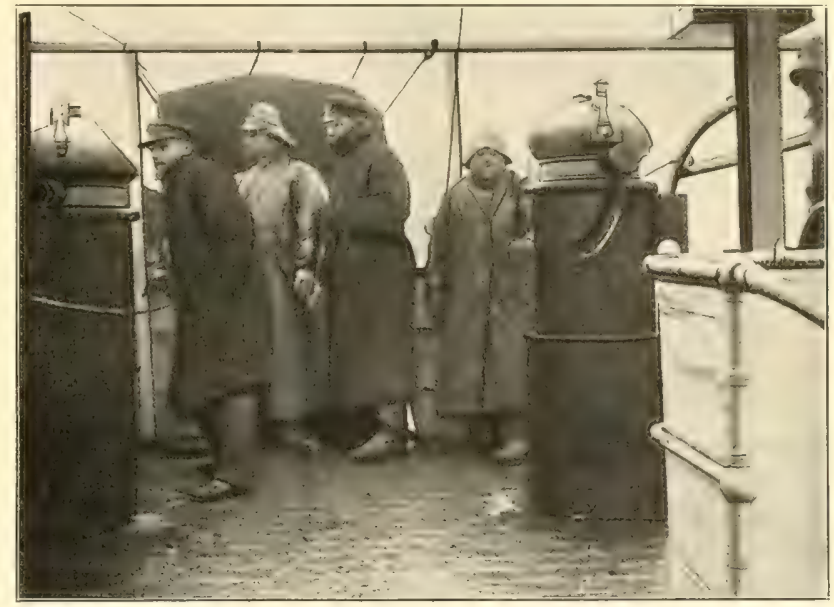

Uaf ber Bräe int antarftifhen meere.

von ftatten ging und cine Tiefe von $4 \pi 47 \mathrm{~m}$ ergab. Dic (Frundoprobe jeigte, wic fhon ant vorhergehenden Cage, nidit mehr remen Diatomenfälit, fondern erwies

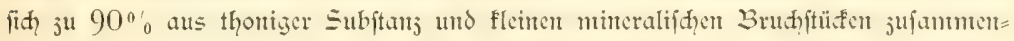

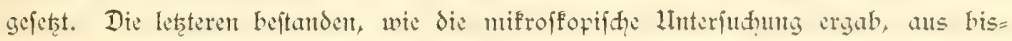
weilen $3 \mathrm{~mm}$ grofien Körnern non Quarj, feldpath, (ธ)limmer, Gormblends und nul=

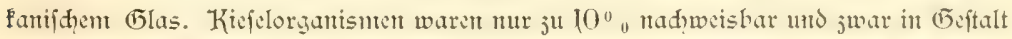

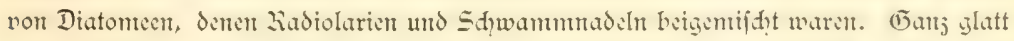

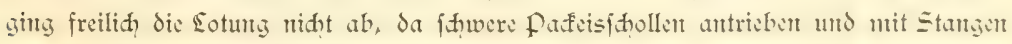
non der Bemammus abgehalten werden musten. Es galt, aus dim Eife fïh heraus=

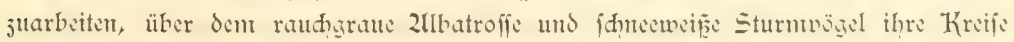


befकrieben. Die "Daldivia" wand fid clegant bet nördliţent Kurs an den Padeeis= fhollen vorbei; dod? wurde es erft gegen 2liorgen lidhter, und uns begreiflidgerweife auch freier zu zliute.

Wir befandent unts mue 102 Seemeilent, niđht viel mehr als cine halbe Tagesfahrt, entfent vou jenem Sande, weldhes der die Brigg "Tula" befehligende "Kapitän Biscoe

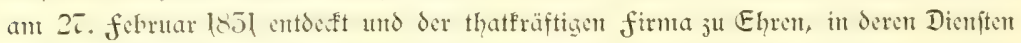
er ftand, Enderby= Eand genamt hatte. Er giebt feine Dofition auf $65^{\circ} 5 z^{\prime}$ f. Br. unt $47^{\circ} 20^{\prime}$ ö. S. ant. Biscoe folgte dem $\mathfrak{E a n d e}$ bis jum 49. Frad öflliḑer Eänge. Drei Jahre fpäter (1857) fidtete Kemp öftid von Enderby= Sand in $66^{\circ} 25^{\prime}$ i. Br.

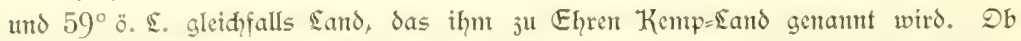

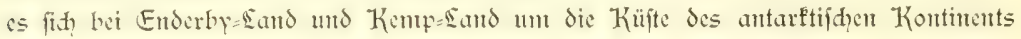
handelt, oder of fie mehr oder minder umfünglide Infeln repräfentieren, wirb hoffent=

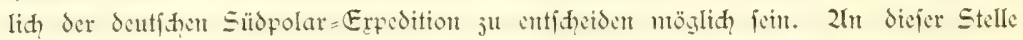
fann nur betont werden, da deffigen Euft in der 2raḑt vont 15. jum 16. Dejember deutliḑe Zlnjeidhen von Eand

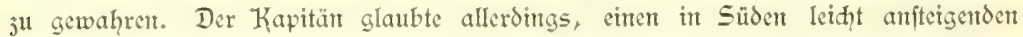

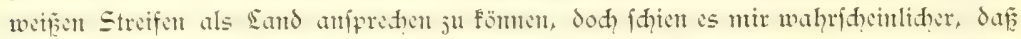

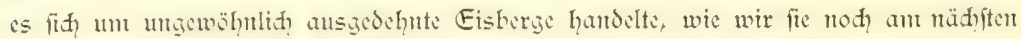
Tage wahrnahmen. Da der Dftwind mur flau auftrat und das Barometer Iangfam weiter fiteg bis auf $754,8 \mathrm{~mm}$, Fontent wir am Zradzmittag des 16 . Dejember, nadh=

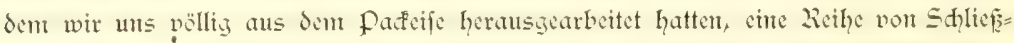
netzjüzen neranftalten und miere Dorkereitumgen für cimen der ergehnistridften Tage im fernen Süden, näutlid, den 17. Dejember, treffert.

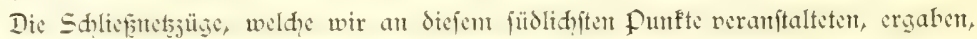

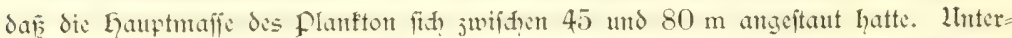
halb $80 \mathrm{~m}$ zeigte es eine reht finnfällige 2lbnahme an Quantum, die auch für die

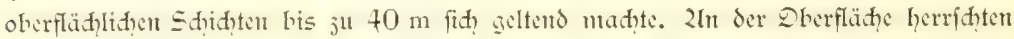
unter den Diatoneen dic wie cine ZTadel geitaltete Synedra thalassothrix und Chaetoceras- und Rhizosolenia-2lrten vor. Zufuällig war es, dar alle diefe formen vielfache

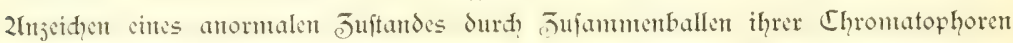
und iḩres plasmaleibes erfenten lief̧en. Die ganj vercinjelt ihnen beigemengten, dofenförmig geftalteten Gattungen Coscinodiscus und Asteromphalus zeigten erit unter= halb $40 \mathrm{~m}$ cine fo ftarfe Junahme, daf fie hier geradeju herridjent wurdent.

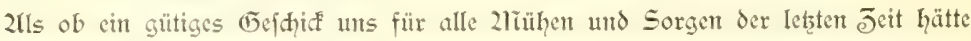

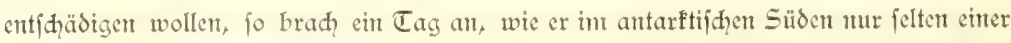
Erpedition befhert wird. Der Wind flaute in der 2iad̨t jumt $1 \bar{k}$. Dejentber volfftändig $a b$, das Barometer ftiteg anhaltent und erreifte am 2liorgen des 17. mit $756 \mathrm{~mm}$ einen fo hohen Stand, wie wir ihn feit Derlaffen der Bouvet= Jnfel nur einmal, am 


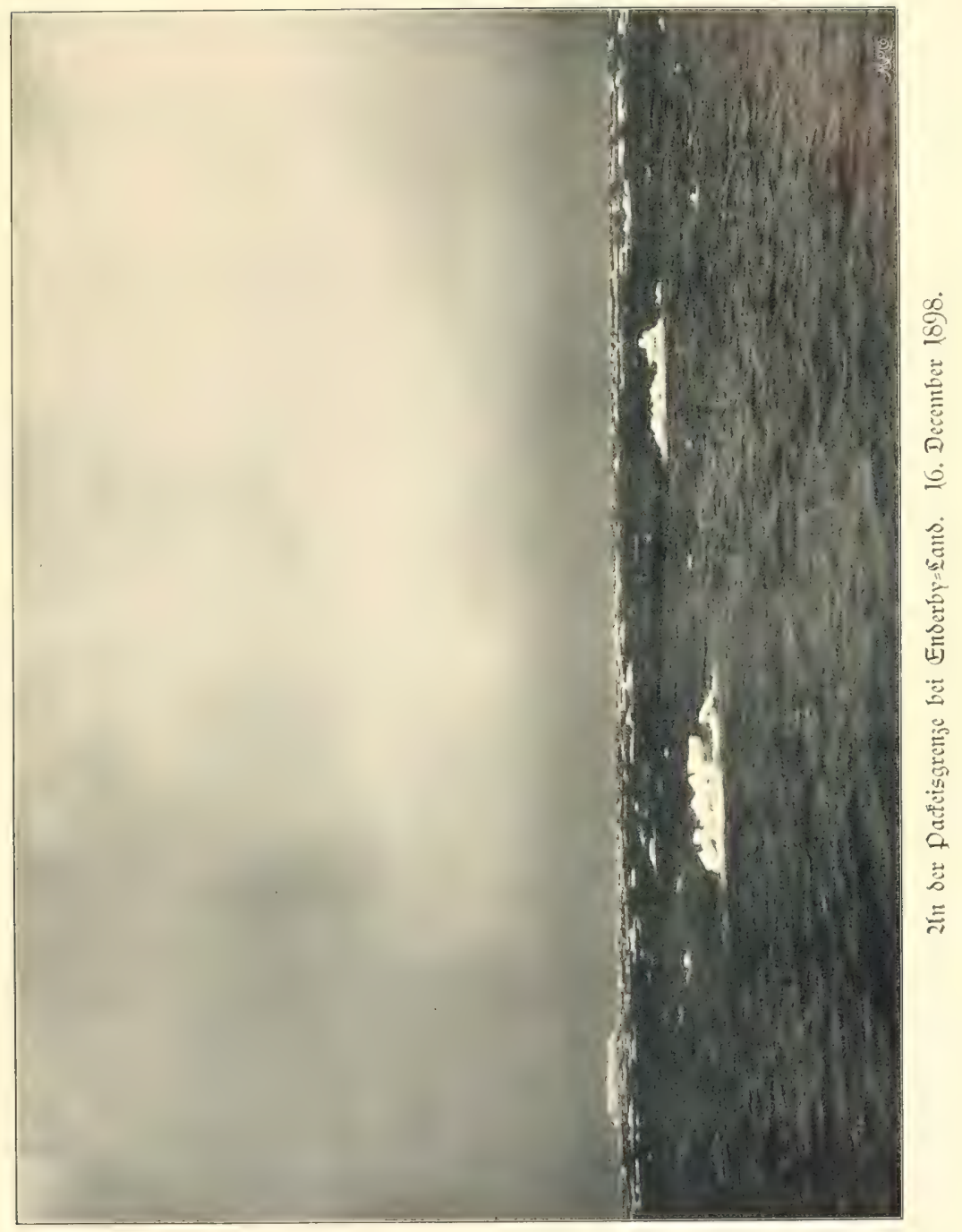


1. Dejember, beobahtet hatten. Wir fuhren in der taghellen 2raḑt fo ruhig, wie

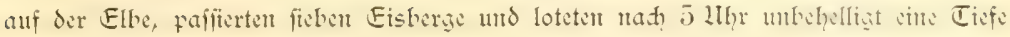
von $4650 \mathrm{~m}$.

Da galt es, die ungewöhnnlid günftigen Derhältniffe ausjumtzen und cin in 2 n $=$

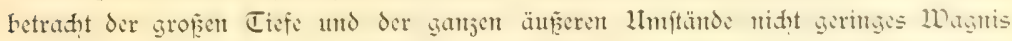

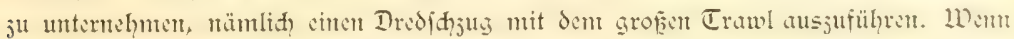
man bedenft, daf man in antarftifhen 2leere niemals vor plöblid cinjetzendem ftümifhem Wetter oder diditem 2rebel in der 2rähe non Eisbergen fidger ift, fo wird

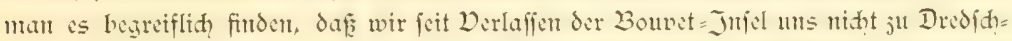

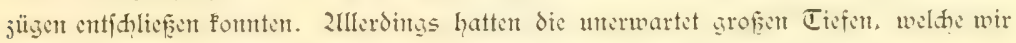
ftändig loteten, wejentlid daju bei=

getragen, unts von einer Ope =

ration abjuhalten, welhic

leidht die bedienende

2liamihaft hätte

gefährdent und uns judent das

Kabel hätte

foften föntrent.

alle sicfe $\mathfrak{B e}=$

denfen wurden in=

deffen auf (5rund

der Erwägung, daई̃

ein Dredfajug niđft mu

über die Tieffeefauna, fon=

dern aud über die Jufanmenjetzung

des Grundes wertvolle 2lufidilüfie
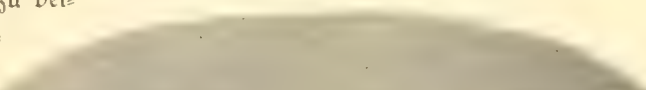
war grau verhängt, und vereingelte Shutectreiben benahmen uns jeitweilig den 2lus= blict. Klarte es dam auf, fo fand man den Gorijont von gewaltigen Eisbergen be= grenjt und überjengte fidh aud durd einen hellen Eisblint im Süden, daf uns dort der $1 \mathrm{D}_{\mathrm{eg}}$ verlegt war.

Reigvoll war das Dogelleben int äuferften Süden. Rauhgraue 2llbatrofie, Diomedea (Phoebetria) fuliginosa, fegelten ruhig über die mit vereinzelten Padeisfdollen bedecte Dberfläd)e. Sie waren unts von der Bouvetregion an treu geblicben und idf

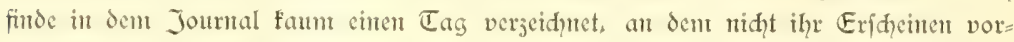
gemerft wäre. Zlieift jeigtent fie fidh ju jueien oder dreien, felten ftieg ithre Jahl auf neut oder jehn. 2liit fdarf cingezogenent Kopfe, den Sdntabel nad abwärts gefenft, folgten fie in amideinend phumper Galtumg ftundent und tagelang dem Sdiffe, ohne

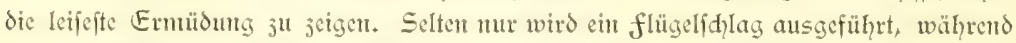
fie den Körper nit feinen mäd,tig langen und fdlanfen Sd,wingen bald horizontal,

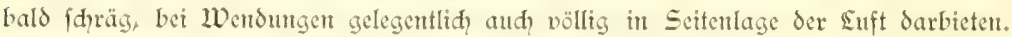
Kein antarftifder Dogel feffelt fo dic 2ufmerffamfeit, wic diefe in unhÿrbarem fluge dem Sdiffe folgenden Segler. LWem fie fidh der Brïte fo mabe hieltent, daf man fie fajt mit Gänden hätte greifen mögen, und dabei mit ihren wei untrandeten 2lugen, die aus dem fanmetnen Sđqwarggrau des Kopfes hervorbliţten, anfmerffan dem Treiben der 2lienfiden folgten, maḑten fie einen fajt geppenfitifhen Eindrut?. 2läan glaubt, die ewigen Juben des antarftifden 2lieeres vor fid ju haben, welde ruhe= und raftlos ihre Kreife jiehen und dann fid am wohlften fühlen, wein die Wogen=

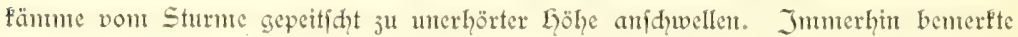
idh eimmal - ant 15. Dejember - mehr als ein Duttend grauer 2llbatroffe, das auf cinem flemen Eisberge behaglid der Ruhe pflegte. Das Esefieder zeigt eine der feinften 2tbifufungen dis (5rau, die wir aus der Tierreihe fennen; der faft in das Sdzwärjlide fpiclende Kopf geht fanft int das lidnte (5) ran volt Baud, und Rüfent tuber, von Sem fith dic flügel und Sdqwanzfeden in dunflerem Sammetton abheben. Einige Erem= plare ficlen durd? den faft filhergranen hals und Räiden auf.

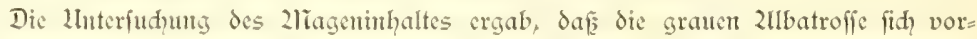
wiegend von Tintenfifकen und pelagifdent Kruftem nähren, aber aud Elentere Dögel miḑt verfdyntähen. Bei ftille liegendent Sdjiff lieşen fie fith auf dent Waffer nieder und hajd̨ten giertig nady allen Zlbfüllen. Der cwige Gyunger fennt fein Bedenten und fo madyten fie fid bistweilen über ihre eigenen von uns erlegten Bentoffen her, haçten ihuen bie 2luget aus und riditeten fie übel ju, bevor das ausgefetzte Boot den auf dem Waffer treibenden Kadaver erreidgte.

Eängit fijon hatten uns die übrigen 2llbatrof =2trten Walet gefagt. Weder der grope (Diomedea exulans), nodh der gelbidnäbelige (D. chlororhynchus), nod) aud?

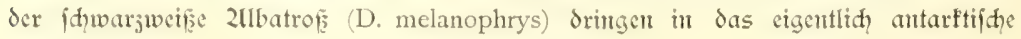


(5ebiet bis jur Eisgrenje vor.

Die flemeren $2 \mathfrak{d}$ rten $b c=$

gegneten uns bei der Zlmüherung an das Kapland und gaben uns mit den grofient das Beleit auf dic $\mathfrak{Z}_{\text {gulhasbant und in }}$ de Weftwindregion. 2lls die Temperatur des Dberflädhenwaffers unter zoll Erras fant, fahen wir die leţten; am weiteften beglei= tete Diomedea melanophrys das Sdiff, Sen wir nod an 24. 2Tovember - be Diomedea (Phoebetria) fuliginosa. Der graue Ulbatrof. vor wir die Bouvet= Infel erreidenten - benterften. Er war es dem auth, der fhon wenige Tage nad der Lmf́ehr von dent füdidhiten punfte fid wieder cinftellte. 2lm 20. Dejember, jwei Tage nad dem Siḑten Jer leţten Eis=

berge, fülırte der fd̨war $=$ weifse 2lbatrof peme flugfünite umt das Sdiffi aus, bei Jentent the unt= Pas

Diomcdea melanophrys. ntomentaufnakme des ffipar $3=$ weifien 2tlbatrof fer Photograph mit der Land = fantera über rajdite. Dout Sturm: vögelı int ê= geren Sinne folgten uns lärgs der Eis= grenje Ser Riefen= fturmuogel (Ossifraga gigantea), deffen werig anmutendes Treiben wir fpäterhin nod werden femen 
lemen, und vor allen Dingen als treuc B̄enofien der antarftifįe Sturmwogel (Thalassoeca antarctica) und der füdlidhe Eisfturmmogel (Priocella glacialoides). Die beiden leţteren find es namentlid, meldye die Brandung der Fisberge als Jagdrevier be= vorjugen und oft in diḑten Shwämmen die nie fehlende Staffage für die Koloffe $a b=$

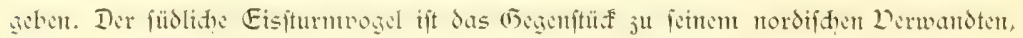
dem er an Ģröfe und färbung ähnelt. Das Weif des Kopfes und Bauḑes geht anf den Rüfen und Sđwwanj in ein Silbergrau über, von dem fid mur die flügel= fpitzen ctwas dunfler abbeben. Der ent wenig fleinere antarftifhe Stummogel ift

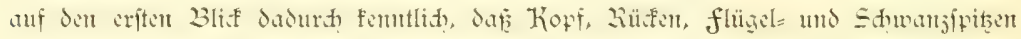
einen bräunlihen Ton zeigen, der von dem Weif der Kehle, des Bauhes urt der

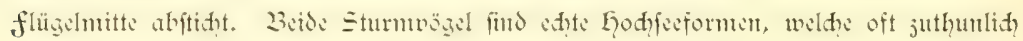
in der zähe des ftilleliegenden Sdiffes fid niederliefent und hierbei die ihnen ein leidh = teres 2luffliegen ermöglidende Euvfeite bevorjugten. Bet Enderby= Sand belebten fie in

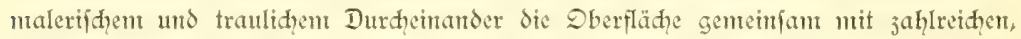
auf ber ganjen fahut uns treu geblicbenen Kaptauben (Daption capense). Wir fütterten fie nit Spet und 2ubfällen, welde die Kaptauben nur von der Sberflähe, die antarftifinen Sturmbögel weit gefhifter durd Tauden ju erhafden fuḑten. So

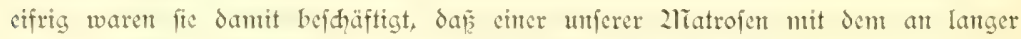
Etange befeftigten Käjher eine Kaptaube von 3 ord aus fing.

Lhiere Sfijje von den Dogelleben auf der antarftifhen Godjiee wäre unvollftändig, wenn wir niḑt nod) Jer ju der Gattung Prion gehörigen blanen Sturnivögel gedenfen

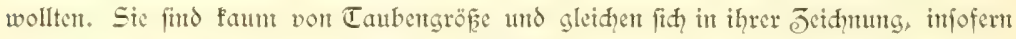
Kehle und Baud đaneeweif. Kopf und Rütfen blaugrau, und die äuperen Shwingen

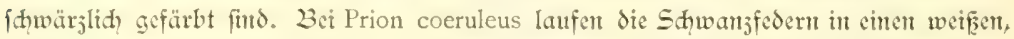
bei P. desolatus und P. Banksi in einen qdwarjen Streifent aus. Dic beiden letst= genamten 2lrten find indeffen leidyt dadurd zu unterjheiden, daf der bei P. Banksi

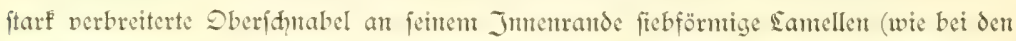

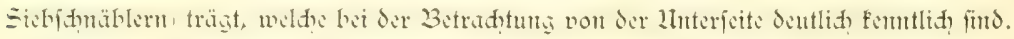

Dic Blanen Sturnvögel begegneten unts fhon in der Weftwindregion unt waren von $\delta a$ an die ftändigen Begleiter bet der fahrt längs der Eisfante bis nah Enderby= sand und weiterbin bis ju den Kerguelen. Sie find fheuer, als die übrigen Sturnt= vögel, hielten fith etwas weiter von dem Sdiffe und fifhten eifrig in dem Kielwaffer. Wern bei den Dorbereitungen jum Soten und fifhen der Dantpfer rüfwärts ging und die Straube weithin das Waffer ju weifen (Eijht aufwühlte, waren fie oft in

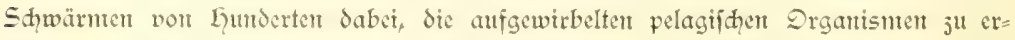
beuten. Jat flug ift umbigig und erimert durh die rafhen Wendungen an jenen der

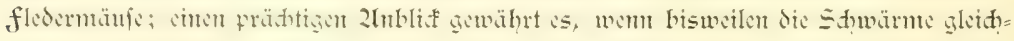
jeitig che Drebung ausfübren und die meifen Baudfläđhen dem Beobahter jufehren. 


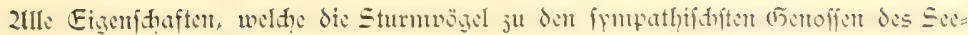
fahrers madhen, finden fid vereint in dem wutderbaren fdnneweipent Sturnwogel

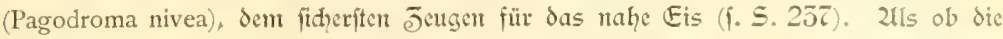
Zatur fid jelbit habe übertreffen wollen, iduf fie einen Dogel, der an 2fmmt des fluges und reijooller färbung feinesgleidhen fudth. Das orefieder ift fintecweif unt wetteifert bei feinem Setdenglantz mit dem $\mathfrak{W}_{\text {eif }}$ des blendend von der Somte be=

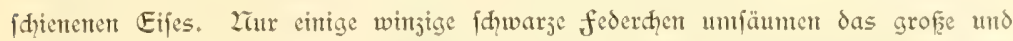

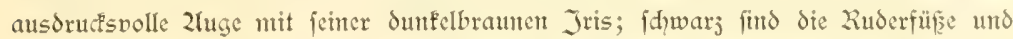
der fleine Sdunabel, mit dem unter grajiös wippenden Bewegungen die Beute im fluge von der Dberflähe gehajht wird. Kein Dogel hat es mir po argethan, wie diefes Edelweif des antanftifhen Südens; ftundenlang folgte man feinem eleganten

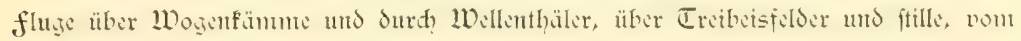
Eife umfäumte Budtert.

Wie ein Grus aus fernen heimatliḑen Gebieten mutete es an, als bei Enderby= Land immitten der fdnneetweifen Sturnwögel cin Sd̨warm niedliḑer idqwarjer petersö̈gel (Oceanites oceanica) auftaudte und jwijden den Padfeisfdollen, von dem Sdiffe

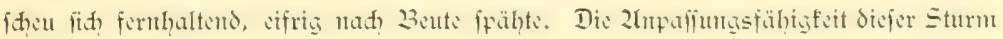

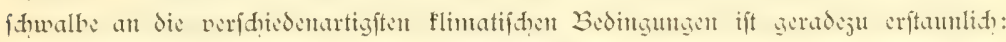
von den Küften Englands bis herab nah Enderby Eand, durd? 120 Breitegrade, be= merften wir fte um das Sdiff. Sängs der Treibeisgrenje taudqte fie öfter, went aud ftets nur vereingelt, auf und nur ungern entfdyloffen wir ans, bet Enderby = Lant ein

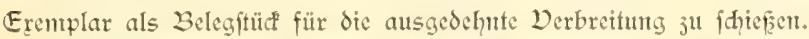

In dem antarftifhen 2Teere ift biefen Shbärmen von Dögeln ftets der Tifd ge

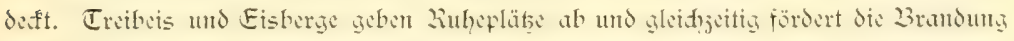
an den ciffgen Steilwänden eine 2rienge pelagifher Drganismen ju Tage, unter denen

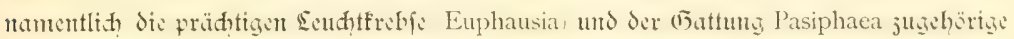
jehnfüß̧ige Krebie mebjt Tintenfifhen als Koft bevorjugt werden. Die in den Kruftem enthaltenen gelblidyen und rötliḑen S̈Itropfen fammeln fid in dem Kropfe der Sturns vögel ju anfehnlid̨en 2raffen an. Das Öl dürfte fowohl eine Zrahrungsreferve für ungünftige Jeiten abgeben, als aud jur Derteidigung dienert. Wer fo unvorfintig ift,

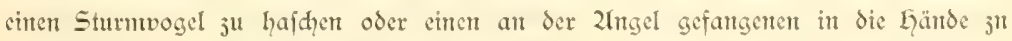
nehmen, wird von dem wenig aromatifhen Thran befudelt, den der Dogel oft mehr = mals hintereinander im Strahle von fid giebt.

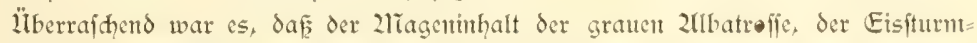
vögel, der antarftifden und fdnteewei von Tintenfifigen bejtand. In unjeren Tiefenteţen fanden fid jwar bisweilen fleine

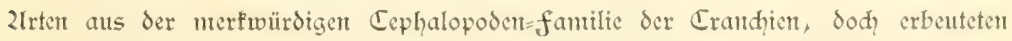
wir niemals den grofen, diefer familie angehörigen Taonius, obwohl en zerfeţtes 
Eremplar in demt 2liagen cintes granen 2ribatrop gefunden wurde. Da aud ein $20 \mathrm{~cm}$ langer horniger Rüfenfdulp, wie er den Calmaren eigen ift, neben den Gornidnübeln in 2liagen cines grauen 2llbatrof gefunden wurde, fo beweifen derartige Befunde,

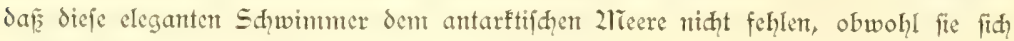
umferen 2reţen entjoget.

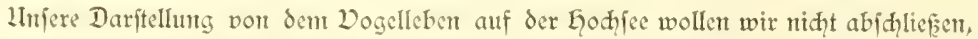

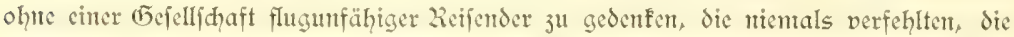

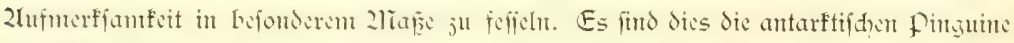
(Pygoscelis antarctica), welhye die niedrigen Plattformen und voripringenden Jüngen der Eisberge als Standquartier bei ihren Wanderungen benukzten. 2luf der Gelio=

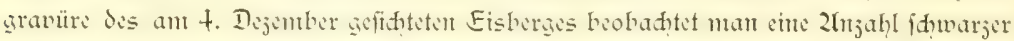
Punfte: es find Pinguine, welhe bei unferer 2tmäherung, erfinect durd flinten=

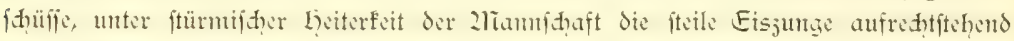
Ginabrutfiten. 2lndere landeten wieder, indem fie gefdicft cine Brandungswelle berutżten, um feften fur ju fafien und vornübergebeugt mit jux Balance vorgezogenen floffen ihre fteile Warte ju erflimmen. 2ritt ihrent fhwarjen Kopfe, Rǚfen und flofien und dem weifen gemäiteten Baudhe, der nur unter der Kehle ein idgwarzes Band aufweift, gleichent fie von weitem fleinen preup̧ijḑen Grenzpfählen. Kommt man dam näher, fo crheben diefe Betjdweftern mit ihren dunfeln 2rantillen unt Kapujen cin lautes (Gejeter, fungen mit jum Eimmel geresten Gälfen ihr Gallelujah,

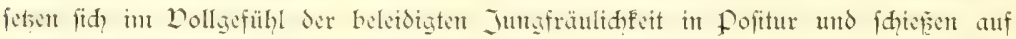
cinem gewiffen Körperteil die Kutphbahn hinab in das Waffer. Fier aber iff der Pinguin in feinem Elemente und hier fordert ar die Bewunderung und Znerfentung deffen heraus, der th̆ juvor nur als drollige und jelbitveritändlidge Staffage für dic antartififhe Scenerie wollte gelten Iaffen. 2liag der Dampfer nod fo rafh feinen Kurs verfolgen, fo überholt ihn der Pinguin mit fpielender Seiditigfeit. Dabei findet er nod? Jeit, mit gefpreiztert floffen auf dem Waffer ju liegen, aus den dunflen, faft fdhalfhaft bliffenden 2lugen das fremde Ltrgetüm anjuftaunen, um dann mit einem

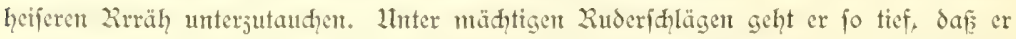

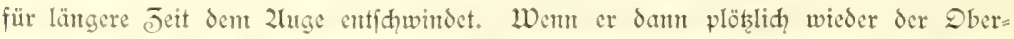

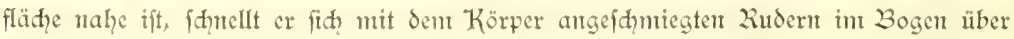

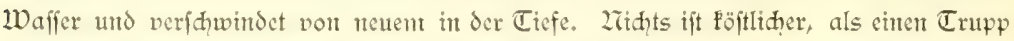
von Pinguinen ju beobadgten, der feinen Eisberg verläplet und wie eine Gerde flemer Delphine in eleganten Sprüngen dem Sdriffe ulftrebt.

Keinem Sturmwogel wird der 2Tahruntgserwerb fo Ieidht gentaḑt, wie diefem pro= feffionierten Tauder; wir fanden den zliagen des antarftifden pinguins oft voll= gepfropft mit $\mathfrak{E} e$ dhtfrebfen, weldhe gröfer waren, als die von uns erbeuteten. 
Es ift fhwer, dic Erregung ju fdildern, Sic fid aller bemäh = tigt hatte, als nad $41 / 2$ ftündigem 2luf= hieven abends gegen fechs Uhr das Trawl der Dberflädye nahe Fam. Zlle Vorrid,tun= gen waren getroffen, unt es raid und unt= verjebet an Bord $3 \mathrm{u}$ befommen, jumal da es fith ergab, dafic dic fhwere sajt, weldic der Dynamometer an=

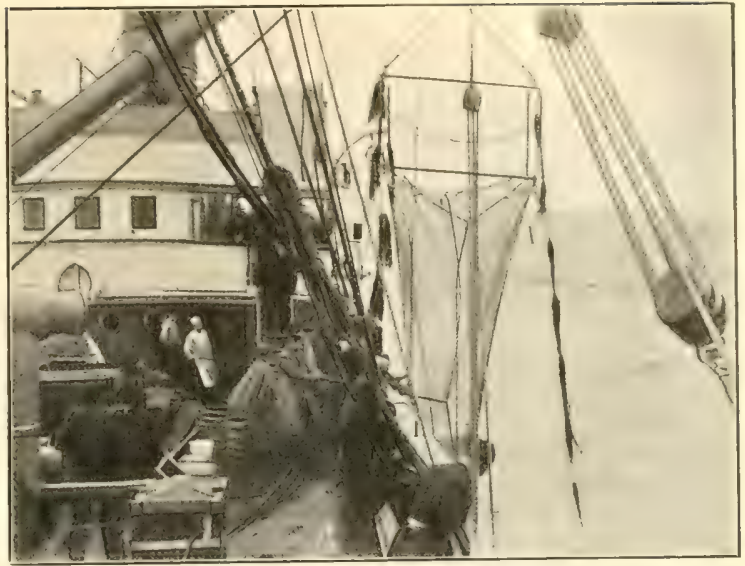

2lufpommen bes Trawl ant 1\%. Dejember 1898 . gejeigt hatte, nidht von Sdplamm, fondern von Gefteinsmaffen herrührte. Da lag

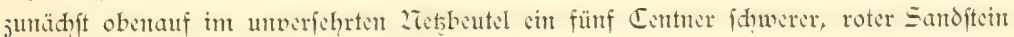

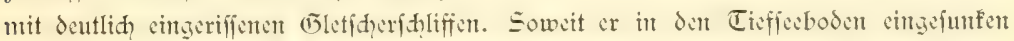

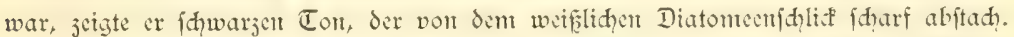

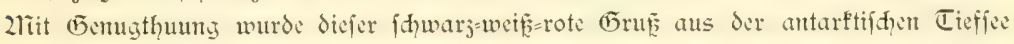

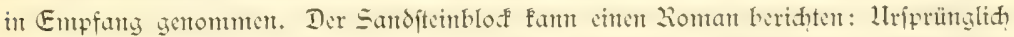

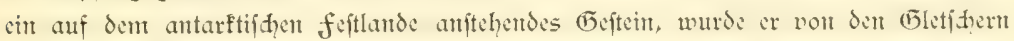

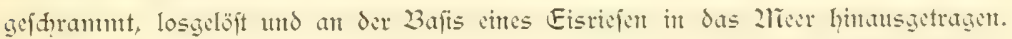
Durd den Einfluf des warmen Tiefenwaffers abgetaut, finft er in $4656 \mathrm{~m}$ nieder,

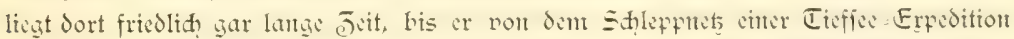

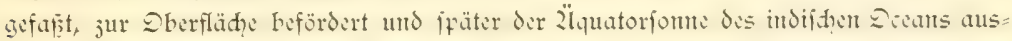
gefetrt wird. Zun paradient er vor einer wifbegierigen Studentenjhaft auf dem Vor= lifungstif als ftummer und dod mider beredter Jiuge, daf Enderby= niḑt vulfanifher 2Tatur ift. Darauf deuten denn auh die übrigen Ēeftente hin, die

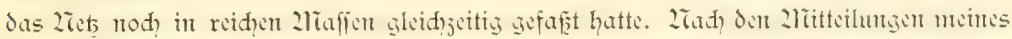
Kollegen Jirfel handelt es fíh bei diefen Repräjentanten des geologijhen 2lufbaues von Enderby= Eand vorwiegend un grantifihe Eefteine und Eneife (einige mit reidh)

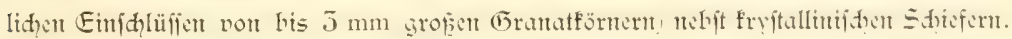

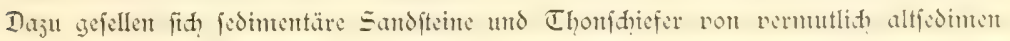

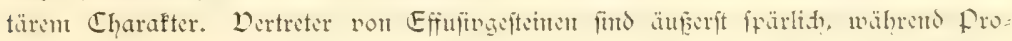
dufte, weldhe unter 2lusfdluf einer anderen Deutung auf cine heutige vulfanifhe Thätigfeit himweifen, überhaupt niḑt gefunden wurdent. 
Wenn wir in 3etraḑt jehen, daf dic Challenger = Expedition - unter antuăherno

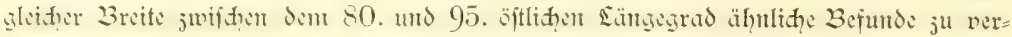

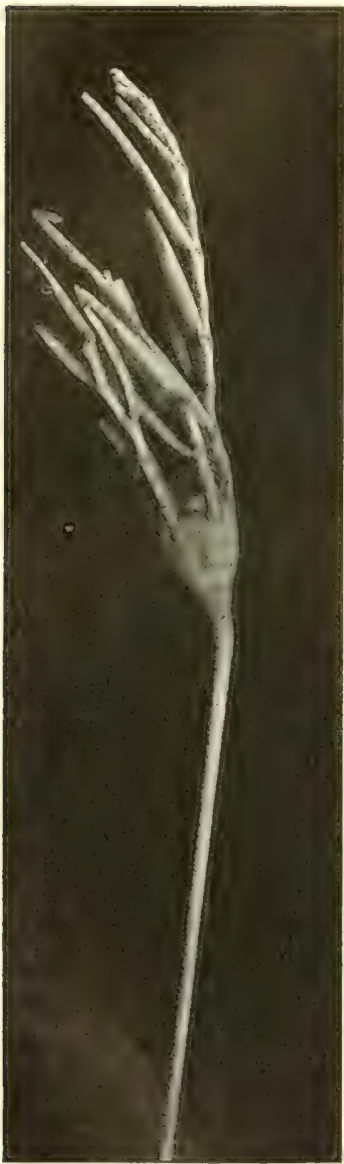

Hyocrinus n, sp. a1s $\$ 656 \mathrm{~m}$.

17. Dezember 1898. 2iat. Fiö̌̆ jeidnen hatte, fo dirfte es vielleiḑt fid ergeben, dak die Lrgebirgsformation den eigentlichen Kern des ant= arfifdien feftlandes bildet, der von den Dulfanfetten des Diftoria $=$ andes und Graham=Landes flanfiert wird.

Gatten fontif fhon allem die gewontmenen (5efteins: proben die zrühen des Dredidjuges reid entfähoigt, fo waren wir nidht ntinder überrajht über die relatio grof̧e כahI tierifher Drganismen, welche in dicjen ge= waltigen Ticfen bei einer Temperatur von $-0,5^{\circ} \mathrm{C}$. leben. In den S丸wabbern des Trawl hingen jwei

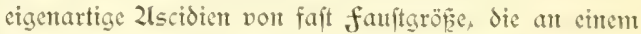
ftrifnadeldumen, über $1 \mathrm{~m}$ langen Stiele auf dem Grunde befeitigt waren. Sie futd verwandt der Gattung Boltenia (Culeolus) und jeifhnen fith durd) die gallertige Befhaffenheit ihres an 2ledufen ermernden Körpers aus. Dffenbar flottieren fie an ifhem ftrifartigen Stiel wie sinte 3oje, da faum abjujehen ift, das er den Körper ju ftützen imjtande ift. Zeben if̧ten fielen uns jwet geftielte Seelilien (Crinoiden) anf, von denen eine ¡đqwefelgelb gefärbte der (5)attung Hyocrinus, die andere der (5)attung Bathycrinus angehört. 2Tach den 2litis= teilungen von profeffor Doeberlein handelt es fid um jtei neue Zlrten, welche den von der Challenger= Expe= Sition weiter nördlid, und in flacherem $\mathfrak{W}_{\text {affer, nämlid }}$ bet den crojet= Infeln, erbeuteten formen nahejtehen.

Die Edhinodermen bildeten überhaupt einen anjehnts lidien Brudjtet der gedredjuten Drganismen. Befont= ders jahlreidh waren die Shlangenferme (Ophiuren) ver= treten. 2rad) der Beftimmutg von Prof. jur Straffen gehören fie vier 2lrten an, von denen cine neu ift, die übrigen aber (Ophioplinthus medusa Lym., Amphiura patula Lym., Ophiocten pallidum Lym.) vor dem "Ehallenger" unter ähnliahen Verhältmiffen, nämlid̆ in Ser 2Tähe der antarftiphen Eisfante, gefunden wurdert. Ju ihnen gejellten fid See= waljen, unter denen nantentlid cine fđöne, dunfelviolett gefärbte 2lrt aus der fantilie der Elpidien und drei weitere, mehr fahl gefürbte Dertreter hervorjuheben find. 
Wenn wir ferner noh hervorheben, da eine jerbrodjene Secigelihale, mehrere wohl

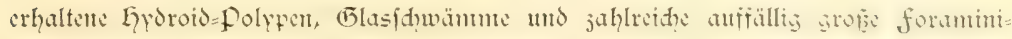
feren in dem 2retse enthalten waren, fo ergiebt fich ein in 2lnbetraḑ der immerhin beträdtliḑen Tiefe benterfentwerter Sieidptum an Drganismen. Da es fidh um den

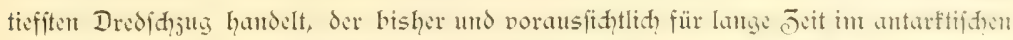
(5ebiet jenfeits des 60 . Breitegrades ausgeführt wurde,

fo haben wir einige Dertreter der erbenteten Tieffee= organismen abgebildet.

Kaum hatten wir das Słleppnets an Bord, als diffter 2rebel fin emitellte, und uns nötigte,

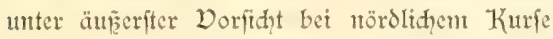
vorjufahren. 2lls es endid um $10 \mathrm{Mhr}$ abents aufflarte, war das Shiff wieder volt idwerem Padeis ungeben. Während wil uns durd das= felbe hindurḑwanden, gewahrten wir in Siten den gröften Fisberg, der uns auf der ganjen fahrt be= gegnete. Wir glaubten erft die antarftilde Eis= nauer vor uns ju haben, libergeugten uns aber ipäterhin, dafes fich um einc

fömlidhe Eisinjel handelte, die wir letder bei dent Eavieren durh das padeis nidyt genamer ju nteffert int ftande waren.

Die Şärfungen von Kapi= tän utd Dffijieren bejügliđ ihrer Breite berwegten fith jwijhen vier und fünf Seemeilen. Wie an dent vorhergehenten Tage, fo trafen wir auh diesmal auf eine burdh erdige Beintengungen thofo: labebraun gefärbte Eisfholle.

Zadidem wir uns jum jweitemulal aus dem Dackeis herausgearbeitet hatten, beganm das Barometer raidh ju fallen. Der aus Dit=2rord= Sft wehende Wind wurde jum vollen Sturnte und errethte ant. Somtag den 18. Dejember unt 2littag die Stärfe 10 nad) der Beaufortifala. Welher Kontrait jwijhen gejtern und heute! Im Sdnee= furm domerten die Wogen gegen das Sdifï, mehrfad auftretende ziebel hinderten an einem rafden Dorwärtsfonment, und nur mit 2liüe war es uns nod in der 


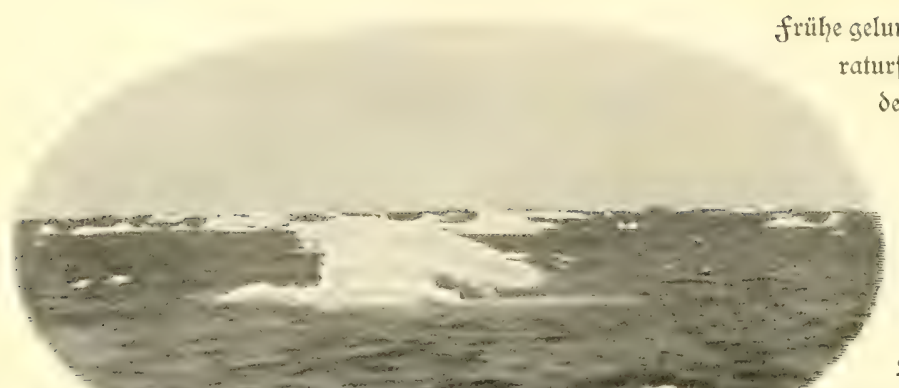

furie durd ente mit Ser Se Blane'fiden Sot= majdine gewomrente Temperaturprobe aus $5000 \mathrm{~m}$ Tie $=$ fe jul ergänjen. $2 \mathrm{ln}$ ein weiteres Dordringen nad Sïden reppeft. Diten war unter siefen Um= ftänden niḑt mehr ju den= fen, und fo wurde dem der Kurs Fadeisihollen bei Enderby = Eand. 16. Dezember 1898. Sh a.m. gegen die Kerguelen genommen. Waren wit bisher dee Woden lang bei unferer

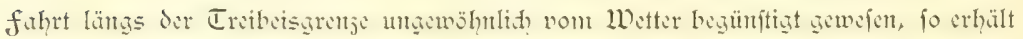
der lefte 2lbidntitt unjerer fahrt in falten Gebiet feine Signatur durch eine fort= laufende Reife fdwwerer Stürme, weldie uns fajt an allen 2lrbeiten behinderten. fünf Tage bindurh (vom 18.-22. Dezember) hielten die ftürmifhen, mit didhtem Shnee= treiben verbundenen öftlichen Winde an und erreidhten jeitweilig, fo am 20. und 22. De= zember, die Winditärfe 10 nah der Beaufortffala. Ein Umíhlag erfolgte unter dem 56. Breitegrad am 22. Dezentber, indem der Wind nach 2Torden, und an ben folgenden Tagen nad, 2Tordweft und Weft umiprang, ohne indefïn an Stärfe einjubüpen. Der Eintritt in die Weftregion wurde ant 22. Dejenter durd energifhe Sdwanfungen im Suftorud angedutet, injofern der Barograph innerhalb 12 Stunden ein fallen um $21 \mathrm{~mm}$ verzeidnete, und mit $725 \mathrm{~mm}$ den niedrigften auf der Reife beobaditeten Euft=

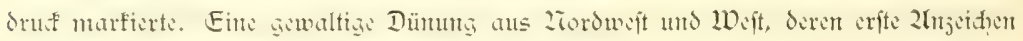
wir bereits unter dent 6h. Frad bemerften, gelangte gegen den durh die öftlifhen und

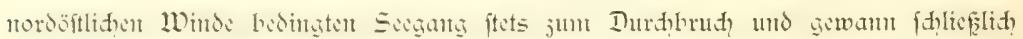
dic Dberhand. 2liehrmals muţten wir beidrehen und gegen dic überholende See an= Sampfen. Dont der Brüde bietet fith dant cin gewaltiges Shaupiel dar: der Stumt heult und pfeift durd 2rapten und Tauwere, der naffe, rajh tauende Shnee wird horizontal in das befiḑt getrieben, und die Wogen erreiḑen eine E⿱丷öhe, wie wir fie auf der ganjen Reife niđt erlebten. Das Shiff erflimmt die Wellenberge und jauft dam in die Thäler nieder, unt, am $3 \mathrm{ng}$ in (5ifht cingehüllt, wieder elegant aufju= fteigen. Selbit das Dethaus wurde überipült, und faum vermoditen wir bei dem fdiweren Rollen den Derfehr an Bord aufredyt ju erhalten. Trotzdem gelang es uns,

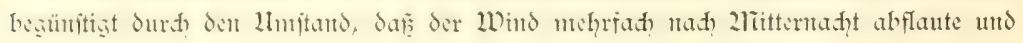


crit int Sauf des Dorntittags wider aufbrifte, bis ju den Kerguelen cine Serte vort fed̨s Sotungen durdjuführen. J̄weimal muften die Sotutgen wegen des fhweren Seeganges abgebroden werden, dod, bewährte fich aud unter dicfen Derhältniffen dic Sigsbee'fde somajdine trefflid, indent fie eber fo eraft, wie unter nomtalen Der= hältniffen, den 2luffilag des Sotes auf dent Grund anjeigfe. Dite Sotungen lehren, dafs der Boden jwifhen Enderby= Sand und den Kerguelen ftarf gefaltet ift. Südlid) der 21ic. Donald = Infeln und Leard = Eiland loteten wir $2588 \mathrm{~m}$ und glanbten, Santit dic

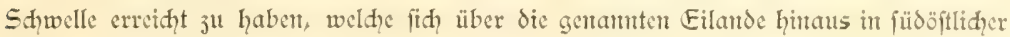
Rithtung verfolgen läfst. Indeffen jeigten die Sotungen der nädften Tage, daf das fladhe Plateau, weldes dic Kerguelen mit Geard= Eiland verbindet, nad, Weiten fehr

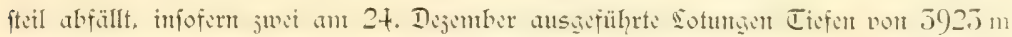
und in direfter zäh) des Rüfens nod $2045 \mathrm{~m}$ ergaben.

Wir haben bereits früher (S.25̄) Belegenheit genommet, darauf hinzuweifen, da范 eine wärmere Strömung von den Kerguelen nad, Süden jetst. Jhrer Fintoirfung

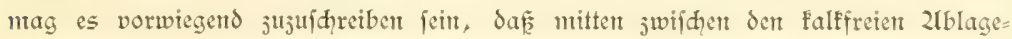

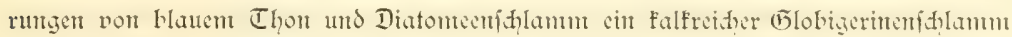
auftritt. Wir fonftatierten dies bemerfenswerte Dorfonmmis durd 2Inalyfe einer am 19. Dezember aus $3548 \mathrm{~m}$ gewomenen (Frundprobe $\left(61^{\circ} 45^{\prime}\right.$ ศ. $3 \mathrm{r} ., 61^{\circ} 16^{\prime}$ ö. E. .).

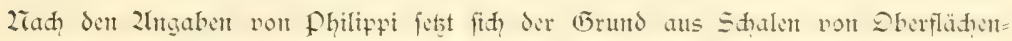
foraminiferen (Globigerina Dutertrei und Gl. pachyderma) urd Bodenforaminiferen (Biloculina, Cassidulina, Rotalia, Truncatulina) jufammen. Die Grundprobe befteht ju $6 \bar{J}^{0}{ }_{0}$ aus fohlenfaurem Kalf, mährend die Kicfilorganismen mur ju 9", o norbanden funs.

Juffällig war auf diefer Route das frühjeitige Derfdwinden der Eisberge; wir trafen am 19. Dezember dic leşten, unter ihnen cinen tafelförmigen Riejen von $455 \mathrm{~m}$

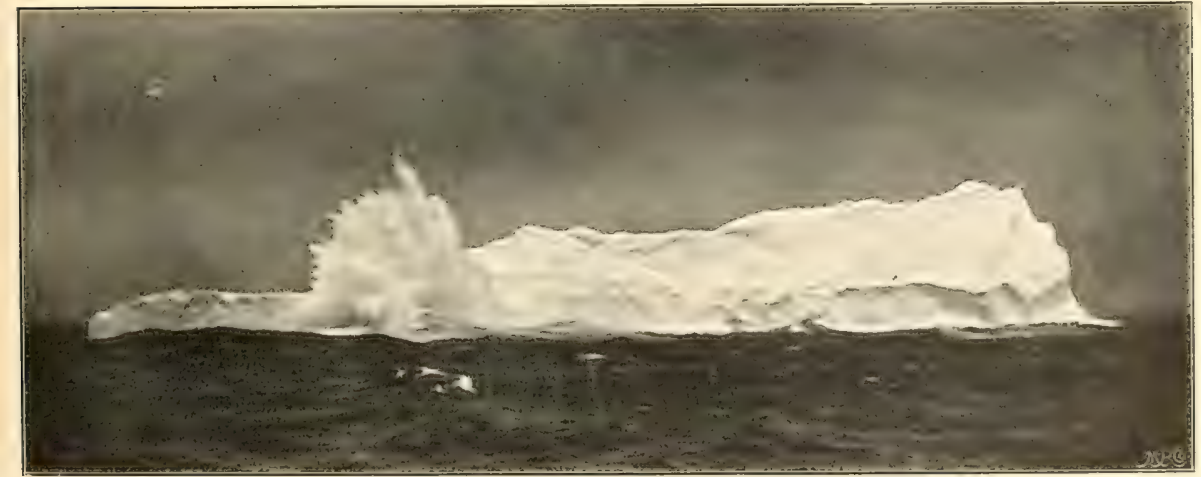

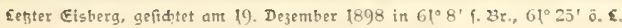
In ber linfen Eältte eine Branbungswoge. 


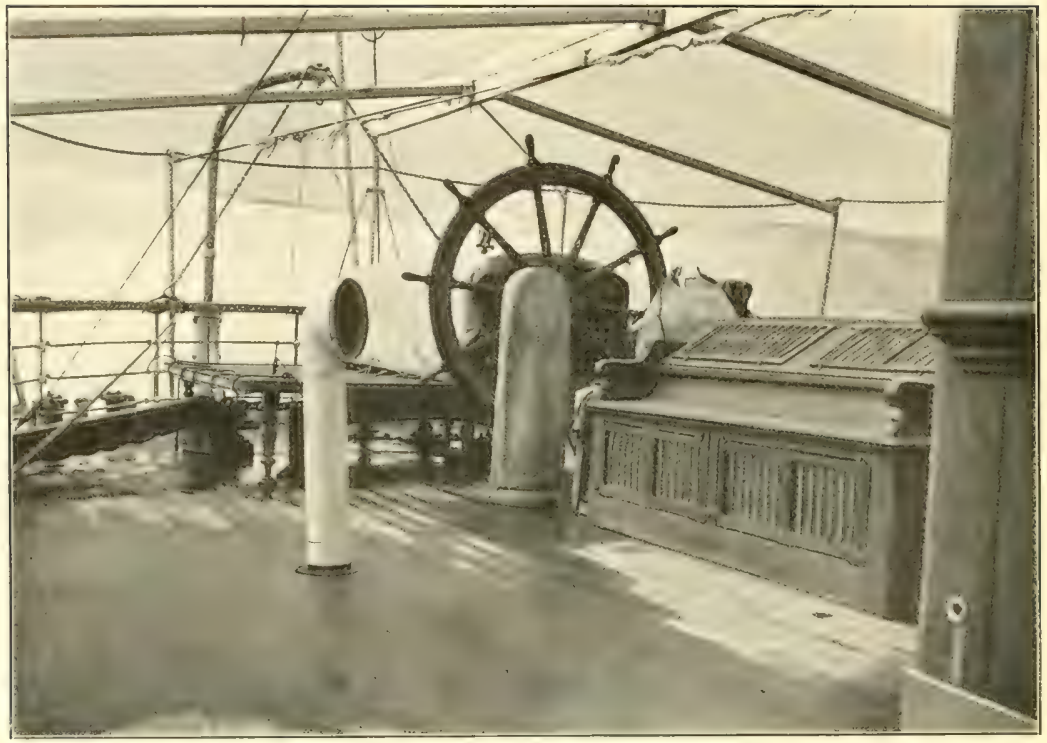

Seegang vont binterded aus gefeher.

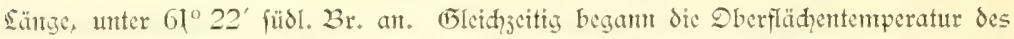
Waffers fid ju heben; während wir am 16. Dejember nod, - 1,80 (inmitten des Pat:= sifes $-0,8^{\circ}$ ) genteffen hatten, betrug ant 20. Dejentber die Dberflädentemtperatur $0^{\circ}$, und ftieg dant anthaltend bis auf $+5^{\circ}$ ant 2t. Dejember.

Den Weihnadytsabend verbradten wir in froher Erwartung des Chriftgeidenfes, das fith uns an folgenden Tage in Gejtalt der Kerguelen darbicten würde. Die fieben=

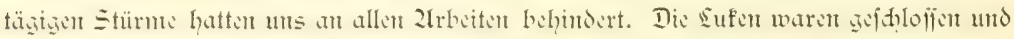
in den saboratorien fah es wunderlid genug aus. 2hit dreiecfigen Klöthen hatte

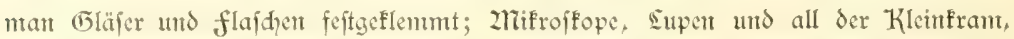
deffen der Beobadter bedarf, waren angefdraubt und mit Sappen und Watte um= widelt. 2lls ob nectifhe Geinjelntämtḑen fïh jeden LInfug hätten erlauben fömen, fo iprang trotzdem gar manthes bet dem Stantpfen des Sdiffes aus feitem Behälter und bisweilen fah es in den 2lrbeitsräumen - um mit frits Reuter ju reden - aus "as up de leime Gottesird vör den iriten Sđäpfungstag".

2lin hatte jeit genug, fidh jum Beifherabend ju rüften. Das Piantino crhielt nette

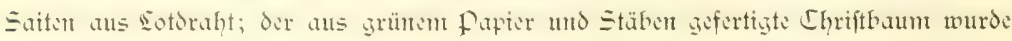
an der Deffe des Salons feiftgebundert, währent die 2liamidhaft cinen eberfoldyen in 
Ser Kambüje mit Konfeft und Würften deforierte. 2lian muşte darauf verjidyter,

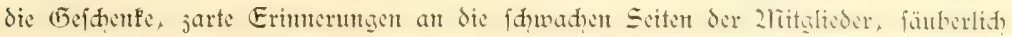
ausjubreiten und war froh, went man fie unverjehrt aus den Rosfajhen hervor= Golen fornte. Gar bald rollten fie, untermijht mit Pfannfudpen, dis der Kod? unter

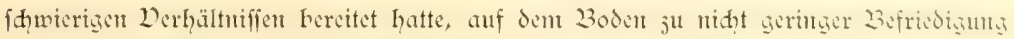
unferes Dadishundes "Dafi". Immterhin lernte man bald, auf das Wohl der 2lnt

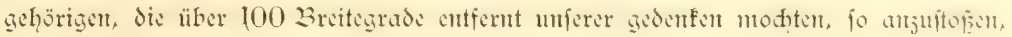
dafi niht der ganje "Eisbredjer" in die Weite des Eegenüber flof.

Weniger Erfolg hatte der Photograph mit feinem Derjuche, diejen denfwürdigen Weihnadtsabens mit Blițlidt aufjutehnen. Er faufte mitfant finten 2lpparate in die andere Efie, das Viagnefum ging in der Suft los und foretend ob des Spules bramte der 2Teger durd. Zidht viel befier war der Seiter der Erpedition daran, den man mit Strifen, die bald riffen, an das Klavier feftgebunden hatte, dantit or unter J̈therbeglettung des Kapitäns dem 2lbend die Weihe gäbe. Jwar gingen Diano, Jither und Dfarina ftets um einen halben Ton auscinander, aber bei dem heulenden

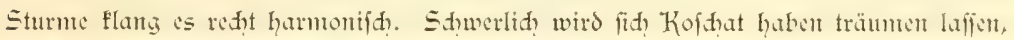

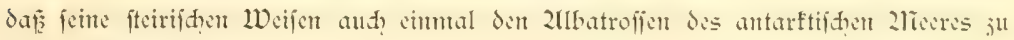
Dhrer fommen follten.

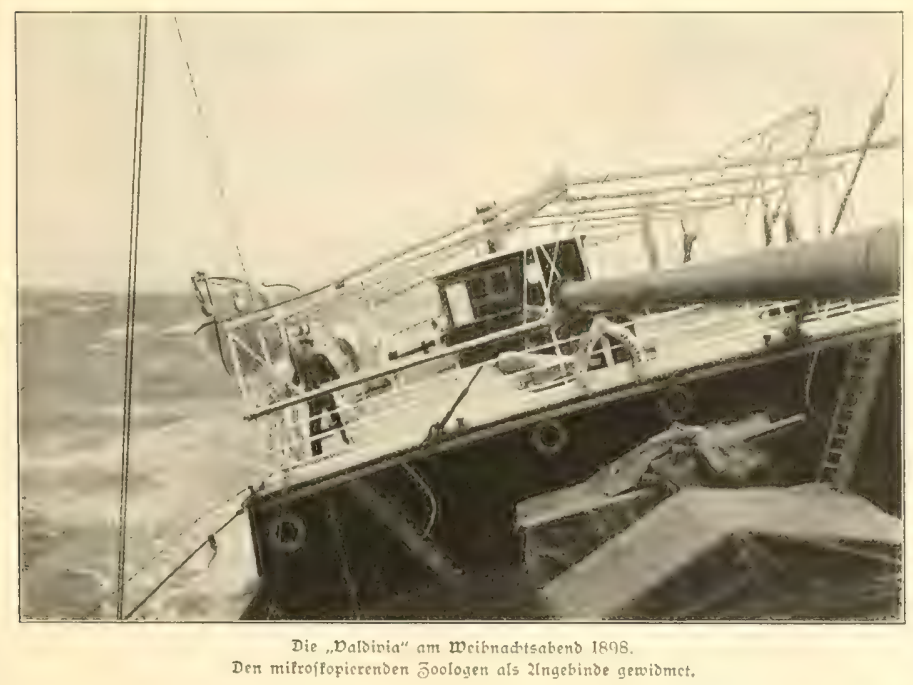




\subsubsection{6.}

\section{Die Kergueler.}

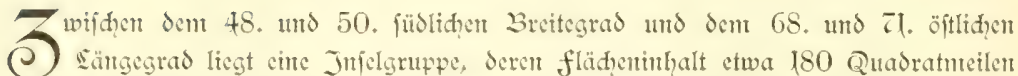
beträgt. Die Kerguelen, wie die Errupe ju Ehrent ihres Entdeders genannt wird,

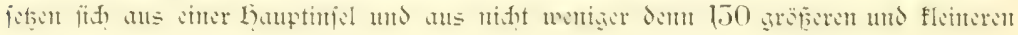

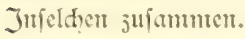

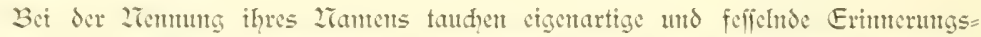
bilder auf. Die Berge fund teilmeife mit ewigem Sthtee und in STletjher auslaufen=

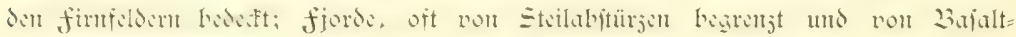
trünmern umfännt, fdunetoen tief in das sand ein; tafelförmige Terraffen, aus horijontalen Bajaltididiten fidh aufbamend, prägen der vulfanifhen Eandofhaft ibren charafter auf; ans jahllofen Süpwaffertümpln fanmeln fid die Sdmmeljwaffer, um in malerifhen Kasfaden liber die Steilwände der fiorde herabjuraujhen; grüte 2liatten, gebildet ans einer eigenartigent flora, bedefen das flade Dorland unt jiehen fid oft weit an den bängen hintauf, und endid wird dies alles belebt von ciner über= wältigent reid, entfalteten Wogelwelt, bic an anmutender Earmlofigfeit mit den den Etrans bedetenden Elefantenrobben wetteifert.

2uif Coof madten die Injeln cinen fo troftlofen Eindruf, daf er fie Defolation=

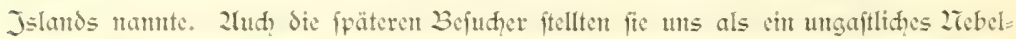
land dar, in defien fiords der Witd, bals kegen, bals Sdunec mit fid führend, mit แแก

Der Eindrut, den fie auf den Befuher maḑen, dürfte freilid niḑt unwefentlid volt dent frifien Bufferimerumgen an volt der Zatur milder und reider ausgeftattete Siggtonen becurflubt werden. Wer das üppige, fontge Kapland mit fenter Blüten= praḑt verlaffen hat, un den Kerguelen jujuftreben, wird diefes fturmgepeitfhte 2Tebelland, das metit neidifh dert Zlusblid auf fem malerifhes Lodigebirge verfagt, Süfter und ungajtlif? finden. Wer aber, wie wir, feit dem Derlafien Kapftadts 52 Tage lanty das antarftiphe 2lieer durdhfuhr, mur eine in Eis gepanjerte Jufel ju

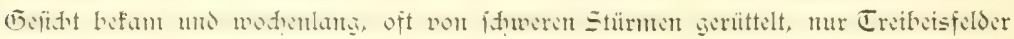
und Eisberge fal, dent erfheinen die Kergnden faft in paradiefifher Pradt. Es war, 
als ob fie fid zur feier unjerer 2lnfunft in ihr feftgewand gefletdet দätfen. Während

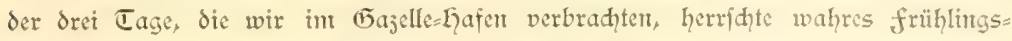
wetter bei einer Temperatur von $4^{\circ} \mathrm{C}$. 2Tah allen Seiten jeritrenten fith die Partien, unt die Umgebung zu durdpfreifen; Fein Sturm warf die Wanderer nieder, fem 2ebel

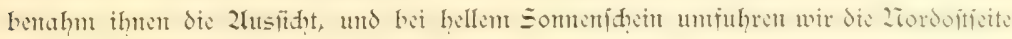
bis junt Weihnađhtshafent.

Wie fehr wir während der vier Tage, dic wir auf den Kerguelen jubrahten, vont Wetter begünţigt waren, lehren die früheren Schilderungen. Jhr Klima fömten wir ant beften nit den Worten von Shleinits wiedergeben: "Es weht fajt beftändig Sturm jwifhen 2rord und Weft mit Sanee $=$ Lagel= und Regenböen, Siefigem Lorijont, aber oftmals flarem Gimmel und fühlem Wetter. $2 \mathfrak{b}$ und 3 w wird diefer Stum Surd flauten oder feltener durd ftürmifipen Wind aus 2rordoft unterbrodpen, weldher diḑten 2rebel und Regen bringt." Die Stärfe der Winditöfre fḑildern fowohl die

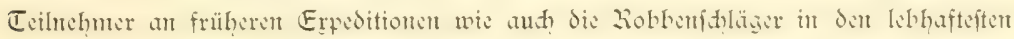
farben. Sie bredhen fo plöţlid, in manḑe Buhten herein, dafi die Sdiffe mit den

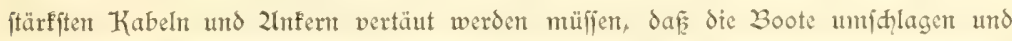
der Wanderer anf dem Eande fíh platt niederwerfen muf. Gegen die dem unermef lidhen antarfifhen 2rieere jugefehrte Weftfeite domern die Wogen ftändig mit fo gewaltigem prall an, daf fie heute nod in ihrer Gliederumg fajt unbefannt ift. Im allgemeinen find die Weftitürne mit cinem Steigen des Barometers verbunden,

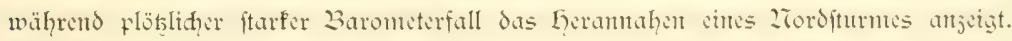
Wie fąwer dic Kerguelen von diejen Stürmen heimgejuht werden, mag der Linweis illuitrieren, daf der "Challenger", der fie im Sommer befudte, an 26 Tagen fedjehnt= mal Sturm verjeidnet, während Rof, der 68 Tage hindurd? in Winter auf den Kerguelen Station madte, niht wentiger als 45 mal Sturm durḑlebte, und nur dret Tage anführt, weldie frei von Sthree und Regen waren.

2Int 12. februar 1762 entoefte der franjöfifhe Kapitän 1) ves Jofeph de Ker= guelen=Trémaree mit femen Sdiffen "fortune" uno "Froswater" die Injelgruppe, weldhe nod, heute feinen 2ramten trägt. 2lnt nädiften Tage fid tete er die fleinen, der

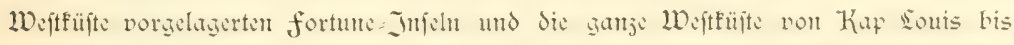
jum Kap Bourbon. Er vermodite jwar die Gauptinfel nidht ju erreiden, doh gelang immerhin ein Eandungsverfud? in ciner Bai, die "Soup narinc" genant wurde.

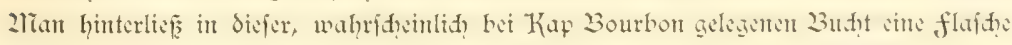

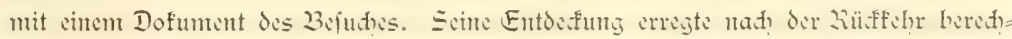
tigtes 2uffehen. 27an glaubte, der damals herrfhenden Dorftellung Kaum gebend,

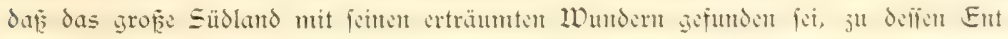

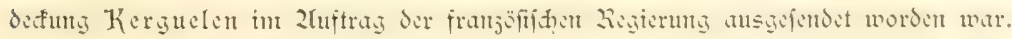
So wurde er dent fdion in folgenden Jahre beauftragt, feine Sandfidtutg weiter ju 
홍

高
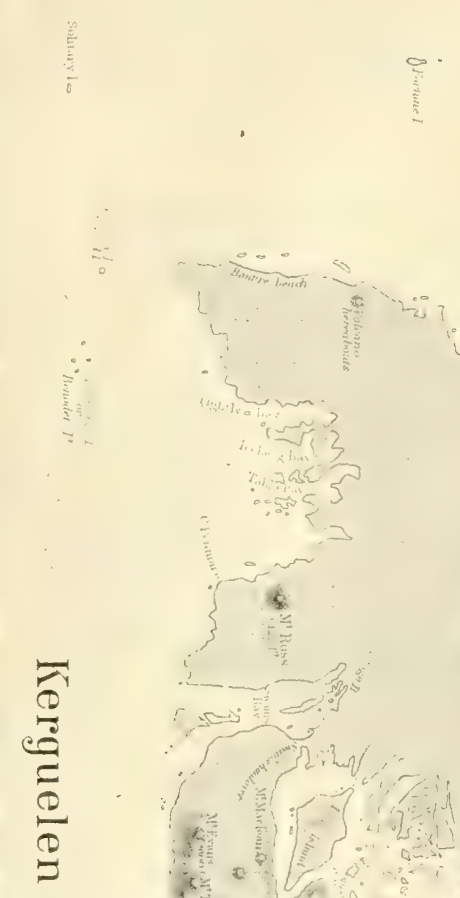

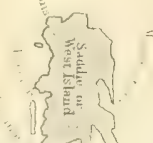

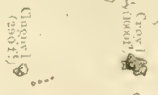

Uan

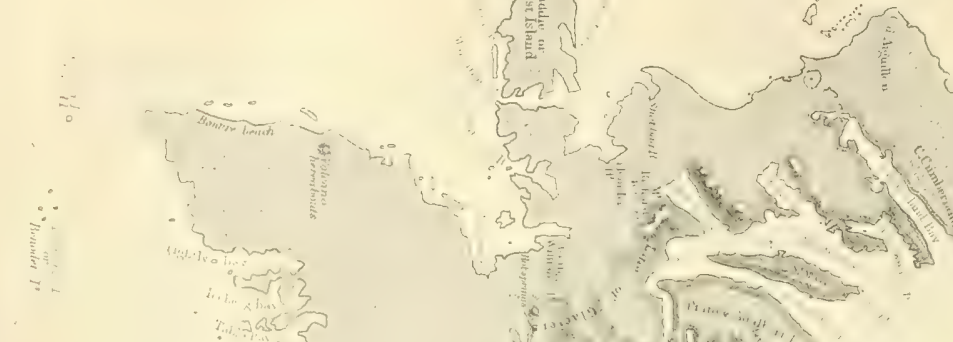

$x=w *$ ?

if 30 ,

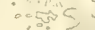

०0द्यक

if

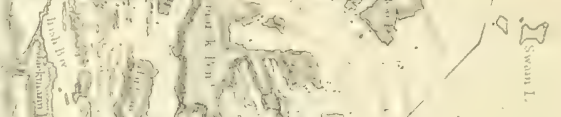

in

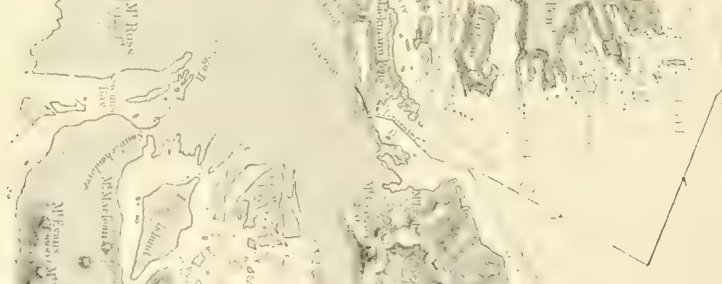

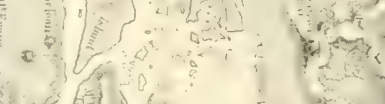

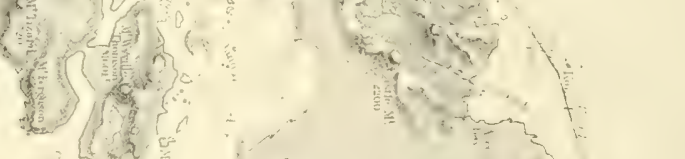


verfolgen. Er gelangte am 14. Dejember 1665 jun jweiten 2liale in Sie 2Tähe der

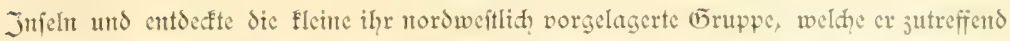
"Wolfen= Jnfeln" (Cloudy= Jslands) namte. Indeffen gelang es ifm nidht, wegen der

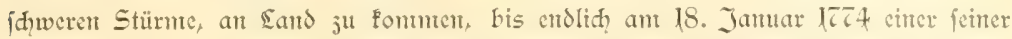
Begleiter, 21r. de Ropnevet, in Weihnadishafen landete und in 2ramen des Köntigs von franfreid von dex Terra australis nodmals Befits ergriff. Die flafhe nit dem hierauf bejüglidhen Dofument wurde fpäterhin von Coof bei feiner dritten Reife wiebergefunden.

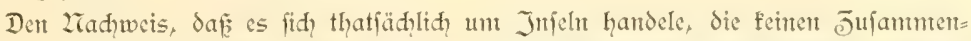

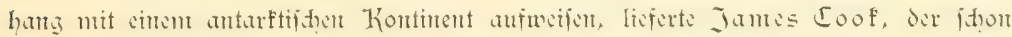
auf feiner jweiten Entdedungsreife füdtid, vont den Kerguelen - obnte fie aller

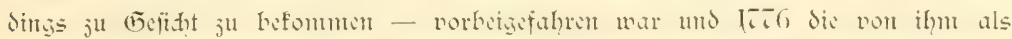
"Defolation= Island" bejetducte (5ruppe jum erften 21Tale genauer unterjudite. Er

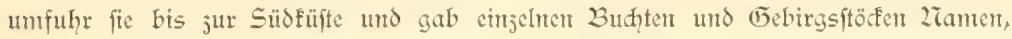
die bis heute nod ihre (1) ltung behalten haben. Die jweite genautere Durdforfdyung der Kerguelen verdanfen wir dent grof̧en Entdefer der antarftijhen Region, James Rof , der an 12. 2lat 1870 im Weihnathtshafen vor 2lnfer ging und nidht weniger als 68 Cage auf die Luterfudung verwendete. Ein junger $2 \mathfrak{l}_{3} \mathrm{t}_{\text {, }}$ der fpäter fo bes rühnt gewordene Botatifer Loofer, begleitete ihn und gab in feiner flafifihen "flora antarctica" die crite cingehende Shilderung der eigenartigen Kerguelen=Degee tation. Späterhin wurden dic Kerguelen von niđ̧t wentger dem fünf Expeditionen angelaufen - ganj abgefehen von den jahllofen Walfifhfängem, weldhe dic 3udhten auf die Kunde von ihrem Robbenrethtum jiemlid regelmäfig befuditen. 2luser der Challenger=Expedition, dic in Jamuar 1864 26 Tage lang bei Sen Kerguelen fremzte, haben jwei deutihe Korvetten, mämlid die "Zlreona" und die "(Ẽajelle" - letstere vont 26. Dftobcr bis 25. Dejember 1874 -, die Kerguelen aufgefudht. Wir fömen mit Befriedigung hervorheben, dafi es wejentlid die fleifigen topographifhen 2luf= nahnten der "Eajelle" gewejen find, die uns über die CEliederung der Dftfeite einen

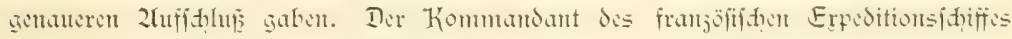
"Eure", welhes im Jamuar 1895 dic alten Zluredite auf die Kerguelen crneuerte urd

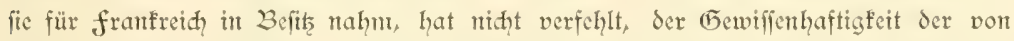
der "(G) $a_{j}$ elle" ausgeführten 2lrbeiten rüdhaltloje 2lnerfennung ju jollen. Wir felbjt haben in vollen Dertrauen auf sie Juverläfïgfeit deutfder forfdungen in der 2Tad,t jum 25. Dejember beide Keffel geheijt und fubren mit voller Kraft von jwölf Knoten an Ser Gand der Sotungen der "(5)ajelle" vorbet an jahllofen Tangfeldern in jenen Lafen cin, der durch feimen Zramen an die Thätigfeit des dentịnen Expeditions. jąiffes erimert. 
2lls Chrifgeident boten fid uns in der frühe des Weihnadtsfortt= tags, des 25. Dejember, die Kerguelen dar. Bet ftirmtifhent Weft, der fdwere Sturgfeen bradte, fant früh unt 6 llhr ein feiter,

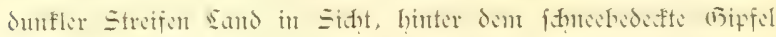
auftauhten. Es war dic Region des Jurh Sen 2ufenthalt der englifhen Expedition 3ur Beobaditutg des Denus= Durdiganges be= fant gewordenen Royal Sound mit dem vorgelagerten Prince of ffiegenber Fornortm. Wales foreland, die wir angefteuert haften. Bei Sent 2iäherfonmten

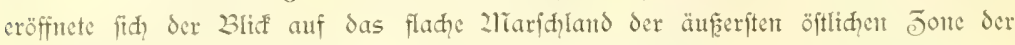
Kerguelen, aus dent cinjelne, niedrige Kegel - unter ihnen giebt namentlid der 21iount Pecper cine trefflidye 2fritencrungsmarfe $a b$ - hervorragten. Eritaunlid reid geftaltete fid das Dogelleben: Taufende der blauen Stumbögel (Prion) fifdten eifrig in dut Strömungen, dret 2llbatrof̃ $=2$ rrten (Diomedea chlororhynchus, melanophrys und fuliginosa) unffeiften das Sđiffi oder fafsen brütend auf dem grünen Dorland

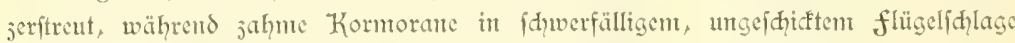
mit lang vorgeftretten Gqälfen nengierig dem Sdiffe fo nahe famen, daf man fie bisweilen hätte greifen mögent.

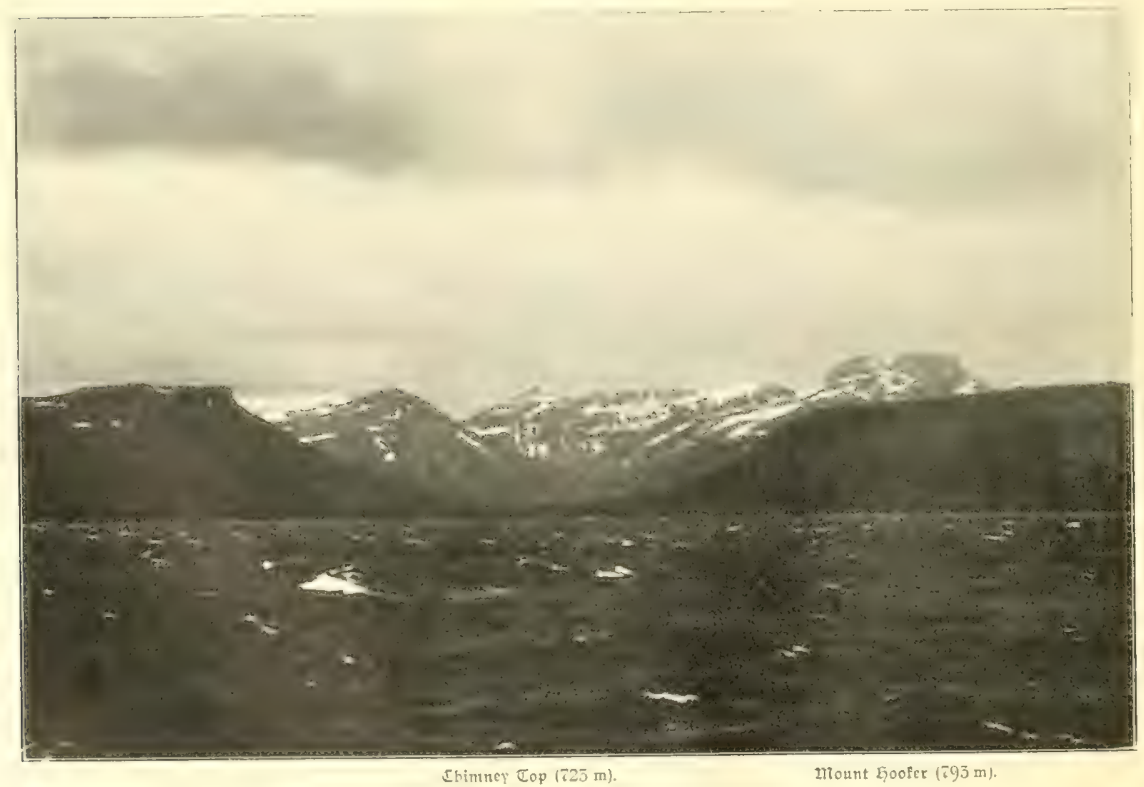



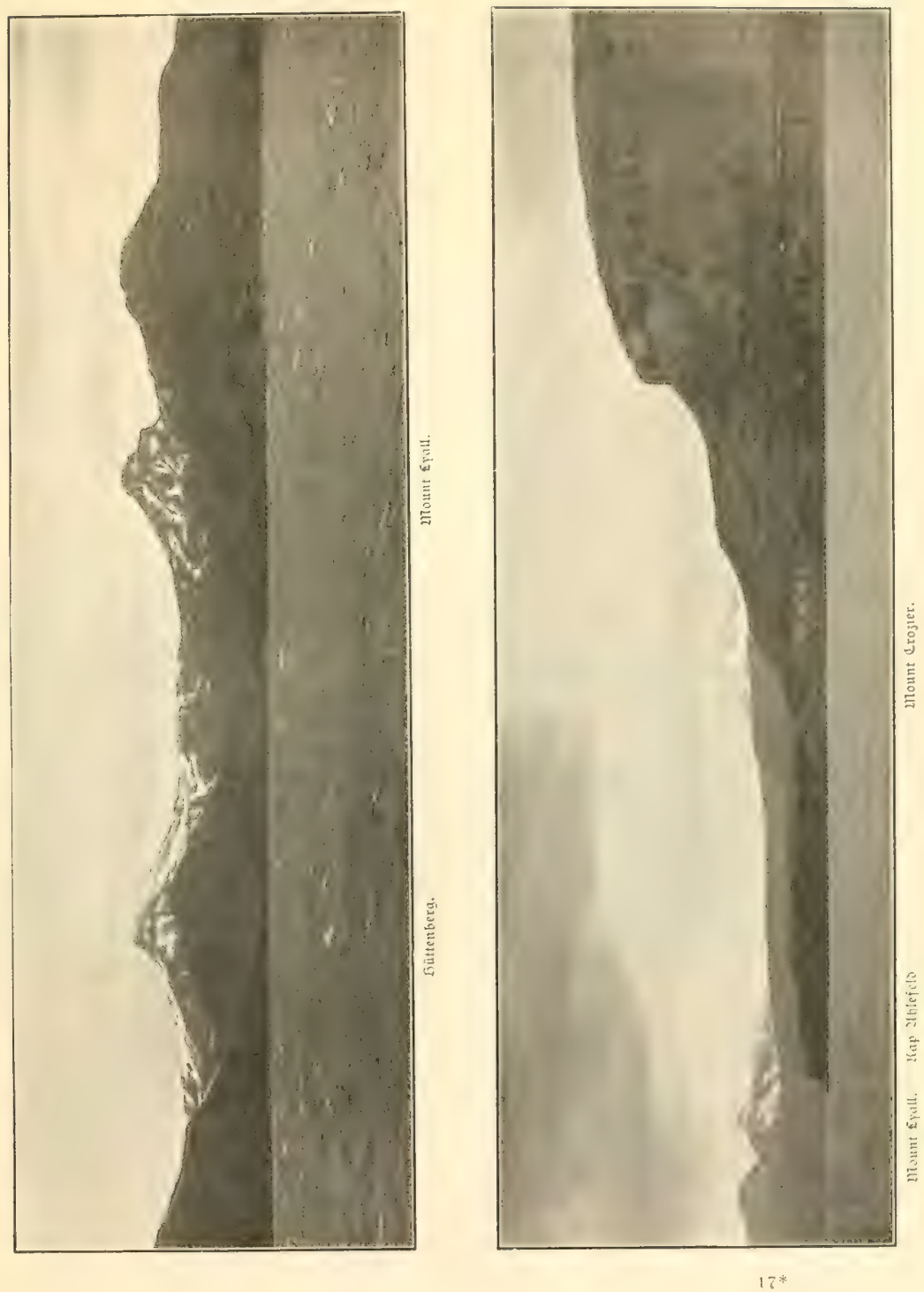
(begen 2littlag uäherten wir uns dent foneebededten Gebirgsfock der Dbicrvationts=

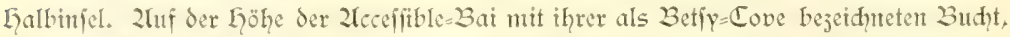

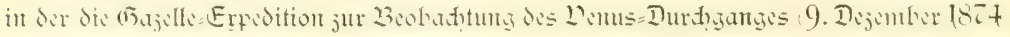
if̣r Stationsgebände crrihtet hatte, genoffen wir emen prädtigen Zusblite auf den Ianggejogenen 2lï. 2liofeley, den chimmey Top mit feinem bijarr geftalteten bajal=

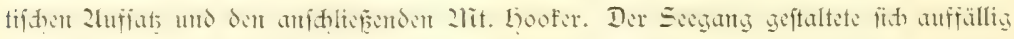

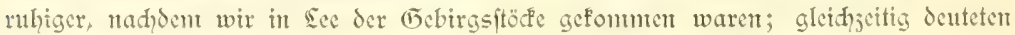

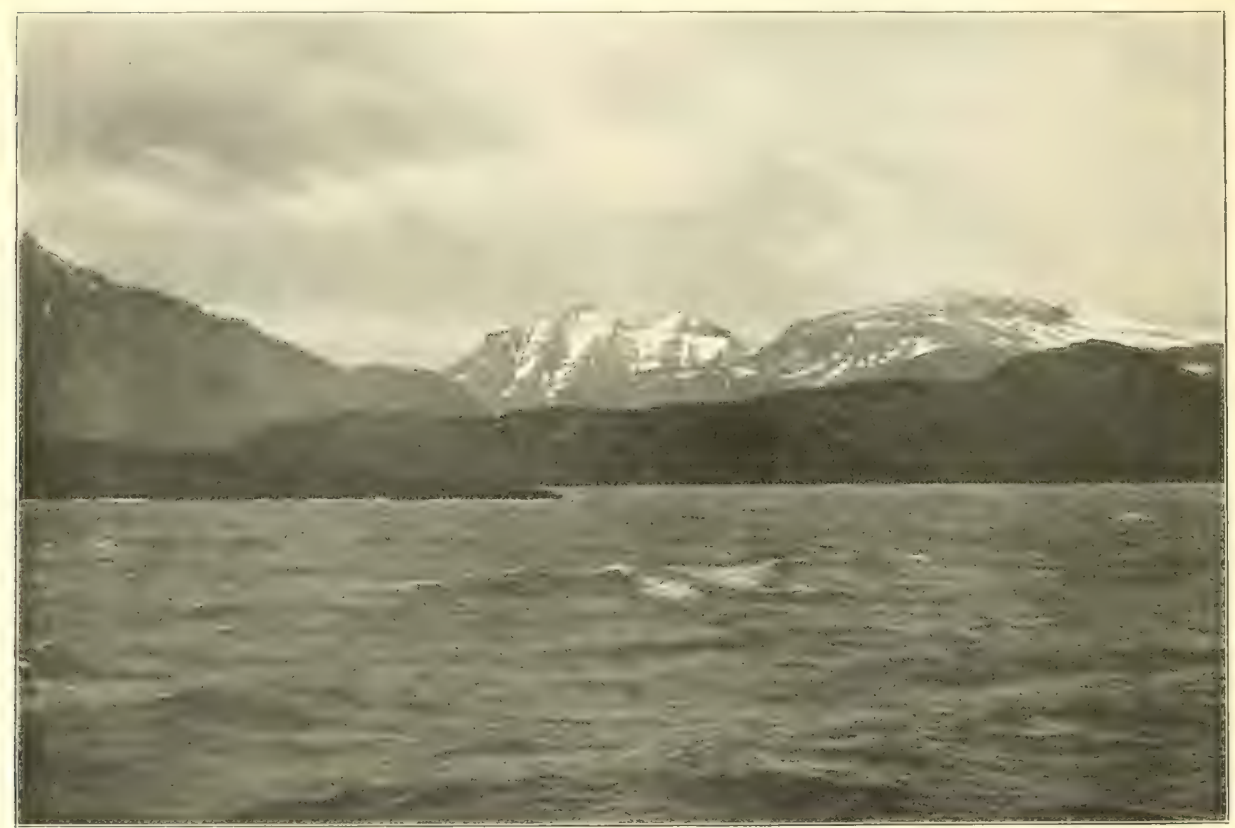

Das Crozier= Bebirge (990 m).

langgejogene, braute Streifen die Stellen an, wo anf fladperent Grunde die gewaltigen Sectange (Makrocystis pyrifera) wurjelnt. Dem 3lafentang ift es wefentlid ju ver=

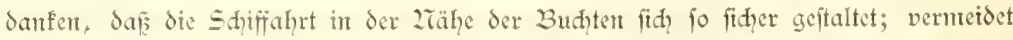
man die Stellen, wo er fich angefiedelt hat, fo fann man mit Siherheit auf tiefes, gefabrlofes fahrwaijer redyiten.

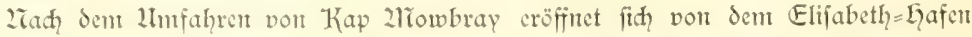
aus cin feffelnder Bliff auf den Güttenberg und 2lount Eyall, hinter denen der 


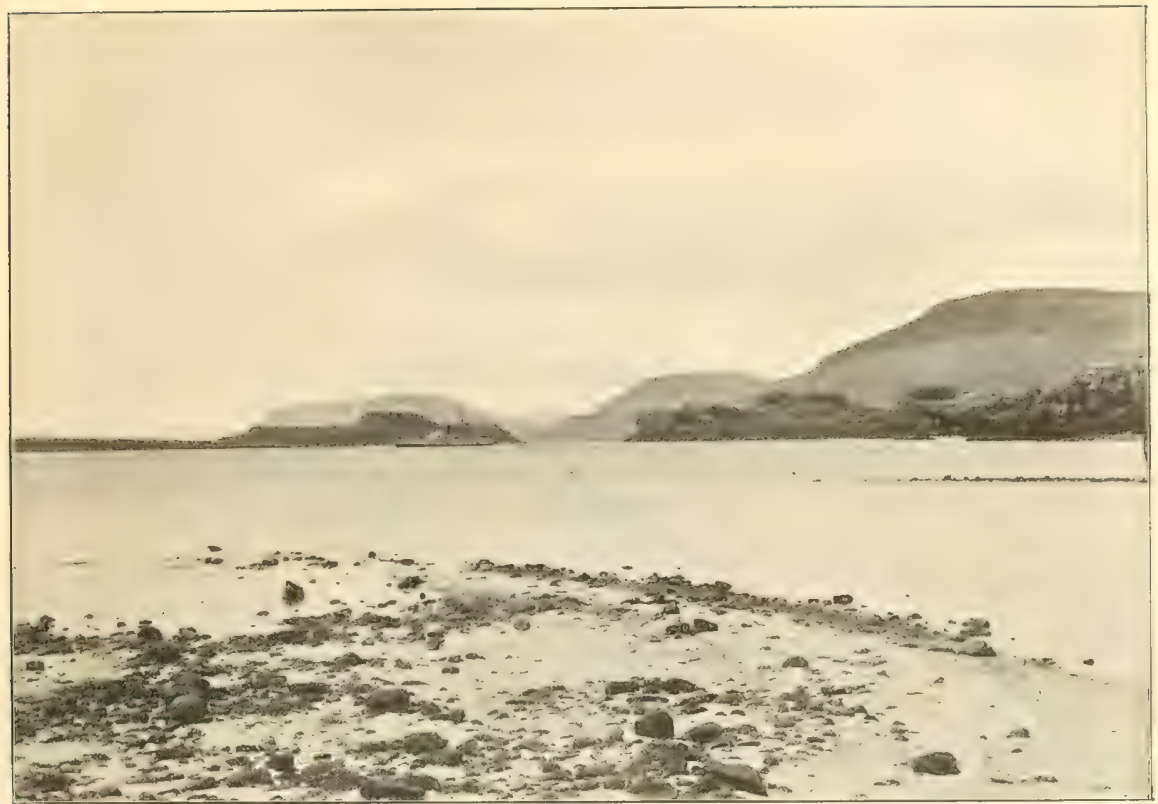

Einfahrt in ben Eazelle= Eqafen, von Jeţterem aus gefehen,

(Sachse phot.)

wildzerflüftete, $990 \mathrm{~m}$ hohe Kamm des Crojter= Gebirges jum Dorfdein fommt.

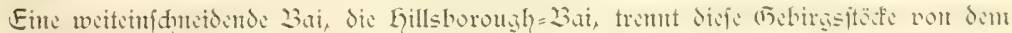
Gewinmel der gropen und fleinen Eilande, welche der Dit $=$ \& Füjte vorltegen. Sie entfendet nad, Sübweft cinen non Kap Zhblefelo und der Jadintam $=\mathfrak{\nwarrow}$ alb= infel begrengten J̄weig, dic foundery= Brandi).

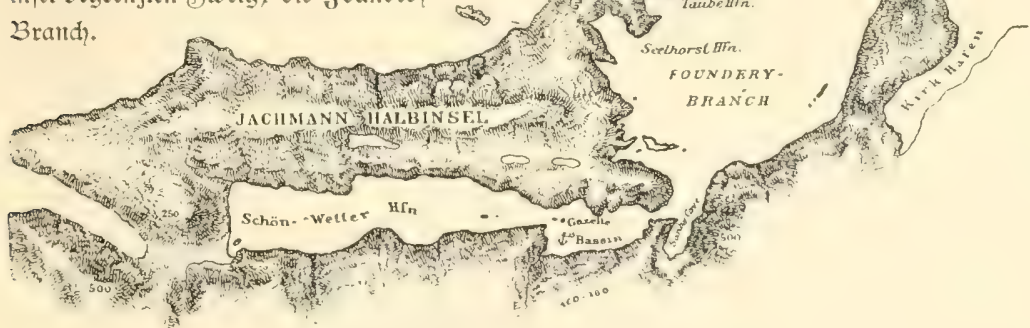

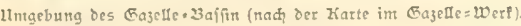




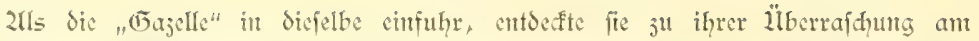

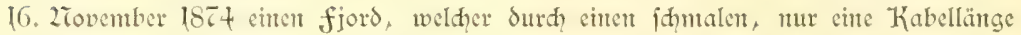
freiten Kanal ansmiütdet. Der leţtere wird von zwet Bafaltfuppen eingeengt, weldhe wie Baftionen den Jugang behertiden.

Der vordere 2lbjhutitt des fjords crhiclt den Zamen (Gajelle:Baffin, der hintere

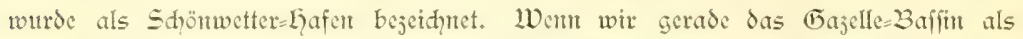

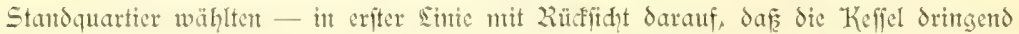
ciner Reinigung bedurften -, fo gab nidht mur der Fajelle=3eridt, fondern aud die

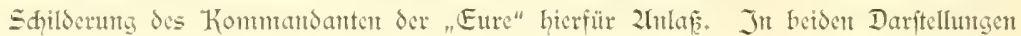

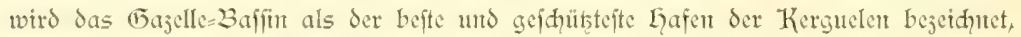
in weldhen die Winde niemals mit fold clementarer Wudt hereinbredzen, wie in dic befanterten fjorde. Jedenfalls fömen wir beftätigen, daf es unts währent der

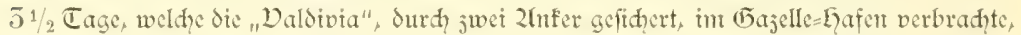
norfam, als ob wir fo ftill und rubig wie im Gamburger Lafen lägen. Es war uns șantj eigenartig ju 2liute, als bie quabratifhen (E)ftelle, die "Sdilingerleiften", von den

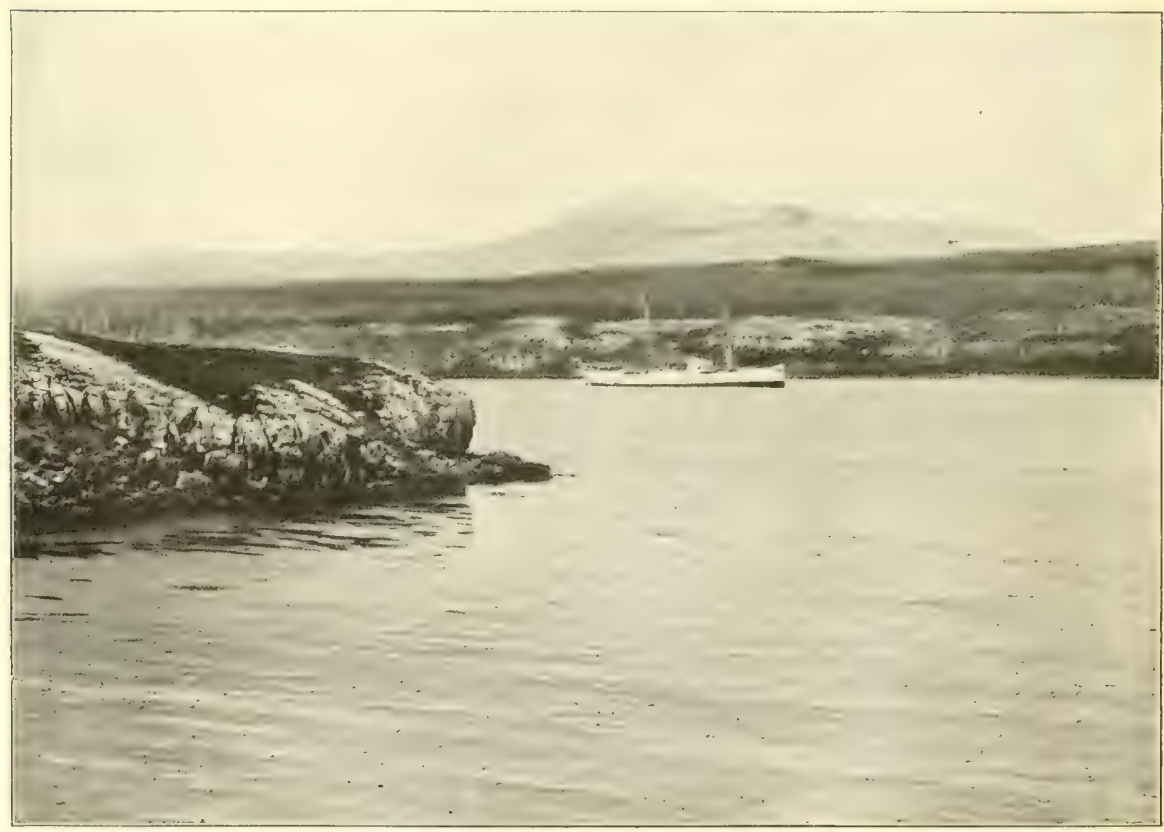

"Valbivia" im Gagelle=LGafen. 3lid nad Saben. 


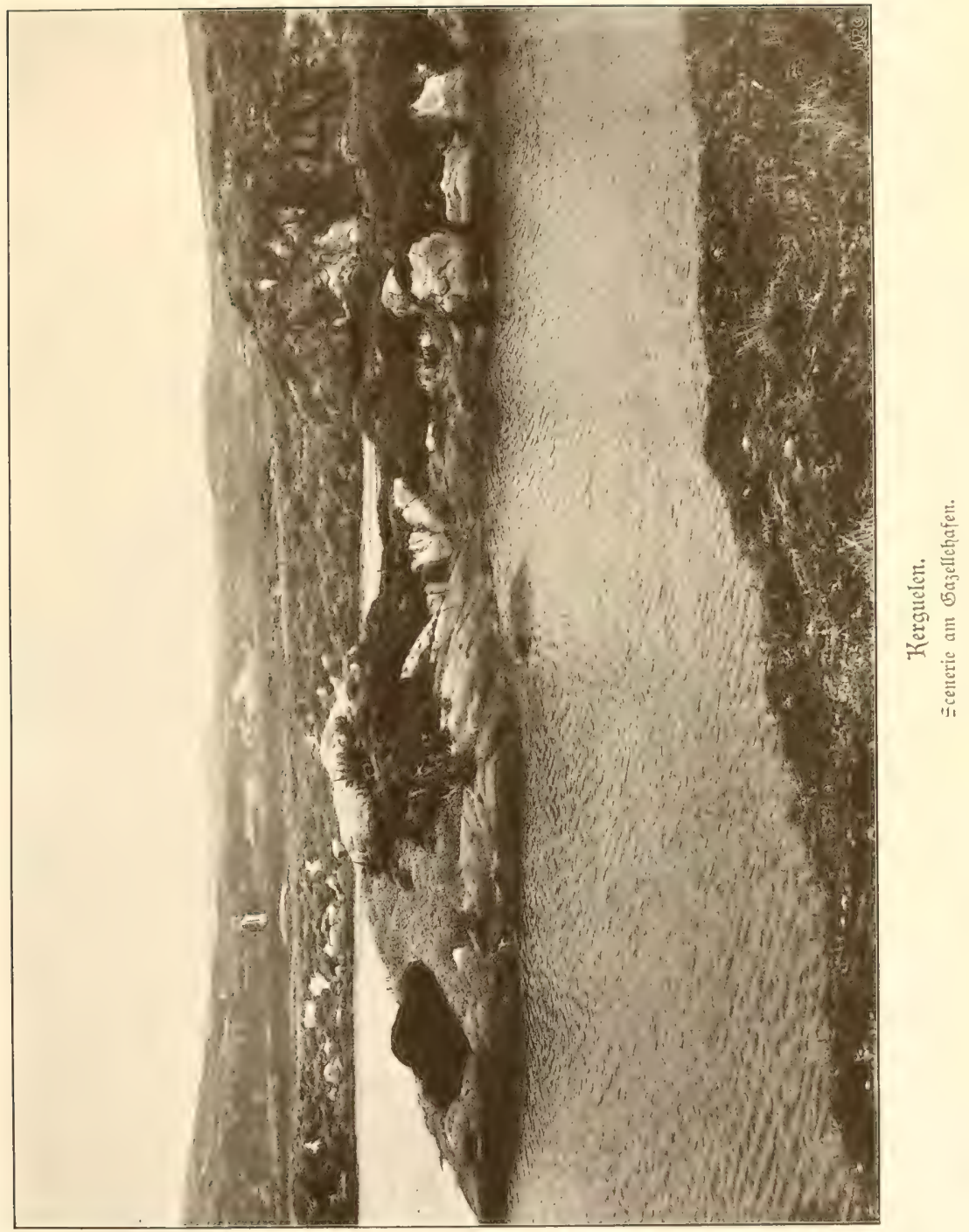





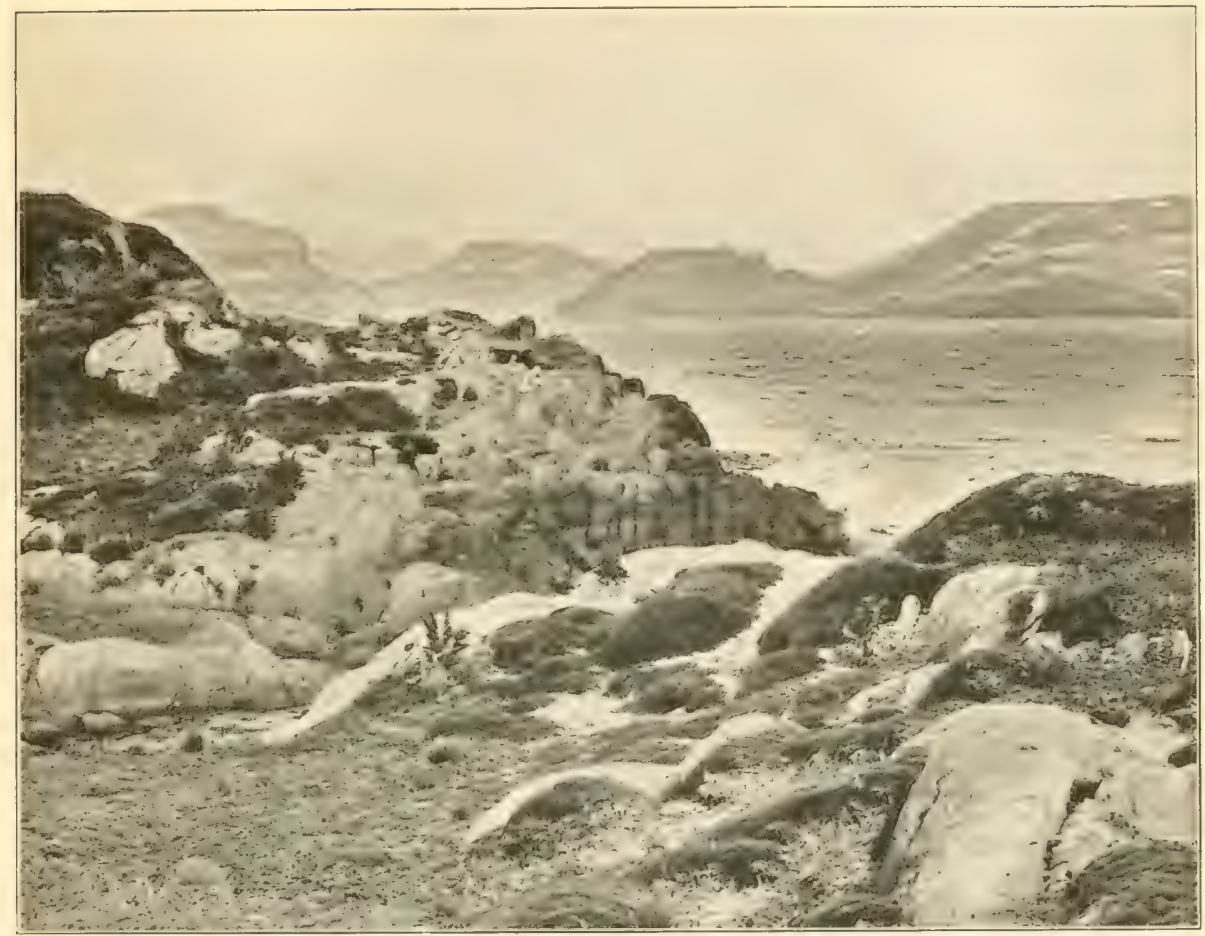

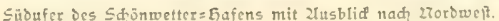

Tijd)en verfhwanden und Inftumente nebft Reagentien auf den 2lubeitspläţen olne fidhertbe Dorfehrungen umheritanden. Dagegen jheint der Sdönwetter=Eqafen jeinen 2iamen wentiger ju verdienten, weil in ihn, wie wir aud jelbit es crfubren, der Wind gelegentlid fräftig ftöft.

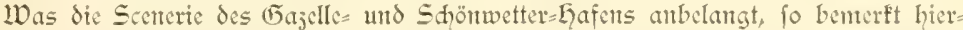
über der (Tajelle=Beridt folgendes: „Diefe beiden Beten fint von einer unumterbrodnenen

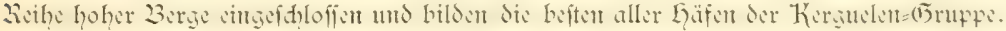

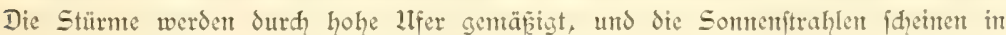
diefem Keffel gröfere Wirfung ausjuüben, als auf anderen Teilen der Infelı, foweit ntan aus der hier üppigeren Degetation fh̆ließ̧en darf."

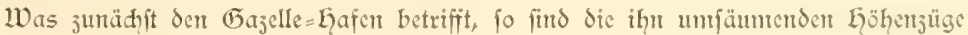


niedriger als it dem Sdiönwetter= Lafen, wo fie an mandien Stellen fteil gegen das 2tfer abfallen. Der letstere madyt wohl cinen romantifderen Eindrut, dafür aber ift

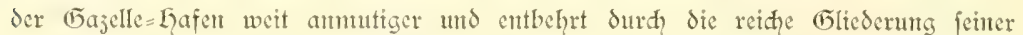

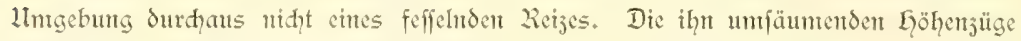
jeigen namentlid, auf ben füblichen llfer jene dharafteriftifhe, horizontale Sagerung der Bafaltdeften, weldie durd? rötliḑe verwitterte Sagen voneinander getrent werdan. 2lan gelangt leiḑt von allen Sciten auf das flahe Plateau, von demt aus fich ein partender

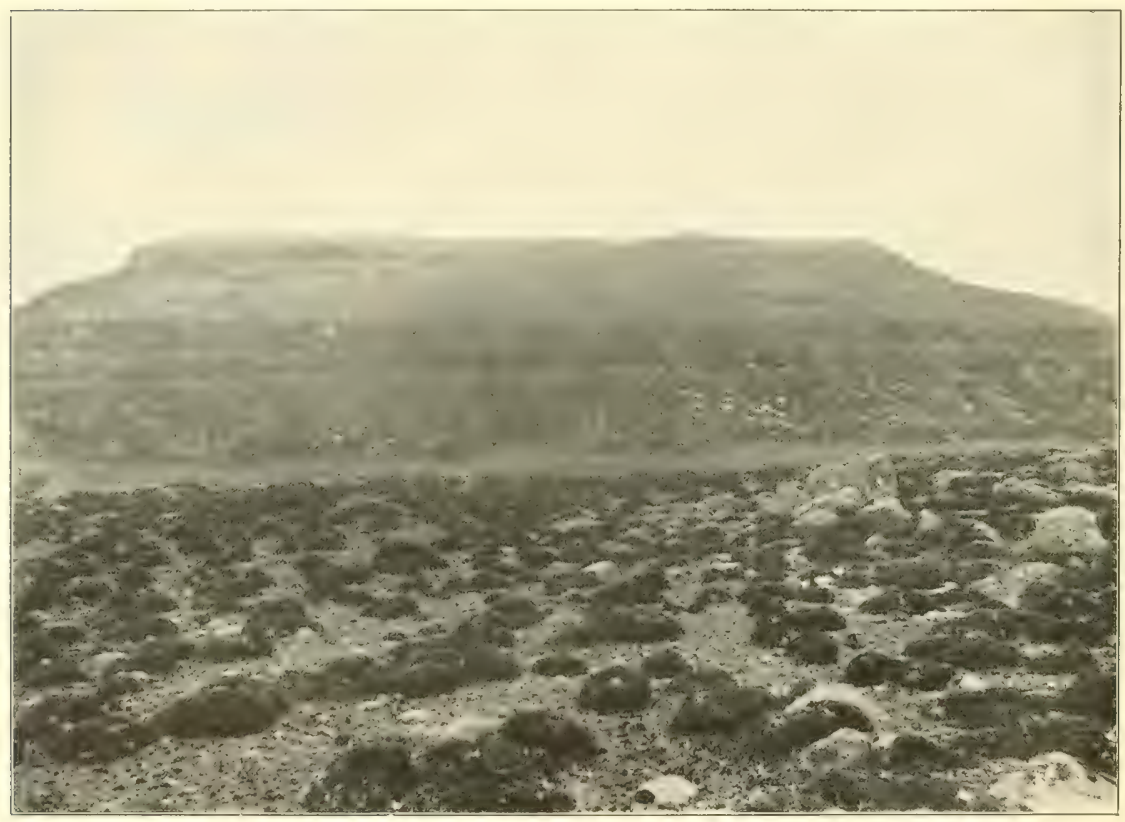

Scenerie auf bent Plateau fablich vont Gazelle $=5$, afen.

Sachse phot.

Int Dordergrand bie polfer von Azorella, im kintergrund tafelformiger 3erg mit horizontaler Sdidtung Der Bafaltbefen.

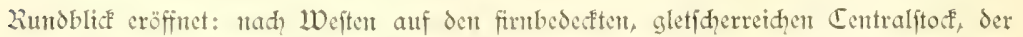
in dem 2liount Sidhards gipfelt, und nad, Dften über das Kap 2lhlefeld uad dem Crojier = (E)birge und den fermen Bipfelut des Chimmey Top, des 2liount Gooker und 2rount spall. 2Tad) Süden gewahnt man jene plateauförntigen Erhebungen, die einen Charafterjug der Kerguelen=Sceneric abgeben; nady 2Torden, von der Jaḑmann= Lalbinfel aus, die den (Bazelle = uns Sḑönwetter=Lafen gegen die Jrifh=2Bay abgrenjt, cröffnet fid der Blid auf das Gewirr von Jufeln und fjorden der Ditfuifte. 


\section{Kerguelen.}

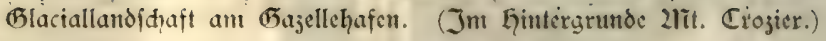




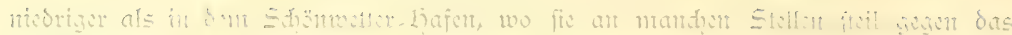

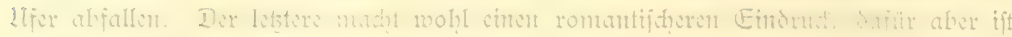

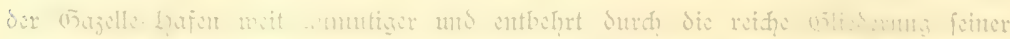

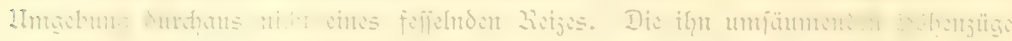

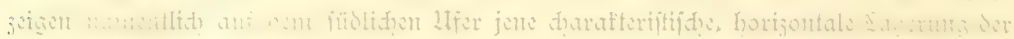

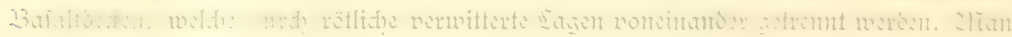

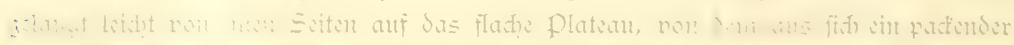

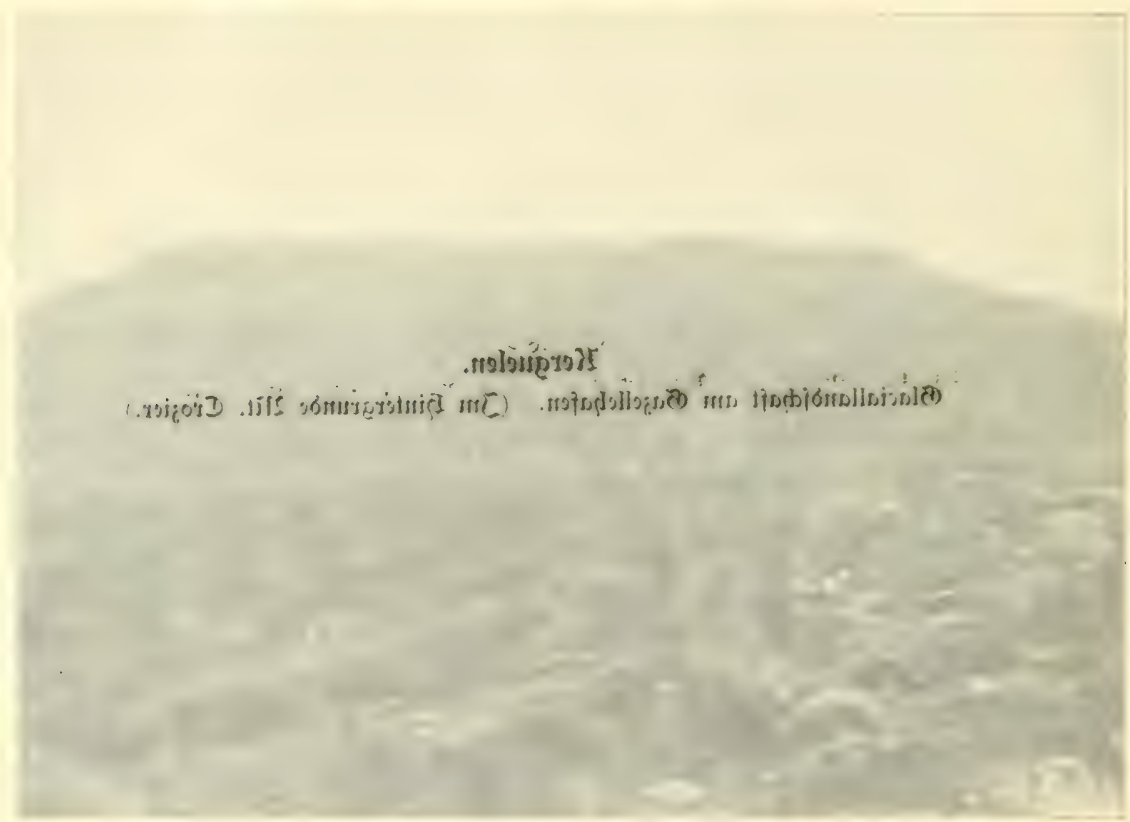

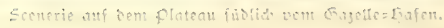

Sixtice plot.

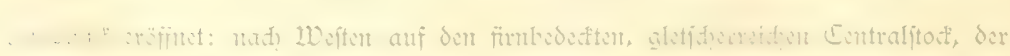

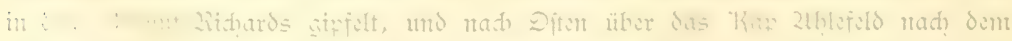

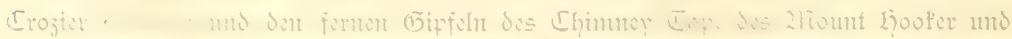

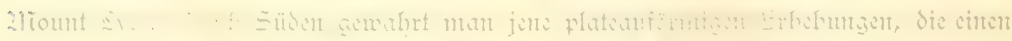

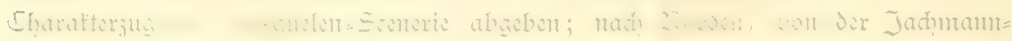

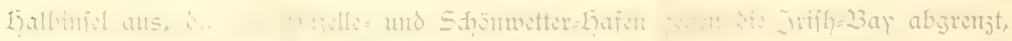

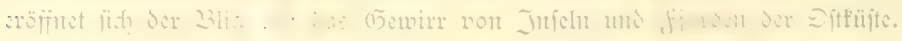




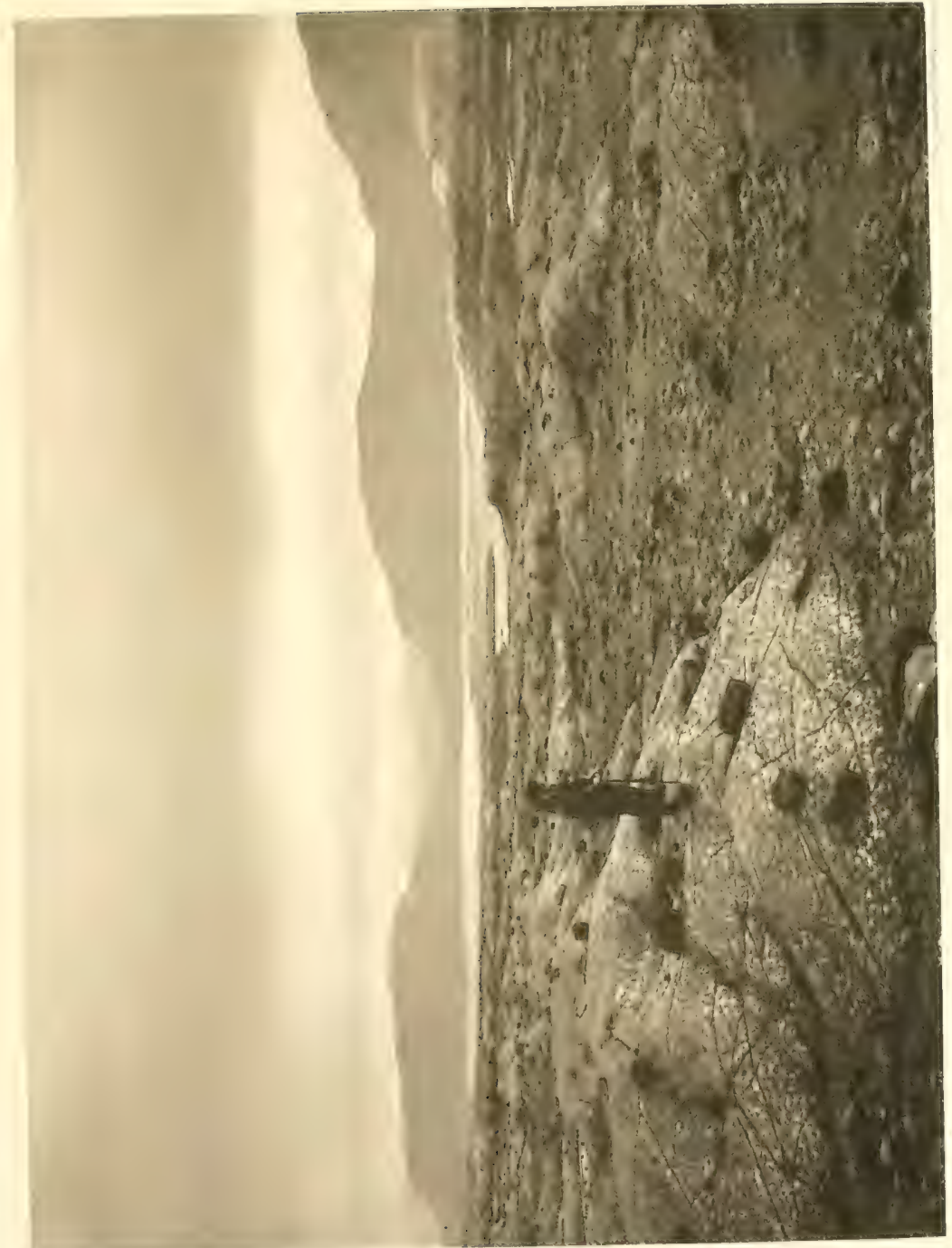



2llle früheren Beobaditer find darauf aufmerfiant geworden, daf dic Ğletfher früher viel weiter gegen die Küfte Gerabragten. Dies Derhalten betont der Thallenger=2Beridt

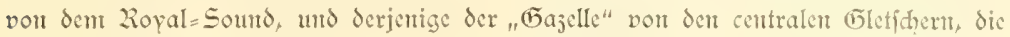
von dem $910 \mathrm{~m}$ hohen 2liount Ridjards ausgehen. Bei dem Bejude des Plateaus der Jahmann= Galbinfel überjeugten wir uns gleidhfalls, daf fie cinft vout einem ge=

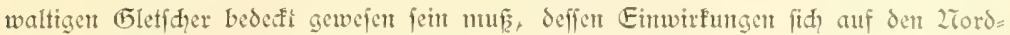
abhängen des Sdionwetter $=$ hafens bis gegen das centrale Gletihergebiet des 21Tount Ridhards verfolgen laffen. Die $3 a=$ faltblöcte, denen er auflag, find runt gefdliffen, fettlidhe Läntge fints $\mathfrak{g e}=$ glättet und mit (5letfderfdyliffer be= dectt, und ïberall liegen jerftreut die transportierten findinge. Dic bei= gegebene Geliogravüre dürfte viel= leid̨̧ beffer, als es $\mathbf{W}$ orte vermögen, Sen eigenartigen, weltverlorenen Ein= Srut verfunliden, den diefe (bla cial=sandidiaft, won 2lienfhenhand unberükrt und vielleidht nod nid)t von mertalichem fufe betreten, anf dent 3cobadyter madyt.

Wo irgento anf den Plateaus fich eine Dertiefung findet, fammeln fid Sie Sdymeljwäfer an, unt $\mathfrak{S} a=$ hent und Tümpel, oder fleinere uno gröpere Süpwafferfeen ju bilden. Der gröfte Süfwafferice der Ker= guelen liegt hinter dem Shönwetter= Lqafer und überbictet den leţteren fait nod an 2lusdehrumg. 2lut fliefendem Waffer fehit es demt

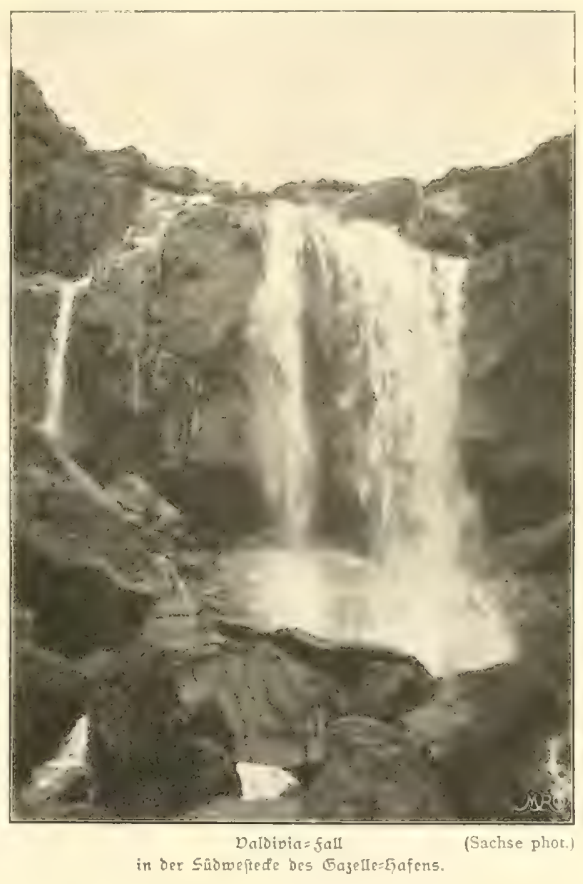
and niḑt; fleine Gebirgsbäḑe ftrömen den fjorden ju, häufig in Kasfaden gegen diefelben abfallend. Einen hübjhen, flemen Wafferfall triftt man an der Wefteffe des Gajelle=hafens an, wo jugleid auf flahem Dorlande Ser flaggftod mit der auf cin 2lietallihild gemalten Trifolore fteht. Jhmt gegenüber, auf der Jadmmantm=5)alb=

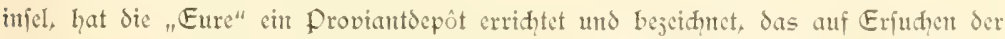
franjëfifhen 2romiralität der Decanograph mit Sen Dffijieren der "Daldivia" revidierte unt volliptändig intaft fand. 
2lus defent Ltmftande darf wohl gefdilofien werden, daf die Kerguelen int lesten

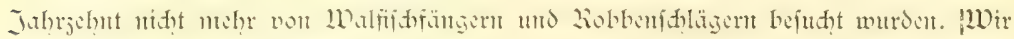
haben nirgends cinen Shoner $3_{\text {th }}$ (5) fitht befommen und benterfen feine verlafiene Eagerftätte, dic auf cinen in den leţten Jahren erfolgten Befuh hingedeutet hätte.

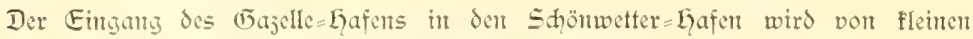
Infeln verengt, die mir in befonders angenchurer Erinnerung ftchen.

Zlls id ibnen gleid nad unferer 2lnfunft in Beglettung des erften 2liajhiniften cinen Befud? abftattete, hatten wir reidhlid, (5)legenheit, den Jauber würoigen ju

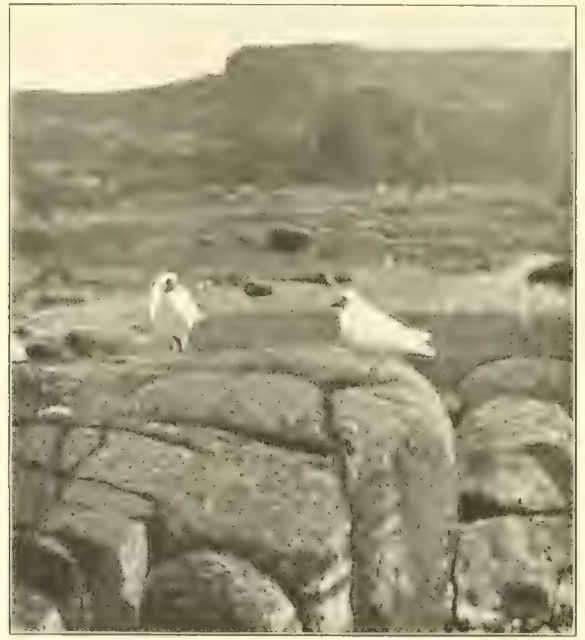

Săeibenjanảbe! (Chionis minor). Iernen, meldhen dic fait paradieftide Garmlofigfeit der Tierwelt der Ker= guclen auf den unbefangenen $3 \mathrm{~B}=$ obaditcr ausübt.

Die grajtöpen Seejdiwalben (Sterna virgata) unflogen uns in Sdwwär= men und licenen fid jutbunlid auf dent Jeltdah der Danipfbarfafie nicder. Zluf den durd die Wogen abgefdilifienen fdywarjen Bajalt= fuppen der Jnjeln trippelten weifa Dögel heran, weldhe flemen Liüh=

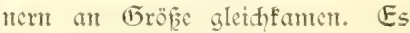
waren dic einjtgen Sandoögel der

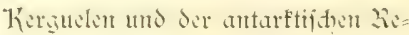
siton ülerbount, nämlid di Etrit. Sertidnäbel (Chionis minor). Jhr (5efieder ift vollitändig fduceweiñ; der fdiwärzliḑe Sduabel ift über

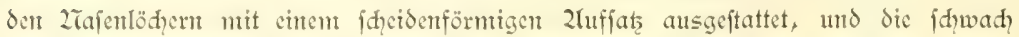

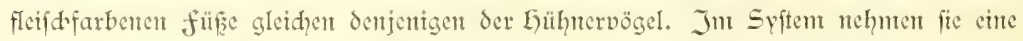
ifolterte Stcllung cin; am cheften dürften fie nod einigen Watögeln angereiht werden.

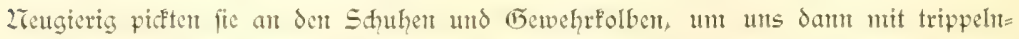
dem (1)ang auf der weiteren WDanderung ju begleiten. Wir hatten mur wenige Shritte gemadit, als wir wie feftgebant ftehen blieben und inftinftio die Gewehre in 2lnjd̨lag bradten. Da lag vor uns ein mädtiges Tier, ein weiblider Sec=Elefant (Macrorhinus leoninus L.) (\$. 268), der mif feinen wumbervoll grofen, faftantenbraunen 2lugen uns anihaute, obne fid ju rüheen. Erit als unfer Dadishund ihn anfläffe, iperrte er 


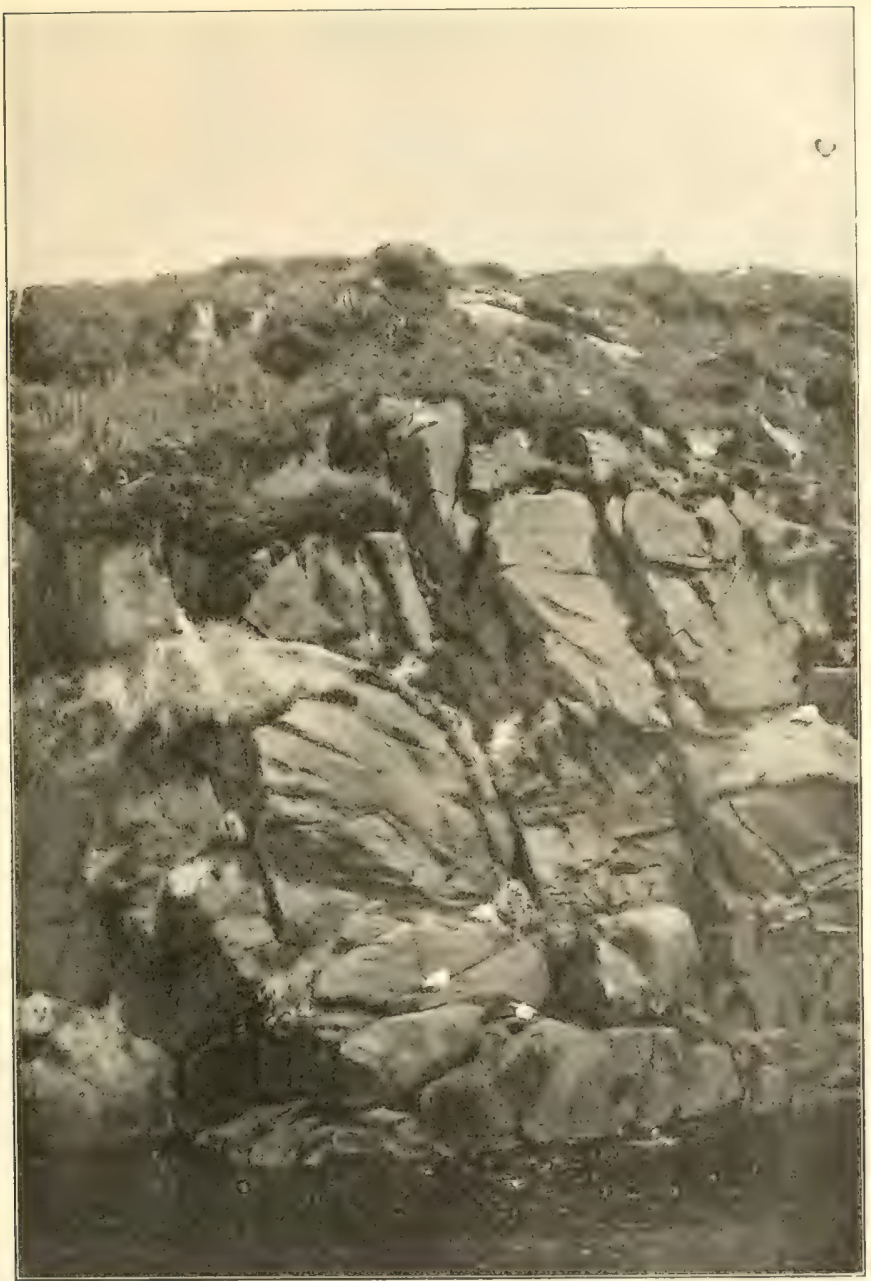

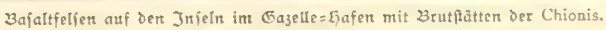
Die Degetation befteht zumeift aus Eräfern (Festuca, Poa).

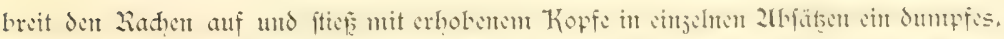

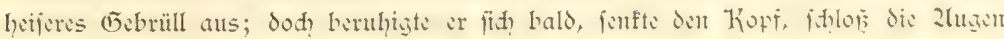




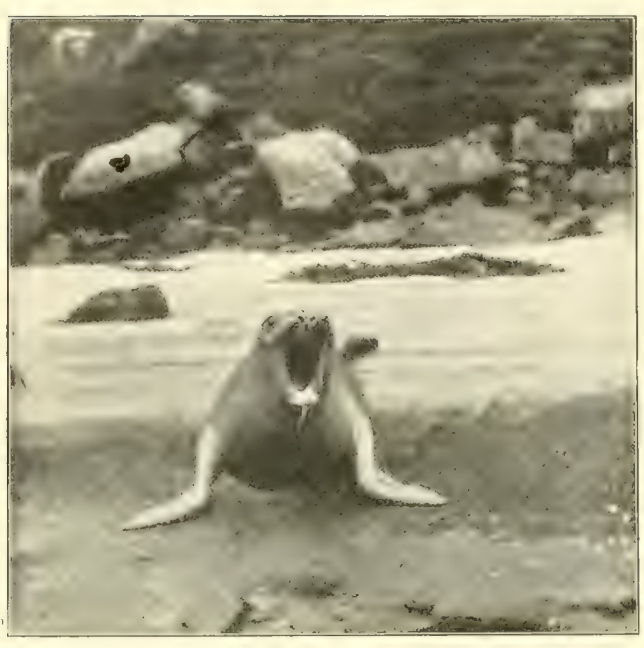

Brüllender Eee= Elefant.

und fhlief weiter. Wer an cine derartige Larmtofigleit ciner feine Derfolger femen= den Tierwelt niḑt gewöhnt ift, nähert ftch nur fhühtern demt $5 \mathrm{~m}$ Iangen Tiere, bis er end. lid, dreifter wird und durd? cinige flatichende Sdläge den brüllenden Elefanten jum $\mathcal{D} e r=$ laffen feines Eagers bemegt. - Ein ganjer Sdqwarm der präd)tig fhwarj und weif ge= jeiffucten und mit jharfer Silhouette von dem Gintme! fid) abhebenden Dominifaner= möven hatte fïđ erhoben und begleitete, diḑt über den Köpfen fliegend, mit dem wie saden Flingenden "hähähä" die Wanderer. Dod, man follte fobald nod niḑt von fentem Erftaunen fid erfolen. 2lis wir uns niederfezten und dem Treiben der Sdeiden= fduäbel, dem wieder jur Ruhe gefommenen Sce=Elefanten und den um uns fid fam = melnden Doututfanemtöven jufhanten, fanden es jwei Kormorane (Phalacrocorax verrucosus) für angezcigt, uns auf demfelben Raferpolfter (Defellfhaft ju lcipten, indem fie faft fdalfhaft den Kopf auf dem Kalfe reckten. Prädhtige Dögel, diefe Kormorane der Kerguelen! Der Band ift fhneeweif gejeidnet, der Rücfen ftahlfarben und der Sthrabel at feincr 2 afis durd cinen rot= aclben, bis zum 2luge fid, erftredenden, warjigen Wulit ausgejeidnet. Bald ge= fellten fid nod jüngere Jubividuen binţ̄u, die cin cinförmig brautes Jugendgefteder aufwicjert. Die ganje Injel war bedect mit Shalen non 2litesmufdyeln (Mytilus) und 2Tapf= idinedien (Patella), fo da man mand?= mal hätte glauben ntögen, es handele fith un Kjöffen=2rösdinger, jene prä= hiftoridhen Küd)enabfallhaufen der däni= fden Jufelu; das alles hatten die Dommifaner=

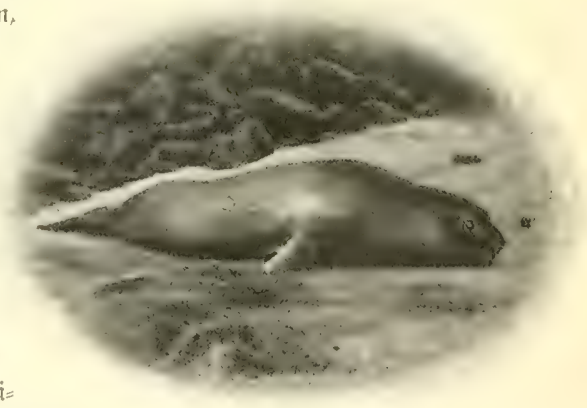
Weiblider $S_{c e}=$ Elefont. 
mövent angeiḑleppt und namentlid? vor den 2Tiftpläten angehäuft. Wir fandent ihre zahlreidgen funftlojen mit Gras gepoliterten 2refter, in denen \$-5 bräun= lid) gefärbte Junge in ifhem ftruppigen braumen Durtenfletde fläglid piepiten. 2lls id in einte fleme Löhlung griff, fulpr cine Ente heraus vou der Gröfe unjerer Kriflente; fie faf brü= tent auf einem weinen Eic und gefellte fich ihren (benoffen bet, deren wir bald eine gröfere อ̄ahl bemerften. Don allen Befudient wurde dieje cinjige Entertart der Kerguelen (Querquedula Eatoni) wegen ifpres wohlidumedenden fletjhes gefhätzt.

2idyt muther wird der Blicf durd die cigentartige Eandfauna niederer Drganismen gefeffelt. Bei dem తึurüefbiegen der Blätter des Kerguelenfohls fallen in den Blattíheiden grofze den Blattläufen gleidiende Jufeften $\int_{1}^{2}$ auf, sie freilith bei genaterem Julfehen als edte fliegen fid cutpuppen. Daf mant fie

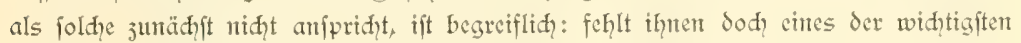
Uttribute der fliegen, nümlid, die flügel. Eine wundervolle 2lmpaffung an das Seben in enter fturmourdbranften Region giebt fid in diefer flügellofigfeit der Calycopteryx Moseleyi fund, dent es liegt auf der $\mathfrak{L} a n \delta$, daf cine nit flügeln und flugverntögen ausgeftattete fliege bald der Dernidhtung antheimfallen würde, wem fie niḑt cinen judem nodh fo gefdüţten 2lufenthalt jwifden den fräftigen Blattjdeiden einer wetter= feften Pflanje wählte. Z̈lbrigens fei erwähnt, dafe die Kerguelen nidłt weniger als fieben fliegenartige Infeftengattungen aufweijen, bon benen die ente, nämlid, Amalopteryx maritima $(\subseteq .2 \bar{\tau} 0)$, eigentümlich ver $=$ fünmerte flügel erfennen läfist. Sic vermag fid biefer fenfenförmig geftalteten Sdywingen dent aud niḑt mehr jut bedienen, ift aber durd die fräftig entwidelten Shenfel der Einterbeine befähigt, durd, weite Sprünge davonjuciler.

Dieje flügellofigfeit ift aud haraf= teriftifh für dic Käfer der Kerguelen,

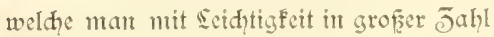

Calycopteryx Moseleyi. Eaton. Dergr. ${ }^{20 \%}$. fligellofe flicae $\delta$. (Enderlein gez.) 
unter Steinen ju fantmeln vermag. Bei ihnen find die weidh häutigen binterent flügel perfümmert, während dic ftarren vor= deren flügeldecten, wie bet fật allen Käfern, als fhüţ̧ende Gü̈llen dem Körper anfliegen. 2herfwüroigerweife handolt es fïd haupt=

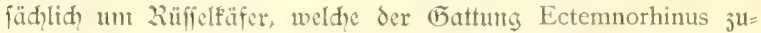

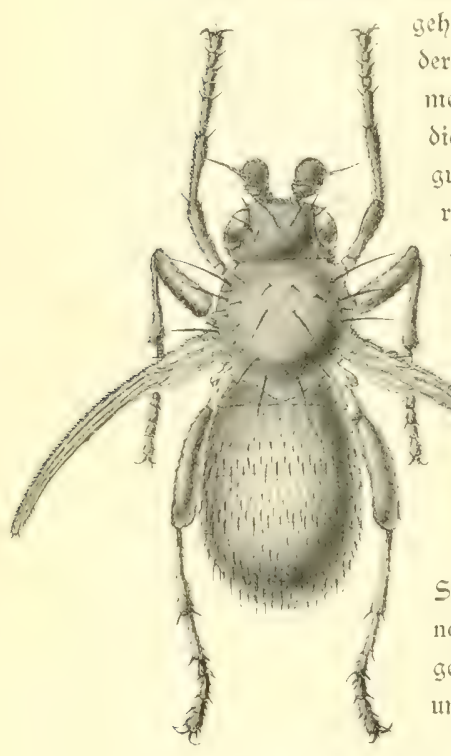

(Enderlein gez A malopteryx maritima. Eaton, 2ergx. $18 / 4$. fliege ntit Derfümmerten flígeIn. Jehören. Wir finden fie in andern Eän= dern metfit unter der kinde von Bäu= ment, und faon biefer limitand legt dic Dermutumg nahe, daf einft die Ker= guelen mit Bauntwuds ausgeftattet wa: ren. Thatf̧äḑlid? hat dentn auth fdon Ro for daraf hingewicjen, daf int Weihnaḑtshafen in gewiffen Sđid)=

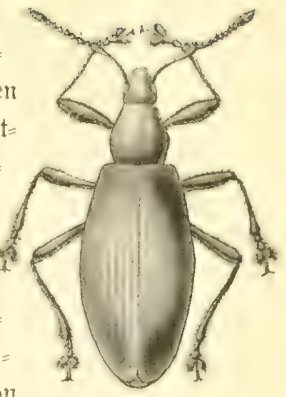

(Enderlein gez.) Ectemnorhinus viridis. Waterhouse. Dergr. $6 / 1$. Ziüficlfäfer. ten verfiefelte 3aumftümute gefunden werden. 2ludy bas

Dorfommen von Kohlenlagen deutet daranf hin, daf urfprünglid dic Kerguelen mit $\mathfrak{W}$ ald bedectit waren. Dir fömten daher Studer nur beiftimmen, wemn er das 2luftreten volt Riulfielfäfern mit einter ehrmali= gen Walsbedefturg in Jufammentiang braḑte.

Zur ein cinziger Shunetterling, cine 2riotte (Embryonopsis), ift den Kerguelen eigen. Es gelang uns, aud von diefert flug= unfähigen falter Eremtplare mit den verfürzłten flügeln, und die int Kerguelenfoht fid auf= haltenden Raupen ju erbeuten.

2 thr nod der übrigen Glieder der Eandfauna ju gedenfen, fo fet erwähnt, da man unter den Steinen Dertreter der niedrigit ftehenden flügellofen Juffeften, nämlid der Collembolen Tulbergia), cint Epime (Myro kerguclensis, che fleme Sungenfdutecle (Helix Hookeri), und endlid, in der Erde

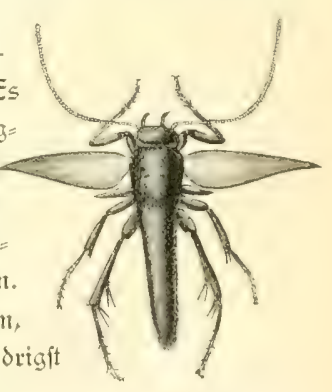

(Enderlein gez.) Limbryonopsis halticella. Euton. Dergr. $6 / 1$. Sḍmetterling mit verfümmerten flutueln.

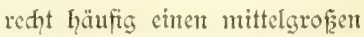

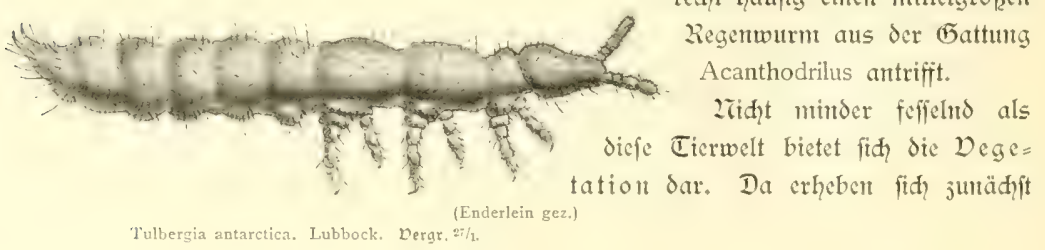


dic Sunfelgrünen Dolfter ciner Charafterpflanze der Kergutlen, nänlid, der Azorella selago. Ste ift überall auf den Infeln jerftent, bildet auf den Plateans halbfingelige Erhebungen, in dic der fur leidht cinfinft, fteight hinauf bis zu $500 \mathrm{~m}$ 5öhe, und an einigen gefdützten Stellen felbit nod barüler hinaus. Soldz riefige polfter, wie fie

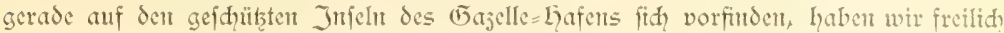
fpäterhin nidht mehre beobaditet. Es handelt fid unt cine freujblütige DFlanje, weldre

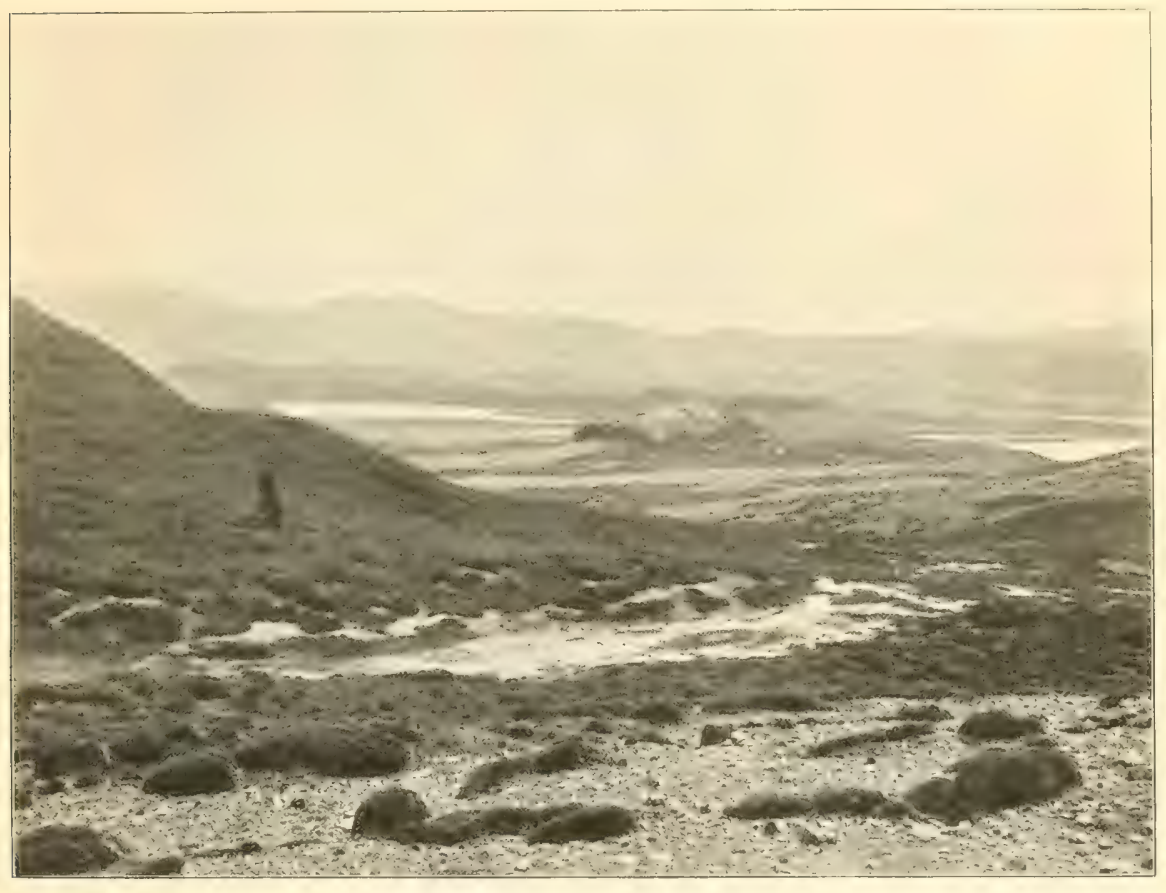

Azorella - polpter auf bent platrau füblich pon Bazelie = 5)afen.

Man bemerft bie beioen 3ajaltpupen, welthe den Eingang zun Eafen verenaen

(Sachse phot.)

über alle antarftijhen Infeln und felbft aud über die Sübipitse von feuerland verbreitet iff. Einen wirfungsvollen Saum un dic polfter bilden dic mit filberglänzendem flaum bedecten Blätter ciner Kontpofite, der Cotula plumosa, welde fonft mur nod, auf den Infeln füblith von Zienfecland vorfommt. Zieben ihx find es dic gramgrünen Blätter einer Rojacee, näntlid der Acaena affinis, weldhe cine Charafterpflanje der unteren อ̄onen abgiebt un $\delta$ oft auf weite fläd)en hin faft allentherridend auftritt. 


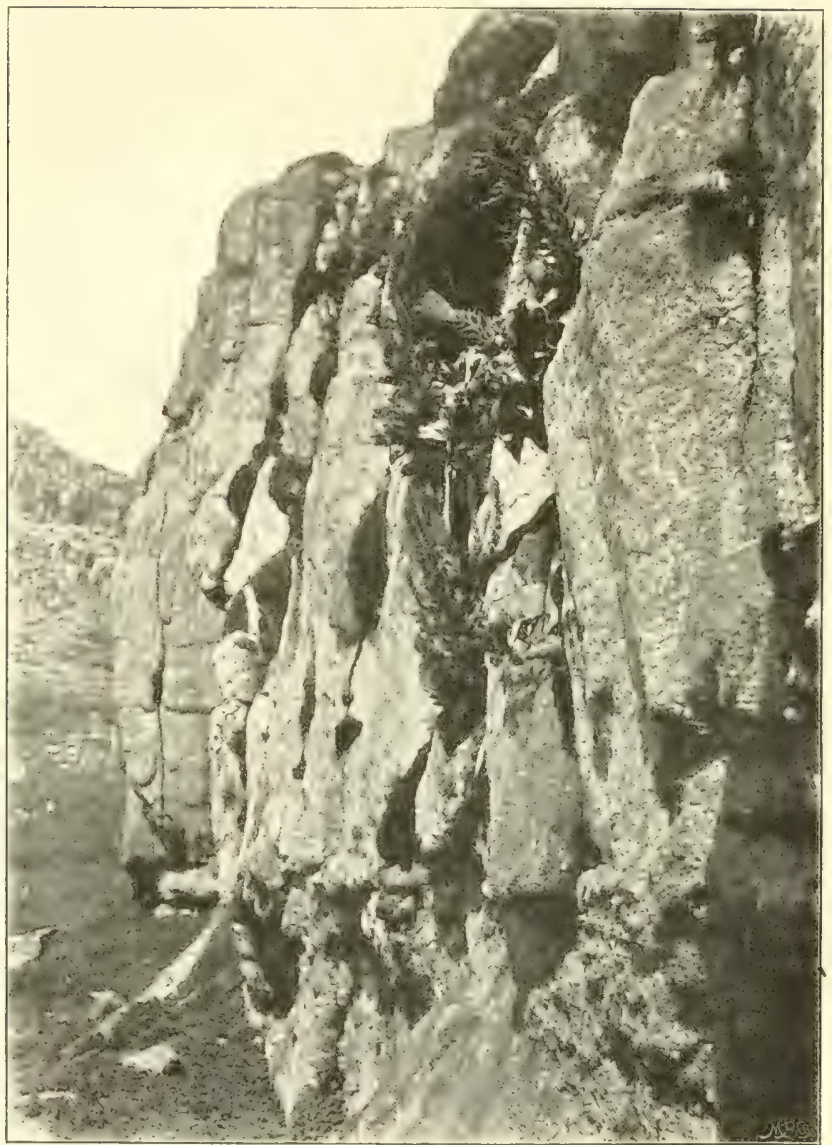

(Sachse phot.)

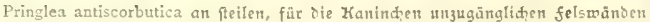

Das gröfte Jntereffe crregt indeffen der feit den Jeiten von Rof berühmt ge= wordene Kerguelenfohl (Pringlea antiscorbutica). Scine eiförmtgen oder Ianjettlidhen, filjigen Blätter umideiden faft $1 \mathrm{~m}$ hod werdende Blütenfiande, die teils abgeftorben anf dent Boden liegen, teils fraftịtrotsent fidh it dic Göhe erheben. Der Kergutelent= fohl ift die einjige endemifate Pflante, welde auf Erdent feine näheren Vermandten 


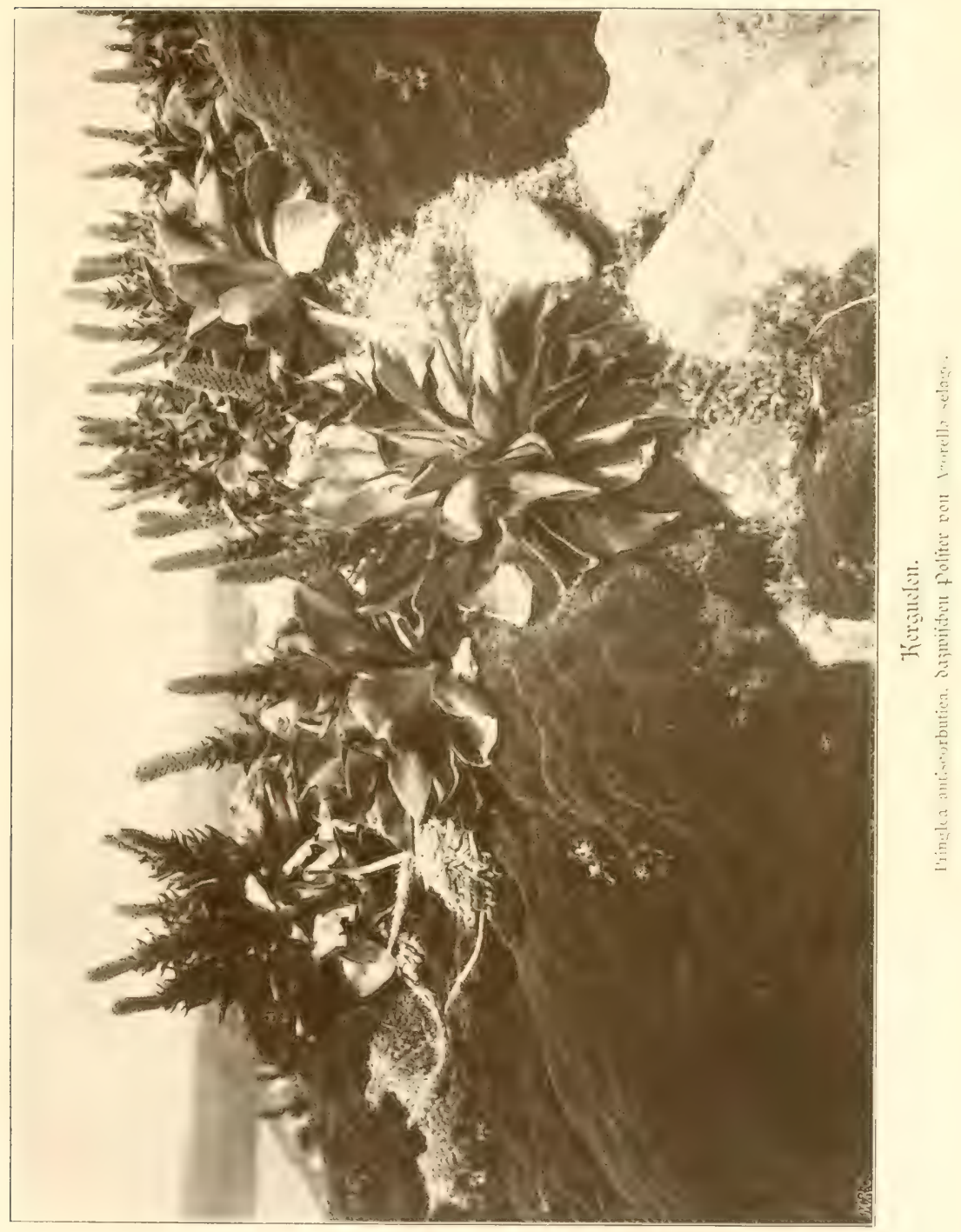



aufweift und aufer auf den Kerguelen nur noh auf dem füblicher gelegenen Eeard= Filand und auf der 2liarion= und Crojet=Gruppe vorfonmt. Die 2liamidhaft vont Rof nährte fich von den Blättern, die als wirffames (Ẽegenmittel gegen Sforbut ge= rühmt werden, und daher aud zur Species=Bezeidhnutg Veranlafjung gaber. Wir habent nidit verfehlt, uns cin (5)müje aus Kerguelenfohl bereiten ju laffent, das that=

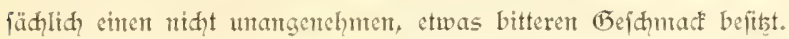

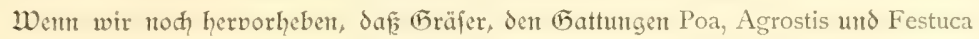
angehörig (unter ihnen die endemijd̨en 2rrten Poa Cookii und Festuca kerguelensis), überall in Büjhen jeritreut aufitreben (f. S. 26र), fo hätten wir der hervorragendften Charafterpflanzen, weldye die Phpfognontie des Sandes beherrihen, Erwähmung ge= than. Sie alle bedingen ienten graugrünen (F̃rundton, welder den 2ratten und Ȩängen der Kerguelen eigen iit.

Daneben ift es mu nod ein Geer von Eryptogamilhen Pflanzen, nanentid von fledyten und 2roofen, die alle felstrümmer übergiehen und oft durd ihre lebhaften, gelben, filbergrauen und fdqwarjen Töne die färbutg der Sandihaft beftimmert. Es ift erftaunlich, in weldier fülle die Kryptogamen, und jwar gerade ihre miederiten Sandoformen, auf den Kerguelen wiederfehren. Den 21 von dort befant gemordenen Blütenpflanjen ftehen niḑt weniger als 160 2lrten von 2liooien, fledpten und Eeber= moofen gegenüber. כ) ihnen gejellen fith nod, vier 2lrten von farnen, unter denen

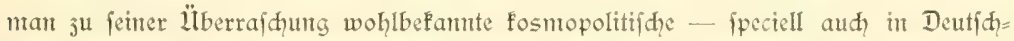
land verbreitete - 2lrten, nämlich das derbe Polypodium vulgare und die jarte Cystopteris fragilis neben den für sie füdiḑen fühleren Regionen typifhen formen (Lomaria alpina, Polypodium australe) antrifft.

Dergleidht man die phanerogamifhen Pflanjen der Kerguelen mit jenen der arf = tifhen Region, fo füllt es auf, daf̧ einerfeits die Jahl der Zlrten cine relatio geringe ijt,

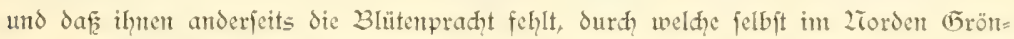
lands und in Spitbergen während der furgen Sommermonate die arftifde flora den Reifenden feffelt. Darwin hat uns zuerft den Blicé dafür geöfnet, dafs duftige und farbenprädtigen Blüten beftimmt find, Injeften anjulocken, weldhe ihren 2reftar fangen und dabet zugleid die Beftäubung übernehmen. Thatfädlid find denn aud die art= tifhen Regionen durh jahlecide fliegende Injeften, felbit nod durd mehrere bunte falter, dqarafteriftert, während in diejer Limfiḑt das antarftifhe Eebiet - und jwar ipeciell die Kerguelen - jurüfitehen. Dfienbar fehlen den Kerguelen Jnfelten, welde die Beftäubung der Blütenpflanjen übernehnten fömten. Wem man aud wohl ge= legentlich vermutct hat, dafs die flügellofen fliegen durd, ihr Imberfriechen auf den

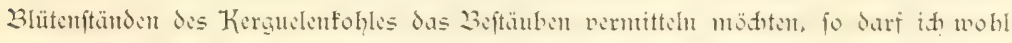
herworheben, dafi idh niemals an den ungewöhnlich fhönen und fomigen Tagen, dic uns befhert waren, die fliegen auf den Blütenftänden bemerfte, fondern fie ftets mur 
dann ju C̄efint befant, went man die Blattfheiden des Kohles jurüfbog. Sdon

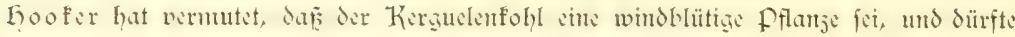

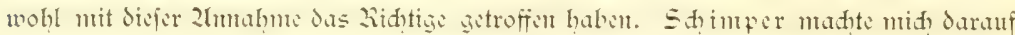

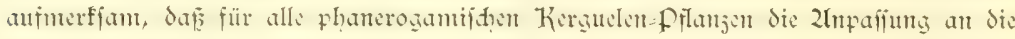
Beftüubung durch dent Wind fimfüllig entgegentritt. Es fehlen die bunten Blumen= blätter, weldhe jum 2lnlocken der Jnfeftent dienen, nid̨t mur der Pringlea, fondent aud den beiden, für die Kerguelen ḑarafterifififin zielfenarten (Lyallia und Colobanthus). Bei den jwet Ramunfelarten (Ranunculus crassipes, R. trullifolius) find die Blumen= blätter ju fdmalen, weišen Streifen rüdgebildet, und der Kompofite Cotula fehlen dic

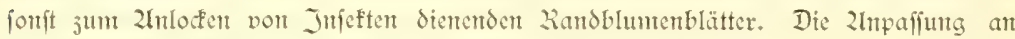
dic Windblütigfeit hat es wohl in criter sinte bedingt, da aud im Sommer der höheren Pflanjenwelt durd den 2hangel des Blütenflores ein gewiffer nelandolifder Julg cigen ift.

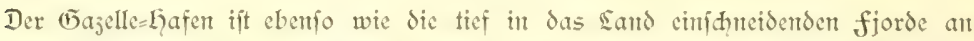
allen jenen Stellen, wo die felswände an das Waffer herantreten, mit cinem Trünuter= feld von Bafaltblöfen bedectt, weldhe mit mannigfad gefärbten fledtenarten über jogen find. Dic Jertrümmerung des Coefteits mur fid in einer Region befonders energil geltent maḑen, wo häufig die Temperatur fidh um den Zrullpunft bewegt, und das zwiidgen dic Spalten fitfertide Waffer bei dem Eefrieren feine Sprengwirfung ausübt. Diçe Trümmerfelder find die tppifden Wohnpläţe für eine Pinguinart, dic niḑt wentig jur Belebung der phyltognomie der Jufeln beiträgt. $E_{S}$ ift der präḑ̧tig

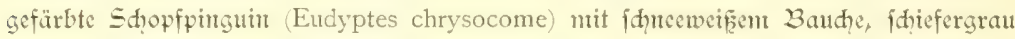
gefärbtem Rüfen und floffen, hodprotem Sdntabel, roten 2 fugen und cintem fofettent Shopf goldglänjender feden jederfetts an Kopfe. Zrähert man fin ihren felfigen

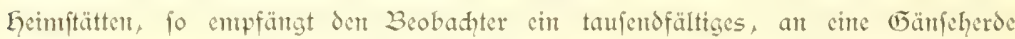
crimerndes (5efdrei. Ewiger Janf unt Streit herridgt unter diefen Dögeln, die ihre

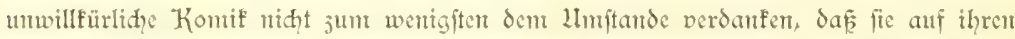
weit nadh hinten gerïften füfen wie fleine (Fronten anfredt ftehen und in abjonder= lidzer Hubehilflidffeit mit ihren zu floffer umgebildeten flügeln herumwirfidafter. Ü̈berall ftehen auf den Kuppen der felsblöte die 2rämnden in Gruppen jufantmen,

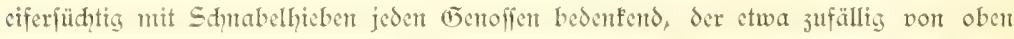
herabrutfifte und unter fie gertet. Ziiḑt anders geht es dem frembling, der neu= gierig unt gefeffelt von dent eigenartigen Shaupiel jum erften 2lä cine Pinguin= folonie befudt. Das Klettern auf den Blöfen ift fhont an und für fith mübyelig und wird dadurd nidgt ntod angentehmer geftaltet, daf überall fḑlüpfriger und ïbelrieḑender Hnrat cinen feften Falt verwehrt. Kommt man dam cinem Trupp näher, fo crhebt fid allgenteines (bejeter; den Kopf dem Beobadter jugewendet fuḍt die Gefillihaft 


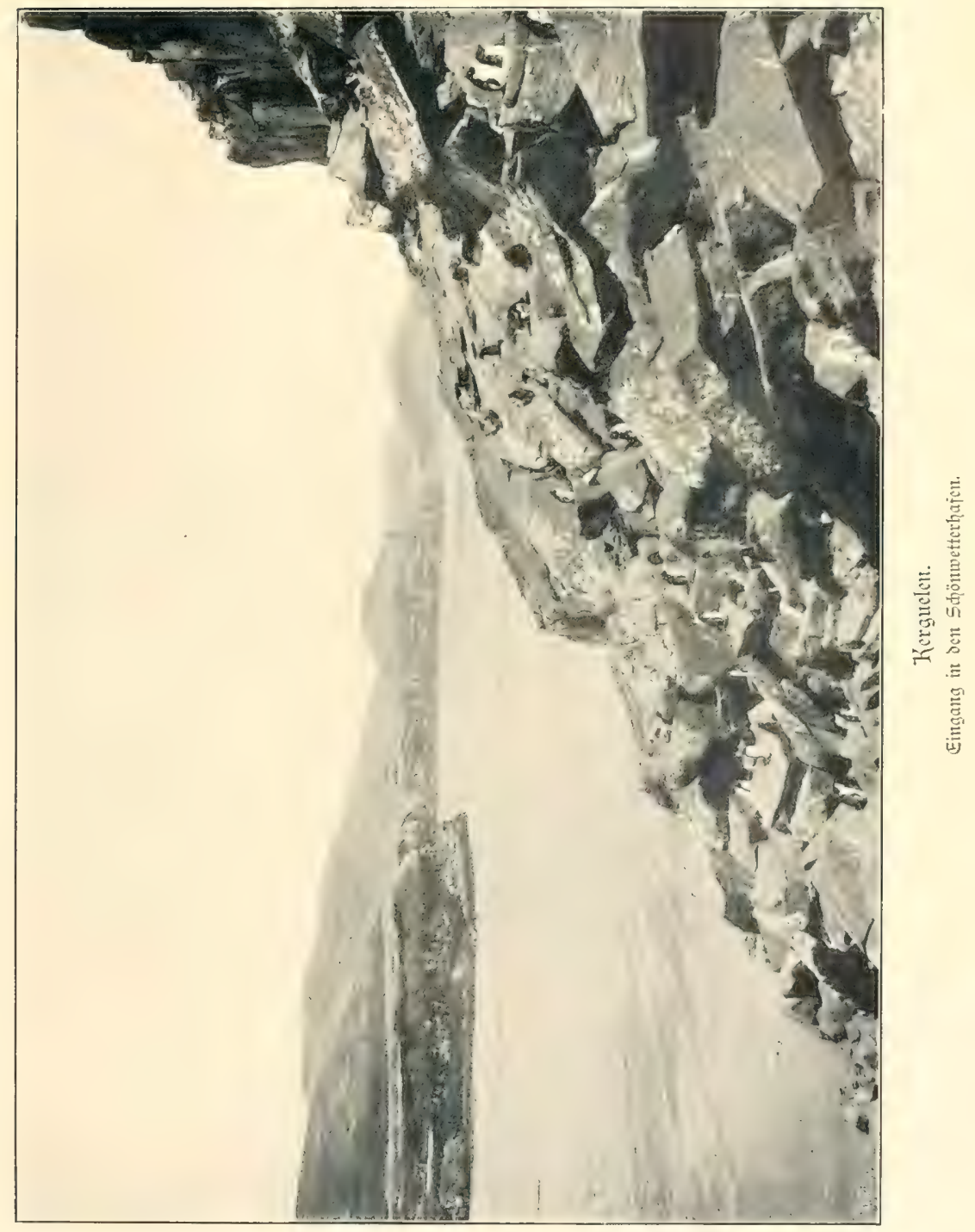





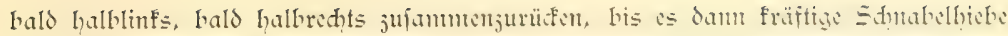
und Sdläge mit den floffen abfetst. 2Tidht mur auf den Blöder, fondern aud unter denfelben giebt fidh unwilliges (Fefhret fund. Da fitzen in den geidüthten Göhlen die Weibothen auf ifrem funftlojen 2repte, falls man überhaupt dic meift mit Dung bedectent flachen Gruben fo rennen will, und brüten auf ifhen cinjigen weisen, gewöhnlich ftarE mit Sđmuts bedeften $E_{i}$. Sie lafien es fid, von cinigen Shnabelhieben $a b=$

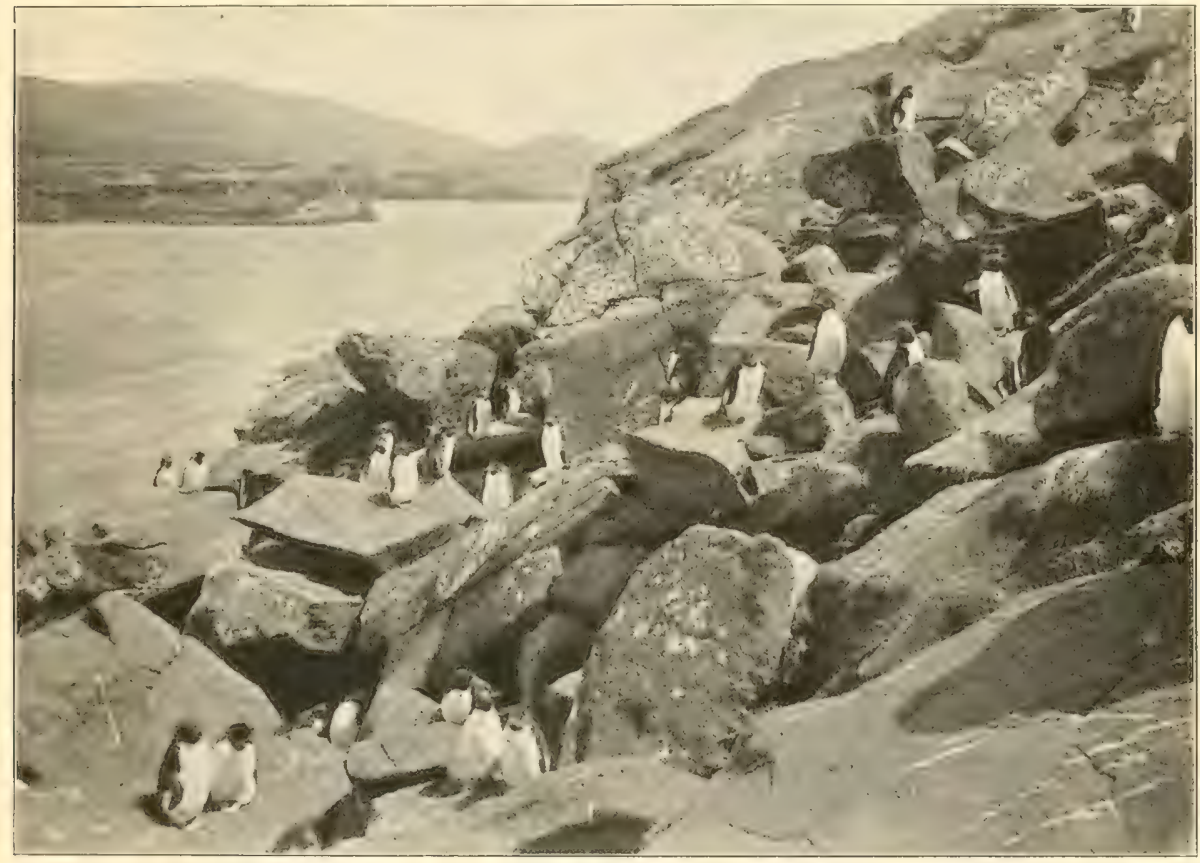

PinguinPolonic (Eudyptes chrysocome) an Eingang 3 u bent Sdünwettcr=Ljafen.

gefehen, meift mhig gefallen, daf man ihnen diefelben wegnimmt. Da wir viele Fier fammelten, fo ergab es fith bald, daf fie fait durdweg Embryonen enthiclten, weldye dem 2lusfhlüpfen nahe waren; nirgends fanden wir in einem 2iefte bercits ansgefdlüpfte Junge. Der von Sent Eihüllen befreite junge Pinguin jeigt gantj dic

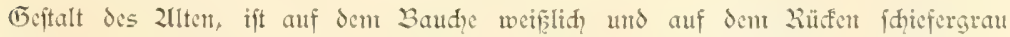
gefärbt, entbehrt aber nod der beiden federidöpfe an Kopfe. Ein ftarfer Lorn= wulft auf dent Shnabelrïfen bildet den fogenannten Eijahn, vermittelft deffer dic 


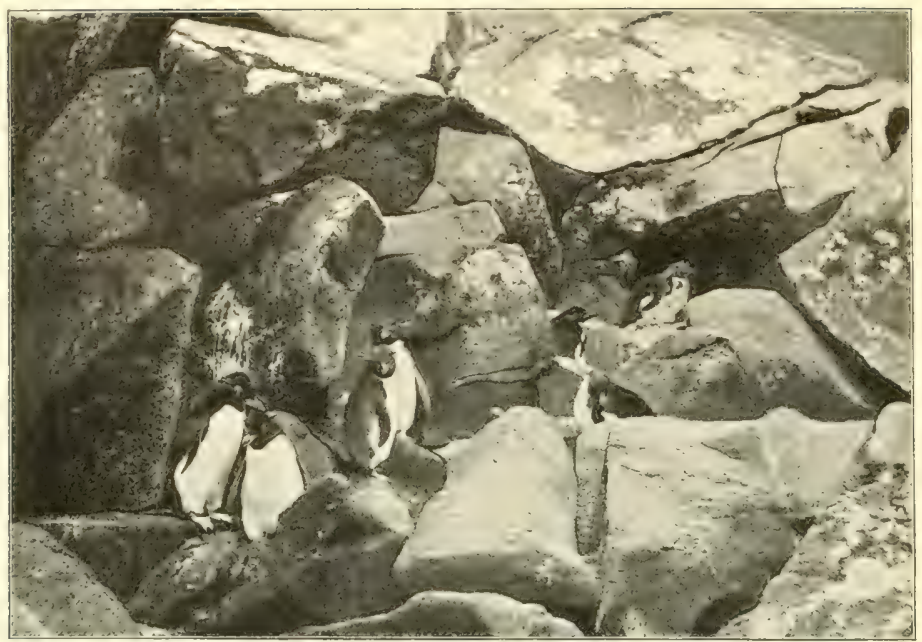

Eudyptes chiysocome

(Schmidt phot.)

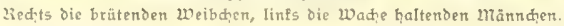

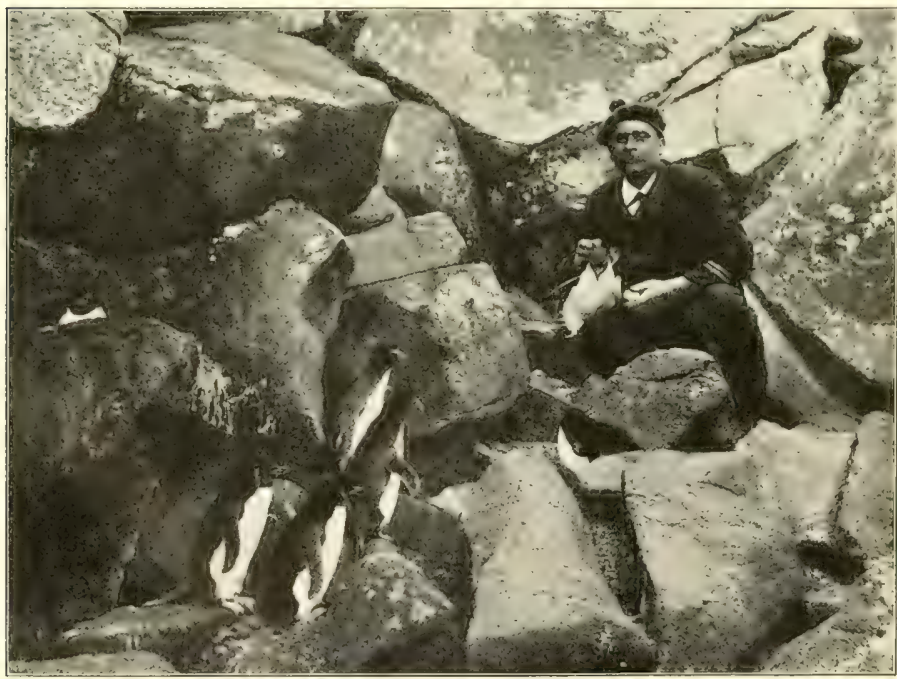

Die exflaunten pinguine. 


\section{Kerguelen.}

Koloni: von finguintu (Fudyptes chrysocome) ant (5ajollehafen.

IIquarell wou $f$. Winter. 


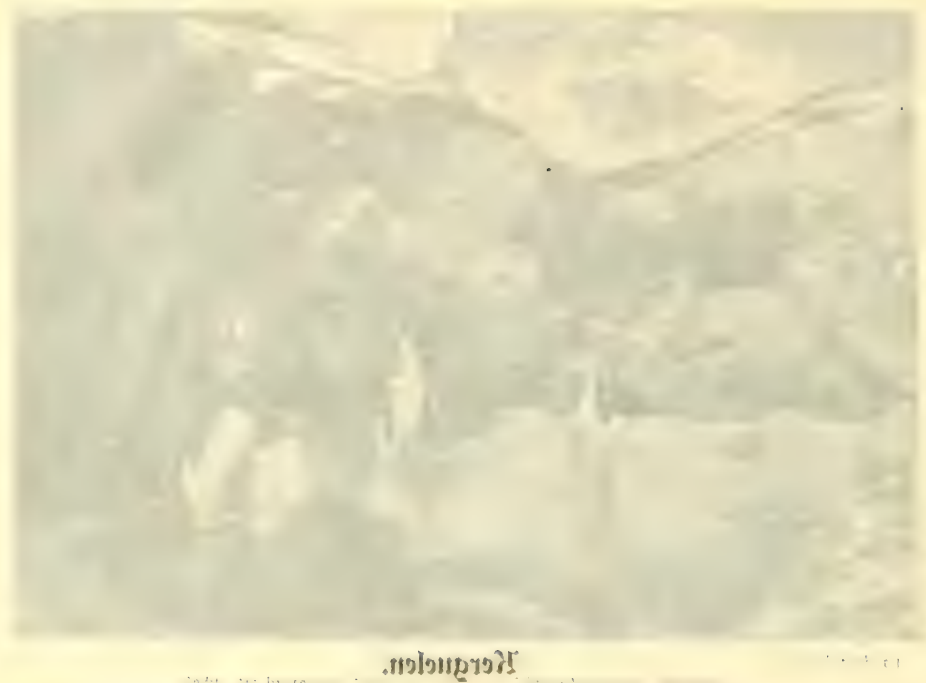

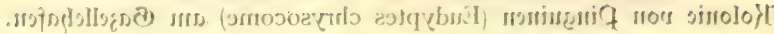

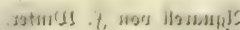




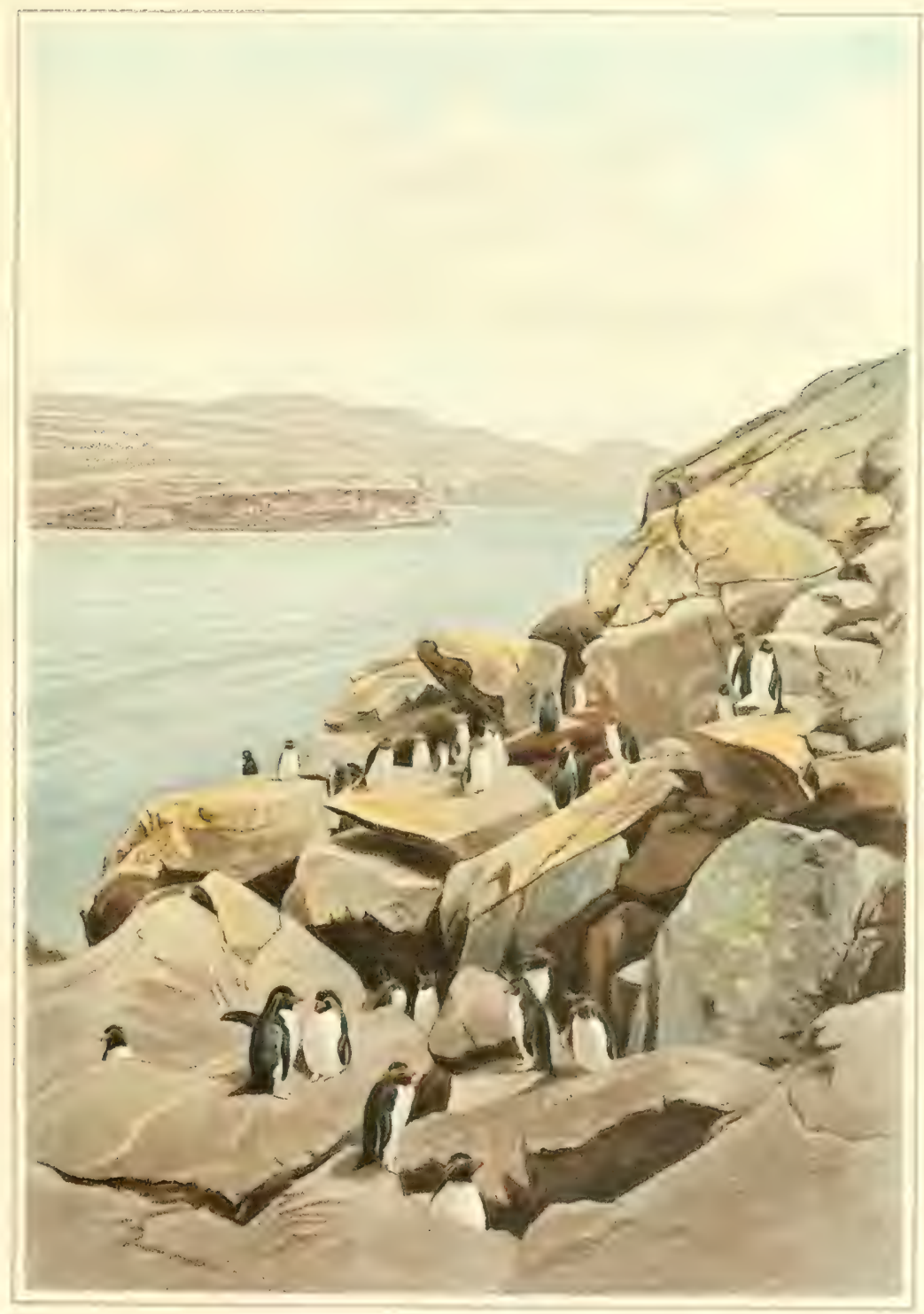





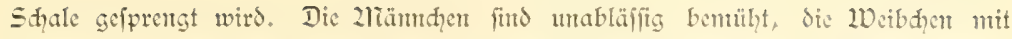
2rahrung ju verjorgen, indem fie mit beiden Beinen gleidheitig dic felfer hinab= hüpfent und mit ibrent vorgeftredten Kopfe, gefrümmten 2raden und fąräg gehaltenen floffen an den Pater filucius crimern, wie ihn Bufd jeidntet. Sind fie dam ant Waffer angelangt, fo geht es mit eitem Kopfiprung in dasjelbe, und mu jeigt fid erjt der Pinguin in feinem wahren Elemente. Die floffen dienen als Riuder, und mit irfaunlider (5ejdqwindigfett fdowimmt und taudit er oder fpringt er wie cin Delphin über die Dberflähe. Stutden fant man in emer Pingutnfolonic virbringen, ohne des originellen Treiberts mübe ju werden. Da ftehen fie um uns herum, puten und ordnen das Befieder, mit dem Kopf und den goldigen federidöpfen ftändig in Bewegung,

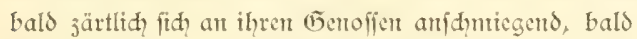
jornig Sdinabel= und floffenhicbe austeilend. Id ver= itehe jwar niht die Sprache der Pinguine, durfte aber wohl annebmen, daf das, was fie mit funfelndent roten 2lugen und hämifक jur Seite gebogenent Kopfe dem Eindringling ju vernebmen gaben, fehr beleidigender 2rt gewejen fein muह.

Stets fieht man aud jwifhen den felien verteilt sine 2 njahl von Sdeidenvögeln (Chionis), deren Trei= ben und 2lbjhten freilid durdyaus feine harmlofen find. Fat ein Dinguinweibdyen cimmal das 2iejt ver= laffen, fo find fie gleid, bei der Gand, um mit einem frätigen Sdinabelhieb das $\mathbb{E}_{i}$ ju jertrümmern und gierig den Jnhalt ju geniefen. Wie Studer, der Joologe der (5)ajelle = Expedition, bemerft, fo dienen die faneidenförmigen Zuffäte auf dem Sdnabel (\$. 295 wefentlich daju, das Derfleben der Zrajenlödher mit dem Einhalt ju verhütert.

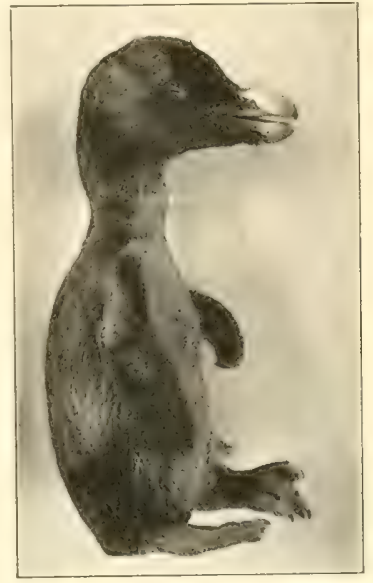

Embryo pon Eudyptes vor Dem Zusfhlüffen. 2Rat. Br.

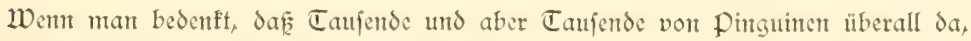
wo felfentrümmer am Kande der 3 uḑten fị aufhäufen, ihre Wohnftätten aufge=

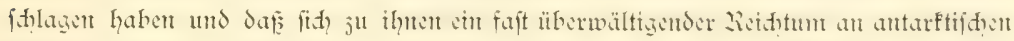

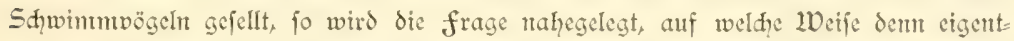
lid diefe Dogelwelt ihr 2rahrungsbedurfnis befriedigt. Sehrten es nidit fihon dic

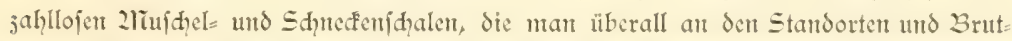

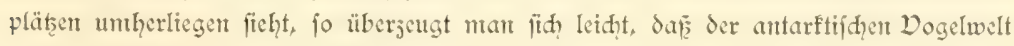
in dem 2lieere ftändig der Tif gedecft ift. Erjtaunlid reth ift dic marnte Strando fauna der Kerguelen entwifelt. Lebt man einen Stein auf, fo fam nan fidher fein, 


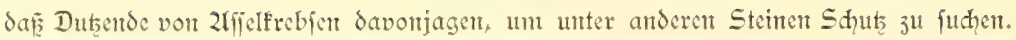
2liande derfelben, fo 3. 3. Sie Serolis latifrons, erimnem auffällig an die foffiten Trilobiten. Zeben ihuen fonmten Borftenwürmer und cin Leer ntederer Drgantsmten

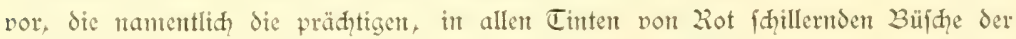
floriben und 2llgen bewohnen, an denen der felfige Strand fo reih ift. WWir femen

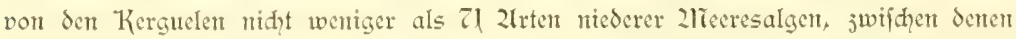
fid rötlid gefürbte Seefterte, Sđllangenfteme, Krabben (Halicarcinus) unthertreiben, oder auf denen fid Secfderden (IIscidien), 2lioostierden (Bry̧ojoen), Zlftinten und Eypdroidpolppen angefiedelt haben. Wo dic Büfhe der fleinen, Guntgefürbten flori= deen fehlen, trifft man in der Strandjone auf die grofé, tangartig geftaltete Durvillea mit thren grotesFen, gelappten Blättem. Ziehen ihr beherriḑt der Riefentang (Macrocystis pyrifera) die Secterti. Er wurzelt etwas tiefer als dic Durvillea auf felsblöfen,

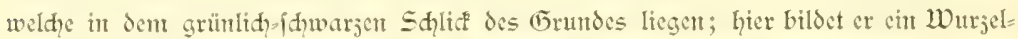
werf, das wie ein ZTeft miteinander verwadfiener Korallenjwetge fid ausnimmt. Don ihmm gehen enorm lange Stiele aus, welḑe lanjettlidge Blätter mit flajhenförntigen Suftbehältent tragen. 2lĩm hat z̈lite genteffen, die cine Eänge von nidyt wentger als $500 \mathrm{~m}$ anfweifer. Da der Tantg auf den felsblöffen bis ju $20 \mathrm{~m}$ Titcfe fith anjiedelt

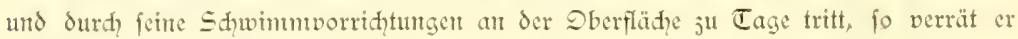
mit Sidperheit dem Secfahrer alle Stellen, die bei der Einfahth in die Gyäfer jul ver=

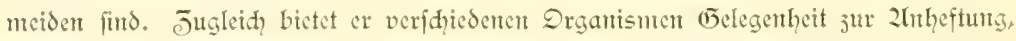
weldhe mit Vorliebe von den Dögelft genoffen werden. Vor allen Dingen find es die Zapfiduneffen (Patella), die mit ihrer wie cin Saugnapf geftalteten fubidneibe feften Galt an den glatten Blättern gewimnen. Z̈lltere Blätter fint oft gantz tiberzogen von

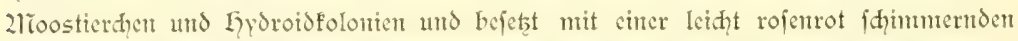
Seewalje (Pentactella laevigata), die ifhe feinverjweigten jehn Kiemenbuifd clel ansftrectt.

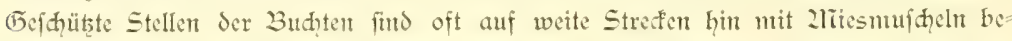

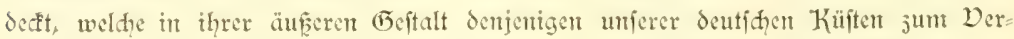

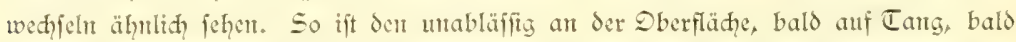

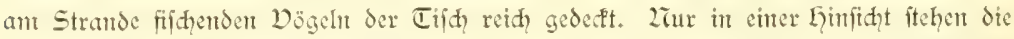
Kerguelen jurü, infofern ihe fifdfauna relatio ärmlid entroiffelt ijt. Sie bejdränft

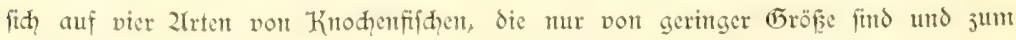
Teil der für die antarftijhe Region harafteriftifden (5attung Notothenia angehören. Zlud die teferen Regionen der Budoten unterhalb $20 \mathrm{~m}$ weifen eine fülle eigenartiget (Brundbewolyner auf, denen fith allntählid wetter auserhalb, auf dent die Kerguelen mit Geard= Jslanto verbindenden Plateau, Typen jugejellen, weldhe den L̈lbergang ju der Tieffecfauna vermitteln.

Wir haben von unferer Dampfbarfaffe aus jwei Tage lang im Gajelle und

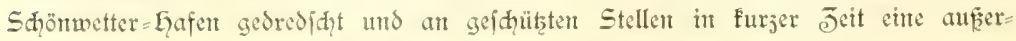


ordentlich reide $\mathfrak{Z}_{11 s b e u t e}$ gewonnen. 2lus den Beriḑten früherer Erpeditionen geht hervor, daf die einjelnen Budten oft cigentümliche formen Echerbergen, welde an anderen Stellen felten find oder fehlen. Da die marine fauna des Gajelle= Bafmus und Sdïnmetter=Lafens unbefannt war, fo mag es diejent Lntftende mit ju verdanfen fein, ১af wir cine beträdtlide כahl für die Kerguelen neuer Küftenformen erbenteten. So jei nur darauf hingewiefen, dafi wir im Shönwetter=Lifen den Blätten des Blajentangs aufiffende, cigentünlide zledujen auffanden, die ihre fduwinmtento Sebensweife aufgegeben haben und mit ihren verzweigten Tentafeln friedien. In unferen nordifhen zliecren find fie durd die (5attung Eleutheria vertreten, weldie aht diḑotom gegabelte 2lrme befitzt. Die neue Kerguelenform weift cinten ganjen Wald

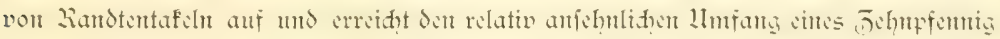

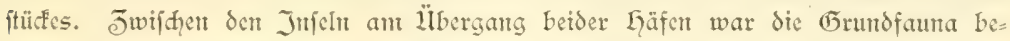
fonders üppig entwiffelt, und hier gelang es uns aud, cinen grofien, aḑtarmigen, rotbraunen Tintenfiid ju erbeuten, deffen Eriftent auf den Kerguelen nod nidit mit Sidqerheit nadigewiefen war.

Den früheren Beobaditern ift es bereits aufgefallen, daf faft alle dic hier genamten marinen Drganismen Brutpflege ausüben. Sie befiţen feine frei fdwämtenden Sarven, fondern bergen thre ziahfommenfigaft fo lange in gefhütsten Tajden, bis diefelbe, dent 2lĩuttertier vollftändig gleidjend, felbfändig ihrent Zahrungserwerb nahgehen fann. In dem Challenger= Beriḑt finden fid anjichende Beipicle diefer Brutpflege von Seeigeln (Hemiaster), Seefternen unt Seewaljent abgebildet. Zllle diefe von den Kerguelen be= fant geworde= nen 2raten haben wir wiedergefurt= Sert, und fo mag jul Jlluitration diefes Derhaltens auf die beiftehende abbiloung von Shlangenfternen hirigewiefen wer= den, weldhe die ju= gendlidhen Erent= plare in den er= öfiteten Brutta= forin anjọaulit? vorführen. Selbit

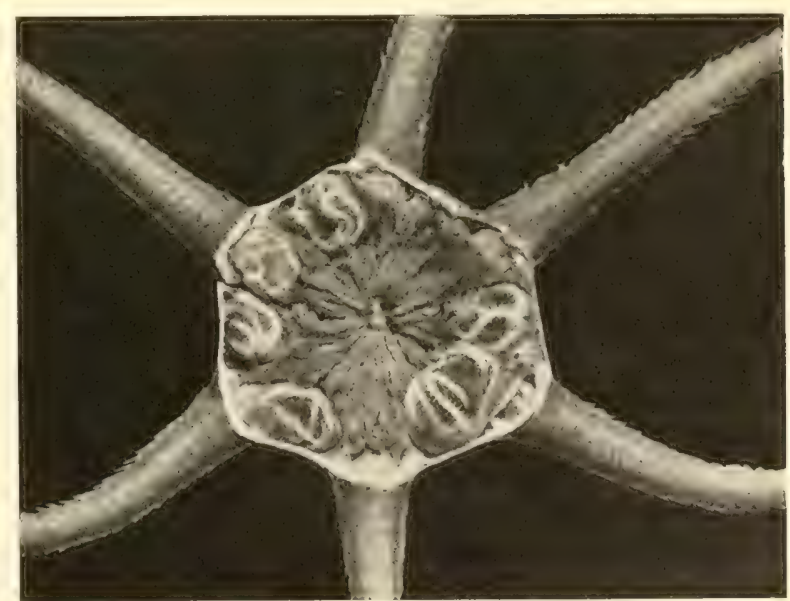

Ophioglypha hexactis mit Embryoner in Den Brutfäen. ratũrlią̧e Erófęe. 


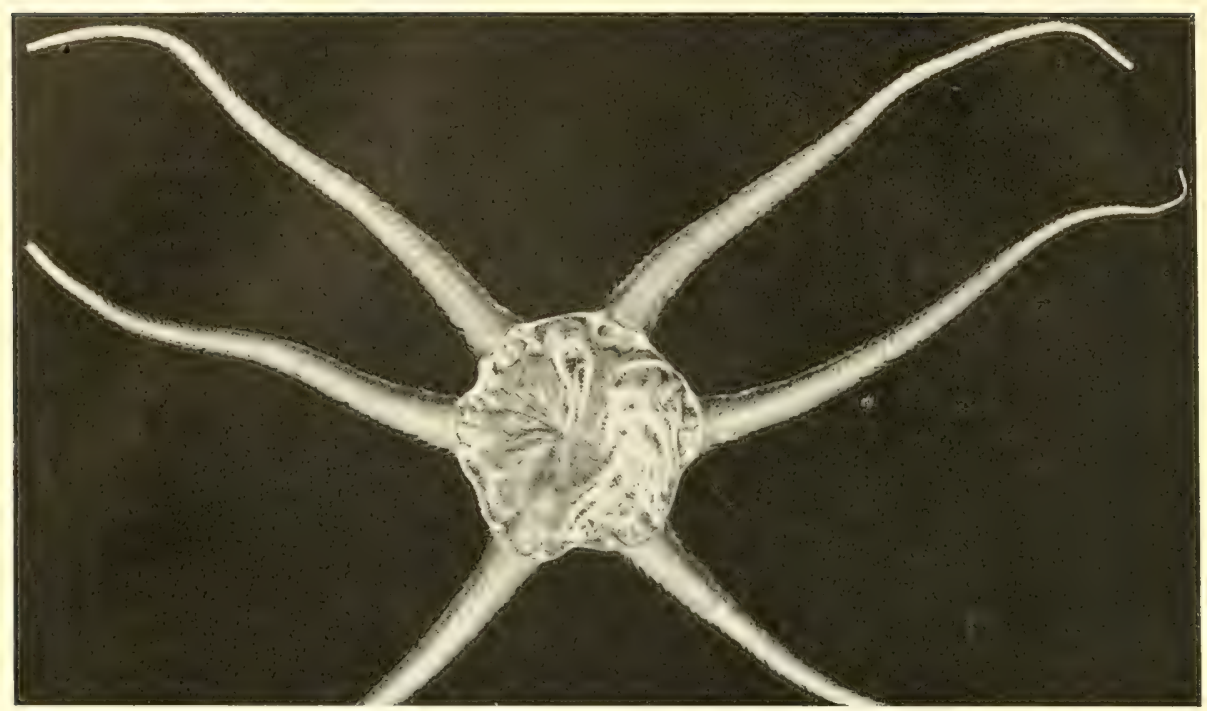

Ophioglypha hexactis mit Enbryonen.

ratürliţe Brö̧̨,

von formen, bei denen sine Brutpflege bisher nidit befannt war, ift fie an der hand des von uns gefanmelten zTaterials nadgewiefen wordett. So beriḑtet Dr. Carlgren, daf̧ eine teue (5)ttung der fhönen, rofenrot gefärbten Seerofen der Kerguclen, die er Marsupifer Valdiviae nannte, ihre junge Brut in fedis jwifhen die Septen fid ein=

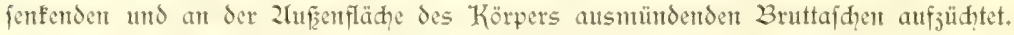
Es fällt niḑt leid̨t, eine Erflärung für dicfe in fo weitent Umfange geübte 3rut=

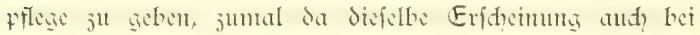
den arfitiphen Secticen wiederfehrt. Es liegt auf der Land, daf die Derbreitung der 2lrt in bejonderem

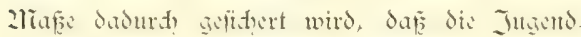
formen nidht auf friikeren Entwidelungsftadien ausiḑwärmen, und den fäbrlidyfeiten entgehen, denen fie in arftifben und antarfitionen (5ebic ten ait der Sberfläde ausgefețt find. Weshalb indeffen die Brutpflege den in gentäfigten tro= pifden Klimaten vorfommenden fornten fehlt refpct. nur untergeoronct in Erfdeinung tritt,

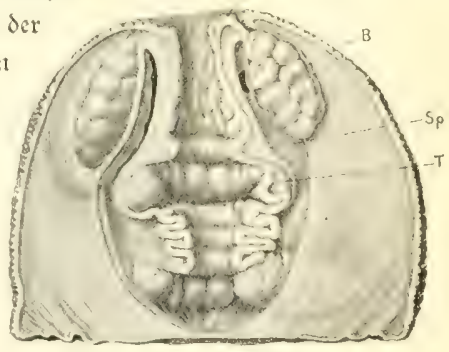

Marsupifer Valdiviae Carlgr, $3 / 1$.

In jedem der feds Brutfäcfe (B) ftno 50-100 Em= brronen enthalten. $T$ ber cingejogene Eentafelfrans.

Sp Ringmuspcin (Spbintteren. 


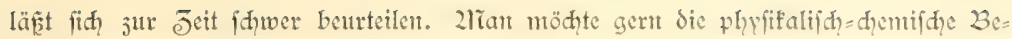

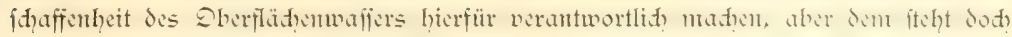
andererfeits wieder im Wege, da gerade an den Kerguelen felbit die jarteften Dber= fläd)en= Drganismen in überrafhender fülle auftretent. Das zlieer ift belebt vont durdy= fithtigen 2kedufen, duftigen Rippenquallen aus den Eattungen Bolina und Callianira und von Siphonophoren=Kolonten aus der (5attuntg Agalma. Entlid jeigt fid in der Kerguelen=Region befonders reid, jene pelagifdye Eebewelt entwidfelt, die als Zahrungsproducent den umverfieglidhen Quell abgiebt, aus dent alles fhöpft, was auf dem Boden, alm Strande und auf dem Eande lebt. Jut den antarftifthen Diato= meen gefellen fïh grünliḑe, fhleimige zliafien bildende KugelaIgen, weldye oft anf weite Streffer hin dic Dberflüdse verfärben.

Es war begreiflid, da die 2ritglieder der Expedition fid nad, allen Seiten jer= ftreuten und je nadh ihren zreigungen bald der höheren und niederent Tierwelt, bald der pflanjendecfe und geologifhen Befhaftenheit der Llmgebung des Gajelle=Lafens ihre 2lufmerffamfeit juvendeten. Lnfere Dffiziere hatten genteinfam mit dem Kapitän

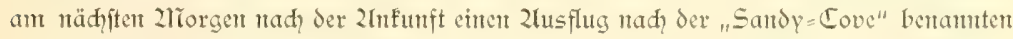
Butht unternommen, weldhe gleidy linfs neben dem engert Eingang in den ẼajelleGafen liegt. Dort waren fie anf eine Gerde Elefantenrobben aufmerffan geworden, welḑe in grubenförmigen, von Acaena ausgepolfterten Dertiefungen nahe dem Strande lagen, um den Eqaarwedfel durdjuntahen. Sie erlegten nidht wentger als 18 Stür(', weldhe wir am nädften Tage durh die Sdififsmannihaft abbalgen und jum Teil

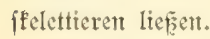

21 an gelangt fehr leidg̨t ju fur nadh Sandy Cove, indem man den Göhenrü̈fen

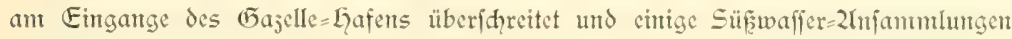

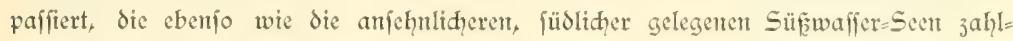
reidye Rimmiale nadh dem Ende der Buḑt entfenden. Die mitgeführten 2liafien von (5)eöll und Sd̨lamm bilden Zllluvialbänfe, welche ju der Bejeidpunng Sandy Cove Deranlafjunts gaben. Die Budjt ift von fanft geneigten, mit diḑten Rajent von Acaena bewadyentn Lqängen umgeben. Zluf der Ditfette begrengt fie cin ungefähr $500 \mathrm{~m}$ hoher, unbentanter Berg, an dent ebenfo wie bei allen diefen Rätefen von mittlerer Löhe der Zufbau aus horfjontal gelagerten, durdy rötliḑe Derwittenumgserde getremten Bafaltifhidhten flar hervortritt. Dffenbar handelt es fid hier um mehrfad wieder-

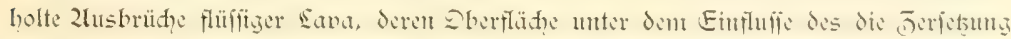
begünftigenden Klimas verwitterte oder mit vulfanifher 2lidhe bedeft und dant durd?

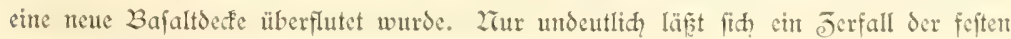
Bafaltbefen in fenfredte Säulen naḑweifen. 


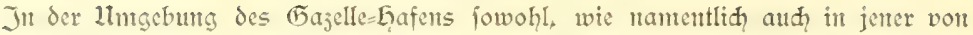
Sandy Cove, fielen uns die maffenhaft in ihren Erdöhern verifhwindenden Kanmdhen auf, welde vort der englifden "Dolage"= Expedition jur Beobahtung des Denusdurd = gangs auf Rat von Kapitän Zares, dem Kommandanten des "Challenger", ausgeiefzt worben waren. 2llles wimmelte von grauen, feltener fhwarjen 2ragern, die int Eegenfats ju der harmlofen, femte Derfolger fentenden sandfauta der Kerguelen ifpe furditjanteit und flüdtgfeit nidht verloren hatten: cin bemerfenswertes Beifpiel von Dererbutg pifdyifder Eigenfaften unter DerhäIntiffen, die dod immerhin ju der Erwartung bereditigten, dap die Zrwpaffung an nene Eriftenjbedingungen aud cine allmähliche Lerabminderung des Jnftinftes im Eefolge gehabt häte. Seider hat diefe

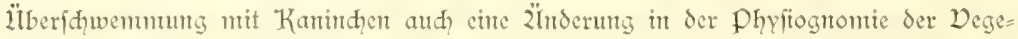
tation herbeigeführt. 2llle früheren Expeditionen beriḑten, dafF der Kerguelenfohl in 2lienge über die ganje Jnfel zeritreut vorfonmt; Zof fammelte nod furj vor feiner 2lbfahrt von ben Kerguelen fo viel Kohl, da für zhonate feine 2liantufhaft mit juträglióner Koft verjehen war. Eleutjutage möhte dies fibwer fallen, infofern an allen den Kaninḑen jugängliḑen Stellen die Pringlea vollftändig ausgerottet ift; man trifit fie mur nod) an fenfrechten felswänden (S. 2飞2) oder auf dert it dent fjorden gelegenten Injelnt.

Dbwohl dic See= Elefanten erft an 2rorgen erlegt worden waren, fo hatten fith dod? fhon Taujende von Dögeln um diẹelben angefanmelt, eifrig damit befäaftigt, den Seib aufjuhaden und fid Jugang nah den Imtern ju veridaffen. Dies gelang freilid mur den mit mäḍtigen Słnäbeln ausgẹtatteten grof̧en Sturmwögcht (Ossifraga gigantea), weldhe von weitem in threm Berehmen an dic (5eier der wärmeren (5egen= den eximerten. 2lìt f̧hlafi herabhängenden flügeln, Kopf und Gals mit Blut befudelt, ungaben fie ju Gundertent die Kadaver und hatten fith jum Teil fo voll gefrefien, dafi fie ritht in ftande waren, aufjuflegen. Raub= und Dominifanemtöven belagerten in sidten Wolfen die Stätte, wo unfere 2liatrojen eifrig damit bejdäftigt waren, unter 2nleitutig des fleifhers die Kabaver abjubalgen. 2ur ein gantj junges

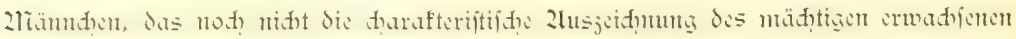
Bulfen, nänlid, die rüffelartige Derlängerung der 2Tafentegion, aufwies, befand fith unter der $\mathfrak{L}$ erde.

Die Paarungsjeit der Elefantenrobben fällt in den Septentber. 2Tađ den Beriḑten von 2ugenjeugen werden an hutbert Weib̧en von nur einem 2liännhen bewadht, das fie an Gröfe mindeitens um das Doppelte überbietet (es erreidht cinte Sänge von 9-10 m) und mit mäd̨tigen Gauern fidh feiner Rivalen erwehrt. Die ungefąlahten Tiere follen fid unter weithin fhallendem (Eebrüll anfridten, den Rüffel mit Suft

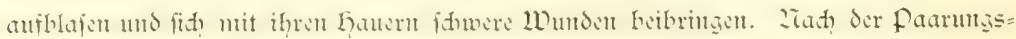
jeit jerftreut fid die ganze Elerde und die Weibdien fommen crit int nädiften September 


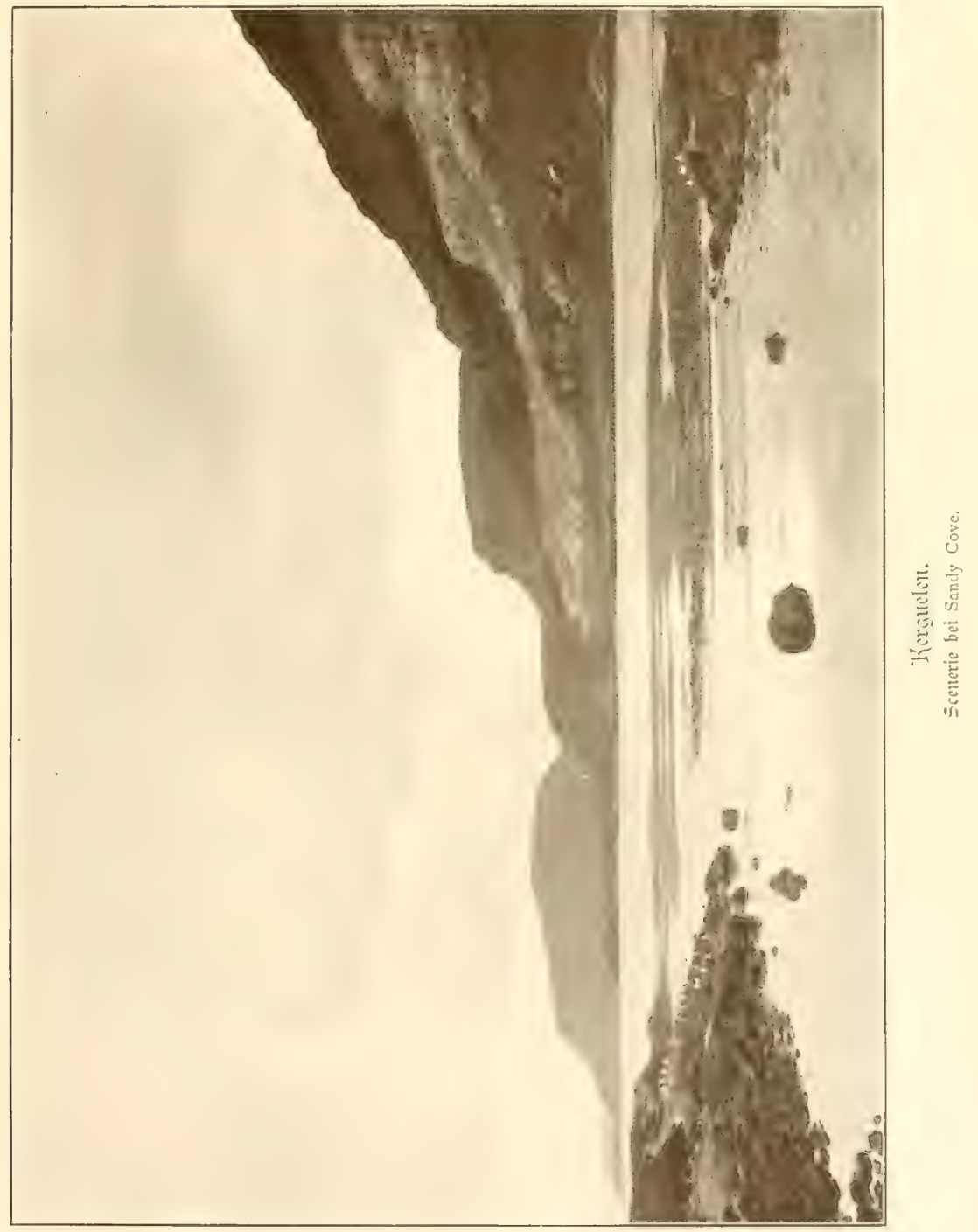



wieder an Sand, um ihe cinjiges Junge ju werfen, das nad 6 bis 8 Jahren fort= pflanjungsfähig wird. In Dejember erfheinen fie dann wiederum, um apathij ohne zahrung ju fith ju nehmen, in ihren grubenförmigen sagent den Laarwedfel durhjumadyen. Wir fanden dent and den zliagen der erlegten Tiere vollftündig leer.

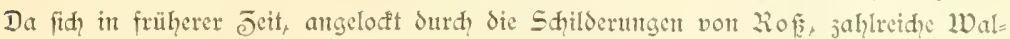
fif $=$ und Robbenfiläger mad? den Kerguelen begaben, wurbe unter den Elefanten= robben um fo mehr aufgeräumt, als man bei den 2letefeleten, dic man unter den wehr=

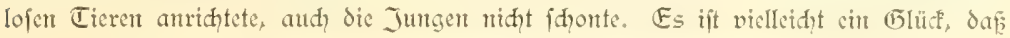

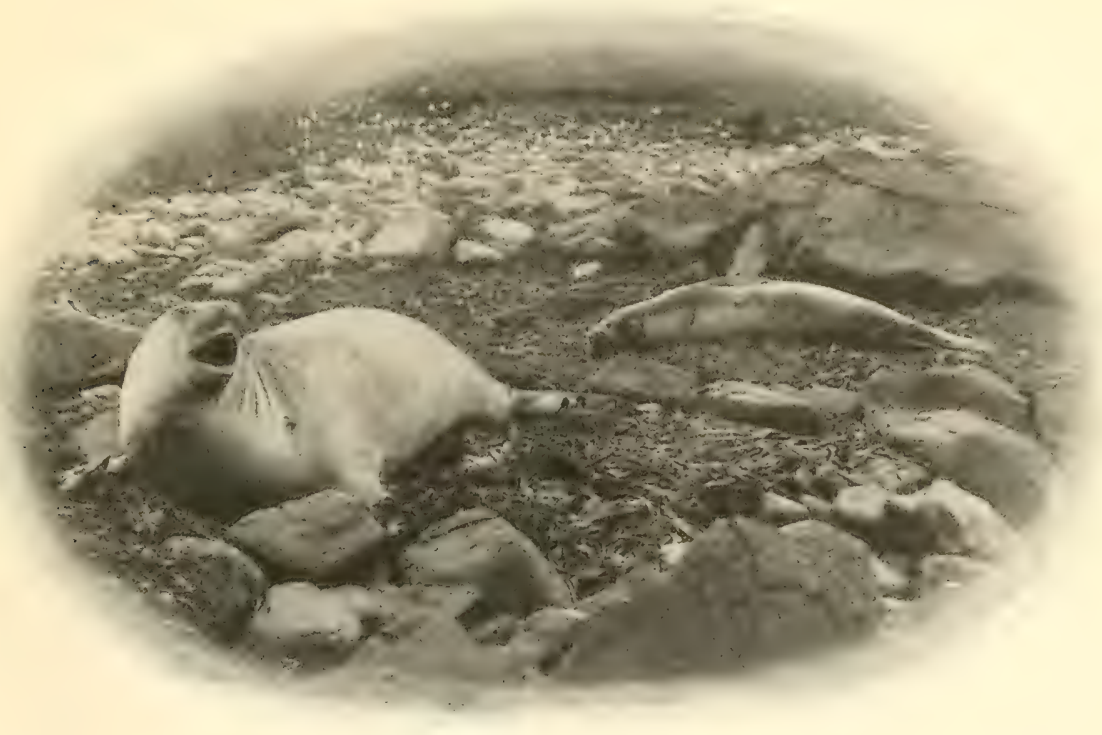

Weibliche Elefantenrobbe mit Junaem.

Der Boden if nit Blattern Der Durvillea bedeft.

allmählid der Robbenidjlag niḑt mehre lohnte, und der Bejud der Kerguelen feltener wurde. Der Kontmandant der "Eure" beridtet, Jafi er nur nod cinen Kapitän an= traf, welher jum Robbenfhlag die Kerguelen aufiuhte. In neuerer Jeit fheint feit fangldiff mehr dort gewejen $j^{\mathrm{u}}$ jein, und diejem llmftande allein war es ju ver= danfert, daf wir alle $\mathcal{B}$ uditen wieder voll von Kiobben fanden und in der furzer Jeit

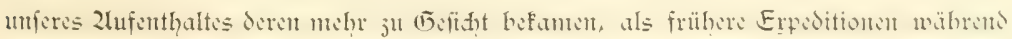

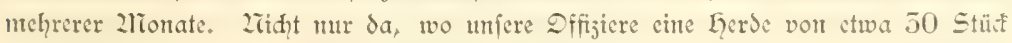
ïberraiht hatten (das gröfte dericlben ma $5,25 \mathrm{~m}$ ), trafen wir auf ihre Eager, 


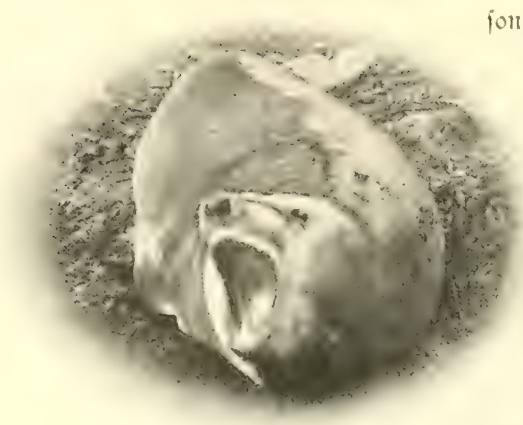

Gännende Elefantentobbe.

fortem aud an allen Stellen, wo Sandy Cove Surd fanftgentigtes Dorland güntige $\mathfrak{S a n}_{=}$ dungsitellen darbietet. Zlian hatte es bald verlernt, den harmlofen Tieren nit dem Eewehr jul seibe ju gehen, wie dern überkaupt der Jäger auf Injeln, wo cr Tiere nicht erft jut befdleidgen braud,t, die Bühle jur Ecite ftellt. (T)ar mand bei den Robben, dic mu dann, wemn fie vorber durd dic zliatrofen gejheudt waren, ein heiferes (5ebrüll ausftiefen und siner friedfenden 2liade erimertent, ju flüdten verfudten. Sonit aber verbielten fie fid

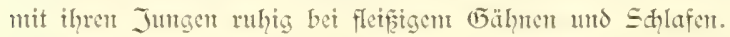

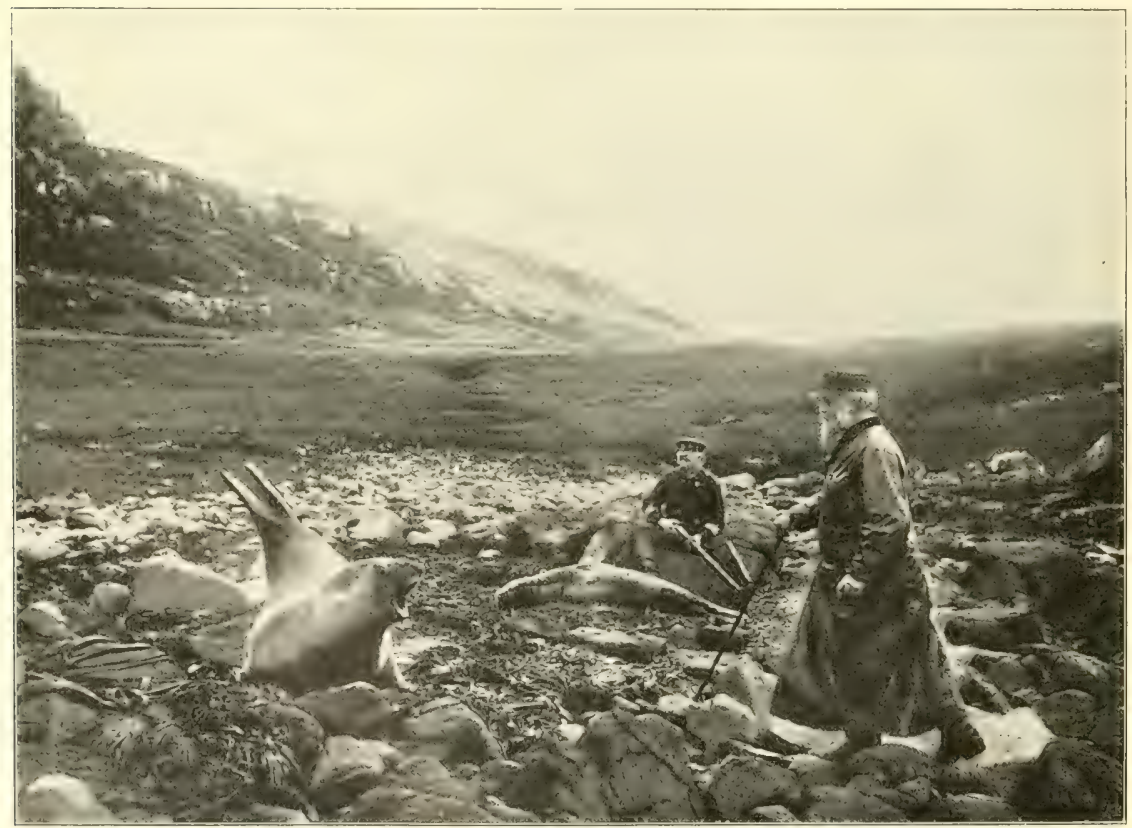

Welgtiofe Elefantentobbe mit f́llafentem 3unaen. 
Warnt fie munter, fo Iagen fie gern anf der Seite, dent Kopf leidt crhoben, mit ihrent praditvollen ausdrutfsvollen Zugen die Llmgebung muftemb, oder fo grajiös,

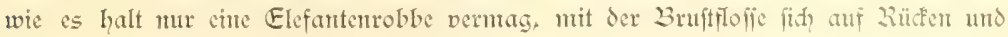
flanfen fratento.

Gegen 2lbend des 28. Dejember waren die Reinigungsarbeiten an den Kefleln beendigt und 2liorgens $5 \mathrm{llhr}$ am 29. Dejember wurden die 2unfer geliditet. Das

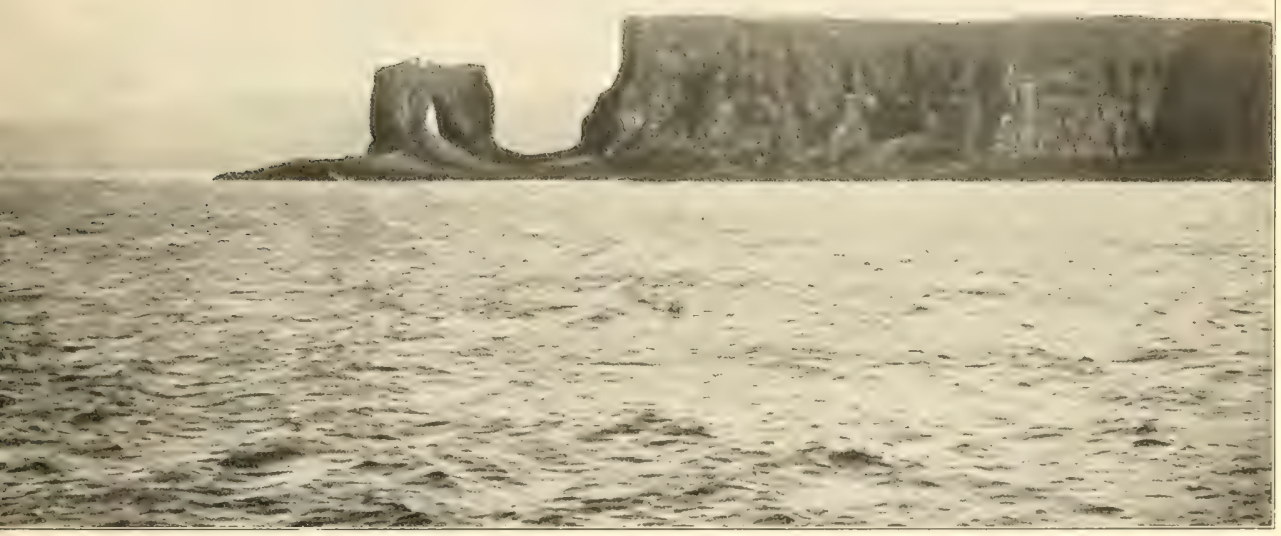

felfephor am Eingang 3um weihnadts= Gafen.

Barometer war von $660 \mathrm{~mm}$ (in der ZTadtt von 27. jum 28. Dejember) anf $741 \mathrm{~mm}$

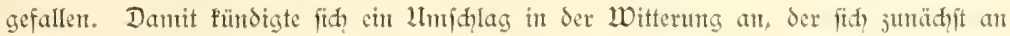
cinem leihten 2rordołt=ङuge benterfbar mahte. Während das Shiff ftill und ruhig

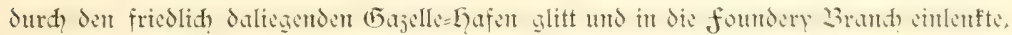
hob fich allmählich der 2iebel, weldher in der Zraht fidh cingeftellt hatte, und jum letsten

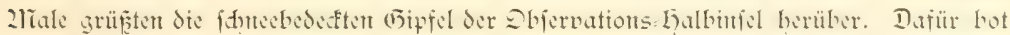
fid) jum eriten 2liale der Zusblif auf den fernent, in blendendem Weif fdinmerndent VTount Rof $(1860 \mathrm{~m})$, den hödjiten Gipfel der Kerguelen, dar. 


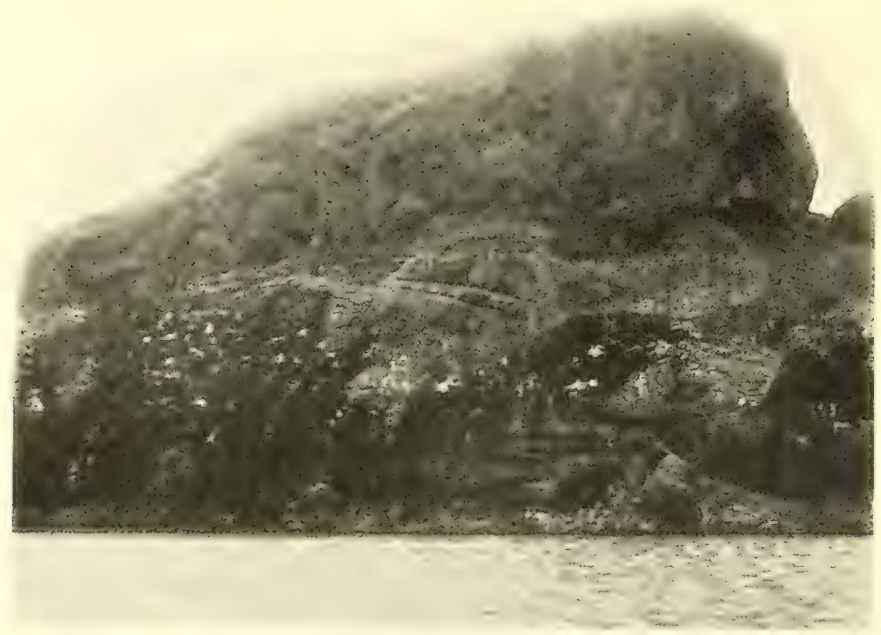

Mount Eavergal auf der Sabjeite bes weihnahtshafens.

Bei ruhigen Wetter veranfalteten wir in $88 \mathrm{~m}$ Tiefe auferhalb Ser Jufelt auf

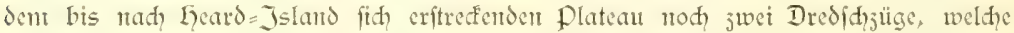
uns cine fülle intereffanter Dertreter der merfwïdigen Kerguelen=fauna leferten. Da hingen in den Zliajden des 2refzes blutrote kiefenformen von Zlfelfpinten (Pyeno= gontden), während der Beutel ganj gefüllt war mit Blumenpolypen, Secfterter, See= igeln, Sdplangenftemen, prahtwollen Sdupfenwümern, 2lffelfrebjen (Serolis) uno 乌rof̧en Kodjent.

Wir unfubren in wettent Bogen dis 3ismarte Galbinfel und gelangten jwijhen Ser bowe= Jufel und Swain= Jaland un 5 llhe in den berühnten Weihnadhtshafen. Scine Einfahtt wirs fhor won weitem durd das befamte felfenthor gefennjeidnet,

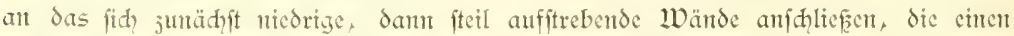
vorderen weifen Keffel und einen hitteren verengten 2lbidnutt begrenjen. Drohend ragt an der Sildfeite ber unförmige 2liount Lavergal auf, während dic 2Tordfeite von dent in 厄eraffen fid aufbauenden Tafelberge begrengt wird. 2lit Romantif

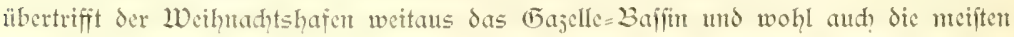

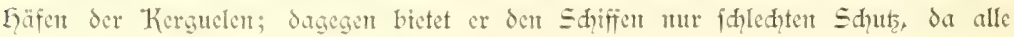

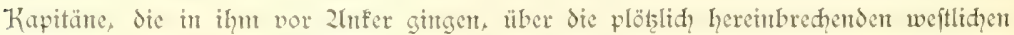
Windftöfe flagen, welden mur die mäd)tigiten Kabel und 2lnfer gewadjen find. Da

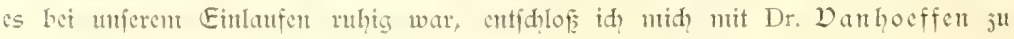


ciner Bootpartie, um das Kohlen=Dorfonmen an den von den felienthor ausgehenden Steilwänden fennen ju lernen. Die fahrt längs der fenfrediten 2lbiftürze ift ungemein malerifh; nid, weniger als vier Bähhe ftürjen in Staub fid auflöend auf die fels= trūmmer herab, welhe von Taujenden und aber Taujenden von Pinguinen belebt find.

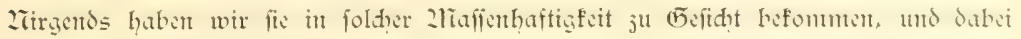
madite die Gejellihaft einen Speftafel, als ob in dent Wiener Reidsrat über die Sprahenverordnutgen debattiert würde. Eeider gelang es uns nidht, wegen der fräf= tigen Dünung an Sand ju fommen, obwohl wir deutlid die dumflen Queraden be= merften, wo die Kohle arfteht. Es handelt fid freilid un cin minderwertiges 3 renn= material, das den 2lbbau oder die Ergänjung des Kohlenvorrates niđht lohnt. 2iađ

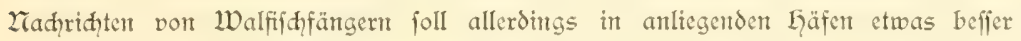
bremtende Kohle ju Tage treten. Bei der Rüdfahrt ju dem in der imteren Budht feft veranferten Sdiffe hatten wir reiḑlid Gelegenheit, die. Tüfen des Weifhradits= hafens fenten ju Iernen: plötzlith herembredpende Winditöfe bedingten furje, hohe Wellen, deren Gijd)t uns bald vollftändig durdnäpte. Erift nad? jweiftündiger, an= ftrengender 2lrbeit, bei der alle Lände an die kituder angelegt wurden, gelang es uns, an das nahe Sdifï ju fommen.

Don dort aus hatten ingwifhen die Undern den flaḑen Strand im Gintergrunde der Buht aufgejuḑt und waren gleț nad dent Sanden auf einen mäntidien Secleoparden (Ogmorhinus leptonyx) geftofent, ber, weit bewegliher unt fheter, als die See=Elefanten,

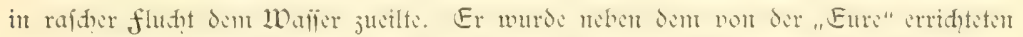

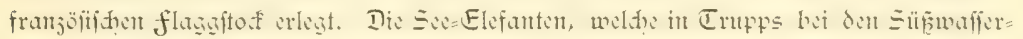

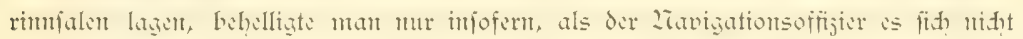
veriagen fonte, fie als Reittiere ju benuten. Da mant aud auf Köntgspinguine fitef von denen einige gefdlagen wurden, fo fudten wir nodymals die betreffenden Stellen auf, um den Seeleoparden abzubalgen und die Pinguine an 30 ord ju fhaffen.

Es war denn and, ein 3 ill antartifihen Tierlebens ohnegleidhen, weldyes fidh uns an der Budjt darbot. Dbwohl der Seeleopard erft furj vorher crlegt worden war, fo hatten fich dodh fhon didhte Sharen der gropaen Sturmbögel und brammen kaub= möven angefammelt. 2lan fonte fith des hungrigen (5ejindels fanm erwehen; cine Raubmöve rif mir das ausgefhnittene Eerj des Ecoparden aus der Land, und andere waren damit bejhäftigt, jwei der gejd̨lagenen Pinguine, welhe fïh crholt hatten und aufredyt daftanden, in der widerwärtigften Weife ju jerfleifden. Un= befünmert um das, was neben ihnen vorging, lagen die Elefantenrobben in ihren Sagern, umftanden von Efelspinguinen (Pygoscelis papua) und ciner Lecrde von etwa 50 fait $1 \mathrm{~m}$ hohen Köntgspinguinten (Aptenodytes longirostris). Dic Köntge funt dic ftoljeften Dögel der antarftifhen Region. Der fhneeweip gefärbte Baud wird unter

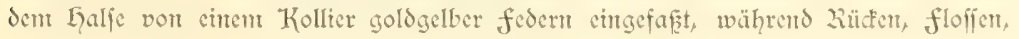


und der mit langent, fräftigent S丸ฺnabel ausgeftattete Kopf fhieferblau gefärbt fint. 2lls ob tie fid bewupt wären, Sie 2luserwählten ibre Sippe ju fein, benchnen fie fith nit bejonderer Würde. Ingleith den ewig jeternden und hüpfenden Sđopf= pinguinten fetzen fie langfam und gravitätifd einen fup vor den andern. Woblgefällig

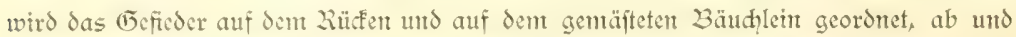
ju wird der 5 als gereft und nit gen Limmel geridtetem Sdnabel cin heiferes fräh,

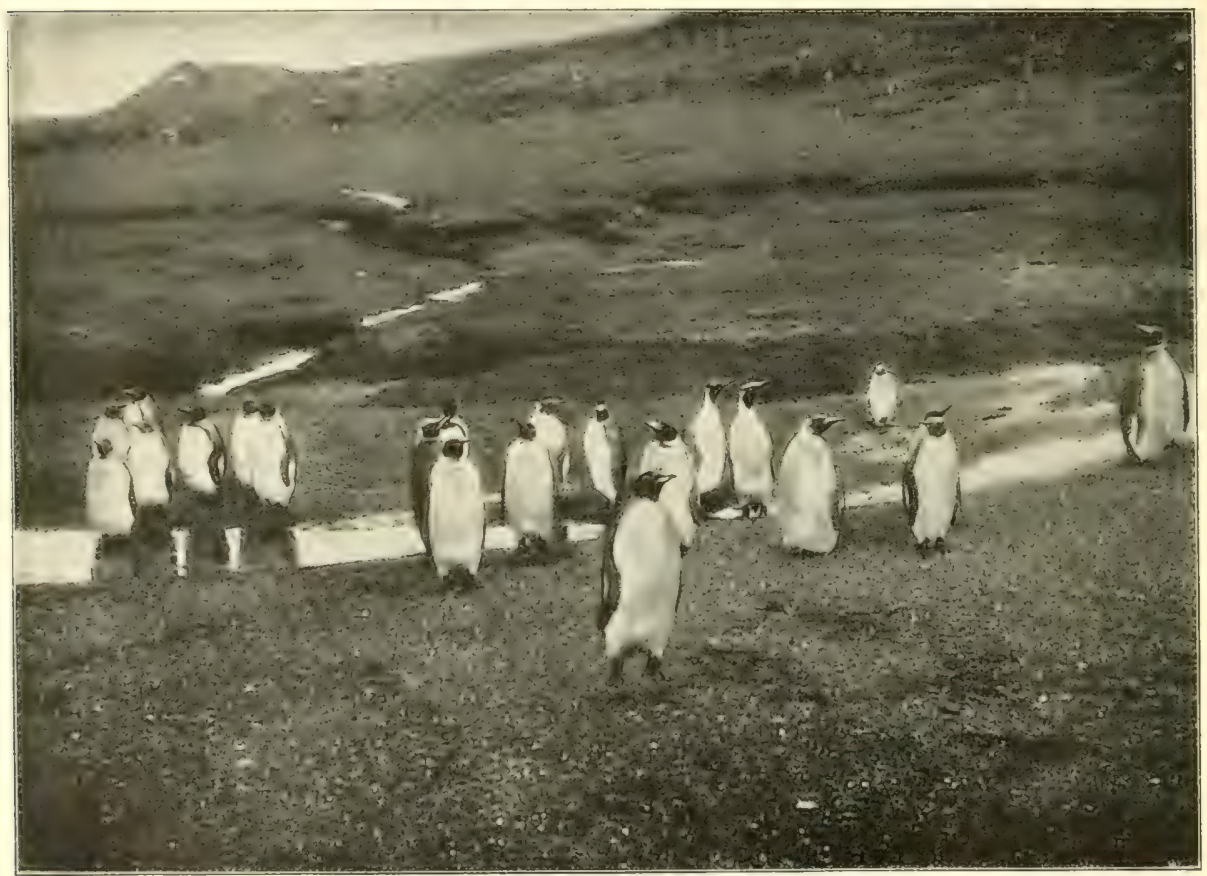

Königspinguine (Aptenodytes Iongirostris) am Weihnattishafen.

(Sacbse phot)

Eräh, fräh ausgcftofien. 27reift aber ftehen fie mit cingejogenem bals unt fanräg nad oben geriftetem Kopfe als philojophen des Unbewninten da, im fett faft erftifend und geduldig abwartend, bis das Gefieder - denn es war gerade die jeit der 2liauer - ertencrt mar.

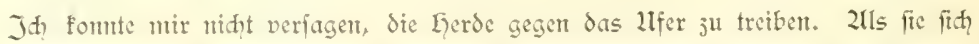

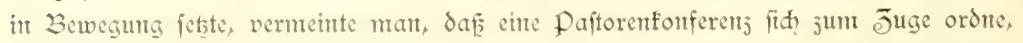
oder daf die Reftoren der Elodjidulen im Drnate, jeder non dem etgenen Werte 


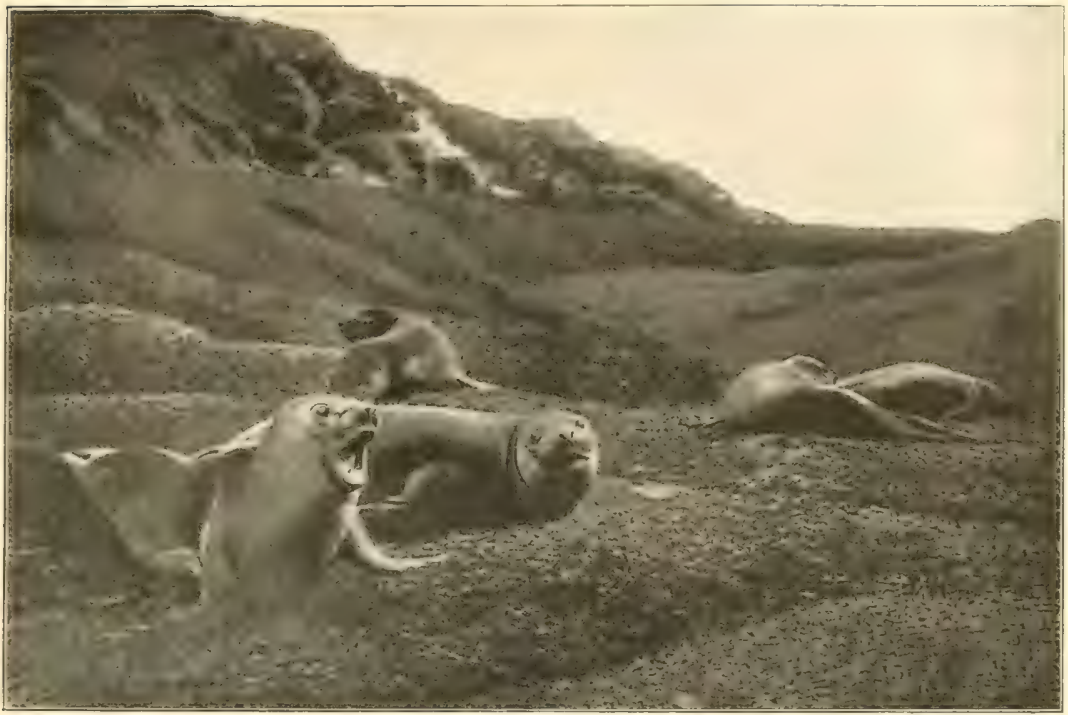

Weiblithe Elefantenrobben an Weitunaditshafen.

(Sachse pho:,)

genügend durdibrungen, jur Zudienj antreten. Fing es ju rafd, fo wurde nan durd

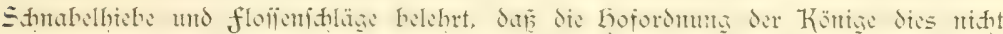
julafie; ftand man nad, jebn Sdiritten ftill, fo war dic erfdöpfte Derfamtmlung mur fhwer jum Weitergehen ju bewegen. 2lis ich mir indeffen beifommen liefi, ein Galle:

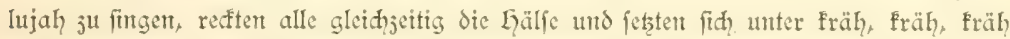
in Bewegung. Itnter ammutigem Wechelgejang der Pilgeriofaft langten wir nad emer halben Stunde bei den Boote an. Den 2ratrojen, welḑe den nötigen Exrft wenig wahrten und bie vier jhönften Könige herausgriffen, unt fie nebit jwei Elels: pinguinen lebend an Bord ju f̧haffen, wurde mit Shnäbeln und floffen fo jugejetst, dar fie finwerlich ein jweites 2lial ju cinem derartigem 2lttentat fid werden bewegen laffer.

Um 8 Uhr abends wurde ber Znfer gelidtet, und nad einem letsten Slicf auf die malerifhen Wände des Weihnadishafens, die von den trippeinden Chionis unt pon ১en Gunderttaufenden der lärmenden Pinguine belebt waren, wurde der Kurs nördlid, in der Riditurg auf St. Paul, gefef̧t. 
Wir verliefent eine eigenartige Infelgruppe, die mir ftets als das gelobte Sand für

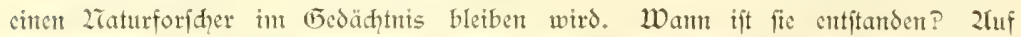
weldem Wege hat fie ihre eigenartige flora und fauna erhalten? Das find fragen, denen die forlder fett der Entdeflung der Kerguelen gern nadigegangen find.

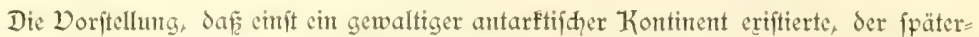
hin ins 2lieer fant und nur wentige Spuren feiner Exiftenz in den weltberlorenen,

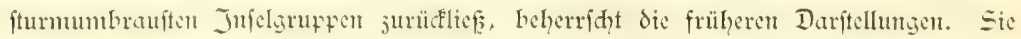
fpiegelt fich audh in der bis ju unferer fahrt allgemein gültigen 2Innahme wider, daf der antarftifde Deean nur geringe Tiefe aufweife. Durdh unferen 2raḑweis der

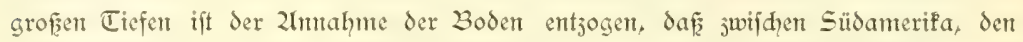
falfland = Jufeln und den weiter im Süden vorgelagerten antarftifhen Infelgruppen

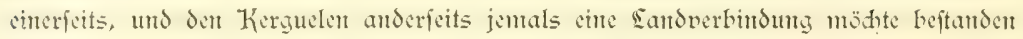
haben.

2lus einent gewaltig tiefen 2lieere ragen nur einjelne vulfanifhe Injeln, wie die

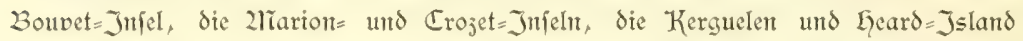

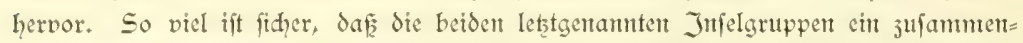

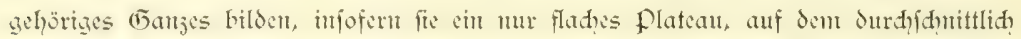
ctwa 200 bis $500 \mathrm{~m}$ Ticfe gelotet wurden, miteinander verbindet. 2rad Weften fällt dasfelbe, wie unfere Sotungen ergaben, fteil in die Tieffee ab. Es fdeint, daf and die 2rarion= und Crojet= Jnfeln mit den Kerguelen durd) cinen unterfecifden kiüden, der freilidy nody niḑt genügend ausgelotet ift, verbunden find. $\mathcal{D b}$ aber eine Der=

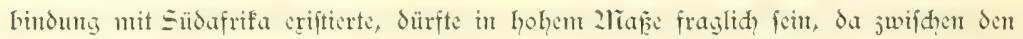
Ietżgenanntent Infelgruppent und dem Kontinent wieder grofe Tiefen gelotet wutrden.

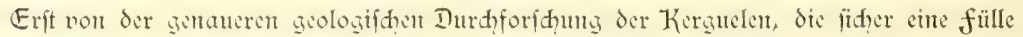

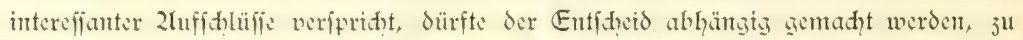
weldyer Jeit die Kerguelen fidh über den 2riecrespiptegel erhoben. 2lup̧er den ver=

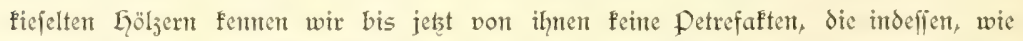
einzelne Berihte von Walfifhfüngent lehren, mit Sidperheit fich werden nadqweifen laffer. Studer vermutet, dafis fie fich, wie vicle bajaltifhe Jnfelgruppen, zu Beginn der Tertiärjeit erhoben, und wir werden fpäter nodh Eclegenheit firden, auf cinen Iminfand aufmerffam ju madhen, der diefe Dermutumg ftützent dürfte.

Went wir mun auf ihren fauniftifhen und florifijiden Charafter einen Blif werfen,

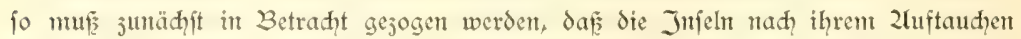
fidh wieder teilweife gefenfft haben. Einzelne Gebirgsjüge ragten nod über Waffer

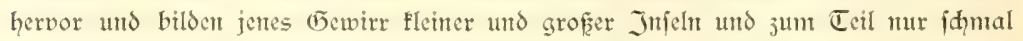
mit der Gauptinfel nod jufammenhängender Lqalbinfeln, welḑes wir namentlid auf

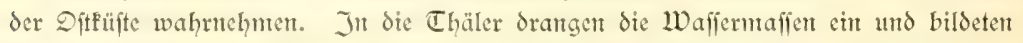

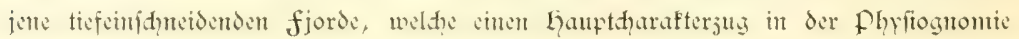


der Injeln abgeben. Die Lppotheje ciner Senfung wird dadurd unterftübt, daf auf cine Lebung dentende Strandinien nod nidit nadgeniefen fint. Db der oben erwähnte Rüd gang der Êletfher als ein Beweis für die Senfung des Sandes angejogen werden fann, dürfte inmerhin fraglith fem. Wahriheinlidher ift $\mathrm{es,} \mathrm{dafis} \mathrm{er} \mathrm{ciner} \mathrm{langlanten}$ Erwärmung jujufdreiben ijt, die nađ einer Eisjeit fid geltend maḑte. Dafí die 2ln= nahme ciner foldien durd das Dorfommen rein antarftifher Drganismen auf der heutjutage von cinem warmen Strome überfluteten $\mathfrak{X}_{g u l h a s=3 a n f}$ nahegelegt wird, haben wir bereits frïherhin (S. 175) ausjuführen gefud̨t. Weiterhin müfjen woir mit Ser Thatiade rednen, dafs die Kerguelen emft ntit Wäldern bededt waren, wie wir fie heute nođ in Beftalt prädhtiger Buchenwälder auf dem viel weiter nah Süden reidenden Patagonten und auf den falflands= Jufeln beobahten. Da die mittlere Jahrestemperatur $4^{\circ} \mathrm{C}$. beträgt und, wie bei allen oceanijhen Injeln, immerhalb ge= ringer (T)enzen fdwwanft, fo würde des dem Dorfonmen von Waldungent an gegen

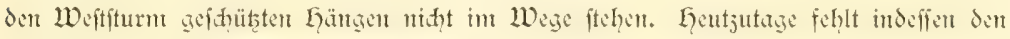
Kerguelen (ธ̋ebüf) und Golj volljtändig.

Was die höheren Pflanjen anbelangt, fo jeigen fie jum Teil nahe Derwands = fhaft mit jenen des feuerlandes. Dies betrifft fpeciell die Ramunfelarten, eine 2elfe

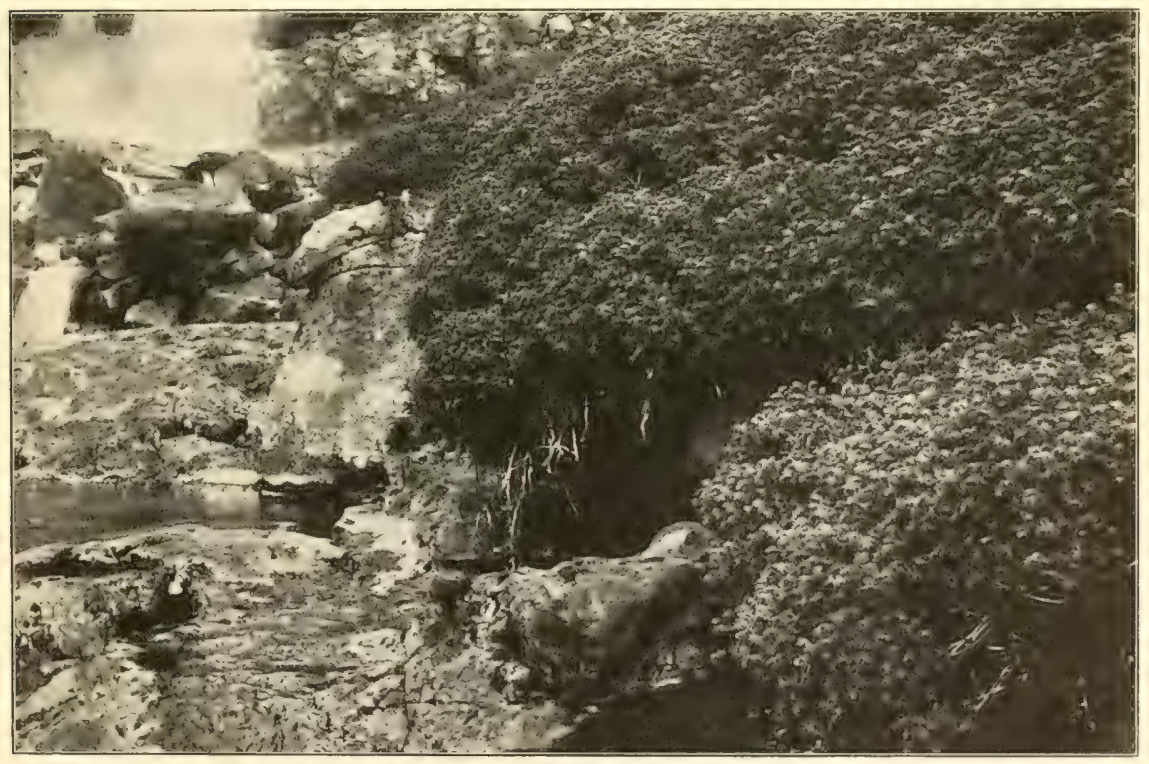


(Colobanthus), die Acaena und die beiden Grasarten. fünf Pflanzenarten find fogar identifal mit jenen vom fenerlant, und ju diefen gehört aud fpectell die Charafter= form der Kerguelen, nämlich Azorella selago. Ein endemiijdes (5enus weift wieder=

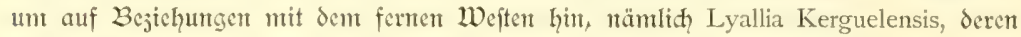

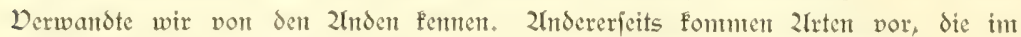
fernen Diten wieder auftauden. Llnter diefen mag namentlid, auf die Kompofite Cotula hingewiefen werden, die wir thiḑt vom feuerland, wohl aber von den füblid von Zeufeeland gelegenen Zutflands= Infeln fenten. Während fidh alfo hiter einerfeits $B_{e}=$

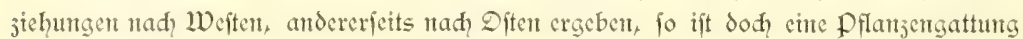
den Kerguelen, heard= Island, den 2rarton= und Crojet = Jnfeln allein etgen, nämlidh der Kerguelenfohl (Pringlea). 2lus dem Dorfonmen ciner fo cigenartigen phanerogamen

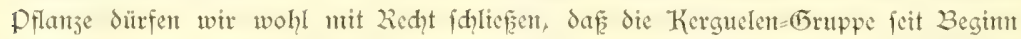
der Tertiärzeit, wo die Bildung der Blütenpflanzen anhebt, eine ifolierte Stellumg cimahm. Dhne weiter anf die Bejiehungen einjugehen, weldie die Kryptoganten

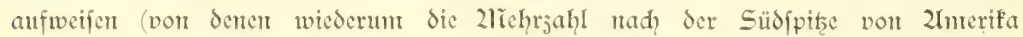
Ginneift), fo drängt fith fhon allem bei unbefangener Prüfung der floriftifden

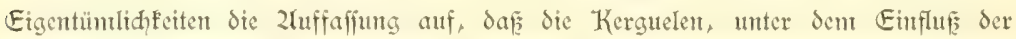
herrificnden Weftwinde, ihle wenigen höheren Pflanjenformen gröptenteils von dem fenerland jugeteilt crhicltent. Intmerhin aber beftanden fic fo lange ifoliert, daf fic and) neue, eigenartige endentifde (E) nera herausbildeten, von denten eineś, näntid dic Cotula, wiederum unter dem Einfluf der Weftwinde bis füblid von Zieufeeland ver= breitet wurde.

So werden denn aud die Joologen zur Erflärung der fauniftifd̨en Charafterż̈̈ge

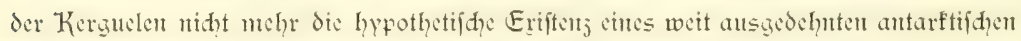
Kontinents heranjiehen dürfen, fondern die zlïttel ju erörtern haben, durd? weldye unter dem Einfluf der Weftwinde die Kerguelen mif Sandformen befiedelt wurden,

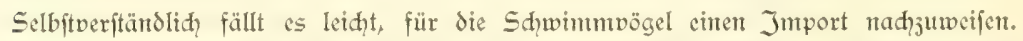

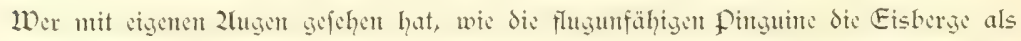
Transportmittel benutzen, wic 2llbatroffe, Sturmbägel und Seefd̨walben über das antarftifde 2liecr hin das Sdiffi begleiten, wird fidh niḑt wumbern, diefe formen über die ganje antarftijhe kegion verbreitet 3 finden. Lnter den Eandvögeln ift es die Chionis, weldse widernm ihren nädffen Vermanden auf den antarftifthen Jufelt der füdamerifanif hen Region aufweift.

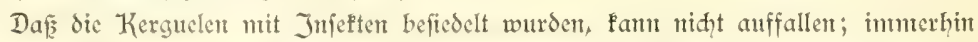

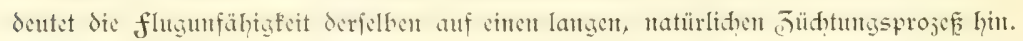
Es handelt füh bei der Rä̈lbildung der flügel um ein felbjtändiges 2luftreten einer 2ripaffung ant das $\mathfrak{S e b e n}_{\text {int }}$ von Stürmen fdwer heimgefudten Regionen; auf den

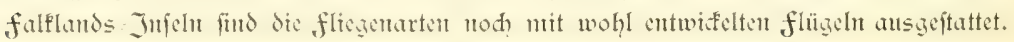




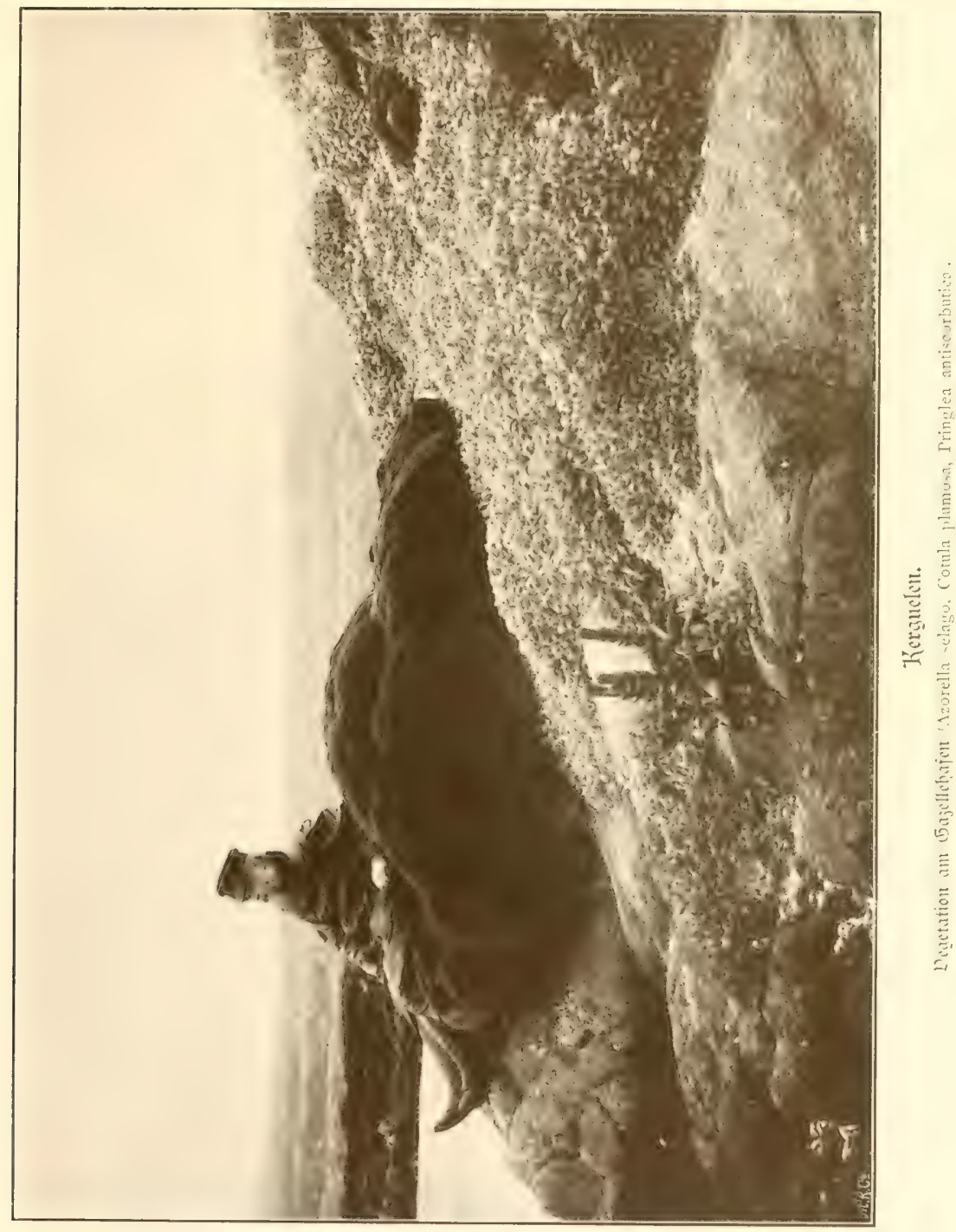



Das Dorfommen von Rüffelfäfern hat fion Studer mit vollem Red in ठujamment hang mit einer cinfitigen Waldbedectung gebraḑt. Sḑwieriger fällt es inmterhin, zu erflären, durh welde Transportmittel die cinjige Eungenfhnede (Helix Hookeri) und der Regenwurn auf die Kerguelen gelangten. Jmmerhit ift aud hierbet ju bedenfen,

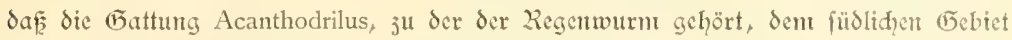

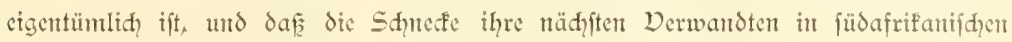
und feucrändifdien formten aufweift. 


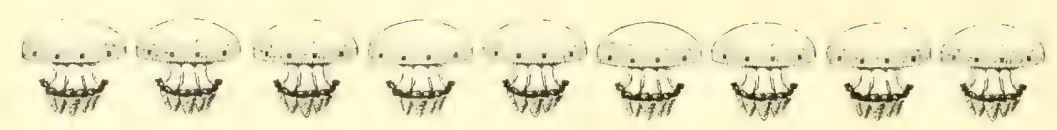

\section{In jiislichen Inbijhen (1)ean.}

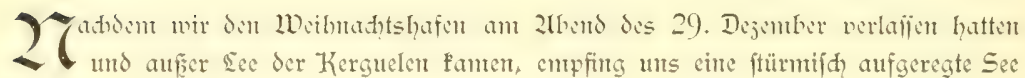
mit cher gemaltig hohen Dünung aus We ft mo 2Tordnordweft. Das Sdiff begann faft unerbört ju rollent, während der Wind allmählid junahm uno um die 2lïttagszeit des 50. Dezember de Starfe 10 crrethte. Während des Weftiturmes fitieg das Baro= meter innerhall 12 Stunden un nidht wenger dent $20 \mathrm{~mm}$ und erreidte am 2lbend des 50. Dejember cinen Stand von $600 \mathrm{~mm}$, nadbent es nod im Weifnaditshafen bis auf $555 \mathrm{~mm}$ gefallen war. Dabet mad) fid eine Erwämmug der Suft bereits fühlbar geltend (dic zlorgentemperatur betrug $7,2^{\circ} \mathrm{C}$ ), obmohl dic Sonne nur ge= legentlich jum Durḑbrud? gelangte und cin grïnlid verfärbtes 2lieer mit feinen ge= waltiger Wogenfänmen beleud)tete.

Shwärme von fł̣wärjliḑen Sturnwögeln (Majaqueus) begleiteten unts, denen fid? mchrere 2lbatrofie (Diomedea melanophrys und exulans) hinjugeicliten. Lnjere Köntgs= pingume batten wir in cinem Derfalage im Steuerborbgang untergebradit, wo fie uns

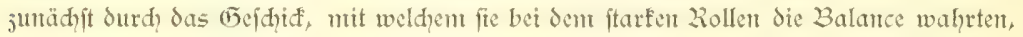
ïberrafhten. Inter fid waren fie fretlid, fo unverträglic, Saf wir ein diffes Weib= dient, dem volt jwet 2rämdhen mit Sdytabelhieben ftart jugeiest worden war, d)loro= formerten und ber Sammlung cinverletbter. Bei bem Zbbalgen ergab es fid, daf dasfelbe gerade in Begim der 2liaujer ftand. 2fud die dret rod übrig geblebenen nușten durd Bretterverfdiläge voneinander getrent werden, da es ftändig unter ctuem hämifden Beifeitebiegen des Kopfes und chten heiferen, günfeähnlidgen Sdret Stöbe und Giebe mit den Sdüäbeln abfetste. 2liti dicfen wurde aud der Befucher,

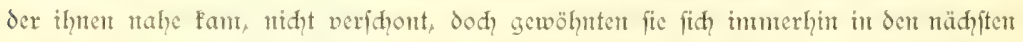
Tagen an den 21enfiden und nahmen es befonders gern auf, went fie in regelmäpigen

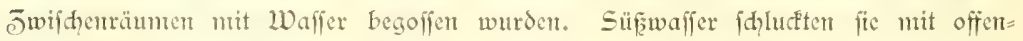
barem Wohlgefallen, verhiclten fid aher gegen jeglide fonftige Koft ablehnend. fret= lid waren fie fo fett, daf fie offenbar dic zlauferperiode, vor der fie ftanden, of nete Tahrungsaufnahne ju überdanen verntögen. Den ganjen Tag warent fie dant be= ihäftigt, das (Eefieder ju ordmen; namentliक, wem fie mit Waffer übergoffen waren, ging es an ein Refen des Laljes, an ein Sdütteln des Körpers, Sdylagen mit den 
flofien und forgfältiges Dronen der federn auf Rüfen und Bauth mit dent langen, überallhin reichenden Sdnabel.

Un 51. Dezember bedingte der Weitfurm einen fo gewaltigen Seegang, da zis wir gegen $10 \mathrm{Lthr}$ morgens genötigt waren, beijudrehen und gegen den Seegang anju= dampfen. 2lu irgend welhe 2lrbeiten war nidht zu denfen, dod wurden wir immerhin Surd, unfere Temperatumefiungen darauf aufuerfian, daf wir, wie cinft bei der Znmäherm!g an die Bonvet= Jnfel, fo hier bet dem Eintritt in wämere Regionen unter dem $450^{\circ}$ i. 3. mit jenen auffäligen, fhort früher enwähnten Temperaturfprüngen $3_{11}$ reḑren hatter. Das fómusiggegrünlid verfärbte falte Waffer von $4-4,5^{\circ}$ wurbe gelegentlid von rein blauen Streifen Warmwaffers, deffen Temperatur jwifhen $7,6^{\circ}$

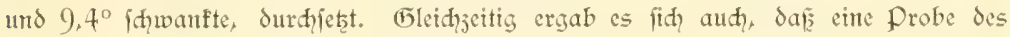
DEerflähenplanftons, weldhe wir nit vieler 2lübe fifhten, eine vollfändige z̈̈nderung in der Jujammenfeţung der mifroftopifden Drganismen aufwies. Die Diatoment, weldhe in dem falten Waffer herridend find, jeigten fid abgeftorben oder jerfetzt, während andererjeits die für das Warmwaffer typifhen Ceratien jul überwiegen be= gannen. Wollitändig fehlten die Seitformen des falten Waffers, nämlid dic Chaetocerasund Fragilaria-2leten; mit ifnen waren aud die in der Kerguclenregion fo maffenhaft auftretenden fugeligen Zlgen gejdwunden.

So feicrten wir dent wiederum im Sturme das anbrehende neue Jahr. Einen eigenartigen Eindrud madjte es, als man in der Sylvejtemadyt auf der Brüle des

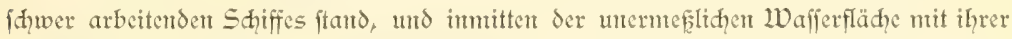
gigantifacer Weftoünung die Dantpfpfeife ertönte, un das neue Jahr ju verfünden.

Wünfhe, die man für unerreidhbar hiclt, hatte das alte in Exfüllung gebrad)t: wird das neue den Erwartungen entfpredien und weitere Zlufidhlüfle über Regionten bieten, die Feines 2lienfien 2luge jemals ju fhauen vermag?

21nt 1. Januar 1899 näherten wir uns der Region des Suftoructmarimums, das in Derbindung mit Windftillen twährend des fübliden Sommers für den Jndifhen Deean jwifhen dent 58. und 54. Breitegrad कarakteriftif ift. Das Baronteter ftand andauend hoh und jeigte un die Jahreswende bereits cinen Drud von $768 \mathrm{~mm}$. Zllerdings begann es bald wieder etwas ju fallen unter der Wirfung einer während 24. Stunden int entgegengefetzten Sime der Bewegung des llhrjetgers crfolgendun

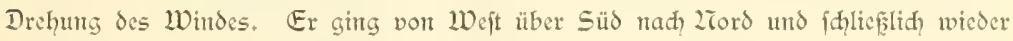
nad Weit um und hatte trübe Euft, Regen und in der 2iadit jum 2. Jantuar difent 2rebel in Gefolge. Jnmerhin gelang es uns, fowohl an 1. Jammar wie aud am

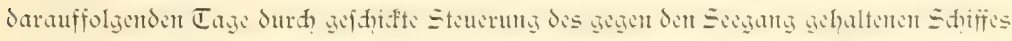
jwei Sotungen bis jum (5runde durchjuführen, welḑe Tiefen von $5455 \mathrm{refp} .5296 \mathrm{~m}$ ergaben. Die Grundproben lehrten, dafs wir nidht ntehr den für die antarftifhe Region

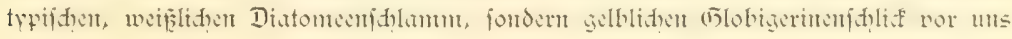


hatten. Die Bodententperatur in diefen Tiefen betrug $+1,4^{\circ}$, während die Dberflädhe bereits auf $12,5-15,5^{\circ}$ erwärmt war. Da die Sufttemperatur derientigen der Dberflädxe jiemlich genau entiprad, fo bedingte dic junehntende $\mathfrak{D}_{\text {ärme ein }}$ Befhlagen der ftarf ausgefühlten Sdifffswände und veraulaß̧te uns bald jum Ztulegen leidhterer Kleidung.

Eine Gerde von 20 Grindwalen, weldhe während des Sotens erihthen, betehrte uns Gleidffalls, daf wir in wärmere 2liceresgebiete eingetreten waren; feit langen Woden hatten wir das Blafen der $\mathbb{V}_{\text {ale }}$ nid\}t mehr vernonmen.

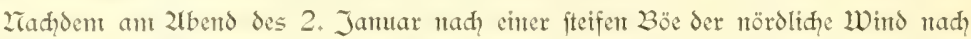
Weiffïbweft ungefprungen war, begam er rafd abjuflauen, indem aud, gleidzzetitg der Seegang abnahnt.

\section{St. Paul.}

Wir hatten den 40. Breitegrad iiberfdyritten und feit drei Tagen bei dem bedecften Gimmel feine aftronomifde Dbjervation gewinten fönnen, fo dafis twir im Jweifel waren, ob argefidts des jweintal erfolgten Beidrehens und der leid̨ten Kursänderungen,

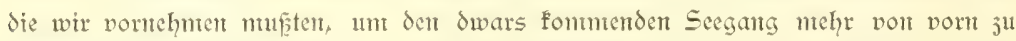
nehmen, genau die kinhtung auf St. Paul feitgehalten worden war. Trotzent hatte das frarfe 2luge des Kapitäns fithon in der frühe des 5. Jamar nad Tagesanbrud? das cirfam gelegene, vulfanifhe Eiland wahrgenommen. 2llmählid dämmerte es intmer deutliḑer bei vollftändig flarem Fimmel und ruhigem Seegang auf. Kurj mad 8 the raffelten vor dent Kraterbetten die 2hffer nieder, und gefpamt auf das, was uns dicfes, mitten int Jndifden Deean 5150 Seenteilen vom Kap der guten Gofinumg und von der auftralijhen Küfite entfente Eiland bieter follte, ruberten wir in Booten demiclben 3n. St. Paul hat feiten Zamten vont feinem Geringeren als dem

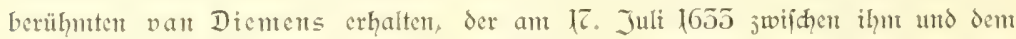

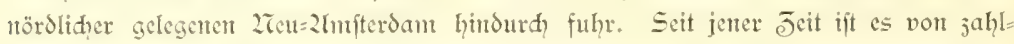
reiden Sdiffen und mehreren Erpeditionen befuḑt worden; vor allent war cs die öfterretdifthe 2rovara=Erpedition, die vont 19. 2rovember bis jum 6. Dejember $185 \bar{r}$ fid auf St. Paul behufs Dornahme aftronomifher, magnetifder und geologifdyer Beobady= tungen auffitelt. Durd cinen anjehenden, Ser feder von K. von S herzer entiftanmenden

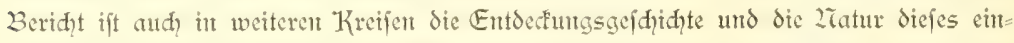
fanten Filatdes befannt geworden. Da wir mur wentge Stunden auf dem in den meiffen

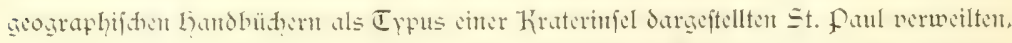

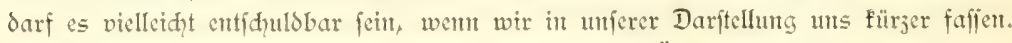

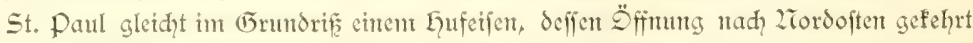
ift. Es befteht aus cincm Vulfane, der bei ciner Eruption teilweife zerftört worde. Etwa ein Drittel des Kegels ftürjte auf der Pfteite cin bis auf einen fleinen, als ZTinepin=Rod bejciduteten, fteil aufragenden Reft. Weit flafft hier der impofante Krater, 
Seffen Grund von dem 2licere ats mit Waffer gefüllt worde.

Dour der Ditfeite gefehen, bietet fid, sie Intel als ein grofiartiges 2fmphi= theater $\delta a x$, ju dem mur eint

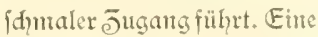
Barre verwehrt die Eitt= fahrt in das tiefe, itille Berfert, das alliet= tig vort

fteil $a b=$ fallenden, bis ju $2 \overline{c l}$ $m$ auffeigenden 20 änden untgeben wird. Willent $\delta \mathrm{c}$ flaming fand dic Barre bei feinem Befud in Jahre 1697 nody nidyt durdibrodien. Erft jpäterhin hat der Wogen=

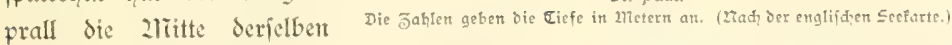
erodiert und cinen leider für gröfere Sđiffe umpafferbaren ฮ̄ugang gefdaffen. Dic Erwartung, daf: man den Sftindient= und 2luftralienfahrern mitten it dem von

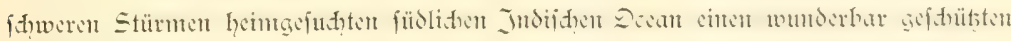
Gafen fdaffen föme, wird wohl fduwerlid jemals in Erfüllung gehen. Dent $a b=$ gejehen von den erfyebliden Koften, welde cin durd, Sprengen der Barre gefdaffener Jugang für grof̧e Sdiffe bedingen würbe, bietet das Kraterbecten nidyt bet jedem Wetter Sduts. 2Tamentlid, follen nad) dem Berihte der "Eure", welde anf der von 


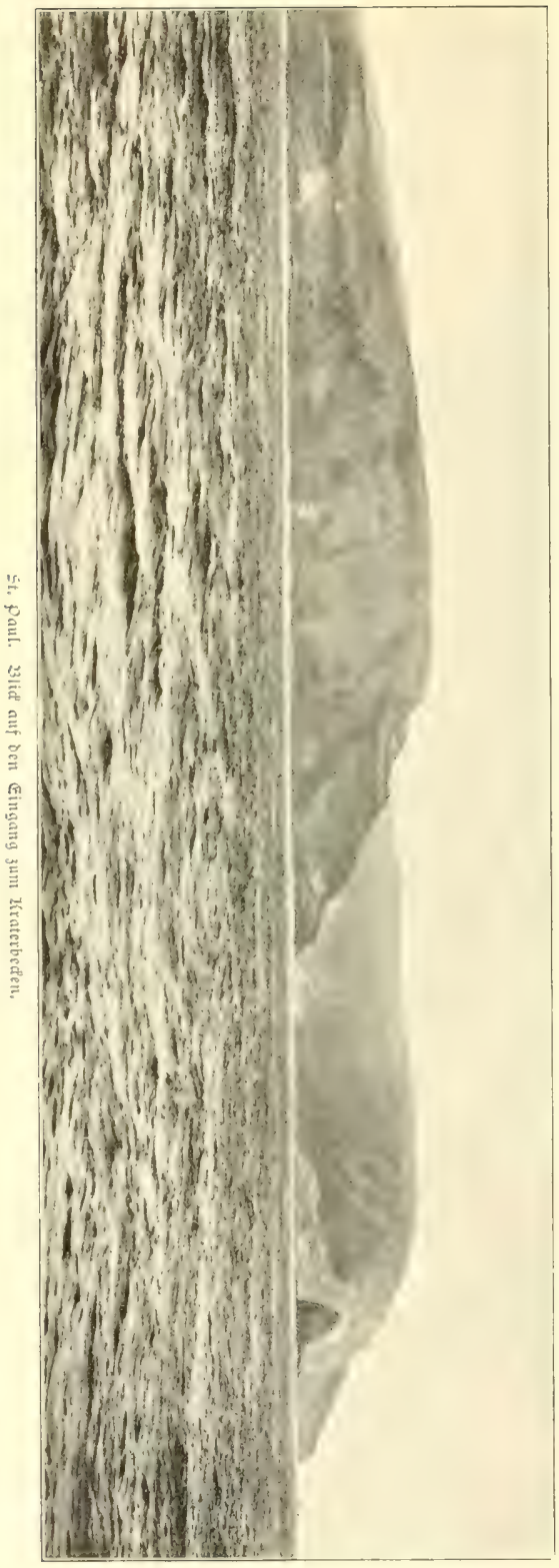

fifher.

franfreid in Befits genommentent Infel cin Proviantbepot errid̨tete, fübweftliche Winditöfe derartige Wirbel in dem trid = terförmigen Krater erjengen, da m mr Jic ftärfiten Ketten und 2lnfer Sidherheit gegen das Eosreifen bieten.

2lls wir uns der Jnjel täherten, wurde auf der nördlidhen Stelle der Barre mit ciner franjöfifhen flagge gewinft. Bals erfanten wir eine 2lnjahl von 2Tenfhen, dic uns bei dem sanden mit ber den franjofen eigenen, licbenswüt= digen Courtoifie begrüfente Es war der Intertelqmer Gerrntann vont Réunton mit feinem Sohne, der in (G̃entemihaft mit etwa 20 farbigen und Sdmwarzen den fifhfang Jort betreibt. Ein fifher= fhoner mit jwei 2liaften lag im Jmern des Kraterbefens in der zähe der aus cinfad)en Steinhäujern errid)teten 2unfede= Iung. 2rad naheju jwei zlionaten trafen wit junt erftem wal wieder mit fremben 2rienjhen jufammen, die aud ihrerfeits midht verfeblter, ihrer freude darüber 2lusbrut ju geben, daf̃ in die 2liono= tonie des Dafents cinige 2lbwedfelung. wenn aud mur für Stunden, fam. Zlir. Gerrmant, dent man jeme c0 Jahre faum anfaly, erimerte fid nod febr wohl der Jeit, wo dic "(5)ajclle" einen ganj Furzen 2lufenthalt auf St. Paul nahm, und gab uns bereitwillig über alle Der= hältuiffc zusfunft.

St. Paul ift ebenfo wie 2umfterdam erfaunlich fifdreid. Lauptfädlid werden grope, der familie der cirrbitiden ju= gehörige wohlidpmedtende fijde (Chilodactylus fasciatus und Latris hecataia) 
erbeutet, welhe eingejaljen und hauptiäd)= lid nah 2liauritus und Réunion vertrieben werdent. Wir waren überrafht über dic Sorgfalt und Sauberfeit, mit der hierbei verfahren wurbe. Die fifdie waren durd?= aus gerudilos, was wohl wejentlid dem limitande ju verdanfen ift, dafi fie jwei Tage nad dem Einfaljen geprefit werden, unt alles fett ausjutretben. Dhwohl nad der 2lngabe von Lermant gerade jur Jeit unferes Eintreffers die idled fle fifh = periode bei allerdings gutem Wetter eits= getreten war, fo gelang es dod der 2liann= ihaft, vort Bord aus eine reiche כ̄ahl fdimathafter fifhe ju pülfen. Jmmerhalk des Kraterbectens erbenteten unfere fifher it furzer ēeit einc Sdyar prädtiger San=

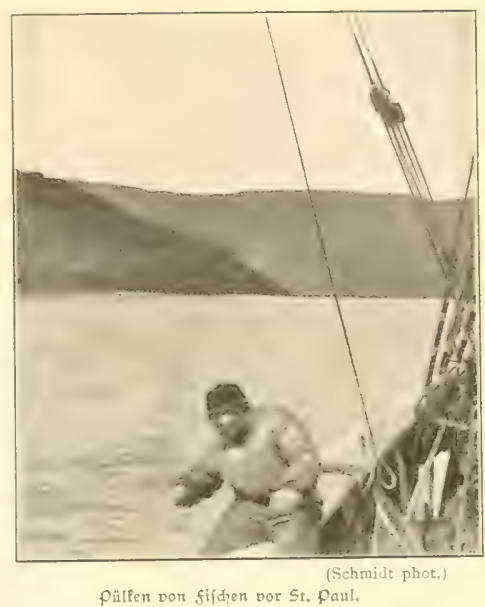
guften, die allgemeinen Bcifall wegen thres wohlihntedenden fleifhes fanden. 2ludh die Einfiedler auf St. Paul verfahen uns retđlid mit frifhen fifhen und Sanguften (Palinurus Lalandei) und nahnten dafür mit ftrahlendent Blide Cigaren, Tabaf und Rotwein in Empiang. 2ran glaubte fid in dic früheften Jeiten des Taufhhandels

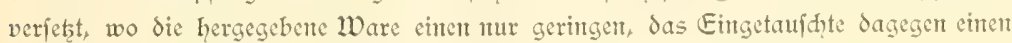
unt fo böheren Wert in den 2lugen des Entpfängers befitit.

$\mathfrak{Z}_{n}$ dem Strande, und jwar fowohl ant nördliden Ende der Barre, wie aud etwa 5 2rimuten bavon entfernt am Kraterberten, fontmen als Jengen der nie crößhenden

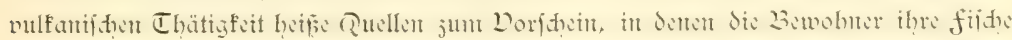
und Kreble foden. 2uffällig war es uns, daf troţ der hohen Temperatur grüne 2Igenrajen die Steine des heifen Befens bededten. Einte reidhe Degetation von florideen tritt überall an der Strandjone auf, während grof̧e Bänfe von Blafentang (Macrocystis) vor der Einfahrt in dic Barre ju bemerfen find.

Einen etwas melandholifhen Eindrucf macht es, twent man über dic gerwaltigent

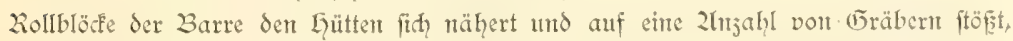
deren Inidififten freilich jum Teil fhon verwijht find. Eines derjelben barg einen

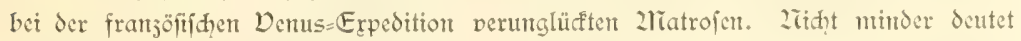
aud das Wrad eimer englifhen Brigg vor der Barre daranf him, daf die 2lmäherung bei ftürmifhent Wetfer feine gefahtloje ift.

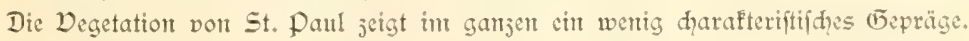
Sträuḑe und Bäumre fehlen vollftändig, und dafür find dic Wände des Imphitheatcrs 
bedeft mit hohet (5rasbüfdent (Poa Novarae und Scirpus nodosus), weldhe bei demt Klettern einen willfommenen Ealt gewähren. J̈wifhen iłnen fprię̧en Polfter von 21toofen und Eebermoofen, unter denten die fosmopolitif verbreitete Marchantia polymorpha als alte Befante auffällt. (5egen den Kraterrant ju treten damn nod eintige farnfräuter, nämliđh Blechnum boreale, cine $3 a ̈ r l a p p=2 \mathfrak{l}$ rt (Lycopodium cernuum) unt die aud auf den Kerguelent vegetierende Lomaria alpina, untermif ht mit einer ZInjahl phateroganter Blütenpflanjen, auf.

Von der thöhe gentefig man cine 2lusfidht, dic unt fo packender wirft, als cirte derartige Scencrie wohl faum junt jwettenmal auf Erden wiederfehrt. Sdroff und

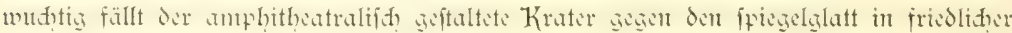

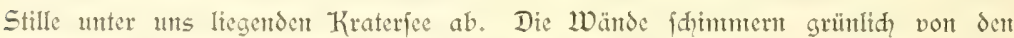

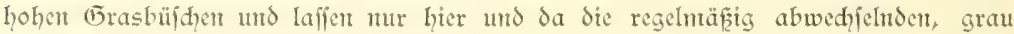

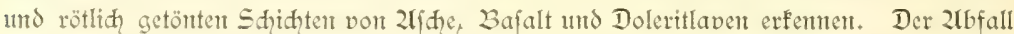
ift fo fteil, da man glaubt, mit cinem Steinwurf das Derdect des Shoners oder die Däder der vier Güften treffen „u fömen, oberhalb deren cin armfeliger friedhof Gräber

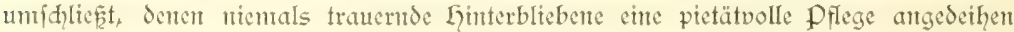
laffen. Dbwobl dic See glatt ift, arbeitet bod die langgezogent Dümung unabläfiftg an der

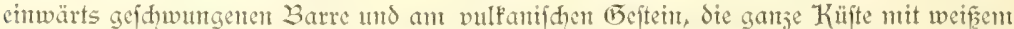

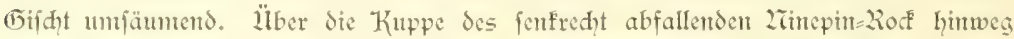

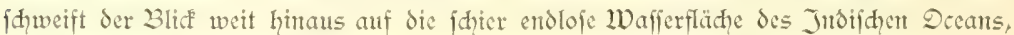

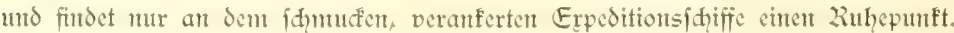

Wer an diefen welffernent Kraterwänden entlang flettert, indem er öfter an den (5rashüfden feften Lalt ju gewinnen fudt, wird nifht wentg überrafdt fein, in halber

Göhe des Stcilabfalls viel= ftimtmiges (5ejdret ju vernehmen und bei dem zräherfont= men auf eine

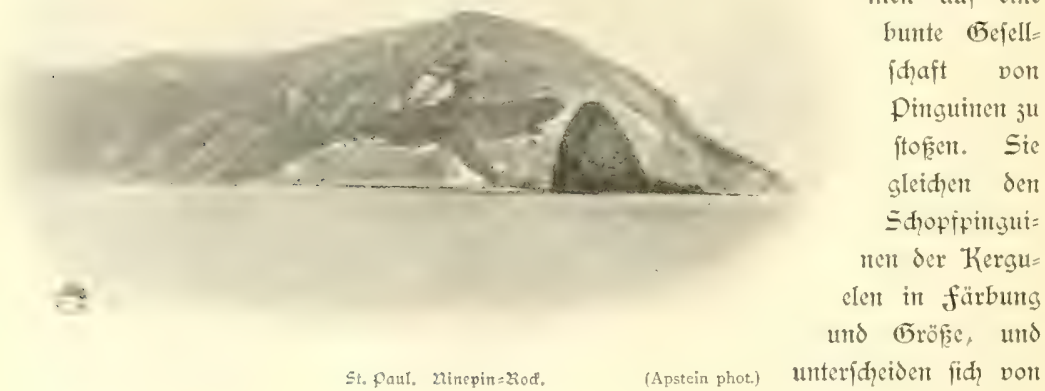




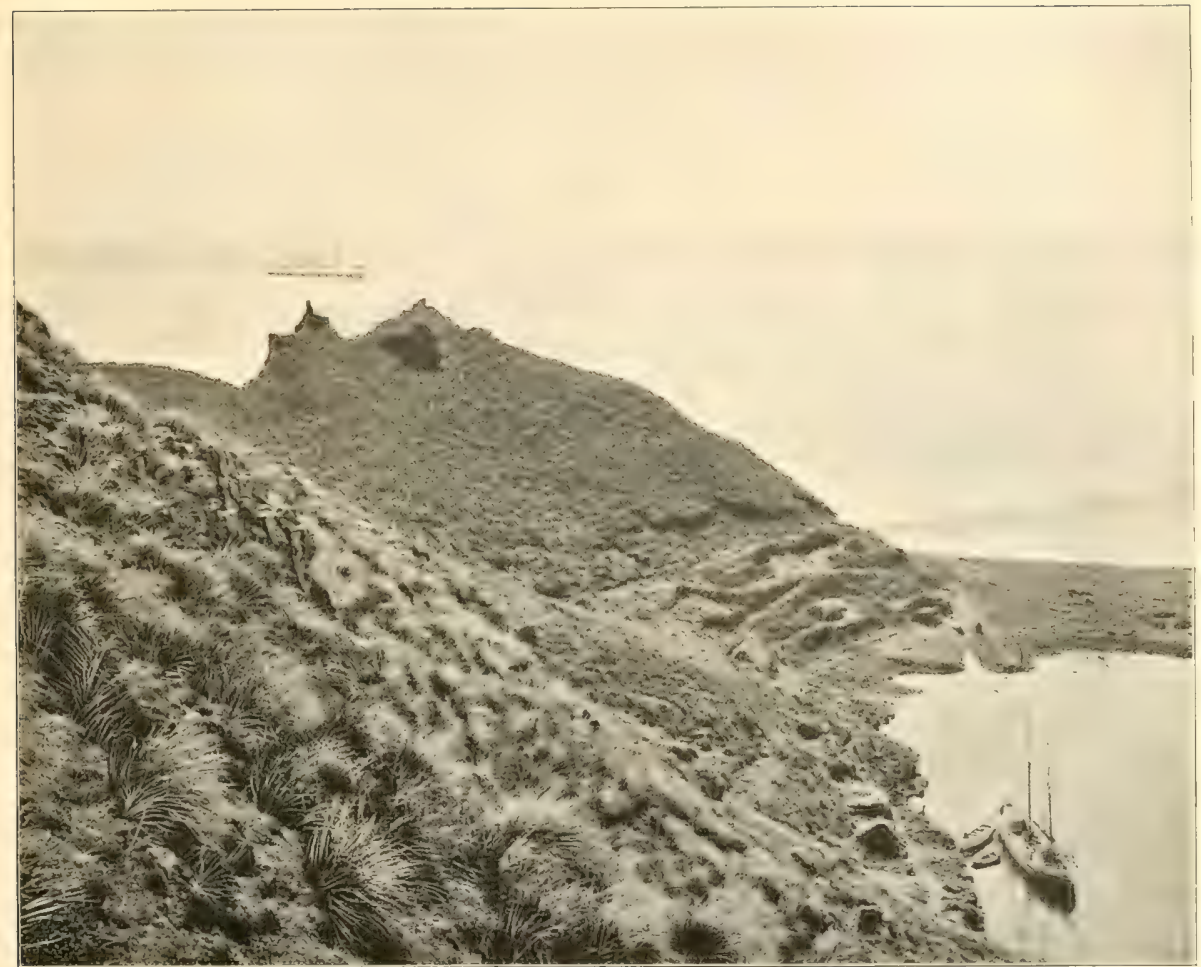

St. Pauf. Blidf auf bie 2lnīedelung ber fifđ̧er.

Jm Gintergrunde 2lnferflaţ der Daloivia.

ihnen mefentlí, mur durd die längeren goldgelben federbilichel am Kopfe. Bei ge= nauerent อెulehen benterft man allerdings nod weitere Linteridiede, unter denen nur ciner hervorgehober feit mag. Bet Eudyptes chrysocome von den Kerguelen bleibt Ser 2lundwinfel und der Rand des Lnterfdutabels als fleifuroter Streifen frei vort federn, während bei Eud. chrysolophus, wie man die auf St. Paul vorfommtende Zrt benamte, dic betreffende partic befiedert ift.

Zud in dem Benehmen weiden die Bewohner des Kraterbefens etwas ab, indem fie bei dem Sdyreien den Gals refen und mit gen Limmel gevanden Sdintabel fändig den Kopf mit fhönent federbufd fhütteln. Während auf den Kerguelen die $\mathbb{W}_{\text {cib }}$ hen nod brütetent, fo waren hiex unter cinem wärmeren Limmel die Jungen bereits 


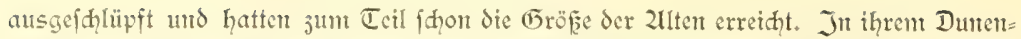
fleide fehen fie niedlidy und fauber aus; der Baud ift finneemein, Rüfen und floffen fint fditcferblau gefürbt. Ltm fo drolliger nebmen fich jene aus, weldie das Dunen= geficder wedfieln: wie cin differ, wollener pely, der hier und da bereits abgefallen war, fithen die Erftlingsfedem dem neufpriefenden, definitioen Gefieder auf. Da Taufende von Jungen gerade in der 2raujer begriffen waren und den Eindruté erwedten, als ob fie mit von zliotten zerfreffenen Theaterpelzen befleidet feien, fo wirbelte es in der Suft von federn, wie wem ein Sdnteegeftöber eingefetzt hätte. Dft rannte die ganje befellidaft wie cine Kerde einige Sdpritte vorwärts und geriet unter die benahbarten

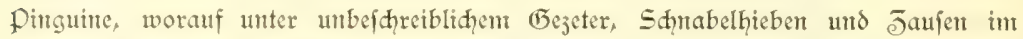
Zaăen die ungebetenen (5äfte wieder herausgeworfent wurden: 2lndere wieder blieben

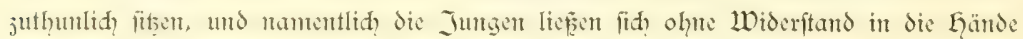
nehmert.

Die Ziefter find äuperft funftlos hergeftellt, indem ein fleines Bündel Gras als Interlage dient. Sie entwendeten es firt oft gegenfeitig, was freilid ftets einen Sturm der Entrüftung bei den Beraubten erregte, dem durd, energifdes Sdqütteln Ser feder=

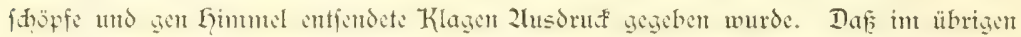
der (5erud in ciner fo unfängliden finguin Kolonie mit dent überall umberliegenden

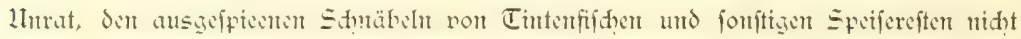
gerade eit aromatificer ift, mag nebenbei bemerft werden.

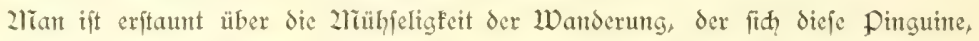
bergab hüpfend, untergithen. Deutlith Iaffen fich die im Eaufe der Jahrhunderte ges bahnten Wege beobadten, auf denten fie aus diefer Göbe fid tad dem 2lieeresftrande gegenüber dem ZTinepin=Ro begeben, utm dant mit der Beute im Kropfe das müh= felige Klettern naḑ aufwärts ju unternehmen. Da die Jungen auf̧erordentlid fett waren, fo befonmt man 2lđhtung vor der Seiftungsfäḩigfeit der 2llten, die ftändig bergauf, bergab in Bewegung fint, um die Zahoung herbeijufhleppent. Bet dem füttern, ober genauer gefagt "Kröpfen" der Jungen, ftehen fie weit auseinander, ftets bedaht, da niḑ⿻ etwa frembe Junge fid judrängen.

Die fifher geniefäent weder die Eier nod das fleifd der pinguine, zumal da ithnen

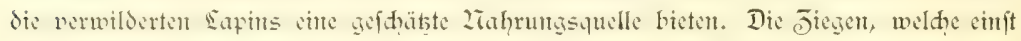
von der 2rovara=Expedition ausgefeţt wurden, fđ̧enten fith cbenfowentig wie die durd, die Kaninḑen ausgerotteten (5emuifearten gehalten zu haben.

$W_{\text {ent }}$ aud der Dulfanfegel bon St. Paul ein aufererordentlid malerifher punft ift, Der durd? feimen geologifhen 2 lufbau niđgt wenig feffelt, fo dürften dod diejenigen niḑt ju beneiden fein, weldhe darauf angewiefen find, auf diejer nur drei Seenteilen breiten Jufel ihy Dapeir ju friften. Kein Baum fpendet Sdyatten, fein Badh raujht in an=

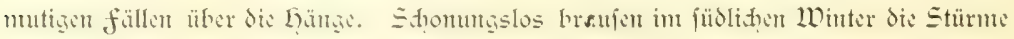


über dicies Eiland, in vulfarifhen Tridter fid verfangend und Surd ithe Wirbel Sen Kraterfec aufwühlend. Tagelantg fitsen dam dic Bewohner dumpf hinbrütend in Steinhütten, denen die Windsbraut oft das Dah entführt, und es fehlt thren an allem, was die 2lionotonte mildern mödte. Da der Kraterfee für gröfere Sdiffe

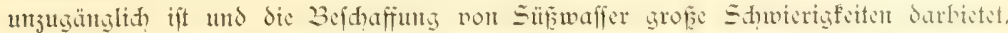
wird St. Paul weder von Zluftralien= nod von Ditindienfahrern angelanfen. Die 2Inter

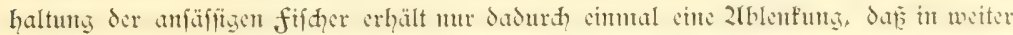
ferne ein Segel oder der Raud eines Dampfers gefthtet wird, und wie Sidptpunfte in

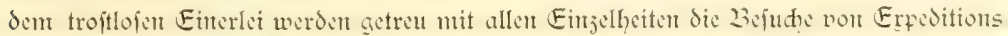

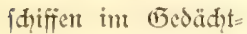
nis feitgehalten.

Wir lidteten um 2 Ulbr nadinittags den Zufer, dampften einige Seenteilen weit in öftlicher Riकhtung, um dam, Madjoem das Sot eitre Ticfe vor $672 \mathrm{~m}$ ergeben hatte, einten Dredid= jug ju wagen. Daf́ wir uns freilid auf einem gefährliकen Terrain befanden, lehrte der 2liangel ciner Grundprobe in Ser Sotröbre, weldye offenbar auf feljen aufgerdlagen hatte. Bald jeigte dem aud? der hobe Drud an dent Dynamometer, daf das 2iets feftge= Fommen war. Wir vermoditer es zwar $a b_{j} u b r i n g e n ~ u n d ~ a u f=$

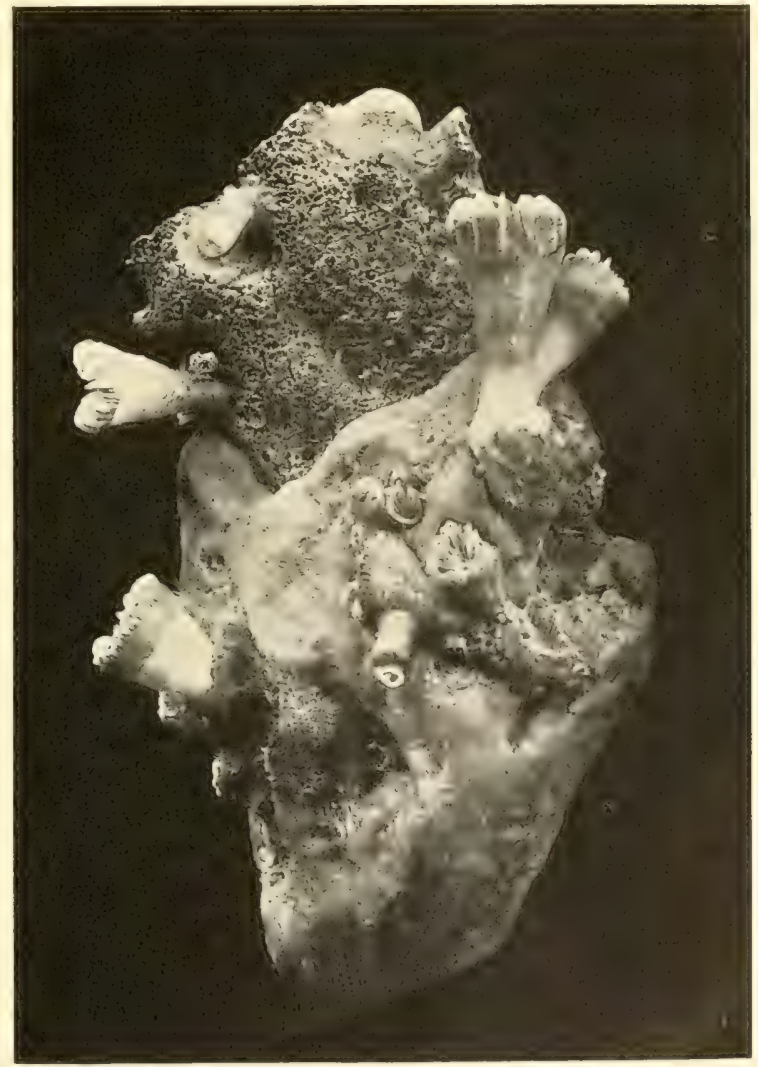

Korallen (Caryophyllia paradoxa) und Sdwämmte (Ancosina und Erylus) aus $672 \mathrm{~m}$ bei St. Paut 
juhieven, dody fan es in flägliḑen Juftande an dic Sberfläde: der halbe Rahmen fehlte, die ant Ende des 2reţbentels angebradten eifernen Dliven waren abgeriffen, unt der Sad hing in fetsen herunter. Trotzden hatten wir einen reidien und wert= vollen fang gemad)t. Der Boden um St. Paul mus mit einen unterieeifhen Walde von Korallen bededit feit, ju denen fid nod pradtwolle Kinden =Korallen und Pemta= tuliden aus der (5attung Anthoptilum gefellten. Jhr blänlid fdimmernder Stamm

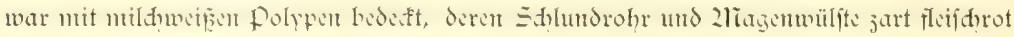
durdjfinmerten. Dies alles hing nebit Lybroibpolypen, Geractinelliden, Bradjio= poden, Witrmern und den Korallenitöden auffitzenden zart fleifidroten 2letimien im zer= fetsten 23 eutel.

2Tad den zlittetlumgen non 2liarenjeller's erweifen fid unfere reidhen Korallen= funde bei St. Panl und 2ieu=2lmfterdam als befonters wertvoll für die Frfentnis des ङ) uiammenhanges der atlantifipen und indijhen Tieffee fauna. Wir fanden an diefen sinfamen Injeln dic Solenosmilia variabilis, Desmophyllum crista galli, Lophohelia prolifera und Caryophyllia paradoxa in einer ähnlidyen Dergefellihaftung wieder, wie die "Poreupinc" und der "Challenger" int atlantifhen Gebiet. Die reijvolle Solenosmilia variabilis, juerft bet der jweiten fahrt der "Porcupine" an der Küfte von Portugal crbeutet und fpäter von dem "Challenger" bet Triftan d'2leunha und bei den Prinj= Edwards= Injeln wiedergefunden, taud bet St. Paul in Eremplaren auf, welhe iden= tijh find mit den vom "Inveftigator" bei Travancore gefifhten und mit Lhred)t unter cinem neuen 2iamen bejdriebenen.

\section{Taแ 2 mftersam.}

Wir liefsen uns in der fternflaren 2rad bet ruhigem Wetter treiben, da wir am nädfiten 2lorgen unferen 2lrbeiten vor Zeu=2lmfterdam nadgehen wollten, das bereits gegen 2lbend in femem Dufte gefiditet wurde. 2lls wir ihm in der frühe näher ge= fommen waren, hatten wir den feltenen (Eenuk, die Infel vollftïndig fret von Wolfen ¡u fehen, währento gleidjeitig das 2lieer fpiegelglatt dalag.

2ren=2lmiterdant wird beherrfot von cinem fanft auffetgenden, mur cine fleme Kratermündung aufweifenden Dulfanfegel von etwa $920 \mathrm{~m}$ Göhe. Jahlreidhe fleine Eruptionsfegel, deren man bei der Zlnnäherung von 2rordoft nicht weniger als etwa aḑt jählt, laffen fid fdon aus der ferne erfennen, während aufer der hödjiten Spitze mur nod, ein im Weften der Jnfel gelegener Berg deutlider fid abhebt. Zllle früberen Befuder madhten fhon die Exfahrung, daf fie auperordentlid, fdwwer $3 \mathrm{u}=$ gänglidh ift. Der gantje Süden und Weften fällt mit einer durdjidnittlid $80 \mathrm{~m}$ hohen ftetlen Wand in das 2lieer $a b$, dic im Diten und 2Tordoften nitedriger wird und in mädtige, eine Eandung vereitelnde Eavablöde übergeht. Zur in 2Tordoften ift der 


\section{St. paul.}

23lif anf dic 23arte an Eintann in das Kraterbefen. Int Dorderarund sin fingumtolonie (Eudyptes chrysolophus). 


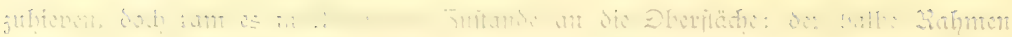

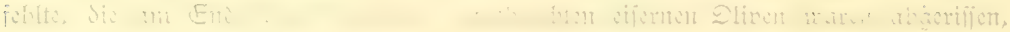

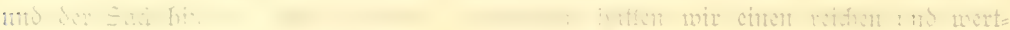

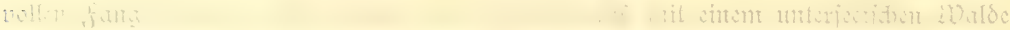

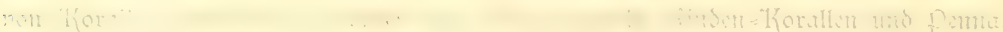

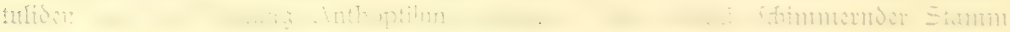
m

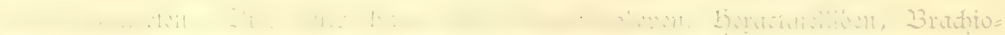

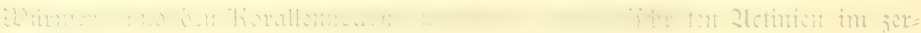
.in Wiliat

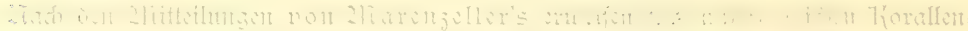

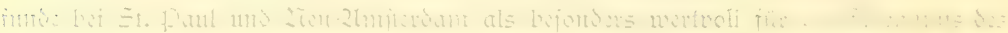

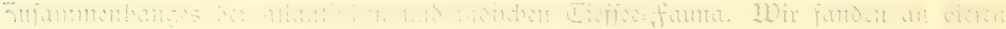

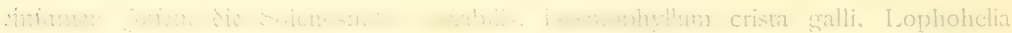

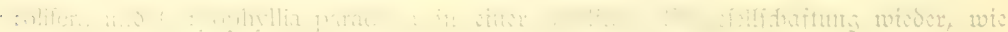

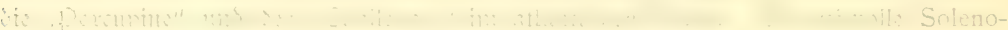
..., iil

\section{.lunct.t?}

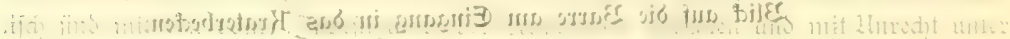

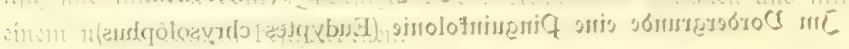

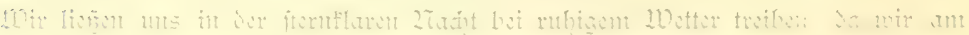

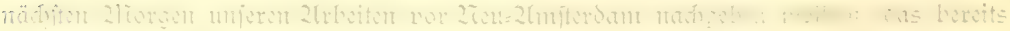

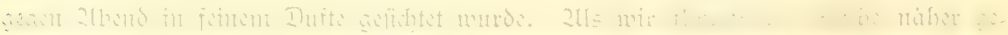

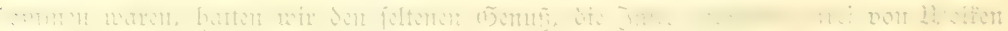

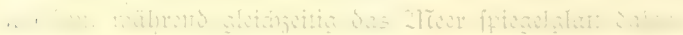

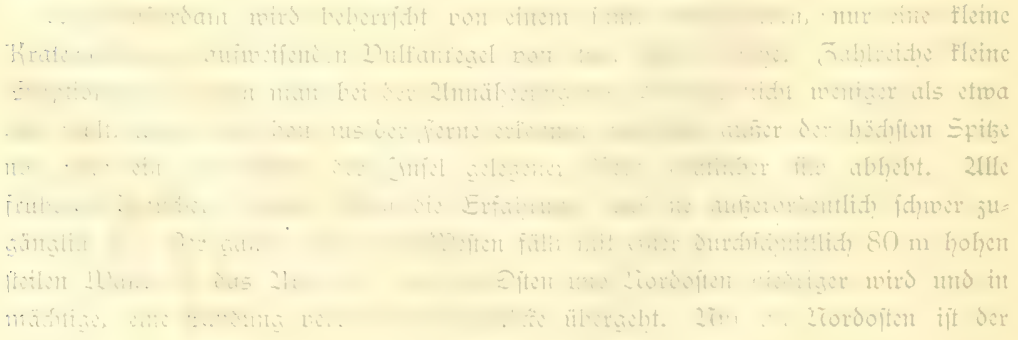




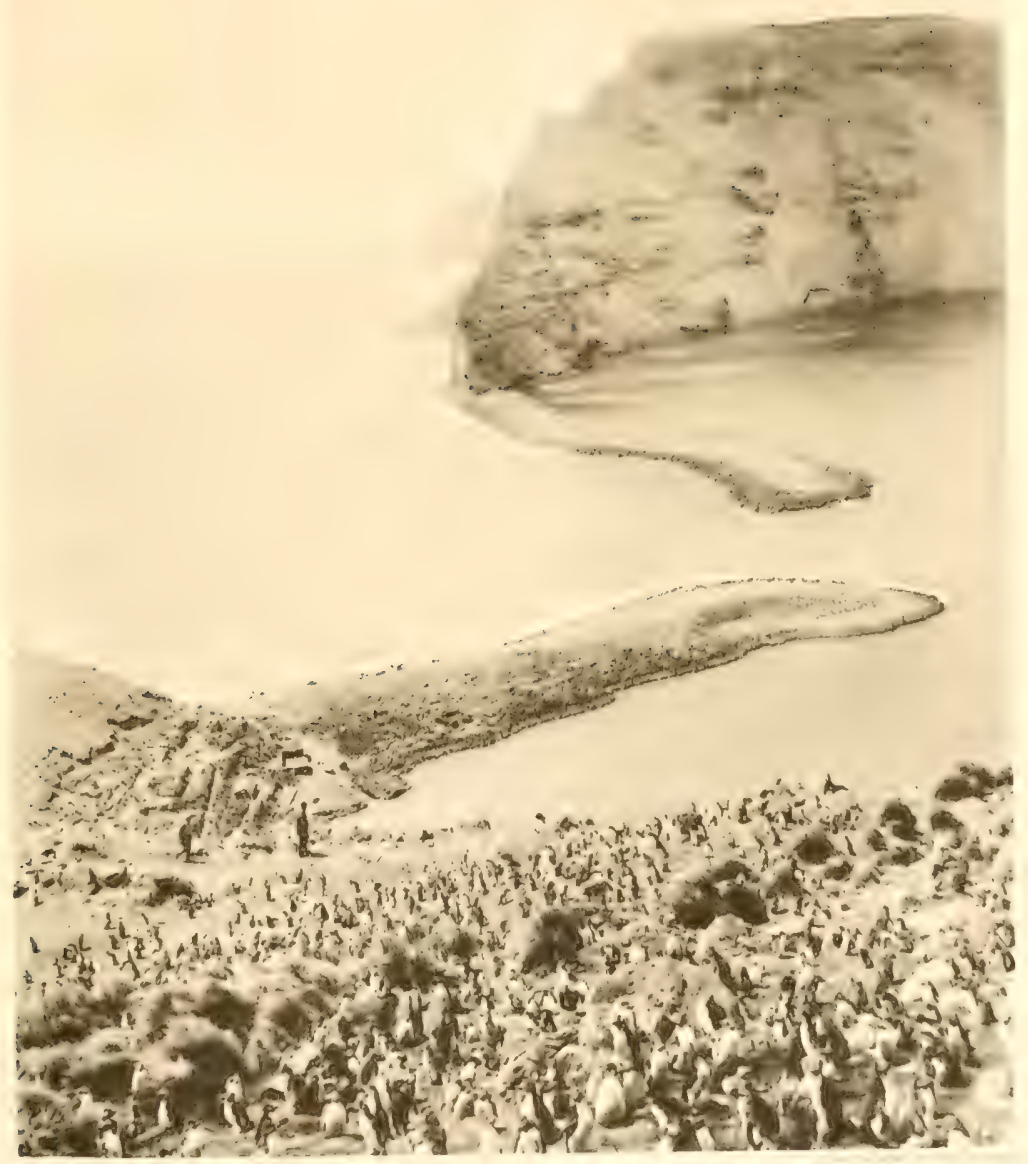

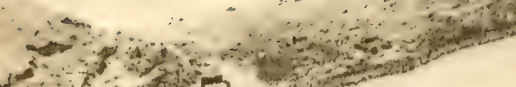





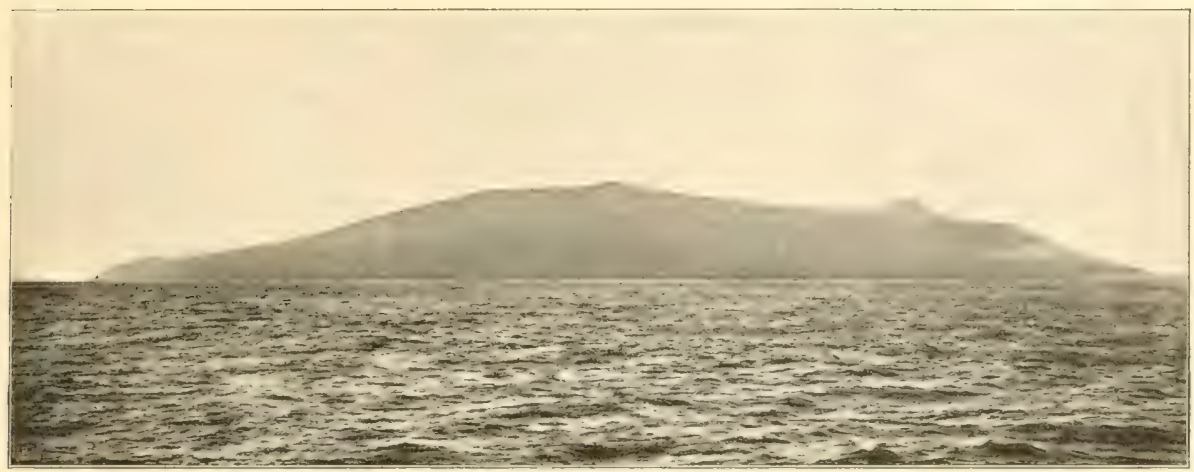

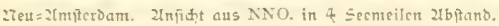

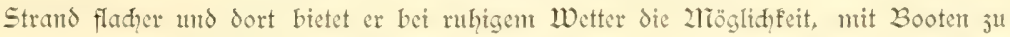
landen. Eier hatte der Konmandant der "Eure" in Jamuar 1895 enten flaggftof erriditen und jugleid ein Proviantdepot anlegen lafien. Zradidem wir etwa 4 See= meilen von der Jnfel entfernt in einer immerhin nod beträhtliden Tiefe von $1465 \mathrm{~m}$ cinen wenig crgebnisreiden Dredfhjug ausgeführt hatten, fuhren wir auf fie ju, um an Der genamten Stelle einen Sandungsveriud mit Booten ju maden. Selbit nidjt in direfter zähe der 2rordofteufte fanden wir bei vorfidtiger 2lnfteuerung troţ der aus=

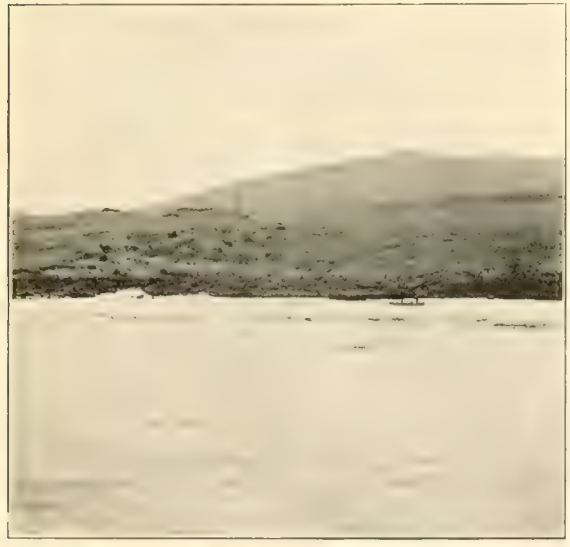

Eandungsfelle auf 2Teu $=21 \mathrm{~m}$ fterdam.

chun, Zlus den Ciefen des weltmeeres. zedehntent Bänfe des Blafentangs günitigen 2lnfergrund. Dic Küfte ift, wie uns die fifduer von St. Paul beriditeter, befonders reich an mohl= fimectenden fijhen und Eanguften, umb diefen limftande durfte es wohl wefentlid juyufdretben fein, dafs die ergiebigen (ธีründe von $\mathfrak{W}_{\text {alen }}$ ไ̆u= figer aufgefud)t werden. Wir faben mehrere derielben oft in geringer Entfermung von dem Sdiffe blajen.

Sdon von weiten waren uns jahlreidhe fdivarze unt rötliḑe Puntete aufgefallen, die über die Länge jers frreut fid berogten und ju um jo mantigfadperen Deutungen 2lula gaben, als in fement Reifeberidite 
des Dorfonmens von größzeren Sandtieren Erwähnung gethan wird. Bei dem 2Täher= fontmen erfantent wir ju unferer l̈lberrafdung, baf es fid un Rinderberden handelte, die, von mäd̦tigen Stieren bewadit, fowohl in der 2Tähe des Strandes, wie aud in den höheren Regionen waideten.

Ein rotbramer 3 ulle hatte neben dem flaggftod poften gefapit, ftarrte den Dampfer an und peitidte ab und ju nit dem Sdweif die flanfen. Zuf cinen fo refpeftabelen Derteidiger der Trifolore gegen germaniphe Eindringlinge waren wir mun freilid nidht gefät. Ilniere beiden beften Sđühen, der erfte Dffijier und der Ziavigations= offijier, bramten darauf, dent Stier anjugreifen. Da - wie vertraulich benterft werden darf - niemand ifnen die Ehre des Dortritts ftreitig maḑte, fo wurde ein Boot

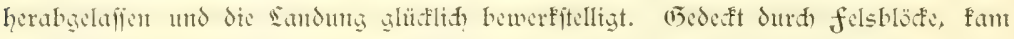
junädyit der erfte Dffijter an den ctwa $100 \mathrm{~m}$ landeinwäts ftehenden Stier heran und

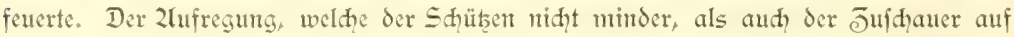
den Dampfer fid bemädhtigt hatte, mag es jujuldqreiben fein, daf cin Dulfanfegel angefdoffen wurde und aud einte jweite Kugel fehl ging. Ziun aber geftaltete fid bic Sage fritifh: mit gefenftem Kopfe ging der Stier jun 2lngriff auf feinen (1) gener vor, mahte aber auf cinen britten Sduf hin Lalt, peifihte die flanfen und trollte dan langfam den längft flüdttg gegangenen Kühen und Kälbern nad).

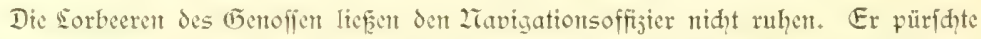

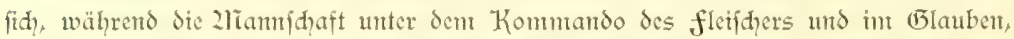
daf der Stier nermuntet fei, an Land ging, an cinen jweiten mädytigen, đdjwarjent Bullew heran, den wir fdion fett faft cinter Stunde beobadtet hatten. Es gelang ifm, gedeft durd cinen felsblod, nit cinem wohlgejiclten Blattfhup das gewaltige Tier niederzuftrecfen. Während cin lautes L Lurrah dem glüfliḑen Shützen danfte, fant der Stier wieder in die 5 b̈he, fdlenderte mit den 5 önern die Eavablöfe hod auf unt

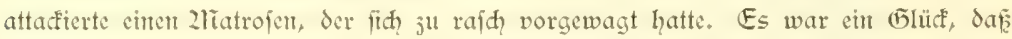
gerade nod in redpten 2roment cin jweiter etwas hod gegangener Sdub das Rüdent= marf verleţte und das. Tier endgültig ju fall brahte.

Ziun ging es an cin funftgeredites Jerlegen, und unverdroffen fịleppte die 2liann= fhaft die jentnerfhweren fleifdntaffen tiber bas gefährlide Terrain an den Strand. Zllgemeine Bewunderung erregte bie Dede mit ifrer langen Shwanjquafte und dem jottigen Delj, nidit minder der Sđäbel mit den fräftigen Lërnern: cine ftolje Jago= trophäe, die freilich ber Kapitän mifstrauifh darauf prifte, ob fie etwa einem vor den Pflug gefpantent Tiere angehört haben möd)te. Wir hatten an nädjiten Tage den fel= tenen und langentbehrten (ธัenue ciner frifden fleifhbrïhe, went aud verfidhert werden

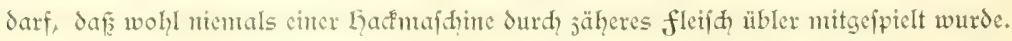

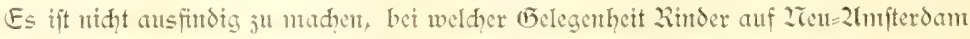
ansgefetst wurden. Der Kommandant der "Eure", weldher 1895 auf der Jnfel landete 


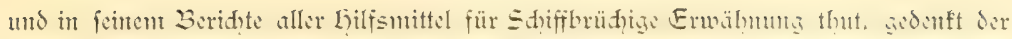
Rinder ebenjomenig wie frühere Befuder. Wenm mat fie in ber 2ubfiḑt ausfetste,

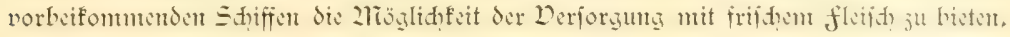

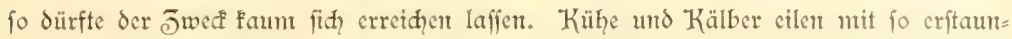

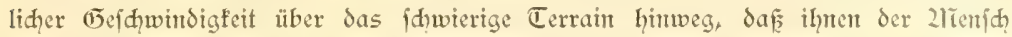
faum ju folgen vermag. für Sdiffibrüdige, welche ohne 6̃ewehre und 2lintition auf der cinfamen Infel feften fuF ju faffen bermögen, find judem die Stiere lebens= gefährlid). Wollte man den z̈rmften unter den 2lrmen frifhes fleifh bieten, fo wäre es beffer gewefen, Sapins und Jiegen ausjujetzen. 2lud dürte es fid empfehlen, in den Segelanweifungen nadjorüclich ju bemerfen, daf man mif Reufen, dic aus dent auf der Jnfel vorhandenen 2haterial gefloditen werden fömten, Sanguften im l̈̈ber= Fluf ju erbeuten vermag.

2rah dent Stiergefedt war die Bahn frei für eine eingehendere Beffditigung dev Jufel. Sie ift bededft mit mädtigen, vulfanifhen Bomben, weldye das Wandern ju cinen auferordentlid mühfeligen und niđat ungefährlichen geftalten. Wie fọwierig Sas Dorwärtsfommen über die Jnfel fid geftaltet, mag folgendes Dorfonmmis er= weifen. 2Unt 24. 2lugujt 1855 fheiterte das englifhe Sdiff "zTeridian" bei zieu= 2umfterdam. Der Befahung gelang es mit Eilfe von Tauen, das fteile Llfer ju cr= flimmen. 2iadh fünf Tagen eridien ein Sdiff, der "zliomouth", und bemerfte die feuerfignale der an sand Befindidien, vermodyte aber nidit wegen der fdweren 3ran=

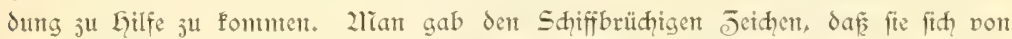
dem Südftrande nad) der ZTordoftfette begeben möd ten, wo Boote fie aufuehmen wür=

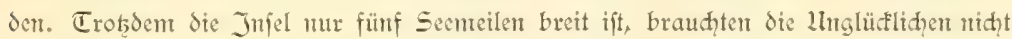
weniger als fedps Tage, um, ofter von allen Qualen des Durites heingefudit, über das (ื)röll und die felsblöde hinweg an den Drt ju gelangen, wo and wir die sanding bewerffelligten.

Überall gähnen fđwwarze Söḑer, in denen leiḑt der fuf́ verfüf; man ift froh, went $a b$ und ju cin Glattes Bafaltbett fiheren Untergrund abgiebt. Läütg hängen

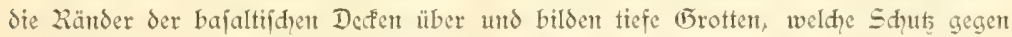
Sie ltrbilden der Witterung gewährets. Die vulfanifhe Befhaffenheit der Jufel ver= rät fith fhon von meitem burd, fdywäryliche Eruptionsfegel, weldhe liberall, fowohl in der Zähye des Strandes wie aud, an den flanfen des hauptécgels, auftreten. ङwei nidit weit von der Sandungsftelle oberhalb des flaggftod's gelegene Eruptionsfrater bildeten das nädfte Jiel unferer Wanderung. Sie bauen fidh aus fhwärjlidon Bont= ben unt Shladen auf, fint fehr regelmäfitg geftaltet und fo wenig jerjeţt, daf fte offenbar auf neuere Zlusbrühe hindeuten.

Der vulfanifhen Eandjhaft wird der Eindrucf ftarrer D̈se unt troftlofer Der= wüjturg dadurd? benomment, daf fie mit eiter üppigen (Frasvezetation, einent wahren 
(5rasmecre, bedeft ift. Dor allen Dingen treten dic aud auf St. Panl vorfonmenden Poa Novarae und Scirpus nodosus in mädtigen Bühthen von halber 2liameshöhe auf. (begen den Strand liberwiegt das ftattlidhe Tufiofgras, die Spartina arundinacea. อై nid̦t mintor aud die auf den Kerguelen verbreitete Lomaria alpina. 2Tamentlín in den geidütsten böblungen jwifhen dent vulfanifhen (5eftein fanden wir wahre Pradt= eremplare von Nephrodium, deffen 2Wedel $1 \frac{1}{2} \mathrm{~m}$ Lhöhe erreidten. 2lnt freudigiten be=

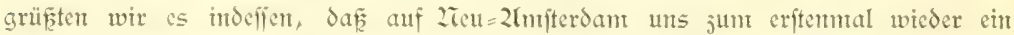
niedriger Baum begegnete, nänliक dic Phylica nitida, welde - mutderbar yenty auf dent cinfant in Suldatlantifhen Decan gelegenen Trif́tan J'2leunha rebit dem

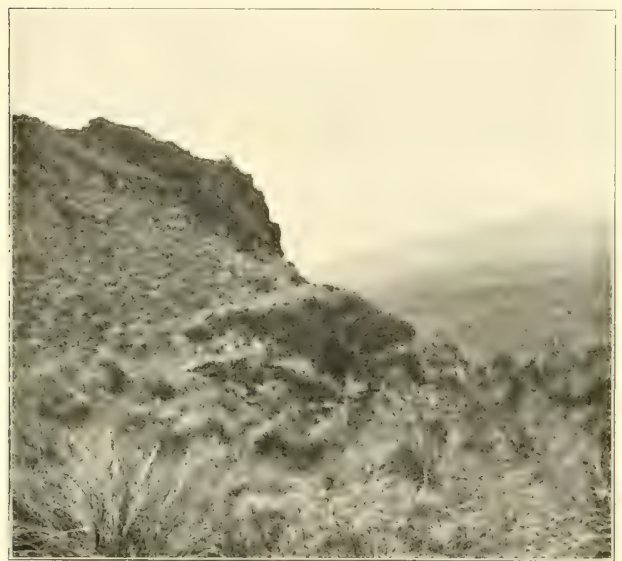

(Schmidt phot.)
23 lid von einem Eruptionsfratet auf ben Biffel.

Stämmudicn ftehen bald perein= jelt, bald treten fie ju fleinen Wälddent jufammen.

Demt aud dic Scenterie in manther Einfidt an bie (bras= region des Kanterunpifs er= imterte, fo fiel es dod, bald auf, ১af mit bunten Blüten ausgeftattete Pflanjen vollftär = Sig fehlen: ein Jeidhen für dic Inpaifung an Windblütigfeit in diejen weltwerlorenen, fturm= Surdibrauften Regionen.

fliefendes Waffer benterf tett wir nirgends in oer $2 \mathrm{~m}=$ gebung. frühere Reifende be= rihten allerdings, daf es an foldem auf der Subfeite der Infel nidht fehlt; das (5edeihen der Kinderherden wäre denn aud unerflärlid), went in Sommer die Waffer= läufe verfiechen würdent.

อ̄wifhen den mädtigen an Strande aufentander getürmten Bajaltblöfen niften Sthopfpinguine, deren Junge wir übrigens and weitab in der Grasregion be= nterftert.

Sie finden reidjlide Zialyrung an den überall fidh anfiedelnden marinen Drganismen.

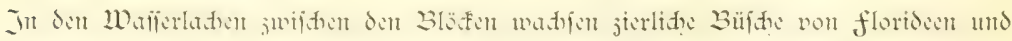
Korallinenalgen, jwifhen denen fid jahlreide fleine Kruiter und Seeigel unthertreiben. Dic 2lnpaffung an dic fhwere Brandung, dic dort meift fteht, jeigte fid namentid bet einer 2lnzahl von Secfternen jehr auffällig dadurd, daf der pentagonale Körper 


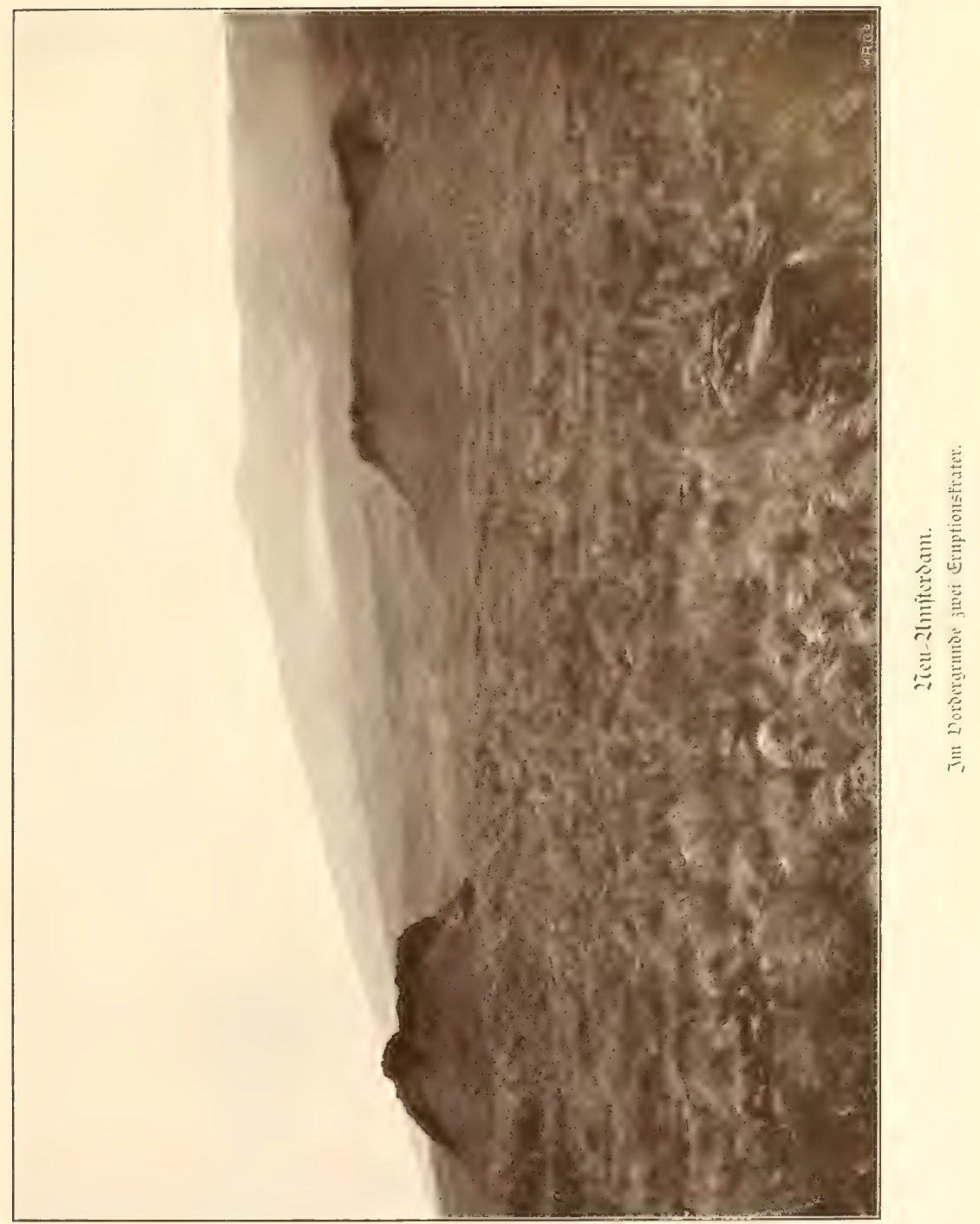




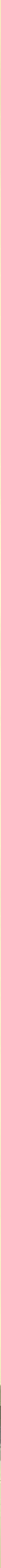


wie mit einer Sangfheibe dem felfen feit anfap uns oft mur nit einigent Kraftanfwand abzetremut werden formte.

Der Decanograph hatte injwifhen das von der "Eure" erriditete Depot, das an

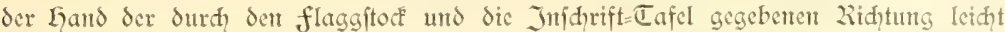

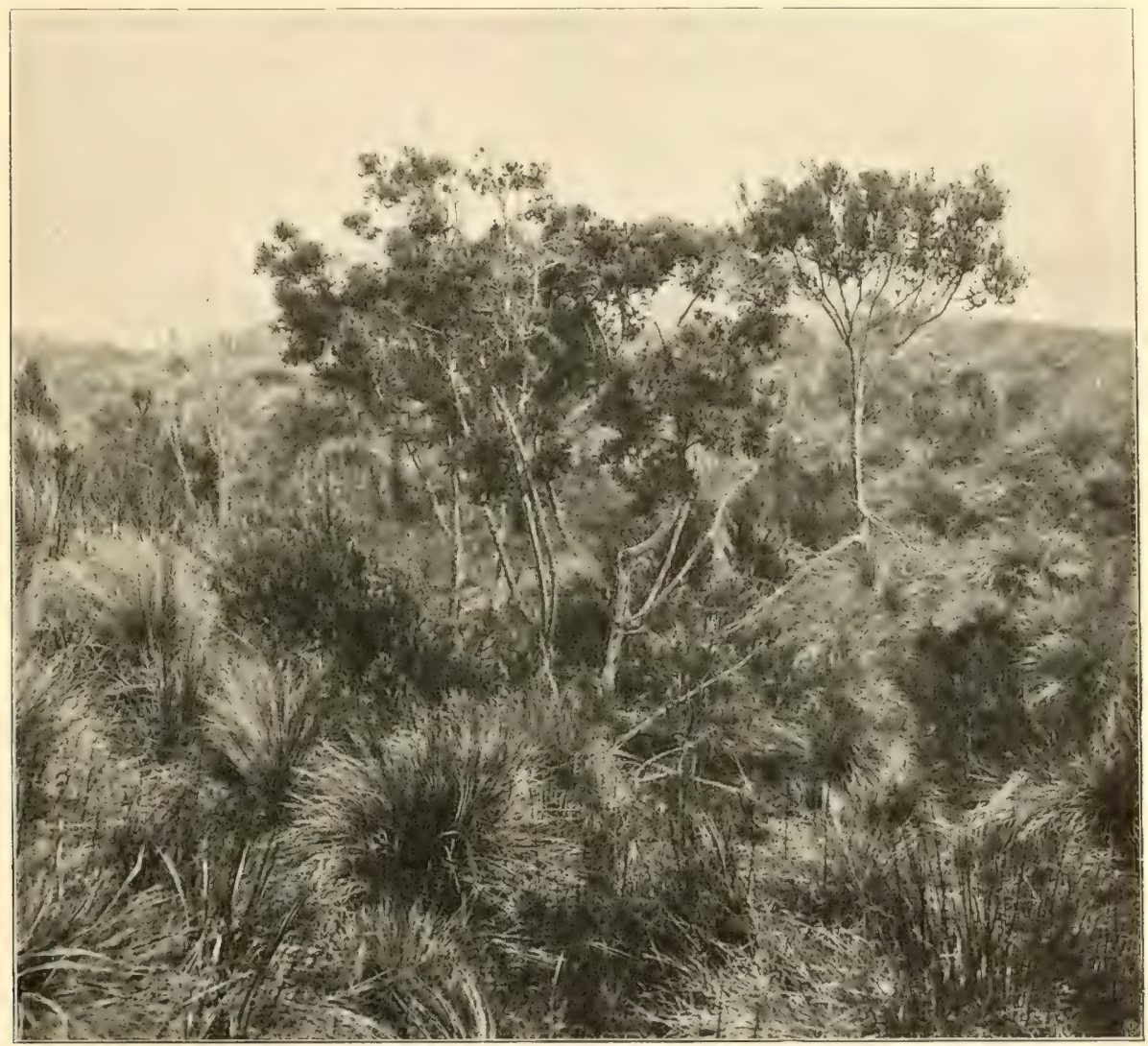

Degetation von Reu $=21$ mfterdant. 23afde Don Poa Novarae uno Scirpus nodosus, Stamme pon Phylica nitida.

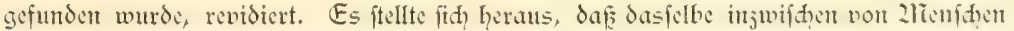
Eefudpt worden war, infofem von den 15 durd die "Eure" nicdergilegten fäfiem mur nod) 8 voll und unberührt daftanden. 
Zadhdent wir im ganjen vier Stundert auf der Infel verbraḑt und juleţ̧t nodh unfere melandholifhen Betraḑtungen über Sdiffistrümmer, die hier angeiḑwentmt worden waren, angeftellt hatten, lidtetent wir nad 52 hr den Znfer. Durd unadifantes

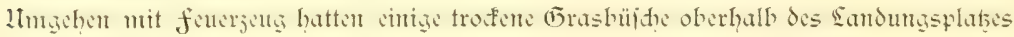
feuer gefaf̧t. Sangam breitete fïh der Savannenbrant gegen den Wind aus, und fo hatten wir von Bord cin ähnlidies Sđanfpiel, wie es einft aud der 2tovara= Expedition guboten wurde: ungeheure Raudtwolfen wurden aufgewirbelt, dic von weitem den Eindrute crwedten, als ob ein vulfanifder 2lusbrud ftattinte.

ziidt weit ab vort dem Eande, in $500 \mathrm{~m}$ Tiefe, verfudter wir es mit cinem

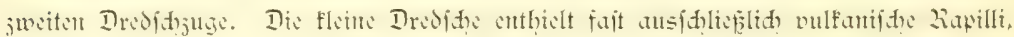
auf denien fidh mu fpärlidie Tiere angefeţt hatten. Der Jerftreuntgsfreis der vul=

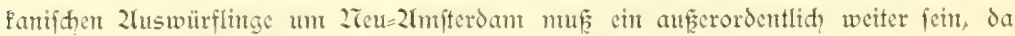
wir now an nädiften Tage in ciner Entfernung von 114 Seentetlen bei einem Dredidy= juge in $2414 \mathrm{~m}$ Tiefe das Trawl mit sentnerifhweren, bafaltiffien Bontben gefüllt fanden.

\section{In jüliden Inotiden (1) cean.}

ZTah Derlaffen von Ziell=2 Tmpterdam wurde der Kurs etwas nordöftlith genommen, um in möglidffte Entfernumg von der Eotumgslinie der "Egerta" ju fonmen. Wir traten in dic Region des Suftorucfimarimums cit, die uns dem bald aud einen Baro= meterftand vort $765 \mathrm{~mm}$ bradte. Zad, den ftürmifden $\mathbb{T}_{\mathrm{agen}}$, dic wir bis ju unferer Infunft vor St. Paul mo Zeu=2tmifterdan durdlebt hatten, entpfanden wir es als cine wahre Wohlthat, als die Some wieder ftündig vom blauen Eimmel figien.

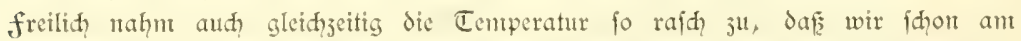

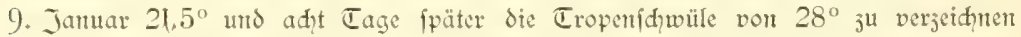
hatten. 2lan riditete bald wieder an Derdect die Dulde ein, verlangte nidht mehr nad einent wärmenden Grog, holte Sommenfegel aus und verbraḑte den 2thend auf dem Derdeff, gefeffelt durh die Pradt des Sternenhimmels. Die zriaghellanwolfen hoben fid deutlid redts von der 2lïldyitra官e $a b$, das fternlofe feld, der fogenamte

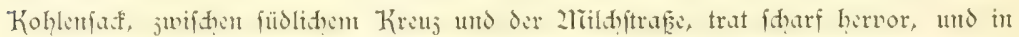
nie gejehener Praht ftrahlte der Drion. In habe es mir nie erflären fömten, wie es eigentitid gefonmen fein mag, dafis man dem an und für fich fo unbedentenden füblichen Kreuz den preis unter den fübliden Sternbildern erteilt; wie unifheinfar nimme es fidh neben jenen aus, die ju fḑauen aud dem auf der nördliḑen Gemifphäre Wohnenden vergönt ift!

Die Dberflähe des im ftromlofen (Sebiete fpiegelglatten zlieeres bedefite fid fidon

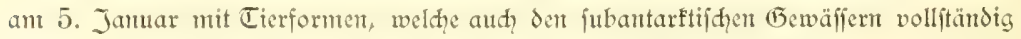
fehlen. Kleinere und gröpere Secblafen oder Phyfalien wiegten fid anmutig auf der 


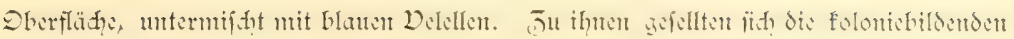

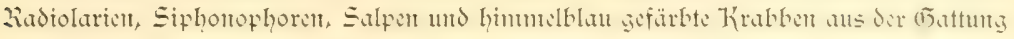
Halicarcinus, welde eifrig die Bordwände des ftillliegenden Sdiffes abjuḑtent. bödfft cigentümlich nabm es fidh aus, als wir am 6. unt 7 . Jammar auf Lumberte von Zlbatroffer fttefen, dic in largen Reihen auf der Dberflädie des 2liceres fafent und erft aufflogert, wern das Sdiffi ihnert allju nahe fam. Es gelang mir, vom 30ote aus vier derfelben ju erlegen, die fid als Dertreter des gelbiduabeligen 2ubatrof (Diomedea chlororhynchus) crwiefen: ein feingejeidnneter Dogel, deffen fạwarze flügel fid fharf von dent weifen Körper abheben und deffen dunfler Sdyrabel in eine rötlid = gelbe firfte ausläuft. Sffenbar veriammeln fid die Dögel in fo didten Sdywämen, unt ihren Brutpläten jujutreben. Shauins=

land fiel es gelegentlid, feines 2lufent= haltes auf der int pacifificher Scean chrjan gelegenen Infel Sayjan auf, dafe sic 2ubatrofie an gantj beftimmten Cagen int did?= ten Sđ̧wärmen anfanten unঠ ihrem Brutgejhäft nahgint= ger. Sidperlid, gaben fid un= pere (belbidnäbler in biefem wintoftillen, fromlofen (5ebiet ein Rendez-vous, von dem aus fie ihre Reije untermehmen.

2Tadidem wir cimmal dicje 2lbatrof Derianmilung paffert hatten, nabm frei= (id) das Dogelleben um das Sdiff aufer:= ordentlid rajih $a b$. Die leţten grauen 2ubatroffi hatten wir bei St. Paul gefełen, den Ieţten Majaqueus

Diomedea chlororhynchus. Der gelbíanâalige Albarrof́. fhoffen wir am 7. Jamuar, und pon da ab nermipten wir oft gar fehr das an= jiehende Treiben der jüßliḑen bejhwingten Bejellihaft.

Während nah dem Derlaffen von 2Teu=2Imiferdam umfere Eotungen durchaus nidit, wie wir anfünglid crmartet hatten, sinc allmäblid junchmende Tiefe ergaben, fondern cin ftark gefaltetes Bodenrelief enthillten, traten wir erit an 11 . Januar unter dem 28. füblidien Breitegrad und 92. öfliden Eätgegrad in cine Region eitt wo über $4000 \mathrm{~m}$, bald aud? über $5000 \mathrm{~m}$ Tiefe gelotet wurden. (1)leidjeitig ergab es fith, daf ber 2reeresboden aus jenem ḑarafteriftifhen "roten Thon" (red clay) gebildet wird, wie er für die grof̣en Tiefen der zliere wämmerer Klimate tppijh ift. Das Sot fhlug oft tief in ihn ein und förderte cine dyofolabebraune, jähe 2liaffe an 
bie Dberfläd)e, weld\}e beim Trodfnen fehr feft wurde und etwas hellere farbe annahm. Sie beftand bisweilen bis ju $94 \%$ aus amrorpher thoniger Subitanj, in weldhe fiff zähne, wentge Kiefelorganismen (Radiolarien und Sđұwanmmadeln) und fleine Brud)=

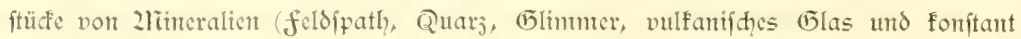
Nantganfömer) cingciprengt waren. Da das 2luftreten des roten Thones in defen Regionen des Judifden Deeants bisher nodh nidgt erwicfen war, fo fei bemerft, da wir thn durd ctwa 10 Breitegrade (bis in die 2rähe der Kof́os= Jurfel) nadhumeifen nermodhter.

2huter dent 27. Breitegrad feţte der ittoifhe Südoft= Paffat cin, der anfänglid nur

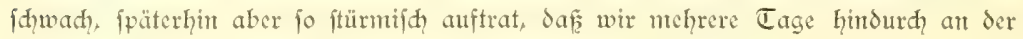
Dornahme feinerer 2tnterfudyungen gehindert wurden.

Der rajde l̈tbergang aus der falten in die warme Region wurde jwar von dent meiftent 2lïitglieden der Expedition ohne 2tubehagen hingenommen, erwies fidh aber verhängrisvoll für cinent uns befonders teuer gewordenen Reifegefährten. Dr. Bađh= mann, umfer 2lrzt, der nod, auf St. Paul und 2teu=2fmfterdam cimer der rüftigften Kletterer war, wurde bei dent Eintritt in das warme (bebiet von cinem fitweren, alten seiden, das nit heftiger 2lïgräne verbunden war, befallen. Wir fahen ihn

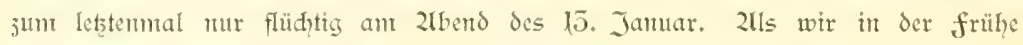
des 14. Feine Kabine öfnen Itefen, lag der Genoffe als Ecidge in Bett.

In thm verloren wir einen ungewöhnlidy befähigten ärjtidyen Berater, der als früherer 2lfiffent an der medijinifhen und dirurgifhen Klinif in Breslau das (Fefamt=

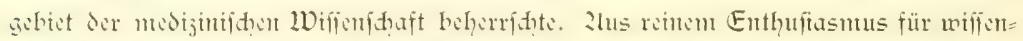
đhaftlidie Bethätigutg gab Dr. Badmatn, der einer angefehenen Roftofer Pro=

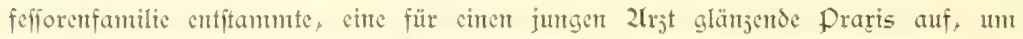
feinen Joealen auf der Erpedition nadjugehen. Dor 2lbgantg derfelben hatte er fid

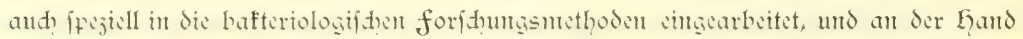
der Ratidgläge von flügge, Kod und fifdper das bafteriologifhe Eaboratorium auf Der "Daldivia" cingerihtet. L̈tber feine Befähigung fpriḑt fïh eint fompetenter Beurtetler, Prof. fifder, folgenderma pen aus: "In Lerrn Dr. Bađ̧mann, der für Sie Expedition als 2lrjt und Bafteriologe berufen war, hatte man einen ebenio be= gabten wie ftrcbianten, im flügge'iden Infittut bafteriologifd vorzüglidh gefdulten forfher gewomten. Wie gut or fidh auf feine 2lufgabe vorbereitet hatte, und mit weldher Sorgfalt er feine 2lusrïftung für die baftertologif he forfdung betrieb, davon

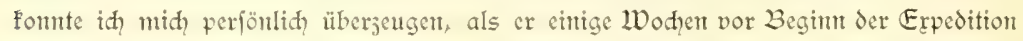
midh in Kiel befudte, unt mit mir das linterfudungsprogramm und die 2lusrüftung

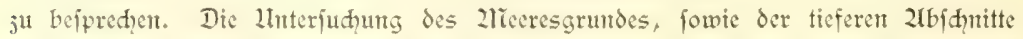
des 2lieeres hatte er fid in erfter Einte zur 2lufgabe gemad̨t; forveit als möglid follte aber aut das Derhalten der Bafterien an der 2lieeresoberfläde, namentlid in den 


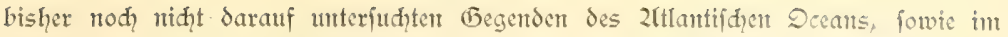

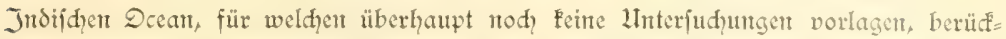
fidhtigt werden. Es war ihm nidht pergömt, das WerÉ, weldhent or bis jum lef̧ten Zlugenbliff feine ganje Kraft gewiomet hatte, zu vollenden."

Wir verdanfen Dr. Badhmann den widhtigen 2raḑweis, dafí fowohl das Tiefent= waffer, wie aud? die (5rumbroben - felbft noth in grofen Tiefen - Bafterien ent= halten. 2lls ihn fpäterhin die häuf̈gen 2lĩalaria=

Recidive der Erpeditionsmitglieder vielfach

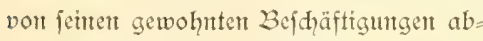
lenften, ftellte er es fid jur 2lufgabe, Sie durch die 2lialariaparapten beding= ten Veränderungen an den $\mathcal{B}$ นutför $=$ perdyen ju ftudieren, weldye infofern von Jntereffe waren, als nady un= ferer 2lbfahrt aus Kanterun dic 2riöglidfeit ciner weiteren 2ra= laria= Infeftion ausgejd]loffen er fdien. Die Gingebung, ntif der er bie Patienten bei iflren fieber= anfällen pflegte, indem ex häufig Sie 2radyt jum Tage mađte, wird Feiner vergeffen, dem ein derar= tiger ärjtidher Berater zur Seite ftand. Es war cin fdwwerer Sdlag für uns, da ș wir diefen talentvollen und bewährten freund miffen muF = tent, Soppelt fichwer, weil wir von nut an das unheimlithe (Ge fühl nidht los wur= den, bei Erfranfungen und Lnglüd'sfällen, dic fid derm aud thatfählidy bald nad pei= nem binicheiden ereigneten, eines medijinifd ge= fhiulten Beraters ju entbehrent. Tief erifhüttert

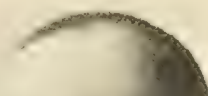
(5) übergaben wir am Sonntag den 15. Jamuar vor verfammelter 2liamidhaft nad 2ln= fpradyen des Seiters und des Kapitäns den in die deutjdye flagge gehüllten und

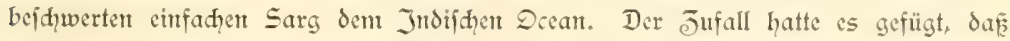
wir gerade an dicfem Tage eine Tiefe von $5911 \mathrm{~m}$, die gröfte, weldye wir überhaupt auf der fahrt loteten, nadpwicjen. So ruht er denn nun auf einent Grunde, der nies mals entweiht werden wird, und deffen Rätjel ju entịf̨leiern fein heifes Beftreben war. 
Der Sildoft=Pafiat, in deffen Gebiet wir ctwa an 11 . Jamuar eintratelt, wehte ungewöbnlid fräftig uno nötigte uns, auf das fifden mit den feineren 2reţen ju verjidyten. Erft als wir ant 17. Jamuar in die Zähe von Kofos= Island gelangten, entid)loffen wir uns, in Ece der Korallenriffe ju dredihen. Sie müffen auferordentlid fteil in die Ticffec abfallen, da wir mur zwei 2lieilen von der gröf̨ten Infel, nämlich Sop Jisland, entfint dic anfihnlide Tite non $215+\mathrm{m}$ loteten. Während des Dredid? juges hatten wir alle 2liufe, den frembartigen Endrud" auf uns wirfen ju laffen, den

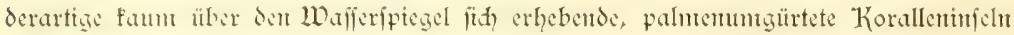

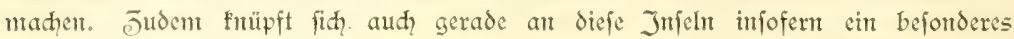
hiftorifdes Intereffe, als fie es gewefen find, auf denen Darwin jwei 2lonate ver= weilte und den Grund zu femen flafifihen Studien über die Korallentffe legte. Wir

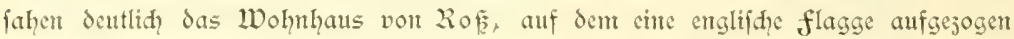
wurde, Fonten uns aber, als das Sdpleppnets ein red̨t flägliḑes Rejultat erjielte,

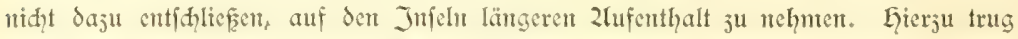

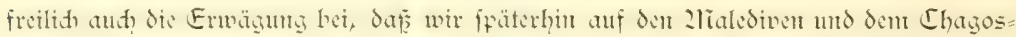
2lrḑipel hiureidyend Ẽelegenheit finden würden, ein Korallenatoll fenten ju Iermen.

Zad Derlaffen von Kofos J Jland änderte fith bald das Wetter. Die Temperatur fiteg fdyon des 2liorgens auf $28^{\circ}$, der Limmel war bedeft und jeitweilig wurde

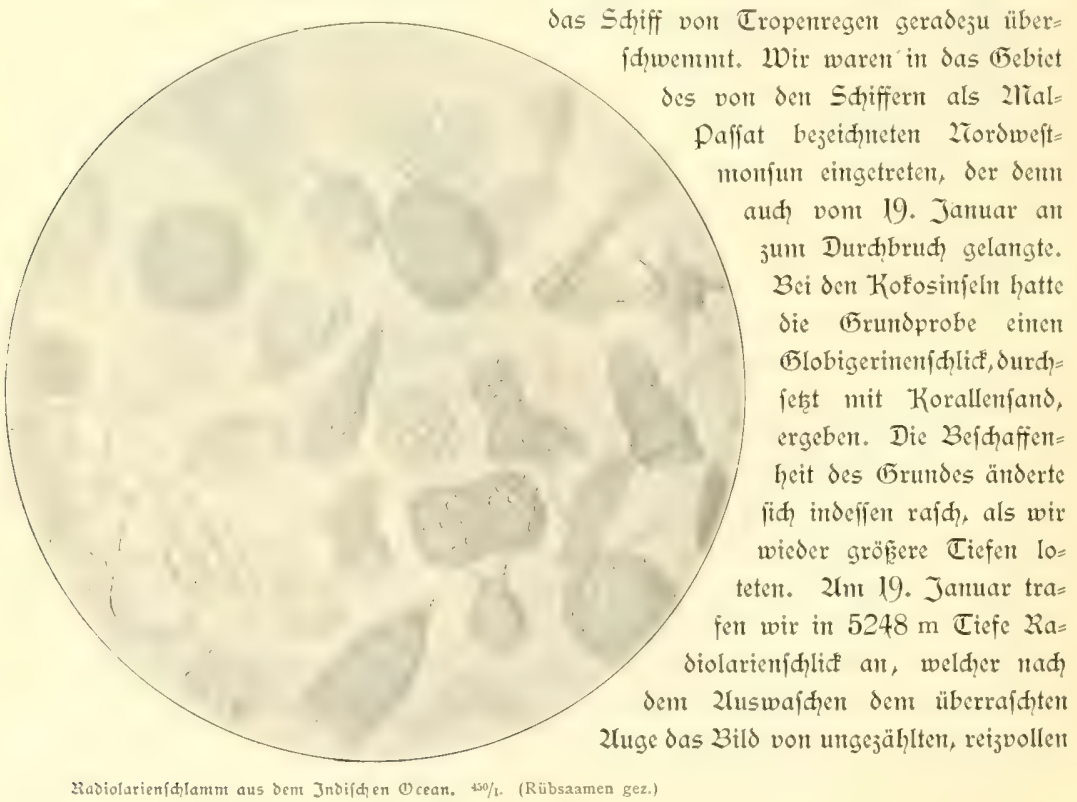




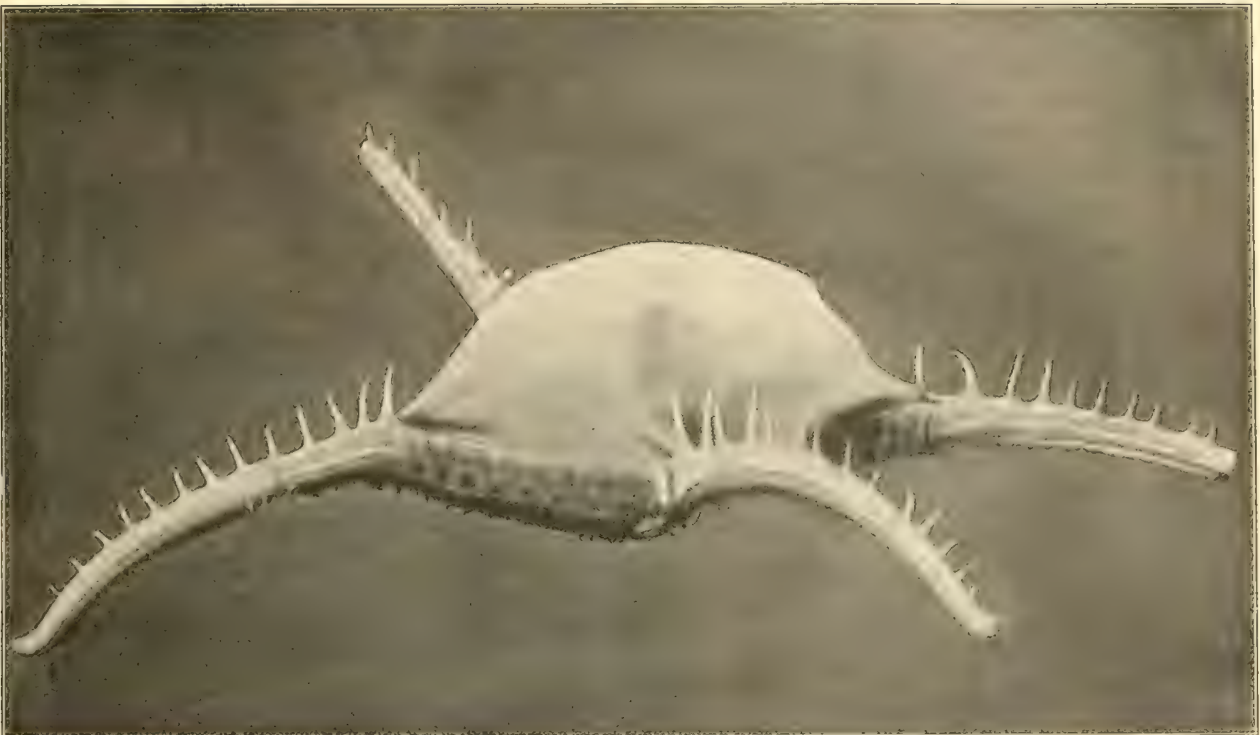

Styracaster $n$, sp, aus $5278 \mathrm{~m}$ Tiefe. Tatủrliche Grö5e.

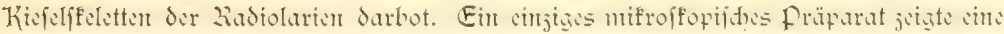

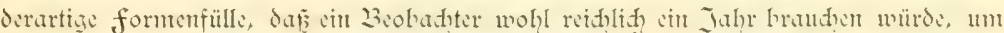
die verfdjiedenen Sfelette ju jeidnnen unt ju ftudieren. Im übrigen beftand die Probe ju $50 \%$ aus zrineralien (2lugit, feldpat, (5limmer), unter denen namentlid die jahl reiden Bimsftemfetsen auffielen, welhe - wie philippi vernmet - von dent Zlusbrud des Krafatau herrühren dürften. 2In Kiefelorganismen enthielt fie $15 \% \%$ und der Reft fetzte fich aus foraminiferen $(6 \%)$ und antorpher thoniger Subftanj jufantnten. Da auf dem roten Thon erfahrungsmäf äuerft menige Drganismen Ieben, fo wurde be=

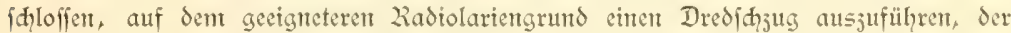
denn aud der tieffte auf der Expedition veranjtaltete war. Es wurden $7000 \mathrm{~m}$ Draht= fabel ausgegeben, und nady 9 Stunten fam nadmittags nad, 5 lthr das 2rets wieder auf. Zuf emen reiden fang war von vornherein nidt ju rednen, dafür aber bieten die Drganisment, welde in fo gewaltiger Tiefe unter eittem Drude von mehr dent 500 2ltmofphären Ieben, bejonderes Intereffe. Das 2Tet enthielt einen der Gattung

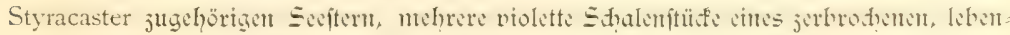
den Seeigels, und aukerdem 5 polypen einer neuen 2 rtt aus der 6attung Cereanthus,

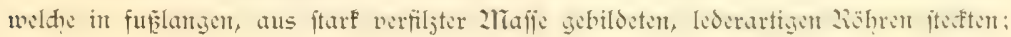




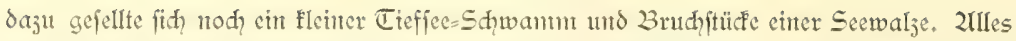
in allen genommen zeigt demmad biefer Befund, daf immerhin aud in fo grozen Tiefen

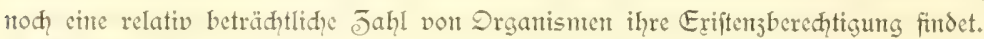

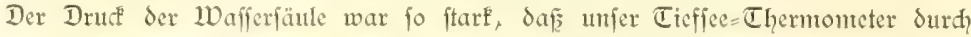
denfelben zertrimmmert wurbe. Erft an nädyten Tage vermodten wir nadjüueifent, daf in einer Tiefe von $4885 \mathrm{~m}$ eine Temperatur von $+1,1^{\circ} \mathrm{C}$. herridht. Eine fo

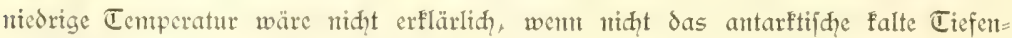
waffer langian femen $W_{e}$ bis in die zrähe des Sunda=2lrdipels fände.

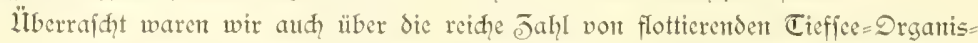
men, die wir gerade in dicjen Regionen erbeuteten. Ein Dertifalneţjug, welḑen wir am 18. Januar bis zu $2500 \mathrm{~m}$ Ticfe ausführten, überifhüttete uns geradeju mit den feltenftent Tieffeeformen, unter denent nidt weniger als vier neue 2lrtent der grofent, blutroten Krebje aus der Gattung Notostomus, cinte blutrote Gnathophausia, fünf

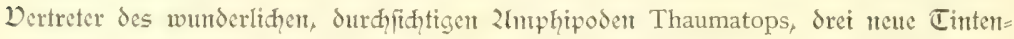

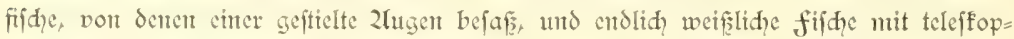

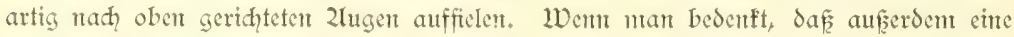

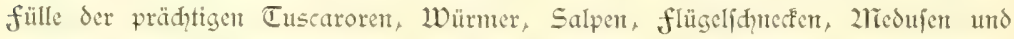
Elemerer Kruffer in diefem cinen Juge enthalten war, fo läpt es fid faum abjehen, weldige Jeit und zliühe deremft darauf verwendet werden wird, um alle diefe föftlidenen, meift neuen formen ju zergliedern und ju befdreiben.

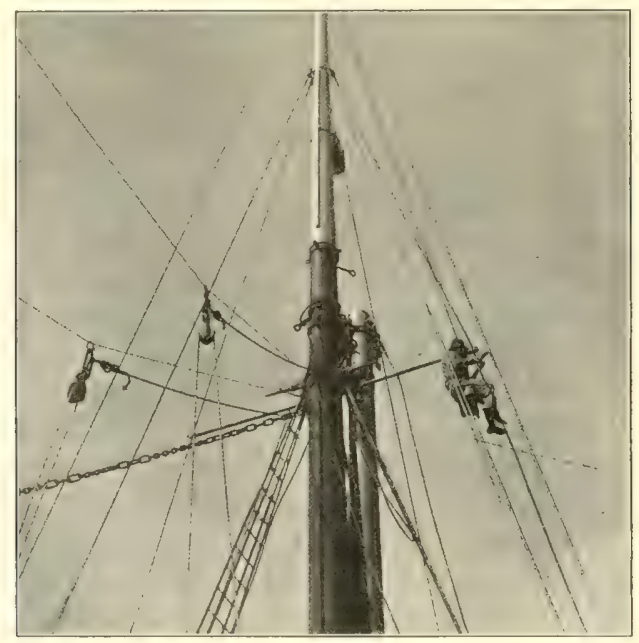




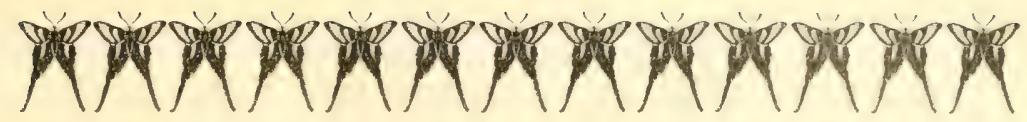

\section{Simtatra.}

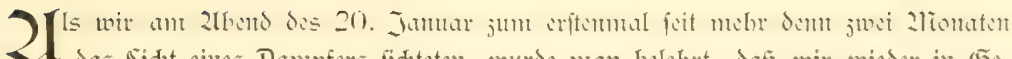

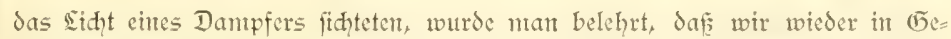
biete gelangten, weldhe weniger veremfant find, als bis bisher befahrenen. Die rafh abnehmende 2lieerestiefe dentete die Zmmäherung an Sumatra an, bas dent aud am 2liorgen des 21. Jamuar in Sidyt fam. Wie cinft bei der 2lnfpeuerung von Diftoria, fo war aud, hier der Gimmel mit fhweren Regenwolfen verhängt, welḑe Eräftige Regenböen entfendeten. Dod, flarte es bald auf und bei dem Dorbeifahren an der

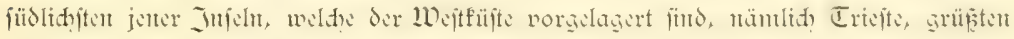
in feitem Duft die hohen Kegel des Barifangebirges. Der Seegang beruhigte fid, und wir traten in en burd Sumatra und die ifm vorgelagerte Jnfelrethe abgegrentes

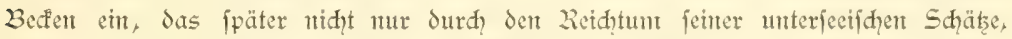

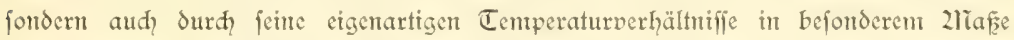
unfer Jntereffe erregen follte. Jn Ser Zaaḑt jum 22. Januar gingen fo fdqwere Regenmaffen nieder, dafi das Waffer eindrang und unferen Salon durdqweidte. Gleid = jeitig wurde bet ftürmifacm 2Tordweft=21Tonfun die Suft fo unfiftig, daf in der 2raḑt Signale mit der Dampfpfeife gegeben werden muf̈ten. (5)gen 2liorgen flarte es auf und min bot fid eine Scenerie dar, an der man mit fajt trunfentent Blicf haftete. In dret bis vier Etagen baut fich das Kyod,land von Sumatra auf, überragt von in violettem Dufte fdimmernden Dulfanfegeln. Dic Thäler waren durd Wolfen= făleter verhängt, welḑe den gewaltigen Ltrwald in ftändige fenditigfeit baden. Eine

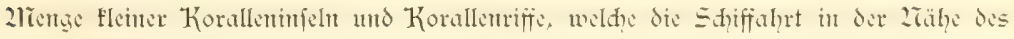
Sandes 3 u einer redit gefahrvollen geftalten, ift dem feftlande vorgelagert. Sie alle fint, wie das Vorland, diđ̧t bewaldet und an ihrent Saunte mit Palnten umgürtet, welche ihre Wipfel nad, dent 2reere neigen. 2lan wird nidgt milde, diefe föftlidgent, bald niedrigen, bald zu domförmigen Kuppen fid, erkebenden Jufeldyen ju nuftem, Sie nad dem treffenden Dergleide cines forfdiutgsreifendent wie fdwimmende Blumen= förbe fid ansnehmen. Das Land fheint längs des füdichen Zlbfalls ber Barifanfette niḑt diḑt bevöleert, unt erft bei der 2lmtäheruntg an Padang bemerft mant deutlidhere Spuren menfhlither Thätigfeit. 
2iadimittags $11 \mathrm{~m} 5 \mathrm{Hhr}$ ant Sonntag den 22. Januar gingen wir in dem anntutigen Enmahafen der Kontinginne= $B$ at vor 2lnfer. Die Kafenanlagen wurden erft 1892 be endet und dent Derfehr übergeben. 2In Stelle der offenen Reede vor Padang bei dent

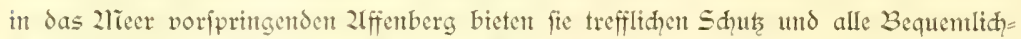
feiten für rafdes Söfden der Sadung. Durḑ dic Bahnverbindung mit padang und den Kohlenfeldern der Foḑlande gieft zudem der Emmahafen dent natürliḑen 2fus= gangspunft für chir fo rethes Ginterland $a b$, da ber 2luffdiwung des transoceanifinen Dampferverfehrs niḑt ausblieb. Seit dem Begimm des Sommers 1900 laufen die

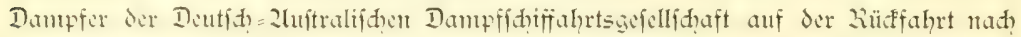
Deutifhland monatlich cinmal padang an und fonfurrieren nit den holländilḑen

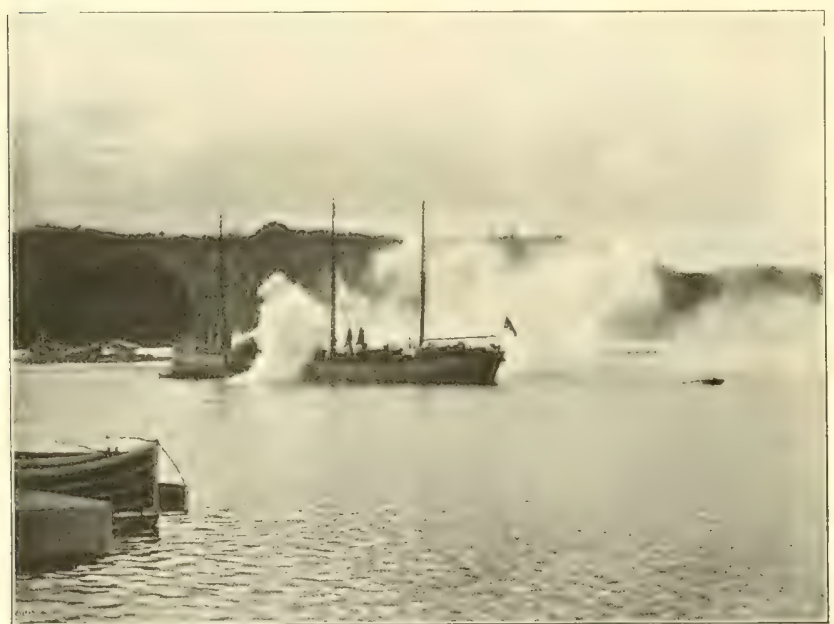

5. 27. 5. "3uffard" im Enmahafen Salut \{chiefeno.
Dampfergefell= idhafter, welche bisher allein dert DerFehr mit $\mathfrak{W}_{\text {eft }}=\mathbf{S} \mathfrak{u}=$ matra vermit= telter.

Wir haben adt Tage in dem ftillen und io) llifiden Em mahafen vor Zlnfer gelegen und ihn mit feiner malert= fdyen Ltmrah = mung faft licb gewomret, ob=

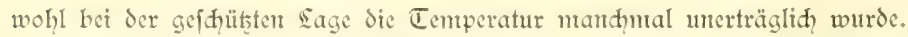

Die Körtigin=Bai, deren nordweftliḑe Edé jum Eafen ungewandelt wurde, wird in weitent Galbfreis vort bis jum Strande bewaldeten Löhenjügen umgeben. Sic tragent den Eharafter ciner alten Kraterumwallung unt bieten Sdqut gegen öfliḑe, nördliḑe und nordweflliţe Winde. Ein $898 \mathrm{~m}$ Ianger neu aufgeführter Dantm geht von dem Ziordweftitrande der $\mathcal{B}$ at aus und dient als Wellenbrecher gegen den fül= weftlidfen und fübliḑen Secgang. Bet der fundamentientug für die Quaimtauen, das Stationsgebände und die grof̧en, für Zlufnahme der Llmbilien=Kohlen beftintmen Epeider ftefe man infofem anf erheblide Sdiwierigfeiten, als die im Liordweften den

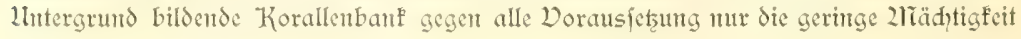




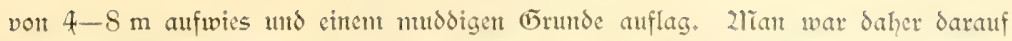

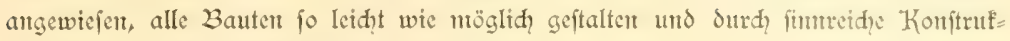
tionen für die nötige Stabilität Sorge $j u$ tragen.

Sebende Korallenitöte, jwijhen denten ein ganjes Leer von dunflen Secigelu, See= fternen und holothurien fich unhertreibt, haben fid überall auf Sem Boden angefedelt.

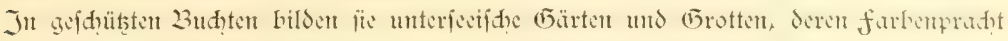
aud die glühendfte phantafie in 1 Dorten nidit wiederjugeben vermödte.

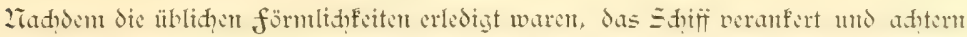
an einer Boje vertäut Iag, nuţte iक mit dem Derwalter nod den leţten 2 Ubendjug naḩ padang aus, um, went möglidh, die von 2lllen erjebnten 2raḑriḑten aus der

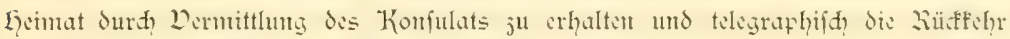
der "Daldivia" aus dem antarftifhen 2licere ju meldert.

In dent fieben Kilometer von dem Emmahafen entfernten Padang trafen wir auf unfern Konful, Gerru Sdilld, dem bereits die 2lnfunft der "Daldivia" gemeldet worden war, holten dret fifwere Säte voll Brieffhaften $a b$, und Ictifeten dant der liebens= würdigen Finladung jum 2lbentontahl in feitent Lqaufe folge. Sängit war die 2Tadyt hereingebrohent, und man fant fich faft wie in ein 2lïrdhenland verfetst vor, deffen ङauber nid, mur der Konjul, fondern aud, alle anderen feit langer Jett anfäfitgent Sandsleute mit beredten Worten fhilderten. 2lis wir bam in der Tropennaht, von einem malayifhen Kutiher geleitet, Surd, dic diḑten Palment= und Bambusgebuifhe bei blendendem 2lionofhein nah den Lafen fuhren, vorbei an den laufdigen, im

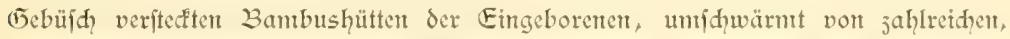
posphorescierenden (5)lühwürmḑen, da wirfte dies alles auf dic durd lange fahrt be= fheiden Gewordenen fo eit, dafe man fid mand?mal fragte, ob es Wirflidifeit oder cin Traum aus 1001 2radyt fei. Dbwohl wir fpät an 3ord famen, waren dod, alle

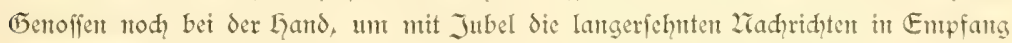
ju nehmen.

Der näd)ite Tag galt den Befuhen bei den holländifhen Behörden, die fowohl durd)

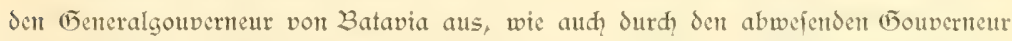
von Sumatras Wefteüte angewiejen waren, uns mit Rat und That jur Sctte ju ftehen. Es hätte deffen freilid nidht erft bedurft: wir wurden ohnehin fo warm auf= genommen, daf fith rafh ein (E)fühl fidheren Behagens einftellte. - In erfter Sintic

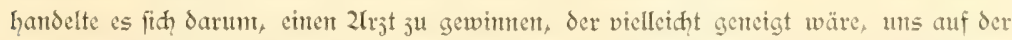
weiteren fahrt ju begleiten. Ja war nidht wenig erfreut, als chef des holländifhen Santiätswejens auf Sumatra cinen Sdilefier, Dberit Kubnert, anjutreffen. Er tele= graphierte fofort nad? Batavia, um einen focben beurlaubten holländifकen 2lïlitärarjt jur Teilnahme an der Expedition ju bewegett; leider war derfelbe an Tage vor miferer 
Zlnfunft abgereift. Wix muten uns in das Lnvermeidlide fügen und uns mit dem Gedanfen vertrant maden, daf es erft in Ceylon gelingen würde, einen Erjats für Dr. Badimann ३all crhaltert.

\section{paball g.}

Padang weift durdiaus dent typifdyen Charafter cinter faft endlos ausgedehnten Tropenftadt auf: breite, vorzügltch gehaltene fabrwege durdfreujen es nad, allen 2idfuntgen, und went fie aud biswetlen cinte lange Peripeftive geftatten, fo verliert fith dod, alles in Einjelheiten, die mu fo melye feffeln, je unvermittelter man ihnen gegenübertritt. Immerhin fällt es niđht fạwer, in der von einem buntfhecfigen Dölfer= gemif bewohnten Stadt jene Diertel herausjufinden, welde teils durd die natülidien Jufuhrwege für den Gandel, teils Jurd dic nationalen Eigentümlid̨etten threr $\mathcal{B}_{e}=$ wohner cir hejonberes (E)epräge erhalten.

Padang jählt nad, den mir durd Konful Edjillo jutr Derfügung gejtelten meneren Emrittelungen ctwa 53000 Einwohner. Sie verteilen fỉh der 2iationalität nach auf 1900 Enropäer (das 2lïtltär und dic Indo= Europäer cingejdloffen), 26000 ein= geborene 2lialayen, 4000 Ehinejen, 1000 2rraber uno Jnder. Der Reft entfällt auf Eingehorene Ser Infel Zitas, weldhe als fleifige Kulis, Jimmerleute und Gärtner von den Europäern den 2lialayen vorgejogen werden. Das Centrum für den Gandel liegt ant redien llfer des Padangfuffes. Gier trifft man auf die Kontore und sagerräume für die (5)rof̧handungshäufer, auf die Konfulate, die veridicdenen Bureaus der Re= gicrung und auf die unfänglihen (5ouvernements=Kaffec=sagerhäufer. Den natür=

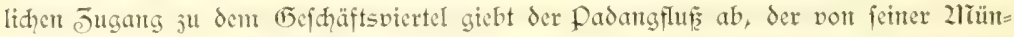

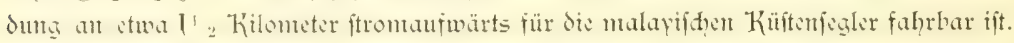
Unt die malerifden prau's, weldhe ju beiden Seiten des fluffes did̨tgedrängt veranfert

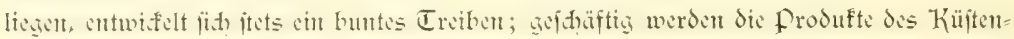

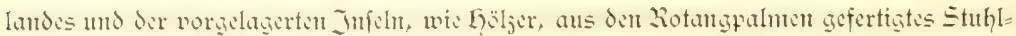
robr, Larje, Copra, Kofosmüfe, Reis, frühte uto Ecfligel durd Kulis ausgeladen.

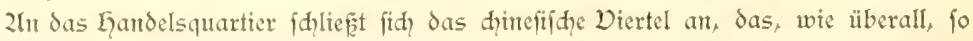
aud hier die nationalen Eigentüntidfeiten der langbejopften Jufafien wiederipiegelt. Dor ihren aus Stein crrihteten und wegen den häufigen Erdbeben nur eirftöctig gehaltenen நäufern breiten dic dimefifhen Gändler in gefdmadvoller 2lrordmung

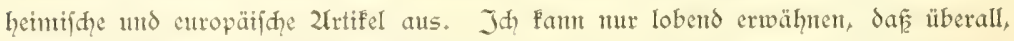

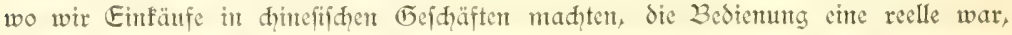
unt die Junorfommenheit der Chinejen nidits jut wünjhen übrig lief. Sie werden dent aud, wie man mir verficherte, im allgentemen nidit als unlicbfante Eindringlinge

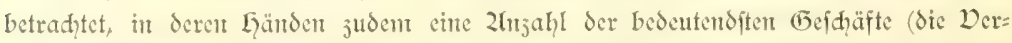
proviantierung der "Daldivia" hatte gleidfalls en Chinefe übernommen) fidh befindet. 
In Begleitung des Konfuls madite ith eines 2lbends dem angefehenten Dertreter der

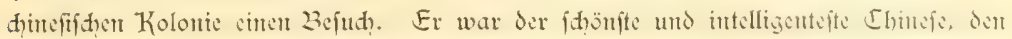
id je gejehen habe. 2lit vollendeter Ritterlidfeit maḑte er die Loments des Laujes.

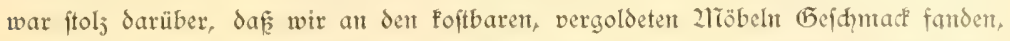
und jeigte uns mit befonderem Wohlgefallen fein praditvoll gefdnitztes fimmelbett. Zitht minder reich ift der Sdymud in dem dineitiden Tempel, in weldhent mant den frembling mit groper Juoorfommenbeit aufnimmt und durd? eine Taffe delifaten, volt einem Priefter gereiditen Thee erquidf. 2ln demt 2lltar waren in den eindring=

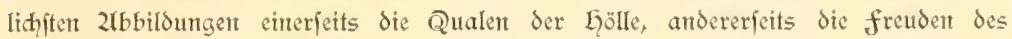
Paradiefes dargeftellt: die erfteren unteriheiden fid mur wenig von den abjhrecfenden

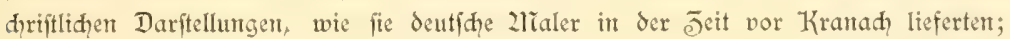
die leţteren feffeln dagegen oft durd, fmnige 2luffafiung. Gern wante idy den Blif von den dargeftellten Graufamfeiten $a \mathfrak{b}$ ju jerren Bildhen, wo ein holdes 2liägdelein chnem Chinejen im Paradiefe den hödjten Dienft leiftet, inden es ihn mit einem fäher die 2liosquitos wegwedelt.

Zeben angenthmen Eindrïcent bleiben freilid aud dic minder anjiehenden dem frembling in dem dinefifden Kampong nidit exfpart. Staub und 2usdünftungen -

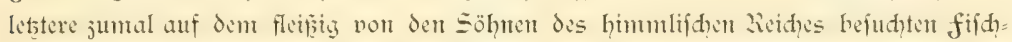
und (Genüfemarft - geftalten den 2lufenthalt ju einem niḑt gerade aromatifhen, und die Verfaufsläben vot Dpium, nebent denen dasfelbe gerauht wird, eröffinen den Ein= blic in die fhlimmiten Eafterhöhlen der 2lienjhbett. Ja werde den widrigen Ein=

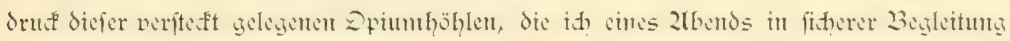
auffuchte, fo bald nidit vergeffer.

Don dem dintefifden Diertel führt eine breite Strape längs dev Werfifätten der

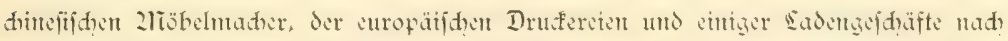
dent europäti̧hen Stadtteil. Er trägt den Charafter einer weit ausgedehnten und wohl= gepflizgten farflandfouft. 23rite, sutgehalteme Shauffen durtfrengen ihn, auf heiden Seiten von Kofospalmen, tropifąen Baumgruppen und den eingelnftehenden Wolnn= häufern untäumt. Der praftifhe Sinn des Golländers bethätigt fith aud in der den tropifhen Derhältniffen Redpuntg tragenden Bauart der Läuper. Sie find fajt durh = weg aus Lloljwerf erridhtet, ftehen eimen Zlieter hod über dent Boden auf cinge= rammiten Pfählen und haben ein mit den Blättern der 2ltap=Palme gedecftes Dah. Da die Suft unter dicfen Pfablbanten fret hindurdftretht, Glethen die Wolnuräune trots des feudten Küftenflimas und der häufigen Tropenregen trocken und dod and wieder

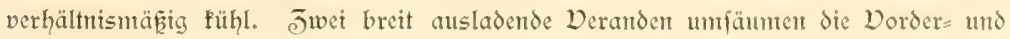
Einterfront; die vordere dient als Empfangsraum, in dem nad Sonnenuntergantg von F-8 Hhr die Befudhe abgeftattet werden; die hintere benutzt man mit Dorlicbe als

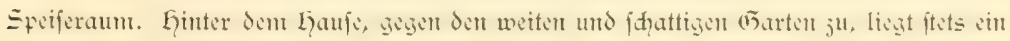




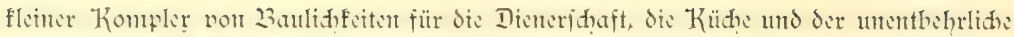
3aderaum. Eine Cifterne enthält das fühle 2 affer, mit demt man fid des 21torgens unt 2 fhends aus Shöpfeiment begieß̧t. In den Wohnräunten fdaltet, umgebent vont einer faft allju zahlreiden Dieneridaft, bie Dante des Faujes, die 2tonja, int ihrer fleidjanten,

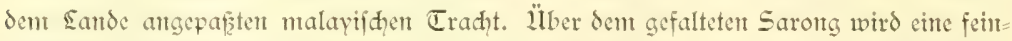

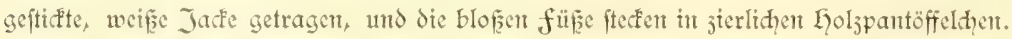
Zur bei 2lusgängen vertaufden die Danten die hemifhe Traḑt mit der europäifden.

Int centrum des europäifhen Stadttetls wurden umfängliđhe frete plär̨e angelegt, die mit ihren Rafenflädien und anmutigen 2lusbliden nad den bewaldeten Gïhen eimen

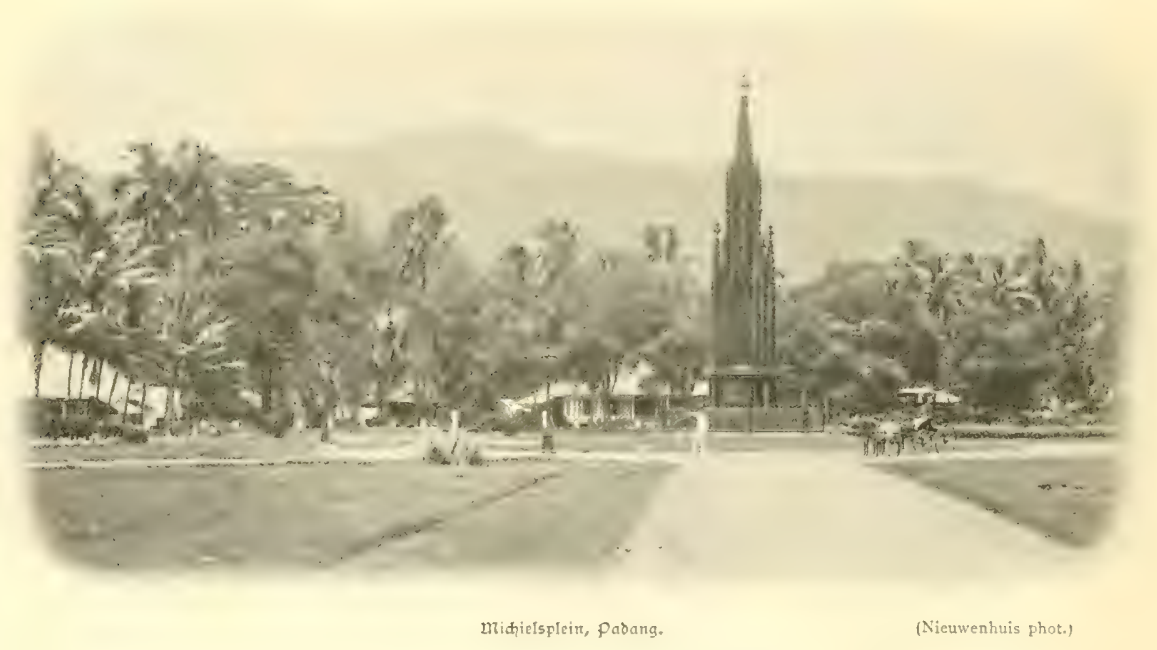

frieblifhent und ftillen Eindut madien. Sic werden umfäamt von Klubhäujem, treff=

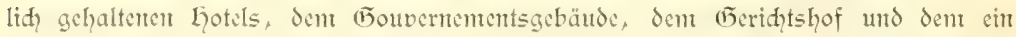

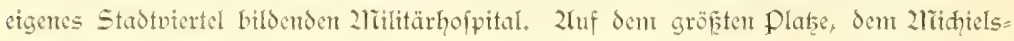
plein, erbebt fich ein gotifdes zliomument jur Erimterung an den int hinterindifdent 2lrdipel hod in Ehren ftehenten Genteral 2lithicls, dent Eroberer der Bovenlande und der Jufel Bali.

Wer endidh fent nout dent Setricbe der Stabt fid, ergehen will, findet auf dem

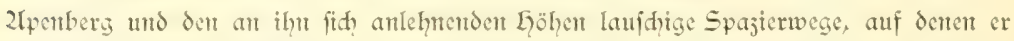

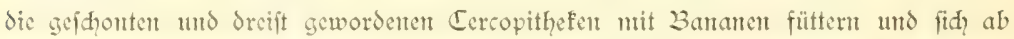
und ju an den malerijden Duthblifen erfreuen mag. Dem paffionierten Jäger bietet 
fith die Gelegenthit, nahe der Stadt in den jumpfigen, mit Bambus, 2tipa= Palmen unt Pandanus beftandenen Diffibten mannigfaltige Dögel und Wildjąmeine (Sus vittatus) zu erjagen.

Wer das malerifhe Durdecitander der verfhiedenartigen in padang antäfïgen Dölfertypen genief̧en will, der verfäume nidht, an chen Zliarftage den Pajar (2larft) jt befudien. Es ift ein groß̧er, nit jahllofen, in regelmäfïgen Reihen ftehenden Buden bedecfter Plat, an deffen Peripherie fich die Junft der (5old = und Silberfduriede ant= geffedelt hat. Jhre filigranarbeiten haben wir namentlid, nod? in Sen Lodflanden

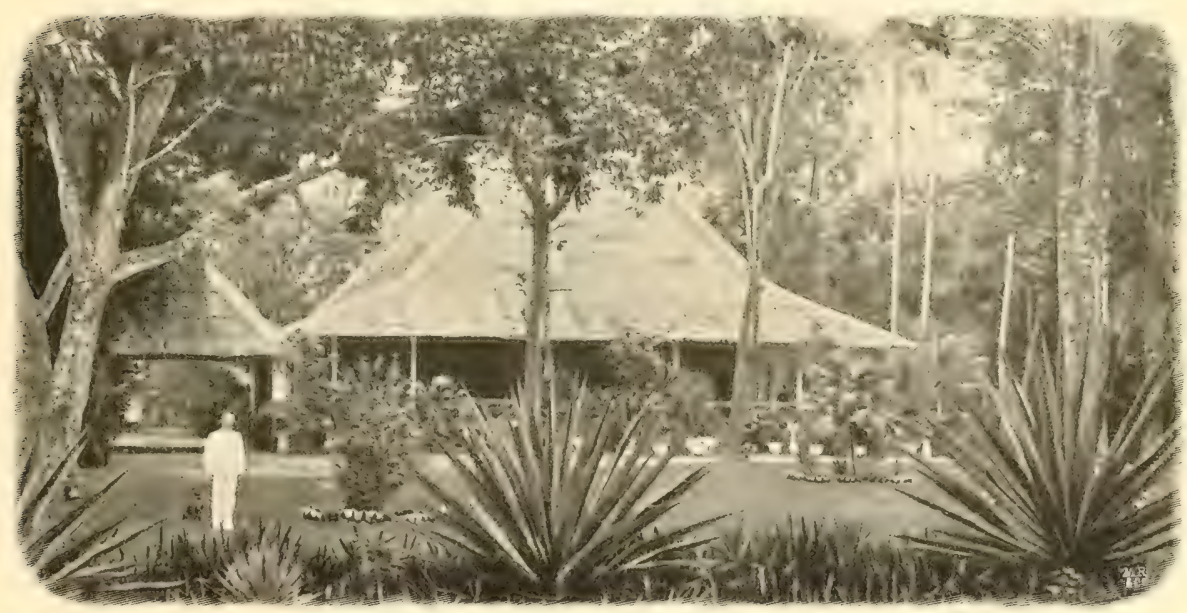

Wohnhas des deutiden Conjuls 3. 5hilo

auf dem Pajar von fort be Kod ju bewurdern (5elegenheit gefunden. Don allen Seiten fommen fhon in der frühe dic von dent funtrantiden Büffel, dem Karbau, gejogenten Wagen herbei, die ju einem faft undurdibringliden Wagenparf jufammen= geftant werder. Eifrig ift man damit bejhäftigt, dic auf ihnen anfgeftapelten Sdiäţe ausjuladen und fie gejdyntacfvoll bald auf der Erde, bald it den 3 uden ausjubrettent.

In langen Reihen liegen da die verif̧icdenen (5)müfearten neben den föftlidgen Tropenfrüdten, weldhe das Padang' fhe Ziederland erjengt. Bananen, 2huatas, Citronen, Drangen, die gelben früdte der 2liangas (Mangifera indica) und der 2helonenbäume (Carica papaya) werden neben den durḑaus auf bas hinterindifhe (5)biet befdränften

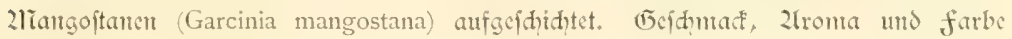


vereinigen fidh, um den 2liangoftan mit feiner dunfelroten Shale, die fed!s bis aht

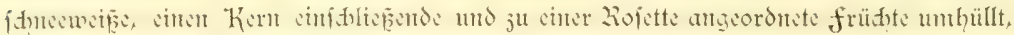
ju ciner der föflidfiten (5aben aus pontonas füllhorn jut geftalten. Daneben liegen in

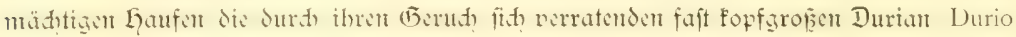
Zibethinus). L̈̈ber faum cine fruḑt geht das 2trteil weiter auseinander: währent die Eiten, fo j. B. Wallace, fie als das Köftlidjte rübmen, was der hinterindifhe 2lrdipel crzeugt, und den rahmartigen, von ciner derben, grünlid, =grauen, in ipitzen Warjen vorfpringenden Sḑale umifhlofienen Inhalt jeder anderen fruđ̆t vorjiehent, fömmen die

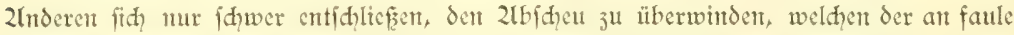

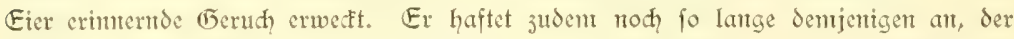

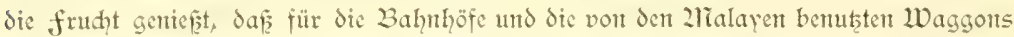

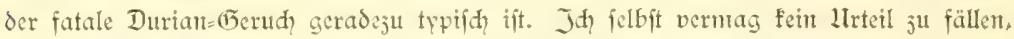

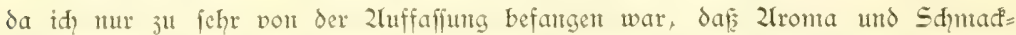
haftigfeit bei früdhten untrembar mitchander verbundent fein follten. Daneben fallen fpantifher Pfeffer, die langgeftreften Knollen der Bataten, und die dem Betclfauen Sienenden zrïffe der Pinangpalme (Areca Catechu) dem Befucher auf. Dem Betel=

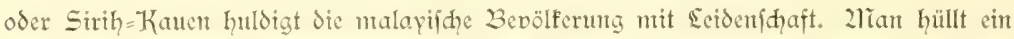
Stüf( der 2tuf nebit gebramntem Kalf in das 23latt des 23 etelpfeffers (Piper betel) und

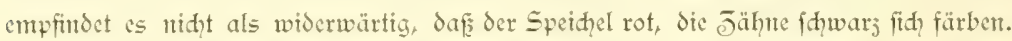

Saljhändler haben ifye Stände neben dent fif

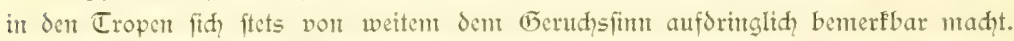
Da⿸厃㔾 neben dent fleifhmarfte fliegende Küdyen erridqtet find, an denen die Ein= geborentent dent Reis mit Gäntoen effen, liegt in der Vratur der Sadhe.

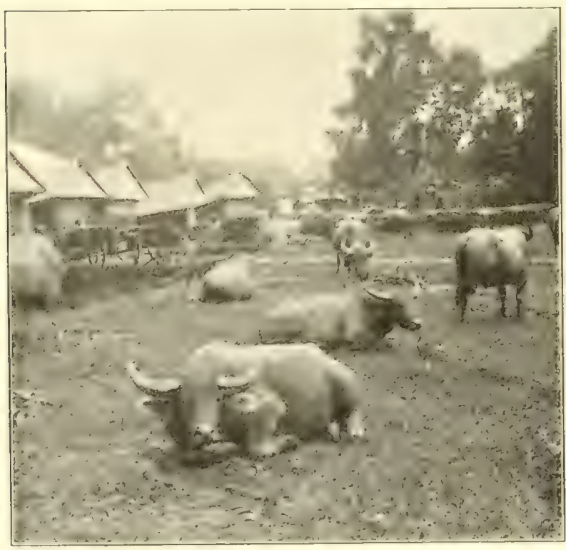

Karbau (fort of Kodf)

Bejonters anjehend find die lan= gen Stände, itt denen dic oft mit fünftlevifdem (5efdmad hergeftellten fledtwaren $3 u$ billigen Preijen aus= geboten werder. I $h$ fonte der $\mathcal{D e r}=$ juchung nidit widerftehen, midh mit L)üten, Korbwaren und mit den reij= vollent flemen Dogelbauern ju bela= den, in denen der vogelliebende 2ria= laye jeine Tauben oder den von ihm hod)gefwätsten, die Klangfarbe der menidiliden Spradie täulhend nah = ahmende 23co (Eulabes religiosa) über

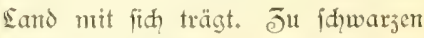
Bündeln aufgeftapelt liegt das vor= 
jüglid, haltbare Taumerf, weldhes aus der כựerpalme (Arenga saccharifera) hergeftellt wird; es find dunfle fajen, von den 2lialayen Joju ge= namnt, weldhe jwifhen den unteren Blatticheiden und dem Stamme fid finden unt in dent Godtlanden wegen ihrer Widerftandsfähigheit mit Dor= liebe aud zunt Dectert der Dädyer bes nuţt werdert.

Bei der allgemein verbreiteten Eeidenfalaft des Raudans trifft man auf jablreidue Stände mit Sigarettert= tabak, der in 3 lätter der Ztipa=Palme eingefd̨lagen wird. 2iamentlid in den Koḑlanden fällt es nidł̨ făber,

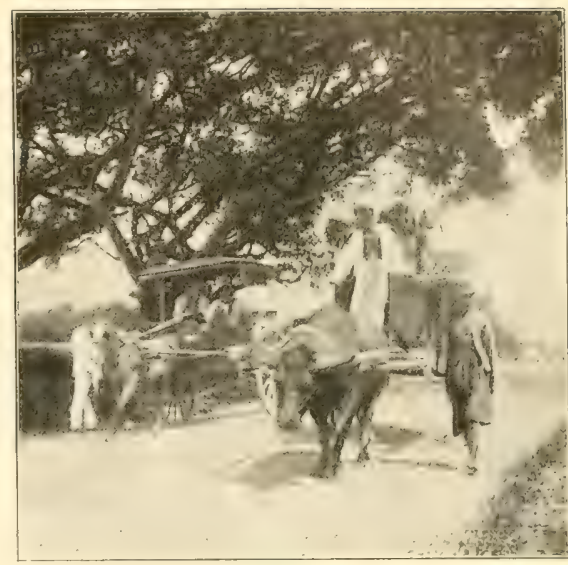

3 uีffelmagetr.

(Schmidt phot.)

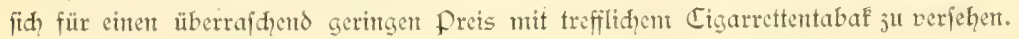

2luth die produfte der in den 2Irwäldern wild wadfenden Bäume, fo der Kampher,

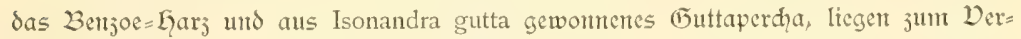
faufe aus. Durd Dermittelung des Konfuls erhielt id aus (T)uttaperda gearbeitete Reitpeitfhen, welḑe nur it einen Drte des Jnmeren von dem Dorfhäuptling, dent Parghulu Kapala $\mathbb{E} a g o$, erjeugt werden. Die Deitfigen, weldye dent Stentpel des Ver= fertigers tragen, haben wegen iheer geidmmadfollen Feritellung aus gewellten brautent uno weísen Lagen gar mandimal die Bewunderung von Kantern erregt.

Der Pajar erhält dadurdh nod, fein befonderes Gepräge, daf einerfeits die nie

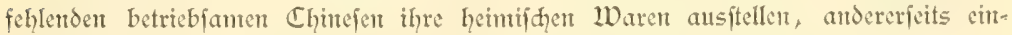
hemitiche Tröbler europäifhen Tand der fdquulujtigen 2rienge anpreifen. Es war

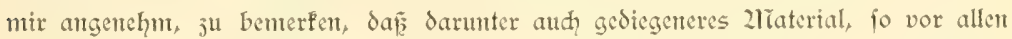
Dingen an Solinger Eifentwaren, fidf befindet. Sie feffeln niḑt minter dic 2lufmere= fanteit der fic prüfend umftehenden 2Ralapen, als die elegant gearbeiteten Erzeugniffe heimifher Sdumiede in Geftalt von Kris und Doldhen. 2reben den importierten Kattunt= waren in oft fdreienden 2rütem find es namentlid dic einheimifhen Sarongs, dic dem Befudher wegen ihrer oft gefhmadfollen 2lüufter und damerhaften $2 \mathrm{Debung}$ in das 2luge fallen. Zlllerdings wird man auf einem Pafar wohl fdqwerlid jene foftbaren,

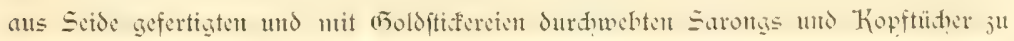

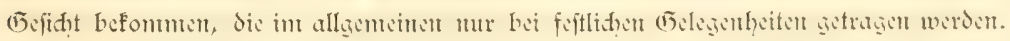

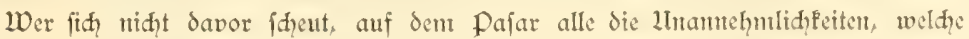

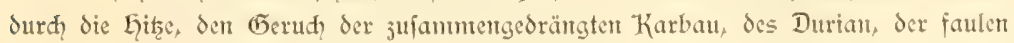




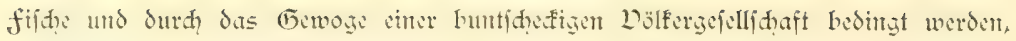
mit in Kauf ju nehmen, wird nirgents antiehendere Bilder und anregendere Gelegen= heit jum Studium des Dolfes geboten befommen.

Lnt indeffen über den Kleinhandel aud, den Grof̧handel nidht zu vergeffen, fo fei crwähnt, dafe padang in langlantem aber ftetigem Zluffdywung fid ju dem erften Landelsplat Sumatras entwiffelt. In Jahre 1898 belief fid der Wert der Einfuhr auf 7100000 holl. Gulden, der 2lusfuhr auf 5200000 Gulden. Die wiḑtigften 2lusfulyrartifel find Kaffee, Copra, 2liusfatminffe, 2rušatblïte, Guttaperdha, Kaut= iduke, Güute, Jimt und Stuhlrohr aus Rotang=Palment.

falls die deutihge Induftrie es verfteht, fith dem Geidmmadfe der Bevölferung cines reidhen und aufnahmefähigen Eqinterlandes amjupaffen, fo eröfintet fïh ihr in den Padang'fden sanden sin lohnendes 2lbjatggebiet.

\section{7ad padang pandjang.}

Don allen Soiten wurde uns geraten, Sen 2rufenthalt in padang 3 u cinent 2tusflug

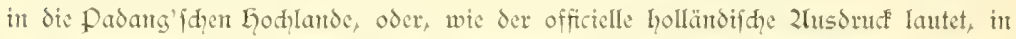

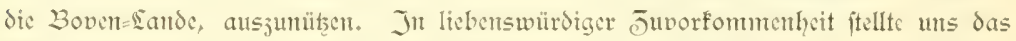

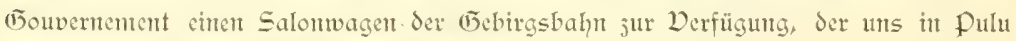
2 fjer, einem Dororte von Padang, erwartete.

Der Enmahafen ift der 2lusgatgspunft cines Syftems von Sdmalipurbahnen, weldhes in erfter Sinte der Derwertung der fumatranifacn Kohle dient. Sie wird öftlif von dem See von Singfarał in dent von dent Dberlanfe des Intbilien=fluffes Jurdfftrönten Sebirgs: Terrain abgebaut und an dem Endpunfte der Bahn in Sawah= Sunto verladen. Die Kohlenfelder wutden in den Jaheen 1867 und 1868 durd den

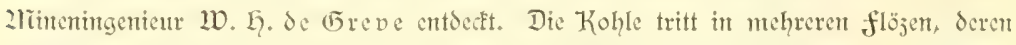
sines eine 2lädhtigfeit volt $6 \mathrm{~m}$ erreidet, ju Tage unto ftamm aus der früheften Tertiärzeit. Es handelt fith alfo niḑt un Steinfohlen, fondert unt Braunfohlen, die allerdings etwa $76 \%$ Kohlenftofi enthalten und fontit den Steinfohlen der Kohlenteriode an Brennwert beinahe gleddfonmen. de Greve erfante fofort die Bedeutung feiter Entdectung und ging mit wahren fetereifer daran, die Regierung 3 ul ciner Derwertung des unerwartet reiden Kohlenvorfonmmens ju drängetr. 1822 wurde eitre Kommiffiton unter feiner führung in das Kohlenterrain entfendet, un Dorfd̨läge hiber den gecig=

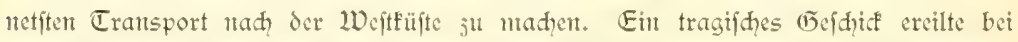
Sicfer (Jelegenbeit den verdienten Entbefer: das Boot, von dem aus die Dernteffungent

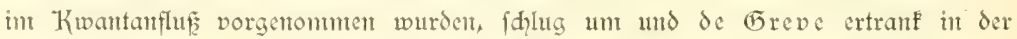
reifenden Strömung. 2läan hatte inzwifhen erfannt, dą̧ cin Transport der Kohlen lüber Sant unter teilweifer Bentinung der Wafferläufe unausführbar war, und fo 


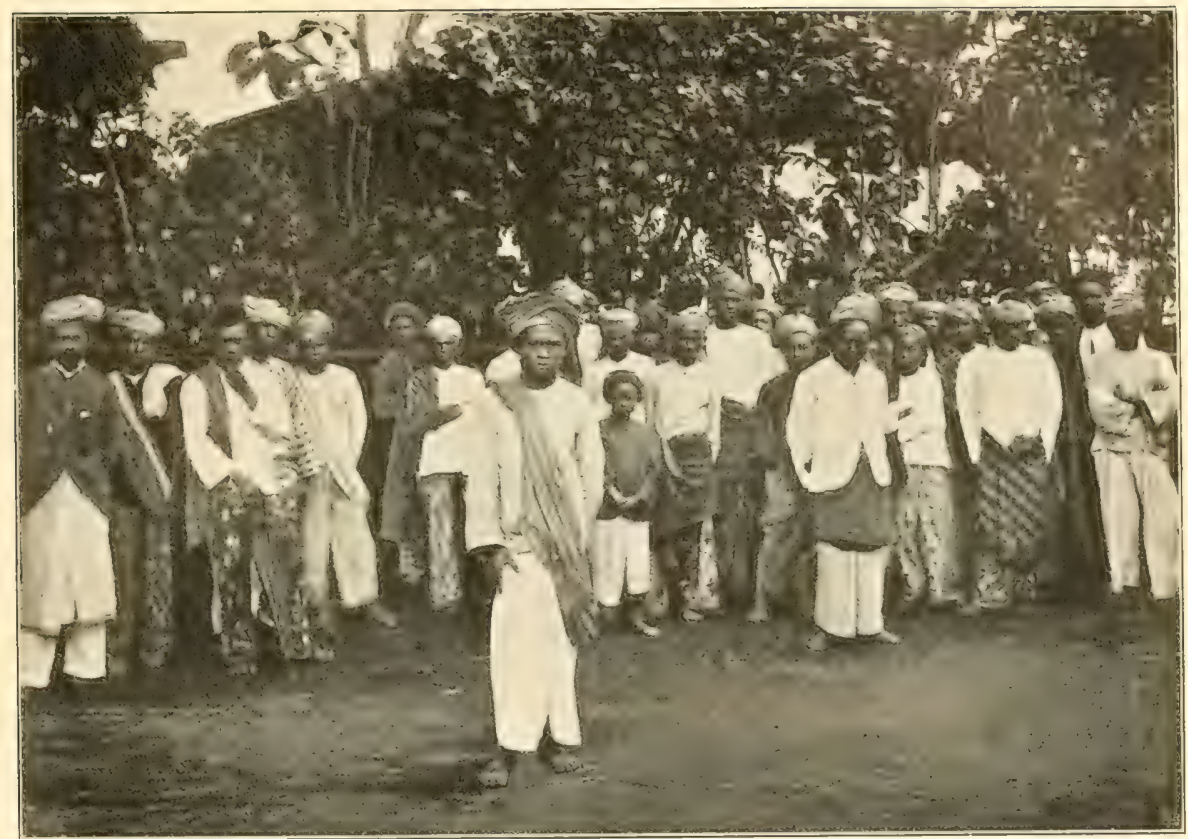

Malayifase Ippen (padang= pandjang).

machte fid dent aud die Regicrung mit de (5reve's Gedanten vertraut, eine 23ahn= verbindung ju fhaffen. Sic beaufragte 1865 den Jngenteur Cluyfenar mit Der= mefiungen und der 2Iusarbeitung cines Bahnprojeftes. Jwei Wege ftanden jur Der= fügung, um dic Kohlen nah padang ju fhaffen: ein fürzerer, der durd den Paf́ von Subang (1125 m) die Barifan=Kette überjhreitet, und ein längerer, welder bei padang= Pandjang $(725 \mathrm{~m})$ die Wafferideide erreidht und durch die Kloof des 2unet in die

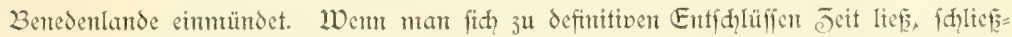
lich die längeren Trace wählte und das Untemehmen niḑt in bände von Prinat: gefillidaftert gab, fo trugen bierzu nod andere Erwägungen bei. Dic Padang'fdent God lande gehören ju den did̨teft bevölferten Teilen von Sumatra und vielleiht von ganj Ginterindien. Es ift ch sand uralter Kultur, bas man ourd einen Sdienenueg

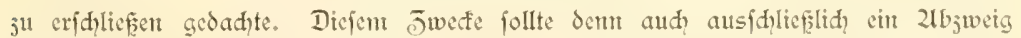
dienen, der von Padang=Pandjang nad? fort de Kot und Pajafombo in das 2luge gefapit wurde. 


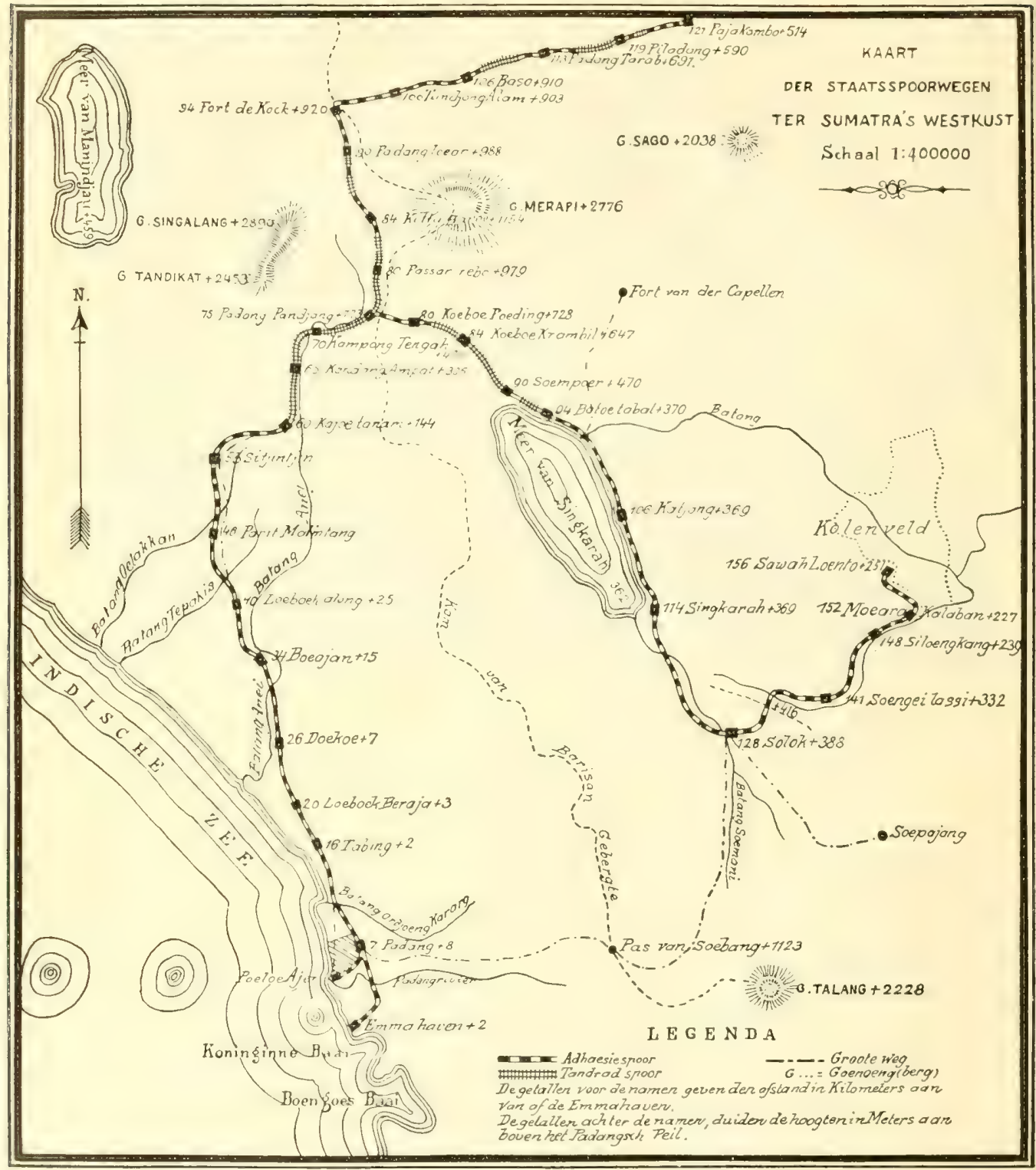




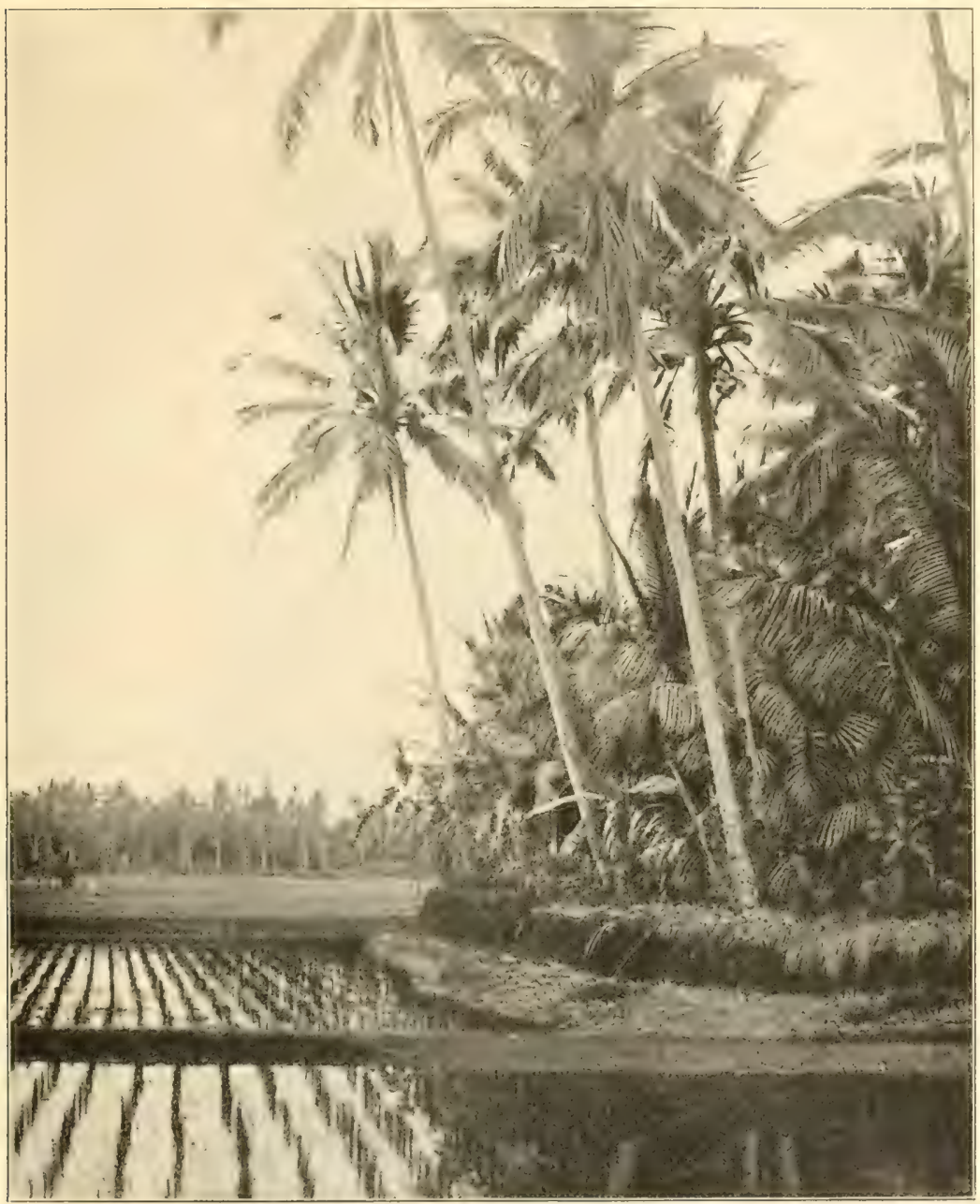

Zieisfelber mit jungen planzungen, umgeben von Koopspalmen.

Der Gauptitgenieur der Javantifhen Staatsbahnen, Jjzermant, wurde ange=

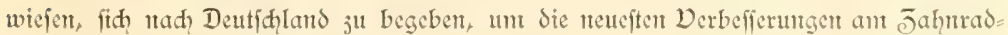
betrieb femten ju flernen und dam die Dberleituntg für den Ban der Padang'fdent 
Staatshahnen ju jibernchmen. Ende 1887 begam dor Bau, 1892 fomte dic Streffe Padang=fort de Koif cröfinct werden, und furj vor unferer 2uffunft waren die ge= famten 2lnlagen dem Betriebe übergeben worden. 2lls Sdmalipurbahn mit fombinterten 2lohäfions= und Jahntrabhetriebe fteht fie hei ciner Gefamtlänge von 506 Kilontern

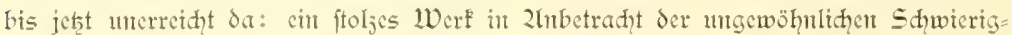
feitem, die fith nuter den Z̈lquator dem Ban emer Êebirgsbahn in den Weg ftellen. Kaun erëfinet murde dent aud der fdwererigite Teil der Streffe von dent Wildwafier des durd cinen Wolfenbrud? angefdwollenen 2lnet fluffes in der Kloof jerftöt; die alte

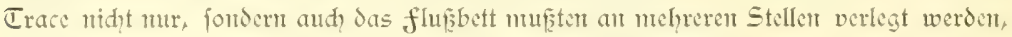
bevor man auf chut gegen tropijdye Wolfenbrübe gefiderten Betrieb ridnen durfte. $\mathbb{W}_{\text {as }}$ dic Steigutgen atbelangt, dic durd, Jahntrabetricb überwunden werden, fo drängen fie fith jumeift auf dic nïhere Lntgebung von Padang= Pandjang jufammen.

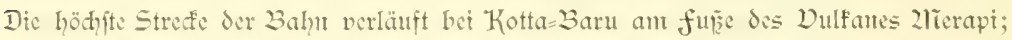

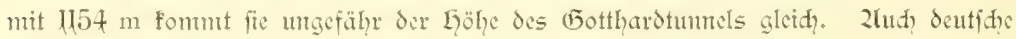
Jntereffen famen bei dem 3 au der $3 a h n$ in Betradt: die Sofomotiven ftammen aus

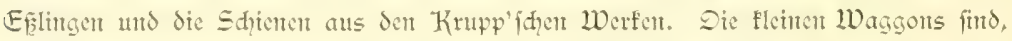
den Derbältriffen entpredhend, Inftig gebaut und führen jwet Klaffen, deren cine von dent auf der Bahn cifrig verfehrenden, niederen Dolfe, derent andere von den Euro päern, residen Chinefen und wohlhabenden 2lialayen benutgt wird.

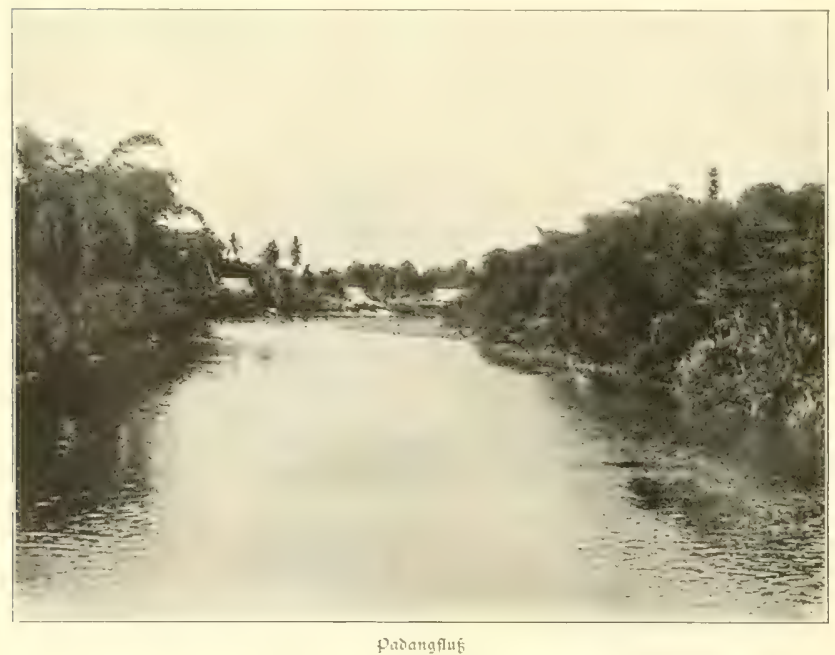

Es fällt fhwer, die fuil= Ie nont sand. fouftshilderm und neuen Eint= ortïfen, mit Senten der Rei= jende faft über= forüttet wird, feitjuhaltert.

Die $3 a$ hn überietzt auf cinct elegant gefd)wungenen etfernen Brücte sent pabang= Fluf und ourd) 
fährt nath dem $\mathcal{D}$ erlafien von Padang in nördlither Riḑtung das üppig fultt= vierte Ziicderland oder $\mathfrak{B}_{e}=$ nedenland. In feinem $\mathbb{C h a} a$ rafter gleiḑt es ciner weitert Parflandidaftl: dic Sawa's oder füntitlid bewäfferten Reisfelder wedfieln ab nit den vort Palment und frudyt= bäumen überidhatteten (ธิ)

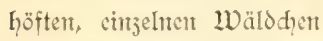
und fleinen Sumpfnicde= rungen, die mit Furjitüm= niget 2tipa=Palmen (Nipa fruticans), Sagopalnten und Pandanus beftanden find. Der Interiauf des 2lnci=

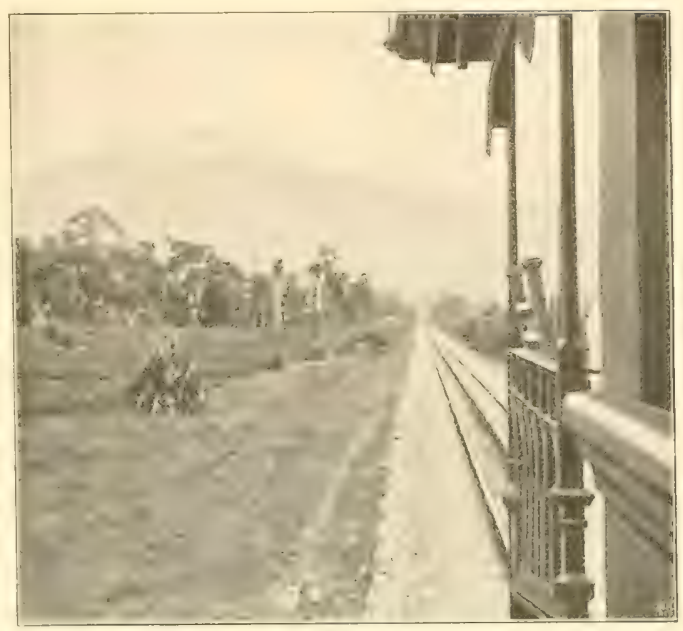

3ahnfrede bei Ziajufaman mit Jusblid auf oen Mteropi.

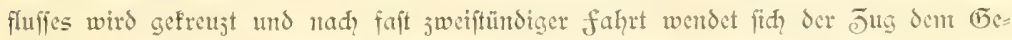

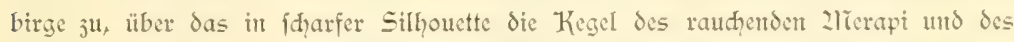
Doppeldulfans Singgalang= Tandifat hinansragen. Bei der Station Tajutantan, wo die Eofomotive gewechfelt wird, tritt die Bahn in ent Querthal - die Sḑludit des 2lnei - cint. Die Länge des $2455 \mathrm{~m}$ hohen Tandifat verengen dic Kloof, und mแ

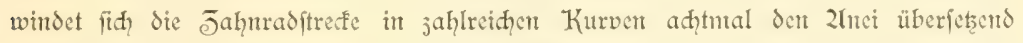
Surd ene Sdhludt, weldhe die wilde Rontantif des Fodgebirges mit dem Jauber der üppigiten Tropentegetation vereint. Die Gănge find mit Ltrwald bedecft, in dent dic langarmigen fdwwarjent (Jibbonts, dic Siantang (Hylobates syndactylus), ihr infer: nalijdes Geheul anftimmen; Gier und da ftehen bald verentyelt, fold in Eruppen neben dem Bahnförper Baumfarne, während in der Tiefe über Tradyłt mo Shieferblöte hinweg der aus den Goḑlanden fommende 2lnci raufht. 2in ver= fhicdenen Stellen benterften wir nodh die Refte jerftörter Brüfen und die Spuren der

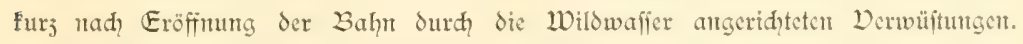
So wird dent cin Wedyfel von Bildern gefiflafent, der ftets ju neuen 2lusrufen der 2̈̈berrajdqutg veranlap̧; bald ift es ein Wafferfall, der did̨̧ neben dem Bafnt= förper herniederraufdt (S.552), bald finte es entg jufammentretende Wünde, bald wieder nod nie gefehene Dertreter der tropifdyen flora, weldhe den Blite feffeln. Die Bahn fteigt bis ju $770 \mathrm{~m}$ auf und verläß̈t crif umnittelbar vor padang=Pandjang Sic Sdiludţt. 
Padang= Pandjang enttänfht denjenigen, der in ihm eines der vielgerïhnten hod =

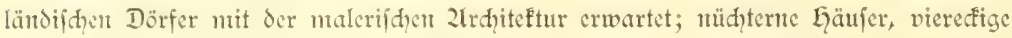
Kajten aus Steit, mit Dädyern aus Wellbled? reihen fitd monoton aneinander. Der hollän= difhe Beante belehrt uns, daf megen der fenersgefahr neuerdings dic Derwertung von Wellblech an Stelle der Palmfajerdectuntg vorgefdrieben wurde. So rationell audh Siefe 2rafaregel fein mag, fo trägt fie dod, wie id ju meinem Ecidwejen fpäterhin vielfad zu bemerfen (1)elegenheit fand, nidht wenig daju bei, den malerifhen Charafter

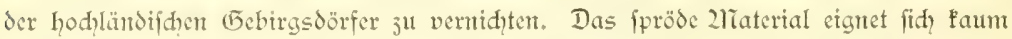
für den grajiöfen Sdqwung des Daḑes, und fo nimut der Lubenttelte bet Zreubauten

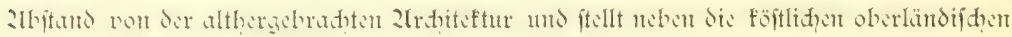

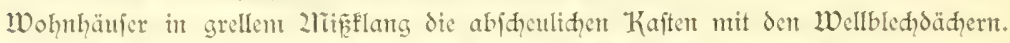

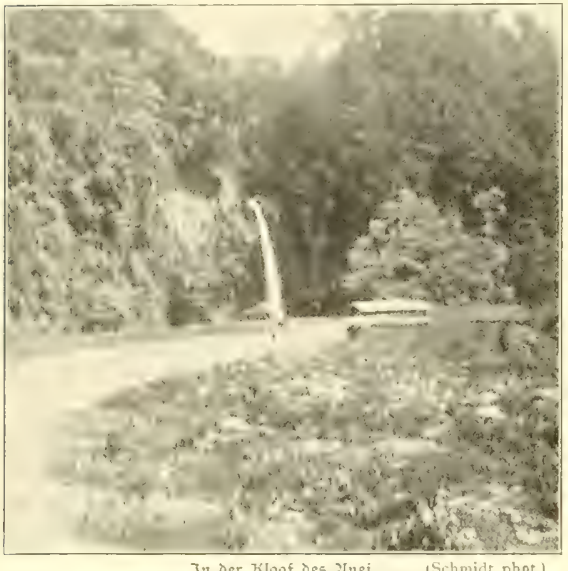

Erit wenn man den Drt felbit durd = wandert hat und auf die Eanditraf̧e gelantst, an weldher ein 2rititürfaino und der Wohufiti des 2lififitent $=$ Refit = denten gelegen fint, madyen die an= jiehenden holländifhen Dillen, end= [id, aud bie nod erhaltenen ober= ländifhen bäusdent cinent freund= Itchcren Eindruck. Daju trägt mun freilidy nidyt wentig der impofante 2lusblice auf den mäđtigen, bis in die zäthe des Gipfels bewaldetent Ilierapi $(2 \pi 66 \mathrm{~m})$ bet, der $a b$ und 3ll peine dutflen Raudiwolfent aus dem foniffar Krater entfendet.

In der fühleren (e)birgsluft fühlt man fidh nady dent Derlaffen der heifen Ziederung faft wie neugeboren. 2lian ver=

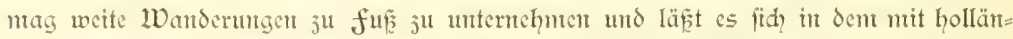
Sijher Sauberfeit von cinem biederen Ehepaar geleiteten Eajthaus "Ilierapi" wohl fein. Des 2liorgens erquift eine fräftige Duifhe Fühlen Ẽebirgswaffers; nađ̆ der Wanderung mundet die Iandesübliche "reisfpets" mit ihrem Dufzend von pifanten Juthatent trefflid, gegen 2lbend fiţt man im Earten und fhaut dem malerifden Trei= ben der heinfehrenden Bevölferung ju, bis die 2rad̨t herembridgt und Lqunderte von (5lühwürmdyen in mie gefehenter praḑt aufflanmen.

2riöge der Sefer es freundith aufuchmen, wemt wir ihit aus den Tiefen des Welt= meeres in dic padangifhen Godqlande geleiten und dic dort gewonnenen Eindrücke in cin befweidenes Eefantbilo vereinen! 


\section{Die pasang iden Bovenlande.}

Die Sübweftëffte von Sumatra wird von mehr oder minder fteil abfallenden (5ebirgs= fetten eingenommen, weldye in drei bis vier Parallelen die Jnfel in ifher ganjen Länge vort Süboft nady 2rordweft durdjitreidhen. Bis auf dic Känme hinauf futd fie bewaldet und gelegentlid) von Querthälern durḑbroḑen, weldhe raufhende (5ebirgsbähe ju der Küfte entfenden. Zur felten tritt dicjes Barifangebirge jurï, um erweiterte Quer= thäler mit frudhtbarem 2llluvialboden ju bilden, weldhe gelegentlid von jun 2rieere fit $a_{3}$ weigenden Rebengebirgstülen begrengt werden. Die Greitejte diejer Ebenen ift dis

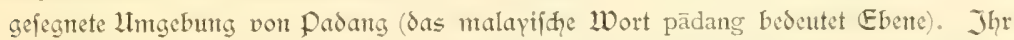
rebengebirgsrücfen endet in dem andefitifhen 2lpenberg, nadident er nod vorker durd einten alten Krater die Koninginte=3at gebildet hat. Der Weftabhang des Barifan= Gebirges wird überragt von den fegelförmigen Gäpfeln der Dulfare, unter denen heute nod elf thätig find. Die Jabl der thätigen Dulfane ift geringer als dicjentige Javas mit feinen 14 rauhenden Sdyloten; ob indeffen Sumatra aud an Jahl erlofhener

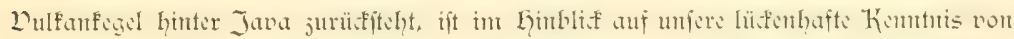

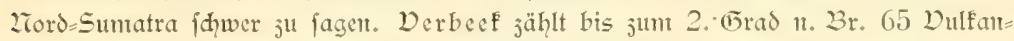
fegel auf und berednet, dafi auf $19 \mathrm{~km}$ Infellänge durdffdnttlid, cin feuerberg fonmt. Der hödyte ift der Dif von Jndrapura, der fübliक der Bovenlande bis $3415090 \mathrm{~m}$ aufragt. Went wir nun in Betradit jiehen, daf fidh ju den genauer befannten Kegeln nod) 20-25 in den Battaflanden und eine nod niḑt ermittelte 2Injahl in 2Toro $=5 u=$ matra hinjugefellen, fo burften wir fdwerlid, ju hod greifen, werm wir Sumatra anmäherno 100 Dulfane jujdreiben, von denen freilid, mur etwa ein 2ieuntel thätig ift.

2ln mehreven Stellen treten die Kegel enger zufammen, inden fie 2nhüufungsgebiete

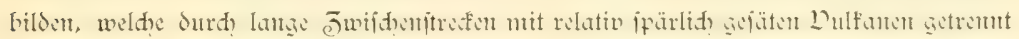

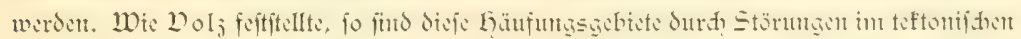
2lufbau der Sdidten in Ecftalt von Grabenverfenfungen und Spaltenverwerfungent harafterifiert. Es find "Bruhgebiete", an welche die Gauptentwiflung der vulfanifdien Thätigfeit anfmüpft. Das ift j. 3. Ser fall in den Battaflanden und jenen Ẽ Eegenden, die hier eingehender gefdildert werden follen, nämlid in Sen Padang'fįen Eodplanden. Sie erhaltent ihre Signatur durd den raudjenden, $2676 \mathrm{~m}$ hohen 21 terapt und den gegen= überltegenden, gleidfalls thätigen $2891 \mathrm{~m}$ hohen Singgalang. Der letztere tritt als cin J̄willingsvulfan uns entgegen, infofent cine füdlid̨e Spife, der Tandifat $(2455 \mathrm{~m})$,

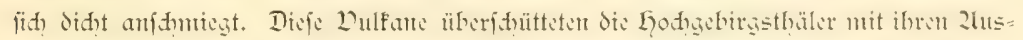
würfingen, unterbrahen ihren Derlanf und bildeten das 5 odplatean von 2lgant.

Wenn in alten Traditionen vielfad die Stammfif̧e der 2licnidien in die füblen, frudtbaren Kodhebenen tropifher (E)biete perlegt wurden, fo trifft dies fidderlid für das

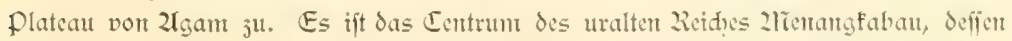




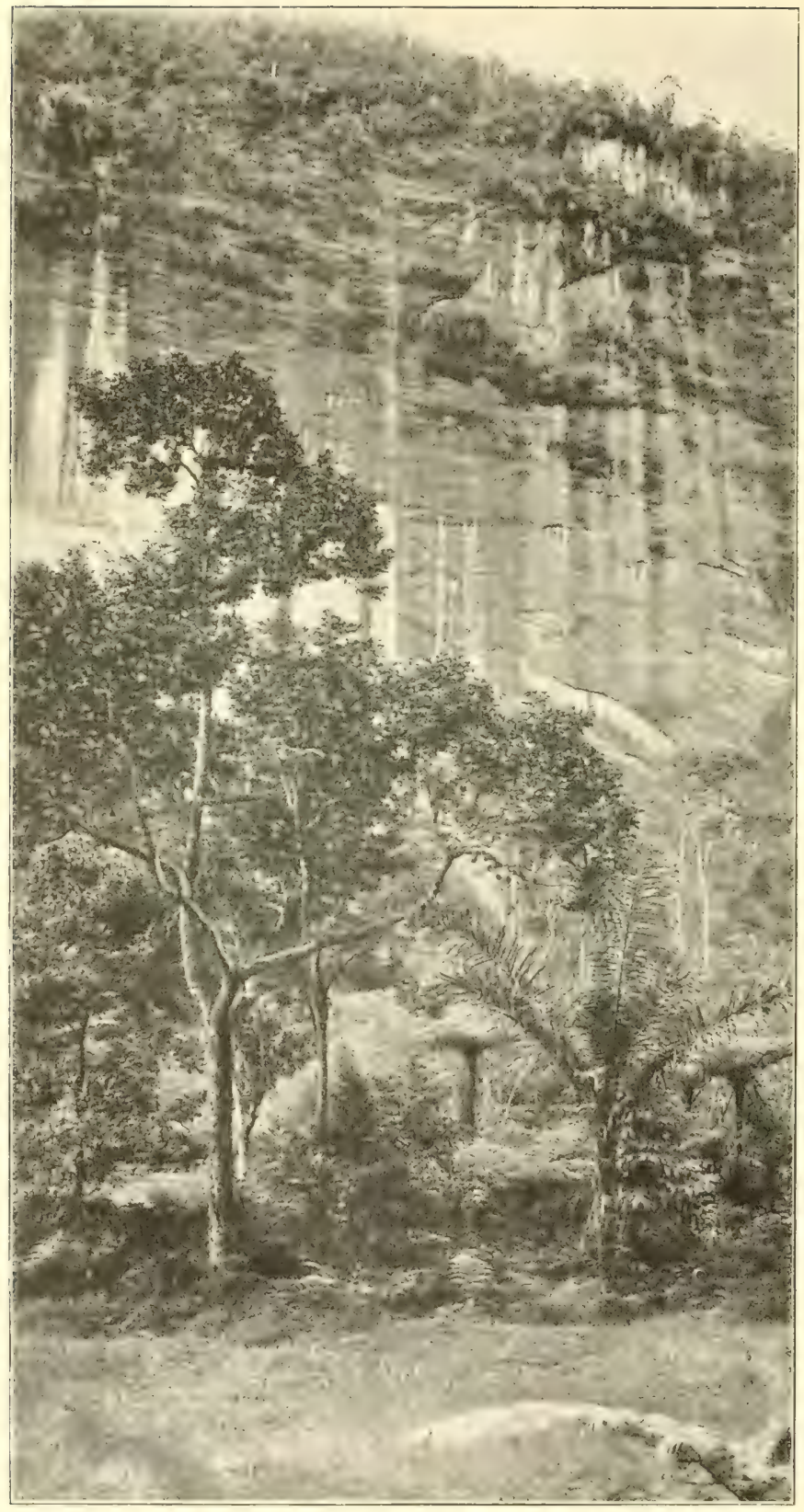

Durd Etofion arbiforte Stcilmüne; Kloof von 2trau alte Gauptitadt Prian= gan, heute nod in ver= witterten Rutiten erhal= ten, an bie flanfen des 2lierapi fid antehnte. Die alte Bevölferung huldigte dem 2rahnta= ismus, der nah dem J̄eugnis von Raffles crit im 15., nad) an= Deren bereits gegen $\mathbb{E}_{\mathrm{n}=}$ de des 12. Jabrhunderts surdh den Jslam ver= drängt wurde. So vicl ift fider, da年 in Jahre 1160 die 2lialaren bon der übervölferten Liod! = chene jum teil aus= wanderten, had Ma= Lafféa überfetsten undo fid, non dort aus imt $\varsigma_{1110} \delta$ a 2rdhipel verbreiteten. In den padang'ftien Elodilanden ftehen wir auf dent flafitiden $B_{0}=$ den uralter 'Kultur, für die freilid mur nod? wenige ftumme Refte Jెeugnis ablegen. Was vor dem 12. Jahrhut= dert liegt, verfowinnmt im Dämmerlidyt der (5eididfte; weldher 2trt Sic 2lieniden warent, dic auf dicfer von der 2tatur veridwenderifd bedad = ten Godnebente ihre $\mathbb{S e}=$ bensarbeit verridtetert. 


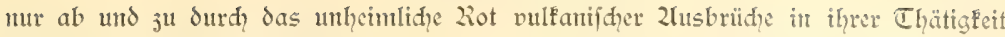
gettört, - wer will es fagen?

$\mathfrak{W}_{\mathrm{enn}}$ wir uns an den (Ẽcologen wenden, um 2lusfunft über dic Entftchung der Padang'fhen Lioḑlande und wohl aud des gröfften Teils von Sumatra zu erhaltem, fo belehrt er uns, daf das Eand nod ju Ende der Kreidejeit vont 2lieer bedectt war und crft im früheften Beginn des Tertiär fid ju heben beganm. Die vulfantifhen Durḑbrüche erfolgten durd, ein Hrgebirge aus Sdiefern und Granten, das vielfad? von Kohlenfalf und devonifhen Sedimenten überlagert wird. Jhten liegen in den Boventanden

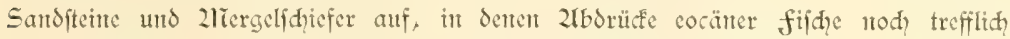
erhalten fund. Ziadident das sant fid gehoben hatte, bedefte es fid mit einer üppigen Degetation, deren Refte in den Kohlenflöjen heute nod vorliegent. Sie finden fid in einer nerfteinerumgsarmen Sandftinfdidht, dic gelegentlid $1000 \mathrm{fuz}$ 2rädhtigfeit crreiḑt. Die Entdectung der Llmbilten= Kohlenflöje gab der Kolonie cine ungeahnte Bedeutung

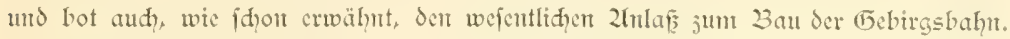

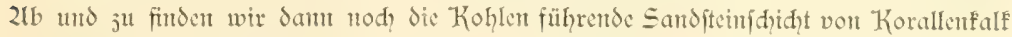

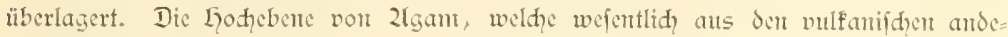
jitifden 2luffichüttungen gebildet wird, zeigt längs der flanfen des Singgalang und 2lierapt tiefe Spalten, de wohl durd? vulfanifhe Thätigfeit cntffanden fein mögen und durd? Erofion der fie Surdiraufichenden Gebirgsbädhe nodh erweitert wurden. Die

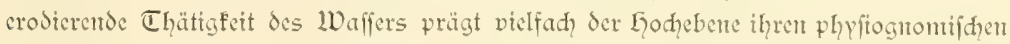
Charafter auf. Breite Thalfeffel oder 2lülden, weldhe dann durd enge Sdiludten

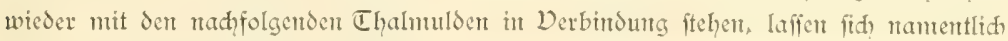
in der Untgebung von fort de Kocf bis rad Pajafombo (am inftrulfivivftert bei $3 a j o$ ) Feobaditen. Zlnderer= feits bedirgte dic Erofion die Ent= ftehung jener als "Kloof" bejeidneten Sdluhten, von deren oft fenfredtt $a b=$ fallenden $\mathfrak{W}_{\text {ät }}$ ent die Ğebirgsbädhe in raufdenden Kasfaden oder in Staub fïh) auflöpenden fällen herabitürzert.

So werden dent Sandidaftsbilder gefdaffen, die oft trotz aller Derid\}is= denheiten an diejenigen des Berner Dberlandes erimmern. freilid fehlt cin 2lusblit auf fantrebedefte (Fipfel, deren Stelle hier die $\mathcal{W}$ ulfanfegel ver= tretert. Zlber dic raufdenden, von

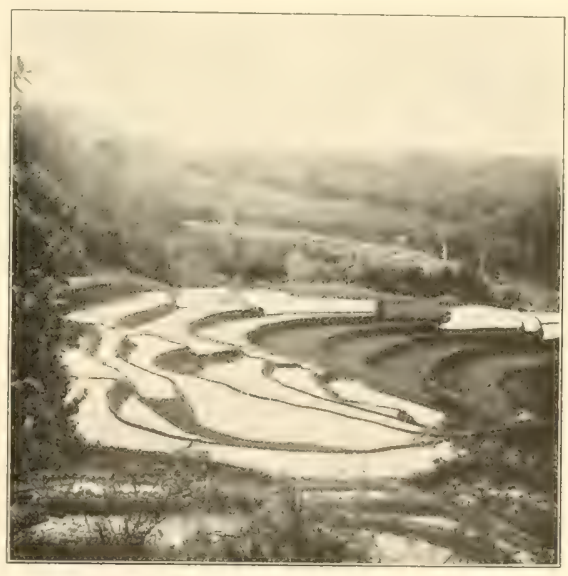

tSchmidt phor. In एerralien angelegte Reisfelber ( teilmeife unter Waljex gejețt. 
lippiger Degetation cingefäunten Gebirgsbähe, die Wafferfälle, die den grünen Zlatten vergleid,baren, pon Reisfeldern bedeften Kulturfläden, die reijooll jwifhen

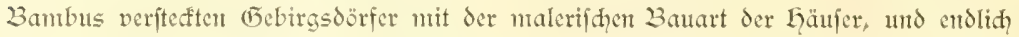
die erfridaende (B)birssluft laffen dod, inmer wieder alte Erinmerungsbilder auf= taudyen. Lat man fid durd die tiefsingeriffenen Sd?luditen durdigearbeitet, fo fowweift

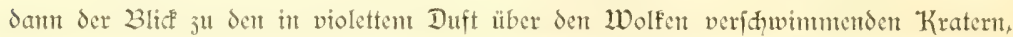

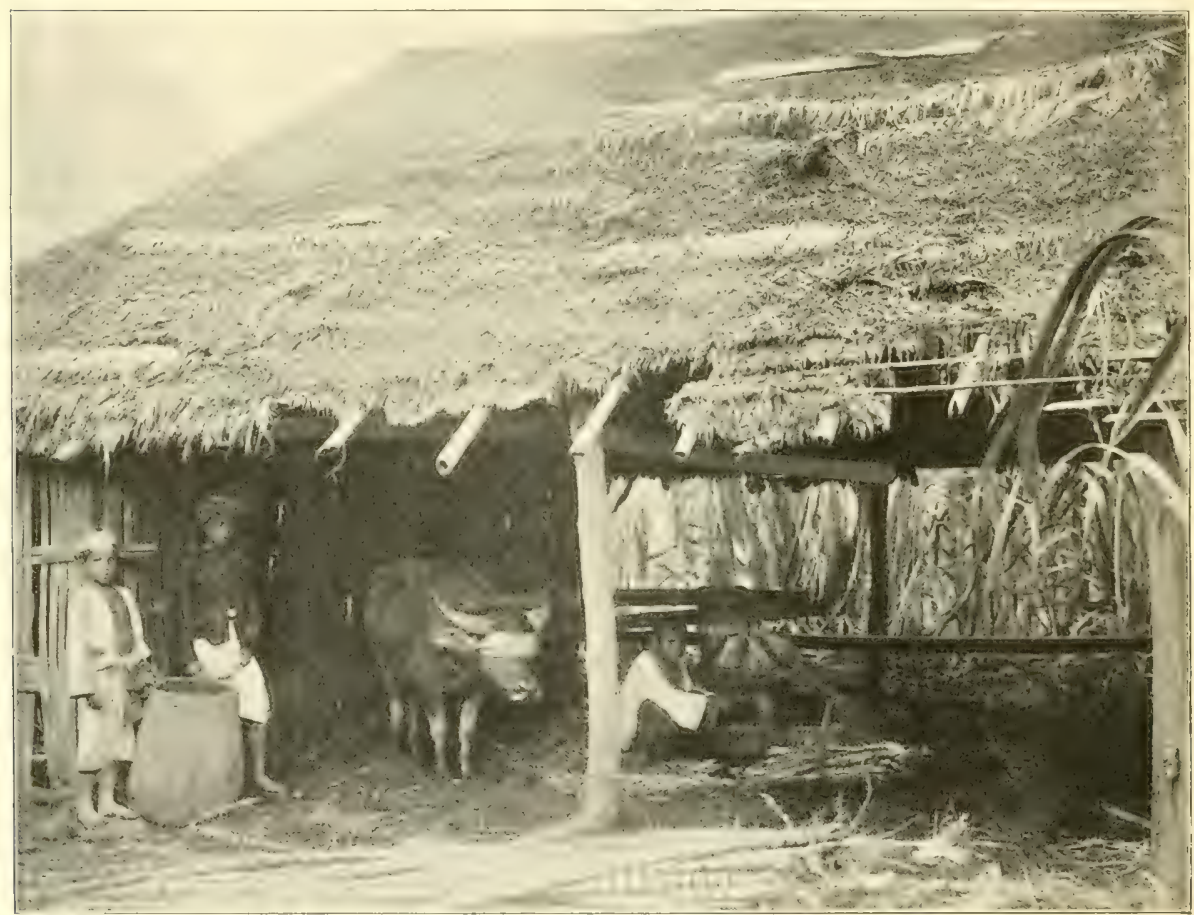

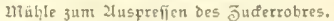

¡u den Ketten des Barifangebirges und ju dem Blauffimmernden Spiegel des Sees von Singfarah, der den an die Kodfflähe angrenjenden Einbruh ausfüllt.

Der vulfanifhe Derwitterungsboden, die ftändige feudtigfsit, weldhe häufige Zrieder= idiläge bedingt, \{hafien alle Dorbedingungen für che reid und üppig entwidelte Dege= tation, dic freilid, foweit der 2lrwald in Betraḑt fontmt, vielfach jurüdgedrängt wird durdy weitausgedehnte Kulturflähnen. Dor allen Dingen ift es die Reis= oder 


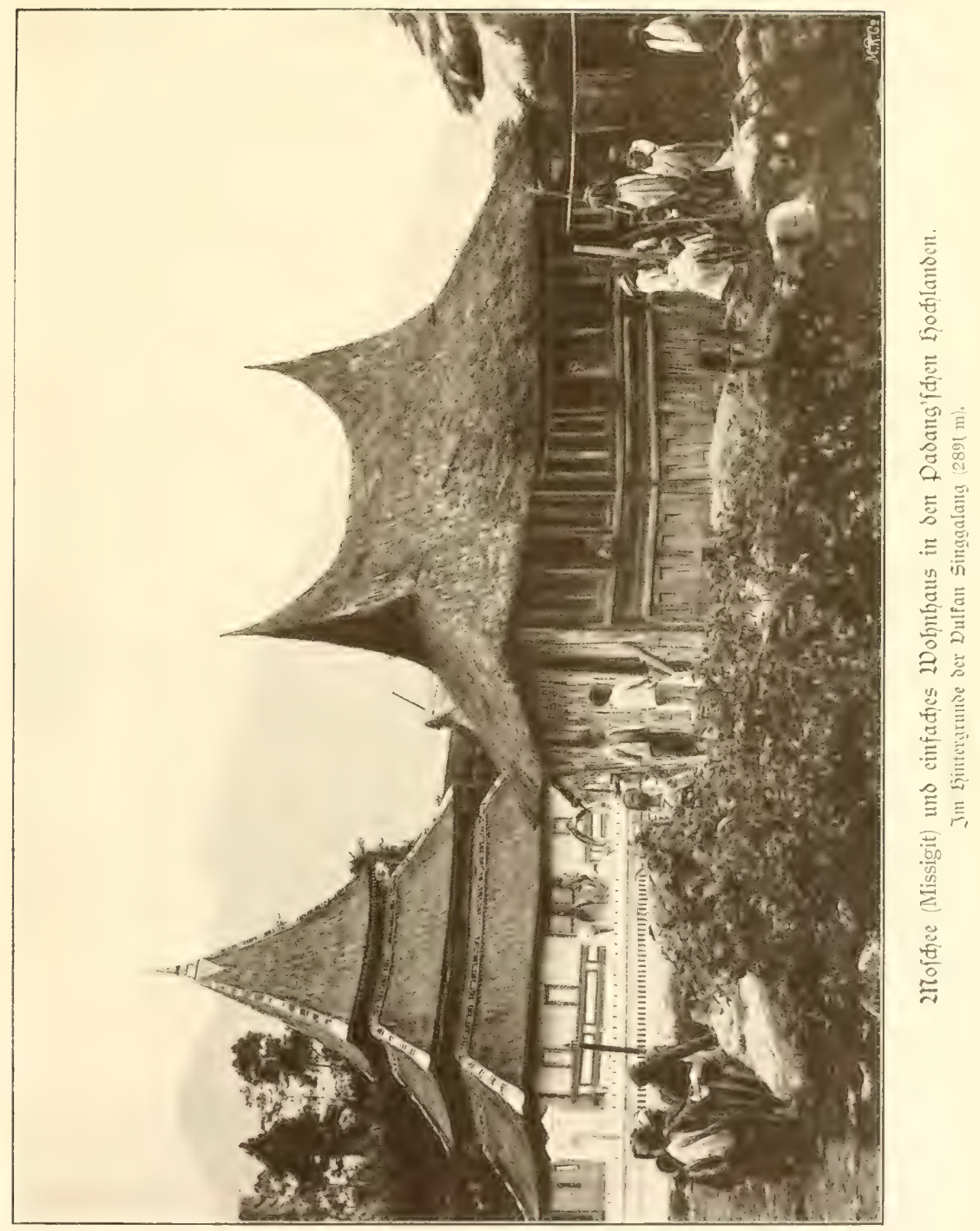



Sawafultur (5.555), weldhe ïberall in den Dordergrund tritt. Dic felder werden durd) ein finnreidyes Beriefelungsyffem, deffen Derbefferung die holländifie Regienung fid ganj bejonders angelegen fein läp̧t, unter Waffer gefeţt. 2ran wird überrajdyt durd di

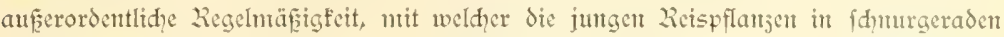
Sinten in den Sumpfboden eingepflangt werden. Der Reis, von dem der Eingeborene mit jharfem 2luge an 14 Körnerarten unterjheidet, wird jweimal in Jahre geentet

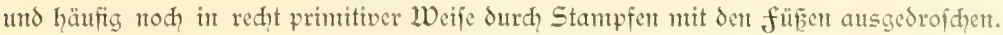

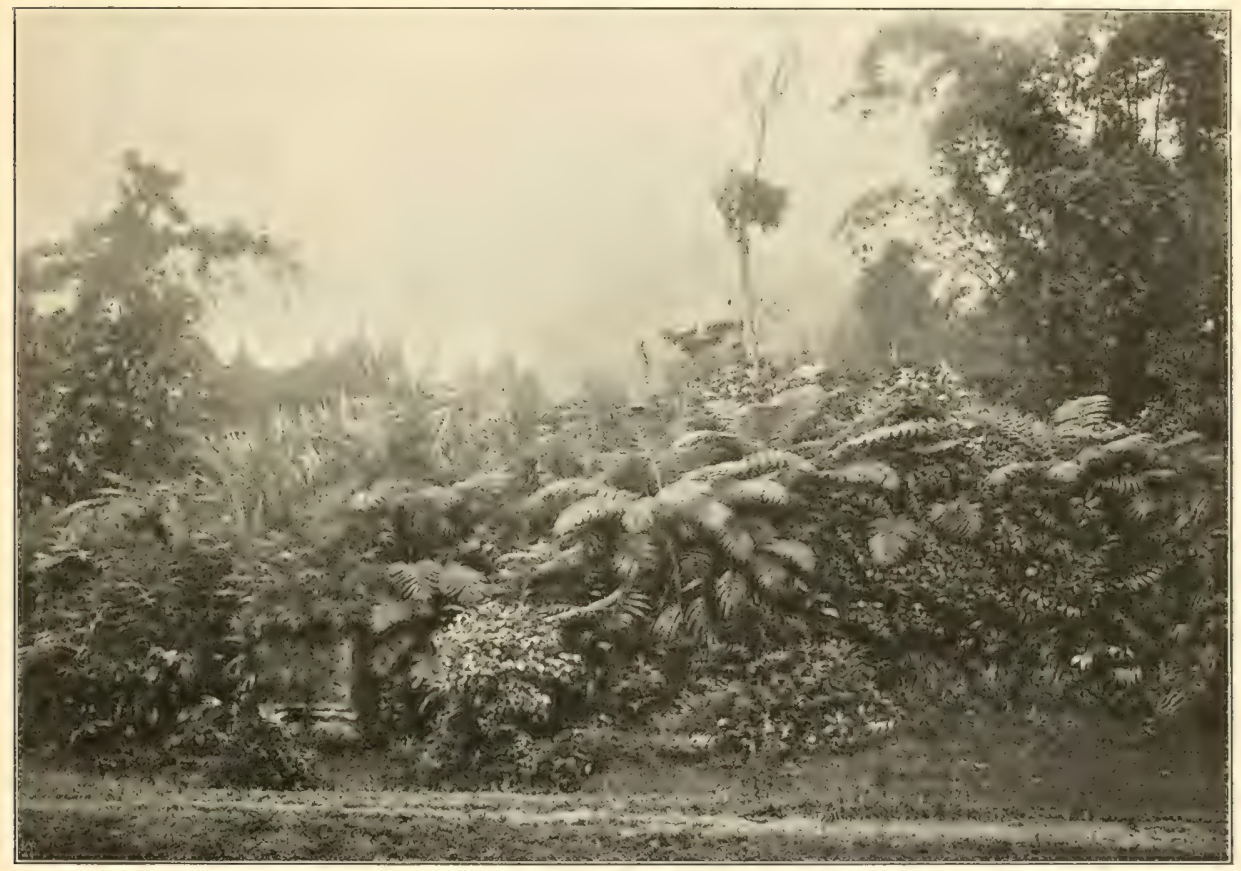

Oberländifạer Dorfmald (bei Pafar Rebo).

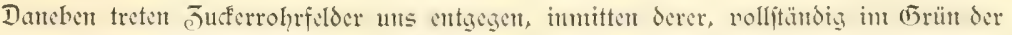
hohen Rohrbüfhe veritedt, dic ङudermühlen angelegt find. Sie werden von cinem Büfel, dent Karbau, getrieben, der mit verbundenen 2lugen an ciner Querftange im

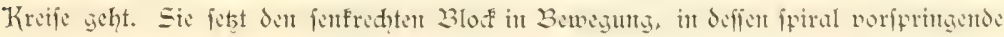

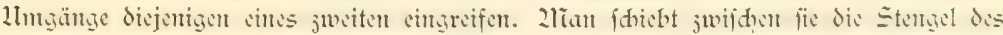

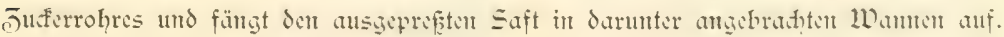
हhun, Zus ben Eiefer des welmecres. ลีweite Zluflage. 


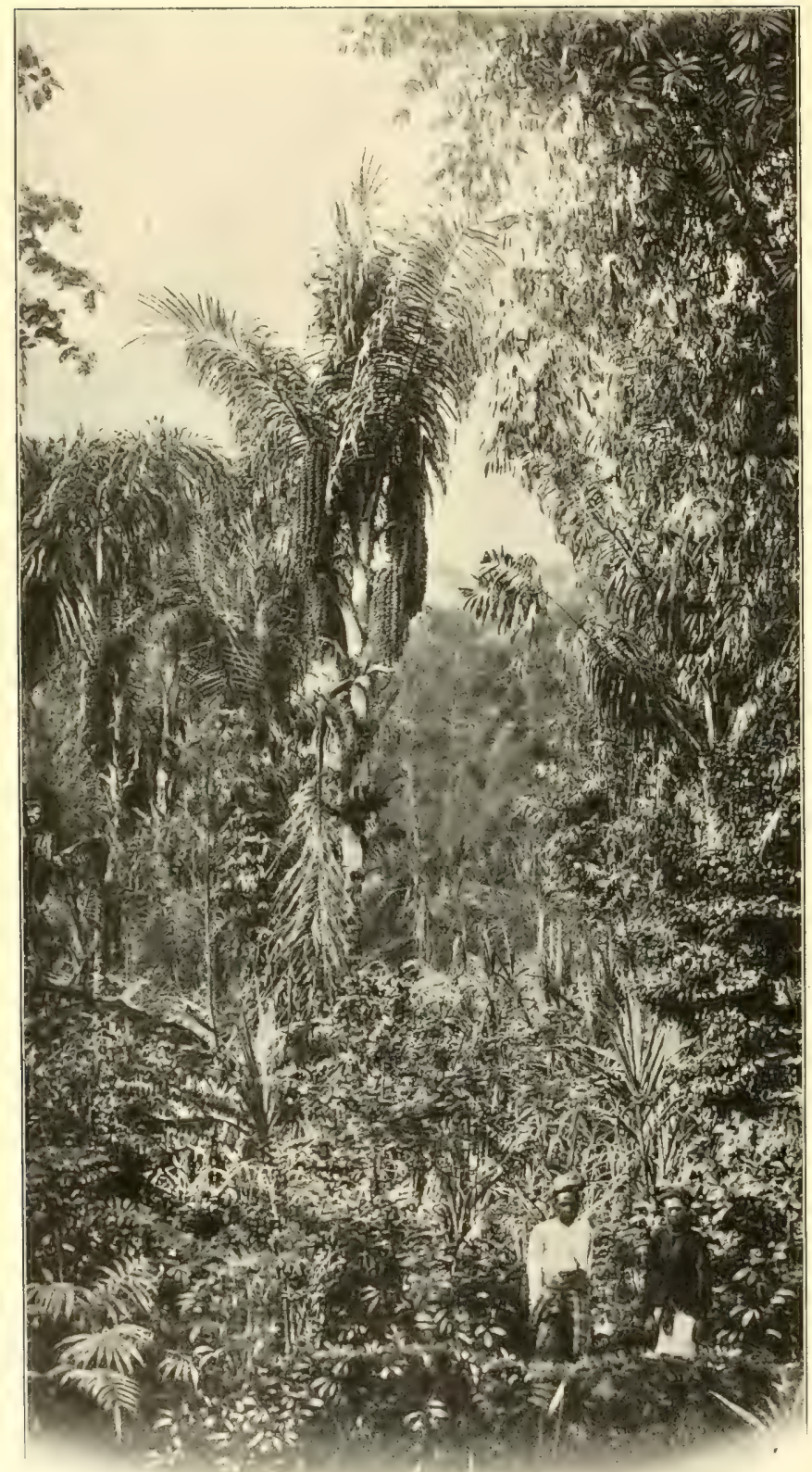

Wie in Sent Lnter land, fo find aud in den Boventanden die palmen reid vertretert. Қäufig trifft mast auf die Jufferpalnte (Arenga saccharifera), deren Baftfajern das 2liate= rial jum Defert der Gäufer bieten, während ihre angefonttenen, in lantgen Trauben herab= hängenden Blütenfol= ben den gefhäz̨ten fü= Ben Saft lieferm. 2lichr vereinzelt ftehen sie $P i=$ nangpalmen (Areca catechu), deren früdte als 2 etel gefaut werden und die Caryota urens mit ihrent in Etagen an= geordneten, einem farn= wedel nidht unäbrlid geftalteten Saubmafifen. Dor allen Dingen aber ift es die Kofospalme (Cocos nucifera), wel= dye herridyend auftritt. ju ungewöhnlidher $\mathfrak{h o ̈ h}$ entporfhief̧t und bis= weilen vollatändige $\mathfrak{W}$ al= der bildet. Das hod:= [andomađt durhaus den Findrud einer Parf= Landidjaft, deren grü= ne Kulturfläden unter= brodien find bon den Dorfwäldern. 2lïhtige 


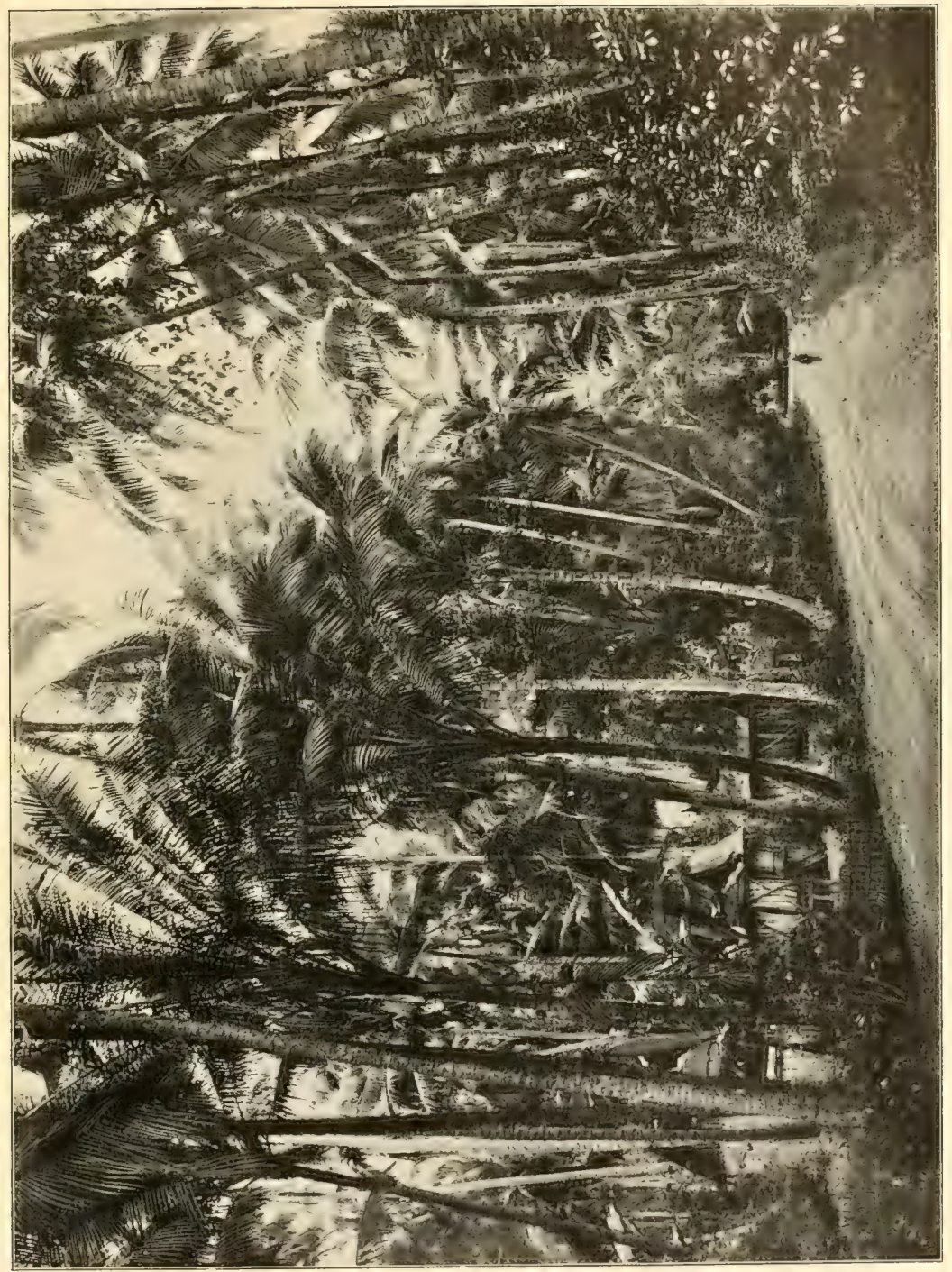


Bantbusgebüide, neben denen bisweilen wahre Ricjen non frudibäumen mit ihren

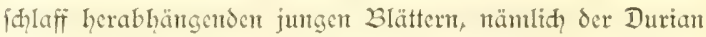
(Durio zibethinus), 2liangas (Mangifera indica) und 2rangoftare (Garcinia mangostana), auffreben,

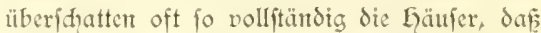
fie erft dent 2iahefonmenden ins 2luge fallen. Das Bild wird belebt ourch Sie Ervthrinen, die Cassia mit ihren roten Blättern an den 2litipitent und durd dic farnbäume, weldhe den tropifher $2 \mathrm{ici}$ dicfer Dorfwälder ausdrut"s = voll erhöher.

2lls ob der 2lienidh mit der 2Tatur ha= be wetteifern wol= Ien, unt ben כaul= ber, dell die Lod lante auf dent frembling aus: üben, ju erböhent, gab er feinten Wohnitätten cinc fo reizvolle, fünjt= lerijuc Beftal= tung, wie fie auf den ganjert ma= layijd̨et Urdipel nidht ricderfehrt. Die Dorfhäujer ftehen durdwoeg auf Bambus: pfählet, und der eigentliḑe Wohn= Wratetur an einem Wolinhaus (Solot). raum liegt min= deftens fünf fuf̈ über der Erde. Das Dah reiht tief hernieder und fällt fdyon von weiten durd, feinen elegant gefdwwungenen, fonfaven Biebel auf, der feitlid in mit 
2retall beihlagene oder vergoldete Spitsen ausläuft. Dem Eauje fehlen untaufende Deranden, dafür aber ift es nantentlid bei wohlhabenden zlalayen überreth mit ge=

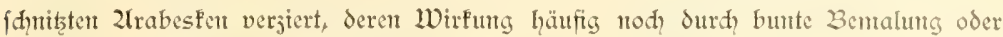
cingelaffene 2lietallblättden verftärft wird. Die fenfiter fund relatio flem, nidht minder aud Der Eingang, ju dem eine leiter artige Treppe, bei Dornehmen cinc fteinernefreitreppe, fülyrt. Befonders eigenartig ift der Findruct der grö= Eeren fantilien= häuer mit den dem Stammhaus angegliederten feit= liduen Znbauten. deren jeder in eine gefhneifte (5) iebel= firfte ausläuft.

2rehreve der $f a=$ milienbäujer bill Sen einer Kant= portg, der faft fitets mit einer 2lîfifigit (2liojhe) ausge= fitattet ift. 2lud dicie feffelt wieder surd ihre male= rifhe Bauart. Jhr (5rundrif ift qua= Sratijh, und das fteil wie cine Pyra= mide auffeigends

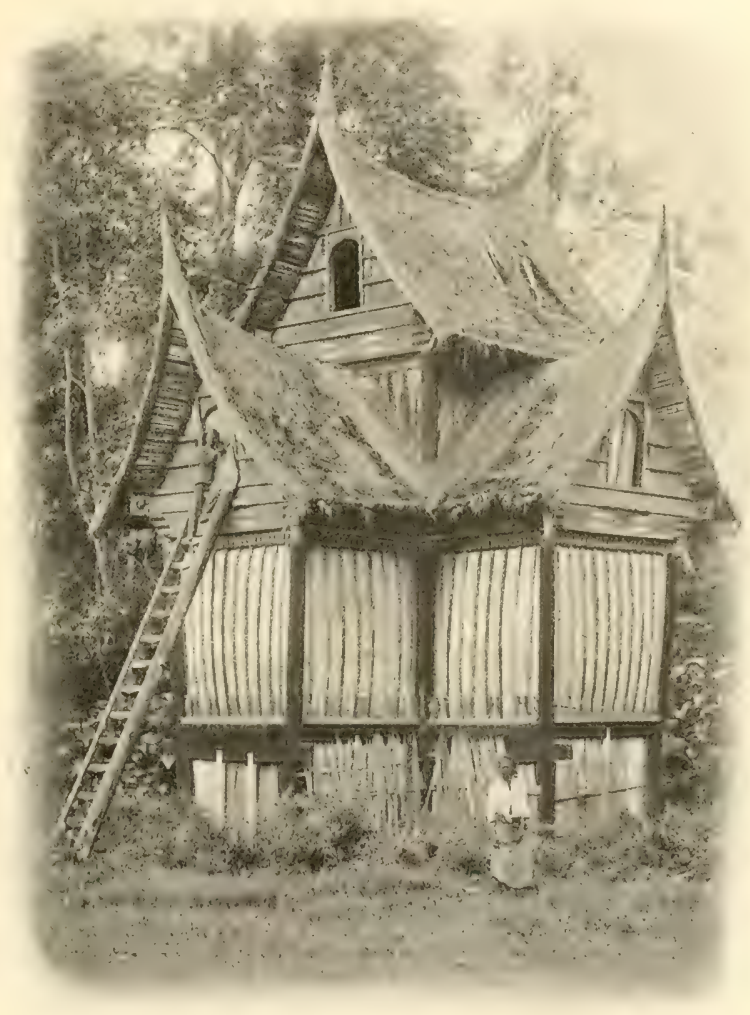

Reisjiheuer (pabang= Panojang.

Dadh ift in mehrere Etagen gegliedert. Je nah der Wohlhabentheit der cumzelnen Kampongs wird die 2liofhee pon aufen mehr oder minder reid mit in 2lamtor oder

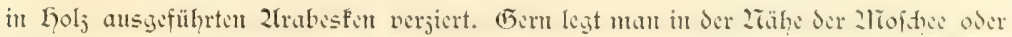

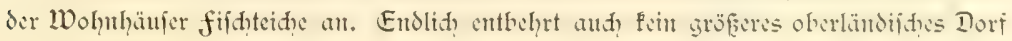




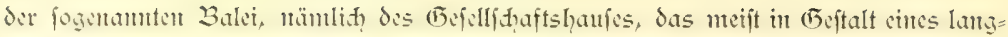

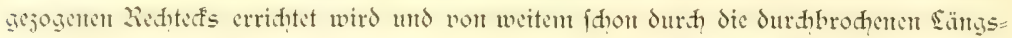

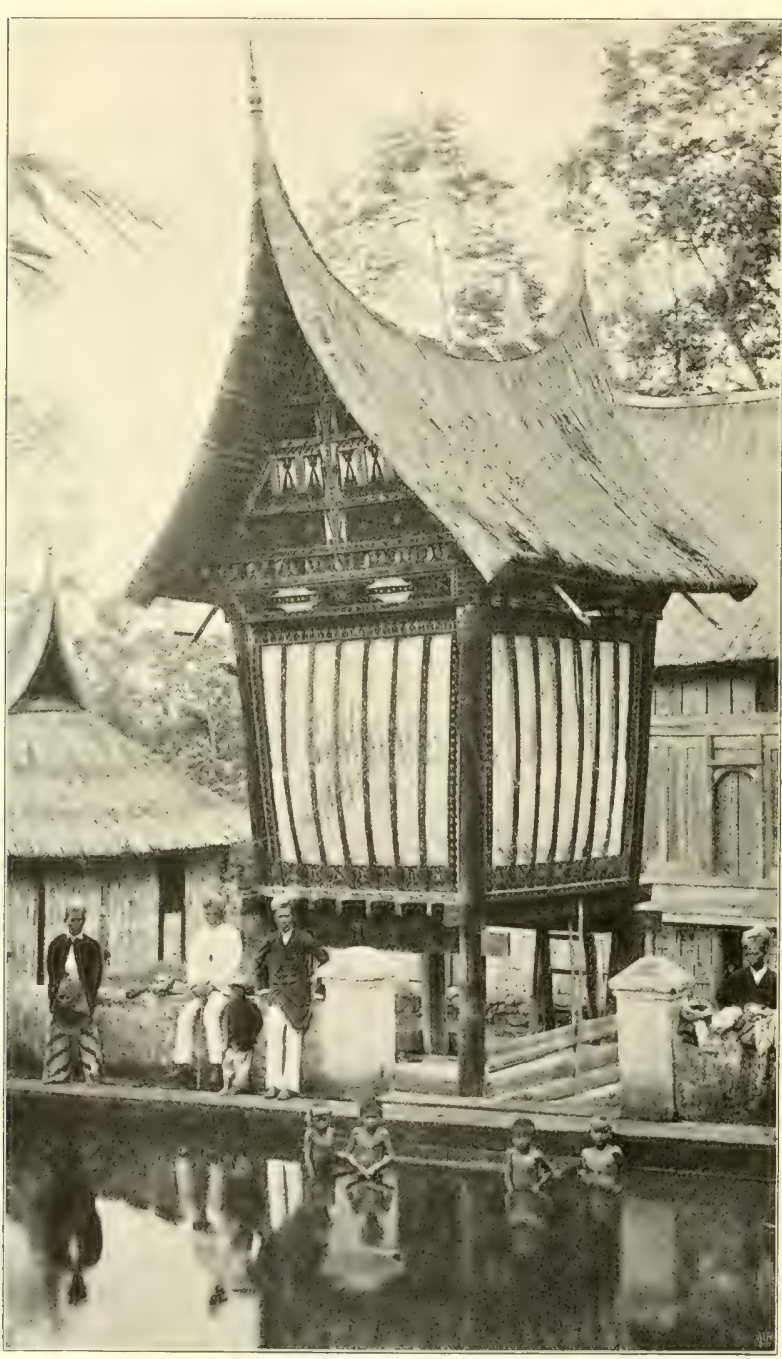

Bipis(dieuce (pabang = pandiang). wände als foldhes perntlid erfdeint.

Die föpltichite Beigabe ju dent Wohnhäufern bils den die fonmucfen Reisidenern. 2luf hohen Pfählen itehend, im Quer= fontitt quadra= tijo, felten freuz= förmig geitaltet, und nadh oben breiter autsIadend, madhen fic mit ihren gefoweiften (5iebeln und dem reidien Sdumutr an 2trabesten und bunten 2luiftern cinen fajt fofetten Eindrut.

2ran nente mir ein Dorf auf $E_{\mathrm{r}}$ den, das in Line blict auf harmo= nifde und fünit= lerifuce Durdbil= Jung von Kirdie, Beratungshaus, Wohnhaus und Dorratsräumen es mit dert an= mutigen Kant= pongs der Boven= lande aufnimut! 


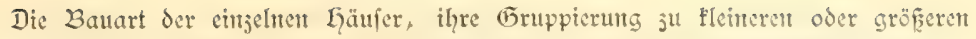
Dorffhaftert würde faum verftändlid, fein, went wir niḑt einen 3 lick auf sic, in

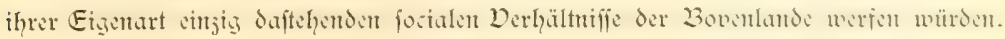

Die Grundlage des malayifhen Staates, der familienverband, ift nirgends in fo altertünlich erideinende formen gegolien, wie gerade in den Dberlanden. Jedes einjelne $\mathfrak{L}$ aus, ob groff, ob flein, repräfentiert ein fantilienhaus, in weldhem nitht mu die Zngehörigen ciner fantilie, fondern aud gleidjeitig diejenigen ber nädfiten $2 \mathfrak{A n}=$ verwandten haujent. Der mittlere, grofe Eingangsraum dient als allgementer Der= fammlungsort, in dem dic Kinder und unverheirateten Flieder der familie näd,tigen,

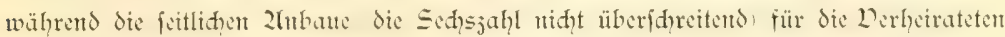
in 2lnppruch gentommen werden. Da itdeffen die Jahl der zu dent engeren familien verband gehörigen Glieder leiht gewiffe Grenzen überfhreitet, fo werden in der 2rähe des Stammbaufes weitere familienhäufer angebaut, welhe dam als Kanpong eine fleine Dotfgenteinde abgeben. Ïther jedes familienhaus wadit cin Lausvoritand, der Panghulu, meift der ältejte Eruder der 2lutter, dent alle familientmitglieder groke Ehrerbiefung entgegenbringen. Der ältefte der Panghulus wird mut wiederum jum

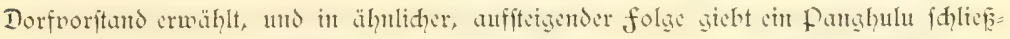
(id) aud den Chef des Diftrifts oder oer Kota $a b$, ju der die cinjelnen Dorffhaften vereinigt find.

2ridgt minder lebhaft als der Sim für die familienjugehörigfeit ift bem Dber=

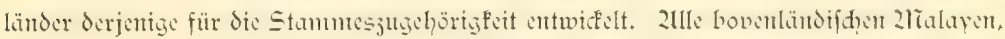
aber aud nody mande der angrenjenden (bebirgsgegenden, teilen fid in cinige (B) = foledtsftäntme oder Sufus, die ihrent Urjprung in leţter sinte nid) von cintem Utrahnen, fondern ciner Ltahnin herleiten. Die Z̈ngehörigen der cinjelnen Sufus fund

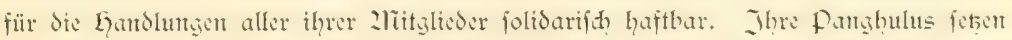
den Diftriftsrat oder Eara jufammen, weldher nach dent alten (E)wohnheitsred, dem 2ldat, das dent Dberländer als heilig gilt, entfheidet. Die holländifhe Regierung hat in weifer Einftht das uralte Gewohnheitsred zu jhonen verjucht und foruf fid im Saufe der Jeit treu ergebene malapijdye Beamte, indent fie auf Voridylag der Bevölferung Sie Dorfitzenden der Saras anftellt und befoldet. Wenn aud die Würde eines folhen cinheimifijen "Earashoofd" häufig in der familie erblich ift, fo ift dod immerhin eil gewiffer demof́ratifher Jug infofern gewahrt, als nidht unter allen Untftänden bet der Wahl hieran feftgehalten wird. Bei unferen Befuch in Padang=Pandjang war gerade eit Sarashoofd anwefend, der fid anf Deranlaffung des libhastourdigen Zlfiftent= Refidenten oc Sannoy bewegen lief, unferem photographen cinc Siţun ju gemähren.

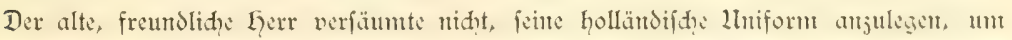
die nod ein Furzer, foftbarer Sarong in Boldifteferei gefhlungen wurde. 2luf dem Bilde iff jusleid, nod) der gejhäftize, malayifhe folizemeifter dargeftellt, sine fehr 


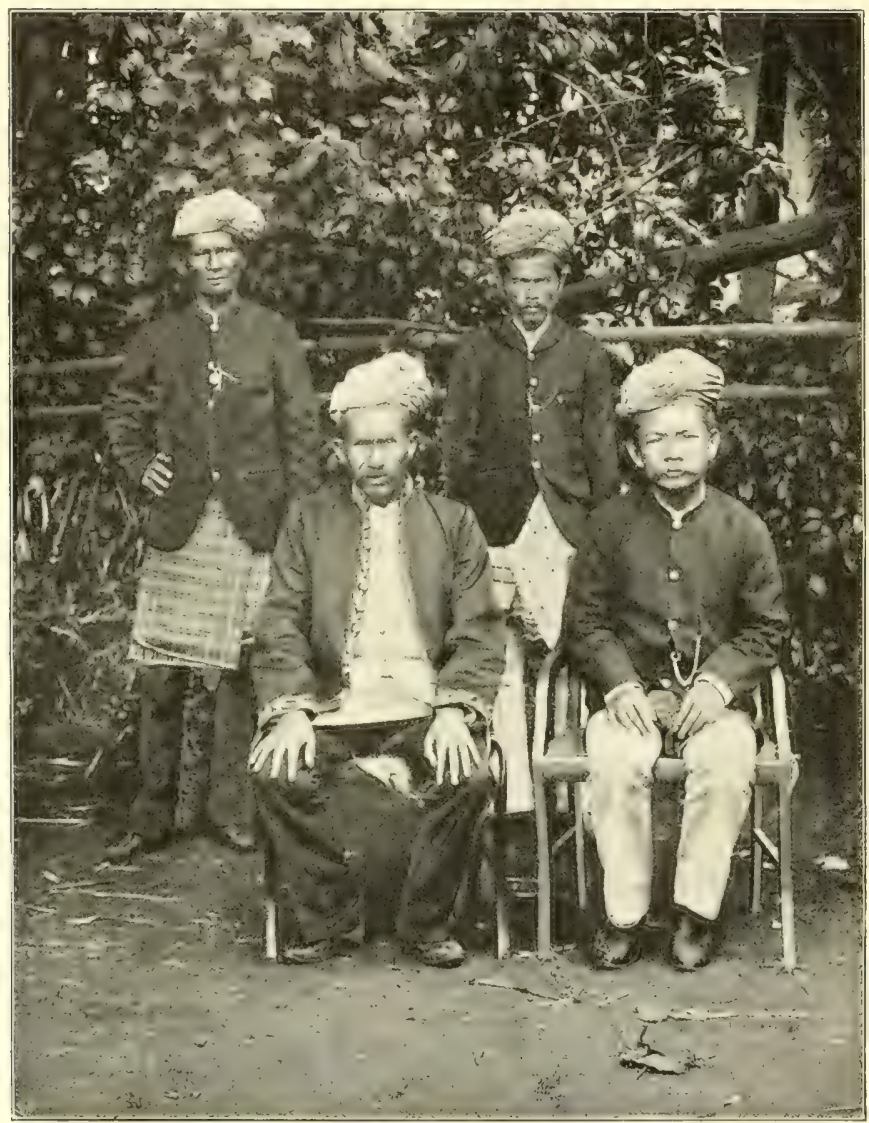

Earashooí ban VI Kota.

cinflufreidye und von der cingeborenen Bevölferung in hohem Reipeft gehaltente Per= fönliḑfeit.

für den holländifden Beamten, namentlich für den jungen, in einfamen Diftriften lebenden Kontrolleur, ift es Pein leiḑtes Ding, fidh in die verwidfelten oberländifhen Verbältniffe hincinjufindert, walde das alte 2roat gefdafien hat und an dem der Ein= gehorene troţ der islamittiḑen Einflüfle mit Jähigfeit hängt. Es gehört der dem

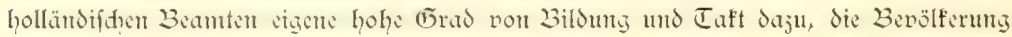




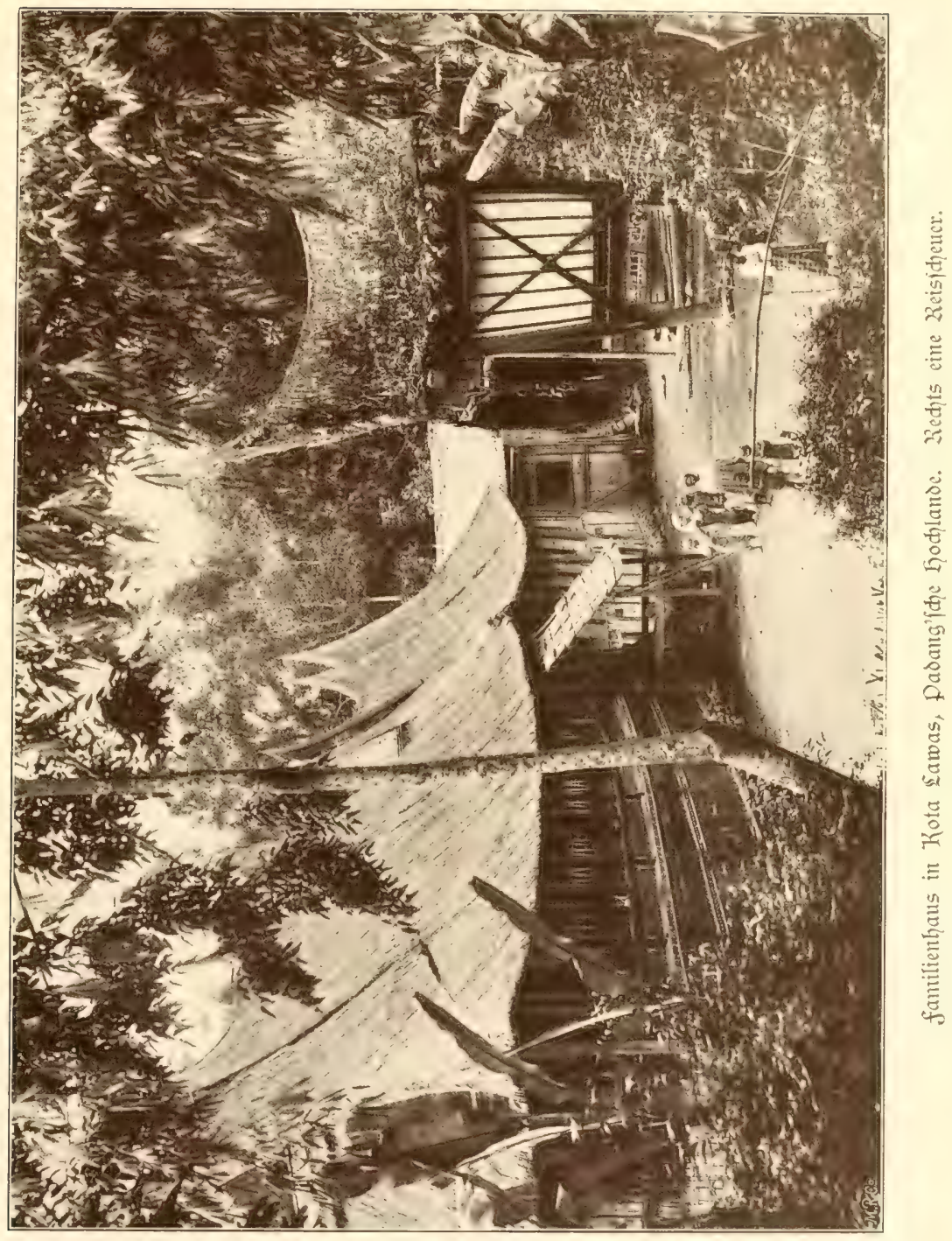



mit bent milden Regiment einer andersgläubigen Raffe ju befreunden, und es jutwege ¡u bringen, daf die cinfluf̣reiden Earashoofde willige und, wic wohl gefagt werden

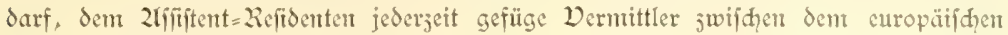
und einheimitiden Element dariftllen.

IInter allen Saţuntgen des 218ats mutet feine den Europäer fremtartiger an, als dic Gerrifhaft des 2ratriardyats. Spuren desfelben finden wir ja bet verihiedenen Dölferfhaften, aber nirgends ift es itl fo feite, altertüm= lidge formen gefügt, wie in dem Sberlan=

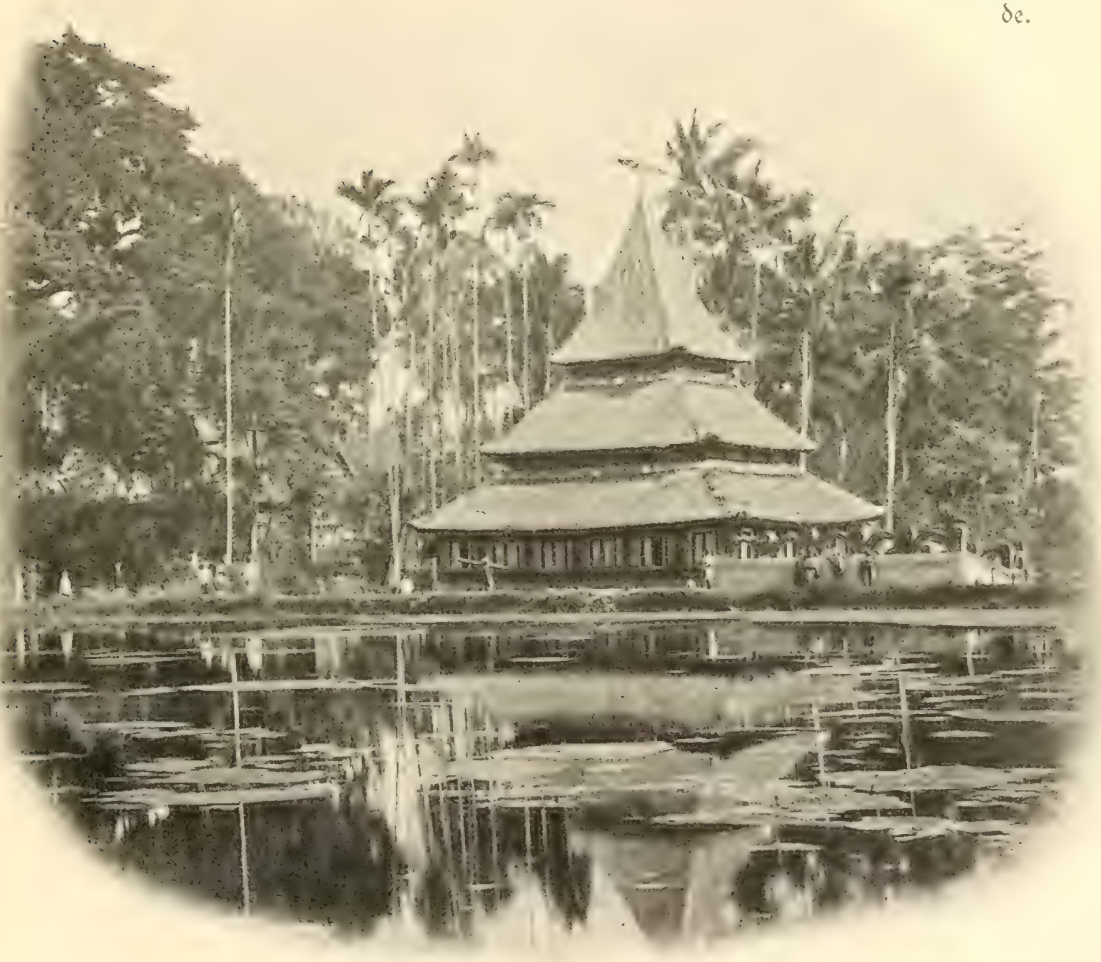

(Nieuvenhuis phot.)

Miifrigit (mofdee) bei fort de zoof. 
Wie die cinjelnen Sufus oder (Gefdledtsftänme fith von ciner Lrahnin herleiten, fo beftimmt dem auch sic 2liutter dic Stammesangehörigfeit und den Denwandt= fhaftsgrad. Die 2lũuter, niḩt der Vater, bildet den 2lïttelpunft der familie; die entgere fantilic fotst fidh mur aus 2lugehörigen mütterlicher Seite zufammen. Der ältefte Buber der 2lütter oder der ältefte 3ruderiohn wird jum Panghulu erwählt, und bei allen höheren Rängen ift es ftets die Derwandfihaft mütterliderfeits, welde den 2lusfdilag giebt. Der Dater wird nientals in den familienverband anfgenommen, in weldyen er hineinheiratet; er bleibt ftets em B Glied des Sufu, aus dem er entiftanmte. Eine weife Einriḑtung ift es hierbei, daf in allgememen Blieder besfelben Sufu niḑt unteremander heiraten. Das chelidge Band erfhemt unter foldhen Derhälntffen als cin relativ loderes. 2iur in Ser erften Jeit nad der Derheiratung lebt der junge Ehentam ftändig bei der fran und hilft ihe bei den Zlrbeiten auf den Reisfeldern, während $\mathrm{cr}$ fräterhin feine 2trbeitsfraft wieder im Juterefic feiner eigenen familie den Sd)weften und Shwefterfindern jur Derfügung ftellt und fid mur auf furje Befuche bei fran und Kindern befdränft. Int allgenteinen deutet denn aud an dem famtilicnlauj̣ die Jahl

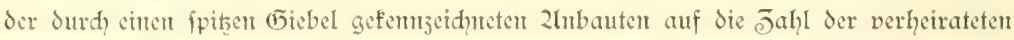

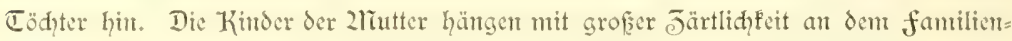
voritande, meift aljo an ihrent Sufel, während die Bejiehungen ju dem Dater wertiger intige find.

Land in Gand mit den 2liatriardat hat fid aud bas Erbredit entwiffelt. Im allgementen fantn hier mu crwähnt werden, daf das Dermögen von frau und Kintern Ser mütterliden familie verbleibt und nidht auf diejenige des Daters übergeht. Er fant alferdings cintert Teil defien, was er durd cigene 2lrbeit erworben hat, feinen Kindern vernadyen, ift aber verpflidhtet, den anderen Teil feinen Sdubeften oder deren Kindern ju hinterlaffen. "De dantes hebben ter Wejtfuit dan oof heel wat meer te vertellen dan de heeren," fo vermeldet ein holländifder Beridht. Dies mag wohl in gewiffer Linfidft jutreffen, went aud? anderericts nidyt ju überfehen ift, baf̧ dod, der

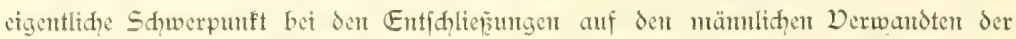
2rutter, ihren Brüdent und ihren Dnfehn müterliderfets, liegt. Jmmerhin ift es von Intereffe, dafis felbft der Jslam nidyt int ftande wax, dic Geltung und Stellumg der frau in fo langen Jeiträumen wejentlid in feinem Sinne ju beeinfluffen und dic 2lusbreitung der Polygamic jul begünftigen.

Was den charafter des 2lĩalayen der 30 ovenlande anbelangt, fo fteht es dem, der mur furje Jeit unter ilpnen weilte, niḑt ju, ein Itrteil abjugeben. Jn erfter Sinte fällt die freie, felbitbenuffe 2lrt auf, mit der er, ganj im Ëegenfat ju den friedertoen Javanen, dent frenten gegenübertritt. Dateben freilid, mahen alle holländifhen 
Beamten und Kemter des Dolfes darauf aufmerffam, daf ein Kardinalfehler des malayifden Stantmes, nämlid die angeborene Trägheit, in befonderent 2liaf̧e dem Dberländer eigen ift. Es mag dies fïherlich mit dent eigenartigen (5ewohntheitsred̨te

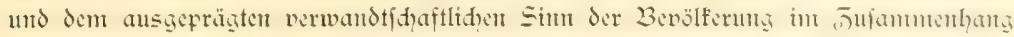

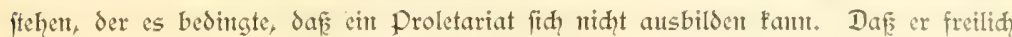
aud) Zluswüdfe, wie die Blutradhe, im Gefolge haben fam, ift nifit in 2lbrede ju ftellen. Went man weiter von ihnen fagt, dafi fie falfh und naditragend, fdjedt von Sitten und treulos find, fo rïhnen doh auch andererjeits Pompetente Beurteiler

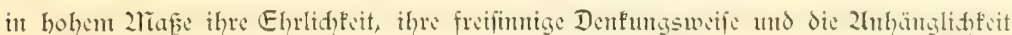
an das Geburtstand. In enem amtlidien Beriḑte über den Bau der Staatsbahn wird als ein כ̄eugnts für den guten Geift der oberländifhen 23evölfermug hervor= gehoben, daf́ die Enteignung der Taufende von Parzellen nienals ju erniten 2litip =

helligfeiten Znla gab. Jnt Einblit: auf die verwidfelten Bifitzverhältniff: geftalteten fid allerdings dic Ver handlungen mit den familienhäup= tern meift ju un fo langwierige= ren, als der Dberländer cin ge= borenter Zdovofat ift. Da er fidf nidht ju Bahnarbeiten bequemen wollte, lief man flimte Javanen und Sundanefen fommen, die in (t)e

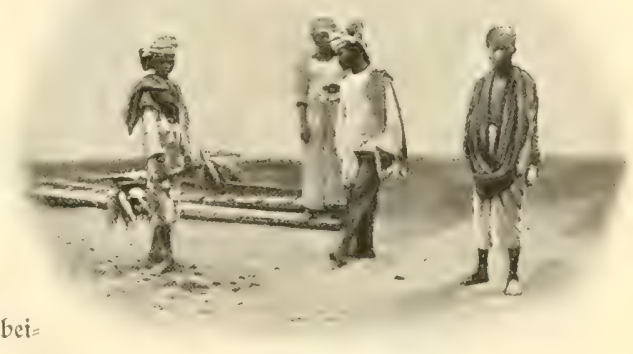
meinfdaft mit den für fhwerere $2 \mathfrak{l}$ rbei= ten herangezogenen dimefifden Kults unt

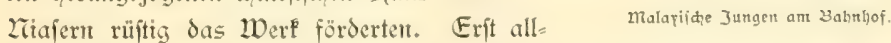
mäblich ftellten fỉ die 2ralayen cin, anfänglid, fehr von ibrem eigenen Werte über= jeugt, dod bald dent übrigen an Braudbarfeit nidit naḑftehend.

Keinesfalls find die Dberländer fantifide 2Tohammedaner, wem aud gelegentlid? unter den Gadjis, den in hoher Derehrung ftehenden 2lieffapilgern, 2lufätze ju fana tijd)er Bethätigung ihres (5laubens fith geltend madhen. Jih hatte felbft (5) slezgenthit,

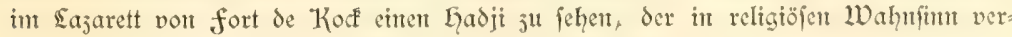
fallen als gemeingefährlich in einer Jiolierjelle gehaltent wurde.

כu 2ufang des Jahrhunderts hatte allerdings eine allgemene Sittenverderbnis in

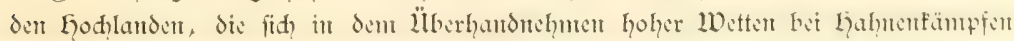

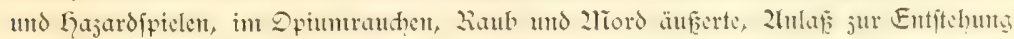
einer geiftlithen Scfte, der Padries, gegeben. 2rit den ganzen Defpotismus ciner unduldamen Gierarhie nerpute fit die Bovenlande ju reformicren und ibre lierrfiaft 
auch über dic Batta:Sänder, weldhe fie in ummenidbliden Kriegen nahezu entvölferte, ausjudehmen. Der unerträglidie J̄watg, unter dem die Padries von ihrer Fauptítadt

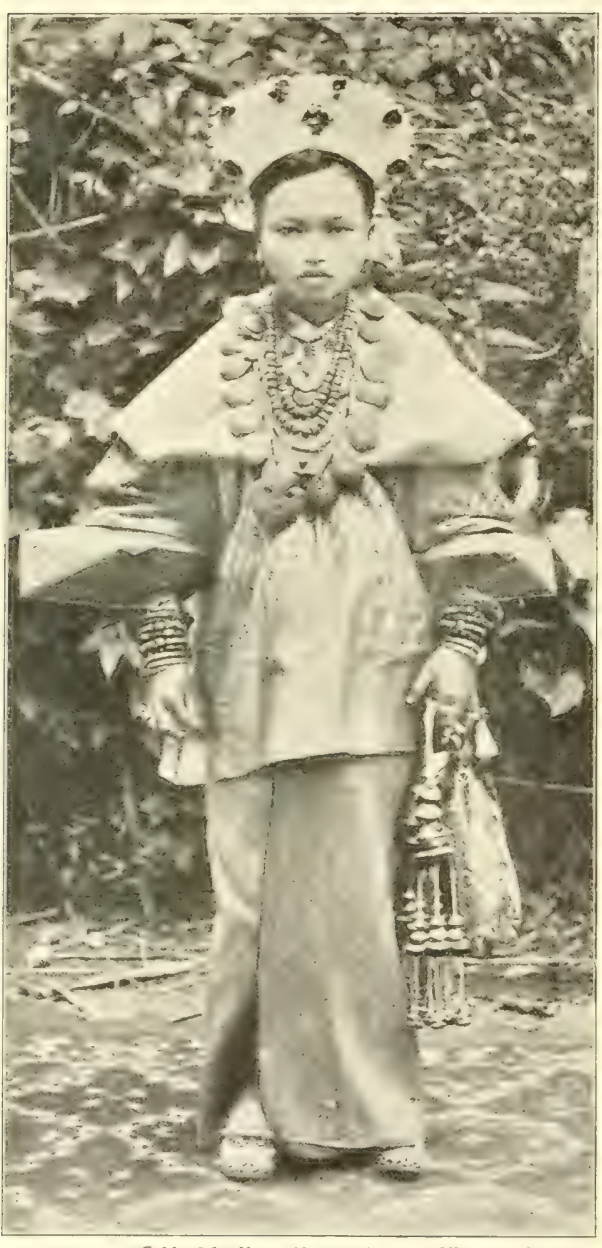

Befintüfte 3raut (fort be Kod). (Nieuwenhuis phot.) Bondjol aus das sand nieder= hieltert, gab der holländifden Regierung den 2lulap jum Ein= greifen. Sie fübrte, von cinem Teile der eingeborenen Gäuptlinge ju Lilfe gerufen, von 1825 bis 1858 jene denfwürdigen Käntpfe, in derren fidh holländifde führer, wie der junge Raaff (os (5rab. dentmal dicjes Gelden fteht am Strande bet Padang), Coditus und 2liditels, hohen Rubm er= warben.

Went aud tod hier und da iid) gelegentlich en 2lufflactern des finjteren Geiftes der Padries bei manden zreffapilgem geltend mad,s fo bürfte dod inmerbin Ser rubige Befith der Bovenlande dent holländifhen (5) gefinhert fein. Es läpt es an midhts fehlen, un auf die Bevölferung erjichlid) einjumirfen und ibre un= leugbare Begabung jur Bethätt= gung anzuregen. (5)iebt fith fhon in der Bauart der Gäujer cin fünflerifder, auf uralter Tradi= tion beruhettder Sim wieder, fo überrająt or in nod höheren (5rade durch ihre Befähigung für alle Zrten von Webercient, Stide= reien, fledtwerf und filigran= arbeiten. Wem es vergönnt war, auf dem Paiar von fort de Koof jene unvergleidyliḑen Shauftüfe der Goldihntedefunt ju bewundern, die mit den denfbar cinfadjter Gandwerfsjeugen hergeftelt werden, der wird nidgt hod gemug 


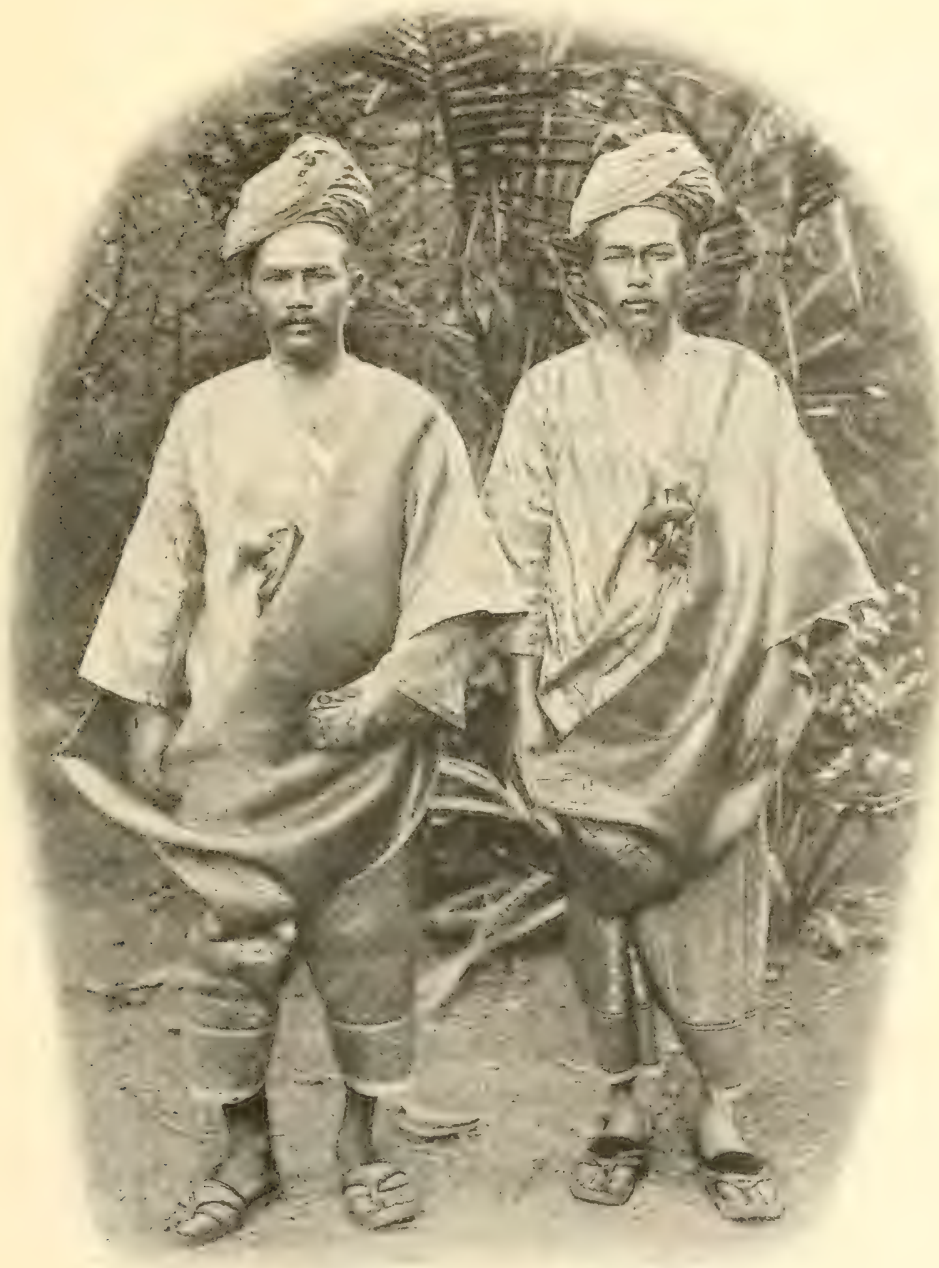

(Nieuwenhuis phot.)

Dornehme malayen in feftgewand (Kota Bedang bei fort be Zof ).

über dic it eintem fo begabten Dolfe fdilummernden Talente urteilen. 2Tidit mint= der erregen manche feinere flechtwaren aus pandanusblättern und dic fünftlerifh 
vollendeten 2lufter der Stifereien die geredifertigte Bemunderung des Kenners.

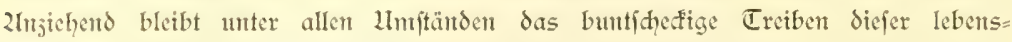
freudigen 3 coölferung, die es nidht veriäumt, jeden 2unlaf ju einer feftliḑen $\mathcal{D e r}=$ anjtaltung ausjuntsen oder von einem 2liarfte nad dem andern zu jiehen, in Witz und Sptel fid ju ergehen, Gahnenfämpfe ju veranjtalten und fidh eifrig an dem Wett= remen in fort de Kodf ju beteiligen. Bet feterliden Eelegenheiten, einer $50 d_{3}$ eit oder cinem forffigen fefte, befommt man dann aud, die malerifhen Tradten $j^{4}$ fhauen, bei denen freilid oft cine fajt überladene Praht entfaltet wird. Die ernftent (5efidter der älteren 2lämner, bei denen der malayifhe Typus mit hervortretenden Baffenfttod̨en, furjer bretter 2raje, mehr oder minder aufgeworfenen Sippen und mur fparlidier Bartentwiflum auffällt, fontrafteren mit den bismeilen geradeju anmutisen, feirten Phyfrognomien der fhwarjhaarigen 2lädd)en mit thren blitgenden 2lugen. 2lan rüḩnt die frauen von Solof und Pajafombo wegen ihree Shönheit, und that=

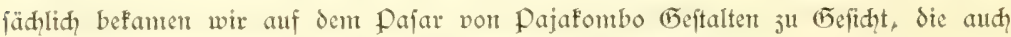
vor cinem verwöhnten europäifhen Zluge beftehen formtert.

für denjenigen, der von Zraturvölfern bisher nu die Bewohner des fhwargen Erdteils femten gelernt hatte, war es ein wahrer Lodhgenuf unter eine Bevölferung

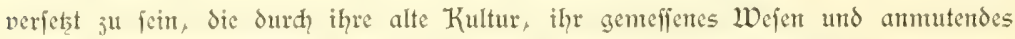
z̈lupere angenehm abftadh gegen die brutale Ltrwïdfigfeit des 2iegers. So war es

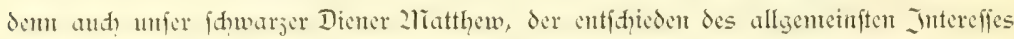
in den Bovenlanden fid zu erfreuen hatte. Die wenigiten hatten jemals emen 2reger

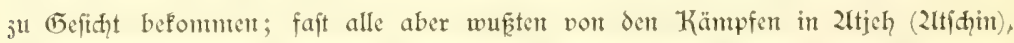
wo die Lolländer früher einige Sđwwarje in Sold gentommen hatten, daf es fid unt jalimme Raufbolde hantle. In den (Fafthöfen verfehlten miemals die malayifden Diener ju fragen, was man dem ,orang hitam" vorjetsen folle, und wo derjelbe fein rahtlager aufiḑlage. Wls idh ihnen antwortete, dafis er gewohnt jei, täglid einen 2malayen ju veripeifen, nahnt die Godhadtung faft bedenflidge Dimenftonen an.

Inter den Drtihaften in den Padarg'finen Lodblanden erfreuen fich jwei, näntid fort de Kod und Pajafombo, niđt mur wegen ihrer zaturjhönheit, jondern aud, mesen ihrer gïnftigen fanitären Verhältniffe mit kicht in ganjen hinterindifdgen 2lrdhipel des beften Rufes. fort de Korf liegt $922 \mathrm{~m}$ hod inmitten der Lodfflähe von 2Igam jiemlid, frei und trägt den Charafter einer freundidgen Dillenfolonie, die fid int Saufe der כeit um das alte fort gruppierte. Seine Refte find nit dent es umgebenden Sturm=Parf ju cinter anmutigen gärtnerifien 2lnlage umgewandelt worden, von der ans man cinen weiten, abwedyslungsvollen Blit nad, Süden auf die Dulfante 27erapi und Singgalang, nad Diten und ZTorden auf das fteil jerflüfete Kamanggebirge, und 
nad, Weftent auf die den Krater= fee von 2lantindju umiäumenten Känme gentefist. Es ift der Sits ciner ftändigen Ẽamifon von der Stärfe eines Bataillonts, die gerade, als wir anlangten, ju einer l̈tbung ausrücte. Sowohl dic eingebore nen, barfuk gehenden Trupper, wie auh die europäifhen, ange= worbenen Soldaten der Infanteric und Gebirgsartilleric madyten in ifren gutgehaltenen Huiformen und in ihrem ganjer 2uftreten einen vorteilhaftert Eindrut.

Bejonderes Intereffe crregte das Sajarett, welhes, wic alle

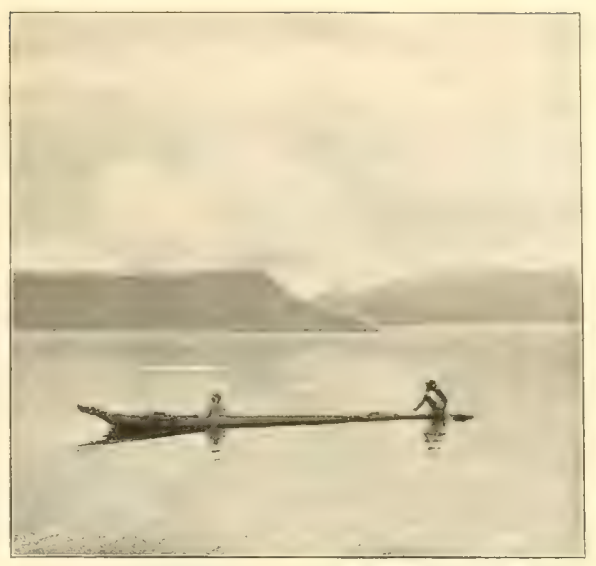

Ituf demt Kraterjec von Maninoju. (Schmidt phot.) holländifhen Eajarettbauten, nad) dem Barafenfyitem angelegt ift. Wir waren an= gentehm überrajht, als Vorfteher desjelben wiederum einent deutjhen Eandsmant aus Bayern, Dr. Preitner, femten ju lernen, cinen älteren Lerm, der uns mit freundidier Juvorfommentheit die Einridytungen des Eajaretts erflärte. Sbwohl es aud? Eint= geborene aufninmt, fo war es bod, wefentlid mit Refonvalescenten von 2lijeh belegt. Bei dem Eintritt des 2rates in die Kranfenfäle erheben fid dic 2ralayen, foweit es ifynen möglid ift, und fitzen aufre⿻̧一㇂㇒ mit gefreujten Bemen im Bett. Wir hatten hier

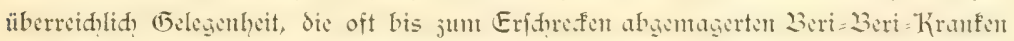

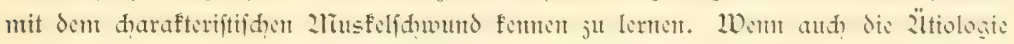

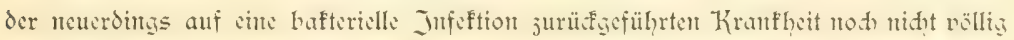
aufgeflärt ift, fo fteht es dod, feft, daf es für die Letlung fdqwerer fälle fein anderes 2hittel giteht, als dic Enafuation ans dem rerufenen 2ltjohgibiet. Dasfolle gitt and? für dic fạwer an 2lialaria Erfranten, wilhe cin mindeftens ahemo hohis Kontinsint an Patienten bilden. Die 2ralaria ift die Geifel des Ginterindifhen 2trdipels, und dic Gejundheit entes cinjelnen Drtes mird wefentlid nad der Läufuffit und Intenitut

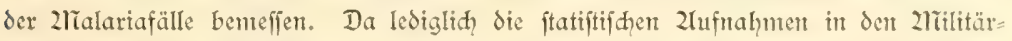
hofpitälern uns ein Irteil über dic Derbreitung der 2ralaria ermöglidhen, fo mą er=

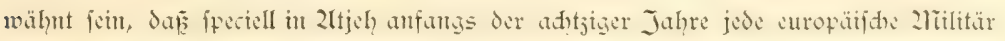
perfon wenigitens eimmal an fdwwerer zlialaria erfranfte. Die Derbältniffe haben fid? neuerdings, wie idh den zritteilungen cines hollätdifhen 2hititärarjtes, Dr. Ent, ent= nehme, injofern gebeffert, als mur der je jweite 2ltann, von den 2lifaten joder vierte 2liam erfranft. ZTur Sann, went die 2lialaria wie ein Würgengel durd das sanb 
geht und ganje (bebiete heimfuht, erbält gelegentlid) der den Derhälntffen femer Stchende cinen Begriff von dem Lntfange der durh fie antgeridteten Derwüftumgen.

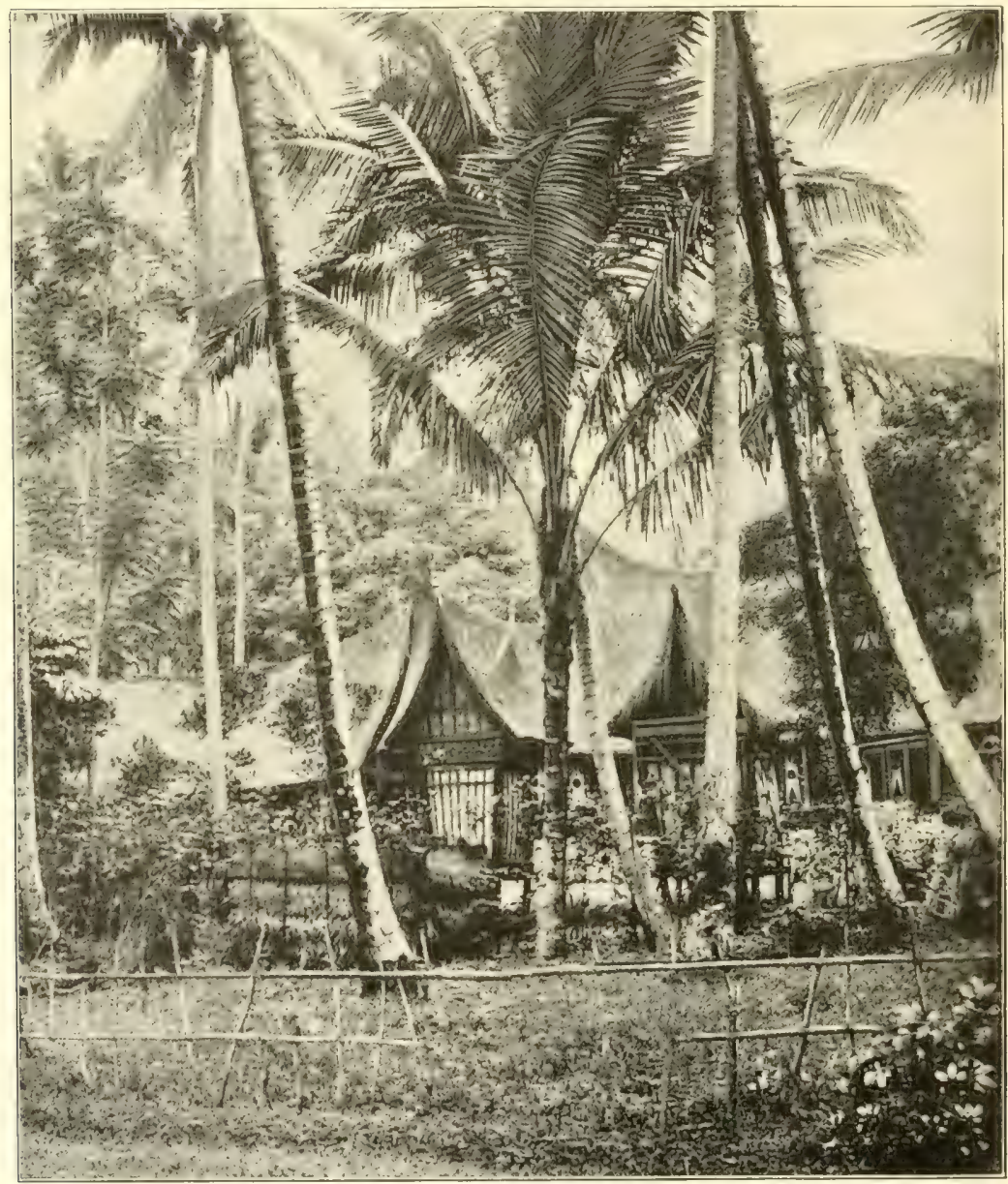

familienhäufer in pajafombo.

Die holländifde Regierung hat es nidht an Derfuden fehlen laffer, aud die Bevolferung der Wohlthaten des Chiningenuffes teilhaftig werden zu Iaffen. 2luf 
Deranlafijung des holländifhen Kolonialminifters $p a h u d$ begab fid 1855 der $B_{0}=$

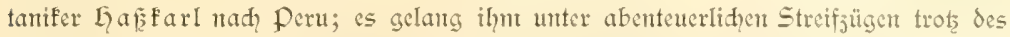

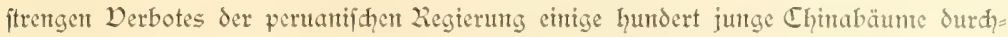

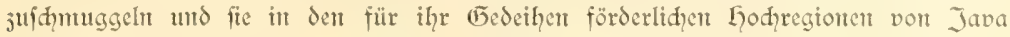
zwifhen 1500 bis $2000 \mathrm{~m}$ antıuflanjen. Jehn Jahre fpäter warfen die treffilid ge deihenden und durdh Steflinge vermehrten Stämmdịen bereits fo hohe Erträge $a b$, da f das faft mit (5old aufgewogene Chinin erheblid im Preffe fanf. Die zlialapen haben

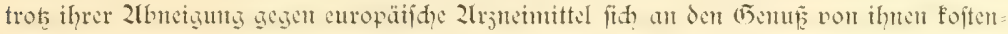

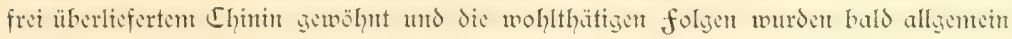
verfpürt. Immerhin bildet in fawereren fällen die Evafuation anf die See oder in

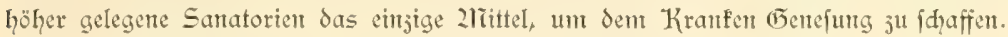

So hat fin dem ein in feiner grofartigen Eiberalität einjig daftehendes Spitem der Evafuation in den holländifhen Kolonten ausgebildet, von dent man einen ungefähren Begriff erlangt, wenn mant erfährt, da í im Jahre 1897 in den Ginterindifđhen 2litilitär= holpitälern 60451 Kranfe in Behandlung waren, von denen nidht weniger als 16692

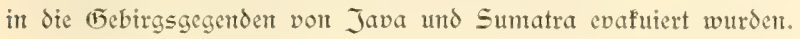

für Suntatra fontmet in erfter Sinie fort de Koof in Betradyt. Die fühle (bebirgs= Iuft wirft fajt wunderbar auf die an 2ralaria und Beri=Bert Erfranften cin: Ser 2lppetit wird reger, der Sthlaf tiefer, die Elafticität des Ganges ftellt fith wieder ein und nah wentgen 2lionaten ift meift vollftändige Geilung erjielt. 2lllerdings bedarf der "Kranfe in fort de Kod" infofern befonderer fürforge, als die Ltnterfidiede jwifden

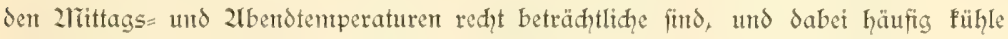
Winde vont 2herapi und Singgalang die Grefahr von Erfältungen nahelegen.

Da es fid wefentlich um Patienten aus 2ltjeh handelt, fo fet mur crwähnt, daf

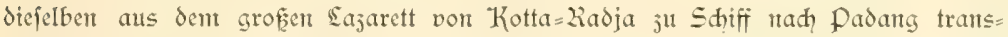
portiert werden, wo cin groferer Teil in dent dortigen Sajarett 2fufnahme findet. Dberft Kuhnert führte miक in diefem geräumigen, aus jahlrethen Barafen und Kranfen= fälen fïh jufammenfeţenden Sazarett umher, das jur Jeit der aufregendften Kämpfe in 2itjeh gelegentlid nidht weniger dem 3000 Kranfe aufnahm. Das Eajarett be= deçt einen gantzen Stadtteil, durd den cin Bad geleitet wurde behufs 2lbfuhr der fäfalien in den padangfluf. Don Padang aus werden die des 2lufenthalts in der 5öhe bedürftigen Kranfen teils nach den Eajarettanlagen in Kajutanan, teils nad? fort de Koot und pajafombo mit der Bahn übergefülyrt. Ergiebt fith and dort feine Eeilung, fo iteht es den Pffizieren und Beanten frei, einen zweijährigen Hrlaub nach Europa fidh ausjumirfen. Ein foldher wird überhaupt allen Beamten bewilligh, die 10 Jaḩre in Ginterindien verbraḑ̨t haben.

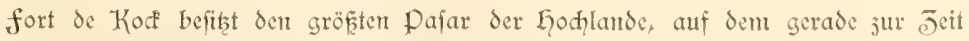
unferer 2lnfunft ein buntes und gefdaftiges Tretben herriḑte. כ̄u fur und ju 
Wagen hatte ïđ die Scuöl forung in $\mathcal{B}:$ megung gefetst: Sie Weiber meift fdwer be: laftet, dic?lian: ner nur jelten fid abithlep=

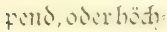
ftens in ben jicrlid geflodi= tenten Dogel= baucrn Tau= bert mit fith tragent. Dic vortebnteren 2lialayent be=

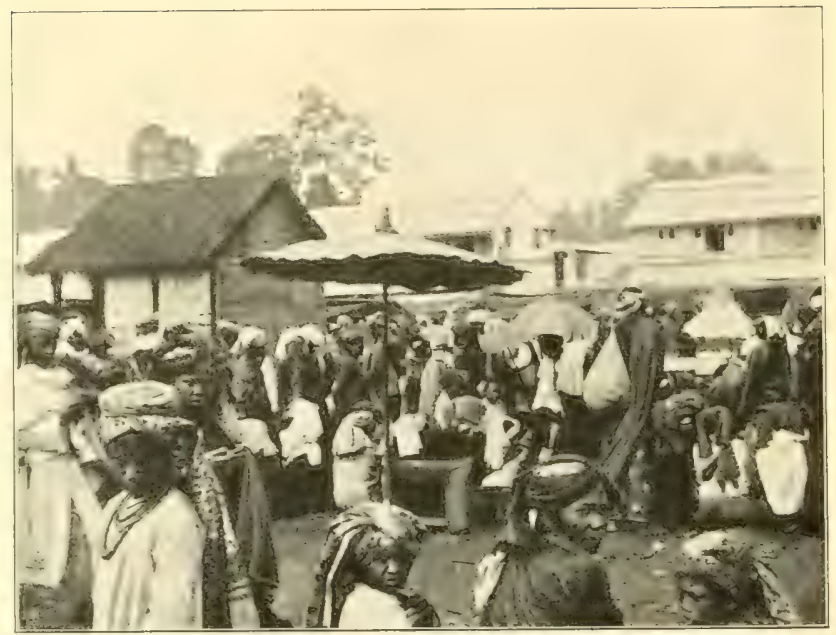
Jutsen die flemen, Inftigen (1)efährte, jwifden die fidh die von dem Karban oder einem

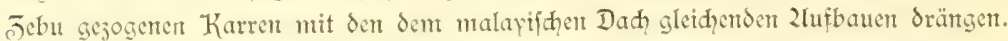
Ein Pafar in den Fodplanden giebt die befte Eelegenheit, die freude des 2ralayen an bunten, oft auffäligen Traditen femten ju lernen. Dielfad ntifdit fid freilid fdon

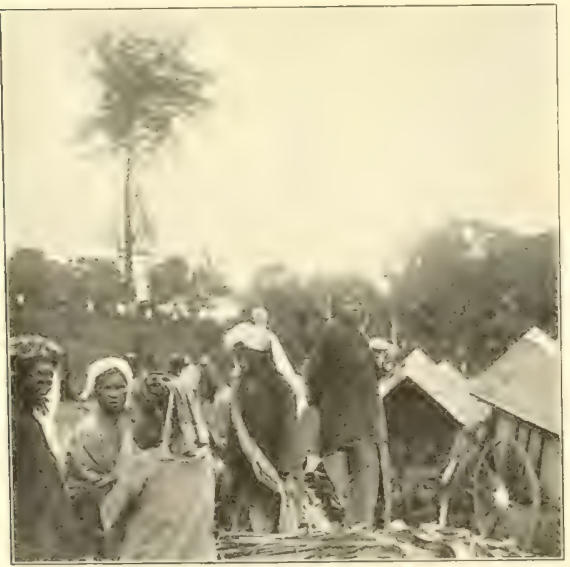

paiar in fort be kiof europaitide Tradit eit, Sod? fehlt ntentals der Sarong, der entweder um dic Elüten gejdlungen, oder wic ein Plaib über die Sdulter getrager wird. 2lls Kopfbededung dient den 2 iämen bald cin turbanartig ge= (d)lungenes (ud), bald cin einfathes Strobfäppden, oder bei regnerificer Witterung die breiten, fpits julaufen= den, aus Palntblättern gefloditenen 5)üte, währent dic Weiber faidene Tildher, unt bei feften cinent fait bijarr fid ausmebmenden Kopf = ¡d)mute aus Silber = und (5̃oldfiligran tragent. 27tctft verthült cin decent anlicgentes, fhwarjes (5) wand den 


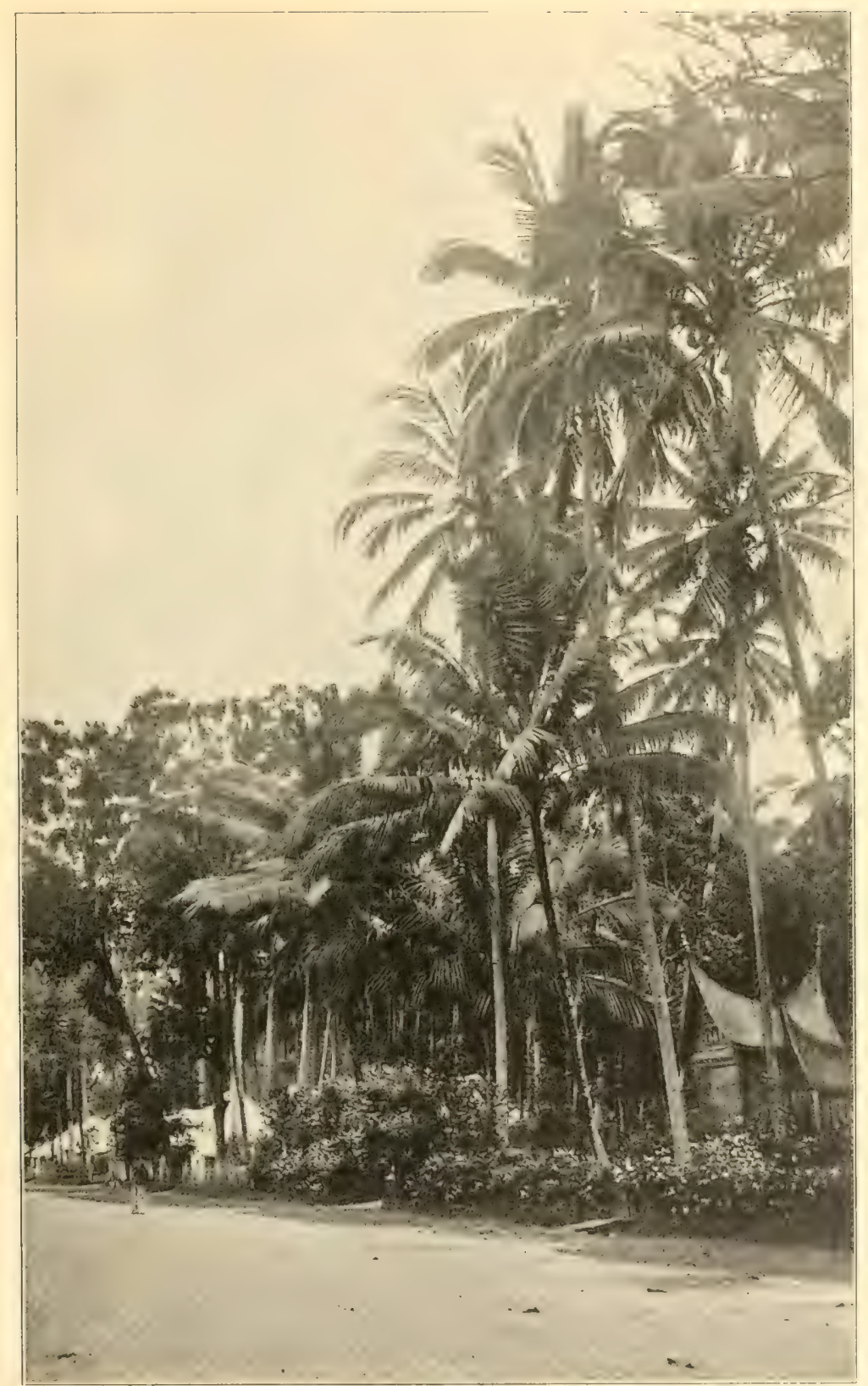

Strafe in Fajafombo. 


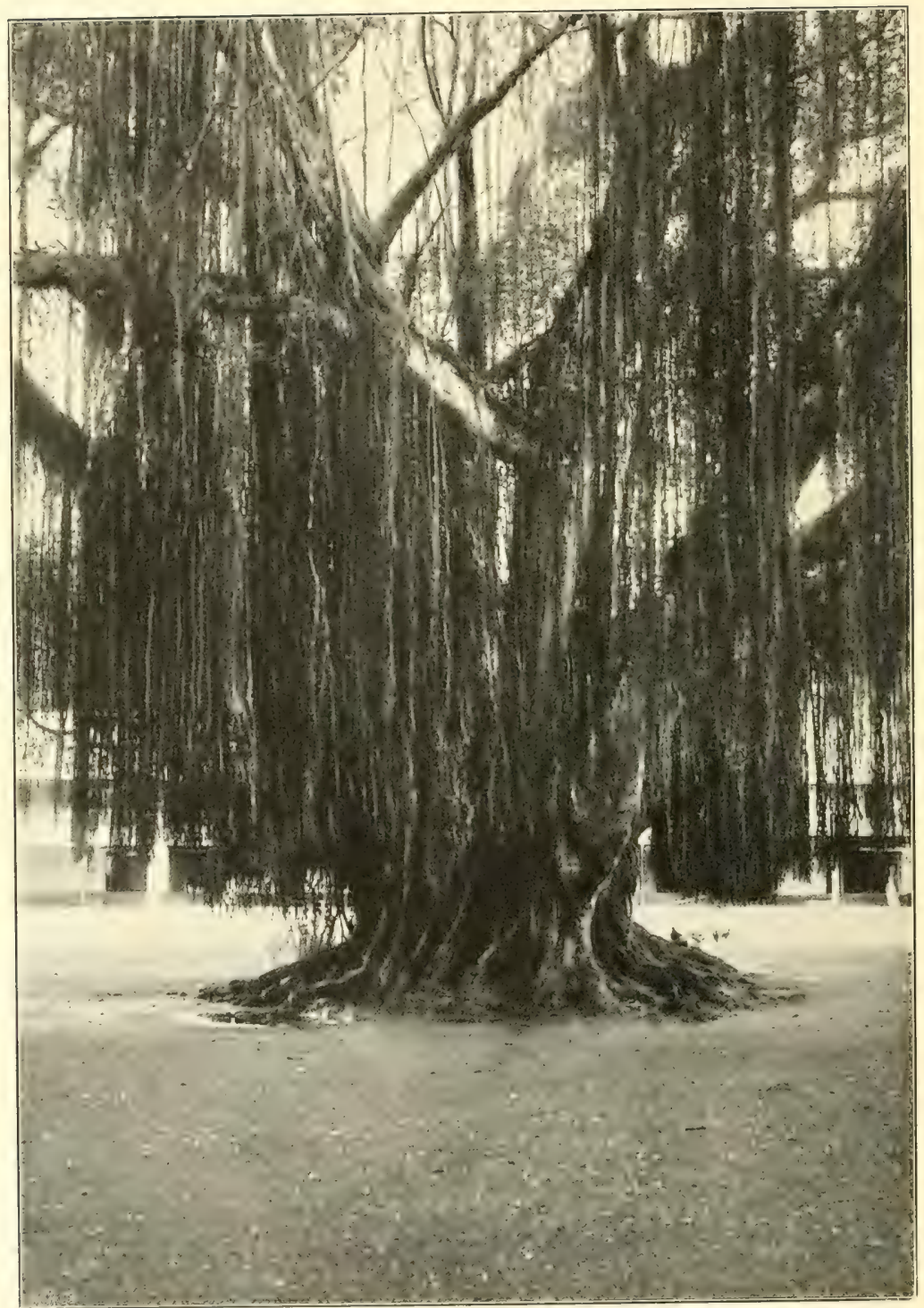

Etamm cires Waringin (Ficus indical auf dem pafar don pajafombo. 
Dbetförper, über das die Reideren foftbar geitifte feidente Sarongs in mantugfaltiger Drapierung gefollungen habert.

Don fort de Korf führt dic neueröffnete Bahnitrede weiter bis Pajafombo. Der Jug durdffähnt weite, mit Sawa's (Reisfeldern) beftellte und von Kampongs überjäte Erofitonsthäler, die naḑ Süden den 2lusblice ju dent $2080 \mathrm{~m}$ hohen Dulfan Sago

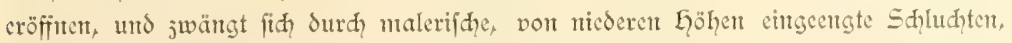
bis fid endid die Sandfhaft ju entem breiten Keffel ausweitet, der mit chent Kofos. wald bededt ift. 2Tur auf den Koralleninfeln des Indifhen 2lrdyipels fund uns ähulid? ausgedehnte Kofoswaldungen entgegengetreten, wie hier in dent Lodylande it der $U_{n=}$ gebung von Pajafonbo. Der Drt felbit liegt in einer Göhe von $514 \mathrm{~m}$ und befiţt ein milderes Klima als fort de Kock. Da er vollitändig in den Kofoswald eintgebaut

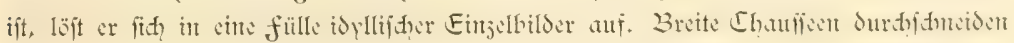

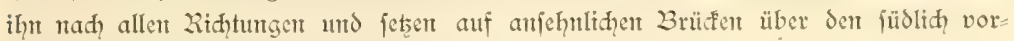
beriftömenden 2lgamifup. Derdefft von dent Grün des Huterholjes und der Bamanen,

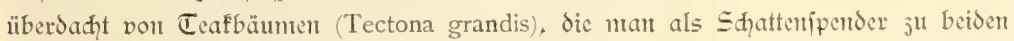
Seiten der Strafen anpflante, und überragt von den ftoljen Kronten der Palnten

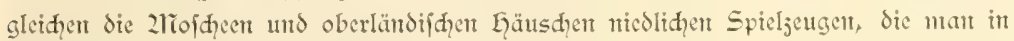
bunten Durdyenander durd diejen grandiojen Tropenparf verteilt.

Finen feffelnden 2lnblit gewähren auf dem Pafar jwet 1Daringin (Ficus indica), von deren Z̈̈lten wie Couliffen Sie Snffwurjeln niederhängen; da fie offenbar befd̨nitten werdent, fo haben fie nidit in dem Boden Wurzel gefaf̧t.

Während unferes jweitägigen 2lufenthaltes in Pajafonbo verfeflten wir nidit, cinten 2lusflug nad, ciner jener Sđluditen ju maḑen, die cinen Charafterjug ber Padang'fhen Llodilande abgebent. Es war die Kloof von 2lrau, die wir in einem

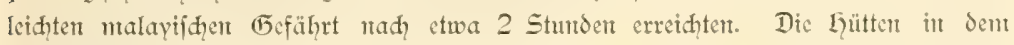
wiederum intenfiv Eultivierten fladland madien cinch etwas ämtidyeren Eindrud, während die Sceneric bald cinen ganj eigenartigen Charafter amtimmt. 2lm 3ande der Ebene, gegen 2lrau ju, ftürjen die Wände des Erofionsthales fentred?t $a b$, unt Samt bei einem fleinen Gehöft, dem "Koffiepafluis", näher jufanmtenjurüfen tmo cine Sdludt ju bilden, die fo lebhaft die Scenerie des Sauterbrumer Thales wiber=

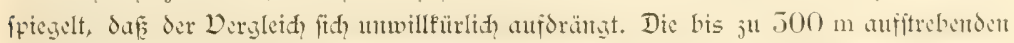
Wände bef̣tehen aus horijontal gefhiḑteten, zu einer Breccie verbafenen Sedinenten,

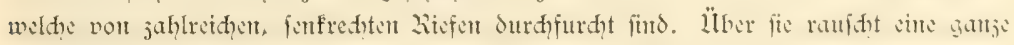
Zunahl vort Wafferfällen hernieder, unter denen der vont Batang=2lrau gebildete auf

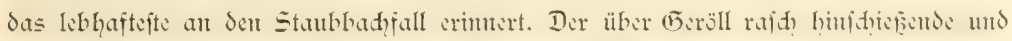
von der üppigen Degetation oft halb verdedfe Bah bewäffert die Reisfelder, weldye nod bis jum Eingang der Sdyluḑt angelegt werden.

Die Steilwände nähern fid an ciner Stelle bis ju $20 \mathrm{~m}$ unt weidhen danm 


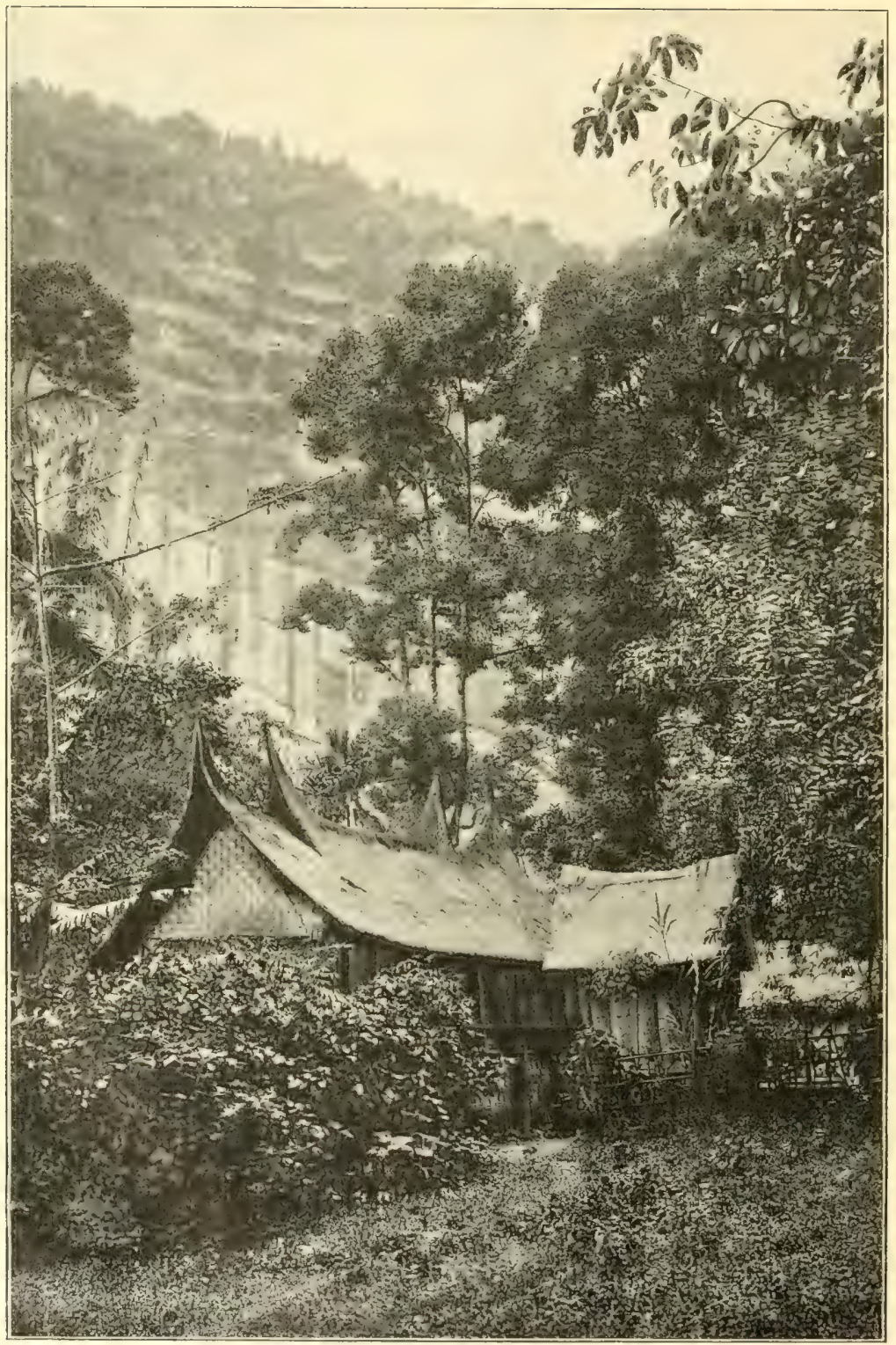

Eingarg in bie zloof par 2trau. 


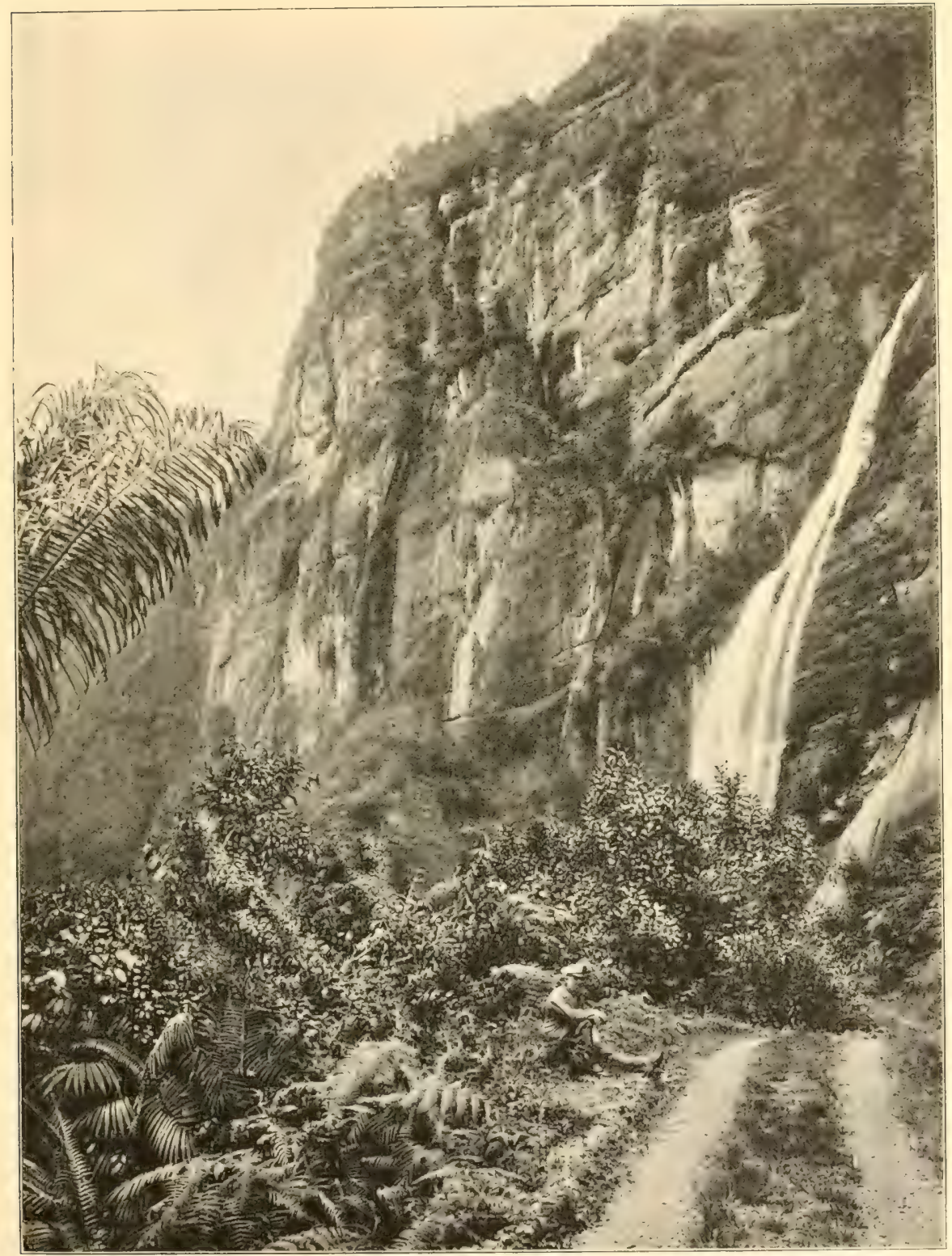


alscintander, um langgejogene Becken ju bilden, in denten das Edo der abgefenerten Sduüfe präđhtig widerhallt. 2rur an dem erweiterten Eingang, hinter Sem Packhaus,

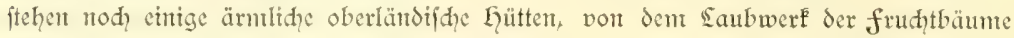
faft vollfommen verdecft un von dem wuđhtigen Gintergnunde faft crorüçt. l̈̈berall, wo fie unr irgend Eqalt finden fann, fprief̧t an den Gängen cine üppige Vegetation von Kletterfarten Lygodium, rothlühenden 2lielaftontacen und britblüttrigen Sinzilberasen. Der Boden wird von den in den Tropen weitberbreiteten farnen aus der familie der (Eleidheniacent bedeft, jwifhen denen die fosmtopolitifhen 210lerfarne und einige Praditeremplare von Baumfarnen (Cyathea) aufragen. Bunte falter, unter thnen die glanjwollen Dertreter der (5̃attung Ornithoptera, fliegen langfan und dod nieder 3 rafd, als daßz man fie hätte erhafden fömten, dahin. Nian giebt dem auth bald den Verfud, ihnen nadjuteilen, auf, da die üppige Degetation feitab vom gebahnten Wige cir fortfonmen fajt ausfdile fít.

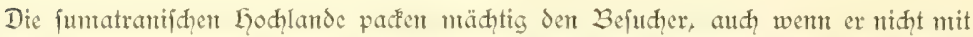
frifhen Büfferimterungen an Eisberge und cinfame von Stürmen unbranfte Injeln

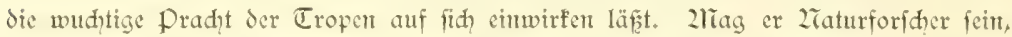
mag er für fociale Derhältniffe Jntereffe hegen, fo wird or in diefem alten Kultur= Iande, dem eine anfgetlärte Ziation eine weife und nufterhafte Derwaltung gab, fíh ftändig jur Bethätigung angeregt fühlen. W Wer dic Tropen mit ihrer überjhäumenden füfle vor Seben in befdaulidhen Behagen will fennen lemten, der gentefe fie auf den

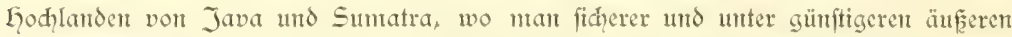
Bedingungen reift, als in manden enropäifden Sanden. Die (5egenjätse treffen freilid, nirgends idroffer aufeinander, als in Sumatra. Im 2rorden grentht die Fodiebene vor 2lgam an das Sand ber Battafer, weldhe noh vor wertigen Jahren dem Kanni= balisnus huldigten; int Süben und Dften behnen fidh weite, faum erforidgte Gebrete

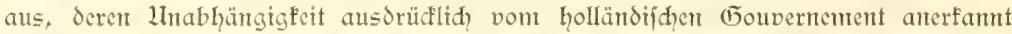
wurde, und cndlid liegt weftlid von Padang, nur eine halbe Tagesfahrt entfernt, dic größ̧⿻ der 2lientawei= Jujeln, deren Eingeborene mit Bogen und pergifteten Pfeilen fith des fremtlings erwehren.

Erfrifht und faft beraujht von den Scenterten des paradiefifhen Fodhlandes fehrte man nady dem heipen Emmahafen jurüc", in dem injwifhen der "Buffard" fith vor 2trtfer gelegt hatte. War die "Daldivia" der zweite deutfhe Dantpfer, der dic Koningime $=$ Bai aufiud)te, fo wurde dem "Buffard" die Ehre zu teil, als erftes deutides Kriegsiniff in dem Emmahafen Salut zu fenern. Rafh entwidelte fid wie überall, wo wir mit den fleinen im 2lusland ftationterten Kriegsfhiffen jufammen= trafent - ein ungejwungener Derfehr jwifden den Befaţungen. Das deutifhe Element 


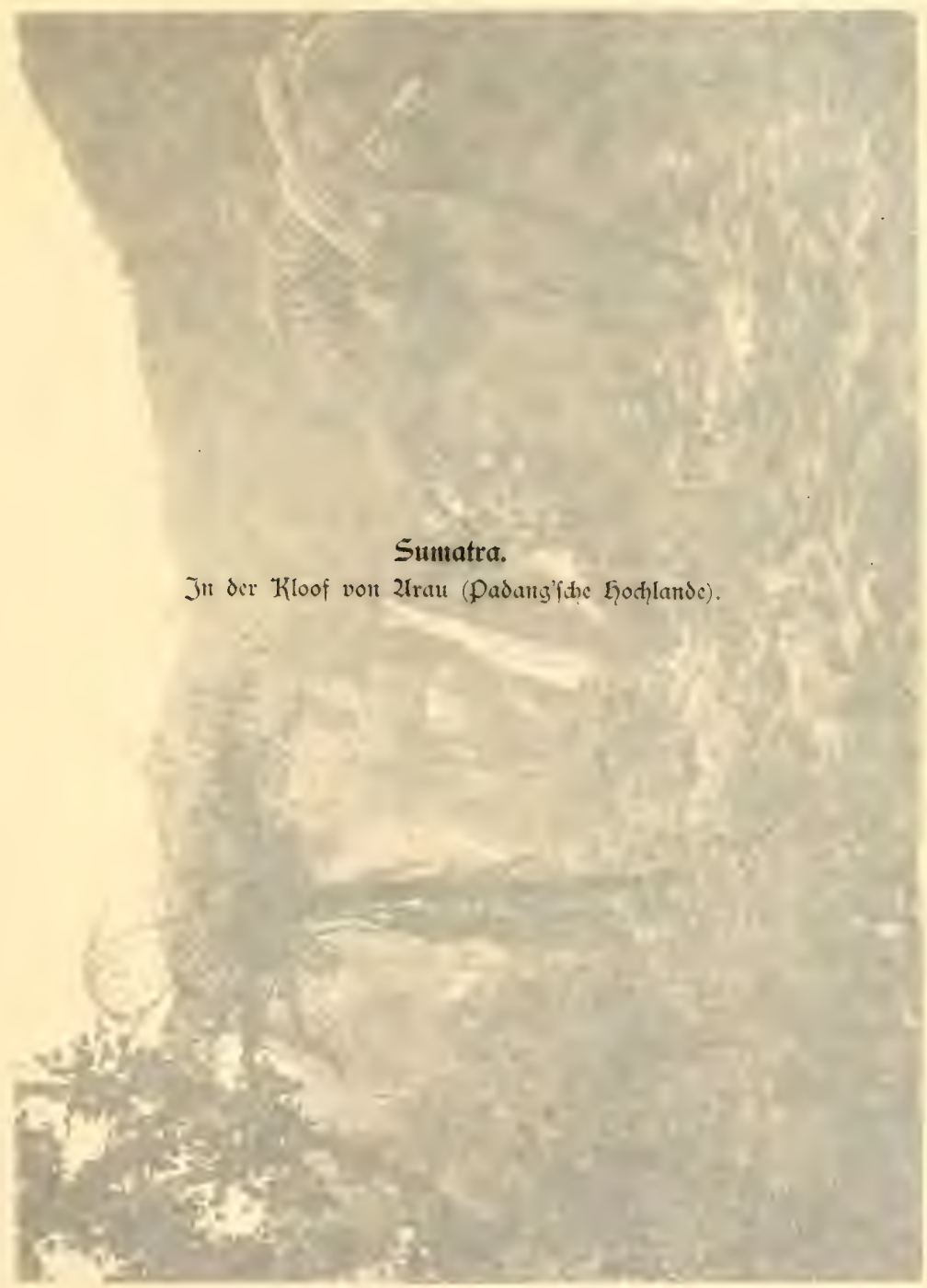




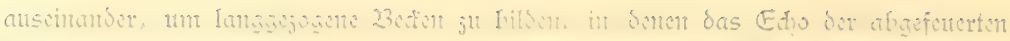

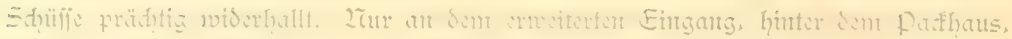

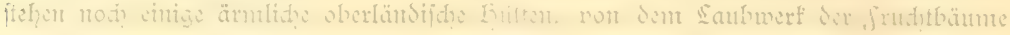

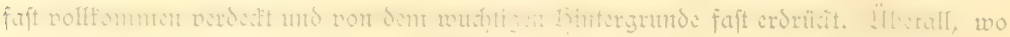

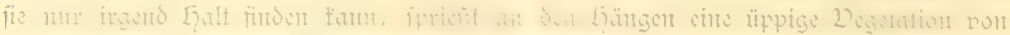

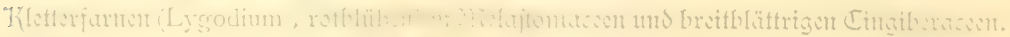

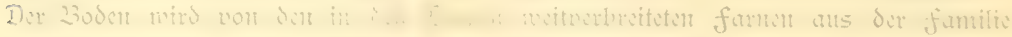
Solv की

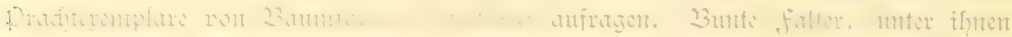

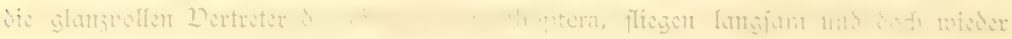

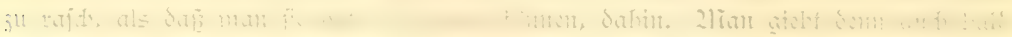

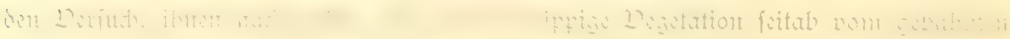

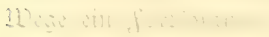

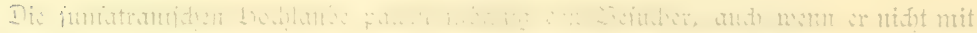

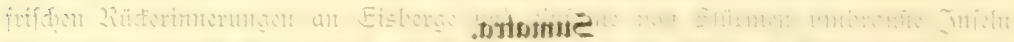

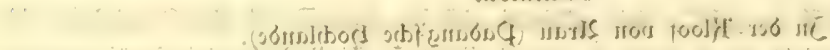

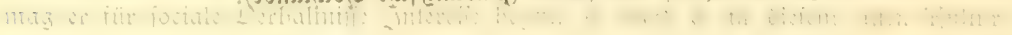

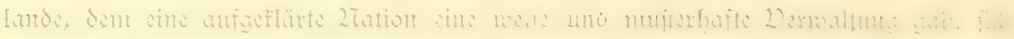

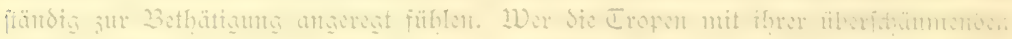
fölle rom a

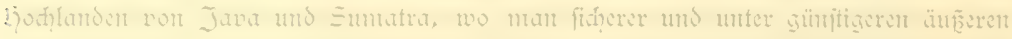

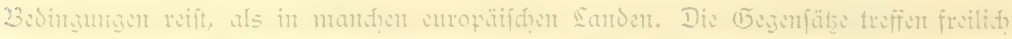

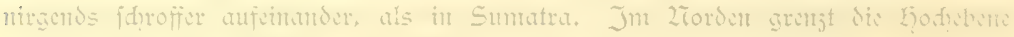

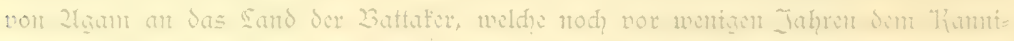

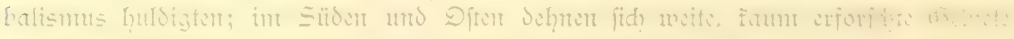

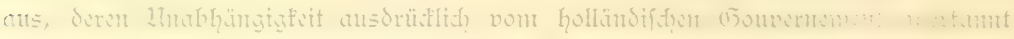

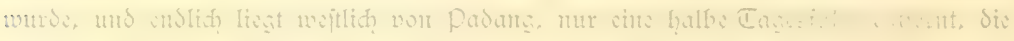

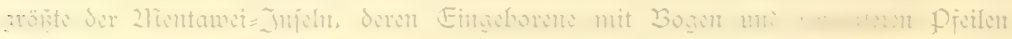

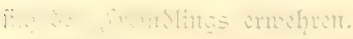

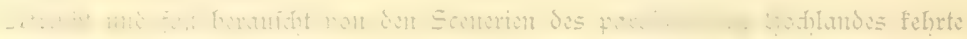

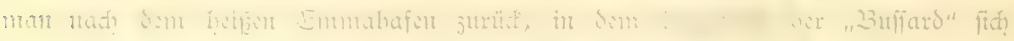

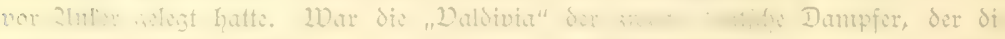

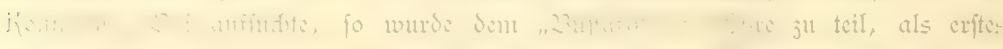

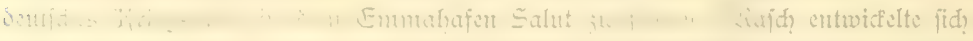

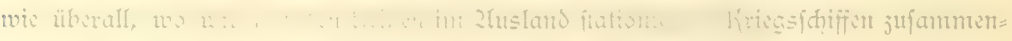

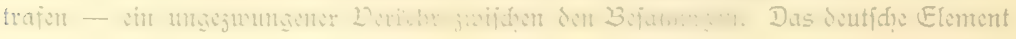




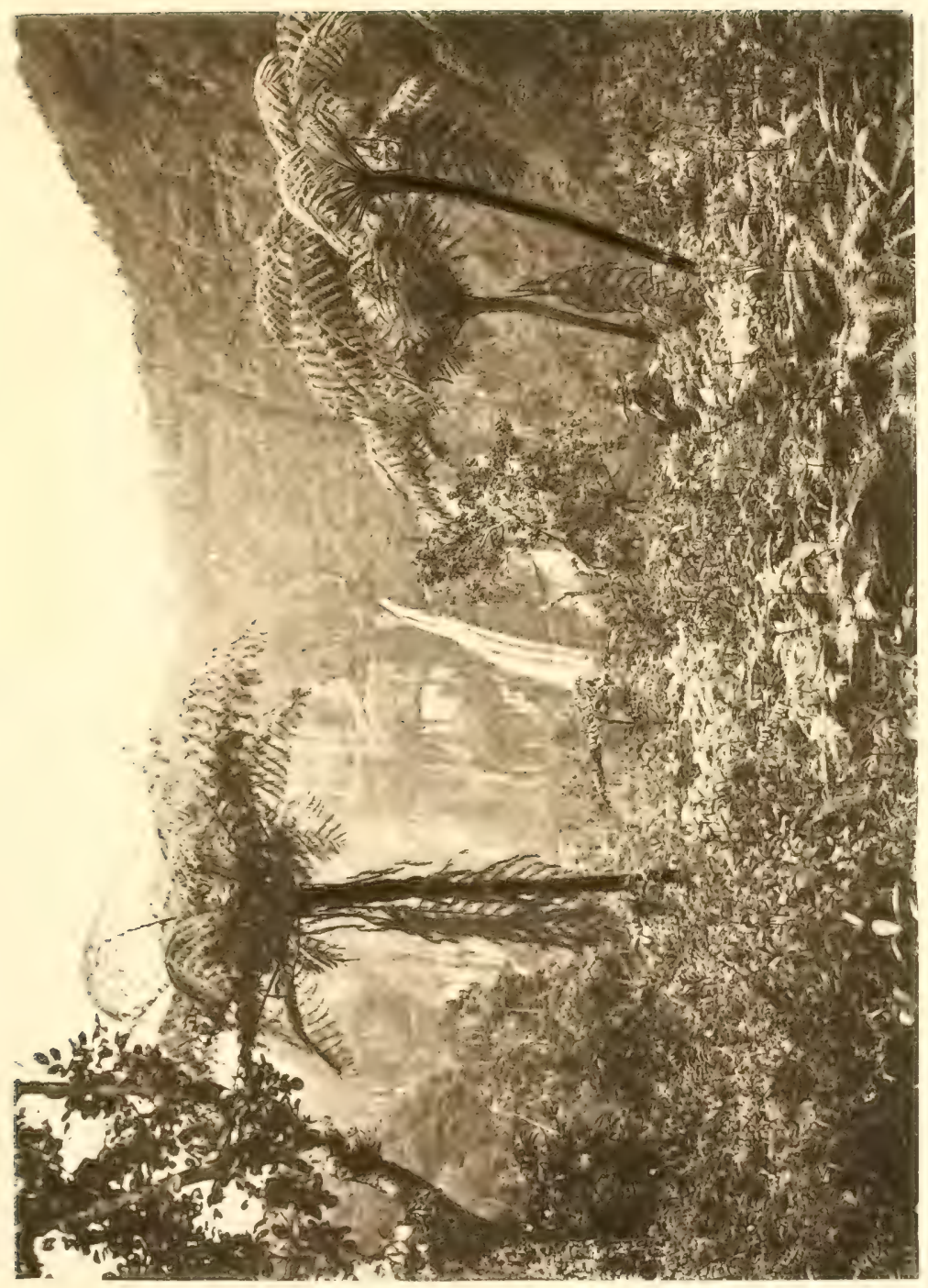


. 
modhte denn audh wohl ebenfo ftarf wie das holländifice vertretent fein, als wir der

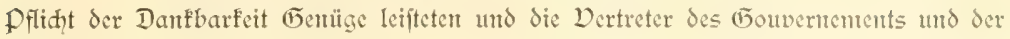
Kaufmamidhaft mit ihren Dament an 2lbend por der 2lbfahrt auf der "Daldivia" als Gäfte begrüß̨en durften. Der warme Danf für das Entgegenfonmen flang in das God auf die annutige Königin Wilhelmine aus und bie Kapelle des "Buffard" intonierte die holländifde 2iationalhymme. Unter Dorantritt der 2lìnfif geleiteten wir

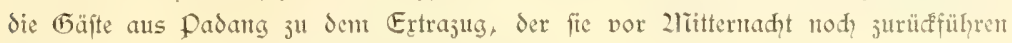
follte. Er fuhtr nit vier Stunden Derfpätung $a b$.

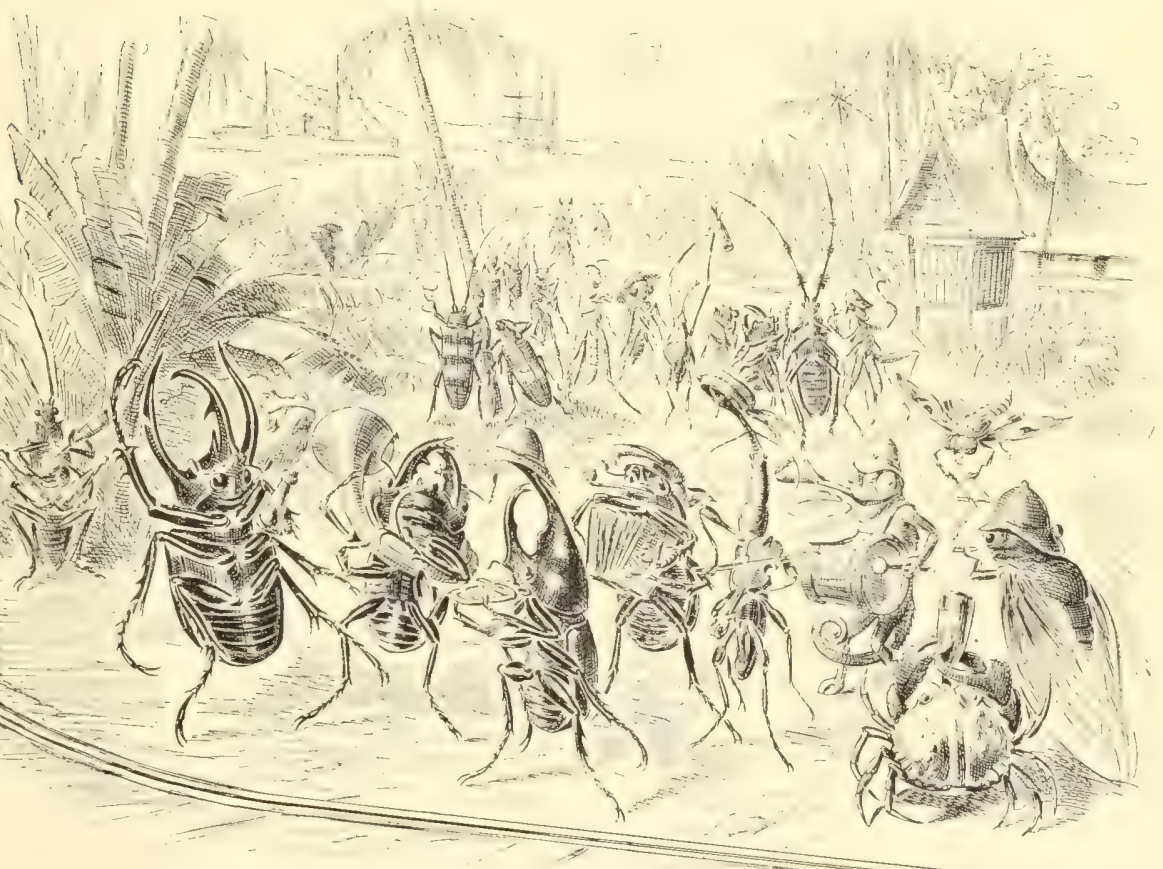




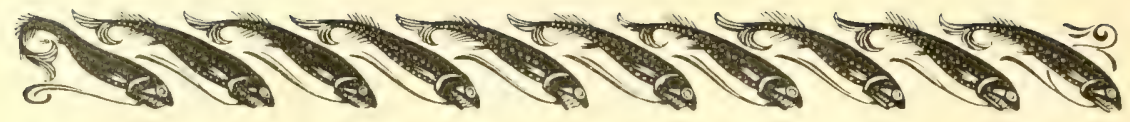

\section{Int MTentawei=Becfen.}

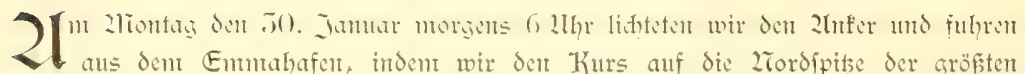

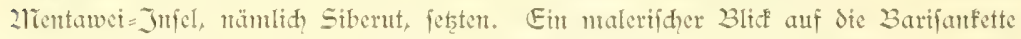
mit den biden dic Scenerio beherrigenden Dulfanen Singgalang und 2lierapi bot fid uns bet fpregelulatter See dar, nadjom wir den 2lffenberg und die jahlreidhen flemen Riffe und Infeln, welde der Recde von pandang vorgelagert find, paffict hatten. Im ZTorden tandite duftig violett der fagenumwobene vulfanifde Kegel des pafantan oder Birits Dpthir auf. Wie es gefommen fein mag, daf mat gerade hierher das sand

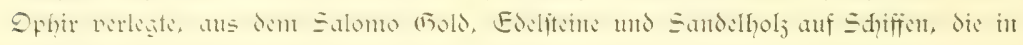

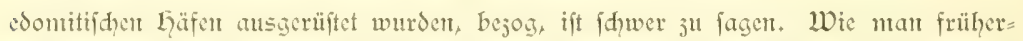
Gin die Göhe des Sphir (5000 m) bedentend überfhätste, fo haben fid and die $E_{r=}$ wartungent, die man an reides Goldvorfommen in Sunatra fmüpfte, nid̨t erfüllt.

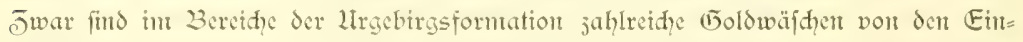
geborencu angelegt wordm, aber der Ertray ift dod inmterhin ein fo mäfitger, daf Eumatra bis jetst den ihm in alten Traditionen juerteilten Ruf eines Goldlandes nidyt geredtfertigt hat.

Unfere weiteren Lnterfuḑungen galter jenem Becken, das jwijđen der Sübweftëufte von Sumatra uno ber ify vorgelagerten Infelfette fid erftreft. Die letstere befteht aus gröferen, in regelmäfigen 2lbfänden fith folgenden Jufeln und aus zahllofen flemen Eilanden und Biffen, welde tetls dic umfänglid̨eren Erbebungen umfäumen, teils den nördidyen flad̨en Teil des Bedents ausfüllent. Die füdlitjpte Infel ift Engano nit feiter neurdings rapid dahinfterbenden 3evölferunt, dent in weiterem 2ubfande dic von uns bei der 2)mäherung an Sumatra gefiḑtete Jnjel Triefte folgt. Zlu dicfe

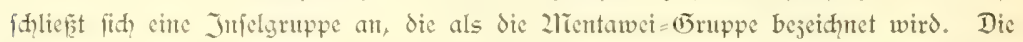
beiden füdlidiften Infeln der genantent (5)uppe, nämlid, 2Tord= und Süd=Pageh, werden

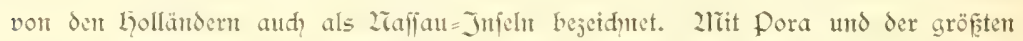

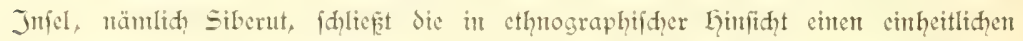
Kompler bildende 2lientawei=(5ruppe ab. Die in der fyöhe von padang liegende Siberut= ftrafe trentht fie volt den 3 atu= Jnfelst. 2luf dicfe folgt dic gröpte und bedeutungsvollife 
Jnfel, nämlich Zias, an die weiter= hin die flemen, das Becfent aus= füllenden Banjaf = Juteln, nnd endlid Pulo $=2$ abi fidh anreilyen. L̈lber den geologifgen 2lufbau der genamten Jnjeln fint wir leider mur fehr un= vollfommen ortentiert. Sie fint alle didit bewaldet, faum aufgeidloffen, und fo würde es fidh nidht verlohnen, die eirjelner geologifaten Datert, dic wir namentlich pon Zias befitsen, genauer ju darafteriferen. $\mathbb{E}_{S}$ mag gentigen, ju erwähnen, daf́ ein vul= fantider 2lufbau im (5̃egenjats ju Sumatra nod micht mit Sidherheit nahgewiejen wurde, wem aud dic häufigen von dort ausftrablenden Erobeben thren Eridyüterungstreis bis ju den Jufelgruppen ausdehrten. Es jheint, daf fie einen Kern aus Urgebirgsformation beftsen, dem jün= gere, fedimentäre Sdidhten (itt 2rias wurden jungmiocäne 2liergel mit Braunfohlenlagern und pliocäne Ko= rallenfalfe nadjgewiefen) aufliegen.

Das Becfen jwificen der Küfte von Sumatra und der genonnten Infelreihe ftart in feinent nördliden 2lbfhnitte von jahllofen Korallent= riffen, welche die Shiffahrt ju enter gefährlichen geftalten. Im Süden be= fdränft fid dic Riffbildung auf dic fumatranifhe Küfte, der dem aud? dic jahllofen, bereits früher erwähnt= ten fleinen und dihtbewaldeten Ko= ralleneilande vorgelagert fint.

Die Seefarten geben lediglich dic Tiefen bis ju 60 faden in der

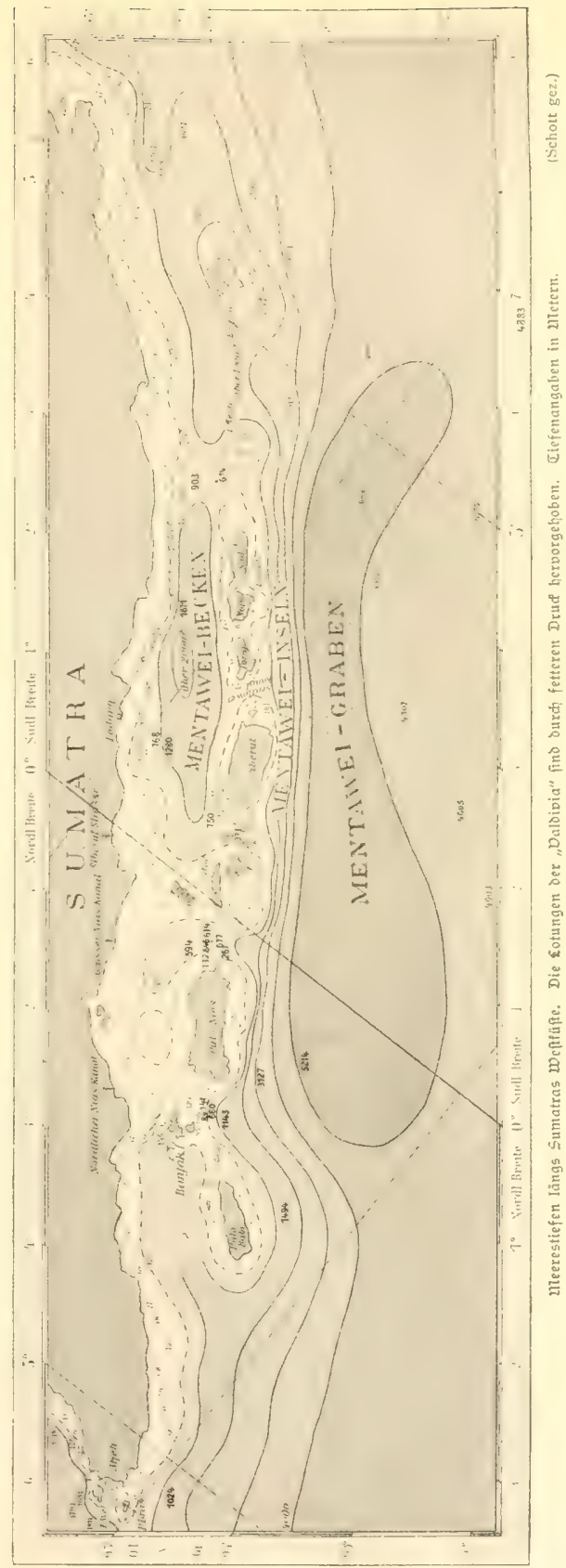




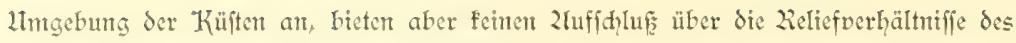

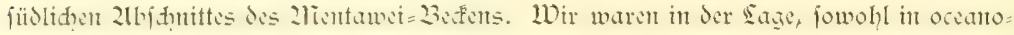
graphifher, wie in joologifder Limfidit eine Reihe neuer Zluffillüfe ju gewmen, unter

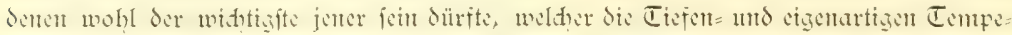

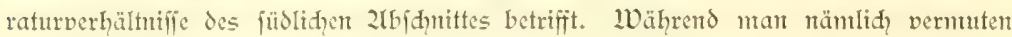
Surfte, dafs es fid um cin relatio flahes (Ẽebiet handele, fo waren wir fdion bei unferer 2lmäherung ant die fumatranifhe Küfte nidt wentg überxajht, immitten des Bectens sine Tiefe vort $167 \mathrm{~m}$ jul loten. fünf sotungen jetgen dent aud, dafz wir es mit cintent relativ abagefdloffenen Ranbbeten ju thun haben, das wohl eine Tiefe von $2000 \mathrm{~m}$ aufweifen mag. Es fehren alfo hier ähnlidhe Derhältniffe wieder, wie fie

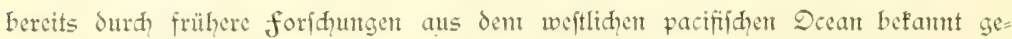

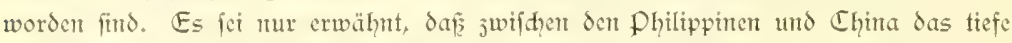
China=Befen ansgebildet ift, dem dant nod? fünf weitere Becfen — unter thuten das Celebes $=$, das Timor $=$ und das Banda=Beffen - fih amreihen. ïber die Gliederung, die Tiefen= und Temperaturverhältniffe diefer Becten hat injwijhen die unter der Seitung vout prof. Weber ftehende holländifhe Siboga= Expedition durd ihre fleifigen Interiuhungen cine fülle neuer und widhtiger 2lufiḑlïffe gebradit. Es mag genügen,

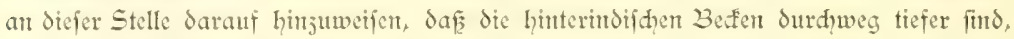
als das nou der "Daldivia" nahgewiefene funtatranilde, weldhes Prof. Supan als "2licntawei=Becten" bejechnete. Jutent wir dicje 23 enenmung beibehalten, fei bemerft,

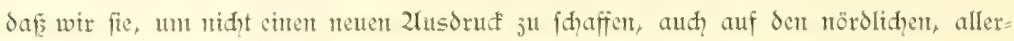
Jitgs fladien, 2lbjonitt ausdehnen.

Der Tieffecboden des 2Tentawei=3eckens befteht nad uneren Interfudyungen int

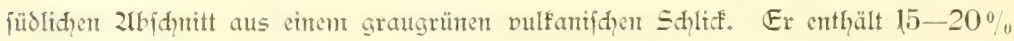

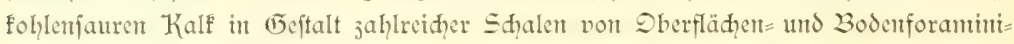
feren mit engệtreuten Coccolithen. Kiejelorganismen, wie Diatomeen, Rabiolarien

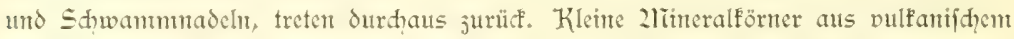
(15las, feldipat, Quarj, 2lugit, Lomblende - gelegentlid, aud 2ragneteifen und Sd)wefelfies - find in die anorphe thonige Subfanj entgefprengt.

Durd frühere Sotungen war berets der 2Tadwweis geführt morden, daf auperhalb der Sumatra norgelagerten Inịelreike die Küfte ftetl in grofe Tiefen abfällt. Wir

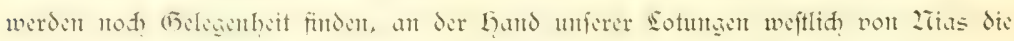
Derhältniffe etwas fpecieller flarjulegen. J̈wijhen den einjelnen Jnfeln jeigen num die

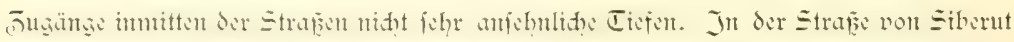
loteten wir $750 \mathrm{~m}$ und in der 2litte des grofen 27ias= Kanals (ï̈did) von 2tias) $677 \mathrm{~m}$. Die ఏugänge dürten fduwerlich eine gröfere Tiefe als $900 \mathrm{~m}$ aufweifen, wie dies aus

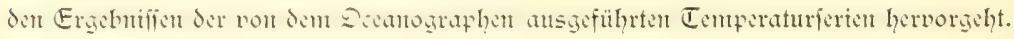
Wenn wir Ietstere efwas fpecieller in Betradit jitehen, fo ergaben fie folgende Refultate: 
Jitifịer (1) cean. 1899.

Ciefieetemperatureu ( ${ }^{\circ}$ C.).

\begin{tabular}{|c|c|c|c|c|c|c|}
\hline \multirow[b]{6}{*}{ Eiefe in $\mathrm{m}$} & $\begin{array}{l}\text { Station } \\
27 r .168\end{array}$ & $\begin{array}{c}\text { Station } \\
2 \pi \mathrm{r} .179 \mathrm{u}_{0} 180\end{array}$ & $\begin{array}{l}\text { Station } \\
27.221\end{array}$ & $\begin{array}{l}\text { Station } \\
\text { 27r. } 190\end{array}$ & $\begin{array}{l}\text { Station } \\
27.214\end{array}$ & \multirow[b]{6}{*}{ Cicfe in $\mathrm{m}$} \\
\hline & $\begin{array}{l}\text { Datum } \\
\text { 5. I. }\end{array}$ & $\begin{array}{l}\text { Datum } \\
\text { 16. I. }\end{array}$ & $\begin{array}{l}\text { Datum } \\
\text { 22. } 11 .\end{array}$ & $\begin{array}{l}\text { Datum } \\
\text { jo. I. }\end{array}$ & $\begin{array}{l}\text { Datum } \\
\text { 10. II. }\end{array}$ & \\
\hline & $\begin{array}{l}\text { 3reite S. } \\
36^{\circ} 14 ! 3\end{array}$ & $\begin{array}{l}\text { Breite S. } \\
\left\{5^{\circ} 8: 1\right.\end{array}$ & $\begin{array}{c}\text { Breite S. } \\
4^{\circ} 6^{\prime}\end{array}$ & $\begin{array}{l}\text { Breite S. } \\
0^{\circ} 58.12\end{array}$ & $\begin{array}{l}\text { Breite N. } \\
\tau^{\circ} 4.3 !^{\prime}=\end{array}$ & \\
\hline & $\begin{array}{l}\text { Eange } 0 . \\
78^{\circ} 45^{\prime} 5\end{array}$ & $\begin{array}{l}\text { Eänge } 0 . \\
96^{\circ} 20 .^{\prime} 3\end{array}$ & $\begin{array}{l}\text { Eänge } 0 \text {. } \\
73^{\circ} 34^{\prime}\end{array}$ & $\begin{array}{l}\text { Eänge } 0 . \\
99^{\circ} 45^{\prime 2}\end{array}$ & $\begin{array}{l}\text { Eanue } 0 \text {. } \\
88^{\circ} 44^{\prime} 9\end{array}$ & \\
\hline & \multirow{2}{*}{ 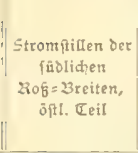 } & \multirow{2}{*}{$\begin{array}{l}\text { Sübāquatorial= } \\
\text { Strom } \\
\text { (SO.-Palfat) } \\
\text { Öjît. Teil bei } \\
\text { o. Kolos=Injel }\end{array}$} & \multicolumn{2}{|c|}{ 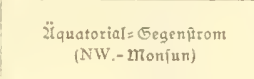 } & \multirow{2}{*}{\begin{tabular}{|} 
ZTordáquatorial= \\
Strom \\
(NO.-Monfun) \\
Butl. Ceil, \\
Bai von \\
Bengalen
\end{tabular}} & \\
\hline & & & $\begin{array}{c}\text { Centr. Ceil, } \\
\text { Chagos=Begeno }\end{array}$ & $\begin{array}{l}\text { Ërt. Teil, } \\
\text { mentabei= } \\
\text { z̧eđen }\end{array}$ & & \\
\hline 0 & 17.4 & $27^{0}+4$ & $27^{\circ} .5$ & $29: 7$ & 27.7 & 0 \\
\hline 25 & 16.0 & 27.5 & 26.9 & 28.3 & 27.1 & 25 \\
\hline 50 & 15.1 & 27.0 & 26.0 & 27.7 & & 50 \\
\hline 75 & $1+.0$ & 25.7 & 21.8 & & $\|$ & 75 \\
\hline .100 & 15.0 & 27.2 & 20.3 & 27.4 & 23.3 & 100 \\
\hline 125 & 12.8 & 23.1 & & 19.7 & & 125 \\
\hline 150 & 12.6 & 21.7 & & 16.2 & 16.9 & 150 \\
\hline 175 & & & 16.2 & 15.0 & $\|$ & 175 \\
\hline 200 & 12.4 & 18.2 & 14.7 & 12.6 & 15.9 & 200 \\
\hline 250 & & & 11.9 & & & 250 \\
\hline 300 & 11.9 & 15.2 & & 11.3 & 11.5 & 500 \\
\hline 700 & 11.5 & & & 9.9 & & 400 \\
\hline 500 & & 9.2 & 9.7 & 9.1 & $\|$ & 500 \\
\hline 600 & 10.2 & & & 9.0 & 9.9 & 600 \\
\hline 800 & 2.6 & 6.5 & & 3.1 & & 800 \\
\hline 1000 & 4.9 & 5.2 & 6.1 & 5.9 & 2.4 & 1000 \\
\hline 1500 & 3.1 & 5.5 & & & 4.6 & 1500 \\
\hline 2000 & 2.5 & & 2.5 & & & 2000 \\
\hline $\begin{array}{l}\text { Bodert in } \\
\text { m Eicfe }\end{array}$ & $2+17$ & 5857 & 2926 & 1280 & 5692 & $\begin{array}{l}\text { Soden in } \\
\text { m Cicfe }\end{array}$ \\
\hline $\begin{array}{l}\text { Cemperatur } \\
\text { am Booen }\end{array}$ & 2.1 & 1.3 & 1.8 & $5.91)$ & 1.2 & $\begin{array}{l}\text { Cemperatur } \\
\text { am Boden }\end{array}$ \\
\hline
\end{tabular}

1) und it Stat. 27r. 187: Bodentiefe $1671 \mathrm{~m}$, Bodentemperatur ebenfalls 5\%.

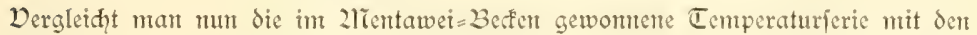
auferhalb der Infelreihe im freien Indifden Deean gewonnenen, fo ergiebt es fith,

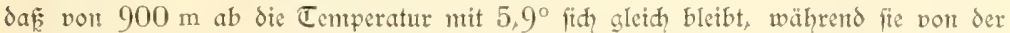
gentanten Tiefe ab int freien Deean fontimuierlid abrimmt und j. 2. bet $1500 \mathrm{~m} 40$, bei $1700 \mathrm{~m} 5^{\circ}$ trägt. 2rus diejen Interifhieden in den Tiefentemperaturen fömten wir

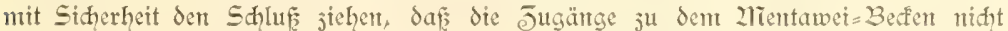
tiefer als $900 \mathrm{~m}$ liegen, und daf́ von der gentannten Tiefe an die Temperatur, 
wic in allen derartigen relativ abgefdloffenen Beffen, fid unabhängig von derjenigen Des freien Deeans geftaltet.

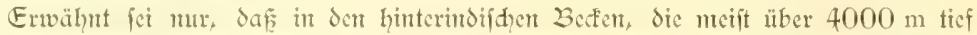
fint (im Banda= Betfen lotete dic "Siboga" $5684 \mathrm{~m}$ ), die Jugänge zumt freien Decan

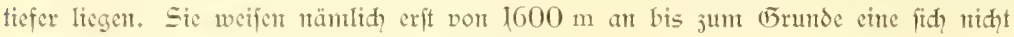
erniedrigende Temperatur von durdjidyittlid) $5^{\circ}$ auf.

Bemerfenswert ift weiferfin nod Ser 2Imftand, Saf der Saljgehalt im 2lientawet= Becfen an der Dberfläd me mit durdfidmittlid, 55,8\% gexinger ift, als in gröferer Tiefe, wo $\mathrm{cr}$ j. 3. in $600 \mathrm{~m}$ den 3 etrag volt $55,5 \%$ erreidt. Die Gerabminderung an der Dberfläde mag wohl wefentlidh dadurd, bedingt werden, daf es fich un ein (5) biet handelt, weldhes int Bereidhe des 2rordweft=2lionfuns mit peinen reidylidien Regengüffen gelegen ift.

Es wiederholen fid hier ähnlidhe Derhältutffe, wie wir fie fhon früherhin bei Befpreduntg des Dutneaftromes ju erwähnen Belegenheit fandent. Wie dort, fo ift es

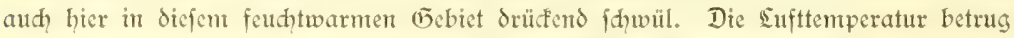

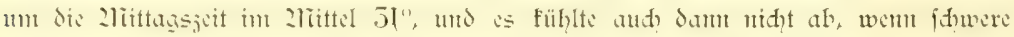

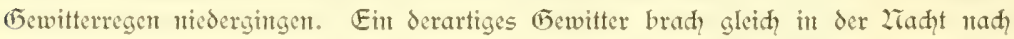
Derlaffen volt Padang herein; wer nad demfelben das 2lieer im Stheine des Doll= mondes ruhig glitern fah, hätte nidyt geglaubt, daf furz vorber nod ein wilder 2 luf = rubr der Elemente herrid)te.

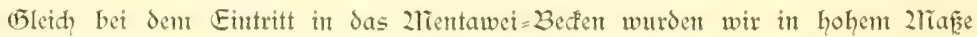
durd das Ergebnis unjerer Sdleppnetzjüge überraidht, welḩes der Erwartung Raum

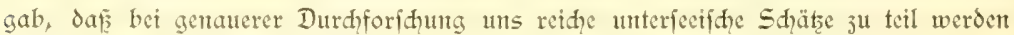
würden. Infere fofinungen find in vollem 2lĩąe in Erfüllung gegangen, und fo verweilten wir viel länger, als wir urfprünglid, beabfidtigt hatten, bei den Jufel=

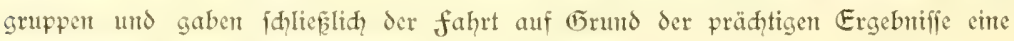
2lusdebmung bis ju den Zrifobaren.

\section{Die Mentaweis Infulaner.}

Bevor wir dic joologifhen Ergebniffe furj ffijzicren, fet es geftattet, den Infeln fellyt und ibren Zemohnem unfere Zufmerfiamfeit jujumenden. 2ls wir gegen 2lbend des 50. Jamar vor Siberut anlangten und während der 2Tađt uns mit ausgeworfenem

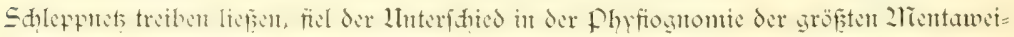
Injel mit Sumatra redit nahbrüflidh auf. Die Jnfel ift jwar gebirgig, aber im ganjen niedrig und, fo weit das 2luge reidt, port dihtem Llrwald bedeft, liber dem fhwere

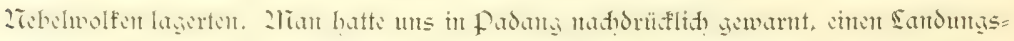
verfud in Siberut ju untermehmen, oa die Bewohner in fdledten 2ufe fteher. Id 
habe nadher es aufriditig bedauert, dap̧ wir, went niḑt Siberut, fo dod, den füblidger gelegenen Jnfeln femen Befud abjtatteten. 2In cinen foldyen dadte man freilid? faum

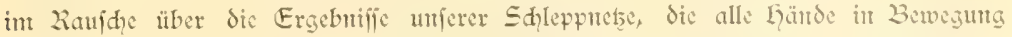

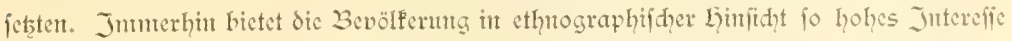
dar, daf man es vielletht entiduldigen wird, went ihe hier cinte furge Bsfipred)ung ju teil wird. Jat vermag fie durd cirte 2litjahl

photographijher, den Typus jentes eigen=

artigen Volfes trefflid wiedergebender

2tufrahmen ju beleben, dic mir Gerr Tieurocuhuis in padang jur ver= fügung ftellte. 2rifht minter bit id Konful Shild ju Danf verpflid?= tet, daf er mix mit groper ฮ̄u= vorfonmenheit cine Sammlung ethrographifder Objefte von 2rord=Pageh jufommen lief. $D_{a}$ derartige Dbjefte in un= jeren 2lüujeen nod ju grof̧en Seltenheiten gehören, fo er= laube id mir an der Fand eintger Bemerfungen diejelben ju reprodujieren.

Der erfte Furopäer, der uns über die Eingeborenen der 2lientawei=(5ruppe unterriditete, war eit Deutifher, 5. von $20_{0}=$ ienberg, der in holländijhen Dienften ftand und im 2luftrage des Gouverneurs die Jnjeln bereifte. $2 \mathrm{ab}=$ gefehen von fpäteren Befuḑen holländifher Beamten (bei weldier Gelegentheit aud bic taditebenden Photographien aufinmomm wurden) haben neuerdings (1897) 2liaaf und

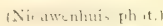

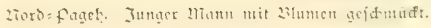
2liorris, weld lefterem wir cine treffliche 2lbhandung liber sic Spradie der 2rentaweier verdanken, die Intel Pora crforjdyt.

Was die Bemohner der 2rentawei=Gruppe anbelangt, fo handelt es fid um einen

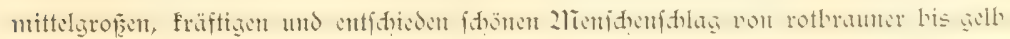
brauter farbe. Der Typus weidgt fehr ab von jenten des 2lialayen auf Sumatra 


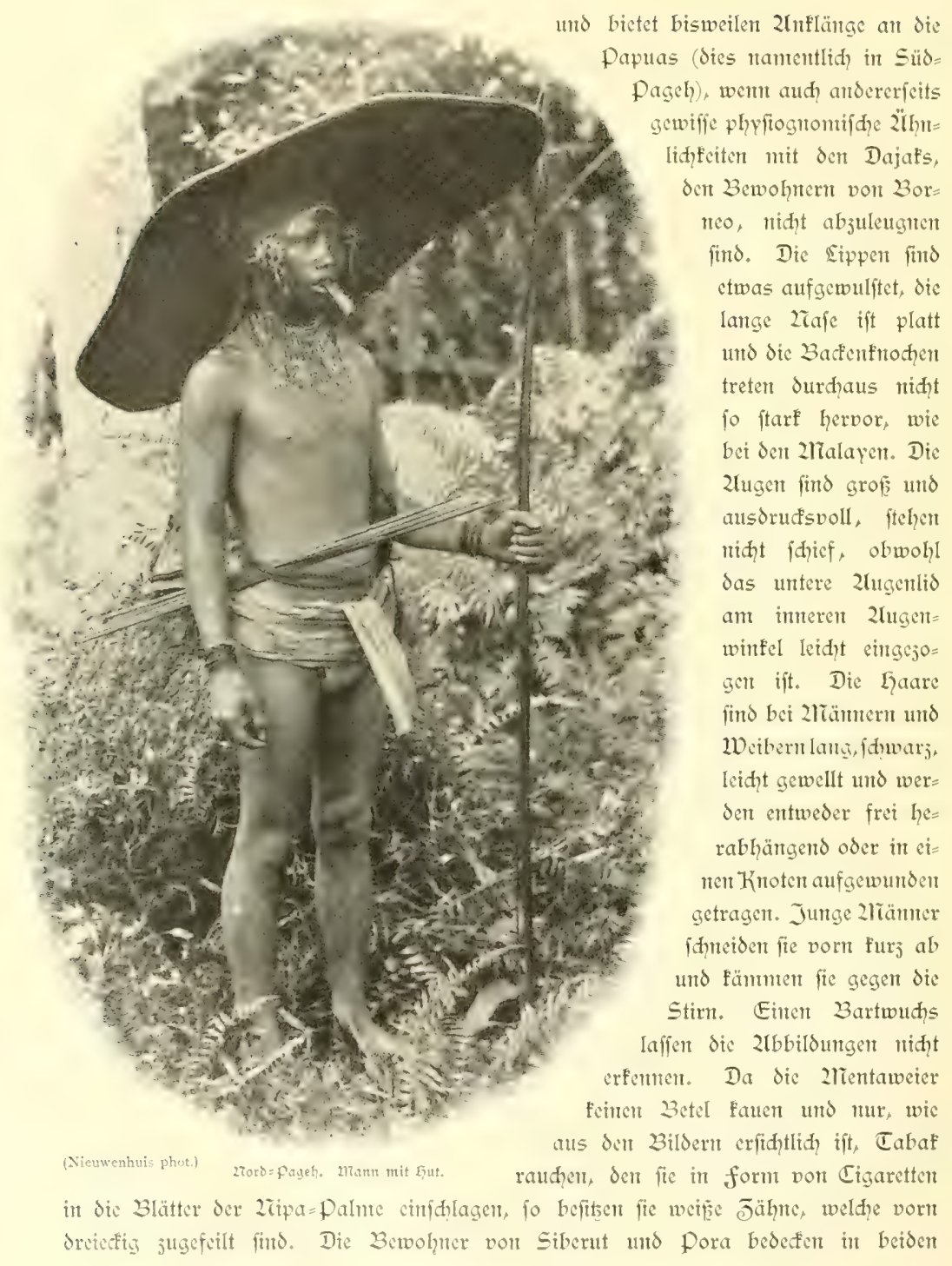




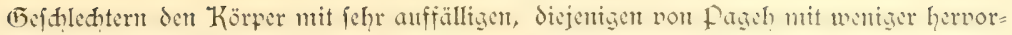
fted̨enden 厄ätowierungen. Die Kleidung ift die denfbar primitivfte. Die 2länner gehen naft bis auf einen $6 \mathrm{~m}$ langen Sendengürtel, der aus Baumbaft hergeftellt und braun gefärbt wird. Daju fommt ein mädtiger Lut, wie er ähnlid groß wohl von faum einem Katurvolf befant ift. Er wird aus den Blattidietden der Sagopalme verfertigt und am Rande mit Rotang veritärft. Die Kleidung der Weiber befteht aus einem Eqüftuch aus Baumbajt oder erhandelter Baumwolle. Daju fonmt bei 2lus= gängen ein wunderlidher ङierat, der geradeju als Charafteriftifum für die Bemohner gelten darf, nämlich eine Eendentrauje aus zer=

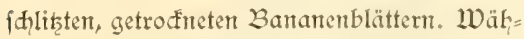
rend bei den 2liädhen der Dberförper ent= blöft ift, tragen dic frauen nod? eine Bruftfraufe, und in Pageh einen dic Bruft einfọnürenden Baftftreifen. Die frauenhüte haben in Siberut und pora die form von Kinderhelmen; in Pageh werden aus jeridhlitsten $\mathcal{B}$ ananenblät tern gefertigte Spiţüte bevorzugt.

Fin irmmathifher ฮ̄ug ift es, daf

- 2ränner und Weiber es lieber, fít? täglid nen mit bunten Blüten und $f e=$ dern ju fdumilfen. In eine Stimbinde fteden fie die roten Blüten des von ifhnen befonders verehrten Hibiscus rosa Sinensis und verfditedenter $C_{\text {roton }}=2$ Irten. Präd)

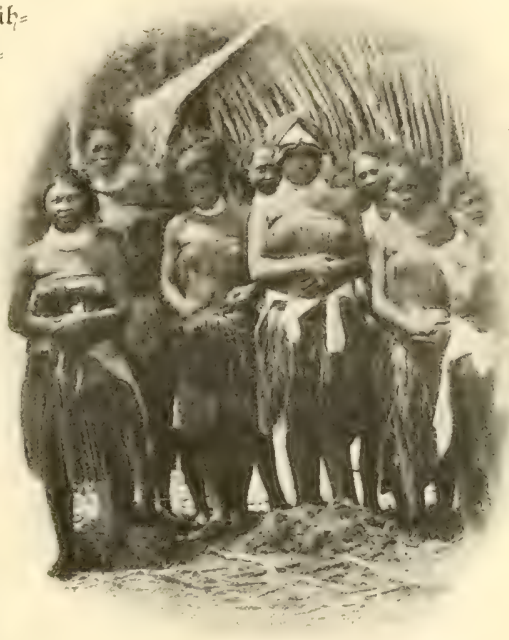
tig foll diefer anmutige Sdmmut mit $\delta \mathrm{er}$ dunflen Laut, die durh fleifiges Baden und durd Einreiben veridiedener Säfte gepflegt wird, Weiber von Sibrrut. (Nieuwenhuis phot.)

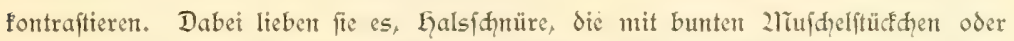
orhandelten ferlen befeţt find, und Eendenfdunüre aus lantgen Rotanģfreifen anjulegen. fingerringe und 2lrmfpangen werden, wie aus den Photographien erfictlid, ift, von 2räntern und Weibern getragen.

Wenn die 2rentawei $=$ Gruppe von den Europäern fo wentg bejuht wurde, fo liegt

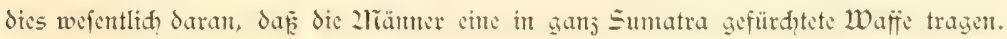

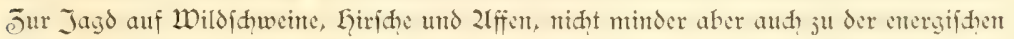
2lbwehr gebrauchen fie nämlid Bogen und vergiftete Pfeile, mit denter fie auf 50 - 60 Shritt Entfermung faum das Jiel fehlen. Die fhwarzen Bogen werden aus dem elaiftifịen Golje der Salap=Palnte (Arenga obtusifolia) hergeftellt, die Eibntin aus 3ajt, chut, Jus den Eiefen bes Weltnecres. Jweite 2ruflage. 
Ser mit Lara verfetst ift. Die Pfeile bejtehen aus jwei Teilen, nämlid eintem ans dent Blattitiel der ZTipa=Palme gefertigten Sduaft und ciner aus dem Llolje der Caryota urens gefertigten, über fener gehärteten Spitse. (5elegentlid bringen fie an Stelle der

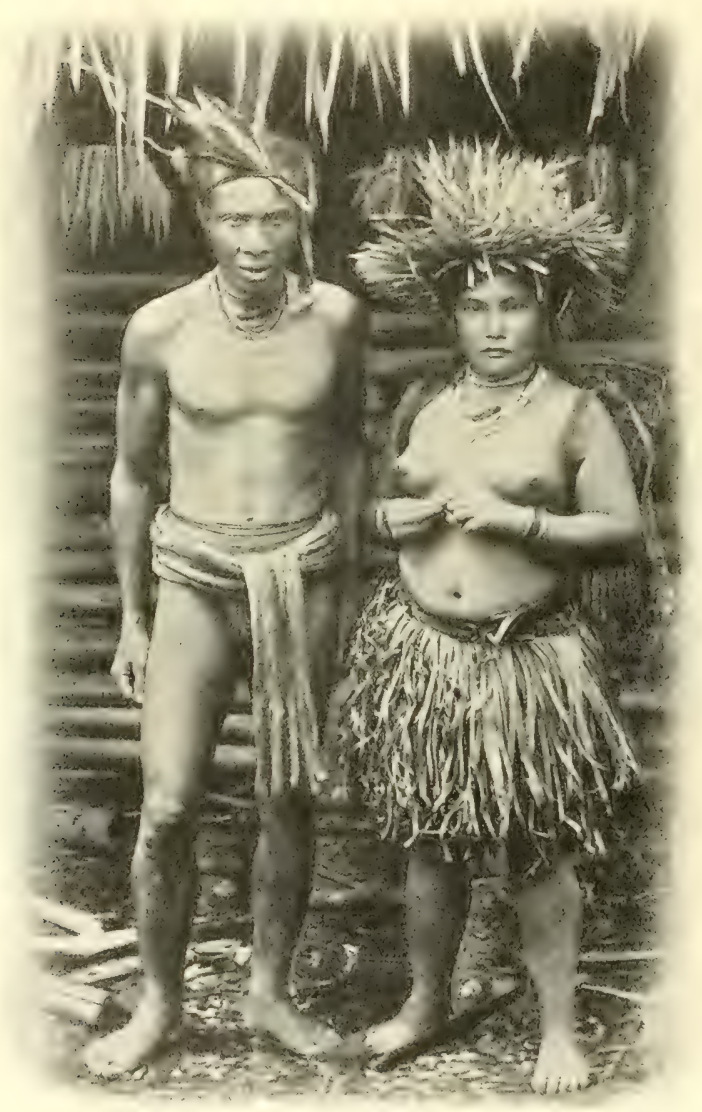

Zoto = Pagel?. Z̈lferer Mann und Mädden. (Nieuwenhuis phot.) langen Spitze Stadieln von Rodhen oder aus zlictall gcfertigte jwei= idneidige Sfalpelle an. 2Taक den Zitgaben von Rofenberg foll das (5ift dent Umet= $\mathcal{B}$ aum entitamment und mit $\mathbb{E}_{\mathrm{r}}=$ traft dex Wurgel cines Cocculus=Straudies, dem Tabaf und Capficum beigenifat wird, verist werder. Id habe die Pfeile aus jwei Ködern (jeder Ködher enthält 40 bis 50 Pfetle) meinem Kollegen Boehm, dent befanten Pharmafolo= gen, jur Ulrterfudung übermittelt. Es ergab (id), daf die in dem eirten Köd)er enthaltenten leine Giftwirfung erfenter lief̧en, während diejent= gen des anderen, obwohl fie fhon lange डeit aufer (5ebraud waren, nod, phrenergifdue Reattionen hervorricfen. Der furje Beridit lautet folgender= maf̣en: "Die Pfeile des jwciten Ködiers find an

Ser Spite jur befferen firienung des (Tiffes mit fäben umwicfelt und daranf ift die

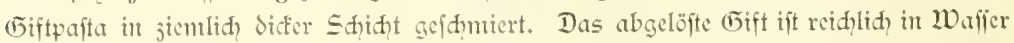
löslich. Das Söslidic von 5-10 mg gerügt, um bet fröfhen den dqarafteriftifd̨en 


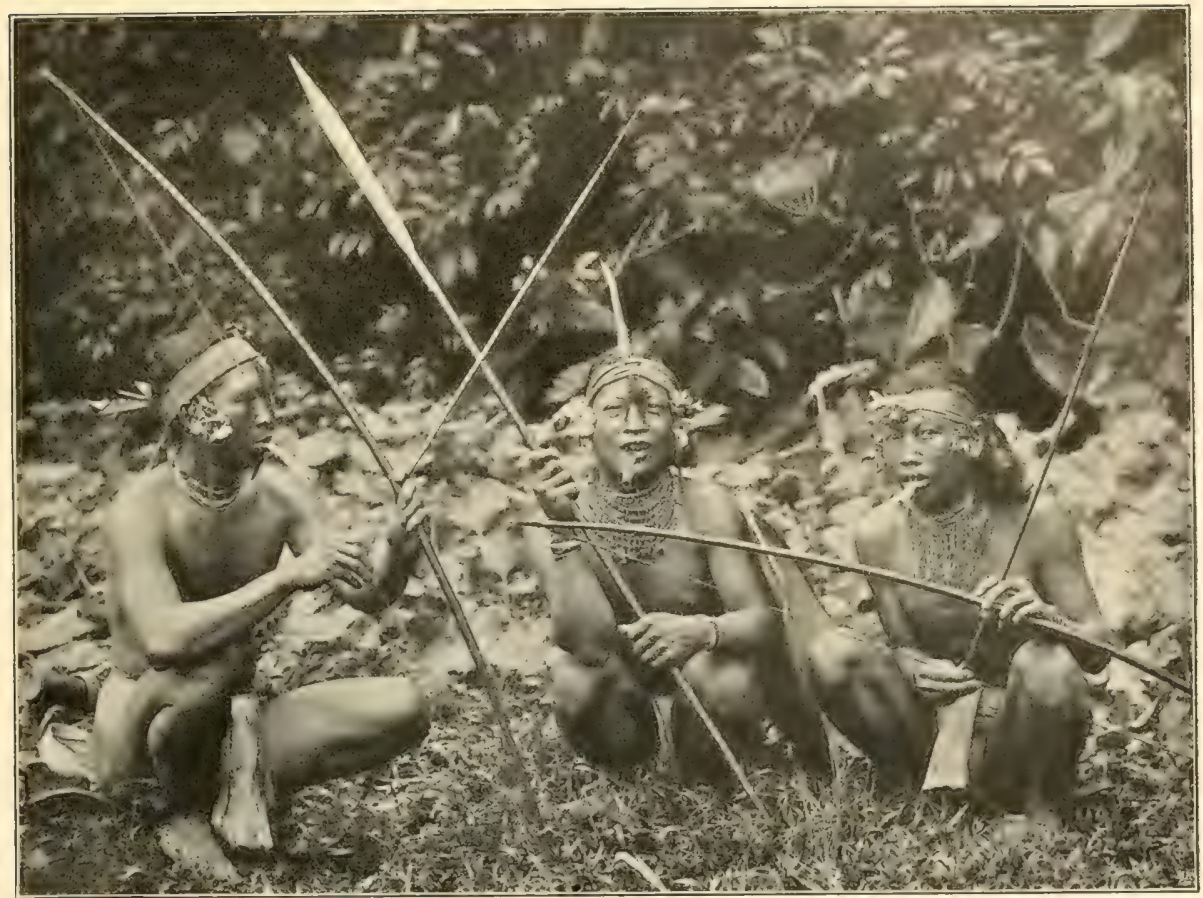

zior $\delta=$ Pageh. Junge mānner.

(Nieuwenhuis phot.)

ipfolifhen Gerjitillifand nadh cirea $1 / 2$ Stunde hervorjurufen. Fine Katse verendet I Stunde nadh jubfutaner Jnjeftion der Sojung von $0,06 \mathrm{~g}$ gleidfalls unter den für die Lerzgifte harafteriftifhen Spmptomen. Zllfaloide find in der Giftlöung nidht nadpweisbar. Es ift fonah zweifellos, daf das (bift eit Glufoft aus der 3eihe der Gerjgifte enthält, höḑftwahrfłcinlid aus Antiaris toxicaria hergeftelltes 2lntiarm." Zufbewahrt werden die Pfeile in einem langen Bambusfödyex, der an einer Sdyur oder an einem Baftitreifen getragen wird und einen Dedel jum Sdut gegen Regen= und Seewaffer aufweift.

Zuf̧er Pfeilen und Bogen werden auth nod Sanjen und Doldhe als 2rahwaffen verwendet. Die Spitzen der Sanjen und Klingen der Doldhe find jweifhneidig und aus

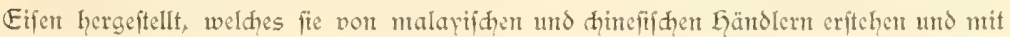

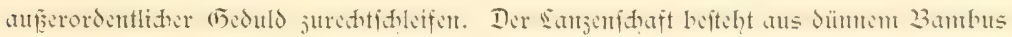
und läuft in eine 2reffinghülfe aus, welde die jweifdueidige lange Spitse trägt. Die 
Dolhgriffe und die Sdyeiden der Doldhe find jehr eraft aus einem bellen Golje ge=

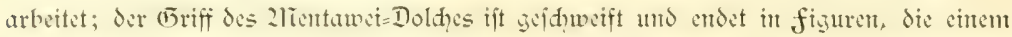
Dogelfopf gleiकen. Der Dold wird an der rehten Seite im Bauchgürtel getragen. 2luffällig flein und leiḑt find bie fowohl inmen wie aufen mit bunten figuren be= dedten Sdilde. Sdmmäler und faum länger als der Lqut fdrumpfen fie faft ju einem

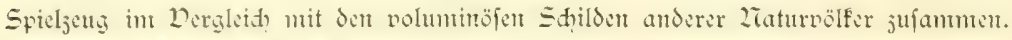
Jmmerhin dürfte die leidt ju hanbhabende Defung wohl gevignet feint, anjdywirrende Pfeile abzufangen.

Zlle Bewohner find leidenfdhaftlidge Jäger und fif dịer, weldhe in einfaden Prau's, die aus einem ausgehöhlten Baumitanm

hergeftellt werden, fith auf das zreer

hinanswagen. Die Prau's find

von den verfhiedenjten Brö=

Een; auf Pora befitzen

die Dorfhäuptlinge gro:

Be Boote, welche 120

zierihen falfen, wäh =

rend dem gewöhrt=

liden (Gebraud) Flei=

nere Käbne dicnen,

in weldhen 2liant

mo frau Enicend

mit auferordentlid?

jierlich gearbeiteten

fleinen pasdeh ru=

dern. Selbit die Kin=

der wagen fith in

niedlichen, wie eine

2liondidyel geformten

Kähnen auf bas zlieer.

2uf $S$ üb=Pageh find sic

gewöhnlidien Ruderboote, wic

die 2lbbildung jeigt, mit Doppel=

auslegern veriehen. Die formen

(Nieuwenhuis phot.)

$S_{\text {ab }}=$ pageh. Eingeborene und 30ot mit 2tusleger.

Ser Ruder fund fehr verifieden; bald wird ein rundes Ruderblatt durh Rotang mit dent Stabe verbunden, bald find Stab und Blatt aus einem Stüd als iharf ju= gefpitste Padseln gearbeitet. Die gröferen Boote befitzen einen oder jwei 2liaften; an denen 2liattenfegel aus Baft angebraḑt werden. Zuf̧er fijdneţen verwenden fic 
Garpunen, die, wie cin mir vorliegendes Eremplar bejeugt, offenbar bon dem Bogen

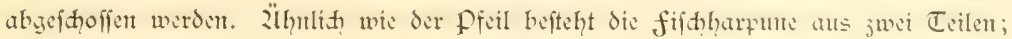
Der untere ift fehr leidft und aus einem dünen Bambusftabe gefertigt, der obere fant ihm aufgefeţt werden und trägt drei aus Miefing gearbeitete Widerhafen. Durh einen langen, um den unteren 2lbjhnitt gewiffelten Bindfaden hängt die Earpunenfpitze mit dem Stabe aud dann nod sulammen, went fie

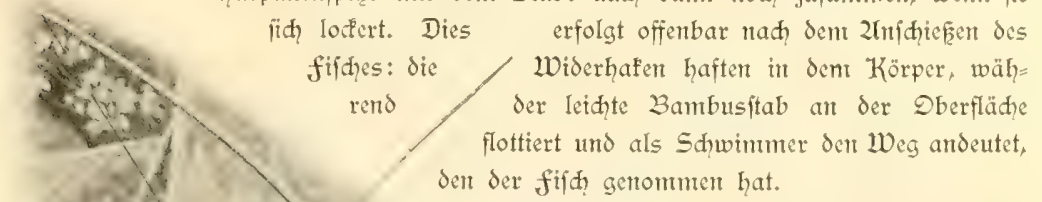
Q17) Jhre Wohnungen liegen ftets entfernt vom Strande 13 an fleinen fluês= oder Baḑläufen. Sie beftehen

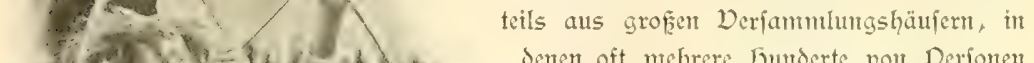

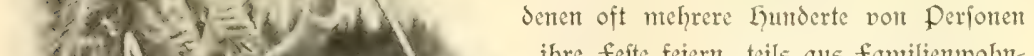

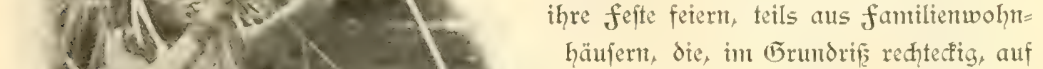
II Bambuspfählen ftehen und bisweilen cine geidymadipoll gearbeitete front mit einer voripringenden Plattform aufweifen. Den כugang ju den platt= formen bilden Stänmte, in welḑe Stufen gehauten werden; aud? führen fie Knüppeldämme und Eaufftege vont

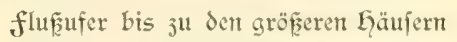
auf, über weldhe der 2lientaweier "loopt als een Parijjenaar over jijn Boule= vard".

In der Llmgebung der Dorfiḑaften werden auf fleinen Parzellen primitive Pflanjungen von Colocaften, Banamen, כufferrohr, KoFos = und

Sago= Palmen angelegt.
Salt

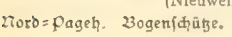

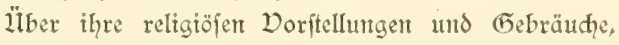
welthe eine fo ausgiebige Rolle in der Sebenshaltung ipielen, daf oft für Wodent dem frembling der Befud der Dörfer unterfagt wird, find wir mur unvollfommen unterriḩtet. Sie glauben an einen guten Ẽeift, dem fie

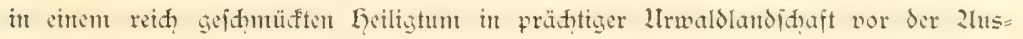

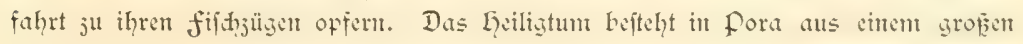




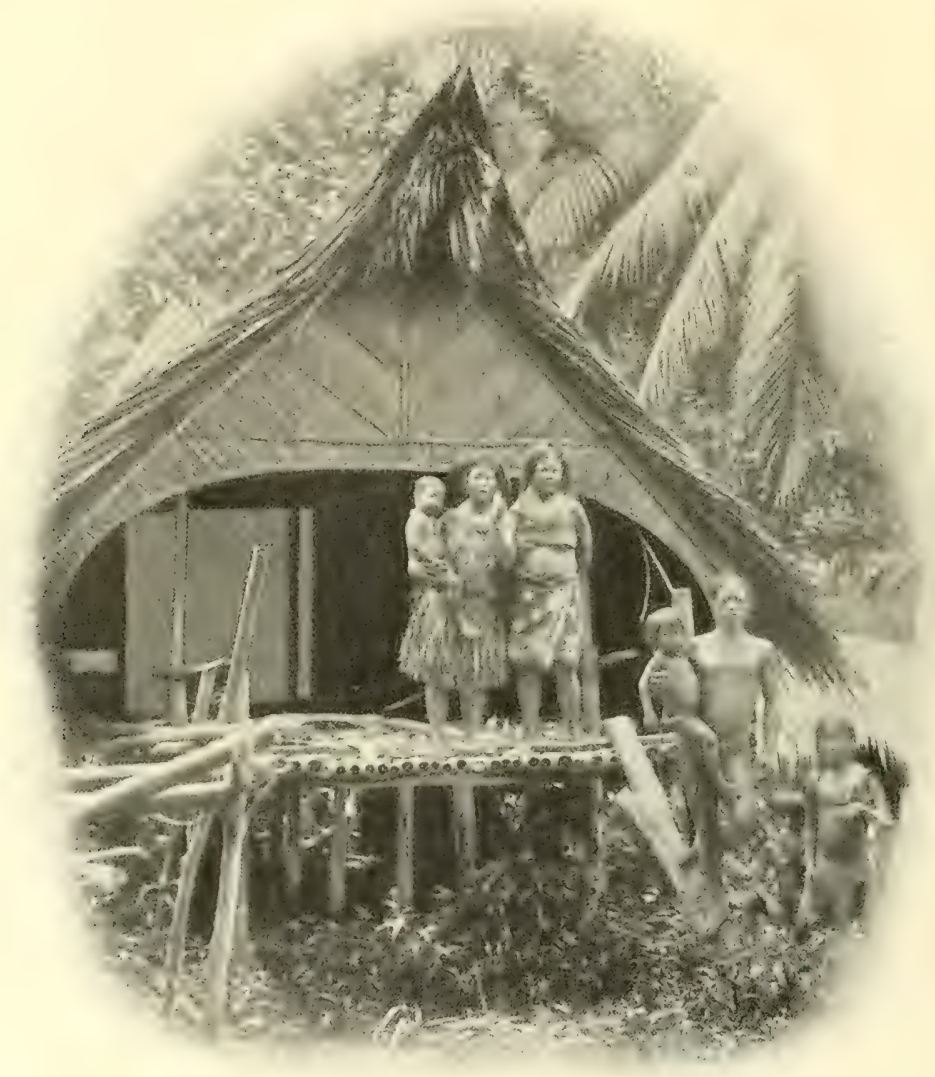

Sä $\delta=$ Pageh. Wohnhiutte.

(Nieuwenhuis phot.)

Banbus= Cylinder, der mit bunten Streifen Jeug und Blumen behangen ift. Klemere

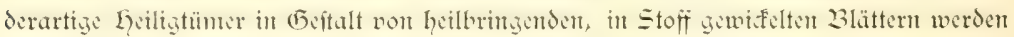
in den Gäufern aufbewahrt. Das Shnitien roher fetifhe ift thnen fremt; in den

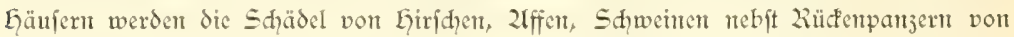
Sdyildfröten aufgehängt und angeblich verehrt. Die furḑt vor böfent Geiftern und dic Sorge un Befänftigung derfelben fheint bet allen widtigen 21ngelegenheiten, wie (5e)= burt, Ecirat und Tod, das zrotiv ju gewifferhaft befolgten Gebrüuden abjugeben. 


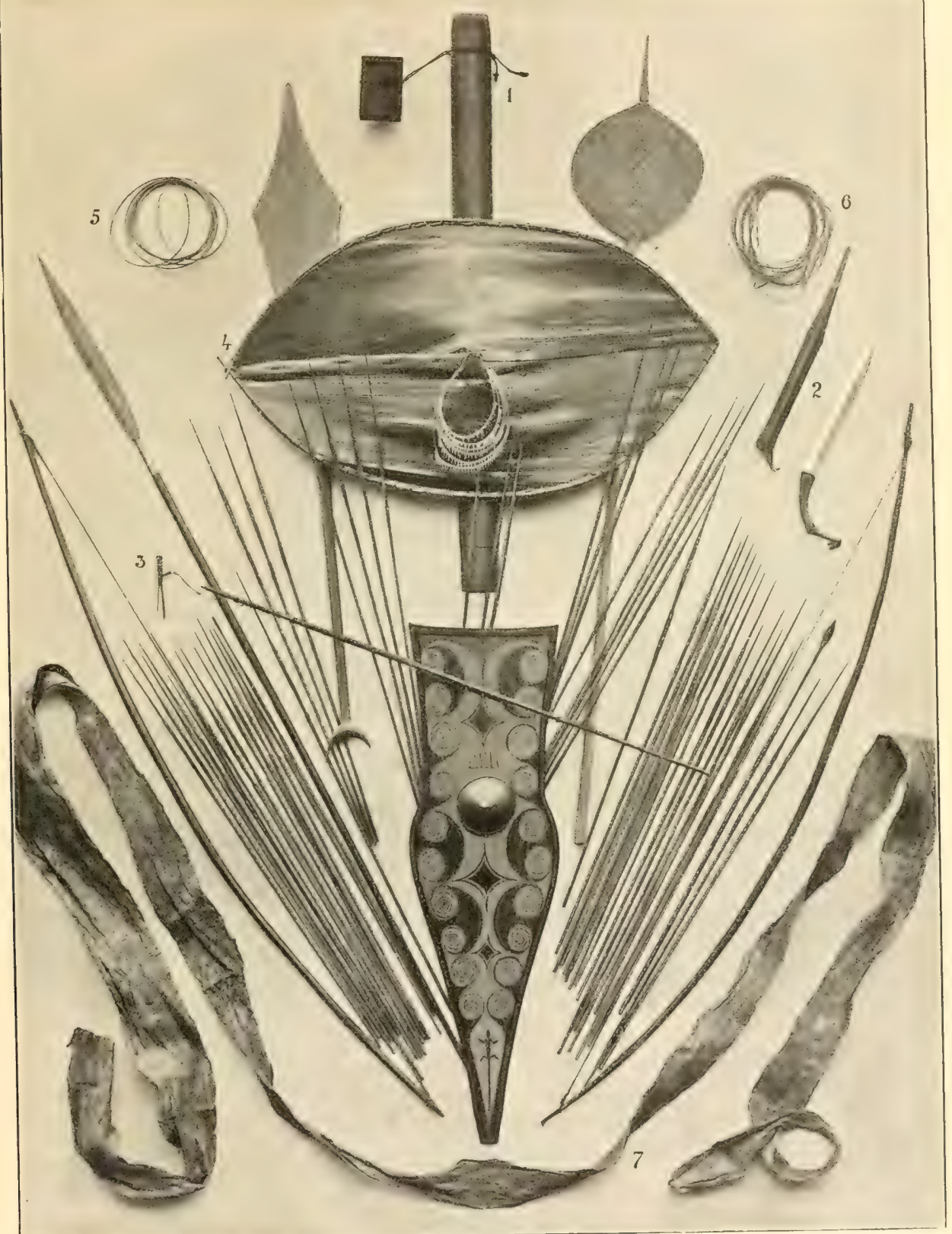

Totd= Pageh. Waffen und Beräte ber Mlentamei=Jufulancr.

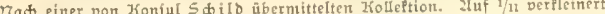

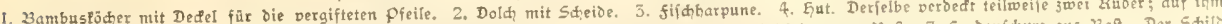

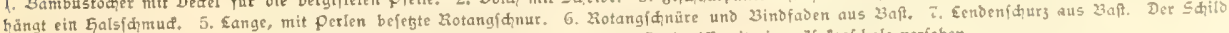
if $1 \mathrm{~m}$ hod, aufer und intren bemalt uno ant Ejandgriff mit einer Kofosfdaie verfeher. 


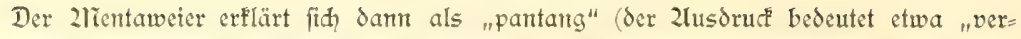
boten") und es ift ihm unterfagt, während eines beftimmten Deitraumes mit anderen ju fpreḑen oder Landel ju treífen. Bei auf̧ergewöhnliḑen Dorfommniffen fant ein ganjes Dorf "pantang" werden: cin bequenter und gerade in neuerer Deit offer ge= Iraudter Dorwand, um Derhandungen mit fremben und holländifhen Regterumgs= beamten aus dem $\mathfrak{W}_{\text {ege }}$ ju gehen und ihnent das Betreten der Drtfhaften ju unterfagen.

Int übrigen ift es eirt lebensfrohes Dolk, das in Eefang und Tany, in Bogen=

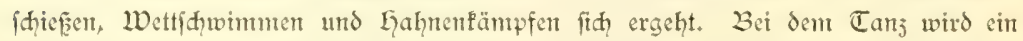
Tanjiḑürjhent getragen und unter anmutigen Bewegungen der flug der Dögel nađ)=

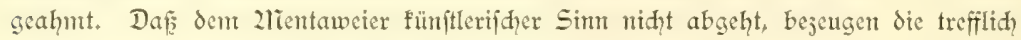
ausgeführten Sduniţercien und die lebenswahren bildlid̨en Darftellungen von Tieren.

2lian hat die Derwendung von fernwaffen in Geftalt von Bogen und peeil ge= legentlidy als cin Charafteriftifum der ntelaneffihen Raffe bezeidhnet. Jmmerhin nuf hierbei in Betradit gejogen werden, dafe cinerfeits nidit alle 2relantefer diefe fern=

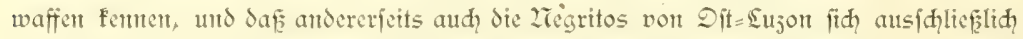

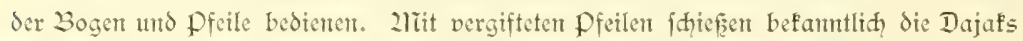
von Borne; allerdings verwenden fie zum Zlbidmellen nidht den Bogen, fondern das 3lastohr. Im allgemeinen fteht öftlid von Sumbawa, Celebes und den philippinen der Bogen, weitlidy das Blasrohr im Gebraud. LIm fo mehr nu管 es auffallen, dafi

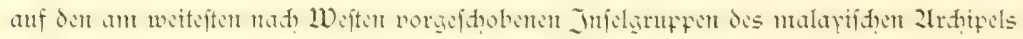
cin Dolf wiederfehrt, weldhes Bogen und vergiftete Pfeile gebraudpt. Diefe Fennen weder die Bewohner von Engano, nod diejenigen von 2tias. Die Geggenfätze ftofien auf diefen nod wenig durhforfhten Jnfeln hart aufeinander: in Engano verwendet man zur 2lbwehr fo ungefüge und fłwere Sdilde, da fie faft wie Sditiderhäujer den 2 liam decéen - auf den Zlientawei= Jnfeln wird der Sđtild jum rudimentären Drgan!

Wir haben in den zlientaweiern unftreitig einen in ethnographifher hinfiḑt fharf

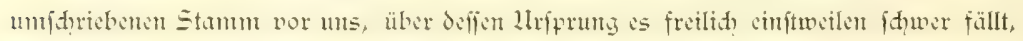

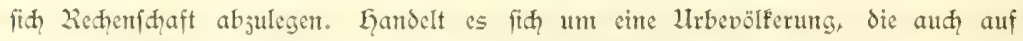

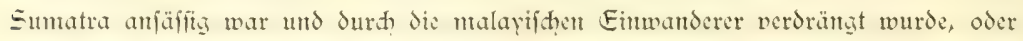

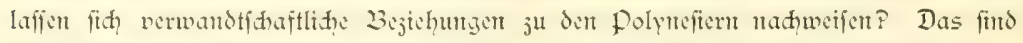

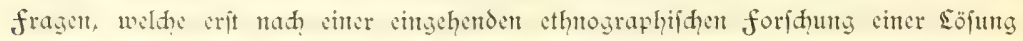

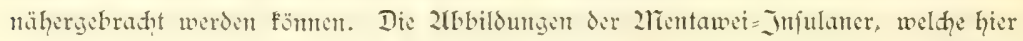

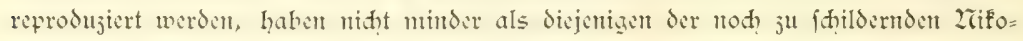
barer in hohem zliake das Intereffe fontpetenter und befreundeter forfher - unter

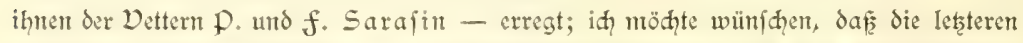

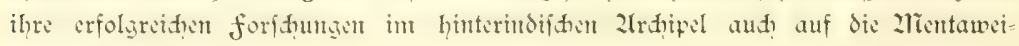
(5ruppe ausdehnen! 


\section{zTias.}

Es dürfte nidit ohne Interefie fein, der Shildenung der 2lientawei= Intulaner dic= jenige der Bewohner von Zias folgen ju laffen. Dem fetifdismus ergeben, als Kopf= jäger verrufen, nebmen diefe begabten Bewohner ciner reidhen Injel eine niḑt minder ifolierte Stellung in dem bunten malayifden Dölfergetriebe ein, als die 2lientawoi= Injulaner. Dabei haben fie auf dem füdlidien Teile von Zias, unberübrt von dent Einfluffe der Kultur, ihre Eigen= art io vollfommen bewahrt, dafí der Sejer es vielleidt entjuldigen wird, went wir den flüđ = tigen Eindrud ut: jeres furjet Bejudies wiedergeben.

2radidem wir un= fere 2lrbeiten in der Siberut $=$ Strafe er= ledigt hatten, fuhren wir an den niedrigen Batu= Injeln vorbei, denen ein flemes $\mathbb{F}_{i=}$ land, Pulo Bodjo, in der Siberut $=$ Strape vorgelagert ift. Sein idlanter, fharf von

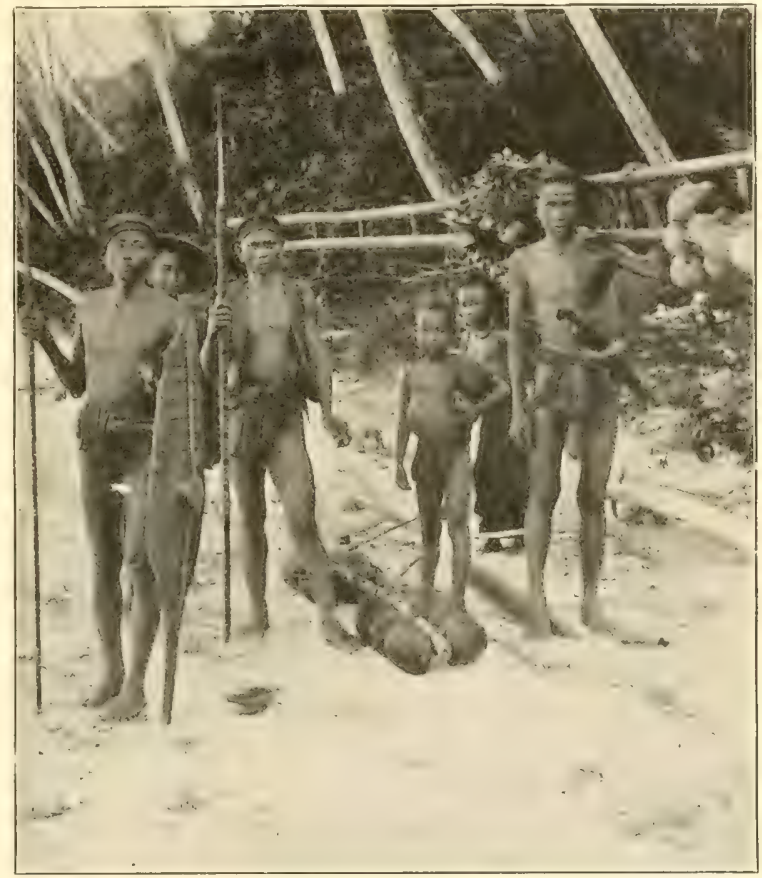

Eingeborene von Sù $=27 i a s$.

(Sachse phot.)

dem dunflen Ltrwald fith abhebender Eeuhtturm ragt bis ju 561 fun auf und entfendet jweintal in der 2nimute cin Bliflidt, das auf 27 Seemetlen in Unfreis fidhtbar ift. Im 1. februar paffterten wir jum viertemmal den 2̈̈quator und freujten jwet Tage lang, belohnt durh eine faft überreide 2lusbeute, in der Süd=27ias=Straf̧e. Da wir

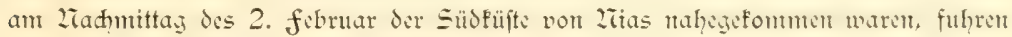
wir in die ftille Buḑt von Talof = Dalam ein. Palmenumrahnt, auf der Dfteite mit hohem Urwald beftanden, der bis junt Strande herabragt, bietet fie mit ifrent teils 
bemaldeten, teils mit grünen flähen bedecten, hügeligen bintergund ein lieblidhes und friedidges Bild. Wir anferten anf 16 faden Tiefe, und id entiflof mid, $\delta a$ wir an dem Strande zahlreidue bratne 2rienthen (1) bemerften, mit einigen Gefährten 3 einem $\mathfrak{s} a n=$ Sungsverfuch.

Die Buht ift bis in direfte 2Tähe des Strandes tief uto wird von einem Korallenriff um= fäunt, das hauptiählich aus 2liadreporen mit ihren bläulthen ङ̄weigipiţen gebildet wird. Bei cintiger Dorfidyt gelangt man mit dem Boote über die einen feenhaften 2nublic gewährenden Riffe bis in die Tähe des Llfers, das wir nad Durd)= waten des Riffes ungefährdet erreidten. Don allen Seiter fament die Einwohner herbei, und es bot fid dem Zeuling jum critermal ber Zublict faft nacter, bewaff= neter 2läanter $\delta a r$, die man nur allju bereit= willig als "Wilde" zu bejeidnen pflegt. Sic nahmen uns freundid auf, fiüuttelten uns dic Lände und begannen eine Icbhafte Konveriation in (Sachse phot, Junger 2riafer. ihrer wohllautenden, von dem zralayifden gäujlid

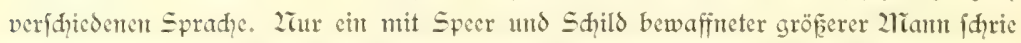
fhon von weitem, fprang mit gefhumengenem Speer auf mid? zu und ftick ifh vor mir in den Sarto. Da er dam jehr aufgeregt mit demfelben herumfudptelte, war es mix in erften 2lioment unangenehn, dafe id feine Waffen bet mir hatte. 2lls id? ihm indeffen meine bremende Cigarre in ben zlund ftecte, beruhigte er fith rafh und raudite wie ein Sdilot.

Wir hatten reidylid, Eelegenheit, an den vont allen Seiten herbeifonmenden

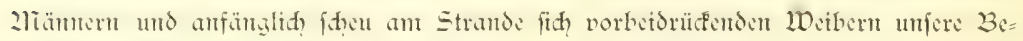
obaḑtungen anjuftllen.

In feiner Phpfrognomic fteht der Bemobner von Litas dem 2lialayen entfifieden

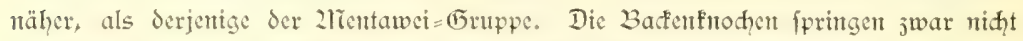
fo ftarf nor wie bei dent Zlialayen, dod, find die Eippen gewulftet und Sle 2Taje platt. In allgemeinen erreidyen dic bartlojen, hell laffecbram gefärbten 2lianner faum 2litttelgröfe, feffelu aber durd die fd̆lanfe, fehrige Geftalt. Jhr Lqaar hängt entweder ftraff herab oder wird in cinen Knoten gebunden; mandhe hatten es vollitändig rafitert, andere wiederum liefen mur cinen Kranz von furzen Gaaren ftehen. Die Saneidezähne, 


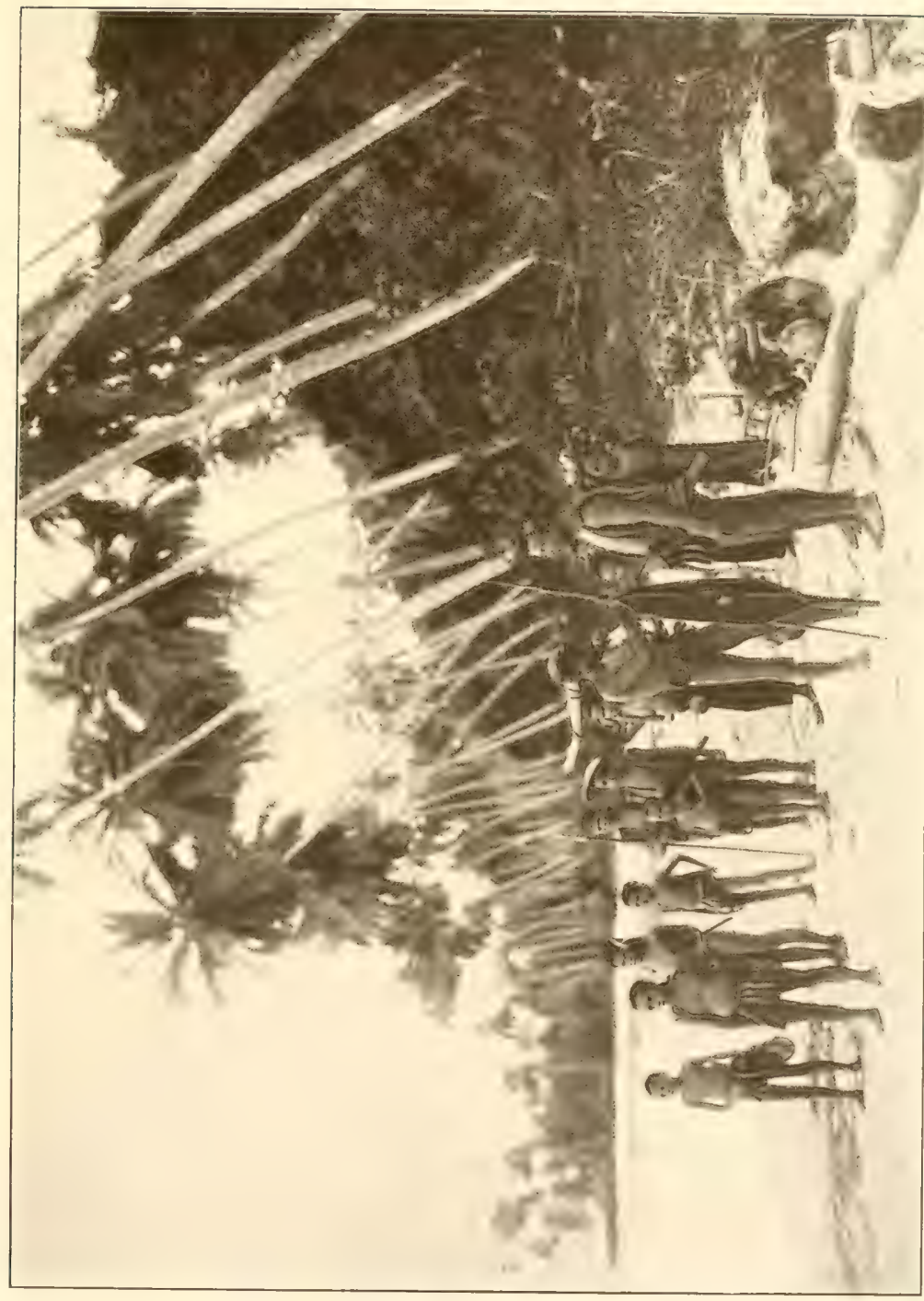

苛 

¡đwarj vom Betelfauen, find etwas abgefeilt, aber nidjt dreiefig jugefpitht. Inter

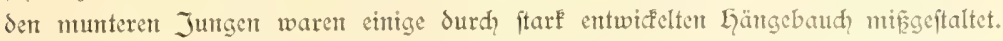
Die Weiber find fajt einen Kopf fleiner als die 2länner. Jhre 3rupt ijt fdiwad ent=

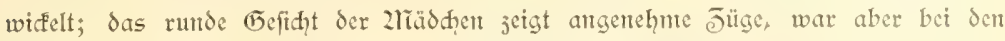
frauen verfallen und abgehämt. Die Kleidung der 2länner ift eine fehr primitive, infofern die meiften fid, mit cinem Sendentud begnïgen, deffen ausgefranfte Enden vorn herunterhängen. Eintge trugen aus 3 ajt gefertigte ämellofe, auf der Bruft offerte Jacfert. Sie fallen durdh inre Shwere auf und find dabet fo feft gewebt, dafs fie wie ein Panjer Sdut gegen Liebwaffen verlethen. Lth dic Stim legen mandic Vänmer ein $\mathcal{B}$ and refp. cine Sdmur jum fefthalten ber Laare, während andere mit cinem Tud, das nad 2 Irt ciner 2lütje gefhlungen wird, oder aud mit cinem runden, geflodtenen Eut den Kopf bededen. Die eingefantmelten Kofosmüfe trugen fie auf Bambusftäbert, welde durd Querfproffen nad, 2lrt einer Sciter miteinander verbunden waren. Bei den frauen ift der Dberförper naf́t, während der Ltuterförper in cinem engen, dunfelbrauner, weit herabreidiendent

Sarong fteft. Sie tragen die rmben ma= layifhen Güte aus Palmblättern, die fie bei dem Shleppen der Eaften in aus Baft geflodtenen Ludfäaten $a b=$ nehmen. Unt den Gals windent fie Shnüre aus blanen (Glasperlen, und in Sen Dhren ftediten fo grofe und ¡dwere, flberne Ohrunge, daf dic Shrläppden lang ausgejogen waren. Bet den 2liämtern bemterfte man 3war feine Dhrringe, dod befafen mehrere durḑbohrte Dhrläppdien, und einige trugen gleihfalls Shnüre um den $\mathfrak{K}$ als. Die älteren zlänner gingen bewaffnet mit den für dic Infel Zias fo harafteriftiphen sant= zent uns Sdilden. Der Eanjenthaft befteht aus Palmenholj (Arenga), das mit regelmäfítg abwediclnden Ringen aus Rotang umfloditen ift. Die eiferne Spitze ift einfoneidig und mit einem zilaper mit 3apjaren langen Widerhafen ausgeftattet. Der 2uias=Shild, deffent form aus der 2lbbildung crifhtlid ift, jeidinet fid durd feitte geringe Breite und durd fein 2luslaufen in jwei 
Spitzen aus, vont denen die untere die längere ift. Ein jeder - Die Jungen nid̨̧t ausgenonmen - trägt einen furzen Kris in geflodtener Sd̨eide, der linf́s im Senden= tuif fieft.

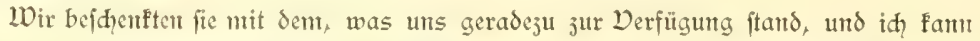

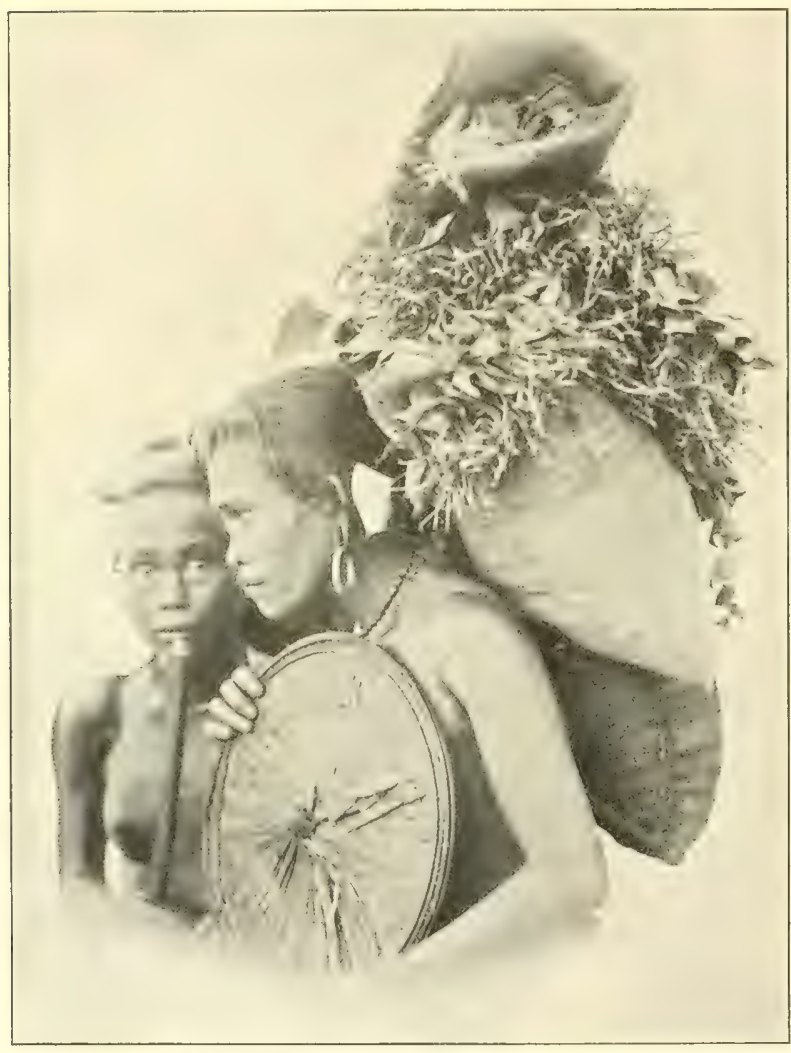

fraten don $S_{\text {Hid }}=27 i a s$. verfichern, $\delta a$ 施 mid jelten einen Zachutittag hin= ourch beffer un= terhalten habe: fic fpradten Liafitst? und ith frante furter Dialeft. Dic allgemeine $B$ efrie= digung fand derm aud darin thren

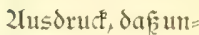
fer Derwalter, der alle um Gauptes= länge überragte, nut der ermorbe. nen Sanze unter mäđţigem "han, hau"eimenKriegs tanไ aufฺ̧führen begamn; die $2 \pi i=$ afer jogen thre Krife, fhwangen Sanzen und Sdyit= de, und bald tanjte die ganje Gerellidaft in den gewagteften Sprüngen amt

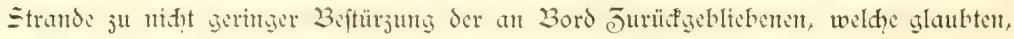
wir feien überfallen worden.

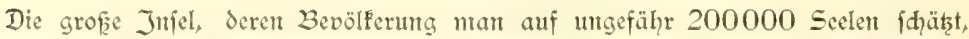
fłcht nur jum 区eil unter holländifd̨em Einfur. In dem Eqauptorte der Diffüfte, 
(5umung Sitoli, refidiert cin holländifher Kontrolleur, den cine Eleme Cruppe unter dent Konmando cines Dberleutnants beigegeben ift. Der Kontrolleur präfidiert dem

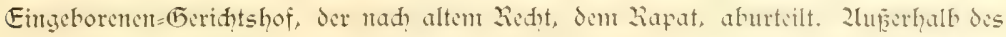
in Llmfreis von Gunung Sitoli gelegenen Rapatgebietes dürfte die Bevölferung als naheju unahhängił gelten. Jahlreihe הajas, denen wieder Dorfhäuptlingi unterftenen. ïben die 2liadt über ein jeweiliges eng umgrenjtes (5̈bict aus. Dic eitflufreidferen

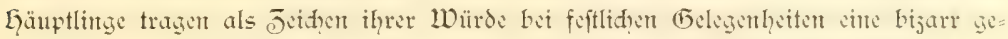
arbeitete goldene Krone und die Staatslanje nebit einem rot umfpannten fäher.

(Berade in neuefter Jeit wurde Iebhaft Klage darüber geführt, daf namentlid, in Süd=2 Tias durh die ftändigen fehden jwifden den einjelnen (5emeinmejen die Unfidherheit überhandnehnte. Die $\mathfrak{B}_{e}=$ wohner von Süd=2tias find berüdtigte Kopfjäger oder "Koppenfucllers", wel= dhe beradbarte Dörfer überfallen uno die Bewohner, foweit fie nidht nteder= gehauent werden, ju Sflavent mahent. 2lod in 2lpril 1900 wurden nahe der Budt, in die wir eingelaufen waren, ant Strande fünf Seident, datunter cine framenleidhe, mit abgefduttenen "Kopfe gefunden. In älterer כeit gebraudyten die Zriafer bei ihren Zahfämpfen (auk̨er den jigon oben erwährten Waffen) Sturmhauben, weldhe aus Eifenbled? gefertigt wurden; audh legten fie aus gleidien 2raterial hergeftellte Shnurr: bärte au, um fid eit martialifhes Zusjeben $3^{u}$ verlethen. Derartige $a b=$

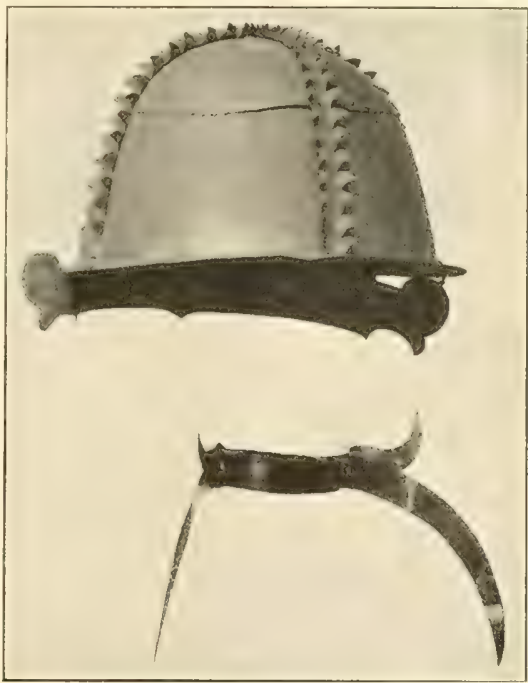

27iafijher Felm uno Sţ̧urrbart aus Eijenbled.

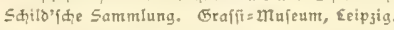

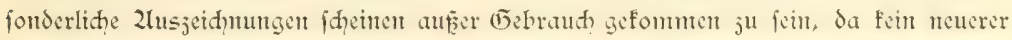
Reifender derfelben Erwähmung thut. Es dürft daber einizes Jinterefie darbisten, dicje fojtbaren und in unferen 2liufeen wohl faum vertretenen Stüfe, weldhe wir der Sammelthätigfeit von Conjul Sdill verdanfen, int Bilde vorjuführen.

Während bis 1827 ein einträglidher Sflavenhandel blühte (mant führte jährlich

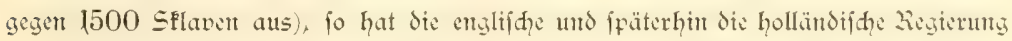
mit Erfolg dem Llnwefen gefteuert. Inmerhin verfallen in Sflanerei nidht nur bie bit den verräterifकृen überfällen Geraubten, fondern aud die Sduloner der enżelnen Gäuptlinge. Da leţtere durd? ein raffintertes Syftem die Sduld von Jahr ju Jahr 


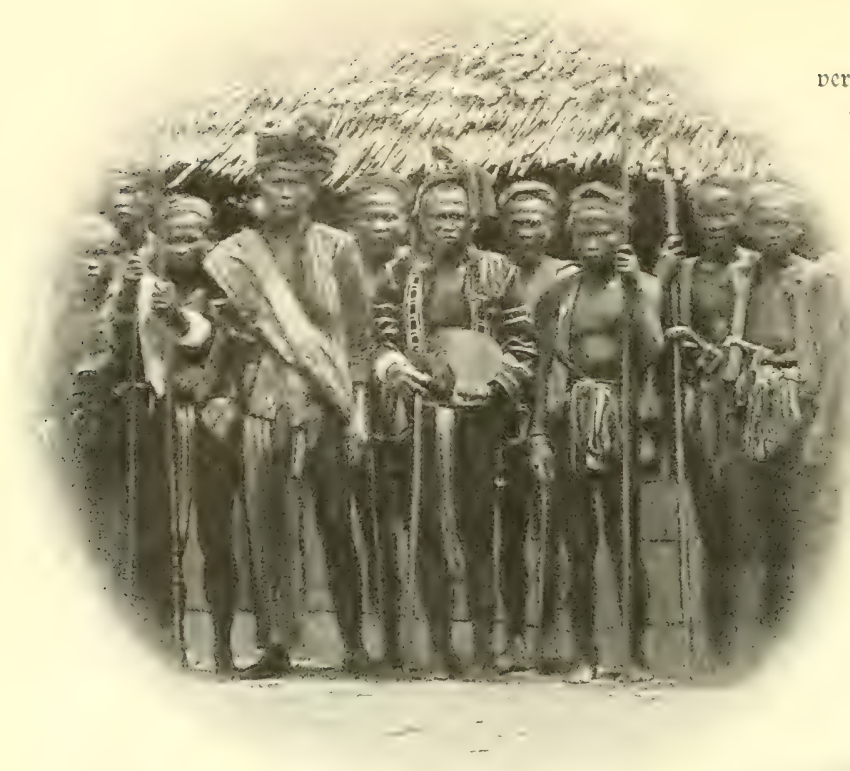

verdoppeln, getät nidłt mur der Betreffende, fondern aud feine familic in Sfla= verci oder - bef= fer gejagt - in scibeigenfhaft, aus der ifum felten ein in mübfanter $2 \mathfrak{l r}=$ beit dem $21 \mathrm{l}=$ tragender Sdul= Sen gewiome= tes Sebert befreit. Stirbt ein ange= fchener Läuptling. io werden je nad

(Nieuwenhuis phot.) 2iajah von Gunung: Sitolt (27oro=27ias).

feinent Range einte gröfere oder getingere $\mathfrak{Z}_{1 \mathrm{t}}=$ jahl vout Splaven, oft unter raffinterter (5rau= famfeit, gefḑlad)tet, deren Kö̈pfe bei dem scihenfefte jur Derjierung des (5rabes Der= wertung findent.

Die Bewohner von Zitias find fetijdiften. Jntmerḩin foll niḑt utrerwähnt bleiben, dafi naw den Beridtent der Rheinifhen kitifitons= scjellid aft neuerdings 2Tordz-2tias cir frudte bares feld für ihre Thätigfeit abgiebt, in= fofern in Jahre 1901 jebn Stationen mit $5 \pi 68$ Chriften aufgeführt werden.

zllle thre religiöfen Dorftellungen werden beherridyt von dem ẼIauben an gute unto böfe Geifter. Deme Einflue der letzeteren fdreibt man Lhuglül'sfälle, Erfrantungen umb fonftige Wiorigfeiten 3u. Dorfprtefter, dic fogenamiten

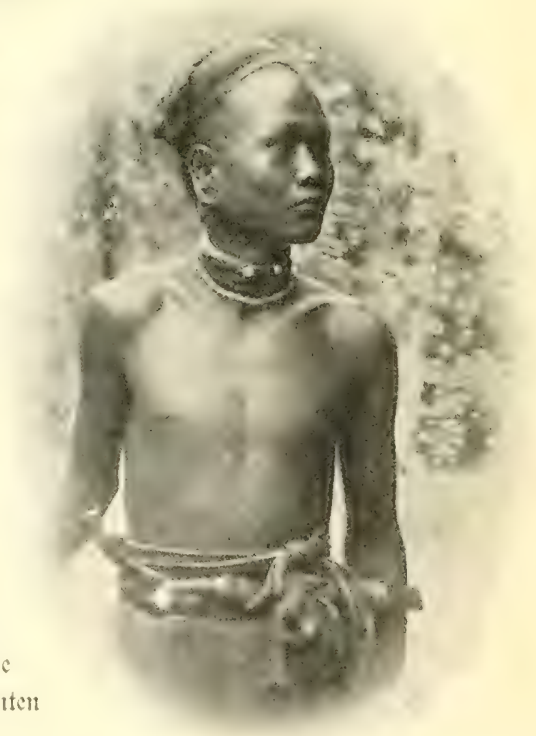


Ereh's, fuhen diefelben als profeffionierte Befduörer unto Charlatane 3 th Eammen. Die guten Exeifter, welhe namentlity in den Seelen der Derftorbenen fortleben, werden als 2thnenbilder und Gausgötzen. fogenannten 2loju, gefdntizt, in dent Gaule auf= geftellt und je nad der 2ratur irgend eines Ereigniffes angerufen. Int den Dörfern ftellt man gröfere, oft aus Stein gefertigte Joole als Dorfiduthgeifter auf, wie dem aud? andererieits die fürften Wert auf reiक gefdnithte und befleidete 2lhnenbilder legen. Bei eintgen der mir vorliegenden, rohen Şnttswerfe fällt die Tendenj auf, fie dent Europäer äbulid? ju geftalten.

Was den Charafter der 2rit= ajer anbelangt, fo bietet er eine zlifijung von abfopenden unt fympathifhen ङ̈̈口en Sar. Dic (5) ranfanteit, mit der fie bei ibren L̈berfällen felbit Weiber und Kin= der nidht jhonen, das zlbihlad)= ten der Sflaven bei seidenfeiern. die Gabgier der Gäuptlinge bei der Dermehrung der Sduulden ihrer Seibeigenen haben dic $2 \pi$ i ajer in fdilediteren Ruf gebraht, als er ihnen gebührt. WDer län= ger mit ihnen jujammenlebte, oder gar mit den nad Sumatra Jusgewanderten ju thun hatte, rühnt ihr offenhergiges, fanftes und ehrlidies Wefert. Zlls froh= fimnige Rienfhen lieben fie Tanj und 5 cfang, als fleifige 2 rbeiter werden fie in den Gandelsftädten in hohent 2liafe gefhäkt. Dor allen Dingen haben fie fidh als tüdtige L andwerfer, geübte Eifen=

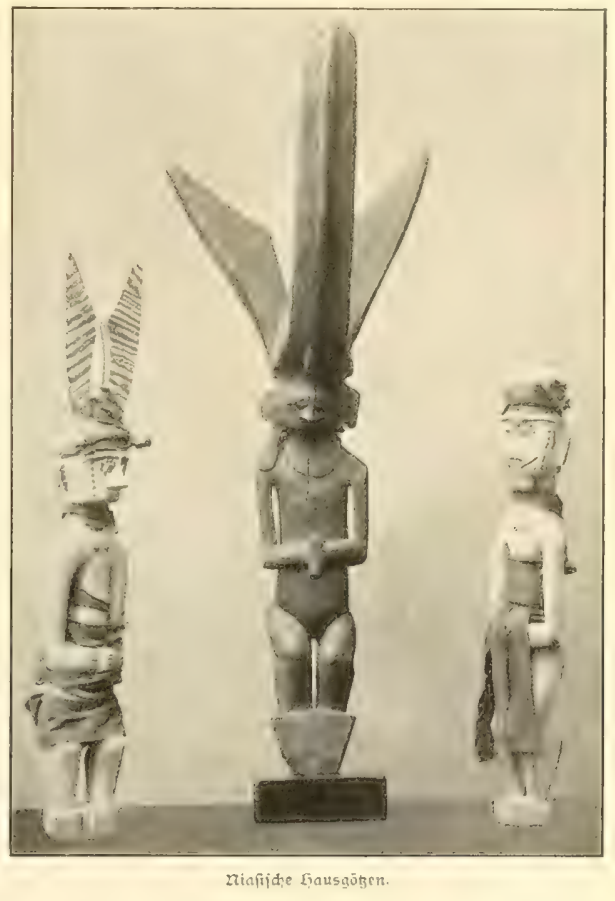
fapmiede und Weber entgeführt. Dap fie vortrefflide Jintmerleute find, beweifen nid̨t nur ihre anf mädhtigen Pfählen erriḑteten Wohnhäujer, fondern and die ge= legentlid fehr foftbar hergeftellten paläfte ber eingeborenen füríten.

Wenn aud der nah Sumatra wandernde Ztiafer fid dent Einfluffe der Kultur midt entjieht und weit über den in monotonen Einerlei dahinlebenden Eingeborenen hiut= fidtlid feiner Sebenshaltung fteht, fo hängt ex dod jäh an femen hergebraditen Sitten. 


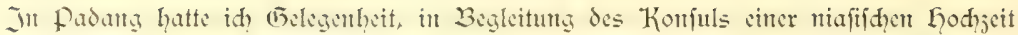

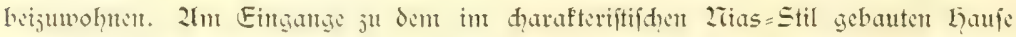
waren dic Gausgötzen aufgeftellt, und int Innern bewegte fid in auffällig gemefiener

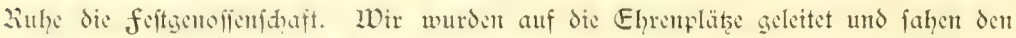

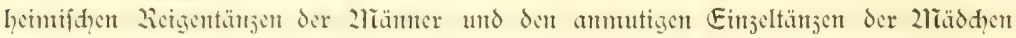

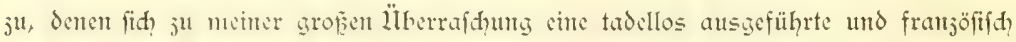

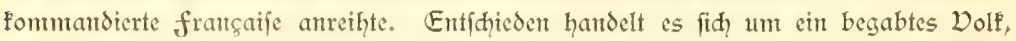
das in feiner wohllautenden Sprache (jedes niafifhe Wort endet auf einen Vofal) fith in finnigen Wedfielgefängen, den "Eailo", ergeht und unter demt Einfluffe geftteter 2lnthaumugen tühtige Eigenihaften entfaltet.

Belingt es den Golländern, auf Ziias fefteren fur zu faffen, der Imnftherheit und den Craupanteiten cin Ende zu mahen, fo fteht zul erwarten, daf die Bevölferung fid als eines der braudbarfen Galieder des malayifhen Stammes erweifent wird.

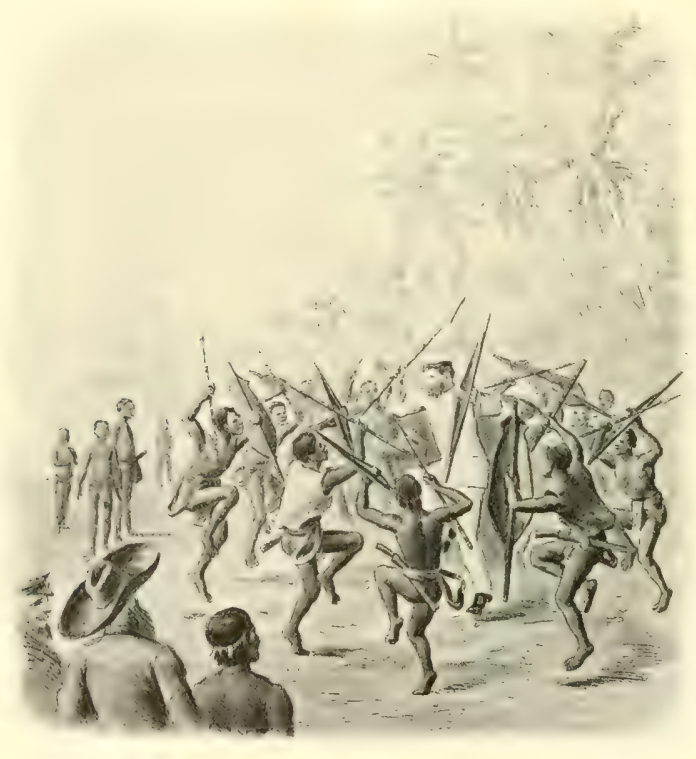

fahrt bis 2ltidin.

Durd frühere Eotungen war bereits der ZTahweis geführt worden, dafí die dem Indifhen Decan jugefehten Küften von Java und Sumatra in cin 2reer, Das Tiefen 
3wifhen 5-6000 m aufweift, abfallen. Derartige Stcilabfälle find, wie wir früher ju ermähnen (5elegenheit fanden (S. 4), nidhts Befremblidyes in Kegionen, wo der Dulfanismus Etörungsinten in dem Edidftenthau der Erdoberfläde bedingt. Da das Bodenrelief längs der 2Tordwefteüfte von Sumatra nod nidt genauer erforfdyt war,

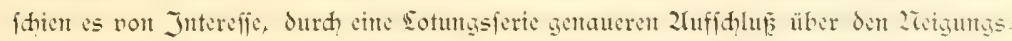
winfel des Sandes gegen die Tieffee ju erhalten. Wir fuhren daher am 5. februar 60 Secmeilen wejtlid, von zrias und loteten hier dic beträdtlide Ticfe von $5214 \mathrm{~m}$. Die Bodentemperatur betrug $1,2^{\circ}$ und der (5rmo erwies fith als ein feiner, grangrüner Sḑlid, der ju $9 \overline{\%} \%$ aus amorpher thoniger Subjtanj beftand. Die in regelmäfigen 2lbfitäten gegen die Küjte ju veranjtalteten Sotungen, welde Tiefen von 512 unt $660 \mathrm{~m}$ ergaben, bieten ein anjhaulidhes Bild für den Steilabfall interhalb einer furjett Strefe dar.

für die Dornahme fonfiger IInterfudiungen mit Tiefenthermometern und feinen Ziefsen erwies fich eine ftarfe nah Zrorden gerihtete Strömung fehr hinderlid. Sic führte reidliḑes Sargaffumfraut mit fid, jwijhen dent cine redt cigenartige fauna niederer Drganismen fid umbertrieb. Jn vieler Linfidt erimert fie an dic sebewelt der Sargaffolee in 2ltantifhen Deean: dies nidht jun wenigften durd die ausgeprägte Sdutzfärbung, welḑe alle Zlrten erfemen laflen. Jhre gelb= ober grünliḑbramen

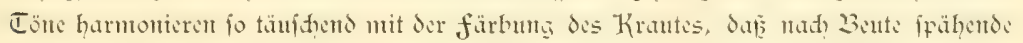
Shwimmtögel wohl fhwerlich die Infaffen wahrnehmen möhtent. Die fauma des Sargafiumfrautes beftand aus fifhen, 2lollusfen, Kruftern und Würmert. Dic fifhe jetzten fith aus Dertretern der auth in 2ltantifhen Deean dicfelbe Eebensweife führenden कิatung Antennarius und aus cinem Squantipenter jufammen, deffen bijarr ausgefranfte Rüfenfloffe nidjt mur in färbung, fondern aud in ifrer Ecftalt dic Blätter des Krautes nađhahmte. Dasfelbe gilt für cine mit blattähnliden fortfäßzen ausgeftattete 2raftidneffe (Elysia), die rafd friedyt und fidh völlig auf das seben im treibenden Kraut angepant hat: losgelöt von demifelben beninmt fic fid fehr un= gefhidt, indem fic fich von ciner Sette nad der andern frünt, ohne redt vom flect ju Fommen. Ltuter den Kruftern waren es zroet Fleine Krabbenarten, den Gattungen Nautilograpsus und Neptunus jugehörig, welḑe nidht minder durd dic vollendete

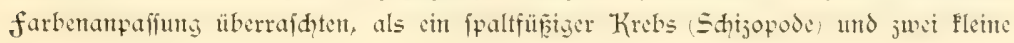
Ringelwürmer.

Wie in dem Sü $=2$ tias = Kantal, fo veranftalteten wir auch in dem 2Tord=2Tias= Kanal

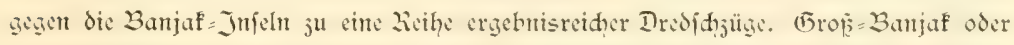
fulo Tumangfu ift relativ nicdris und bis jum Strande dift bemaldet. Da das etmas höhere und Flemere Wejt= Banjal (Pulo Bangfaru) cinen suten Fafen beftst, fubren wir auf dasfalbe ju, murden aber non mäatigen Kegenbs̈en derart sinģhült, da: wir. obwohl wir der Jnjel auf eine halbe Seenteile nahegefonmen fein mughten, bei dem 
386

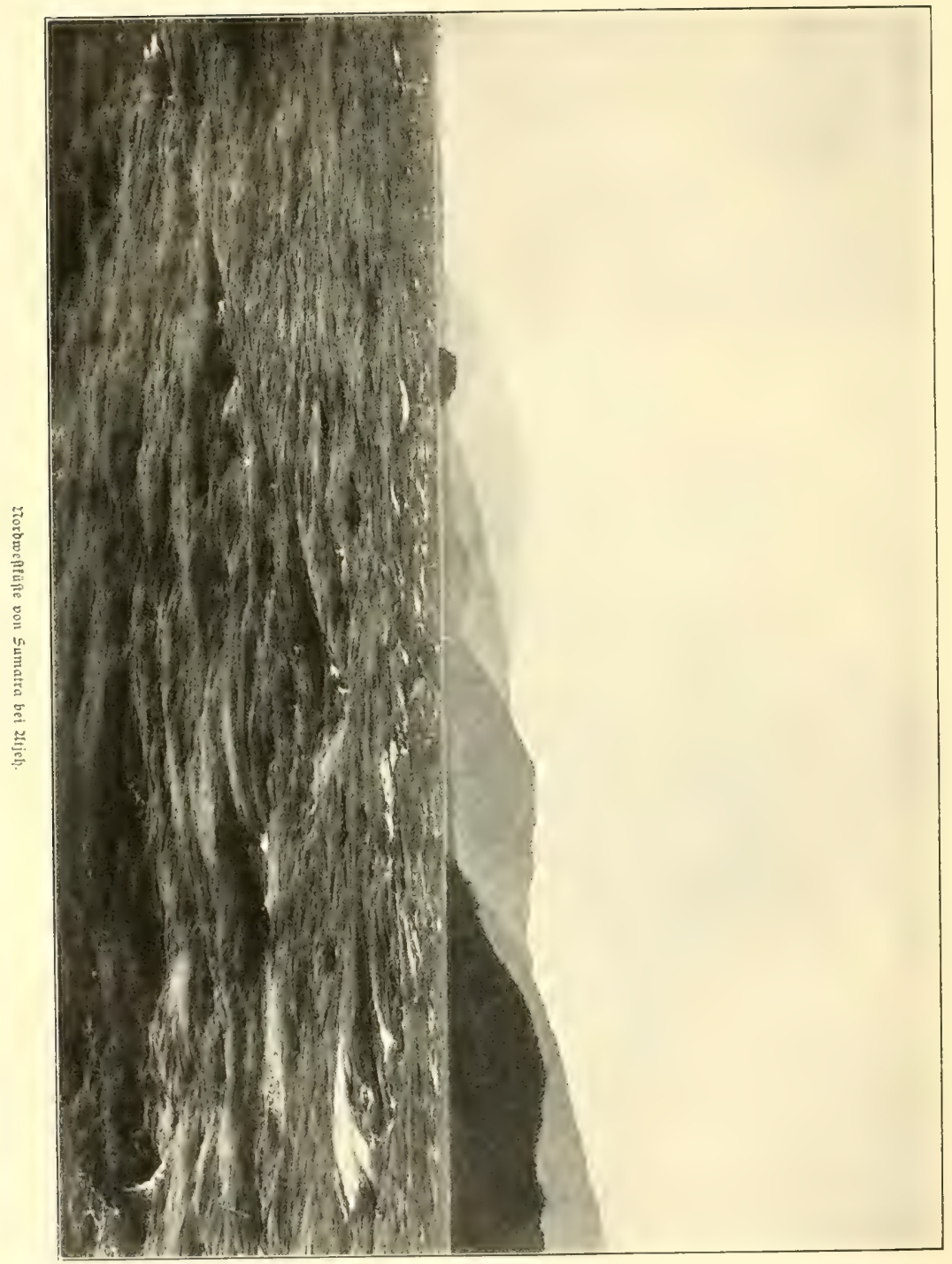




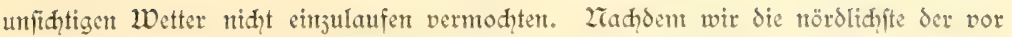

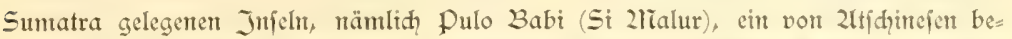

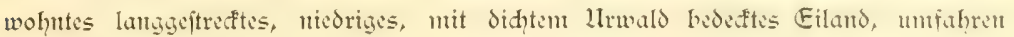
hatten, wurde der Kurs auf 2ltjeh (2lthdin) abgefeçt. Wir befandent uns in einer. niḑt nur durch die Kiffe, fondern auh durh die Bevölferung verrufenen Ẽegend. Die Segelanweijungen ntahnen jur äuB̧erften Dorfiḑt bei dem Eanden und beridten

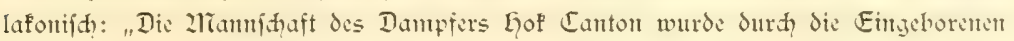
überwältigt, als er vor Kigas im Junt 1886 nor 2 lnfer lag, und der größzte Teil der

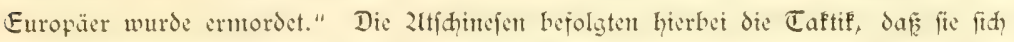
зи Eilfeleiftungen auf dem Sdiffe anwerben lieken, um damn vort dem verftecft ge= tragenen Kris eitten vandalifden Bebraudh zu maden.

Wie wenn die Sonne hätte andeuten wollen, dafí der Boden mit Blut gedüngt jei,

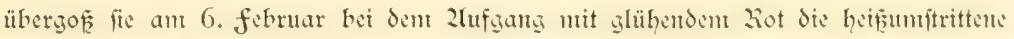
Sandfhaft von 2ltjeh. 2rod einmal jeigte unts Sumtatra den ganzen Jauber fenter wilden Romantif. Ie mehr man fich der Külite - und jwar fpeciell der Surrat= palfage - nähert, def́to wuḑ̧tger treten die leţten Zlusläufer der Barifanfette hervor, um in dem mädţtigen Batu 2liufurah (1942 m) thren 2lbiḑ̨luf ju fitden. Beim

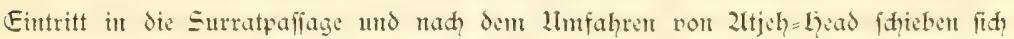
die Farallelfetten des Gebirges wie Couliffen vor, und in fiment Duft taudht der 2lus= läufer der hinteriten Kette, nämliđh der $1226 \mathrm{~m}$ hohe fogentante (5olden 2liount (Elawah djanten) auf. Dis Surratpafiage ift eine der malerifhiten des Finterindifthen

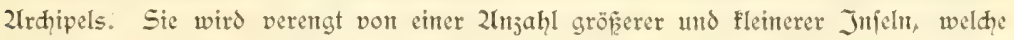
dem feiflande diḑt vorliegen. Inter ihmen fei das dihgt bewaldete und bis faft jum

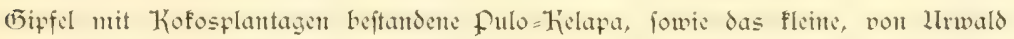
und fandanus bedefte Pulo= Batu hernorighoben. Der ziordoft: Palfat hatte injwifhen jiemlidh frifh eingefetzt, fegte dic $\mathfrak{W}$ olfent weg und flärte den 2lusblit auf die Reede

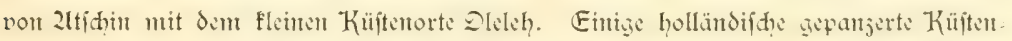
dantpfer und ein Kriegsidjiff, dent wir unfere Koute fignalifiterten, lagen vor 2lnfer

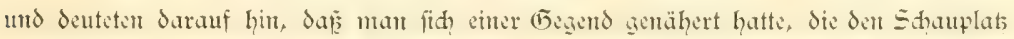

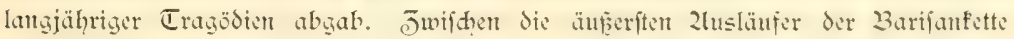
Whiebt fidh die Zitederutg von Kotta Kabja ein, durd 2Talaria und Beri=Beri ver=

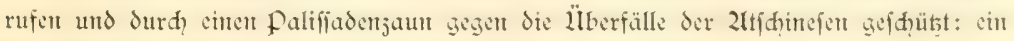
Danaergefhent, das fihon Jehntaufenden das Eeben foittete.

Wir fanden nod? Jeit, gegen 2tbend auf einer der Reede von Dleleh gegenüber=

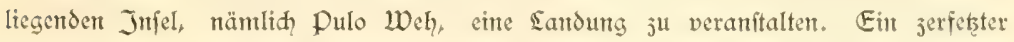

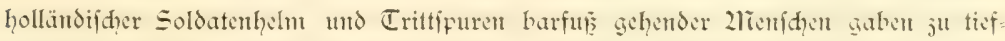

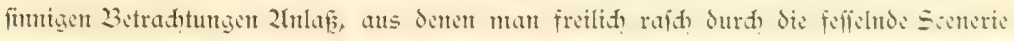

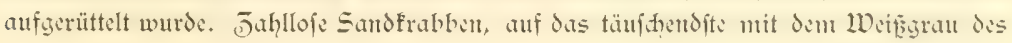


Indo = malayijhe Stranoflora.

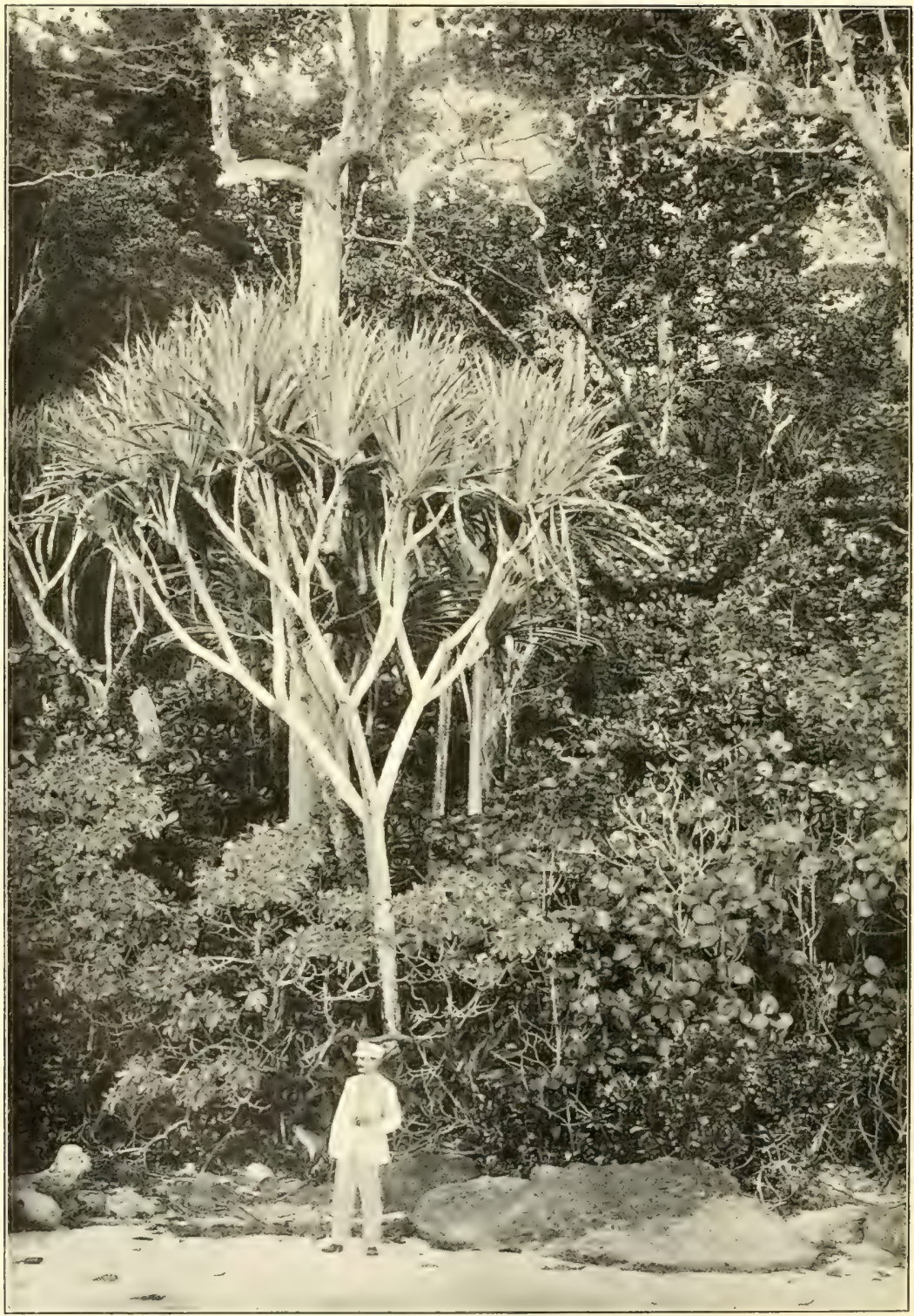

Tournefortia arzentea.

Pandanus.

Eirandflora auf $\mathrm{Pulo}=\mathrm{m} \mathrm{ch}$. 
Korallenjandes überinfimmend, hufhten nehit Kaubfäfern aus der (hattung Cicindela nad, allen Seiten auseinander. Bunte Shmetterlinge flatterten un das (5ebüfक und in dem Walde führten die Cicaden im Werein mit feltfam frähzenten Dögeln ihr

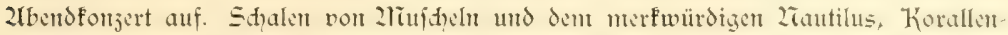

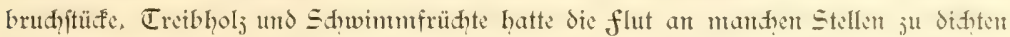
Bänfen aufgehäuft, die mur da unterbrochen waren, wo felien und (5rotten bis jum Waffer vordrängten. Der dïftere Lrwald giebt den Gintergrund für eine Strand

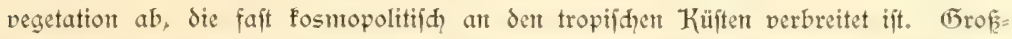
blätterige Barringtonien, Teminalen und blühende Erythrinen überdad) die äuperft כ̄one des Strandwaldes, weldye von fletnen Stämmen der Tournefortia argentea und Scaevola Koenigii, untermif̧̨t mit den grop̧en Rojetten des wohlrieḑenden Crinum asiaticum, gebildet wird. Looh ragen über fie die Stämme des Pandanus mit dent

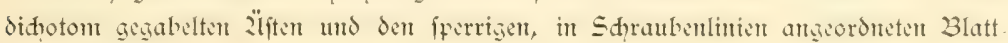
malfen hinaus.

\section{Die Tiefieefant bes 2Mentaweiszectens.}

Wir wollen vort Sumatra und den 2lientawei=Beden nidht fheident, obne wenigftens noळ mit cinigen Worten der Ergebriffe unferer joologifhen Iinterfuhungen ju ge= denten. Waren fie es dod, die vorwiegend 2lnlaf zu den jifljadfahrten tunt die

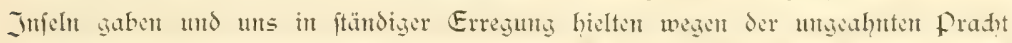
und des Reiditums der Tieffecfauna. Shon bet dem Eintritt in das 2rientawei=Becken am 21. Jamar fiel es uns auf, dafi die Sdlepprtet= jüge aus gröperer Tiefe fifhe lieferten, dic wir bisher mur aus den Bofdrethungen früherer
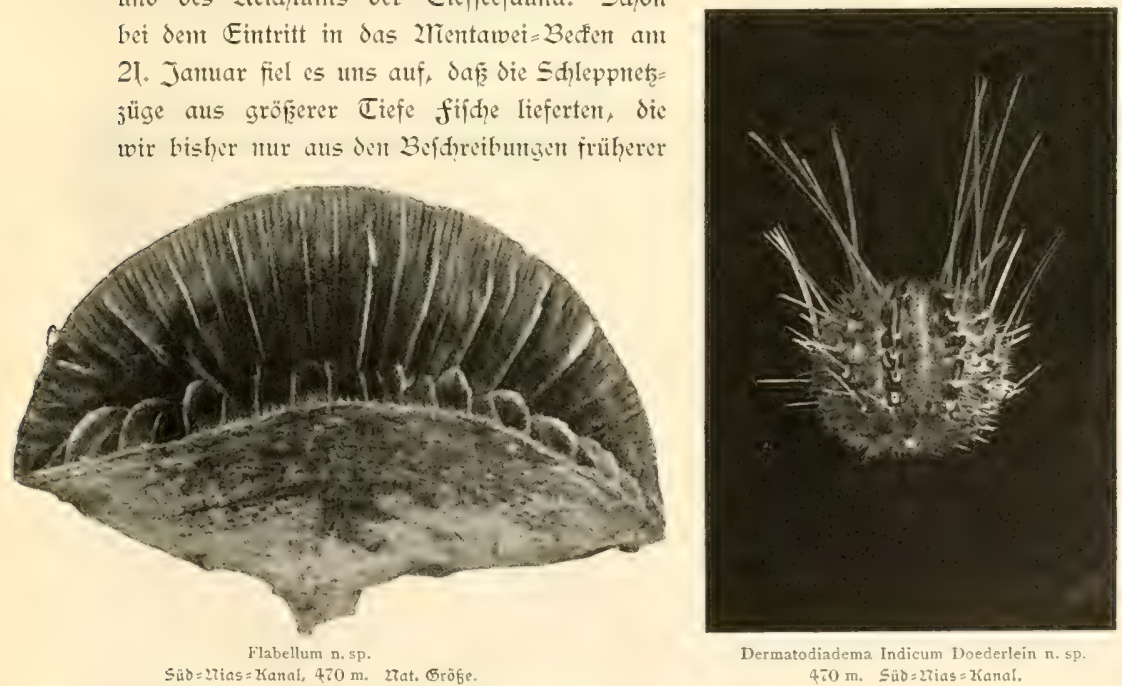

Dermatodiadema Indicum Doederlein n. sp. $4 \overline{6} 0 \mathrm{~m} . \quad S$ üb $=27$ ias $=$ Zanal. 


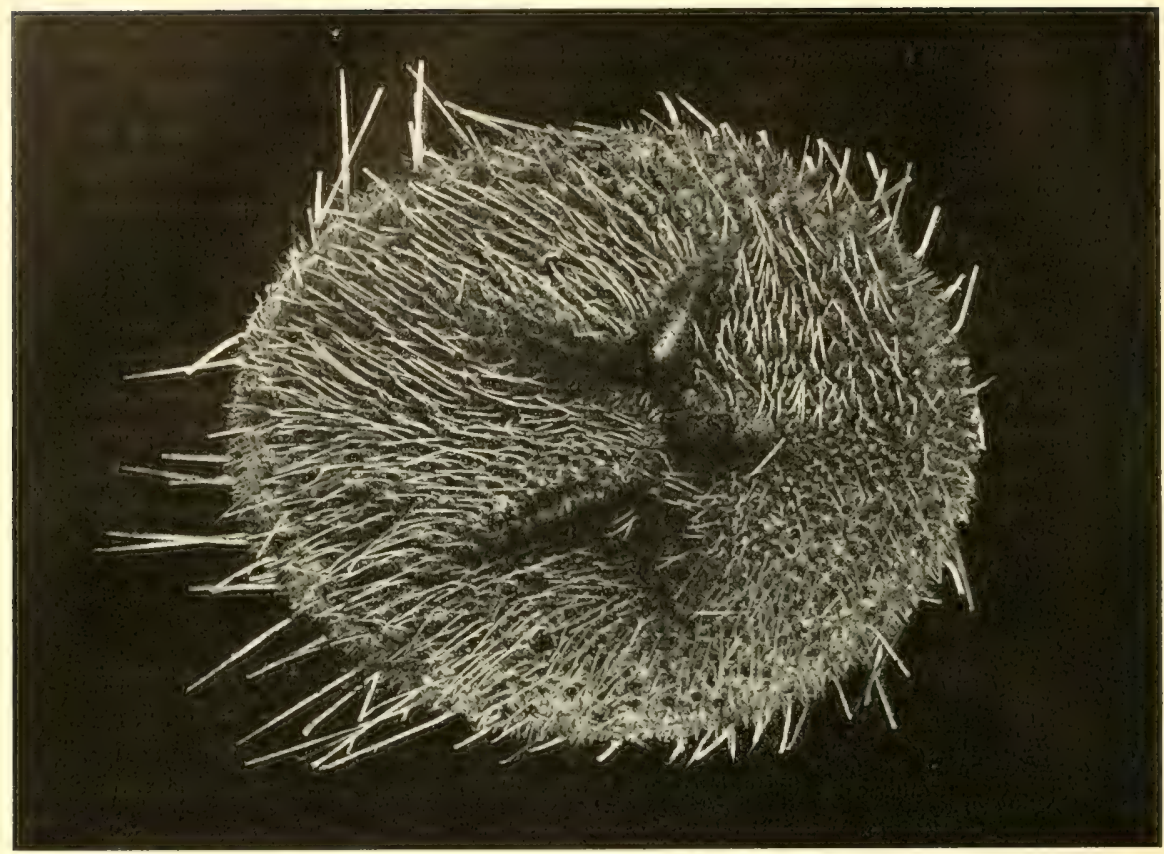

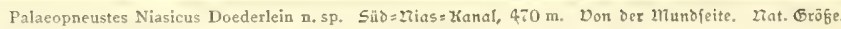

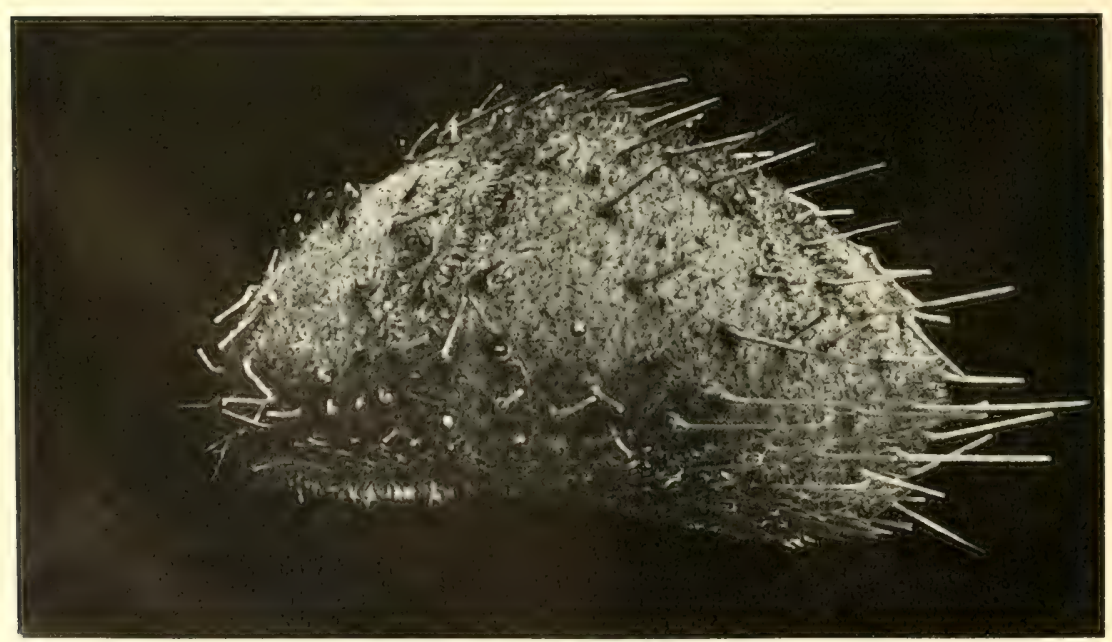




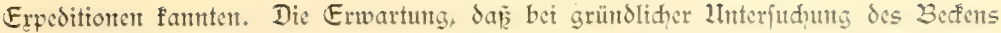
in erheblihem 2liafe die Süfen unferer bisherigen Sammlungen fiđ mödten aus= füllen laffen, wurde denn aud, nid’t getäufd̆t. Im Ginbliç auf dic l̈lberfülle von Organismen, welthe die 2retse enthielten, begnügen wir uns an diefer Stelle mit mur

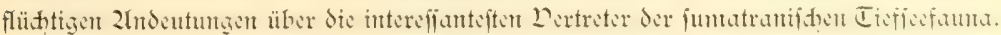

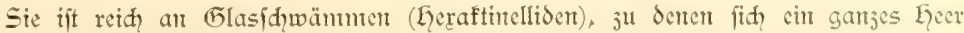
von Rindenforallen, Seefedern (Dentatuliden) und Jitdeen gefellt. 2fuh dic Sten= forallen waren häufig, und jwar nidit mur die folontebildenden Sprof̧forallen, fondern aud die folttären formen. Inter den leţteren überrajdenten namentlid dic Dertreter der Gattung Flabellum mit ibrem feitlid Fomprimicrten Kelḑe durd? ungewöhnlihe Dimenitonen $(5.589)$.

Ein befonderes Intereffe bietent die von uns gefanmelten Stadiclhäuter Sar. Dic juerit aus den nordif̧en 2lieeren befannt gewordene Secftern= (5attung Brisinga erbeuteten wir mehrfad in grofen, wohlerhaltenen, fleifhroten Exemplaren, vergefell= ihaftet mit violetten Tieffee= Golothurien, Sdhlangenfternen und Sceigeln. Ilnter den leţteren feien na=

mentlid die mit lederartiger Gaut und fitateten mit (็̃ifftadein ausge= tuin Dertreter der (ธ)at= hervorge=

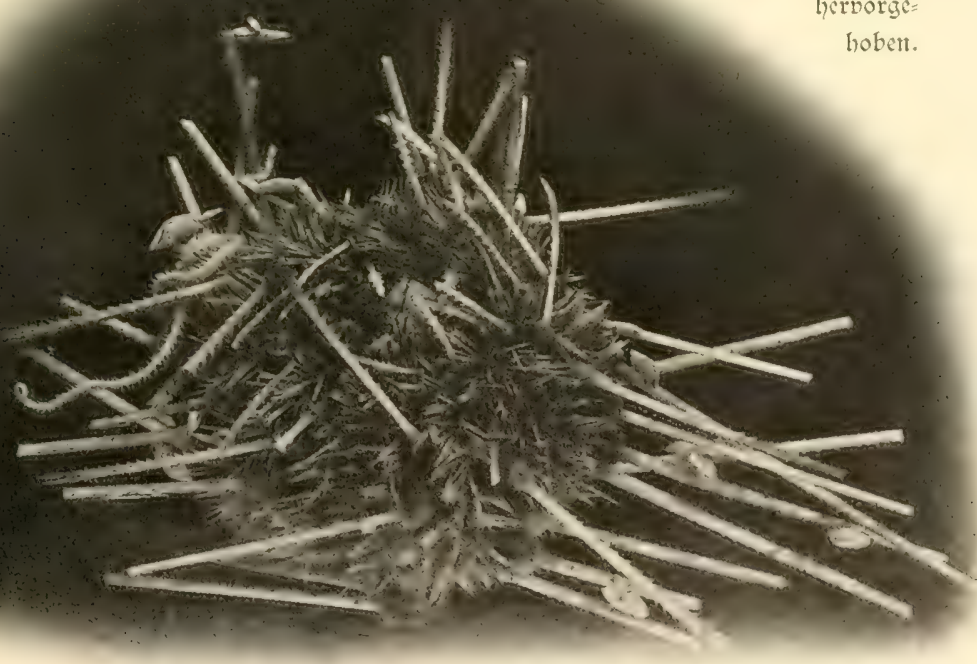


Int 2rord=2itas= Kanal gefellten fith ju ihnen jahlrethe Exentalare der Gattung Palaeopneustes als ciner der intereffanteften funde unter den Ediniden des Jir difhen Deeans. Sic waren prädntig gefärbt, infofern die fhwefelgelben größzeren Rüfenitadiel fich fharf bon dem Dunfelviolett der Shale abhoben. Zufer fleineren, mit langen feinen Stacheln ausgeftatteten Diadematiden (Dermatodiadema) imponieren

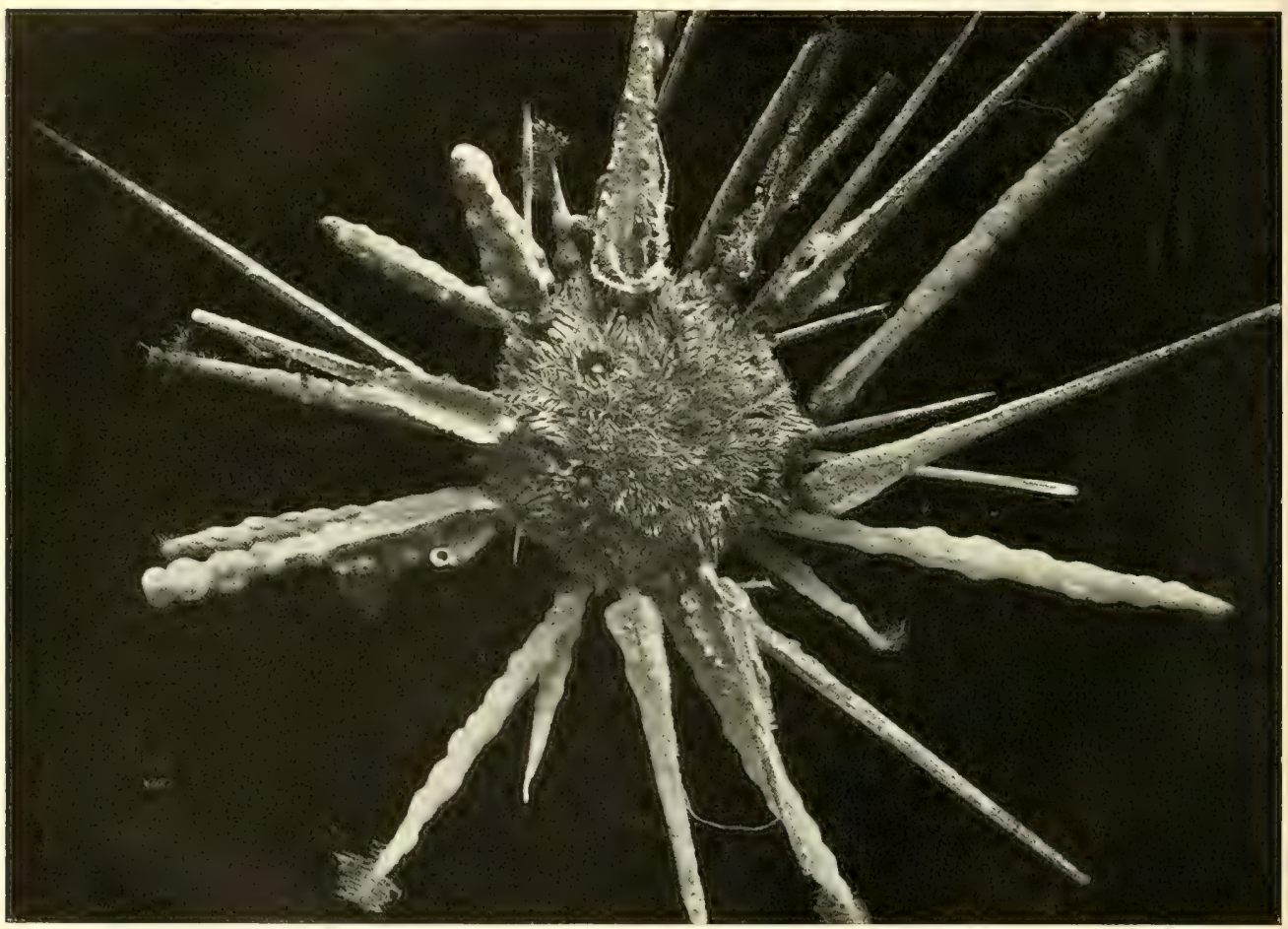

Stereocidaris Indica. Doederlein n. sp. Sad=27ias=Kanal, $4 \overline{60} \mathrm{~m}$. Wenig verpleinert

(Doederlein phot.)

prädtige neue Dertreter der indifhen EFattungen Porocidaris, Dorocidaris und Stereocidaris mit ihren gewaltigen oreifantigen Stadeln, auf denen oft ein ganjes Gear niederer Drganismen fid. angeftedelt hat. freudig überrajdite uns weiterhin das 2luffinden vort vier neuen Dertretern der Seelitien (Crinoiden). Sie gehören den (5attungen Pentacrinus und Metacrinus an; dic in der 2lbbildung dargeftellten, aus der Silerutftrafic ftammindin fleineren formen waren olingrün sefürbt, währeno 


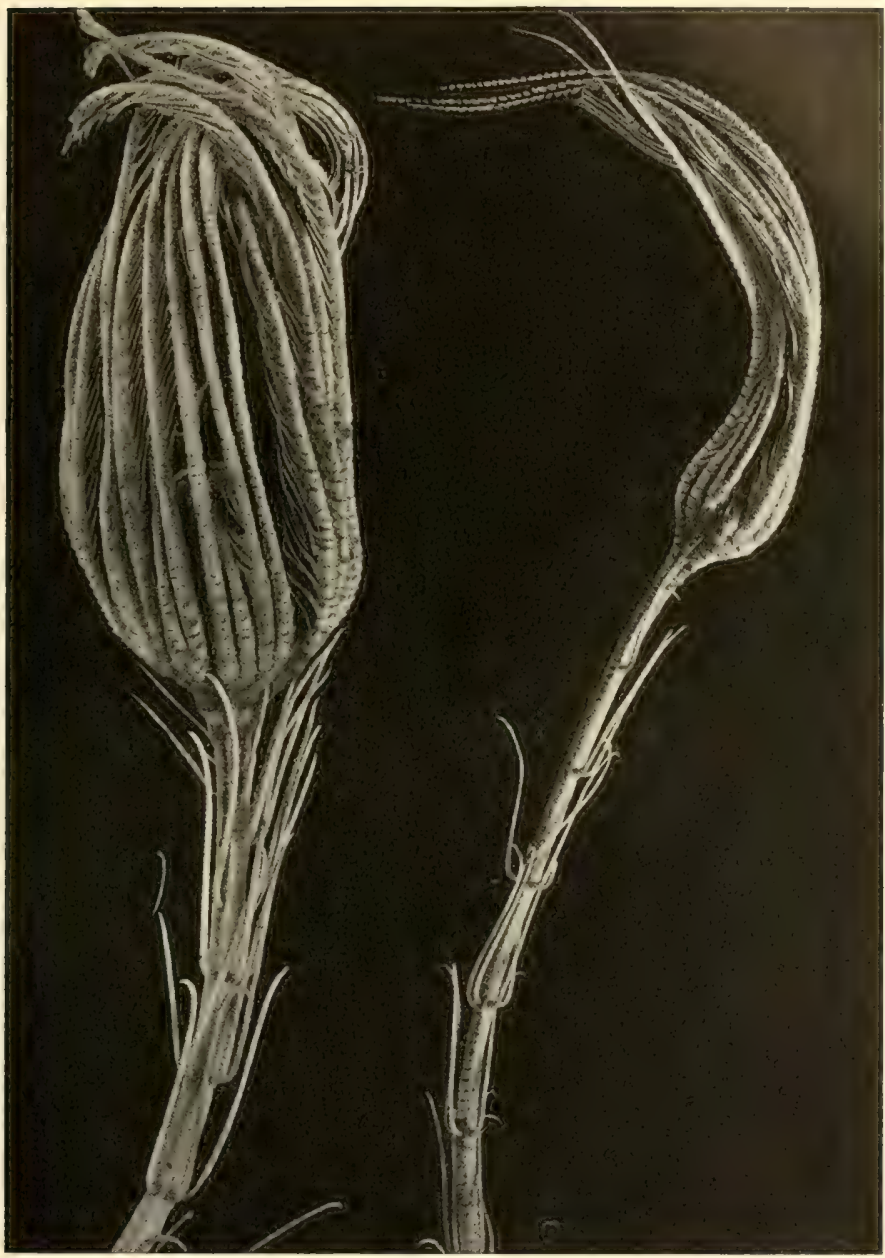

Pentacrinus n. sp, Siberutfrafo, $1280 \mathrm{~m}$.

(Doederlein phot.)

Prahteremplare eines grofen Metacrinus, den wir fpäter nod in Bilde vorführen werden, den Ton von lithographifhem Sdiefer aufwicien.

Inter den Cruftacen begegneten uns gleidfalls einte fülle von formen, die wir 


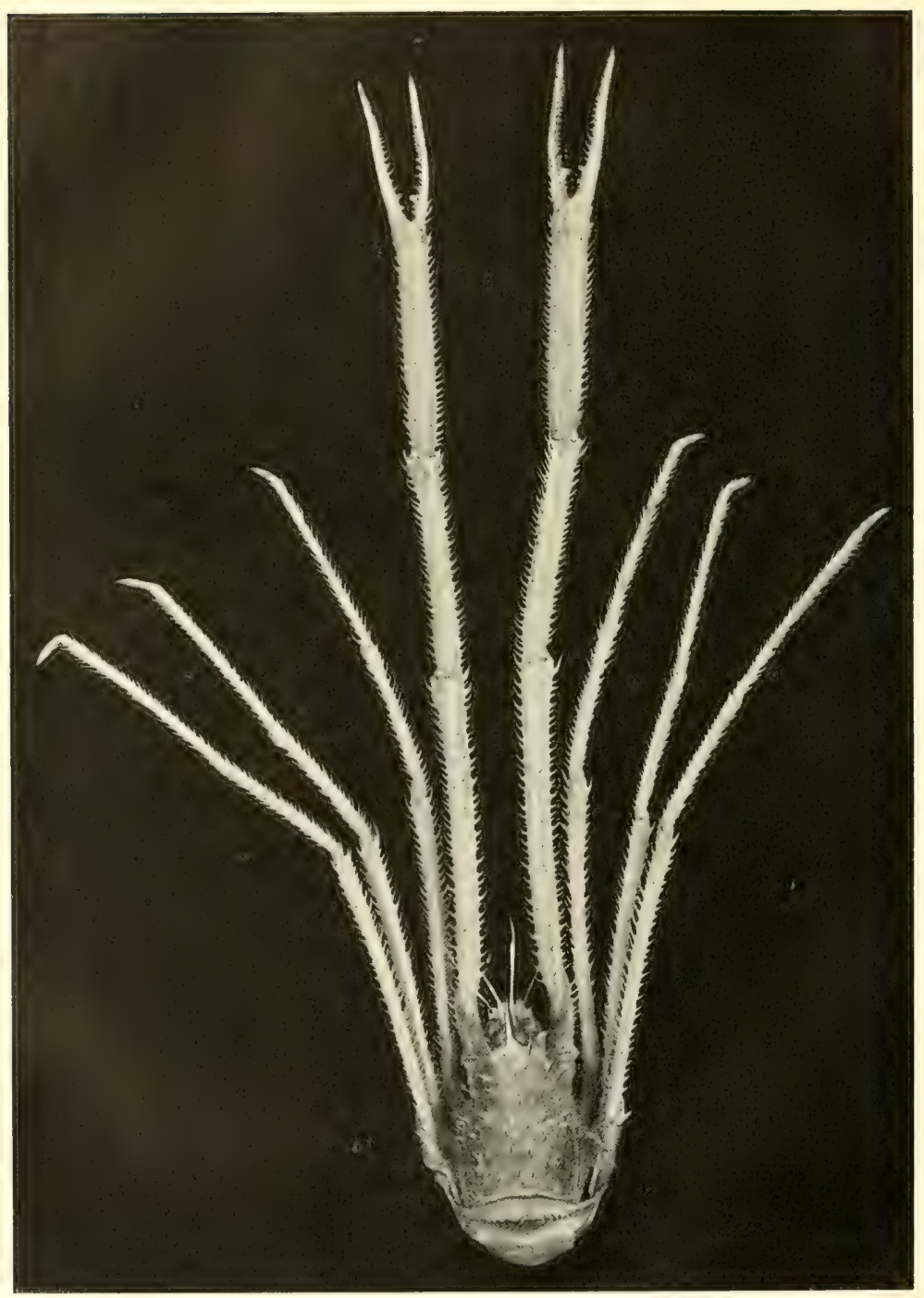

Munidopsis sp. $\subseteq$ äb=2has=Kanal $646 \mathrm{~m}$. 27at. Bröfe. 
bisher nidht erbeutet hatten. Es waren por allen Dingen Ticfiegameelen aus der Gattung Nematocarcinus mit monftrös verlängerten Beinen, weldhe durch oft blendende

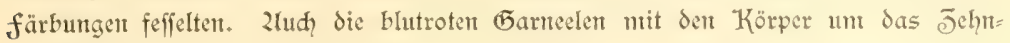
bis ङुwölffache an Sänge übertreffen=

den fühlern (Aristaeus, Aristae-

opsis) traten häufig auf. כ̄u

ibner gefellten fid jahlreidhe

Krabben, unter denen

namentlich Dertreter

Ser mit einem

Walde fharf $=$

ipitziger Sta=

dheln bejeţten

(5attung Li-

thodes ber=

vorjubqeer

find. Ein=

fiedertebic

hatten in $\mathbb{E}_{r=}$

mangelung

von Sdinef=

fenthalen ih=

ren jarten bin

terleib, biswei=

len aud den

garjen Körper,

in hohle Eloljftücts

oder in fingerlange

Sdyalen der abjonderlidien

2rollusfengattung Dentalium

eingejwängt. 2reben Kruftern nit

grof̧en, purpurrot glühenden 2lugen,

wie fie namentlid dem ntehrfach er=

Xenophora, pon be: Shalenni indung (3auhfeite).

$614 \mathrm{~m}$. Süb- Zlias= Kanal. 2Tat. Bröвe.

beuteten grofen Nephrops Andamanicus

jufommen, wurben aud foldhe mit rüdgebildeten Stielaugen gefunden. In geringerem

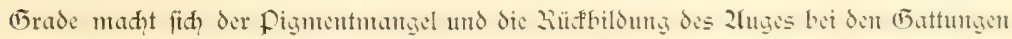
Munida und Nunidopsis geltend, während hei dar unfuren flupfents ähnelnden (5attuns Nephropsis, die ju unferer Z̈̈berrafhiung in Jndifhen Deean auftauhte (2Igaffij 
hatte fie in pacifie gedredfht), sie 2lugen bereits hodgradig verfünmtert find. Sie fehlen endlid) völlig der (5attung Pentacheles, ciment Dertreter der fantilie der Ery̧oniden, der dem 2lientawei=Befen nidit fremb ift. Interefie erregte weiterhin der fund einter kiiefenform von Cirripedien, nämlidy des aus den oftaftatijhen 2rieeren befaunt gewordenen Scalpellum

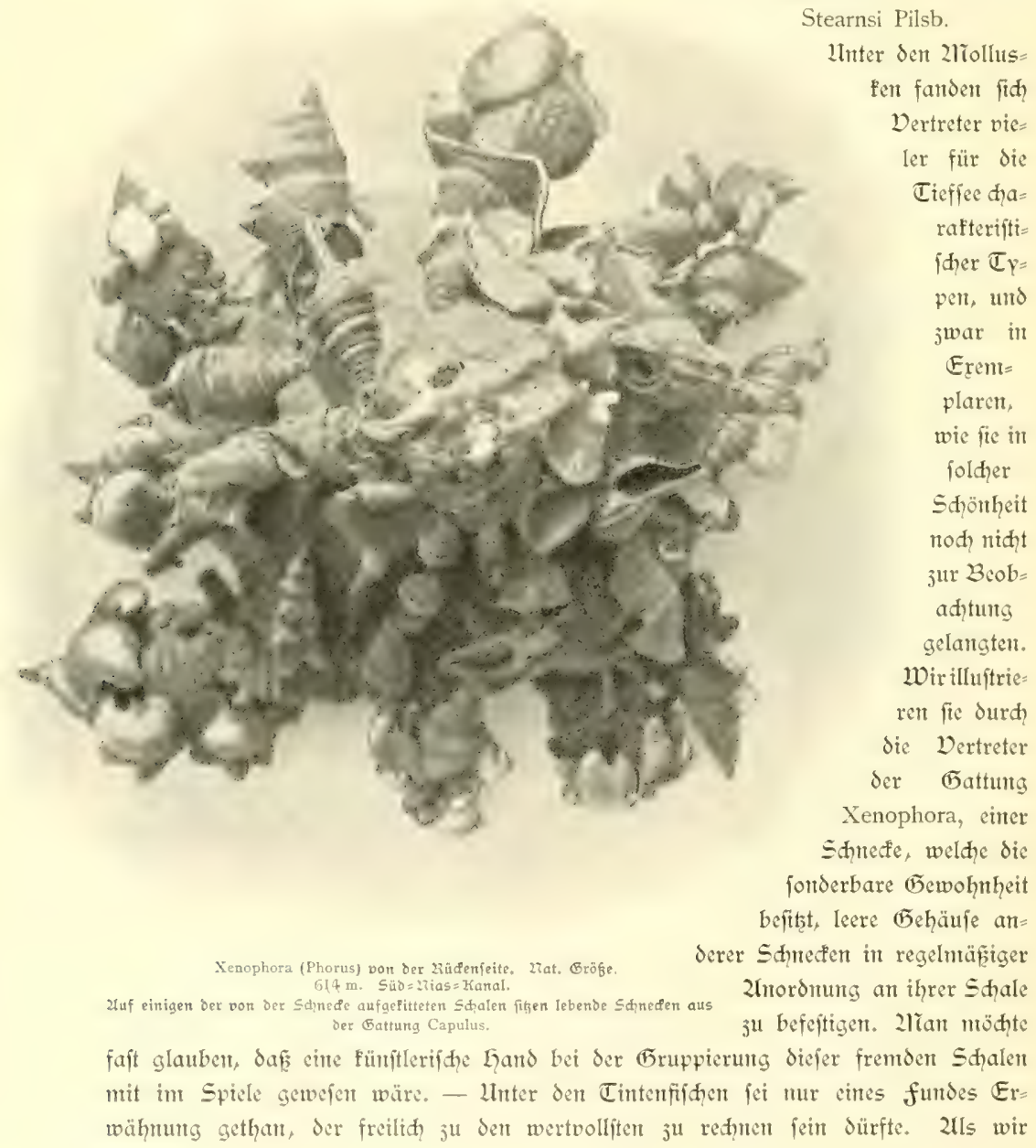


im Süb=2tias= Kanal aus $594 \mathrm{~m}$ das Shleppnets an die Dberflähe bradten, fiten es nidht den Grund berührt ju haben, wies aber ein in den 2liajden hängendes Eremplar der CGattung Spirula in trefflider Erhaltung auf. 2ln mandhen Küften= ftrefen finden fidh dic pofthornförmig gefrümmten Edalen derfelfen maffenbaft an= getrieben; merfwürdig aber ift es, dafe Erentplare mit wohlerhaltenen Weidförper

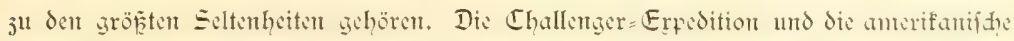
Blafe= Expedition haben mur je ein lebendes Erentplar der Spirula erbentet: man fann fid die Befriedigung vorftellen, dic wir empfanden, als es aud uns be= fdieden war, ein fo foltbares Stüf der Sammlung einjuverleiben.

Llm endidy nod der fild me mit einigen Worten ju gedenfen, fo fei hervorgehoben, dafi wir eine grof̉e Jahl jener 2lrten erbeuteten, weldie bereits durh die indifhen forihungen des "Inveftigator" befannt geworden waren. 2ramentlid? häufig waren die grof̧en, fdhwarjett Dertreter der (5)attung Lamprogrammus und Tiefiee $=2$ lale aus der (5attung Congermuraena mit ifren pupurnen 2lugen. Ju ifhen gefellen fids? die bizarr geftalteten 2lrten aus der familic der Sophitoen, wie Chaunax und Dibranchus. 2liandhe diefer formen follen uns fpäterhin wegen der Zusbildung wunderliher Drgane an ihrer Sdrtaujenfipite nod) eingehender befhäftigen. Daneben waren es die mit Seudytorganen ausgeitatteten Dertreter der Sfopeliden (Neoscopelus, Echiostoma u. a.), weldhe in hödhit abjonderlitien forment uns entgegentraten. Sowohl unter den auf dent Frunde lebenden, wie in gröperen Tiefen fdwimt= menden fifhen fielen uns 2Irten auf, die wir auf feine Weife in den Syitem unterjubringen vermtodhten. 2lls wir gar bei den Banjaf = Jnjeln in $1145 \mathrm{~m}$ einen fanmetfobwarjen, leidt bläuliक jhinmernden jouppenlojen fifh von einent halben 2lieter Sänge erbeuteten, deffen breiter, mit ungewöhnlid, grof̧en 2lugen ausgeftatteter Kopf und deffen floffenftellung an die Karpfen erinmerte, während dic Seitenteile des Körpers mit fegelförmigen Cirren befetzt waren, da gab man es auf, ver=

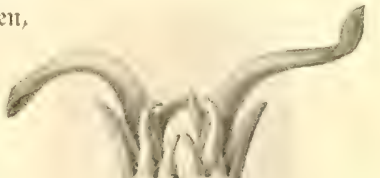
geblich über derartige 2Tonitra in der Sitteratur nad Beincio jt fuden.

In allgenteinen ift es uns aufgefallen, dafe in der fumatranifhen Tieffee die ver

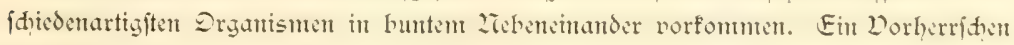

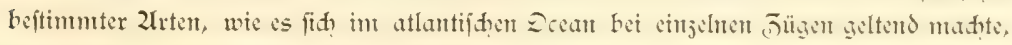
war nidit ju beobahten. Der Reiकhtum an formen, die fid hier auf engem Terrain

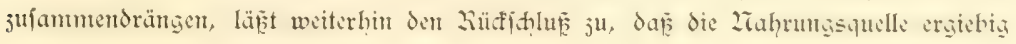


fliefen mur. Die 2lnterfudung des planfton im 2lientawei=Beften ergab dem aud eine üppig entwidfelte flora niederer Drganismen. Die für den freien Deean diarafte=

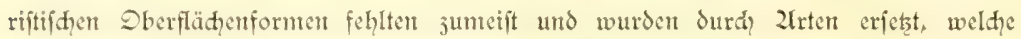
mehr an die zä̈he der Küjten gebunden fint. Vor allen Dingen war es eine fpiral

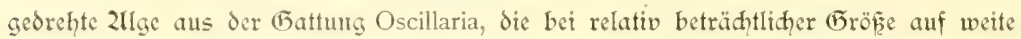
Strefen hin das Waffer verfärbte und als bräunlider Brei gelegentlid? den Laupt= inhalt unferer Dertifalnetse abgab. Dabei jeigte der Tieffeeboden einen olingrünen, bisweilen mehre ins (Fraue oder Bräuntidge fpiclenden Ton, wie wir ihn von dem Tieffecgrunde des Golfes von Bengalen und neuerdings aud durd die holländifhen

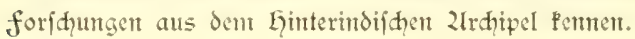

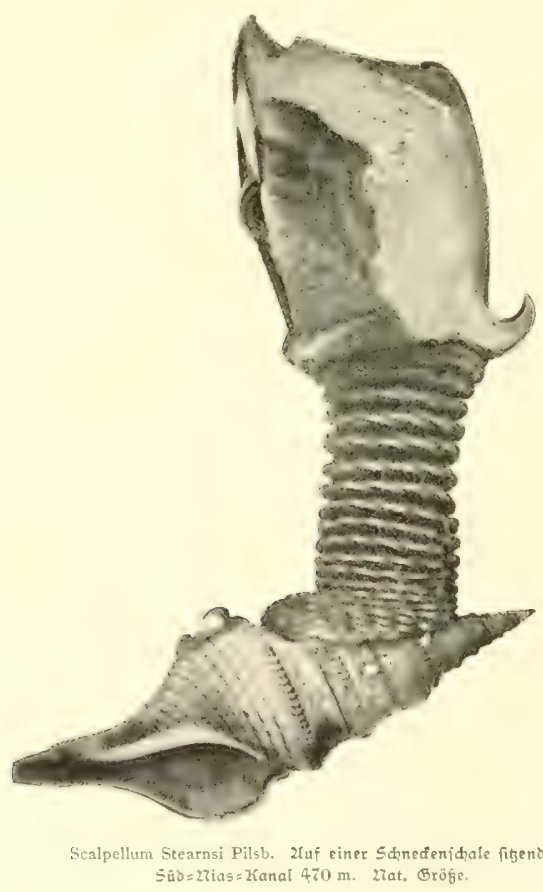




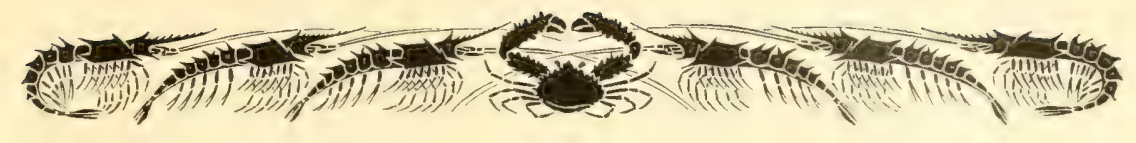

\section{Die Zifobaren.}

E war volt vornherein ju erwarten, daf dis von uns in 2lientawi = 23eten nah: gewiefene Tieffecfauna mandherlet l̈̈bereinftimmung nit der durd? das indifhe

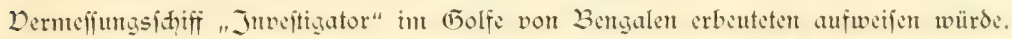

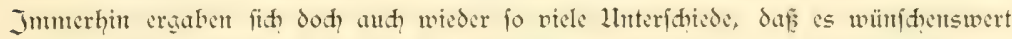

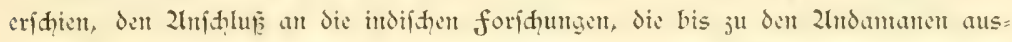
gedehnt worden waren, durd ein Dorfahren bis ju den 2rifobaren ju gewinmen.

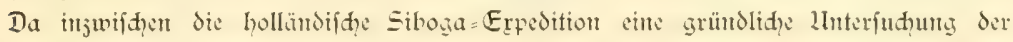
hinterindifhen Tieffee durdigeführt hat, fo fteht ju crwarten, dafi dic von oret Expeditionen in benabbarten und gegenfettig fid ergängenden (5ebieten gimomenten

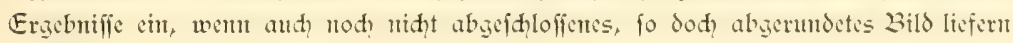
werdert.

Daf wir aud nad, dem Derlafien von Sumatra auf cinent für Tieffecforjdutgen flaffifigen Boden unferen LInterfudiungen nadjingen, lehrte eine keihe von Dredid) jügen, die wir am 7 . und 8. februar jwifhen 300 und $800 \mathrm{~m}$ Tiefe ausführten.

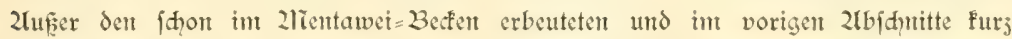
dharafterifterten formen fiel uns hier namentlich der Reidtum an Glasfidwämmen (Geraftinclliden) auf, die fhon in geringeren Tiefen in wahten Pradhterentplaren er= beutet wurden. Dertreter der (E)atturgen Pheronena, Hyalonema, Aphrocallistes, und ein bemahe $80 \mathrm{~cm}$ hohes Exemplar der (Ẽattung Semperella, cincs der föoniten Sd)au=

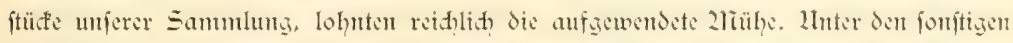
funden fei nod ppeciell auf die Krabben hingewiejen, die niḑt nur eine 2Injahl neuer formen, fondern aud die intereffanteften, vom "Challenger" erbeuteten Typen lieferten. So wurde die bisher nur nath cinem jerbrodenen Eremplar befant gewordene Cyrtomaia Suhmi häufig gefundent, nidłt minder aud die grof̣e Platymaia Wyville-Thomsoni. Der Challenger $=$ Beriḑt bejeidnet dic leţtere 2 ret als cinc der interefianteften Ent decfungen der Expedition; fic fand fith mur in einem Exemplar in pacififhen Decan, während wir bei den Zifobaren deren nid̨t weniger als 25, Sic meiften in tadellofer Erhaltung, dredidten. Da fid unter den Exemplaren, weldie durd dic 2lbplattung Ser monftrös geftalteten, vorn mit mädtigen Dornen bewehrten Beine ausgejeidntet 
find, aud Jugendformen von mu $1 \mathrm{~cm}$ (5röpe befandent, fo erhalten wir aud einige 2luffdilüfe über dic Entwidilungsgejhidite eines jo bijarren Drganismus.

Der Grund erwies fith in der Imgebung der Zifobaren bis ju Tiefen von $900 \mathrm{~m}$ als cin redit vieläeftaltiger; grobe Sande und olingrüner vulfanifher Sdlif wedpelten mit Pteropodent $=$ Sd lamm ab. Der Ieştere trat in geringeren Tiefen fübweftlid, von

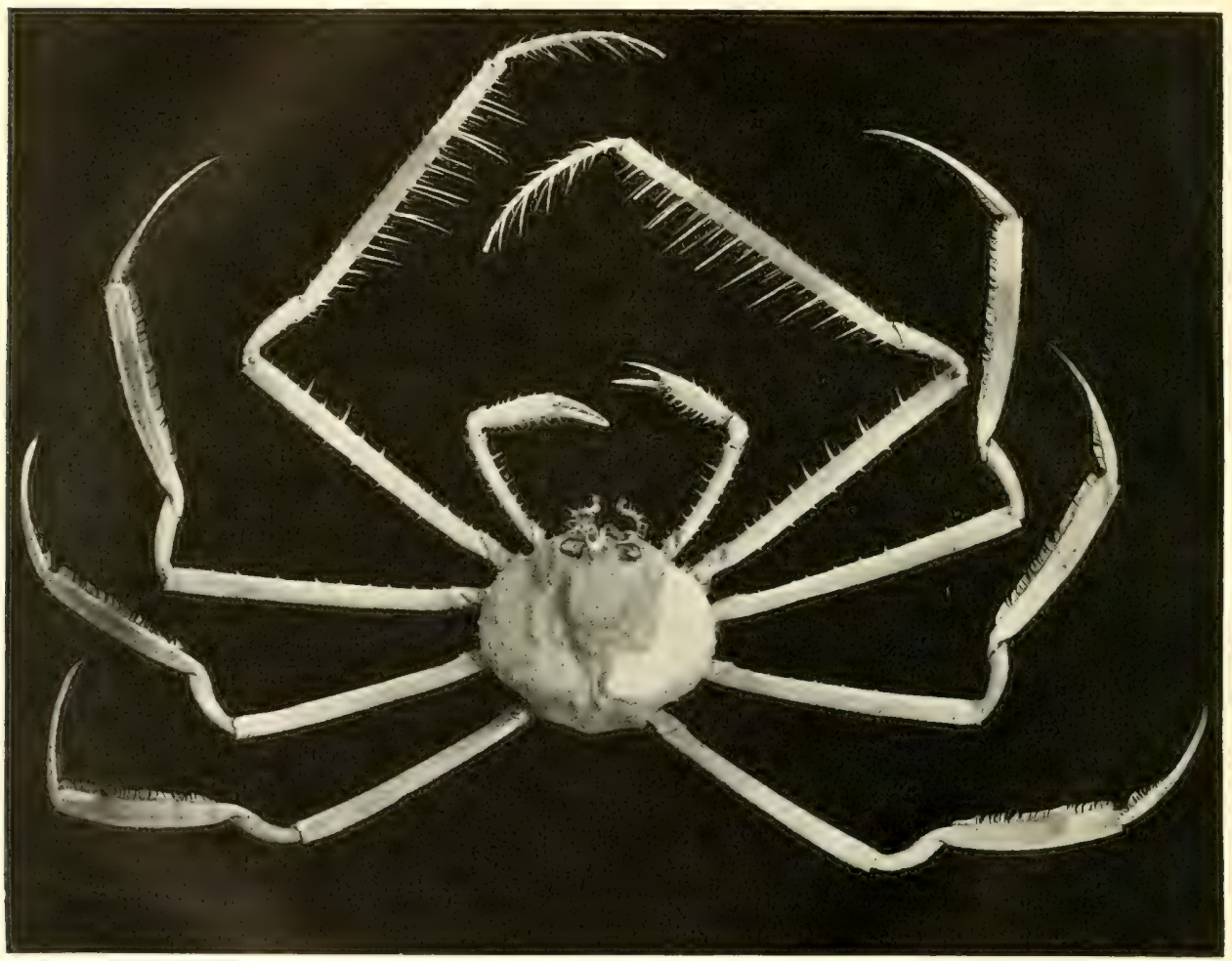

Platymaia Wyville-Thomsoni Miers. $296 \mathrm{~m}$, Ealbe nat. Fröfe.

Grofs=27ifobar anf und jeigte cine fo bunte Julfammentesung aus den Shalenreften verfuicdenartiger Drganismen, dafiz wir ihn durh eine 2lbbildung illuftrieren. Bei der Durḑmufterung des Bildes fallen junähit die tutenförmigent Shalen von flügel=

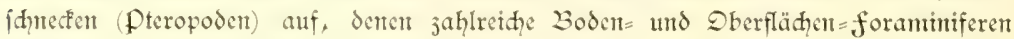
beigemengt find. Daju gefellen fid fleine Shalen vor Riujheln und Stmeden, 
Sdwanmmadelnt und grofe eiförntige Cobilde, die fid als Excrentente vort Edino= dermen erweifen. Zls wir weftlif von Kahal cine Tiefe von $805 \mathrm{~m}$ loteten, erhielten wir feine Grundprobe, und das herabgelafiene Trawl fam ftarf jerriffen an dic Sber=

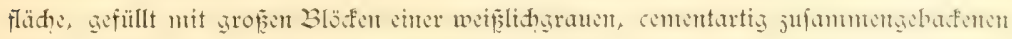
2laffe. Wir musten diefen aus grobem Sand beftehenden Tiefenjhlamm mit dem Beile jerjdlagen, um die jahlreiden, der Gattung Phascolosoma jugehörigen, grün= lidhen Sternwürmer mit ihrem furzen Shöpfrüffel ju gewimen, welche die harte Zĩaffe mit thren langen $1 \mathrm{~cm}$ breiten Gängen durdffetcten. Da es indeffen nidit ratfam er= fhien, auf einem für unjerc Zreţe fo verhängnis=

vollen, went aud den Geraftinelliden be= fonders jujagenden 30 en dic Llnter= fudoungen fortjufețen, fo entifiloffen wir uns jur Weiterfahrt, nidht

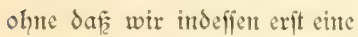
Sandoung im Kanfauri $=\mathbb{L}$ a a en veranitaltet hätten.

Die Ziffobarenteilen fith in Srei Gruppert, deren jüd= lidhite von Klcit = und (5rof $=$ 2rifobar gebildet wird. Das lebtere ift langgeftredt, did̨t bewaldet und mit nidht fehr hohen, bis $600 \mathrm{~m}$ auffei= genden Bergfetten ausgeftattet. อ̄เซjhen beiden Inteln verläuft der St. Feorgs= Kanal, in dem wir am 2tbend des Z. Februar unter dent Sduts eines flcinen Jnjeldiens, nänlid Kantul, vor 2lufer gingen. Eine Bootfahrt,
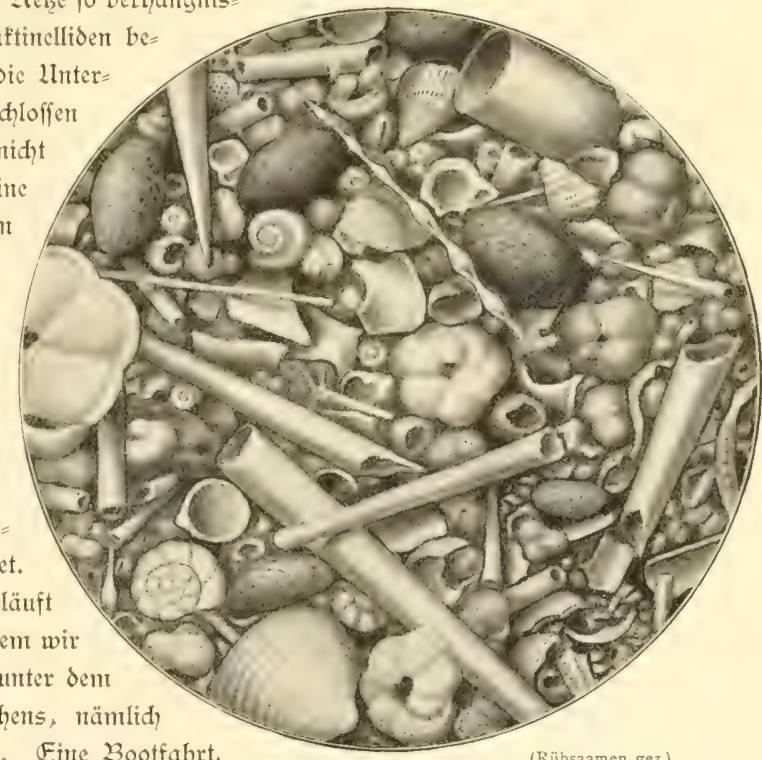
dic wir nath Kandul unternahnent, crgab, dafi die Injel unbewohnt ijt. Der fandige Strand war bedecft mit ptcropoden=Shlamm. Stat.208 (SW. von Wrof=27ipobar) $296 \mathrm{~m}, 25 / 1$.

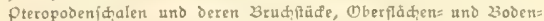
foraminiferen, Sd wammnadeln, fleine J̈weif haler (Baftropoden), eiförmige Ercremente von Edhinobermen.

Brudiftülen vost Riffforallen und Drgelforallen (Tubipora); jahlretde Krabben mit

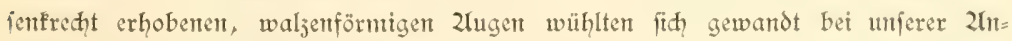
mäherung in den Korallenfand ein. 2lu Strande trat wiederum die auf faljiges Eerrain befdranfte Etrandfora auf, welde fid aus Barringtomien nit ifren srofin

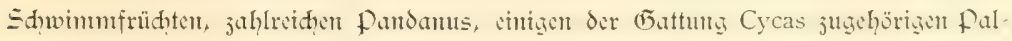
men und jahlreidhen Cajuarinen, die mit ihrem feinen saube die fteilen Eänge decften, 


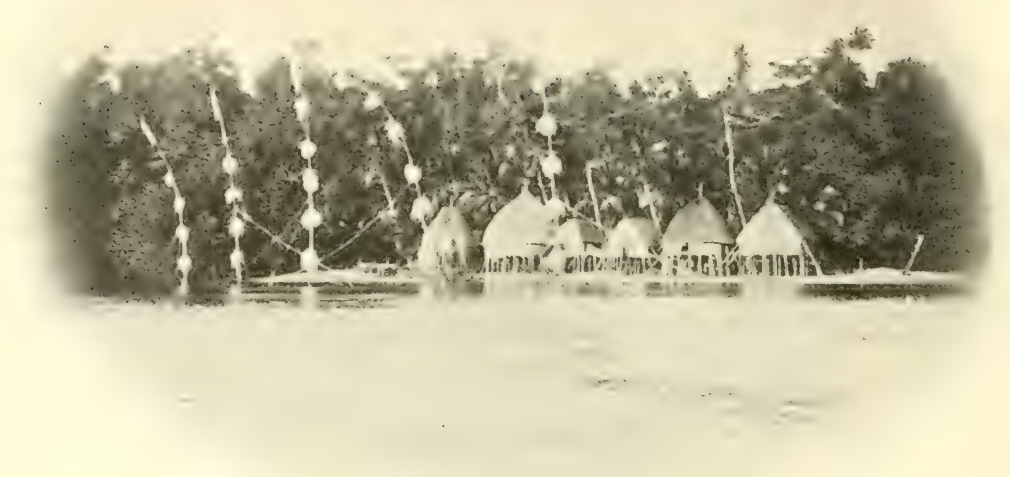

(Apstein phot.)

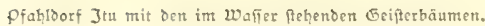

jujammenfetste, flicgende Lunde hatten fich in den Bämmen aufgehängt und führten cin wahrhaft infernalifhes Konzert auf.

Die mittlere Gruppe der Ziffobaren fest fĭh aus brei gröferen Jnfeln jufammen, nämlid Kađ̆al, Zanfauri unt Karntorta. Zadłbent wir das ganj bewaldete Kađal umfahren hatten, cröfntete fich junähịt der 2lusblic auf das fahlere Karmorta mit

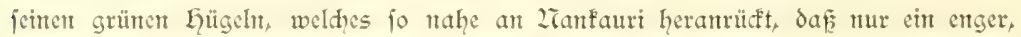

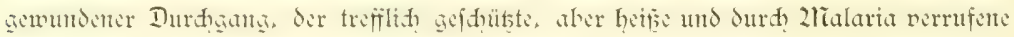
Gafen von zanfauri, freibleibt. Scine lmgebung ift cine auferordentlich malerifhe: der llrwald tritt bis at das Ilfer heran, und fharf heben fich die Gütten der Ein= geborenen von dent dunflen Eintergrunde ab. Bei der Finfahrt wurden wir it hohent (5rade gefeffelt durd, rotbraune, nadte 2räuner, die mit Liamunenlanjen auf den Klippen ftehens dem fifhfange oblagen. Dbwohl in den Segelhandbühern die $\mathfrak{B}_{e}=$ wohner der Ziffobaren als Seeräuber dargeftellt werden und Dorficht bet cintem $\mathfrak{B}_{e}=$ iuhe der Infeln anempfohlen wird, reijten dod, die beiden 2lnfedlungen derart ju einem Befudie, dafi wir vor ciner derielben, nänlid, Itu, auf 16 faden Tiefe anferten, cin Soot ausjetsten und cine Sandutg unternahmen.

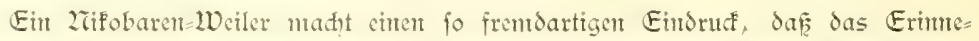
rungsbild getren bis in alle Eingelheiten uns haften gebleben ift. Scdis grop̉e Gütten, 


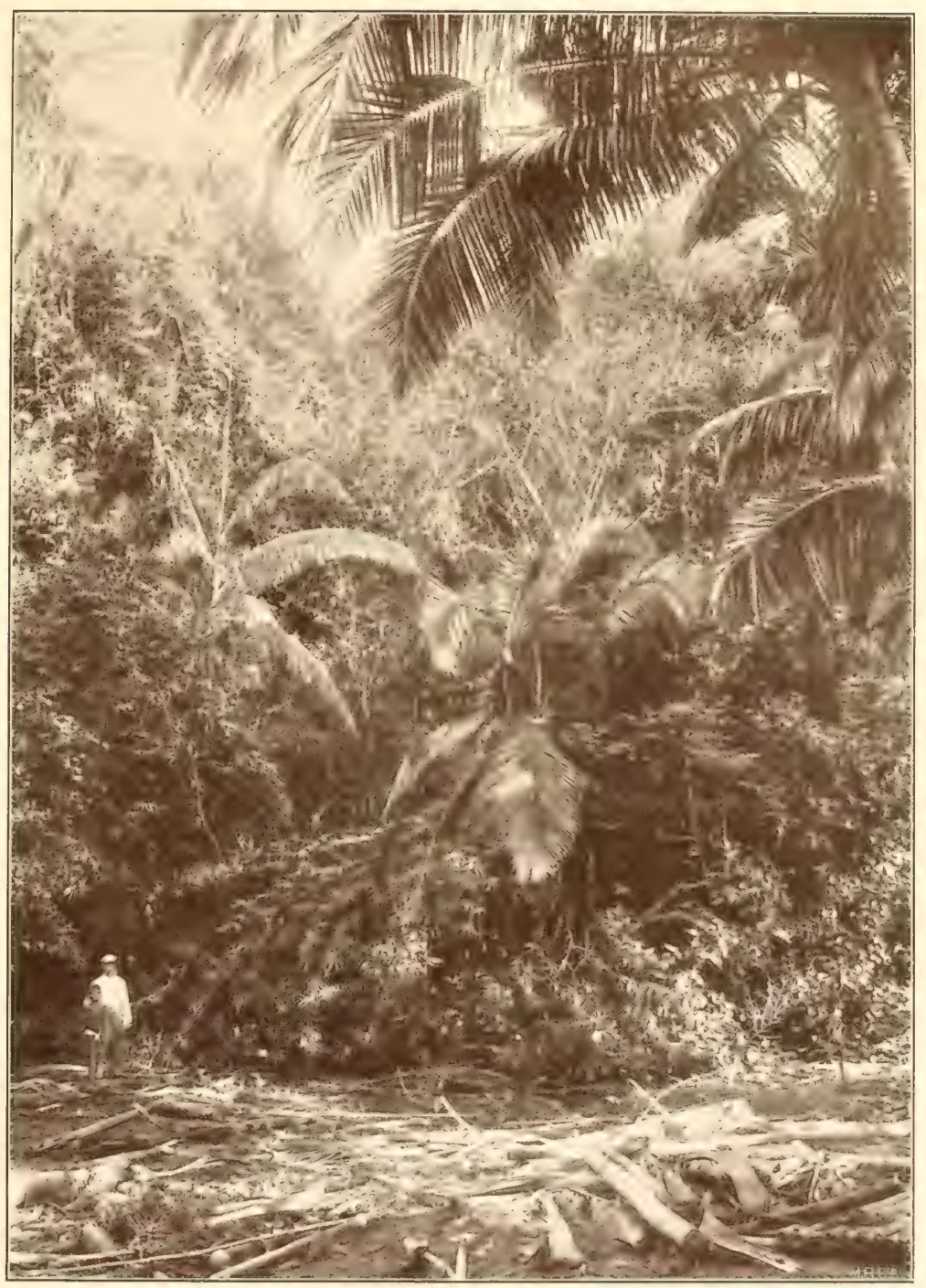

Urwald mit Cocos = und Rotang=Palmen auf Zianfauri (Zitfobarm). 

Sic meiften wic Bienenförbe geftaltet und auf hohen

pfählen ftehend, find an dem Strande in flut=

höhe angelegt. Der Lrwald, gebildet aus

präd)tigen Exemplaren des Calophyllum

mit jeinen duftenden weif̌en Blüter,

aus der Heritiera litoralis mit ihren

brettförmigen Wurjelplanfen, aus

Erythrimen und Pongamien, über weldhe die eleganten 1 Dedel der $\mathrm{Ko}=$ fos $=$, Rotang $=$ und Pinang $=P a l=$ ment hinausragen, tritt diḑt bis an die 2lnfiedelung heran. Don weitem fhon ift fie daburch fennt= Iid), daf in das Waffer Bambus= ftämme eingerammt find, an $b e=$ nen in regelmäfigen Jntervallen $5-\tau$ Blattquirle angebrad wer $=$ den. Wir zählten fechs foldher mit Tauen aus Rotang gegen das Untfallen gefidherten und den aber= gläubifhen Sinn der Bevölf́erung von vornherein andeutenden Geifter= bäume. Die Zlnnäherung wird Surd? Korallenbänfe erjḩwert, jwifhen de= nen zahlreidhe fowwarje Golothurien und elegant fanwinmtende Seefhlant= gen fith umbertrieber. Ein mit weifser Jad́e und einem Sarong befleideter jüt= gerer zrann orientierte uns in gebrodienem Engliph über die Sandungsftelle und ver: ficherte, daf wir freundith aufgenommen werden würden. Durh einen mehriährigen 2lufenthalt auf Zrifobarifher Greis. den Zndamanen war er wenigftens infoweit bon der Kultur belecft worden, daf er

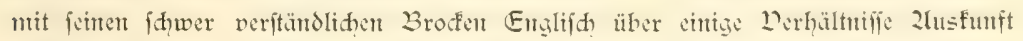

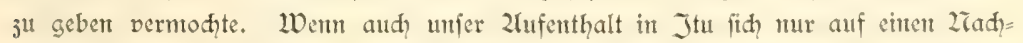
mittag exftredte, fo düfte es bod, vielleidit von Intereffe fein, über das feffelnde

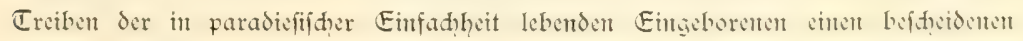

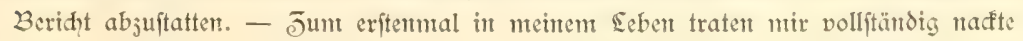




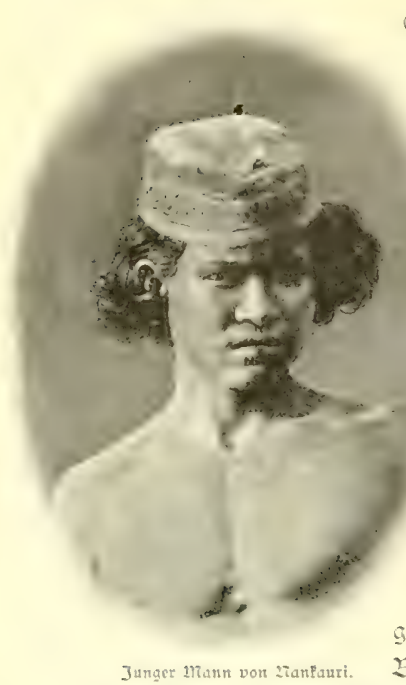

Eingeborene entgegen, dic nur cinc bünte $\mathbb{S} e n d e n j$ hnur tru= gen. Es waren jwet alte 2ränter, die würdig auf uns jufanten uno freundlid dic Gände qhütteltert. "2ith)ts ijt jüdtiger und anftändiger, als die fimple zratur": unwillfürlid, dađte man an den 2lusiprud, non Seffing, als diefe unbefleideten 2lenfiden unbe= fangen uns begrüften und ju dem Befude des Weilers einluden. Die übrigen Eingeborenen hatten offenbar อ̄eit gefunden, weniger aus Sdamgefühl, demt aus ciner kegung der Eitelfect, Klcioungs= ftïffe anjulegen; die einen trugen einen Sarong, die anderen furje Sduwinmhofen oder Jaden, und nur die Jungen gingen natt bis auf einen Streifen weifen oder roten Sendentudes, deffen Ende fie fofett $111 \pi$ cirren 2lrm gefdilumgen hatter. Das crift, was uns an allen älteren seuten aufficl, war die geradeju grauenoolle 2litifgeftaltung des (5ebiffes durd übermäfiges

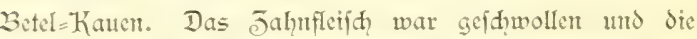
Borderjähne fehlten oder ftanden in Stumpfen fdyräg heroor: cin widerwärtiger 2ln= bliț, an den man fid erfit allmählid ju gewöhnen hatte. 2flle früheren Retfenden

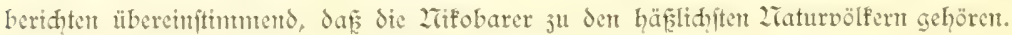
Jdh fant diefem Itrteile nidht ganj beiftinmen. Dic beiden alten 2liämer, welhe uns juerfit entgegenfamten, waren wohlgebaute, fräftige (Gejtalten und wiejen, abgefchen von der $\mathcal{D}$ erunftaltung des 2liundes, cntidhiedent intereffante

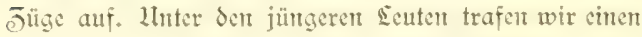
an, der, wemn nidut als f̧ün, fo dod mindeitens als wohlgeftaltet bejeidunet werden muri, und die Jungen waren durdiweg das, was man gewöhnlith "aller= liebite Bengels" nemt. Bereitwillig gingen die Eirt= scborenent darauf ein, fid photographieren ju lafjen, und fo dürften demt unfere untgefduninften 2lufuah= men auक dem Sefer ein Mrteil ermögliden. Wem dic Phyitognomien crnft und mistrauifh fdeinen, fo mag man dies auf kedunung des 2tubehagens fetert, wel= Wes der geheimnisvolle photographifhe 2lpparat crwedte.

Die Gautfarbe der Ziffobarer ift etwas dunfler, als die= jentge der 2Talapen, und jeigt einen ganj entidicdenten Stid? 


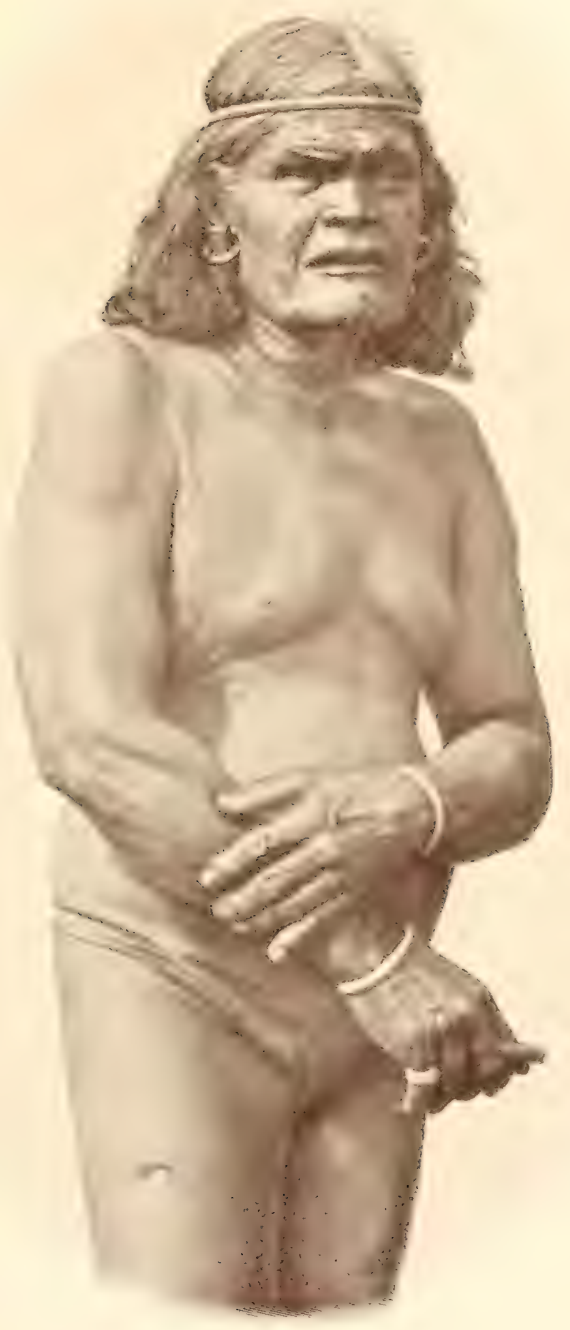

Zliter 2Tifobarer. 

in das Rotbraun, der nantentlid bei den am LIfer fifhenden, juerit bemerften seuten fo auffällig hervortrat, daf man an bie Rothäute 2rordamerif́as crimert wurde. Die ztifobarer find ourdjifutittlid etwas gröper als die NTalapen; nit etwa $1,6 \mathrm{~m}$ fommen fie der Gröfąe des Europäers gleich. Die Kinnbaffen treten ftarf her= vor, die Zafe ift abgeplattet und der breite 2hint etwas aufgeworfen. Eine Sdief $=$ ftellung der Zlugen fiel bei feintem auf; fic liegen meift tief, find von fräftigen 2lugen= brauenbogen überdaht und jeigen das obere Sid durch eine übergreifende Lautfalte ver= defft. Eine 21bfladung des Ginterhauptes, Sie nad früheren Beriḑten bei den Kin= dern Fünftlid herbeigeführt wird, trat niđ̆t

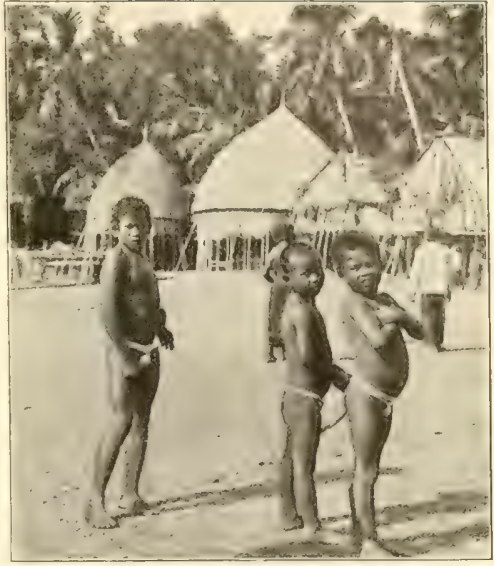

27ilobarifhe Jungen.

(Schmidt phot.) gerade auffällig hervor. Die fdzwarjen Laare find didht und lang; ein alter 2Nam trug ein fo ftattlidhes, auf die Sdqultern herabwallendes und durh einen Reifen ju= fammengehaltenes graues Gelof, daf id es freund Dahn als Dorbild für feine Sthilderung der Germanen anempfehle. Bei anderen 2lämem wurde das bald ftarf gewellte, bald ftraffe Lqaar etwas fürzer getragen. Jwe 2liänter - darunter umfer Dolmeticher - hatten es in der 2rittte gefḑeitelt und reiđ̧liđh mit Kofosöl gefalbt glatt herabgefämmt, während die Jungen furz gejđoren gingen. Keiner befaß̨ aud? nur einen 2rnfug von Bartwuds. Der Körper ift wohl proportioniert und jeigte mit 2lusnahme eines älteren, ju fettanfałz neigenden

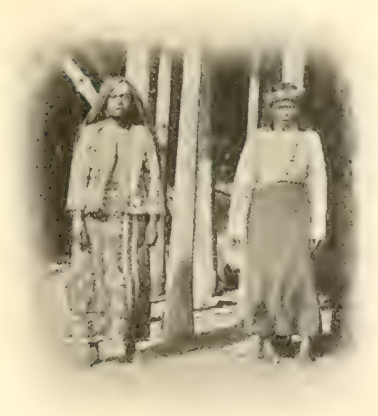

Weiber von Jtu.
2 Trannes cine fräftig ausgearbeitete 2liusfulatur uno ftarf hervortretente Denen. In den bei älteren Eeutent durḑbohrten Dhrläppḑen fteften Stäbe aus Bambus; auch dienten fie bei dem 2liangel der $\mathcal{B}_{e}=$ Eletdung als Taidhen oder Etuis für die Cigarren, weldhe mit freuden entgegengentontmen wurder. Einc Tätowierung war niḑt $\mathfrak{j u}$ bemerfen. 2ln Sdmmud trugen die 21tämner filberne 2lemtreifen und finger= ringe. Jhre Spradhe fiel durdh die and fihon von frihheren Retienden erwähnten gurgelnden Eaute auf, Sie freilid den Jungen wentiger eigentümlid, waren. ülber die Weiber vermag idh leider feine weiteren 
2lugaben ju mad)en, als daf die älteren mit ihren ftark vortretenden Badenfnodien,

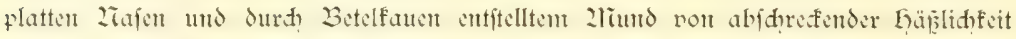
waren. Sie hodfen mit nađfem Dberförper in ihren verrauhten Fütten, und es foftete 2lühe, ifmen flar ju maden, da fie difelben behufs fhotographifher Ifuftabmen verlaffen mödten. 2lls fie dann endid' jum Doridein famen, erweffent fie die un=

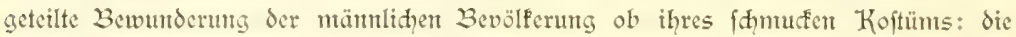
Gaare tricften von Kofosöl und der Körper fteffte in baumwollenen Tüdtern mit

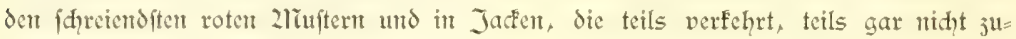
gefnöpft waren.

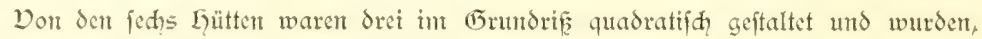
wie wir bald bemerften, nur als Dorratsräume benutht. Dempelbent Jెweffe diente cine Fleinere ficbente Gü̈te, die in weiterer Entfernung ctwas verfteff erridutet war. Die Wohnthütten jeigen eine form, wie fie in dem gantzent malapifden 2trditipel mit Zlusnahme der Infel Engano niḑt wiederfehrt: fie find rund und gletḑen von weitem

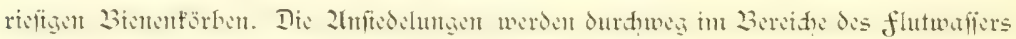
angelegt, möglidfit gefdütht gegen den Südweft=2lionfun, aber dem heiteren 2iordoft= 2Tonfun ausgefetst. 2llle Gütten fthen auf hohen Pfählen, welḑe aus jugehauenen Baumfitummen gefertigt find. Die Kundhütten wiefen chwa 18 in cinen Kreis geftellte

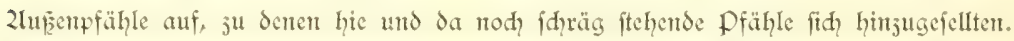
Jumerhalb der Zußzenpfähle trifft man nod cine 2lnzahl in Reihen ftehender Jumen=

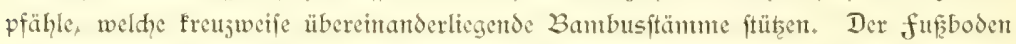

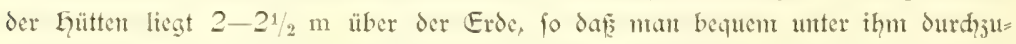
gehen vermag. Jmmerhalb der den Boden ftüz̧enden Pfojten wird der Raum zum Zufftapeln von Vorräten bemušt, die entweder auf rohen Geftellen oder auf Dlattformen liegen, weldhe an Botangftrtfent aufgchängt find. Das fuppelförmig geftaltete, mit cinem gefdntitzen Pfahle gefrönte Dadh ift hodgewölbt und gededt mit den fajem der Ziipa=Palme. Die Sittenwände des Wohntrames werden durd eine Bretterveridhalung

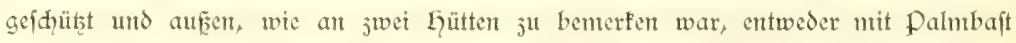

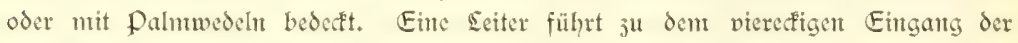
Gütte, der durd cine Klappe aus palmfafern gefdloffen werden fam.

Was bet demt Betretent des cigentlidzen Wohnraumes in erfter Sinic auffällt, ift dic

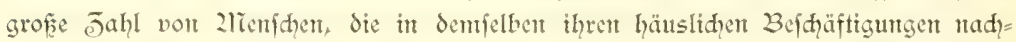

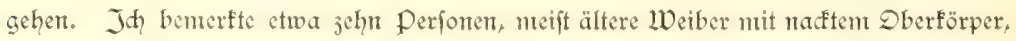

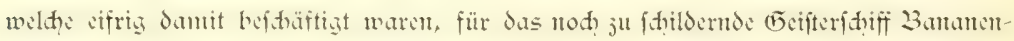
blätter ju zeriḑliţen. In der 2ritte der Gülte hing ein bunt bentaltes vierediges Brett, das mit grünen Guirlanden aus jerfhliţten Blättern behängt war. Id hielt

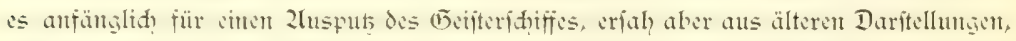

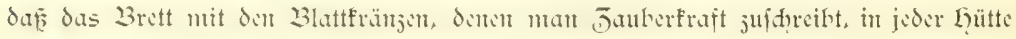




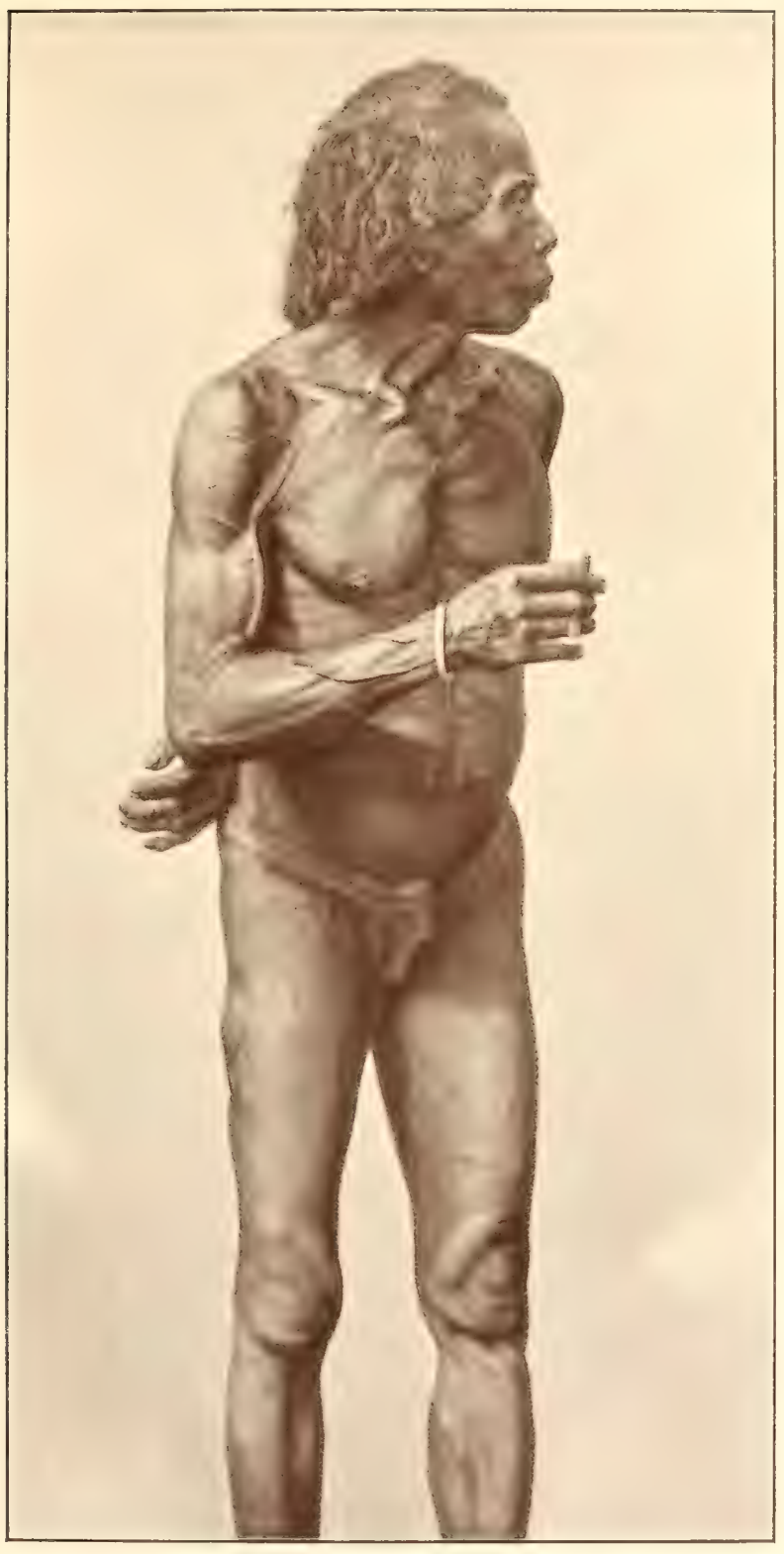

Ziter Ziifobart. 



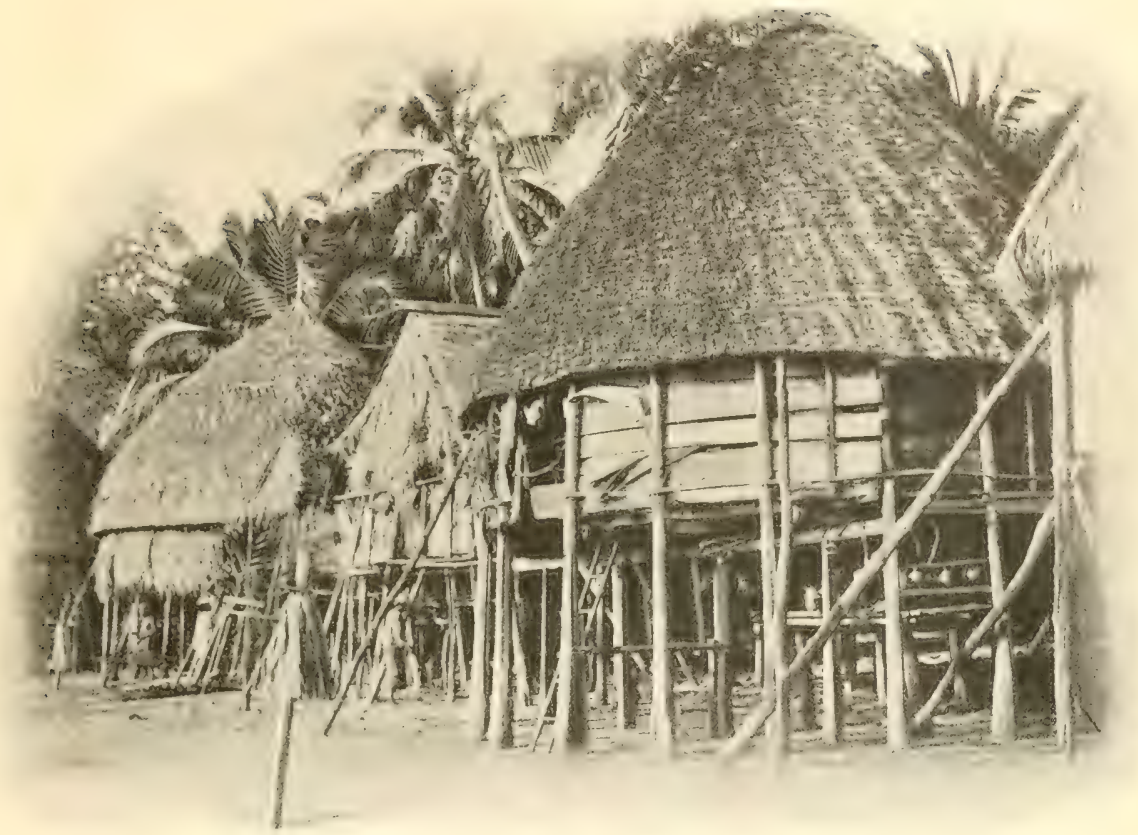

Wohnhïtten mit Bretterverfatalung; linfs ein Geifterpfaht.

(Sachse phot.)

fith findet. Da die Blattftänze bet feftliđen (E)lagen jur 2lbwehr gegen böje (5)ijter um den Lals gelegt werden, erhielten fie von den biederen 2liffifonaren, den mährifhen Brüdern, den 2ramen "Sauffran". Ëegenüber dem Eingang befindet fich der niedrige, von Steinen untrahmte Gerd aus fandiger Erde. 2luf thm briet ein älterer 2liam sin in zwei Teile jerlegtes 5ubn, wobei getrodnete Palmblätter als feucrungsmaterial

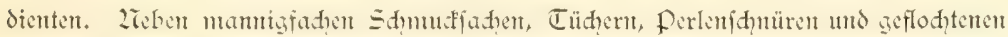
runden Körben, welche an der Dede der Kütte aufgehängt waren, fielen vor allen Dingen die bizarren fetifhe auf, welthe an den Wänden aufgeftellt waren: faft lebens= grope gefdniţte figuren mit Sendenbinden befleidet und Waffen in den fteif ausge= ftredten Gänden fuwingent. Wahrlid - etwas Wunderlideres, als dieje groteste

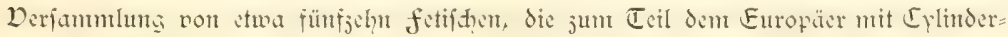
hut nadgebildet waren, habe id in meinem seben nidht ju Gefidgt befonmten!

Der 2lufenthalt in der Gütte war durd den kaud und den (Gerud der ju= fantmengedrängten 2lĩenfden fein angenehmer, aber entjhieden dod infofern für den 
Eingeborenen cin jwetfotenlicher, als fhwerlid die das fieber bedingenden 2liosfitos

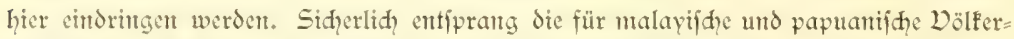

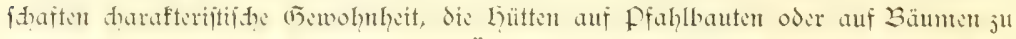

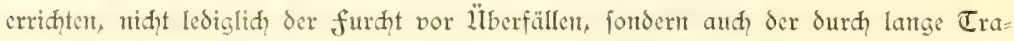
dition gefräftigten Erfahrumg, daf fie Sdyuts gegen die 2Talaria bietet. Die 2liosfitos fliegen im allgentenen nidht fehr hod); went der italienifde birt in der Canmagna auf hohen (5) ftellen iक̧läft, unterhalb deren er ein qualntendes feuer anjündet, fo fuḑt er fid in dericlben Weife gegen das fieber ju fhützen, wie die in verrauḑten und fajt

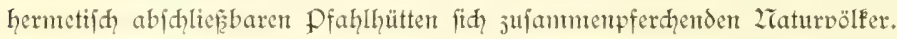

In Lausticren bemerften wix fdywarge Sdweine, jablreidhe Gillhner und eine mittel grofe, jiemlid fanfte Lunderaffe. Das Shwein giebt den feftbraten des Zifobarers $a b$, dem in librigent die tropifhe lutgebung reidhlid, den Tild dect. Seme Sieblings= nahrung ift cine aus den früd?ten des Pandanus mellori bereitetete Pafta, weldye die Stelle des Brotes vertritt. Ïberall fanden wir auf den Dorratsgeftellen die cinge= fammelten Dandamusfühte aufgejtapelt. Daneben ift es die Kofos=Palne, der trene Begleiter des tropifden 2lienjden, welhe aud dent Zifobarer jur Beftreitung des Sebensunterhaltes untentbehrlid ift. 2ran reidjte uns, als wir eine jeit lang in der glïhenden Sommenthitze am Strande gegangen waren, aufgefdilagene Kofosmüffe, deren wäfleriger Juhalt uns ein wahres Sabfal war. Durh Znjwneiden der Knofpen= unt Blütenftengel gewinnt der Zifobarer feinen Palnwein oder Toddy, den er in Bambus= gefäfen auffängt. 2lus der Sagopalme, der Cycas Rumphii, bereitet er den ftärfe= mehlreident Kuden, während jonịt nod Bananen, Dapayas, 2rangas und 2lnanas genoffert werden.

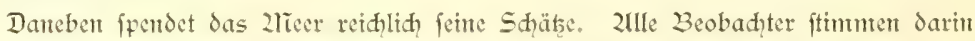

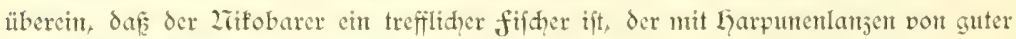
2rbeit, mit Renfen und Zietsen die veridjiedenartigen fdmathaften fifhe erbeutet. Weniger facint er bie Jagd ju lieben, die fement furdffamen 2iaturell nidpt jufagt.

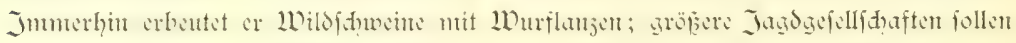
jogar den behenden Büffeln ju Seibe gehen. Wie alle 2raturvölfer find aud die Zifobarer tharfe 3cobadter der umgebenden Zatur, welhe die verfhiedenartigen Pflanjen und Ticre wohI unterfactden und mit befonderen Ztamen belegen.

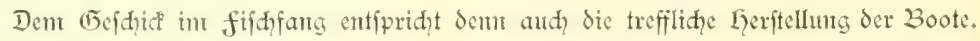
Si: werden aus den Stänmen des Calophyllum gefertigt, fund nti 2luslegern, emem 2liafte und mit aus Rotangblättern oder aus crhandelter Segelleinwand gefertigten Segehn verfehen. Das Dorderende länft in cinten elegant gefhweiften Bug aus; mehrere

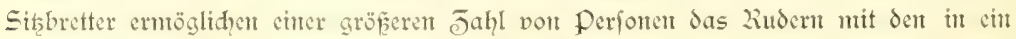
Langes Rutoerblatt auslaufenden Paddeln, weldye ans dem roten Eolje des wilden viangoftan hergeftellt werden. Es gelang mir, vor der 2lbfahrt cines der Ruberboote 


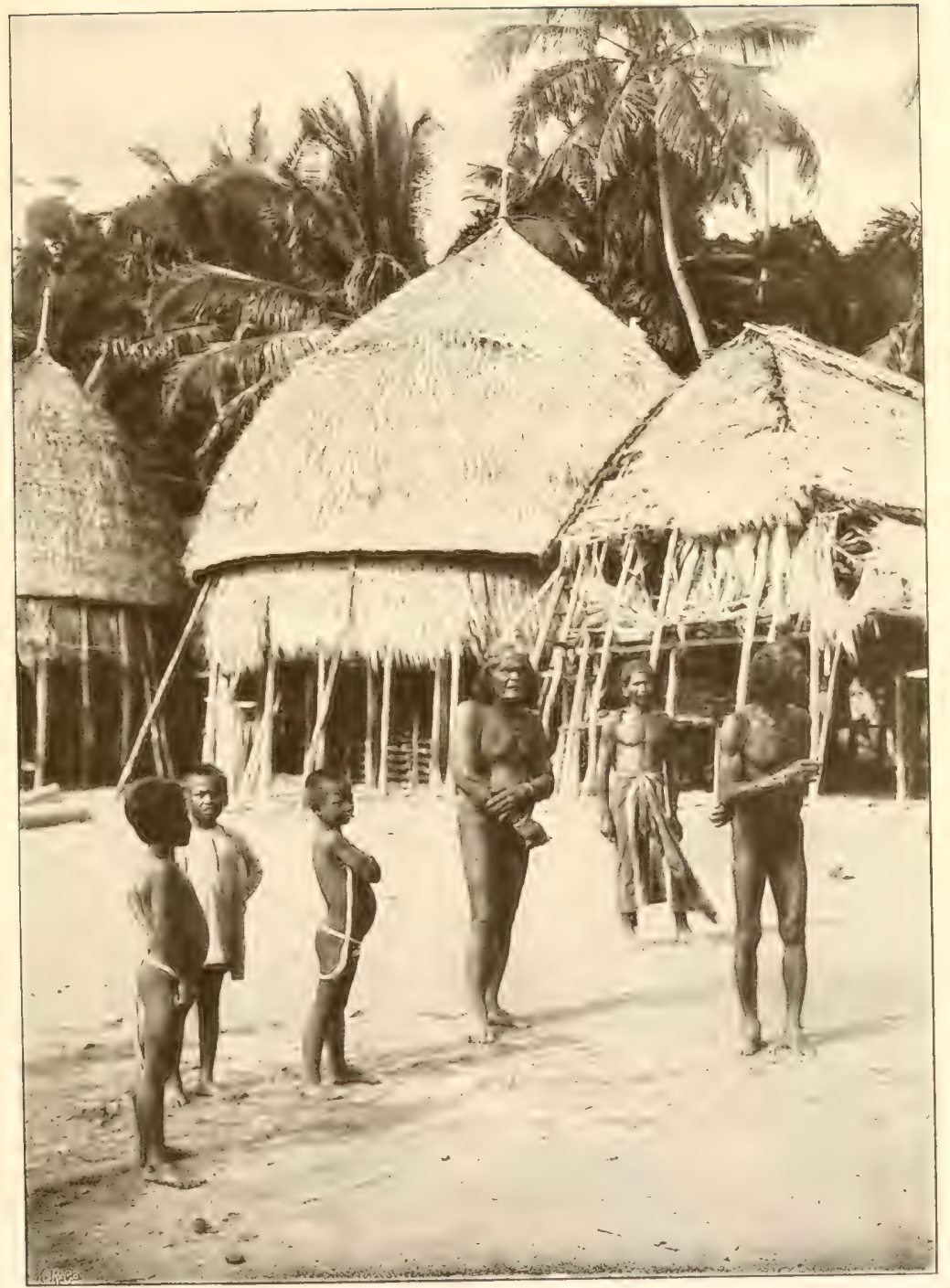

Eingeborene auf 2Tanfauri. 2itfoharen. 

ju erwerben, in denen die Eingeborenen an bas Sdiff herangefontment waren; es fteht

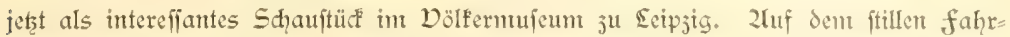
waffer längs des Strandes benterfte id auferdem nod cinzelne Eingeborene, die von auffälig Fleinen Booten aus ftehent fifd̨ten.

Ein merfwübiger Jufall brahte es mit fid, daf wir die Eingeborenen bei ciner

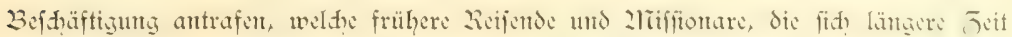
auf den zrifobaren aufhielten, faft nur von Lörenfagen famten. Sie mühtent fid nänlich eifrig mit der Lerftellung eintes eigentartigen fahrzenges $a b$, das als (5)eifter= fhiff in ihren abergläubifhen Dorftellungen cine wiḑtige Rolle fpielt. Wir befizen nur eine juverläfïge Bejdreibung eines Eeifteridiffes aus der feder des trefflidien Sänifden Beobaditers de Roepftorff, der auf Karntorta - nidit von Zifobarem, fortern von cinent Sepoy - crmordet wurde. Es dürfte daher vielleidt cintiges Intereffe darbieten, wenn wir das, was wir fahen, erjählen und an der Land der 2litteilungen von 2liffionaren und Kenmern des Dolfes eine gedrängte Sditlderung

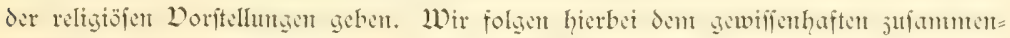
faffenden Beridit von Sooboda, einent öftereidifhen 2larinearjt, der furze Jeit auf den Zifobaren weilte.

Diḑten und Tradten des Zifobarers wird, wie bei allen 2Tatur=

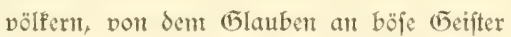
beherriht. Insbejonder: find es die (5eifter der Der=

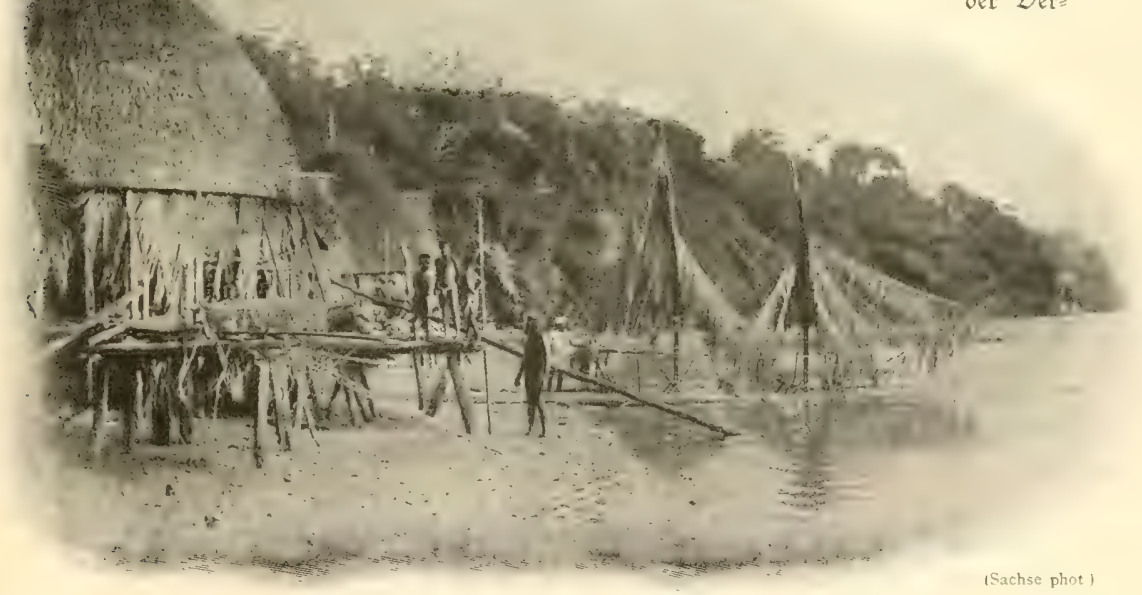

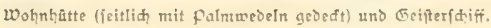


ftorbenen, dic Jwi's, welthe fith wieder nad einem Körper fehten und in irgend jemand bereinzufahrin nerfuthen. Der (5etít des Coten bleibt ohnte Geimat, ohne Eigentum und freuden und veriudit, fidh ganj von dem toten Körper losjumahen und von irgend ciner Derion 23 efit ju ergreifen. Lat ar fid eines Scbenden bemähtigt, fo bemerft is der Batreffonde bald an allerhand Gimtuftumen, unter demen mamentlid das fieher cine Gauptrolle pielt. Lm dies ju verhüten und dem Jwt das Derweilen bei der Ecide annebmlidier ju madhen, giebt man dem Veritorbenen alles mit it das Grab, was thm im scben von Wert war. ङugleid entiagen die 2tnverwandten für längere כeit allen fruden und (Genüffen - namentlid aud? dent Betelfauen -, um den Geift ju veriöhnen. Der 2rame des Derfditedenen wird nidht mehr genamt, und jede Bejiehutg wird dadurd abgebroden, dats man fid von der Linterlaffenfhaft losfagt. Der 2lberglaube gewimnt die Dberhand über die (Biter nad Befts: Ser Sdintut wird der Scidie beigegeben und die Waffen nebft dent Gausgerät ftellt man verpacft oder jerbrodien auf dem (Erabe auf. Die Eingeborenen führten midh nad dem diḑt hinter dor listen Gütte salisinen fribhof, stum flemen, malerift im Kofossibuif ner=

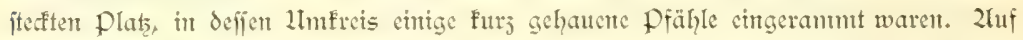

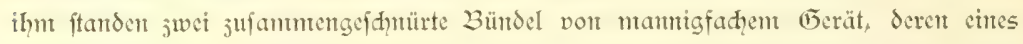
an einer über die 2litgabeln von jwei Stämmen gelegten Querftange befeftigt war. In der 2ritte jwifden diejen Bündeln ftand nod cin Pad jufanmengebundener Speere und 2ungelharpunen. $\mathfrak{W}_{\text {as }}$ in den feft verfduürten und teilweife mit Kattunlappen umwickelten Bündeln enthalten war, fonte id nidit erfenten; an chen hingen Kofos= ihalen, an den anderen ein forgfältig verbundentes pafet. 2luf den Boden lagen gefloditene Körbe, jerbrodyente Thonfhalen, sin Lammer, und auferdem waren an siner Kotangidnur Kalebafjen aus Kofosid̨alen aufgehängt.

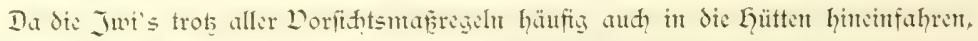
fo werden die fdon erwähntent Geifterbäume int Waffer erridtet. Roepftorff hielt diefe Wahrzeiden der Zifobarenwetler für Eandmarfen, beftimmt, den landenden Bootent die feidtin, unjugänglifin Stillen anjudeuten. 2fndere Beobaditer nermuten in ifnen Dorriditungen, weldhe mit dem Glauben an böfe Geifter in Jufammenthang

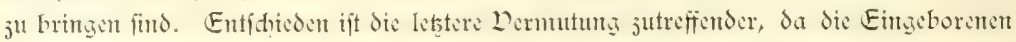

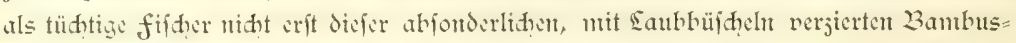
pfähle bedürfen, um fĭ ḧber die fahrrimen ju orientieren. Went id die Ecifter=

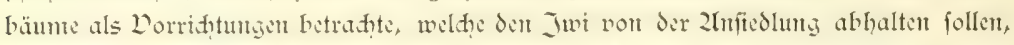

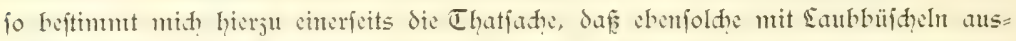

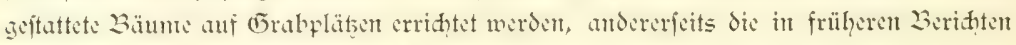

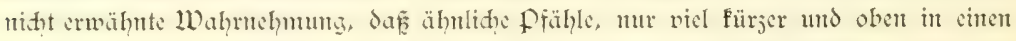
cinjigen Quirl von Blättern auslaufend, vor jeder der dret Wohnhütten aufgettellt waren. Sie gleidgen jenen, welhe man bisweilen auf Gräbern antrifft, wo fie als 
Eräftiger Jauber gegen den Jwi gelten. Wie die leţteren, fo tragen aud die Geifter= pfähle vor den Gütten Kof́osiḑalen.

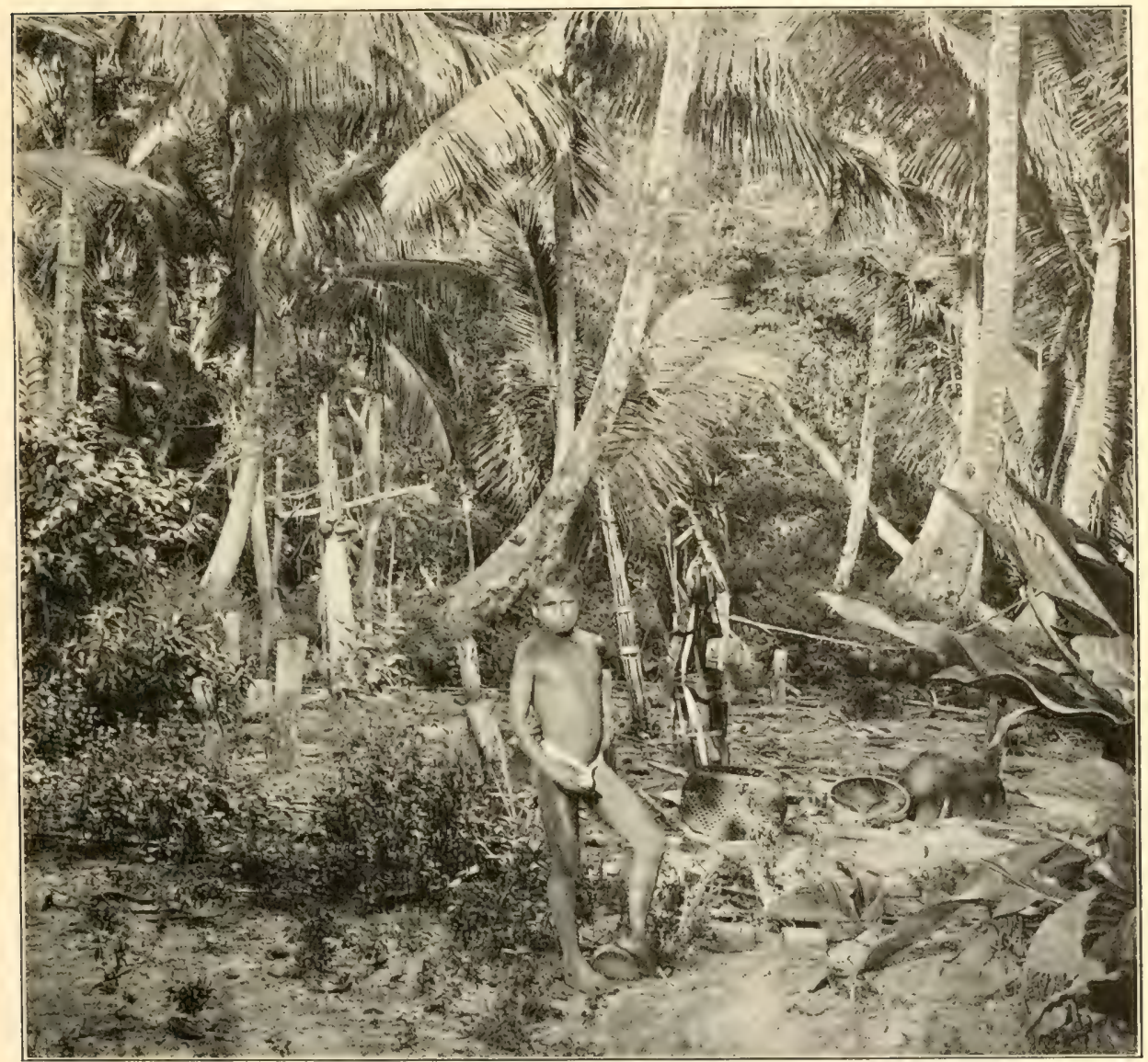

nifobarijめer 3egräbnisflatz.

Wie man die Weiler und die Wohnhütten gegen die Einwirfungen des Jwi fdütst, fo fudhen auh die einjelnen Perfonen fich mit einem tühtigen Jauber ju umgeben, der den böfen Geift idrecft und verjagt. Diejem Jwwede dienen jene fetifhe oder "Kareau", 
welde aus weidhen Golje geidnutiţ an den Wänden der Wohnräume aufgeftellt find und in ihrer naiven Zadhahmung curopäifher Juthaten geradezu grotesf wirfen. Lntter den jahlteiden Kareau, die wir dort fahen, habe id feinen bemerft, der aud

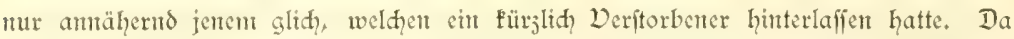
iळ auch in der Sitteratur feine 2lndeutung über ähntlide Joole von den Zrifobaren finde, mag der gegent eine flafhe Whisfy mir hereitwillig übergebene fetifh im Bilde vorgeführt werden. Es handelt fith um eint weiblidhes Jool, ju dem des Teufels Grommter 2rodoll geftanden zu haben \{heint, wohl geeignet, einem fid einflileidyenden Jwi geheimes Grauen ju erregen. Das Gejidyt ift rot bemalt, die herab= Gängenden Brüfte find mit Blat bejofmiert und die 2fugen mit Perlmutter ansgelegt. Uls id thn auf dem Sande vor= fid titig hinlegte, fam rajh ciner der älteren 2länner herbei, um thrt wieder aufred ht hinguffellen.

Tretent nah der Beerdigung des Derftorbenen wi= drige Jufualle oder fieber bet den Ģinterbliebenen ein, fo werben junädjit Dorbereitungen getroffen, um den Jwo ju verjagen. 2lian veranftaltet cin Teufelsfeft, vertilgt ein Sdyein, trinft reiḑlid, Palntwein unt raudt, während dic Weiber unter Geheul ihre Geräte und Sebensmittel opferm. Die Jauberer oder kranloëne, weldhe die fähigkeit befitzen, in der Trunfenheit den Jivi ju fehen und ju binden, geraten allmählid in 2lufregung und begimen die $\mathcal{B}_{\mathcal{E}}=$ ¡̈hwörung. Sie ftinmen cin Klagelied ant, laufent dem Jww nad, unt ihnt ju fangen und in cinem (5eifter= Forb auf das Geifteridjiff jull bringen. 2lit deffen Ger= ftellung war die Bevölferung von Jtu befhäftigt. Sine Srundlage bildet cin aus dret lantgert 3 aumftämment hergeftelltes flof, dent dadurd halt gegeben wird, dafi

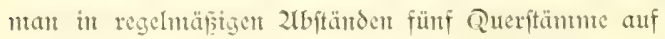
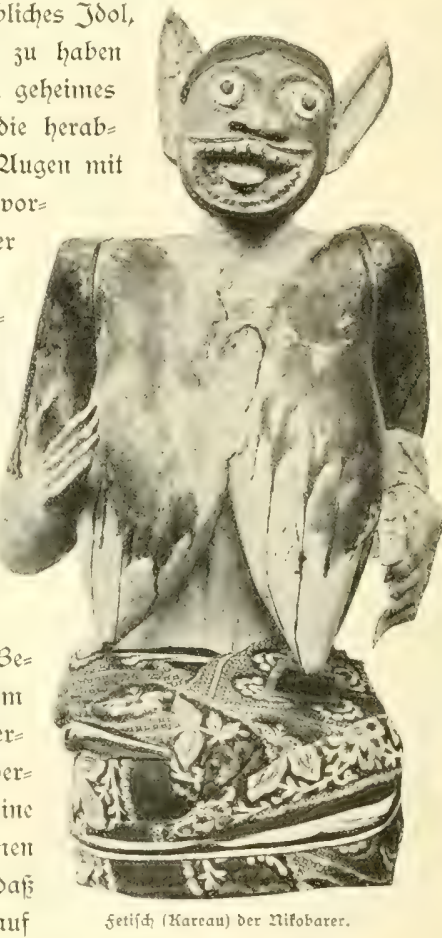
fidh freujenden Pflöfen feftbindet. Das Sdiiff war mit jwet 2liaften aus Bambus verfehen und trutg an fethen dent Waffer zugefehrten Ende ein Bugfpriet. Ein Tau= werf ans Kotang geht von den 2liaften aus und ift behängt mit Gutirlantoen aus jerfajerten PaImblättern. 2lm Eintermaft bildeten dic Guturlanden cine 2lut von Segel;

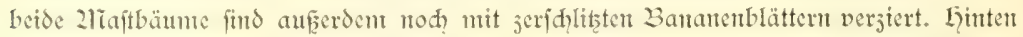

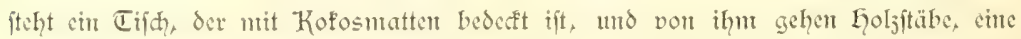
Reeling andentent, bis jum Buggipriet. 2luf den Tifh wird nadi Riocpitorff 


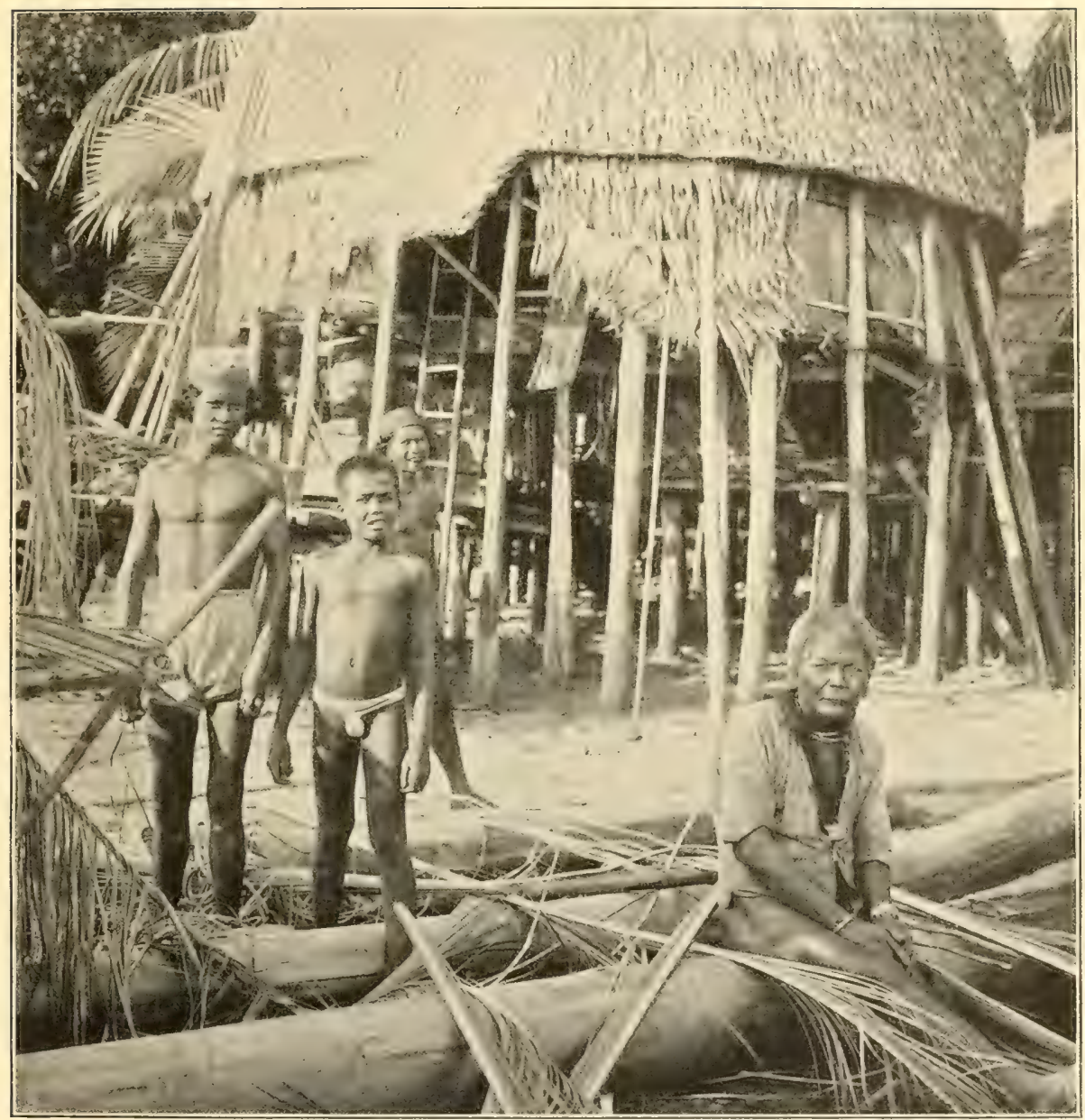

Mit ber Eerifellurg des Beiferfdiffes befđäftigte ZTifobarer.

Zahbrung für drei Tage dem Jow hingelegt, und auf̧erden follen nod Geifter: förbe zum Einfangen des Jwi aufgehängt werden. Dffenbar gehörtent jun 2usput des Geifterfifies nod etwa feds an eme Gütte angelebnte Bambuspfäble nit 
33lattwirteln, welḑe durdqaus den vor den Giütten erriđteten Geifferpfählen gliḑer. Ob freilid die auf cinem Geftell neben dent Shiffe liegenden Pandanus= und Kofos:

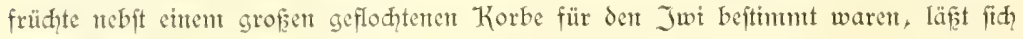
fhwer jagen.

Das Geifteridgiff wird von jungen Seuten in das Sdylepptau genonment und auf das 2lieer hinaus gentdert, wo man es dam dem Spiel von Wind und Strömungen

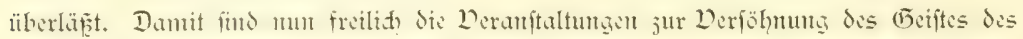
Derftorbenen nod? niḑt abgefḑloffen. Drei 2lionate nađh dem Tode b̧alten nähere und entferntere 2Inverwandte eine Totenfeter bei facfellidyt ab und oft erft nah Jahren bildet das grofece Totenfeft - bei dem jugleidh aud der naḑträglid Deritorbenen ge=

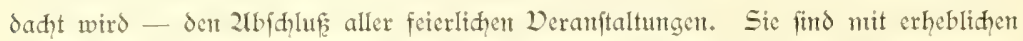
Koftent und viel 2lufwand verbunden, jutntal ba jut demt grofenen fefte aud aus benad! = barten Dörfent die Geladenen erfdeinen. Sie crwarten, da man mit Speije und Tranf - vorab mit Sđjweinebraten und Palnwwein - nidht fargt. 2ran fängt des= halb fhon lange vor dem fejt die Sdyweme in Bambusftälle ein, mäftet fie mit Kofos und Pandanus und fiduert fie gegen den Jivi (denn dic Shweine leident aud unter dem

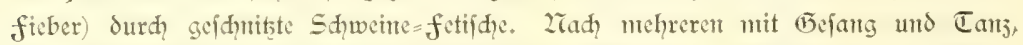

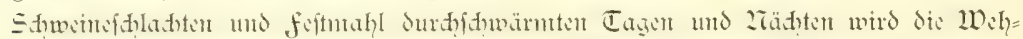
Elage angeftimmt und die Eeidhe ausgegraben. 2lian reinigt den Sdyädel, bringt thn

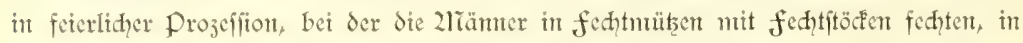

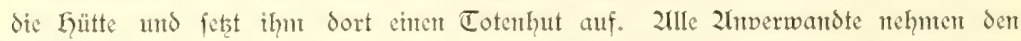

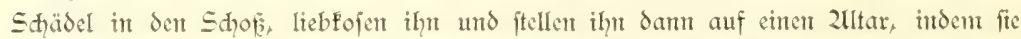
ifhm Betel, Eigaretten unto cin fejtmahl vorjetzent. Fat der Tote fidh vont der tiefen

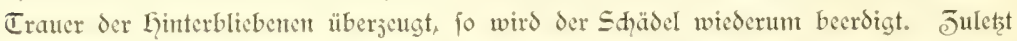
verbremt man die troffinen Blätter der Deforationen, wobet die nadfen (5)eftaltent Surdh das feucr fpritgen, unt fidh die Kälte (das fieber) ju pertreiben. Ziadłbent mit fadfeln die Jwi's aus den โqütten verjagt fitto, wird eine Votipplatte aufgehängt und mun beginnt für die famtilie ein neuer 2lbfhnitt in dent durd? den Ẽlauben an Sie böfent Geifter geplagten Dajein.

Deelleift wird mandjer der Sejer mitleidig die Vertrungen des 2lberglaubens be= Flagen, weldye es jumege bringen, da dem Ziatumenfigen ein gutes Teil der Dafeins= frende vergällt wird. Es maḑt den Eindrud, als ob er in einer gewitterfifwangeren

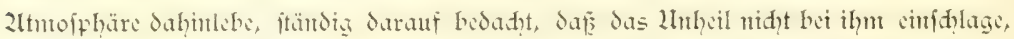
und immer bereit, fid den cigenartigiten Seiftungen 31 unterwerfen, um es abjuwehren.

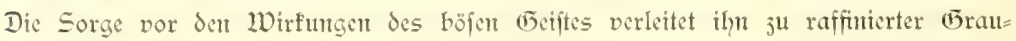

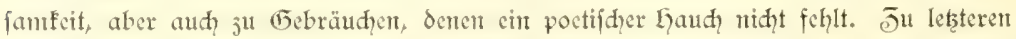
dürfen wir wohl die Gerftellung eines Geifteridfiffes rednen, das jur Derjöhnung der Scele des Derftorbenten in feltiantem 2lufputs auf das 2lieer befördert und dort feinem 


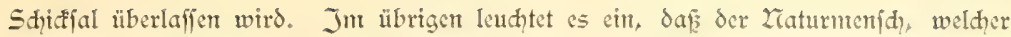
in einer übel verrufenen fiebergegend lebt, der furdht vor Keimjuḑungen cinen finn= fälligeren 2łusdrud giebt, als der Bewohner gefunder Ḡebirgsgegenden. Jut Gafen von Zanfauri hat eine zriifiton der anderen weichen müffen, ohne daf trots aller 2lufopferuntg eine nahhaltige Einwirfung auf die Eingeborenen erjiclt wordent wäre;

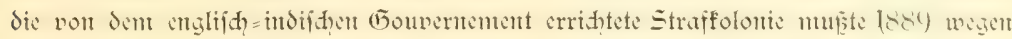
des fiebers aufgegeben werden - mur der Eingeborene, obwohl felbjt nidjt geger das fieber gefeit, hat ausgehalten. Sein ganjes Diditen und Traḑten geht darauf hinaus, fith gegen die Wirfungen einer ihm untheimliḑen, im Didungel Lauemden

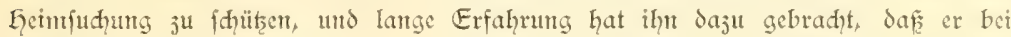
feinen Deriuḑen, fidh des Jwi - wir dürfen wohl fagen: der Zlialaria - ju erwehren, eintige rationelle Wege cinfdlägt. freilid läuft gar mandher Spuf mit unter, aber immerhin hat es dod, der Zaifobarer verftanden, das utile cum dulci ju vereinem,

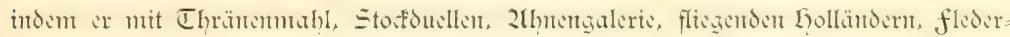
wifhen, Palmweinraujd und Sd,weinebraten feinem Jwi ju Seibe geht.

Der fetifdismus beruht darauf, daf irgend einemt förperlidgen Gegenftande einte übernatürliđge Ennwirfung beigelegt wird. Der geläuterten Denfweife wideriftrbt die Zlmnahme einer derartigen Bejiehung, niḑt aber der naiven 2luffafinutg des Volfes.

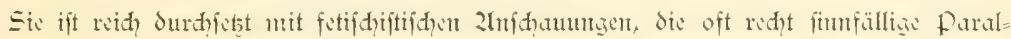

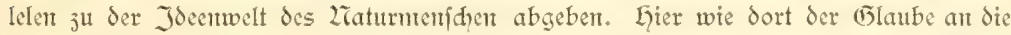
Einwirfung der Beifter, die man durd, 2lmulette, Reliquien, gentalte und gefdntižte

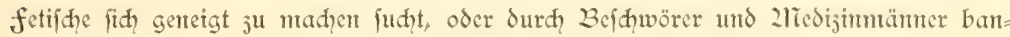

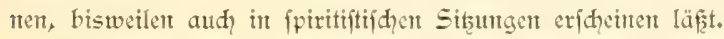

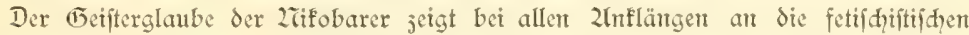
Doritellungen malayifder Dölfer dod, aud fo viele eigenartige Jüge, da in intmer

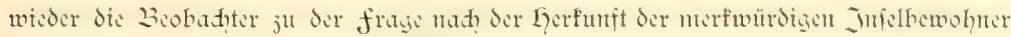
Stellung nehmen. Sie find auf dent nördident Injeln mit der Kultur meḩ in $B_{e}=$

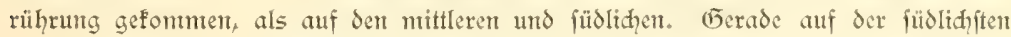
Infel, nämlidh auf Grofzzzifobar, haben fie fith im Intern und an einigen Küften= orten am reinften erhalten. Dort haujen die Shompén, welḑe naḑ den Beriḑtent von Roepforff, der fie zuerft ju Gefidgt befant, und von 2lian, dem frïheren Super=

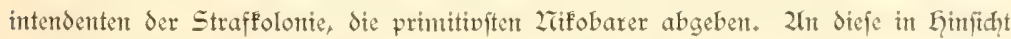
auf förperlidhe Erjheinumg, Spraḑe und Gebräuḑe den übrigen Infelbewohnern ähnelnden, aber auf nod niedrigerer Kulturftufe ftehenden Ltrbewohner mu官 cine

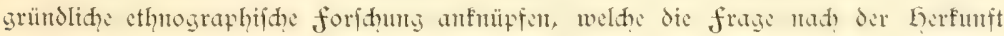
der Zitfobarer flären will. Die Zntffht von Rocpftorff, daf fie der mongolifden

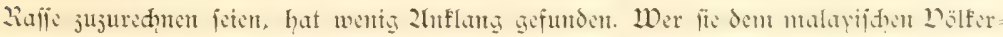

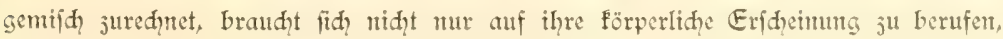


fonden fant auh eine widhtige Thatfadye geltent madien: dic Kundhütten, auf dem gantzen malapifigen 2Trḑipel unbefannt, fehren an ciner entlegenen Stelle, näntid,

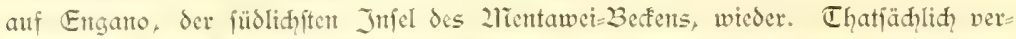
fithert som and (n) 2rodigliani anfertigte, cine bemerfenswerte 2̈̈hnlidyfeit zwifhen den Bewohnern von Engano und der Ziffobaren aufweifen.

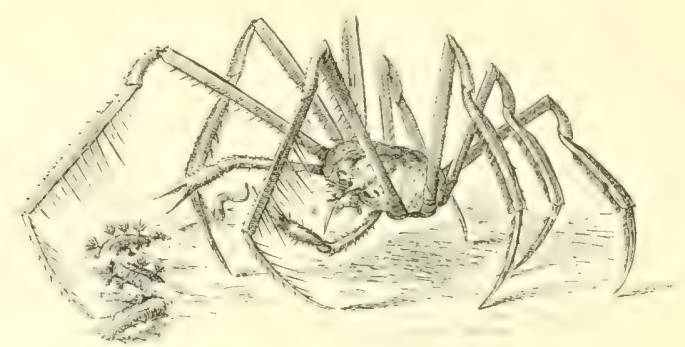


Das Iifobarendorf Itu auf Ranfauti mit dem Giefterfatf. 


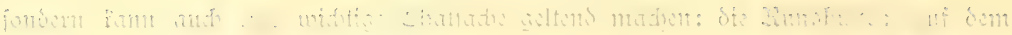

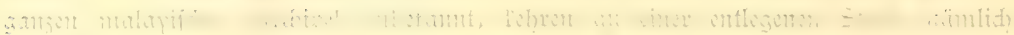

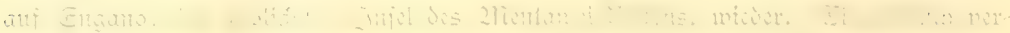

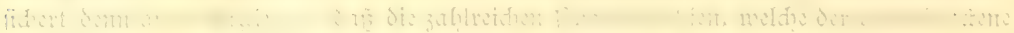

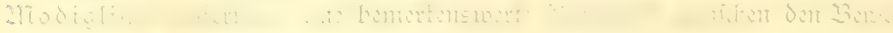

Emant 11 mitis tim.

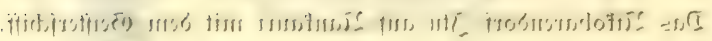




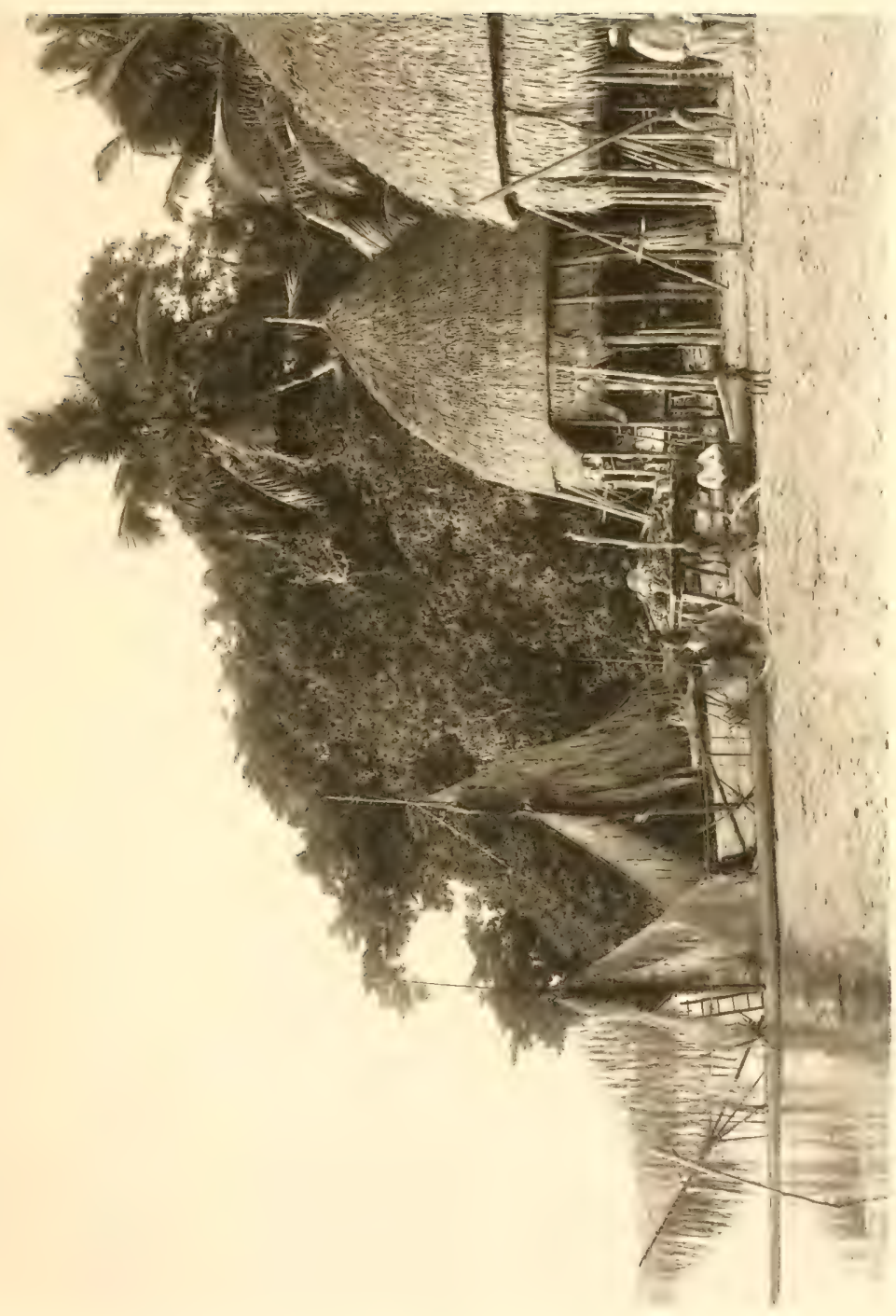





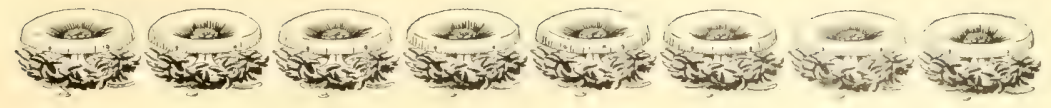

\section{Kach den Malediven.}

23 ei cinem ftimmmngsvollen Sonnenuntergang fuhren wir am 2lbend des 9. fibruar aus dent idyllifhen 2Tanfauri= 5 afen aus. friedid, lagen die Gütten in ihrer dunflen Lmmahmung $\delta a$, während die Eingeborenen von thren Booten aus uns $2 \mathfrak{d b}=$ futed juwinften. Die Dunfelheit brah rafh herem; am molfenlojen fimmel erslänten im ङentth der Drior und der Sirius, und gern begrüfte man auh wieder das Stern= bild des grofenen Bären als Jetithen, daf̧ wir uns aht Breitegrade nördich vom

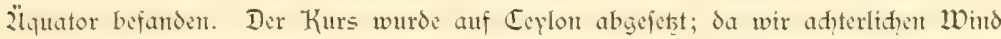
und mitlaufende Strömung hatten, famen wir rafh durh den füdlidien Teil des (5) von Bengalen vorwärts. Jwei Sotungent mit $59 \tau 4$ reip. $3692 \mathrm{~m}$ jeigten, dafi der Tiefenjhlamm aus blanem Shlit" und aus Globigerinenfalamm beftand.

Da in librigen in diefer Region bereits durd die indijhe Expedition die Tiefen=

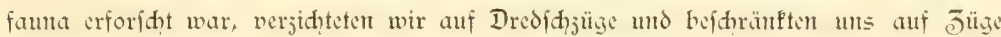
mit den Dertifalnetsen, Sie, wie früher im 2ltlantifhen Deean, fo aud hier im In Sifhen Decan ein auf̧erordentlid reidhes Ergebnis lieferten.

In der Dberflähe trafen wir einte ähnline mifroffoptiche Sebewelt an, wie fie für den tropifhen 2ltantifhen Deean und wohl aud für alle tropifden 2reeresgebiete tppifa, fein dürfte. Die fugeligen Pyrocystis, dic Ribijofolenien, Langamiga caratien und die früher $(\varsigma .70-22)$ bereits dargeitellten präḑtigen Dertreter der Perioineen, wie Amphisolenia, Ornithocercus, Ceratocorys, Goniodoma, und in gröferer Tiefe dic Planktoniella, Halosphaera uno Asteromphalus gaben unieren כ̄ügen das dharafte= rifitifhe Gepräge.

Das Derded hatti fid injwifhen in emen joologifhen ofarten nermandelt. Keiner der 2liatrofen verfäunte es, fith in padang einen 2 ffen zuzulegen, und fo faf dent

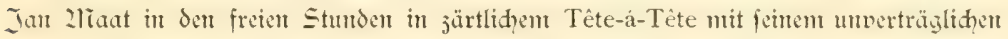
Eisbling. Wurde in Dredihjug veranftaltet, fo hodten an 20 Dierhänder nengierty unther und verfehiten nidht, die Begeifterung der Joologen über einen neuen, mert=

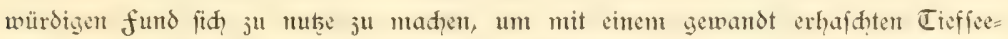
frus in die Wanten aufjuentern und ihn gewiffenhaft ju jergltedert. Wir mutent die

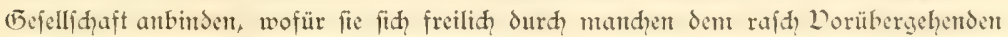


verfeteten 3 in fhadlos ju halten fuḑte. Ein grofer Cercopithecus, der fid losgeriffen hatte und eifrig gejagt wurde, fiel bei einem feiter waghalfigen Sprünge über $B_{\text {ord }}$, als das Sdiff in voller fahrt war. Bei feitrer ausgeprodpenten zlbuetgung gegen cintge Deranitalter oceanographifher und biologifher llnterfudunten war er der Siebling der 2riamifhaft und jein Sdyicffal erregte alleitiges Bedauern. 2lber ntan

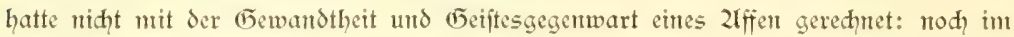
letzten 2loment erwijdte er das ftets hinter dem Sdiffe nadigefdleppte patentlogg. hielt fich an demfelben feft, obwohl er ftändig hernumgewirbelt wurde, und gelangte thatfädylid, mit der aufgejogenen Soggleme wieder an Bord, wo er durd, Jähne= fletiden feine Danfbarfeit bewies. Sdjwerlidy mödte ihnt ein anderes Tier oder gar cin 2lienfín dies Bravourfitü nadmaden!

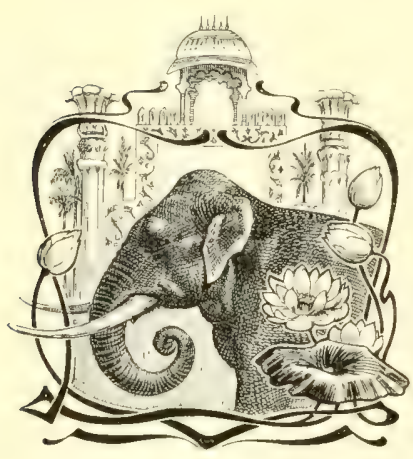

2 m 2lbend des 12. februar fidteten wir die füd= lidyen Eeuditfener von Ceylon, das trot des wolfen= lofen Limmels vollifändig in Dunft gehüllt wax. 2uls wir dam am näd)iten 2liorgen, umid)wärmt von den Booten der Singhalefen, in den ftattlitien Lafen von Colombo cinfuhren, als wir mit einem Shlage in das Getricbe des transoceanifhen Dampferverfehrs und in das gefhäftig pulfierende (5rof̧itadtleben verietst wurden, da überfan einen faft die Sehniudt nah den ftillen fjorden und Sudten, die wir in der leţten Jeit befuht hattert. 2lber dentrod fann fid feiner dem ëauber der vielgeprieferen Tropeninfel entjiehen und das felbft dam nidt, wenn er vorher Bebiete bejudt hat, in denen die Degetation wudhtiger fith entfaltet und die (5ebirge mädtiger auffreben. Denn mit den in ftändige feuḑtigkeit gebadeten Regen= wäldern des Kanterumpif und der Weftüfte von Sumatra vermag es fo leiḑt niḑt

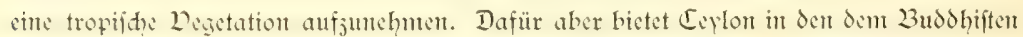
Geiligen Banyanen (Ficus religiosa) mit ihren Säulenwald von in die Erde fich fen= fenden und ju Stämmen eritarfenden Suftwurzeln, in feinen Talipotpalmen (Corypha umbraculifera), weldhe in einer ungehenren Blütenrifpe ihre ganje Kraft und Shönheit erihöpfen, um dam abjufterben, und endich in den grofartigen Bambuffen des bo= tantifhen Fartens von Peradenyia Pflanjenformen dax, die von der (Geftaltungsfraft der Tropen ein faft überwältigentes Jeugnis ablegen.

2luf der 5odfläd)e von 2lgant mag ein Dolf gelebt haben, deffen Kultur ähnlid weif jurüfreidt, wie dejentige der fughalefifden Eroberer von Ceylon. 2lber es fehlt die biftorifal beglaubigte Tradition. Diefe ift es, weldye den Befuher pact, wem er 
den vielumftrittenen $230=$

dent Ceylons betritt unto nad einer an male= sifdien 2lusbliten überreiden fahrt in der finghaleft= ihen Körnigftadt Kandy umher= pilgert. $\tilde{6} \mathrm{~cm}$ entflieht er dem lärmendenฮั rei= ben in demt Bubdgiftentent= pel, der eire 2litilfionen von 2lienfhen heili= ge Reliquie, den อ̄ahu des $\mathcal{B} u d=$ Sha, birgt, um auf einfamer fahrt über die umgebenden Göhenjüge den Runoblitá auf fich wirten ju laffen. Da liegt im Thalfeffel der fitille See, umrahnut von Tempeln, Diflen und dent volt ge= radlinigen Straf̧en durdyzogenen häujer= gewirr der Stadt; ant anderen Stellen eröfinet Bambus (Dendrocalamus giganteus) im 3otanifhen Barten zu peraberria (Eerion).

(iid) naw dent 2ustritt aus dem did̨ten Lrwald der Bltf in das That des 2hahawelli (5anga und foweift weiter nadh dent centralen Gebirgitoof der Injel mit feinen hohen im Süden gelegenen 


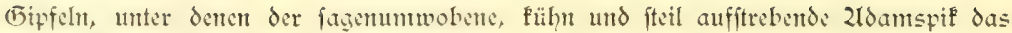
Wahrzetden von Ceplon abgicbt.

2liag man auh nah der küdfahrt durd das intenfiv fultivierte, in der Göhen= region mit Theeplantagen überäte Eand von dem 2rienfhengewühl des volfreidyen Colombo fajt aus dem (Bleidigewiaht gebraht werden, fo wird mant doh gem an=

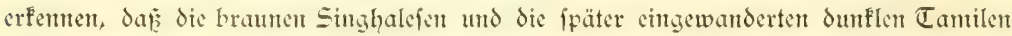
an Ebenmafs des Wudfes, an Sdmtegiamfeit und anmutiger Galtung ibresgleidyen

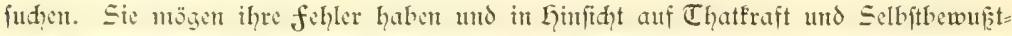
fen hinter anderen Stämmen jurüfftehen, aber tie werden diefe drawidifhen Sivah= Derchrer und finghalefifan Bubdiften verfehlem, cinen fympathifacn Eindrut ju hinterlafien.

Wenn wir mur flüḑtig Ceylons gedenfen, fo gefhieht dies nid̨t zum wentigiten

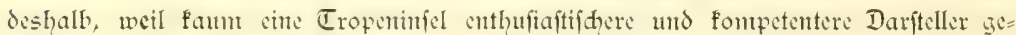
funden hat. Wer nur wentge Tage dort weilte, in Colombo, Kandy, in dent bota= mifhen Garten von Peradenyia von neuen Eindrüdent überidüttet wurde, der ver= mag faum die fülle des (Bebotenen ju verarbeiten, gefdwetge den ein jutreffendes Bild ju entwerfen. Er fann nur der Pflid̨t der Danfbarfeit Zlusdrut geben dafür, dap der furge 2ufenthalt durh das Entzezenfommen der Direftoren des präđtizen

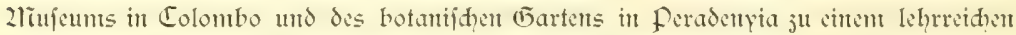
und unferer deutihen Sandslente zu cinem genufeciden fid geftaltete. Wer fern von dent Betriebe des geräufdoollen Lafens in der eleganten Dilla "Siriniwefa" unferes Konfuls, Germ Ph. freudenberg, Gaftfreundihaft genof und nad, erquidender 2adhtuhe in dem wohlgepflegten (5arten den Tropenmorgen anbred)en fab, zählt foldhe 2liomente ju den wenigen erlefenen, die das Seben bejhert.

Den Benühungen des Konfulats war es dent auh ju verdanfen, daf ein junger

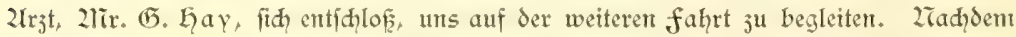
wir ihn in der frühe des 16. februar an Bord genommen hatten, lidhteten wir den Unfer und fuhren bei fpiegelglatter See an der impofanten Reihe von Dampfent vor= bei, welde für die Bedeutung Colombos beredtes Jeugnis ablegen. 2Tit der auper= halb dis Eafens nor 2lnfer gegangenen "Kaiferin Elifabeth" tanfhten wir (5rüpe aus

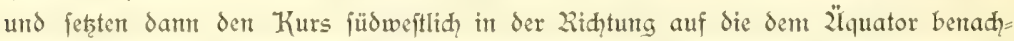
barten 2ltolle der 2lialediven. Unfere Sotungen nahmen wir wieder regelmäfĭg auf, Sa wir in Gebiete famen, die in oceanographijher himitht entweder nod gar midht oder boh nur ungenügend erforidgt waren. Sie ergaben an 17 . und 18. februar an=

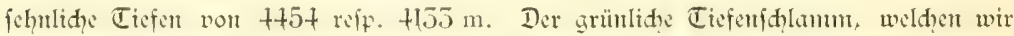
peit dem Eintritt in das 2lientawei= Becfen als Brundprobe erhalten hatten, gint in

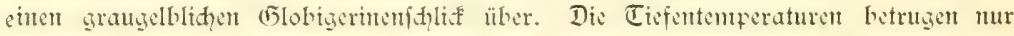

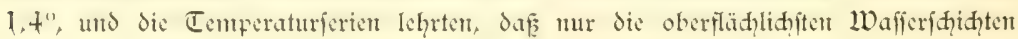


bis höhiftens $3^{u} 100 \mathrm{~m}$ cine ftarf́e Durḩwärnung aufweifen, worauf mit raihem Sprunge dic Temperatur fontinuterlid bis jum Boden fintet.

Währent wit bisher die unter dem Einfluffe des 2Tordoft=21Tonfuns fid geltend maḑende, nach Weiten gerihtete Strömung oft derart verfpürt hatten, daf das Eerab=

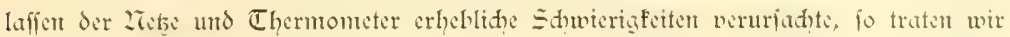
an 18. februar in ein ftromlofes Ébiet ein. Wir nuţten die günftigen Derhältniffe von früh bis fpät am zrahntittag ju den verjhicdenartigften oceanographifhen und biologifiden Unterifųungen aus.

Befonders überrajhten uns hier die Ergebniffe der Dertifalnetzjüge. Der Reidtum

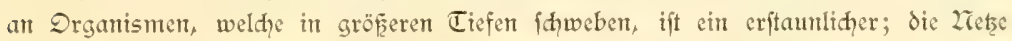

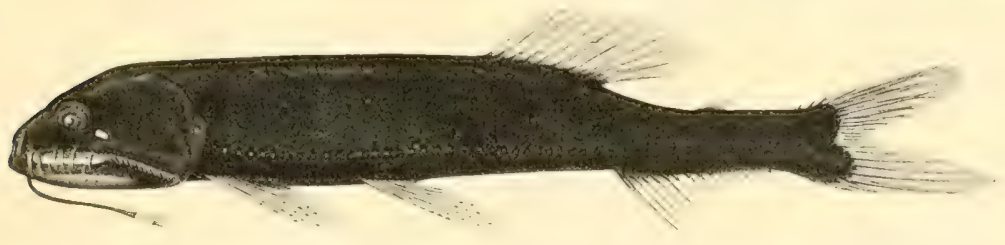

Astronesthes splendidus n. sp. Brauer (fam. Astronesthidae).

(Winter gez.)

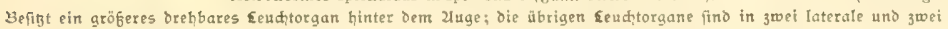

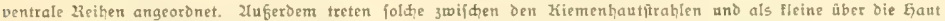

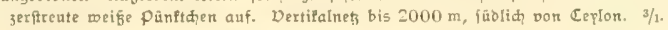

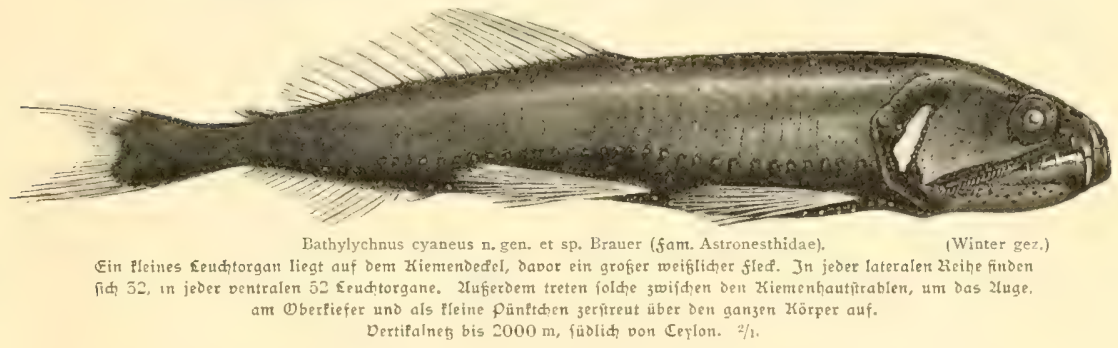

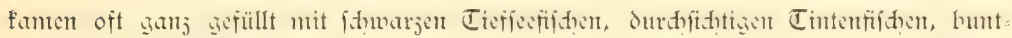
gefärbten jehnfüfïigen Krebjen (Sergejtiden), violetten Tieffeemedufen (Atolla) und ner= (diledenartigen Wurmformen, unter denen namentlid, dic pelagilid lebenden Sdnur= würmer (Pelagonemertes) auffielen, an Bord. Zriht wentg Erftaunen erregte der fund einer fielfüfigen Sdnede aus der Gattung Carinaria, die bet einer Eänge von $5 \tilde{\mathrm{cm}}$ den Riejen ifres Befdledits abgiebt.

Zus der Reihe der hier erbeuteten Tieffeformen fübren wir im Bilde jwei fammet= fhwarze neue Irten volt fifhen vor, auf deren 2usftattung mit Eeuhtorganen wir ipäter nod zu fpredien fommen. 
Zud an der Sberflähe herridhte ein reihes Seben von gröperen Drganismen. Dor allen Dingen waren es die Gqaie, welde nah dem Derlaffen des Gebietes der füdidhen Rof $=$ Breiten fid wieder regelmäfig einjtellten. Wir wagten es niht mehr, cin Boot

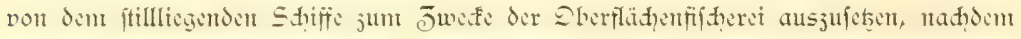
eimual eine der Beftien cin Ruder gefapt hatte. 2lnt 17. februar fingen wir unter

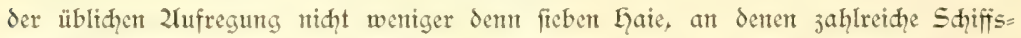
halter (Echeneïs) anfaf̧en. Zllmählith lernte man es, fie aud durd, wohlgeztelte Shülfe ju erlegen, die freilich mur dam emihlugen, wenn der bai nady einer aus= gemorfenen flafde fhnappte und die Sdnnauje ctwas über Waffer jeigte. Saf der

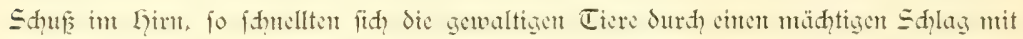
der Sdqwanjfloffe über Waffer, um dam in Sdraubenlinien in die Tiefe ju verfinfen.

Don befonderem Jutereffe war ein fund, den wir am $1 \bar{t}$. februar an der Sber= flädhe maḑtert. In der zrähe des Sdiffes trieb eine 2rautilusidale, weldhe, wie es fdien, nod von dem Tiere bewohnt war. Es gelang uns, diefelbe aufjuffiden, wo= bet es fith freilich ergab, daf die Wohnfammer nidht den lebenden Cephalopoden, fondern fifhe enthielt, die fith fheu in diefelbe dutten. Da wir neben dem Dampfer nod cinige fifde benterften, weldhe unfät umberfdwammen, warfert wir de leere Shale tod cimmal in das Waffer und hatten bald die Genugthuung, daf alle rafd? auf diefelbe jufdiwanmen und fith in ihr bargen. Wir hiclten diefe fifhe noth einte Jettlang lebert in unferem Bafin und es ergab fith hierbei, daf es fid um Dertreter der Baliftiden handelte, von denen wir mur einen (Glyphidodon Bengalensis) ju $b e=$ fimmen verntodhten. Sie flappen gejdift ihren Rüfenjtadel in eine furdhe en unto fuhen bei der Zlmäherung des Zlenfhen rajh die Wohnfammer der mit Gyoroiden unt 2llgen bewadjenen Shale ju gewimmen, un fid platt mit dem Kopfe voran an die Seitenwände ju duffen. 2lls fhledyte Sdwwimmer befitsen fie eine relativ fleme Sdqwanjfloffe. 2kierfwürdig rafh ändern fie bei der Erregung die farbe: helle flecte traten auf dent grauen (Frunde auf, der raid bläulihe färbung amahm und fid bis= weilen mit weikliđen mäandrifhen כeidnungen bedectite.

Ie meḩr wir unts den z̈lquator näherten, defto ftärfer bewölfte fid der Limmel, indent gleidjeitig der Wind aus Weften ju wehen begant. Selten haben wir ftint= mungsvollere Somenuntergänge genoffen, als hier immitten des tropifhen Indifhen Deeans; die farbempradit der blutrot und goldig umfäumten Wolfen und das eigent= artige Bletgrau des mit Rot übergoffenen 2liecres vermödte fhwerlid cin 2lialer mit

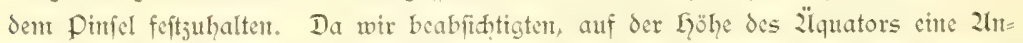
jahl von Unterfuhungen ausjuführen, fteuerten wir an 2Tadhnittag des 19. februar eines der fübliden 2halediven=2ltolle, nämlid das Suadina=2ltoll, an und anferten Sidyt vor dem kiff 'anf 10 faden Tiefe bei der als Kanduhuludu bejeidneten Jnfel. 


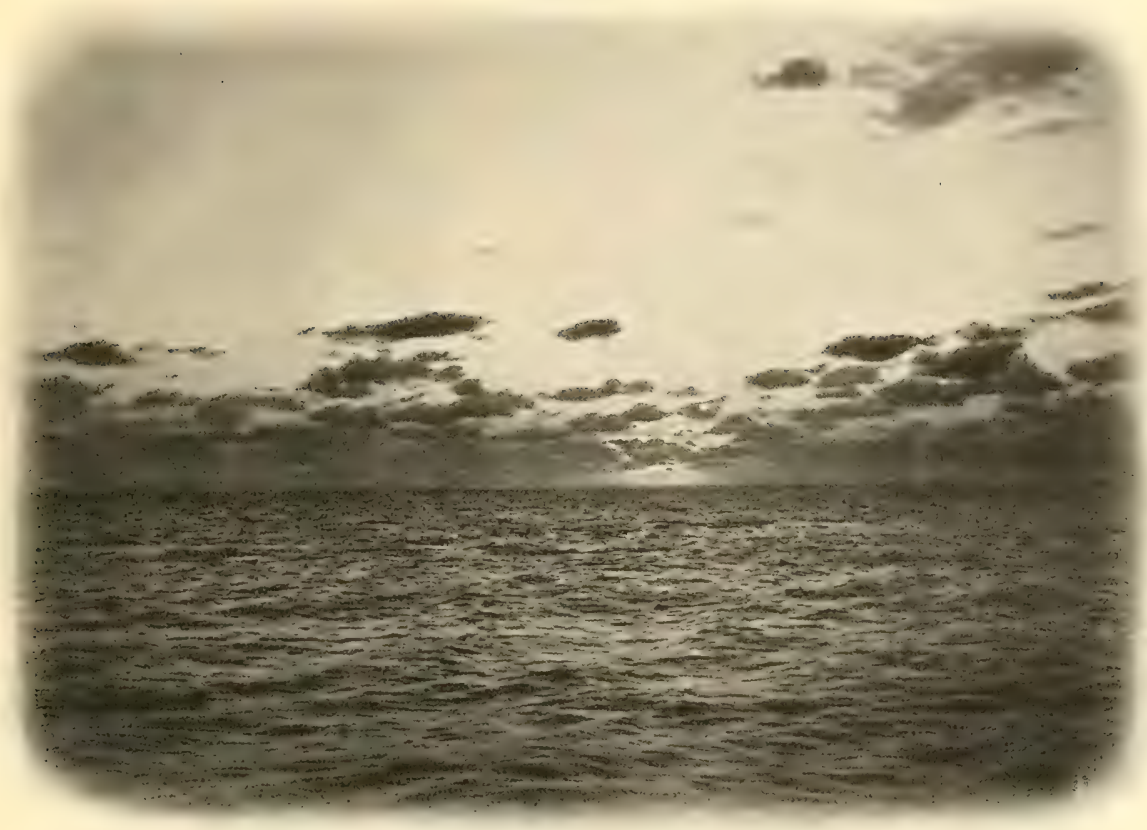

Sonnenuntergang bei dem paffieren des z̈quators. 20. februar 1899.

Die 2Malediven ftellen bifantlith cine lamggeftrefte kicihe non Korallem 2ltollen dar, die fid volt $0^{\circ} 42^{\prime}$ \%. Br. bis ju $\tau^{\circ} 6^{\prime} \mathrm{r}$. Br., aljo naheju über adt Breitegrads,

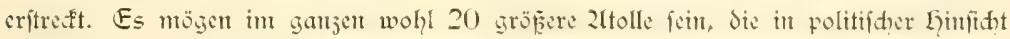
von dem auf zlälé refidierenden Sultan in jwölf Gruppen eingeteilt werdert. Die Zltolle find durh breite, tiefe Kanäle voneinander gejhieden, welhe ohne Gefahr von den gröpten Seedampfern paffert werden fömen. Der breitefte Kanal ift der 2̈̈qua= torial=Kanal jwijhen dent Suadiwa = und 2ldu=2ltoll; gerade diefer war es, dent unfere nächiten Unterfudungen gelten follten.

Die 2ltolle fallen nah Weft und Dit in ein mehr als $4000 \mathrm{~m}$ tiefes 2lieer fteil ab. Die Kanäle jwifhen den Zltollen waren bisher mit Zlusnahme des 2lätgrad= und

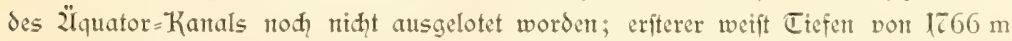
auf, in lefsterem loteten wir direft unter den z̈lquator $2255 \mathrm{~m}$. Erft in vergangenen Jahre (1900) unterfuhte 21. 2lgaffij auf feiner Expedition nad dent 2lalediven 
Genauer die Siliefnerbültniffi dis

2liceresbodens int 2lutfreis der Zltolle. Es ergab Mäle jwifłcn den flather find, als den fübliden;

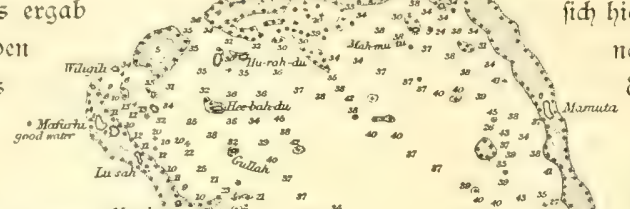

Man-du
High Water full \& Change Itoo"
Fise and tall 4 feet id hierbei, dafí die Ka= nördlider zltollen

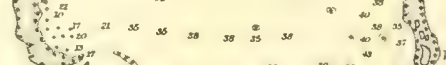

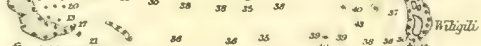

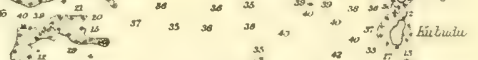

C.: $i=0$

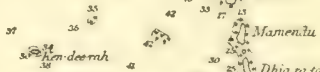

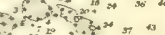

to $\rightarrow 00,0$

$\because x_{0}=0$

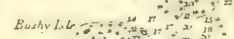

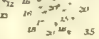

$\therefore \therefore$,

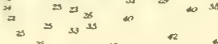

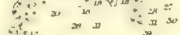

if $x^{3}=$

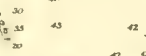

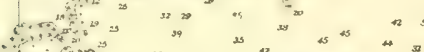
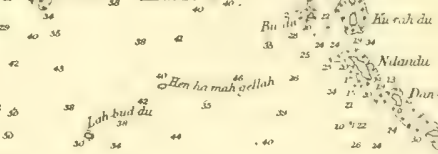

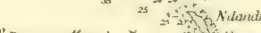
diejentigen jwifden it den erfteren be= trug die gröfte Tiefe $684 \mathrm{~m}$ (jwi= ¡đđen S.21ialé und

phalidu),

während in

den brei= teren füd $=$ lichen Kanälen bereits
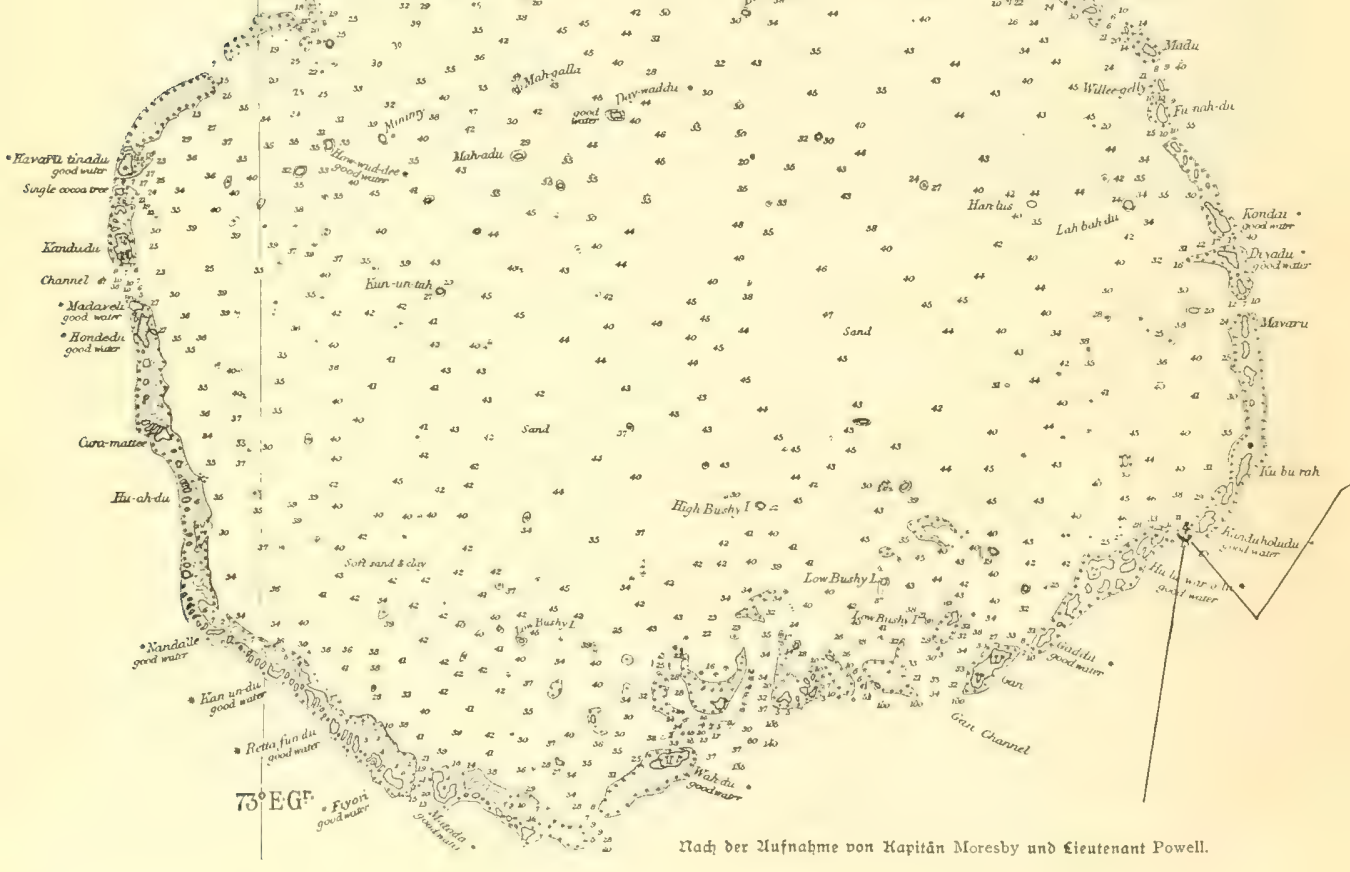


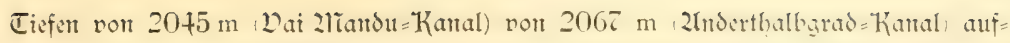
treten. Llnter der Berüffidtizung der oben ermähnten Eotungim in jüsliden Kanale

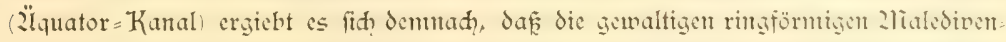

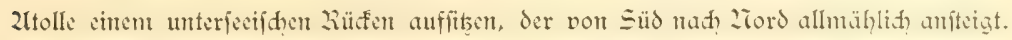
Wir werden bald noth Belegentheit finden, an der Gand unferer sotumben den widitigen 2Tadpeis ju führen, daf diefer Rüden fith bis ju der Chagos= Gruppe fortfetzt.

Das Suadiva=2ltoll befitst einen nord=füblichen Durdhmeffer von nidht wentger als

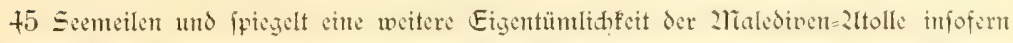
wieder, als es nidht einen geidilofienen Ring darftellt, fondern von zahllofen (mehr. denn 100) Kanälen durḑbrodhen ijt. So wird es denn in eme zrenge fleiner Injel= dien jerlegt, deren jede von ement flachen Saumrifi umgeben ift. 2ud das Intrere Ses Zltolls ift mit einer 2Injahl flemer Jnjeln ausgeitattet und weift relativ geringe, niđḥt über $80 \mathrm{~m}$ betragende Tiefen auf. In den Kanälen jwijhen den Infeln läß̨t fid je nah den Gejeiten eine jiemlid, ftarfe Strömung wahnehmen. Der Kanal, vor dent wir anferten, jeigte an Ubend einen fräftigen, nad Süboft geriḑteten ausgehen=

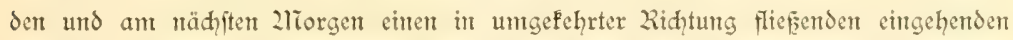
Strom. Während die nördliden 2ltolle nod von den indijhen 2lionfut = Winden beeinflupst werden, fo übert dieje thre Wirfung niḑt mehr auf die füdlichen aus;

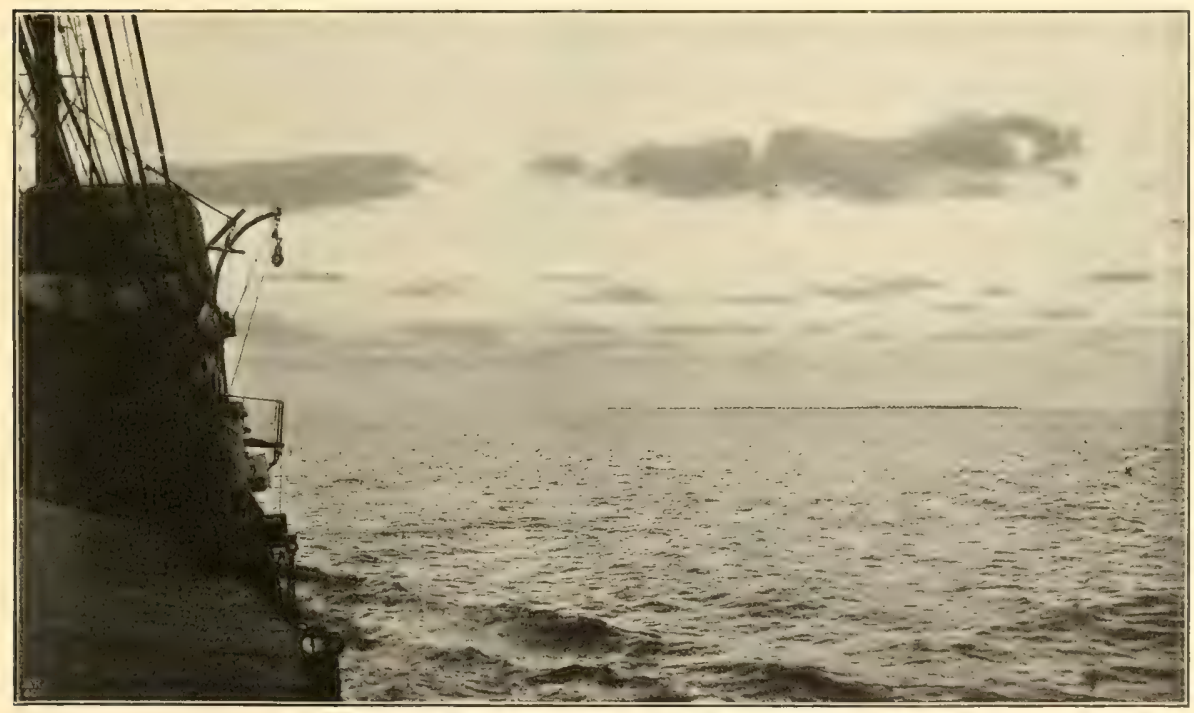

Inteuerung des Suabiva $=21$ tolls am abent des 19 . februar. 
hier ift Wind und Wetter bei häufigen Regenfhauern und gelegentliḑen Stürmen finumfins.

Kurj nahbem wir vor 2lufer gegangen waren, Fam ein grofeses, fladhes Boot ohne 2husleger, das non etwa 20 2rann gerudert wurde, at das Shiff heran. Da dic Eeute cinen vertranenerwedenden Eindrut madyten, liepen wir fie an Bord Plettern. Es war der Dorfältefte non Kanduhuludu, ein freundliher, älterer 2liam, der mit cinent Teile der Bewohner uns begrüfen wollte. Wir waren überrafd̨t über die

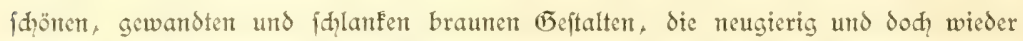
mit ciner gewiffen fheuen ङurüdhaltung das Sdiff mufterten. Rajd entwidelte fich cine eifrige Konveriation. 2lienid bleibt 2lienjh: der pantomintipe Zlusdruc der cinfaheren kegungen und Gefühle ijt auf dent ganjen Erdentund eit fo finnfälliger.

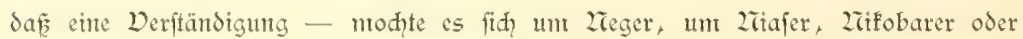
2lialediver handeln - rafh jumege fommt. Erlethtert wurde der Derfehr ein wentg dadurd, daf der 2lite über etwa jehs Worte gebrodenes Englifh verfügte. Er ftellte

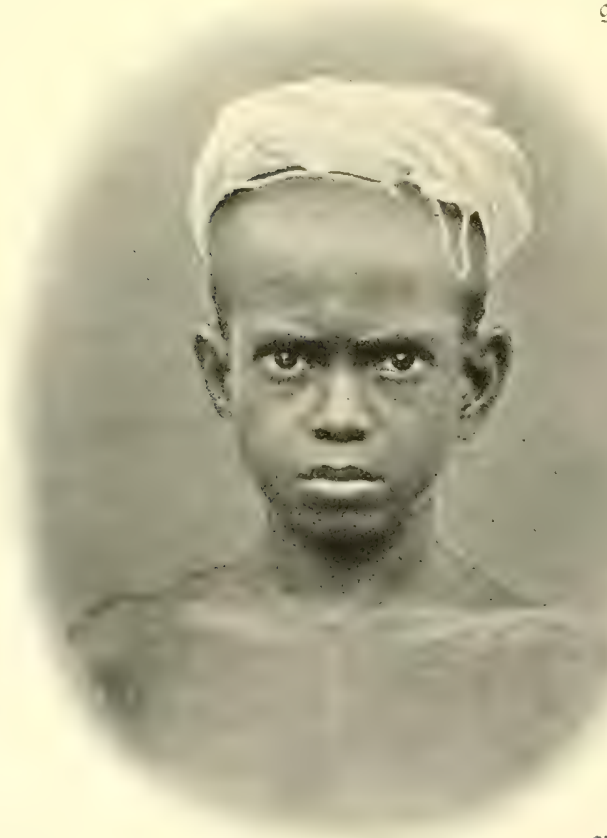

uns feinet Bruder vor utt lud mich cin, die 2radit in feiner Wohnung an Sand ju verbringen. Id lehnte Sies $a b$, veriprad ihm aber, in der frühe des nädyften zliorgens cinen 3 eiud abjuftatter und Suppenfidildfröten (eine 2rbbil= dung derfelben eröfnete das Deritändris für unjer vor= haben) cinjubandeln.

2lian hatte injwifhen כeit, den eigenartigen Typus der fübliden zralediver genauer ins 2luge $\jmath^{\prime}$ fafien. Er ift durhaus veridieden von jenem der 2ralayen und jeigt 2lnflänge att indifhes, bisweilen fogar an arabijhes Blut. Das (Befidht verrät in jeder Gintfidt Jntelligentj; die 2lugen find grof und ausdrudsooll, die sippen fleifinig, die 2rafe bald breit, bald durh = aus nad dem arifhen Typus geftaltet. $U_{1 \mathrm{t}}=$ Maledivifher Junge. ter den jüngeren Ecuten fielen allgentein die oft 


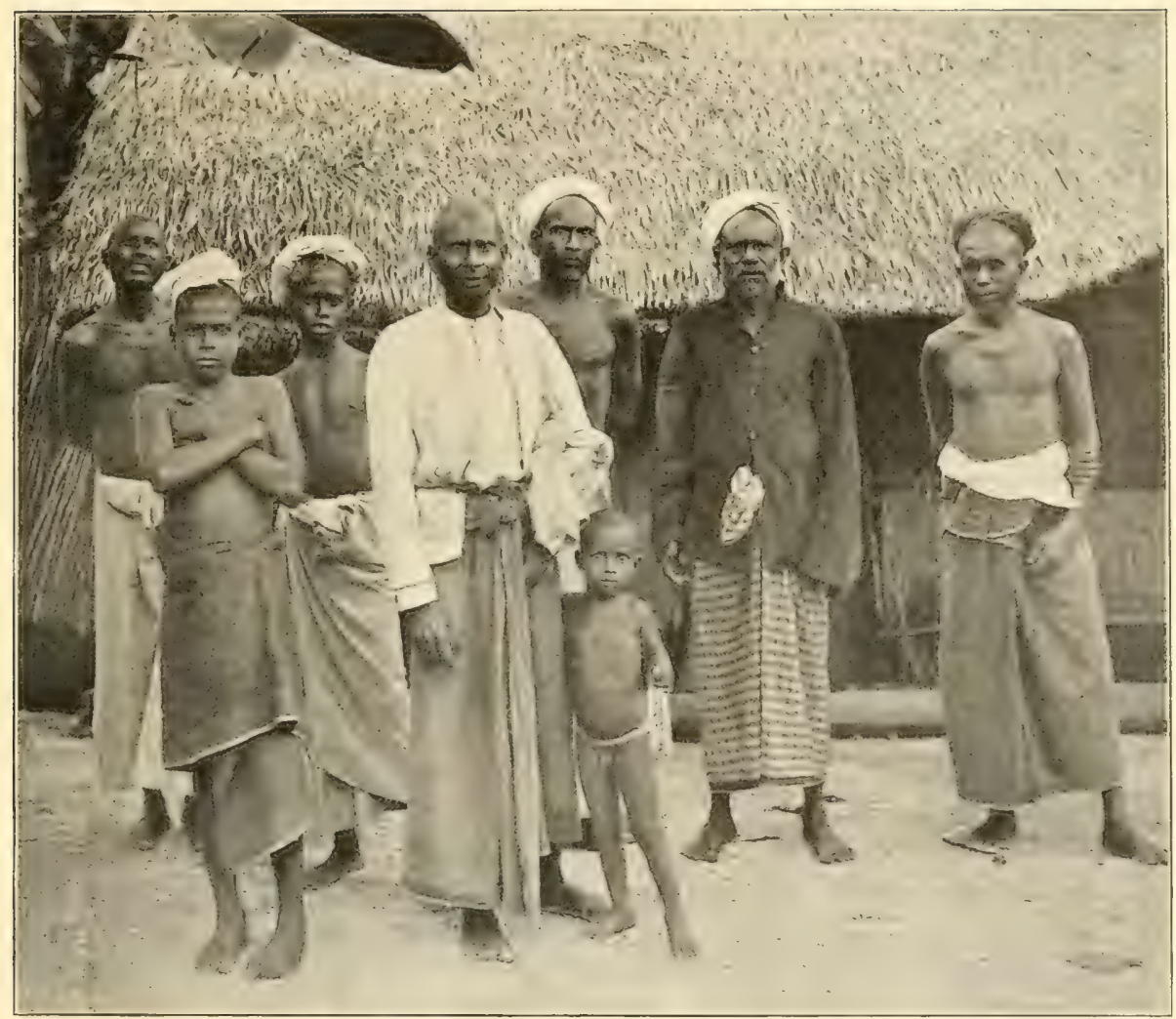

Der Dorfältepte und Eingeborene von Kanouhuluðu.

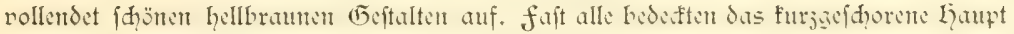
im Gegenfat ju den 2lialedivern der nördidyen 2ltolle mit cintent Turban von weifem oder buntem Tuक. Der Dberförper bleibt bei den jüngeren unbefleidet; die älteren trugen ver=

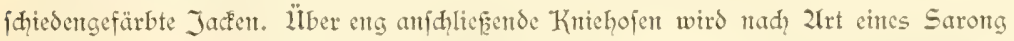
cin Tud gefdlungen und durd cinen Gürtel feitgehalten, in dem ein offenes 2lieffer fteft.

frühmorgens, nod vor Tagesanbrud, fuhr id mit cintgen (Gefährten in den Eist= gang zum 2ltoll. Das fortfommen wurde jwar durd den cingehenden Strom er= Ieiditert, aber in der zähe der Infel durd) das vorgelagerte Saumriff faft völlig ge: bindert. Da uns indefien bei Tagesgrauen einige an Strande nerjammelte Sewohner 


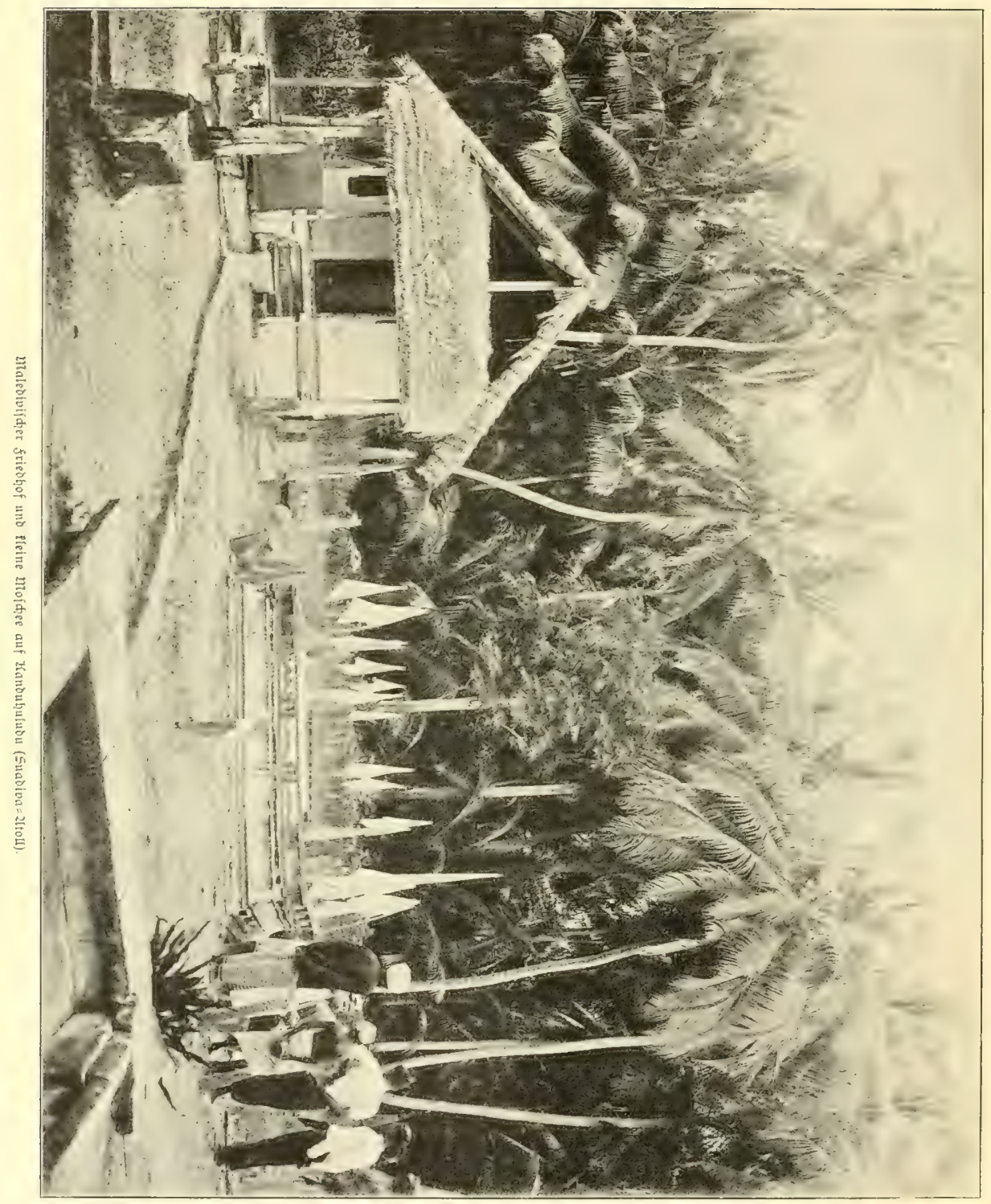




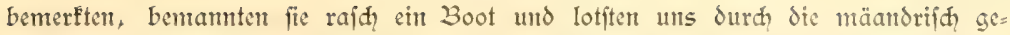
wundene fahrrinte jum Strand. Wir wurden dort von der ganjen männliḑen $\mathcal{B}_{e}=$ rölferung in Entpfang genommen und juntähit ju stma 30 auf dem siüfin lisgendon Seefdildfröten (Chelonia viridis) geleitet, die man uns gegen geringes Entgelt jur Verfügung ftellte. Etwas weiter landeinwärts, veritett jwifhen Kofospalmen, 2liangas, Granatbäumen und Bananten liegt das Dorf. Das Geäft der Bäume war von zahl lofen fliegenden Fundent und Krähen belebt. Wir idholfen einige Eremplare und es

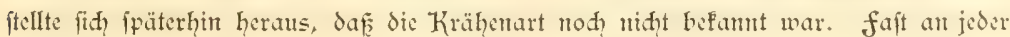
Palme fislen uns fleine Edulţdäher und fallent auf, die mant jur 2lfmehr der Kofos ratten ange= bradit hatte.

Das Dorf felbit befteht aus niedri= gen rechtecti= gen দৃütter, die ganj aus dem zliate= rial der $\mathrm{K}_{\mathrm{o}}=$ fospalmen hergeftellt find; die mit weirem $K_{0}=$ rallentiand belegter $2 \mathrm{D} e$ s ge fielen nidht minder als

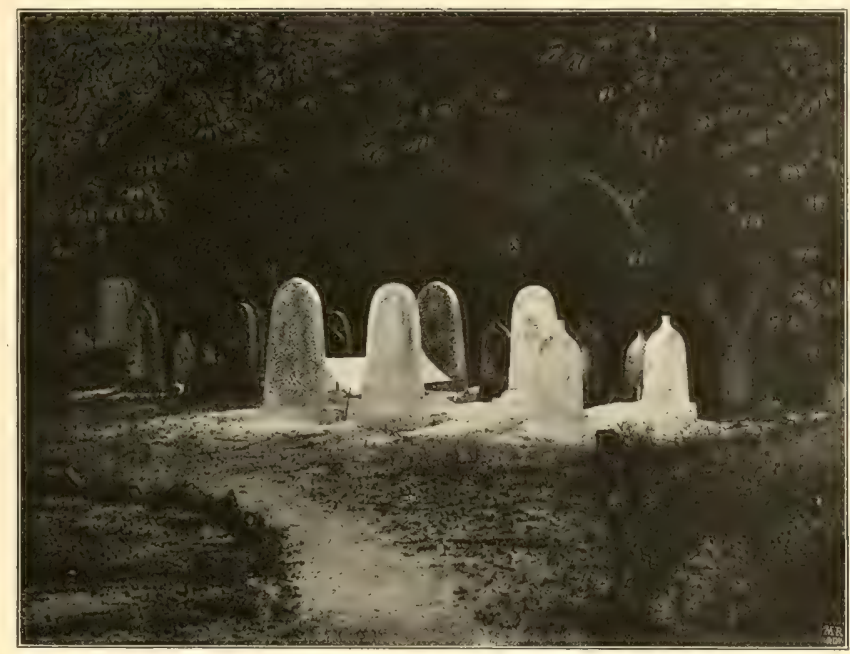
die Elütten Grabmale aus Korallempalp.

durd ihre Sauberkeit uns auf. Unjer freundliḑer führer, der Dorfältefte, geleitete midh in fein Wohnhaus und jeigte mit Stolj die Wanduhr, die bremnende 2 mmel und das (5efdirr aus porjellan. 2lls id die fauberen Betten und den reinlid̨en, mit fdọnn geflodtenten 2liatten belegten Boden fah, bedauerte idh fajt, die Einladung jum libernaḑ̧en niḑt angenommen zu haben.

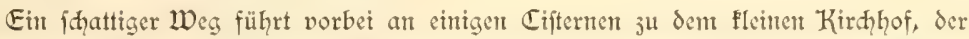

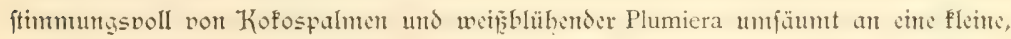
bejhcidene 2liofhee fich anlehnt. Unfere Begleter verriđhteten ihre Gebet, während deffen wir Jeit hatten, die (5rabmale aus Korallenfalf, die nit 2trabesfen und ge=

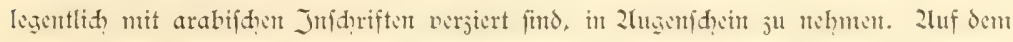




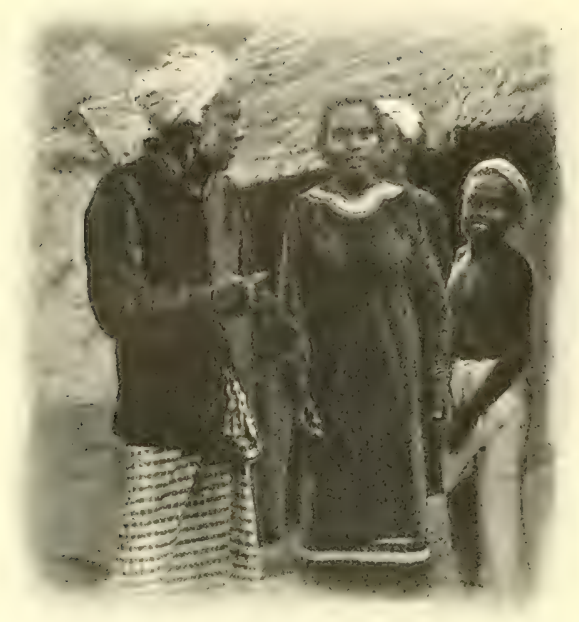

Malèivijacs MTâdhen.

familiengrabe des Dorfälteffen hatte man zahlreidge weine fähndhen auf= geftellt; andere (5) räber waren mit 2ruffelin überipannt.

Bet der Rülffehr in das Dorf wurden aud allmählid, dic Kinder jutraulider und wagten fid follief = Iid) mit den frauen und 2liädden heran. 2liit Stoly ftellte mir der alte zrann feime Todpter nor, die

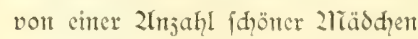
ungeben war. Sic alle trager ein bis über die Knie reidendes röt= lides Dbergewand, unter dem nodh cin buntes Lintergewant heraus= ragt. Fals und Bruft waren mit gefdmackvollen Stickercten in Silber und Gold bedeft, unt ntadit wents überrajdte der rethe Sdmuta all goldenen Lalsfetten, goldenen 2trunbätdern und aufgerethten 2rüngen. Lhuftreitig er= freut fid die Bevölferung cines gewiffen Wohlitandes, auf dent aud die 2usftattung der İütten Gindeutet. Silbernünjen, Sie id ihnen gaf, wurden gent angenonmen, Kuғfermünzen aber durdhaus verweigert. ZTan wut=

Derte fith offenbar, da官 wir feiner Sdymur trugen.

unt äuferte eine naive frende, als man wenig=

ftens einen goldenen Trauring benterfte. Es war ein lieblides Joyll, weldhes fith hier in dem Dorfe entfaltete: lauter ammutige,

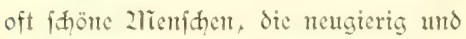
dod? wicder mit feiner Jurücthalturg dic fremblinge muftertent und ifnen mit cinem gewiffer Stolz cinen Einblicf in ihe Geimueien geftatteten.

Die 2lämmer gaben uns das (5̋eleit jum Sdiffe, indem fie ihre Boote nit Gühntem unto Sdifildröten beluden. Sie rudern im Sițen mit lantgen Ruderftangen, an denen cine furje Sdraufel angebraḑt ift, und gebraud̦en

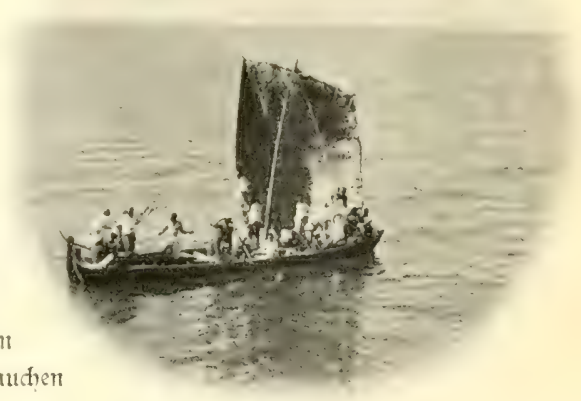

Boot mit Segel aus Kolosmatte 
als Segel entweder vierefige Kofosmatten oder dreiefig jugefdutittene, erhandelt: Eigel= leinmand. Ein malerifhes Treiben entfaltete fich bet umferer 2lbfahrt, als die 2liali=

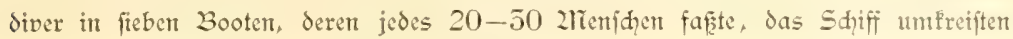
und unter lautent อెurnf uns Dalet fagten.

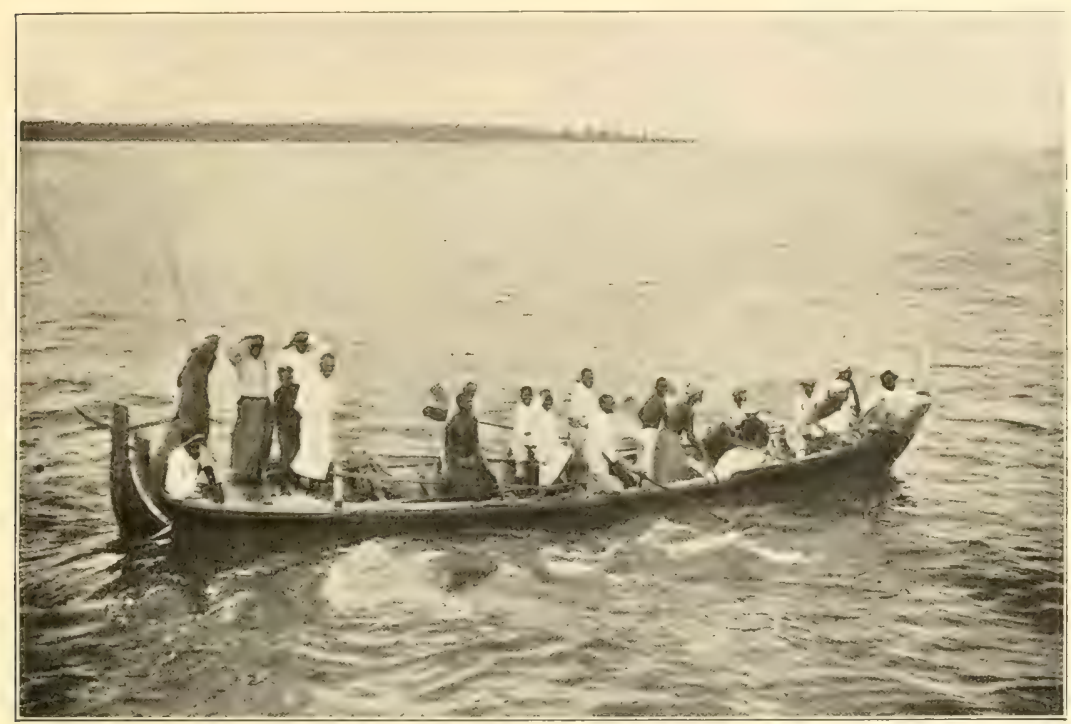

malediviftes flahboot.

(Apstein phot.)

Es fällt miht leidt, den ethnographifhen Tharafter der Bevölferung der 2läalediven fharf ju beftimmen, jumal da die hifforifhen Daten über dic Bewohner der 2ltolle

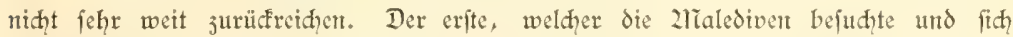
längere Jeit, nämlid $1_{1 / 2}^{1 / 2}$ Jahre, auf ihnen aufhielt, war der berübntte arabifḑe Reifende Jbn Batuta. Zlus Tanger gebürtig folgte er teitweife den Pfaden eines

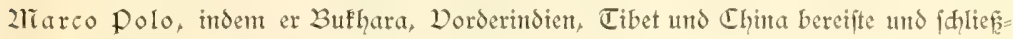
lich im Jahre 1545 nah den 2lĩalediven gelangte. Dort verheiratete or fid mit frauen aus den angejehenften fantilien, gelangte zu hohem 2lnjehen, das in feiner

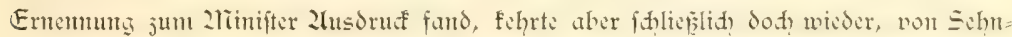

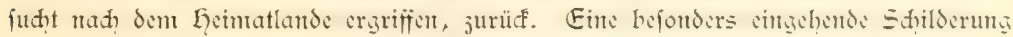
der 2lialediven gab dann fpäterhin ein franjöfifther Edelmann, Pprard de Eaval.

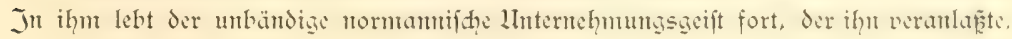


non Eaint 2lialo aus un das Kap und über 2liadagasfar die vielgepriejenen, reidyen indifden Ë̈nder aujuludir. Er litt Ediffibrud auf den 2rialedinen und murde dort niḑt weniger als 5 Jahre lang gefangen gehalten, aber immerhin freundich be= hatoelt. Durd den ïfferfall cines Bengalenherrihers 1607 befreit, Fehrte er nah nod manhen abenteuerliकen Erlebriffen wieder nad franfreid jurüd.

2lus den Birtaten diefer beiden Keifenden geht hernor, da jedenfalls feit der Jeit, wo tie dic zlialedinen aufuhtent, der ethnographifhe charafter des Dolfes bis auf den heutigen Tag fĭh faum geändert hat.

In neuerer jeit wurden die 2Talediven von mir wenigen Reifenden aufgefuht, obmohl der transocanifite Nerfehr nah Jndien und Dft=2lipen zwifden ihren 2ltollen

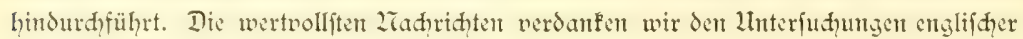

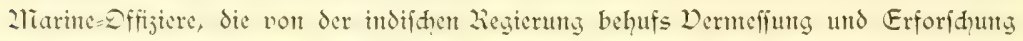
Jer Jnieln in den Jahren $1854-1850$ ausgefendet wurden. Die topographifhen $21 u f=$ nahment dor 2Itolli durd Kapitän 2liorisby und fene Dffijiere find wahre 2linjter gewiflenhafter 2frbeiten und für die Kenntniffe der Korallenbildungen um fo mertwoller, als fidc an der bant ihrer Karten die fpäter durd Gebunt und Eenfung crfolgten 2̈̈n= derumien leidet fontrollieren laffen. Wem man bedenft, daf alle Dffijiere und zhann= fatafen an fawerer 2lialaria exfrauften, fo wird man ihrer 2lusdauer und Energie nur das häfffte sol jollen fönten. Eimen 2lusjug ans ifren Sdilderungen der 2lialedirn, nervollitändigt durd cizent Beohadtungen, neröfentlidte Bell und neuerdings Roffet,

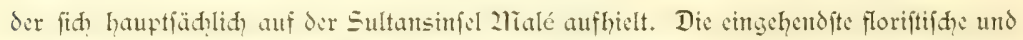
fauniftifine Llnterfudiung der Zltolle verdanfen wir Stanley Gardinger. Seine treff=

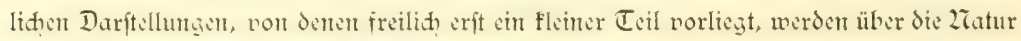

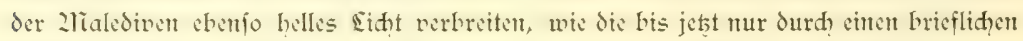

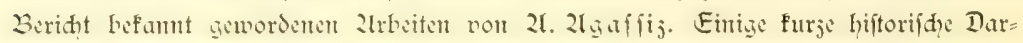

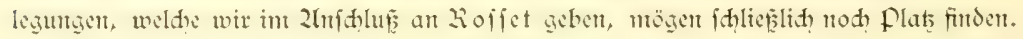

Wir dürfen wohl amehmen, dafí die rralediven juerft von Ceylon aus bevölert wurden. Dem finghalefifthen Blute mifaten fid, wie wir ficher wiffen, arabifhe Elemente von 2lialabar aus, aber aud, fhwarje von der afrikanifjen Küfte bet. Keinesfalls haben wir es mit einer reinen Rafie ju thum, fondern mit einer jedenfalls

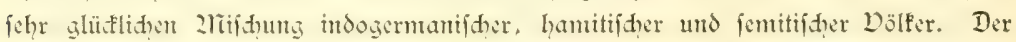
Einfluf des Islam fdeint fhon nom 8. Jabrhundert ab fith geltend gentaht ju haben, und offenbar waren die 2lialediver bereits im 12. Jahrhundert, wo fie unter der

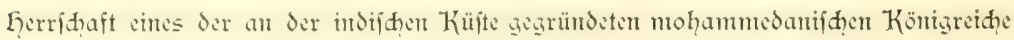
ftunden, jun Jislam befehrt. 2lls mit dem Beginn des 16. Jahrhunderts dic portugiefent als Weltmadt aufraten, gerteten and dic 2lialediver in ein 2lbhängigfeitsverhälntis von denfelben. Don mun an fpiegelt fidh auf den weltfernen 2ltollen jenter grofzartige

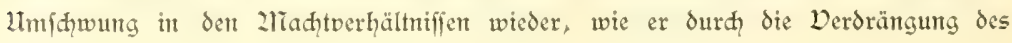




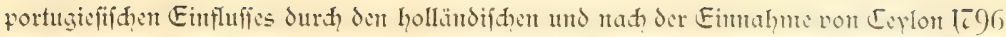

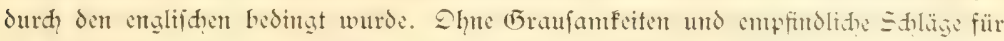

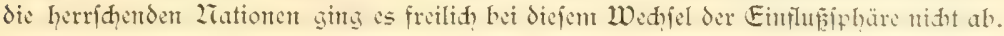

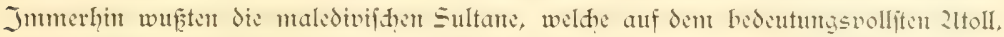

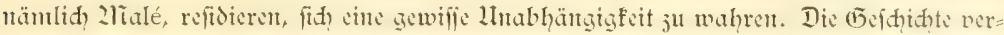

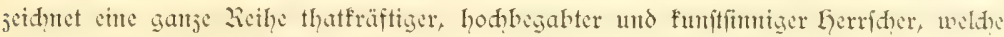

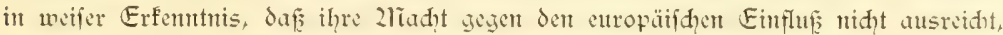

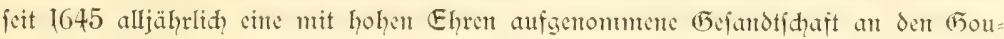
verneur von Ceylon fenden. Die Greuel, welde in den mohammedanifhen Gerrider= häufern dud die ungeregelte Thronfolge bedingt merden, Glieven freilid aud den 2rate

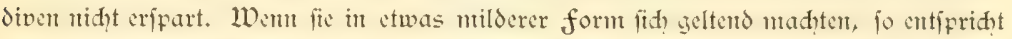

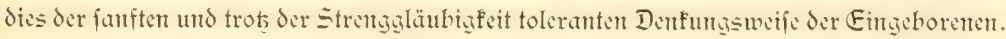

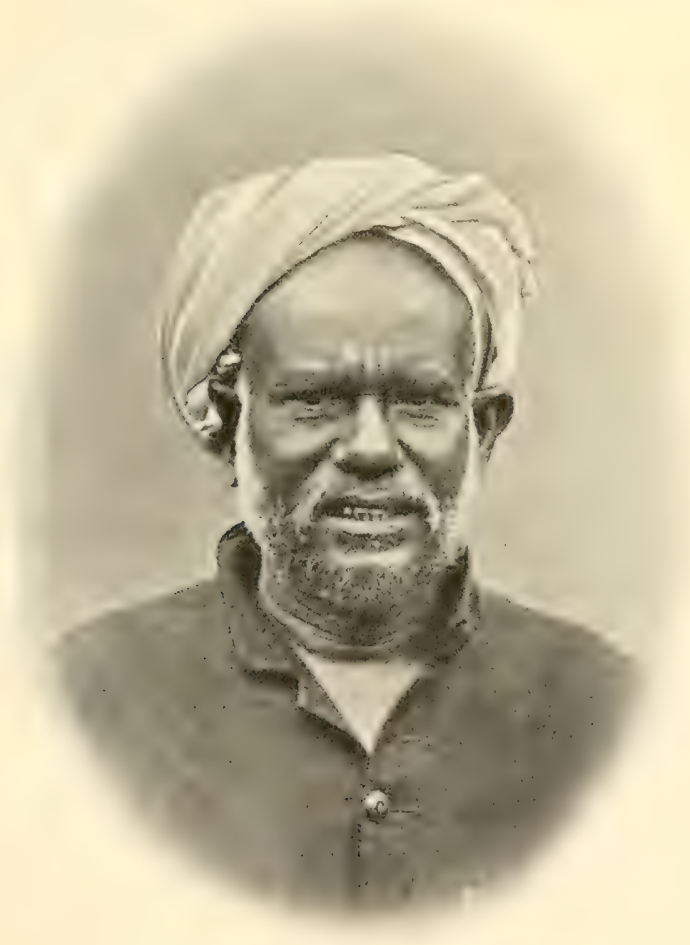

Der Dorfältepe von Ranouhuluou (Suabiva=2tod) 

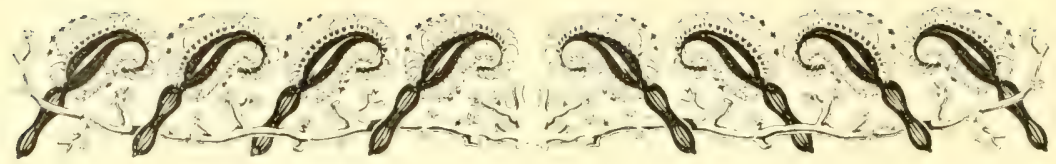

\section{Diego ந5areta.}

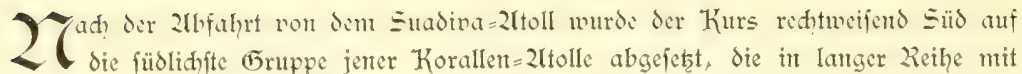
den Saffadiven begintend ihren 2lbidhlup in dem Chagos=2lrdiper finden. Wir ver= amitalteten während der viertägigent fahrt vom 20. -25 . februar cine Serie von 5 Sotungen, welthe jedenfalls ein in geographifher bintiłd wid̨tiges Ergebnis, nänlidh den Ziah = weis eines unterfecijach Der= bindungsrütfens jwijhen der Chagos=(5Truppe und den 2lialedinen lieferten. Weft= lid wie oftlid von den $g e=$ narnten Korallen $=21$ tollen hatten fhon frühere Sotun= gen den ZTad?weis cines $t$ bis $5000 \mathrm{~m}$ tiefen 2riceres erbraht. Unfere Sotungen er= gaben auf der dircften $\mathcal{D e r}=$ bindungslinie jwifhen den zlate= Siven und den Chagos= Infeln $g e=$ ringere Tiefen, die fith jwifhen $225 \overline{5}$, 2524,2926 und $5596 \mathrm{~m}$ bewegen. Fier= mit erweift fith jenes ganje Syitent pon Korallent $=2$ ltwipelen, die in nord= fiidlider Riditung in den centralent Indifden Seeant vorgefhoben eridyet=

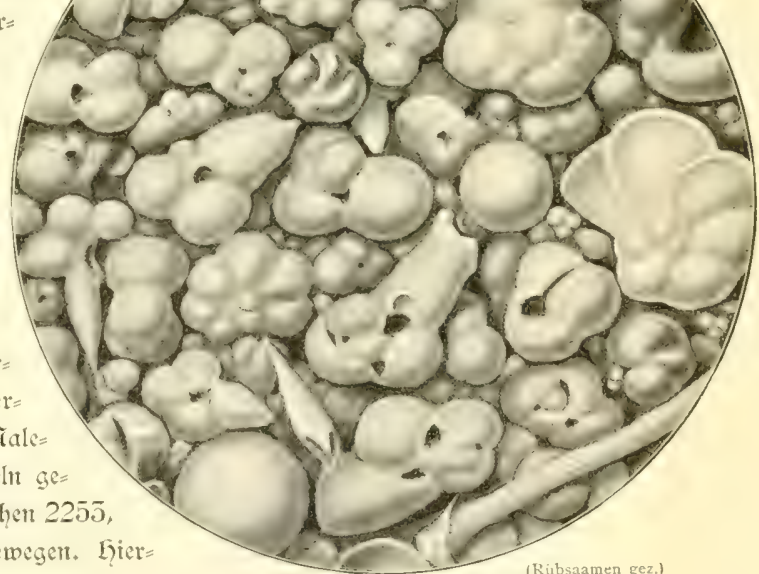

Eropifuer Elobigerinen = Shlamm aus oent Jnoifhen Decan. Stut $222,2253 \mathrm{~m}$.

Enthält: Globigerina bulloides, sacculifera, digitata, dubia, Pulleria obliqueloculata, Pulvinulina menardii, Orbulina universa, Zoden= foraminiferen, Esinibenftacheln $3 c .25 / 1$

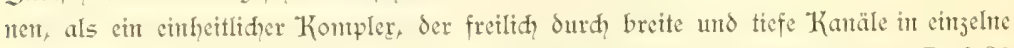
Gruppet jerfällt. Die Grundproben ergaben bei ciner Bodententperatur von $1, \bar{\tau}-1,8^{\circ}$ 


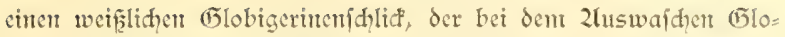
bigerinen, aber aud zahlreidhe Kiefelfhalen von Rabiolarien

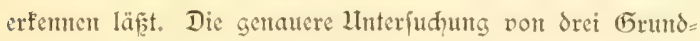
proben ergab einen hauptfählid durd Globigerinen be= dingten Gehalt an fohlenfaurem Kalf von $59-69 \%$. Die Kiefelorganismen waren nit $15-20 \%$ reidjlid, ver= treten. Der Reft beftand aus thoniger Subitanz mit

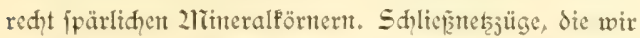
bis diḑt über dem Grunde ausfühtten, enthielten neben lebenden Drganismen, wie Copepoden und mit rotem

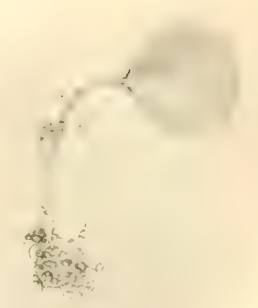

Darm ausgeitatteten $S a=$

gitten, foldhe 2lien=

gen leerer 2 ra $=$

Diolarient $=$ und

(5lobige=

rinen=

(Blochmann gez.) mit verzweigtem fuge

idalen, dafi der fang cine weiplith trübe färbung anfwies. Die gün= fitge $\mathfrak{D}$ itterung crmöglidłte es 11 s. 


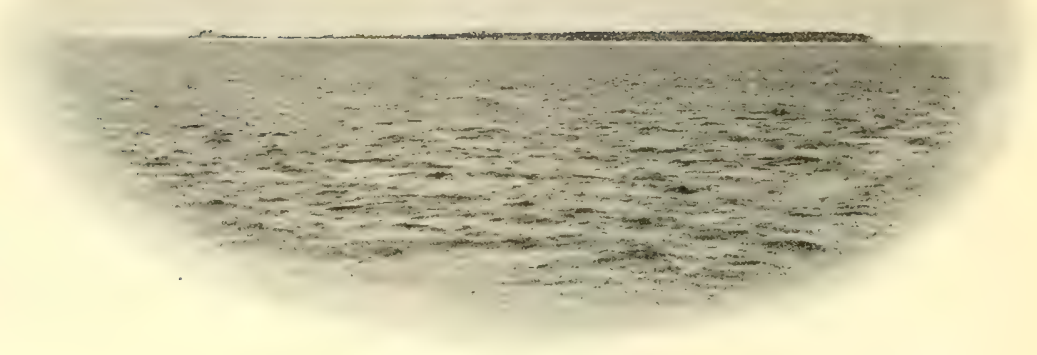

Maleriven=3niel phua 21tula?

nidyt nur zahlreide jüge mit den Dertifalneţen auszuführen, die unts mit cinent foft=

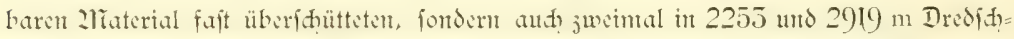
jüge ju veranftalten. Die Ẽrundfauna in biefent Regionen iff zwar niḑt fehr reich cntwidelt, weift aber intmerhin eime 2luz̧ahl intereffanter formen auf. Lhnter if̧nen fielent ttamentlid die fđönen Dertreter der Gattung Umbellula (vergl. S. 185), Penta= tuliden, Zntipathiden, violett gefärbte Seeigel (Dermatodiadema), Seefterne und vor allem reḑt eigenartige Braḑiopoden auf. Die Ietzteren laffen eine bemerfenswerte 2hn=

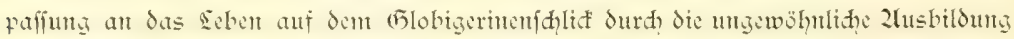
thres fukes erfentren. Derielbe ift int Gegenfat ju den der Gattung Terebratulina angehörizen Rorwanden ftarf verlängert und mit jahleethen feinen Evitunaften hefețt. vermittelift deren die (5)lobigerinen umipontmen oder durd̨bohrt werden. Eine derartige LImformung des fuzes if bis jeţt, wie mir Prof. Bloḑmant mitteilt, von feinem Brađiopoden befant gemorden.

In den erften Tagen nach der 2lbfahrt pon den 2lialediven war es unter dem

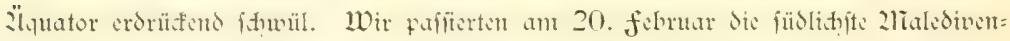
Infel, nämlich phua 2rülafu, die als niedriges diḑt mit Kofoshainen beftandentes Korallenriff erft aus gröperer zähe gefidtet wurde. Pffenbar hatten die Einwohner feit langer Jeit feinen Dampfer vor 2lugen gehabt, da fie auf eitt Signal mit der Dampfpfeife hin von allen Sciten $j_{4}$ Gunderten herbeiramten. Ein Boot mit roter flagge wurde von der Injel abgelaffen, worauf wir ftoppten, um dasfelbe abjuwarten. 


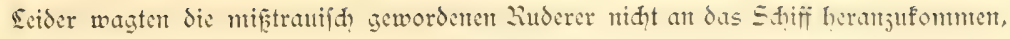
fo daf wir, ohne ju landen, unfern Kurs fortjetzten.

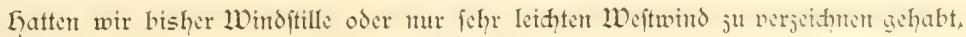
fo feţte feit dem 21. februar immer fräftiger der 2rordweft=2lionjun ein. Unter heftigen Gemitterböen wehte er an 22. und 25. februar fteif und bedingte einte fehr fühlbar fĭh geltend maḑende, nach Südofit geriđhtete Strömung.

2lm 2radimittag des 25. februar fant Diego (5)arcia in Sidht, dod, dunfelte es be= reits, bevor wir uns der Einfahet jur Bimenlagune näherten. Bet dem ftarfen See= gang fibien es wentg behagliक, die 2radit hindurd, vor dem 2ltoll ju freujen, und fo fubr der Kapitän an der Gand der trefflid̨en englif̧̨en $320 \quad 510$ 2lomiralitätsfarte bei Dollmondjhein in die gewal= tige, von Korallemrifien ftarrende Binturt= lagure eirt, obwohl die Secjethen fdyon feit cinigen Jahren aus ihr entfernt worden waren. Die Bevölferung von Diego Earcia war nid̨̨t wenig überrafdit, als fte am nädiften 2liorgen den grofen in der sagune vor Unfer gegangenen Dampfer erbliffe. ES dauerte dent aud ridht lange, bis ein von Sdwwarjen in fonmuder 2lia= trojentraḑt gerudertes 300 von Ser Gqauptanfiedelung, Eajt= Point, Geranfant. Der $218=$ miniftrator von Diego Gar= cia, Mrr. de Caila, ftenerte es und $s$ war einigermafen erftaunt, als auf feine frage, ob wir Kranfheit an Bord hätten und was der כ̄wed unjerer 2lnfunft jei, von der Brülfe geant= wortet wurde, dấ wir jeine Jufel bejehen und Sdweine einfaufen wollten.

In Bord orientierte er firh $\frac{1}{\frac{2}{\text { seare of Sea Mues. }}}$ indefien raid über den Cha= rafter unferer fahrt und erbot fid mit der dem Süb= franjofen eigenten liebenswürdigen und weltmännifhent Lnbefangenheit, als Sotfe bei der weiteren fahrt durch die Sagune bis ju dem Sandungsteg am Gauptetablifiement 
ju dienen, nidjt ohne daf er dent Kapitän feine 2fnerfenumug über das von feinem früheren Dampfer untemommente Wagnis, bei 2iaḑt in die Sagune einjufahren, aus= geíproḑen hätte.

Bevor wir indefien dent sefer das eigenartige fociale Getriebe auf ciner emfamen, immitten des tropifapen Indifhen Deeans gelegenen, von dem grofien Weltuerłehr

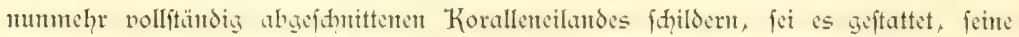
Beftaltung, Degitation und Tiermilt, wie wir fie während cines $2{ }_{1 / 2}$ täjigan Befuhes fenten lernten, furz darzulegen.

Diego Garcia liegt unter $7^{\circ} 15^{\prime}$ f. $3 r$. unt $72^{\circ} 25^{\prime}$ ö. S. Es repräfentiert ein

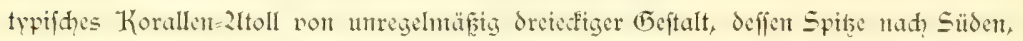
deffen Bafts nad 2Tordweft gewendet ift. Das Eand ift faum breiter als eine Seenteile,

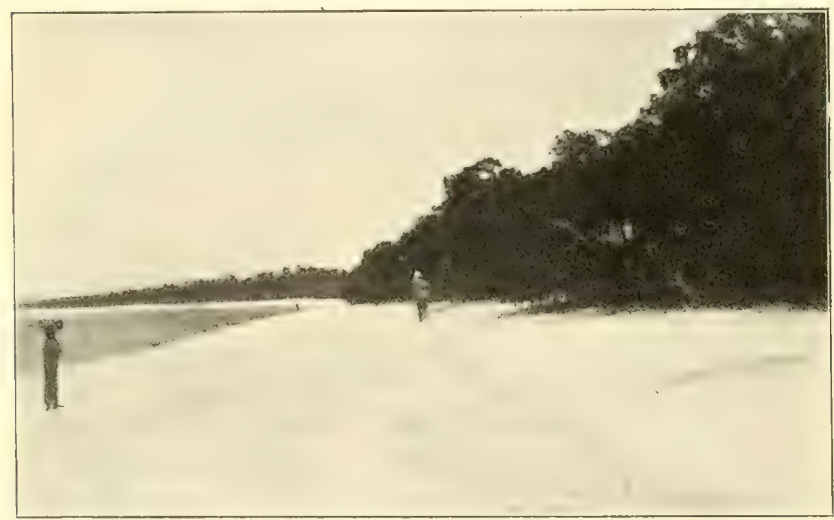

Dine aus weifient Korallenfand jwifder 2 ubenriff uno Etranoflora.

an mandien Stellen now

bedentens

¡đ)mäler, und untgrengt eine grofartiansa gume, dic im 2Tordweiten nad) dem frei= en Deean fith offinet. Der Eingang ju der sagune wird durd oret Jntieln: die Dit $=$ dic

2rittel $=$ und die Weit = oder Dogel= Jnfel in eine entiprechende ङahl von Kanälen ge= teilt. Unter ibnen ift der für die 2lnfteuerung geeignetfte und fitherite jener, welher

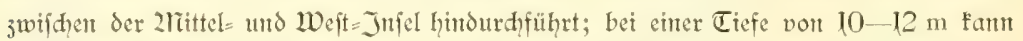
cr von dent grofen Decandampfern paffiert werdcn. Da von hier aus eine tiefe fahr= rime jwifhen unterferifhen Korallemiffen bis gegen die Gauptanfiedelung, nämlid

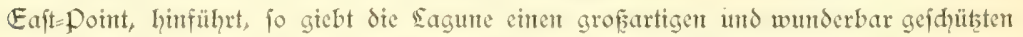
Gafen $a b$. Die 2lusdehnung von Diego (Earcia in nord füblicher Kidhtung beträgt $12^{1}, 2$, in oft=weitlidier an der breiteften Stelle $\bar{z}$ Senteilen. Das Sand ift flad, und erhebt fidh nur wenige zlieter über den zlieeresfpiegel. Es befteht aus Korallenblösen und Koralleniand, der mu alt wentigen Stellen durh den von Zlpril bis September wehen= den Sïdoft=paffat ju ctwa $8-10 \mathrm{~m}$ hohen Dünen aufgehäuft wird. Wo es mit ciner 
üppigen Degetation bedeft ift, bilden abgefallenes Saub und sie Liullen der Kolos= früdte einen frudhbaren 2Tulm. (Gegen bie Sagune fällt ber Strand flad $a b$; nad

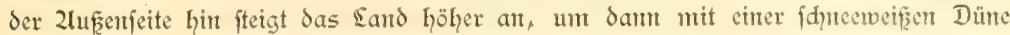
fdroffer fth ju dent während der Ebbe freiliegenden $1 / 4$ bis $1 / 2$ Seemeile breiten Saumriff 3 fenfen. Die Eagune ift im 2rittel $20 \mathrm{~m}$ tief; die gröpte in ibre gelotete Tiefe beträgt $50 \mathrm{~m}$. Begen ihr jugefpitztes füblides Ende facint fie fith in den lesten Jahrjebnten langiam ju verflahen. Keime Worte vermögen die farbenpraḑt des

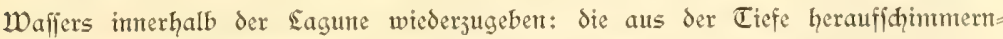
den Korallenriffe bedingen in dem Blauen Grundton die mannigfahiten Reflere in Weiß̨̌, (5rün und Gelb=

rot. Gqauptïählid

find es 2riadre=

poren, Stert=

foralfen ( $\mathcal{U}$ jträ =

en), 2lïandri=

nen, 2litllepo=

ren und pily=

forallen (fun=

gien), welche

ebenfowohl im

Jnmern der $\mathfrak{S} a=$

gune, wie an

der 2lufenjette

des Riffes ge=

deiher. 2luf

dem Saum =

rifie, das ju=

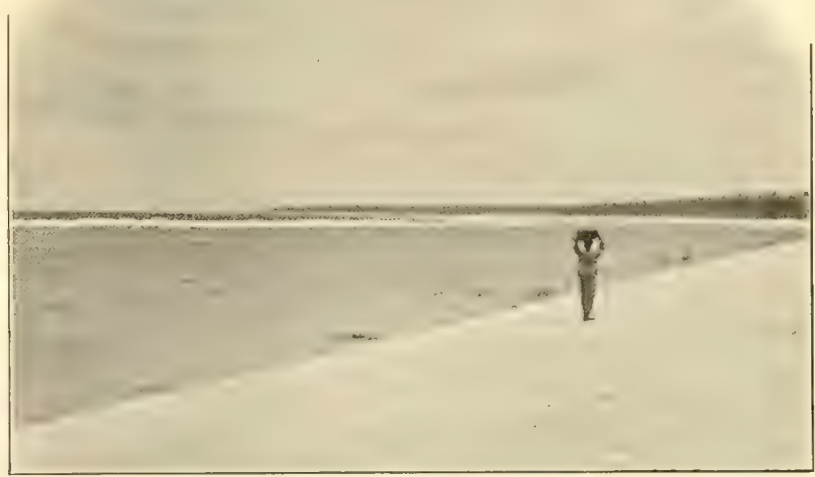

Sufentifi und 3ranoungszone.

dent bei Ebbe nux teilweife von Waffer bedectit wird, vegetieren feine lebenden $\mathrm{K}_{0}=$

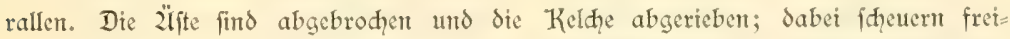
liegente Blöfe auf den hänfig jufammengebafinen 『rümmern der üLrigen Korallen.

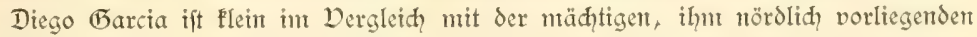
grofen Chagos=Banf, welde im Sïden und 2Torden von jwei fleinen, über Waffer liegenden 21tollen, nänliक den Sir Jslants und den Peros Banhos untäunt wird. Die gewaltige Chagos=Bante, nid̨t weriger als 95 Seemeilen lang und 65 2lieilen breit, ftellt ein riefiges, verfunfenes 2ltoll $\delta a r$, deffen Rand Z- $18 \mathrm{~m}$ unter Waffer liegt und deffen Eagute Tiefen bis 3 u $82 \mathrm{~m}$ aufweift. Wit Diego Ẽarcia und den ge= namten fleinen 2ltollen bildet die grofe chagos=Bant einen julammengehörigen Kompler, der als Chagos=coruppe bezeidunt wird. Währent des füdlihen Winters 
non dem Südoft = Paflat beftrithen, gilt Diego (5arcia troţ der häufigen Regen, melde während des ganjen Tahres midergehen, als verbältnismäpäg gejund. 2lialaria ift nid, befannt, dagezen flagen die Europäer über Seberletden, dic bei längeren 2lufent= halt fich häufig einfteller.

Eine gropartige Degetation bedectt die Injel. Dem Pflanjengeographen bereitet

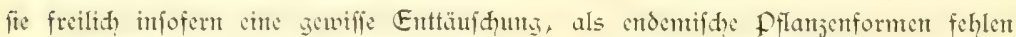

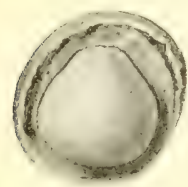

fruhtetein von Calophyl-

lum inophyllum.

Geörinet und das

Stwimmgemebe jeigeno. rat. Bröfe.

(rzach Schimper.) und im allgenteinen nur jene wiederfehren, dic wir durd den gejamten Tropengürtel auf den Koralleninieln nadzuweifen vermögen. In= deffen dürften wentge 2ltolle cine ähntid wudhtige Entwidlung der Pflanjendede aufweifen, wie gerade Diego (Garcia. Dor allen Dingen finto es die zlitlionen von Kofospalnten, dic mit ilhen trad, dent zleere und nad der Eagune geneigten Wipfeln die phyfitognomie beherriden und en fo didites Saubdad bilden, daf man hier that= fädlid, unter dent Shatten der Palmen wandelt. 2ln mehreren Stellen werden fie vort den Kajuarinen (Casuarina equisetifolia) mit ihrem dünen an Tamarisfen erimenten Saube und dent fḍlanf aufftebenden 2 ijt= werf überragt.

Dor den Ziederlafjungen ftehen wahre Prađtftäntme des Calophyllum inophyllum und der Barringtonien, dic wohl fhon vor langer Jeif dort angepflangt murden. Der uralte Stanm des Calophyllum - Sie Einwohner nenten ihn mit dem. aud auf den Sepđollen gebräuḑliḑen zianten: bois Tatamaca - , weldier vor Point 2larianne fteht und mit feiner wudtig aus= ladenden Krone das Etabliffement überihattet, möळte wohl auf Erden nidjt feinesgleidgen finten. Künjtlid, angepflangt dürfte ein groper Banyan (Ficus Bengalensis) hinter dem Wohnhauje vort Eaft= Doint fein, der mit feinen im Boden haftenden Euftwurjeln ein weites Territorium beherriht. Gegen den Jnnen= und 2tuFen= frand drängent fith dam weiterhin nod Terminalien, Derfreter der Gattung Hernandia, Scaevola und Tournefortia cin. Die beident leţgenamnten Dattungen bilden namentlid, an der 2ufsenjeite des Etrandes gegen die abfallende Düne cin faft undurchdringlidus Disfid,t, binter dent die ftoljent Kronen der Kof́ospalmen auf= ragen. Zuf den Bäumen fahen wir als Sḑmarobergewädfe häufig das Asplenium nidus, während der Boden von farnen aus der (5)attung Gleichenia unt vor allen Dingen vort Bär= lapp = Gewädien aus der (Eattung Psilotum bedecft ift.
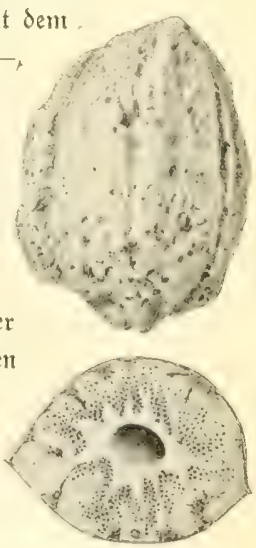

frudit von Terminalia Katappa (unten burdifinitten). Viat. Br.

Wenn aud auf den weltentlegenen Diego Garcia feine ihn cigentünliḑe Pflanzen= formen entdedt wurden, fo ift es bod von niḑt geringem Intereffe, die faftoren 


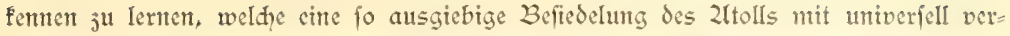

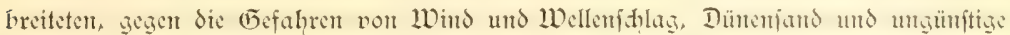

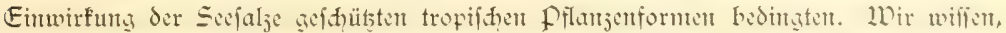

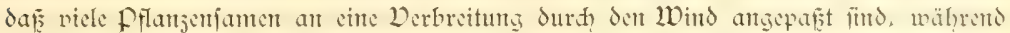
andere durd, Dögel, deren Darnt fie pafferen oder an deren füfen und Gefieder fie anhaften, weithin jerftreut werden. für die tropifale Strandflora erweift fich indefien, wie dies fhon sinné erfannte, der Transport der früđhte ourch 2lieeresftröntungen als weit bedentungsvoller. 2in dem

flachen Strande findet man neben Tretbholy und fon= ftigen 2luswürflingen des 2reeres oft bantweife die frühte gerade je= ner Pflanjen aufge: (d)idhtet, weldhe dic Phyfiognomic der Strandjone bedingen. Ein gुmaneres อँ= fehert lehrt, dafi fie ihre Keintfraft nidt cingebüst haber, ob= wohl fie oft aus weiter fene ange= fhwentmt wurden. Die Samen werden vor Giüllen ungeben, welde nidit nur dic đđädlichen Einwirfut = gen des Seewaffers $a b=$ halten, jondern aud gleidzeitig durक 2lus= bildung volt lufthal= tigen ฮ̄ellen แnd Räแ= men Sđwimmorgane dariftlen. für die uns pecieller interef= fierende indo=ntalayi= fide Strandflora hat

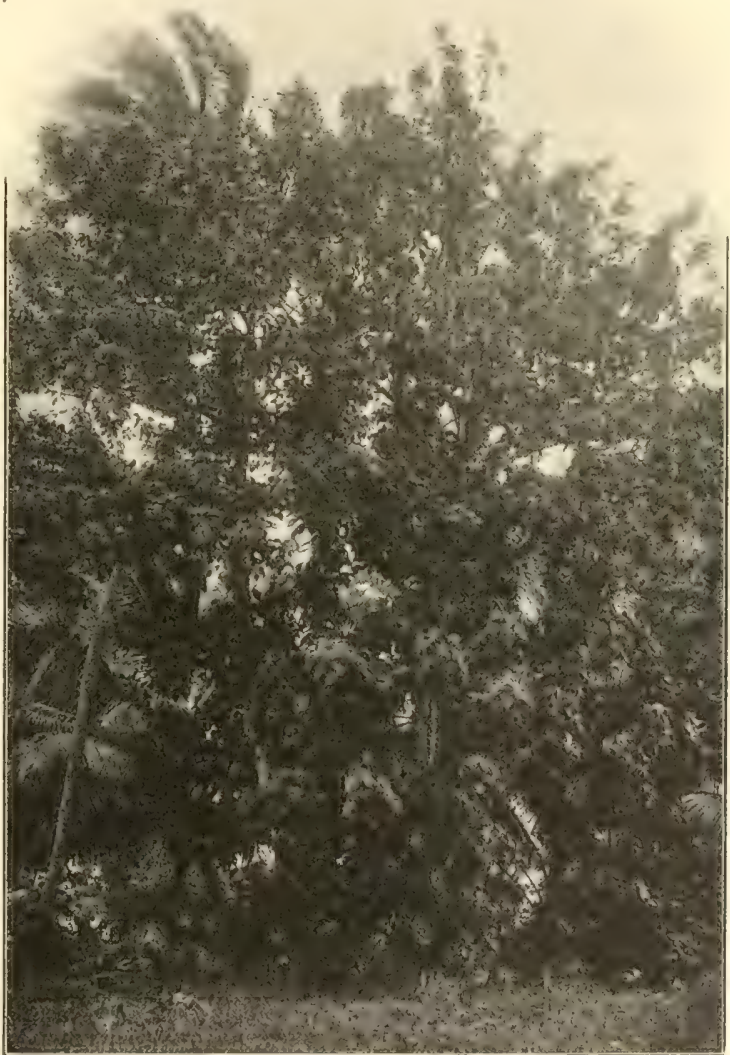

Hernandia sp. 


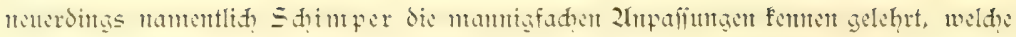
in der 2lusbildung von Sdqwimmgeweben fiḑ fund geben. Die mäđḩtigen luftreiḑen Güllen (Ilefocarp) der Kofostüffe, der vierfantigen frühte der Barringtontien, der weit verbreiteten Terminalia katappa, der Tournefortia, Scaevola, des Calophyllum und wie alle die Charafterformen der tropifhen Strandfora heifen mögen, fint für die geographifhe Derbreitung vont einfinneidender Bedeutung.

Zitht minter als die flora feffelt das Treiben der höheren Tierwelt von Diego (5arcia. Sdyon bei der 2tmäherung fallen die Sdywärme von weifen und grauen Seeffwalbent auf, die in drei 2trten namentliक auf den am Eingange ju dem Zltoll gelegenen Jniphr niften.

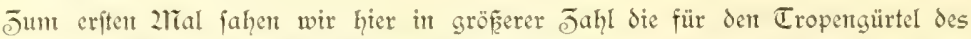

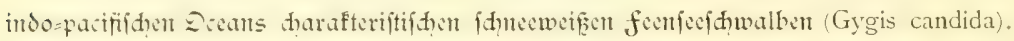
Jhren poetifden 2tanten nerdienen fie mif vollem Redjte. Zlls tropifhes Gegeniftü

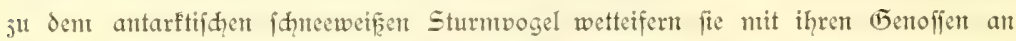
2lnmut des fluges und der färbuntg. Ziiduts ifł föfltiḑer, als diefe grajiöfen Segler

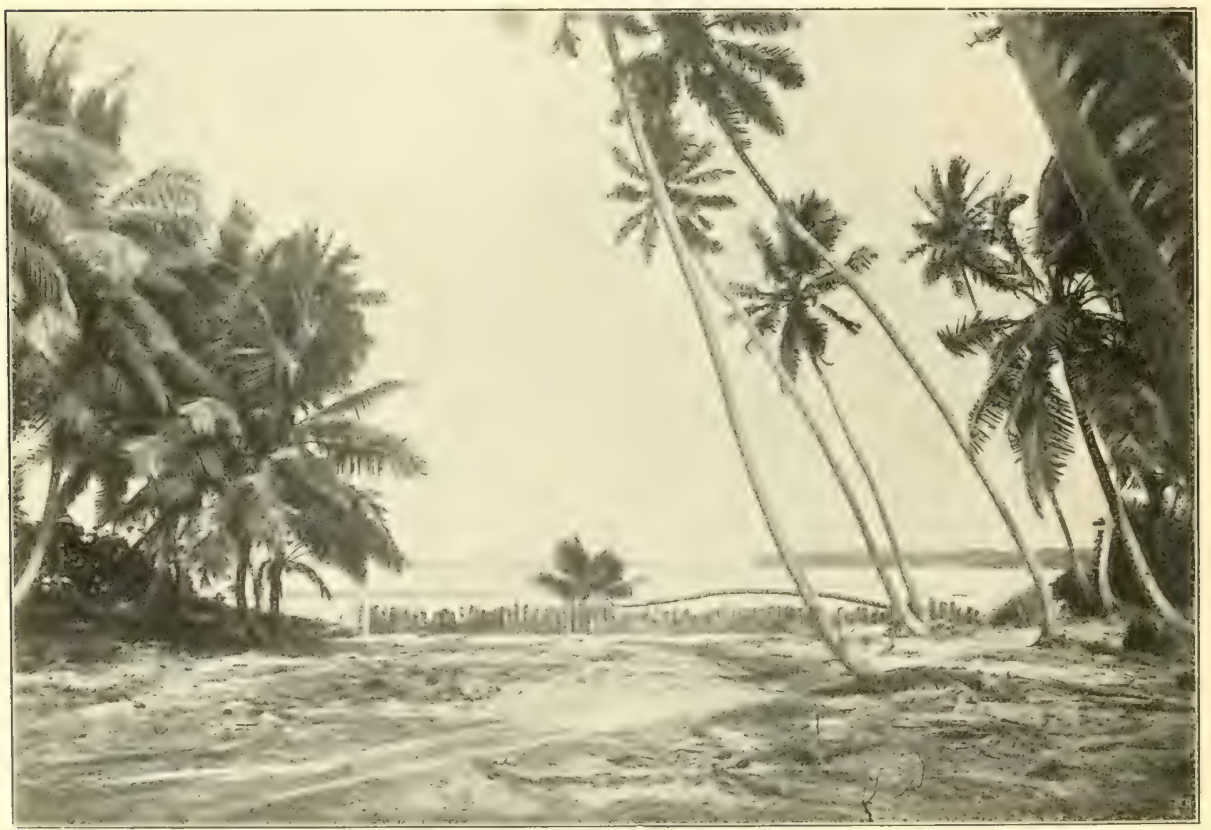

3lid auf bic 3innenlagune. 
mit ihrem feidenweidien blen=

Send weiffen (5efieder

von dem (ธॅrün der

Palmenfronen uns

tropifhen $\mathfrak{E} a u b b a ̈ u=$

me fid abheben ju

feben; wemt fie nad?

Sommenuntergang

die Kafuarmen

aufiuhen, auf

denen fie aud

bei Tage mit

Dorliebe aus=

ruhen, mödte

man thatiäclich

glauben, dafEl=

fen ihren fitlen

Reigen um das

fưvante Gcäjt

ausfübren. Ungleid

ihren Derwandten ni=

ften fie denn auch auf

Bäumen, indent das

Weibden das einjige $E_{i}$ jwijhen die 2litgabeln ablegt. Id war ange= nebme überrajdyt, als it? ipäterbin auf den Sey= chellen die feenieefhwal= bent ant ciner Stelle wie= Seriah, wo man fie am werigften erwartet hätte, nämlid in den Wipfeln des die hohen Bergfup= pen bedecfenden lltwal= des.

2rit den Secidwal= bert beleben sic cölpel
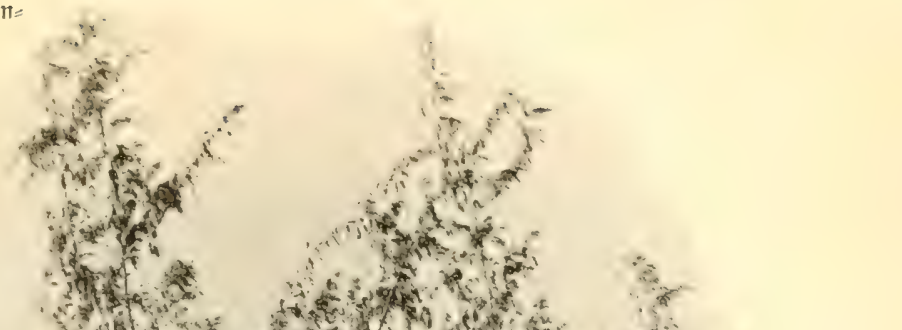


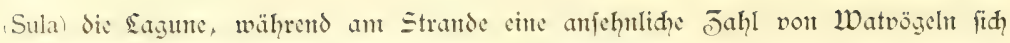

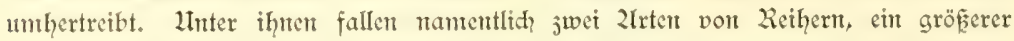
und cin כ̄wergreiher, auf. Bet der Sidłtung der von uns heimgebradten Dogelbälge

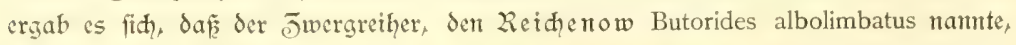

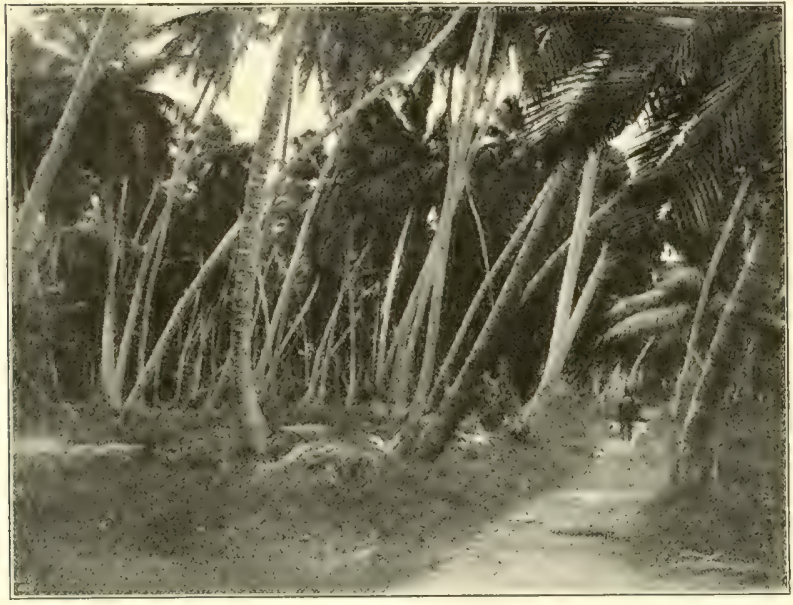

Int Kiofoswats. cine nene 2 ret re= präfentiert. Don Eandoögeltr war bisher mur ein der madagafit = ithen Region an= gehöriger, prädh= tig rot gefürb= ter 2 ebervogel (Foudia madagascariensis) be= fant geworden. In Ginfidit auf den längeren $2 \mathfrak{l} \mathfrak{u}=$ fenthalt, den neu= erdings cin tüđh= tiger englifher 3 cobatitir,

Bourne, auf Diego Jarcia nahm, mures auffallent, dafi ihm voliftündig cine Tauben= art entging, die wir gar niḑt fo feltent in den Wipfelt der Bäume bemerftent. 2luth fie crwies fin als cine neue 2lrt, dic infofern befonderes Jntereffe beanfpruht, als fie die cintige endentifhe 2lyt von Sandvögeln abgiebt, die auf der Chagos=5ruppe vor= fonmt. Ste gehört ciner wiederum für das madagaffifde Chebiet dharafterifitifhen (5ruppe an und wurde von dent fdjon genanten Drnthlyologen als eine neue 2lut der (5attuntg Homopelia bejđ̧rieben. Sic ähnelt der madagaffithen H. picturata, ift aber sunfler gefärbt; von dem verwajhen weinfarbenen Grundton, der an mandhen Stellen in cin düfteres (Grau übergeht, hebt fid cin finwarjes fled"enhalsband ab, wie es aud, den nädiften Derwandten diejer Tautbe jufommt.

2rit Rüfficht auf dent furzen 2lufenthalt, den wir auf der Chagos=(5ruppe nahmen, darf es immterhin als cin befriedigendes Ergebnis bejeidynet werden, daf wir $j^{\text {wei }}$ neue Dogelarten, unter ithnen die cinjige endemifhe 2lrt pon Eandformen, erbeuteten.

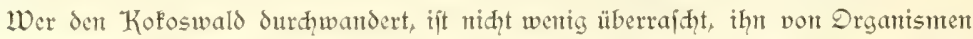
durdfif̧wärmt zu finden, weldhe wir fonft mur als Bewohner des 2lieeres femmen. Es find die zahtlofen, der Eattuntg Gecarcinus zugehörigen, in fontifher Laft feitwärts 
davoneilenden Sandfrabben, weldie an dent überall umberliegenden früdten retdilid Zahrung findert. Den originellften Dertreter derielben nimmt man freilid bei Tage niḑt wahr. Es ift der in den Kofoswäldern aller Korallentiffe verbreitete Palmen= dieb (Birgus latro), ein Krebs, der ourch den ntäðhtig entwidelten Ginterleib von den Krabben fich unteriheidet. Die Zeger wiffen fehr gefhicht diefen an dem fuß̧⿻ der Palntenitänme in tiefen Gruben bei Tag fid bergenden Krufter herausjuholen und verjhafften uns wahre Praḑteremplare derjelben, die cine Sänge pon etwa $55 \mathrm{~cm}$ erreidntert.

Wie die Eandfrabben, fo ift aud der Birgus latro mit einemt Refpirationsapparat

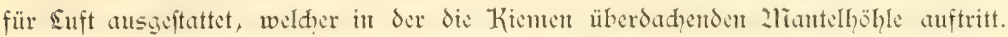
Die Eier legt er, ebenjo wie die Sandfrabben, in Waffer $a b$, und erft nah vollendeter 2Tetamorphofe begiebt er fid auf das sand, wo er ntit femen fräftigen Jangen fehr

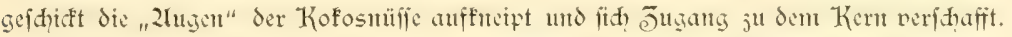

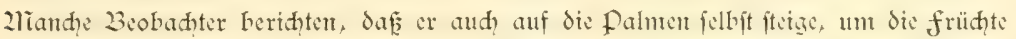
abjufneipen. Jndeffen verfiderten mir fowohl dic Europäer wie die Sdwwarjen auf

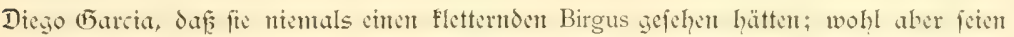
fie häufizer daranf anfmerffam geworden, daf mitten im Walde mit Esmaffer gitüllte Kofosidalen gefunden wurden, die auf feinem anderen Wege als durd den Trans= port von jeiten des Birgus dahin geraten feit fonnten.

In den weifen Korallenfande, wie er namentlid, jwifhen dent Korallentiff und Sen von den Tournefortien und Seävolen gebildeten Bebühen auftritt, halten fid mafienhaft der Gattung Ocypoda juzehörige

Sandfrabben auf, weldhe tiefe (bänge bilden und diefe, unt ein כ̋ fallen zu verhütert, mit saub aus= tapezierent.

2In Infeften fehlt es nidht auf Diego Earcia, wenn auh die Jahl der zrten gering ift. ङ) gewiffen כeiten erfheiren fliegent in enormen Shwärnten, Seren Zluftreten won Sen Ein= wohnern mit um fo gemijhteren (5)efühlen entgegengefehen wird, als gleid)jeitig 2lugenentjündun= ger ganj allgentein fïh cinfellen.

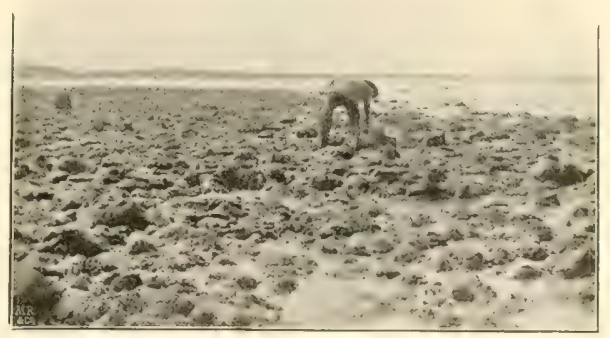

2luf bem 2lufenriti. 2liosfitos fehlen ebenfonenig, wie die überall auftretenden Zuneifen. Termiten, Bienen und dex famtlie der Danaer jugehörige Sdumetterlinge. Eine foblimme plage für sic 


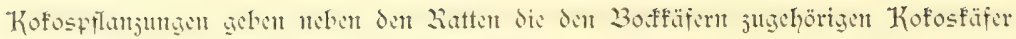
$a b$, deren Earven den Kern der 2ü jeritören.

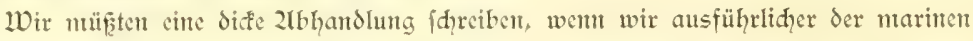
Drganismen gedenfen wollten, weldye jwifhen den unterfeeifhen, von den Korallen gebildeten Paläften unt Grotten fidh unthertreiben. So fei mur hervorgehoben, dar dic

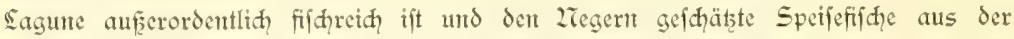
familie der Scaroiden liefert. Daju gefellen fith Zfale, unter denen einige Dertreter

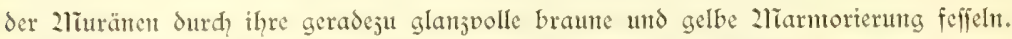

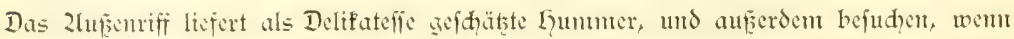

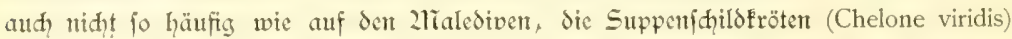
und die wertvolle Earettidilidröte, von der wỉr cin Exemplar jum Gejhenf erhielten, das 2ltoll. Wir haben Stumden verbrad,t, um auf den Riffen watend die fülle von niederen Drganismen ju fammeln, weldhe teils in den Sahen jwiphen den Korallen=

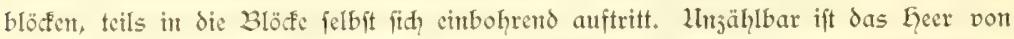
Eolothurien, non Eecifernen danunter intenfin dunfilrofa gefürbte Dertreter der (5attung Culcita), von Sceigeln aus dent Gattungen Eucidaris, Echinothrix und Brissus, and von Würmern, unter dener namentlid, praḑtvolle Euntciden auffallen.

Es wird dem Scjer nidgt ohne Jntereffe fein, ju erfahren, wie fidh mitten im Jndifhen Decan anf einer welffremden Korallentmel, die nur wenige 2lieter über die Qberflüdye ragt, cin foctales (5)emeinwejen herausbildete, deffen Getriebe wohlgeordnet

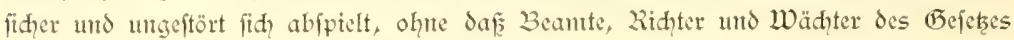
singreifen.

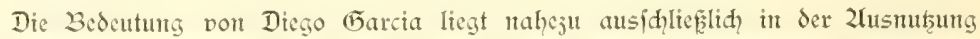
des pradtwollen Beftandes von Kofospalmen. Sdyon in früheren jeiten hatten cintzelne Bepitser farment auf dent Etlande crrifftet, dic allmtählich in die Gände einer in 2lauritus anfäfifgen Kontpagnie gelangtet, als deren 2loniniftrator nod, ju jener Deif, wo ein junger englifher 2Taturforider, Bourne, bie Jnjeln bejuhte (1887), 21ir. Jules Secomte, und jur Jeit unfers Bejudes deffen Sdiwiegerjohn, 2lir. Phi= lippe de Caila, thätig war. Geutjutage fommen mur jwei grofe farmen in $\mathcal{B}_{e}=$

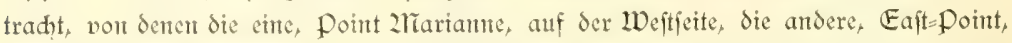
auf der Ditfette gelegen ift. Da Diego Garcia unter englifher Dberhoheit fteht und dent Derwaltungsbejirf von 2lauritius antgegliedert ift, fo wurde bet dem Erfineinen

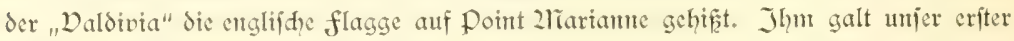
Befud . Ein langer, aus Folj gebauter Pier führt über das Korallenriff ju der Zlut= fiedelunts, dic von Prahteremplaren des an uralte Eidgen erinternden Calophyllum inophyllum mit feinen weifen, wie Drangen duftenden Blüten überihattet wird. 
Wahrideinlich haben diefe herrliḑen Stämme ju der in den Segelanweifungen ent=

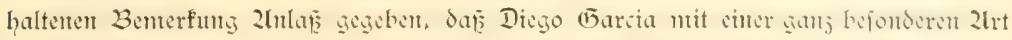

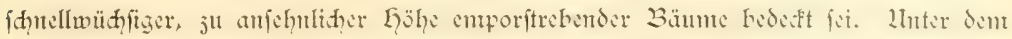
Eaubdad diefer Riefen ift das Wohnhaus mit feinen Inftigen Deranden erriḑtet, um= geben von Sagerräumen und Shuppen, in denen dic Copra bearbettet wird. Die jur כeit unferes Befuhes einem Engländer, 2rir. 2rinnings, unterftellte farm wird von

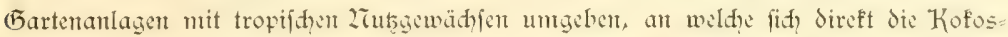

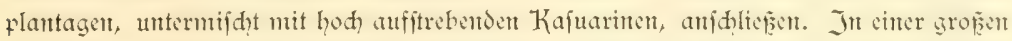

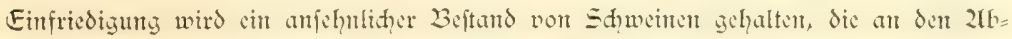
fällen der Copra eine trefflidic 2liaft finden. Erbält man ihon hier den Findrud sines weitidiḑtigen und energifhen 23etriebes, fo wird derielbe noth gefteigert bei der Znfunft in dem Gauptetabliffentent ju Eaft=Point, bei dent die "Daldivia" vor 2lnfer ging. Da der höljerne Pier von einem Sturm jeritört worden war, fo ftand man gerade in Begriff, sinen neuen in Eifenfonftruftion anfjufübren, der mit simem Edienten= weg ausgeftattet ift.

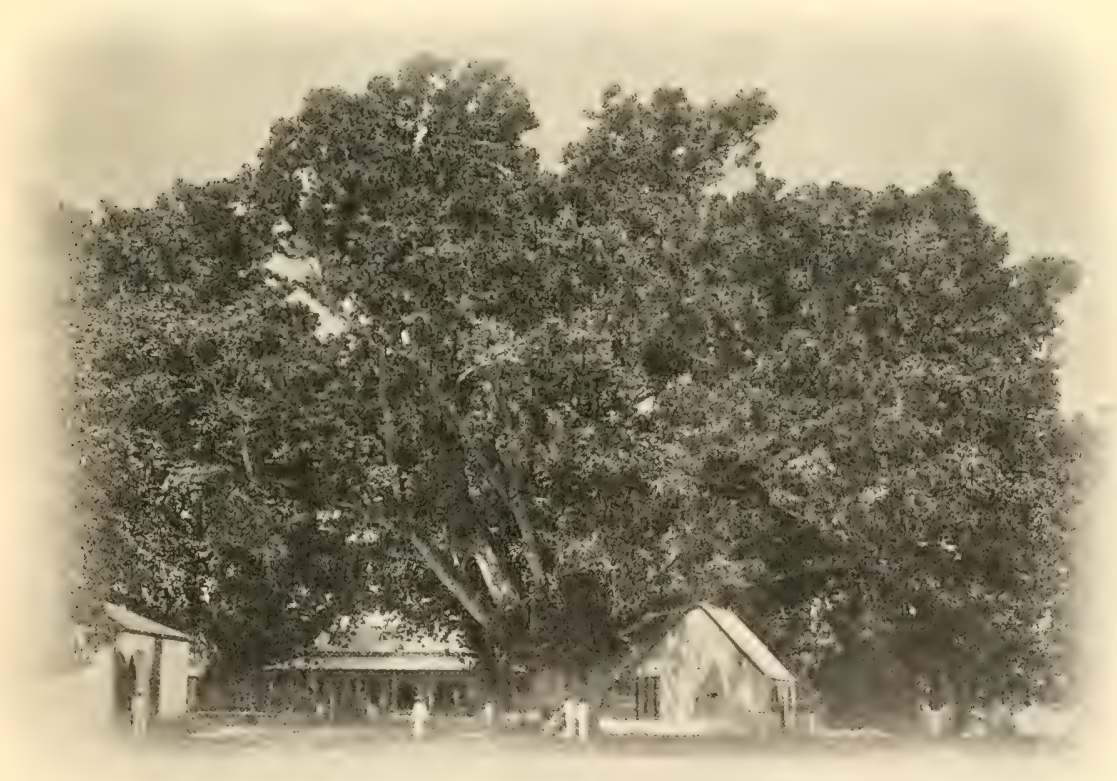




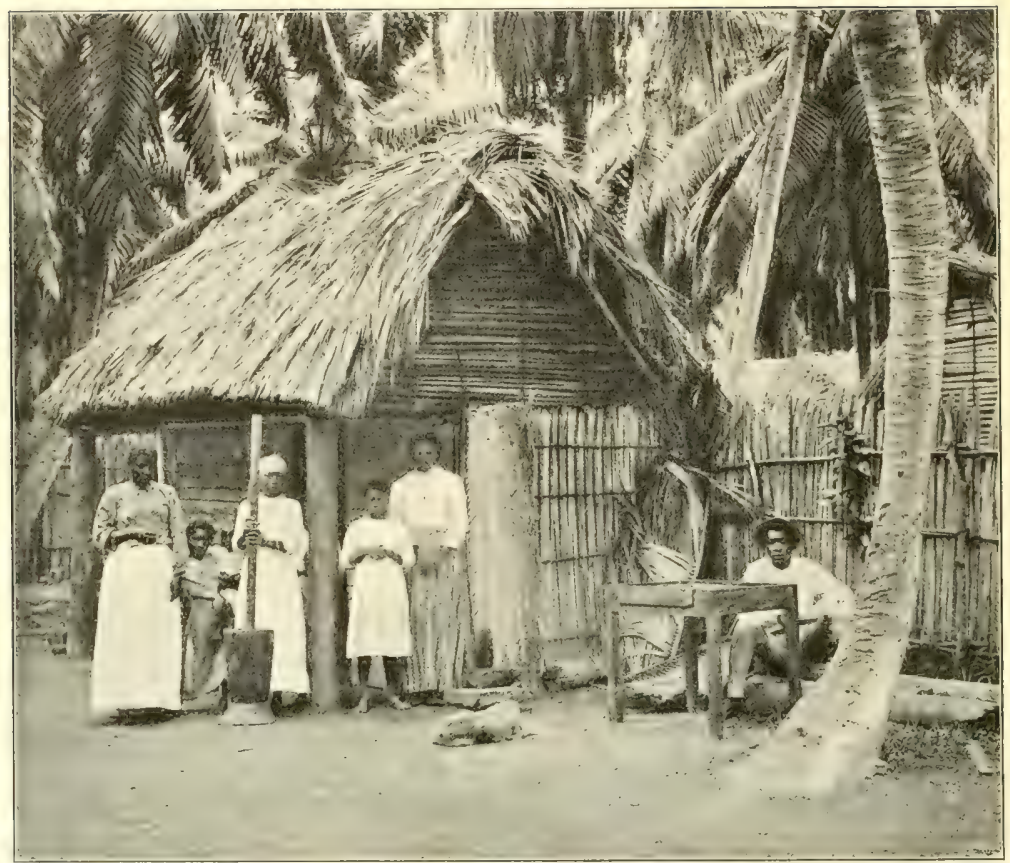

iregerküte.

(Sachse phot.)

Wie in Point 2liarianne, fo fällt aud in Eajt=Doint cinte Zllece prädntiger Stänmte auf, an deren Ende das Lerrihaftshaus gelegen ift. Sints und redits gliedern fid (5̃ebäube jur 2lufnahne des Kofosöles in grof̧en cifernen Kufen, Stallungen für Dferde und Efel, Sdmiedcwerfftätten und die Sagerräume für die Copra an. Etwas weiter landemwärts fteht nod cin fleines Wohnhaus für die fantile eines oritten $B_{e}=$ amten, 2lir. 2liulnier, dem fïh dann füdlid, die anfpruchslojen, vollitündig aus Kofos erridhteten und mit Palmwedeln gedeften Lüuten der fhwarjen Bevölferung an=

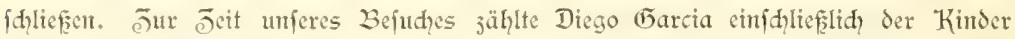
527 Bewohner. Das Lauptfontingent bilden aus 2liauritius ftanmende Patholifde unt das franjöfifhe Kreolen = Patois fpredyende 2ieger, ju denen fidh wentge Inder gefellen. In den Plantagen von Eaft= Point arbeiteten 145 2länner und 85 frauen, in point 2larianne etwa kalb fo viele. 2lianhe, unb jwar, wie perfichert wurde, dic tüdtigften Zlrbeiter, fint auf der Jnfel felbit geborent, während der Reft fich für dré Jahre fontraftlid verpflidtet hat. Die 2nämer erhalten monatlid 8, sie Weiber 6 Rupien 


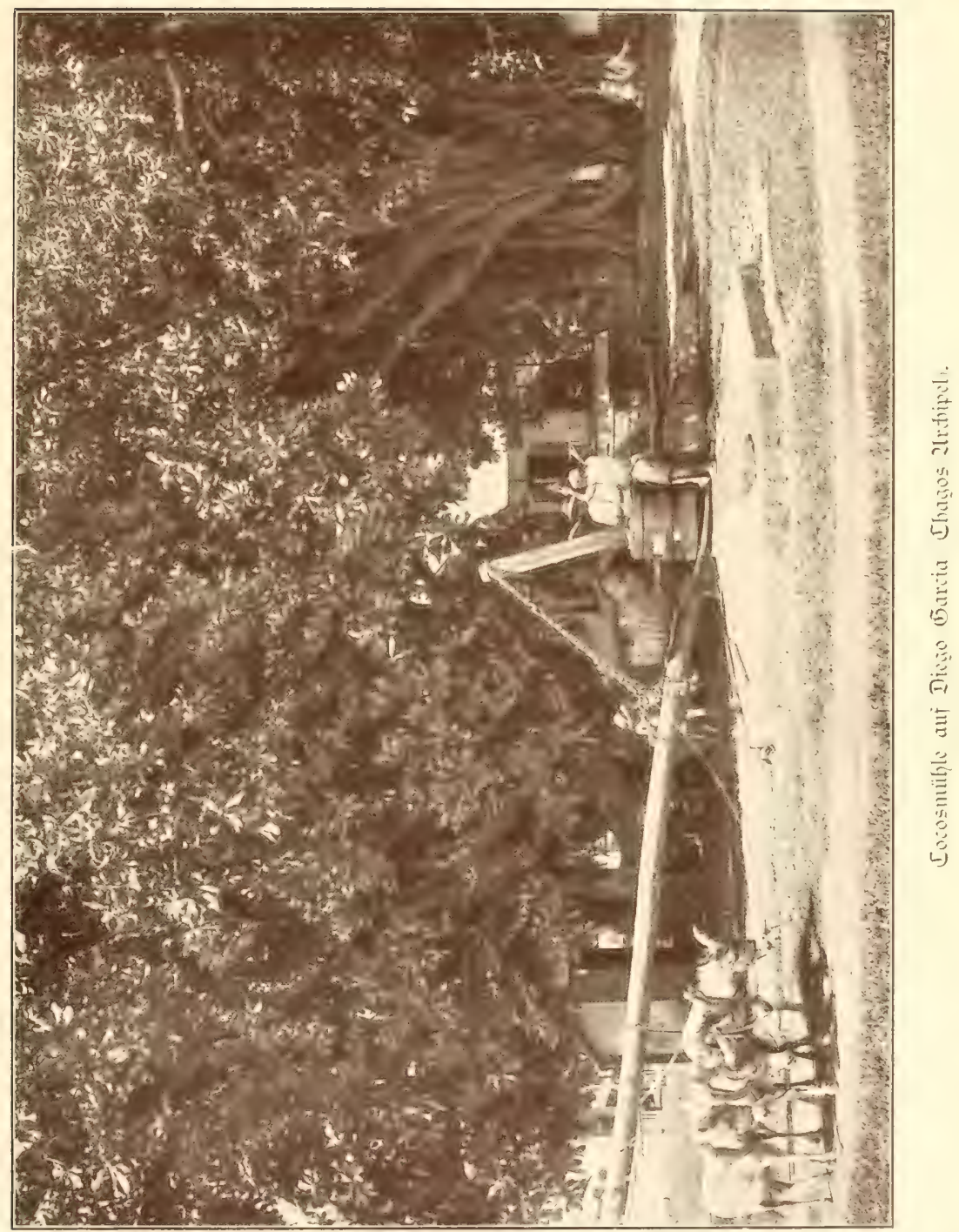



Sohn bet einer midit jhweren 2lrbettsjeit von morgens 6 bis abends 5 2lhr. Don dent Sohne werden ihnen der $3_{11}$ näpigem Preis abgegebene Reis und dic fonftigen Sebensutttel abgeredinet; auf̧erdent erhalten fie täglid eine halbe, an Somabend eine ganze flafhe Rotwein. Da die 2urbeit fontraftlich in der Weife geregelt ift, daf entem jeden feit Quantum für Sie Wodye jugewiejen wird, fo vermag ein gewandter 2lrbeiter mit Eeiditigfeit fdon vor Ende der Wodhe fein Penfun ju erledigen und fid dam dem

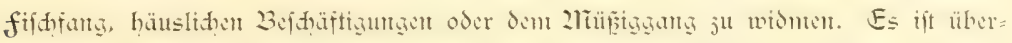
raphend, daf nur vier weife fantilien die duntle Eejellfhaft in Dronung halten, wobei freilich fait alles auf den Taft und die Energie des 2lominifitrators antommt. Zufitände der Zeger, wie fie früherhin unter naiven, fommuniftifhen forderungen mehrfach fid ereigneten, find in neuerer Jeit nidht mehr vorgefonment. 2ullerdings trägt hierju weicntid bet, daf in der 2lbgabe von Wein ftrenge kegelung herriht unto die 2lögliḑfeit jum Erwerb von Spirtuofen Jurd das 2lusbleiben der Dampfer neuerdings ausgejd̨loffen erideint. 2llles crhält fid in fo fidperem jufriedenem $\mathbf{B}_{e}=$ triebe, daf felbit cinige der Zlnitifter frihherer Revolten, dic fich als tühtige 2lrbeiter bewährten, ju 2luffebern mit befferen Eöhnen ertamt wurdert.

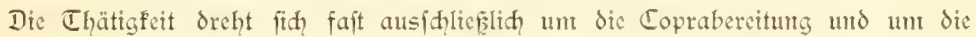
daran anfrüpfenden 2iebenleiftungen. Went aud der Bejtand an Kofospalmen olyne Zadppflanjungen fid erhält, fo ift man dod, newerdings rationeller vorgegangen und hat grofe Stredert mit jungen 2Tadwuds aufgeforftet. Don der Palme bleibt faum

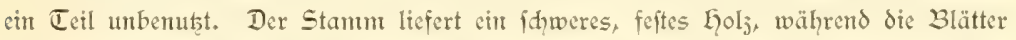
als Dadbedectung und ju fledtwerf Derwendung futden, wie es namentlich die Zregerimen in Geftalt trefflider 2ratten herjuftellen peritehen. Die ausgefdnittenen

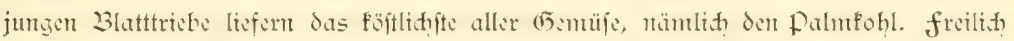
foftet das Zlusidneiden der Palme das Seben, und fo haben wir mit befonderer $2 \mathrm{In}=$ dadit eine als. Salat angentadte Speife verjeht, die mant aufer auf einer Kofosinfel fhwerlich dent frembling vorjetzen wird. faft der ganje Betrieb oreht fich un die Derarbeitung der Ztüffe, welche von den Sdwwarzen in cinjelnen Trupps unter der

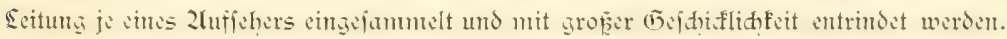
Eierbei fedt der Zrbeiter cin fpeerartiges Inftrument in den Boden und entfernt auf ihm mit wenig Kraftaufwand die dife, fajerige Gülle. Die cingefanmelten 2rüfie werden dann in die farmen befördert, wo die Wetber und Kinder damit befhäftigt find, fie ju jerfhlagen und ausjubreiten. 2lan unterwirft fie junädjt einer fermen= tation auf Trodendarren, wobei fie forgfältig vor den hüufig niedergehenden kegen=

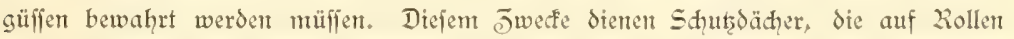
über die Darren weggefhoben werden. Sind die Kerne der 2rüffe als Copra genügend vorbereitet, fo gelangen fie dam in die Kofosmühlen, weldhe in primitiver Weife Jurd Efel getrieben werden. 2lichr als hundert (5rantiere werden in dem gुrop̧en Efelitalle 
gehalten oder tummeln fid aufererhalb desfelben frei umher, wo fie an Copra=2lbfällen und an einigen Eิ

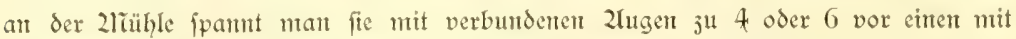
Korallenblöfen befawerten Querbalfen, der feinerfetts die 2Tïhile treibt. Das aus

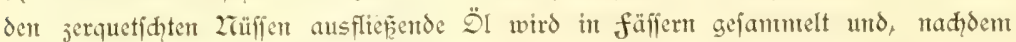
es Surdh filtration geflärt ift, in grofen, eifernen Wamen aufbewahrt. Fin dem

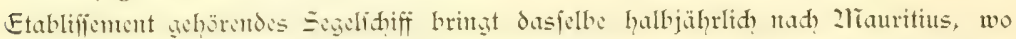
es mit Dorliebe von den 2regern für die Jubereitung der Speifen und jum Einjalben der Gaare verwendet wird. Der Europäer maḑt im allgenteinen mur untergcordneten

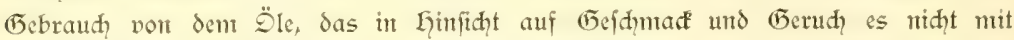
Dent Dlinenöl auftehmen Fann. Ziach den zrïtteilungen des 2lominiftrators werden auf Diego Garcia vierteljährrlid 24000 Weltes (170000 l) Kofosöl bereitet. 2Ul=

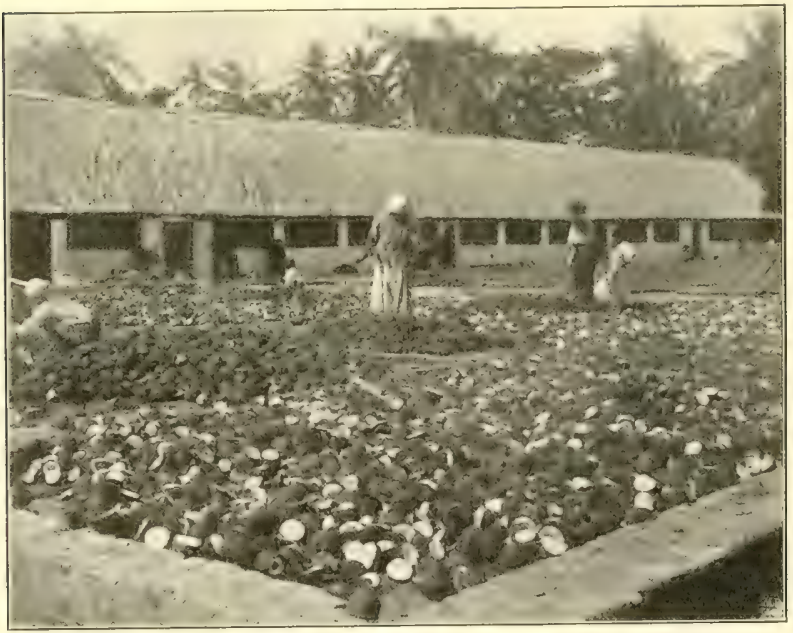

बెeriflagen uno Zusbecten ber Koposnifle. Ies, was jur Eer= ftellung der Ge= bäude, der (beräte unt ju notwen= Sigen Repara= turen gebraud?t wird, fertigt man auf der Infel pelbit an. Sdputie= de unt อ̄immer= leute fint ftändig befdäftigt; man ift cbenjo über= rajdht über ihr

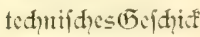
wie tuber thre Dielfeitigkeit uno findigfeit. Wor die cleganten, auf der Infel hergeftellen Ruderboote fah, wird von der Qualität der fdqwarjen 2Trbeiter cinen hohen Begriff befonment.

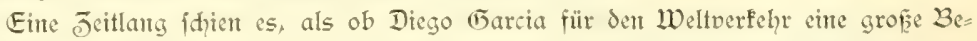
deutung gewimten follte, da es gerade auf der direften Ronte der durd, den Suejtanal fahrenden 2luftralien=Damtpfer gelegen ift. Dic Orient Steam Navigation Company und die firma sund in sondon erridgteten auf dem zltoll Kohlenftationen, und fo herrfhte dem dort eine Jeitlang ein Iebhafter transatlantifder Derfehr, auf deffen Steigerung die Infelbewohner die fühnjten Goffinngen feb̆ten. Sie find niḑt in 
Frfüllung gegargen, und dies wohl wefentlich aus dem Grunts, weil der Preis für die Kohle mit amtähernd 60 Sdilling pro Tonne ein fajt erorbitanter war. 2lls wir anlangten, waren denn aud, alle Seezeidhen wieder entfernt bis auf eine 23oje, und nur ein Quantum vort 60 Tontmen Kohlen lag nod, auf einter den Eingang junt 3toll beherridenden Infel.

So ijt es denn wieder cinjant geworden auf Diego Garcia, und wemn es mumehr vort dem Weltuerfehr abgejdnitten ift, fo ftellte fid dod aud andererieits Ruhe und

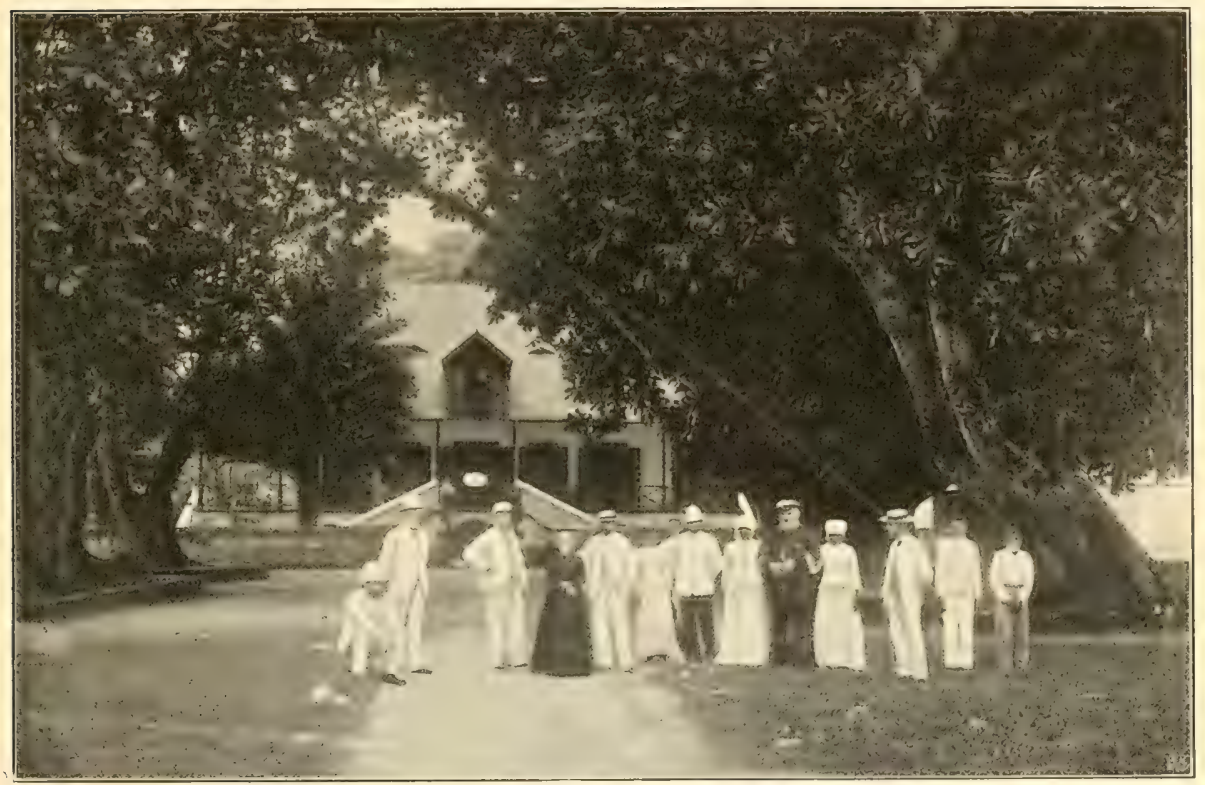

vor dem Eerridaftshaufe von Eaft $=$ point.

ङufriedenheit wieder ein. Den Zegen ward die Miöglideit jum Enwerb von Spiri=

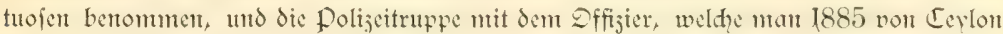
fommen lief, hat man längít aus ihrent angenehmen zlüßziggang auf dent jeţt ver= laffenen 2lïmi=2rimi wieder jurüđf́berufen.

Seit jenen Jeiten, wo forfter und Chamifio thre begeiftertent Sdyilderungen von den Koralleneilanden des Stillen Deeans entwarfen, wurde gar mandintal in

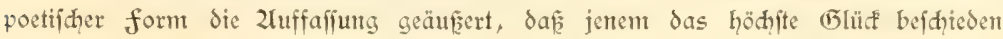


fei, der, fern von dem Getriebe der Welt, auf cinter palntenumtgürteten Infel unter harmlofen zienfden cin befdaulidges Seben verbringe. Die Zieujeit ift nüdtemer geworden. Sie beurteilt die ziaturbölfer anders als die groken Entdeferer des 18. Jahrhunderts, unto mur felten flingt in poefie und profa das Sehnen nad dem Seben auf weltentlegenen Eilanden dutrdy. Fierer in Diego Garcia mödten fdyon alle Bedingungen 3ufammentrefien, weldhe den 2lufenthalt als einen beneidenswerten er= fheinen laffen: ein gefundes Klima, cine üppige Degetation, cine unvergleidglidge Garmontie der tropifinen farbentöne, ein fhaffensfrohes Treiben harmlofer fhwarzer 2renfdhen, weldye freud und seto mit ihren 2trbeitgebern teilen. 2tber id glaube

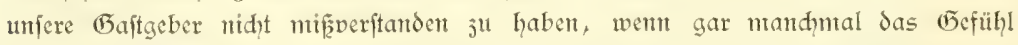
der Dercinjantung aus der Ltuterhaltung hervorflang und tie veranlap̧te, dent

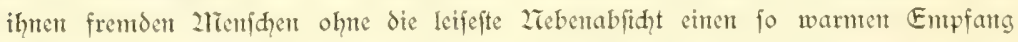
3u bereiten. Danfbar nahmen fie es auf, da k unfer $2 \mathfrak{r}_{3} \mathrm{t}$ Konfultationen erteilte, und es that ifhnen wohl, dafi für einige Tage die Bejichungen jur Zlufenenwelt wieder hergeftellt waren. 2hrausgefproḑen, vicllidit unbewuß̨t, fam dasfelbe (5efühl des Zlusgefdloffenfeins von einer Llungebung, die dem Seben cinen reideren Inthalt giebt,

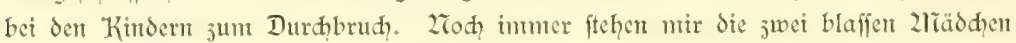
mit blondgeloften Gaaren vor 2lugen, wie fie fimmend die Photographien ihrer 2llters= genofümen in der Kabine des Danufers betrad?teten und jum Zlbihiced das Sdiönfte,

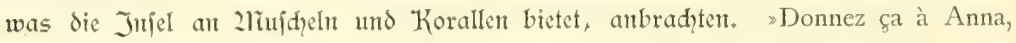
mes compliments à Lily" - fei es ihnen nodh von hier alls warm gedanft!

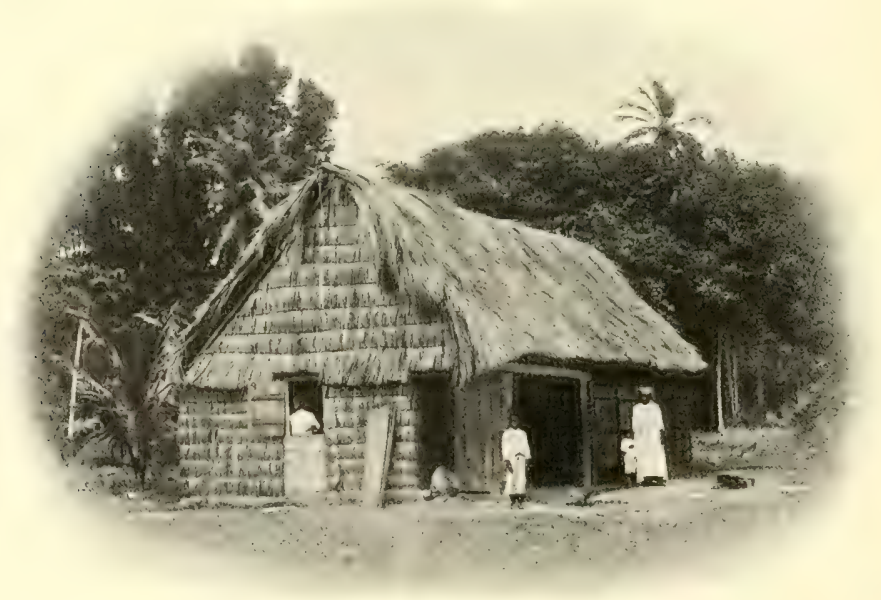

(Sachse phot.)

2regerhâtte auf Diego Garcia. 


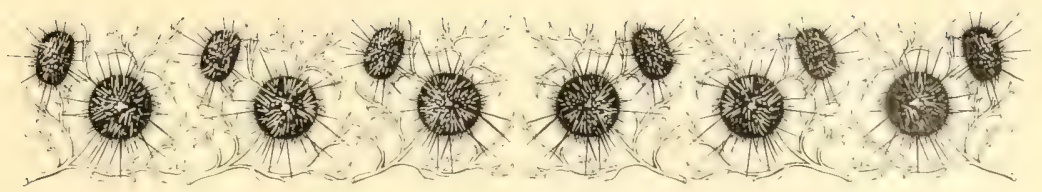

\section{Die Seychellen.}

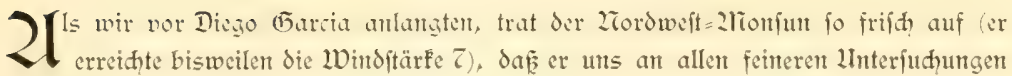
behinderte. Da er auh nod während mieres 2lufenthaltes in der Eagune unter ge= legentlid, cinfetsenden Regenböen fteif wehte, fhiten es angezetgt, bet der fahrt rach den Sephellen niht eine füdlihe Route über die Saya de 2ralha= Banf zu wählen, fondern in nordwejtlider Riditung vorjufahren, um wieder günjtigere Witterungs= verhältniffe anjutreffen. Zllerbings famen wir damit etwas näher an eine frühere Sotumgslinie, nämlith diejenige der "Enterprife", heran, aber andererfeits eröffuete fid die 2Uusfidt, unfere biologifden Unterfudungent, auf denen ja der Sdywerpunft der Expedition lag, nahhaltig fördern 3 fömren.

Im allgenteinen ift dem aud diefe Erwbartung in Erfüllung gegangen. Der Wind Flaute etwas $a b$, behielt $a b e r$, indem er allmählich von 2iordweften mehr nad 2rorden herumging, immerhin durdhidnittlich die Stärfe 4 bei; erit direft vor den Seydellen madten Windfillen mit fpiegelglatter See fỉh geltend. Da die Strömungen anfänglid cntweder dem Winde direft entgegengefetzt oder redtwintlig auf ihn verliefen, fo hatten wix felbjt bei bewegter See den Worteil, daf das bet bereits ftarf genumdertem Kohlen= vorrat hod aus dent Waffer liegende Sdiff während des Sotens und fiihens nidht fo ftar abgetrieben wurbe, wie wir befürdyteten.

$\mathfrak{W}_{\text {as }}$ die auf diefer Route ausgeführten Sotungen anbelangt, to ergaben fie cir jiemlid ftarf gefaltetes Bodenrelief. 2lnt Tage nad unjerer 2lbfahrt von Diego (barcia loteten wir 20 Semteilen weftiti) der grofenen Chagos=3anf bejw. der flemen Sir Jslands $2127 \mathrm{~m}$ und an Tage darauf die beträhtlide Tiefe vort $4129 \mathrm{~m}$. 21an

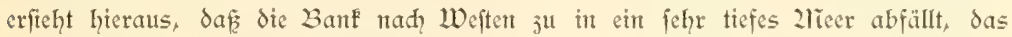

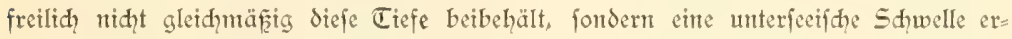
fenten läft. J̄wijhen die beiden Sotungen vom 27. februar und 2. 2liäry, weldye Tiefen von über $4000 \mathrm{~m}$ ergaben (am 2. 21Tärj $4599 \mathrm{~m}$ ), fhaltet fid ränlid eine Erhebung, auf der wir $2745 \mathrm{~m}$ loteten, eir. Die Tentperaturen betrugen in den 


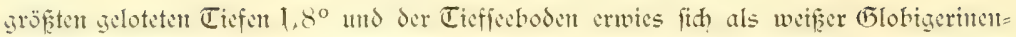

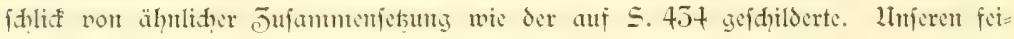
neren biologijden Unterfuduntgen fomten wir bereits am dritten Tage nad der $2 \mathrm{fb}=$ fahrt von Diego Garcia nadigehen. Insbejondere hatten wir es uns jur 2rufgabe

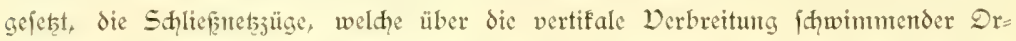

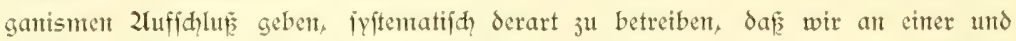
derfelben Stelle Serien von Jügen durdfühţrten. So waren wir 3. B. am 2. 2härs in der Eage, eine Sdliefnetferic von 6 Jügen, weldhe ftufenweife das Dorfonmen der Drgantsmen von $1600 \mathrm{~m}$ Tiefe an bis jur Dberflädhe illuftriert, vorzunehment.

Reidh an neuen 2lufidhliffen waren denn aud wiederum die Jüge mit den Dertifal= netsen, weldhe an manthen Tagen formen von allgemeinerem Intereffe licferten. Lluter ihnen fei namentlid auf bie Tieffeefifde hingewiejen, von denen wiederum einige durd

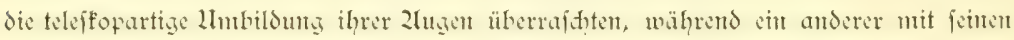
auf enorm langen Stielen fitzenden 2lugen eines der bijarrft geftalteten Wirbeltiere $a b=$ giebt. Weiterhin fiel es uns bei diefen Jügen auf, da wir pelagifde Tiefenformen irbeuteten, die uns früher in identifhen Dertretern im 2ftlantifinen Decan in die Zief̧e geraten waren. Wentger ergebutsreid) war ein Sdleppretżug, weldhen wir am 28. februar in $2645 \mathrm{~m}$ Tiefe nerantfalteten. Dbwohl wir uns weitab von den Riffen bifanden uno nad allen früheren Erfahrumgen mit Eidnerheit darauf redunen formten, dap der Boden cben fei, fo hafte dody das 2reţ nad eintiger jeit feft; und nur mit groferer 2lühe gelang es nad) faft halbftündiger 2frbeit, dasfelbe fref ju befonmen; als es auffam, war es ju unferer l̈berrafdung unverfehrt, dagegen jeigte das Kabel furz vor dem Vorläufer Kinfe, die darauf hindeuteten, da es fid auf irgend eine

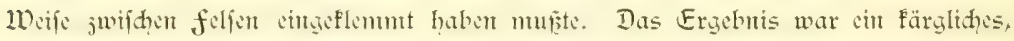

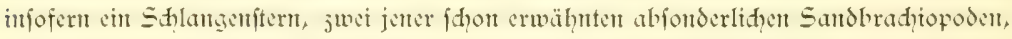
sine Sprogeforalle und eine fduwarge kindenforalle (2fntipathide) die ganje 2lusbeute abgabert.

\section{MTahé.}

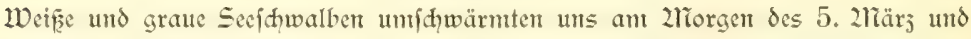
sin grünlidh verfärbtes 2lieer, in dent reidllidy Sargaffum trieb, dentete die Zä̈he der Sepdellen an. Bei Sontenaufgang taudten fteil und wudthtig fid erhebende Inieln anf, die dem an niebrige Korallenatolle gemöhnten 3lid doppelt impofant eridienen.

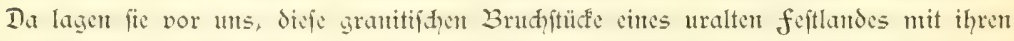

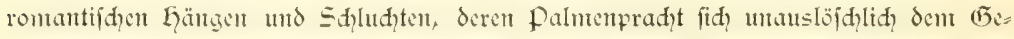

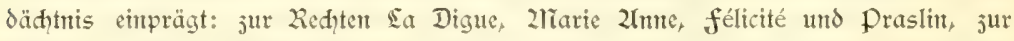
sinfen das cinfame frez̧ate und im hintergrunto, alle andern üherragend, 2lăahé mit dem in Wolfen verferten 2liorne Sepdellois. 
Die Seydeflen beftehen aus etwa 29 Infeln, von denen freilidh mu $z$ anfehnlidhere Gröf̧e erreidhen, während der keft aus oft reḍt flemen Eilanden gebildet wird. Sie

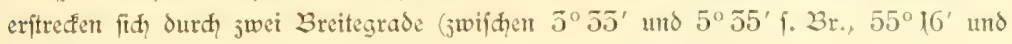

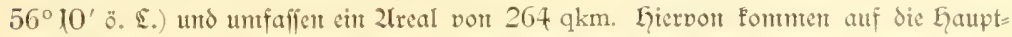

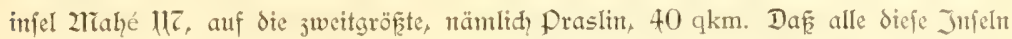
cinen cinbeitliden Kompler bildent, Iehrt das Tiefenrelief; fie fitzent einer nur $18-80 \mathrm{~m}$ tiefen Banf auf, welde gegen die benaḑbarten Korallenriffe der Zlmiranten cbenfo fteil

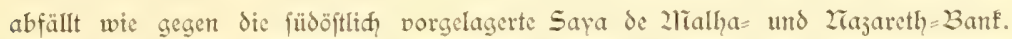
Don den 2lmiranten tremt fie cin mindeftens $2000 \mathrm{~m}$ tiefes, von den letstgenannten Bänfen nebft 2liauritus und Réunton cin über $5000 \mathrm{~m}$ tiefes 2licer. Einte nod be= trädtlliḑere Einfenfung von über $4000 \mathrm{~m}$, aus der nur vereinzelte flente Eilande hervorragen, fheidet fie von 2liadagasfar.

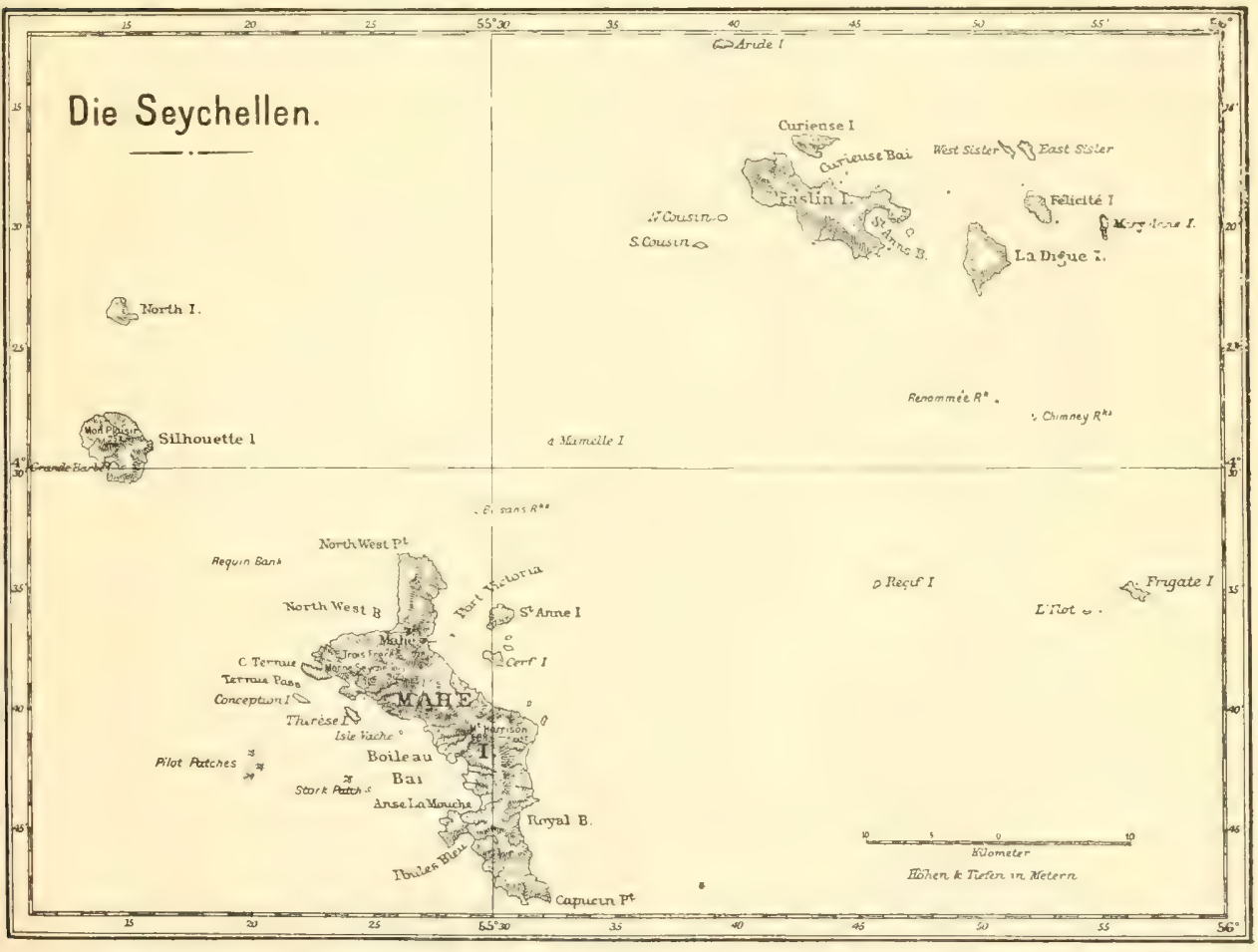

(Zad, Brauer.) 
Will mat cinen uralten verjuffenen Kontinent "Semurien" fonfitruieren, auf den man gar vielerlei, unter anderem auh die Wiege des 2lïndhengefdledts, verlegte, fo bieten die grof̧en Tiefen für cine Dereinigung 2liabagasfars und der 2Masfarenen mit den Seydyellen erheblidie Sdwierigfeiten dar. In geologifher Gimfiḑt meifen freilith die letsteren weif mehr lïberemfitimmung mit 2liadagasfar, als mit dent vul= fanifhen 2liauritus und Réunion auf. Sie bauen fid durdpweg aus (5rantit auf, der nur hier und da ant Strande von bis ju $25 \mathrm{~m}$ gehobenen Korallentiffen überlagert wird. 2lls wir uns gegen 2littag 2liahé näherten, lehrte idion die Phyfitognomie der Infel, daf ntan es niḑt mit cinem vulfanifden sande ju thun hat. Es fehlen

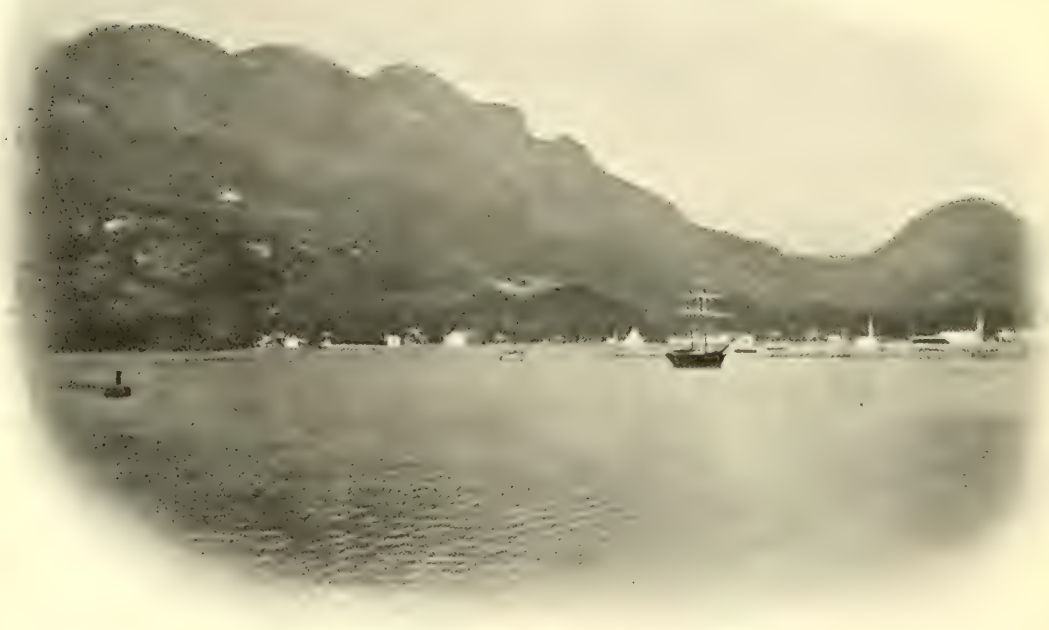

port Wiftoria auf $2 m a h e ́$.

Kegelberge oder jerzaçte Kraterränder, und an deren Stelle treten fteil aufragende Kuppen, dic häufig wie Baftionen geftaltet find. 2lian ift überrajht über die fülle von Sandjhaftsbildem, die diefe reth gegliderte und im 2rome Seydellois bis ju $988 \mathrm{~m}$ aufiteigende Jnfel crfenten läpt. Dabei ift fie bis hod himauf bewaldet, an thren bängen mit üpptger Kultur bededt, in ihren Sdhluḑten von Gebirgsbäden durdiraufat und gegen das 2lieer ju von einem Sammiff umgeber.

Die 2hntenerung von Port Diftoria ift cme jientidy fdqwierige, went aud sut

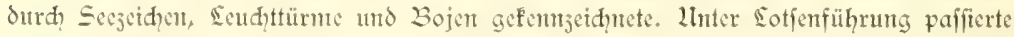


die "Daldivia" die enge, gewundente fahritraf̧e jwifhen den Riffen, un in der 2ähe des langgejogenen Dammes vor 2lnfer ju gehert.

Während der Einfahrt wird man nidyt wenig durh die farbenprad, des in eine Tiefe von 7-9 faden abfallenden kiffrandes gefeffelt. Die 2liadreporen mit ihren blauen 2lïtpitzen, die mehr bräunlich getönten 2läandrinen und Sternforallen faim= mern aus dex dämmerigen dunfelblauen Tiefe bis jur Dberflädge hervor und verlethen der Buht ein fo abwed)slumgsreides Kolorit, dak ein 2lialer fid vergeblich abmühen möhte, dieje gelbliḑen, grünliḑen, braunen, blauen und weifen Tinten zu einem harmonifhen Gejamtbild ju veremen. Gegen bas sand ju geftalten fid die $\mathcal{D}_{\mathrm{er}}=$ hälmiffe für das Wadistum der Korallen ungünjtiger, jumal aud ein Teil des Riffes bei der Ebbe freigelegt wird. Shlieflich nimmt der Korallenfand überhand und um= fäunt als weifer, von dent dutflen Grün der Strandflora fharf fith abhebender Strid das Lffer. Un thm jieht fith lang die etwa 8000 Einwohner jählende malerifhe Gauptitads der Seydellen, 2liahé, hin. Lqat man den weit in den Lafen eingebauten, aus Korallenblöfen erriḑtefer Danm paffiert, fo feffeln die fdmucfen Dillen dex an= fäfifgen Engländer und wohlhabenderen Kreolen Surd? die Draḑt det Gartenanlagen mit ihrer l̈tberfülle von tropifhen Charafterpflangen. Der dem Engländer eigene

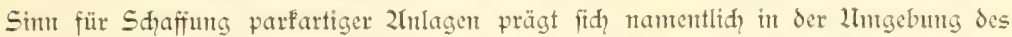
Gouvernements aus, das im (5rün mäđtiger 2llleen verfteft und vort cinem Exemplar der ftolzeften aller Palmen, der Lodoicea, überragt, einen pafienden Lintergrund durd? den Steilabfall der Trois frères erhält. In ihnt empfing uns der 21 dntiniptrator, 2lir. Codburn=Stewart, mit der den feingebildeten Engländer eigenen Siebens= würdigfeit. 2lït deutjhen Derhältniffen aus eigener 2lnfhaunng wohlvertraut, bot er alles auf, unt in Gemeindaft mit Dr. Broofs, unferem humorvollen Konjul, 21r. Baty, dent Jufpeftor der forften und deffen Bruder, dem Befitser der Infel

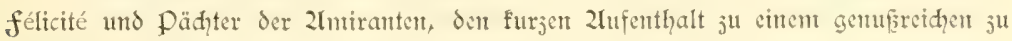
geftalten.

Die einer Dillenfolonie gleidgende Stadt läuft in eine fdgattige, den Strand cntlang führende Sandftrafe aus. Dic fie cinfüumenden Wohnhäufer ber Kreolent nehmen all= mählid cinen anjprudisloferen Charafter an und gehen in dic aus $\mathcal{B}$ ambus erriditeten unts mit Kofoswedeln gedecften 2regerhütten über.

Ilm die buntihecfige Jujammenjetsung der Bevölferung, welhe gröftenteils das Kreolenpatois fpridht, ju verftehen, dürfte es antgejeigt feit, emen furjen Riücblide auf die Entdefungsgefdidgte der Sepdellen ju werfen. Went aud dic Jufeht in geolo.

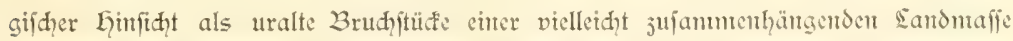
erifheinen, fo femen wir fie dod, erft feit dent Jahre $1 \overline{6}+2$ gentater. Damals ent= fendete der thatfraftige Gouverneur von Jle de france unb Bourbon (Réunion), näm= lił 2răhé de sabourdonnais, den Kapitün Eajare Picault, um die nördid 


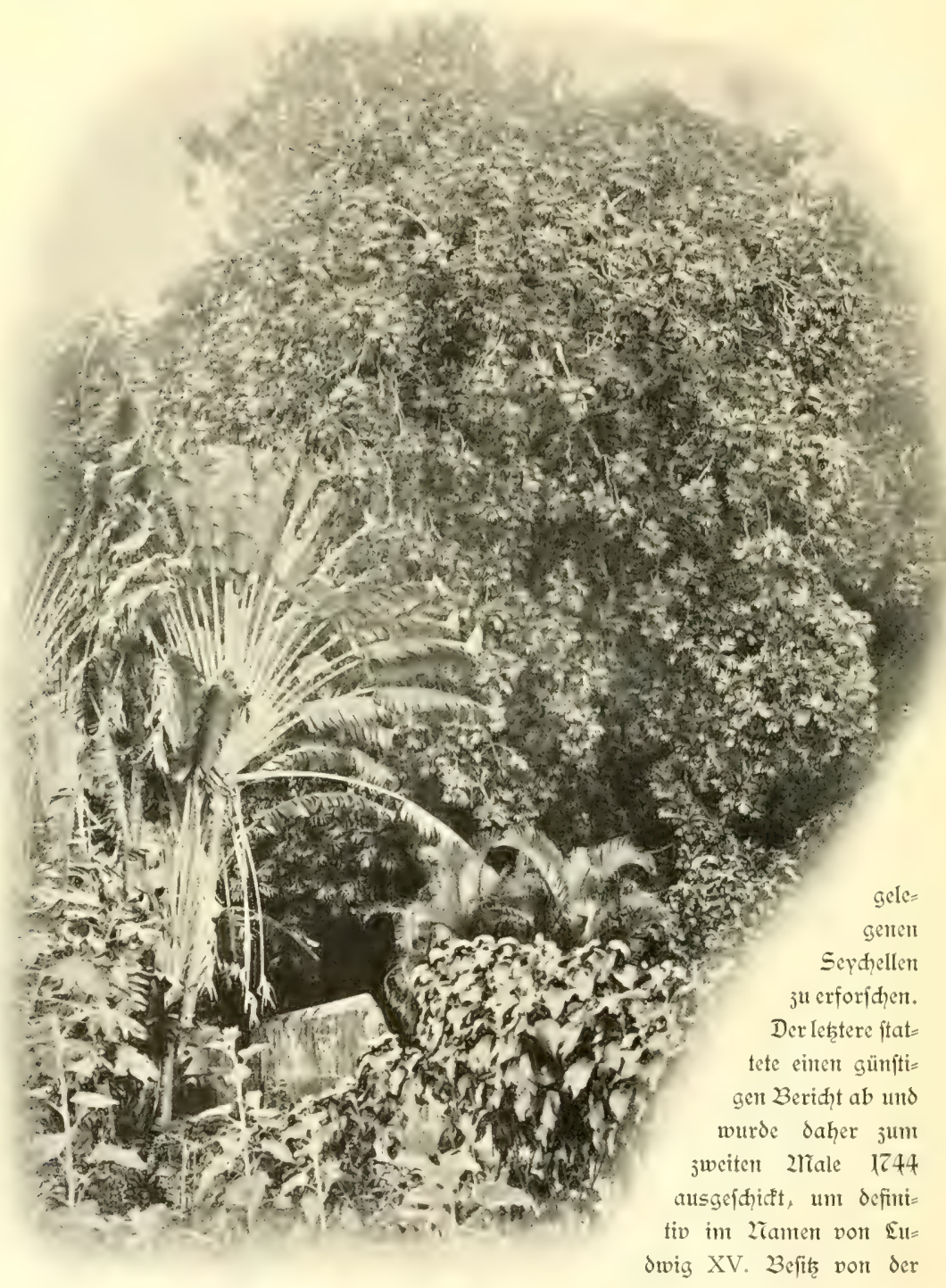

Degctation an ber sandetrafe. 


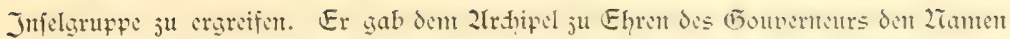
Eabourdomtais und nante die gröfíte Infel 2liahé. Keime Spur von 2lĩenfdent war bei diefer erften Erforfdumg der Eeydellen nadijumeifert. Ziadident Eabourdontrats in Ungnade gefallen war, fendete fein Zadffolger 2liagon lï56 den Sientenant 27ior= phep aus, weldher den 2tamen der Cruppe änderte und ihe die heute nodh gültige

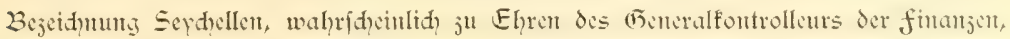
2Toreau de Sédnelles, beilegte. כ̄wölf Jahre päter wurde wiederum ein frant= zöfither Kapitän, kFarion Dufrène, ausgefendet, um die 2lrbeiten fenter Dorgänger

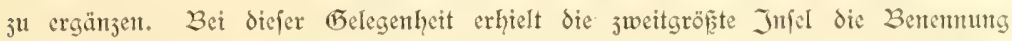
Praslin, $3^{\text {ul }}$ Ehren des Kriegsminifters, Gerjog von Praslin. Die erften Koloniften frantöfiffhen Lrfprungs famten von Jle de france und Bourbon tzzo nad, den Seps hellen. Etwa 20 Jahre fpäter beftand die ganje Bevölferunts aus 20 Weiçen und 250 ifwarjen Sklaben.

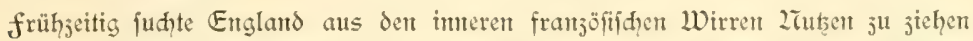
und die Seydhellen unter britijhe Dberhoheit ju ftellen. Der erfte Derính (1294) wurde niḑt ratificiert und Bonaparte felbjt verbannte 1801 al perfonen nad den

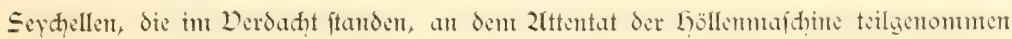
ju haben. Erft int 2lpril 18ll fielen die Seydhellen mit Jle de france, deffen Lrame in "2rauritus" geändert wurde, definitiv an England. 2ullerdintgs muß̨te das englifhe Gouvernement fidh verpflidgten, dic franjöfifde Eigenart in Spradhe und Kuitus zu fhonen, die dem aud, heute nod derart in den Dordergrund tritt, da die Jnjeln den Eindrut einer franjö̈rfifhen Kolonie erweten.

Der Grundftod der Bevölfe= rung wird gebildet von Kreolen, die aus 2riauritutus und Réunion cinwanderten, anfärtglid? von dem Ertrage der abgeholzten Urwälder lebten und erf́t unter dem Ein= fluffe der englifhen herridaft $j^{4}$ Plantagenwirtifaft übergingen. Sie gelten als gaftrei, gefellig, gewandt und liebenswürdig im Derkehr. Indeffen betonen alle Kenner des Eandes, daf biefe an= gentehme $\mathfrak{Z}$ uß̨̌enfeite nidht hinweg=

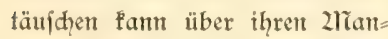
gel an Energie, ifhre Zreigung 3u Trunk und 2fusidqweifungen.

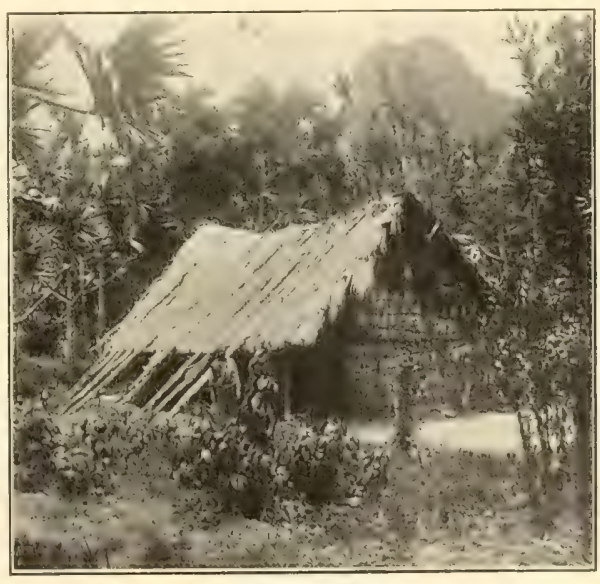

Regerhütte auf mahé, 
Dies alles hat jur folge, daf die plantagen der eitgeborenen Kreolen, wem fie nidit überhaupt verfallen, fo dod, feinen Dergleid? mit jenen der ZTauritianer und eingewan= derten Europäer aushalten.

Das farbige Element bejteht wefentlidy aus 2regent, die man namentlid von 2rojambique cinführte, weiterhin ans einigen 2liadagafen, Findus und den als Gändlent thätigen Chineien. Kreolen und frete Zeger geben cin Element $a b$, das cine

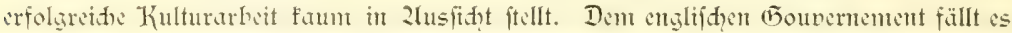

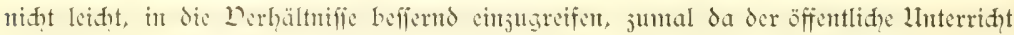

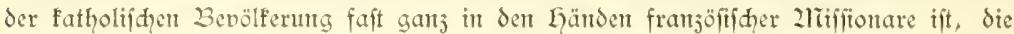
24. Sdulent unterhalten. Erwähnt mag mur nod feir, da fa 189l die gefamte $\mathfrak{B}_{e}=$ völferung der Sephellen 16440 perfonent betrug: cine geringe Jahl int Dergleid mit dem ansgedehnten, gefunden und fruḑtbaren Ztreal.

Da unter der englifhen Kerrifhaft der Plantagenbetrieb mehr und mehr in 2luf=

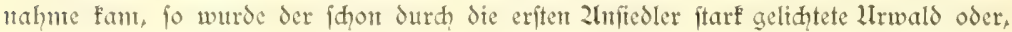
wic man ihn dort nemut, der alte Wald, mehre und mehr zurüdfgedrängt. Er hat fid, itt voller 2trwüdffigfeit mur nod auf den entlegeneren Göhenjonen in der Untgebung des 2liount Garrifon auf dem füdlitgen Teil der Jufel erhalten. Jhut galt che der

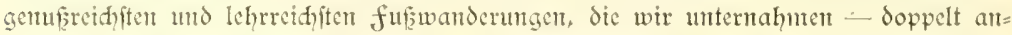
jiehend, weil cincr unferer freunde und Reffegefährten, Prof. 3 raucr, der fid cin Jahx lang auf den Seydyellen aufgehalten hatte, den gewiegten führer abgab. Baci Tagesgraten madten wir uns auf den $\mathfrak{D}_{\mathrm{eg}}$ und genoffen in der 2loorgenfrifhe die föpllithen Zlusblife nad? red̨ts anf die fteil abfallenden, bie und da von Gebirgsbäden

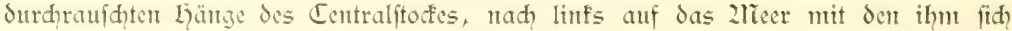
juneigenden Kofospalmen und den dümen Kajuarinen, durh die der Wind wie durd

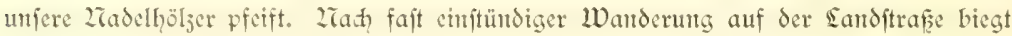

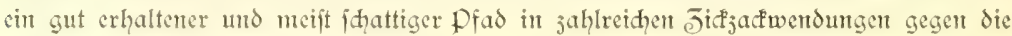
mit Plantagen bedeftent böhent ab.

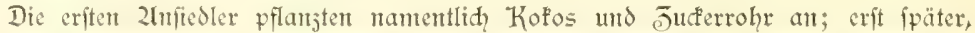

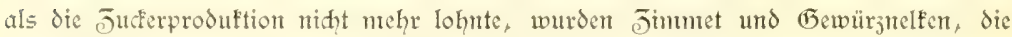
¡thon lazl von den Sutda= Juffeln durd, Poivre eingeführt wurden, ausgiebiger fultiviert, ju denen dan weiterhin der Kafao als ausiditsreides und gut gedeihendes Produft fid Gingugefellte. Seider haufen die cingefdleppten Ratten trotz aller in

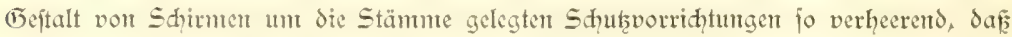
an mandhen Stellen der Betrieb aufgegeben wurde. So ijt es demn neuerdings die

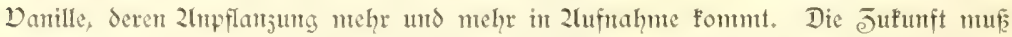
lehren, ob dic an ihre Kultur gefnüpften hod,fliegenden Erwartungen in Erfüllung 


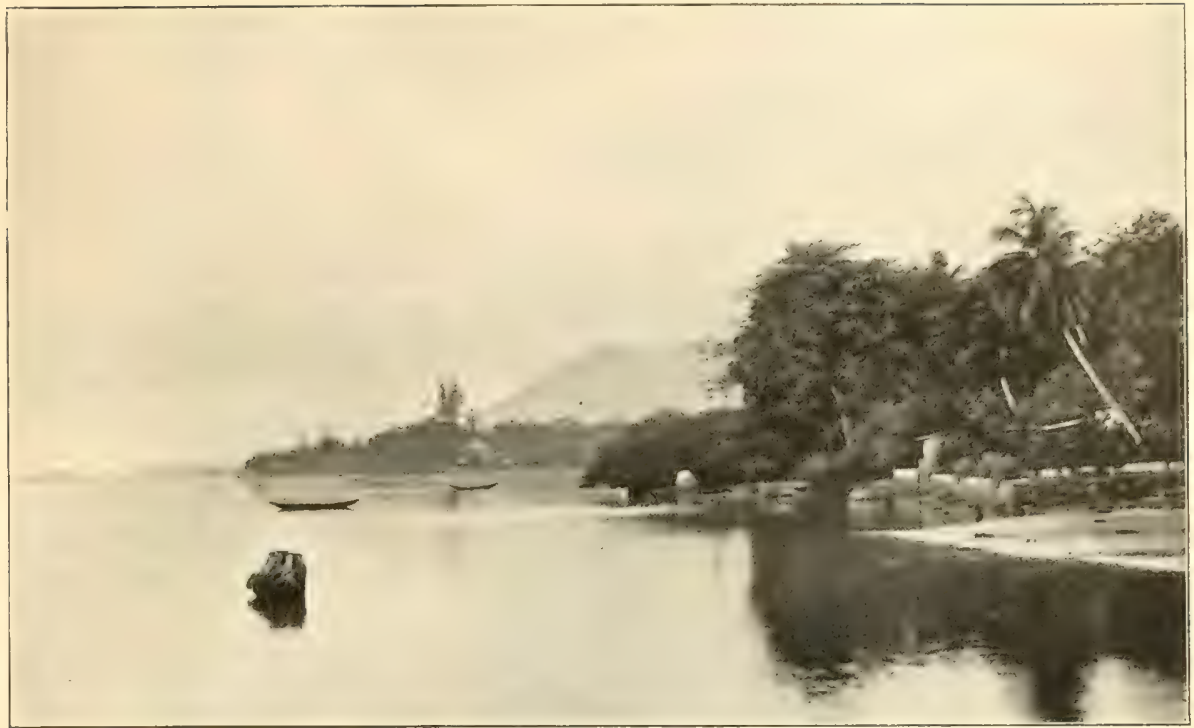

Strandfeneris von Port Diftoria.

gehen werden, da gerade dic Danille in ihren Erträgen fïh fehr lantif erweift uno

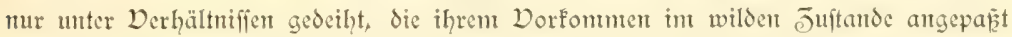
find. Das Bonvernement felbft hat eine 2lnjabl pon Danille=Plantagen angelegt, deren früdte mit Stichen genarft find, un die Defraudation ju verhüten.

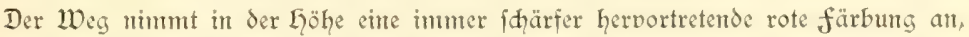
Sie durd den Eaterit, den für die Tropen dharafteriftifhen Derwitterungsboden des Granifes, bedingt wird. Un den (Franitblöden, die teils vom zliorne Seychellois herab= gerollt find, teils in weiterer Entfermung nod anftehen, mad) nich Prof. Braner auf jenfredite Zillen aufmerffam, die im Eanfe der Jahrtaufende durd das Regenmaffer und mitgeführti Quarjfömthen ausgefaliffen wurden. 23afonders anjichend seftaltet fith die Wanderung berganf dadurh, daf hie und da noh Refte des alten Waldes in Geitalt von auf Steljen ftehenden Pandanus und Palmen fid erhalten haben. 2/n den Gängen des 2lorne Seydyellois treten fie bisweilen nod ju gröfzeren Beftänden jufammen, umrahmt von wahren Wiejen der für die Tropen typifhen farne aus der fantilie der Eleidhenien. Durh ihre didhotonte Derjweigung und ihr gefelliges Dorfommen an fonnigen Standorten beftimmen fie nidht wenig den Charafter der Sandidiaft. 


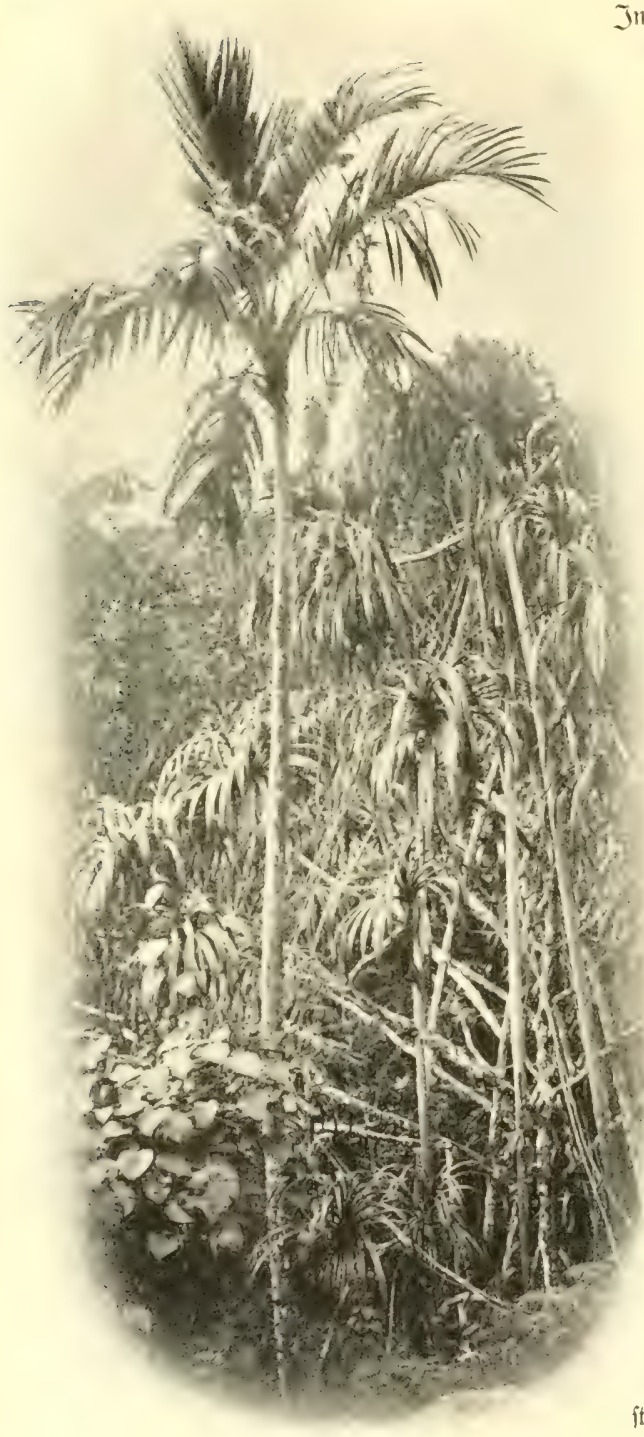

In der fühleren Göhenregion ha= ben vermögende Bewohner vou Tăahé elegante, von wohlge= pflegten (5ärten umgebene $\mathbb{S a n t}$ = häufer erbaut, weldie fith um cinen als sa zrifière bezeidy= neten Bergrüden gruppieren. Die 2lusfitht, die man hier geniefift, ift eine der pacfend= ften, weldhe die Tropen ju bieten vermögen. Ütber die Santhäufer, die Ģärtent und plantagen hinweg fdrweift der Blitế zu dem fühn auf= ftrebendent 2liome Seydel= lois, deffen Giöhe man um fo mehr 强 überidützen ge= neigt ift, als den (⿹弋ipfel sine rebelfappe verdect. Redits flanficren ihn dic orei Gipfel der Trois frè= res, linfs ragt fühn der 2liome Blane auf, um fteil gegent dic $\mathfrak{W}_{\text {eiffüifte }} a b=$ jufallen. Diçen Ğipfeln find abgerumbete, bewaldete Kuppen und Baftionen mit Steilabfällen vorgelagert.

2Nant überidgant die weit in den tiefblauen Indifden Decan vorgejogene, von wei= Ëer Branduntg unţäumte Torbhälfte der Jufel mit ih= ren wie Couliffen fidh einridie= benden Gähentrüđen; deutlich erfemt man die weif̧et Ģäuler= maffen von 2rahé, den langge= ftrefften Diftoria $=$ Picr, und die imt 


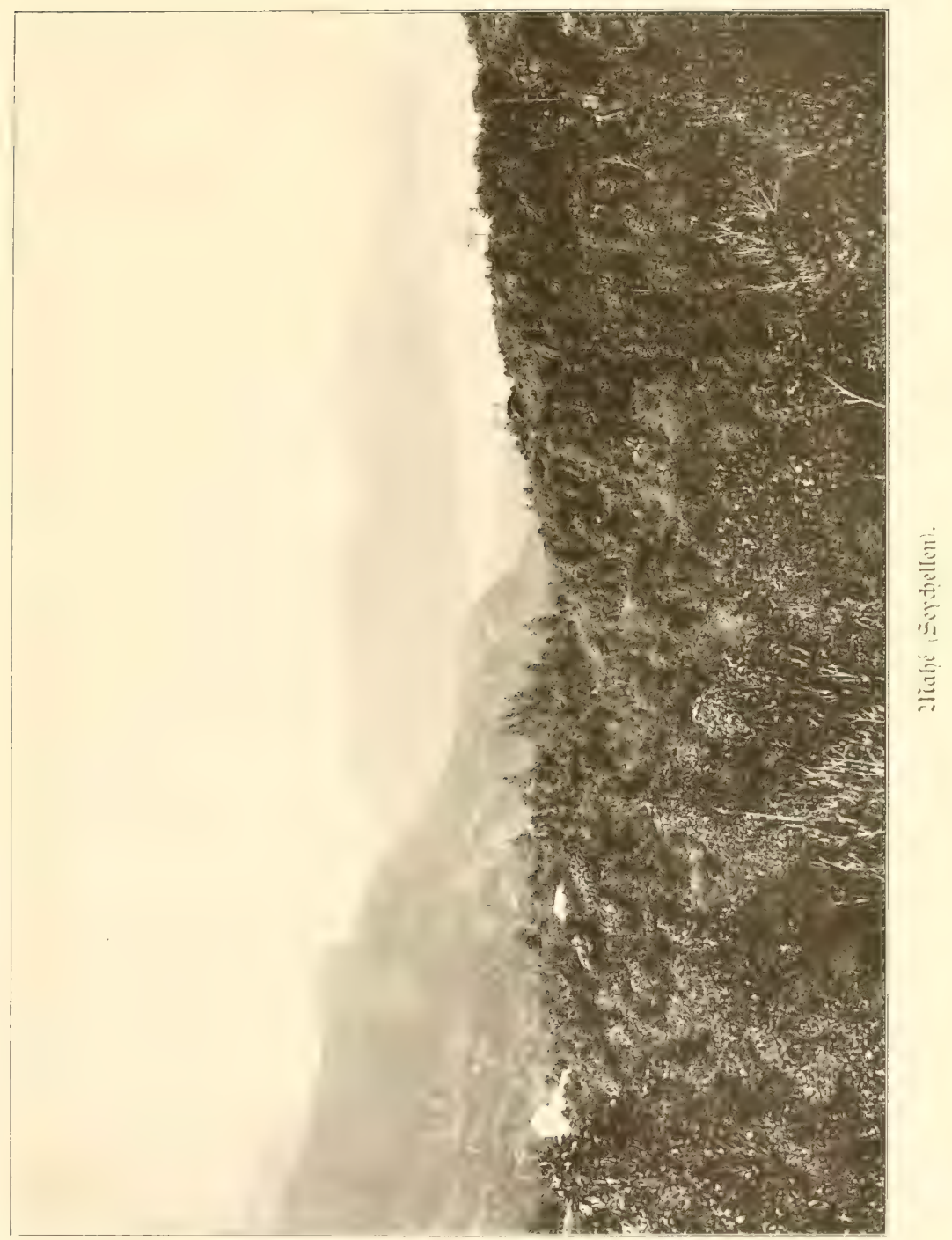



farbenreidhen, von fletnen Jnfeln umfäunten Gafen peranferte "Daldivia". Die Sceneric erimert an italienifhe Küftenlandfhaften, übertrifft fie aber durd die fatten leudtenden farben und durh die Pradt der tropifinen Degetation. 2lian begreift es wohl, da mant fin in einer fo paradiefifhen Lmesbung in fein Sandhaus jurück= jieht, unbehelligt von den fährlithfeiten, die in Geftalt von fieber und Eyflonen den füblidher gelegenen 2lĩasfarenen jufontmen.

Das Klima der Seydellen wird mit vollem Redyt gerühnt wegen feiner (5leidy= förmigfeit und des freibleibens von exceffiven Gitzegraden. Die mittlere Jahres= temperatur beträgt $2 \bar{z}-29^{\circ} \mathrm{C}$. bet tägliḑen Sdiwantungen von $6-z^{\circ}$, und fann hier oben in der Liohenregion bis auf $20^{\circ}$ funfen. 2iiḑt jum mindeften verdanfft indeffen

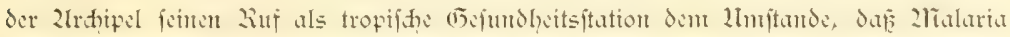
auf ihm naheju unbefant ift. Dies mag wohl wefentlid dadurd bedingt werdẹt,

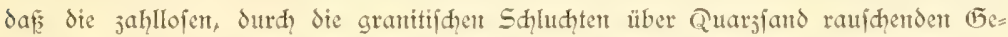
birgsbähe auf den fteil nach allen Seitent abfallenden Injeln feme funtpfigen Zite= derungen bilden. Sie funden fith mur auf dem flachen füdliḑen Teil von 2lĩahé, der

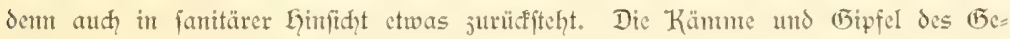
birges find fajt ftets in Wolfen verfteft, und die ftändige fenditigfeit trägt daju bei, daß die Baḑlüufe niḑt verfiegen. Pbwohl wir im füdliḑen Sommer während der von Dejember bis 2lpril dauernden Regenzeit entuetroffen waren, fo hatten dod gerade in diefem Jahre anomtale Derhälntiffe geherridt, infofern feit fieben 1 od en fein Regen gefallen war. Es war dem aud glïhend heip. als wir um dic 2rittagszeit surdy fhattenlofe Sdquḑten auf fteinigent, wentig begangenem Pfade uns dem zlount

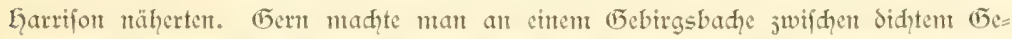
büfh von Tropenfanten aus der familie der 2liarattiaceen Falt, un cin bejcheibentes

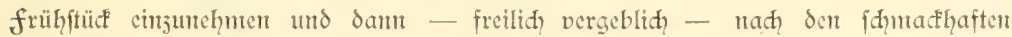
Krebfen ju fahnden, an detren es int den Wafferläufen der Seydellen nidyt fehlt. Bes

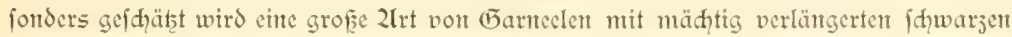
Dorderbeinen (Bithynis), weldye den Zlufenthalt im 2lieere mit dem Ieben im Sïßz= waffer der (5ebtrgsflüfie vertaufd?t hat.

Zur nod cine furje Wanderung und dann eröfinnete fiḍ der 2lusblit auf die be= waldeten Gänge des 2liount Garrifon mit feinen mädttigen Kapujinerbäumen (Sideroxylon), deren gewaltiger, 5-6 m breiter Stantm bis ju $50 \mathrm{~m}$ föh fï fid erhebt.

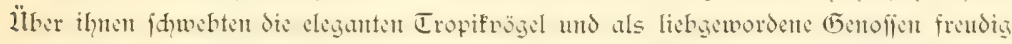

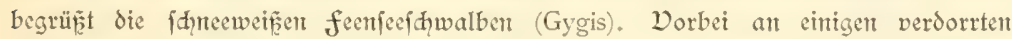
Stämmen, die gefpenitifh ihre z̈lifte reften; ging es in das geheinnisvolle Dumél des alten Sephellenwaldes.

Er trägt einen fo eigenartigen Charafter jur Sdhau, wie er uns bisher in Feinem

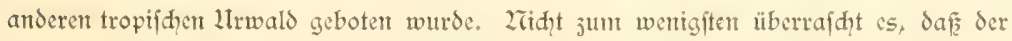


Pandanus (P. Hornei und Seychellarum), fonjt an dic Küftenregion gebunden, hier in der böhe walbbildend auftritt.

(3) ihm gefellen fid cine 2ujahl den Seydhelfen cigentünlider Palnten, die nidyt

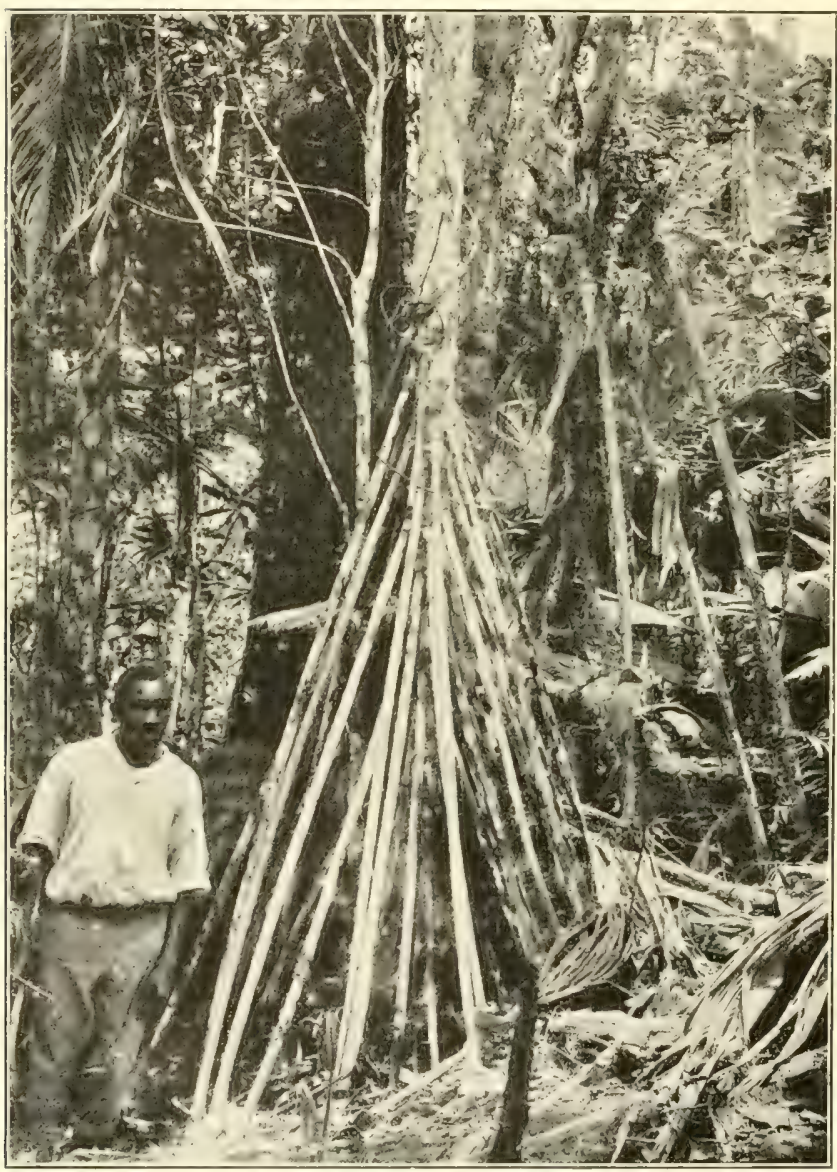

Wurzelifelyen oer Verschaffeltia splendida. wertic $d a=$ Surd feffelit, daf fic anf Etclint $\mathrm{fte}=$ ben. Diss gill nament: lid) für dic Verschaffeltia splendida, neben der Roscheria melanochaetes und dic mit breiten fädhern aus: geítattcte Stevensonia grandifolia herridiend auftreter. zrian glaubt in ein liber= fülltes Treib= hans ju font= men untd fin= det faum den Weg durd diefes (1) wirr pradhtvoller palmwedel. ab und ju drängt fithein Baumfarn.

die grajiöfe Cyathea Seychellarum, ein, während der Boden an viclen Stellen von den cin hohes Difint bildenton Cyperacen (Hypolytrum latifolium) bedect wird. Die 


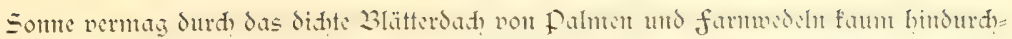

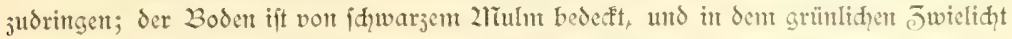
herridht jener eigenartige Urwaldduft, wie ihn der 2lioder und die fane bedingen.

reben Palmen, Pandanten und farnen birgt ber alte Seydyllemwald nod einte fülle von Saubhöljertt. Der Kreole belegt fie mit eigenen Ziamen und unterideidet fite fhärfer als der 30 ta= nifer, der ntanthe deriflben nod) nidht in das Syftem cingereiht hat. Wir exhiel= ten von dem Gouvementent cine Santntlung von etwa 40 verihiedenen Golzarten jum (Befकhent, unter dentr mandie durd ifre Sdwere unto feftigfeit fich ausjeich nill.

Das Tierleben ift im Urwalde nid̨t gerade reta entfaltet; immerhin ver: moditen wir in ihm einte 2lnzahl für die Seydellent ty= pijher Sungenfhnetent uno Infeften 3 fanmeln. Ilns ter den letsteren fanden fid aud Vertreter der (1) cipenfit= heufdreden - allerdings midet jenter 2lrt, dic als "wandelndes 23latt" (Phyllium siccifolium) von den ¡đ̆arfäugigen Jungen an fontigen Standorten gejam= nelt und gern dem frent= den angeboten wird. Sic

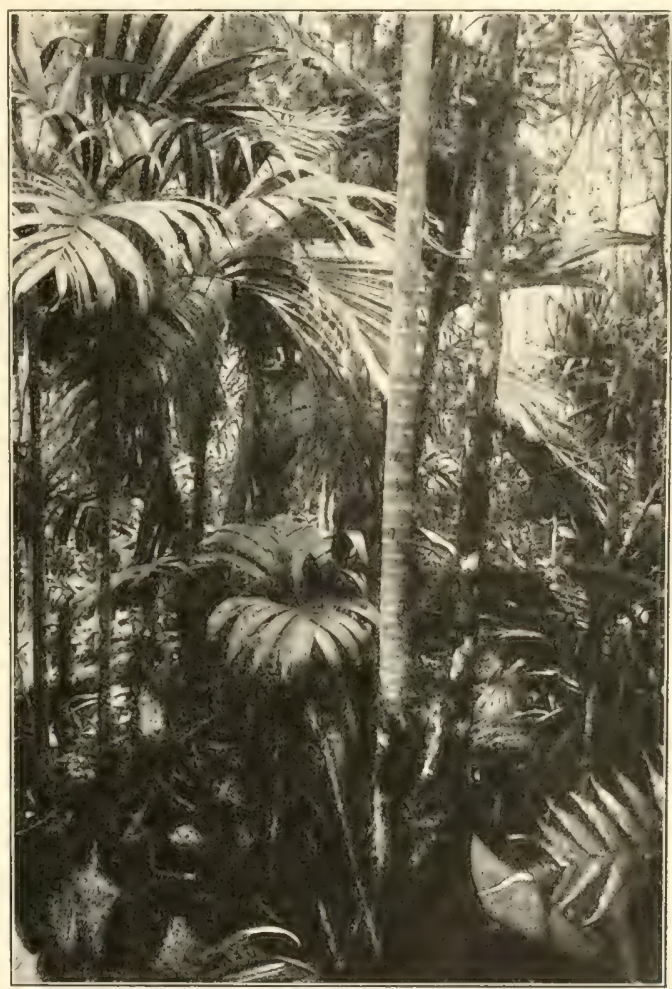

Urmalo auf Mtahé (27tount Earrifon). ahmt fo täujhend in farbe und Geftalt grüne Blätter nad, daf̧ man felbit auf einem

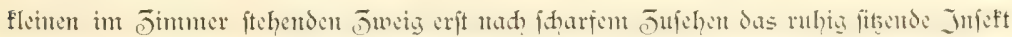
crfennt. Die eigentartigiten Dertreter der Seydyellenfauna funt die Blindwühle (Coe= cilien), welthe indeffen niḑt nur in dem 2lium und den mrodernden Stämmen des Lrwaldes, fondern aud, bis hinab ju der Strandregion in fenditer Erde gefunden 


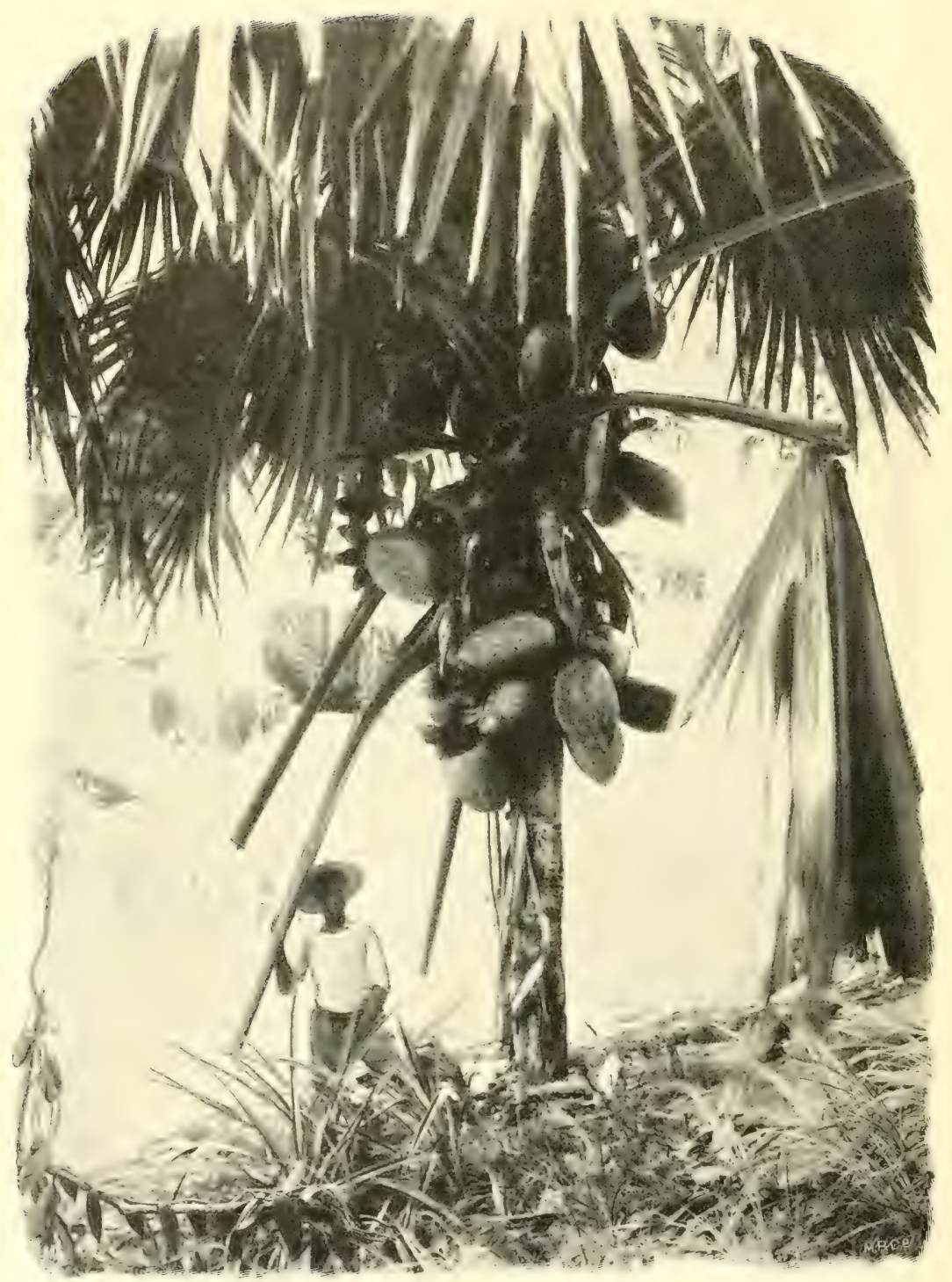

Etamm einer jüngeren weibliden Lodoicea mit frühten 


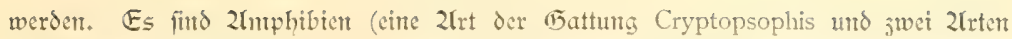
der (Gattung Hypogeophis), die freilid in 2lnpafiung an die unterirdifhe Ecbensweife niḑt mux ihre 2lugen, fonden aud ihre (1)lisomafen verloren haben und äuf̧erlid?

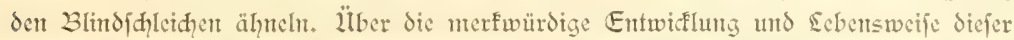
uralten formen haben dic Unterjudungen von Prof. Brauer - nidit minter aud diejenigen der Dettern Sarafin liber die Ceylonifden Blindwühle - befriedigende Zufflärung gebrad̨t.

\section{praslir.}

In dem Botanijhen (5atten von Perabentia auf Ceylon wurde uns vont dem Direftor als cines der ftolzeften Sdauftüfe cin Eremplar der Lodoicea gejeigt, das freilid ein Jwerg war im Vergleid, mit dem Stamme, der bas (Jouvernements= gebäube in 2liahé überragt. Zls iđ ftaunend vor sicjer Wunderpalme mit ihren

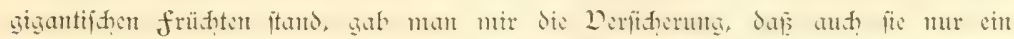

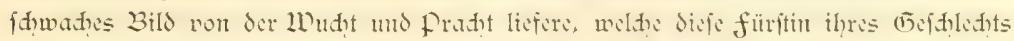
an dem natürlidien Standorte darbiete. $E_{1}$ ift freilid ein auferordentlid befdränfter, infofern fie fitc tur auf Praslin und der Radibarinjel Curieufe - audy dort wieder nur an engumgrenjten Stellen — findet.

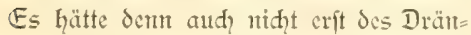
gens von freund Sdimtper bedurft. um uns ju veranlaffen, cinen Stand=

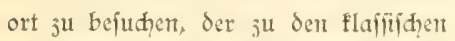
der Erde gehört. Wer niḑt die Lodoicea in den emfamten Thälern fah, wo fie heimifid ift, der femt nidit die Sephellen! Der Jufpeftor der forften, 2lir. Baty, gab uns mit feiner (5)mahlin und feinem Bruber das (5eleit, als wir am 8. 2liär m mit dem โqafenfapitän an Bord vor Somtenauf= gang den 2lnfer lich = teten, um durd, die ipiegelglatte See, dic

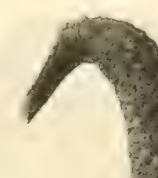




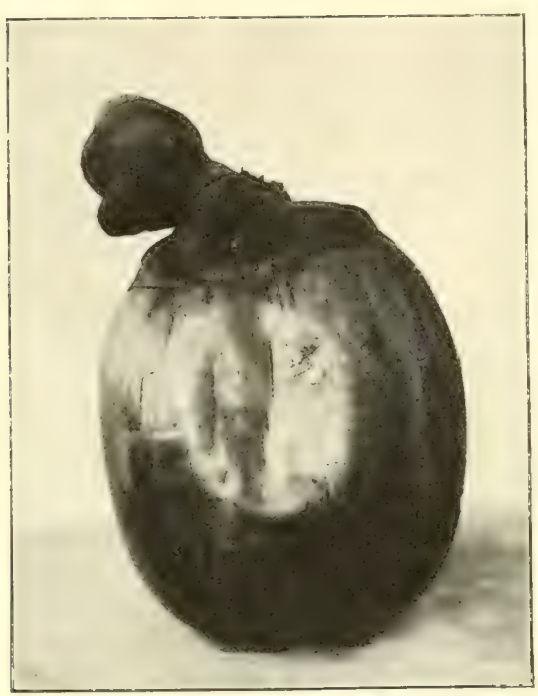

Lodoicea, frudt mit erhaltener duģerer Eille. ab und ju von fliegenden fijhen unt Delphinen belebt wurde, nach Praslin abjufahrer. 2rad dret Stundert trat die grüne Jnfel immer impofanter her: vor, und nidyt wentig fteigerte fid die Erwartung, als wir bet der 2lmäherung ithon von 30 r $^{\circ}$ aus mit dem fermohr die gelblid =grün fiđ abhebenden Kro= nen der Palmen benterften. Wir war= fent bet der Bat non St. 2fme an der Sitfeite der Jufel 2fnfer und fubren in ber Dantpfbarfalie auf die mit Sar= gafium didyt bewadiente Riffregion ju. 2h dem fandigen Strande erwarteten uns Zieger und gern fuhte man Sdut vor der glüherton Some in Shatten eintes fichen, mit Palmen gededten Goljhaufes. Fin roter Sateritpfad führt berganf nad der 2rordoftfeite der Jnfel, wo in mur jwei Sdiludten sie Palnen wadifen.

Es lägt fid fhwex der erite Eindruf wiedergeben, den bei eiter überrafhenden Wenduns des Pfades an ciner teilwetie geliditetent Sdoluht die gewaltigen Stämme madon. Die Wudit in der Entfaltung der Saubfäder, die Sdönheit und Elezanj der

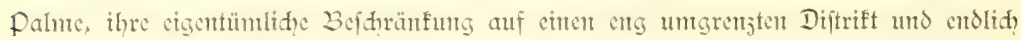

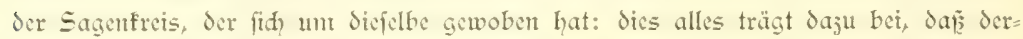

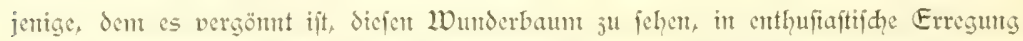
gerät. Zlä begreift wohl, daf̧ sinmé die Palmen als Principes bejeidnnete und fie an die Spitse feines Srftentes ftelite, weil cr, volt der Zliajeftät ihrer Erfochumg ge= faft, nidyt wagte, fie in cine der übrigen Pflanjenflaffen cinjureihen.

Kerjengerade erheben fïh die mähtigen, hellen Stämme bis ju eimer Löhe von $40 \mathrm{~m}$, dancben dic jüngeren Palmen, welche anfheinend direft aus dem $300 \mathrm{ct}$ ihre gewaltigen, bis ju $7 \mathrm{~m}$ hohent und $4 \mathrm{~m}$ breiten Blattwedel fpricfen laffert. faft mödte

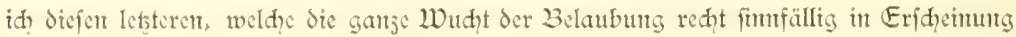
treten laffen, den prets vor den älteften, hod, über die Kronen der l̈brigen Bäunte ragenden Stämme crteilen. Die mittelgrof̧en weiblidhen Stämme find riber und über

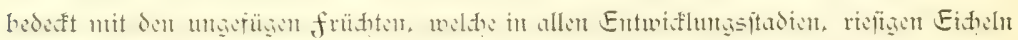
gleidiend, dem frudititande anfitsen. Wie der Wedel, fo ift aud? die frudit die mäh=

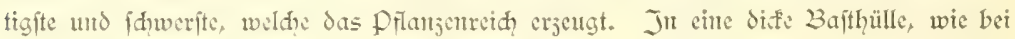




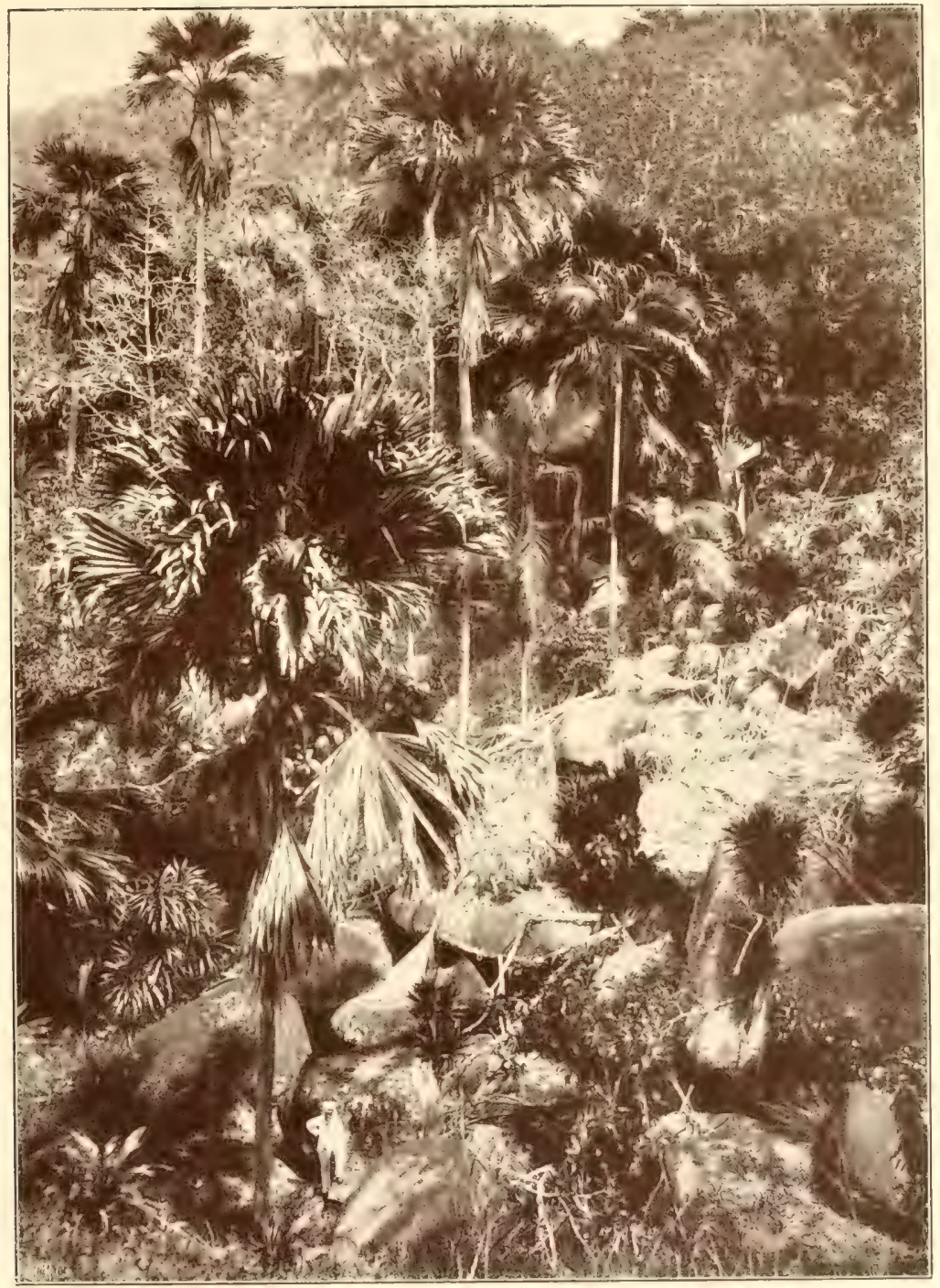

Lodoicea Seychellarum auf Praslin. 

der Kofosfrudt, cingehüllt liegt der cigentlide Kern mit finter hergförntig cingeferbten Shale, die policut fowwarj wie Elfenbeir erjheint.

Dieje wunderlidien, cinn balben Centuer jhweren fridite waren es, weldhe $a b$ und ju von den Strönumgen an die 2lialediven und weftlï̧en Küften von Judien ge= trieben wurden und dort feit alter eౌeit geredhtfertigtes Erftaumen crregten. Da man über thre Gerfunft in unflaren twar, Gielt man fe für 2liecresprodufte und gab thnen

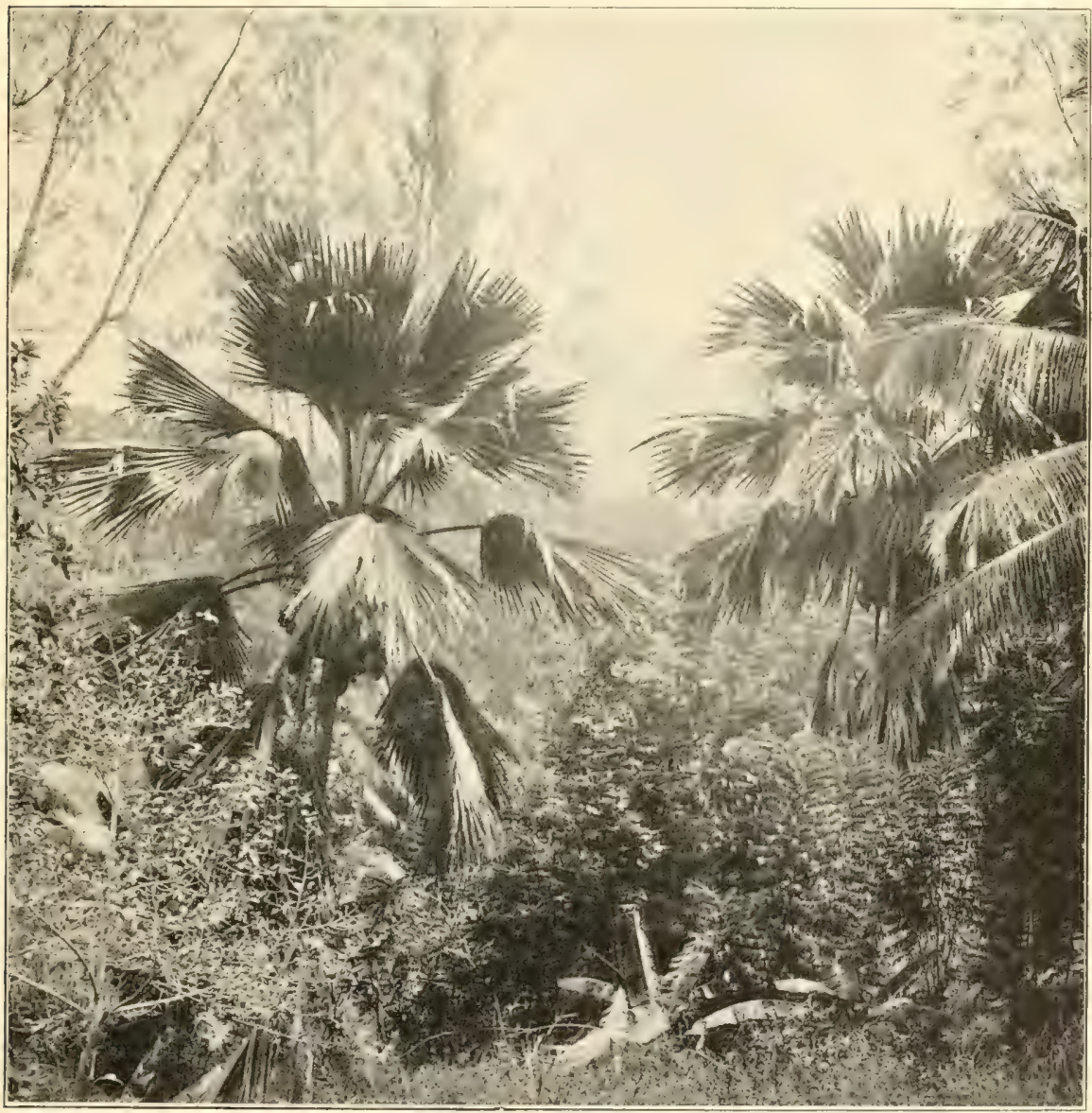




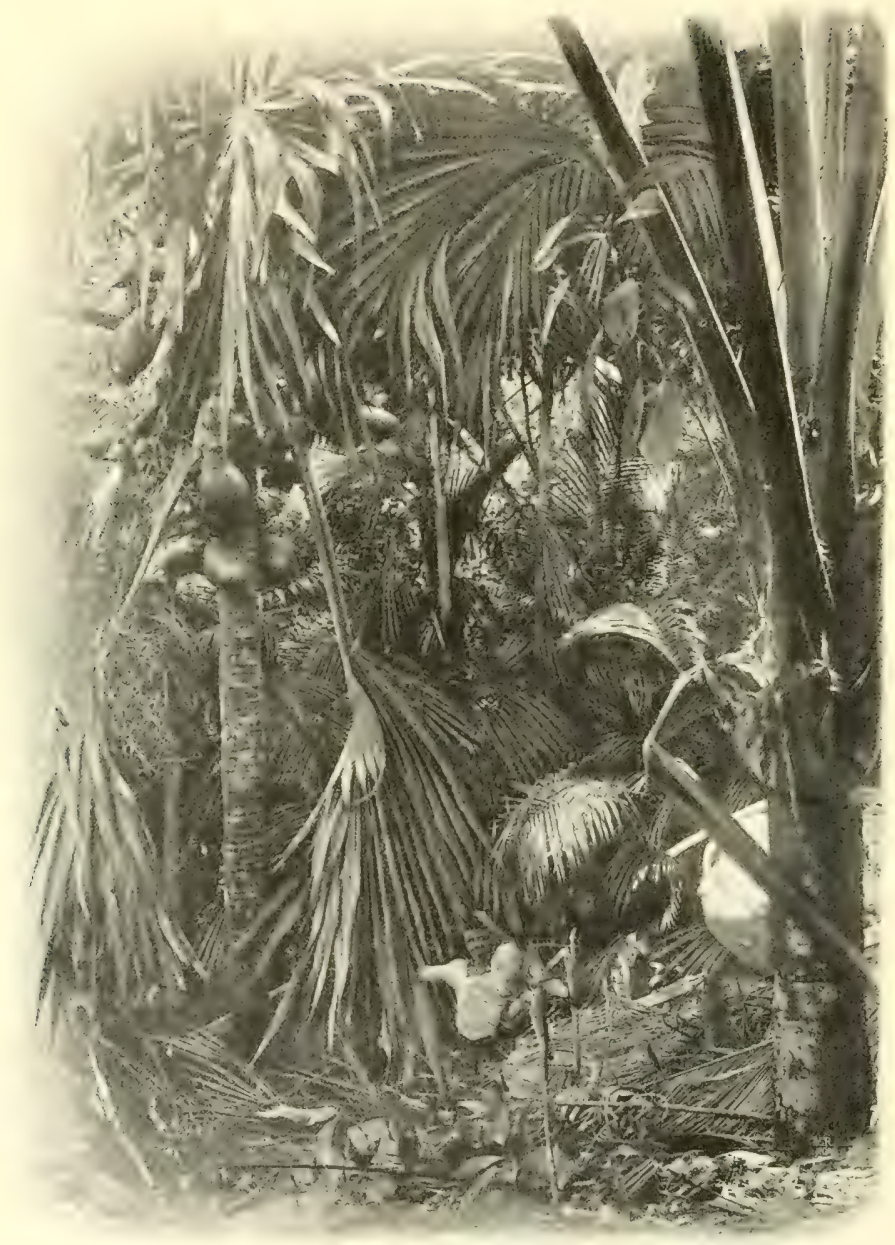

Lltwald auf Praslin.

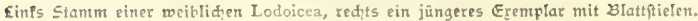

den heute nod gebrüuḑlidien 2tamen Coco de mer. 2lian legte ihnen geheimuts= volle Kräfte bei und wog fie fajt mit (5old auf: foll dod Rudolf von Ķabsburg für eine cinjige frud,t 4000 Goldgulden bejahlit haben! Erift im Jaḩre 1269 wurde 
gelegentlith der vont dent Due de prastin angeordneten 2Interfuḑung der Sepdiellen dic

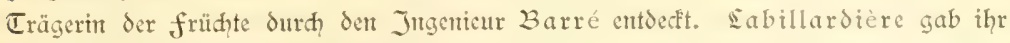
dann den heute nod ju Ređịt beftehenden Zramen Lodoicea Seychellarum. Barré war fo unvorfiḑtig, cine Korvette nit Coco de mer zu befrahten und nad Indien

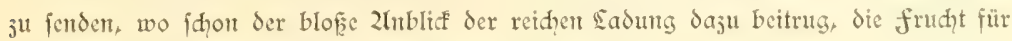
alle Jeiten int Werte ganj erheblid fallen ju laffen.

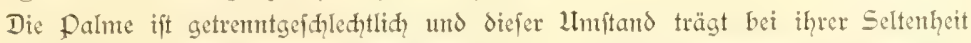

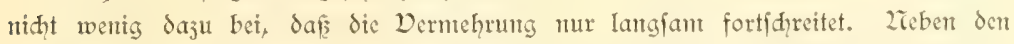
weibliden palment wurdent wir balo auf dic mämlidenen aufmerfiant, weldhe an cinem etra I m langen Blütenfhaft jahlreiḑe uniḑentbare, gelbliḑe Blüten tragen,

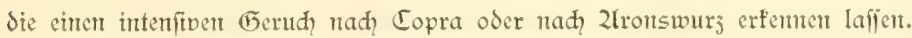

feffelt die Palme fhon durd ihren fraffitrofenden Wudss, fo futd ihre fonftigent

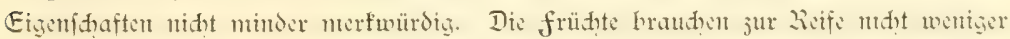
als 7 Jahre; werden fie int den Boden cingepflanjt, fo dauert es 1 Jahr, bis der Kcim eridheint, häufig mehrere 2lieter unter der Dberfläḩe hintfrieḑend, bevor cr nadh

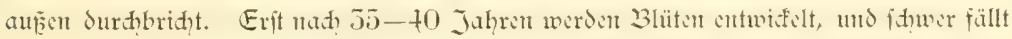

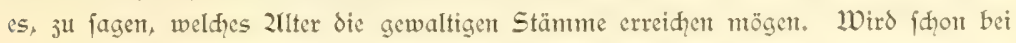
der Kolospalme jeder Teil des Baumes verwertet und gefhäht, fo gilt dies in rod ḩöheremt Grade für die Lodoicea. Das Ģoly des Stammes ift fdqwärzlid unt fheint

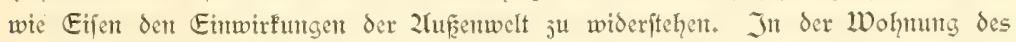
dentifen Konfuls, Dr. Brooks, fah id eimige Stänme der Lodoicea in den En= pfangstaum eingebaut: cit $\mathfrak{G}_{0} \mathrm{I}_{\mathfrak{j}}$, niḑt ninder foftbar und wideritandsfähig, als das= jentge des Kanarienlorbeers. Dic Blattwedel verwendeten die Eingeborenen von Pras: lin zum Deffen der Gü̈ten, aus den Blatffafen fertigen fie fledttwer und elegant gearbeitete Dantenhüte, und die harte Sdłale der fruḑt verarbeiten fie zu mamnig=

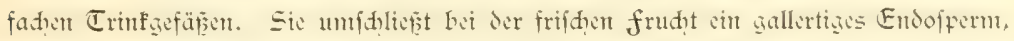

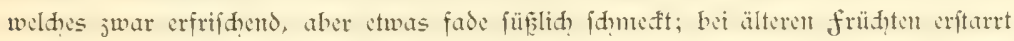
es ju einer harten, weifen 2rafafe. Die Palme wäre vielletdyt fidon ausgerottet, wemt niḑt John Gornc, der verdiente Dircftor des Botanifhen Cartens von zliauritius,

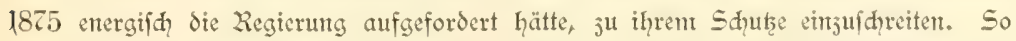
wurde denn das cine Thal auf Draslin, in dem die fhönften Exemplare ftehen, und

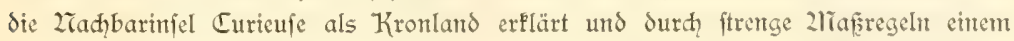
2usrotten aud der übrigen Eremplare vorgebeugt. Dic Lodoicea fommt in dent

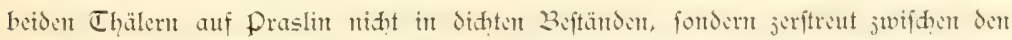

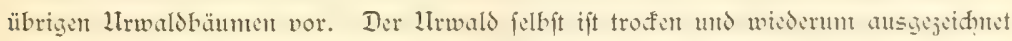
durd den Reidtum an fonfifigen Palmen, unter denen namentlid Ser elegante, ende= mifhe palmift (Deckenia nobilis) auffällt. Wie in 2liahé, fo fehrt aud hier die Stevensonia mit ihren gewaltigen 3 lattwedeln und woll $\mathbb{E a u b h o ̈ l j e r n ~ d a s ~ s ~ b o i s ~ r o u g e . ~}$ 
(Wormia) wieder. (E)gent das 2licer $j^{u}$ traten, untermifht mit Lodoicea, Kafuarinen und prädtige Stänme des auf den Seydellen als bois Tatamaka bezeiduneten Calophyllum auf. Dereinjelt war bent aud nod der Pandanus Hornei eingeftreut.

Ein Pifnif unter dent näḑtigen Eaubdad einter Lodoicea bejdlof den erften Tcil

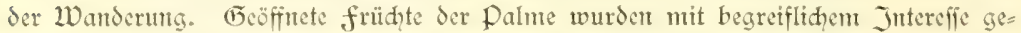
noffen, und hicran fdilof fidh cin luFullijhes 2liahl, das dent Sterbliden wohl nur einmal ju teil wird: Palm= fohl aus einer män = lidhen Lodoicea berei= tet, der als Salat mit feinem mandel= äbnlidhen (5)efdurat nod mehrmals an Bord - derm wir erbielten cinter fol= hen Trieb jum (E) $=$ jhenf - wohl die feinfte Delifatefie $a b=$ $g a b$, weldewir über= haupt auf der Reife genoffert.

Den Beiduluf un= feres 2lusfluges mad? Praslin bildete cine freilid heiffe 10 an $=$ derung über Sen L)öhenrüden an dic 2Tordfüfte, two twir vort den dort ant= fäfigen Kreolen und Zegern liebenswür= dig aufgenommen und fpäter in $200=$ ter trad dem ver= anferten Sdiff ju= rütbefördert wurden.

Dort wartete unferer cine reue l̈berrajhung. 


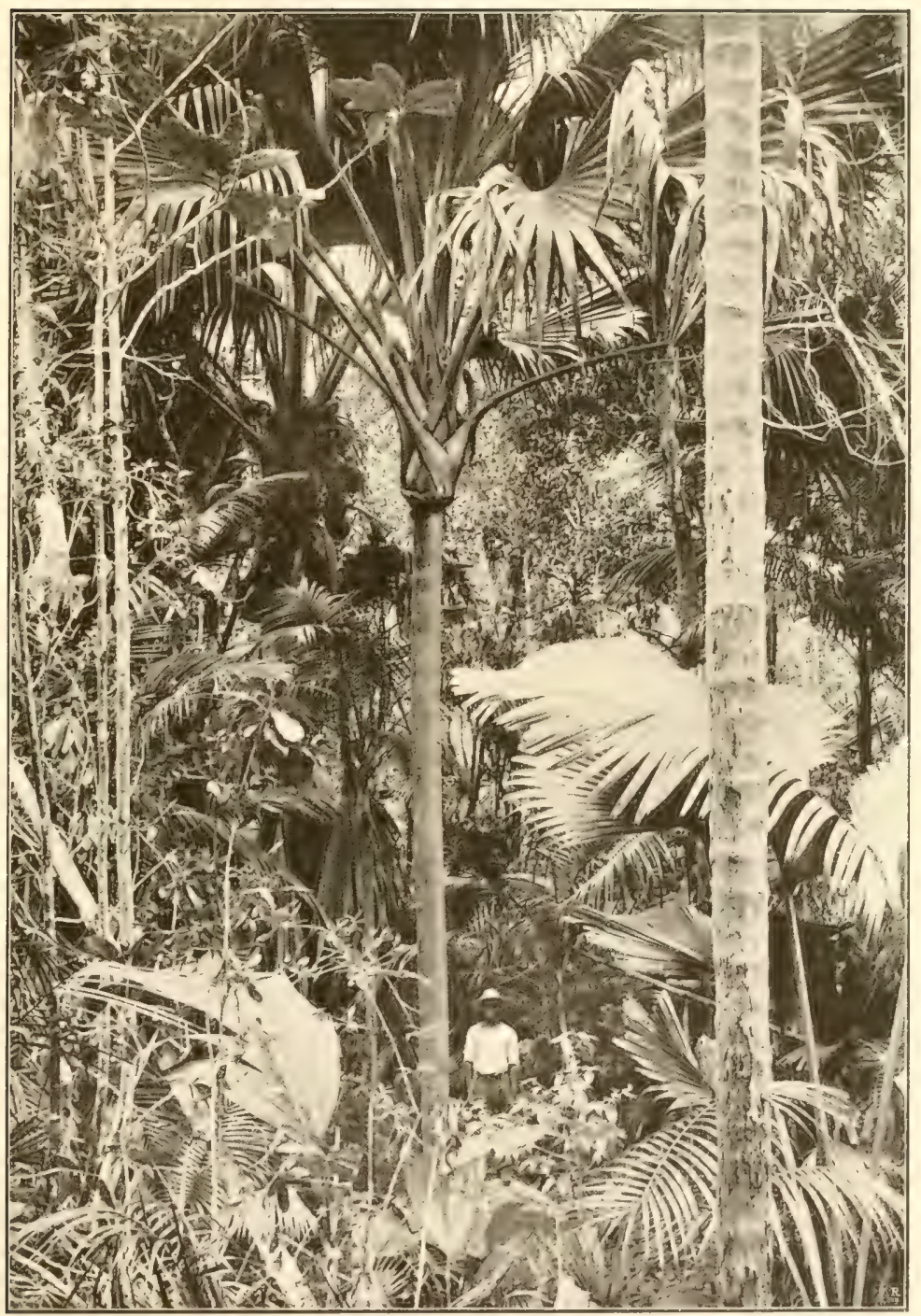

Lrwald auf Praslin mit sodoicea. 

Der Befitzer von félicité, 2lìr. Garald 3aty, war in Beglettumg umferes 2iaví= gationsoffiziers in der Dampfbarfaffe nad feiner Jufel gefahren und hatte von eitrem

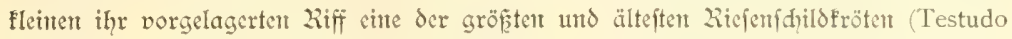
elefantina) abgeholt, unt fic der Expedition jum (befqen£ zu maḑen. Es war dem aud thatfädlid ein faft antediluvianifd fid ausmehmendes 2lionftrtm, weldhes vor mehre als hundert Jahren (der Grof̧pater eines auf félicité anjäfígent bejahrten 2egers hatte beretts die Sđildfröte gefannt) von 2lldabra übergcfühnt worden war. Da uns 2lir. Baty nod jwet weitere, allerdings jüngere Excmplare, fhenfte unto Dr. Broof́s diefen enn für $S_{e}$. 2lajacität den Kaifer beftimmtes hinzufügte, fo war

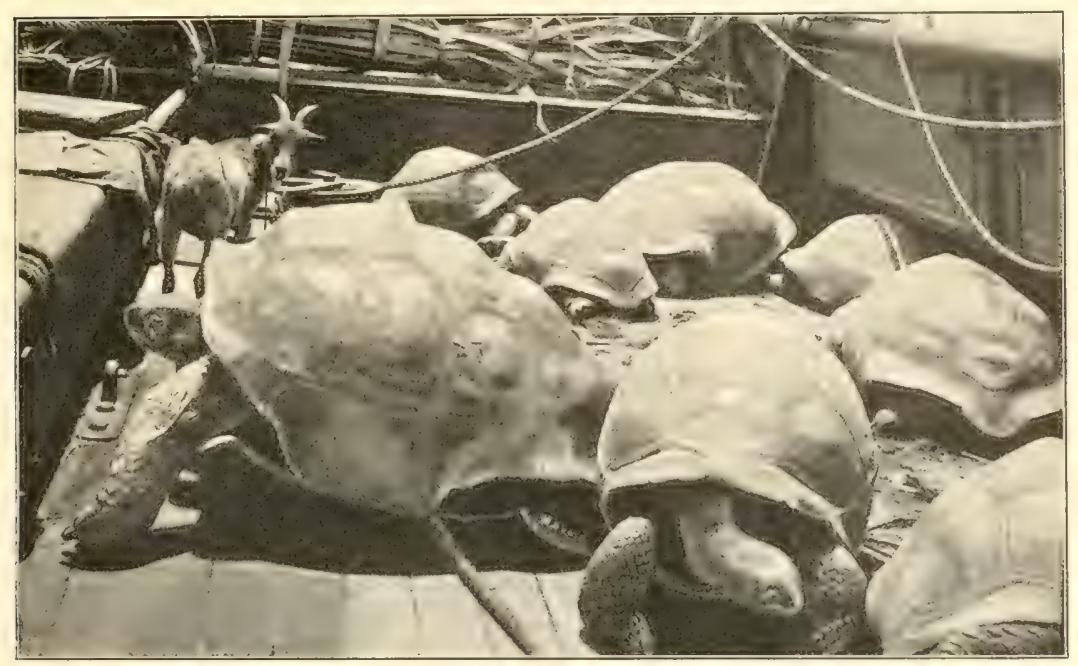

Die Elefanterfdilofeöten an Bord ber, "Daldivia".

es eit ftattlidfer Beftant ftumpffinmiger Riejen, der fid an Bord der "Waldivia" unthertrieb.

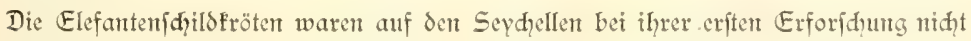

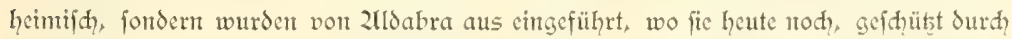
die 2lbgelegenheit der Jnfel und durd ihre verftefte Sebensweife int didten 3 ufd in

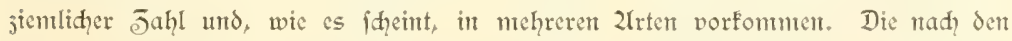
Sepdellen eingeführtent pflanjent fid mit Eeiditgfeit fort, und fo hält man dent auf den meiften farmen cinen fleinen Beftand von Elefanteriffildsfröten, dic bei feftlid̨en

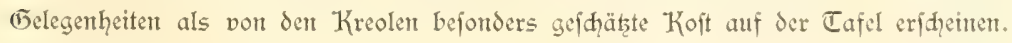


Da uns aud geftattet worden war, einige der feltenen endemifhen Dogelarten der

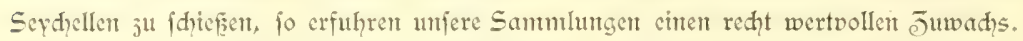
Dic Infeln des Seydullenardipels müffen fdion feit langer J̄eit getrennt beftanden haben, da faft jede der gröferen cine 2luzahl ihr cigentüntidier Sandformen aufweift. Dies betrifft fpeciell dic taubenartigen Dögel, unter denen die prähtigfte, nämlid Alectroenas pulcherrima, auf félicité erlegt wurde.

Uls wir mit botantifhen und joologifden Shäţen reid beladen ant Zabend wieder vor Port Diftoria angelangt waren und unfere fympathifien Reifegenofien ausgejetzt hatten, Fonnten wix die gaftlide Zufnahme, die wir auf den Sepdellen gefunden hatten, mux mit cincm befdeidenen Gegendienft erwidern. Seit 6 wodhen hatte Fein Dampfer 2lĩahé angelaufen, und fo übernabmen wir gent die poit, unt fie in Samfibar ge= wifferhaft weiter ju befördernt.

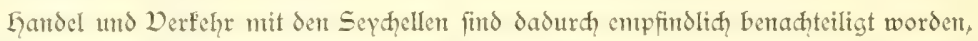
daf feit curer Reihe von Jahren die Messageries Maritimes ilqre fahrten nad zrahé fowohl, wie nad, Réunion und 2lauritus emitellten. 2ur felten - höḑitens den 2rionat cimmal - geht ein englifher Dampfer im Port Diftoria vor 2hnfer, und es find wefentlid, englifhe und unfere fleineren dentidyen Kriegsidiffe, weldye $a b$ und ju ctwas Eeben in das cinförnige Dajein bringent, intem fie die von der 2ratur fo reid gefegneten Jufeln als (5efundheitsftation aufiuḑen.

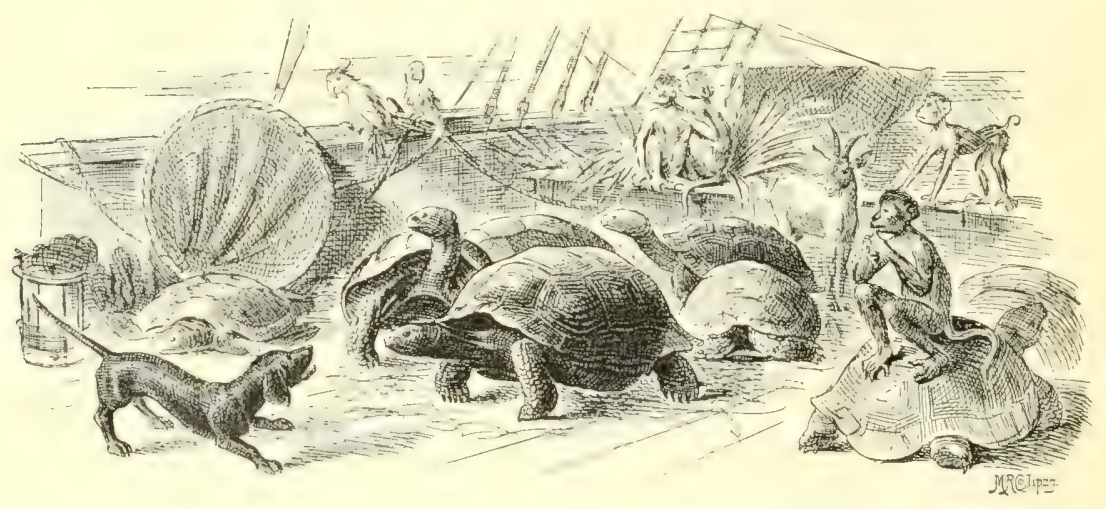




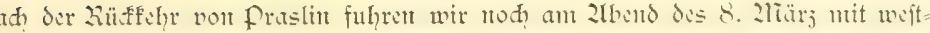

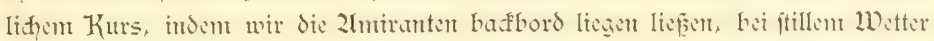
und wolfentofen Gimmel von den Sephellen $a b$. Während der adttägigent Reije bis zux oftafrifanifaen Küfte hatten wir ganj flauen Witd, der langfant 1tad 2Tordoft

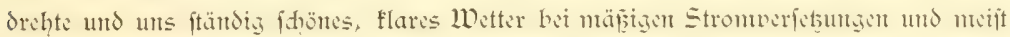
ipiegelglatter Sce bradite.

IIm die Erfheinungen an der 2reeresoberflädic, fpeciell aud den 2liangel aus= gefprodhener Strömungen auf diefent fahrtabidnitte würoigen zu fömen, dürfte es antgejeigh fein, einen Befantbliç auf die Strömungsverhältniffe des Indifąen Deeans während des füdlichen Sommers (des nördlihen Winters) zu werfen unt hierbei auf cinige Punfte jurüfjufonmen, deren wir bereits mehrfad bei der Sdilderung unferer

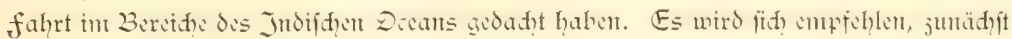

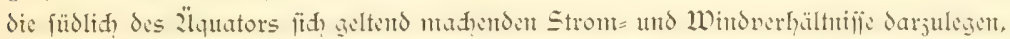

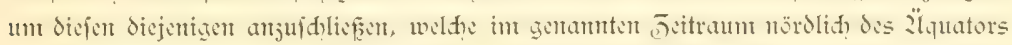

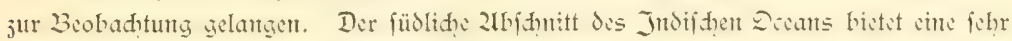
finnfällige Parallele ju ben Strömungen im fübliḑen 2ttlantifdyen Deean dar. Liter wie dort haben wir es mit einem gewaltigen Stromfreis ju thun, deffer 3 cwegung

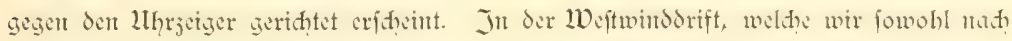
Derlaffen von Kapitadt, wie bei der fahrt nah den Kerguelen und St. Paul pafferten, werden die Waffermaffen durd dic "Branen Wiftwints", die meift ftürmifí auftreten, in fräftigen Strom nah Diten getrieben. Fin Ceil des falten Waffers trifft auf die Weftfüfte 2luftraliens, wird hier nad 2Tord und 2Tordweft abgelentft unt bildet den fogenanten Weft=2luftralitrom, der mit feintem fühlen Waffer ein (Begenftüs zu dem Benguelaftrom an der Suidweftfüfte 2lfrifas abgiebt. Er verliert fid in die von dent

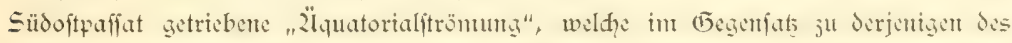

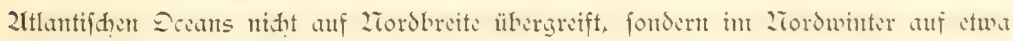
$10^{\circ}$ Sübbreite, in 2rordfommer etwas weiter bis auf $5^{\circ}$ Sübbreite fid geltend madt.

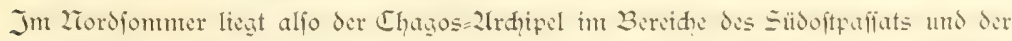

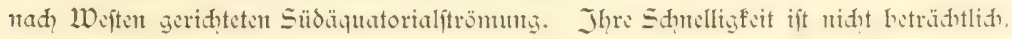




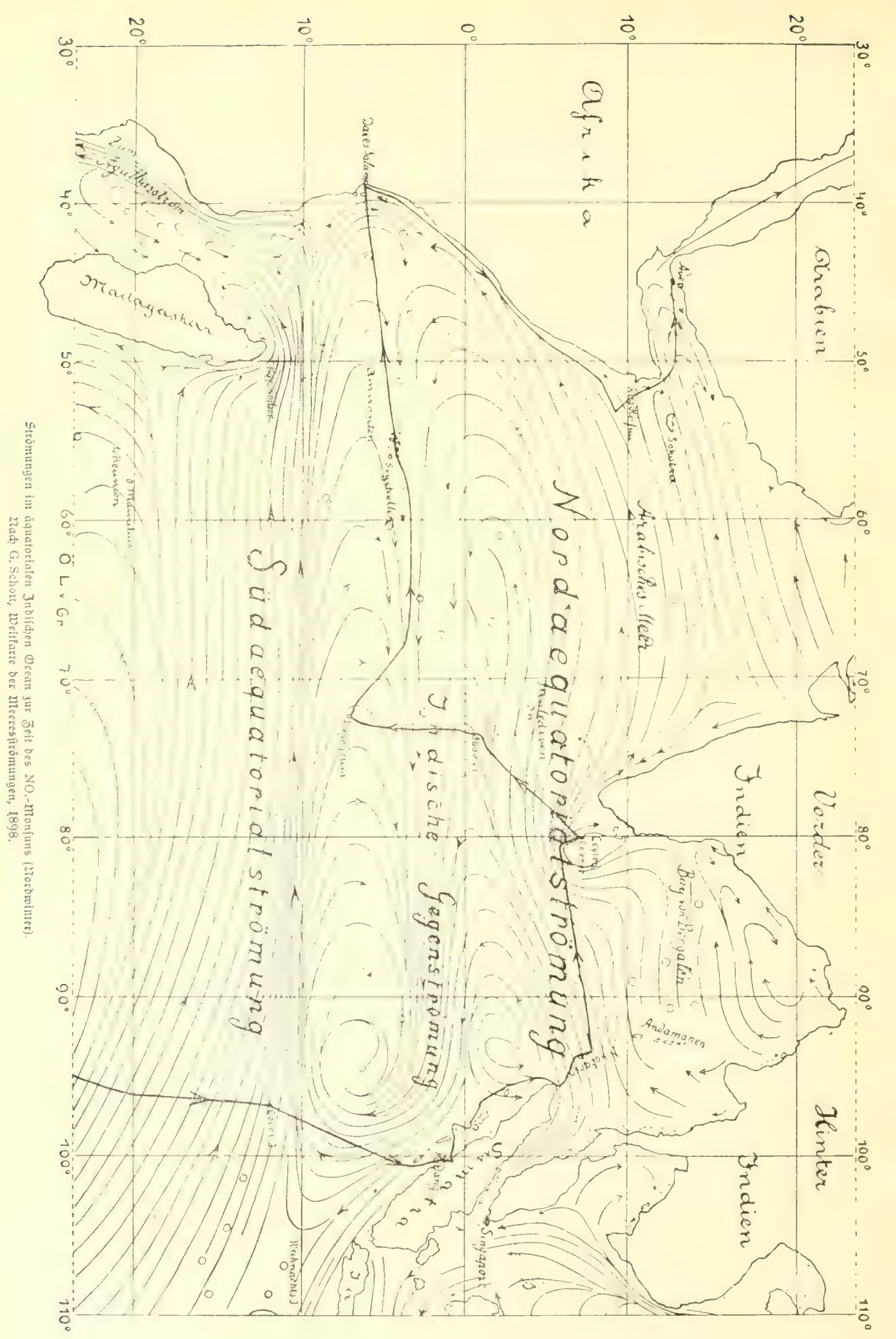


und nur ftellenweife, fo j. B. in der Ztähe der 2rordfitįe 2liadagasfars, bet Kap 2lutber, gewinnt der Stron über zwei Secmeilen ftündliđe Bewegung. Er trifft damt ungefähr in der Göhe des 10. fübl. Brettegrades auf die oftafrifanifhe Küfife und gabelt fid hier

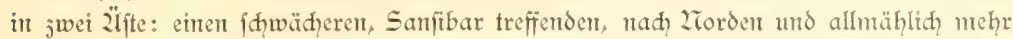

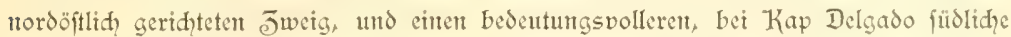
und allmählid mehr fiidweftlihe Riḑtung gewinnenden 2lit, den 2lgulhas:Stront. Ex bietet des Gegenftüt' des atlantififen Brafiltenftromes dar, ift indeffen weit mädqfiger, fräftiger und jugleiø, ciner der fonftanteften Ströme, den wir fennen. In feinem Znfangsteil aud als 2kojambique=Strom bejeiḑnet jieht er mit immer zunehntender

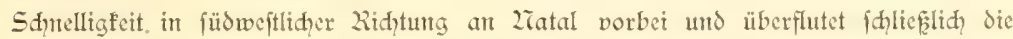
2lgulhas, Banf, um, wie wir bereits früherhin erwähnten, fith endlid in jahlloje

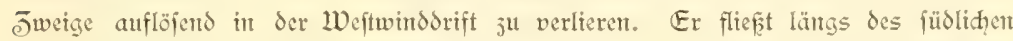
Kaplandes fo raid, dafi hier Sdiffe fhon bis ju 100 Scenteilen in 24 Stunden (im Etmal) nad Wejten verịeţt wurden.

Was mun die nördlidq vom z̈lquator gelegenen Stromgebiete des Indifden Dreans

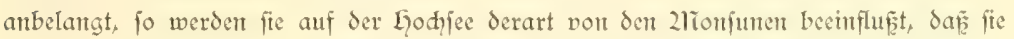
int saufe des Jahres ihre kidhtung wechfeltr. Int nördliḑen Winter, jur Jeit des heiteren 2Tordoft=2lionfuns, flief̧en die Waffermaffen faft durdhweg nad Weftent, int nördiḑen Sontmer, wenn der oft ftürmifh auftretende Südweftz2lionfun weht, ftrömt das Waffer der Dberfläde, hänfig ftarfe Derfetzungen bedingent, nad, Ditert. 2lït Redht hat man diefe mit der herrfhenden Windriđhtumg übercinftimmende Lhméf in der Stronesridtung als das gewidtigfte und fhlagendife Beifpiel dafür angeführt, dak in erfter Sinie die Strönungen durth bie herrifhenden Windriḑtumgen bedingt werden. Da wir im nördlichen Winter und frühjahr den Jndifden Dcean durdfuhtent, fo inter= effieren uns an diefer Stelle fpecieller die ju jener Deit fith fundgebenden Strönungen. Die Waffermaffen werden unter dem Einflus des 2Tordoftz2lionfuns fowohl im Golf von Bengalen, wie in dent arabifhen 2lieere, wie endlich aud in dent Breitenftridge jwifhen der 2rordipitze Sumatras, Ceplons und der ganjen jwifden den 2lialediwen

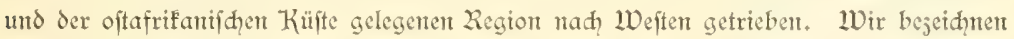
diefe ganje weftliche Ströntung als 2rordäquatorialftëmunts. Zllerdings treten fowohl im nordweftlidien Teile der Bai von Bengalen, wie aud andererfeits im $218 \mathrm{cn}=5$ Folf und unter der arabifh̨en Küfte Gegenftrömungen nah Dftnordoft refp. Ziordoft auf.

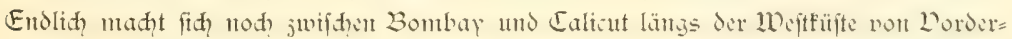
intient cin "longshore=Stront" nach Süden geltend. Ceylons 2ror $\delta=$ mo Sü̊füfte wir $\delta$ von der 2konjundrift umfloffen, dic hier und ant ZTordausgang der 2lialaffa=Strafe

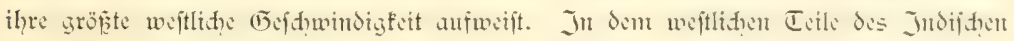
Deeans jwifh̨en dem z̈lquator und etwa $8^{\circ}$ Sübbreite find ganj veränderlidie und fehr fhwadhe Bewegungen vorhanden. Ziur nad Diten hin, in der kidhtung anf die 


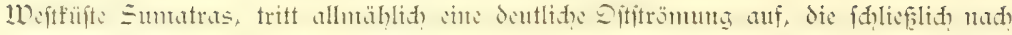
Süboft mit ciner bei ftarfen 2Tordweft=2lionjun oft jehr grofen (5ejdinindigfeit flieft. Diefe öflidhe (begenftrönumb ift, wic leidht cinjufehen, das indifhe, auf Sübbreite ver=

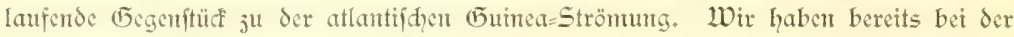
Sditlerung der 2lmäherung an Sumatra Ẽelegenhett gefunden, diejer im Bereidh des regenfipwangeren 2Tordwejt=2lionfuns gelegenen, fehr warnten Strömung ju gedenfen.

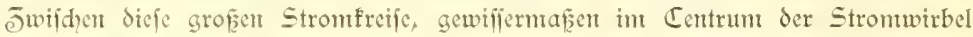
gelegen, f̧alten fid ftromlofe Eebiete mit Windfillen und bisweilen hohem Suftoruf cin. Ein folhes ftromlojes Gebiet pafferten wir füdlin des Z̈̈quators nad Derlafien vort St. Paul und 2Tcu=2lnfterdant, und in cin foldhes warent wir dent auch eint getreten furz nov 2lnfteuem uno nad, Derlaffen der Seyhellen bis in die zähe der oftafrifarifder Küfte.

Da bet Tage der Wind metft abflaute und nur in der Zadit fehr leidht aufbrifte, fo war es bei dem hetteren Limmel glühend heif. Das Thermometer zetgte bei direfter Injolation $50^{\circ}$, während fonft die Temperatur in Shatten jwifhen $28^{\circ}$ und $52^{\circ}$ idqwanfte. Das find mun freilid Temperaturen, die fiḑ im Bimenlande häufig geltend madhen und nidht gerade als unerträglid heif cmpfunden werden. Wenn fie aber auf dent tropifhen Decau drüfend fḑwill eridhemen, fo wito dies dadurd, bedingt, daf die

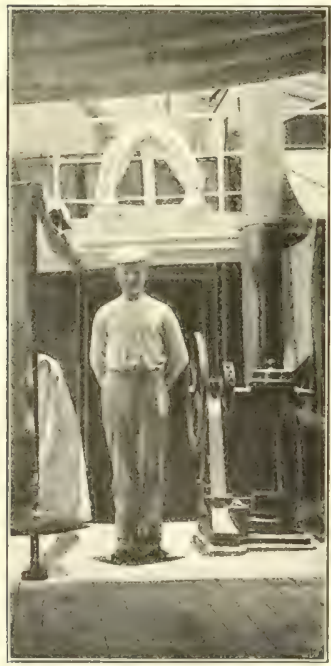

mittag unter bem Somenáquator. suft mit feuditigfeit bis jum Sättigungsgrade gefdiwän= gert ift. Der Sdyweif verdumtet faum anf der Laut und jede förperlide 2lrbeit erjdeint doppelt erfdqwert. 2lian fühlt fid felten mehr eriḑlafft, als gerade hier, wo wir im Bercidye des Somenäquators fubren und fhon gleid? ant Tage nah unjerer 2lbfabrt von den Seydyellen, am 9. 2läry, un die 2lïttagsjeit das Shaufpicl genoffen. daf cin ferffredyt ftchender Stab feinen Shatten warf.

lian lift jwar nidyt am Tropentoller, ftellte aber Sod) fülntere Bchauptungen auf, als man unter nor= malen Derhältniffen verantworten fonnte, und atmete erjt auf, wem das ftundenlang bei Wirditille im Somen= brand daliegende Sdiff nadh Beendigung der 2lrbeiten wieder mit Dolldampf weiter fuhr. Da berreidete man Sen Kapitän, ber fich aus einem in der zlittte ourd?= gefägten falfe, an dem die Gälfte der fafzdaubert als Rüffenlehne crhalten war, cinen Scffel hafte juriditen Iaffen, unter den aus der Eismaidinte ein tüdtiges Quantum Fis cingelegt wurde. 2luch wunderte man 


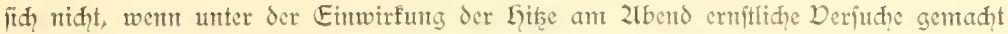
wurden, 2liomentaufnahmen der Wolfen mit Bliţlitḩt anjufertigen.

Wer freilid dantals auf den Einfall gefonmen wäre, ju behaupten, da k anderthalb Jahre fpäter Kapitän Kred auf der "Fanburg" den Stab des Erafen Loalderfec nad Shanghai überführen würde, und da Eie "Daldivia" als Trantsportidyiff für die Beförderung deutịher Truppent nađ China Derwendung finden würde - der wäre für unheilbar erflärt worden.

Die Sotungen, weldie wir auf diefer Route vortahmen, ergaben gleid, nach Der=

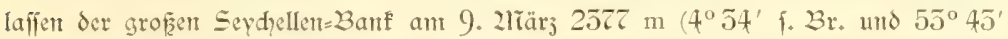
o. S.), und am 11. 2lärz die überrafhend grofe Tiefe von $50 \bar{l}$ m $\left(4^{\circ} 45^{\prime} \%\right.$. $\mathrm{Br}$. แnd $48^{\circ} 59^{\prime}$ ö. [.). Dic 2heerestemperatur be $=$ trug in rund $5000 \mathrm{~m}$ Tiefe $1,2^{\circ} \mathrm{C}$, und der Boden erwies fid als ein gelblith weifer,

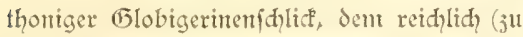
$25 \%$ ) Kiepelorganismen beigemengt waren. Da die Zietze und sotleiten bet dem zrangel ausgefprodicner Strömungen fait vertifal ftan= Den, fo unţten wir dicjen fahrtabfdnitt wefentlidy daju aus, Tenrperaturreihen und Stufenfänge mit den Sd?lefneten ausju= führen. Zlls wir die grof̧e Tiefe von $5071 \mathrm{~m}$ loteten, fdien es von Jntereffe, surd, cinen

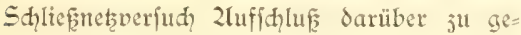
wimnen, weldhe Drganismen dirct luber dem

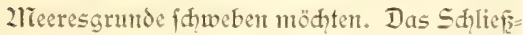
nets wurde in $5000 \mathrm{~m}$ hinabgelaffen unt be= rührte, wie fidh aus den dem Ǧchäuje des Propellers anbängenden Sdilammrejten er=

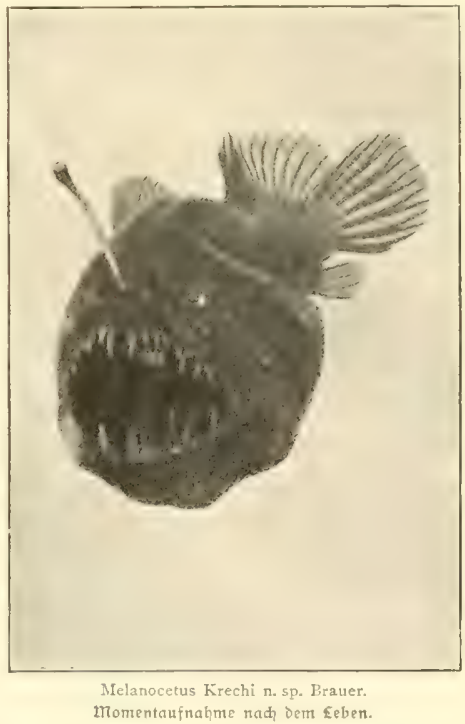
wies, den Grund. Da es indeffen, aud, werm es dem Grunde auflag, fidh nidit öffnen fonnte, fo muiffen die Drganismen, die in ihm enthalten waren, direft über dem Frunde, und jwar, da es fid erit nad cintger Jeit bet dent 2lufhieven öfinet, etwa von $60 \mathrm{~m}$ an über thm gefdqwebt haben. Don lebenden Drganismen enthielt das Ziets Copepoden mit ihren Earven und Radiolarien aus der familie der Ehallentgeriden. (Ẽeradeju erftaunlid, war aber der Reichtum an leeren Sdalen von Tintimnen, Radio= larien und (Flobigerinen, weld leţtere jum Teil fogar nod ihren Stadelbefat auf= wiefen. Es fifeint aus diefem Befunde hervorjugehen, dafi in fo groferer Tiefe fïh die Ieeren Shalen von Drganismen bejonders didyt über dent Grunde anjtauen. 
Ein erfreulides Ergebnis licferten weiterhin die fänge mit den Dertifalnetzen. Eine

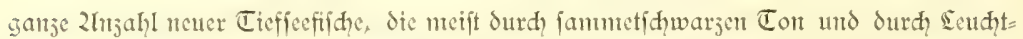
organe ausgezetdnet find, wurden auf diefer fahrftrefe erbeutet. Wir fönnen unts

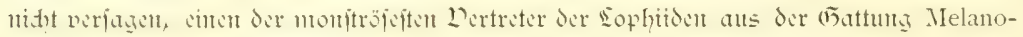
cetus, welder now Iebend an die Sberflähe fam und in dem abgefüblten 2lquarim 2 Stunden gehalten wurde, nađ ciner 2Tomentphotographie im Bilde vorzuführen. Der bijarrfte fund unter den fifhent war freilid cine fifdylarve, deren wir wegen ibrer auf Iangen Stielen ftehenden Zlugen fpäterhin nod gedenfen wollen. Daju gejellten fid? Cephalopoden, deren cintige glcidfalls gejtelte 2lugen befafen, und cin Leer von Crujta=

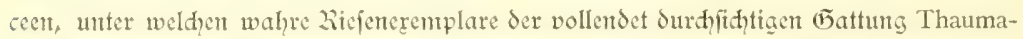
tops uns auffielen. In mehreren Eremplaren erbenteten wir aud die wunderbaren, wie 2lftinten fid ausmehntenden, jarten fowwinmenden Seewaljen aus der Gattung Pelagothuria.

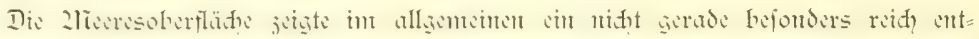
wideltes Tierleben. Dagegen begletteten uns nad dem Derlafien der Seydellen die Delphinte in ganjen Ecerden, nidht minter and die fliegenden fifhe, die wir in fo diḑten Sdywärmen über das Waffer fdwirren fahen, wic niemals jubor. Ecider ftellten fid regelmäşig neben dem ftillitegenden Shiff die grofen haie in fo anjehnlidger Jahl

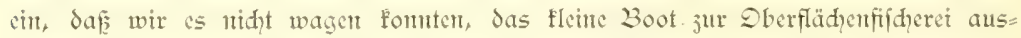
jufetsen. 2lian war fleisig Sabei, fie ju fhiesen, indent man fie mit jerbrochenen flafhen und in 2llfohol fonfervierten fleifhftïfen föberte, die fie gewifienhaft ver=

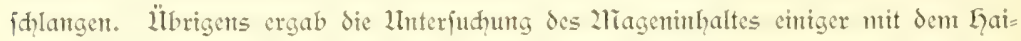
hafen erbenteter Eremplare, bafi fie and die thnen anfitzenden Sangfifhe (Echeneis) ju idnappen verftanden. Das 2lieerleudyten war, wie überhaupt im Indifhen Deean, fo aud auf diefer Strecte mu fdiwad entwidelt und wurde wefentlid durd flemte Krufter (Sdijopoden, Leucifer, Pleuromma) bedingt.

2lis wir an 14. 27ärz der oftafrifanifden Küifte bereits nabegefommen unt eme

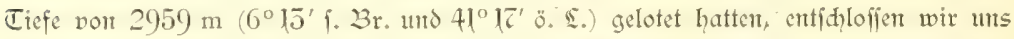

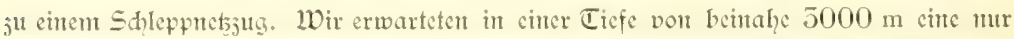
färgliक entwifelte fauna und waren daher angenehn überrafht über den 2frtenreid =

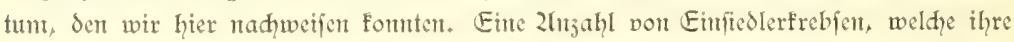
nit feinen Simeshaaren bededfen Sdyeren aus den Sdnefenfhalen hervorftreften, der

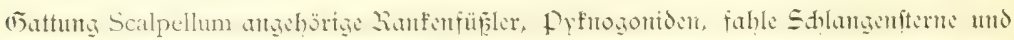
Seciterne aus der (5attung Styracaster, Wümer, Geraftinclliden und einte 2njahl fdylet=

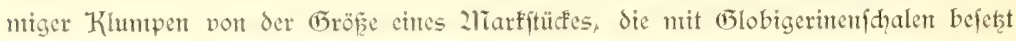

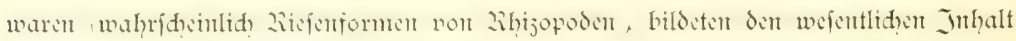
Ses fanges. Er beftärfte uns niḑt wenig in Sem Dorhaben, fpäterhin nod cint=

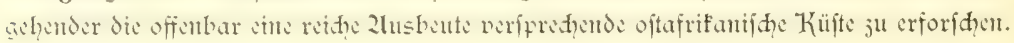




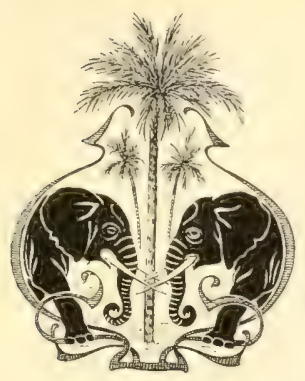

\section{Daryes"salâm.}

In der frïhe des 15. 2rärz fam die oftafuffanifhe Küüte in Siḑt. In niḑt geringer Spannung ftand man auf Deff und mujterte bie fleinen Koralleninfeln, derent einte als Quarantänteftation cingeridtet ift, deren andere, Hafatumbe, den fdfwarz= weir geringelten Seuḑtturm trägt. Ein niedriges Dortand, das in weiter ferne von den in bläu=

liḑem Duft verifhwimmenden puhu= Bergen überragt woird, gewaltige Baobabs als Wahrgethen des fhwarjen Erdteils und ein palaftartiges CGebäude, das jwifd?en KoF́ospalmen durd?= fhintmerte und fith fpäterhin als das grofaratige Lofpt: tal erwies - dies waren die erfiten Findrüde, weldye ntan von unferem oftafrifanifden Küiftenland $\mathrm{em}=$ pfing. Bald taudte auf ciner füblid gelegenen Zluhöhe dic idyllifde, von den zlitfifonaren er= ridhtete fatholifdne litifiton auf, und mu begant die gewundene, durd Bojen wohlgefennzeidnete Einfahrt in den fanalartig fith vorjiehenden อ̄ipfel etrer ticf in das fand cinfinnet= denden Budt. 2luf der Reife haben wir felten cinen über= rajhenderent 2lusblitf genoffen, als jenen, der fïh rad, ciner fharfen Biegung des en= gen Kanals auf dic grofic und fitlle Bimnenlagune von Dar=es= Salâmt dar= bot. So malerifh hatten wir uns die Gqauptiftadt unferer oftafrifanifich Kolonte niḑt vorgeftellt! Da liegt an der 2iord= feite des weiten Becterts, faft als ob es fich um einen wirfungsvoll

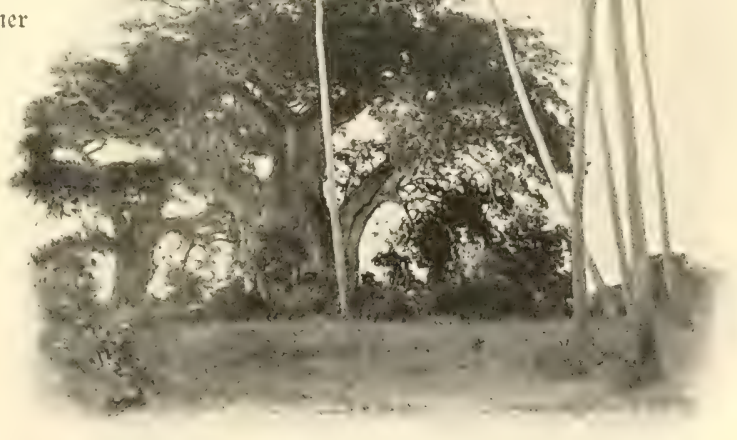




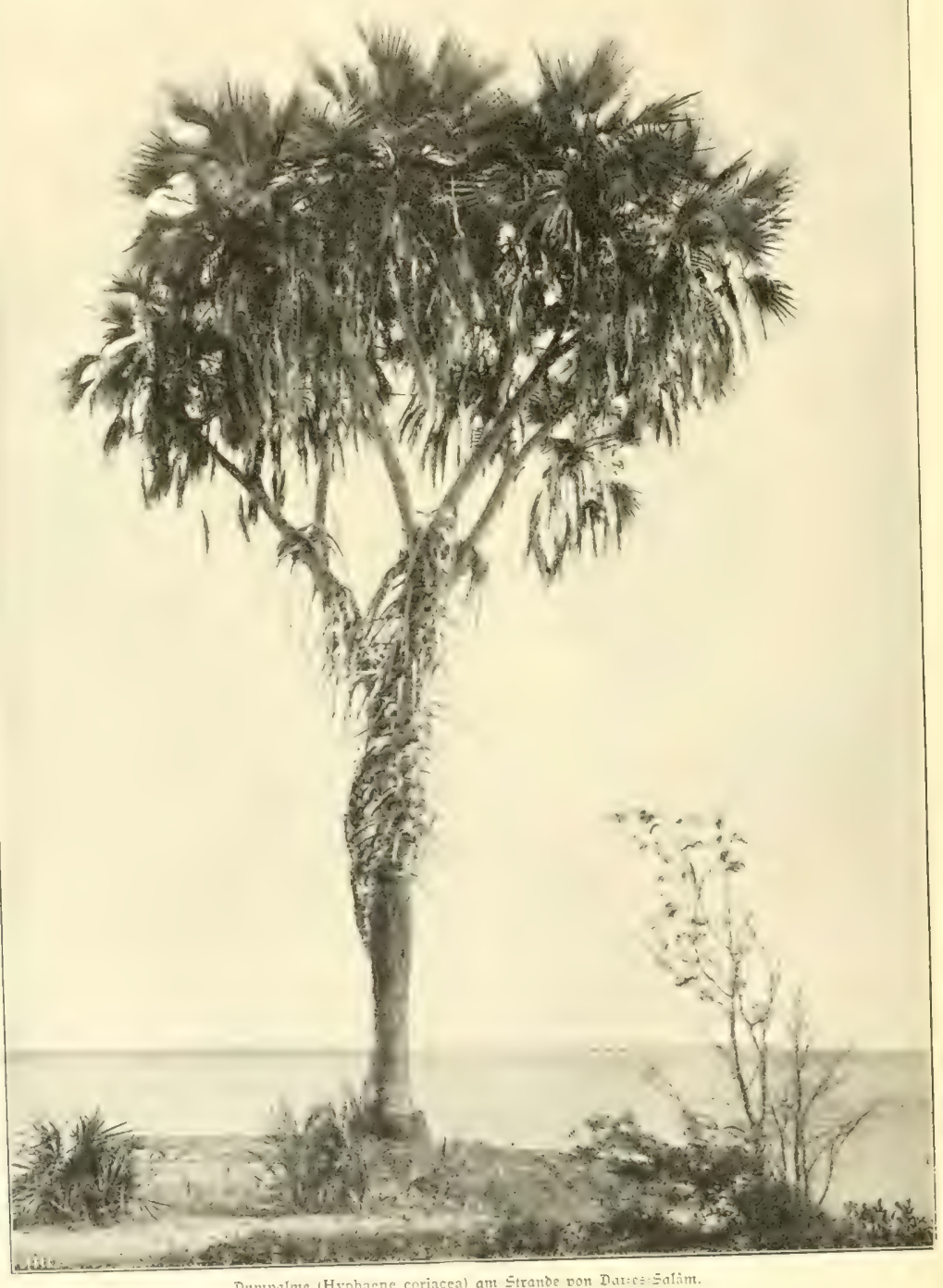

Dumwatme (Hyphene coriaceal am Strande von Dure: Saläm. 
aufgebauten theatralifaen Lintergrunt Gandele, die ganje fludt der ftattlid forim = mernden Regierungsgebäude. Es ift erftaunlich, was hicr in Eaufe weniger Jahre nah dem Ziederwerfen des 2luffandes geleiftet wurde. Don den jwifhen Palnen

veritedten Gouvernententsgebäude đáweift der Blid über die Beantenmeffen, das Gotel "Deutider Kaifer", die im Bau begriffene fatholiphe und nod wentig fortge=

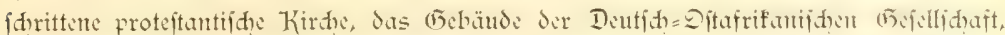
das Jollamt und die Regierungswerfitätten. Jahlreidhe Dhau's belebent die Sagune, auf der wir zu unferer angenehmen l̈̈berrajhung aud die "Sdwalbe" als guten $\mathcal{B}_{e}=$ fannten von Kapitadt her veranfert fanden. Gegen Silden fetst fidf die sagune in cinen weiten Creef fort, der pon 2liangroven und niebrigen Löhenjügen mit ihren

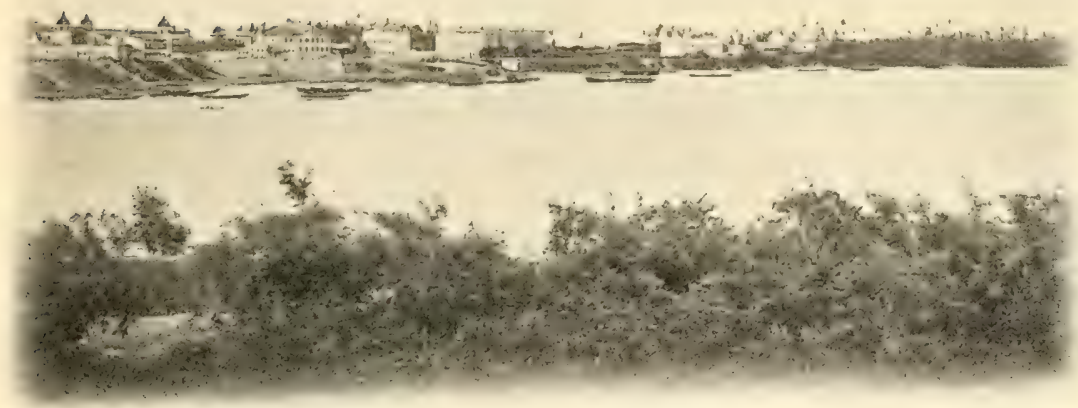

3liđ̛ über bie Eagune aư Dar=es=Salân.

Kulturfläđen, Savanten, 3aobabs und Sthimafajien umfäumt ijt. Die Scenerie war fo paçend, daf der größte Teil der 2lätglicder fith bereits in Dar=es=Salûm zer ftreut hatte, che die Sanität in CFeftalt des Dberitabsarztes Dr. Sinton und des $\mathfrak{B}_{\mathrm{c}}=$ zirfsamtmanns von Strantzerfiden. Selten ift chte deutide Erpedition mit gröferen Ehrungen und gewinnenderer Lerjlidfeit aufgenonmen worden, als fie uns hier in Ditafrifa entgegengebraht wurden. Die Stadt flaggte und der (5) wenent, (Feneral von Siebert, wetteiferte mit den Beanten und anjäffigen Kaufleuten, uns den 2ufent=

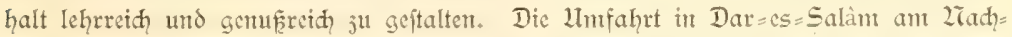
mittag unferer 2lnfunft unter führung des Gouberneurs belehrte dem aud bald, daf 


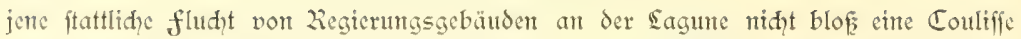

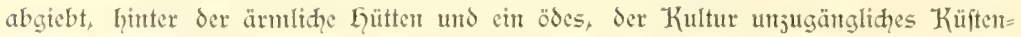
land fid fergen. 2lion fomte mur inmer feiner (5enugthung 2lusdruc geben über die folide und für tropifhe Derhältniffe grofartige 2lnlage der übrigen Baulichfeiten, unter denen in erfter Einte das palaftartige Koopital und die Dr. Stuhlmann unter= ftellte Eandesfulturanftalt feffeln. Breite fahriftafenen, umfäumt, von Dillen und den 3aumgruppen des parfartig angelegten botanifden (5artens, durdfidneiden den euro=

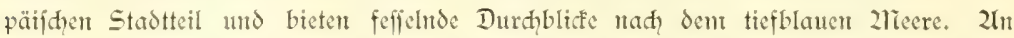
dem Strande hebt fid cinfam, wie cin WWahrzeiden, von dem Gintergrmbe der Kofos= palmen eine Dumpalme mit ihten mehrfad gegabelten žliten und fperrigen fähern ab.

Seitdem dic Eingeborenten fith übergeugt haben, daf fie nirgends fidgerer und unter

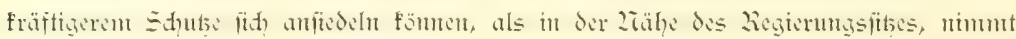
fowohl die 2lraber=, wie vor allen Dingen die 2iegerftadt an 2tmfang ftändig ju.

23 i dem Durdimandern der langen, von foliden Eütten eingerahnten Etraken=

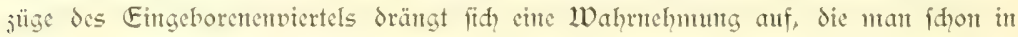
Eumratra mo in mod) höherem (Frade auf den 2răalediven maḑte. Sie betrifft dic Rüfwirfung des 2ruhanmedanismus anf Dölferfdaftem, weldhe ju fanatifder $\mathfrak{B e}_{e}$ thätigung ihres (5)laubens zwar niḑt neigen, aber es dod, mit den religiöfen Vor= fibriften gewiffenhaft nebment. Thre Signatur läpt fid in dret Worte zufantmenfaffen:

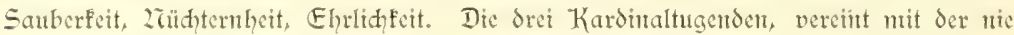
fehlendert (5ajtfreundidaft find es, welde den 2lufenthalt unter mandhen muhammedani= fanen Dölferidaften ju cinem wohlthuenden geftalten. Sie unterifgeiden dent aud den Zieger der oftafrifantifden Küijte vorteilhaft von dem fetifdiften in Weftafrifa, der an Inflat, Trunfentheit und Betrug es mandhmal nidgt gemug thun fam. Wird der lettere von der Kultur belect, fo funft er häufig jur Karifatur des Europäers herab. Znders der muhanmedanifhe zieger, der fhon äuferlich durh die fleidame orien= talifde Traḑt einen fympathifderen Eindruc maḑt.

Die weife Derordmung, da Ba Beamte und Europäer im Derfehr mit den Ein= geborenen das Kifuaheli fpredyen, trägt nidht wenig daju bei, dic Bevölferutg enger mit der Regierung 3 verfnüpen. 2lian dringt in die Denfweife des Dolfes ein,

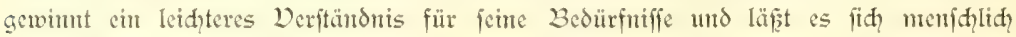
näher rüđđer.

Dic Llmtgebung volt Dar=es=Salimt ift fo oft und von fo fompetenten Beobahtern gefdyildert worden, da fir wir uns damit begnügen wollen, mehr das it den Vordergrund

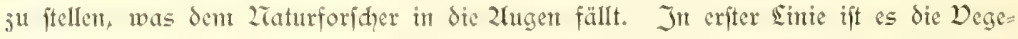
tation, weldie viel reider, als wir crwartet hatten, entwitelt ift und der Sandidaft ihren Charafter aufprägt. Der Gouverneur mod̨te es wohl herausgefühlt haben, da É wir gerade hierfür emtpfänglid, waren, und fo gingen wir gern auf feinen Voriḑlag 
ein, fhon am nädfifen Tage in der frühe einen 2 itt in den "Sadjienmald" von Dar= ess=Salân zu unternehmen. Es war die jeit des 2lionjunwedffels, und der biswetlen auf Furje Jeit bedefte Eimmel entfendete nad langer und peinliḑer Trodenjeit, dic im Innern eine Gungersnot im: (E)folge gehabt hatte, dic erften Regengüffe. Zluf der breiten, weit in das Jumere führen=

den Eanditraf̧e herridgte ein re=

ges Treiber. 2lït freundliḑem "Jambo" grüpten uns dic Eingeborenen, unter denent ab und ju bis jum $\mathbb{E}_{\mathbf{r}}$ fdrectent afgemagerte (5e=

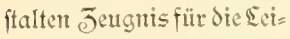
den ablegten, die fie durd)= 3umadįn hatter. 2riḑt minder eindringlid lehts= ten die Wedel der Kofos palmet volt eitrer ande=

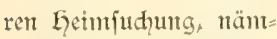
lidh der ḩeuidurețenplage. Sie fahen jum Teil mit threm abgefreffenen Sau= be, vont dem mur die mittleren Blattrippen jtehengeblieben waren, troftlos aus.

Je weiter man land= cinwärts reitet, defto mehr maht fïh der Charafter einer $B$ ujplavante geltend, die in buntent Wedfiel mit Bujḑwald für die oftafrifantifd?e Küftentegiont typifd ift. Der Wald ift auf flaḑe 2riulden bef̧ränft, in Regerweiber aus Daz=es=Salàm. (Sachse phot.) weldhen während der Regenzeit das Waffer fid anjammelt.

Wo das Grundwaffer während der Trodenjeit fehlt, tritt mehr dic Savanme in den Dordergrund. Sie ftellt fid als cine von meift fleineren Bäumen und Sträudern

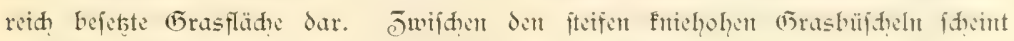
während der Regenzeit cin reiḑer 3lumenflor ju iprię̧en. In den meiften füllen 


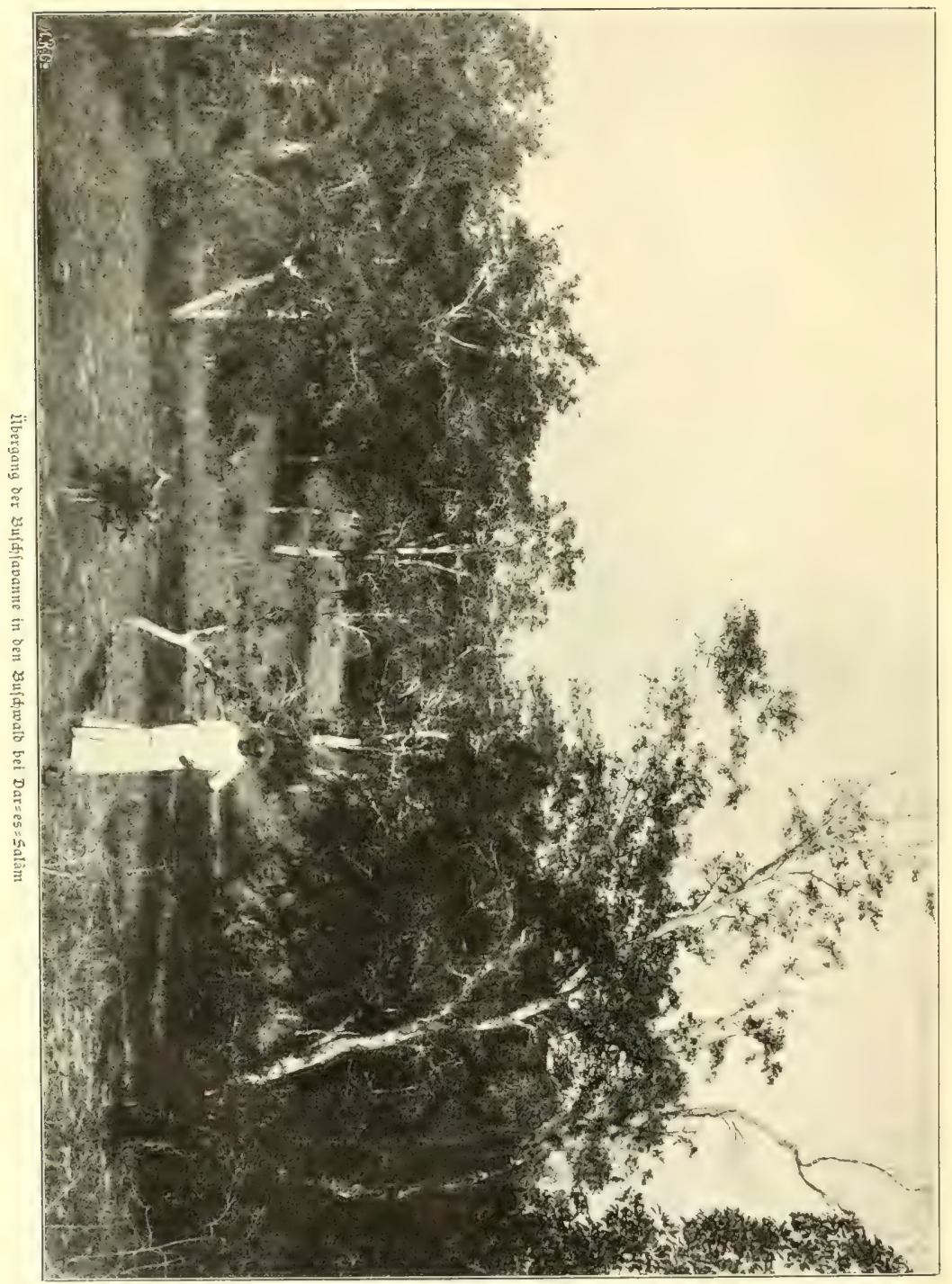




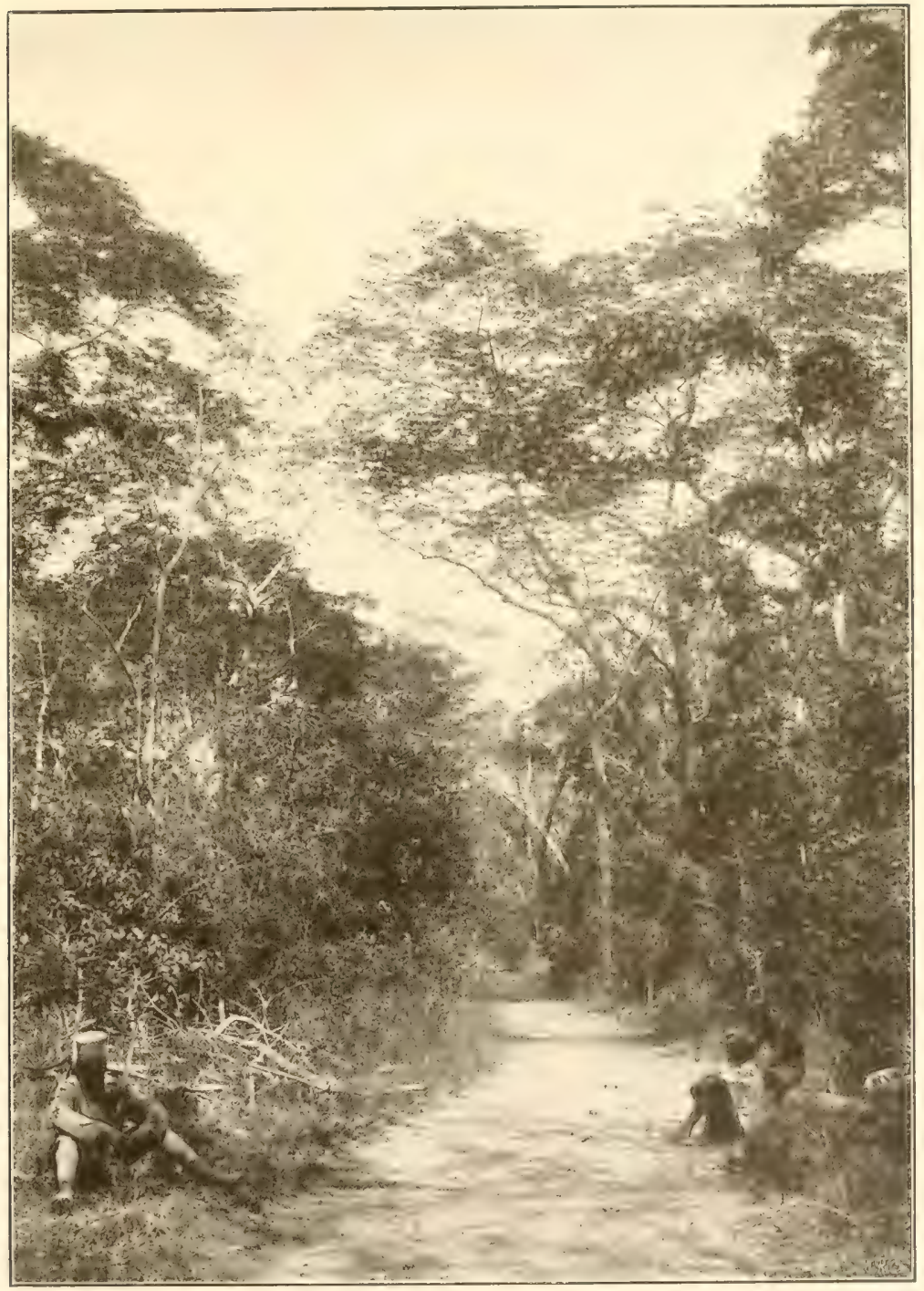

Dit 2 litif́a.

Im Eadientualo non Dares: Salam. 

erheben fid dic (5ruppen der Goljgewädffe auf alten, ver=

laffenen, rumbhügeligen Termitenteftern. Der höḑ̧te

Baum der Savante ift das wegen feines dent

2liahagoni ähnliđen Loljes

gefd,ätstc Erythrophyllum

Guineense : ein ctwa $50 \mathrm{~m}$

hoher Baum mit gera=

dent Stamme und lof:

ferer, fhirmtörmiger

Krone. Zieben ibm crreidht aud der Ta= marindenbaum, der ausiḑlieflid auf alten Termitemieftern wädyit, beträdtlid)eren $\quad I_{\mathrm{m}}=$ fang. Daju gefellt fid? cine $2 f_{n j a b l}$ wentg be= fannter, vielleidt aud nod gar nidyt bejuric= berter $\mathcal{B}$ aumformten aus den familien der Eegu= minofen und 2lfajicn, die faum höher als unịere Dbftbäunte wer= den, aber j. T. ein ge= hhähtes Lolj aufwet= fen. 2alle Bännte find immergrün und befitsen die Eigentümlidyfeit der (B)wädfie trodener tro= pifher (5)biete, nämliक lederartige, fleme oder mur mäß่̧ groß̨c, oft $g e=$

fiederte Blätter, relativ diffé, Walaranto; Püftemaher oltafrifunifiter Etamm. ¡duppige Borfe an Stanme und diḑt behaarte Knolpen. 2luf vielen war bereits das junge, rötliḑ oder gelblid) getönte [aub jux Entwidtung gelangt. Da die 3lütejeit

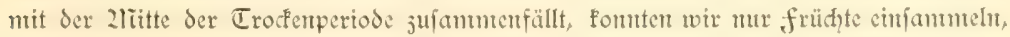
welde teils an die Derbreitung durd ben Wind, teils an cine folde durd? Tiere, unter 
Senen nantentlid) die in der Savame häufigen Tauben in Betradit ju jiehen fein Sürten, angepafst fund. Dielfach waren die niedrigeren Sträuder und Bäume von cinter parafitificu Eaureaces, nämlich der Cassytha filiformis, mit thren jtegelrotent oder grünliden fäben fajt vollfommen überjogen.

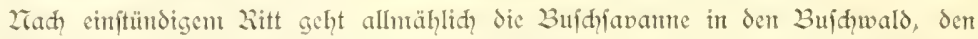
"Sadjenwals" über, der einen Kauptanjiehungspunft der llmgebung von Dar=es=Salàm abgiebt. Es fehit aud? nidht das forfthaus friedridssuh, in dem wir von cinem Inder ntit rot gefärbtem Barte devot empfangen und mit erfrifhenden (5etränfest gelabt wurden. Es ift dic Domäne von forfiffeffor v. Brudhaufen, der fich um fo lieber Profeffor Sdimper jur Derfïgung ftellte, als der praftifde forftntam im Beginn der rationellen Bewirtidaftung entes tropifden Waldreviers nit dem wiffenfifaftiden Botanifer Lants in liand ju gehen hat. Ja hate mid, dem aud, wic bei der fur= jen Charafteriftif der Bufd =

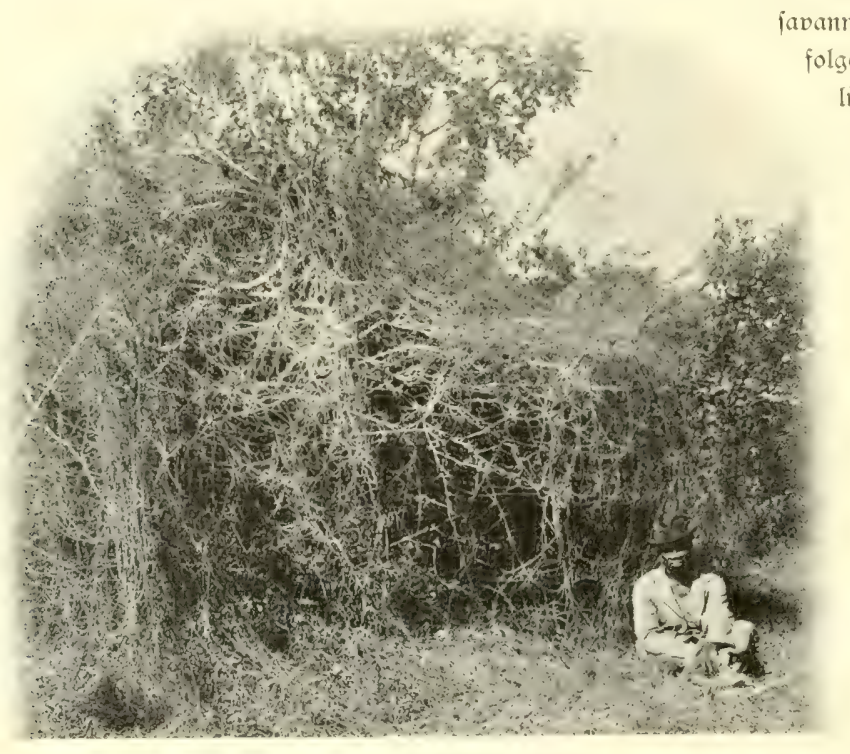

Cassytha filiformis bas 2 ufdomerp ûberroudierno. folgender fo bei der olgenden Daritel= limg an dic 2lit= teilumgen, die mitr unfer $30=$ tanifer gab. Wenn ntan es aud fichon längft verlernt Gatte, cinen Tropenwals nad) dem Cha rafter unterer cinbeintifiden Wälder ju be= urteilen, fo muste man fith doch $d a=$ ran gewöh = nert, den oit = afrifanifden

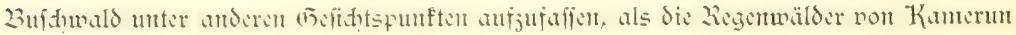
und Suntatra.

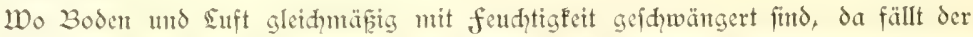

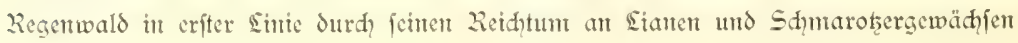




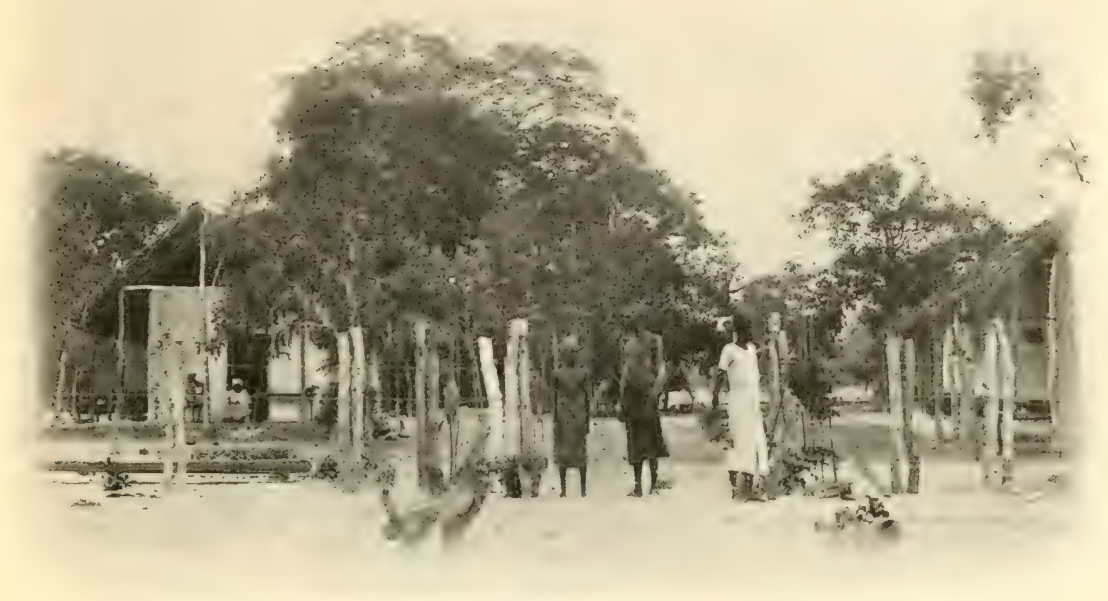

formhaus "fricbrihsruh" bei Dar=es=Salàm.

auf, pon denten erftere an feuḑtert Boden, leţtere an feuḑte Suft gebunden find. Dic Sianen fehlent dem Sahjenwald niḑt und treten jogar überrajhent reid auf; fie flettern hod empor und befitzen bisweilen redit ftattlide, didfe Stämme. Jhr Dorfonmen beweift, daf ber Wald auf wafferreihem Bodut fteht. Dagegen dentet der faft voll= fommtene 2rangel von höheren Sdmmarotzen, deren wir mur jwei fleinere Orḑideen bemerften, darauf hin, das die Eluft niḑt die genügende feud̨tigfeit befift, un felbjt den äuĘerịt genüganten farnfrüutern die Eriftenj ju ermöglid̨en. Die Bäume des Waldes fund jum grofen Teil verfhieden von jenen der Savanne, freilid aud wegen

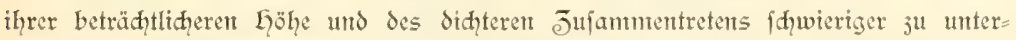
hactden. 2lud ihnen fchlt das für die Strahlen der Sonne fajt undurdidringlide

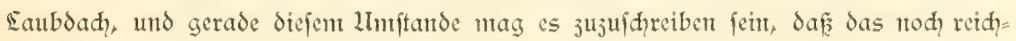
lidhes Eiḑt entpangende Lnterholj cint bejonders üppizi Entwiflunz anfmift. Fintge Rubiaceen und eine gefellig wadjende Sanseviera traten ant häufigften ftraudbildend auf. Jedenfalls find für das Ltnterholj unter dem dünnen, das siḑt niḑt ftarf

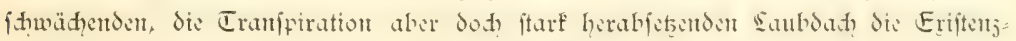
bedingungen günftiger, als für dic Bäume felbit, deren Kronen wälprend der Troden= periode dent Einfluß der Sonne und der Sufttrofentheit untittelbar ausgejeţt finto. 2lehrere Straudiarten des Unterholjes nebit der Sanseviera ftanden in voller Blüte. 
2licift waren dic 3 lüten weip gefärbt, mit langer, enger Röhre nub ftemförmiger Krone ausgeftattet. Da fie cinen intenfiven Wohlgerud entfalteten, darf man ver=

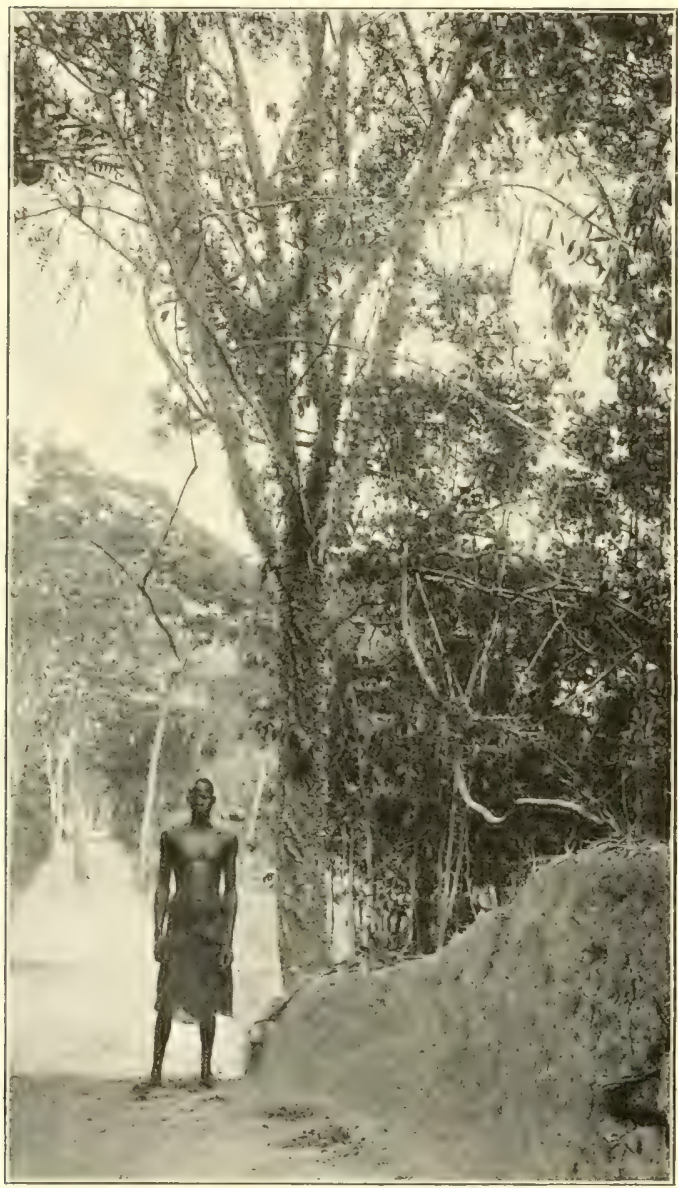

Xanthoxylum sp. auf verlaffenem Terntitenhügel freheno. mutent, daf fie an die $B_{e}=$ ftäubung durd 2lbendfalter angepafit find.

Einen ctwas abweidicn= den Charafter nimmt die Degetation bei Dar =es= Salàn in der zTähe der Küfte und auf den flemen, the vorgelagerten Korallen= cilanden an.

Direft am Strande ift Fowoht in dem Creef, der von der Sagurte ausgeht, wie aud gegen das 2liecr ju eine 2liangrove= Degetation ausgebildet, sie hauptiät)= lid) von den mittelhohen Stänmen der Sonneratia acida gebildet wird. 2iidhts ift eigenartiger, als wäly= rend der Ebbejeit ifyre jahlreidyen, fubhohen, bis armlangen Zebenwurgeln ju beobahtert, welde wie Spargel direft aus der Erde emporfteben. Sie dienen als "Pneuntatophoren" jur Salerftofficriorgutg der unterirdifient Teile uno fommen and den meiftent übrigen 2liangrovebäumen mit 2lusnahnte der Rhijo= phora $=2$ Irten 3 h.

Wo die 2liangrove fehlt, madit fih an Strande der Pandanns geltent, während weiter landemuärts Praḑtïtäme des $3 a 0 b a b$ der Sandidhaft ihren Charafter auf= prägen. Wir hatten fite in der Kongo=Savante entlanbt mit ihren gefpenftifa aus: 


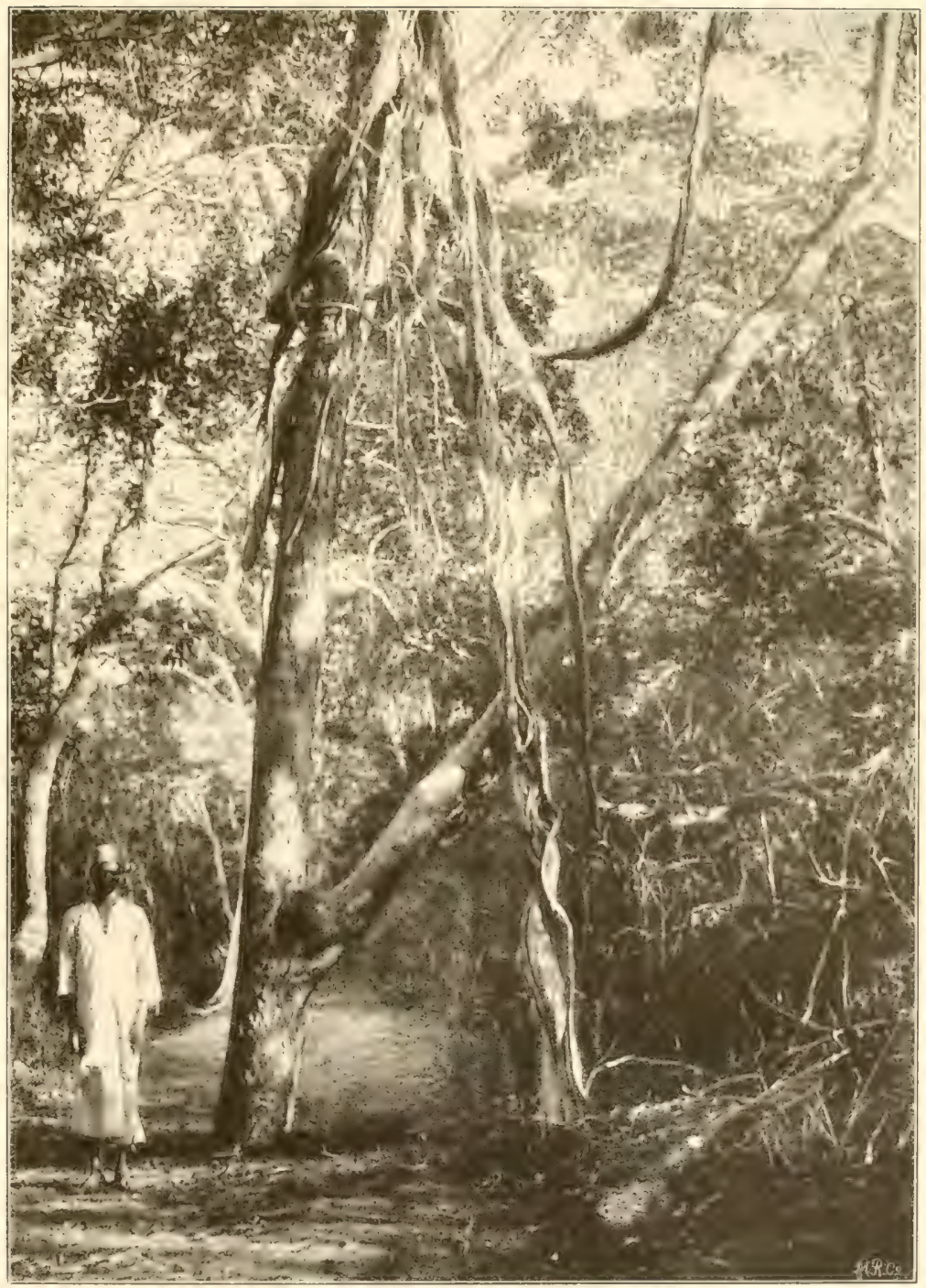

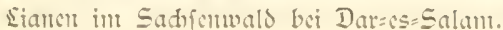



gereften z̈lften gefehen, während fie hicr in vollent, üppigent Grün als grotesfe Riefen nur rod von den Kofos=Palmen überragt wurden. Ltnter den fonftigen Pflanjen= forment waren es nicdrige Steppenpalmen (Hyphaene), Sdimmafajien und cinjelne

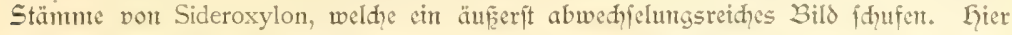

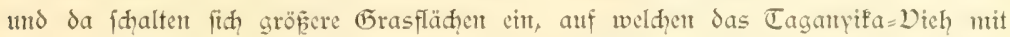

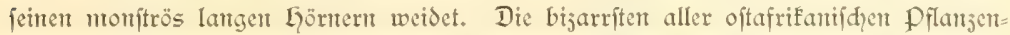
formen find indeffen dic baumfömtigen Euphorbien mit ihren wie riefige Kandelaber

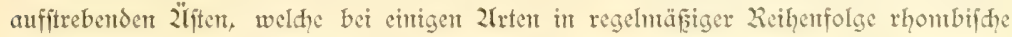
fteife Verbreiterungen aufweifen. Sie waren es, die namentlid auf den KoralleninfeIn Sen Charafter der Sandidhaft beftimmten.

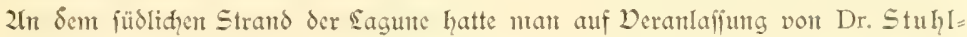
mann eine Zlnjahl von 2loe=Plantagen angelegt, die freilid in ihren fdnurgeraden, fteifen Reihen nidt gerabe anjichend wirfen. 2Int fo höher fteht the 2utwert. Die

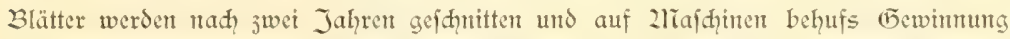
bes langen $B$ aftes gequetidt. Bei cinfader 2ranipulation ift es ein lohnender 3 etricb, denn der fdneeweife 3 aft ift von emer 5 altefraft, die nahe an 2liantahanf heranridit. In den Plantagen riduten die wenigen 2Tilpferde, weldhe nod in dem Creef vorfommtent, oft jhlimme Derwüptungen an. Id maḑte mid) mit dem Kapitän eines 2liorgens in

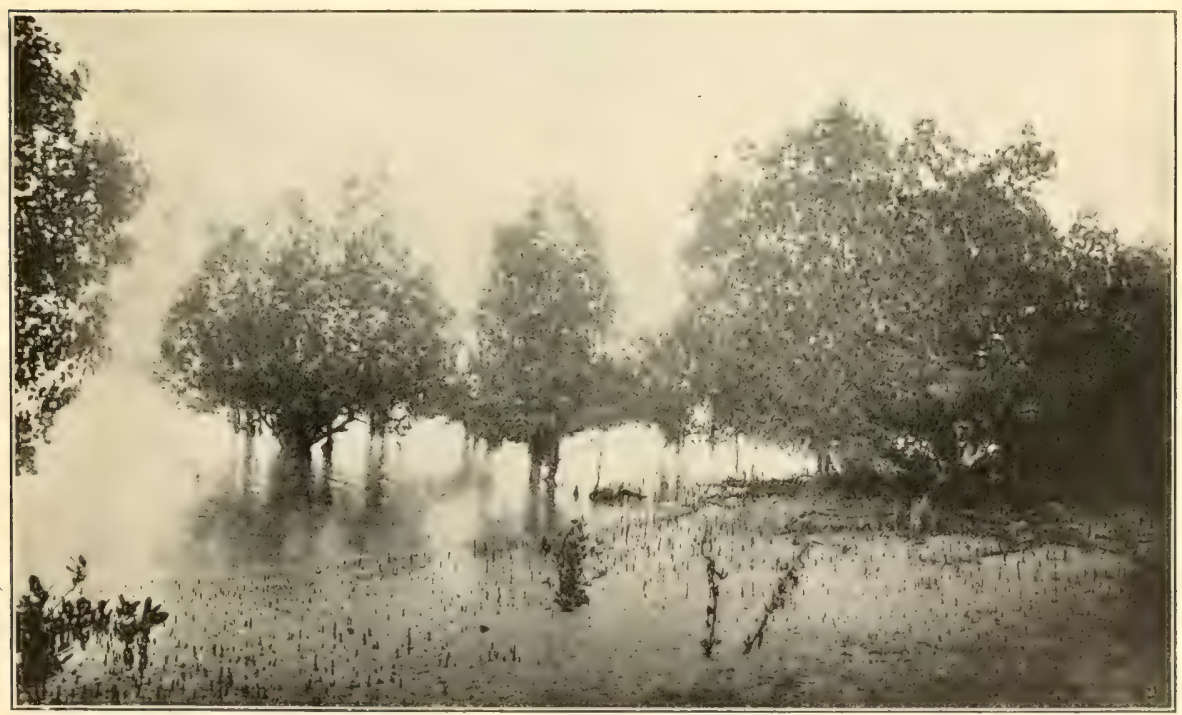

Gifafrifanifthe mangrove (Sonneratia acida) 


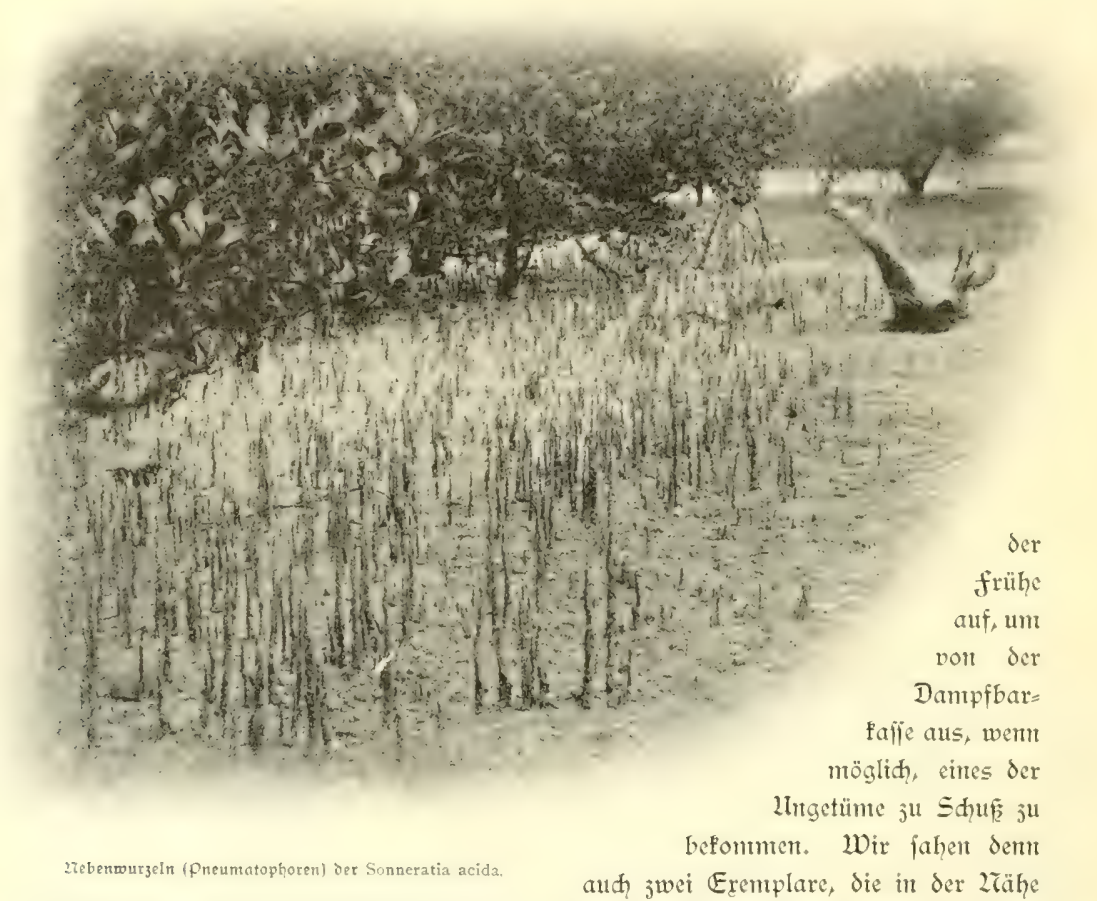

der 2liangroven ifren ungef̧ladten Kopf über Walfer jetgten. 2lber längit, ehe man in Sdufineite fant, tauḑtert fie unter unt verfdwwanden. - Dafür genoffen wir cinten Somtenanfgang, der uns die oftafrifanifhe Sandidaft in ihrem verführerifaften (5e= want jeigte. Dic dunflen Kronen der Baobabs und der fhirmförmigen 2lfajien, die Wedel der Kofos= und Dumpalmen exhielten von der Palette der aufgehenden Sonne farben juerteilt, dic fein 2haler in ihrer leuḑtenden (5)lut wiederjugeben vermöđte.

Der feftlidue Entpfang, den mant uns in Dar=es=Salàm bereitet hatte, fantd feinen

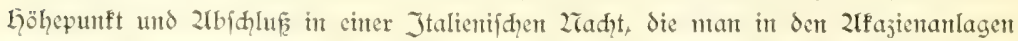
neben der Boma didt an der Sagune varantaltete. Buntfarbige Eampions und ben= galiface feuer erleudpteter den weiten Plat, auf dem alle Deutigen und die aus= ländifhen 2Totabilitäten fidh eit Stelldihein gegeben hatten. Der intelligente Walt feffelte niḑt minder als die jympathifhe (Geftalt des depoffedierten Sultans von San= fithar, Said chaled, der mit jener dem vornehmen 2lraber eigenen, ritterliden 


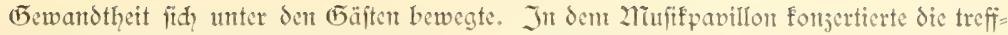

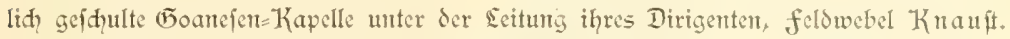

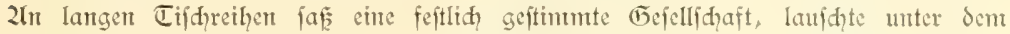
glitzernden tropifhen Stemenhimmel den Klängen des Sohengrin=2liarihes, und lief fith bei dem Sdein der von der "Daldivia" geworfenen Rafeten bie abgetühlten (5e= tränfe munden. 2fus der ungejwuntgenen Unterhaltung wurde man jäh aufgejdrect

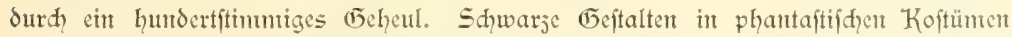
und meift nit Stöden bewafinet durdbrahen die Tifhrethen, ftürmtent in das Dunfel

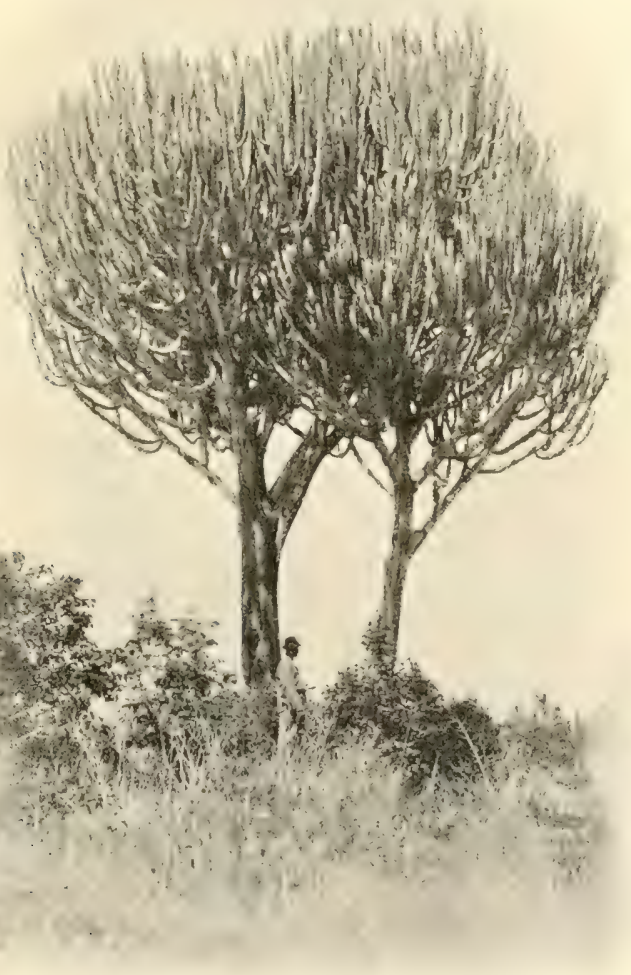

Baumförmige Euphorbien in ber Rähe des Strandes. 


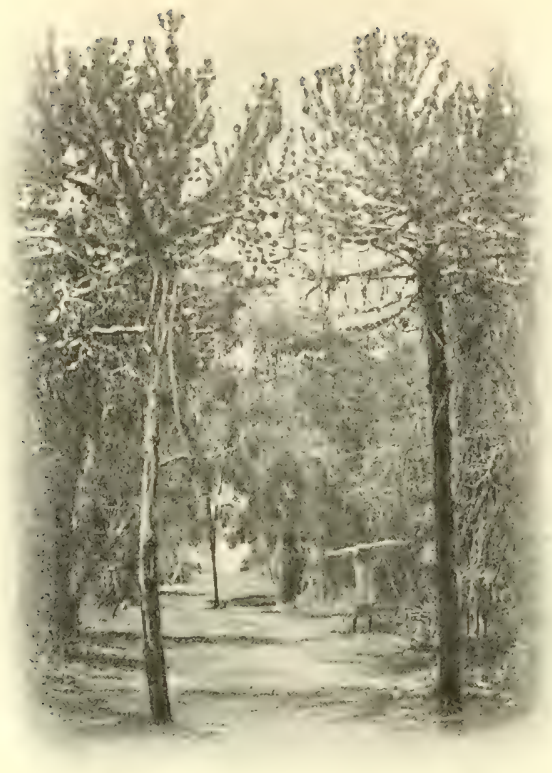

Baumförntige Euptarbien auf oer Quarantäne $=$ Infel. 2i.xo111.

und wurden dort von Shuellfeuer em= pfangen. 2ran hatte uns mit einem afrifanifhen Kriegsfpiel überrafdyt. und nidht lange dauerte es, bis die abgefdlagenen Sdmarzen unter in= fernalifḑem (ธ่ebrüll วurüdfluteten. Jhnen folgten die 2lsfari's, welde unter dent Kommatdo von Gaupt= mam sangheld einen tadellofen parademarifh ausführten.

21ud die ithwarze Finwohner ¡d haft wollte ihr Teil an der allge= meinen freude abhaben, indem fie mit viel Rumor und 2lusdauer cine Zigomta veranitaltete. 2lls der zlior $=$ gen graute und dic "Daldivia" fid ju cinter Zlusfahrt rüftete, hallte nod? rhythntifक der die 2regertänje be= gleitende Gejang liber die ftille $\mathfrak{S} a=$ gune herüber.

Es galt, den leşten Tag ju Sdlepp=

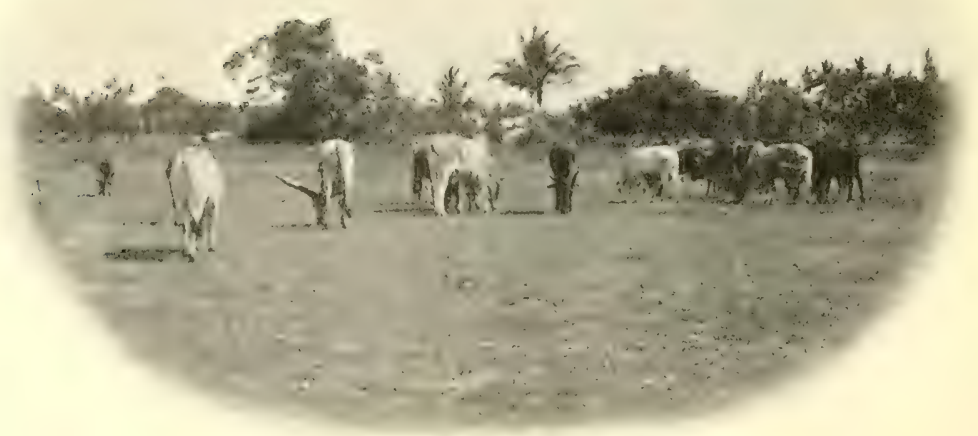




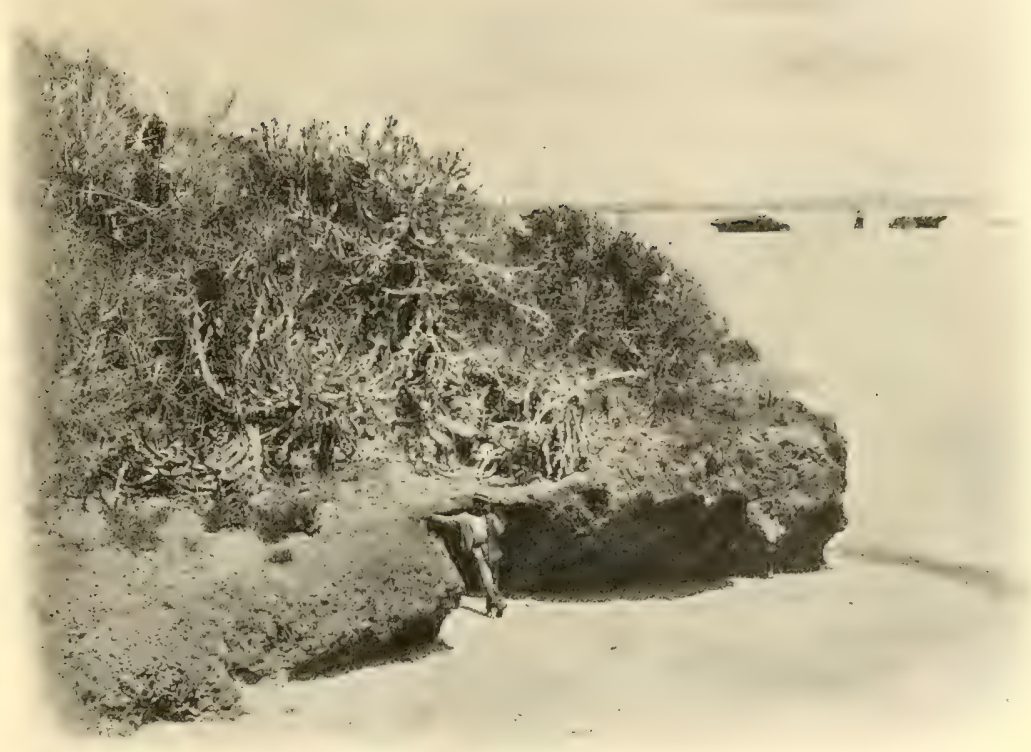

Euphorbienvegetation am Stranic.

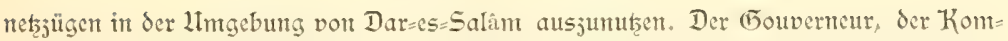

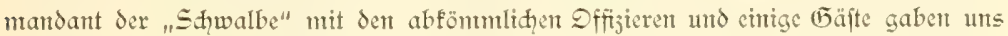
das Geleit. 2fud der $\mathfrak{W}$ alt hatte fith eingefunden, folgte fehr aufmerfiam den Dpera= tionen und ftellte dam ganj forreft feme fragen: weshalb wir dem das 2lieer an Stellen ausloteten, wo feine Gefahe für das feftfomment der Sthiffe vorliege, und warum wir mit gropen Koften unt umfängliḑen Inftrumenten Tieffectere herauf= holten, für die mant Feme praftijhe Derwendung habe. Die gegebene 2lusfunft fditen ifhn etwas ju verwirren; wir fanton ihn bald auf einem Schnfeffel cingeldlummert.

Die Sotung crgab füblith von Samitbar eine jwar nur geringe Tiefe von $404 \mathrm{~m}$,

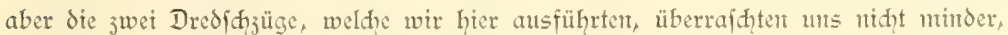
als der in gröperer Ticfe bet der Zlmtäberumg an die oftafrifanifde Külife veranitaltete

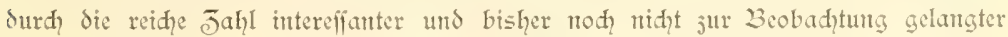


Tieffectierc. Einige bijarr geftaltete Tieffecfidge, Eephalopoden aus der Gattung Opistoteuthis, Geraftinelliden und Garncelen bildeten den bemerfenswerteften Juhalt der fünge.

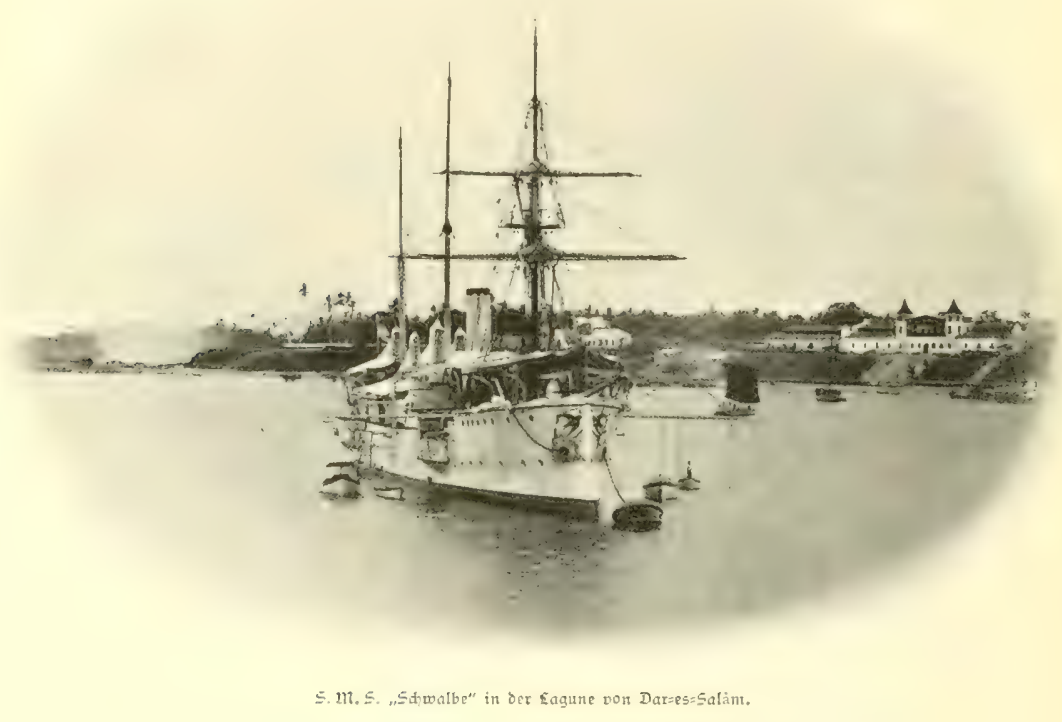

Iängs oer oftafrifanifden Küfte.

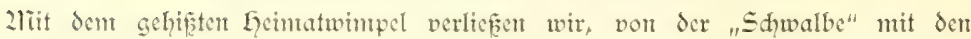
Wünfhen für gute fahrt begleitet, in der frïhe des 21. 2rärj das gaftlidye Dar=es= Salam und die toyllifh daliegende Sagune. Sange nod glänjte das Eofpital in den Strahlen der aufgehenden Sonte und bald fam die niedrige Küijte von Sanfibar, un= fäumt von bewaldeten Koralleninfeln, in Siḑt.

Die deutfice Kolonic hatte uns eine Einladung jum Befudie von Sanfibar über= mitteln laffen, der wir niḑt verfehlten, folge zu leiften. Tiad dreiftündiger fahrt fammerte in der ferne die weike Stadt, und bald gewahrten wir die in flaggen=

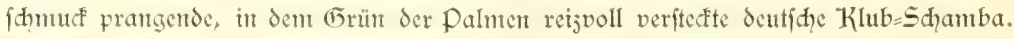
Ein (Gewirr von Echmhütten der 2ieger, niedrige Steinbauten und hohe ftattlide Konfulate löfen fidh der Beihe nad) $a b$, bis bet einer redttwintligen Biegung der 
dreiectigen Sandjunge, auf der die Stadt Sanjibar liegt, faft überrafhend das Palaft= viertel mit feinen von Dampien, 'Kriegsidiffen und Dhau's mit roter Sultansflagge belebten Reede auftauht. Baugerüfte un den grof̧en Palaft und die Trümmer des

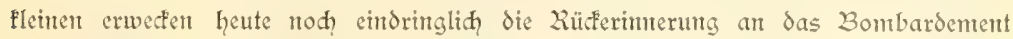
der englifden Kriegsfilfie im 2luguft 1896. Es bedeutet den 21bid̨lufi jener Hm=

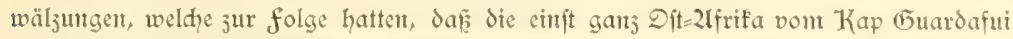

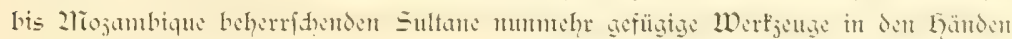
ihrer englifhen zlinifter abgeben.

Zahbem wir vor 2lnfer gegangen waren, fam der dentide Konful, (5raf Llarden= berg, mif einer $2 \mathfrak{l n}_{j}$ ahl von Dertretern der deutfhen Kolonie, darunter den Chefs des weltbefamten Laufes D'Swald und $\mathfrak{L}$ anfing, an Bord, um uns ju einem Befudpe der Stadt und threr limgebung eimjuladent.

Went irgentowo, fo wird hier in Santibar der Zreuling aus dem (b)eletie gebrad̦t über dies fimnerwirrende Durdeinander von afrifanifjen und afiatifḑen $\mathfrak{D}$ ölfer=

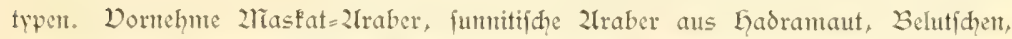

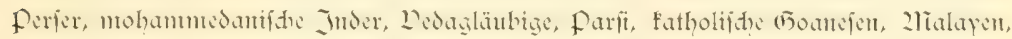
Chinefen, Comorenfer, Sudanefen und eine fhwarje Sflavenbevölerung, weldhe alle Stänme Central=2lfrifas unfaft: wer will fid in diefen Iebendigen ethnographifhen 2liufeum juredtfinden? 2lian bewundert die Sidperheit, mit der unfer Begleiter an einem oft nidht in Worte zu faffenden phyftognomifhen Etroas es herausfindet, of man es unter den mohammedanifhen Jndern mit cinem Sditten aus der Sefte der Kojas oder der Bohoras ju thut hat, ob diefer eit Parfi oder ein Goanefe ijt, ob

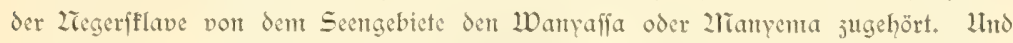
wären es mur Dertreter reiner Rafien! zlber da hat fid gar vielerlei mitemander fo

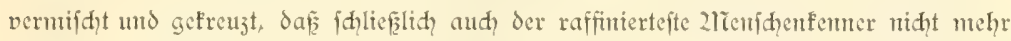
weif, ob der 2leger, der 2lraber oder Jnder mehr jum Durdibrud gefommen ift. Das lärmt und drängt fĭh gefdäftig durdheinander, fautert auf der Strafe oder fiţt hinter gefdmacfvoll angeordneten 2luslagen und in berücfend reid ausgeftatteten Säben, bewegt fid, in gentefenem Emft oder crgeht fid in uneridöpflidem Wit, huldigt dem 2liohammed, dem Kalifen Zli, dem Buddha, Sivah und Chriftengott, oder betet feucr und fetifhe an. Da mag man es noch fo oft lefen, daf Samibar den Bajar für Dit=2lfrifa abgiebt, fo muf́ man halt mit eigenen 2lugen dicjes Drängen um Erwerb, diefen Kampf um das Dafein jwifhen fdplauen und ffrupellofent 5 ändlert Zlfrifas und 2lfiens gefehen haben, un vollanf die Bedeutung eines derartigen Landels= emporiums ju ermeffert.

Unjeren Sandsleuten, welde ju Ehren der 2Infunf̣t der "Daldivia" die Gejhafte gefhloffen hatten und uns in der Klub=Shamba enten folemen Empfang bereiteten, fint wir ju warmem Danf verpflidhtet, daf fie mit ihrer eingehenden Kenntnis von 


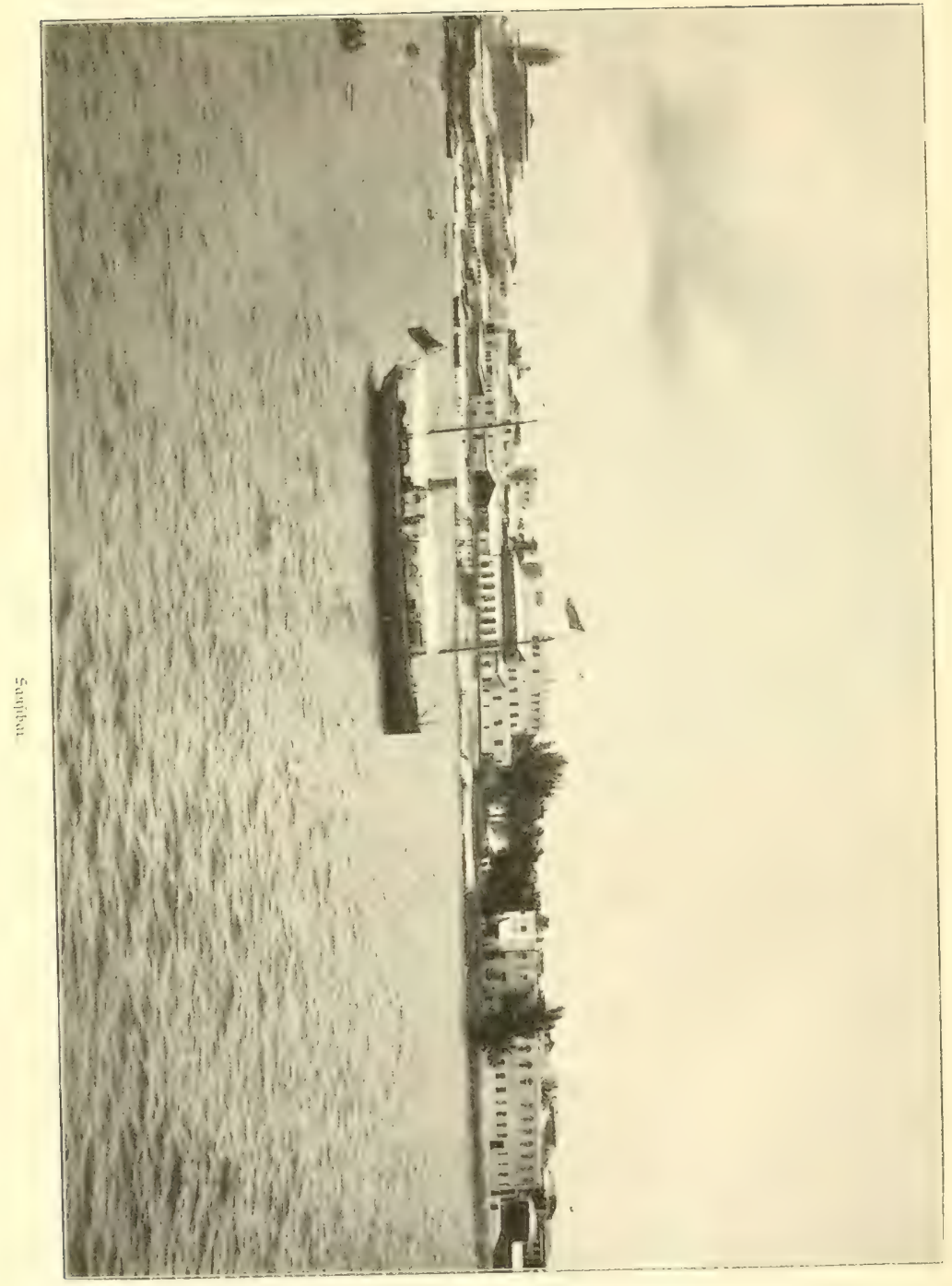


Sand unt Bevölferung fo viele 2atffilüfie gaben, als der furze Befud emöglidute. Der 2lusflug, den wir in ciner ftattliden WOagenrethe in die malerifhe Intgebung der Stadt unternahmen, cröfinete uns den 2lusblitf auf eine lippig fultivierte Fügelland= fdaft mit ihren Parfanlagen, (5)ären, Lainen und 2Telfenplantagen.

Es mar das leţte 2lial, daf uns die gerade in Sanfibar befonders fdmut ge= deifhenden Kofospalmen liberidyatteten; als wir cine Wodhe päter uns der Sontit= Küfte näherten und die troftlofe 2lionotontic der $1 \mathcal{D}$ üfte vor 2lugen hatten, überfan gar manhen die Sehnfuht tad, diefen ftoljen pprincipes des Pflantzenreidhes, unter deren Jeiden wir nummehr cin Dierteljahr verbraḍt hattent.

Indem wir uns der Sdillderung des letzten zlbidnuttes unjerer fahrt juwenden, fo fet hervorgehoben, daf die in einem Sandabitand von $15-20$ Seemeilen an der oftafrifanifhen Küite nadqweisbaren Tiefen von rund $1000-1500 \mathrm{~m}$ fïh für die fifheret mit den Shleppnesen als bejonders ergebnisreid crwiefelt. Wir veranftalteten

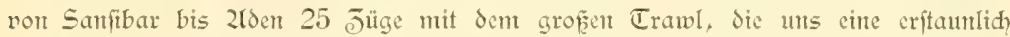
reide, ourd eine fülle cigenartiger formen ausgejeidnete Ticffecfauna enthülltert. 2lu Quantität und Qualität fteht die hier von der Expedition crbeutete Drganismenwelt in feiner Finfidht hinter der bei Sumatra und den Ziffobaren von uns nadigewicjenen

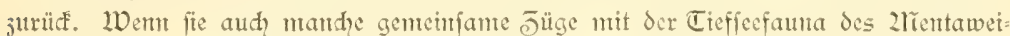
Beckens und des Coolfes von Bengalen anfweit, fo ergab fie dod, auf diejem jumg=

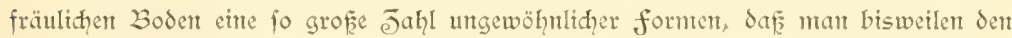
Eindruct hatte, als ob eine neue unterfeeifhe Welt fid vor den erfannten Bliden ausbreite.

Was dic ETrundprobent anbelangt, fo jeigten fie eine grau=grüne färbung, dic dadurth bedingt ward, dafi in Sanduähe dic fogenannten terrigenen 2lblagerungen einen mehr oder minder grofen Brudteil des Tiefenfdilanmes ausmadien. Diefem "Blauen Sd hlid" waren indeffen ftets (1)lobigerinen, bisweilen and Pteropodenidhalen

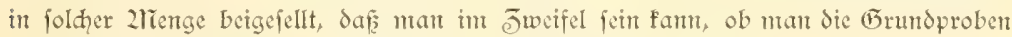
als (Globigerinenidlamm oder als blauen Sd)lid" bejeidnen foll.

Der Küfte felbft fanten wir nur cimmal, am 26. 2Tärj, auf $f^{\circ}$ nörol. Breite nahe. Sie erhebt fith hier ju cinen jienlid, hohen öben Plateau, deffen roter Sateritboden deutlidh zu Tage tritt. Jlmm fint flaḑe Gügel und monotone Sandoüten vorgelagert. auf denten hier und da graue Bülhe und veremzelte Sdimafajten ftehen. Da wir die dort gelegene fleite feftung Brava in nur jwei Secmeilen Entfermutg paffterten, wurden auf dem fort die italienifhe und Sultansflagge gehifft. Bei der Stadt lagerten einige Karawanen und niḑt weit entfernt davon jogen die Drontedare in Ianger Reibe durd die obe Wüftenlandidaft. 
Es war an manḑen Tagen faft unerträglid fđwwïl und wir entpfanden es an= genebm, daf̧ etwa von jwei (5rad Sübbreite an der 2rordoft=2lionfun mit ftändig flaren Wetter cinfetste und cintige Erfrifdung bradite. Eqatten wir dam unfer er= gebnisreides und oft anftrengendes Tagewerf vollendet, fo gentof man an 2lbend die Pradit des fternflaren Tropenhimmels. Gäufig fiel uns die Jintenfitüt des int Weften ftehenden Jodiafallidites auf, das fid vom Gorijont bis ju den Plejaden, manḑmal felbit bis jum Drton crftrefte. 2lls wir uns chige 3rettegrade nördlid von dent Z̈quator befanden, fonnte man gelegentlidh faft fämtlidhe firfterne 1. und

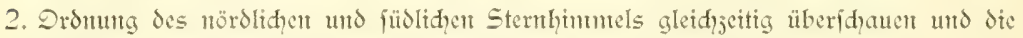
Pradyt der Sternbilder von dem groken Bären bis ju dem füdliden Kreuj und den 2liaghellan = Wolfen ntuftern.

Den volt dent 2Tordoft=2lionfut geregelten Strom entpanden wir als ftarfe, nad? Südweft geriḑtete (begenftrömung mu nahe unter Eand. Sic trifft in $2^{1 / 2}{ }^{\circ}$ füdr. Br. auf die leţten 2lusläufer ber nad) ZTordoft abgelenften S̈ld=2̈lquatorialitrönung. (Dergl. die Karte auf S. 476.) Es ift nidht ohte Intereffe, die tiefgreifenden Deriditedenheiten in

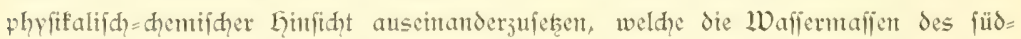

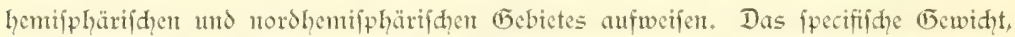
der Saljgehalt und die Temperatur des 2leerwaffers deuten mindeftens ebento fharf wie die auf Grumb der Stromverfetimgen ermittelten Wafferbewegungen den l̈bertritt in ein neues Strongebiet an. Die int nadfolgendent wiedergegebene Tabelle mag das (5̋afagte vielled beffer als längere 2lusführungen illuftrieren.

Sïblid vou der Strongrenje.

1. 2lusläufer des Süo=z̈lquatorialitromes

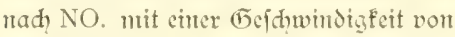
2,4 Secmetlen it der Stunde fliefend. Süblemifphärifdes 10 affer.

2. Waffertemperatur ftets hod,; $28,0^{\circ}$ bis $28,8^{\circ}$.

5. Wafferfarbe ticfblau, nad) der forel EFala $=1$.

4. Durdyfiditigeit des $\mathfrak{W}$ affers (für die fletue weifse Sheibe) $45 \mathrm{~m}$.

5. Specifidaes (5ewidit des Wafiers

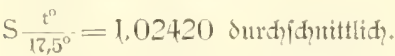

Lhe einen widtigen Teil mimerer Ltuterfudyungen, nämlid, die Ermittelung der

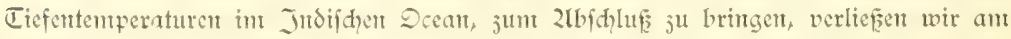

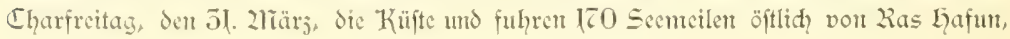

\section{Cördid volt der Stromgrenje.}

1. Trift des NO.-21ronfuts nad, SW. mit ciner (5efhwindigteit vor 2,2 Scentélen in der Stunde fliefsend. (2Tordhemit= iplärifdes 2Dafier.)

2. Waffertenteratur plötlid herunter gehent auf $2 \bar{\tau}, 1^{\circ}, 26,4^{\circ}$ und $25,8^{\circ}$.

5. Waffcrfarbe grünblan bis grablan ver= färbt, forel $=5$ fala $=5-5$ ).

4. Durdfidtigfeit bes Waffers nur $15 \mathrm{~m}$.

5. Specififdes Gewidit des Waffers

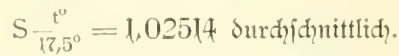


wo wir cine bodifeftation mit $5064 \mathrm{~m}$ Tiefe $\left(9^{\circ} 6, \lambda^{\prime}\right.$ nördr. 3r., $55^{\circ} 41.2^{\prime}$ öft. $\left.\mathbb{E}.\right)$ erreiditen. Das 27eer war fait fpiegelglatt, eme deut= lidhe Strömung war niḑt wahrju= nebmen, und da fein Zlbtreiben des Shifies exfolgte, formtert wir mit 2ruge alle feineren 2 interithungen vornehmen. Es war citter ber ar= beitsreiditen Tage während der gant= jen fahrt: Temperafurperien, fänge mit den Dertifalneten, Dlanfton= neţen und S丸̨liefinetzen wurden von früh bis jum 2lbend ausgeführt, und eine Beredthung ergab, daf wir an diefem Tage niḍt weniger als $55000 \mathrm{~m}$ Draht beroegt hattert.

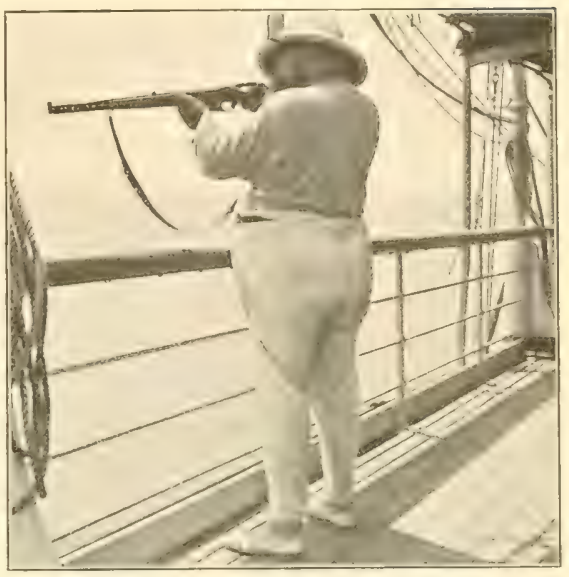

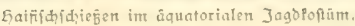

Was die Temperaturferic anbelangt, die wir dort gewamnen, fo ergab fie fols gende Werte:

$0 \mathrm{~m} 27,5^{\circ} \mathrm{C}$

$25,2 \tau^{\prime}, 0^{\circ}$ "

50 " $26,4^{\circ} "$

$100 " 25,5^{\circ} "$

$200 " 15,1^{\circ} "$

500 " $12,2^{\circ} "$

$400 " 12,5^{\prime \prime} "$

$600 " 11,6^{\circ} "$

$700 " \quad 11,5^{\circ} n$

$800 " 10,9^{\circ} "$

$1000 " 9,2^{\circ} "$

$2000 " 5,7^{\circ} "$ $5064,1,2^{\circ}$ "

Die Reihe jeigt infofernt eine Eigentünliḑłeit, als die

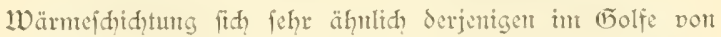
Bengalen geftaltet, und die in den übrigen Teilen des Jndifhen Decans oft fehr ansgeprägte Sprumgidfithte von 80 bis $100 \mathrm{~m}$ an hier wentiger fimfällig hervortritt. Jutireffant ift aut? die relativ hohe Temperatur, weldhe dic mittleren Sdiditen vour etwa $400 \mathrm{~m}$ ab erÉenten laffen. Da bie Bodentemperatur $1,2^{\circ}$ beträgt, fo geht hieraus hervor, daf das falte antaré $=$

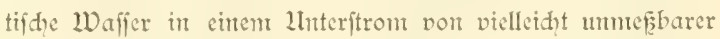
Grejdiwindigfeit bis jum Golf von 2lown hin feinen $\mathfrak{W}_{\mathrm{eg}}$ findet. Gierfür fpridgt aud der Saljgehalt des Tiefenwaffers in $5000 \mathrm{~m}$, der mit $55,1^{0}, v_{0}$ (an der 2 berflädye betrug er $56,0^{\circ} \%$ oo) naheju denfelben Wert wie in gleid̦en Ticfert des antarftifden (5) bietes aufweift.

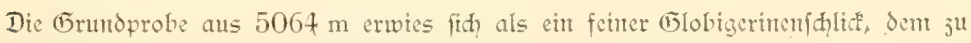
$20^{\circ}$, Radiolarien und andere Kiefelorgantismen beigemengt waren.

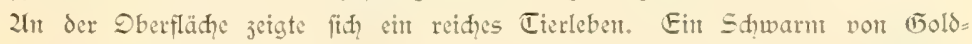
mafreelen (Coryphaena) eilte in mädtigen Sprüngen auf das Sđiffi ju. Es war ein

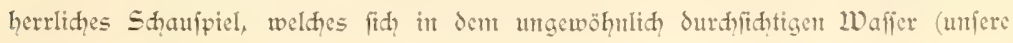


weife 3lechldactbe blieb bis $46 \mathrm{~m}$ Tiefe fiḑtbar) unts Sarbot. Die faft $1 \mathrm{~m}$ langen, in

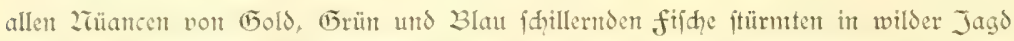
unter den elezanteften $\mathfrak{W}_{\text {entongen }}$ auf bie an den 21ngeln herabgelaffenen Bleififye

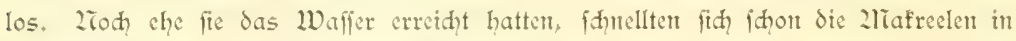
die hähe, fo dak wir in wenigen zhimuten eine ganze 2tnjahl derfelben an Bord liegen hatten, wo fie mit ihren Sdiwangfloffen fräftig das Derded peitjhten.

Wundervoll nahm fid der rafde 1 Dedfel der farben bet den gefangenen Tieren aus: ihre Blau wiđ cintem goldenen (5runton, über den bald blaue fleffe, bald filber= graue Sdatten finweghufdten. Ziad) furzer Jeit aber wurden die fifde vorifidiger, jumal nadjoem entige fid won dir Zingel losgerifien hatten; obwohl fie nod lange das Shiff umfhwammen, bit dody feiner mehr an. Es dauerte nidht lange, fo ges

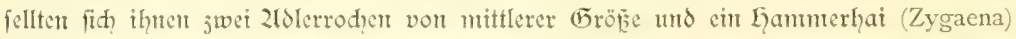
mit feinent monffröfen, feetliţ perbreiterten Kopje bei. Wir vermod,ten peinen derfelben ju erbeuten, wohl aber fdoffen wir niđht wentger als fünf Lqaie, Sie wir mit flafhen föderten. Ltuter wilden, fpiraligen Drehungen, bei denen der nah oben gefehrte weislithe Baud hervoridimin =

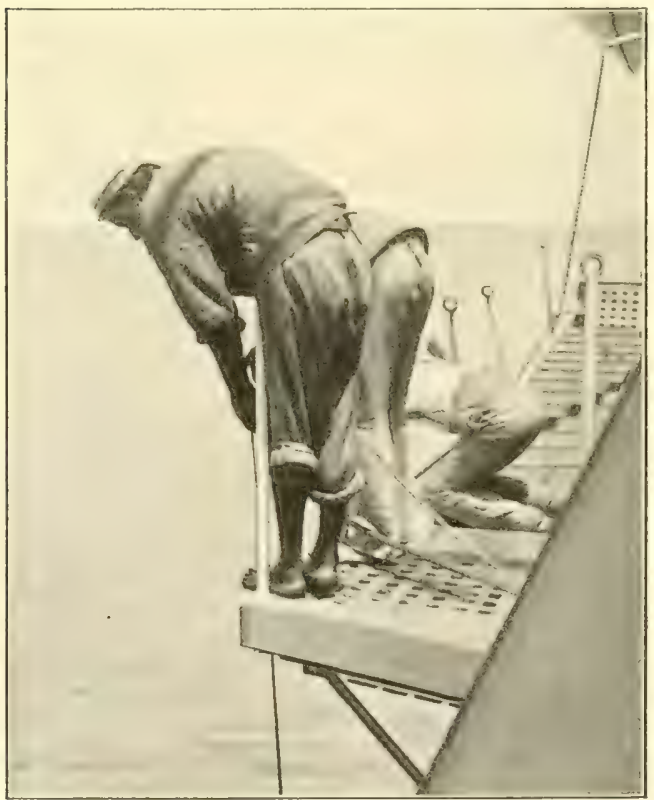

Eetste oceartographijhe 2interfuding am 1. 2lptil 1899. merte, nerfanfen fie, nod lange dem Zluge fentlid, in die Tiefe.

Don der Eodffeeftation aus wurde der Kurs auf Kap जัuardafut und 2lden gefetrt. 2Im 2lbend des Diter= formtags (2. 2lpril) famen Sie hohen, plateanförntigen Bergriltén, welḑe ftaffelför= mig in das Kap auslaufen, bei biefiger Euft in Sidyt: bald belehrte dimn aud dic z̈nnderung in der farbe des Waffers unt in dent Salj= gehalt, der $56 \%$ überifieg, da getreten waren, weldes den ป̈lbergang ju den für das Zaote Zlieer typifden $\mathcal{V}_{\mathrm{er}}=$ hältniffen bildet. Ziahdem wir im Golf von $218 \mathrm{en}$ nod? 
$j_{\text {wei }}$ ergebnisreide Dredidjüge in $1840 \mathrm{~m}$ und $1470 \mathrm{~m}$ ausgefilhrt batten, cröfinete fid in der frübe des 5. Zpril der überrafjente und malerifde Zlusblit auf die hohen, nulfanifhen Berge, welde den (1)olf von 2lden beherrfden. 2lles ift fdivärolidgrau, unterbrodhen von rötlidien oder weiflidyen Streifen: troftlos, fahl und öds für jenen, der nod mentige Wodien juvor die Praht der Tropenoegetation gefhaut hat. Uls wir freilich alt Sant gingen und von Seapoint auts der Stadt 2lden mit ifren im= pojanten Befejtigungen und dem berïhmten Wafferrefervoir cinen Befuch abitatteten, da übergeugte man fid immerhin, dak aud hier sie Degetation nidht fehlt. Dic

Berafette bei zioen.

Reifenden, denen zlden als eine felswüfte erjheint, dürften wohl fiqwerlid ahnen, daf fie fid in einent pflanzengeographifhen Eldorado befinden, infofern nidgt wentger als 95 endemifde Pflanjenarten auf die zldenthalbinfel befdränt find. Da es vor 7 Woden geregnet hatte, fo ftand ein Teil diejer durd thre 21npafingen an die Trofenheit merfwürdigen flora in 3lüte. Eigentümlich wird man freilid berührt, went die 2Iraber und Somali mit einer fait fheuen Elyrfurd)t auf den Brument, der in den Wafierwerfen das foftbare Tafe ipendet, und auf den ihn üferfdattenden Banyan (Ficus bengalensis) als höd fite 2ricrfwürdigfeit 21dens himwetfen. 
Wir hatten monatelang (E)biete durdfahren, in denen die Sonte nur felten jum Durḑbrudh gelangte, hatten die tropifden Regengüfie und dic feudite Sdwwïle unter

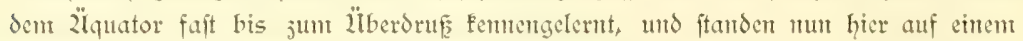

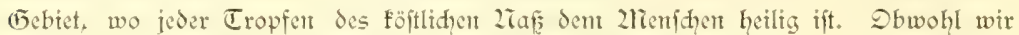
utts nod elf Breitegrade fïblid Dont Wendefreis befanden, fo war es uns dod ju 21iut, als ob wir der Tropenpradit nummehr für alle Jeiten Dalet gejagt hätten. Die

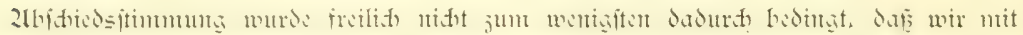
dent Eintreffen it 2loen cine der widtigften 2lufgaben der Erpedition, nänlid die Erforjhutng der Tiefen des Indifhen Dreans, jum 2lbihluf gebradit hatten. In raider fahrt ftrebten wir durd bas Rote und 2littelländifhe 2lieer der Leimat ju.

Die eigenartigen 2lupafingen, welde die flora von 2lden an das trockene Wuijten= flima erfemen laffen, erregten in fo hohem 2liapic das Jntereffe unicres Botanifers, Prof. Wilhelm Sdimper, daf́ er in Snej von uns fdied, um die Erenjgebiete der Sahara ju Surdfitreifen und dic Wüfenflora ju ftudieren. Wir haben dicjen ausgejeidneten forfher niht mehre widdergefehen. Sdywer von den Rectsiven ber Kameruner zĩalaria beingefudt, denen fith nad) dem Derlaffen von Zloen Diabetes Ginjugeflite, wurde er an 9. Siptember 1901 durd einen fanften cos in neuen Botanifden Jnjtitut ju 3 a jel von feinen Sciden erlöft.

Das bimfdeiden des unvergefilident freundes und Reifegefährten mag unfomehr 2nlaf bieten feiner Thätigfeit ju gedenfen, als es fidh unt cinen 23otanifer handelt,

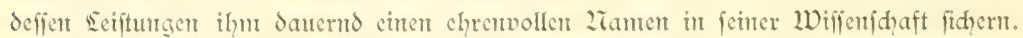

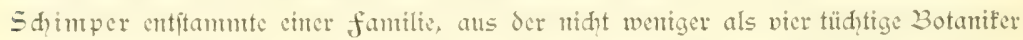
hervorgegargen fint. Die cirjelnen (Ẽlieder dor familie waren teils in dom Elfaf, teils in Baben heimijo. Dem Eljäfier Juscig gehörte Wilhelm philipp Sdimper, der Dater unferes verftorbenen Reifegefäbrten, an, der 1862 jum Profeffor an der Strafiburger fafultät crmamt wurde. Er blicb Sem Elfaf trotzenes verlotfenden kiufes an den Jardin des Plantes in Paris aud tad dem Kricge treu bis ju feinem Tode int Jahre 1880. 2lls Pflanjenpaläontologe und als treffither Kenter der 2lioofe bat ex fidy einen 2ramen gemadt. Don dent badifhen Jweig ber familie Sdimper find die beiden Dettern des Straf̧burger Profefiors, Karl Shimper mo Wilheln Shimper, and in weiteren Kreifen befamt geworden. Der erftere dojterte in pä = terer อ̄eit in 2lïndhen und wurde der Begründer der berühmten Blattfellungstheoric, während $\mathfrak{W}$ ilhelm Sdimper fich uriprünglid der militärifhen Saufbahn wiontete,

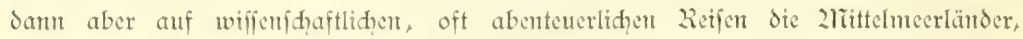
2rabien und 2lbeffuten durdhitreifte. In 2lbefinien heiratete or die Sdiwefter des Körigs Ubié und ftarb $18 \pi 8$ in 2roua. 
In dent jungen Wilhelm Shimper, dent am 12. 217at 1856 geborenen Sohnte des Strafburger Profeffors, jeigte fidh idon früh die trabittontlle Begabuntg für botanifhe Studien. Die treffliḑe Sduule, welche ihm cinerfeits durd feitren Dater, andererfeits durd feinen sehrer de $\mathcal{B} a r y$ ju teil ward, bradte es mit fidy, dafer weit umfaffender als feine Dorfahrent dem (Gefamtgebiete der Botanif feite 2lufmerf= fantfit juwendete. Behandelten die Ieţteren porwiegend pflanzenpaläontologifhe, ivftematijhe und morphologifde fragen, fo liegt der Sdywerpunft von Wilhelm Sdjimpers 2rbeiten auf pflanzenphyfiologifdem und biologithent Gebiete. Sente Lnteriudungen über das Wadłstum der Stärfcförner, über dic Chromatophoren und über die Bildung und Wanderung der Kohlenhydrate in den Saubblätern haben

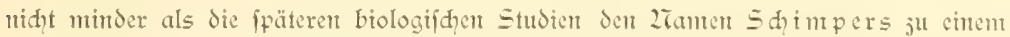
geadhteten gemaḑt. Die Wanderlupt, gleidfalls cin Erbteil feiner Dorfahrem, trich thy früh hinaus. Zadidem er bon $1880 \mathrm{ab}$ cin Jahr lang an Johnt Lopfins lhiverfity j" Baltimore ftudist und bei diefer (B̃elegenheit 2lusflüge nad florida und Weftindien unternomment hatte, łehrte er 1882 nad, Europa jurücs, um in Bont, wo cr fpäter jum auferordentliḑen profeffor cmant wurde, als pribatdojent fith jut habiliticrent. Shimper war freilid feit freund des ftillen Einfitsms, und fo unternahn er dem

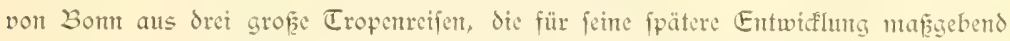
wurden. Die erfite führte ihn nad Weftindien und Dencjucla, wo er fein fpejielles Interefie den tropifden Sdimaroţergewähifu (Epiphyten) juwendete. für bie jweite

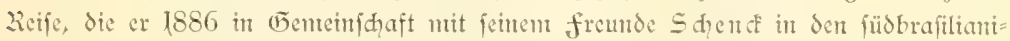
finen Lluwals unternahm, gab eine Einladung des ausgejetdenten frith zhüller den 2lusidylag. Dem antregenden Derfehre mit whüler mag es denn aud wefentlid jul=

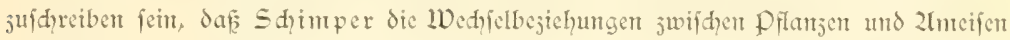
im tropifhen 2tmertifa in Betradyt jog: Studien, weldhe ebenfowohl das Jutereffe der Botanifer, wie der Joologen in hohem 2räa erregten. Sdon in Südamerifa feffelte then die tropifhe Strandflora, deren linterfudyung er fid wefentlid auf cince $1889 / 90$ unternonmenen Studienreife nad? Java wibntete. Seine grop angelegten Lnterfuḑungen iiber die Sduthmittel des tropifden Eaubes gegen Trampiration und über die indo= malayijhe Strandflora lezen Jengnis ab für die unermüldide ThätigFeit im Tropen= gebiete. Begreiflid, daf cin Botanifer, weldher die Degetation Ser Erde aus eigener Zlufhauming eingehender, als die meiften feiner fadgenoffen hatte fenten Iernen, fid

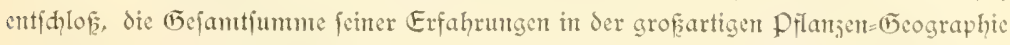
miderjulegen. Ex betitelt das Werf́ "Pflanjent=(5eographie auf phyflologifdyer (5)rund= lage" unt betont hiermit den Gegenfats ju der bisher üblidgen fyftematifden Behand= lung. Jhm ift es wentger darum ju thun, bie einjelnen florentareale abjugrenjer, als

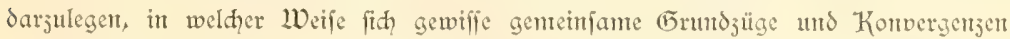

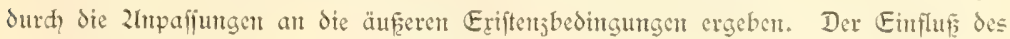


Klimas, der Beliditunt, des Wintos, der Bodenbejoffienheit unto endidh der Tierwelt auf die Pflanjengenoffmidjaften tritt in den Dordergrumb der Betradtung.

zls dem setter der Tieffec=Erpedition von fetten des preufifinen Kultusminifteriums Ser Wurfd nahegelegt wurde, prof. Sdjintper jut Teilnahnte ju bewegen, veritand is fid von felbit, dafi er dicfent mit frenden entiprad. (5)lüflid, der, dem bet ben Eintritt in cin florengebiet, wo alles neu und frembartig den Befhauer fid darbietet, eir foldher Gefährte jur Sette fteht! Der Reij einer gemeinfamen 20 anderung mit

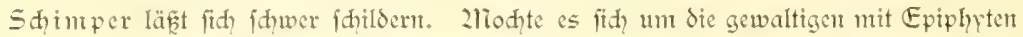
überiäten Kiefen des tropifden Regenvaldes in Kamerun und Sumatra handeln, oder um die Steppengebiete uno 2liangrove=formationen des Kongo und von Sitafrifa, oder modten dic Kanaren, dic Kerguelen, die Kofoseilande und die Seychellen durd = wandert werden, fo war man mit wenigen Striden, ohne daf das (5edädnts nit jahllofen fyftematifden ZTamen befdwert wurde, über den Degetationsdyarafter belehrt.

Dem ohnehin niḑt fehr widerftandsfähigen Körper mutete Sdimper fduwere Strapajen 34 : nmbefümmert un tropifhe Regengüffe gintg es hinaus auf dic mit Itrwald beftandenen $50 ̈$ hen, Jurdjog er die Karroo dret Wodhen lang auf ement Ddfent= wagen, fubierte er auf unwegfanten Pfaden die Degetation der Kerguelen, oder durd? = pilgerte er im glühenden Somenbrande dic Steppe. Zriemals crlahmte der Enthufias= mus und die Spantraft. Wir fehen ihn nod vor uns ftehen, wie er mit diden Päłen von Kerguelenpflangen unter den 2lrmen jurüffehrte und begeiftert die eigenartige

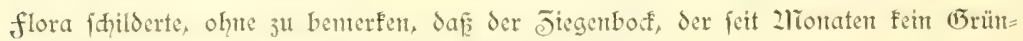
futter nubr gefeben hatte, eifrig an feinen 3üfden fraf.

Die Expedition gab Sdimper (Belegenheit, fid mit cinem neuen 2lrbeitsgebiet vertraut ju madien, itdent er fidh gleid nad der 2lbfahet an der Interfudfung der Planftonjüge beteiligte. 2liti jentem fleipe und jenter findigfeit, dic ifm eigen waren. arbeitete $\mathrm{cr}$ fith raid in die Syftematif der Diatomeen und peridineen cin, um Sann den Einflus der veribiedenen Strongebiete auf die Derteilung des pflanjlidhen planftons

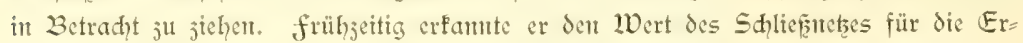
forfdung der vertifalen Derbreitung affimtilterender Drganismen, und fo gelangte er namentlid? in der antarfifiden Region ju jenen wiḑtigen Refultatent, die wir frïherbin mitteilten. Ltnerntïdid faf er von früh bis fpät hinter dem 2lififroffope, mod)te es ftürmen, oder moḑte die z̈lquatorforme den 2lufenthalt anf Ded ju einem nitht be= neidenswerten geftalten.

War die 2lrbeit beendet, fo jeigte fid der fonft fo ftille 2liann von einer nenen Sette. Sdimper war eit Caupur in beften Sinne des Wortes. 2lit feinem Lumor wuf̧te ar dic Unterhaltung ju beleber, und da gab es nientanden, der if̧m nidit gern gelaufht hätte, went er von feinen Wanderungen in Denejuela, vort der Befteigung der Dulfangipfel Javas, von der gaftliden Zufnahne, die thm durd fritz 2liuller 
in Blumenau, durd, Treub it Butenjorg ju teil ward, plauderte. Dabei war ibm trots peiner l̈berlegenheit in Wiffen und Erfaḩrung eine bejdeidene Juräfhaltung eigen; jeinen feinften formen des Ltmgangs wideritrebte das (5eltendnadien cigener Seiftungen und fharf urteilte er nur $\delta a$, wo ifm llberhebung und Kaftengerft begegnet waren.

2Tidit umfonft hat er während und nad der Erpedition rajtlos gefhafit; feine 2luf= jeithungen, die er in der Vorahnung des frühen Todes anf die widgtigften Kapitel bejhränfte, geben cine folide Grundage für die Eerausgabe des botanifden Teiles des Reifewerfes $a b$, weld̨er - deffen fut wir fidher - cinen Ehrenplats in der biolo= gifhen Sitteratur cinthehten wird.

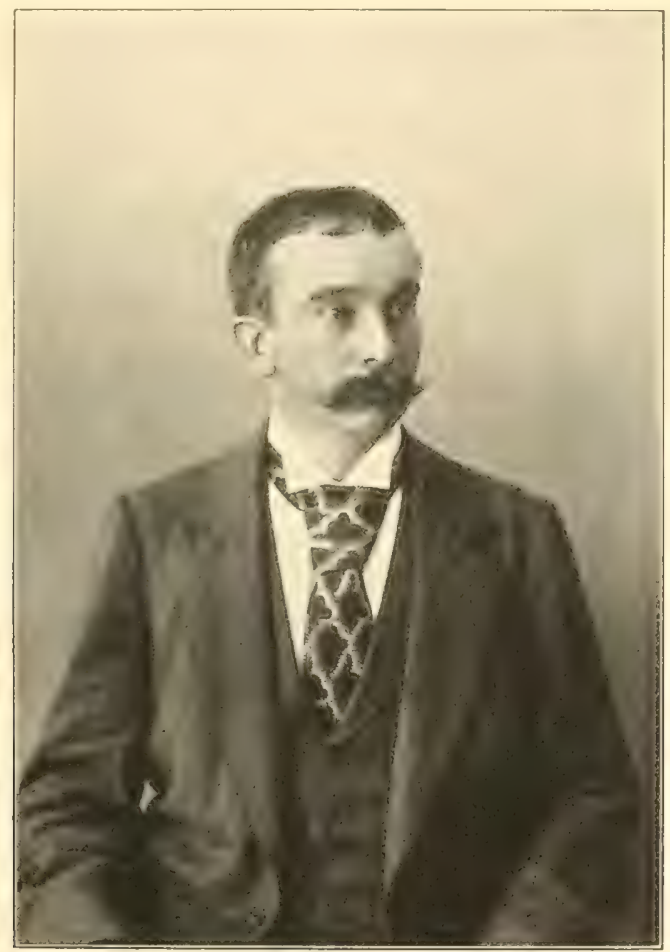

Prof. Wilbelm $S$ dintper. 


\section{Die Tieffectanta.}

12 D Tieffeconamismen vorjufübren, fo darf es wohl geftattet fein, chwas weiter ansju= zreifen und uns nidht blop̧ anf jenes Ecebiet ju befdyränfen, das uns allerdings feine

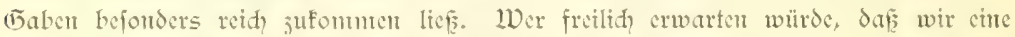
and mu antäherut erfhöpfende Daritellung vor dem währent der fahrt erbenteten

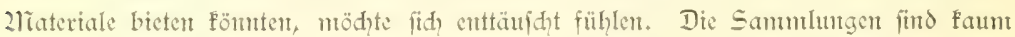
erft in die Lände Ser cinjelnen Bearheiter gelangt, und es verden Jahe vergehen, ehe

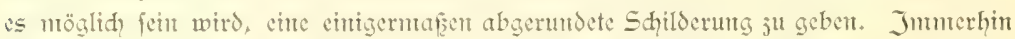
mödten wir den Derfuch wagen, an der Gand der während der fahrt gewomtenten Findrïfe und der uns injwifhen volt den Bearbeitern jugegangenen Beridyte dem vejer cine 2mzahl typifder Tieffecorganismen in Wort und 3 ild norjuführen.

Es wird fid hierbet cmpfellen, cine Shcidung der Ticffecorganismen in foldhe, welde auf das Seben an Êrunde angewiefen find, wno in foldhe, weldye in unbelidteten Titefen fowebend ein fogchanntes pelagifdes Dajen führen, cintreten ju laffen. Unjere Expedition ift namentlid, Jurd dic ausgiebige Derwendung der Dertifalnetse in der sage, fdärfer, als es früher gefhehen ift, cine derartige Sidptung ju ermöglidhen.

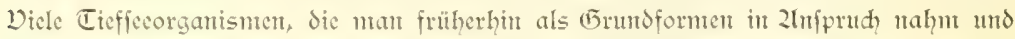
als an das feben in Sdlanme hervorragend angepafit betradptete, haben fid als pelagiface formen heransgeftellt. Da fie gelegentlid in die Shleppnef̧e bei dem Zluf=

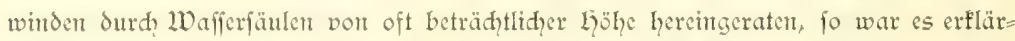
liक, daf man cine ganje 2 nnahl serartiger formen als (5) 
und ihnen cin Dorfonmen in gröferer Tiefe jujdrieb, als es thatfählid der fall ifit. Es mag indeffen gleid, volt vornherein hervorgehoben werden, das eine fharfe

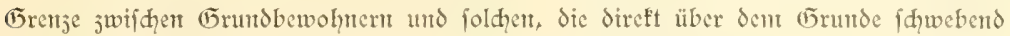
fidh aufhalten, nidyt ju jichen ift. Zramentlid vermögen wir von ciner ganten 2unjahl langiđwänjiger Krebje und cigentünlid geftalteter Tieffeefifhe nid̨t mit Sidherheit ju entfheiden, ob fie lediglid auf Sem (Frunde leben, oder aud nod in beträđt= lidher böhe über demiclben fowweben.

2riht minder idweierig ift der Entideid, von welder Tiefe ab man Drganismen als Tieffeeformen will gelten laffer. Wem man früher vielfad die Lundert=faden= Sinte als Brenjmarfe jwijden Oberfläden= und Tiefenformen hinjtellte, fo ergiebt

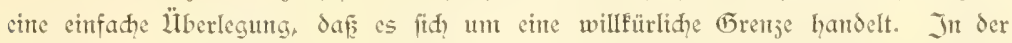
arftifhen und antarftifdyen Region herridht in ctmer Ticfe von 100 faden, aljo etwa $180 \mathrm{~m}$, eine Temperatur, dic fid um den Ziullpunft bewegt; in mandyen tropifden (5ebieten ift $e s$ hier nod) fo warm, daf von vornherein nidht abjufehen ift, weshalb gewiffe Dberflähenformen jene Tiefe meiden follten.

Int allgemeinen läfst fid, nux fagen, dap die Tieffeefauma da cinfetst, wo ciner= feits das abgejd̨wäd)te Somtenlidit den Pflanjen eine afîmilatorifhe Thätigfeit un=

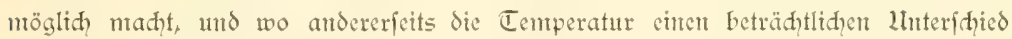
gegen die Dberfläde anfweift. für dic arftifhen und antarftifhent (5ebiete fomm int wejentliden nur der erifgenamte fattor in Betraḑt, während für die tropifhen und

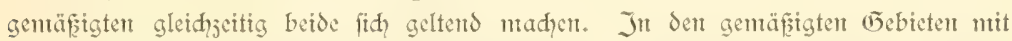
ihrer jhwanfenden Dberflädgentemperafur begimut die Tiefenfauna im allgememen erit Sa, wo dic Tiefententperatur fonftant der nttfleren Dberflädentemperatur währens des Winters entipridįt.

Infere Unterfudungen über Sic Tiefenverbreitung des pflanjliden Planftons habent racben, daf unterhalb $550 \mathrm{~m}$ feine affimilierenden Drganismen vorfonmen. Die Gauptmaffe derfelben ftaut fith bis $80 \mathrm{~m}$ Tiefe at und nur wenige formen find es, die als cine "Sdiattenflora" nod, bis ju $550 \mathrm{~m}$ herabreidhen. 2lian darf aljo nidht überrajht jein, wenn in antartifden (5ebiete fhon in relativ gernger Tiefe bet der

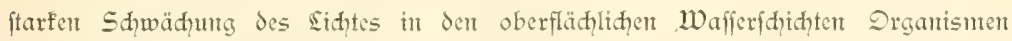
erbentet werden, die den Charafter von Tieffeeformen tragen. In den Tropen Itegt

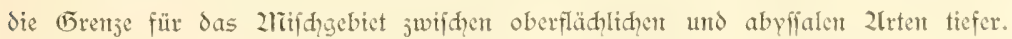
Wir waren oft in Derlegenheit, went wir in etwa $500 \mathrm{~m}$ Tiefe dredidytert, ju be= ftintmen, ob bei sen erbeuteten Drganismen ntehr der Charafter von Dherflädyenformen oder von Tiefenformen in den Vordergrund trat. Int allgementen dürfen wir wohl

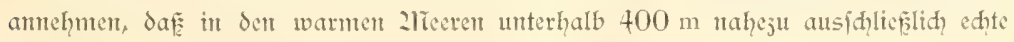
Ticfiecformen auftreten. 


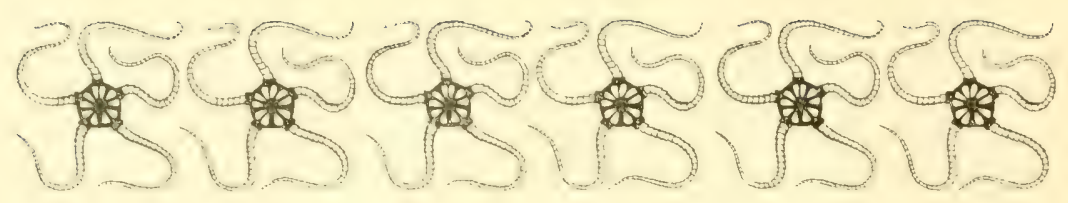

\section{Die (5rimtsianta ser Tiefies.}

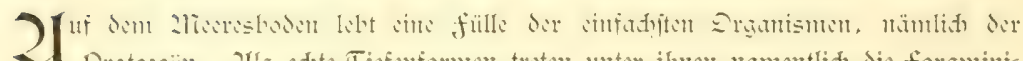
Protojoër. 2les edpte Tiefenformen treten unter ihnen namentlid die foramini=

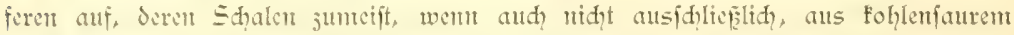

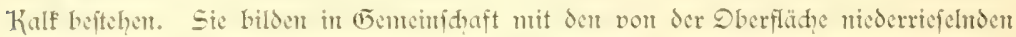

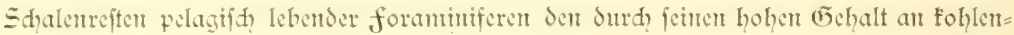
faurem Kalf ausgejeiduteten "Ẽlobigerintenfdlanm", auf beffen Verbreitung uno

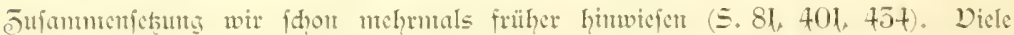

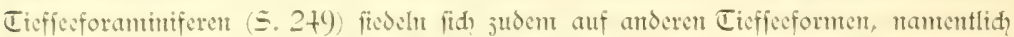
auf Korallen und Wurzelidiöpfen der Eeraftincliden, oft fo maffenhaft an, das fie

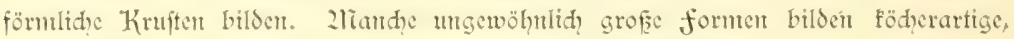
verjuetgte oder rutblidge (5)häufo aus jujammengefitteten partifeln des Tieffee=

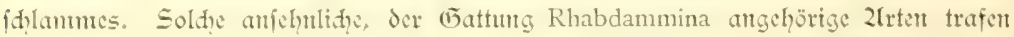
wir nantentlid, an bent atlantifinen 2lbfall ber 2lgulhas=3anf in $564 \mathrm{~m}$ Tiefe maffen=

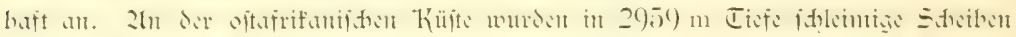

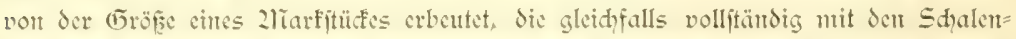
reften mon (क)

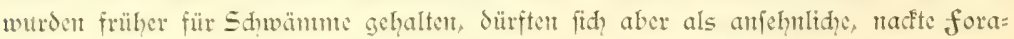
mintferen erweifert.

J̈แ den glarjvolliten Dertreten von Tiefferorganismen gehören cine 2fnjahl von

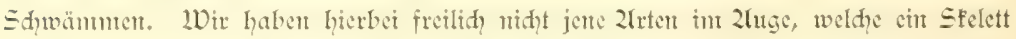

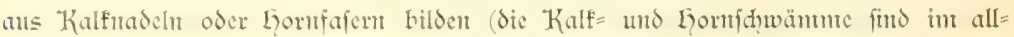

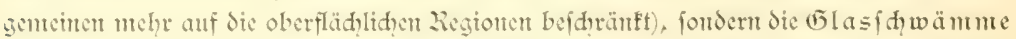
oder Geraftincliden mit ibren wutdervoll zart gewobenen Sfeletten aus remer Kiefel= füure. Bei den folgenden Darlegungen halte id nidh an den Beridht, weldhen der aus=

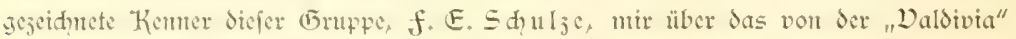
srbeutete Leraftincllident=?liaterial jufommen liç.

Den Zamen Leraftinelliden habeu die in Kebe ftehenden Sdwäntme erhalten, weil ihre aus Kiefelfäure beftehenden Sfeletteile cinfade Sedisftrahler (Eeraftime) oder von 


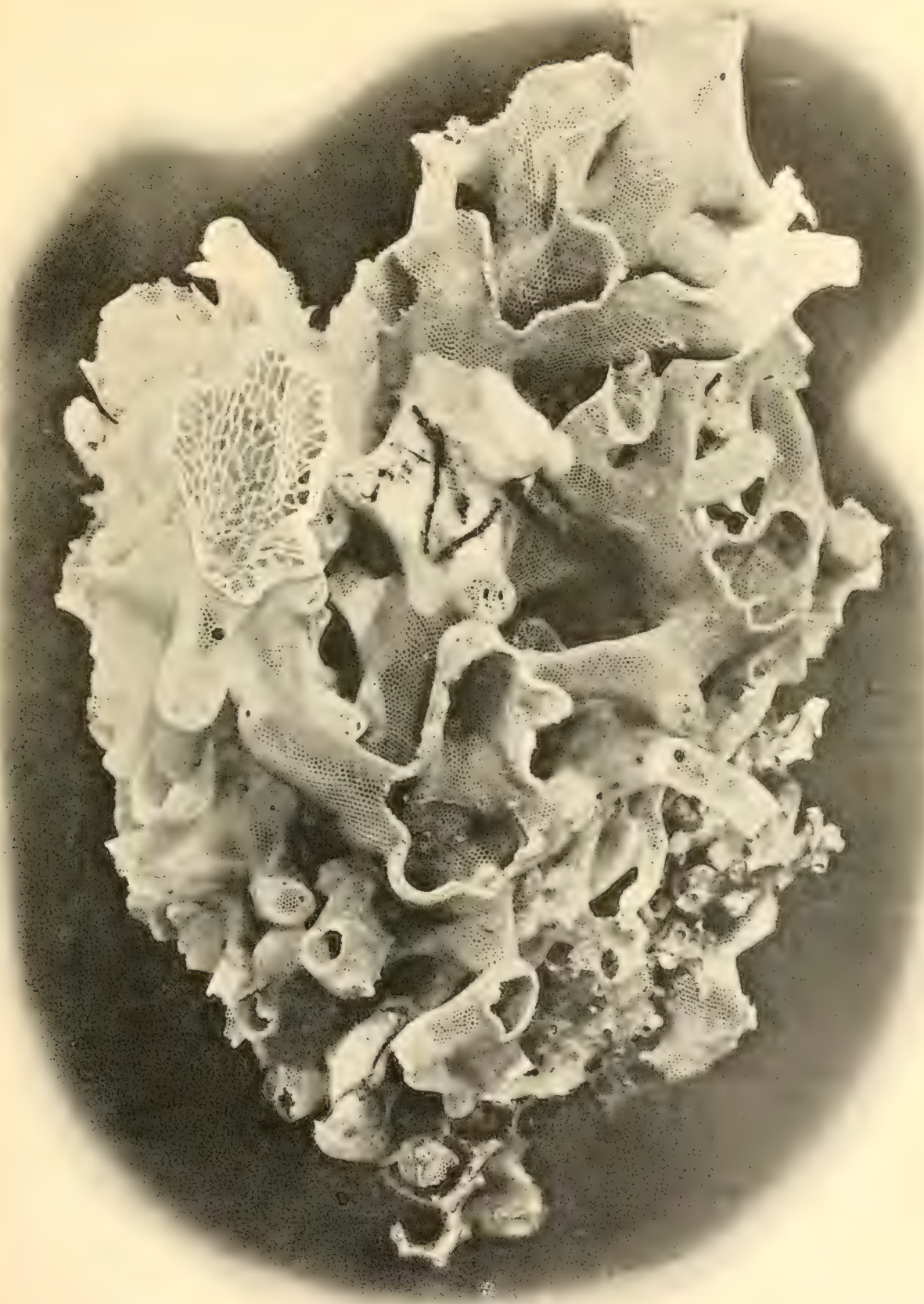


Siefen Iciḑt abzuleitende 2radelformen daritellen. Bald fonmen diefe Glasnadeln von verfhiedener und meiftens auferordentlid, jierlider (Eeftalt nur ifoliert, bald ju feften Gittergerüften vereinigt vor.

folgen wir der Route der "Daldivia". Juerit jeigtent fith in $1626 \mathrm{~m}$ nordweftlid? von Shottland eintige bereits durd frühere Erpeditionen befamt gewordene Geraf= fineliden, fodam traten fie in gröferer Jahl in der Gegend jwifhen den Kanarifden und Kap Derdifhen Injeln auf, wo einige neue mit dem befanten "Demusförbdien" (Euplectella aspergillum R. Swent) nahewerwandte formen gefunden wurden.

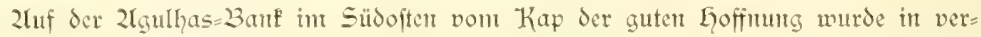
hältnismäfitg flahen $\mathfrak{W}$ affer (in $100-120 \mathrm{~m}$ Tiefe) cinte newe form emporgebradt, deren fadförmtger Körper mit einer fđlemäbnliḑen Gülle jierlider (6)lasmadeln um= geben ijt.

Während die Bouvet=Region feine Eeraftinelliden lieferte, fo famen in der 2rähc bes Enderby:sandes ans cinem $2 \mathfrak{b g r u n d e}$ von $4656 \mathrm{~m}$ neue Repräfentanten von jwei (Eattungen - Holascus und Caulophacus - herauf, welde ju dent typifden Bewoh= nern der gröften 2lieerestiefert gehören. Wäh= rend die Holascus glatte Röhren daritellen,
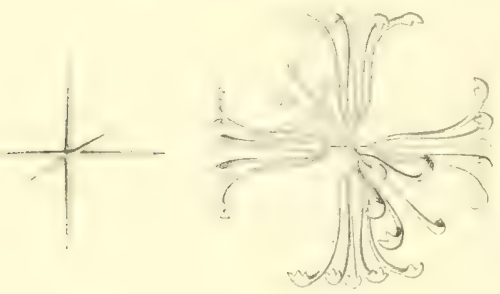
welde mit einem Kiefelnadelihopfe im Sdlamme wurjelt, bilden die Caulophacus hutpilzäbulidis formen, deren füsthenför= migar Kärper pon sinem fḑlunfen, am (Grunde feftgewadfenen Sticle getragen wird. 2luf der ganzen Tour durd den füblidhen đeil Sedisfrahler Der Egegaftinelfioen tnath F. E. Schulze). des Indifaen Decans erbenteten wir lediglid in der 2uähe von St. Paul cinige (5lasfowämme, utd jwar fhon befannte Dertreter bolt (5)attungen, weldye auf felfigem $230 d \mathrm{en}$ fitsen.

2Int fo reider ward damt aber die Ente vor der Weftfüjte Sumatras, wo jahl= reide Jndividuen veridiedener 2frten erbeutet wurden, Sarunter in befonders groper 2lienge jene fd̆lanten dümmandigen Kelde mit radiür vorragenden handjunhfinger=

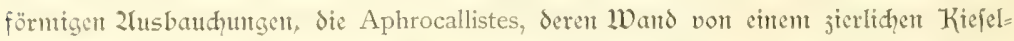

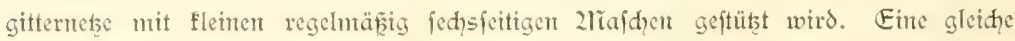

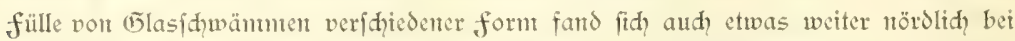
Sen 2Tifobaren, wo an ciner cinjigen Stelle, nämlith an Wefteingange zum Sombrero= Kanal in $805 \mathrm{~m}$ allein fünf veridjiedene Species in jahlreiḑen und teilweife jehr ane fehnlidfen Exemplaren gefifdt wurden, darunter etwa 50 faupt= bis fopfgrofe Stüfe jones rettigfömigen Sd)wanmes, Pheronema raphanus, weldher fdon früher von anSeren Expeditionten in der Bat von Bengalen aufgefunden ift. Kleinere Repräfentanten derjelben 21rt, fowie cine merfwüroige nene form "von der (5ejtalt cines antifen 
2liifdfrnges lieferte cine benadbarte

Stationt itt $752 \mathrm{~m}$, währent weiter füßlid in $562 \mathrm{~m}$

Bicfenerentalare einer langgeftrecter $c^{\circ}=$ Iindrijder Semperella bis jt $80 \mathrm{~cm}$ sünţ⿻ mit

wobl=

crhalte

nem jier:

lithent bautgit=

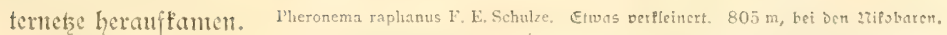

2luf ber falyt von den Zïfobaren quer Jurdy den Judifden Decan bis jur afrifantifhen Küfte fanden fid? nut wentig Glasfdwänme, dagegen trat wieder cine Ehun 2tus ben Tiefen des weltntectes. B̈weite 2tuflage. 


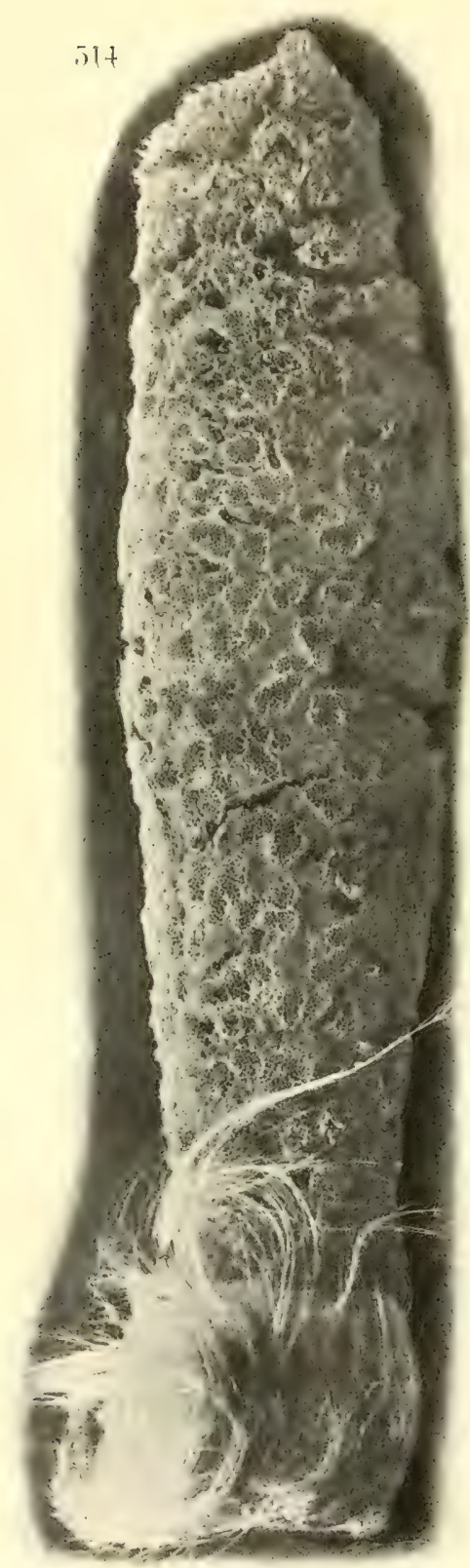

Oitafrifanifice Geraftinellidet.

wahrhaft überrafhende llienge in ber Zähe des afrifantifonen Kontinents auf. Lnter ben vielen hier gefammelten $\mathfrak{Z} r=$ tert fimb befonders jwei newe formen volt hervorragendem Intereffe, welthe beide jul der fharf begrenjten (5ruppe der Amphidiscophora gehören. Setztere find ausge= jeidnet burch die eleganten mifroffopifhen Doppelanfer oder Zlmphidisfen, weldie ju Taufenden Sen Wethförper Surdjetzen, fowie durh feine tamnenbaumähnlithe vielpitizige ziadeln, Pimule genannt, weldhe die gange freie Sberflähe didyt befetsen und Pallifaden gleich die zln= näherung lüfterter feinde verhindern.

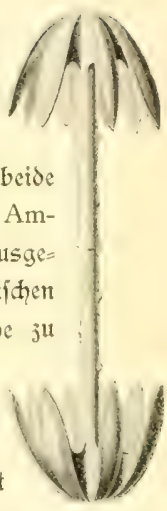

Intphtoist (nach Schulze).

Eine diefer Almphidisfophoren hat die Beftalt ciner folofialen fladen Sdyöfffelle nit etwas auf= gebogentem Rande. Won dem den Gandgriff der Kelle daritellenden unteren fortiat ragt ein Shopf ftricfnadeldider Kiejelnadeln frei hervor, die fith mit einer jweizähnigen $\mathbb{E}_{n} \delta=\mathcal{D}$ erbreiterung im Sande des 2liceresgrundes veranfert. Wegen der äuferen z̈hnnlidfeit mit cinem plattfiche foll fic die Bejeiduntung Platylistrum (= Sđäpffelle) platessa exhaltert.

Fine andere form derjelben (E)tuppe, Monorhaphis n. gen., ftellt einen ambiffen cylindrifhen Körper dar, bon deffen linterrande nidht ein Sdyopf dünner Kiejelnadelnt, fondern eine ein= jige lange fräftige 2radel weit hervorifteht und fĭ jweifellos tief in den Zireeresboden cintbohrt.

Fine in $1644 \mathrm{~m}$ gedredidyte, jiemlid voll= ftändig erhaltene Zradel der 2lrt weift bei einer gröpten Didfe von $5 \mathrm{~mm}$ cine Sänge vort $1.5 \mathrm{~m}$ anf. Da mut eit von cinem atteren Exemplare herrührendes 2Tadelbrudiftü Kleinfitgerdidfe befitgt, fo läfit fid mit

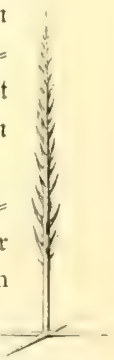

Pinul (nadi Schulze) 
Wahraheintid)feit auf einc Sänge der betreffenden 2ia= Sel von etwa $5 \mathrm{~m}$ fdilię̧en.

Dieje Riejenformen von Sdwantmmadelt, welde ḩäufig mit Sprop̧forallet und 2lftimien bejeft waren, haben midit verfehlt, das gerehtfertigte Eritaunen der Јౌoologent wadzurufen.

Wenn wir uns mun dent Dolypen der Tieffee ju= wenden, fo fet junädhit er= wähnt, daf die jierliđ̆en Lyjopolypen in grofectie=

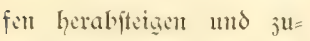
weilen geradeju gigantif he

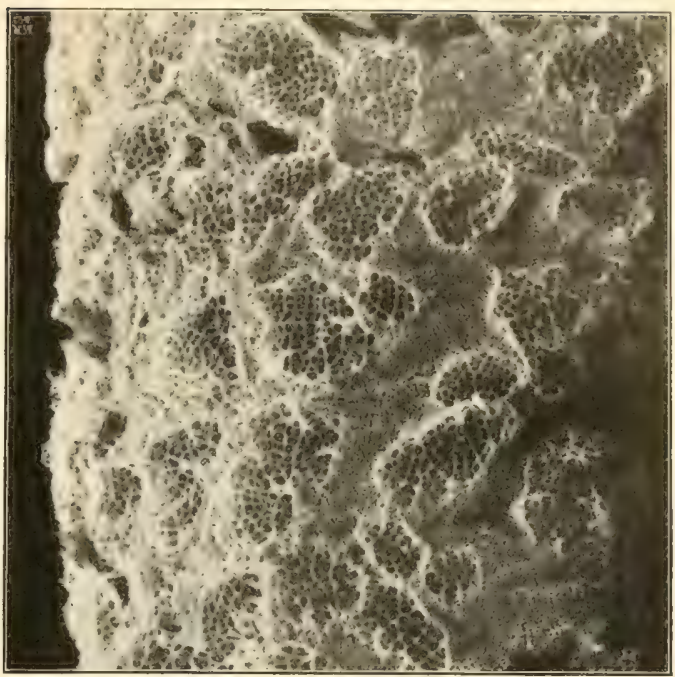

Fautgitterneţ ber Semperella in nat, Bröge.

Dimenfionent annehmen. Dies gilt fpeciell für einen Soltär=Polypen, den fiton dic Thallenger= Expedition in Grofen Tiefen des pacififhen Sieans itreutet und als Monocaulus imperator bezeidnet hat. 2ludh uns war es vergömt, diefen (Éiganten feines Befdled,ts an der oftafrifanifhen Küjte aus eirter Tiefe von $1019 \mathrm{~m}{ }^{u}$ drediden. Das erfte Eremplar, welhez wir erbeuteten, war jugleid aud etnes der größ̨ten und prädtigft gefärbten; ungleich näntich den Leraftinelliden, die fait durḑweg einen fablent, an den lithographijhen Sdicfer erimternden Ton aufweifen, jeigt diefer Monocaulus eine feine farbenjufammenifellung in Rot. Sein Stamm, der mit den Bafalabidnuttt in Sdlamme ftect, erreidyt cine Sänge von $1,15 \mathrm{~m}$ und trägt einen oberen, feldförmigen 2lbidntitt, der von jwei hodhrot gefärbtent Tentafel=Kränjen umiäunt wird. Jwijhent ihnen fitzen verjweigte Stiele, weldie die fortpflanjungsorgane (Gonophoren) tragen. Die Tentafeln find nidht, wie dies die erjte Befhreibung der von "Challenger" erbeuteten Eremplare vermuten lief, radiär, fondern bilateral=fynmetrifd angeordnet. Wir haben noh drei fleinere Eremplare des Monocaulus aus geringerer Tiefe $(628 \mathrm{~m})$ an der Somali=Küfe erbeutet, welche in

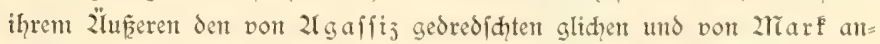
fänglich mit Unredłt für einc 2lftintic (Branchiocerianthus) erflätt wurden.

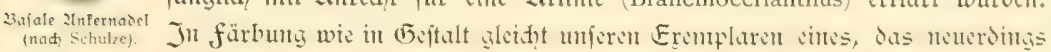

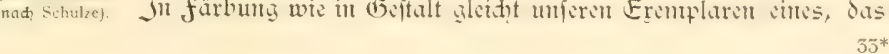


i. I 11

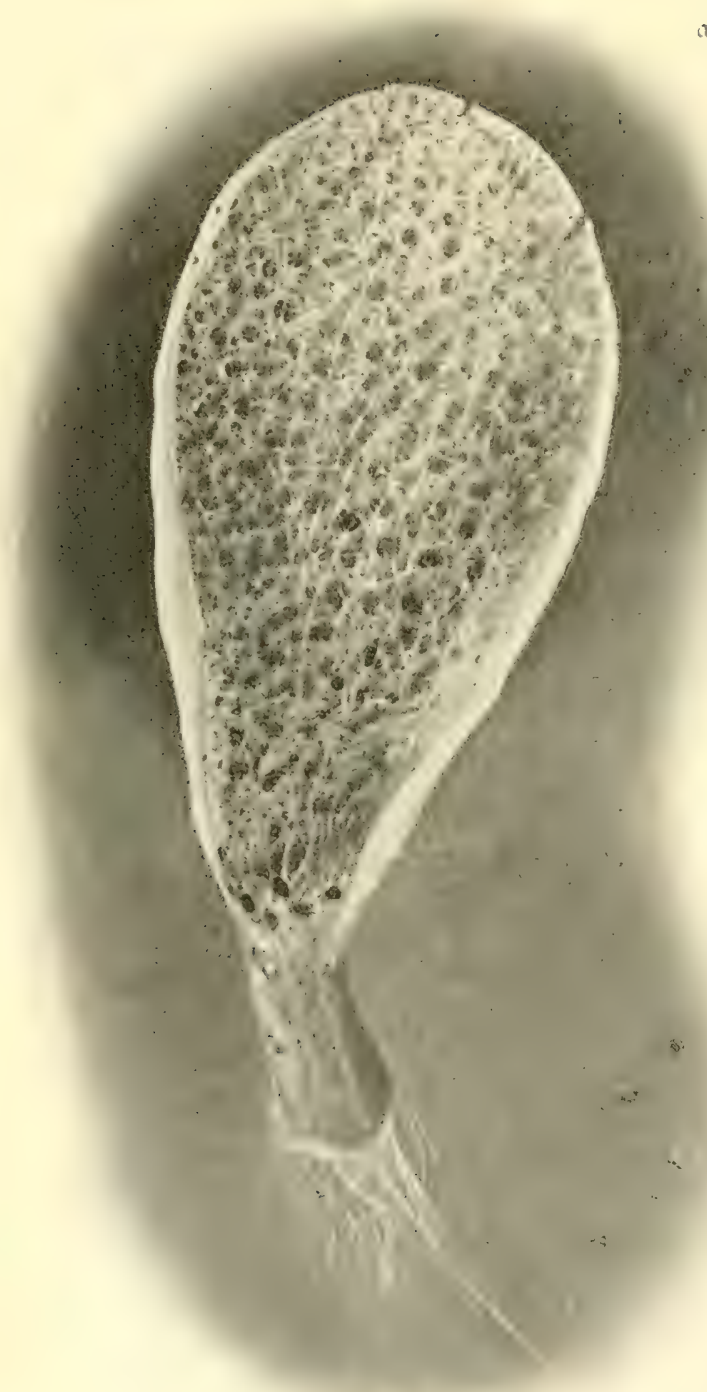

Die Ulcyonatien.

an ber japanifden Küpte gefunden und volt Profeffor 2litfufuri als Branchiocerianthus imperator befdricben wurde. ltufere Expedition mar befonders crfolgreich int Erbenten jener Polypen, weldie Jurd en von epp $^{2}$ ten geftüstes Shlund= roly und adit fang= fäben harafteriftent find und als 2llcyourien bejeidnet werder. Der Bearbeiter dicfer (5ruppe, Profeffor Küfenthal, wer= fidyert mir, daf in dem von der "Daldivia" gewomenen 2liateriale nidit mur dic widt = tigften der bisher befannt ge= wordenen Typen, fontern aud? sine überraficul grof̧e ఏahl neuer und durd ifren $B$ au fej= felnder Urten vertreten find.

Wir haben bereits (5) le = genheit gefunden, auf jene präd)tigen 2llcyonarien aus der (5attung Umbellula binguweifen $(\Xi .185)$, wel= the juerit in norbifden treeren gefunden wur= dent. Sie gehören ju der Drdmung der Pennatuliden und wurden fithon in der criten Lälfte des 18. Jahe bunderts pon 21 driaanj, dem Konmandeur des Sdiffes "Bri= tantria", an der Käfte (n) mit ber Sotleme aus 500 faden Tiefe 


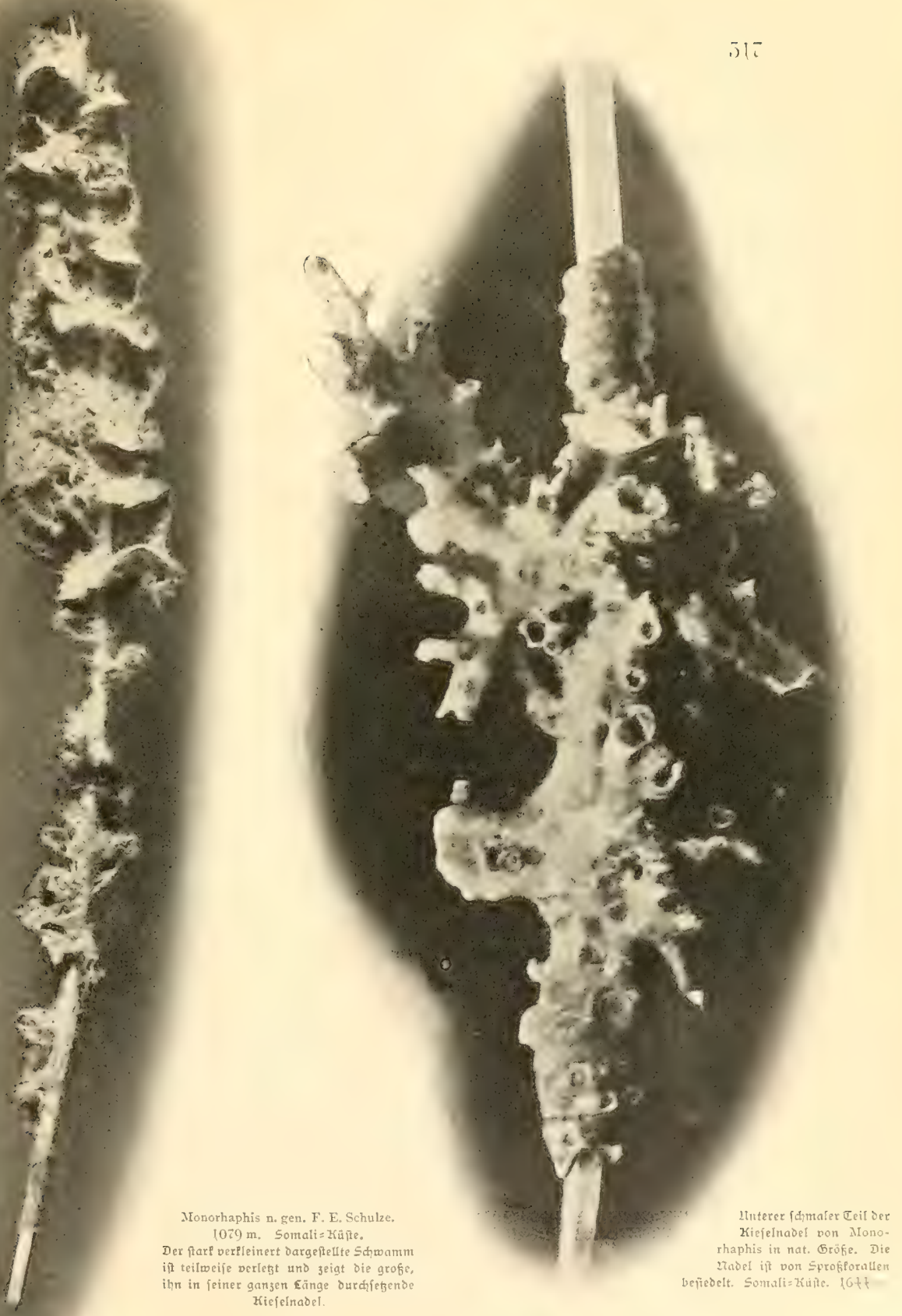




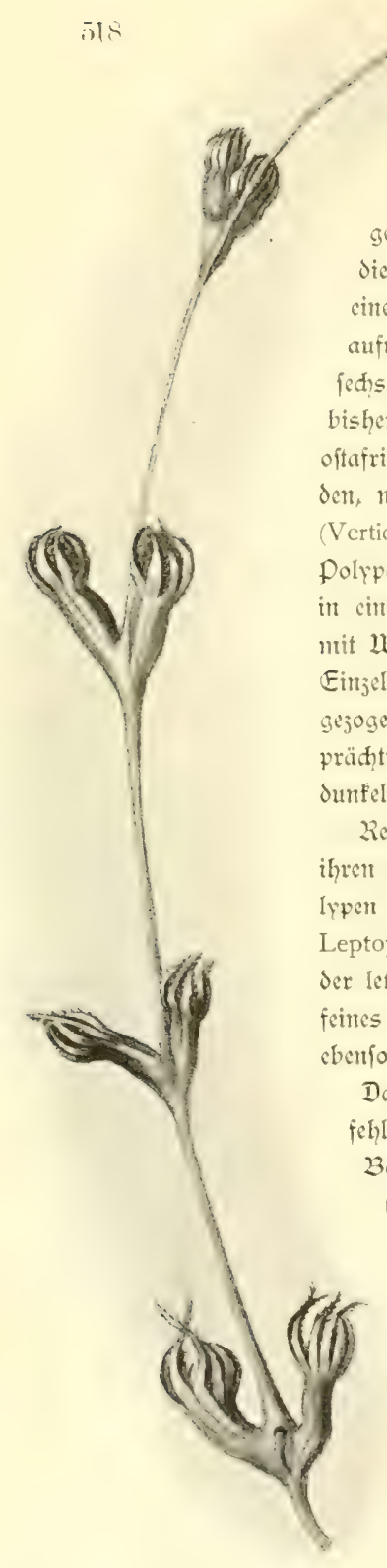

2Tese familie vort pernatulioen.

gebradit. 2̈lhnlidie Praḑterent= wir fie aus dem 2Torden fenten, wohl an ber Bouvet = Jnjel wic Grebiete des Indifhen Deeans feffeln durh ifyre feine färbung. Polypen in Betradt fommen, oder diofoladebramen Ton dicfe formen, von denen wir fechs neue 21rten erbeuteten, in ifrem Gabitus nidht von dent bisher befannten abweiden, fo lieferten unjere fänge bei der oftafrifanifon Küfte Dertreter ciner den LImbelluliden naheftehen= den, neuen und durdiaus eigenartigen familte von Pematuliden (Verticilladeae Kükenthal). Es handelt fid um etwa meterlange Polypare, deren fđlanfer Stiel nitht, wie bei der (5)attung Umbellula, in cinen Shopf jufammengedrängter Polypen ausläuft, fondern mit Wirteln von ju je jwei oder ju je orei jujamtmenfitzenden Einjelpolypen ausgeftattet ift. 2lm Ende des faft haarfin aus= gejogenert Stammes fitst der älefte Polyp. 2lian vermag an diefent präđtigen Kolonten geradeju das Knofpungsgejets, nah dent die ounfelvioletten Dolyper angelegt werden, abjulejert.

Reich ift die ప̄ahl der Rindenforallen (5̄orgonident), dic mit ihren prädtigen, orange, forallenrot unt weiklta gefärbten po= Lpen als Dertreter der (E)attungen Isis, Isidigorgia, Dasygorgia, Leptoptilum und Chrysogorgia erbeutet wurden. 2ramentlich dic ber lef̧tgenannten Gattung angehörenden formen feffeln durd ihr feines Kolorit. Die Stammahfe ift fpiral gewunden und fhillert cbento wie die Sciteräfte in goldigent 2lietallglanj.

Daf aud die Jleyoniden in engeren Simte der Tiefiee nidht fehlen und in mehreren neuen formen namentlid? bei der Bouvet = Infel crbeutet wurden, haben wir bereits früher (\$. 186) hervorgehoben.

ङैu diejer fülle von adtftrahligen 2ulcyonarien gefellen fid die mit eiter grökeren Jahl von fangfädent ausge= ftatteten fleifypolypen oder 2lftinien, die uns namentlid? in der antarftifden Region durd? ihre auffälligen hod = rotent farbentöne feffelten. Die ben 2lftinter jugehörige (5)attung Cerianthus wiefen wir als cinen Bewohner ber gemaltigen Ticfe von $5248 \mathrm{~m}$ nad. Selbit in diefer 


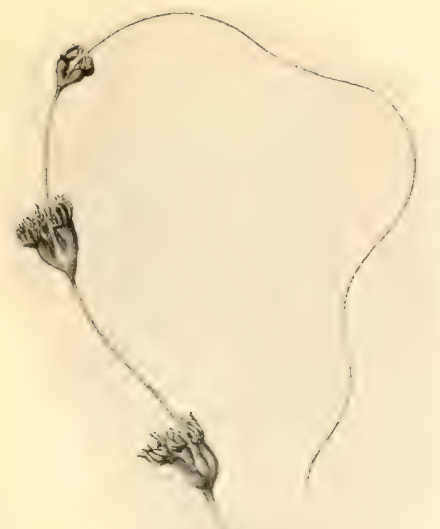

UIcyonariett.
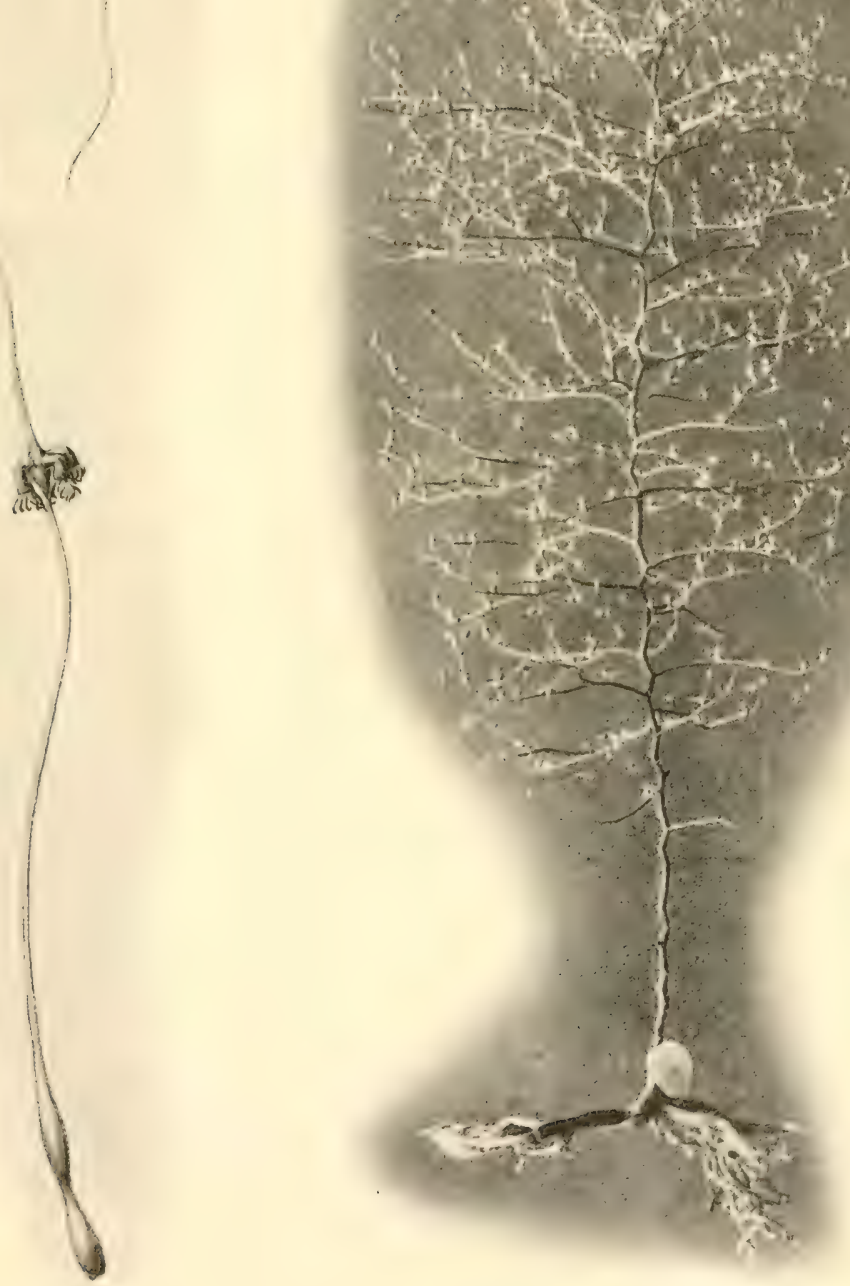

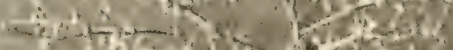
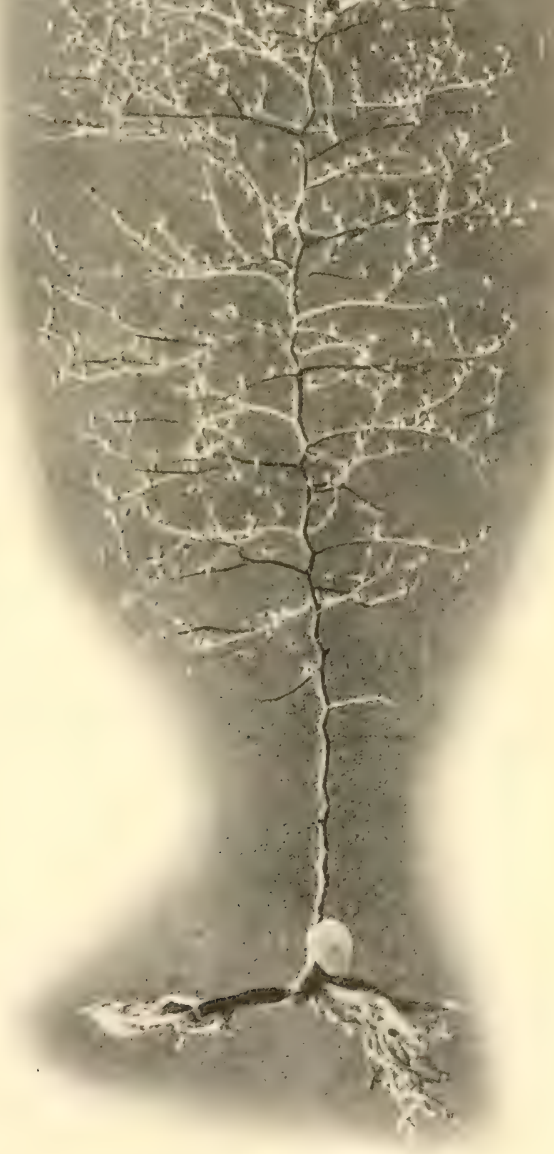

Chunella gracillima Kukenthal n, gen, n. sp.

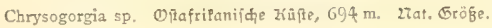
Die polren find 31 ie orei in Wirtel angeordnet. $818 \mathrm{~m}$. Wftafrif Kẵte. $1 / 3$ nat. Orö́c. 
Tiefe zeigten dic vier erbeuteten Excmilare cine fhöne violette färbung der fantg= fäben. Dic Tiere fteften in fehr lantgen, aus ciner filgigen 2lĩafe hergeftellten leder= artigen Lülilett.

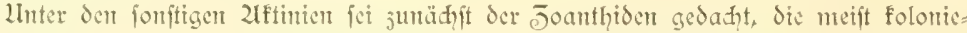

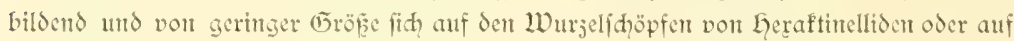
den SFeletten anderer Drganismen (S. 160) anfiedeln. 2luf der 2lgul has=Banf dredid= ten wir in feidten WDaffer cine Biefenform von Joanthiben, welde nad Earlgren

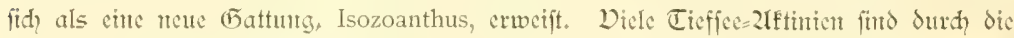
verfürsten und fnopfförmig geftalteten Tentafel ausgegeidutet. Dies trifft fpeciell

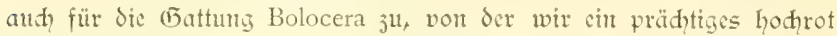
gefärbtes Eremiplar auf S. 160 abbildeter. Die Tentafel fömmen (wohl cine Sduttientriditumg gegen feinde) von dem Titr abgeidnürt werdent.

llm indefien die Sdilderming der Cölenteraten der Tieffee abzufḑlie= Een, fei nod, hervorgehoben, da dic Steinforallen den abrifalen Re= gionet nidht feblent. Das non der ". Daldivia" erbentete 2liaterial faim fich jwar an 2trtenreidfum niḑt nit den Simoenforallen und fouftigen zlleyonarien meffen, erweift fith aber rad den zlitteilumgen von 2liaren= jeller's als befonders wertboll für die Erfemtnis der geogra= phifden Derbreitumi. Da wir gar mandes jungfräulifie (5ebiet Surdforfden, fo erfahren unfere bisherigen Dorftellungen von dent Vorfommen der Tiefiecforallen eine oft reht überrafdente Ertweiterung. Insbefondere darf herborgehoben werden, dap cine erflecflide Sabl von bisher mur ans dem 2tilan= tiifhen Secall befannt gewordenen Korallen audh in Isozoanthns giganteus n. gen. n.sp. Carlgr. dem Jndifien Befen verbreitet ift. Weftindifde $2 \mathfrak{l}=$ 2lgulhas=3anf. $86 \mathrm{~m}$. Werig verfleinert. ten, die fhon Pourtalès dredidgte (3. 3. Amphihelia rostrata), tauchen bei den ziifobaren wicder anf, und insbefondere erweifen fid unfere reidgen Korallenfunde bei St. Paul und 2ich=2lmfterdant, wic wir auf $S .30+$ betonten, als wertwoll für dic Enfemntuis des Jufanmenhanges der atlantifhen und indifden Ticfenfauta. Wir

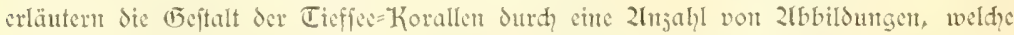
teils an intereffante neue formen, teils an bomerfenswerte fundorte anfmipfen.

Sic betreffen Dertecter dir Gattumgent Caryophyllia. Stephanotrochus, Solenosmilia, Flabellum (气. 589) und Bathyactis. 


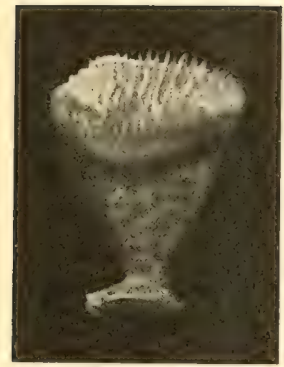

Caryophyllia antarctica Marenz,n.sp. 3ouvet=3niel. $566 \mathrm{~m}$. 2Tat. Grö̧e

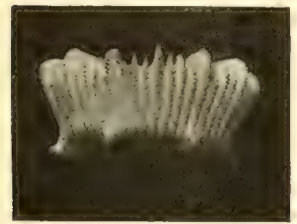

Stephanotrochus explanans Mar. in, sp. 3 ei Sanfibar, $400 \mathrm{~m}$. Zrat. Grōęe.

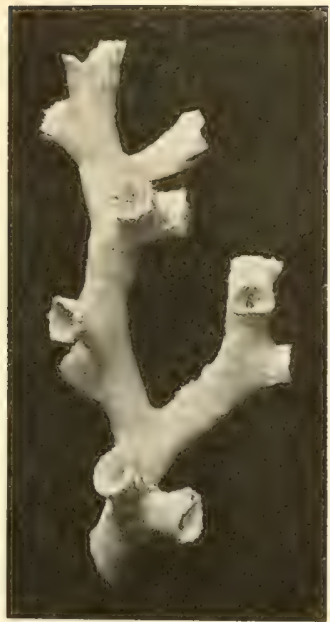

Solenosmilia variabilis Duncan. 23ei St. Paul. G:2 m. Nat. Grö5e. (Marktanner phot.)

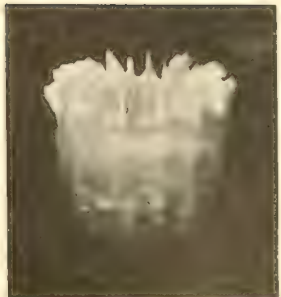

Stephanotruchus campaniform! Iatenz. a. sp. Südatiant. Drcon. [Daldivia:23ant] $956 \mathrm{~m}$

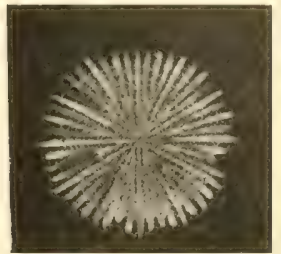

Wathyactis symmetrica Mos. Fomba:Kanal (1)itafrifa). $463 \mathrm{~m}$. ziat. Sröfe.

Ein herborrageno wiḑtiges Kontingent jur Tieffecfauma ftellt der Typus der Stadiel= häuter oder Edinodermen. Id wüpste faun einen Dreddhug ju nennen, in dem nidit wenigftens einige Dertreter der Ecewaljen (E)lothurien), Secftente (2lfteriden), Sdjlangeniteme (Dphiuriden) und Secigel (Edintiden) nadhweisbar gewejen wären. Seltener freilid find die prädtigen und für die Tieffee befonders dyarafteriftifhen See= lilien (Erinoident), die niemals verfehlten, unfere 2lufmerffanteit in befonderen Grade ju feffelr. Wem wir an die Ietcteren anfnüpfen, fo fei beneetet, daf bis jetst T Ĕattungen geftielter Crinoiden, welde jum Ceil ausgeftorbenen formen feht mahe ftehen, in der Tieffee nadhgewiefen wurder. 2tufere Erpedition hat nad dem mir zut= gegangenen Beridjte von Prof. Dococrlein 5 (5)attungen in 8 veridicdenten 2lrten wiedergefundert. Eine neue (Fattung mar unter ifnen nidit vertreten, dod ergab es fid, daf nur che 2lut (Rhizocrinus Rawsoni) bisher befdrieben war, währent alle übrigen neu find. Unter den niḑt widergefundenen jwei (5)attungen gehört die einte (Holopus) dent weifindijacu, dic andere (Calamocrinus) dent pacififdyen (b̆ebiete ant.

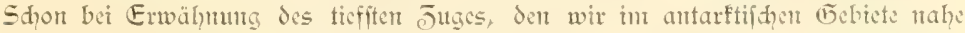

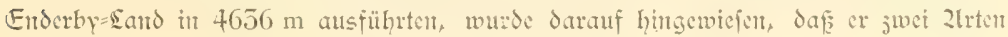




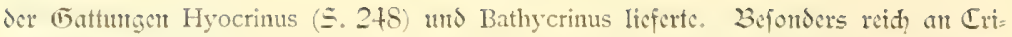
noiden crutes fid das 2licutnuei=3stem, in Sem wir tidht wentiger als vier neue 2frten von Pentacrinider nadjuweifen vimodpten $(5,595)$. Inter ifnen befinden fid brei oliogrün gefärbte 2lrten dex (5̄attung Pentacrinus, dic wir bei Siberut dredidten, und

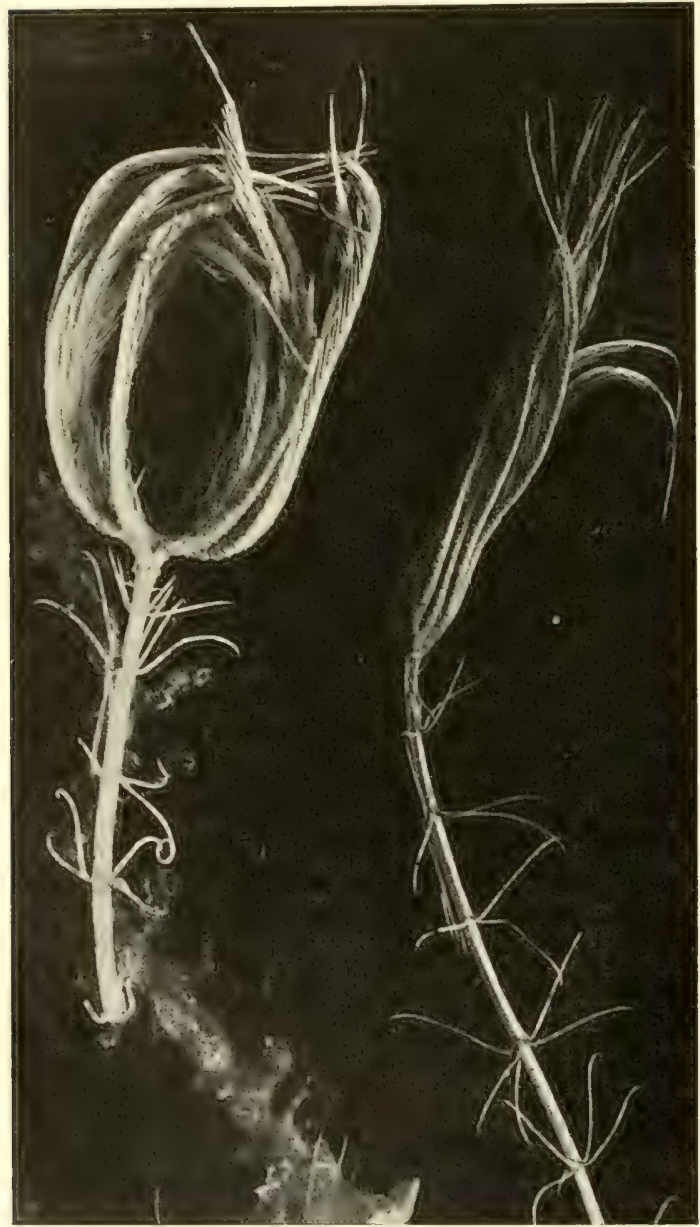

P'entacrinus л. sp. Siberut $=S$ trafe, $850 \mathrm{~m}$. Wenig verfleinert, (Doederlein phot)
Srei fahl gcfärbte Erent= plare der (5attung Metacrinus alls dem Sito= Zias= Kanal, weldo wahre (ธ)lanjftücfe unferer Samm = lung abgeben. Wäbrens dic hier genamnten renen Zrten fith in den Rahmen des vort ifrert Derwand= ten befant gemordenent Derbrcitungsgebietes cin= fïgct, fo bedcutet dic Ent= detfung ciner neuen 2 rit des Rhizocrinus voli der Somali= Küfte aus $164+$ und $1668 \mathrm{~m}$ Tiefe cinc überrajhende Ermeite= rung unierer Kemmifife liber die geographifde Derbreitung. Es handelt (id) um joterliḑe Crinoidert, dic wir mit leider faft surdiweg abgebrodquen 2lrmen in jientid groficr Jabl auffanden. Sic fte= Jent dem volt 2lidiael Sars, dem ausgejeid = neten norwegifhen for= fdice, entdecten Rhizocrinus Lofotensis nabe, unterfideiden fid jedod von ihnt nidyt nur ourd? thre anferntidge (1) röbse, fonbert aud burd andere 


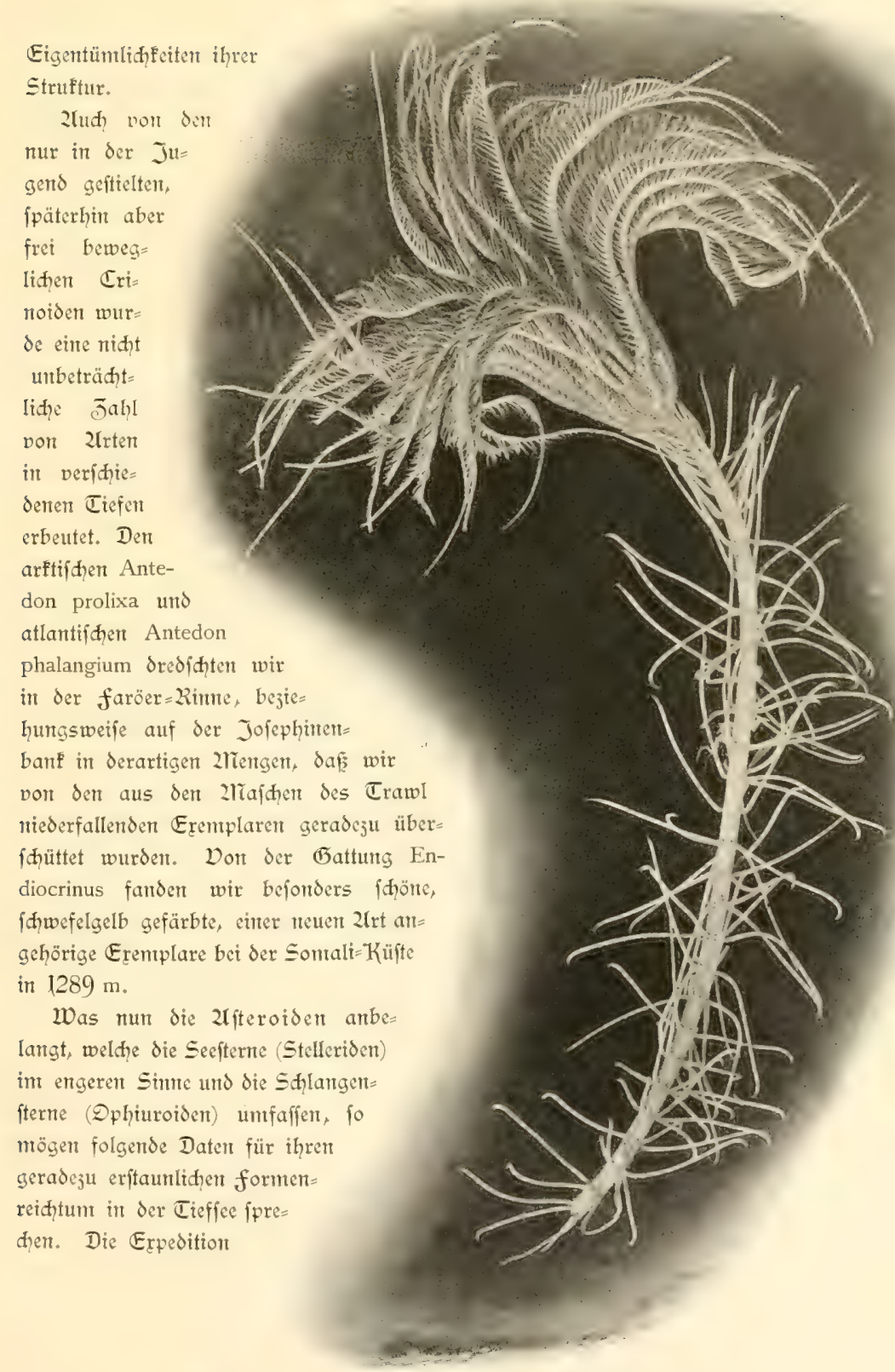




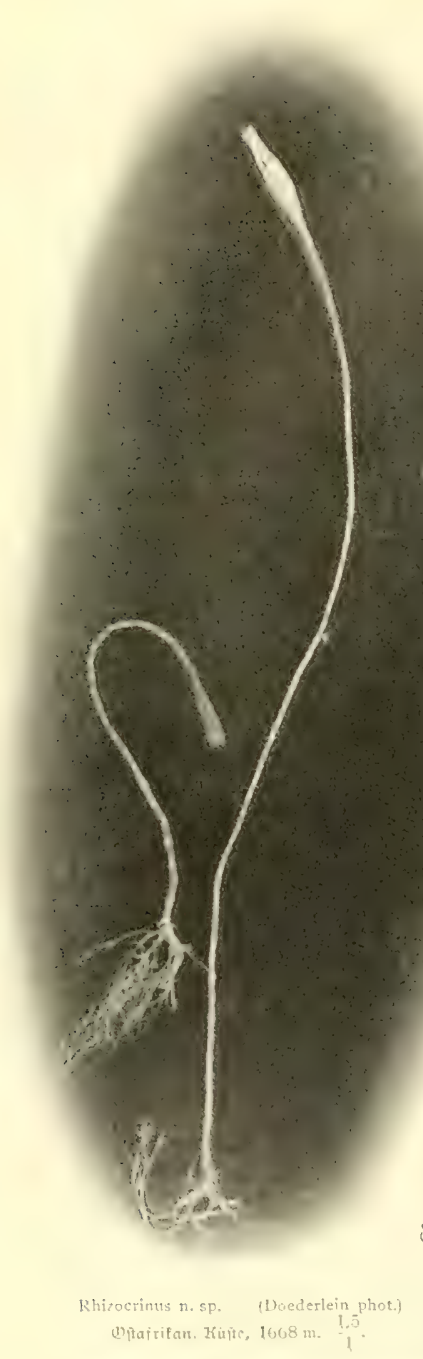

crbeutete allem an Dphiuren nah der vorläufigen Zuffitellung von Prof. jur Straffen etwa 50 (5)at. tungen und 220 2lrten, unter denen mehrere (benera und viele 2laten neu fint. Won den t15 fängen, die überhaupt mit (5)rundnetzen ausgeführt wurden, waren in nidit weniger als $8+\mathcal{W}$ ertreter von Shlangenfternen (ein= mal jugleid neun veridiedene 2lrten) ent= b)alten.

Es wäre niḑt möglid, int Rabquen Sicfer fnappen Darftellung aud mur an= näherno der formenfülle vort Dphiuren ju gedenfen und fo beidiränfent wir uns Sarauf, cinen präditigen fleif̧rot gefärb= ten Dertreter dir Ẽattung Ophiocreas, ber mit feinen Ed)langenament cinen gleidffalls fleifaproten Bufd von Rinden= foraller unflammert, in Bilde vorju fübrent. Eine äbnlidie bei der Bouvet= Jnjel erbeutste form ftellten wir früher S. 18б) dar; auh fei daran crimtert, daß wir fowohl der merfwürdigen (5)attutg Astrophiura $(\Xi, 1 \tau 1)$, als aud der von den Kergutenformen ansgeubten Brutplege S. 279) gedaditert.

Da die von früberen Expeditionen erbeuteten Seefterne (Stelleriden) in ciner Reihe gehalt= noller littirfudungen befonders eingehend durie fellt murden, fo mag bier stmas ausführlifier an der Land der 2littfélungen des fontpetenten Kent ners Ser Edinodernent, Prof. Subwig, die Erwet= terutg unferer Kemtniffe durd die fahrt der "Dal divia daracleat merden.

Dic 2lusbeute ans dem 2utantifiten Deean bictet, wie 3u ermarten war, eit mur geringeres Juterefie, da wir bier meift tur befante formen, went aud gelegentlid?

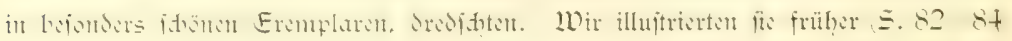
Surth den non Whpille Thomion bejuriebenen Zoroaster fulgens und durd) den 
prähtigen in naheju $5000 \mathrm{~m}$ erbeuteten Hyphalaster Valdiviae. Bejonders typifde Ciefenformen fint jente Porzellanafteriden, weldie fith durd cinen Stadyelbefats auf der dorjalen 2litttellinie der IIrnte ausjeidnten. Wir Latten bereits (5elegen= beit genommen, einen neuen Dertreter derjel= bett aus der gröbett volt uns ourdiforih = ten Tiefe von $5248 \mathrm{~m}$ im Bilde vorjuführen (5.515) und illujtrieren diefelben durd eine neue atlantifide 2lrt, die nad Derlaffen non Kamerut in $2492 \mathrm{~m}$ erbentet wurde.

Das Interefie an den Seefternen fteigert fid bei der 2lmäherung an bie in tiergeographifdice Einficht fo intereffante 2loulhas= BantF. Lier tauḑte der grog̉e, den 2lftropef: tiniden jugchörige Di. psacaster Sladeni Alcock, weldhent der "Inveftigator" bei derr Zndamanen gedredidyt hatte, in geringer Ticfe auf. Der 2lgulhas= Banf

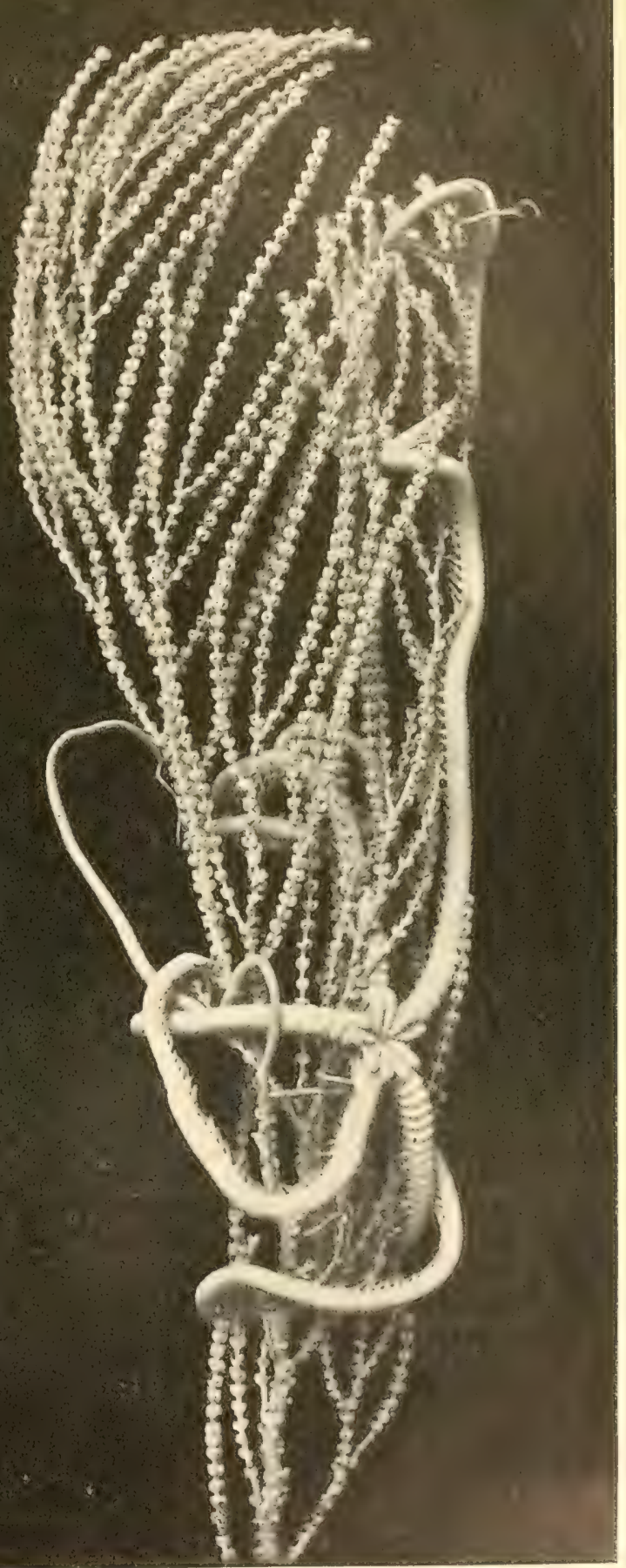




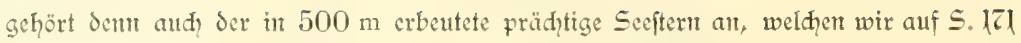
dariftllter.

Da

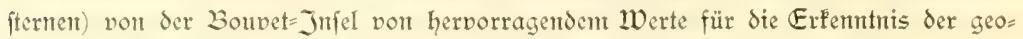
graphifden Derbreitung ift, wurde gleidfalls früher (\$. 186-188) betont.

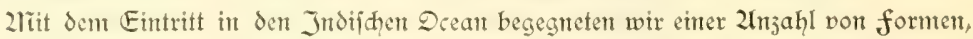
die bereits durd die forjhungen des "Inveftigator" befannt geworden waren. In feimem weftlidhen Teile (bis ju den Chagos = Jufeln) lieferte er namentlidh im 2lientawei=

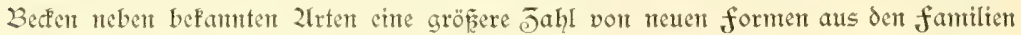
der Brifingiden $(600-2900 \mathrm{~m})$ und Joroafteriden $(500-2250 \mathrm{~m})$. Daju gejellen fich 2lrten aus den Eattungen Pararchaster, Pontaster, Pseudarchaster, Aphroditaster, Persephonaster und Dictyaster. WDir illuftrieren dicje dem

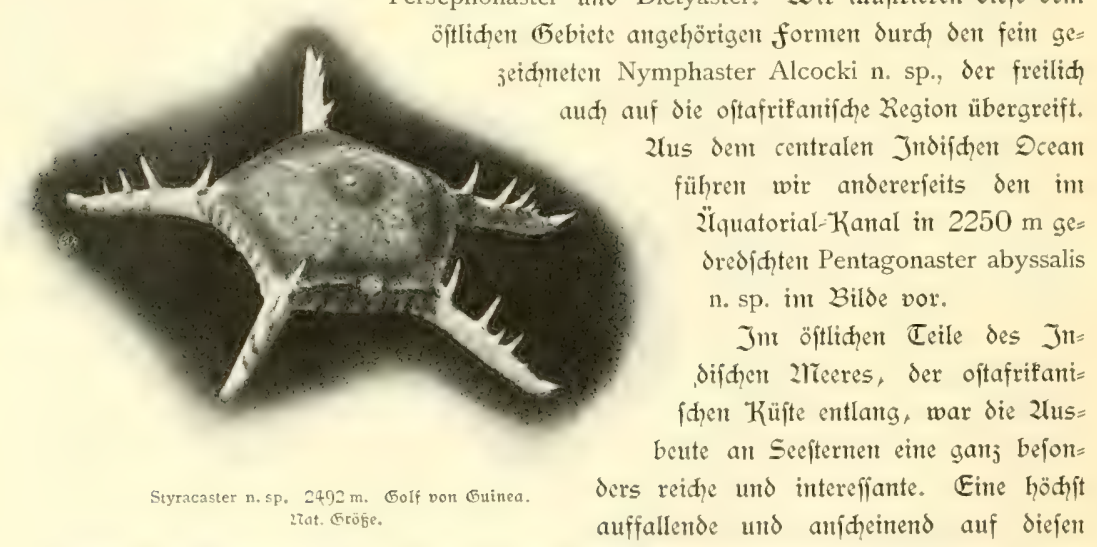

Bejirf der Tieffee hefdränft: form ift dic neuc Eattung und 2lrt Pectinidiscus Annae, die ju den porjellanafteriden gehört und fiđ fhier in den meiften 2Nerfmalen an die

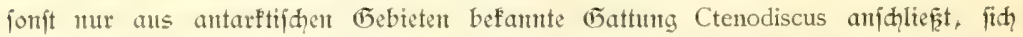
aber non ihr mefontlid durd den auffallenden 2 lmitand unterfacidet, da die Rand= platten it jedent 2lemminfel mit einer unpaaren platte beginnen. In demtelben Gebiete fanten fith befonders viele formen aus der fantilie der 2lrdiafteriden: Plutonaster-, Pontaster-, Persephonaster-, Pararchaster-, Dytaster- und Aphroditaster-2 $\mathfrak{U}$ rten, ferner 2lifropectiniden (Psilaster), Pentagonajteriden (darunter neue 2lrten aus den (5attumgen Pentagonaster und Iconaster), und porjellanafteriden. 2tnter den Pentagon= aftern zeidytet fidh ein Exemplar von Pentagonaster excellens n. sp. von der Somali= Küfte dudurd aus, das anf feiner Bandfiete mehreere Eremplare einer eftoparafitifhen Sdynede jdmaroten. 


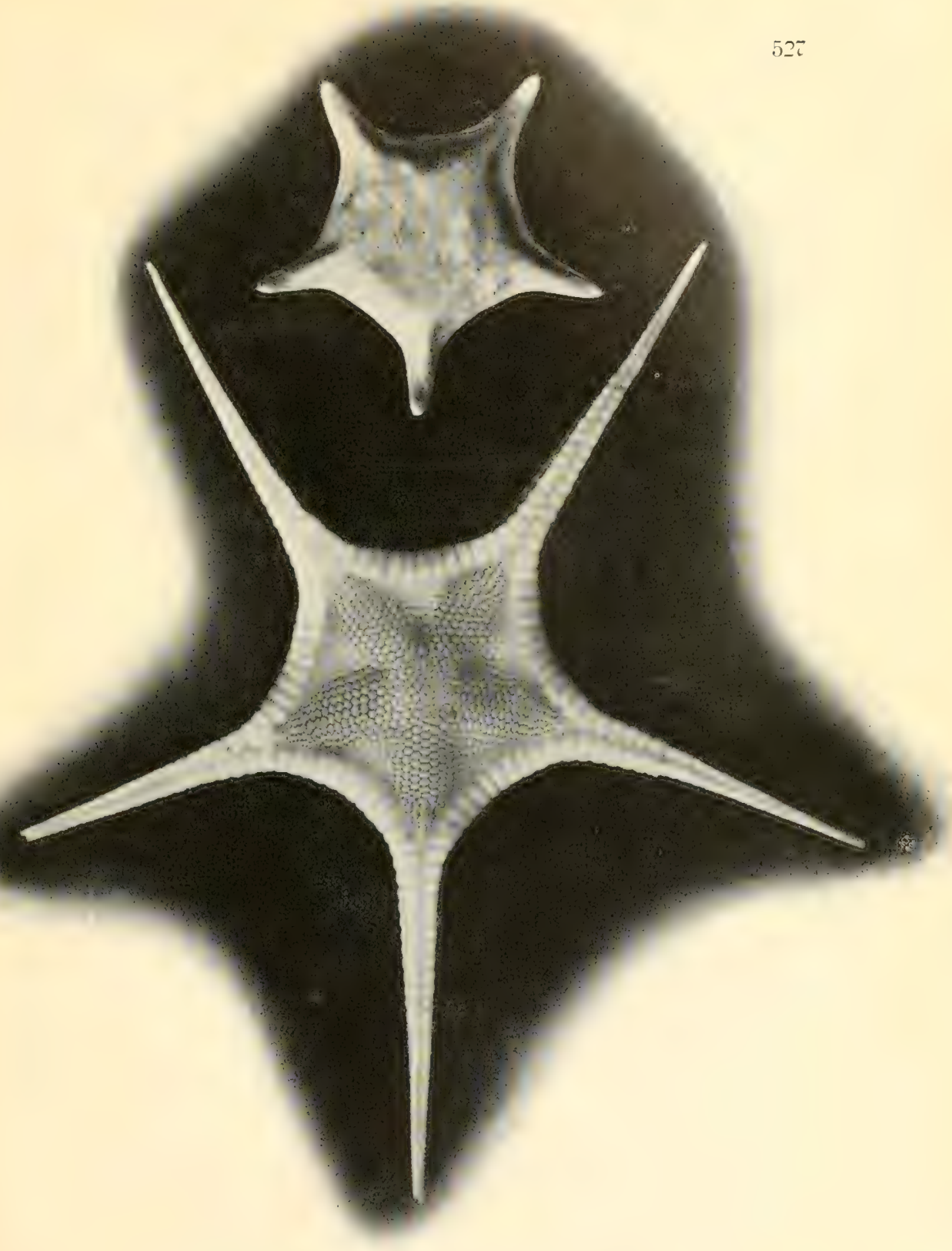

Pentagonaster abyssalis Ludwiz n, sp. $2253 \mathrm{~m}$. Z̈̈quator= Kanal (27)aledipen). Zrat. Gröfse

Nymphaster Alcocki Ludwig n, sp. 1469 m. Bolf pon 210en. 

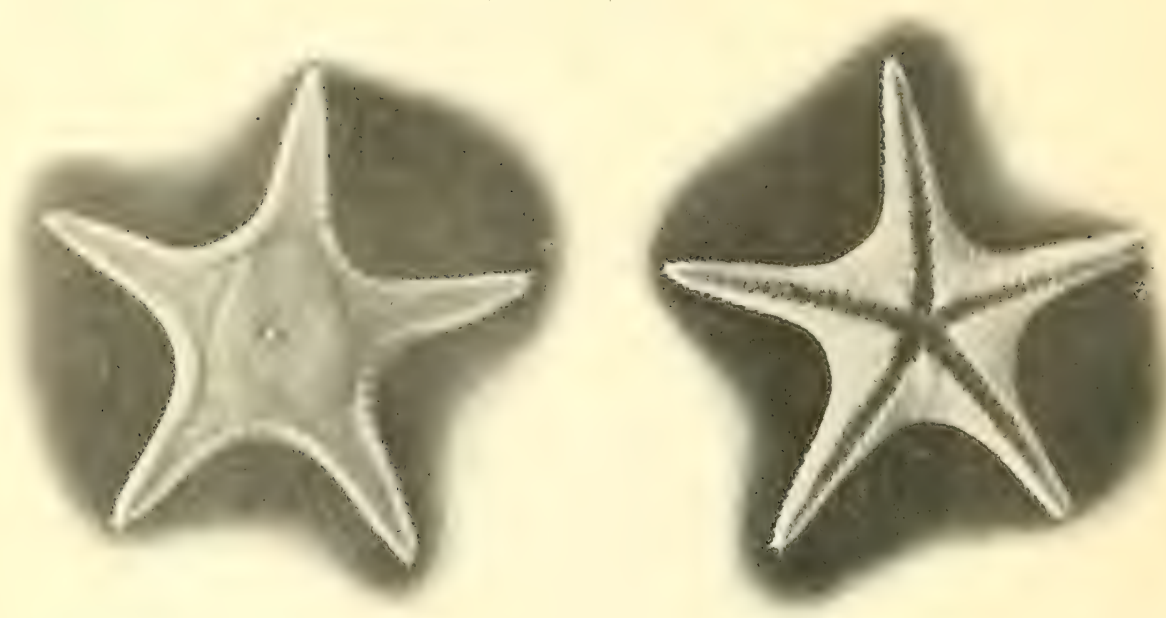

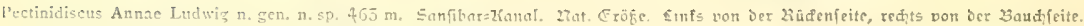

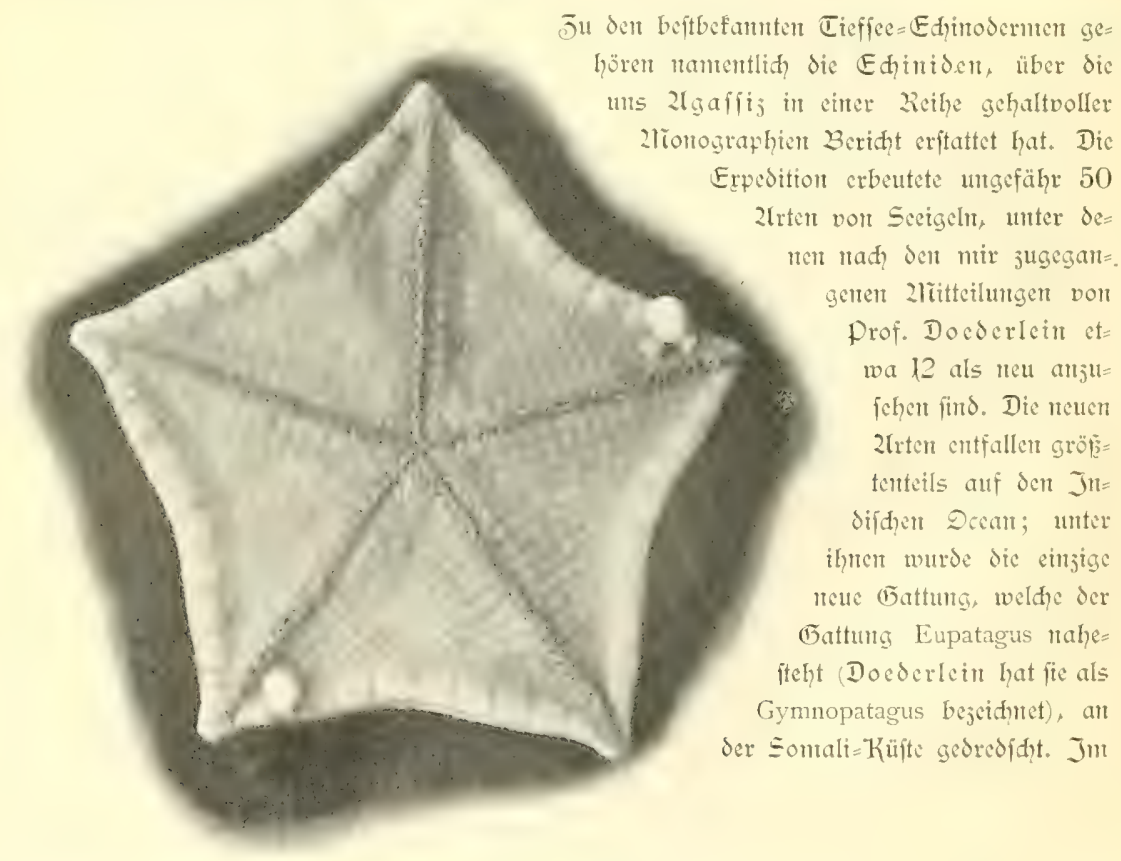




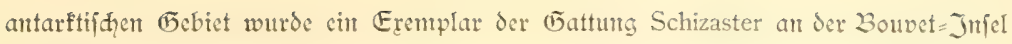
erbentet.

Was num die Edintoen des indifden Gebietes anbetrifft, fo fetsen fie, wie wir be= reits früherhin herborhoben, fhon auf $\operatorname{der} 2$ lgulhas $=\mathcal{B}$ anf ein, wo fie fith mit atlan= tijhen und antarftifhen formen mijacn. 2rur wenge waren bereits früberbin befant:

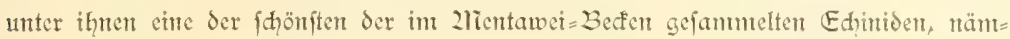
Iidh Dorocidaris elegans $(5.59 \mathrm{~J})$. Zlle anderen 2frten find entweder men, oder dod nidht ohne weiteres mit figon bef̧riebenen ju vereinigen. Alnter den merfwürdigen Edinothuriden fand fidh die erfit feit wenigen Jahren aus dem 2ltlantic befannte (a)= tung Sperosoma an der Küfte von Ditafrifa, und ebendaber ftammt das einjige von der Erpedition erbeutete

Erentplar der (5)at= turtg Asthenosoma in cinter, dem ja= panificen Asthenosoma longispinum naheitehen= den 21rt. Dagegen war forwohl in 2lìentamet= Becten wie an ber oftafri= fanifhenKüfte die (5)attung Phormosoma mit ibrer leder= artigen, der ftarren Kalfplatten entbebrenden Gaut und ifren Giftitadeh häufig und gelegentlich in riefigen Eremplaren vertre=

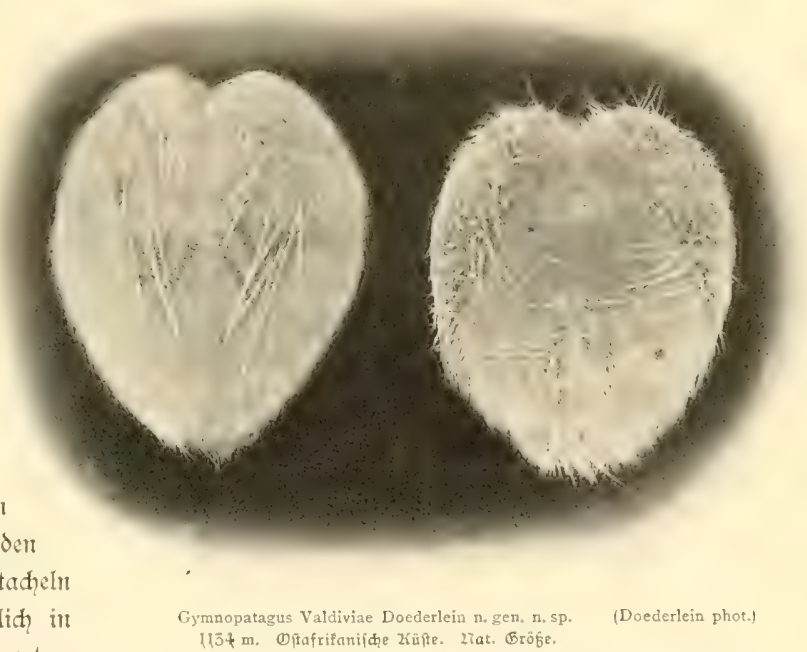

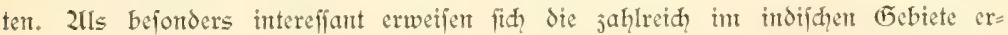
beuteten Cidariden, weldye den einander fahr naheftehenden Gattungen Stereocidaris (S. 592) und Dorocidaris angehören. Ein anffallender Charafter, den die meiften den genannten Gattungen angehörigen 2lrten vom Kapland bis nah Sunatra jeigent, ift $\delta_{e r}, \delta a \tilde{E}$ an ihren Staheln cine oder jwei, gelegentlid aud orei Sängs= rippen blattartig hervorragen, wie dies bisher für Dorocidaris Alcocki befant ge= worden ift.

Befonders erwähnenswert ift nod das Dorfonmen der beiden Diadematiden=(T)at= tungen Aspidodiadema und Dermatodiadema (S.589) in indijđen (Tebiete. Eriftere 


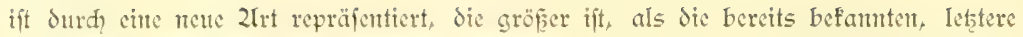
fand fid in jwei 2lrten im Jitsifden zlieere.

ङ" den intereffanteften formen aus dem Jndijhen Decan gehört die neue 2lrt der (5attung Palaeopneustes $(\mathbf{S . 5 9 0 )}$, die wir in jahlreidgen Eremplaren im Süd=2tias= Kanal crbenteten. Zuffällig ift $s$, dafi in dem ganjen indifhen Gebiete fein Dertreter der merfwürdig geftalteten (B)attumg Pourtalesia, dic in dent atlantijhen cine weitc Derbreitung befitst, nadgemicfen wurde.

Went wir der Seewaljen (Golothurien) feme weitere Erwähnung thun, obwohl fie uns reḑt häufig bis ju den gröfsten Tiefen begegneten, fo gefhieḩt dies nit Riüfitht darauf, dafi der intereffantefte Dertreter derfelben fpäter nod cingehendere Würdigung finden foll.

Wir fömen es uns niḑt verfagen, mit einigen Worten der Cruftacen ju ge= dentert, jumal da fre für die Tieffee nidit minder typifh find, als die Ehinodermen.

Was junähft die Krabben (Brahyuren) anbelangt, fo darf wohl hervorgehoben werden, daf wir faft alle intereffanteren (5attungen, welhe frïhere Erpeditionen fam= melten, wiederfander.

In dem indifhen Gebiete überrajht namentlid die grof̧e Jahl von Dreiefféfrabben (Dryriynden). Wir haben bercits früher der merfwürdigen Ẽattung Scyramathia (与. 172), und Platymaja (5.400) gedaht und illuptrieren die Dreieffrabben durch die Cyrtomaia Suhmi Miers. Don dicier 2lrt erbeuteten die Challengererpedition und der Invejtigator mur je ein Exemplar, während wit fie an nidit weniger als 7 Stationen fowohl bei Sumatra, wie an der Ditafrifantifden Küfte in grofer Jahl aus Tiefert vort $650-1562 \mathrm{~m}$ drediditert.

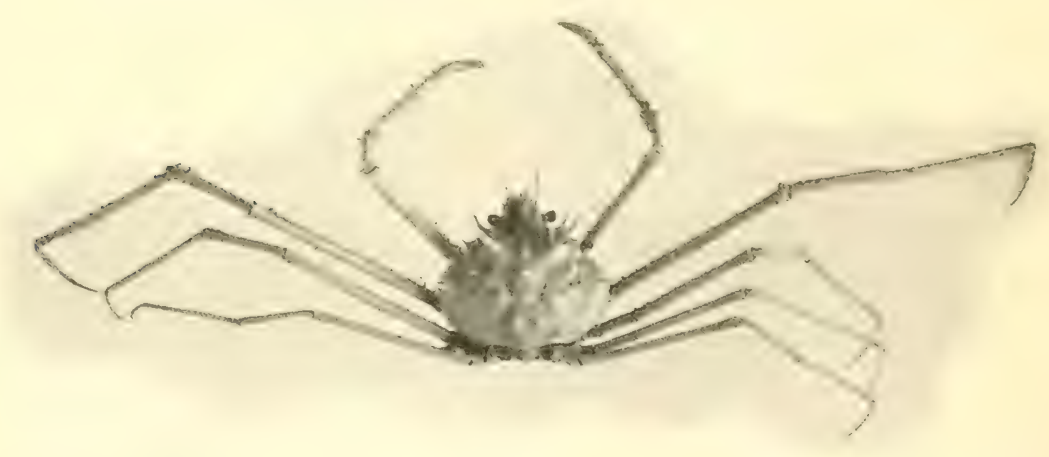


Don fonjtigen in= tereffanteren funden fei junäd)ft jweier. indijdyer formen gedadit, weldie der Jnveftigator int Bolfe port Bengalen entded" = te und die wir längs Sumatra wiederfandert.

Die cine betrifft cine trele 2trt der bijarren Gattung Tricho-

peltarium, dic andere dic durdh federartige Linterbeine dharafterifierte Retropluma notopus. Die letzige= naunte 2lut nimmt int Syitem cinte fo tifolierte Stellung ein, dafis cs fdower fällt, ihre Der= wandtidhaftsverbältniffe flarjulftllen.

Jus gröperer Tiefs ftammt cine neue jart fleifdrot gefärbte 2lrt der Battung Geryon, vort der wix fdon früher (\$.159) Dertreter Sar= ftelltert. Der hier abgebildete Geryon Paulensis repräjentiert jugleid? einen der füdlidjiten Krabben= futde der Expedition. In dent eigentliḑen antarf= tijक⿻n (5ebiete fällt die 2lemut an Krabben niḑt minder

(Doflein phot.) Trichopeltarium Alcocki $\bar{\delta}$ n. sp. Dof.

$750 \mathrm{~m}$. Siberut $=$ Strafge. 27at. Eröge. auf, als in dem arftifden.

Wenn wir weiterhin nod des bet den Zifobaren er=

beutetert Benthochascon Hemingi gedettert, io ge= jhieht dies wentiger aus dem Grunde, weil das hier abge= bildete 2liändhen bisher unbefaunt war, als weil es fid) um eine der wenigen aus gröperer Tiefe befannt gewordencu

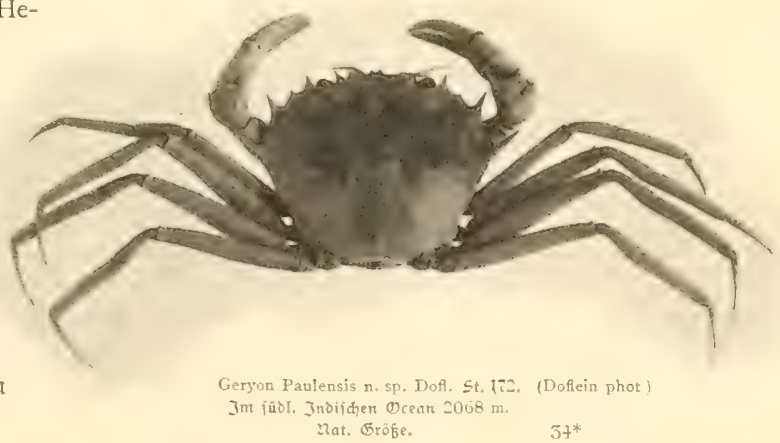




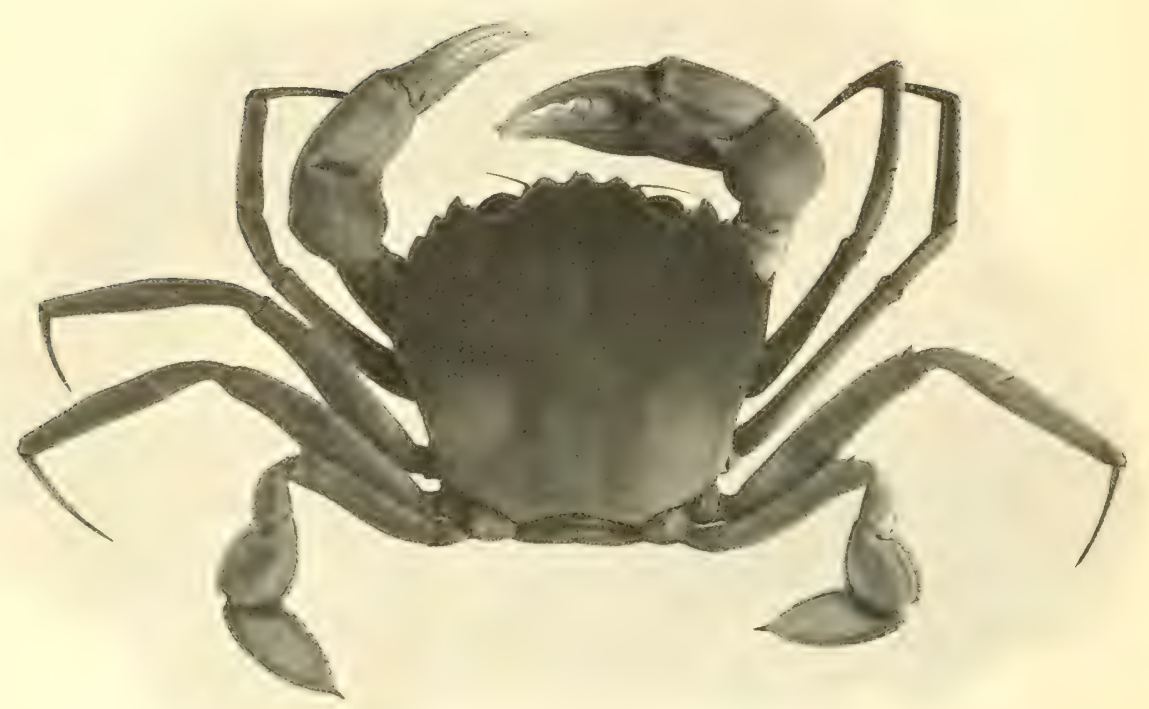

Sdwwinmffrabben handelt. Ste fudpen jwar ftets wieder den Boden auf, find aber ju weiten 2tusflügen in den freten Desan durch ifre breiten hinteren Kuderbeine befähigt.

(]) den intereffanteften Entbefungen der Expedition dürfte cine Lomolide von der oftafrifanifden Küjte gehören, welde dadurd ausgejeidnet ift, daf fie am hinterften Beimpare des Thorar cine Sdrere trïgt. Dermutlich erfafit fie vemittelit derfelben frembförper als Sdythdad, wie es ifye an der Dberfläde lebenden Derwandten mit dem auf die Rüfenflähe des Panjers erhobenen fünften Beimpare ju thun pflegen. Wir erbenteten mehrere Exentplare dicjer wunderliden, im Seben dunfelrofa gefärbten Krabbe aus ether Ticfe von $975 \mathrm{~m}$. Die Krabben der Tieffec jeigen meift die fdion prüher $(\Xi .14 \bar{\tau}$ ) betonten lebhaften färbungen in verjdiedenen 2lbitufungen des Rot. Eelten treten bleiḑe oder gelbe Cöne auf, wie fie cinem Riefenerentplar der Gattung Geryon zufanen, das wir an der Sontali= Küfte in $1562 \mathrm{~m}$ Ticfe dredfhten.

2iid)t minder fällt es auf, wie nir Dr. Doflein beridted, daf bet dett Tieffeeformen die Eier bedentend größzer find, als bei den Dberflähenfomen. Dies deutet darauf 
hin, da官 die Earven auf weit vorgerüften Stadien auşकlüpfen und ciner verwidfelten 2refamorphoic entbehren.

Zahe verwandt find den Krabben die Dertreter der durd enten Wald nadelipitier Staheln ausgejeidhretent (5attungen Lithodes und Echinoplax. Sic haben gar mandh= mal bet unvorfidtigem Durdifuden des von dem Trawl heraufgebradten Tieffee= fdhlanmes redt cindringlith ihre 2lnwefonţeit verraten.

Befonders reidhlid? traten uns im 2lientawei=Befen und an der Somali=Küfte die Einfiedlerfreble (Paguriden) entgegen. Sie lieben es befamtlid, ihren weidien,

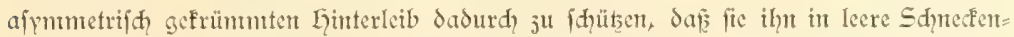
gehäufe oder in hohle Goljftülé ftecken. Wir illuftrieren das Derhaltent durdh eine form, weldie fidh cine grofe Sdhale des Dentalium als Wohnthaus ausfuḑte und mit Ser reditsfeitig mädtig entwidelten Kuncipjange des erften furpaares den Eingang

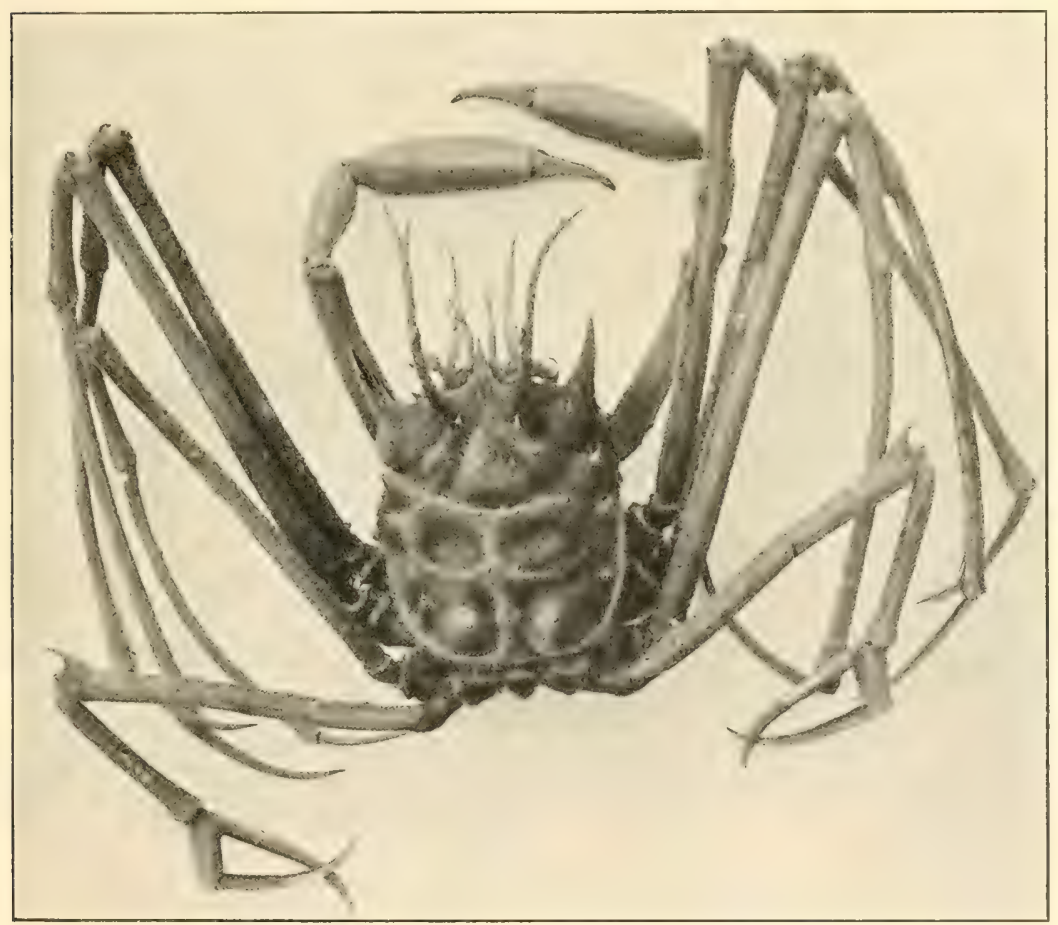

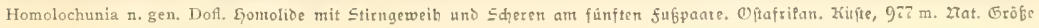




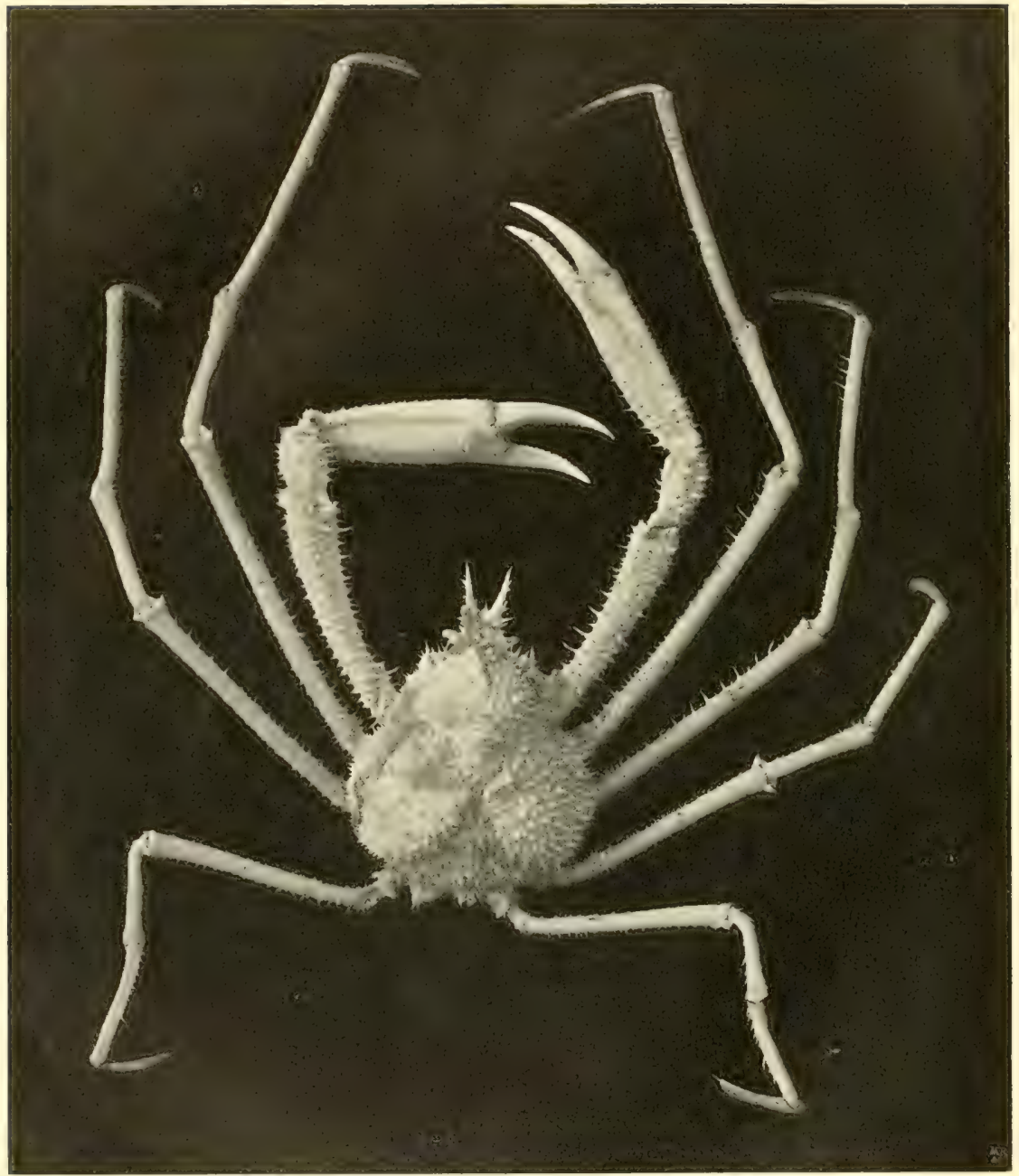

Échinoplax pungens Wood-Mason. $296 \mathrm{~m}$. 23ei Den 27ifobaren. 27at。 Gröfc.

verfdilef̧. Sie befitst cbenfo wie die Dertreter der CGattung Xylopagurus cinen gerade

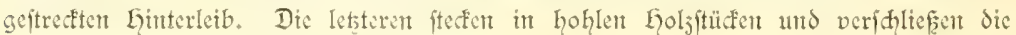


hintere D̈frnung vermittelft ciner Garten dectelartigen Derbreiterung der leţten Körper= jegmente.

Wie an der Dberflähe, fo finden wir auh in der Tieffec die Einfiedlerfrebje häufig mit 2lftinien aus den (5)attungen Epizoanthus und Adamsia vergefelliḑaftet. Die Epizoanthus-2lrten löjen hier= bei die Kalfihale des Sduteten= gehäufes auf, bieten aber dadurd? Sduts, dafiz fic fnorpelharte $\mathfrak{B}_{e}=$ fhaffenheit gewimen und bisweilen ungewöhnlidhe Dimenftonen erreidien (5. 160).

Die den Paguriden taheftehen= ben Galatheen liefern namentlich in den Gattungen Munida und Munidopsis typifhe Dertreter der Tieffee, die häufig in den präditigiten roten farben fđillern. In gröferer Tiefe geht das intenfive Rot mehr in entert jarten fleifhfarbenen Ton über, und jugleid fhwindet das Pigment alt Sen Zlugen (5.594).

Unter den langįwärtjigen $\mathrm{Kreb}=$ fen (2Tafruren) möge junädjit dic volt allen Tieffee=Expeditionen nad)= gewiejene Gattung Glyphocrangon als ein wehrhafter Krufter erwähnt werden, der mit monftrös grofien Zugen ausgeftattet ift, und deffen Panzer eine fräftige Bedornung er: fenten läft. Dabei find die letz= ten Segmente des Ginterleibes mit Sdnappgelenfen veriehen, fo daf fie gefperrt gehalten werden fömen

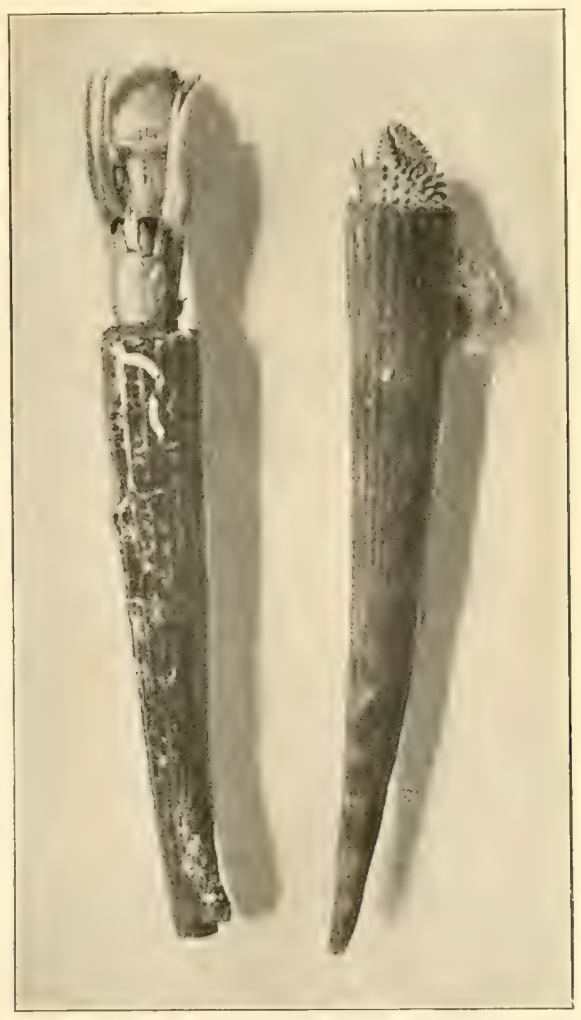

pagurioen in grofen $\subseteq$ halen wort Dentalium. $638 \mathrm{~m}$. Sontali=Küfte. Nat. Gröfic. und mit thren Dornen eine wirfungsvolle 2lbweht darftellen.

Die familie der 2litaciden, ju denen aud unfer flufferebs gehört, ift durd die (5attung Nephrops vertreten, von der wir den prähtigen, vom "Juneftigator" er= beuteten Nephrops Andamanicus int 21ientawei=Beden wiederfanden. Dort überraihte

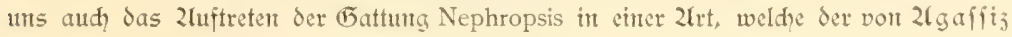


an der pacifidgen Ssite von Zlmerifa erbeuteten Nephropsis occidentalis nahefteht. Sie gleiđht äuß̧erliक eintem flufffrebfe und jeigt fowohl den bräunliđen Körper, wie and dic jart rötlid, gefärbten füfe (nantentlich das erite Sderenpaar) mit einem Pelje feiner Laare bededt. Jn Zlupaffutg an das seben in der Tieffee find bie 2lugen zu fleinen, pigmentlofen Rubimenten rüdgebildet. Wir werden wid̨t verfehlen, diefe inter= effante 2Urt fpäterfin noक den sefer im Bilde vorjuführen.

2lls ciner der fđöniten funde der Challenger=Expediton darf wohl die Entdectung jener Tieffectreble gelten, weldhe uns bisher mur ats trefflith erhaltenen 2lbdrucfen im lithographifhen Sdiefer vont Solenhofen befant waren. Die Eryontoen, wie fie ge= namit werden, fhemen in der juraffifhen Jeit Bewohner der oberfläd)liḑen Sdiḑten gewejen ju fein, wie dies aus den (Fefantdharafter der Solenhofer fauna hervor= geht. Späterhin find fie in die Tieffee eingewandert und gingen fo vollfommen ihrer Zlugen verluftig, dafi bei manhen 2lrten niḑt cimmal ntehr die grof̧en 2lugenhöhlen ant Panzer naḑweisbar find. Die den Eryoniden jugebörigen Ẽattungen Pentacheles, Willemoesia und Polycheles find für alle Tiefen darafteriftifd, und po haben wir aud? nidht verfeblt, eitren an der oftafrifanifonen Küfte erbeuteten Dertreter derjelben mit

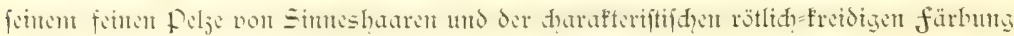
auf der lithographierten Tafel dem Sefer vorjuführen.

2luf derfelben firton fith weiterhin nod cinige Zlrten von Garmeelen abgebildet, dic surd ibre blutrote färbung in hohem 2liafe feffeltr. Dbwohl fie alle trefflidye

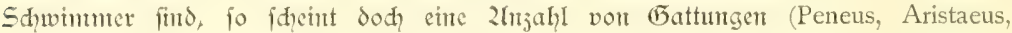
Aristaeopsis, Heterocarpus und Nematocarcinus) direft über dem (5runde zu đd̨weben. Ste find alle mit wohlentwidelten 2lugen ausgeftattet und imponteren j. T. durd dic gerabeju ntonftröfe Entwiflung ihrer 2fntennen. Don dem auf der Tafel in ftarf verflemerten 2lbbille wiedergegebenen Dertreter der Gattung Aristaeopsis fanden wir in cinem อ̈uge an der Somalt=Küfte aus $9 \pi \mathrm{m}$ fünfzehn Eremplare, weldhe bei ciner Körperlänge von $28 \mathrm{~cm}$ 2lntenten von naheju anderthalb 2licter Sänge aufwiefen.

Eine befonders eigenartige 2lnpaffung an das Sđweben über dem Grunde zeigt die gleidfalls im Bilde vorgcführte (5attung Nematocarcinus injofern, als ihre jehn Thoracalfüfe nad 2lrt der Spintenteine monftrös verlängert find und in ein Büjhel von Simesborften anslaufen. Dabet weifen fie wiederum prädtige rote Töne auf, dic bei einer im 2lientawei=Becten aus $900 \mathrm{~m}$ erbeuteten 2lrt in eine Sängsftreifung aus

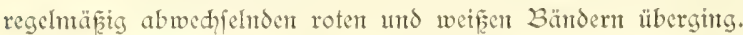

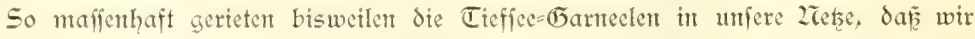

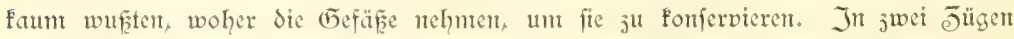

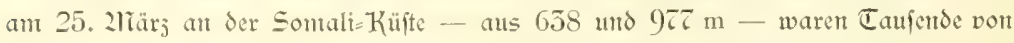
Eremplaren aus den (5)attungen Heterocarpus und Plesionika vorhanden. Da wir den Segen nidt ju bewältigen vermoditen, wurde cin Teil gefodyt und jum frühitülf 


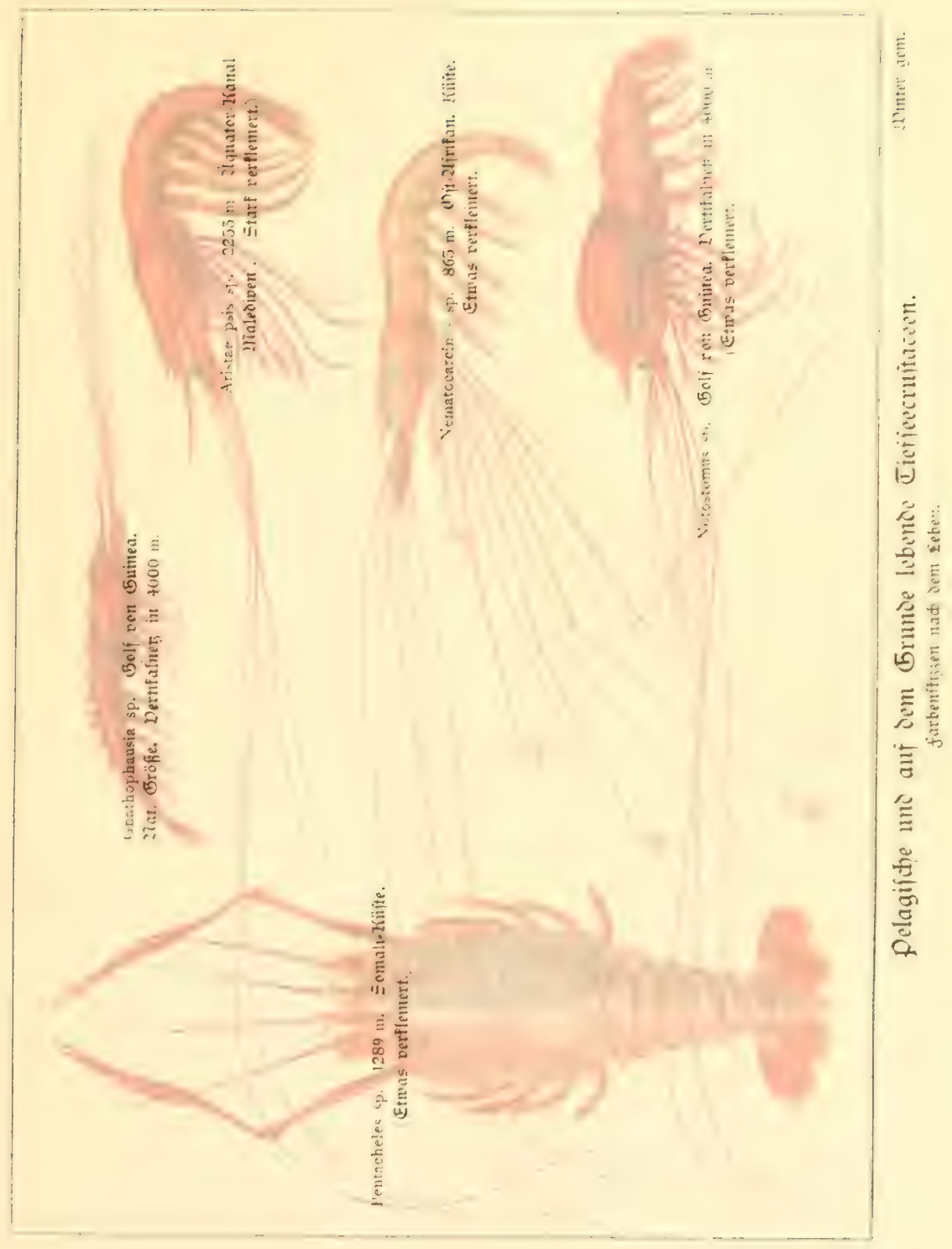


$3 \pi)$ anmose 5 mmetm.

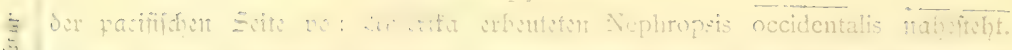

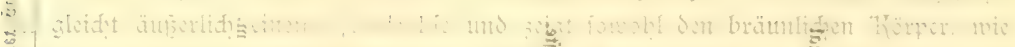

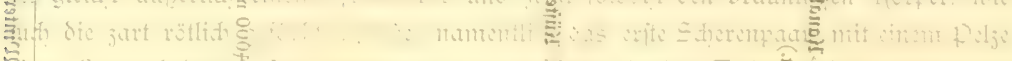

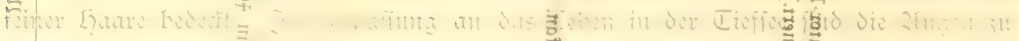

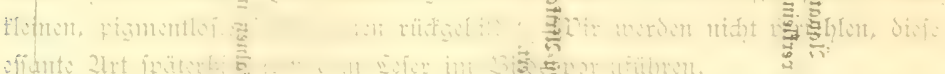
sflute 2lrt if jutre Iiticun - Tithostathith a

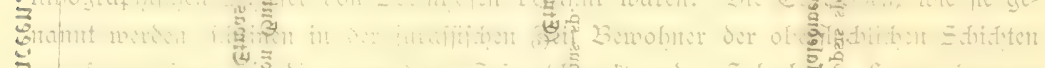

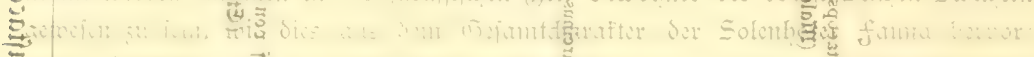

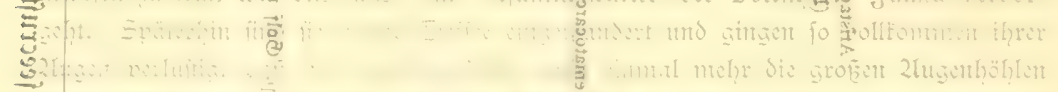

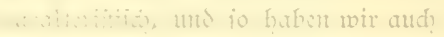

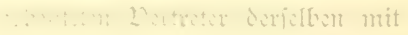

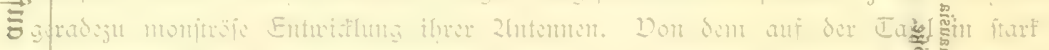

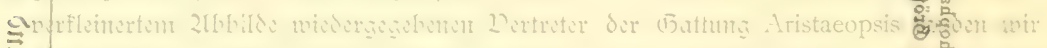

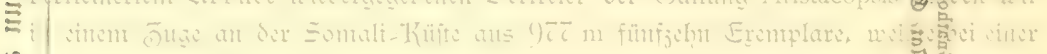

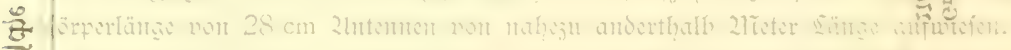

हु

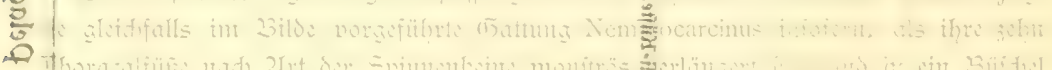

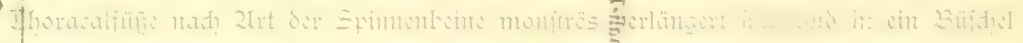

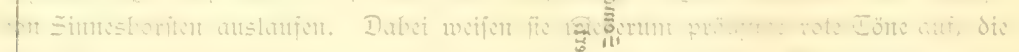

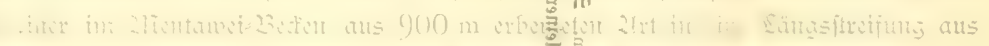

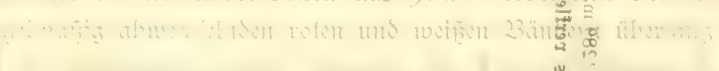

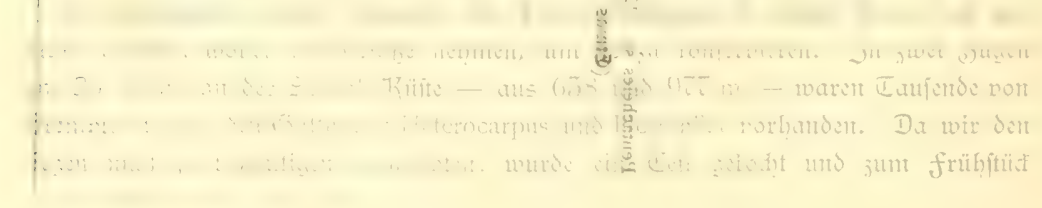




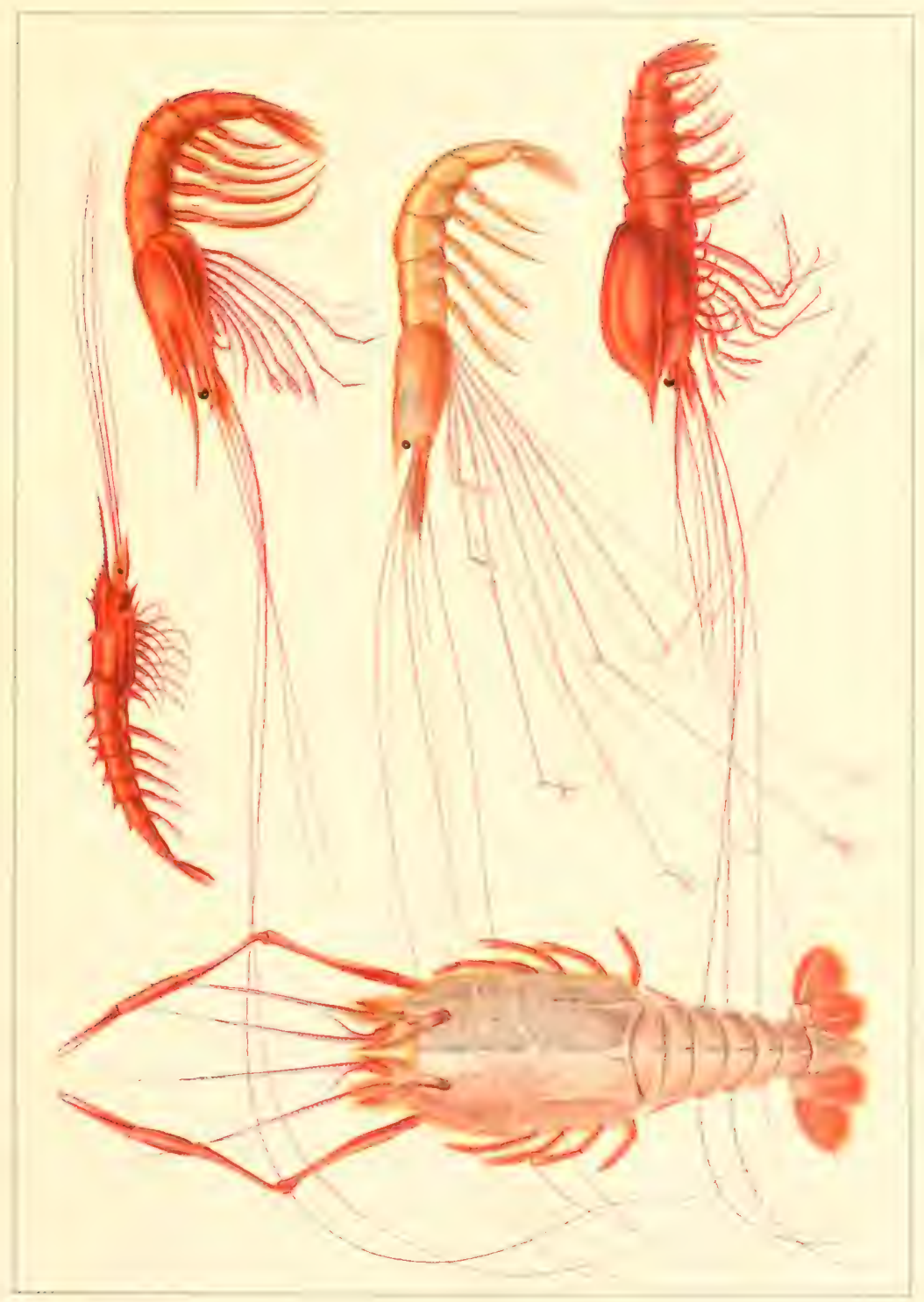


ferviert. Wem man allerdings bedenft, weldhe Koften das Deutjhe Reid aufwendete,

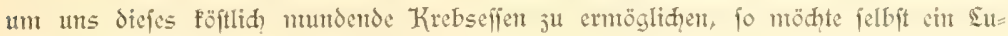
Fullus fopfitutitic geworden fein.

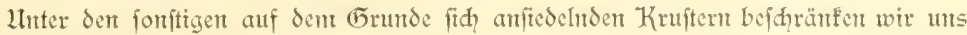
darauf, der Ranfenfüf̧ler (Eirripedien) Erwähnutg jut thun. Sie heften fid an allemt, was ifprent feften Gqalt gewährt, ant, unt fo findet man fie nidft mu Steinen und leeren Sdinedenthalen, fondent aud? den Stadeln von Edziniden und dem Panzer

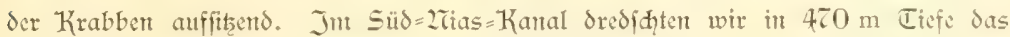
auf 5.598 dargeftellte Praḑteremplar eines Cirripeds, weldyes den zur Jeit größ̨ten befannten Dertreter der Dromung abgiebt.

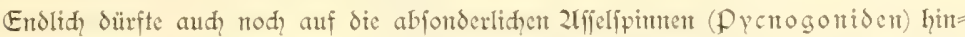
gewiefen werden, deren Körper flein fđ̨eint in Dergleid, ju den monftös entwidelten, von Darmanhängen durdjogenten vier Beinpaaren. Wir erbeuteten nadh den 2litt= teilumgen von Prof. 2rocbius 14 neue 2rrten derfelben und fitefen fiton bei den

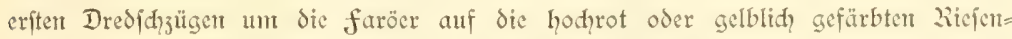
formen aus der Gattung Collossendeis, Z̈hntlid grof̧e 2frten erbeuteten wir an der Bouvet= Infel und auf dent Kerguelen=Plateau, wo fie durd ihre blutrote fürbung unt abenteueritiche Geftalt fofort auffielen.

$\mathfrak{W}_{\text {ent }}$ wir der RTollusfen des Tieffeebodens mit nur wentigen Worten gedenfen, fo geldieht dies wefentlich deshalb, weil wir faum in der sage wären, die füllle

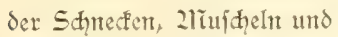
Dentalien cridzöpfend ju dharafterifieren. Es pei deshalb nur darauf
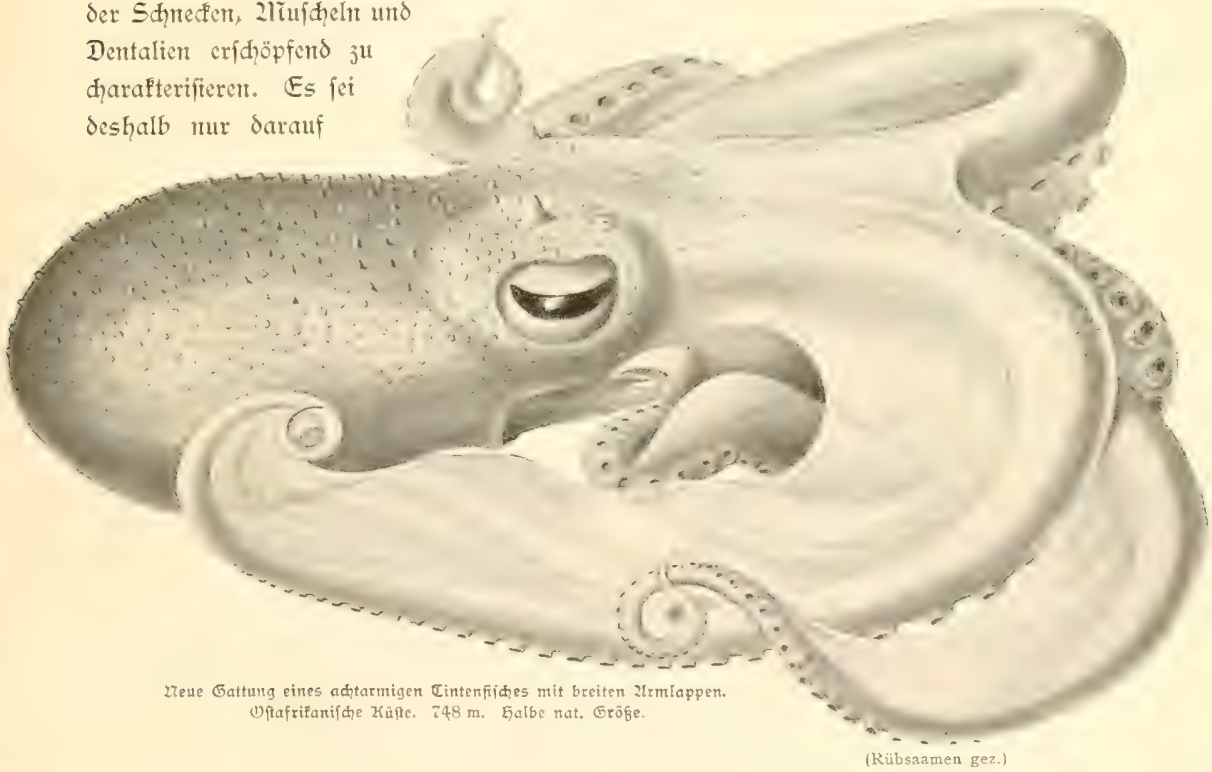
bingewiefen, da and cinige Tintenfifhe (Eephalopoden) fid dem Seben auf

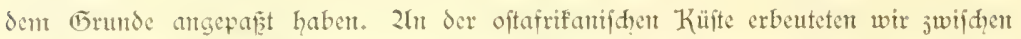
400 und $700 \mathrm{~m}$ Tiefe ungewöhnliđ grofe Eremplare der Ğattung Heteroteuthis und der aud im 2lientawei=3effen porfommenden (5)attung Opistoteuthis mit ihrem qdeiben= förntig abgeplatteten, dofoladebraun gefärbten Körper. Der benerfenswertefte fund

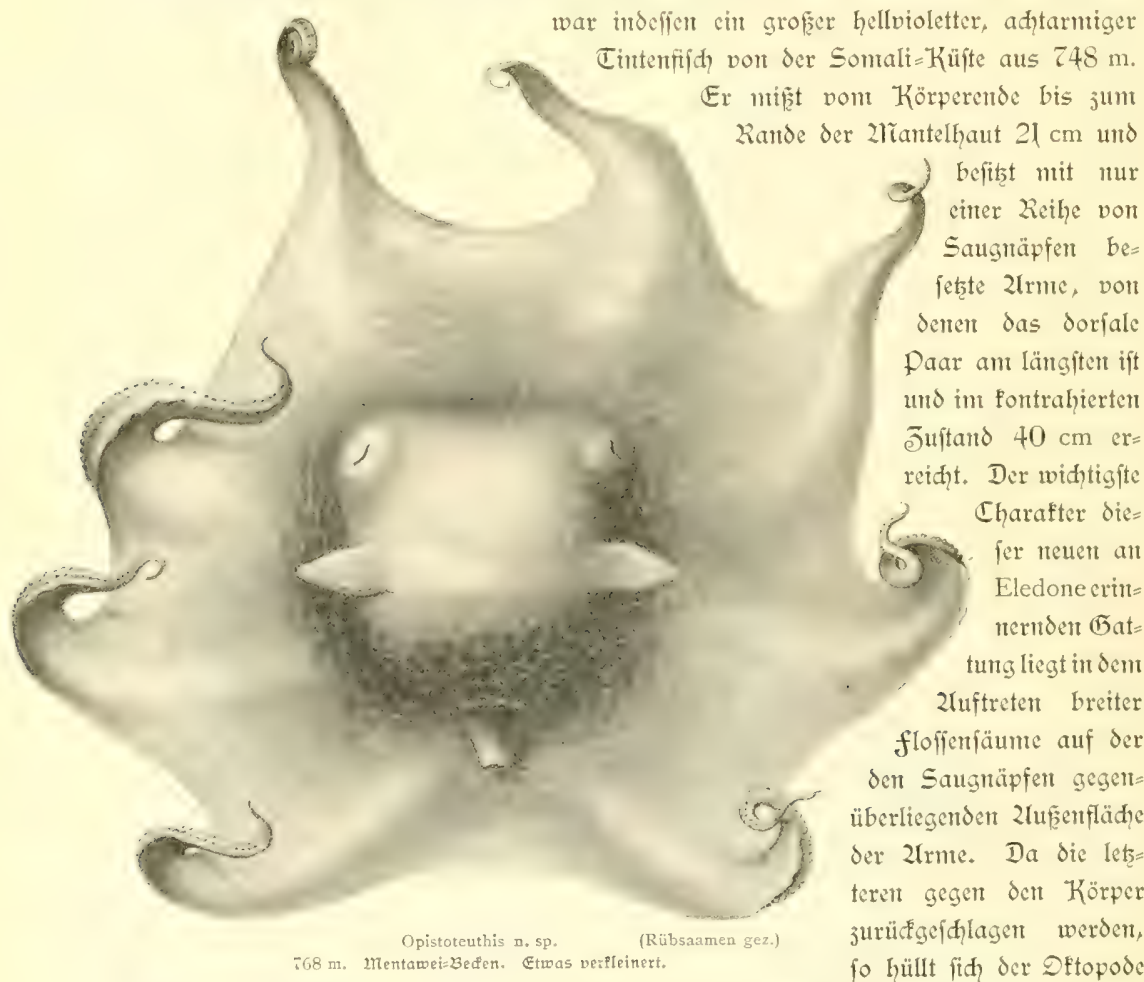

Er mist vom Körperende bis jum Rande der 2liantelkaut $21 \mathrm{~cm}$ und befitst mit nur
ciner Reihe von
Saugnäpfen be= jetrte 2lrme, von denent das dorfale Paar an längiten ift und in fontrabierten (3)utand $40 \mathrm{~cm}$ er= reidit. Der widhtigfte Charafter die $=$ (o) fer neuen an Eledonecrin= nernden Gat= turg liegt in dem 2luftreten breiter flofienfäume auf der den Saugnäpfen gegen= überliegenden 2fuE़enfläde dev 2frmte. Da die lets= terent gegen den Körper zurüdgefhlagen werden, fo hüllt fith der Sftopode

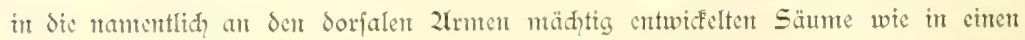

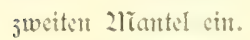

Was dic (5) ruthdifhe der Tieffec anbelangt, fo gehören dicfelben zum gröftert

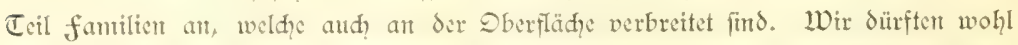
aus dent meipten der bisher in der Tieffee nadgewieferen familien diarafteriftifice Der=

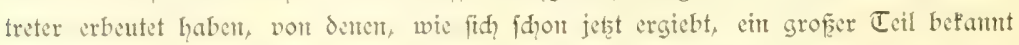
war, wemt aud inmerhin cine 2lijabl neuer 2lrten und Gattungen uns unter ilqnen 
entgegentraten. Da die fifhe beweglider fimb, als andere j. T. ja aud fejtfitgende Tiefieformen, fo erflärt es fih, daf wir in delt bisher nod, nidyt erforfhtent Gebieten des Indifhen Deeans (Frundfifhe aufanden, die wir entweder aus den 2ltlantifhen oder aus dem Pacifidien Deean fentengelemt haben. Erft eint genaueres Studium wird uns darüber aufflären, ob thatfädlid dent indifden Ẽebiete, wic es allerdings den 2fnfhein hat, gewiffe Typen ausihlief̧lich eigentünlich find.

Es würde den Sejer crmüden, went wir alle die cinjelnen familien rad thren joologifhen Charafteren namhaft mahen wollten, welhe in der Tieffee verbreitet find. So mag der Linweis genügen, daf Knorpelftidge aus den familien der zundntäuler (Cycloftomen), Rodhen, Lqaie und Lolocephalen nidht fehlen. Insbejondere war es wiederum die oftafrifanifhe Küfte, an der wir eine fleme neue form von Tieffee=5aien

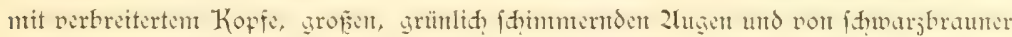
färbung in $1840 \mathrm{~m}$ auffarden, nid,t minder audh eine neue 21rt cines gropen, fdionen

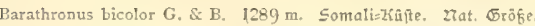

Jitterrodhen (Torpedo) aus $825 \mathrm{~m}$ Tiefe. Unter den Knohenfifinen fehlten niemals dic 2lafruren mit ihren grof̧en Köpfen und bisweilen monftös vergröferten 2lugen. Sie find die gemeinften, in jahlreihen 21rten verbreiteten Tieffeefifdre, die wir fenten.

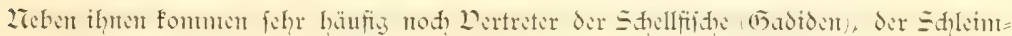
fifde (Dphididon), der Bruftfloffer (Pediculaten), der Zale (Zruränident) und der jauppentofen Zllepocephaliden vor. Don manden derjelben haben wir wahre Riefen crbeutet, welche die größ̧ten bis jeţt befanten Dertreter der genannten fantilien re=

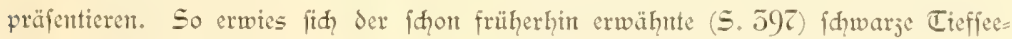
fifd aus dem 2rientawet=Becfen als der gröpte 2llepocephalide, und ebenfo fanden wir an der Somali=Küpte in $1289 \mathrm{~m}$ ein $90 \mathrm{~cm}$ langes, fdwwarjes 2lionitrum, das ciner nettent (5attung vort Dphtditdent angehört. Es fteht dicfer mädtige Tiefen= bewohner dex indijhen (5)attung Lamprogrammus nahe, unterideidet fid aber von iht 

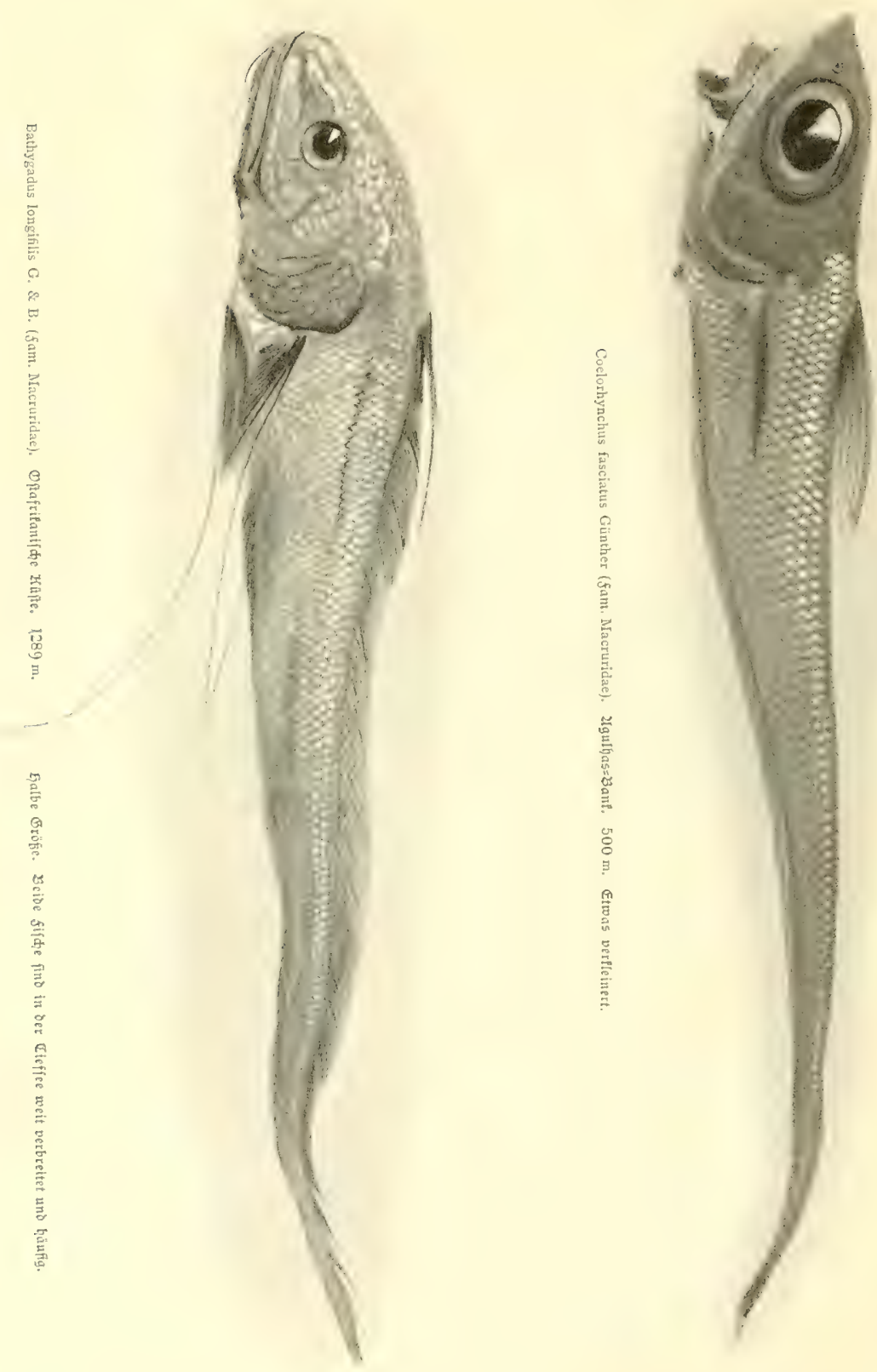
durd den 2Mangel der Scitenlinte. Die echten Teffeefifge jeigen im allgenteinen cine geringe Entwifflung der Baudifloffen, einen Langen, fpit julaufendent Sdtwanj, ein ventral geriḑtetes 2liaul, häufig eine 2lbplattung des Körpers und cine Linuwandlung der floffen ju Stützorganten. Daju fonmt in feltenen fällen eine Derfümmerung der 2lugen und 2liangel von pigntent.

Einen derartigen blinden fifd, dent aus dem 2Itlantifhen Drean durh bie forfhungen des "Blafe" befannt gewordene Barathronus bicolor, führen wir in der 2lbbildung vor. Er wurde in $1289 \mathrm{~m}$ Tiefe bet der Somali=Küfte erbentet, weift cin volffändig fnor=

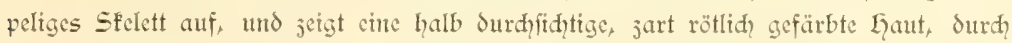

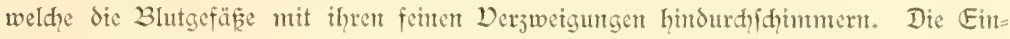
geweibe find nid̨t fidhtbar, weil die Seibeshöhle mit cinent dunfclviolettent Pigntent aus= gefleidet ift, weldes ju der Bejeidjuntg bicolor (jweiefarbig) Deranlaffung gegeben hat.

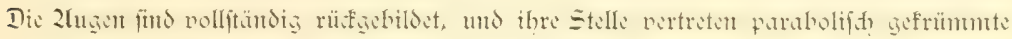
Gohlipiegel, weldhe in goldigem (5lanje refleftieren.

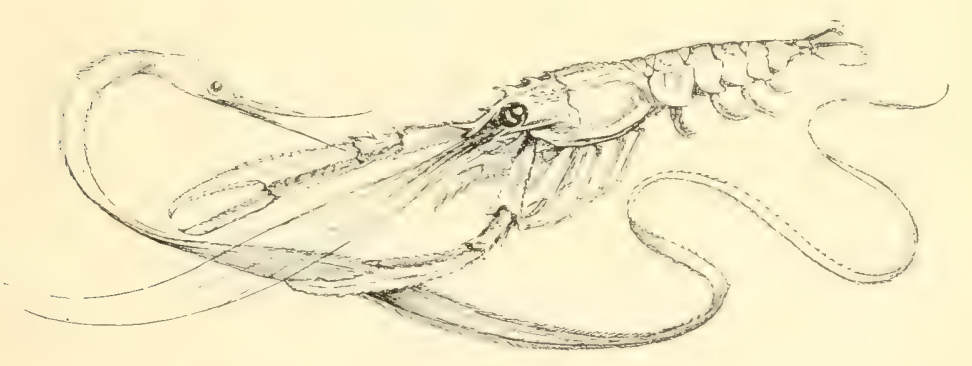




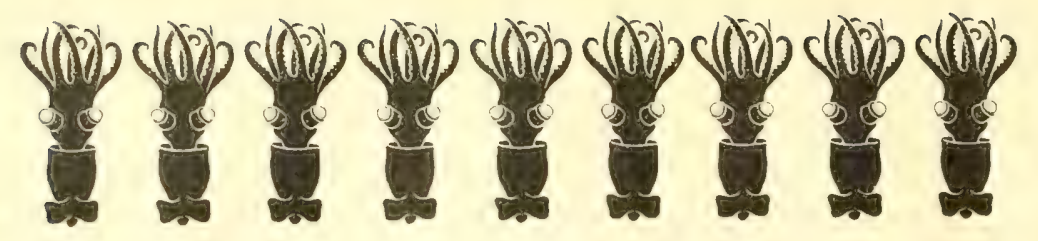

\section{Die pelagifhe Tiefenfanta.}

$\mathfrak{W}$

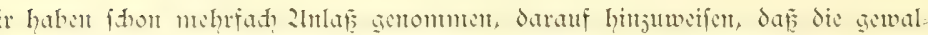
tigen Wafferjhid)ten jwifhen Ser Dberflädye und dem 2liceresgrunde nidit ajoifd find, fondern cinc reide fauna von Drganismen aufweifen, weldye jum Teil mit den an der Dberflüde lebenden übereinftimmen, jum Tetl aber and rect cigenartig ge=

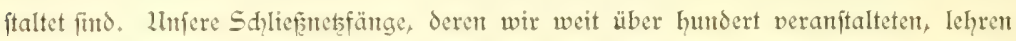
dies fo unjweideutig, daf man fḑwerlid, nod, dic 2luffaffung wird verfediten fömen, es eriftice feme pelagifoc Tiefenfauna. Wir haben gewiffenhaft jede fehlerquelle

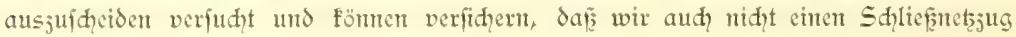
veranftalteten, in dem fidh nidht lebende Drganismen hätten nadweifen Iaffen.

In 3 ejug auf das Quantum an lebender, organtifher Subftanj laffen fich die Wafferfhidhten in drei Etagen gliedem. Die oberfte Etage reidht bis jut $80 \mathrm{~m}$ hintab

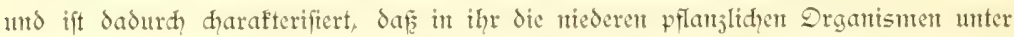
dem Einfluffe des Somenliḑts üppig gedeihen, indem fie durd 2lifmtilation ifren Eeib aufbauen. Die jweite Etage reid,t vot $80 \mathrm{~m}$ bis $j \mathrm{ll}$ etwa $550 \mathrm{~m}$. Sie jeidnet fid? dadurd aus, dafi in the mur wenig pflanjlidic Drganismen, ganj unabhängig vont dent veriditedenen dort obwaltenden Temperaturen, ifire Exiftenjbedingungen finden. Diefe "Sdattenflora", wie fie Sdintper genamt hat, fetst fid aus emigen Diatomengat= tungen (Planctoniella, Asteromphalus, Coscinodiscus) und aus der fugeligen 2ugen= (5attung Halosphaera jufammter (S.77). Unterhalb $550 \mathrm{~m}$ bis jum (5̃unde ver= mögen feine pflanjliḍen Drganismen ju eriftieren. Sie jetgen ftets deutlidhe Spuren Ses Jerfalles, der fith jutädit in einer abnormen Znhbänfung von Chrontatophoren und Stärfeförnern fundgiebt. Da indeffen, wie wir bereits auseinandergufetzen ver= fudpter, die pflanjliḑen Refte mit mehr oder minder jerfez̧tem Juhalt maffenhaft

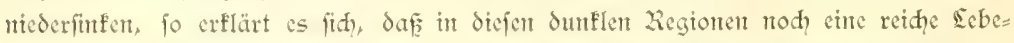
welt tierifder Drganismen auftritt. Jumerhin ergeben unfere Sd?liefnetgänge von ctma $800 \mathrm{~m}$ an cine der Tiefe proportional verlanfende, ftändige 2lbnahme im Quan= tum tierijact Drganismen.

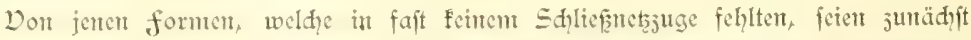
Dertreter der Radolarten aus den familien der 2leanthometriden, der Phäodarten, 
der Challengeriden und ber nad unferen 1hterfudungen als typifac Tiefenformen fid crweifenden Tuscaroriden erwähnt. Ebenfowenig fehlten bis ju den gröfsten Tiefen Gerab Cruftacen aus den Drdmungen der Dftracoden und Copepoden. In mitfleren Tiefen vorn $1000 \mathrm{~m}$ bis ju $5000 \mathrm{~m}$ gefalten fith ju ihnen Icberde Sagitten, Wurm= Iarven (Pelagobia) und Znmeliden aus den fantilien der Tomopteriden und Tpphlo=

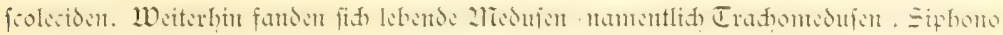
phoren, uns von Kruftern Dertreter der 2Jmphipoden und namentlid der Euphanften.

ङiemlid, häufig beobahteten wir dem aud nod 2liollusfent ans der Klaffe der flügelidntefen (Pteropoden) und fleine, den Scopeliden zugehörige fifde (Cyclothone). Don allen den genannten Drdmungen fanden fid aud gleidyettig dic Larven, und über= rajdend war es; daf namentlid, die als 2Tauplien bejeidneten sarven der Copepoden felbit aus den gewaltigen Tiefen von 5000 und $4000 \mathrm{~m}$ nod Iebhaft beweglion an

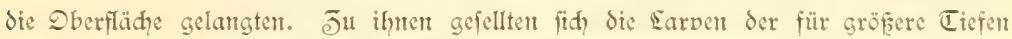
ganj bejonders typifhen jehnfüfigen Krebje aus der Drdnung der Sergejtiden. Er= wähnt fei mur nod, dafi in dent leţten Sdilef̧netzjuge, den wir aufierhalb Ras Lafun jwijhen 5000 und $4000 \mathrm{~m}$ veranftalteten, ein grofer, blutroter Sergestes enthalten war, deflen weifilich fdimmternde 2lugen cine ftarfe Rückbildung erfahren hatten und des Pigntents entbehrten.

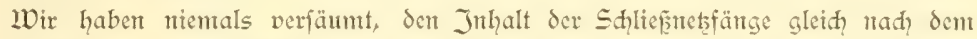
Eerauffommen ju unterfuchen und diejentgen formen zu verjeidnen, weldie nod lebend refp. mit wohlerhaltenem Weiḑförper, der feine Spur von Jerfeţurg aufwies, an= getroffen wurden. Da alle Joologen it Ẽememfhaft mit dem Botantfer an diejen Interfudqungen fid beteiligten und das Ergebuis wegen feines hohen biologifhen In: tereffes ftets eifrig disfuticten, fo fanm wohl verfichert werden, daf die fhärffte Kritif an dem gewonnenen 2liateriale und an dem tadellofen funftionieren des Zetses geübt murde.

Das Sdyliefnets erbeutet allerdings, wie fhon aus der 2lufjählutg der oben er: wähnten Drganismen hervorgeht, bei feiner furjen D̈finungsdaner (es war dic Ein= riḑtung getroffen, daf es nah Belieben verftellt werden fornte und dentgenäf ent= weder Wafferjäulen von nur $20 \mathrm{~m}$ oder foldhe bis ju $600 \mathrm{~m}$ höhe ourdffidite) und feinem nidht jehr grofen Durdhnteffer nur Eleinere Drgantismen.

Wir haben indeffen allen 2lnlaf ju der 2lmabute, daf aud grofic formten in un= beliḑteten Tiefen leben, weldhe wir $j$. T. mit unferen riefigen Dertifalneţen ju crbenten vermoditen. Die ausgiebige Derwendung diefer 2ietse ift unferer Erpedition eigen=

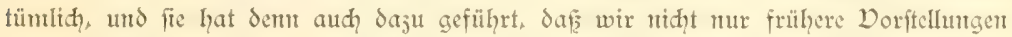
über die Eebensweife von Tieffecorganismen ju beriditigen in der sage find, fondern aut eine ganje Reihe neuer formen entbeften. Sie das Intereffe der Joologen in befonderem 2laface wahgerufen haben. 
Wir dürfen weiterhin auf Grund der Lunderte von Dertifalneţängen, die wir in Sen veriḑiedenften Tiefen ausführten, bchaupten, dafi die intereffantejten Dertreter diefer pelagifuen Tiefenfuna crif unterhalb $600-800 \mathrm{~m}$ vorfommen. Da das Dertifal= thets alles fijdit, was fowohl in der Tiefe, wie in der 27ähe der Dberfläđhe fhwebt, fo peranfalteten wir mehrmals an cincr und derfelben Stelle Stufenfänge, die ftets mur dann dicfe cigenartigen formen lieferten, wenn wir das 2iet in größpere Tiefent als $800 \mathrm{~m}$ verfentert.

Bevor wir die biologifhe Eigenart manḑer diefer pelagifdyen Tiefenformen mit

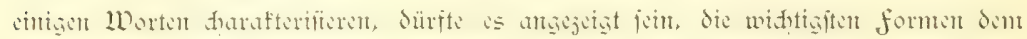
Sefer in Wort und 3 ilo vorzuführett.

lluter den niederfen formen, den LItieren, fheinen Iebende foraminiferen in den gröperen Tiefen felten zu feit. In den Sdyltefineffängen fallen allerdings die jahl=

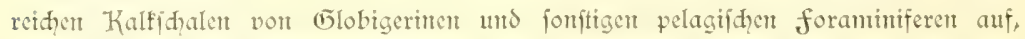

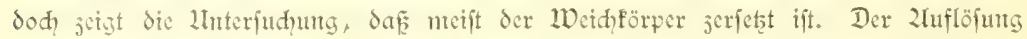

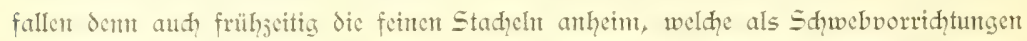
den an der Dberflähe flotticrenden formen jufommen. Daf́ die maffenthaft nieder=

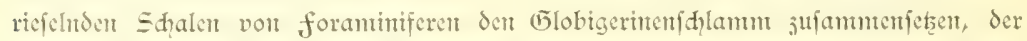
in gemäfigten tropifden Jonen auf weite Strefen hin den Tieffecgrunt bildet, haben wir nebrfad im Sanf umperer Daritellung betont. Dagegen überrafdit vor allen Dingen Ser Reidutum an Rabiolarien. Gädel hat in einer praḑtoollen, mit 140 Tafelt ausgeftatteten 21onographie die Radiolarien der Challenger= Expedition gefditldert. Ith Glaube verïhern ju fömten, daf der Bearbeiter der von uns erbeuteten Radiolarin cin nidft minder voluminöfes Lerf verfafien wird, went er den ganjen Rethtum an formen, die jum Teil fogar bisher nod nidht befannte fantilien enthalten, eingehent fhildern will. Da wir an der hand der neueren Konfervienungsnethoden anf $\mathbb{E}_{\mathrm{r}}=$ haltung des Wethföpers Wert legten, fo düfte gerade in diefer Limftht de Bear= beitunty der Rabiolarien cincn willfommenen Konpens ju $\mathfrak{L}$ äd els Darftellung abgeben.

Ihter den 2liedufen find wir gleidfalls auf cine ganje Zlnjah! von forntent auf= merffan geworden, weldie als edite Tieffee=2liedufen teils fiton von früheren Erpedi= tionen erbentet wurden, teils aber aud unbefannt blieben. Dr. Danboeffen, der fith während der Erpedition ffecisll mit den 2licoufen befhäftigte, beriḑtet, daf von

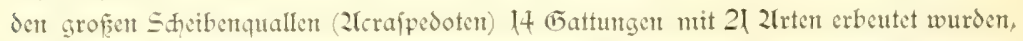

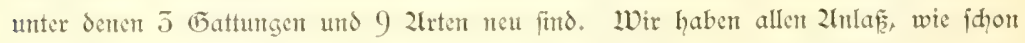
Gädel vermutete, die ourh thre purpurnen, violetten oder bräunlidgen Töne ausge=

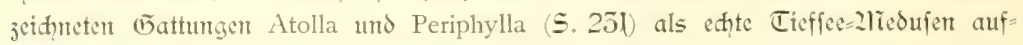

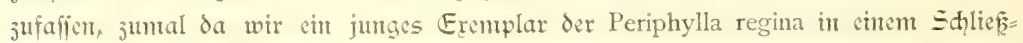
neţjuge aus 1500-1000 m erbeuteten. Die alten groß̧en Exemplare der Atolla

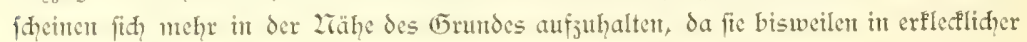


Jahl mit Scm Sdlepputs erbentet wurden.

Diefe pradgtwollen formen feffelten nidht

minder unfer Jnterefie, als durdfitid =

tige oder rot und tief braunviolett

gefärbte Dertreter der Sdleier=

quallen (Craspedoten), von de=

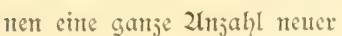

2lrten und (ธattungen häufig

in die 2reţe gerietert.

Wie fhor Studer bei (ธ)e

legentleit der (5)ajelle = Erpedition

nahwics, fo gehören aud cintige

(5)attungen und fantilicn jenter wunder=

baren Kolonien vort Sdrwimmpolypen

(Siphonophoren) ju den edthten pelagifhen Atolla n. sp. Dertipalmets bis $2000 \mathrm{~m}$. Rat. Eröfe. Tiefenformen. Dies betrifft namentlid̆ Sic Rhijo= Jwiftien Kiaf und 23ouvet=2iegion.

phyfen, welḑe, wie bet frihberen Erpeditionen, fo audh bei der unfrigen häufig an der sotleine und an Dredfhfabel in gröferer Tiefe fidh verfingen. Jhr Stamm fann enom lang ausgejogen werden: wir haben eimal cine Rhijophyfide von $4 \mathrm{~m}$ Sänge genteffer. Seider gelantg es uns nidht, Dertreter der vom "Challenger" erbeuteten 2luronectiden aufzufinden, dafür aber wurden wir mehrmals auf neue formen von Phyfophoriden aufmerfian, die wiedcrum durd ihren Sunfel=violetten Ton fid ausjeid̨neten.

Fine freudige l̈berrajhung war es für uns, da fir wir aud? ans der Klafje der Rippenquallen (Ctenophoren) formen erbeuteten,

die als edte Tieffecorgantsuten in 2lniprud ju nehntent find. Da es die crftert Tieffec=Cteno= phoren find, die überhaupt befantt werden, jo fei erwähnt, sa wir fowohl im 2ltantifacet wie Jubijhen Deean che 2liertenfie auffant= Sen, deren abogeplatteter Körper $4-5 \mathrm{~cm}$ breit wird und fidd durd ein mildig getrübtes

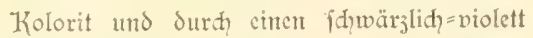
gefärbten 2lagatr ausjeidnet. Er läuft in cute breite 2lundöfinung aus, derent dunfle sippenränder bals feft aufemander geprefist, bals breit vorgewulitet werden. Dic Ctentophoren, welthe

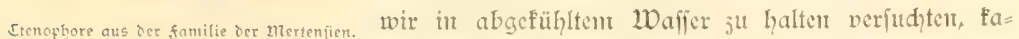

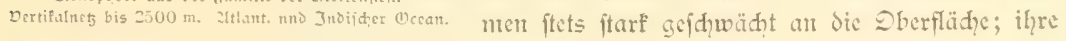




\section{Liolothurien.}

Ed)wimmtätthen waren jwar nodh in Bewegung. aber niemals entfalteten fie ihre fangfäden. Ein= mal erbeuteten wir in cinent leider ftark verletsten Eremplare sine blutrote Cyoippide von cylindri= fher (e)ptalt, deren zliagen durd) feinen fammet= fowwarzen Ton aufficl. Es ijt bemerfenswert, daf bei diejen jeltenen Ctenophoren jene violetten

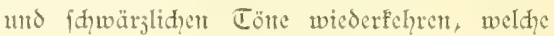
den Ticffeemedufen eigentünlidh find und den Oberflädenformen - foweit wentgitens dic Etenophoren in Betradit fommen - surḑaus feblen.

Fine $\delta_{e r}$ interefianteften Entdecfungen der unter der Seitung volt 21 gaffij ftehenden $2 \mathfrak{l}=$ batrof = Erpedition an ber pacifitiden Seite der anterifantifhen Küfte war der 2Tadweis von fumimmenden Edinodermen aus der Klaffe der Ecewaljert (Eolothurient). Prof. Endwig hat defelben an der Land der Sfijzen vort 2lgafit und der freilid febr unvollfommen fonjervierten Eremplare als Pelagothuria be= fdrieben. Sdyon in dem Zltlantifden Deean wurden wir anf bie Jugendformen diefer Golo= thurie aufnterffant, dod gelang es uns crit im Indifhen Deant - namentlid auf der fahrt von den Seydellen jur oftafrifanifdyen Küifte-, dic gefdledptsreifen Ticre ju erbeuteu. Jh fann verfithern, dafes faum eine jartere und dabei glanzoollere Eridyeinung unter den pelagifhen Tieffectieren giebt, als dicje auf den eriten Blick an eine 2licdufe oder an ente Sceantmonte $\mathfrak{c}=$ innernde Golothuric. Der weidye gallertige Kör= per, weldher Ser für dic Edhitodermen typiffen Kalfërper entbehrt, iit leidit rofa gefärbt uns nur das Linterende jeigt cinen duffleren, violetten Ton. Daf es fich unt cinte edte Tiefenform hat: belt, weldhe fretlid aud der Sberflähe nahe fommen 
fann, leb̧rt ihx 2luftreten in cincm Sdyliefnetzang (bei dent Seydellen) aus 1000 fis $800 \mathrm{~m}$.

Da de bisherigen 2lbbildungen chne mu ungenügende Joec von dicfent munter: baren Drganismus geben, fo mögen die SFijjen, weldhe id, naћ dem lebenden und in abgefühltem Waffer gehaltenen Eremplare fertigte, den Scfer vorgefübrt werdm. ङum

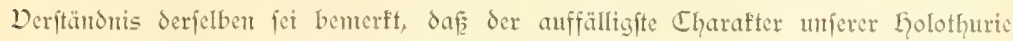
in der 2lusbildung einer mäd)tigen Sd wimmidgeibe liegt, die von 12 Tentafeln ourdi= jogen wird. Sie find fymmetriid, un eine 2redianebente angeordnet, welhe unt dem langgejogenen 2lundfdith jufammenfält. Die feitlidhen Tentafel übertreffen die übrigen an sänge und meffen bei grof̧en Eremplaren $8 \mathrm{~cm}$. Jnturhalb des Tentafelfranjes der Sdutwmidheibe fteht ein jweiter Krantj

von fürzeren fühlent, welde an ihrem Ende fidy in furje Kiemenbäundyent gabeln. Jhre Jabl fimtmt nidht mit Serjentigen der Tentafel überem, infofern fie fonftant 14 beträgt. Sic fint glcidfalls frmme trif verteilt und durd wei= We (1)allerte mit den 12 Tentakeln nerbunden. Die von betden Krän= รen untitelite 2ltund = freibe weift cine jwar gelcgentlid rundid verbreiter= te, meift aber in der Riubelage idlits: förntig geftaltete 2liutdöffiung auf. Der Dorderdarnt geht in cinen fdleifenförmig gebogenen 2litteldarm über, dent eit ant binteren Körperende ausmündender Enbdarm folgt. Der Darm war ftets mit ciner gelbbraunen 2liafie erfüllt. die fid bei mifroffopijher Unterfudyutis als sine 2htfammlung von Radiolarten 


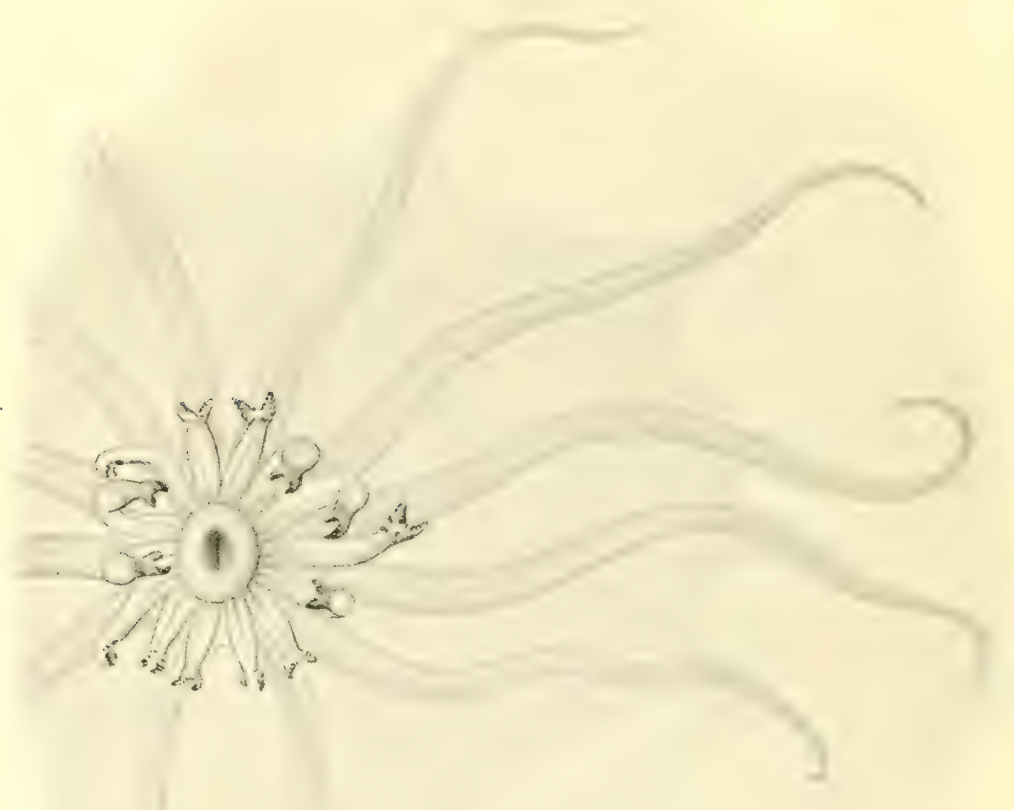

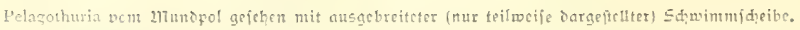

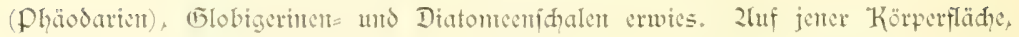

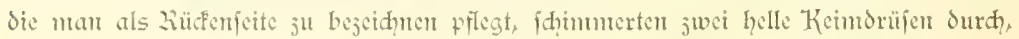

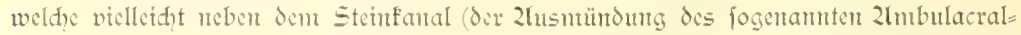
gefäbifitems) anf cinter langgejogentent Papille mündent. Sic wird bei der indifdyen

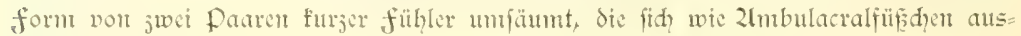
nelmen. 
Jarte Sangsmusfelfafern unt Sängsmerven verftreiden über dic Tentafel und Kiemenfühler. Die Zerven der lefteren gehen von cinent 27erventring aus, weldher dic 2liundideibe umfretft; diejentgen der Tentafeln entfpritgen in fireng fprmtetrifher Derteilung aus vier Radiänerven der hinteren Körperregion.

Bei ruhigem Sdqweben wird ftets der 2lünd nach oben gewendet. Die Shwimm fdecibe, gebildet aus den 12 Tentafeln unt $\delta \mathrm{er}$ fie an threm prorimalen Teile cin= fäumenden jarten (5allerte, wird bald horijontal ansgebreitet getragen, bald gegen den wurmiförmigen Linterförper cingejdlagen. Dic Bewegungen gefdehen fo langfant, daf feinesfalls (hicrju ift aud dic 2liusfulatur viel ju jart) durd) pumpende $\mathrm{B}_{\mathrm{e}}=$ wegurgen naत, Zlrt der 2liedufen cine Drtsveränderung crfolgt.

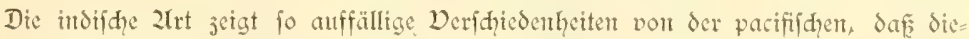
felben nidgt allein auf Redinung ungenügender Beobadytung ju fetsen find. Sic mag Saher, dem Begründer der (5attung ju Elyren, den 2Tamen Pelagothuria Ludwigi tragen.

Linter den Würmern fehlten niemals im Jinhalt der Ticfemetze grofect Pfeilwürmer (Sagitten) mit gelblidient oder rotem Damt. Seltener waren prädtig rot oder orange gefärbte Typhlofeolectden, während in antař = tifhen Gebiete prahtoolle durthidatige Tomopteriden von faft finger=

länge mit rofa gefärbten fuffiftummeln (Parapodien) beinahe mit jedent Tiefenjug an die Sberflähe gelangten. 2lngentehm überrafde uns aud das Wiederfinden der pelagifh lebenden Dertreter won 2iemertinen. Don dicjer, fonft mur auf dem 2lieeresboden Iebenden Wurmgruppe, bejdurteb etiner der Teil= nehmer an der Challenger $=$ Expedition, 2lofeley, nah ju= gendidyen Exemplaren die von thmt als Pelagonemertes bejeifhnete, flottierende Gattung. Da fie in mehreren wohl= crhaltenen Exemplaren vorliegt, deren verjweigter Darm rot oder orange gefärbt war, dürfen wir ente Reihe neuer Zluf=

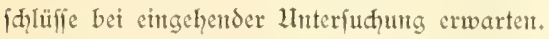

Eine 2lumee von Cruftaceen duthihweift die tieferen Waffer= fhibten. Stets hungrig und beutegierig, erwehrt fie fidh mit Dornen und Sanjen der 2lngreifer, ftöbert mit übermäd)tigen füblern und Zugen - bisweilen fretlid aud blind - ibrer Beute nah, Lodt die Opfer mit Blendlatenten an und padft fie mit in Sheren oder Spief̧en auslaufenden Raubfüzen.

Ob unter den niederen Kruftern, ipeciell den copepoden, die ja uniere Shliebretzänge bis

Pelagonemertes von der Baudffeite gefeher. Det Rüffel ift ausgeftredt; bie im Eeben hod,rot ge: fürbten 3 belige des Darntes treten oeutlid hervor. $8 / 1$. Tiefen Des 2tiJant. uno Inditinen Deeans. 
3u den gröfsten Tiefen pijige Tisfenformen dic genaucre Sidntung Jidentalls wiffen wir,

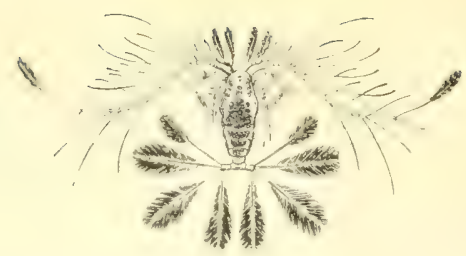

lebent nadiwiefen, ty= vorfommen, muf erft des 2liaterials lehren. daf pon den fleinen

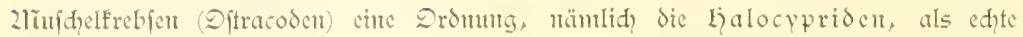
pelagifue Tiefenformen anfufaffen find, infofern fie eme ziüfbildung ber 2lugen erfahren haben und unter nomalen Dorhältniffen die Dberfläd me men. Lnter defen trafen wir wahre Sitcfen non über $1 \mathrm{~cm}$ कbröpe ant. Dor allent Dingen feffelt cinc von 10. 2lïller als Gigantocypris bejdriebene (5attung, deren fugelig geftaltete

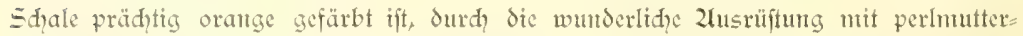
Glängender Refleftoren an den Kopfabidnitt. Da idh dicfe abfonderliḑen Eebilde nidht lendten fah, fällt es cinftweilen fower, fid Redenidhaft über thre funftion

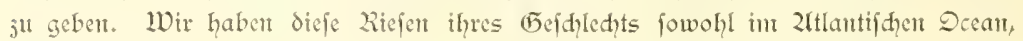
wie aud int indifhen (B.bicte bis jur oftafrifantifden Küife in identifinen Erem= plaren ertrentet.

Erwähnt fei mur nod, dafi cin ganjes Geer von 2lmthipoden der Tieffec 


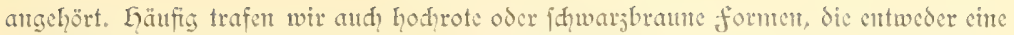

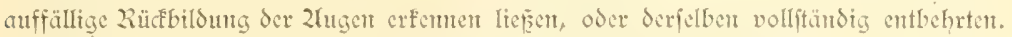

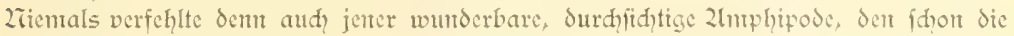
Challenger = Erpedition entoeffe und als Thaumatops in dic Wiffenjdaft einführte, dic

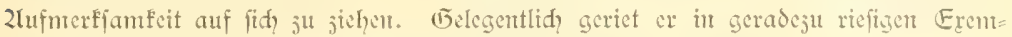
plaren, deren auf ber Stimfädhe jufammenftofiende facettenaugen an Limfang von feinent anderen 2trthropodentange übertroffen werdent, in dic 2ietze.

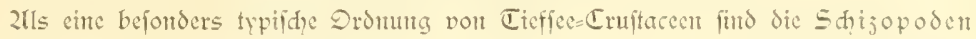
aufjufaffer. Unter thmen fonment nantentlid die Dertreter der Euphaufident (5attungen Nematoscelis und Stylocheiron von ctwa $500 \mathrm{~m}$ Tiefe ab in chormen Sdzwärmen

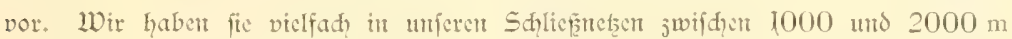

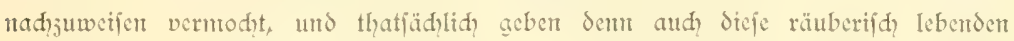

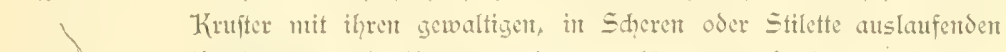
Raubfüren, mit ihrent ntomftös verlängerten fühlem, mit ihren

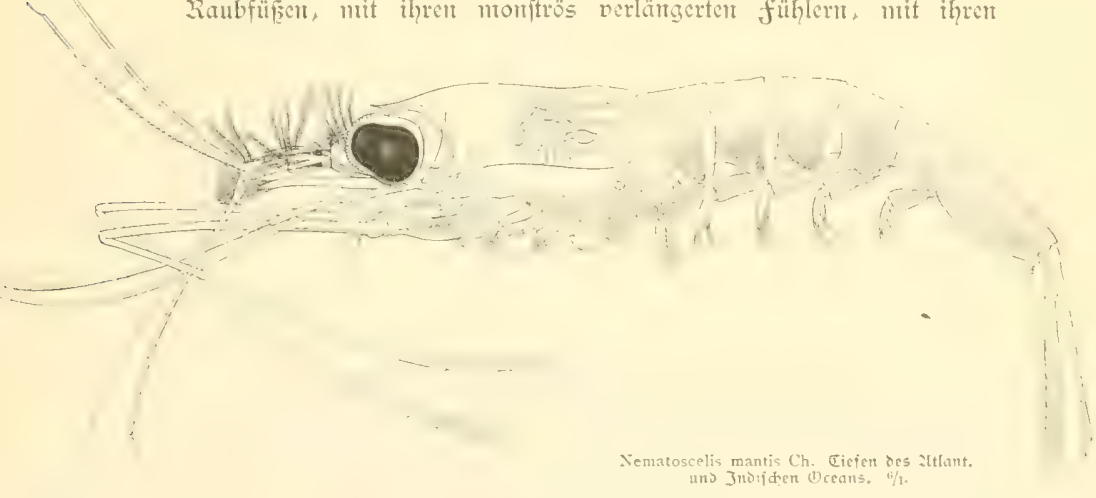

pradịtrollen, jweigetcilten und für das Sehen in Dänmerlidit cingeriḑteten 2lugen,

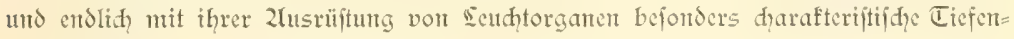
forment $a b$.

Ein intereffantes Ergebuts der Challenger= Expedition war der 2radyweis von Ricfett= formen der Sdijopoden, weldye als Gnathophausia bejeidunet wurden. Es handelt fid? unt blutrote Sdijopoden (ein Dertreter dericlbent ift auf der lithographierten Tafel dar= geftellt), deren wir cigentliḑ bei Befpredhung der Grundfauna bereits hätten Erwäh= nung thun follen, weil fie offenbar mit Dorliebe fid didft über dem 2lieeresboden auf= halten. Wenn wir ihree hier erft Erwähnumg thum, fo gejdicht dies auf (5)rund der Thatiaḑe, dafis wir fie mehrmals mit dent Dertifalnets 1000 oder $2000 \mathrm{~m}$ über dem 2lieeresgrunde fhwebent auffanden. 


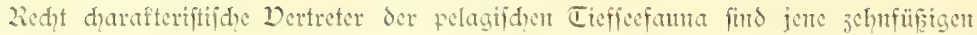

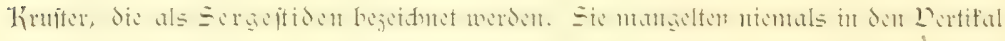
netsen, fobald sicjelben in anfebnlidgere Ticfen herabgelaffen wurben; aud haben wir bereits 2lnlap gentonmen, ju erwähnter, daf ein Dertreter derfelben fid in einem

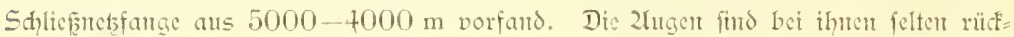

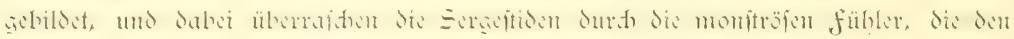

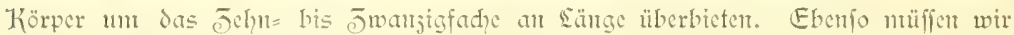

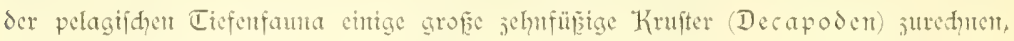
die deı (D̄attungent Acanthephyra und Notostomus angehören. Einen Dertreter der Icţtgenannten (ñathung haben wir gleidfalls auf der Tafel daruefellt, un die prädtige, blutrote färbung ju illuftrieren. Eine ganje sicibe neuer Zlrten dicjer pratitvollen Krufter geriet in unfere Ziefse. Die Gattung wurde erft durd die Expedition des

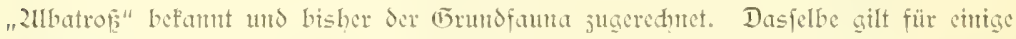
Dertreter Jer blinden Eryoniben. Sis gebören der (1)attme Eryonicus an und jeidnen fidh not ifren auf dem Grunde lebenden Derwanden, den Pentacheles- mo IVillemoesia-2frten, dadurd? ans, daf der rot oder nithig gefärbte Körper in Zupafiuns an bie flottierend: Eebensweife ballonfömitg aufgetrieben ift.

Die in gröferen Tiefen flottierenden 2löollusfen weifen namentlid unter den flügel:

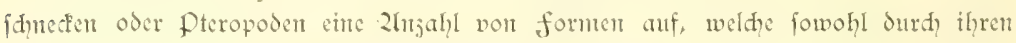

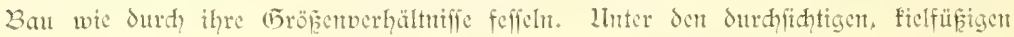

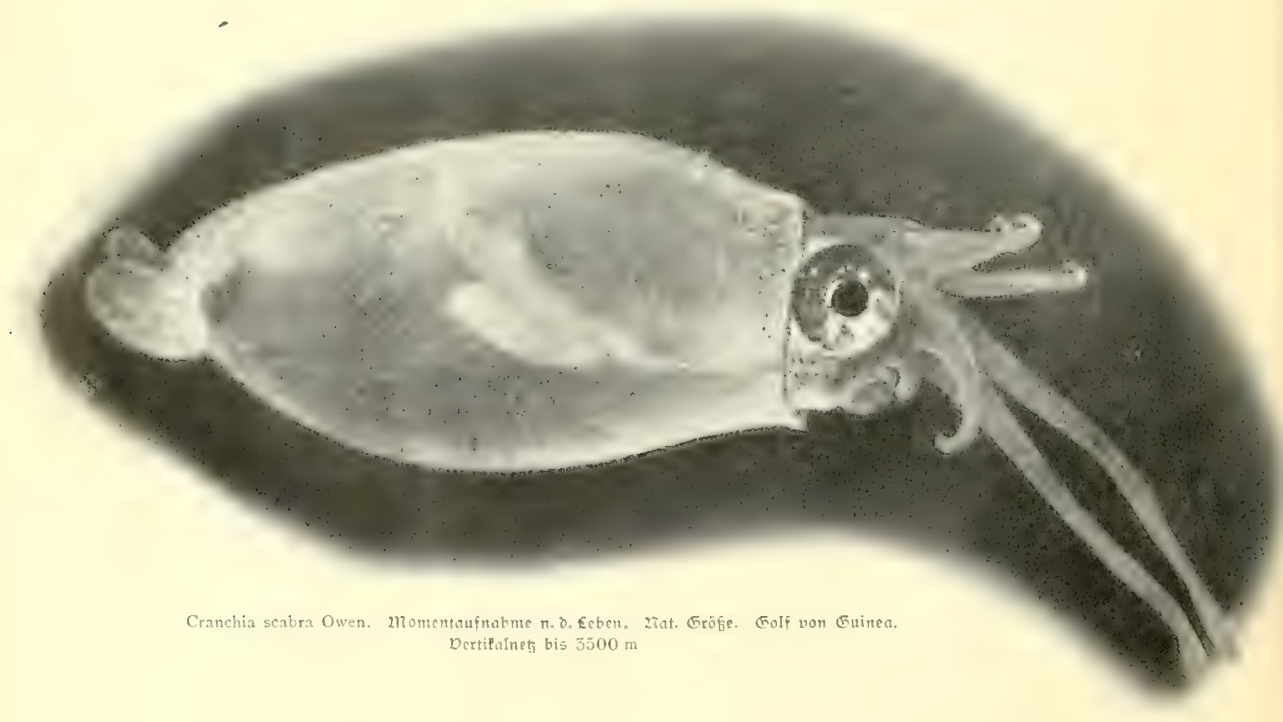




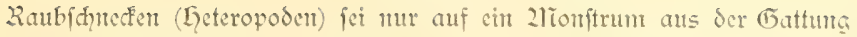
Carinaria hingemiefen, das nady dem Derlaffen von Ceylon mit dem Dertifalnete gefangen wurde. Es miff $52 \mathrm{~cm}$ und maridiert fomit, was Dimenfonen anbelangt, an der Spithe ber Drdmung.

Befonders reth war die Zusbeute an pelagijh lebenden Tinten= fifden (Eephalopoden), fobald wir die 2retse unterhalb $1000 \mathrm{~m}$ herab. liefen. Zlandhe diefer of red)t jarten und durdfithtigen formen find unter den bisher befannten Gattungen nidt unterjubringent. Da wir nod) (5elegenheit nehmen werden, anf cintge derfelben wegen ihrer biolo=

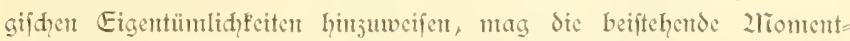

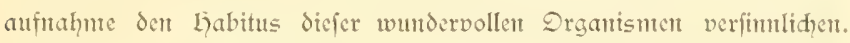
Sie betrifft dic Cranchia scabra, weldhe $D$ wen nah cinem jugendidfen Eremtar befdricb. Da bisher von dent feltenten Crandiaden faft mur

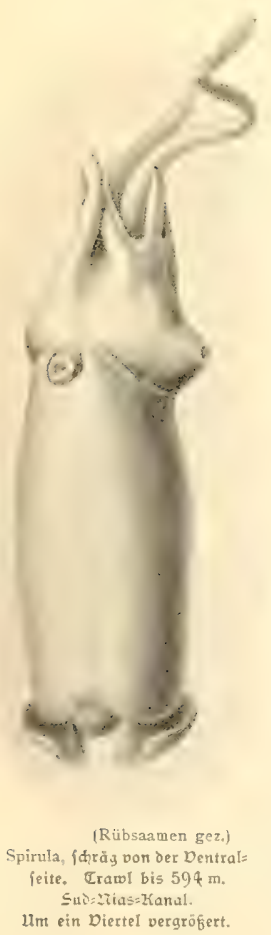
fleme Jugendformen befannt geworden waren, hat unfer fund des grofent erwahienen Tieres $u m$ fo mehr Juterefic erregt, als es fid? um cin zliäms

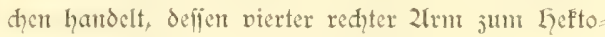
fotylus (Begattutgsarm) untgebildet ift.

l̈berhaupt wird die Kenntnis der Crandfiaden durd die Entbectung mehrerer neuer (Eattungen, von denen wir bereits einige im Bilde vorfülyten (5. 252), wefentlich gefördert. Dic nebenfitehende כetdunts giebt den Gabitus einer form wieder, weldye durd die pfeilförnige (5eftalt und durd? die geftielten Zlıgen befonders auffällt.

2ls pelagija lebender Cephalopode dürfte dem aud einer der foptbariten funde der Expedition, nämlich die im Sild=2tias=Kanal lebend exbentete Spirula ju gelten haben. Sie hing in den 2liafhen des bis 594 m herab gelaffenen Trawl (S. 50z). Dasielbe hatte Iephalopoden aus der fant. Der Cranchiae, Derufulnety his 2000 t.1. 3no acean (bei der Cocosinfel). Dergr, $3 / 2$ indeffen den (5rund nidht erreiht und enthiclt auf̧er der Spirula nod cine Atolla und einen pelagtid lebenden Tieficefifd. Unter Eremplar jeigt am hinteren Körperende deutlid einen Teil der pofthornförmig gefrümmten Shale und den merfwürdigen, cinem Saugnapf gleidenden fortiatz. Ein trefficher alter $\mathcal{B}_{e}=$ obadter, Rumphius, bejdreibt 1705 in feiner "2lntboin'fhe Rariteiffammer" das erfte, freilid ftarf jerfetste Exemplar der 
Spirula und fpridgt bet diefer (belegenheit dic 2rnfidgt aus, da fie fie an den felfent feft= hafte. Epätere Beobadter betradten demm aud ben genanten fortiats geradeju als cinen Saugnapf. Eeme Struftur gleidgt indeffen fo wentig den an den Zlrmen der cephalopoden vorfommenden glctdntantigen Bildungen, da í id vermute, es möge fid

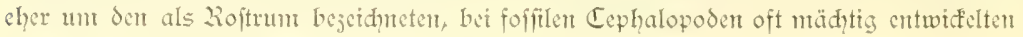
fortfats or Edale handiln.

2 fus dem Typus der 2lanteltiere oder Tnnteaten fandent wir juar bisweilen int

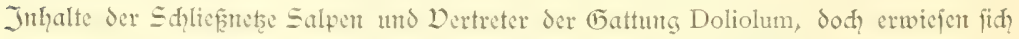
dicfelben als 2raten, wilhe bereits von der Dberflädhe befannt waren. 2ludy ift es fraglidy, ob die ourd the herrlides Eeudten ausgejeid = netert futerwaljen ober Pyrofomen in eingelnen 2frtent anf gröfere Tiefen befdränft find. faft mödte man is virntuten, da im Int= difden Decan das Trawl bisweilen cinen 3 ret rötlidfer Pprojomen an Ste Dberflädqe beförderte. Siḑer aber ift es, dafi von ciner Tunteaten= Klafie, die durdans pelagifd lebt, nämlid den $2 l p p e n d i c u l a r i e n$, Dirtreter crbentet wurden, die niemals an der $\mathcal{}$ berflädye jur Beobad! = tung gelangter. Wenn man bedenft, da is is fid um fleme Drganis= men fandelt, zu deren Etudium wir ftarfe Dergröperungent antenden milfen, fo fant mant fĭ wohl sie liberraffung vorftllen, die uns Jurd das Erbeuten jweter vollendet durdyithtiger, farblofer, $81 / 2 \mathrm{~cm}$ grofer Biefencremplare von 2lppendicularien bercitet wurde. Dic gröpte bisher fofant gewordene 2lppendicularie ift der Megalo-

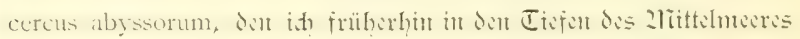
auffand: er ift cill Jwerg im Dergleide nit diefert Drađtformen, Sie in jwei Eremplaren bei der 2lmmäherung ant das Kapland fid? in dem bis $2000 \mathrm{~m}$ herabgelaffenen Dertifalnetse fanden. Da die Entbefung diefer Riefenformen das Jnterefie der Joologen in be:

Bathochordaeus Charon Ch. Rat. Fr. Sitbatant. Mcean. Dertifunets bis $2500 \mathrm{~m}$. weste, fei es geftattet, inren Bau etwas cingehender an der Fland fonderem 2hape erwecte, fei es getate
beiftehender 2lbbildungen flarjulegen.

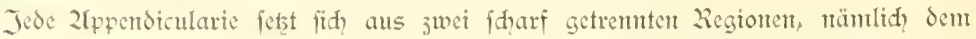
Rumpfe und dent Ruderiduwanje jufamment. Der Rumnf erreidit bei den an der Dber=

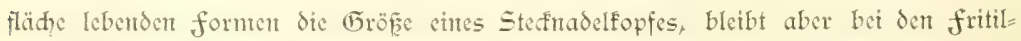
larien fo flein, da

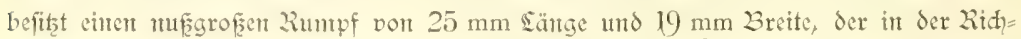

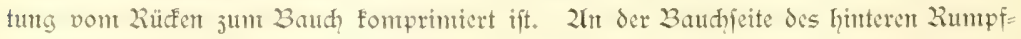

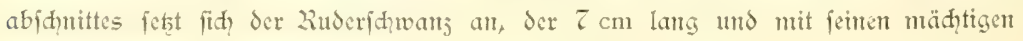
flofferfäunten $5 \mathrm{~cm}$ breit wirb. 
Don den interen Drganen überifhant man den geglieberten Darntratus in feiner ganjer 2lusdehnung mit bloficm 2luge. Er befteht bet allen 2lppendicularten aus cinent refiratorijhen Kientendarm und aus dent verdanenden 2lbjonitt. 23ei unferer 2lut jeigt der refpiratorijhe 2lbidnitt infofert cin abweidendes Derbalten, als der mit

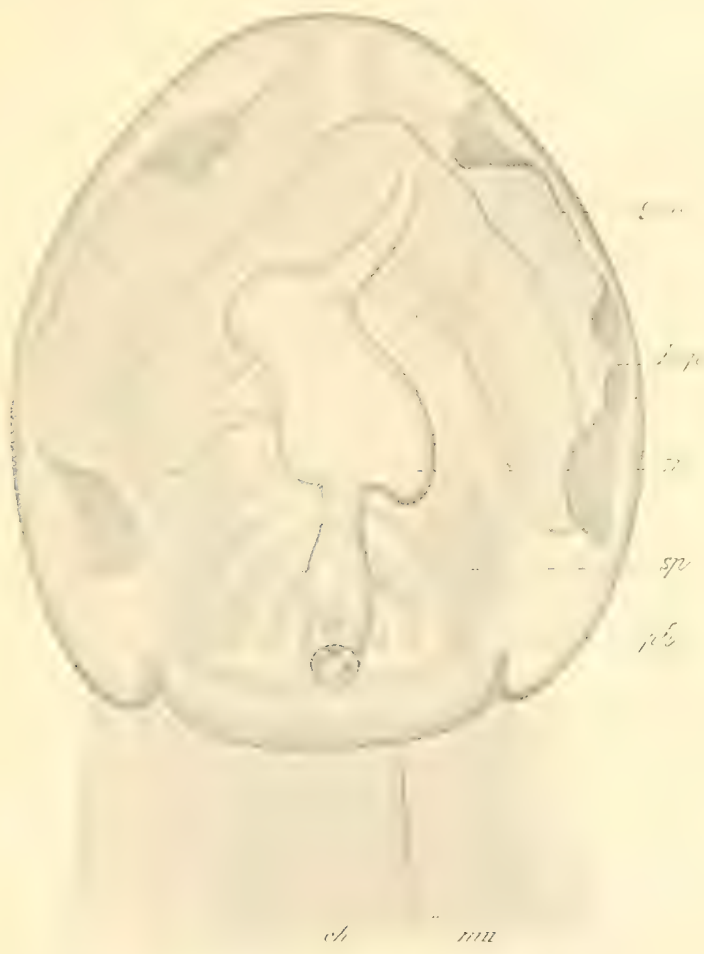

Eathochordaeus Charon. Ch. 4/1. Rumpf von Det Dorjalipite.

3wei Kiemenipalten ausgeftattete Kiementarnt $(p / L)$ ungerwöhnlid flem, der darauf

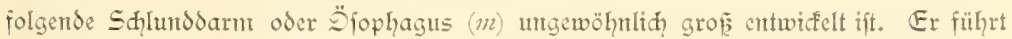
ftark verengt in ben mit cinem gewaltigen lintsfeitigen seberjad (hep) ausgeftatteten 2liagen, welder fith vort dent Darme mur wenig abjeţt. Der Enddarm biegt in fạarfent Knid gegen die 2lïtte der Bauhfläde um und mündet unterhalb der 


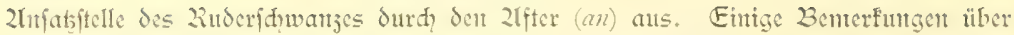
Sen Kiemendarm (ph) mögent jur Erläutermb der in der figur angedenteten Derbält= niffe dienten. Der dorfal gelegente 2liund ift anffallig flem int Dergleide mit den betdent

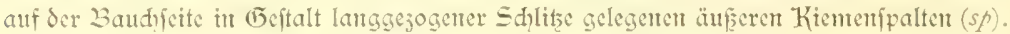

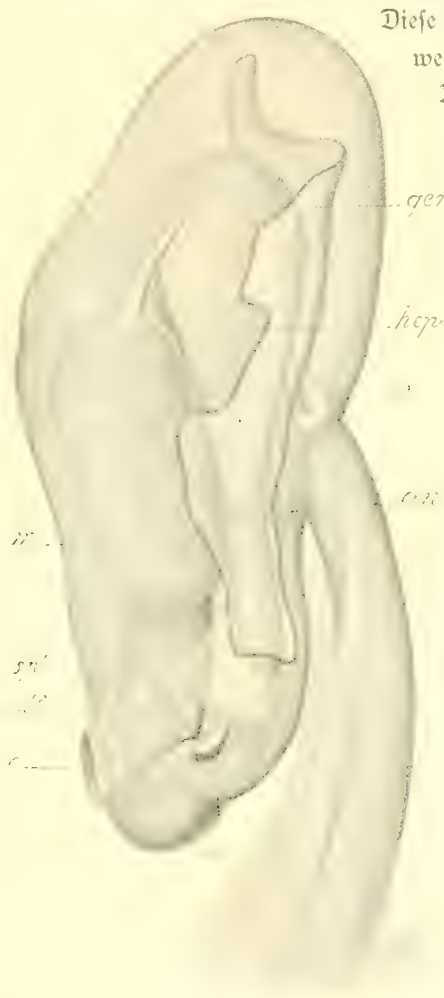

Bathochurdaeus Charon. Ch. "y Rumpf von oer linfen Sette. Exflärung im Eert. (Rübsamer gez.) weldhe vermittelft interer Kiementipalten $\left(s p^{\prime}\right)$ den Dorderdarm durdhbeden. In einer ventralen 2lus= facfung des Iețteren liegt der allen Tunicaten $\jmath^{u}=$ Fommende Endoftyl $(e n)$ als Centrum des zum Gerbeiftrudelr der Zahrung beftimmten 2lapa= rates. Don ilzm verlaufon drei flimmerleiften jum D̈fophagus und jwet nađ vorn jur 2rumb=

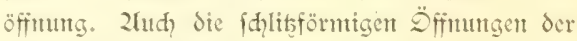
Kiementpalten werden von flintmernden Bändern umก ü̈แnเt.

Dou fonftigen Drganfyftemten fet nur furj des afmmetrifh nad redits verihobenten Limgan= glions mit der angrenzenden (5)erudysgrube (olf) unt des ventral gelegenen Ferjens (c) gedadyt. deffen lebhafte pulfationen man mit blofent 2luge jut erfement vermag. Eine anjehnlid entwidelte

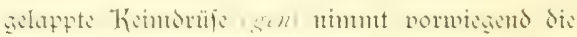
Esitmpläton dis Rumpris sin.

2fit dent kinderfdqwanje fällt vor allen Dittgent der and den niederen Wirbeltieren jufommende Sfelettftab, dic Chorda dorsalis $(c / 2)$, auf. Sie ift fo diff wie dic Chorda der Ziemnaugen mo wird von jwei mäđłtigen 2liusficlbändem $(m u)$ in $\mathfrak{B}_{\mathfrak{c}}$. wegung geftrt.

Dic 2lppendicularien fheiden jarte Gallert= (5)häufe $a b$, die fie fretlid Ieiḑt ju verlaffen ver=

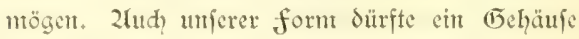
jufonment, da die vordere Dorfalflähe des Kör= pers mit cinem Drüfenpolfter belegt ift, das im IInterets des 2rundes vier wie Shmurbärte geftaltete Wülfte bildet. Wir haben die (5) häufe nitht erbeutet; da fie in Dergleidg ju dem Körper fehr grof find, fo dürten fie in unferen falle cintem Kürbis an Llmfang niḑt radyitehert.

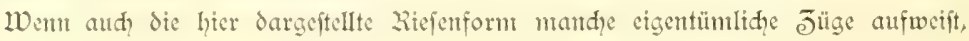


die uns beredigen, fie ju einer neuen (5attung ju $\mathrm{cr}=$ heben, fo durfte dod, dic Erwartung, dafi fie ungeahnte Zuffalüfe über die Bejtehungen der Wirbeltiere ju nte= deren formen gebe, widht in Erfüllung gehent. Sic crweipt fid in jeder Limfidt als edhte 2lppendicularie, und feines ihrer Drganfyfteme fällt auffälig aus dent gewohnten Kah= men herans.

Was die pelagif Iebenden Tiefiecfifde anbelangt, fo glauben wir uns wohl faum ciner l̈bertreiburg fduldig ju madhen, wern wir fagen, daf eine ganje Welt von neuen formen durch dic 2lmwendung der Dertifalnetse entdefft wor: den ift. Der Bearbeiter der fifhe, Dr. Brauer, teilt mitr mit, Jafe dicjelben nid) wentger als 180 2leten angehören, unter denen cin anfrällig grofser Teil mit bisher befannt ge= wordenen niḑt ju identifijieren ift. Sie gehören nteift den $f a=$ milien der Sropeliden (2liyftophiiden), Stontatiden, Sophitien und 2lüräniden an. Es ift indeffen wentger die grobe Jahl pon neuen 2lrten, Ẽattungen und felbit famtilien, dic bier überrafdt, denn dic wunderbare, oft monftröfe Ẽeftalt und die hödift eigenartigen 2lnpaffungen an den 2lufenthalt in unbelidteten Tiefen, weldye dicfelben erfenmen laffen. zlieift find fie fhwarj und fajt ftets mit seuditorganen ausge: ftattet; in feltenen fällen find fie filberglänjento oder bunt gefürbt. Da uns die merfwïrdigen Znpafiumgen dat ganjen Körpergeftalt an cine ränberifhe sebenswetfe in der Ticffee nod in cincm anderen Jufammen= hange beidaftigen werden, fo fei hier mu daranf Gingewiefer, dafi unfere Kenntniffe luber die 3io= logie dicjer Drganismen infofern cine widtige Bereidyerung erfahren haber, als wir nit aller Sđärfe dett 2Tadyweis führen fomten, daf viele bisher für typifde (Ẽrundbewohner gehaltene formen pelagifhe sebensweife fübren. Dies gilt namentlidy für eine 2lnjahl von Ticfice $=2$ falen unto Sophitoen, deren wir cinige int Bilde vor= führen. Dic Phantafie chres gentalen Tentirs ver= mödte faunt bijarreve 2lionjtra anf die Setmont ju jaubuth, als fie bier unter den sophitban uns

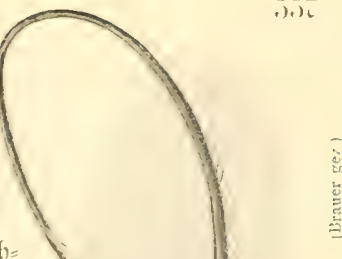




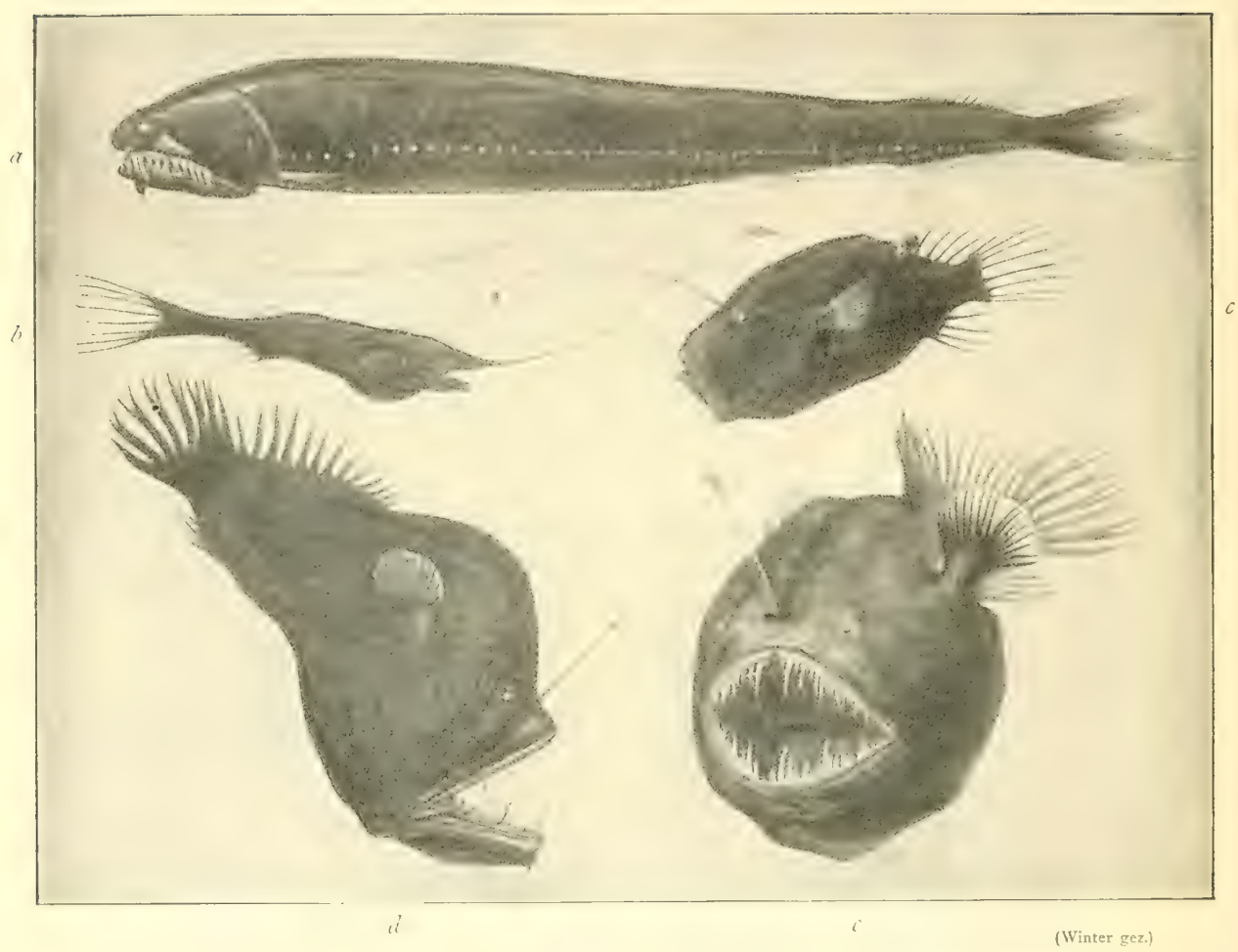

Pelagif lebende Eiefierifide.

a Melanostomias melanops n. gen. et sp. Brauer (famt. Stomiatidae). Indifher Ocean (bci 2Itjeh). Trawl bis 1024 m. Wenlg verflcincrt.

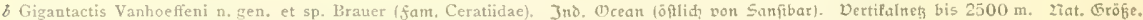
c Cryptopsaras Coutesi (?) Gill. (fam. Ceratiidae). Bolf pot $210 \mathrm{en}$. Erawl bis $1840 \mathrm{~m}$, Wenig verfleinert.

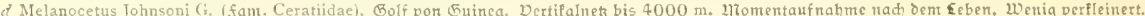

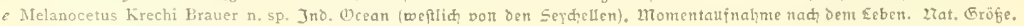

Dorliegen. Diefe Dertreter der (5)attung Melanocetus, dic wir in mehreren neuen Zlten auffanden, wurden von früheren forfhert, fpectell aud von dem be=

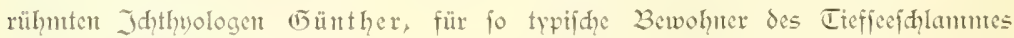
gehalten, dap fie gerabezu in populären Werfen als in den Schlanm eingegraben bargeftellt werden. Wir haben fie durdweg pelagifd lebent, und zwar oft mebrere Taupend 2lieter Hiber dem 2lieeresgrunde flottierend erbentet. In welde Tiefen diefe fifhe hinabfeigen, ift bis jetst fehr fowwer ju fagen: fie entflichen den Sdliefruetzen, und mur die gentemften aller biefer formen, nämlid, die Dertreter der den Scopeliden 
jugehörigen Gaftung Cyclothone, find aud in umperen Sdiliefnetsfängen aus Tiefen vou 1700-600 m vertreten. Durd Lnterftrömungen oder auf fonftigem Wege fömen

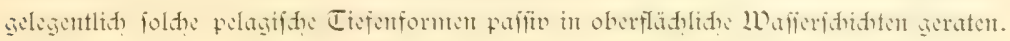
So ift j. 3. einer der Bijarriten Dertreter der Tiefenaale, nänlið der Sảccopharynx ampullaceus, bis

jetst nad?

nur fünf

Eremtila=

rert befannt ge=

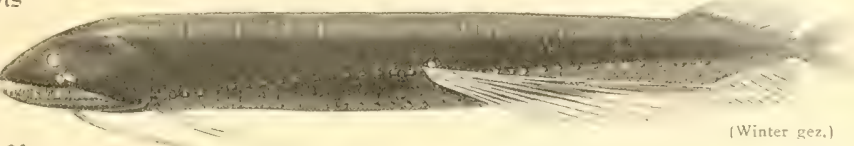

worden, dic it

Dactylostomias ater n. sp. Braner (fam. Stomiatidae).

Wenig vergröfert. Sübatlant. Ocean. $1000 \mathrm{~m}$.

hilflojer Sage an der Dberfladie tricber. Damit indeffen der sefer fich cin ltrteil über Siefe monftöfen Ticfendale mit ihrent gewaltigen 2laul und dümen Körper bilde, führen wir ihm den Dertreter einer neuen (T)attung, Megalopharynx, vor. Er wurde im (5uinea= Golf mit dem in $5500 \mathrm{~m}$ herabgelaficnen Dertifalnets erbentet.

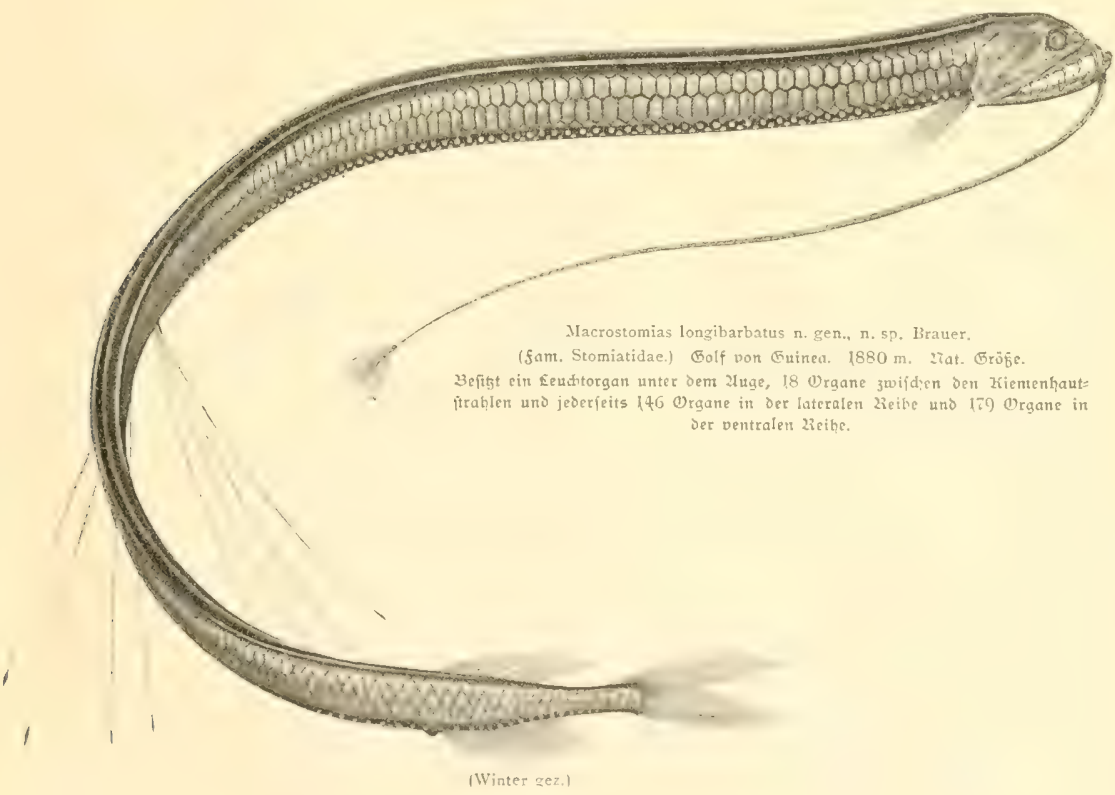




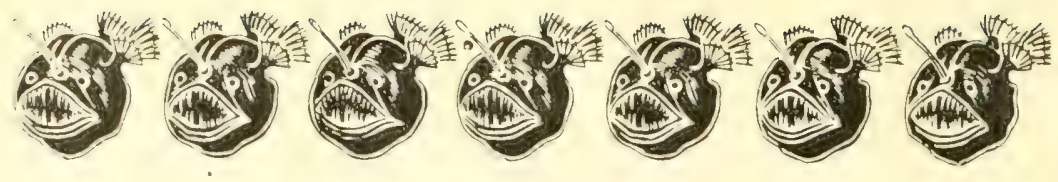

\section{XXIV. जึr Biologic der Tieficeorganisnten.}

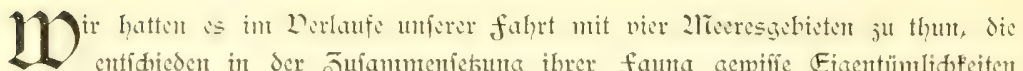
aufwicien. Dics war cineriets das von uns nur in feinent äuferften füblidien 2lus= läufer, nämlid in der faröcr=Shetland=:Bime, bertihrte artifhe (5ebiet, weiterhin dic atlantijace, antartifice und indifhe Region.

Der wohldurdforidte 2ttlantifice Drean hat, forweit dic Erundfanna in Betradt fonmt, nur che relativ geringe 2Injahl neuer 2lrten geliefert. Jufoweit bie bisher befanten fornten in Betrad)t fommen, verftäten fie die Zuffaffuts, daf die (5rund

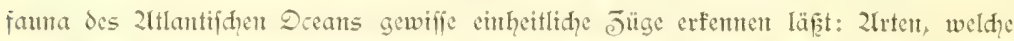
bisher mur von der amerifaniphen Scite befannt waren, taudten aud längs der weft= afrifanifden Küipte wicder anf.

Die Derhältniffe änden fidh mit den Eintritt in das antarftifhe (Febiet. Was namentlid, die bei der Bounet = Jnfel erbeutete Tieffecfauna anbelangt, fo laffen fdon

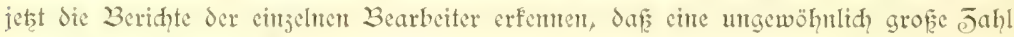
nener formen dicfen (Debieten eigentümlid ift. Ziamentlid werden die bort fo reid vertretenen 2hnthojoct, dic niđht weniger als $\tau$ (battungen angehörigen Seefterne und die ju 9) 2lrten gehörigen Sdlangenfterne nebft den dort erbenteten Kruftern fid für tiergeographifhe 3 etrahtungen als widntig erweifen.

Was endid den Jitdifyen Deean anbelangt, fo haben wir bereits Belegenheit ge funden, darauf hinzuweifen, dap die fanna des 2lientawei=23effens, wie dies and, von vornherem nid̨t anders ju erwarten war, mantigfade gememfame jüge nit ber in (50lf von Bengalen durt) den "Inveftigator" erbenteten aufweift. Dies gilt teilweifo aud für die int centralen Jnbijden Deean und längs der oftafrifantifhen Küfte er: benteten Drgenismen. Inmerhin hat gerade das Ietstgenamte Gebiet che wabre l̈berfülle nener unt cigenartiger formen geliefert.

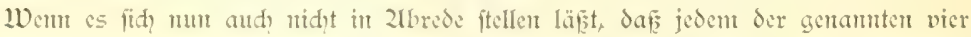
grofien (5ebicte cinte 2tujabl von formen cigentümlid find, fo fam dod andererfeits mur mit ziadjorud darauf himgewiefen werden, daf jahlreide bisher mur aus bent

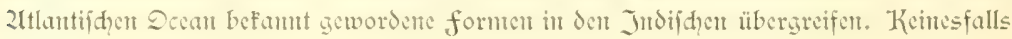




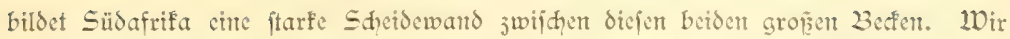

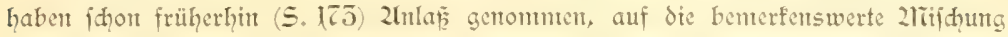

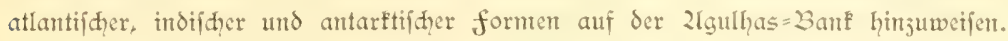
Es wäre int Ginblic anf das rethe, faum erft den Bearbeitenn überwiefcne 2raterial verfrüht, went wir jest fiton eingehender die frage crörtem wollten, inwicweit wir

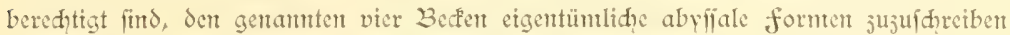
und fie als tiergeographifice Tiefenregionen jul unterfyeiden.

Ebenfowenig vermögen wir jeţt fị̧on die in der Ztenlett vielfady erörterte frage

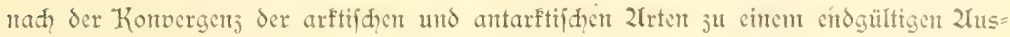
trag ju bringen. Es läpt fid nidht leughten, daf in der antarftifden Begion formten wiederfehren, die eine auffällige z̈lhnliḑfeit mit den arftifhen aufweifen. Dies be=

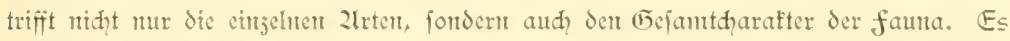
find freilids einftweilen mu wenige 2lrten namhaft gemaḑt worden, weldhe in identi= jđen Eremplaren dent ziorden und Süden zufonmen follen. Ob diefe Jdentität bei genauerer Prüfung des 2liateriales aufredyt erhaltent werden fann, ift immerhin frag= lid. So ähnelt - um nur èn Beifpiel anjuführen - dic bei der Bouvet= Jnfel von

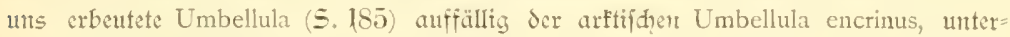

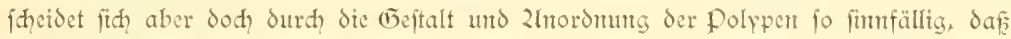
fie von Külenthal als sine Darietät mit der Bejetdmuntg antarctica aufgcführt wird. Bei anderen Gruppen, deren Derbreitungscentren in den beiden polaten Ğbieten liegen, gehent die Linterifhiede nody weiter. So fint - um wieder an früher Erwähntes (S. 189)

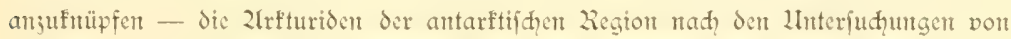

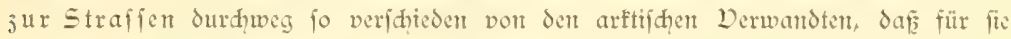
die neue (5attuntg Antarcturus begründet wurde.

Dorausfiḑtid werden die 2fnfidten der Beobahter ausemander gehen, ob die un=

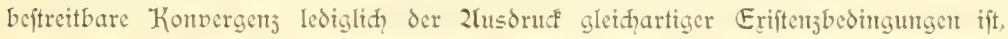

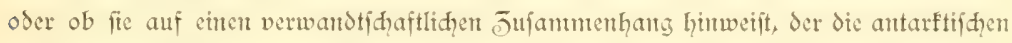
und arfiijhen Tiefenformen gewiffermafen als die Glieder cincr gropen familie er=

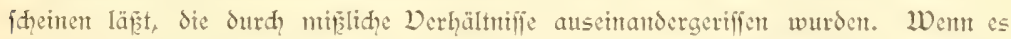
fidh) mun naḑweifen läpt, daf in dort gewaltigen, über vicle Breitegrabe fid erftreffen=

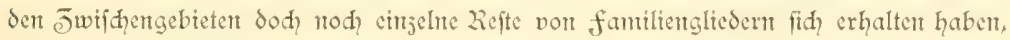
fo wird man die Konvergenj zwifhen arffifden und antarftifhen 2trten auf ein Z̈̈ber= wandern in der Ticffe zurüđjuführen fudpen. Eaffen fid? indeffen derartige Binde= glieder niđht nađ̧weifen, fo wird man die von 2liurea umb Pfeffer vertretene 2hn= fïht antehmen, nach der urfprünglid cite einheitlide fauna den Frund des Meeres bis ju tertiären Jeiten bedecfte, die bei geänderten Eriftenjbedingungen in den äqua=

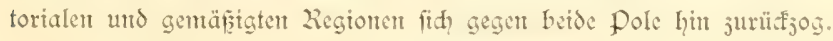




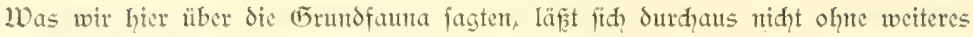
auf die pelagifhe Tiefenfauna übertragen. 2lls cin wertoolles Ergebnis unferer $E_{r}=$

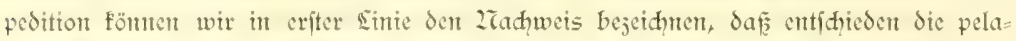

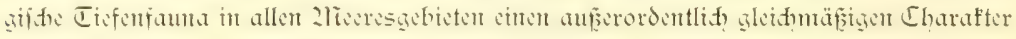
jur Sdyau trägt. Wir haben einen fo auffällig grofien Brudteil der pelagifhen điefen=

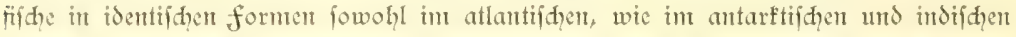
2licere exbeutet, dap man fhwerlid den Deridh maden wird, dic pelagifde Tiefen= fanna in entgelne tiergeographijhe Regionen ju gliedern. Was für bie fifde gilt, trifit cbenfo für die Cephalopoden, Cruftacen, Sagitten, 2rodufen und foritigen dya= rafteriftifden pelagifhen Tiefenformen ju. Wir verjihten darauf, dies an einjelnen

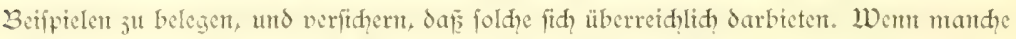
der intereffanteften pelagifhen Tiefenformen mur in chem der genamten Ğebrete zur Beobadtung gelangten, fo liegt dies mefentliक daram, dap es fid un feltene Drganismen handilt, dic überhaupt mur in wenigen Erentalarn in unfere Dertifalnetse gerieten.

2lnders liegen mut freilid Sie Derhälntife für die pelagijhen Dberflühenformen und unter diefon in criter Stute für die auf beliḑtete Regionen angewiefenen affimi= liermben niedent Pflangenformen. Sie reagieren fo fein auf die veridhiedenen Eriftenj= bedingungen in den cinjelnen Stromgebieten, wie fie durh dit Tentperatur, den Salj= gehalt, das fpecifidge (5ewidyt und vor allem durd) die imere Reibung des Secwaffers

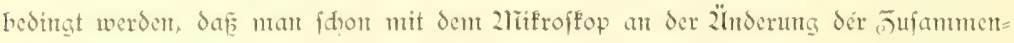
fetsung des piflanjlidien Planftons den Einfritt in ein nenes Strongebiet nadjumbeifen vermas.

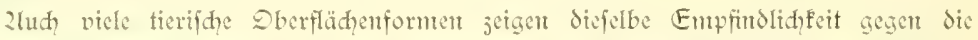

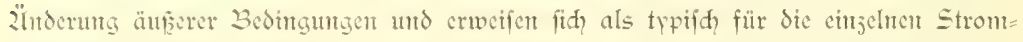
sibite. Daneben aber giebt es eine 2 ujabl vol periobifd an der Dberfläde erfaci= nenden Drganisnten, welde gegen dic Z̈̈nderung in der Belidutung, der Tentperatur und bent Saljgehalt in hohem 2liafe umempfindid fund. Sie eridemen ju ganj be= ftimmen Jabresciten mit ciner überrajdgenden Regelmäfistgfeit an der Dberfläd ve, ver=

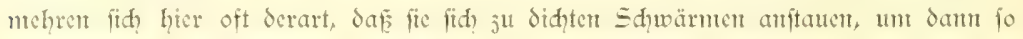
rajd, wic fie gefonmen futd, aud wieder ju verfdywinden. Wenn man fie mu aud in den übrigen Teile des Jahres vergeblich at der Sberflädn ju erbeuten verfudt, fo

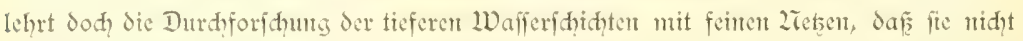
fämtlid abjerben, fondern fid in füble Regionen jurülfjiehen. l̈ber diefe früher von ms nahgewtefent Wanderungen in vertifalem Simte vermag freilid che von Tag

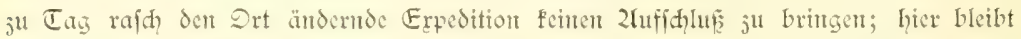
dent eirjelnen forfher, der längere ēeit hindurh an beftimmten Stellent das periodifdic 2luftauhen und Deriduwinden der pelagifhen Dberflädent=Drganismen in Betradit jieht, cin weites und dantbares feld für feinc Bcthätigung offen. 
Jnmerhin hat unfere Erpcdition die Dorftellung nerftärft, da a and int freien Decan cine derartige 1 Danderung in vertifalem Simte ftatfindet. Lim des Derhalten

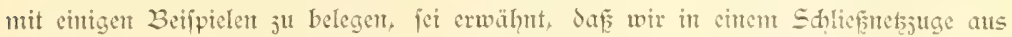

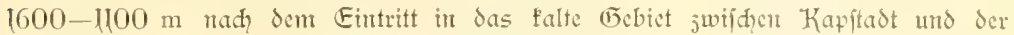
Bouvet= Injel eine typifde Sberflüdenform, nümlid die Salpa fusifornis, auffanden. Der Befund erregte ein fo lebhaftes, allfeitiges Intereffe, da wir an demrelben Tage

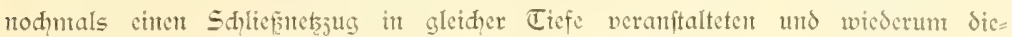
felbe form im Inhalte des Zietzes nadjutweifer vermodten. Ein anderes Beifpiel entlehnen wir jenen prädgtigen und duftigen Kolonien von Sdwimmipolppen oder Siphonophoren, welde in den wamen Strontgebieten des zitlantifdyen Deeans in der

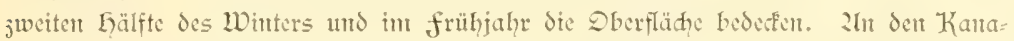
rifdyen Jufehn treten ju biefer Jeit bie Kolonien der 21 galmiden, fpectell die battumg Crystallomia, in folden 21 iengen auf, daf fie ju den gemeniten pelasifiden Drganis= men gehören. Dergeblid, wiro man in Sontmer und Ferbfte nad ihnen fuḑen. Sie fint indeffen nidht abgeftorben, fondern haben die ticfen Wafferidgidzten aufgefudt, aus denen wir fie ju jenter อeit, wo fie an ber Dberflädhe fehlen, mit unferen Dertifal=

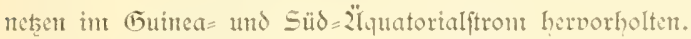

Die vertifalen Wanderungen, weldịc sint Teil der Dberfläd)

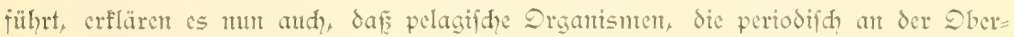

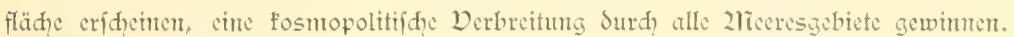
Wemn wir felbft frihgerhin geneigt waren, die füdidy von dem Kaplande fidh fund= gebenden Strönm

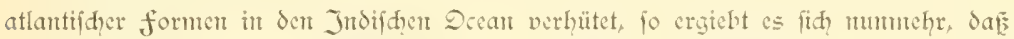
dies lediglith für jene Dberflühenformen der fall ift, die thatfädhlith niemals int das tiefe waffer herabfteigen. 2hitfden fie fidt aber, fei es als sarben, fei es als aus= gebildete formen, der typifdent pelagifhen Tiefenfauna bet, fo werdent fie durd? dent

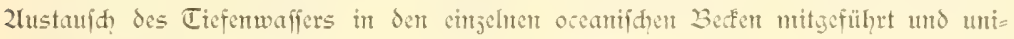
verfell verbreitet.

Endid geben dicfe Wanderuntgen in vertifalemt Sime den Sd̨liffel junt Derftünonis von Erfheinungen $a \mathfrak{b}$, mit deren Erörterung wir wieder jum 2lusgangspunft unferer Darlegung, nämlid, der frage nađ den Konvergenjerideinungen jwifden arftifden

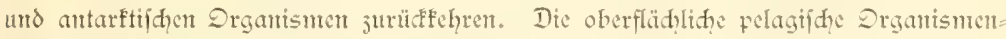
welt der Kaltwaffergebiete ift durḑans verfdicdut von jenter ber warmen Etrontgebiete. Ziduts ift überrafhender, als dieje, wie mit cinem Sdylage erfolgende, rabifale Z̈̈nderung in der Jufammenfețung des Dberflädentrlanftons bet dem ïtbertritt aus dem $\mathcal{W}_{\text {arm }}$ wafier in das Kaltwaffer. Wir erlebten dies felbit, als wir jwifhent dem lap und der Bounetregion aus den leţten 2lusläufen des 2lgulhasftromes in das antarftilde Kaltwaffergebiet eintraten. Da fehlten von dent 2lioment al, wo plöthlithe Tentperatur= 
fprïnge des Dberflädhenmafiers die Einwirfung Ser falten Region anfündigten, alle Drganismen, mit denen wir es monatelang bei dem Durdyfahren der warmen (⿹勹巳es=

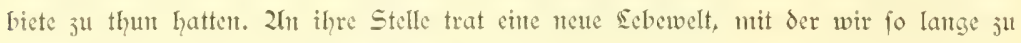
rehnen hatten, bis wir jwifden den Kerguelen und St. Paul wieder in das Warm= waffergebiet des Indifacn Decans gelangtent.

Das antarftifhe Planfton ift crifaunlich reid an veridiedentartigen formen, dic jum grofen Teil crít durd die fahrt der "Daldivia" genauer befamt werden. Imnter=

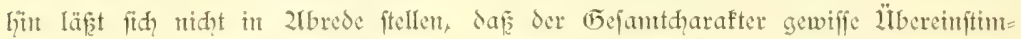
mungen mit den arftifhen Planfton aufweift. Sie gehen foweit, daf fogar identifde formen in betden polaren Wafiergebisten auftreten, welhe in den ungeheuren, jwifden beide fith cinfaltenden Warmwafferjonen durhaus fehlen. Ein Pfeilwurn, die Sagitta hamata, ift fowohl in dem arfifiden wie dem antarftifden Kaltwafier verbreitet, nidpt mindir aud) - um ein neues Beifiel anjuführen - eine bisher mur aus bem arftijden (B)bicte befant gewordene fleme Siphonophore, die Diphyes arctica.

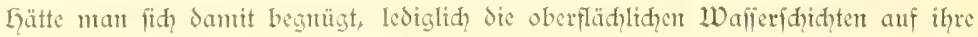
¿ebewelt ju Surdiforiden, fo würden derartige Konvergenjen uns unveritändlid, ge= blieben fein. Sie finden indeffen cine ungezwungene Erflärung durd die Thatjaḑe, daf die Bewohner des Kaltwafiers it die Ticfe vordringen und unterhalb der relativ fladen Warmwaffermaffen gentäfigter und tropifher bebiete weitererifticen. Im

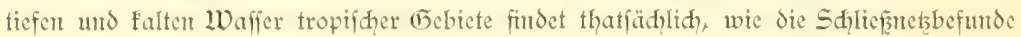

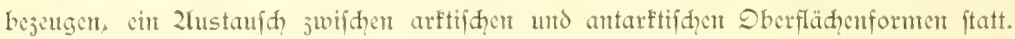

\section{Zlupafiugen an bie Eliftenjbebingungen.}

Es liegt auf der Lland, daf́ die Tieffee= Drganisnten aud in threr äufferen $\mathbb{E}_{\mathrm{r}=}$ Theinung dic 2lnpafinng an die cigenartigen Derhältniffe jur Shau tragen, denent fie in faltent, unbeliditeten Regitonen ausgefetst find. Dor allen Dingen äusert fich eine foldhe in einer Rülfbildutg der 2 ugen. Unter den Bewohnert der Grundfauna treten uns ente ganje 2lnjahl von formen entgegen, welde die Derfümmenung der 2lugen bis jum vollftändigen Derhut in allen Stadien verfolgen laffen. Llnfer 2liaterial bietet ebenfo, wie dasjenige der früheren Erpeditionen, inftuftive 3 eifpiele für eine derartige Rülfbildung unter den fifden und Cruftacen dar. Sie geht fo weit, daf mande Cruftaceen, to j. 3. die Eryoniden, vollitändig crblindent und jede Spur von 2lugen= ftielett und Sehorganent vermiffen laffent. IInter den (Frundfifden mag der auf S. 559 Sargeftellte Barathronus cin typifdes Beifpiel für die Rïffbildung der 2lugen abgeben, an deren Stelle jwet in goldenent 2retallglanj erftrablende Loblipiegel getreten fint.

Zlber aud in jenen fällen, wo bie 2lugen anfheinend wohlerhalten und äuferlict? nur surds cinc gewiffe Pigntentamtut dorafteriftert uns entgegentreten, erweift dic 
anatomifhe Jergliederung cine tiefgehende Rüfbildung des Schorgans. Dies gilt ipeciell für die Galatheiden der Tieffee (Dergl. die auf $5.59+$ dargeftellte Munidopsis), deren Retina fo ungeformt wurde, daf die Struftur niḑt mehr in Finflang ju bringen ift mit dem normalen Derhalten. Dabet wird das äuferlid wohlerhaltene 2luge von Bindegewebe ausgefüllt, in dent ein mädtiger, vielfad, fid verjweigender 2iev auffäll.

Inter den pelagijden Ticfenformen fommt einte küđtbildung der Zugen feltenter vor. Bis jefst femen wir nod fenten pelagijhen Tiefenfif nit rubimentären 2fugen. Da= gegen jeigen viele Krufter entweder cinen vollftändigen Sdimund der 2lugen (Galocy= priden), oder cine weitgchende Rüdbildung, wie fie namentlid, bei nand)en 2lnuphipoden auffällt. Unter den jelpnfüfigen Krebfen jeigten cinige Sergeftiden ftarf verfümmerte 2ugen, und endid, entbehren die pelagif lebenden Eryoniden (Eryonicus) cbenjo der 2lugen und 2lugenfiticle, wie ihre auf dent Grunde lebenden Derwanden.

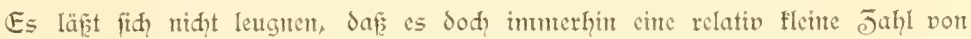

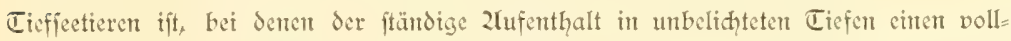
ftändigen Derlujt $\delta \mathrm{er}$ Zugen herbeiführte. Ju Dergleidh mit der Tieffecfauna jeigt 3. 23. Sie fauna der unterirdifhen Grotten weit einheitlidfer die Rä̈bildung der 2lugen.

Das 2luftreten vort wohlentwidelten, oft ungewöhnlid vergröf̧erten 2lugen bei fifhen und Krujtern, welde in ewig dunflen Regionen leben, hat die Biologen nidht werrig überrajd̨t. Zlian verntutete, daf vielleidht ultraviolette Strahlen oder Strahlen uns nod unbefannter 2lut in die Tiefe vordringen und die 2lusbildung von Seh= orgaten bedingen möditen. Der phyftfer ift uns freilidh bis jetzt den Beweis dafür iduuldig geblicben, dafi unterhalb $600 \mathrm{~m}$ cine Wirfung der Belichtung fid geltend maḑt, und bevor diejer 2iad)weis nidyt unwiberleglid geführt wird, haben wir nad anderen Siḑtquellen ju fuhen, welhe den Tieffee= Drganismen jux Derfügung ftehen fömten. Die Dorftellung, dafi diefes Sidpt von den Tieffectieren felbft erjeugt werde, ift ungentein arfprediend und fhon längit durd direfte Beobaditung über allen Jweifel geftellt. Es gewährt cinten feenhaften 2unblick, wem in der Dunfelheit $\delta a s$ Dertifalnets oder die Dredithe mit ihrent tetheije nodh lebenden Inthalt an die Dber= flähe gelangen unb dic in ihnen enthaltenen Drganismen in phosphorifhen Sdem rrglühen. Bald jondent fite Ieuditende Sefrete $a b$, bald eritrahlt der ganje Körper,

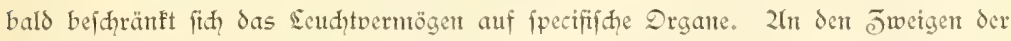
Pennatuliden, die wir an der Sontalifuijte exbenteten, hujdten blitzartig von polyp ju Polyp übergreifend die Strablen auf und ab. Die Protojoen, dic Würmer, der von 2lsbiörnion entdefte Seeftern Brisinga, viele Krufter der Tiefiee und por allen

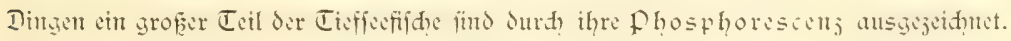
Bei manḩen der Eeţtgenamten umfäumen die Seuhtorgane, als. Blendlaternen mit Gohlipiegeln und Simfen ausgeftattet, die Seitentetle des Körpers und den Baud, während andere fifhe als Diogenteffe der Tieffee thre ôlïhlämphen an Kopfe und 
auf dem Interfiefer tragen. Selfyt die floilenftrahlen, die Region vor der Sdwanj=

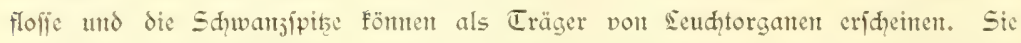

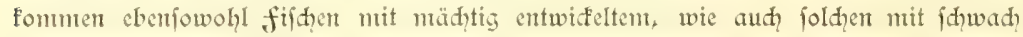

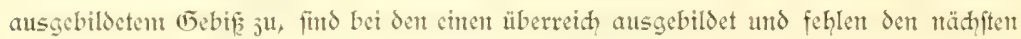
Verwandten. Da die wegen ihrer z̈lhnlidfeit mit Sehorganen früher für "Zrebenaugen" gehaltenen Eenhtapparate von Zerven verjorgt werden, fo dürfen wir wohl amtehmen, dafi die phosphorescenj dent Willen des Tieres unterworfen ift.

2lian darf mun freilich nidgt der 2luffafintug fein, als ob dicfer twunderbare 2lit=

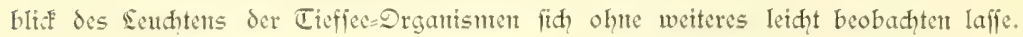

Die meiften fonmen tot oder bod fichon fo ftarf gefdumädyt an

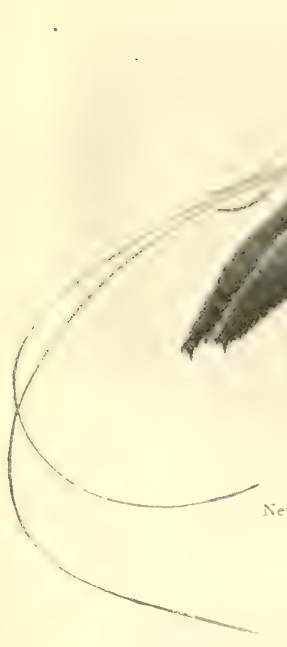
die ९berfläđc, dấ man es geradeju als cirten (5)tüffsfall betradten fantu, wem einmal dic phosphores: cenว นแวฺeiden= tig ju beobadten

ift. Id glaube faum eiten der merf?

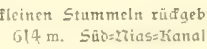

würdigeren pelagifden

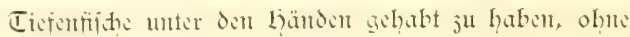
nit ihnt in dic Dunfelfantmer gepilgert ju fein, um than auf feine Phosphorescent hin ju prüfen. 20 ent aud wur in feltenten fällen ein senḑten fonftatiert werden founte, fo. find fie dod infofern von befonderent werte, als die meift redt

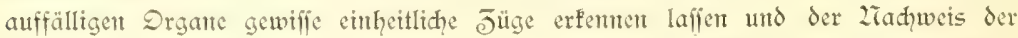

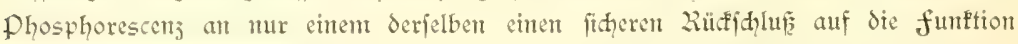
ăntidicer SEebilde geftattet.

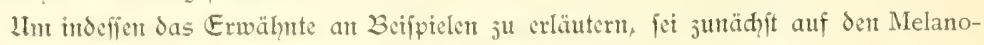
stomias melanops, jenten auffälligen fhwarjen Tiefenfifd, hingewiefen, den wir auf 5. 556 abbildeten. Er zeigt cine pradtitolle, bläulithe phosphorescenj des dreiettigen, aur Dberfiefer hinter den 2lugen gelegenen Drganes. Es ift von einer durdhfithtigen, 


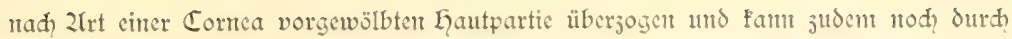

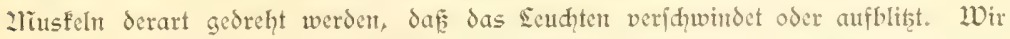
haben nod bet mehreen Dertretern der Stomiatiden und SFopeliden das Seuditen madjuweifen vermoḑt, nidht aber bei jenen abjonderlidgen Tieffecfifden, die wir dem Ecjer bercits in Geftalt der pelagiftien $c_{e}=$ ratiident nor= führten. Dicfe

Glyphocrangon spinulosa Faxon. 2rat. Gröbe. Elpus eines Eieffeeprufters mit grof̈en

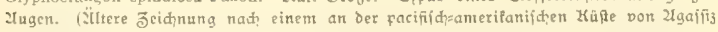
in $1200 \mathrm{~m}$ georejdịter Eremplar.)

monftröfen formen, volt denen wir auf $S .556$ nod vier 2lrten dargeftellt haben, befitzen cine jwifhen den 2 lugen auf der Stimfläde des Kopfes fid erhebende oder Sireft von der vorgejogenen Sd,raujenfpifze ausgehende, lantge, durd? 2liusfeln beweg= lidge Rute, weldhe in einen Knnopf ausläuft. Der leţtere ift mit Drganen befetst, die naक den 2frgaben von Dr. Brauer auf Erund ihrer Struftur als Ecudhtorgante ju betrad,ten find. Dies trifift fpectell aud für cime der abenteuerlidjften formen, Gigantactis Vanhoeffeni, ju, weld̨e wir etwas vergrö̈rert im beiftehenden Bilde vorführen.

Gigantactis beftizt ein flemes, faft rudimen=

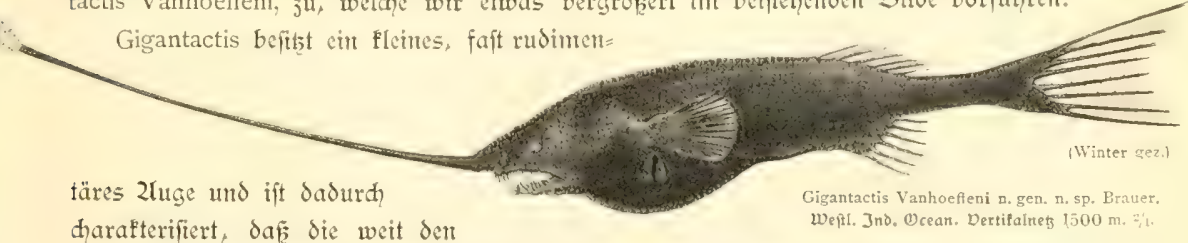

Unterfiefer überragende Sdytanje fith direft in den Iangen, aufriḑtbaren Tentafel

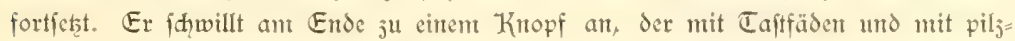

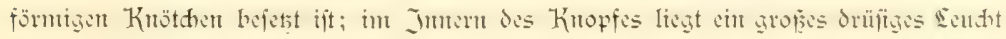
organ, das unten durh einen porus ausmündet. Es fheint, da官 es fich bet diefen

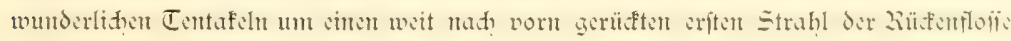




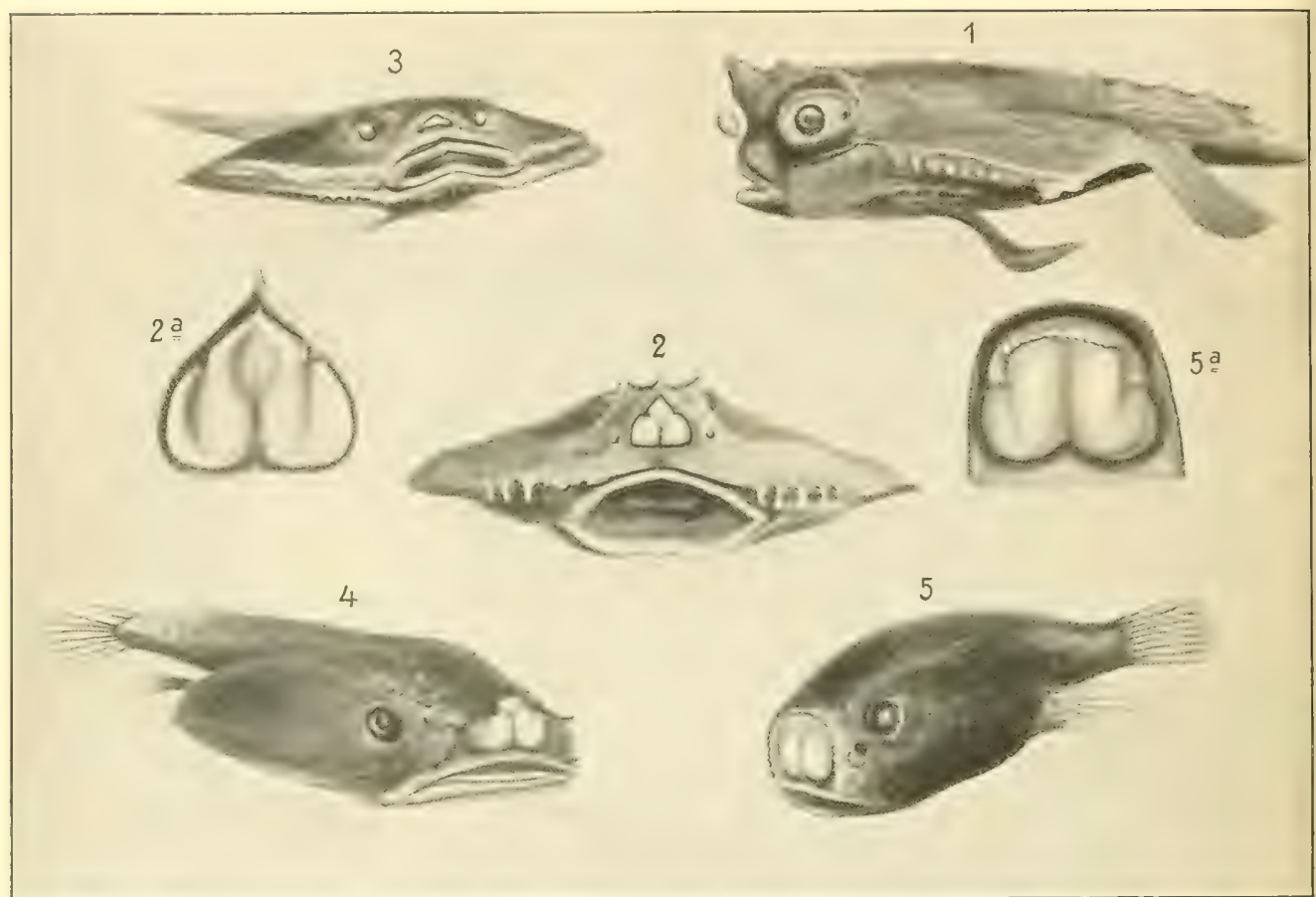

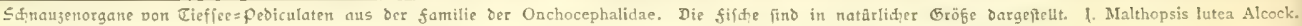

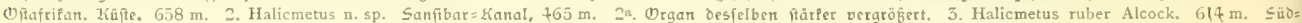

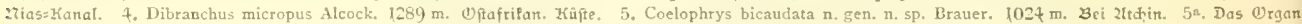

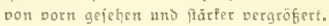

handelt. Wir wollen nidht verfehlen, darauf hinjumeifen, daf manḑe verwandte (Brumbitiac aus der Dromug auh der Dediculaten höhit bizarre Bildungen aufweifen, welhe entfiteden den 2lngeln der pelagif lebenden homolog find. Wir vereinigen im beiftehenden Bilde einige formen, welhe die Zlusbildung diefer merfwürdigen Drgane illuptrieren mögen.

Bei der Gatturg Malthopsis hat fith die 2lngel ju cinem gefnöpften (5ebilde ver= Eürjt. Bet anderen 2lrten jieht es fid mehr und mehr in cinen von der Sdnaujen= region gebildeten bohlraun jurüf und nimmt dreilappige Geftalt an, ähnlich dent Zajenauffätsen der Lufetīenfledermäuje. 2Uls wir jum eritemmal jene bijarren fijhe aus der Pediculatenfantilie der Onchocephalidae erbcuteten, glaubten wir anfäng= lid, dafe ein monftrös geftalteter Ried,lappen des Eirns brudjacförmig fidh aus der 
verletsen Sdutaugenfipitse vorgedrätght habe. Fin genauers Jufehen crgab indefien, daf die fijhe durdhaus unverletst waren und Drgane sui generis befitsen, die entifiteden alle l̈̈bsrgänge bis ju ben Iangen Ruten des Melanocetus und der forfftigen ceratitdent

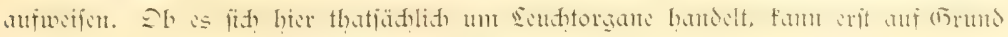
zenaucr anatontifice Lluterfudungen erntittelt werden.

IIm indeffen aud nod von anderen Drganismen cinige neue Bcobahtungen über

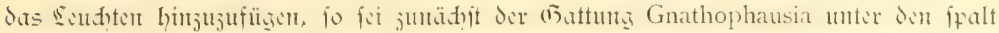
füp̧igen Krebjen Erwähnung gethan. Wir haber cinen Dertreter derjelbent mit feinter prad,toollen, roten färbung auf der Buntoructafel dargeftellt und crwähnen nur, daf Ser Gattungstante von Willemoes=Subm gefhafien wurde auf (5)tund emer an der Bafis des zweiten 2liarillentaares gelegenen, lebhaft pigmentierten Zluftreibung, die $\mathrm{cr}$ für ein 2rebenauge hielt. Der Bearbetter der S hijopoden der Challenger= Expedition, Der trefflithe norwegithe forither (5. Sars, formte feine cinent 2luge ähnlidhe Bildung in Sem genanter Drgane erfenten und vermutete

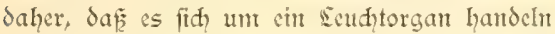
ntöge. 2lît diefer Dermutung hat er das Rid. tige getrofien, wie wir uns johort bei Begim Ser fahrt an cinem Excmplare der Gnathophausia überzengten. Sie fondert nänlid aus diefent Drüfenorgan cur Sefret in langent fäden $a b$, welches präd,tig und intenfito phosphoresciert.

LIn weiterhin dem Sejer nod cin Beifpiel von phosphorescierenden Cephalopoden ju bie= ten, fo möge auf die beiftehende, nady einer Photographie gefertigte zbbildung hingewiefen werden, die furz nad, dem Gerauffommen des Tintenfijhes aufgenonmen wurde. Diefer $\mathcal{D}_{\mathrm{er}}=$ treter der Eattung Lycoteuthis ift mit 24. Dr= ganter ausgeftattet, welde cine cigentïntide (Fruppierung aufweifen. Jeder der beiden grop̧en fangarme befitzt deren jwet; der Linterrant der Zugen ijt von je fünf Drganen umfäumt, und Ser keft tritt in der aus der figur erfidtlidien Unordmung auf der Bauhicite des 2liantels auf. 2lus der anatomifden linterjudung geht hervor, dafi die Baudorgane nidht in dent 2liantel liegert, fondern unterhalb desfelben der

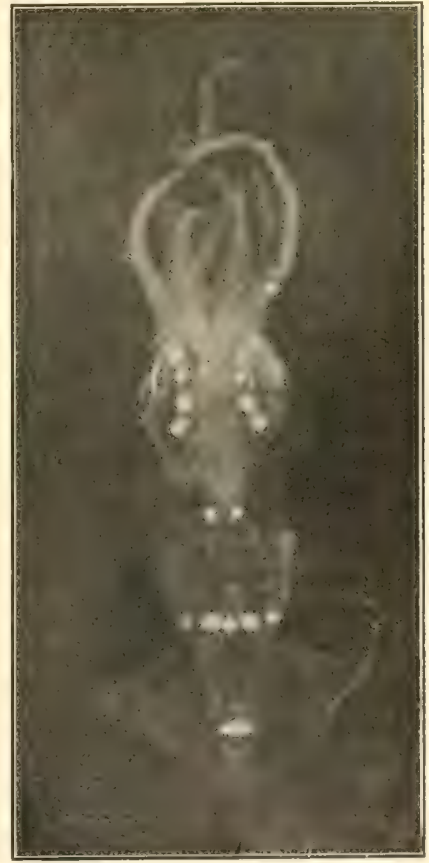

Lycoteuthis diadema Ch, n. sp. por ber 3audifeite Zufnabme nad bem Eeben mit den aläzenden keudt organen. Wefroindrift, nahe 3ouvetziegion. Dertifalnety bis $1500 \mathrm{~m}$. wenig vergrökert 


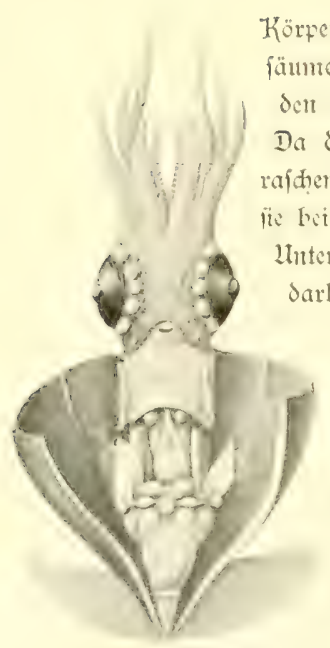

Lrcoteuthis diadema.

Die ziantelhohle ift geofinet uno zeigt Die Vertcilung ber 33auळaraane. Wenig oergrobert.

Körperwand auffitisen. Wie dic beiftehende Jetdunutg lehrt, fo um= Gämren dic beiden oberen Baudqorgane den 2lfter, während von den fünf mittleren die änferften an der 3 afts der Kiement fitzen. Da der 2lintel int Seben durdflidytig ift, fo fann es nidht über: rafhen, wemt Scudtorgane an Körperiftllen auftreten, wo man

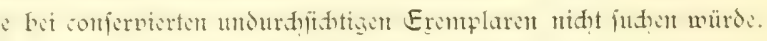
Inter allem, was uns die Tieffectiere an wundervoller färbumg

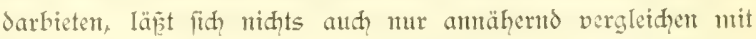
Sem Kolorit diefer Drgante. Mian glaubte, daf der Körper mit einem Diadent bunter Edelfteine bejetzit fei: das mittelife Der 2fugenorgane glärtzte ultrantarinblau und dic feitlidyen wiefen DerImutterglanj auf; von den Drganen auf der Baud! = feite erftrahlten dic vorderen in rubittrotem Ğlanje, während die hinteren fdumeewein oder perl= mutterfarben waren mit 2 lus nahme des mitteliftem, das cinen himmelblauen Ton aufwies. Es war cine Pradt! Die Drgane find napfförmig geftaltet; ihre

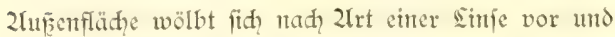
die Immenflädye ift ntif fdwwarjem oder braunem pig= ment befleidet. Bei dem Konfervieren in der Dunfel fammer ergab es fid, dafe fie thatjüthlity nod cinc

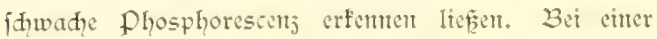
ganjen 2lujahl der volt unts gefammelten und verfdie

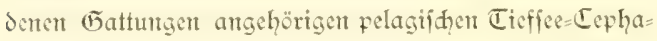
lopoden lafien fid übrigens derartige $D$ rgane int 2 lntfretfe der 2lugen wahnehmen. Dffenbar hat fie aud thon cin trefflidyer älterer Beobadter, Rüppel, deffen Publi= fation freilid faft der Dergeffenheit anheimfiel, bei der vort ihn als Enoploteuthis margaritifera befdricbenen form sefohert.

Z̈̈hnlidhe, wem audh etwas flemere Drgane befeţen bit Dertretern der Gattung Calliteuthis die ganje Körper= oberflähe von den 2frmen bis ju den Sdiwanjflofien. Die Baudfeite ift allerdings aud? hier wieder retḑliḑer mit ihnen ausgeftattet, als die Rüđenfläḑ̧a $\mathfrak{W}_{\text {ir }}$

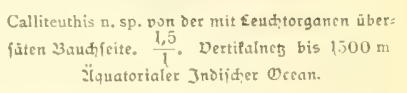


haben fie leider nicht leuhten fehen, dürfen aber wohl vermuten, daf Ser 2lnbliff der it phosphorifhem Sheinte crftrablenden (5)lühlämpḑen fid ju einer pgloria marise geitaltet.

Es fällt aufererordentlich fhwer, über den biologifhen Wert der seudtorgane cutte

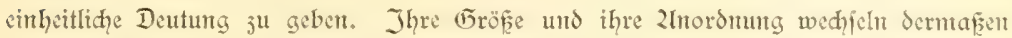
bei naheverwandten formen, dafifie jwar als widhtige fyftematifhe Charaftere gelten fömen, aber anderericits dententigen, der int Einjelfall den biologifden Grund für if̧re 2lnorbmung herausfinden will, wahre Räticl aufgeben. Bald liegen fie vorn an Kopte und ermögliden dent Drgantsmus ein Erfenmen der vor thm befindidien Dbjefte -.. namentlich der Beutetiere - bald wieder mmäumen fie die flanfen, den 3auh ober den Sdywanj, fo daf der von ihnen ausgehende Sihtegel nif̧t direft den 2lugen des Trägers jugänglid erideint. Sdwwerliक dürften fie, wie vielfah geäuf̧ert wurde, als Edfrectnittel zur 2lbwehr von feinden aufjufafien feir. Went wir uns nit einer ber= artigen, den Seuditorganen mehr negativen Wert jufąreibenden Erflärung nidht be=

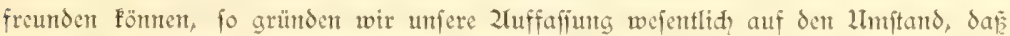

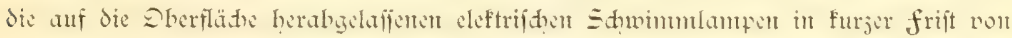

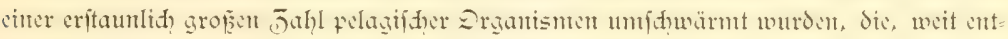
fernt, von dent intenfiven und ftänigen Siđht abgejhrefft ju werden, viehnehr demtelben zuitrebten. Wir dürften wohl cher das Riḑtige treffen, went wir in den Seudtorganen Sodimittel erbliden, beftimmt, pelagifhe Drganismen, welhe den Trägern der Phos phorescenz zur 2rahrung dienen, anjujichen. Da aud viele auf dem Erunde des Zleeres feftifizende oder träge beweglidie Tiere - es fet nur an Zlleponturien und an Seefterne erintert - intenfiv Ieudten, fo würde es fid erflüren, daf beweglidhe Tier formen, mögen fie direft über den Bodent flotteren, oder auf dem Grunde leben, durch Sie Phosphoreseenj angelodt werden und den unbewegliden formen jur Beute fallen.

Es läpt fith indeffen niḑt in 2lbrede ftellen, da sic 2lnordnung und der feinere Bau der Eeuditorgane, wie wir fie an der Land des vont uns erbeuteteu 2lìateriales neuerdings gentuer fenten lemen, es wahriheinlid mahen, dafi fie and nod anderen כ̄weden dienen fömen. Jede (5)attung - häufig aud naheverwandte 2trten von Sdizopoden, Cephalopoden und pelagifh lebenden Tiefenfifinen jeigt ente fo harafteriftifhe Znordnung der Drgane, daf fie fith als trefflihe fyitematifhe Cha= raftere erweifen. Dabei lehrt fhon die oberflählidhe Betraḑtung, daf häufig dic

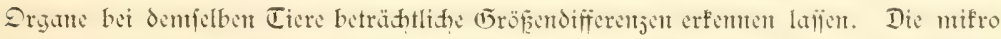

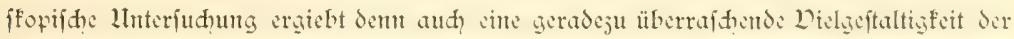
au verfhiedenen Körperftellen bei einem und demfelben Jndividum ausgebildeten Drgane. Bei dent oben erwähnten Tintenfifhe (Leucoteuthis diadema) finde idh die

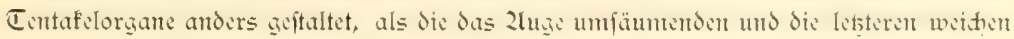
wieder auffälig $a b$ von den Bauhorganen. Dabet ergiebt es fid, daf weder dic 


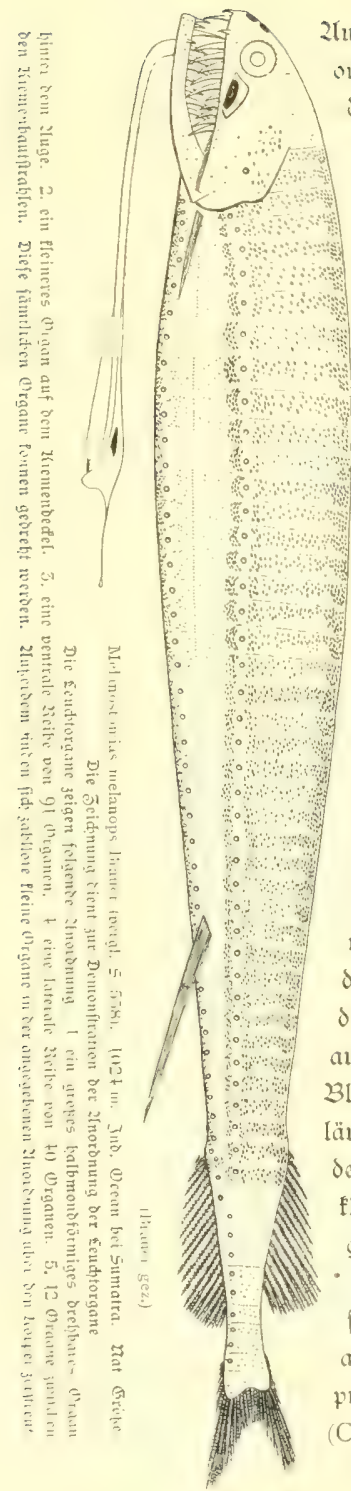

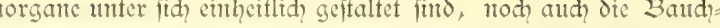

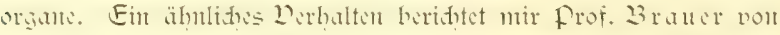

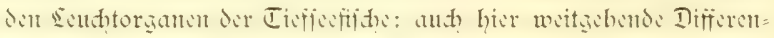
jen in dent feineren 23 au der Drgane je nadbent fie in der Zähe des Zuges, auf den Kicmendefelt, an den (5) an ben flanten, auf dem Baude oder über den ganjen Körper jerftreut auftreten.

Entfhieden mus diefe Dielgeftaltigfeit emen biologifden

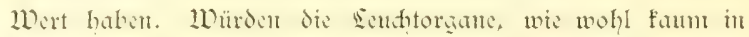
2lbrede ju ftellen ift, lediglid dent 2lnlocfen und Erfenmen von Beutetieren dienen, fo fönnten fie diejen 2 Inforderungen aud

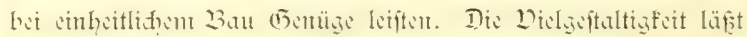
mun junädhit der Dermutung Raum, da Eie Qualität des von den Drganen ausfrahlenden Sidites cine veridiedene ift. Bei Lycoteuthis, deffen Drgante im Eeben rot, himmelblau, ultra= marin und perInutterglänjend find, vermod)te id fretlid nur nod, cin fowwades Eeuditer ju erfennen, bas feinen fidperen

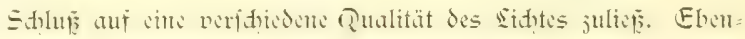
fomentis fonnte bis jetst der Zadhmets erhraht werdem, daf die rubimotent und grïnen Kopforgm des Malacosteus $\equiv . \overline{6}$ t) cin entiprediend gefärbtes siḑt entfenden. Jmmerhin ift die Dor= ftellutg, daf verfhiedenfarbiges [id?t ausgeftrahlt wird, nidit als phantaftift 3 ul bezeidnen.

Sidher aber trifft cine 2luffafiung bas Riditige, die fid Brauer iiber dic Bedeutung der Seudytorgante bildete. Er ift nämlih an der Ganto der Linterfudung unferes 2liateriales von Tieffecfidien darauf aufmerfian geworden, daf niḑt mur die grofen, fondern aud dic fleinen Drgane cine gejeţmäpige 2lnordnung befitsen. Ein Blif auf die beiftehenden 2lbbildungen mag bas Eefagte beffer er= läutern, als lange Darlegungen. Was zunähif Cyclothone, cinen der gementifen pelagifhen Tieffecfijhe, anbelangt, fo ftehen hier bie fleinen punftförmigen Drgane it Querreihen, welthe dem Tier cinten getigerten 2lnftrid, geben. Bei dent Melanostomias, defien Gabitus= bild wir auf 5.556 gaben, ordnen fie fid den Segmenten ent= fpredend ju breiten Querbinden an, die it die grofen Seitentorgane auslaufen. 2lndere Tieffeefilhe jeigen cine (E)ruppierung der fleinen punftförmiget Drgane ju fleder (Malacosteus) oder ju Sängsbindent (Chauliodus). 
Es ergiebt fith alfo ans den Linterfufuntgen vor Brauer, daf faft jedem pela=

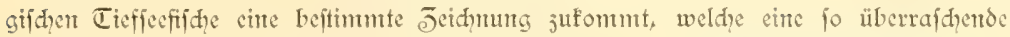

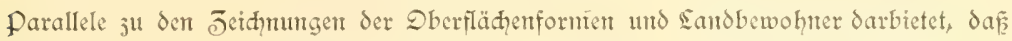
man verfudft ift, Sic über die färbung der leţteren ermittelten 2Tormen aud auf Tieffeebewohner ju thbertragen. Das Jujammenfintoen der (5ejh̨ledfer und die Ver=

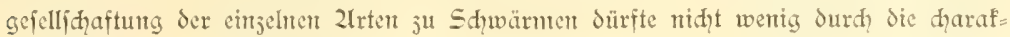
terifitifle Jeciđunung begünftigt werden.

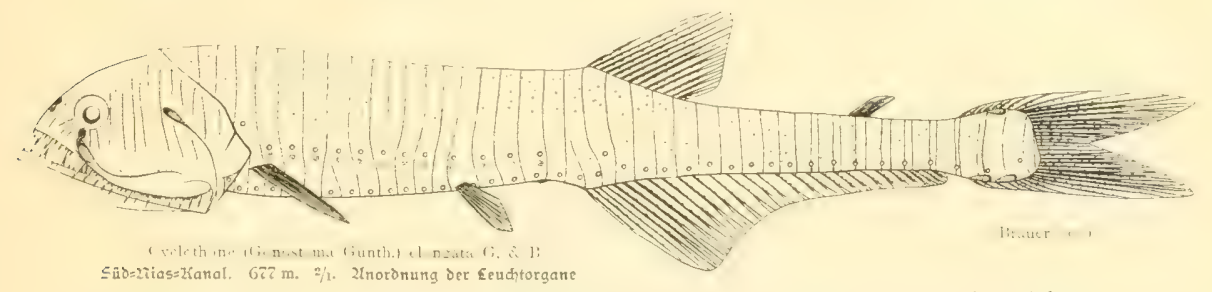

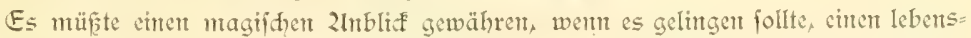
fräftigen pelagifhen Tiefenfijọ in phosphorifhem Sdeine erglühen ju fehen. Sollte aud die Qualität des von den cinjelnen Drganen ausgeftrahlten Sidftes verfdieden fein, fo würde die an cine originelle jeidynung anfnüpfende farbenprädytige Phosphorescenj, welde das geheinmisoolle Dunfel abyiffaler Regionen blitzartig erlcuchtet, ein intereffantes,

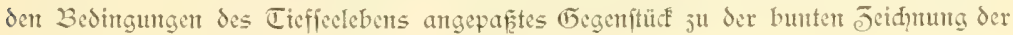
vont der Sontue befhienenen Drganismentwelt abgeben.

Das Dorfommen von Seuditorganen bei den Tiefenbewohnern madit es demt aud, wie wir fhon hervorhoben, veritändlid, dafi fo viele Tieffecorganismen mit wohl= entwidẹlten, häufig fogar monjtröfen 2lugen ausgeftattet find.

Lnter den pelagifh lebenden Tiefenformen hat jubent bisweilen das źluge feime

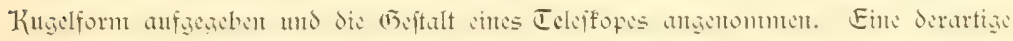
Untbildung ift uns juerft von cintgen, den 2lmphipoden unt Sd̨izopoden zugehörigen

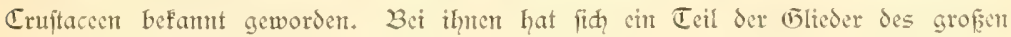
faecttcrauges derart verlängert, daf cine Jెweiteilung in ein "frontauge" und in cin "Seitenauge" „u ftande fonmt. Wir haben früherhin an der Gand der phyfiologithen Unteriudungen von Exner darjulegen verfuḑt, da die frontaugen mit ihren chorm verlängerten facettengliedern befonders geeignet find, in Bewegung befindlide Dbjefte zu erfennen, während die Seitenaugen für Wahnehmung eines detaillierten 3 ildes eingeridetet find. Bei manden pelagifd? lebenden Kruftern ift fogar das Scitenauge vollitändig gefhwunden und nur nod das teleffopartig norgefhobene frontauge er= halten geblieben. 


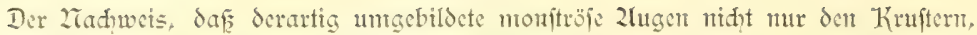
fondert and cintigen pelagifh Iebenden Tiefenformen von fifden und Cephalopoden jufontmen, dirfte cine wertvolle Errungenfdaft unferer Expedition fein. Wir haben auf der Buntoruktafel cinige dicfer aup̌erordentliden fifdformen mit Teleffopaugen Sargeftellt. Zur ciner bericlben (Opisthoproctus) war durd die franjëfifden forjhungen als Jugendform befamt geworden, ohne dak freilid der bemenfenswertefte Charafter, tänlid, die 2lnbildung der 2lugent in jwei nad) aufwärts geridhtete Cylinder, in der Bejdreibutg Erwähmung gefunden häte. Ein Blid auf die 2lbbildungen lehrt nun, dap derartige Zluacm [ald horijontal nad, vorn geridtet, bald vertifal nad oben gi=

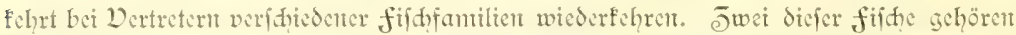

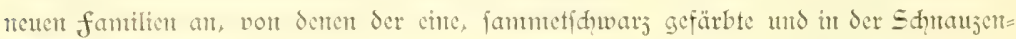

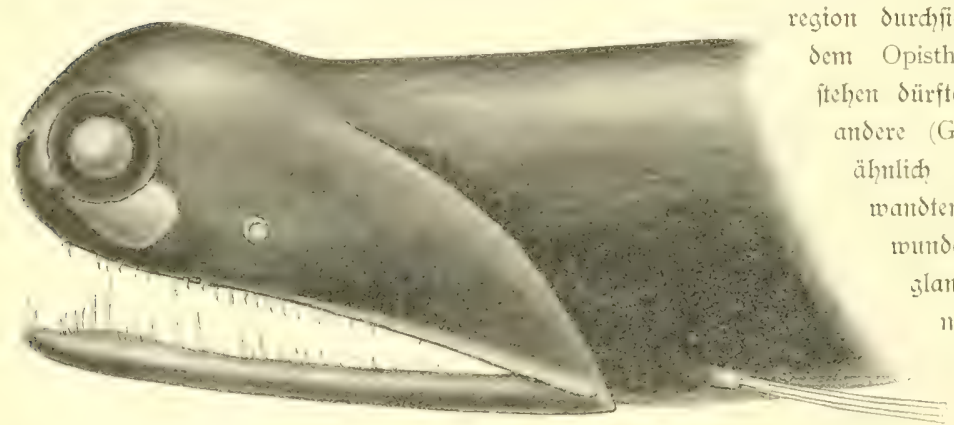

Malacosteus n. sp, mit 3 mei faorer nor Eeuthtoranen.

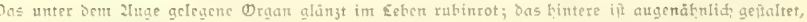

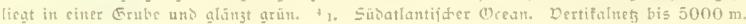
atertall= glanj, feilt grofics mif Raubzähnet befetstes 2liaul, die abinteucr= lid) Derlän= gerutg der witterent

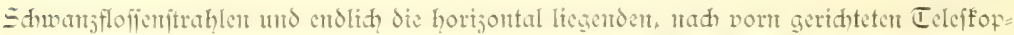

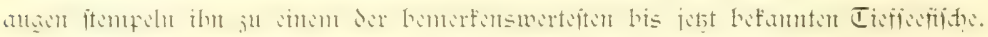

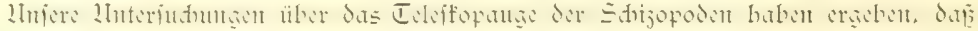

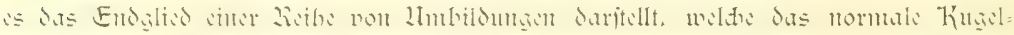
auge betreffen. Dasfelbe Derhalten trifft dem aud? nath den Zlitteilungen von Profeffor Brauer für bas Teleffopange der fifde ju. Int allgemeinen weift das fifdangi

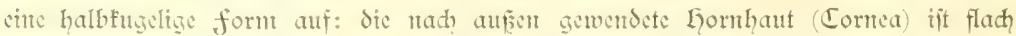

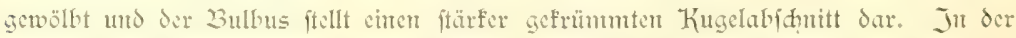
Rube ift das fifhauge für tahe Dbjefte cintgeftellt, infofern dic fugelige Sinfe in Gröferem 2lbftand von der 2Tetshaut liegt; dic Einftellung (2lffomodation) für ent=

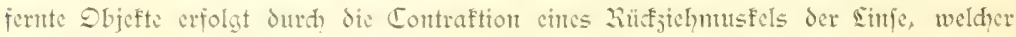

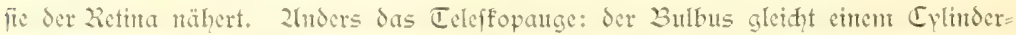
mantel und dic cornea ift fo ftarf gewölbt, wie wie es forrt bet Wafferbewohnern nidit 
beobaditen. Der 2lbitant jwifhen Ser Sinje, welde der Cormea dif̣t anliegt, und der

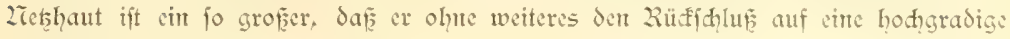
Kurjetditigfeit geftattet.

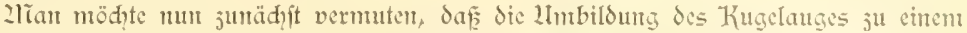
Teleffopauge dadurd erfolgt, dapie dic Gauptadic fid verlängert. Da fie durd die Derbindung des Sinfonmittelpunftes mit der Eintrittsfitlle des Sehnerven giseben ift, fo würde bet diejer 2ln= nahme das 2luge die radiäre Grund= form wahret und es minfte fpectell

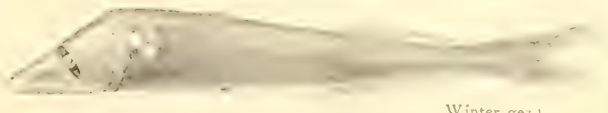

Earve don Disomma anale Dr. mit fpinoclförmia geftultetent zluge. $\$ / t$.

dor Sebnerv in Centrunt der Bafts eimptrablen. Die Lnterindungen volt 3rans haben mun ergebent, daf dic Llmbildung nidit auf diefent Wege erfolgt, fondern durd sine eigertartige afymmetrifhe Derlagerung der imeren Drgane bedingt wird. 2Im Sies im einjelten flarjulegen, jet junädjit erwähnt, daf dic Jugendftadien der mit Teleffopaugen ausgeftatteten fijhe cin nomal geftaltetes Kugclange anfweifen. Die erfte 2litdeutung ju cinter LImbildung mird dadurt? kedingt, daf das 2luge cine fpindelförnige Ģeptalt annimmt. Befonders auffälliz ift die Spindelform bei der Sarne des Disomma ausgebildet, weldhe wir in der nebenfehenden figur abbildert.

Ein Sangsidntitt durd das Spindelauge jeigt feine wejent= liḑe Zlbweidyung pon dem nomalen Derhalten, da bi: Sinfe entral liegt und die Settina in allen Teilen gleid?

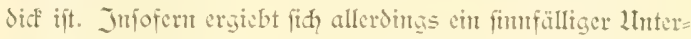
fatied jwifhen oberer mo unterer 2lusenthälfte, als die foge namte Chorioidealorife $(C h /)$, umgeben von Pigntent $\left(P_{i}\right.$ unt der filberglätjenden fajerjdidat $(F a)$ völlig anf die untere

ChK

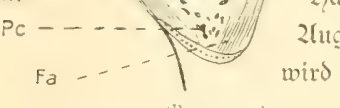

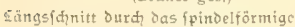
Zluge der Earoe non Disomma. Eo's. Chk chorioidealorüje. PC pigment der ¿lorioidea. Fa fajern ber filberalän jenden IIrgentea. 0 Sehnero.
Eälfte rüft und dadurd jur fpindelfömagen Derlätgerung des 2lugenbulbus beiträgt. Dic Llmformung ju dem Teleffopange

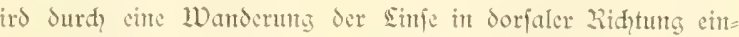
geleitet. Sic volljicht fid naheju fenfredt ju der friber erwähnten Gauptadif des zluges und hat cine afym= metrifare Entwifflung der Jris (ib) ventraler 2ubidntitf wird breitir als der dorjale) jur folge. Wor allent aber

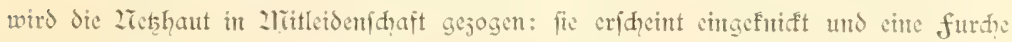
jheidet fie in dex böbe der Eintrittsitelle des Sebnerven in eine dorfale und ventrale

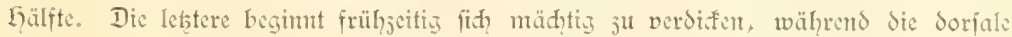
liälfte (rr) in ihrer weiteren Entwifflutg jurüfbleibt und als "robenterbaut" dic der 
Symmetreebene des Körpers jugefehrte Jument= fläde des Zluges ausfleidet. Die "Lompt: metshaut", ${ }^{4}$. h. der verdicte und für den Schvorgang wefentlith in $3 \mathrm{~B}=$ trad) fonmende 2lbifhnitt, nimmt

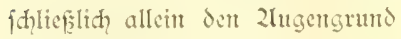
cin. Jubent fid die simfe von ihe inmer weiter cntfornt unt bis fid vorwöllende Connea gleidfalls dorfal verlagert wird, fontunt

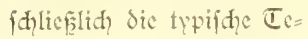
Ieffopform des 2luges ju= itande. Dhwohl das Tile ffopauge hodhgrabig furj= fithtig ift, fo vermag es Sod für entferntere $\tilde{G}_{\mathfrak{c}}$ genftände jul affomos = sicren. Betraditet man nämlidy das 2luge non Disomma und cintger an= derer Tiefiectifhe genauer, jo fällt an Dentralranto Ser weiten pupille eine ovale Derdifing auf, die fidh nad? abwärts in cinc geftreifte Platte fortiefst. 2lus dent oben abgebil= deten Sdunitt durd das

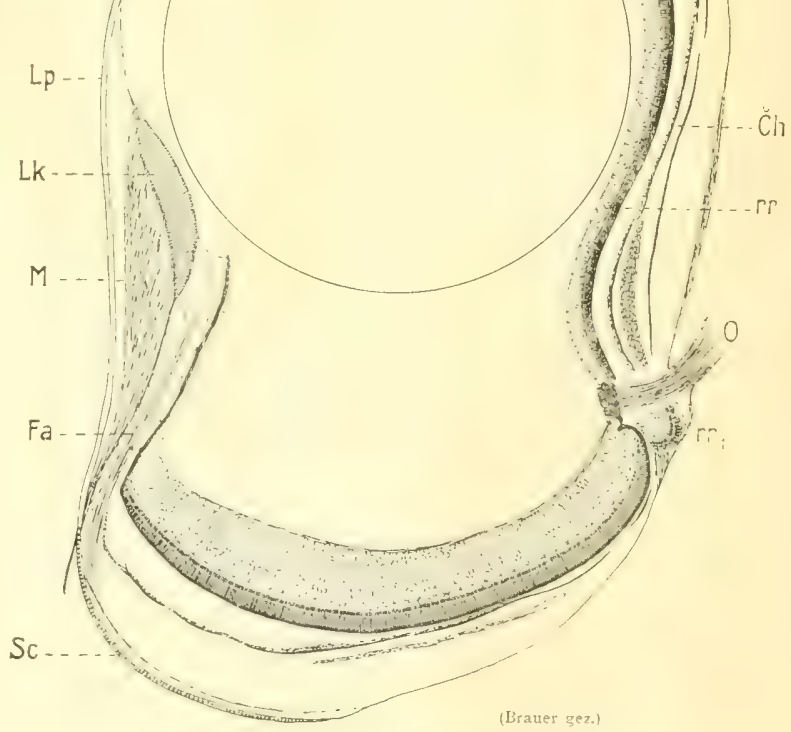

Eängsfannitt (Engittalfanitt) ourd bas ausgebilbete 2 tuge von Disomma. 40 $j$. 0 Sehnerv. $r$ r 2lebenneţhaut. $r r_{1}$ abgejhnürtes Stüư ber 2tebennețhaut. $C / 2$ Chosioidea (2tberfaut). Sc Sclerotica. Lp Ligamentum pectinatum. $L k$ sinjerififier. AI glatter Mustel. Fa fafern der Argentea.

2fuge geht hervor, da年 das ovale polfter ( $L k$ ) aus langgejogenen Jellen gebildit wird,

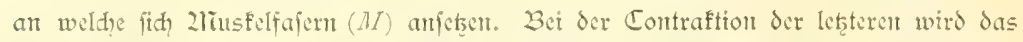
"Sinfenfiffen", auf dem die Kuggelinfe ruht, nađ abwärts gejogen und die Eimfe der

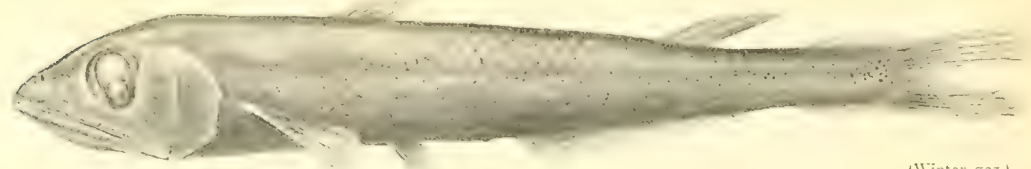

Disomma anale n, gen. n. sp. Brauer (fam. Odontostomidae). 4is. 2ltlant., antarPt. uno 3nd. 1)cean. $600-4000 \mathrm{~m}$. 


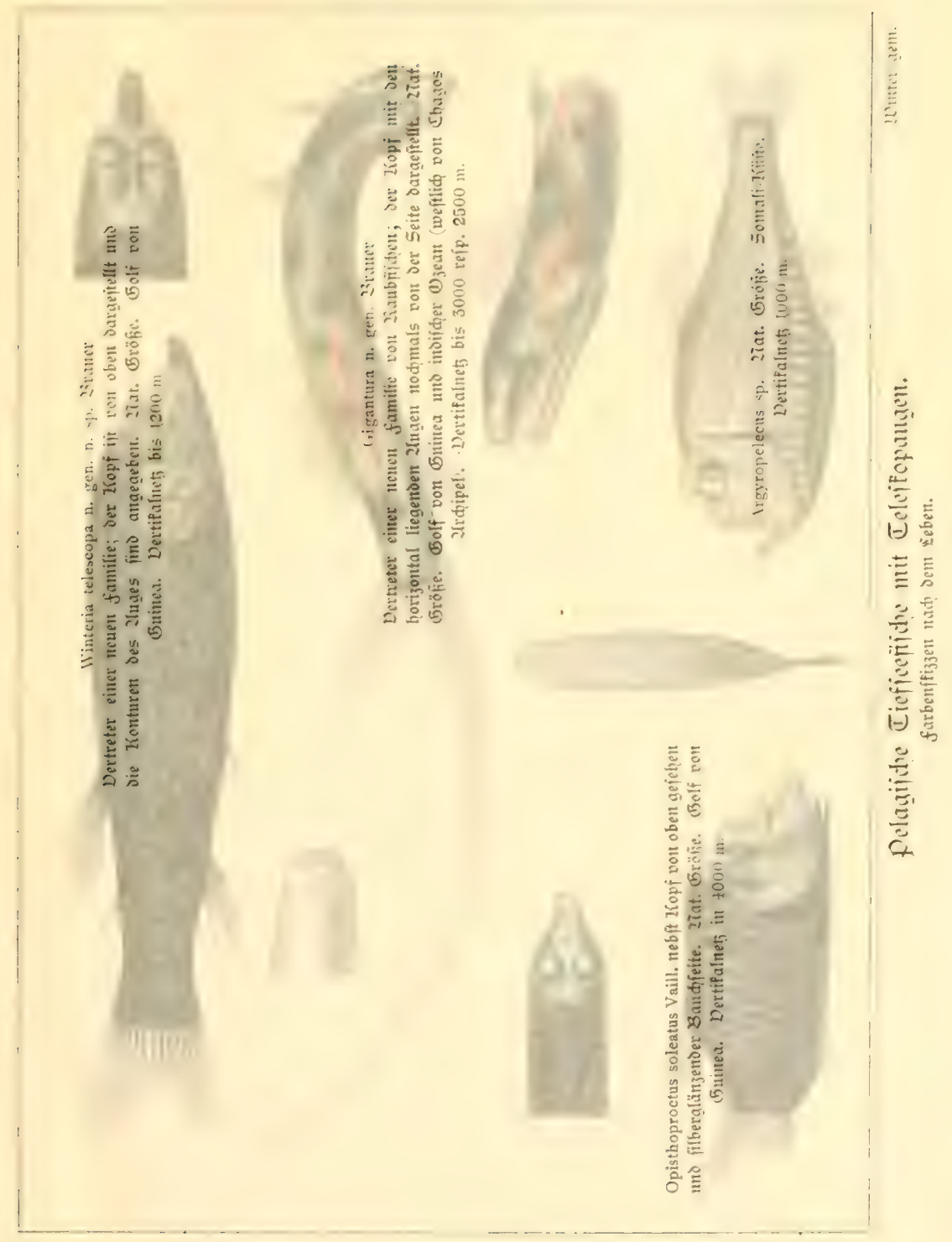




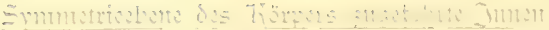

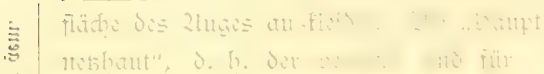

亲

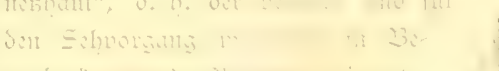

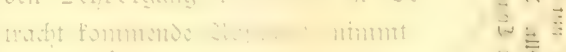

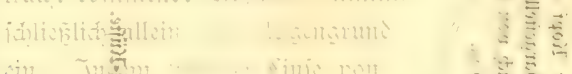

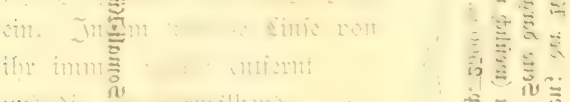

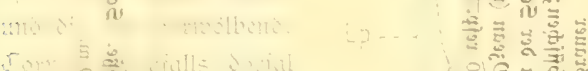

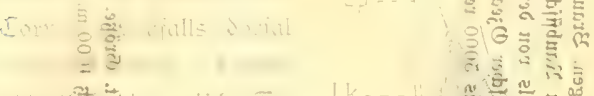

을

这 竞

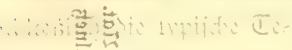

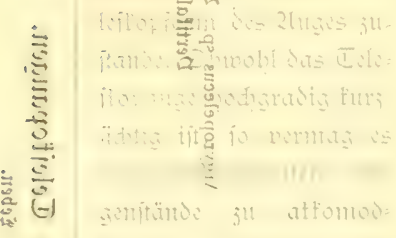

可高要

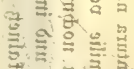

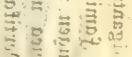

$2 \frac{1}{3}=$

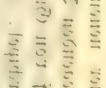

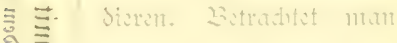

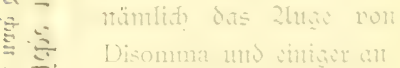

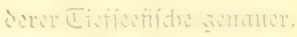

jo tollt sm Pentrolrans

Jer meitem pupille sim

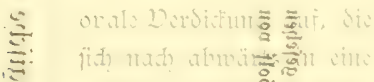

赔要

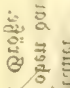

8 范

$M$

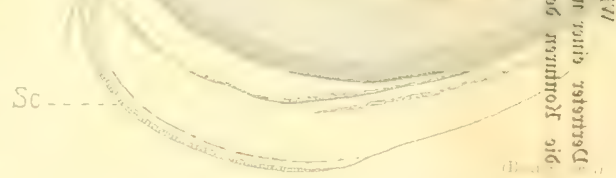

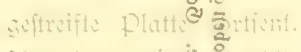

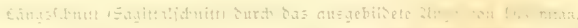

2lus dent o जu:

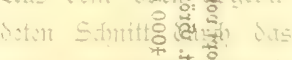

Zivas ant he g.

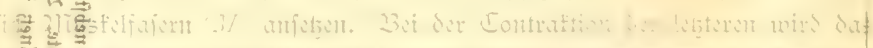
3

3 

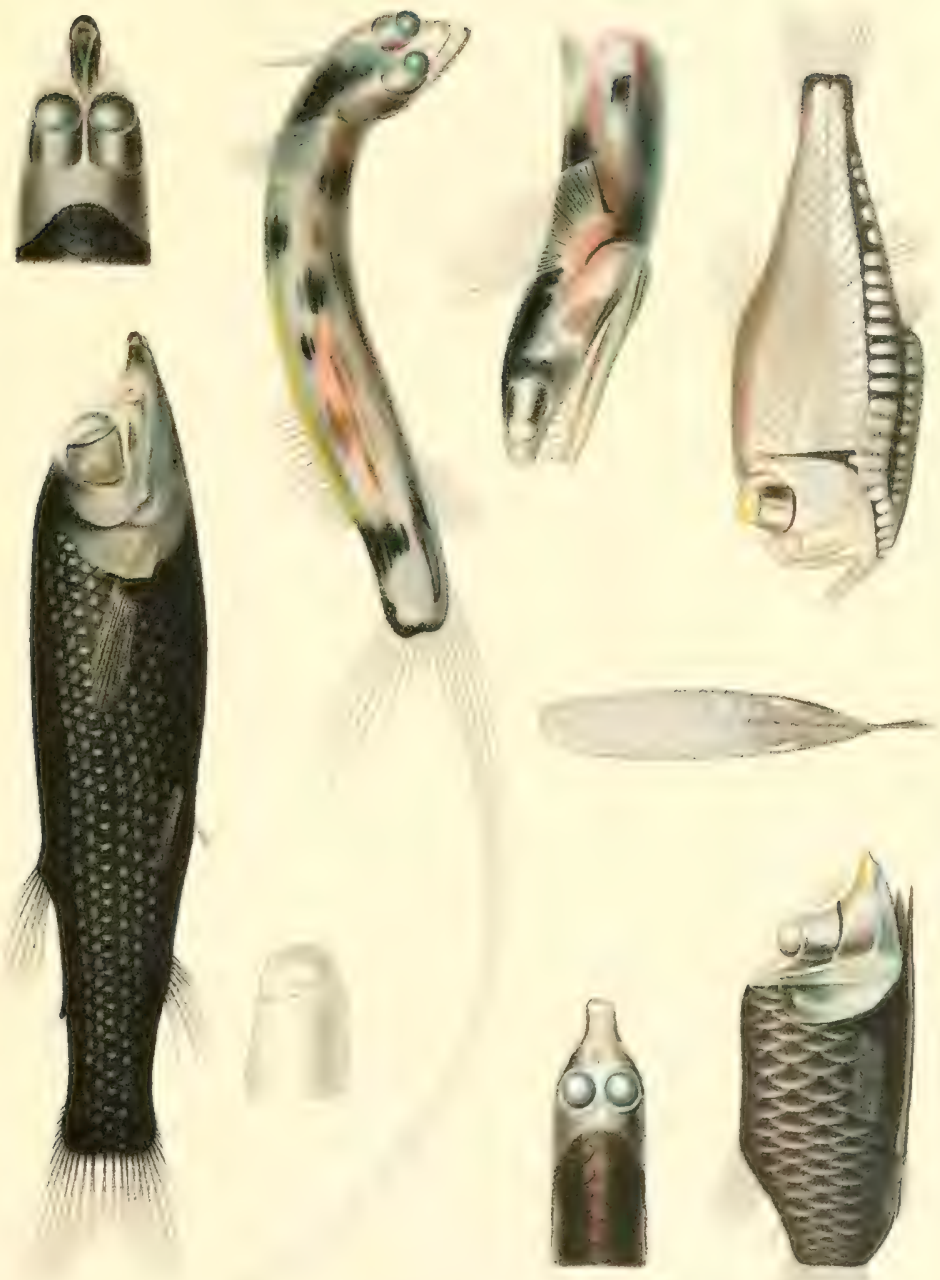



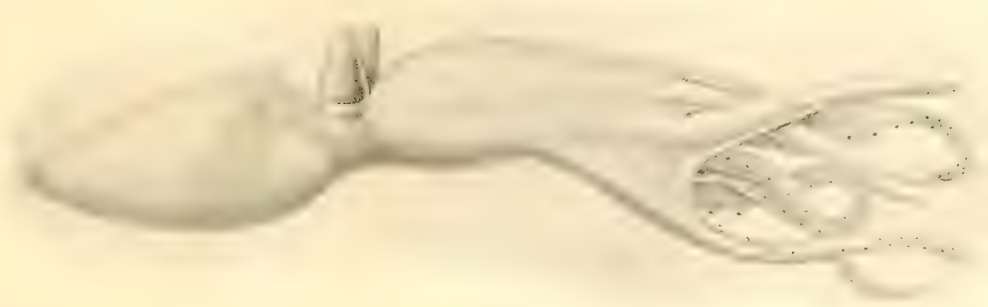

Ietharnitger Eephalopode (Amphitretus) mit Eefeffofaugen. 2laulbas=Strom. Dertifalnets bis $1800 \mathrm{~m}$. Wenig vergrōgert.

Gauptnetshaut genthert. Immerhin dürfte aud bei diefer 2lffomodation für ent= ferntere Objefte fdowerlid? eine Einftellumg anf grofe Diftanecn erfolgen. Es liegt auf der Land, daf in der hohgradigen Kurjfidjtigfeit des Teleffopanges eine Zlnpaffutg an dic Bedingungen des Tieffeelebens gegeben ift. Wie Beer betont, fo find die Tiefiectiere Sarauf angewiefen, in "nädtig engen Lmfreis ihrer cigenen saternen ju fehen, da fie niemals aus weiter ferme Eripäbtes nadjagend verfolgen, fondern felbft blenderto oder irrlidfig locfend die crtaftbar ins Sidht geföderte Bente ans gröfïter 2ähe exiduappen".

Kentesfalls ftehen dic formen mit Teleffopaugen in näherem nerwandfhaftidjem

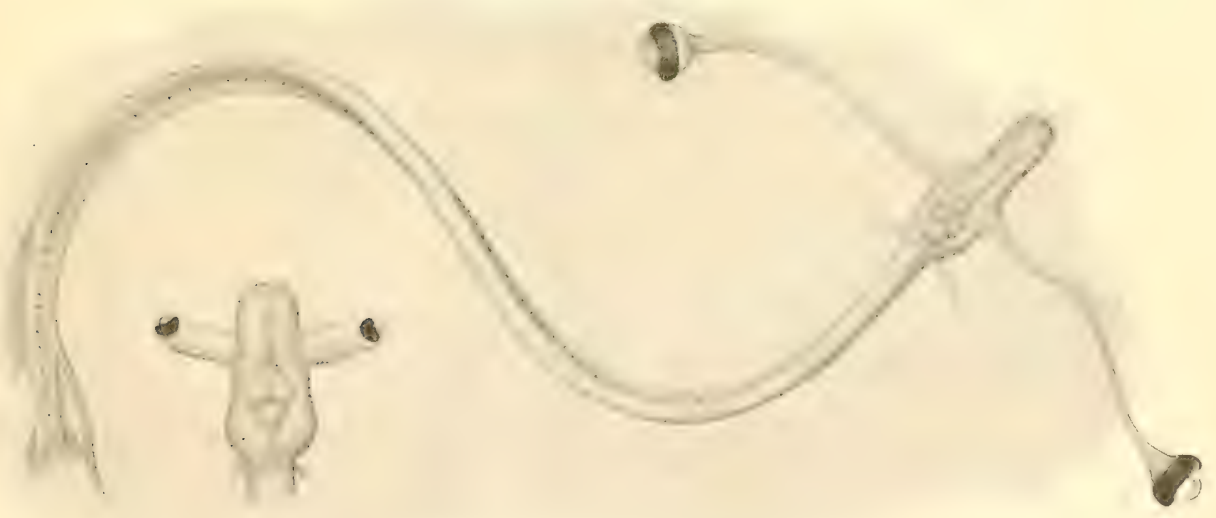

Juarndiorm von jijhen aus dem äquatortalen Inbifhen Qcean mit Slielaugen (Stylophthalmus Braver). Dertifalneţ bis $2000 \mathrm{~m}$. Dergr. $\%$. 2lle Eremplare befitgen vor der 3lfterflofie cinen langen zlnbang. Einfs ift Der Ziopf einer

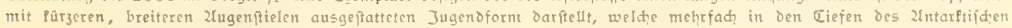
Meetes erbentet wurbe.

Ehur, Itus den Ciefen oes Weltmeeres. Extoite 2tuflage. 
Jufammenthang. Es handelt fid hier vielmehte unt cine Konvergenjerfdyeinmeng, dis vereingelt bei den verfditedenartigiten pelagifden Tiefenformen jum 2lusdrut gelangt.

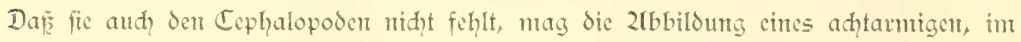
2IGulhasftrom crbeuteten Exemplares crweifen: mif jeinen faft vertifal geftellten 2lugen= cylinden bictet ex cinen hödyit bizarren 2lnbliç dar.

Was es mu für einen Simt hat, daf bei mehreren Jugendformen von fifden, dic wir teils int antarftifhen Bobiet, teils im Jnoifden Drean (leţtere in mehreren Excent= plarent) erbeutetent, dic 2lugen auf Sticlen, und jwar, wie dic 2lbbilduntg lchet, auf

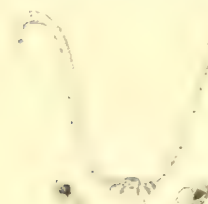
geradeju monftrös langen Stielen ftehen, läß̨t fid, fđ̆wer faget, Wem wir amthmen, dor bet cincr derartigen Jit fertion das Tier cin gröfaces Territoriun überichant, fo ift dies chen un die limidgrethung des thatfädliden Befundes.

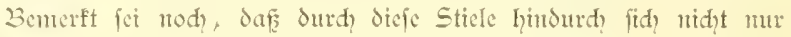
der Zlugemerv, fortoent and dic feds, freilid Strüngen ungebildeten 2lugemusfeln verfolgen laffen. Don den Ietsteren find dic vier geraden Zfugemmefeln auferordentlid lang auszisogen, weil fie in der 2lugenthöhle des Krorpelidädels

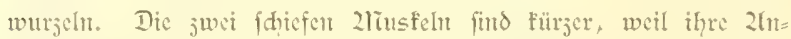
heftungstelle auf der Endplatte eines Kitorpilfteles liegt, der fith weit in dent 2 lugenfitid vorjicht. Diefi abentencelident fifth= Larven, welde Brauer als Stylophthalmus bejeidnnete, dürften Jugendfornten von Stontatidon fein und ciner (ॅ)attung angehören, welde Teleffopaugen befitst.

Daf übrigens Sticlungen niḑ⿻ mur Jugendformen von Tiefent= fificher, fondent aud jenen von Cephalopoden jufonment, mag bis

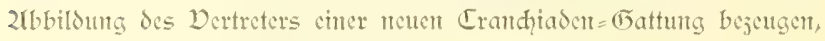
die wir int Bilde vorführen.

(Rubsaamen gez.) Zienc Futtung cincs Einten= fitides ans Der fomilie der Erantiaben mit Stielawaer. Sorjuen Serdellen uno (1) 2tfifts. $\frac{2,5}{1}$ Dertipalnets $2000 \mathrm{~m}$. dem Parietalauge manḑer Reptilien gleidyt. Ob dasfelbe thatfäḑlid bei manden Tieffecfifden nody als 2luge funftiontert, fam erit dic genauere anatomifde Llnter= jud\}ung ergebent.

Ein ewiger Lumger ift dic Signatur für Drganisnen, denen der Zafyungserwerb nidht leidgt gentadit twurde. Selbit währent des 2lufhievens entbrante in dent Ento= зefäf des Dertifaneţes der Kantpf un das Dafein; gar mand?utal bedanerten wir, 
Saf ein Tieffefif andere wertvolle pelagifde Drganismen veridhlungen hatte, oder peinerfeits wieder von den grofen Krnftem durd,biffen und angefreffen wurde.

Dic ganje Drganifation jeigt bet den räuberifd lebenden formen einte oft fitmfällige Zlupaffung an den Erwerb der meift fdwwer ju gewimenden Koít. 2hter den Kruftern

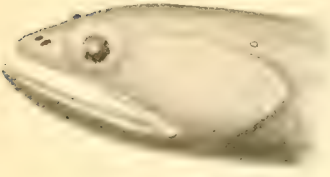

(Brauer gez.) Tioff eines Scopelioen (3no. Ocean bei Ras Safun, Dertifalnetgi) mit Dem parietalorgan. $5 / 1$ werden häuftg dic Extrentitäten зu Raubfüf̧en umgejtaltet, dic entweder mit Dormen ausgeftattet fits oder in Sheren, Eptefe, Sanjert und Stilette auslaufen. Das 2liaul hat fich bei ciniget pelagifh lebenden Tiefferfifien fo monftrös ent= widelt, dafe es über Dreiviertel des Körpers ciminmt: der zanje fifd fhent ju einem Raḑen umgewandelt, deffen

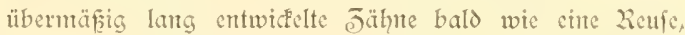
bals wie Widerhafen ein Entzleiten der gefafisten 23eute verhütent. Eintge der Eattung Labichthys jugehörige fiiho jeigent cine hödỵt wunderlidye Unbildung der Kiefer ju gefrünmten, in Küpfe aus= laufenden 2Ingeltuten. Da fie mit feinen Jähnen befest find, fo durften fie befonders gecignet feit, in ihnen fid verftrifende pelagifhe Drganismen feitzulalten.

Es läf fith midht lengnen, daf eine gewifie Korrelation in der Bildung Jer 2lugen und des 2liaules infofern ftatt hat, als manthe der gerade mit den monftröeften 2lïulem ausgeftatteten forment fleine 2rugen aufweifen, währent bei eintigen mit auffällig flemem 2lianle ausgeriffteten formen dic 2lugen mädtig entwifelt oder ju Celeffopen umgebildet find. Ltuter Llmptünden fam freilich das Derbältits fid aud? untfeloren.

Die Steigerung in der Seifungsfähigfett des gefammten Drienticrungsapparates prägt fith cndid nod in der ungewöhnlidhen Entwifflung der fühler ans. Sie zeigen

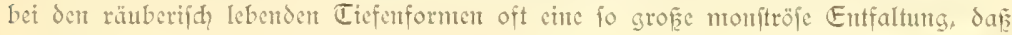

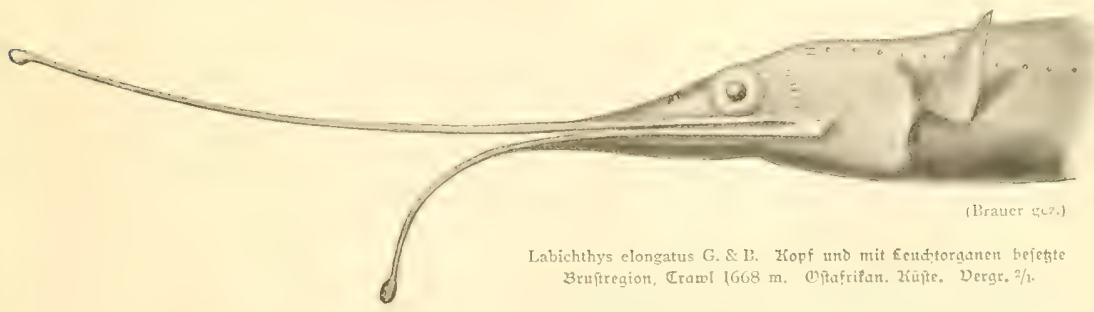

fie den Körper un das D̈ehn bis Jwwanjigfade an Ëange übertreffen. Dies gilt namentid, für dic Sergeftiden und Tiefieeganteclen, unter weld?' Ietzteren wir bei cintgen 2lrten von Aristaeus fühler von anderthalb 2lieter Sänge nadiweifen fonnten. Während fie hicr mit wohlentwidfelten Sehorganen fombintert auftreten, fo findent wir 
bei den blinden Tieffecfruftent den Körper bisweilen mit cinem ganjen Delj von Sinmesharen überiät, wie dies befonders auffällig bei den Eryonioen der fall ift. 2lud? unter den Tieffeefifden begegnet man ciner derartigen übermäḑtigen Entwid"

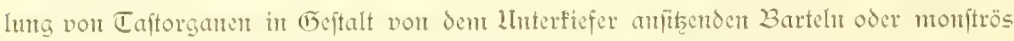
verlängerter floffentrahlen, weldie gelegentlid, in merfwürdige, fnopfartige 3ildungen anslaufen.

Wollten wir die 2Inpaffungen der Tieffecfanta an die eigenartigen Eriftenjbedingungen

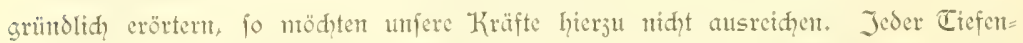
bewohner regt ju Betrad)tungen über den ummodelnden Einflup äuperer Bedingungen an, die fid nidit mur in der ganjen (5̃eftalt, fondern and in der inneren Drganifation und in feiner Entwifflung ausfpredien. Zimmt man ement Tiefenfifd jut Land, fo findet man dic Eqaut überfät pon femen 2iervenendorganten, die bald an das reț ent= faltete Syftem der Scitenlimien und der Seudytorgane anfü̈pfen, bald wieder red fremb= artige, fantwer ju deutende Bildungen daritellen. Sein Drienticnungsapparat jeigt fith uibermäđftig ausgebildet: die 2lugen feffeln durd die eigenartige form des Bulbus nidht minder, als durd den feiteren Bau der mit ungewöhnlid? verlängerten Schitäbchen ausgeftatteten 2Teţhaut; an den Gehörorganen find die Dermittler des ftatifhen Simtes,

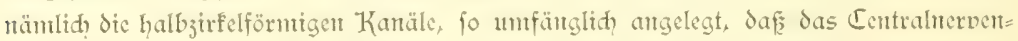
fyftem und die von ihm abgehenden Eirmerven Platz fdyaffen müffent, und endid, ift Ser Taftapparat fo fein und vielgeftaltig entwidelt, daf man mur immer non neuent feinem Staunen über die Esfaltungsfraft der 2ratur 2lusorud giebt. Lhterfuht mant das Zervenfyftem und dic von ihm ausgehende Jirbel mit dem Partetalorgat, fo ftöft man wiederum auf 3 auverhältniffe, die fid nidyt ohne weiteres in den Rahmen des von Dberflädhenbewohnem Befamten einfügen wollen. 2iid)t minder cigenartig ift bie 2Hordmung und der mifroffopifde Bau der 2lustelfafern und des Sfelettes. Dấ das Iestere falfarm ift oder bei den pelagifden Tieffecfifįer überhaupt mur fnorplid vor= liegt, dürte als cine 2fupaffung an die flottierende sebensweife nid̨t minder verjtänd= liḑ feit, als dic Zlusbildung von gallertigem Zindegewebe. Wir virjidten darauf, der Figentünlidfetten in dem Derhalten der vegetativen Drgane ju gedenten, unt ver= fidem, daf das Stubium enes einjigen Tiefenfijhes die Sebensarbeit cines gemiegten foriḑers ausmaden fömte. Zlandye Strufturverhältutffe - fo vor allen ber Bau bes 2luges - dürfter wohl ciner ftreng phyfifalif̧en 2lnalyfe jugänglid fein, während andere uns 2lufgaben ftellen, weldhe das Spiel der phantafie mit Leppothejen ju löjen veriud?t. 
Was bier von Tieferfifin gefagt wurds, gitt für jeden Bewohner abyfaler ke= gionen bis hinab ju cinfadyt gebauten Sebewejen, den protojocn. Wer will dicfe Wunderwelt der Tieffee in allen ihren 3ejichunger crfaffen, wer mödte fít vernteffer,

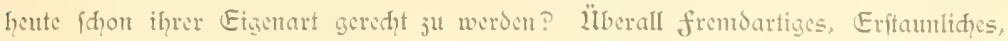
nic Gifdautes. Lhto dod? geht dies niemals fo weit, daf reue Drganifationswerhält=

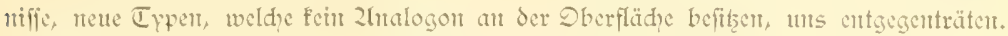
$E_{S}$ handelt fith inmer nut unt 2hupafiungen und Lhuformungen vont (15eftalten, dic

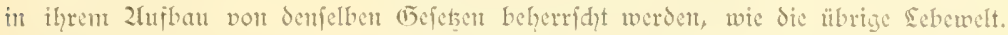
2lian glaubt cine alte, längit vertraute 2lielodie ju vernehuen, dic ftets vont neuem facfent in unendidien Dariationen wiederfehrt.

\section{"In emig}

Wieicrbolter Geftalt wäljen dic Thaten fich um.

2lber jugendith immer, in immer verünoerter Ş̧önt

Ehrit ou, fromme 2iatur, jühọtig das alte Gejets."

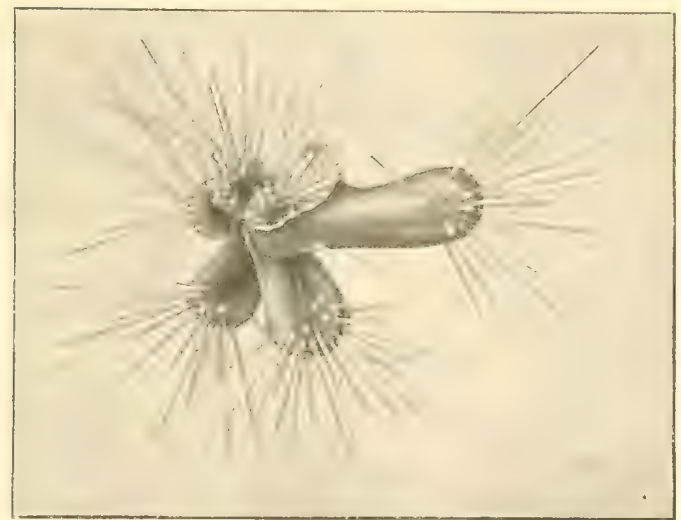

Hastigerina pelagica d'Orb. (forantinifere) mit $\subseteq$ drmebeftaḑeln. 


\section{$2 i$ a d iter.}

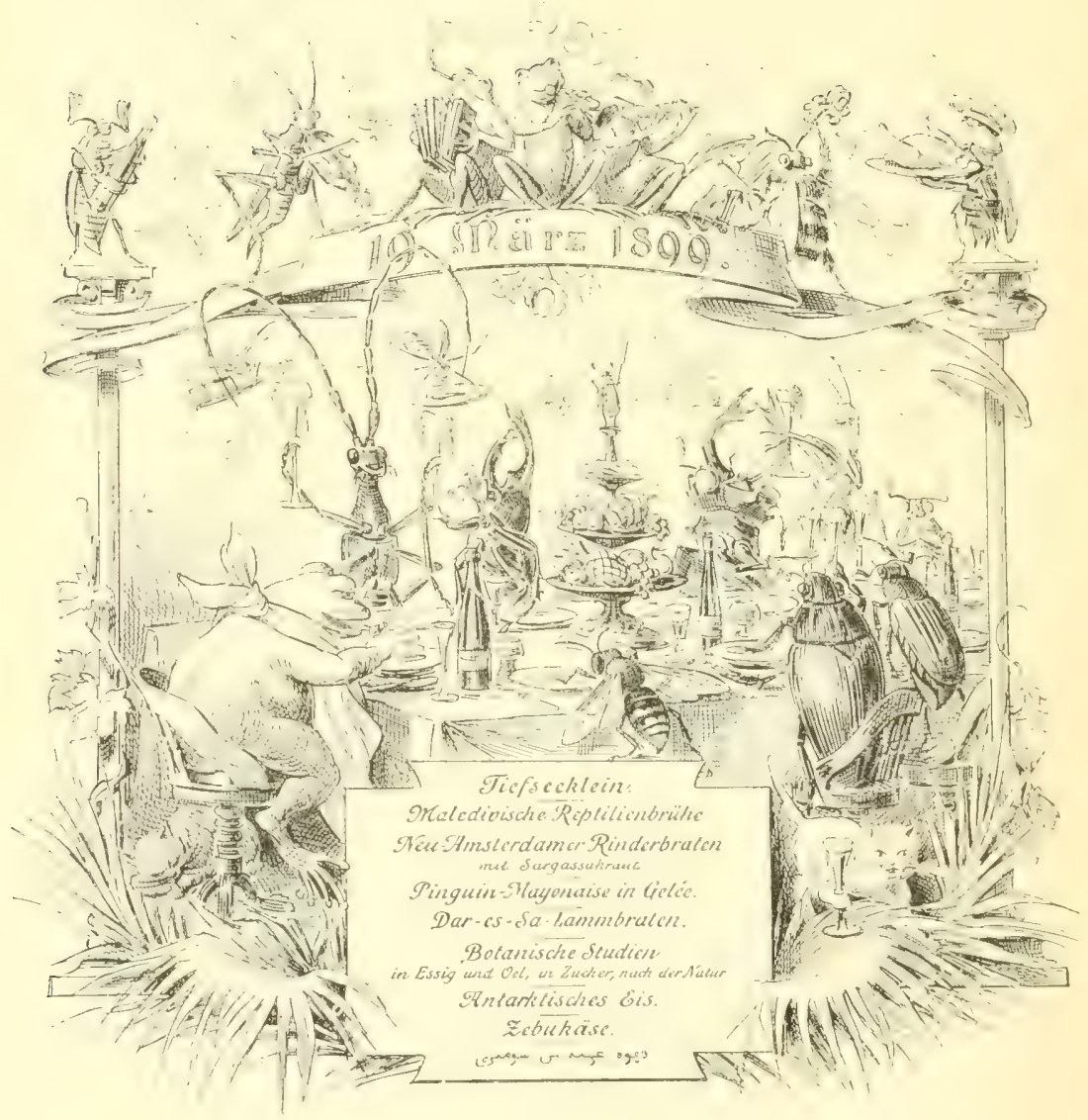


21.

Acaena affinis 221.

Acanthias 141.

Acanthephyra $5 \overline{5} 2$.

Acanthodrilus 270.

Acanthometra 251, 545 .

2lecumulatoren 26.

Adamsia $5 \overline{5} 5$.

Adansonia digitata 151.

$210 \mathrm{cit} 505$.

210lerrodert 502.

21fferbrotbaum 151.

Agalma 281.

Agrostis 272.

Ilgulbasbart $165,169$.

2lguihasfrom 175.

2lftinicu 158, 1760, 185, 518.

2libatros $147,242$.

2llevonarien 516.

Alectroenas pulcherrima $+\overline{6}+$.

2llepocephaliden 559.

2llgoabai 166.

Amalopteryx maritima 269.

2Intbasbuint 90.

Ilmeifer 129.

Amphianthus abyssorum 518.

Amphidiscophora 514.

Amphihelia rostrata 520 .

Zmphipoden 550.

Amphisolenia $7 \%, 417$.

Amphitretus 5\%6.

Amphiura patula 249.

Anacardium 152.

Anhinga rufa 151.

Anona Senegalensis 152.

Zlutartijides 2leer 194.

Treibeis 195.

Eotumgen und Ticfe 199.

Cemperaturverhältnilije 200.

Gehalt an Saueritoff und Kohlen äure 205.

Intarftifhes plaitfor 225.

Antarcturus 189, 561.

Antedon phalangium 51, 525.

Antedon prolixa 523.

Antennarius 585.

Anthomastus antarcticus 186.

Anthoptilum 504.

2lnthojoër 185.

2ntipathioen 455.

Aphrocallistes 511 .

Aphroditaster 526. 2lppendicularien 161, 554.

Aptenodytes longirostris 287.

2lquatortaufe $8 t$.

Arcturus $18 \%$.

Areca catechu 524, 398.

Arenga obtusifolia 309 .

Arenga saccharifera 325, 538.

Aristzeopsis 598, 556.

Aristaeus 598, 556 .

Artocarpus 458.

21 scidien 278 .

Aspidodiadema 529.

Aspidium 508.

Asplenium nidus 440 .

2tifelfrebic 278.

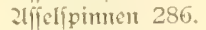

Asterias 187.

21 fterioen 525.

Asteromphalus 255, $41 \overline{6}, 5+2$.

Asteronyx 186.

Asthenosoma 529 .

21 tracen 459 .

Astronesthes 421 .

Astrophiura 171.

Atolla 544.

2ltatin 587.

Azorella 271.

\section{3.}

Bafelli = כ̄werguolf 115.

3afwiri 92, 98.

Balaenoptera 141.

Bali 99.

Balifition 422 .

Bambus 418.

Batgala 125 .

3aniafinjeln 562 ,

3 anyaneit 418.

3 aobab 151 .

Barathronus bicolor 559, 541, 564 .

Barringtonia 589.

Bathochordaeus Charon 554.

Bathyactis 520.

Bathybiaster 186.

Bathycrinus 249, 522.

Bathygadus longifilis 540 .

Bathylychnus 421 .

3 aumameifen 129.

Baumfarte 560.

Benthochascon Hemingi 551 . 
584

2300524.

Betelpfeffer 527

Birgus latro $4+5$.

Bithynis 465 .

Blatedredide 29.

Blafentang 260.

Blechnum boreale 500 .

3linomilite 405.

Boavista 11.

3obiainiel 107 .

Bolina 281.

Bolitaena 86.

Bolocera 520.

Boltenia 249.

Boma $15+$.

Bonvet $=$ Jnel 184 .

Braditiopoden $4 \overrightarrow{6}, 455$.

3 radfuren 530 .

Branchiocerianthus imperator 516 .

Brisinga 187, 391, 565.

Brissopsis lyrifera 165.

Brissus $4+6$.

3rootes Tiefenlot 151.

3 rotfudutbaum 458.

3 rutplleae 269 .

3 ryojocn 185.

Bülbuil 95.

Buca tol.

Butorides albolimbatus 444 .

\section{$\mathfrak{c}$}

Calamocrinus 521 .

Callitenthis $5 \pi 0$.

Callianira 281.

Calophyllum 405, 440.

Calycopteryx Moseleyi 269.

Canarifite Jujelir 55.

capverier 31.

Carcharias lamia 68, 70.

Saretriduilofröte $4+6$.

Carica papaya 97, 525.

Carinaria 421.

Caryophyllia $505,520$.

Caryota urens 558.

Cassia 340.

Cassytha filiformis 488 .

Casuarina equisetifolia $\$ 40$.

Taluarinen 440.

Caulophacus $5 ! 2$.

Iephalopoden 558, 555.

Ceratium 76 .

Ceratium fusus $\tau \sigma$.
Liegifter.

Ceratocorys 417 .

Ceratocorys horrida $\overline{5}$.

Cercopithecus mona 129 .

Cereanthus $515,518$.

Ceryle rudis (20).

Tcylor 418.

Chaetoceras 227.

chagosbant 455 .

Chagos= Jujeln 454.

Shallengerioen $4 \pi 9$.

Charadrius hiaticula 142.

Charadrius rufocinctus 142.

Chaunax $59 \overline{7}$.

Chelonia viridis 429, 446.

Chilodactylus fasciatus 298.

Thimmey Top 258.

Chionis minor 266.

Chrysodium $12 \overline{6}$.

Chrysogorgia 518.

Chunella gracillima Jis).

clarence pif 89 .

Cluper ocellata $1+1$.

Cicindela 389 .

Sinaiberacen 560.

Sirrbitioen 298.

Cirripedien 5.56.

Cirroteuthise 496 .

Cocos= Injelit 514 .

Cocos nucifera $558,440$.

Coecilien 465.

Coelophrys 568.

Coelorhynchus fasciatus $5 \neq 0$.

Colossendeis $55 \overline{6}$.

Colobanthus 2 24 .

Congermuraena $59 \%$.

Songo 125.

5ongo: Savamie 150.

Sopepoicu $5+9$.

Sopra 449.

Corethron 227.

Sormoralt 49, 142, 258.

Corypha umbraculifera $4\lfloor 8$.

Coryphaena 501.

Coscinodiscus $78,255,542$.

Cotula plumosa $2 \pi$.

Cranchia 252, 552, 578.

rraspedoten 545.

Srimoiden 47, 51, 521.

Crinum asiaticum 589).

Sruftaceen $550,5+9$.

Cryptopsaras 558.

Cryptopsophis 466.

Crystallomia 565. 
Etenophoren 545.

Culcita 446.

Culeolus $2+9$.

Cyathea 10t, 360.

Cyathea Seychellarum 464.

Cycas 401.

cpeloptomen 559.

Cyclothone 575.

Cydippe $5+6$.

Cyrtomaia Suhmi 550.

Cystopteris fragilis 275 .

D.

Dactylostomias 559 .

Daption capense $14 \bar{\tau}, 244$.

Dar es Salûn 481 .

3coölferma uno Umacbuna 481 .

33 ij fiavanie 485.

Sachicumalo 489 .

mantarove uno plantagen 491.

Dasygorgia 518.

Deckenia nobilis $+\tau 2$.

Delphine 480.

Dendrocalamus 418.

Dentalium 595.

Dentex rupestris 141.

Dermatodiadema 589, 529.

Desmophyllum crista galli 504.

Diatonteen, antarftifie 181, 226.

Diadematiden 592.

Dibranchus 568.

Dictyaster 526.

Dictyocha 255.

Diego Earcia 45 t.

Diomedea chlororhynchus 245, 258, 511.

Diomedea exulans $147,245,294$.

Diomedea fuliginosa $182,242,258$.

Diomedea melanophrys 245, 258, 294.

Diospyros 104.

Diphyes arctica 564 .

Disomma anale 565.

Dipsacaster Sladeni 525.

Doliolum 55 ł.

Dominifanermöve 268.

Dornhai 141.

Dorocidaris elegans 529 .

Dorocidaris papillata $4 \overline{7}$.

Dracaena draco 57.

Drachenbaum $5 \overline{6}$.

Dreofithe, arofe $2 \pi$.

Dreteffrabbert 550.

Dualladorf 115.
Dumpalme 482.

Dutrian 324.

Durio zibethinus 524 .

Durvillea 278.

Drmamometer 25.

Dytaster 526.

\section{E.}

Ebenhol: 104 .

Echeneis 422.

Echinioen 521 .

Edinodermel 521 .

Echinoplax 555.

Echinothrix 446.

Echinus horridus 165.

Echiostoma $59 \%$.

Ectemnorhinus viridis 270

Esinburgh +2.

Einjicolertrebje 158 .

Eisberge 205.

Eisfturmoogel 25i, $2 \$ 5$.

Elaeis Guineensis 9\%.

Elefantenrobbe 28ł.

Elpioien 249.

Elysia 585.

Embryonopsis halticella $2 \vec{a}$.

Enocrby = Iand $2 \neq 0$.

Enoploteuthis margaritifera 570.

Erica arborea 62.

Eriodendrum anfractuosum 96, 150.

Eryonicus 552, 565.

Eryoniden 556, $50 t$.

Erythrincu 589.

Erythrophyllım Guineense $48 \bar{\tau}$.

Eiclspinauin 28\%.

Eucidaris 446.

Eudyptes chrysocome 2it.

Eudyptes chrysolophus 501.

Eulabes religiosa $52+$.

Euricioen $4+6$.

Euphausia 246.

Euphorbien 58 .

Euplectella aspergillum $5 \nmid 2$.

\section{f.}

farnbäume 104.

faröer 48.

faröer $=$ Shetland $=$ Rime 46 .

feenicefdmalbe $4+2$.

fernatdo po 89 . 
Festuca kerguelensis $2 \vec{\imath} \overrightarrow{0}$.

fetilide 158, 385, 412.

feuermaljen 148 .

Ficus bengalensis $4+0$.

Ficus indica $5 \bar{\pi}$.

Ficus religiosa +18 .

fild bai, arobe 159 .

Flabellum 559, 59).

flagellaten $6 \overline{5}$

flamingo $\$ 50$.

flicaenbe Limbe 402.

flügeliduneden 400, 5.52.

foraminiferen 81, 85, $\$ 5+4,510,531$.

Foudia madagascariensis $4+4$.

Fragilaria $22 \overline{6}, 25 t$.

furgicu +50 .

(1).

(5adident 530.

Garcinia mangostana 525.

Garnelen $\overline{5}, 56$.

Gecarcinus +74.

Seicrader 120 .

Gcib̄clinfujoricn 75 .

Scipterjaift +09 , +12.

Geryon $158,551$.

Gigantactis $\overline{5} \overline{\bar{s}} \mathrm{~s}, \overline{\mathrm{j}}, \overline{\mathrm{c}}$.

Gigantocypris 500 .

Gigantura $5 \bar{\tau}+$.

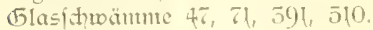

Glaucus 5̃2.

Gleichenia $₫ \neq 0$.

Globigerina bulloides 81.

Globigerinen $81,510$.

5lobiacrineniditict $81,45+$.

Globiocephalus melas 80 .

Glyphidodon Bengalensis $\$ 22$.

Glyphocrangon 555, $56 \overline{6}$.

Gnathaster 171, 187.

Gnathophausia 551, 569 .

(5olomafreelen $\overline{0} 01$.

(5oraonioen 518.

(5rinowal 80, 296.

(5runoproben 81, 181, 514, 401, 457.

5uincajtrom 62.

Gygis candida $\$ 2$.

Gymnopatagus Valdiviae 529.

Gypohierax angolensis 126.

\section{$\mathfrak{6}$.}

Eaic 69, 422 .

Eaifang 69).
Halicarcinus 511.

Halicmetus 568.

Ealocypriden 550, 565.

Halosphaera viridis 68,572 .

Eammerhai 502.

Helix Hookeri 270 .

Hemiaster 279.

Heritiera litoralis 405.

Hermandia 470.

Heterocarpus 5.56 .

Heteronereis 141 .

Geteropoder 555 .

Hetheroteuthis $5 \mathbf{5 8}$.

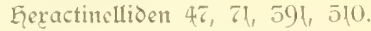

Hibiscus rosa sinensis 369 .

Holascus 512.

Golozephaten 559 .

Holopus 521.

Eqolothurien 520 .

Homolochunia 55.5.

Homopelia picturata $4+7$.

Hyalonema 590.

Eyoroiopolypen 515 .

Hylobates syndactylus 501 .

Hyocrinus 240, 322 .

Hyphaena 152, 49).

Hyphaena coriacea 482 .

Hyphalaster Parfaiti 84.

Hyphalaster Valdiviae 85, 84.

Hypogeophis $46 \pi$.

Hypolytrum latifolium 467 .

3.

Jabaifi 119.

Janthina 52 .

Jeod 59.

Iconaster 526.

Ilex platyphylius 62 .

Jijoeen 591.

Isidigorgia 518 .

Isis $71,518$.

Isozoanthus 520 .

Itu 405.

Jwi 410 .

K.

Kabeltrommel 24.

Käferfhuteden 185.

Kaffernfraal 166.

Kaifer Wilhelm=pif 190.

Kamerun 89. 
Kamernupif, fleiner 89, arofer 90.

Kandy 419.

Kapflora $1 \overline{6} 6$.

Kapland 165.

Kapitaot 174.

Kaptaube $14 \overline{\bar{T}}, 244$.

Kapuzinerbäume 465 .

Kap Valdivia 190.

Karbau 524.

Ka)uarinen 440 .

Kautfdutbaum 10 .

Hergutelen 255.

Klima $25 \overline{5}$.

Entoectutasacididte $2 . \overline{7}$.

5ebirae 260.

Бrazelle: und Shünmetterhafen 262.

5laciallanoidiaft 265 .

Tierleben 260.

zriedere Eandfana 269.

Deactation $2 \bar{c} 1$.

Pinguine 274.

ITarine fauna $2 \pi 7$.

Elefantentobbe 282.

Weinnahtshafen 285.

Entfehung der Kerguelen, ifper flora uno fauna 200.

Zierguelenente 269.

Kerguelentohl 272.

Kletterfarne 500 .

Kofosfäfer 446.

Kofoswals $5 \overline{5}, 4,4$.

Kofospalme 338,440 .

Königspirguin 288.

Korallen 504.

Krabber 444, 550 .

Kuaelalaen $\overline{6}$.

s.

Labichthys elongatus $5 \bar{\tau} 9$. .

Saboratorien der Daldivia 20.

Saguna 64.

Lamprogrammus $39 \overline{7}$.

Landolphia 107.

Sanguften 299.

Lanius senator 71.

Larus marinus 48.

Larus tridactylus 48.

5 as palntas 65.

Latris hecataia 298.

Laurus canariensis 65 .

Leptoptilum 518.

Lestris parasitica 48.
Leucadendron 176 .

Scutiffeble 551 .

senditorgane 566.

Leucifer 480.

एianten $9 \overline{6}, 489$.

Uille Dimor 4.9.

Limacina 251.

Lithodes 555.

Lodoicea Seychellarum $46 \overline{6}$

Lomaria alpina $3 \pi 5,500$.

Eophtioen $55 \bar{\tau}, 567$.

Lophohelia prolifera 304.

sotmajdinen $\overrightarrow{5} \overline{6}, 149$.

Luidia 186.

Inume 48.

Lyallia $2 \bar{c}+$.

Lycodes $4 \bar{\imath}$.

Lycopodium cernuum 500 .

Lycoteuthis diadema 569 .

Lygodium 560 .

\section{1 .}

Macrorhinus leoninus 266.

Macrostomias 559 .

2liacruren 555 .

2liadreporen 459.

2Käanorinen 459 .

Majaqueus aequinoctialis 294.

RTafrelem 141, 501.

Makrocystis pyrifera 260, 2-8.

Malacosteus $\bar{\jmath} \bar{t}+$.

Rialaria 120.

Minalediven $41 \overline{\text {. }}$.

Malthopsis 568 .

2lianganfnollen 162.

Mangifera indica 525.

Miangoftante 525.

2 liangrove 490.

Llanteltice 554 .

Marchantia polymorpha 500 .

Marsupifer 280.

miejulen 544.

Megalocercus abyssorum $5 \bar{j} t$.

Megalopharynx $5 \bar{a}$.

Melanocetus $4 \pi 9$, 55i

Melastomias $558,566$.

Zliclaftomaceen 560.

VTelonenbaum 97, 525.

2)Tentanei: Becten 565.

2lientanoci= Infulanter 566.

Mertensia $\overline{5} 44$.

Metacrinus 592, 522. 
27tidiclsplcin 522.

27icsmmide 278 .

MTilleporen 4.59 .

zliollusfen 556.

Monocaulus imperator $51 \overline{5}$.

Monorhaphis 514 .

2lount Erojier 259).

nionut syall 259 .

Mormon fratercula 48 .

Munida $39 \overline{5}, 5 \overline{5} \bar{j}$.

Munidopsis $.50 .5,5.55$.

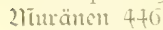

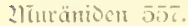

2lüpduclfrebie 550.

21 üidzchn $150,55 \overline{6}$.

2liufferonghes 150 .

2lịetophiiden 535.

Myro Kerguelensis $2 \overline{6} 0$.

ii.

Zimfanti 402.

Ziapfidutecfen $2-88$.

Naucrates ductor 08.

Nautilograpsus 585.

Nautilus 589.

Nematocarcinus $595,556$.

Nematoscelis mantis 551 .

2remertineit 549 .

Neoscopelus 50 .

Nephrodium 308.

Nephrops andamanicus 535.

Nephropsis 535.

Neptunus 585.

2ienstmiterdam 504 .

2rias $5 \pi \%$

2ritobaren 599.

Tieficefauma 309 .

Glicoerung des atrdipels 404 .

Dfahloürfer 402.

Ininlaner 405 .

Gaustiere, 27ahruma 408.

5eifteralauben 409 .

zrilpfero 491.

Nipa fruticans 531.

Notostomus $516,552$.

Notothenia 278.

Nymphaster Alcocki 526.

\section{D.}

Oceanites ocernica $2+6$.

Ocypoda 445 .

Oecophylla 120.
Ogmorhinus leptonyx $28 \%$.

(i)lpalme $9 \overline{6}$.

Onchocephalidae 568.

Ophiacantha cosmica 186.

(1) phibition 539 .

Ophiocreas 524.

Ophiocten pallidum 249.

Ophioglypha Deshayesii 186.

Ophioglypha hexactis 279.

Ophioglypha Lymani 186.

Uphioplinthus medusa 249 .

Ophiopyren 186.

Opistoteuthis 496, 558 .

(1) phinren 524 .

Opisthoproctus $5 \bar{\imath} 4$.

Orbulina universa 81.

(1) raelforallen 40 .

Ornithoptera 500.

Ornithocercus $41 \%$.

Ornithocercus magnificus 65 .

Ussifraga gigantea $2++$.

Oscillaria 598.

(1) ftracosen $5 \overline{5} 0$.

(I)ttertrawl 29.

Owenia 252

\section{f.}

Pacfis 211, 250.

Pagodroma nivea $25 \overline{6}$.

pagurioen 150.

Palaeopneustes 590, 550 .

Palinurus Lalandei 299.

Palmert:

Phoenis canariensis 62.

(ï) Ipalme (Elaeis Guineensis) 97.

Weinpalme (Raphia vinifera) 97, 127.

Stadclpalme (Phoenix spinosa) 126.

Savamempalme (Hyphaene) 152, 491.

Piranapalme (Areca catechu) 524, 358.

Jucferpalme (Arenga saccharifera) 525, 558.

Zipapalme (Nipa fruticans) 351.

Kotospalme (Cocos nucifera) 5.58, +40.

Salappalme (Arenga obtusifolia) 560.

Ziotangpalme 405 .

Talipotpalme (Corypha umbraculifera) 418.

Verschaffeltia splendida 462 .

Roscheria melanochaetes 464 .

Stevensonia grandifolia 464 .

Lodoicea Seychellarum $46 \bar{\tau}$.

Palmift (Deckenia nobilis) $4 \% 2$.

Dumpalme (Hyphaene coriacea) 482. 
Palmendict +75 .

Dalmitit $4{ }^{2} 2$.

Pancratium maritimum $11 \overline{6}$.

Pandanus $9 \overline{6}, 588,464$.

Pandanus Hornei 464.

Pandanus mellori 408.

Pandanus Seychellarum $462,464$.

Papacitaudier 48.

Pararchaster 526.

Paraspongodes antarctica 186.

Pasiphaea 246.

Patella 278.

Pectinidiscus Annae 326.

Pediculatert 568.

Pelagobia 251.

Pelagonemertes 42I, $5+9$ ).

Pelagothuria $5+6$.

Pemratulioen $516,518$.

Pentacheles 536 .

Pentacrinus 502 .

Pentactella laevigata 278.

Pentagonaster abyssalis 526 .

Pentagonaster excellens 526 .

Peribincen 65 .

Peridinium divergens 5 .

Persephonaster 526.

Periphylla 251, 544.

Petersvogel 5l, 246.

Petterion's WWafleridöpfer 156.

Pfeilwoümer 549.

Phacosarient 250.

Phalacrocorax carbo 49,

Phalacrocorax capensis 142 .

Phalacrocorax verrucosus 268.

Phalacroma $6 \overline{0}$.

Phalacroma rapa 75.

Phascolosoma 40\%.

Pheronema 399.

Pheronema raphanus $5[2$,

Phoenicopterus roseus 145.

Phoenix canariensis 62.

Phoenix spinosa 126.

Phormosoma 59l, 529.

Phorus 596.

Phosphorescenz 148, 480, 565.

Phua rrulafu 436.

Phylica nitida 308.

Physalia 510.

Phyiophoriocit 281, 565.

Dit von ฮeneriffa 55.

Pilot 68 .

Piljforallet 459.

Pintangpalme 524.
Pinguin, antarttifder 276.

Pirgunite $145,169$.

Piper betel 527.

planfton 74.

planton des Gunteaftroncs 65 .

Planctoniella $\tau 8,+\tau$.

Planctoniella sol $5+2$.

Plantitomets 30 .

Plasmodium malariae \{2\}.

Platylistrum platessa 514.

Platymaia Wyville-Thomsoni 400 , 5.7.

Plesionika 556.

Pleuromma $\$ 50$.

Plumiera 429.

Plutonaster 520.

Por Cookii 26.5.

Pon Novarae 500.

Polycheles $5 \overline{5} 6$.

Polynoe 185.

polypen 515.

Polypodium australe 275.

Polypodium vulgare 265.

Porrgamicu 403.

Pontaster 186,526

Porania $18 \overline{6}$.

Porocidaris 592.

Port Elijabeth 166.

Port Dietoria (2Trahé) 456, 461.

pojadows fy: (5letidier 190 .

Pourtalesia 550.

Primnoella $18 \%$.

Pringlea antiscorbutica 272.

Priocella glacialoides 244.

Prion Banksi 245.

Prion coeruleus $2+5,258$.

Prion desolatus 245.

Procellaria aequinoctialis 142.

Procellaria glacialis +9 .

Proteacen 17\%.

Protojocit $75,250,510,5+4$.

Pseudarchaster 526.

Psilaster 526.

Psilotum 440.

Pteropoden 552.

Pteroposenichlanm 401.

Puffinus 142, 168.

Puffinus arcticus 51.

Pullenia obliqueloculata 81.

Pulvinulina canariensis 81 .

Pulvinulina menardii 81.

Pyenogoniden 4 $\bar{\imath}, 5 \bar{\zeta}$.

Pycnonotus Gaboonensis 95.

Pygoscelis antarctica 246. 
Pygoscelis papua 287.

Pyrocystis noctiluca 67,47

Pyrosoma 148.

Q.

(1) ualtenoredide 29.

Querquedula Eatoni 260.

2 .

ZRadiolarien 54.4 .

2Radiolarien[t]licf 184, 514.

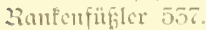

Ranunculus crassipes $2 \bar{\zeta}+$.

Ranunculus trullifolius $2 \bar{i} 4$.

Raphiapalme 9), $12 \overline{6}$.

Raphia vinifera 9\%, 127.

Zaubmöve $48,28 \pi$.

Raubiccidualbe $1+2$.

Ravenala madngascariensis 458 .

Retropluma notopus 551 .

Rhabdammina 510.

Rhizocrints sp. 522, 524.

Rhizocrinus lofotensis 522 .

Rhizocrinus Rawsoni 521.

Rhizophora mangle $11 \overline{6}, 126$.

Rhizosolenia 228, 2+1, 254.

22 hijophyien $5+5$.

Zitcicnithilofröten 463 .

Zicienfurnmoad 282.

Sicientana $2-8$.

Rimbentorallem ists.

Rippenquallen jౌ̄.

Rоћен 286, 502, 559 .

Röbrenminmer $1+2$.

Roscheria melanochaetes $\neq 6+$.

Rotanapalme 40.5 .

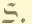

Saaopalme 55l, 408.

Saccopharynx amptllaceus $5 \overline{5} 9$.

Sagitta 5+9, 564.

Salappalme 560).

Salpa flagellifera 161 .

Salpa fusiformis 56.5 .

Sanobratriopoden 45.5 .

Samberaben 58.

Sanseviera 489.

Santa 5rus 64 .

Sargassum $5 \times 5$.
Savamtchalme 152, 491.

Scaevola 589, $4+0$.

Scaevola Koenigii 589 .

Scalpellum 398.

Ecaroiden 446.

Scirpus nodosus 500.

Shattennögcl 150.

Sdyeideniturabel 266.

Edififshalter 422.

Sdimper 504 .

Strimatajic 491.

Schizaster 529 .

Strijopoden 551.

Sdlanacuhalsoogel tot.

Sthlangenfterne 524 .

Etilcierauallen $5+5$.

St)liefuretse 31.

Stureden $55 \overline{\text {. }}$.

Edinurmïrnter $5+9$.

Sdopfpiranin $27+$.

Sdiotilithe liulte 42 .

Sdhupenw ӥrmer 185.

Sthwimmfrïdte 442.

Sd)wimmpolypen 545 .

Sciaena aquila 141.

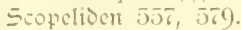

Scopus 150.

Scyramathia Hertwigi $122,550$.

Exblaien 510.

Exiclcfant 260.

Eivfedern 185,501 .

Eciagel 165.

Eilcoparo 287.

Exililien 52l.

Eiroient 520 .

Eochtilofröten 429.

Eccithlantaer 405 .

Eceidwoalbe 266.

Ecefterme 82, 84, $486,188,315,594,524$.

Ecetange 278 .

Eсcualjen $185,249,278,550,546$.

Scejunaen $1+1$.

Ecillcituna 25.

Semperella 515.

Sergestes 545.

Sergeftioen 552, 565.

Serolis latifrons 278.

Scydellert +55 .

zliabé $4 \bar{y} 4$.

Entoedungsacjihidte $45 \bar{z}$.

3 coül Eerung 459 .

Plantaacnbetricb 460 .

Klima 465. 
flora mo fama 465.

praslin 467.

Eodoicea $46 \bar{t}$.

Elcfantenfiłilotröte 475 .

Siamang 531.

Sideroxylon 491 .

Siasbee's sotmajuine 149.

Siasbee's Tieffeclot 152.

Silberbaum 1 \%?.

Siphorophoren $\bar{\jmath} ¥ \overline{.}$.

Solaster 188.

Solenosmilia 50 520 .

Sonneratia acida 490.

Spartina arundinacea 508.

Spartium nubigenum $5 \overline{5}$.

Spatangus Raschi 175.

Sphaerodina dehiscens 81.

Spheniscus demersus $1 \neq 5,160)$.

Spherosoma 529.

spinncufrebic $4 \overline{6}$.

Spirula $59 \vec{\imath}, 5 \overline{5} 5$.

Stahlfabel 24.

Steinforallen 504, 589, 520.

Stephanotrochus 520.

Stereocidaris $175,592,529$.

Sterna 142.

Sterna arctica 48.

Sterna virgata 366.

Sternforallen 439 .

Sternwoümer 40 I.

Stevensonia grandifolia 464 .

Stomiatiden 55i, 550.

5t. panl 296.

Strongylocentrotus $1 \overline{6}$.

Sturmtantier 51, 142, 168.

Stmmoogel $1+2,2+4$.

Sturmoogel, antarftifher $2+7$.

Sturmoügcl, blaue $245,258$.

Stylocheiron 551 .

Stylophthalmus 576.

Styracaster 515.

Sladioa=2itoll 425.

Snderoc 48.

SüDherina $14 \pi$.

Sula bassana 42 .

Sula capensis $1+2$.

Sumatra 51\%.

Enmahafen 318.

padaria 519.

Padang=Pandjana 552.

Padargitie 3ovenlande 553.

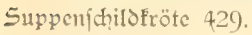

Sus vittatus 52.3.

Synedra 228, 23+.

Synedra thalassothrix $2+1$.

\section{๘.}

Tafelbai 165.

Talipotpalmer 418.

Taonius 246.

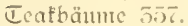

Tectona grandis $55 \pi$

Teleffopanaer $\overline{5} \bar{t}+$.

Tenea muricata $4 \bar{\tau}$.

Eeneriffa 55.

Terebratulina 456.

Terminalia 580.

Terminalia katappa $4+2$.

Testudo elephantina $4 \overline{65}$.

Thalassoeca antarctica $2+t$.

Thaumatops 551 .

Tiefiecifiche 59\%, $421,559,540,55 \bar{\tau}, 56 \bar{\imath}$, $568,5 \overline{2} 2,5 \overline{6} 5,5 \overline{6} 9$.

区icficeforjtungen!.

Tieffechuic $55 \%$ \%.

एieficemesnjen 42!.

Tieffecrenjen 29.

Tieffecf dw

Iieffecthermonter $38,155$.

Tiger $=$ Falbiniel 144 .

Cintenfiga 538.

đölpel 142 .

Tomopterioen $5+9$.

Torpedo 530.

Tournefortia 589, +10 .

Tournefortia argentea 589 .

Eratiomeduicn $5+5$.

Trawl 27.

Treibeis $19 \%$.

Trichomanes radicans 63 .

Trichopeltarium Alcocki 53 I.

Trigla 141.

Trophon magellanicus 160.

Trubipora 401 .

Tulbergia antarctica $2 \widetilde{6} 0$.

Tunicaten 55 t.

Tuscarorem 250, 252.

Tulfofaras 508 .

Typliloscoleciden 549.

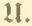

Umbellula $185,516,561$.

Uria arra 48.

Utricularia 106. 
1).

Daloiviasfall 265 .

Vampyroteuthis inferualis 88 .

Velella 52, 510.

Dcursförbthen 512 .

Veretillum $1+2$.

Verschaffeltia splendida 462 .

Verticilladeae 518.

Dertitaluetz 50 .

Dictoria 91.

11.

Warinain $55 \overline{\text {. }}$

Walferįöpfer 59, 156.

Webervoacl 444.

Wcimpalme $9 \bar{\tau}, 12 \overline{6}$.

Willemoesia 556.

Winterin $5 \pi+$
Wollbaum 96.

Woodwardia 63.

Wuriflub 116.

2 Dүville $=\mathbb{T}$ homfon $=2$ Rücfen 45 .

t.

Xanthoxylum too.

Xenophora 5t)( 1 .

Xylopagurus 554.

๘.

Sitterrodien 539

Zoanthus 158.

Zoroaster fulgens 82 .

Suferpalme $325,558$.

jwergreiher $4+4$.

Zygaena 502.

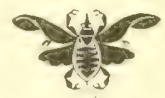




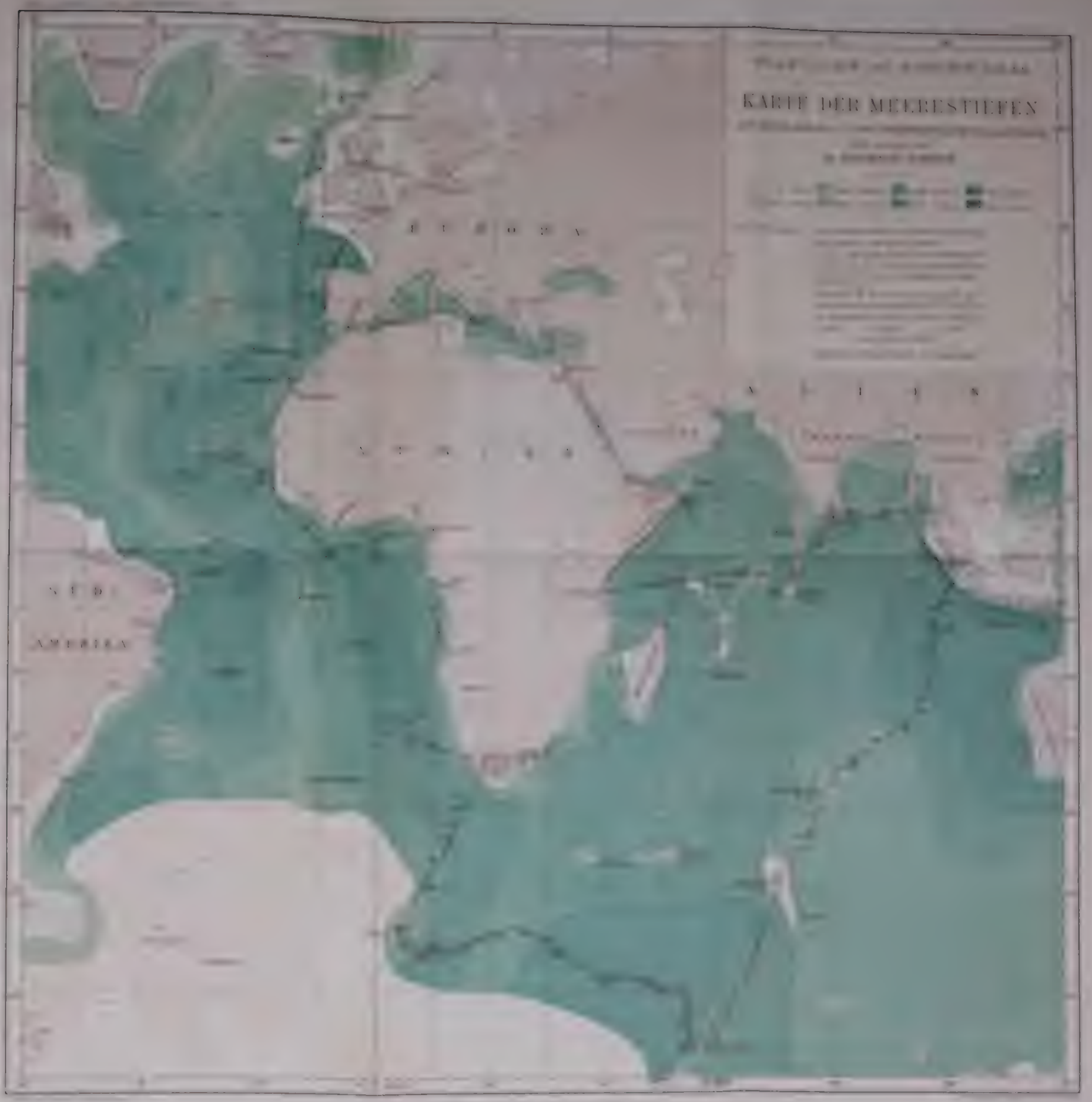






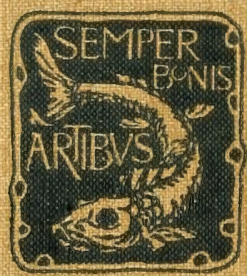

